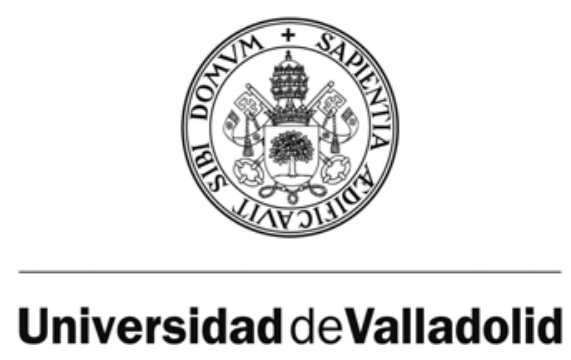

FACULTAD DE EDUCACIÓN Y TRABAJO SOCIAL DEPARTAMENTO DE PSICOLOGÍA

\title{
TESIS DOCTORAL: \\ EI Rol de Líder formal: actitudes y valores frente a la Responsabilidad Social Corporativa
}

Dirigida por: PhD. Raúl de Diego Vallejo Doctorando: Óscar Díaz Chica 

D. Raúl de Diego Vallejo, en calidad de director de la Tesis Doctoral titulada “El Rol de Líder formal: actitudes y valores frente a la Responsabilidad Social Corporativa", realizada por el alumno D. Óscar Díaz Chica para su lectura y defensa ante tribunal,

DESEA HACER CONSTAR que,

dicho trabajo contiene los elementos de originalidad y aportación científica suficientes para ser expuesto y defendido ante tribunal.

Valladolid, Mayo de 2014.

EL DIRECTOR DEL TRABAJO

Fdo. Raúl de Diego Vallejo 

Agradezco la paciencia, la dedicación, la contribución y el impulso que siempre ha supuesto Raúl de Diego, el Director de esta Tesis, en su desarrollo. Sin su guía habría sido imposible realizar esta investigación.

También agradezco el apoyo incondicional de mis padres, María Chica y Domingo Díaz, especialmente importantes en la selección de contactos para la realización del trabajo de campo, así como el de otros familiares, como Delfina Villar y Jacinto Rama, y de otras personas cercanas a mis padres, como Ángeles Quintanilla, María José Alonso, Jose María Astorga, Francisco Santos, Adelina Álvarez, Irene Arias, Susana Mateos, Agustín Flores y María José Torrejón, entre otros.

Asimismo también agradezco la contribución de todos los amigos que han impulsado la investigación o que han facilitado contactos para la muestra, destacando de modo relevante la labor de César Agut, Marylén Rojas, Ignacio Mata, Daniel Argüello, Rafael Llamas, Álvaro Sachi, Guillermo Sánchez, Diego Rodríguez, David Cuenca, Eloy Cuenca, José Antonio Losada, Luis Sánchez, Juan de la Fuente y José Miguel Gómez.

Agradezco el tiempo y los recursos ofrecidos a la institución a la que estoy actualmente vinculado, la Universidad San Jorge, sin los cuales no hubiera encontrado el modo de desarrollar esta investigación. De todo el apoyo entregado por multitud de personas en la institución, destaco en especial medida el recibido por parte de Nerea Vadillo, José Antonio Muñiz, Cristina Sánchez, Laura Fernández, María Pilar Cardos, Manuel 
Viñas, Pedro Larraz, Carmen Gonzalo, Carlos Pérez, César Romero, Manu Viñas y Joseba Bonaut.

También agradezco la ayuda, de incalculable valor, de los compañeros laborales que han colaborado en el tratamiento estadístico de los datos recabados, especialmente Alejandro Tapia y Matías López, y la del resto de colegas que han facilitado contactos para la realización del trabajo de campo, como es el caso de Rosana Fuentes, Almudena Nevado, Paz Aragüés, Juan Francisco Delgado y Alejandro Álvarez.

Asimismo también agradezco a los profesionales, expertos e investigadores que han contribuido como jueces en la redacción de los ítems de la escala ARS19 y en la determinación de su valor. Dentro de este grupo de personas destaco la contribución de Vanessa Rodríguez, Fernando Coca, Ana Koc, Begoña Gómez y Victoria Soto.

También agradezco la inestimable aportación de todos los que han contribuido a clarificar aspectos conceptuales de la investigación, ya sea a través de encuentros personales, como es el caso de José María Herranz, o mediante la referencia a documentos clave, como en el caso de Javier Borraz.

Además también agradezco la enorme ayuda de $M^{a}$ Carmen Dehesa y César Gurría en la revisión del manuscrito final.

A todos aquellos que no han sido nombrados y que han contribuido, de algún modo, a que esta investigación pueda desarrollarse, GRACIAS. 
Dedicada a todos los que orientan su trabajo al beneficio de los demás. 



\section{EL ROL DE LÍDER FORMAL: ACTITUDES Y VALORES}

FRENTE A LA RESPONSABILIDAD SOCIAL CORPORATIVA

\section{ÍNDICE GENERAL}

PARTE I: FUNDAMENTOS TEÓRICOS

INTRODUCCIÓN ................................................ 31

1. LA RESPONSABILIDAD SOCIAL CORPORATIVA..........44

\subsection{DELIMITACIÓN CONCEPTUAL DE LA RESPONSABILIDAD} SOCIAL CORPORATIVA ............................... 45

1.1.1. Concepto de Responsabilidad Social Corporativa ............49

1.1.2. Rasgos asociados al concepto de Responsabilidad Social Corporativa ..........................................54

1.1.3. Otros conceptos cercanos a la Responsabilidad Social

Corporativa

1.2. HISTORIA DE LA RESPONSABILIDAD SOCIAL CORPORATIVA .......................................69 69

1.2.1. Origen de la Responsabilidad Social Corporativa..............69

1.2.2. Evolución de la Responsabilidad Social Corporativa ...........73

1.2.3. Relevancia actual de la Responsabilidad Social Corporativa .83

\subsection{REGULACIÓN DE LA RESPONSABILIDAD SOCIAL} CORPORATIVA ........................................... 101

1.3.1. Informes.............................................. 101

1.3.2. Acuerdos de estandarización ............................... 104

1.3.3. Códigos de conducta ..................................... 108

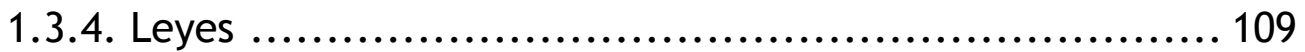




\subsection{LA RESPONSABILIDAD SOCIAL CORPORATIVA EN}

ESPAÑA

1.4.1. Estado de la Responsabilidad Social Corporativa en España

1.4.2. Regulación de la Responsabilidad Social Corporativa en España

2. ACTITUDES Y VALORES 129

2.1. DELIMITACIÓN TEÓRICA DE LA ACTITUD.............. 131

2.1.1. Concepto y características de la actitud 131

2.1.2. Componentes de la actitud 134

2.1.3. Funciones de la actitud. 142

\subsection{ENFOQUES TEÓRICOS SOBRE EL ORIGEN DE LA} ACTITUD 148

2.2.1. Condicionamiento clásico ................................. 148

2.2.2. Condicionamiento instrumental ............................ 152

2.2.3. Modelado................................................ 156

2.2.4. Funcionalismo ......................................... 160

2.2.5. Consideraciones finales sobre el origen de la actitud ....... 163

2.3. ACTITUDES Y CONDUCTA............................ 165

2.3.1. Factores de influencia de las actitudes en el comportamiento ........................................ 166

2.3.2. Inconsistencias entre las actitudes y el comportamiento... 175

2.4. LA MEDICIÓN DE LAS ACTITUDES ....................... 181

2.4.1. Medidas directas de las actitudes......................... 182

2.4.2. Medidas indirectas de las actitudes ........................ 186

2.5. ACTITUDES Y RESPONSABILIDAD SOCIAL CORPORATIVA 190

2.5.1. Factores de influencia en las actitudes hacia la responsabilidad social ..................................... 190

2.5.2. Factores de influencia en el caso español................... 198 
2.6. DELIMITACIÓN CONCEPTUAL DEL VALOR............. 206

2.6.1. Concepto de valor ....................................... 206

2.6.2. Diferencias entre los valores y las actitudes................ 213

2.7. TIPOLOGÍAS DE VALORES............................. 216

2.7.1. Enfoque filosófico ...................................... 216

2.7.2. Enfoque psicológico .................................... 220

2.8. VALORES Y RESPONSABILIDAD SOCIAL CORPORATIVA. 231

3 - LIDERAZGO: AYER, HOY Y MAÑANA ................ 237

3.1. CONCEPTO DE LIDERAZGO .......................... 239

3.2. CARACTERÍSTICAS ASOCIADAS AL CONCEPTO DE LIDERAZGO............................................. 240

3.3. MODELOS TEÓRICOS INICIALES...................... 244

3.3.1. Consideraciones previas .................................... 244

3.3.2. El modelo Análisis del Sistema Humano (ASH) ............... 251

3.3.3. El modelo AMIGO ......................................... 265

\subsection{ENFOQUES TEÓRICOS EN EL ESTUDIO DEL}

LIDERAZGO............................................ 284

3.4.1. Enfoques centrados en el líder ............................ 287

3.4.2. Enfoques contingentes................................... 300

3.4.3. Enfoques centrados en los seguidores...................... 338

3.4.4. Enfoques que toman en consideración la interacción líder- seguidores .......................................... 344

3.4.5. Nuevas teorías sobre liderazgo ......................... 347

PARTE II: ESTUDIO EMPÍRICO

4. OBJETIVOS ........................................ 373

4.1. OBJETIVO GENERAL ............................... 384 
4.2.1. Relativos a aspectos de los líderes ......................... 385

4.2.2. Relacionados con el perfil de la organización ............... 386

4.2.3. Vinculados con el perfil de la organización y la actitud de los líderes frente a la responsabilidad social............ 387

4.2.4. Asociados a características demográficas de los líderes y a su actitud frente a la responsabilidad social............ 387

5. METODOLOGÍA 389

5.1. DISEÑO METODOLÓGICO 391

5.2. HIPÓTESIS 397

5.3. VARIABLES 399

5.3.1. Variables independientes 399

5.3.2. Variables dependientes. 405

5.4. PROCEDIMIENTO. 407

5.5. INSTRUMENTOS 414

5.5.1. Escala ARS19 ........................................... 414

5.5.2. Cuestionario SPV ......................................... 421

5.5.3. Cuestionario LBA II ....................................... 436

5.6. POBLACIÓN .............................................. 441

5.7. MUESTRA......................................... 444

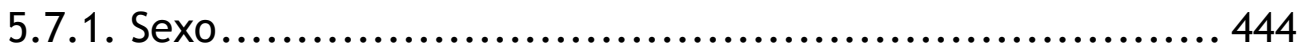

5.7.2. Edad ....................................................... 445

5.7.3. Sector de procedencia ................................. 446

5.7.4. Tamaño de las empresas .................................. 447

5.7.5. Realización de acciones y formación sobre Responsabilidad Social Corporativa en las empresas....... 449

5.8. ANÁLISIS DE DATOS ............................... 454 
6.1. RESULTADOS GENERALES ........................... 458

6.1.1. Actitud ante la Responsabilidad Social Corporativa ........ 458

6.1.2. Valores de los líderes empresariales ...................... 469

6.1.3. Liderazgo .............................................. 480

6.1.4. Sexo y Responsabilidad Social Corporativa .................. 490

6.1.5. Edad y Responsabilidad Social Corporativa.................. 498

6.1.6. Sector y Responsabilidad Social Corporativa................. 503

6.1.7. Tamaño y Responsabilidad Social Corporativa ............... 507

6.1.8. Liderazgo y Responsabilidad Social Corporativa............. 513

6.1.9. Valores y Responsabilidad Social Corporativa................ 529

6.2. RESULTADOS COMPARATIVOS ...................... 542

6.2.1. Sexo, edad y Responsabilidad Social Corporativa ........... 542

6.2.2. Sexo, sector y Responsabilidad Social Corporativa ......... 553

6.2.3. Sexo, tamaño y Responsabilidad Social Corporativa ........ 565

6.2.4. Sexo, liderazgo y Responsabilidad Social Corporativa....... 575

6.2.5. Sexo, valores y Responsabilidad Social Corporativa ........ 593

6.2.6. Edad, sector y Responsabilidad Social Corporativa ......... 611

6.2.7. Edad, tamaño y Responsabilidad Social Corporativa......... 622

6.2.8. Edad, liderazgo y Responsabilidad Social Corporativa ...... 632

6.2.9. Edad, valores y Responsabilidad Social Corporativa ......... 653

6.2.10. Sector, tamaño y Responsabilidad Social Corporativa ..... 675

6.2.11. Sector, liderazgo y Responsabilidad Social Corporativa ... 687

6.2.12. Sector, valores y Responsabilidad Social Corporativa ..... 709

6.2.13. Tamaño, liderazgo y Responsabilidad Social Corporativa . 732

6.2.14. Tamaño, valores y Responsabilidad Social Corporativa.... 753

6.2.15. Liderazgo, valores y Responsabilidad Social Corporativa.. 776

6.3. REVISIÓN DE LA MEDIDA.............................. 795

6.3.1. Relación entre los valores personales........................ 795

6.3.2. Relaciones entre los estilos de liderazgo ................... 798

6.3.3. Relación entre la flexibilidad y el estilo de liderazgo ....... 799

6.3.4. Relación entre la efectividad y el estilo de liderazgo ....... 801

6.3.5. Relación entre la flexibilidad y la efectividad en el estilo de liderazgo ........................................ 801 
6.3.6. Relaciones entre la actitud y los valores personales 802

6.3.7. Relaciones entre la actitud y el estilo de liderazgo 803

6.3.8. Relaciones entre el estilo de liderazgo y los valores personales. 804

6.3.9. Relaciones entre la actitud hacia la responsabilidad social y los ítems de control

6.3.10. Relación entre la formación en responsabilidad social y el desarrollo de acciones en responsabilidad social....

6.3.11. Relaciones entre la flexibilidad, la efectividad y el estilo de liderazgo

6.3.12. Relación entre los valores personales, el estilo de liderazgo y la actitud ante la Responsabilidad Social Corporativa

7. CONCLUSIONES Y DISCUSIÓN 815

7.1. CONCLUSIONES SOBRE LA ACTITUD DE LOS LÍDERES HACIA LA RESPONSABILIDAD SOCIAL Y EL COMPORTAMIENTO SOCIALMENTE RESPONSABLE DE LAS ORGANIZACIONES 817

7.2. CONCLUSIONES SOBRE EL SEXO DE LOS LÍDERES Y LA RESPONSABILIDAD SOCIAL

7.3. CONCLUSIONES SOBRE LA EDAD DE LOS LÍDERES Y LA RESPONSABILIDAD SOCIAL

7.4. CONCLUSIONES SOBRE EL SECTOR DE ACTIVIDAD Y LA RESPONSABILIDAD SOCIAL 845

7.5. CONCLUSIONES SOBRE TAMAÑO DE LAS ORGANIZACIONES Y LA RESPONSABILIDAD SOCIAL 852

7.6. CONCLUSIONES SOBRE EL LIDERAZGO Y LA RESPONSABILIDAD SOCIAL 863

7.7. CONCLUSIONES SOBRE VALORES Y LA RESPONSABILIDAD SOCIAL 868 
7.8.1. Hipótesis 1: Los líderes que tienen una actitud más favorable hacia la responsabilidad social están vinculados a organizaciones que tienen una política de Responsabilidad Social Corporativa más definida

7.8.2. Hipótesis 2: Los líderes que tienen una actitud más favorable hacia la Responsabilidad Social Corporativa utilizan un estilo de liderazgo que presenta preferencia por los estilos "participativo" y "delegativo".

7.8.3. Hipótesis 3: Los líderes que tienen una actitud más favorable hacia la Responsabilidad Social Corporativa presentan una puntuación más elevada en los "valores" personales "resultados" y "practicidad".

7.8.4. Hipótesis 4: Las organizaciones que impulsan la formación de sus colaboradores en materia de responsabilidad social están más implicadas en la realización de acciones en este ámbito

7.8.5. Hipótesis 5: Las organizaciones que actúan en el sector servicios, supuestamente más sensibilizadas con el trato personal, presentan líderes con una actitud más favorable hacia la Responsabilidad Social Corporativa

7.8.6. Hipótesis 6: Las organizaciones de gran tamaño, supuestamente más preocupadas por su reputación corporativa, presentan líderes con una actitud más favorable hacia la Responsabilidad Social Corporativa

7.8.7. Hipótesis 7: La edad de los líderes de las organizaciones no resulta un factor indicativo de cómo de favorable es su actitud hacia la Responsabilidad Social Corporativa ... 898

7.8.8. Hipótesis 8: El sexo de los líderes de las organizaciones no es un factor indicativo de cómo de favorable es su actitud hacia la Responsabilidad Social Corporativa ....... 904

7.8.9. Hipótesis 9: El estilo de liderazgo participativo, de acuerdo a lo que hemos medido los responsables de la investigación, está más asociado a la flexibilidad de estilo que al resto de estilos de liderazgo ..................911

7.8.10.Limitaciones y sugerencias para futuras investigaciones... 913 
ANEXOS

Anexo 1. Escala ARS19.

921

Anexo 2. Cuestionario SPV de Gordon .................... 925

Anexo 3. Cuestionario LBA II.............................. 931

Anexo 4. Definiciones de liderazgo aportadas por Bass en el primer capítulo de su libro "The Bass Handbook of Leadership" 941

Anexo 5. Cuadernillo de recogida de datos 975

Anexo 6. Tablas de validez del SPV 985

REFERENCIAS BIBLIOGRÁFICAS 991 


\section{ÍNDICE DE CUADROS}

Cuadro 1 Actividades más realizadas en el ámbito de la Responsabilidad Social Corporativa.

Cuadro 2: $\quad$ Principales modos de actuación empresarial en materia de responsabilidad social.

Cuadro 3: Diferencias entre empresas socialmente responsables y empresas socialmente no responsables.

Cuadro 4: $\quad$ Algunas indicaciones en textos de referencia sobre la importancia de la atención a los grupos de interés.

Cuadro 5: $\quad$ Otros conceptos cercanos a la Responsabilidad Social Corporativa.

Cuadro 6: La Pirámide de la Responsabilidad Social Corporativa (Carroll)

Cuadro 7: $\quad$ Publicaciones marco sobre Responsabilidad Social Corporativa en el ámbito europeo.

Cuadro 8: $\quad$ Algunas revistas internacionales especializadas en el estudio de la Responsabilidad Social Corporativa.....

Cuadro 9: $\quad$ Algunos datos destacables del estudio sobre competitividad responsable desarrollado por AccountAbility...

Cuadro 10: $\quad$ Algunos de los documentos creados para favorecer la implantación de la responsabilidad social.

Cuadro 11: $\quad$ Algunos de los organismos más representativos implicados en el desarrollo de la Responsabilidad Social Corporativa.

Cuadro 12: $\quad$ Prácticas en materia de responsabilidad social más desarrolladas por las PYMES que por las grandes empresas.

Cuadro 13: $\quad$ Secciones de la Ley de Economía Sostenible (2011) que hacen referencia directamente a aspectos de responsabilidad social

Cuadro 14: Procesos involucrados en el aprendizaje por observación

Cuadro 15: ¿Por qué es débil la relación entre la actitud y el comportamiento?

Cuadro 16: Factores que desempeñan un rol relevante cuando existe oportunidad de razonar.

Cuadro 17: Condiciones que favorecen el efecto "menos lleva a más"

Cuadro 18: $\quad$ Aspectos que motivan una percepción diferente en empresarios y directivos del contrato tácito que la empresa establece con su entorno.

Cuadro 19: Características de los valores.

Cuadro 20: Valores del Rokeach Value Survey (RVS).

Cuadro 21:

Factores subyacentes y bipolares en los valores del Rokeach Value Survey (RVS). 
Cuadro 22: Tipologías de valores o dominios motivacionales de valores (Schwartz y Blisky)

Cuadro 23: Tipologías de valores (Schwartz)

Cuadro 24: $\quad$ Categorías utilizadas por Bass para definir el liderazgo...

Cuadro 25:

$$
\text { Grupos de poder en una organización.. }
$$

Cuadro 26: Dimensiones de la organización.

Cuadro 27: Rasgos y habilidades asociadas en los que se ha centrado el trabajo de investigación desde la década de los 70 del siglo XX.

Cuadro 28: Tipos diferentes de conducta (Bales)

Cuadro 29: Relación entre poder del puesto, estructura de tarea y relaciones entre el líder y los miembros (Fiedler).

Cuadro 30: $\quad$ Algunas influencias de la Teoría del Liderazgo Situacional.

Cuadro 31:

Continuo inmaduro-maduro en la evolución de una persona en un entorno organizacional

Cuadro 32:

Principios no satisfechos por la Teoría del Liderazgo Situacional (Nicholls)

Cuadro 33: Aspectos situacionales de análisis en la Teoría del Camino-Meta.

Cuadro 34: Conductas de liderazgo esperadas por los colaboradores en las Teorías Implícitas.

Cuadro 35: Claves para alcanzar un resultado satisfactorio o insatisfactorio en la relación de acuerdo a la Teoría del Intercambio Líder-Miembro.

Cuadro 36: Características del líder que contribuyen a que se le atribuya carisma.

Cuadro 37: Características comunes y diferencias entre líderes carismáticos y transformacionales.

Cuadro 38: Constructos contemplados en el estudio del liderazgo como fenómeno multinivel.

Cuadro 39: Características del liderazgo de servicio (Spears).

Cuadro 40: Atributos, cualidades y características observadas en el liderazgo de servicio (Russell y Stone)

Cuadro 41: $\quad$ Características del liderazgo de servicio (Page y Wong)...

Cuadro 42: $\quad$ Los 7 hábitos de la gente altamente efectiva (Covey)......

Cuadro 43: Coeficiente de fiabilidad y relaciones entre los elementos del SPV.

Cuadro 44: Análisis de los elementos del SPV.

Cuadro 45: Rasgos de personalidad que muestran conexiones significativas con las escalas del SPV..

Cuadro 46 Dimensiones factoriales del SPV y otras medidas y variables implicadas.

Cuadro 47: Sexo de la muestra.. 
Cuadro 49: Formación en responsabilidad social en las empresas de la muestra

Cuadro 50: Máximo, mínimo, media y desviación típica de la actitud

Cuadro 51: Valor segmentado de la actitud hacia la responsabilidad social

Cuadro 52: Tabla ANOVA de actitud hacia la responsabilidad social, factor Realización de Acciones de Responsabilidad Social.

Cuadro 53: Medidas estadísticas de actitud hacia la responsabilidad social según formación en responsabilidad social

Cuadro 54: Tabla ANOVA de actitud hacia la responsabilidad social, factor Formación en Responsabilidad Social.

Cuadro 55: Valoración concedida al ítem "Conseguir que mi organización sea rentable".

Cuadro 56: Valoración concedida al ítem "Conseguir que mi organización sea líder en el mercado"

Cuadro 57: Resultados de medidas estadísticas sobre los "valores"...

Cuadro 58: Resultados de medidas estadísticas sobre los estilos de liderazgo.

Cuadro 59: Medidas estadísticas sobre la flexibilidad y la efectividad del estilo de liderazgo.

Cuadro 60: Tabla ANOVA de sexo, factor Actitud hacia la Responsabilidad Social.

Cuadro 61: Tabla de contingencia de realización de acciones de responsabilidad social y sexo.

Cuadro 62: Indicadores del Global Reporting Initiative sobre formación interna para la elaboración de memorias de sostenibilidad

Cuadro 63: $\quad$ Acciones de formación de Accenture en España (2012) en públicos internos indicadas en su informe de responsabilidad empresarial.

Cuadro 64: Tabla ANOVA de edad, factor Actitud hacia la Responsabilidad Social.

Cuadro 65: Tabla de contingencia de formación en responsabilidad social y edad.

Cuadro 66: Tabla ANOVA de sector, factor Actitud hacia la Responsabilidad Social.

Cuadro 67: Tabla de contingencia de realización de acciones de responsabilidad social y sector.

Cuadro 68: Medidas estadísticas sobre el tamaño y la actitud hacia la responsabilidad social.

Cuadro 69: Tabla ANOVA de tamaño, factor Actitud hacia la Responsabilidad Social.

Cuadro 70: Tabla de contingencia de tamaño y horas dedicadas a la formación en responsabilidad social en empresas que realizan este tipo de formación

Cuadro 71: Medidas estadísticas sobre la actitud hacia la responsabilidad social y el liderazgo. 
Cuadro 72: $\quad$ Tabla ANOVA de liderazgo, factor Actitud hacia la Responsabilidad Social.

Cuadro 73: Medidas estadísticas de liderazgo según realización de acciones de responsabilidad social..

Cuadro 74: Tabla ANOVA de liderazgo, factor Realización de Acciones de Responsabilidad Social

Cuadro 75: Tabla ANOVA de liderazgo, factor Horas de Formación en Responsabilidad Social.

Cuadro 76: Medidas estadísticas de "valores" según actitud hacia la responsabilidad social..

Cuadro 77: Tabla ANOVA de valores, factor Actitud hacia la Responsabilidad Social.

Cuadro 78: Tabla ANOVA de los valores personales, factor

Realización de Acciones de Responsabilidad Social.

Cuadro 79: Tabla ANOVA de los valores personales, factor Horas de Formación en Responsabilidad Social.

Cuadro 80: Medidas estadísticas de "valores" personales según formación en responsabilidad social.

Cuadro 81: Medidas estadísticas de edad, sexo y actitud hacia la responsabilidad social

Cuadro 82: Tabla ANOVA de la edad y el sexo, factor Actitud hacia la Responsabilidad Social.

Cuadro 83: Tabla de contingencia de realización de acciones de responsabilidad social, sexo y edad.

Cuadro 84: Tabla de contingencia de formación en responsabilidad social, sexo y edad.

Cuadro 85: Medidas estadísticas de sector, sexo y actitud hacia la responsabilidad social

Cuadro 86: Tabla ANOVA del sector y el sexo, factor Actitud hacia la Responsabilidad Social.

Cuadro 87: Tabla de contingencia de realización de acciones de responsabilidad social, sexo y sector.

Cuadro 88: Tabla de contingencia de formación en responsabilidad social, sexo y sector.

Cuadro 89: Medidas estadísticas de tamaño, sexo y actitud hacia la responsabilidad social.

Cuadro 90: Tabla ANOVA del tamaño y el sexo, factor Actitud hacia la Responsabilidad Social.

Cuadro 91: Tabla de contingencia de realización de acciones de responsabilidad social, sexo y tamaño..

Cuadro 92: Tabla de contingencia de formación en responsabilidad social, sexo y tamaño.

Cuadro 93: Medidas estadísticas de liderazgo, sexo y actitud hacia la responsabilidad social.

Cuadro 94: Tabla ANOVA del tamaño y el sexo, factor Actitud hacia la Responsabilidad Social.

Cuadro 95: Medidas estadísticas de liderazgo, sexo y actitud hacia la responsabilidad social. 
Cuadro 96: Medidas estadísticas sobre acciones de responsabilidad social, sexo y liderazgo.

Cuadro 97: Tabla ANOVA de sexo y liderazgo, factor Realización de Acciones de Responsabilidad Social.

Cuadro 98: Tabla ANOVA sexo y liderazgo, factor Horas de Formación en Responsabilidad Social.

Cuadro 99: Medidas estadísticas sobre formación en responsabilidad social, sexo y liderazgo.

Cuadro 100: Tabla ANOVA de los “valores" y el sexo, factor Actitud hacia la Responsabilidad Social.

Cuadro 101: Medidas estadísticas de "valores", sexo y actitud hacia la responsabilidad social.

Cuadro 102: Medidas estadísticas de "valores", sexo y actitud hacia la responsabilidad social...

Cuadro 103: Medidas estadísticas sobre acciones de responsabilidad social, sexo y "valores".

Cuadro 104: Tabla ANOVA de sexo y valores, factor Realización de Acciones de Responsabilidad Social.

Cuadro 105: Medidas estadísticas sobre formación en responsabilidad social, sexo y valores.

Cuadro 106: Tabla ANOVA de sexo y valores, factor Horas de Formación en Responsabilidad Social.

Cuadro 107: Medidas estadísticas de sector, edad y actitud hacia la responsabilidad social

Cuadro 108: Tabla ANOVA sector y edad, factor Actitud hacia la Responsabilidad Social.

Cuadro 109: Tabla de contingencia de realización de acciones de responsabilidad social, sector y edad.

Cuadro 110: Tabla de contingencia de formación en responsabilidad social, sector y edad.

Cuadro 111: Medidas estadísticas de tamaño, edad y actitud hacia la responsabilidad social.

Cuadro 112: Tabla ANOVA tamaño y edad, factor Actitud hacia la Responsabilidad Social.

Cuadro 113: Tabla de contingencia de acciones de responsabilidad social, tamaño y edad.

Cuadro 114: Tabla de contingencia de formación en responsabilidad social, tamaño y edad.

Cuadro 115: Medidas estadísticas de liderazgo, edad y actitud hacia la responsabilidad social..

Cuadro 116: Tabla ANOVA liderazgo y edad, factor Actitud hacia la Responsabilidad Social.

Cuadro 117: Medidas estadísticas de liderazgo, edad y actitud hacia la responsabilidad social.

Cuadro 118: Medidas estadísticas sobre acciones en responsabilidad social, liderazgo y edad.

Cuadro 119: Tabla ANOVA de edad y liderazgo, factor Realización de Acciones de Responsabilidad Social. 
Cuadro 120: Medidas estadísticas sobre formación en responsabilidad social, liderazgo y edad.

Cuadro 121: Tabla ANOVA de la edad y del liderazgo, factor Horas de Formación en Responsabilidad Social.

Cuadro 122: Medidas estadísticas de "valores", edad y actitud hacia la responsabilidad social

Cuadro 123: Tabla ANOVA de edad y "valores", factor Actitud hacia la Responsabilidad Social.

Cuadro 124: Medidas estadísticas de "valores", edad y actitud hacia la responsabilidad social.

Cuadro 125: Medidas estadísticas sobre acciones en responsabilidad social, valores y edad.

Cuadro 126: Tabla ANOVA de edad y valores, factor Realización de Acciones de Responsabilidad Social.

Cuadro 127: Medidas estadísticas sobre formación en responsabilidad social, valores y edad.

Cuadro 128: Tabla ANOVA de edad y valores, factor Horas de Formación en Responsabilidad Social.

Cuadro 129: Medidas estadísticas de sector, tamaño y actitud hacia la responsabilidad social

Cuadro 130: Tabla ANOVA de sector y tamaño, factor Actitud hacia la Responsabilidad Social.

Cuadro 131 Tabla de contingencia de acciones de responsabilidad social, tamaño y sector.

Cuadro 132: Tabla de contingencia de formación en responsabilidad social, tamaño y sector.

Cuadro 133: Tabla ANOVA de sector y liderazgo, factor Actitud hacia la Responsabilidad Social.

Cuadro 134: Medidas estadísticas de liderazgo, sector y actitud hacia la responsabilidad social.

Cuadro 135: Medidas estadísticas de liderazgo, sector y actitud hacia la responsabilidad social.

Cuadro 136: Medidas estadísticas sobre acciones de responsabilidad social, liderazgo y sector.

Cuadro 137: Tabla ANOVA de liderazgo y sector, factor Realización de Acciones de Responsabilidad Social.

Cuadro 138: Medidas estadísticas sobre formación en responsabilidad social, liderazgo y sector.

Cuadro 139: Tabla ANOVA de liderazgo y sector, factor Horas de Formación en Responsabilidad Social.

Cuadro 140: Medidas estadísticas de sector, "valores" y actitud hacia la responsabilidad social.

Cuadro 141: Tabla ANOVA de sector y "valores", factor Actitud hacia la Responsabilidad Social.

Cuadro 142: Medidas estadísticas de sector, "valores" y actitud hacia la responsabilidad social.

Cuadro 143: Tabla ANOVA de "valores" y sector, factor Realización de Acciones de Responsabilidad Social. 
Cuadro 144: Medidas estadísticas sobre acciones de responsabilidad social, "valores" y sector

Cuadro 145: Medidas estadísticas sobre formación en responsabilidad social, "valores" y sector.

Cuadro 146: Tabla ANOVA de "valores" y sector, factor Horas de Formación en Responsabilidad Social.

Cuadro 147: Medidas estadísticas de sector, "valores” y actitud hacia la responsabilidad social.

Cuadro 148: Tabla ANOVA de sector y "valores", factor Actitud hacia la Responsabilidad Social.

Cuadro 149: Medidas estadísticas de sector, "valores” y actitud hacia la responsabilidad social.

Cuadro 150: Medidas estadísticas sobre acciones de responsabilidad social, liderazgo y tamaño.

Cuadro 151: Tabla ANOVA de liderazgo y tamaño, factor Realización de Acciones de Responsabilidad Social.

Cuadro 152: Medidas estadísticas sobre formación en responsabilidad social, liderazgo y tamaño.

Cuadro 153: Tabla ANOVA de liderazgo y tamaño, factor Horas de Formación en Responsabilidad Social.

Cuadro 154: Medidas estadísticas de tamaño, "valores” y actitud hacia la responsabilidad social.

Cuadro 155: Tabla ANOVA de tamaño y "valores", factor Actitud hacia la Responsabilidad Social.

Cuadro 156: Medidas estadísticas de tamaño, "valores" y actitud hacia la responsabilidad social.

Cuadro 157: Medidas estadísticas sobre acciones en responsabilidad social, "valores" y tamaño.

Cuadro 158: Tabla ANOVA de valores y tamaño, factor Realización de Acciones de Responsabilidad Social.

Cuadro 159: Medidas estadísticas sobre formación en responsabilidad social, "valores" y tamaño.

Cuadro 160: Tabla ANOVA de valores y tamaño, factor Horas de Formación en Responsabilidad Social.

Cuadro 161: Medidas estadísticas de liderazgo, "valores” y actitud hacia la responsabilidad social.

Cuadro 162: Tabla ANOVA de liderazgo y "valores", factor Actitud hacia la Responsabilidad Social

Cuadro 163: Tabla ANOVA de "valores" y liderazgo, factor Realización de Acciones de Responsabilidad Social.

Cuadro 164: Medidas estadísticas sobre acciones de responsabilidad social, "valores" y liderazgo

Cuadro 165: Medidas estadísticas sobre formación en responsabilidad social, "valores" y liderazgo.

Cuadro 166: Tabla ANOVA de "valores" y liderazgo, Horas de Formación en Responsabilidad Social.

Cuadro 167: Correlaciones bivariadas entre "valores" personales........

Cuadro 168: $\quad$ Correlaciones bivariadas entre estilos de liderazgo........... 
Cuadro 169: Correlaciones bivariadas entre estilos de liderazgo y flexibilidad.

Cuadro 170: Correlaciones bivariadas entre estilos de liderazgo y efectividad.

Cuadro 171: Correlaciones bivariadas entre flexibilidad y efectividad en el ejercicio del liderazgo

Cuadro 172: Correlaciones bivariadas entre "valores" personales y actitud hacia la responsabilidad social.

Cuadro 173: Correlaciones bivariadas entre estilos de liderazgo y actitud hacia la responsabilidad social.

Cuadro 174: Correlaciones bivariadas entre estilos de liderazgo y "valores" personales.

Cuadro 175: Correlaciones bivariadas entre la actitud hacia la responsabilidad social y los ítems de control sobre la actitud.

Cuadro 176: Correlaciones bivariadas entre la formación en responsabilidad social y las acciones de responsabilidad social.

Cuadro 177: Tabla de contingencia de realización de acciones de responsabilidad social y formación en responsabilidad social.

Cuadro 178: Coeficientes del modelo de regresión entre el estilo directivo y la flexibilidad y efectividad de estilo..

Cuadro 179: Coeficientes del modelo de regresión entre el estilo participativo y la flexibilidad y efectividad de estilo........

Cuadro 180: Coeficientes del modelo de regresión entre la actitud y los valores personales y el estilo de liderazgo.................... 812

Cuadro 181: $\quad$ Relaciones del SPV con otras variables en adultos............. 987

Cuadro 182: $\quad$ Relaciones del SPV con variables aptitudinales................... 987

Cuadro 183: $\quad$ Relaciones del SPV con aptitudes y SIV................................ 988

Cuadro 184: $\quad$ Análisis factoriales de los valores (SPV y SIV)..................... 988

Cuadro 185: $\quad$ Análisis factorial general del SPV.......................................... 989 


\section{ÍNDICE DE FIGURAS}

Figura 1: $\quad$ Un modelo de dos dimensiones de la Responsabilidad Social Corporativa................................................................. 80

Figura 2: $\quad$ How sustainability affects value creation............................. 97

Figura 3: $\quad$ Un marco de trabajo para analizar la Responsabilidad Social Corporativa............................................................... 234

Figura 4: $\quad$ Modelo ASH (Auditoría del Sistema Humano)...................... 256

Figura 5: $\quad$ Modelo AMIGO (Análisis Multifacético para la Intervención y la Gestión Organizacional)............................. $\quad 267$

Figura 6: $\quad$ Estilos de liderazgo (Teoría del Liderazgo Situacional II) 315

Figura 7: $\quad$ Nivel de desarrollo del colaborador (Teoría del Liderazgo Situacional II) ........................................................... 319

Figura 8: $\quad$ Cruce entre el estilo de liderazgo apropiado al nivel de desarrollo del colaborador (Teoría del Liderazgo Situacional II) ............................................................................ 321

Figura 9: $\quad$ Bases de poder descritas para distintos niveles de desarrollo (Teoría del Liderazgo Situacional I).................... 323

Figura 10: $\quad$ Estructura bidimensional subyacente en el SPV................. 431

Figura 11: Características de los líderes más asociadas con una elevada actitud hacia la responsabilidad social................... 


\section{ÍNDICE DE GRÁFICOS}

Gráfico 1: $\quad$ Edad de la muestra.................................................................. 445

Gráfico 2: $\quad$ Tamaño de las empresas de la muestra................................. 447

Gráfico 3: $\quad$ Realización de acciones de responsabilidad social en las empresas de la muestra.

Gráfico 4: $\quad$ Horas dedicadas a la formación en responsabilidad social en las empresas de la muestra.

Gráfico 5: Histograma de las puntuaciones de la actitud hacia la responsabilidad social.

Gráfico 6: $\quad$ Actitud hacia la responsabilidad social y acciones de responsabilidad social

Gráfico 7: Valoración concedida al ítem “Desarrollar políticas de responsabilidad social en mi organización"

Gráfico 8: Histograma de las puntuaciones del "valor" "metas"...... 470

Gráfico 9: Histograma de las puntuaciones del "valor" "variedad"

Gráfico 10: Histograma de las puntuaciones del "valor” “decisión”

Gráfico 11: Histograma de las puntuaciones del "valor” "orden y método".

Gráfico 12: Histograma de las puntuaciones del "valor" "resultados"

Gráfico 13: Histograma de las puntuaciones del "valor" "practicidad".

Gráfico 14: Histograma de las puntuaciones del estilo "delegativo"

Gráfico 15: Selección de estilo primario.

Gráfico 16: Selección de estilo secundario.

Gráfico 17: Histograma de la flexibilidad de estilo.

Gráfico 18: Histograma de la efectividad de estilo.

Gráfico 19: Actitud hacia la responsabilidad social según sexo...........

Gráfico 20: Formación en responsabilidad social según sexo.

Gráfico 21: Actitud hacia la responsabilidad social según edad.

Gráfico 22: Realización de acciones de responsabilidad social y edad

Gráfico 23: $\quad$ Actitud hacia la responsabilidad social y edad..................... 503

Gráfico 24: Formación en responsabilidad social según sector. 506

Gráfico 25: Realización de acciones de responsabilidad social y tamaño.

Gráfico 26: Formación en responsabilidad social según estilo de liderazgo

Gráfico 27: Formación en responsabilidad social según flexibilidad y efectividad de liderazgo. 
Gráfico 28: Realización de acciones de responsabilidad social y

"valores"

Gráfico 29: Edad, sexo y actitud hacia la responsabilidad social........ 544

Gráfico 30: $\quad$ Sexo, edad y acciones de responsabilidad social .............. 548

Gráfico 31: Sexo, edad y formación en responsabilidad social............. 552

Gráfico 32: Sexo, sector y actitud hacia la responsabilidad social...... 556

Gráfico 33: $\quad$ Sexo, sector y acciones de responsabilidad social ............ 560

Gráfico 34: $\quad$ Sexo, sector y formación en responsabilidad social.......... 564

Gráfico 35: Sexo, tamaño y actitud hacia la responsabilidad social... 567

Gráfico 36: $\quad$ Sexo, tamaño y acciones de responsabilidad social.......... 571

Gráfico 37: Sexo, tamaño y formación en responsabilidad social....... 574

Gráfico 38: Sexo, estilos de liderazgo y actitud hacia la responsabilidad social. ............................................................. 579

Gráfico 39: Sexo, flexibilidad, efectividad y actitud hacia la responsabilidad social............................................................. 580

Gráfico 40: Sexo, efectividad, flexibilidad y acciones de responsabilidad social

Gráfico 41: Sexo, estilo de liderazgo y acciones de responsabilidad social

Gráfico 42: $\quad$ Sexo, efectividad, flexibilidad y formación en responsabilidad social

Gráfico 43: Sexo femenino, "valores" y actitud hacia la responsabilidad social

Gráfico 44: Sexo masculino, "valores" y actitud hacia la responsabilidad social

Gráfico 45: Valores y acciones de responsabilidad social en el sexo femenino

Gráfico 46: Valores y acciones de responsabilidad social en el sexo masculino.

Gráfico 47: Valores y formación en responsabilidad social en el sexo femenino.

Gráfico 48: Valores y formación en responsabilidad social en el sexo masculino.

Gráfico 49: Sector, edad y actitud hacia la responsabilidad social.... 614

Gráfico 50: $\quad$ Edad, sector y acciones de responsabilidad social ............ 617

Gráfico 51: $\quad$ Edad, sector y formación en responsabilidad social.......... 621

Gráfico 52: Edad, tamaño, y actitud hacia la responsabilidad social. 624

Gráfico 53: $\quad$ Edad, tamaño y acciones de responsabilidad social.......... 627

Gráfico 54: Edad, tamaño y formación en responsabilidad social....... 631

Gráfico 55: $\quad$ Liderazgo, 20 a 40 años y actitud hacia la responsabilidad social

Gráfico 56: Liderazgo, 41 a 60 años y actitud hacia la responsabilidad social 
Gráfico 57: Liderazgo, 61 años en adelante y actitud hacia la responsabilidad social.

Gráfico 58: Efectividad, flexibilidad, edad y actitud hacia la responsabilidad social.

Gráfico 59: Edad, estilo de liderazgo y acciones de responsabilidad social

Gráfico 60: Edad, efectividad, flexibilidad y acciones de responsabilidad social

Gráfico 61: Edad, efectividad, flexibilidad y formación en responsabilidad social

Gráfico 62: “Valores”, 20 a 40 años y actitud hacia la responsabilidad social

Gráfico 63: "Valores”, 41 a 60 años y actitud hacia la responsabilidad social

Gráfico 64: "Valores”, 61 años en adelante y actitud hacia la responsabilidad social

Gráfico 65: "Valores" y acciones de responsabilidad social en líderes de 20 a 40 años.

Gráfico 66: "Valores” y acciones de responsabilidad social en líderes de 41 a 60 años.

Gráfico 67: "Valores" y acciones de responsabilidad social en líderes de 61 años en adelante.

Gráfico 68: "Valores" y formación en responsabilidad social en líderes de 20 a 40 años.

Gráfico 69: "Valores” y formación en responsabilidad social en líderes de 41 a 60 años.

Gráfico 70: Sector, tamaño y actitud hacia la responsabilidad social

Gráfico 71: Sector y acciones de responsabilidad social.

Gráfico 72: Sector y tamaño.

Gráfico 73: $\quad$ Sector, tamaño y formación en responsabilidad social....

Gráfico 74 Sector servicios, estilos de liderazgo y actitud hacia la responsabilidad social.

Gráfico 75: Sector construcción, estilos de liderazgo y actitud hacia la responsabilidad social.

Gráfico 76: Sector industria, estilos de liderazgo y actitud hacia la responsabilidad social

Gráfico 77: Sector, flexibilidad, efectividad y actitud hacia la responsabilidad social

Gráfico 78: Sector, estilo consultivo, estilo participativo y acciones de responsabilidad social.

Gráfico 79: Sector, efectividad, flexibilidad y acciones de responsabilidad social

Gráfico 80: Sector, estilo consultivo, estilo participativo y formación en responsabilidad social.

Gráfico 81: Efectividad, flexibilidad y formación en responsabilidad social 
Gráfico 82: Sector servicios, "valores” y actitud hacia la responsabilidad social.

Gráfico 83: Sector construcción, "valores" y actitud hacia la responsabilidad social.

Gráfico 84: Sector industria, “valores” y actitud hacia la responsabilidad social

Gráfico 85: "Valores”, sector servicios y acciones de responsabilidad social.

Gráfico 86: "Valores", sector industria y acciones de responsabilidad social

Gráfico 87: “Valores”, sector servicios y acciones de responsabilidad social

Gráfico 88: "Valores", sector industria y acciones de responsabilidad social.

Gráfico 89: Tamaño pequeño, estilos de liderazgo y actitud hacia la responsabilidad social.

Gráfico 90: Tamaño grande, estilos de liderazgo y actitud hacia la responsabilidad social

Gráfico 91: Tamaño, flexibilidad, efectividad y actitud hacia la responsabilidad social

Gráfico 92: Tamaño, estilo consultivo, estilo participativo y acciones de responsabilidad social.

Gráfico 93: Tamaño, efectividad, flexibilidad y acciones de responsabilidad social

Gráfico 94: Tamaño, estilo consultivo, estilo participativo y formación en responsabilidad social.

Gráfico 95: Tamaño, efectividad, flexibilidad y formación en responsabilidad social.

Gráfico 96: Tamaño mediano, "valores" y actitud hacia la responsabilidad social

Gráfico 97: Tamaño grande, “valores” y actitud hacia la responsabilidad social.

Gráfico 98: Tamaño pequeño, "valores” y acciones de responsabilidad social.

Gráfico 99: Tamaño mediano, "valores" y acciones de responsabilidad social.

Gráfico 100: Tamaño grande, “valores” y acciones de responsabilidad social.....

Gráfico 101: Tamaño pequeño, “valores” y formación en responsabilidad social.

Gráfico 102: Tamaño mediano, “valores” y formación en responsabilidad social

Gráfico 103: "Valores” y estilos de liderazgo y actitud hacia la responsabilidad social

Gráfico 104: Flexibilidad, efectividad y actitud hacia la responsabilidad social.

Gráfico 105: “Valores”, estilos de liderazgo y acciones de responsabilidad social. 
Gráfico 106: Flexibilidad, efectividad y acciones de responsabilidad social......

Gráfico 107: “Valores”, estilos de liderazgo y acciones de responsabilidad social

Gráfico 108: Flexibilidad, efectividad y formación en responsabilidad social... 
INTRODUCCIÓN 

El motivo principal que ha impulsado esta investigación ha sido conocer en profundidad algunas de las causas que han motivado que la Responsabilidad Social Corporativa haya estado, en los comienzos del siglo XXI, cada vez más presente en las organizaciones.

El término “Responsabilidad Social Corporativa” (RSC), también llamada "Responsabilidad Social Empresarial” (RSE) (Rodríguez, 2007) y en ocasiones, de forma más escueta, "Responsabilidad Social" (RS), se ha definido como la contribución activa y voluntaria a la mejora social y ambiental por parte de las organizaciones, generalmente con el objetivo de mejorar su situación competitiva y su valoración, a través de un respeto por la ética, las personas, las comunidades y el medio ambiente (Gómez, 2010).

El origen histórico de la Responsabilidad Social Corporativa se ha relacionado con un cambio en la forma de entender la organización. Esta trasformación ha supuesto una mayor preocupación por aspectos que anteriormente han pasado desapercibidos para los responsables empresariales. Por ejemplo se ha producido una mayor concienciación sobre la relevancia que tiene para la organización el establecimiento de relaciones que favorezcan su reputación. Algo que, hace ya bastante tiempo (1759), había sido apuntado por Adam Smith al afirmar que la aprobación social es "el principio rector de la naturaleza humana" (Smith, 1997, 568). 
El cambio de planteamiento que origina la responsabilidad social, también ha motivado la emergencia de un nuevo concepto de organización. Esta ha comenzado a ser entendida como un ente relacional del que solo es posible alcanzar una visión completa si se contemplan, al mismo tiempo, las diferentes relaciones existentes entre sus elementos constitutivos.

En relación con esta corriente han emergido nuevos marcos teóricos, como el que propone el modelo AMIGO (Peiró, 1999a). Este modelo permite profundizar en el análisis de la organización a través del estudio de la compleja interacción de las relaciones entre personas (y grupos) que son miembros de la misma o con los que la propia organización se relaciona.

El liderazgo ha sido ejercido desde que las personas hemos vivido de modo colectivo. Aunque no se ha formulado una definición comúnmente aceptada del concepto de liderazgo, hemos asumido que este emerge como una percepción social desde la confluencia de procesos contextuales y sociales que producen las respuestas cognitivas y afectivas del grupo en el que se enmarca el liderazgo (Lord, Brown y Harvey, 2001).

Para Méndez y Rojas (2009), lo que respalda la conducta de un líder dentro de un grupo es el contexto en el que el liderazgo se desarrolla. Siendo el líder aquel que desempeña un estatus propio, un rol de liderazgo dentro de un ámbito o una función de liderazgo dentro de un perfil. 
Hemos entendido que el éxito de un líder está determinado por la aceptación de sus conductas por parte del colectivo en el que se inscribe su actuación. Esta aceptación parte de un proceso de evaluación que puede realizarse a través del análisis de las actitudes y de los valores que los líderes proyectan en el desarrollo de su rol.

Las actitudes son disposiciones, relativamente estables, de los dinamismos psíquicos en su totalidad hacia un objeto psicosocial cualquiera, sea real o ficticio (Pastor, 1978), mientras los valores son modos deseables de conducta sobre la manera en que un ser humano debería comportarse (Ravlin y Meglino, 1987).

La aceptación de un estilo determinado de liderazgo dentro de un grupo, por tanto, está determinado por su capacidad para impulsar actitudes y valores próximos a las respuestas cognitivas y afectivas que el colectivo espera. $Y$ estas demandas, a su vez, se encuentran establecidas por la influencia del contexto.

En los inicios del siglo XXI se han vivido grandes cambios que, sin duda, han tenido repercusión en la Responsabilidad Social Corporativa y en el liderazgo que las organizaciones desarrollan.

Desde un punto de vista socio-económico, este periodo se ha caracterizado por un alto grado de inestabilidad y complejidad. Este proceso de cambio ha venido definido por la internacionalización y la globalización del mercado, por la continua revolución técnica, por la liberalización de 
determinados sectores, por la fusión entre los competidores, por la pluralidad de la fuerza laboral como consecuencia de los movimientos migratorios y de la incorporación de las mujeres a la vida pública, por los cambios en el entorno familiar (en donde se ha generado una redefinición de los comportamientos estereotipados de hombres y mujeres) y por los nuevos valores de los trabajadores, más centrados en la calidad de vida y la autorrealización que en la seguridad o el bienestar económico propios de la sociedad industrializada (Barberá y Ramos, 2004).

También ha destacado durante este periodo la creciente preocupación por lo medioambiental. En este sentido se ha indicado que a mayor grado de desarrollo económico de un país, más protagonismo parecen adquirir las actitudes pro medioambientales en los ciudadanos (Esteban, 2000).

En este cambio de contexto, las organizaciones altamente jerarquizadas, burocratizadas y con elevada especialización funcional han tenido dificultades para responder a las demandas del mercado. El nuevo escenario ha sido favorable para las organizaciones más flexibles y con menos niveles jerárquicos. Organizaciones en las que las personas han tomado decisiones y han asumido sus responsabilidades implicándose en la consecución de las metas organizacionales (Gracia, Martínez-Tur y Peiró, 2001). 
Algunos de los principios rectores de la Responsabilidad Social Corporativa, como la transparencia, también han favorecido que las organizaciones hayan conquistado este objetivo. Por ejemplo las empresas que han sido consecuentes con sus criterios de decisión no han tenido que preocuparse por invertir esfuerzos en proyectar una imagen corporativa artificial que se adecuara a las expectativas de los consumidores.

La transformación acontecida en los comienzos del siglo XXI ha favorecido la consolidación de una demanda social de organizaciones orientadas hacia la Responsabilidad Social Corporativa. Como consecuencia, estas han buscado líderes estratégicos capaces tanto de crear una visión y unos valores congruentes en todos los niveles de la organización, como de desarrollar relaciones efectivas entre la organización y todos sus grupos de interés (Fry y Cohen, 2008).

Una de las habilidades directivas más demandas en este periodo ha sido la capacidad para fomentar que se asuman las responsabilidades, por parte de los colaboradores de una organización, minimizando las jerarquías (Barberá y Ramos, 2004). Esta destreza se encuentra próxima a otra de las directrices de la responsabilidad social: la aceptación de la responsabilidad por parte de cada actor social en el progreso del contexto donde se enmarca su actuación. Dicha directriz también ha conducido al éxito a líderes políticos. 
Margaret Thatcher ganó tres veces consecutivas las elecciones generales con una propuesta centrada, entre otros factores, en la importancia de la libre elección y en la necesidad de asumir la responsabilidad personal (Crespo, 2009). Su "pragmatismo dio paso al compromiso con unos principios y unos programas. Todo era previsible. Se sabía lo que iba a hacer porque el gobierno había firmado un acuerdo con la ciudadanía para llevar a cabo una política determinada" (Portero, 2006, 1).

Y Obama, en su primera campaña presidencial, además de atraer a sus seguidores con la promesa de cambio (Change) los hizo co-responsables del mismo. Esta implicación se derivó del establecimiento previo de inclinaciones afectivas de simpatía y/o empatía gracias a la identificación de los electores con la historia personal de Obama. Algo que se consiguió a través de un magnífico relato, cuidadosamente dosificado, a lo largo de sus discursos (Ortega y Luque, 2009).

Los investigadores también han indicado que el trato humanizado ha facilitado que las empresas alcancen sus objetivos (Hoyos, Cardona y Correa, 2008).

Este aspecto también se encuentra muy cerca de las directrices que ha promovido la Responsabilidad Social Corporativa. En concreto está muy relacionado con el impulso de una conducta empresarial respetuosa que esté más centrada en las personas y más alejada del pragmatismo tradicional (Méndez y Rojas, 2009). Se ha 
demostrado que los valores de un líder influyen en los procesos cognitivos, afectivos y motivacionales de sus colaboradores. Un guía con actitudes favorables hacia el entorno y preocupado por desarrollar un estilo de liderazgo transformacional es capaz inspirar y motivar a los colaboradores para que: aporten más allá de lo que se les exige y desarrollen comportamientos prosociales fuera del rol que desempeñan (Ng y Burke, 2010).

Tal y como hemos indicado la responsabilidad social no solo se ha caracterizado por impulsar una mayor preocupación de las organizaciones por el progreso social, económico y medioambiental. La Responsabilidad Social Corporativa también se ha constituido en una referencia válida para orientar el camino a la excelencia en el mercado. 

PARTE I:

FUNDAMENTOS TEÓRICOS 



\section{1 - LA RESPONSABILIDAD SOCIAL CORPORATIVA}





\subsection{DELIMITACIÓN CONCEPTUAL DE LA RESPONSABILIDAD SOCIAL CORPORATIVA $^{1}$}

Tal y como indica Vázquez (2006) no se ha formulado una definición o una base comúnmente aceptada sobre la Responsabilidad Social Corporativa.

Desde mediados del siglo XX se han ofrecido muchas definiciones sobre la Responsabilidad Social Corporativa, pero no se ha logrado establecer una concepción del término comúnmente aceptada por tres motivos.

En primera instancia por el carácter intangible de la responsabilidad social. Aspecto que expresa la maleabilidad de la responsabilidad social, ya que según Frankental (2000) se puede asociar a cualquier cosa.

En segundo lugar por el carácter relativo de la responsabilidad social. Muy en relación con este aspecto, Prakash (1975) ha indicado que la Responsabilidad Social Corporativa presenta diferentes acepciones en función del contexto temporal y cultural desde el que se contemple.

\footnotetext{
${ }^{1}$ Algunos autores usan el término Responsabilidad Social Empresarial (Váquez, 2006) en lugar de Responsabilidad Social Corporativa. En el desarrollo de la investigación se ha utilizado el término "Responsabilidad Social Corporativa" para hacer referencia de forma indiferenciada a ambas acepciones.
} 
Un tercer aspecto que explica la dificultad para establecer una concepción de la responsabilidad social es el carácter descriptivo con el que habitualmente se hace referencia a la misma. En este sentido Castillo (1996) ha indicado que las definiciones ofrecidas sobre la Responsabilidad Social Corporativa no poseen la suficiente generalidad y estabilidad como para recoger todas las situaciones posibles.

Para respaldar la adopción de un concepto general de la Responsabilidad Social Corporativa hemos considerado necesario, de modo preliminar, contemplar los diversos enfoques teóricos desde los que se ha intentado explicar la necesidad de responsabilidad social que presentan las empresas.

De los diversos estudios realizados (Wartick y Rude, 1986; Word, 1991; Altman, 1988; Brummer, 1991) sobre las teorías existentes en el ámbito de la Responsabilidad Social Corporativa hemos destacado el desarrollado por Garriga y Melé (2004), que agrupa las propuestas teóricas en cuatro grupos a partir de la relación que establecen la empresa y la sociedad: teorías instrumentales, teorías políticas, teorías integradoras y teorías éticas.

Un primer grupo de teorías son las instrumentales, denominadas de este modo porque entienden que la 
Responsabilidad Social Corporativa es un medio para alcanzar objetivos económicos.

Asumen que la empresa es un instrumento para la creación de valor y esta es su única responsabilidad social. Estas propuestas solo consideran, por tanto, el aspecto económico de las interacciones en las que las empresas intervienen, por lo que solo defienden su participación en aquellas actividades sociales que supongan creación de valor.

De acuerdo con la posición de algunos autores adscritos a esta corriente, la creación de valor puede tener un carácter flexible.

En una posición extrema se encuentra Friedman (1962, 1970), el principal exponente de este enfoque, quien ha indicado que la única responsabilidad social de una empresa, dentro del marco legal y las costumbres éticas de un país, es la maximización de los beneficios para los accionistas (shareholders).

En una posición más permisiva en relación con la maximización del beneficio se sitúan otros autores como Jensen (2000) o Porter y Kramer (2002, 2006). Estos investigadores han indicado que las empresas pueden realizar actividades sociales siempre que supongan ventajas competitivas.

El grupo de teorías políticas ponen especial hincapié en el rol social que las organizaciones poseen. 
Defienden que la empresa es parte de la sociedad y, por tanto, debe aceptar derechos y obligaciones sociales. Autores integrados en este grupo de teorías, como Letza, Sun y Kirkbride (2004), han sostenido que algunas de las obligaciones de la empresa son la equidad, la justicia social y la protección de los trabajadores.

Las teorías integradoras defienden que las exigencias sociales sean parte de la propia actividad de las organizaciones.

Estas propuestas consideran que las demandas sociales deberían integrase en la orientación estratégica de las transacciones porque los negocios dependen de la sociedad en su emergencia, continuidad y crecimiento.

Autores que han desarrollado sus teorías dentro de este enfoque, como Maignan (2001), Simpson y Kohers, (2002) o Garrigues y Trulleque (2008), han indicado que esta dinámica de actuación es muy favorable para las empresas. Cuando estas atienden las necesidades de sus grupos de interés (stakeholders) consolidan su posición en el mercado y generan mayores beneficios.

Las teorías éticas sostienen que las empresas deberían aceptar responsabilidades sociales, como una obligación ética, por encima de cualquier otra consideración.

Estas propuestas defienden que la relación entre la sociedad y los negocios arraiga en los valores éticos, tal y como han defendido Evan y Freeman (1988). 
Como hemos indicado, para tres de los cuatro grupos de teorías expuestas la responsabilidad social es una exigencia a las organizaciones de intensidad variable (teorías políticas, integradoras y éticas). Para las teorías instrumentales la Responsabilidad Social Corporativa es algo que la empresa debe descartar si no se traduce, al menos, en una ventaja competitiva.

\subsubsection{Concepto de Responsabilidad Social Corporativa}

En el corpus sobre Responsabilidad Social Corporativa se han encontrado definiciones que hacen referencia a uno o a varios de los enfoques teóricos que hemos indicado. Se han indicado algunas de las concepciones recabadas más representativas en relación con su proximidad a los enfoques indicados para agrupar las propuestas teóricas sobre responsabilidad social: instrumental, político, integrador y ético.

En relación con el enfoque instrumental, que concibe que la única responsabilidad social de la empresa es la creación de valor, algunos expertos como Hernández (2011) han definido la Responsabilidad Social Corporativa como parte de la respuesta que las empresas ofrecen para obtener el favor de la administración y evitar el conflicto de intereses entre lo público y lo privado. 
Esta definición representa el nivel mínimo de responsabilidad social que se exige habitualmente a las organizaciones.

En relación con el enfoque político, centrado en el rol social que poseen las organizaciones, la literatura ha ofrecido varias acepciones de la Responsabilidad Social Corporativa próximas a este planteamiento.

Una de ellas es la concepción propuesta por el Libro Verde, publicado por la Comisión de las Comunidades Europeas (2001), en el que se ofrecen dos acepciones de la responsabilidad social. Por una parte se indica que "es, esencialmente, un concepto con arreglo al cual las empresas deciden voluntariamente contribuir al logro de una sociedad mejor y un medio ambiente más limpio" ( $p$. 4). También se define como "la integración voluntaria, por parte de las empresas, de las preocupaciones sociales y medioambientales en sus operaciones comerciales y sus relaciones con sus interlocutores" (p. 7).

Otra propuesta es la que sostiene que la Responsabilidad Social Corporativa significa asumir la esencia social de las organizaciones empresariales como conjunto de personas que interactúan en el marco de la sociedad (Lizcano, 2002), tanto desde el punto de vista de su propia composición elemental como desde la óptica de miembro integrante de un sistema social.

También hemos destacado la propuesta del Consejo Empresarial Mundial para el desarrollo sostenible o World 
Business Council on Sustainable Development (WBCSD), que también presenta rasgos del enfoque ético. Define la Responsabilidad Social Corporativa como "el compromiso continuo por parte de las empresas a comportarse de forma ética y contribuir al desarrollo económico sostenible, al tiempo que se mejora la calidad de vida de los trabajadores y sus familias así como de la comunidad local y la sociedad en general" (World Business Council on Sustainable Development, 2002).

En relación con el enfoque integrador, que exige que las empresas incorporen la Responsabilidad Social Corporativa como parte de su actividad, también se han encontrado propuestas teóricas.

Hemos destacado, aunque también hace referencia al enfoque ético, la sostenida por el grupo de organizaciones del ámbito de los consumidores, ONGs y economía social, representados en el Foro de Expertos de Responsabilidad Social Corporativa del Ministerio de Trabajo y Asuntos Sociales (MTAS).

Este foro sostiene que la Responsabilidad Social Corporativa “es, además del cumplimiento estricto de las obligaciones legales vigentes, la integración voluntaria en su gobierno y gestión, en su estrategia, políticas y procedimientos, de las preocupaciones sociales, laborales, medio ambientales y de respeto a los derechos humanos que surgen de la relación y el diálogo transparentes con sus grupos de interés, responsabilizándose así de las 
consecuencias y los impactos que derivan de sus acciones" (Foro de Expertos sobre RSE, 2007, 7).

Debido a su capacidad para integrar, de acuerdo a nuestro juicio, los aspectos más esenciales de la responsabilidad social, sus rasgos integrador y ético, esta es la definición que se ha adoptado como referencia en la investigación.

El enfoque ético, que hace alusión a la importancia de que las empresas acepten las responsabilidades sociales como una obligación ética, también ha estado presente en las definiciones revisadas en el corpus.

Una primera definición que hemos destacado, por su fuerza sintética para integrar la esencia de este enfoque, es la que concibe la Responsabilidad Social Corporativa como "el ejercicio ético de la competitividad" (Guédez, 2006, 83).

También se han incluido en esta orientación los principios en los que se basa el Pacto Mundial de Naciones Unidas o Global Compact, ya que concretan el enfoque ético que demanda la responsabilidad social.

Esta iniciativa internacional ha desarrollado 10 principios universalmente aceptados en las actividades y la estrategia de negocio de las empresas. Estos principios se integran a las áreas de derechos humanos, normas laborales, medio ambiente y lucha contra la corrupción. Los 10 principios son (Naciones Unidas, 2013): 
1. Las empresas deben apoyar y respetar la protección de los derechos humanos fundamentales, reconocidos internacionalmente, dentro de su ámbito de influencia.

2. Las empresas deben asegurarse de no ser cómplices en la vulneración de los derechos humanos.

3. Las empresas deben apoyar la libertad de asociación y el reconocimiento efectivo del derecho a la negociación colectiva.

4. Las empresas deben apoyar la eliminación de toda forma de trabajo forzoso o realizado bajo coacción.

5. Las empresas deben apoyar la erradicación del trabajo infantil.

6. Las empresas deben apoyar la abolición de las prácticas de discriminación en el empleo y la ocupación.

7. Las empresas deben mantener un enfoque preventivo que favorezca el medio ambiente.

8. Las empresas deben fomentar las iniciativas que promuevan una mayor responsabilidad ambiental.

9. Las empresas deben favorecer el desarrollo y la difusión de las tecnologías respetuosas con el medio ambiente. 
10. Las empresas deben trabajar contra la corrupción en todas sus formas, incluidas la extorsión y el soborno.

\subsubsection{Rasgos asociados al concepto de Responsabilidad Social Corporativa}

Hemos indicado a continuación algunas de las características más destacables de la responsabilidad social:

1. Representa una disposición. El término responsabilidad procede de responder, de la “capacidad de dar respuesta por lo que se hace o se deja de hacer, así como por las correspondientes consecuencias de lo que se hizo o no se hizo" (Guédez, 2006, 86). Es un término que, por tanto, hace referencia a la disposición de una organización en relación con el hecho de asumir una postura responsable respecto a algo.

Este carácter actitudinal se manifiesta tanto en la toma de conciencia sobre el impacto de las acciones, como en la expresión del compromiso respecto a diversas cuestiones (Lizcano, 2002).

Un ejemplo de esta disposición y de su materialización ha sido representado por Iberdrola en el 2012. Esta empresa ha perseguido mejorar la responsabilidad corporativa en su cadena de valor para lo que ha desarrollado medidas como la 
medición de gases de efecto invernadero en proveedores o el impulso de las compras de suministro a proveedores locales, que ha alcanzado el 90\% (Iberdrola, 2013).

2. Es voluntaria. Esta aspecto ha sido indicado tanto por organismos internacionales con relevancia en materia de responsabilidad social, como la Organización de Naciones Unidas (ONU) o la Organización para la Cooperación y el Desarrollo Económico (OCDE), como por expertos en el campo (Server y Villalonga, 2005).

De todos modos es importante tener presente, en relación con este rasgo, que el carácter voluntario de responsabilidad social también puede limitar sus posibilidades de éxito. De acuerdo con Guédez (2006) es imprescindible disponer de un control externo que permita garantizar que la implantación de la responsabilidad social en las empresas sea efectiva.

3. Es la expresión de un posicionamiento ético en el mundo empresarial. Muchos expertos, como Vargas y Vaca (2005) o Garrigues y Trullenque (2008), han indicado que la Responsabilidad Social Corporativa está íntimamente ligada a la ética empresarial, pues responsabilidad social y ética son dos términos intrínsecos. 
En este sentido, en el corpus científico se ha destacado la dificultad de pensar en una actuación ética que no contemple gran parte de las directrices que guían un comportamiento empresarial socialmente responsable.

4. Representa una vía a la sostenibilidad. Para autores como Vázquez (2006), la sostenibilidad es el objetivo perfectamente definido que tiene la Responsabilidad Social Corporativa.

Algunos de los textos de referencia en el ámbito de la responsabilidad social, como el Libro Verde (Comisión de las Comunidades Europeas, 2001) o el Pacto Mundial (Naciones Unidas, 2013), representan, en sí mismos, una guía para las organizaciones que están preocupadas por la sostenibilidad.

En algunos de los autores que se han revisado resulta muy común identificar la persecución del equilibrio económico, social y medioambiental, que es una forma de entender la sostenibilidad, como objeto de la Responsabilidad Social Corporativa (Mozas y Puentes, 2010). Esta aspiración representa un triple ámbito de preocupación empresarial en el que canalizar la búsqueda de la sostenibilidad: económico, social y medioambiental (Puentes y Velasco, 2009). 
Peloza y Shang (2011) han realizado una extensa revisión de la literatura internacional sobre las actividades de responsabilidad social realizadas por las organizaciones. En dicha investigación se ha constatado que dentro de los tres ámbitos de actuación de la responsabilidad social corporativa, hay uno que recibe un especial protagonismo: el ámbito social.

A continuación hemos incorporado el cuadro 1 sobre las acciones más impulsadas en el ámbito de la Responsabilidad Social Corporativa, de acuerdo a la investigación mencionada, en la que se constatan las apreciaciones indicadas:

\begin{tabular}{|c|}
\hline $\begin{array}{c}\text { Actividades más realizadas en el ámbito } \\
\text { de la Responsabilidad Social Corporativa }\end{array}$ \\
\hline Marketing relacionado con causa \\
\hline Donaciones \\
\hline Apoyo a la caridad \\
\hline Implicación en la comunidad \\
\hline Voluntarismo de los empleados \\
\hline Promoción de una causa social \\
\hline Donación de productos \\
\hline Cesión de derechos \\
\hline Esponsorización \\
\hline Donaciones de clientes \\
\hline
\end{tabular}

Cuadro 1: Actividades más realizadas en el ámbito de la Responsabilidad Social Corporativa. Fuente: Peloza y Shang (2011). 
5. Está limitada por la naturaleza que enmarca su actividad. La responsabilidad social no puede, por sí sola, provocar los cambios necesarios en los principales elementos del sistema capitalista para evitar aspectos como el desempleo, la pobreza o la exclusión social, debido al carácter consumista del modelo vigente (Romero, 2010). Este capitalismo permite que se produzcan bienes y servicios nocivos para las personas y la sociedad, como las armas o el tabaco, porque generan beneficios, poder $y$ empleo. Aunque también posibilita que la responsabilidad sea un estímulo para impulsar dichos cambios.

Una de las empresas cuyas acciones en materia de responsabilidad social han sido más valoradas en la segunda década del siglo XXI en España, como es el caso de Mercadona, ha centrado sus esfuerzos en el ámbito de la Responsabilidad Social Corporativa en aspectos próximos a su cadena de valor. Por ejemplo ha impulsado la sostenibilidad, entre otras acciones, a través del desarrollo de una cadena agroalimentaria sostenible con sus proveedores (Mercadona, 2012).

Se ha incorporado cuadro 2, "Principales modos de actuación empresarial en materia de responsabilidad social", con algunos de los comportamientos organizacionales más destacados 
en el ámbito de la Responsabilidad Social Corporativa:

\begin{tabular}{|l|l|}
\hline \multicolumn{2}{|c|}{$\begin{array}{c}\text { Principales modos de actuación empresarial } \\
\text { en materia de responsabilidad social }\end{array}$} \\
\hline \multicolumn{1}{|c|}{ Tipos de acciones } & $\begin{array}{c}\text { Ámbito } \\
\text { específico }\end{array}$ \\
\hline Donaciones económicas o de bienes. & Filantropía \\
\hline $\begin{array}{l}\text { Tiempo de las personas que integran la } \\
\text { organización. }\end{array}$ & $\begin{array}{c}\text { Voluntariado } \\
\text { empresarial }\end{array}$ \\
\hline $\begin{array}{l}\text { Impulso de actividades culturales o científicas. } \\
\text { social, económico o medioambiental de la } \\
\text { comunidad o de la sociedad }\end{array}$ & Mecenazgo \\
\hline $\begin{array}{l}\text { Puesta en marca de actividades que favorezcan el } \\
\text { desarrollo de la comunidad o de la sociedad. }\end{array}$ & Marketing social \\
o con causa
\end{tabular}

Cuadro 2: Principales modos de actuación empresarial en materia de responsabilidad social. Fuente: elaboración propia.

6. Es un sistema de gestión. Hemos apoyado esta apreciación en algunas consideraciones.

Por una parte en el hecho de que las Naciones Unidas den a la Responsabilidad Social Corporativa el carácter de "pacto mundial", ya que constituye un reconocimiento a su concepción como un sistema de gestión (Romero, 2010).

Por otra a la existencia de una corriente teórica en la comprensión de la responsabilidad social que defiende que esta debe integrase en los ámbitos de 
gestión de la empresa, ya se trate de cualquier aspecto relacionado con la gestión diaria de la empresa (Server y Capó, 2009), o de cualquier planteamiento de tipo estratégico que afecte a la toma de decisiones y a las operaciones de toda la organización (AECA, 2003).

Además también hemos considerado que la concepción de la responsabilidad social como un sistema de gestión, se ve reforzada por la visión pluralista desde la que es concebida la Responsabilidad Social Corporativa. En este sentido la responsabilidad social ha supuesto una modificación de la tradicional concepción monista de los administradores, exclusivamente dirigida a la obtención del máximo valor para los accionistas (Vázquez, 2006). Como consecuencia, las empresas más afines a la responsabilidad social han modificado su visión de algunos de los aspectos clave del sistema de gestión (De Lara, 2003) que indicamos a continuación en el cuadro 3 "Diferencias entre empresas socialmente responsables y empresas socialmente no responsables": 


\begin{tabular}{|l|l|l|}
\hline \multicolumn{1}{|c|}{ Ámbitos } & \multicolumn{1}{|c|}{$\begin{array}{c}\text { Empresas sin } \\
\text { responsabilidad social }\end{array}$} & \multicolumn{1}{c|}{$\begin{array}{c}\text { Empresas con } \\
\text { responsabilidad social }\end{array}$} \\
\hline $\begin{array}{l}\text { Finalidad de la } \\
\text { empresa }\end{array}$ & $\begin{array}{l}\text { Simple obtención de bienes y } \\
\text { servicios. }\end{array}$ & $\begin{array}{l}\text { Obtención de bienes y } \\
\text { servicios considerando cómo } \\
\text { y a qué precio social. }\end{array}$ \\
\hline $\begin{array}{l}\text { Recursos } \\
\text { productivos }\end{array}$ & $\begin{array}{l}\text { Los recursos existen para ser } \\
\text { usados. }\end{array}$ & $\begin{array}{l}\text { Los recursos son limitados y } \\
\text { hay que conservarlos. }\end{array}$ \\
\hline Decisiones internas & $\begin{array}{l}\text { La Dirección es el único } \\
\text { decisor. }\end{array}$ & $\begin{array}{l}\text { Todo integrante de la } \\
\text { organización puede } \\
\text { colaborar. }\end{array}$ \\
\hline $\begin{array}{l}\text { Decisiones } \\
\text { externas }\end{array}$ & $\begin{array}{l}\text { El mercado es el único que } \\
\text { puede imponer su ley a la } \\
\text { empresa. }\end{array}$ & $\begin{array}{l}\text { Cualquier afectado por las } \\
\text { acciones de la empresa } \\
\text { debe influenciarla. }\end{array}$ \\
\hline Objetivos & $\begin{array}{l}\text { Maximizar el beneficio o } \\
\text { valor actual de la empresa. }\end{array}$ & $\begin{array}{l}\text { Varios objetivos, no siempre } \\
\text { conciliables ni meramente } \\
\text { económicos. }\end{array}$ \\
\hline
\end{tabular}

Cuadro 3: Diferencias entre empresas socialmente responsables y empresas socialmente no responsables. Fuente: De Lara (2003).

En el mercado se han desarrollado proyectos empresariales que han llegado a articular su estrategia de negocio a partir de su concepción de la responsabilidad social. Es el caso de entidades bancarias como Triodos Bank, que "financia empresas, entidades y proyectos que aportan un valor añadido en el campo social, medioambiental y cultural, gracias al apoyo de ahorradores e inversores que optan por el impulso de empresas socialmente responsables y por la construcción de una sociedad más humana y sostenible" (Triodos, 1980).

7. Exige cumplir con la legislación a nivel nacional e internacional (Mozas y Puentes, 2010). Esta exigencia ha sido matizada por los expertos al 
considerar que este es el suelo mínimo de la Responsabilidad Social Corporativa de una organización (Vázquez, 2006).

Algunas empresas con políticas de responsabilidad social muy reconocidas, como CaixaBank, incluyen en su código ético el respeto de las leyes como máxima: "el respecto de las leyes y otras normas vigentes en cada momento debe ser un principio rector de todos los que integran CaixaBank" (2011, $5)$.

Este suelo mínimo plantea un problema cuando las empresas operan en zonas francas carentes de cualquier legislación. También en el caso de las organizaciones que desarrollan su actividad en países que tienen una normativa laxa en el ámbito social y/o medioambiental, o no cuentan con los suficientes mecanismos de control y supervisión para hacer cumplir la legislación vigente.

En estrecha relación con este rasgo, algunos autores han indicado que la responsabilidad social es flexible porque debe permitir que la empresa decida su grado de implicación en materia de responsabilidad social sin que represente una carga excesivamente onerosa (Guédez, 2006).

8. Persigue la satisfacción equilibrada de las necesidades de los grupos de interés (Mozas y Puentes, 2010). 
La relevancia de este aspecto ha sido destacada en algunos de los textos de referencia sobre responsabilidad social. Hemos incorporado el cuadro 4 para hacer alusión a algunas de las indicaciones más específicas sobre los stakeholders que aparecen en los textos de referencia europeos:

\begin{tabular}{|c|c|}
\hline $\begin{array}{l}\text { La interacción con los stakeholders es un aspecto } \\
\text { crucial de la Responsabilidad Social Corporativa. } \\
\text { Por tanto, una política efectiva de responsabilidad } \\
\text { social requiere diálogo con: } \\
\text { sindicatos, } \\
\text { autoridades públicas, } \\
\text { organizaciones no gubernamentales (ONG's), } \\
\text { y organizaciones empresariales. }\end{array}$ & $\begin{array}{l}\text { Informe de } \\
\text { Competitividad } \\
\text { Europea de } 2008 \\
\text { (Comisión de las } \\
\text { Comunidades Europeas, } \\
\text { 2008). }\end{array}$ \\
\hline $\begin{array}{l}\text { La Responsabilidad Social Corporativa hace } \\
\text { referencia a: } \\
\text { la consideración de gestionar adecuadamente } \\
\text { a las personas que integran las } \\
\text { organizaciones, } \\
\text { a cuidar la salud y seguridad de las personas } \\
\text { en el lugar de trabajo, } \\
\text { y a adaptarse al cambio, considerando los } \\
\text { intereses y preocupaciones de todos los } \\
\text { afectados por los cambios y las decisiones } \\
\text { que se adopten. }\end{array}$ & $\begin{array}{c}\text { Libro Verde } \\
\text { (Comisión de las } \\
\text { Comunidades Europeas, } \\
\text { 2001). }\end{array}$ \\
\hline $\begin{array}{l}\text { Es necesario mantener los criterios de } \\
\text { responsabilidad social en las relaciones que las } \\
\text { organizaciones establecen con: } \\
\text { socios comerciales, } \\
\text { proveedores, } \\
\text { y consumidores. }\end{array}$ & $\begin{array}{c}\text { Libro Verde } \\
\text { (Comisión de las } \\
\text { Comunidades Europeas, } \\
\text { 2001). }\end{array}$ \\
\hline
\end{tabular}

Cuadro 4: Algunas indicaciones en textos de referencia sobre la importancia de la atención a los grupos de interés. Fuente: elaboración propia.

La preocupación por los grupos de interés responde a una visión integral de la Responsabilidad Social Corporativa en la que la empresa debe contemplar 
todas las relaciones con sus grupos de interés (Guédez, 2006).

Algunos autores (Romero, 2010) han indicado que esta visión integral implica una concepción de la empresa responsable holística y sistémica, que es asimismo necesaria para que una organización mejore su posición en el mercado.

En este sentido es misión de los líderes empresariales explotar activamente sus relaciones con todas las partes interesadas, con el fin de desarrollar las mejores estrategias de negocio (Freeman y McVea, 2001).

Además de su influencia en la actuación de los líderes, los stakeholders también tienen un peso importante en el desarrollo de acciones responsables desde las organizaciones. La Responsabilidad Social Corporativa únicamente puede ser asumida por las empresas, pero las demás partes interesadas, especialmente los trabajadores, los consumidores y los inversores, también pueden desempeñar un papel fundamental fomentando en las organizaciones el desarrollo de prácticas socialmente responsables (Server y Villalonga, 2005).

Algunas empresas han impulsado el área de comunicación para atender las necesidades de sus grupos de interés. Por ejemplo el Grupo Daorje 
reforzó, en el 2012, el uso de canales específicos para responder a las necesidades en materia de responsabilidad social de sus colaboradores, proveedores, clientes, accionistas y de la sociedad en general (Grupo Daorje, 2013).

\subsubsection{Otros conceptos cercanos a la Responsabilidad Social Corporativa}

\begin{tabular}{|c|c|}
\hline Concepto & Comentarios \\
\hline $\begin{array}{l}\text { Desarrollo } \\
\text { sostenible }\end{array}$ & $\begin{array}{l}\text { Definido por primera vez en el informe "Nuestro futuro común" } \\
\text { o "Informe Brundtland" (Naciones Unidas, 1987, 23). } \\
\text { - Hace referencia al desarrollo que "satisface las necesidades de } \\
\text { las generaciones presentes sin comprometer las posibilidades } \\
\text { de las del futuro para atender sus propias necesidades" } \\
\text { (Naciones Unidas, 1987, 23). }\end{array}$ \\
\hline Sostenibilidad & $\begin{array}{l}\text { Definida por la Asociación Española de Contabilidad y } \\
\text { Administración de Empresas como "la expresión del impacto } \\
\text { de la actividad de la empresa en la triple dimensión económica, } \\
\text { social y medioambiental" (AECA, 2003, 10). } \\
\text { - También se puede concebir como la "capacidad o cualidad } \\
\text { para alcanzar el desarrollo sostenible" (AECA, 2003, 10). }\end{array}$ \\
\hline $\begin{array}{l}\text { Triple cuenta de } \\
\text { resultados o } \\
\text { Triple Bottom } \\
\quad \text { Line }\end{array}$ & $\begin{array}{l}\text { "Representa en términos cuantitativos el valor económico, el } \\
\text { valor para el desarrollo social o para el medio ambiente que } \\
\text { las empresas crean o destruyen". Por tanto, refleja: } \\
\text { - la importancia de considerar las consecuencias } \\
\text { económicas de sus decisiones, } \\
\text { - pero también medioambientales y sociales (AECA, 2003, } \\
\text { 10). }\end{array}$ \\
\hline Acción social & $\begin{array}{l}\text { "Ayuda voluntaria, expresada en recursos económicos o de } \\
\text { otro tipo, otorgada por las empresas a proyectos externos de } \\
\text { carácter filantrópico y desarrollo socioeconómico (asistencia } \\
\text { social, salud, educación, etc.)" (AECA, 2003, 9-10). }\end{array}$ \\
\hline
\end{tabular}




\begin{tabular}{|c|c|}
\hline $\begin{array}{c}\text { Inversión } \\
\text { socialmente } \\
\text { responsable } \\
\text { (ISR) }\end{array}$ & $\begin{array}{l}\text { Incorporación de criterios ASG (criterios ambientales, sociales } \\
\text { y de gobierno corporativo) a las inversiones financieras. } \\
\text { En ocasiones se utiliza la expresión "índice ético" o "índice } \\
\text { social" para hacer referencia a índices bursátiles a los que se } \\
\text { les ha aplicado un filtro ético (Cuestas y Valor, 2003). } \\
\text { - Son índices de empresas en las que se han evaluado diversos } \\
\text { aspectos, como su excelencia en la gestión medioambiental, } \\
\text { sus relaciones laborales o el impacto de sus operaciones en } \\
\text { terceros países (Cuestas y Valor, 2003). }\end{array}$ \\
\hline $\begin{array}{l}\text { Reputación } \\
\text { corporativa }\end{array}$ & $\begin{array}{l}\text { Reconocimiento público alcanzado por la organización y que } \\
\text { es expresión, en cierta medida, de legitimidad social (AECA, } \\
\text { 2003, 10). } \\
\text { En relación con este término es necesario hacer referencia a la } \\
\text { evolución del rol desempeñado por la "marca", que no solo } \\
\text { identifica productos y servicios sino que tiene una gran } \\
\text { influencia en la percepción que el público se construye de una } \\
\text { organización. De acuerdo con Pringue y Thompson (1999, 60- } \\
\text { 82) las marcas: } \\
\text { - han tenido, inicialmente, un enfoque racional, } \\
\text { - posteriormente una orientación emocional, } \\
\text { - y finalmente una perspectiva espiritual y ética, basada en } \\
\text { creencias y valores que se añaden a la marca como } \\
\text { reflejo de la Responsabilidad Social Corporativa de las } \\
\text { organizaciones. }\end{array}$ \\
\hline Filantropía & $\begin{array}{l}\text { Para autores como Bloom (1993, 8-18) es un concepto } \\
\text { relacionado con el marketing con causa porque supone la } \\
\text { contribución de una empresa a una causa social. De todos } \\
\text { modos distingue entre: } \\
\text { - la donación de una cantidad de dinero con porcentaje } \\
\text { sobre las ventas, que supone el marketing con causa, } \\
\text { - de la contribución en dinero o especie a una causa } \\
\text { benéfica, que es lo que define el término filantropía. } \\
\text { Otros expertos (Recio y Ortiz, 2000, 26) consideran que la gran } \\
\text { diferencia entre ambos términos radica en que la filantropía } \\
\text { hace referencia a "una manifestación altruista posiblemente } \\
\text { consecuencia de las convicciones de los directivos de la } \\
\text { empresa". } \\
\text { Para la Asociación Española de Contabilidad y Administración } \\
\text { de Empresas la filantropía es la "acción social de la empresa } \\
\text { formulada e implantada sobre la base de un planteamiento } \\
\text { estratégico de negocio, asociando la acción filantrópica a unos } \\
\text { beneficios determinados en términos económicos y de ventaja } \\
\text { competitiva" (AECA, 2003, 10). } \\
\text { Como sinónimo del término filantropía es frecuente la } \\
\text { utilización del término "mecenazgo", aunque en este caso } \\
\text { haciendo referencia a la filantropía que tiene un marcado } \\
\text { carácter cultural. }\end{array}$ \\
\hline
\end{tabular}




\begin{tabular}{|c|c|}
\hline \multirow{1}{*}{$\begin{array}{c}\text { Gestión } \\
\text { medioambiental }\end{array}$} & "Gestión orientada a la prevención, reducción, minimización y \\
eliminación del impacto medioambiental negativo que \\
ocasiona o puede ocasionar la actividad de la empresa" \\
(AECA, 2003, 9-10). \\
\hline La concepción más aceptada es "el diseño, implementación y \\
control de programas pensados para influir en la aceptación de \\
ideas sociales, implicando consideraciones de planificación de \\
productos, precio, comunicación, distribución e investigación \\
de marketing" (Kotler y Zaltman, 1971, 3-12). \\
Algunos expertos han realizado puntualizaciones en este \\
concepto al diferenciar otros términos más específicos que \\
entiende que ya están incluidos en la definición anterior: \\
- Marketing con causa: (cause-related marketing o cause \\
marketing): "esfuerzos de una empresa por aumentar sus \\
propias ventas, contribuyendo a los objetivos de una o \\
más organizaciones no lucrativas" (Kotler y Andreasen, \\
1996, 304-305). \\
- Marketing social corporativo: "estrategia guiada por el \\
compromiso de determinadas causas sociales tras la que \\
subyacen valores y preocupaciones de los consumidores \\
con el objetivo de que estos se impliquen y sean \\
partícipes de un comportamiento de interés social y, \\
adicionalmente, descubran factores diferenciales en la \\
oferta de la empresa que mejoren su posición en el \\
mercado y su imagen" (García, Gibaja y Mujika, 2001, 27- \\
29).
\end{tabular}




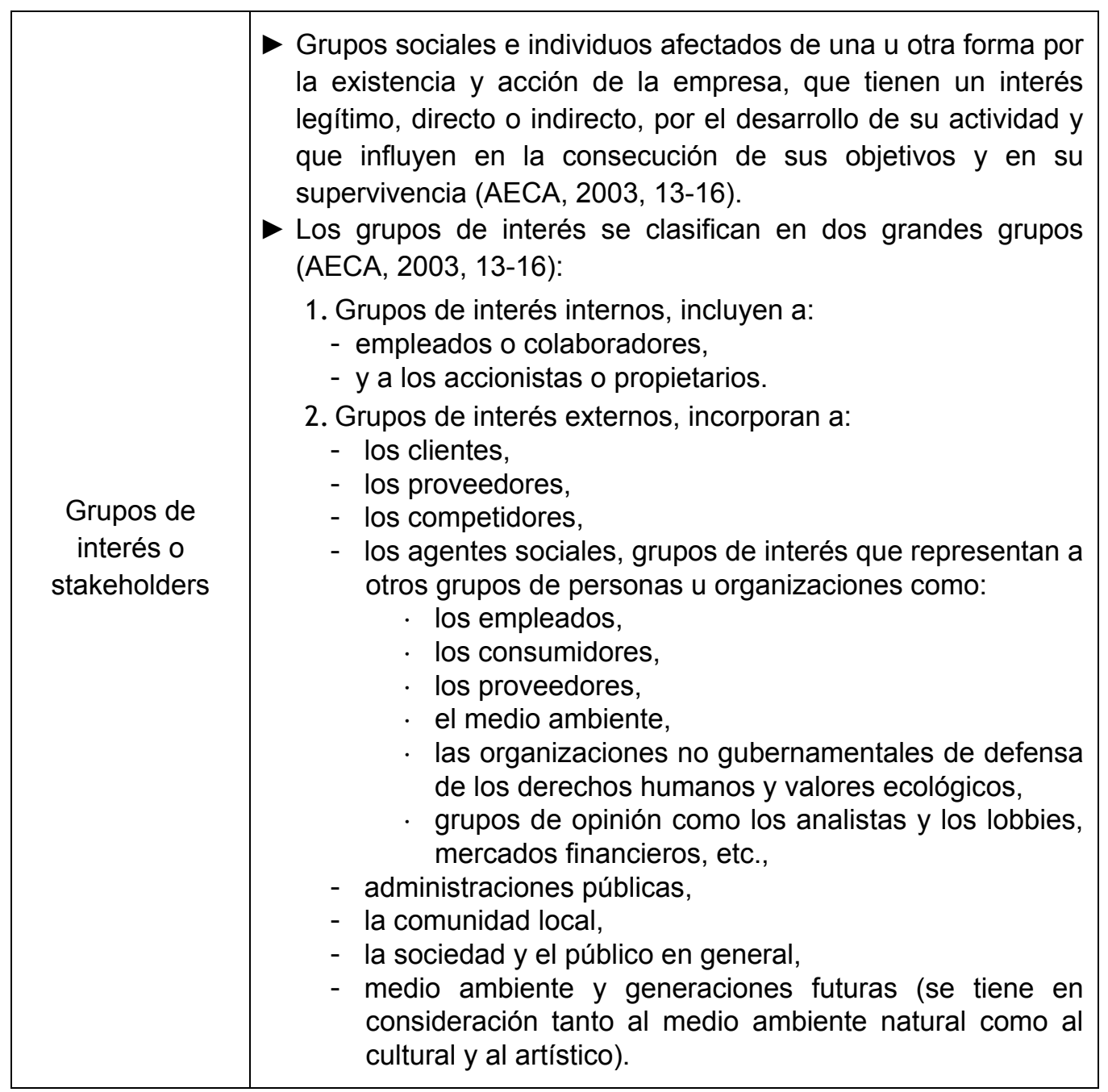

Cuadro 5: Otros conceptos cercanos a la Responsabilidad Social Corporativa. Fuente: elaboración propia. 


\subsection{HISTORIA DE LA RESPONSABILIDAD SOCIAL CORPORATIVA}

\subsubsection{Origen de la Responsabilidad Social Corporativa}

No existe consenso en los expertos a la hora de fijar el inicio de la Responsabilidad Social Corporativa. Algunos autores han indicado, incluso, que resulta complicado establecer un origen exacto (Server y Villalonga, 2005).

De la revisión del corpus científico sobre responsabilidad social hemos destacado tres momentos que hacen referencia al posible origen de la Responsabilidad Social Corporativa: el contexto mercantil norteamericano de finales del s. XVIII y principios del XIX, la publicación de la obra The Philosophy of management (1923) y la mitad del siglo $\mathrm{XX}$.

Para algunos autores la Responsabilidad Social Corporativa surge como práctica empresarial en el contexto mercantil norteamericano de finales del siglo XVIII y principios del siglo XIX.

En este marco la propiedad de las empresas estaba vinculada a su gestión, de forma que los empresarios tenían una responsabilidad jurídica ilimitada ante el capital 
aportado. Sin embargo, eran básicamente irresponsables ante la sociedad por las consecuencias de sus actos.

Una de las grandes excepciones fue Robert Owen. Entre 1797 y 1814 desempeñó el cargo de gerente de la fábrica textil más grande de Gran Bretaña, en New Larnark, integrada por 2000 trabajadores de los cuales una cuarta parte eran menores de edad que habían empezado a trabajar con 5 o 6 años. A la vista de los mortíferos efectos que tenía la producción en las fábricas sobre los trabajadores, desarrolló políticas de responsabilidad social.

Tras conseguir deshacerse de algunos socios y dar entrada a otros más reformadores, desarrolló una serie de medidas como: erradicar el trabajo de los menores de 10 años, reducir la duración de la jornada de los adultos a 10 horas y media (frente a las 13 o 14 de la competencia), elevar los salarios, crear un seguro de desempleo, construir viviendas higiénicas para los trabajadores, ofrecerles atención médica e invertir en infraestructuras básicas y en una escuela de educación infantil y primaria (Domínguez, 2008).

El efecto fue un aumento de los beneficios para la empresa (50\% anual) y para la comunidad.

Otros autores consideran que el planteamiento de Owen, socialista utópico que defendía la posibilidad de desarrollar un sistema económico alternativo al capitalismo, estaba demasiado centrado en el ámbito de la economía social y carecía, por tanto, de una perspectiva económica 
más amplia desde la que es necesario contemplar el origen de la responsabilidad social (Carrasco, 2007).

Otra posible gestación de la Responsabilidad Social Corporativa se encuentra en los años 20 del siglo XX, concretamente a partir de la publicación de la obra de Sheldon The philosophy of management en 1923.

En dicho manuscrito se pone de manifiesto que las responsabilidades básicas de la gestión empresarial son sociales.

Además Sheldon hizo hincapié en la importancia de la ética, estableciendo que los gerentes deben tratar a los colaboradores con justicia y honestidad.

En relación con el otro posible origen de la responsabilidad social, es necesario prestar una especial atención a los años $\mathbf{5 0}$ del siglo XX. Es en este momento cuando se empieza a reconocer en el mercado norteamericano, por primera vez en la historia, que las empresas no solo son responsables de producir bienes y servicios. También son responsables de los riesgos sanitarios de sus trabajadores y de la contaminación que generan (Server y Villalonga, 2005).

Hemos destacado dos hechos concretos de mediados del siglo XX que han tenido una especial relevancia en el nacimiento de la Responsabilidad Social Corporativa: la publicación de la obra Social Responsibilities of the businessman y los escándalos financieros. 
Se ha defendido que el hecho concreto que origina el nacimiento de la Responsabilidad Social Corporativa es la publicación del libro Social Responsibilities of the Businessman por Bowen en 1953.

Bowen sostuvo que las líneas de acción empresarial deben alinearse con los objetivos sociales porque las empresas no solo son responsables de las consecuencias económicas de sus actos, sino que, por ser empresas, también contraen obligaciones con los valores que persigue la sociedad.

También se ha sostenido que el factor clave que desencadena el nacimiento de la Responsabilidad Social Corporativa se ha encontrado en los grandes escándalos financieros a los que tuvo que enfrentarse el mercado a mediados del siglo XX. Se trata de un momento crítico en el que para algunos expertos (Voltes, 2002) finaliza la edad de oro de los escándalos financieros en el mundo.

Algunos autores han indicado que estas malas prácticas presentan dos características específicas especialmente implicadas en el nacimiento de la Responsabilidad Social Corporativa: se desarrollan por organizaciones que operan desde una perspectiva global y hacen referencia a contextos que el mercado no es capaz de corregir (Vázquez, 2006).

Las empresas implicadas en estos escándalos financieros se han visto en la obligación de atender necesidades sociales, por razones estratégicas, para 
restaurar su dañada reputación corporativa (Hernández, 2011). En la revisión del corpus se ha hecho referencia a este modus operandi con un término muy usado en el ámbito publicitario: "operación cosmética”.

Este modo de actuación ha seguido vigente en el siglo XXI. Por ejemplo el laboratorio Merck infló su facturación en el 2002 para equilibrar las cuentas. Aunque esta acción no se considera técnicamente un fraude provocó que la empresa viviera momentos críticos en Wall Street hasta aclarar su situación. En el año 2013 Merck ha tenido en marcha el proyecto Merk for Mothers, que supone una inversión de 500 millones en 10 años en los que la empresa aporta su experiencia científica para ofrecer soluciones probadas de amplia disponibilidad, desarrollando cambios tecnológicos innovadores y mejorando la concienciación social, los esfuerzos políticos y el compromiso del sector privado con la mortalidad materna (Merck, 2013).

\subsubsection{Evolución de la Responsabilidad Social Corporativa}

Siguiendo la clasificación temporal indicada por Mozas y Puentes (2010), hemos establecido seis etapas en la evolución de la Responsabilidad Social Corporativa.

La primera etapa, previa a los años 60 del siglo XX, es definida como "filosófica" por algunos autores, como 
Frederick (1986) o Carroll (1966), quienes consideran la Responsabilidad Social Corporativa como un término abstracto, centrado en la ética y en la moral.

En la segunda década del siglo XX, debido al volumen creciente de los trust a la hora de acaparar renta, creció la alarma pública en Estados Unidos. Como consecuencia, algunos de los grandes empresarios que dirigían estos consorcios se sintieron obligados a mostrar su responsabilidad social como contribuyentes desinteresados y a realizar grandes donaciones económicas. Estas contribuciones se dirigieron, en parte, a las universidades donde se debatió en profundidad sobre la responsabilidad de los negocios (Domínguez, 2008).

Fruto de este impulso surgió el concepto de Responsabilidad Social Corporativa, establecido por Howard Bowen, profesor del College of Commerce de la Universidad de Illinois, para hacer referencia a las “obligaciones de los empresarios en la persecución de aquellas políticas, en la toma de aquellas dediciones, o en el seguimiento de aquellas líneas de acción, que son deseables en términos de objetivos y acciones ante la sociedad" (Bowen, 1953, 6).

La segunda etapa, denominada "económica", se desarrolló durante los años 60 del siglo XX.

Se caracteriza porque se volvió a dar prioridad al aspecto económico de la gestión al considerar que la 
Responsabilidad Social Corporativa y los resultados económicos eran aspectos excluyentes (Lee, 2008).

Algunos autores relevantes de esta etapa (Friedman, 1970; Henderson, 2001) matizaron este enfoque al indicar que las empresas no deben asumir ningún tipo de responsabilidad social sino que, únicamente, tienen que ocuparse de la maximización del beneficio. Además también señalaron que las organizaciones están actuando en detrimento del beneficio de los accionistas si dedican partidas económicas a causas sociales.

La tercera etapa, denominada "moralista", tuvo lugar durante la década de los 70 del siglo XX.

En este periodo volvió a surgir el interés por la Responsabilidad Social Corporativa como una obligación moral por encima de las propias exigencias empresariales.

Como fruto de esta orientación se realizaron los primeros estudios empíricos sobre la Responsabilidad Social Corporativa y se introdujo el concepto, limitado a los aspectos sociales, en el ámbito europeo.

Algunos expertos realizaron aportaciones esenciales en el ámbito de la responsabilidad social. Como el caso de Steiner (1971), quien consideró que las empresas deben seguir siendo fundamentalmente una institución económica, pero también deben asumir sus responsabilidades sociales ayudando a la sociedad a alcanzar sus metas. O Carroll $(1979,500)$, quien defendió la legitimidad de las exigencias sociales al indicar que "la responsabilidad social de las 
empresas abarca las expectativas económicas, legales, éticas o discrecionales de la sociedad sobre la organización en un momento dado en el tiempo".

El impulso teórico también se tradujo en la aparición de diversas iniciativas para ofrecer información sobre la responsabilidad social, que fueron consideradas un modelo a seguir por las empresas. En este sentido se utilizaron anexos descriptivos de indicadores sociales y se impulsaron iniciativas legales con parámetros vinculados a la Responsabilidad Social Corporativa para medir la actividad empresarial (Mugarra, 2001).

La cuarta etapa, denominada "teórica”, se desarrolló en la década de los 80 en el siglo XX.

Este periodo se caracteriza por la formulación de teorías, modelos y términos alternativos a la responsabilidad social como responsabilidad pública, sensibilidad social, ética empresarial, la teoría de los partícipes, ciudadanía empresarial, etc.

Entre las aportaciones teóricas más relevantes en esta etapa hemos destacado a Carroll y a Freeman. Carroll (1983) indicó que la responsabilidad social no solo implica que un negocio sea ético y socialmente solidario sino que también supone que sea rentable y que respete la ley. Freeman (1984) sentó las bases de la Teoría de los grupos implicados o Teoría Stakeholder, supuesto que defiende que la empresa no solo debe atender a los accionistas sino a todos los grupos o individuos que afectan o son afectados 
por la actividad que desarrolla la organización si pretende tener éxito a largo plazo en el mercado.

El desarrollo teórico experimentado por la responsabilidad social durante los años 80 no se correspondió con el auge de esta materia en las empresas. Hubo un retroceso respecto a la década anterior y la maximización del beneficio se convierte, de nuevo, en el principal objetivo y se deja prácticamente al margen cualquier otro aspecto que no sea de naturaleza económica (Server y Villalonga, 2005).

La quinta etapa, denominada "emergente", se desarrolló durante gran parte de la década de los años 90 del siglo XX.

En este periodo la Responsabilidad Social Corporativa cobró un mayor protagonismo fundamentalmente por dos aspectos.

En primer lugar porque surge una mayor consideración de la responsabilidad social y medioambiental de las empresas, ligada en un primer momento a responsabilidades mínimas legales y a actuaciones filantrópicas. Este impulso tuvo mayor aceptación empresarial debido a los escándalos financieros que tuvieron lugar en este periodo -como el caso del Banco Internacional de Crédito y Comercio, $\mathrm{BBCl}$, en el que desaparecieron miles de millones de dólares depositados por pequeños ahorradores (El País, 1994) - y el boom de las 
inversiones socialmente responsables (Mozas y Puentes, 2010).

$Y$ en segundo lugar, porque comienza a profundizarse en el estudio de la relación entre la Responsabilidad Social Corporativa y los resultados financieros, contemplando que las empresas pueden obtener mejores resultados si actúan de un modo socialmente responsable (Lee, 2008).

Hemos destacado dos aportaciones teóricas en esta etapa: la Pirámide de la Responsabilidad Social Corporativa propuesta por Carroll y el Modelo bidimensional sobre la Responsabilidad Social Corporativa aportado por Suazi y O’Brien.

Carroll (1991) defendió que las responsabilidades que las organizaciones deben satisfacer se pueden clasificar en cuatro categorías secuenciales (Carroll, 1991):

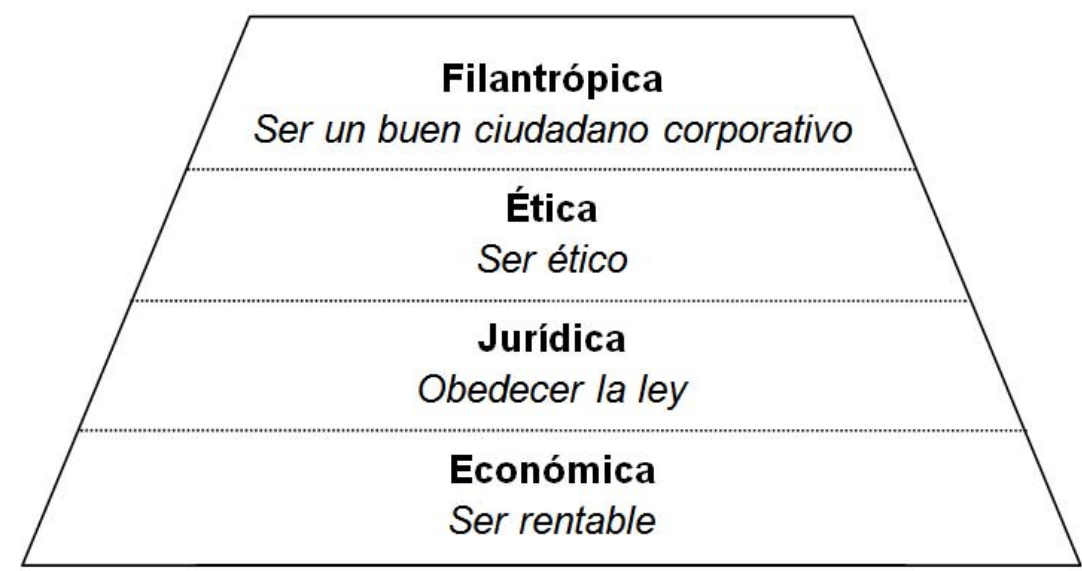

Cuadro 6: La Pirámide de la Responsabilidad Social Corporativa. Fuente: Carroll (1991).

1. Económica: hace alusión al necesario rendimiento económico de la organización para que pueda atender al resto de exigencias. 
2. Jurídica: hace referencia a un comportamiento legal que se espera de la organización.

3. Ética: hace alusión a que se desea que la empresa haga lo correcto, justo y equitativo, evitando o minimizando, de este modo, los daños a los grupos de interés.

4. Filantrópica: hace referencia a que la empresa se comporte como un buen ciudadano corporativo, aportando recursos económicos y humanos a la comunidad para mejorar la calidad de vida.

Esta visión de la Responsabilidad Social Corporativa ha obtenido bastante respaldo, ya que también ha sido compartida por otros autores como Sulbarán (1992) y Ferrer, Fraedrich y Ferrell (2000).

Suazi y O'Brien (2000) propusieron un modelo bidimensional, denominado Modelo bidimensional sobre la Responsabilidad Social, para presentar los enfoques desde los que contemplar desde una perspectiva organizacional la Responsabilidad Social Corporativa: 


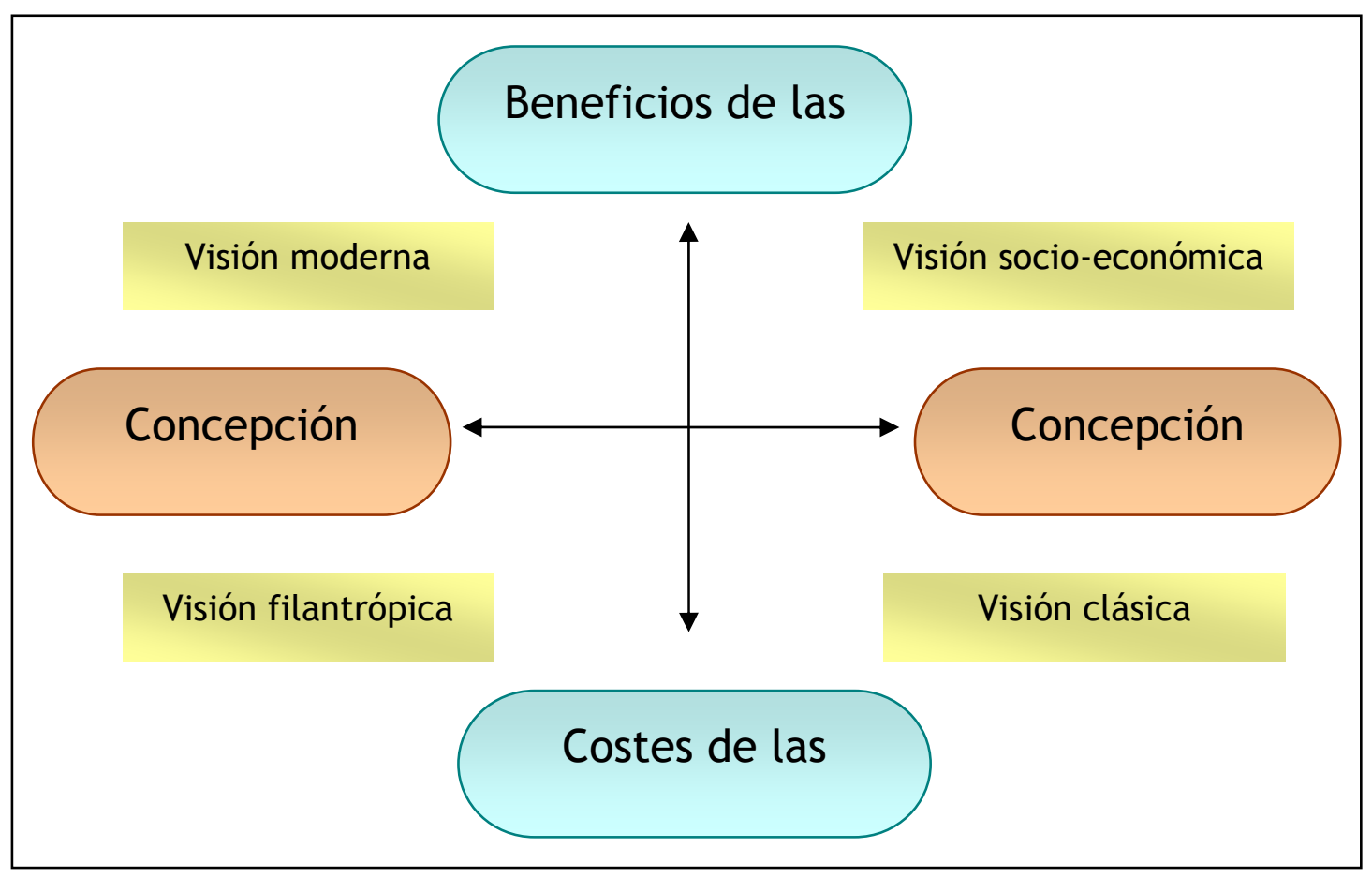

Figura 1: Un modelo de dos dimensiones de la Responsabilidad Social Corporativa. Fuente: Suazi y O’Brien (2000).

Las dos dimensiones que articulan el modelo son el ámbito de la responsabilidad social, que puede ser reducido o amplio, y las percepciones de las consecuencias de la acción social, que puede ser costes o beneficios.

A partir de estas dos dimensiones, Suazi y O'Brien han sugerido cuatro posibles enfoques de la Responsabilidad Social Corporativa:

1. Clásico: ámbito reducido y concepción de la responsabilidad social como coste.

2. Socio-económico: ámbito reducido y concepción de la responsabilidad social como beneficio.

3. Filantrópico: ámbito amplio y concepción de la responsabilidad social como coste.

4. Moderno: ámbito amplio y concepción de la responsabilidad social como beneficio. 
El cuarto enfoque indicado por Suazi y O'Brien, el enfoque moderno, se corresponde con la visión central de la responsabilidad social tal y como la hemos planteado en esta etapa emergente.

La sexta etapa, denominada "estratégica", se inició a finales de los años 90 y principios del siglo XXI, y se caracteriza por el carácter estratégico que adquiere la responsabilidad social.

En este periodo la Responsabilidad Social Corporativa experimenta un mayor grado de integración empresarial. Prueba de ello es que es, en este momento, cuando se comienza a incorporar la orientación social en la misión, visión y principios organizativos (Mozas y Puentes, 2010). Esta orientación se ve reforzada por los augurios de algunos expertos (Werhter y Chandler, 2005), para quienes la maximización del beneficio y la Responsabilidad Social Corporativa serán dos aspectos cada vez más conectados en la realidad de las organizaciones.

Algunos autores como Bronchain (2003) han cuestionado el auge de la orientación social de las organizaciones con carácter estratégico porque está motivado, principalmente, por escándalos financieros. Empresas como Enron, WorldCom o Parmalat han buscado la responsabilidad social como herramienta para mejorar su reputación corporativa a causa de la pérdida de credibilidad y confianza provocada por sus escándalos financieros (Galán, 2005). 
Este tipo de situaciones, que también se han producido previamente, no solo motivan a las organizaciones a mejorar su reputación sino que también indican el medio idóneo de alcanzar este objetivo: a través de una gestión más ética y responsable (De la Fuente y De Quevedo, 2003). De todos modos se ha denunciado que es imposible satisfacer esta aspiración porque el origen del problema se encuentra en el propio mercado al perseguir, de forma exclusiva, la maximización de valor para el accionista (Lizcano, 2002). Desde nuestro humilde punto de vista hemos considerado que quizá sería útil, para favorecer la resolución de este conflicto, realizar un esfuerzo por incorporar en el concepto de valor todos los beneficios no económicos derivados de las acciones de responsabilidad social.

Esta disposición estratégica carente de una real adhesión a la filosofía que representa la responsabilidad social, también se ve manifestada en otro rasgo característico de esta etapa: la ambiguiedad conceptual que rodea a la Responsabilidad Social Corporativa.

Aunque se han producido una gran cantidad de aportaciones teóricas para paliar este problema, especialmente por parte de algunos de los organismos más implicados en la responsabilidad social, la realidad es que la compresión del término es ambigua y a veces, incluso, difusa para las empresas (Mozas y Puentes, 2010).

Por ejemplo existen organizaciones que identifican el término "Responsabilidad Social Corporativa" con otros 
términos de diferente naturaleza (como patrocinio, mecenazgo, donaciones a fondo perdido, etc.). Y también es frecuente que se asocien las acciones de responsabilidad social, de modo exclusivo, con la obtención de beneficios económicos o de ventajas competitivas.

\subsubsection{Relevancia actual de la Responsabilidad Social Corporativa}

Hemos tratado la relevancia actual de la responsabilidad social a través de cuatro cuestiones: la vinculación de la Responsabilidad Social Corporativa con el actual modelo de desarrollo, el impulso que está recibiendo la responsabilidad social desde diversas esferas, el interés de la ciencia por la responsabilidad social y los beneficios que se asocian a la Responsabilidad Social Corporativa.

Hemos incorporado tres críticas sobre el actual modelo de desarrollo que están muy vinculadas con el progreso de la responsabilidad social: el desequilibrio que provoca el propio sistema capitalista, el fomento de un crecimiento económico que está sostenido con recursos limitados y el reduccionista paradigma de la simplicidad que gobierna el planteamiento capitalista neoliberal. 
El sistema económico capitalista ha estimulado el egoísmo, la ambición y el consumismo. Estos aspectos han provocado grandes niveles de crecimiento económico en los países más ricos, pero también graves problemas de pobreza, desempleo, guerras y exclusión para una gran parte de la humanidad (Romero, 2010).

En el ámbito de responsabilidad social, este desequilibrio ha provocado que grandes empresas, que cada vez han ido adquiriendo mayor cuota de poder, se hayan ubicado en países que carecen de un tejido asociativo que les genere conflictos. Su objetivo ha sido reducir los altos costes sociales en los que incurre su producción en los países más industrializados (Klein, 2007).

Algunos autores ya han denunciado que (Kliksberg, 2005) este sistema económico, e incluso el propio modelo democrático según algunos pensadores (Maloof, 2005), solo beneficia a las minorías.

Esta situación también ha provocado respuestas sociales que han incidido en el desarrollo de la responsabilidad social. Han aparecido nuevos movimientos y actores sociales y políticos en contra de aspectos como la contaminación, la globalización o la pobreza.

El actual modelo de desarrollo está basado en un crecimiento económico sostenido que tiene como base la utilización y el consumo de materias primas y recursos naturales que son finitos. 
Sin embargo cada vez son más las evidencias científicas que exponen un deterioro imparable de los ecosistemas por acción directa del hombre, y que están teniendo un efecto inmediato y tremendamente dañino sobre la Tierra como la pérdida de biodiversidad, el calentamiento progresivo del planeta, el aumento de catástrofes naturales de mayor magnitud, etc. (Vázquez, 2006).

Algunos autores, como Morín, han llegado a plantear la necesidad de realizar un cambio de planteamiento radical para liberarse del paradigma de la simplicidad que aún sigue predominando en el sistema capitalista neoliberal (Morín, 1997).

Los defensores de este enfoque simplista analizan los problemas económicos relacionados con el desarrollo de los países a través de una relación lineal sujeto-objeto y de causa-efecto, cuando la comprensión de las dificultades responde en mejor medida a un conjunto complejo de múltiples elementos interrelacionados que interaccionan de manera simultánea (Morín, 1997).

La visión holística de la realidad que caracteriza a la responsabilidad social también responde a este planteamiento. Por ejemplo los stakeholders inciden, a través de sus juicios, en la permanencia de las organizaciones en el mercado (Berbel, Reyes y Gómez, 2007). 
Otro aspecto que demuestra la relevancia actual de la Responsabilidad Social Corporativa es el impulso que ha recibido desde diversos ámbitos.

Un elevado número de organismos internacionales se han implicado en favorecer el desarrollo de la Responsabilidad Social Corporativa: Organización de las Naciones Unidas (ONU), Organización Internacional del Trabajo (OIT), Institute of Social and Ethical AccountAbility, Global Reporting Initiative, etc. (Mozas y Puentes, 2010).

Este impulso ha provocado la aparición de una gran pluralidad de normas y principios que dictan directrices de carácter voluntario para la implantación de la Responsabilidad Social Corporativa.

En el ámbito europeo, la Comisión Europea ha fijado sus objetivos en materia de Responsabilidad Social Corporativa a través de la creación de diferentes informes y soluciones que se encuentran en sus publicaciones marco sobre este tema.

Hemos incorporado a continuación en el cuadro 7 los aspectos más relevantes de las publicaciones: Libro Verde. Fomentar un marco europeo para la responsabilidad social de las empresas, Una contribución empresarial al desarrollo sostenible, Poner en práctica la asociación para el crecimiento y el empleo: hacer de Europa un polo de excelencia de la responsabilidad social de las empresas y 


\section{Estrategia renovada de la UE para 2011-2014 sobre la responsabilidad social de las empresas.}

\begin{tabular}{|c|c|}
\hline Publicación & Comentarios \\
\hline $\begin{array}{l}\text { Libro Verde (2001). Fomentar } \\
\text { un marco europeo para la } \\
\text { responsabilidad social de las } \\
\text { empresas. }\end{array}$ & $\begin{array}{l}\text { En esta publicación la Comisión de las } \\
\text { Comunidades Europeas dio el primer paso } \\
\text { para perfilar el concepto de Responsabilidad } \\
\text { Social Corporativa (Comisión de las } \\
\text { Comunidades Europeas, 2001). }\end{array}$ \\
\hline $\begin{array}{l}\text { Una contribución empresarial } \\
\text { al desarrollo sostenible } \\
\text { (2002). }\end{array}$ & $\begin{array}{l}\text { Este documento se centró en la ampliación y } \\
\text { actualización de la información del Libro Verde } \\
\text { publicado en el } 2001 \text { (Comisión de las } \\
\text { Comunidades Europeas, 2002). }\end{array}$ \\
\hline $\begin{array}{l}\text { Poner en práctica la } \\
\text { asociación para el } \\
\text { crecimiento y el empleo: } \\
\text { hacer de Europa un polo de } \\
\text { excelencia de la } \\
\text { responsabilidad social de las } \\
\text { empresas (2006). }\end{array}$ & $\begin{array}{l}\text { Esta comunicación se orientó a (Comisión de } \\
\text { las Comunidades Europeas, 2006): } \\
\text { - advertir sobre la necesidad de la } \\
\text { responsabilidad social en materia de } \\
\text { empleo, } \\
\text { - y en proponer acciones para llevar a cabo } \\
\text { dicha iniciativa. }\end{array}$ \\
\hline $\begin{array}{l}\text { Estrategia renovada de la UE } \\
\text { para } 2011-2014 \text { sobre la } \\
\text { responsabilidad social de las } \\
\text { empresas (2011). }\end{array}$ & $\begin{array}{l}\text { Esta comunicación se centró en (Comisión } \\
\text { Europea, 2011): } \\
\text { - Realizar recomendaciones de actuación } \\
\text { para las empresas y para los poderes } \\
\text { públicos. } \\
\text { - Actualizar la comprensión del fenómeno } \\
\text { de la responsabilidad social. } \\
\text { - Presentar una nueva propuesta legislativa } \\
\text { sobre transparencia de la información } \\
\text { social y medioambiental para las } \\
\text { empresas. }\end{array}$ \\
\hline
\end{tabular}

Cuadro 7: Publicaciones marco sobre Responsabilidad Social Corporativa en el ámbito europeo. Fuente: elaboración propia.

Pese al impulso de los diversos organismos multilaterales sobre los que se ha asentado la normativa en relación con los derechos humanos y el medio ambiente, la autorregulación voluntaria sobre determinadas cuestiones 
que afectan a bienes públicos globales ha resultado deficiente por dos motivos.

En primer lugar porque las medidas no han sido suficientemente efectivas para corregir actuaciones que generan impactos graves sobre el planeta.

$Y$ en segundo término, porque es necesario que la administración desempeñe un papel más activo directamente, imponiendo unas reglas mínimas aceptadas por todos los agentes involucrados, o indirectamente, condicionando el desarrollo de los mercados a través de sus políticas de compras y contrataciones públicas (Vázquez, 2006).

Algunos autores (Romero, 2010) han indicado que el aumento de la implicación de la administración en materia de responsabilidad social tampoco garantiza la mejora de algunos de los problemas ambientales y sociales que provocan las empresas. Para alcanzar un desarrollo sostenible resulta necesaria una educación que garantice libertad, progreso y felicidad.

El auge que ha ido adquiriendo la Responsabilidad Social Corporativa desde el último tramo del siglo $\mathrm{XX}$ también se ha correspondido con un mayor interés científico por esta materia.

Se han tratado a continuación algunos aspectos que a nuestro juicio reflejan el aumento de la preocupación de la 
ciencia por esta disciplina: las revistas de prestigio especializas en la Responsabilidad Social Corporativa, las revistas internacionales del ámbito de la gestión y de los negocios que han tratado la Responsabilidad Social Corporativa, la producción sobre Responsabilidad Social Corporativa considerando el ámbito geográfico y el desarrollo internacional de prácticas de Responsabilidad Social Corporativa considerando el ámbito geográfico.

Uno de los factores que han reflejado la creciente atención que se concede al estudio de la responsabilidad social es el elevado número de revistas de prestigio que se encargan especialmente de su estudio a nivel internacional. Hemos citado algunas de las más representativas:

\begin{tabular}{|c|}
\hline $\begin{array}{c}\text { Algunas revistas internacionales especializadas en el } \\
\text { estudio de la Responsabilidad Social Corporativa }\end{array}$ \\
\hline Business Ethics Quarterly \\
\hline Business Ethics: A European Review \\
\hline Business and Society \\
\hline Business and Society Review \\
\hline Business Strategy and the Environment \\
\hline Corporate Governance: An International Review \\
\hline Corporate Social Responsibility and Environmental Management \\
\hline Greener Management International \\
\hline Journal of Business Ethics \\
\hline Journal of Corporate Citizenship
\end{tabular}

Cuadro 8: Algunas revistas internacionales especializadas en el estudio de la Responsabilidad Social Corporativa. Fuente: elaboración propia. 
Otra evidencia del interés científico por la responsabilidad social es el número de revistas internacionales orientadas al ámbito de gestión y de los negocios que, sin estar especializadas en la Responsabilidad Social Corporativa, han dedicado regularmente artículos de investigación a la Responsabilidad Social Corporativa.

En el periodo 1998 a 2007 los temas fundamentales en los que han centrado su atención estas publicaciones son afines a la responsabilidad social: ética (37\%), governanza (25\%), entorno (19\%) y ámbito social y grupos de interés (18\%) (Egri y Ralson, 2008).

Hemos destacado dos características de la investigación centrada en la Responsabilidad Social Corporativa en este tipo de revista: por una parte el incremento del contenido dedicado a la responsabilidad social, lo que demuestra la importancia creciente por profundizar en este campo, y por otra la búsqueda de concreción en el ámbito, ya que la gran mayoría de los artículos dedicados a esta materia (75\%) han sido estudios empíricos (Egri y Ralson, 2008).

Desde el punto de vista geográfico, la producción científica sobre Responsabilidad Social Corporativa ha sido variable.

El país con mayor presentación en los estudios empíricos sobre Responsabilidad Social Corporativa ha sido EE.UU. En este sentido es destacable que un $30 \%$ de los 
estudios sobre responsabilidad social utilizan bases de datos norteamericanas (Egri y Ralson, 2008).

También han tenido un especial protagonismo China (16\%), Holanda (12\%), Reino Unido (12\%), Alemania (11\%), Canadá (9\%), Japón (9\%) y Australia (9\%).

Estos resultados han reflejado que en el comienzo del siglo XXI la mayoría de los estudios empíricos sobre Responsabilidad Social Corporativa con repercusión internacional se desarrollan en países que económicamente están muy desarrollados.

Además, también han indicado que se realiza mucha menos investigación sobre Responsabilidad Social Corporativa en las economías menos desarrolladas del mundo.

También es necesario tener presente, en relación con las investigaciones que tienen en cuenta aspectos geográficos en la responsabilidad social, que cuando se generalizan los resultados alcanzados en las investigaciones sobre Responsabilidad Social Corporativa en realidad se está haciendo referencia a estudios centrados en las economías más desarrolladas.

Por otra parte también es importante tener en consideración que existe una necesidad de ampliar el alcance cultural y geográfico de la investigación sobre Responsabilidad Social Corporativa a los espacios geográficos donde es mayor la necesidad de desarrollar iniciativas en este campo en países de África, de Europa Central y del Este, de Asia Central y del Sur, de 
Latinoamérica y de Oriente Medio. En estas zonas hay elevados niveles de pobreza, además de presentar degradación medioambiental y precisar de mejora en su governanza institucional (Egri y Ralson, 2008).

La investigación científica también se ha preocupado por conocer las prácticas responsables que las empresas desarrollan, aspecto que de nuevo varía en función de los países que se contemplen.

A continuación hemos incorporado el cuadro 9 ("Algunos datos destacables del estudio sobre competitividad responsable desarrollado por AccountAbility") que muestra, divididos en cuatro bloques, algunos resultados del análisis del estado de la competitividad responsable de 2007 desarrollado por AccountAbility: información que hace referencia a los países con un mayor nivel de desarrollo económico, datos sobre los países denominados "BRICS" (denominación utilizada para referirse a Brasil, Rusia, India, China y Sudáfrica), algunos resultados del estudio sobre las economías emergentes e información relacionada con los países que presentan un nivel de ingresos más reducido donde no se han registrado datos homogéneos. 
Algunos datos destacables del estudio sobre competitividad responsable desarrollado por AccountAbility (2007)

- Las naciones bien desarrolladas, y los países europeos en especial, se encuentran más avanzados en cuanto al establecimiento de prácticas empresariales responsables en el corazón de sus economías:

- Los países nórdicos han dominado la lista:

- Suecia ha ocupado el primer lugar.

- Dinamarca, Finlandia, Islandia y Noruega se han encontrado entre los primeros seis países junto con el Reino Unido.

- Trece de los 20 países principales han sido europeos, que se han encontrado acompañados por:

- Hong Kong,

- Japón,

- Singapur,

- Canadá,

- Estados Unidos,

- Australia,

- y Nueva Zelanda.

Sudáfrica se ha posicionado al frente de los llamados "BRICS" (denominación utilizada para referirse a Brasil, Rusia, India, China y Sudáfrica) en el lugar 28 de la lista, encontrándose Brasil, India, Rusia y China a continuación.

- En lo que se refiere a las economías emergentes, los países que más han destacado son:

- Chile,

- Malasia

- y la República de Corea.

- Dentro de los países de bajos ingresos:

- Zambia y Uganda han mostrado un mejor desempeño que países con niveles comparables de desarrollo.

- En países como Camboya, Marruecos y Bangladesh las iniciativas de competitividad responsable a nivel sectorial deben todavía generar resultados tangibles a escala nacional.

Cuadro 9: Algunos datos destacables del estudio sobre competitividad responsable desarrollado por AccountAbility. Fuente: AccountAbility (2007). 
Los datos han reflejado que el desarrollo de prácticas responsables es competencia, en gran medida, de los países con mayor desarrollo económico.

También hemos destacado el hecho de que en los países llamados a ser próximos dominadores en el ámbito económico, los denominados BRICS, las prácticas de responsabilidad corporativa tienen cabida.

En cualquier caso es importante tener presente un factor discriminante en el análisis de las prácticas de responsabilidad social que realizan las empresas según el ámbito geográfico en el que desarrollan su actividad: su tamaño. Las organizaciones que desarrollan más actividades de responsabilidad social tiene una dimensión mayor (Graafland, Van de Ven y Stoffele, 2003) y, en muchos casos, desarrollan su actividad económica en varios países.

Otro aspecto que también indica la relevancia de la responsabilidad social es la que trata sobre los beneficios derivados del desarrollo de acciones de responsabilidad social.

Hemos estructurado la información sobre este aspecto en dos bloques: la que hace referencia a la demanda de responsabilidad social por parte de los consumidores, y la que alude al potencial de la responsabilidad social para crear valor para las propias organizaciones.

En relación con el primer aspecto, la demanda de responsabilidad social por parte de los consumidores, es 
importante indicar que desde la finalización del siglo XX las organizaciones se han encontrado, para el desarrollo de acciones de responsabilidad social, con un contexto de receptividad favorable.

Se han realizado investigaciones que demuestran que los consumidores han aumentado su demanda de responsabilidad social a las organizaciones en el siglo XXI (Ramasamy, Yeung y Au, 2010).

También se han realizado investigaciones en jóvenes consumidores que han encontrado una relación significativa y positiva entre su percepción de la dimensión social de las prácticas de responsabilidad social que realizan las empresas, y algunos aspectos de su vida que denotan una orientación al bienestar (Bigné, Chumpitaz, Andreu y Swaen, 2005) como tener éxito en la vida afectiva y familiar, vivir de acuerdo con sus principios y tener buena salud.

Estos resultados muestran que la demanda de responsabilidad social aumenta a medida que se eleva el nivel de bienestar personal.

De todos modos también se ha denunciado que aunque existe un clima favorable hacia la Responsabilidad Social Corporativa, esta será vista con recelo mientras el motivo del desarrollo de acciones de responsabilidad social por parte de las organizaciones sea compensar o encubrir un interés lucrativo. Las empresas tratan de reducir esta desconfianza a través de su comunicación (Hernández, 2011), buena prueba de ello es que en la segunda década 
del siglo XXI ya es común encontrar menciones a las iniciativas en responsabilidad social en las web corporativas de las grandes compañías, pero los consumidores exigen una preocupación en este ámbito menos lucrativa y más altruista.

En relación con el potencial de la responsabilidad social para crear valor para las organizaciones no hay resultados concluyentes, aunque existe una gran producción científica que ha afirmado la existencia de una relación positiva entre ambas variables.

Aunque hay investigaciones que no han dado validez a la relación entre los dos aspectos (McWilliams y Siegel, 2000; Moore, 2001; Peloza y Shang, 2011) existen otros estudios empíricos que sí han verificado la relación entre la responsabilidad social y los beneficios organizacionales derivados de este tipo de acciones (Waddock y Gaves, 1997; Balbains Phillips y Lyall, 1998; Orlitzky, 2001; Tziner, 2013).

Esta conclusión también ha sido alcanzada por otros trabajos centrados en la revisión de estudios realizados. En el extenso análisis que Griffin y Mahon (1997) realizaron de diferentes artículos publicados entre 1972-1997 sobre la relación entre la responsabilidad social y la rentabilidad financiera, concluyeron que la mayor parte de las investigaciones afirmaban la existencia de relaciones positivas entre las dos variables. También se alcanzaron consideraciones similares en el análisis de la relación entre sostenibilidad empresarial y comportamiento bursátil de 36 
estudios. En dicho trabajo se concluyó que el $61 \%$ de tales estudios mostraban una relación positiva entre Responsabilidad Social Corporativa y creación de valor (Mercer, 2009).

Un referente en el valor que aporta el desarrollo de acciones de responsabilidad social a las empresas ha sido el estudio The Business of Sustainability: Results and insights from the first annual MIT Sloan Management Review Global Sustainability, que ha concluido con la existencia de siete palancas de creación de valor para las organizaciones que están asociadas a la sostenibilidad:

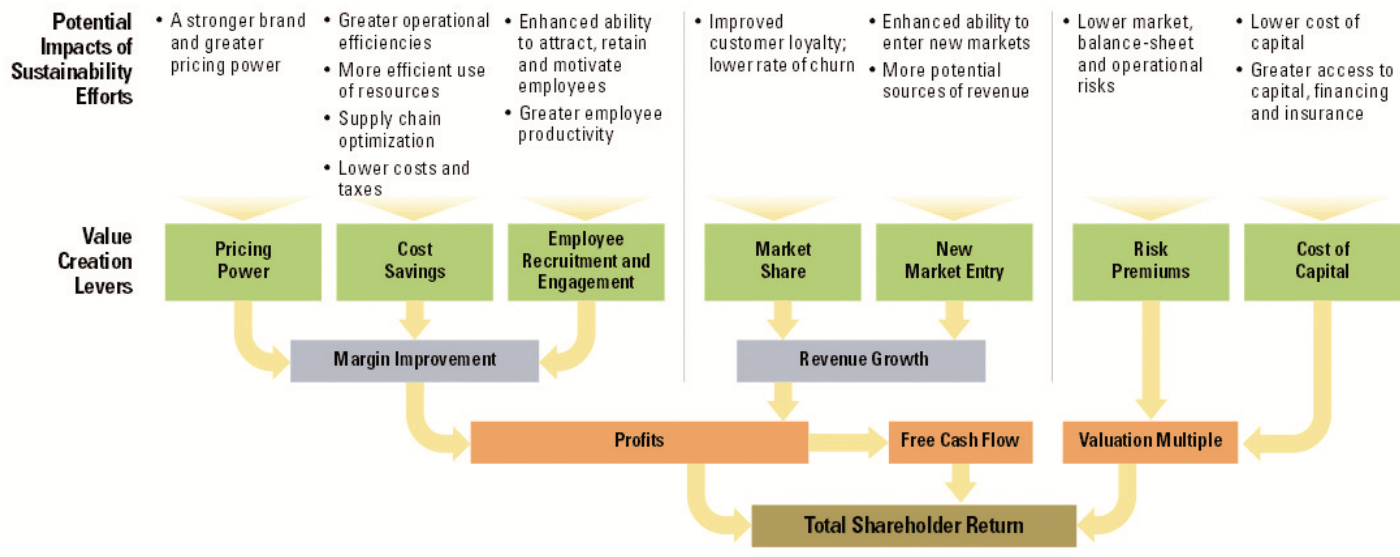

Figura 2: How sustainability affects value creation. Modelo propuesto por el MIT (Massachussets Institute of Technology) junto con BCG (Boston Consulting Group). Fuente: MIT (2009).

La primera palanca, mayor poder para fijar los precios, es consecuencia de la mayor fortaleza de la marca en el mercado.

La segunda palanca, el mayor ahorro de costes, es motivada por la mayor eficiencia en las operaciones, un uso más eficiente de los recursos, una optimización de los 
canales de suministro y una reducción de los costes y los impuestos.

La tercera palanca, el mejor reclutamiento y mayor compromiso de los colaboradores, es posible porque la sostenibilidad ofrece mayor potencial para atraer, retener y motivar a los empleados y favorece un incremento de la productividad en los colaboradores.

Los beneficios derivados de la Responsabilidad Social Corporativa asociados a esta palanca, se corresponden con los alcanzados por diversas investigaciones que han encontrado una relación positiva entre la satisfacción de los públicos internos y su percepción de la responsabilidad social que las organizaciones desarrollan (Jose y Thibodeaux, 1999; Valentine y Barnett, 2003; Valentine y Fleischman, 2008).

La cuarta palanca, la mejora de la cuota de mercado, se produce a través del incremento de la lealtad del cliente y de un menor índice de rotación.

Se han realizado estudios que han verificado los resultados de esta palanca a largo plazo. Lacey y KennettHensel (2010) demostraron que la actuación de una organización en el ámbito de la responsabilidad social influye favorablemente en la relación que esta establece con sus consumidores en el tiempo porque la compañía refuerza la confianza y el compromiso del consumidor, y resulta ser más deseable para este. 
Lo que no está probado es la existencia de una correlación directa a corto plazo entre el desarrollo de una política de Responsabilidad Social Corporativa y la generación de valor (Vázquez, 2006).

Algunos expertos han indicado que los consumidores elegirán antes los productos ofertados por una empresa socialmente responsable (Server y Villalonga, 2005) que los ofrecidos por otras empresas que no desarrollen este tipo de políticas. Sin embargo también se ha indicado que (Server y Capó, 2009) esa percepción competitiva solo es alcanzable a largo plazo. El motivo es que resulta necesario que la responsabilidad social esté integrada en la gestión de las organizaciones para que se produzca esa percepción. Algo que es difícil de materializar en un periodo corto de tiempo.

La quinta palanca, la mayor capacidad para entrar en nuevos mercados, es motivada por la propia sostenibilidad. Gracias a ella, las empresas aumentan su capacidad para entrar en nuevos mercados y su potencial para acceder a fuentes de financiación pública.

La sexta palanca, la reducción de las primas de riesgo, también es causada por la apuesta por la sostenibilidad. Esta disposición favorece la responsabilidad social porque fomenta el mantenimiento de la confianza en la empresa ante retrocesos en el mercado, balances financieros poco sólidos o ante operaciones de riesgo. 
La séptima palanca, la reducción del coste de capital, también es consecuencia de la apuesta por la responsabilidad social. Esta actuación reduce el coste del acceso al capital y facilita que se disponga de la financiación y seguros necesarios para afrontar el desarrollo de las actividades empresariales. 


\subsection{REGULACIÓN DE LA RESPONSABILIDAD SOCIAL CORPORATIVA}

Hemos tratado en este apartado los tipos de medidas que regulan la actuación en materia de Responsabilidad Social Corporativa.

En este sentido hemos incorporado, en primer lugar, algunas consideraciones sobre los principales informes utilizados para reflejar la actuación social de las organizaciones; a continuación hemos abordado otra medida habitual en el mercado: los acuerdos de estandarización sobre responsabilidad social a los que se vinculan las empresas; posteriormente hemos tratado los códigos de conducta a los que las organizaciones se adhieren para orientar su comportamiento en el ámbito de la responsabilidad social y finalmente hemos incorporado algunos aspectos relacionados con las leyes sobre responsabilidad social.

\subsubsection{Informes}

Los tipos de informes más utilizados para comunicar la actuación en materia de Responsabilidad Social Corporativa desarrollada por las empresas son dos: la memoria de sostenibilidad y el balance social. 
Las memorias de sostenibilidad son documentos elaborados por la dirección de las empresas, realizados de forma organizada, periódica y objetiva, que recogen la información sobre los efectos más relevantes (tanto positivos como negativos) de la actividad de la empresa en el desarrollo sostenible de su entorno y hacen referencia tanto a los procesos en los que la organización está inmersa como a los productos o servicios que ofrece (Bañegil y Chamorro, 2001).

Los balances sociales también son informes que las organizaciones realizan para reflejar su actividad social.

Inicialmente se trataba de documentos sin un esquema concreto previamente establecido, con características diferentes en función del país en el que hubieran sido redactados y en los que cada empresa facilitaba la información demandada en función de sus propios intereses.

Con el paso del tiempo este tipo de documentos se ha identificado mucho más con la responsabilidad que las cooperativas tienen con sus socios y con la función social de dichas cooperativas (Server y Villalonga, 2005) y ha permitido verificar hasta qué punto las cooperativas han cumplido con los Principios Cooperativos establecidos por la Alianza Cooperativa Internacional (International Cooperative Alliance, 1844).

De todos modos muchas instituciones, organismos y expertos también han utilizado tanto el término "balance 
social" como el concepto "memoria de sostenibilidad", de forma indistinta, para hacer referencia a los informes de responsabilidad social que presentan las organizaciones de todo tipo de naturaleza jurídica.

A lo largo de los años han aparecido diversas iniciativas para orientar a las empresas en el modo de elaborar los informes de responsabilidad social. Las más destacadas han sido impulsadas por Global Reporting Initiative (GRI) y por Naciones Unidas (PC).

El Global Reporting Initiative (GRI) es una organización sin ánimo de lucro que trabaja por una economía global sostenible aportando indicaciones sobre cómo realizar informes de sostenibilidad.

En el año 2000 desarrolló sus primeras líneas guía sobre cómo desarrollar informes de sostenibilidad 0 memorias de sostenibilidad. Y en el año 2011 actualizó y completó la tercera visión de las guías, lanzada en el año 2006 (Global Reporting Initiative, 2013a).

El número de organizaciones dadas de alta en la aplicación creada por el Global Reporting Initiative para la elaboración de informes de sostenibilidad en el 2013 era 5744 (Global Reporting Initiative, 2013b).

El Naciones Unidas (PC) promovió el Global Compact o Pacto Mundial de es una iniciativa política estratégica para los negocios que está comprometida con el alineamiento de 
operaciones y estrategias con diez principios universalmente aceptados en las áreas de derechos humanos, entorno laboral, medioambiente y anticorrupción (United Nations, 2013a).

Los principios del Global Compact, que han supuesto otra iniciativa destacada en la aportación de directrices sobre cómo elaborar los informes de sostenibilidad, están inspirados en la Declaración Universal de los Derechos Humanos de la ONU, los Principios Fundamentales de la Organización Internacional del Trabajo y los Principios sobre Desarrollo y Medioambiente establecidos en la cumbre de Río de 1992 (Server y Villalonga, 2005).

Las organizaciones que desean incorporarse al Global Compact tienen que firmar una carta de compromiso.

En el año 2013 había 7880 empresas participantes en el Global Compact (United Nations, 2013b).

\subsubsection{Acuerdos de estandarización}

Otra manera de incidir sobre el desarrollo de la responsabilidad social es mediante la promulgación de acuerdos de estandarización o normas a los que se acogen voluntariamente las empresas sin necesidad de intervención regulatoria.

Este tipo de medidas indican qué parámetros son necesarios controlar a las empresas para ser socialmente responsables y son de obligado cumplimiento (Server y Villalonga, 2005). 
Para las organizaciones adheridas a este recurso, ha supuesto un ahorro de costes de garantía la certificación, por terceras partes, de un suministrador (Méndez, 2002).

De las distintas iniciativas internacionales desarrolladas en este ámbito por diversas entidades (Social Accountability Internacional, Institute for Social and Ethical Accountability, International Standard Organization...) hemos destacado la SA8000 y la ISO 26000.

Una norma con gran reconocimiento internacional que ha sido adoptada por multitud de industrias en muchos países (Social Accountability Accreditation Services, 2014) para favorecer entornos de trabajo saludables es el estándar SA8000.

En su origen fue elaborado por expertos de diversos ámbitos (en los que se incluyen a las empresas, ONG's y sindicatos), reunidos por la Agencia de Acreditación del Consejo sobre Prioridades Económicas (Council on Economic Priorities Acreditation Agency, CEPAA) en 1997 para concretar las condiciones laborales que debían ser respetadas en el sector industrial. El objetivo era garantizar a los consumidores de los países desarrollados que los productos habían sido elaborados en unas condiciones aceptables de trabajo (International Institute for Sustainable Development, 2013).

En 1998 se fundó la Social Accountability Internacional (SAI), agencia de acreditación constituida por la CEPAA, 
para dirigir la implementación de la SA8000 y las actividades complementarias de formación. Se trata de una organización no gubernamental que trabaja en favor de los derechos humanos de los trabajadores alrededor del mundo, estableciendo los requisitos voluntarios sobre contratación infantil, explotación de la fuerza de trabajo, seguridad y salud laboral, libertad de asociación y derecho a las negociaciones colectivas, discriminación, medidas disciplinarias, jornadas laborales y remuneración (Social Accountability Internacional, 2013).

Las empresas pueden solicitar la certificación SA8000, de modo voluntario, a través de una de las agencias de certificación aprobadas por la SAI.

La última revisión de la norma se realizó en el 2008, SA8000:2008 (Social Accountability Internacional, 2013) aunque en el 2014 se ha iniciado un nuevo proceso de revisión para mantener su relevancia y adaptabilidad (Social Accountability Internacional, 2014).

El origen del ISO26000 está asociado con la gran diversidad de documentos existentes para favorecer la implantación de la responsabilidad social en las organizaciones: 
Algunos de los documentos creados para favorecer la implantación de la responsabilidad social

- Pacto Mundial de Naciones Unidas o Global Compact.

Líneas Directrices de la Organización para la Cooperación y Desarrollo Económico (OCDE).

- Declaraciones de la Organización Internacional del Trabajo (OIT).

- Prácticas propuestas a las organizaciones por la Comisión Europea en el Libro Verde.

- Norma de aseguramiento de sostenibilidad AA1000AS.

Cuadro 10: Algunos de los documentos creados para favorecer la implantación de la responsabilidad social. Fuente: elaboración propia.

Este hecho ha motivado que se trabaje a nivel internacional para elaborar un documento, de carácter voluntario y no certificable, que permita una normalización de las recomendaciones indicadas por los diferentes organismos en relación con la Responsabilidad Social Corporativa (Mozas y Puentes, 2010).

Este documento ha sido desarrollado por la International Organization for Standardization (ISO) y ha sido denominado "ISO 26000:2010".

El objetivo del ISO 26000:2010 ha sido ofrecer a las organizaciones un modo estándar de actuación ética y transparente que contribuya a la salud y al bienestar de la sociedad (International Organization for Standardization, 2013). 


\subsubsection{Códigos de conducta}

Los códigos de conducta son medidas que se proponen a las empresas para evitar que sus pautas de actuación empresarial sean destructivas tanto para sus normas de convivencia, en particular, como para los seres humanos, en general.

La Asociación Española de Contabilidad y Administración de Empresas (AECA, 2003) los ha definido como una expresión formal de valores y buenas prácticas de la organización, que son enunciados con carácter orientador y normativo, que presentan el rango de precepto a cumplir por todos los integrantes de la corporación y que a veces también se aplican a los proveedores y otros suministradores de servicios.

Para expertos como Vázquez resultan una medida insuficiente para corregir los defectos del mercado porque cuando se trata de bienes públicos, como los derechos humanos y los medioambientales, los máximos responsables son los Estados (Vázquez, 2006). En el propio Libro Verde se ha hecho mención a esta cuestión:

“...la responsabilidad social de las empresas no se debe considerar sustitutiva de la reglamentación o legislación sobre derechos sociales o normas medioambientales, ni permite tampoco soslayar la elaboración de nuevas normas apropiadas. En los países que carecen de tales reglamentaciones, los esfuerzos se deberían centrar en la instauración del 
marco legislativo o reglamentario adecuado a fin de definir un entorno uniforme a partir del cual desarrollar prácticas socialmente responsables" (Comisión de las Comunidades Europeas, 2001, 7).

Aunque se trate de una medida que tiene sus limitaciones muchas organizaciones los valoran de forma positiva por su elevada repercusión en la reputación organizacional, ya que la utilización de códigos incentiva el interés por el buen comportamiento empresarial (Vázquez, 2006). Además también se valora su flexibilidad en contenido y alcance (Vázquez, 2006), lo que facilita la adopción de códigos en culturas empresariales de todo tipo (Romero, 2010).

\subsubsection{Leyes}

Algunos países ya han venido tomando medidas para regular la presentación de los datos relativos a la responsabilidad social de las empresas.

Por ejemplo en Francia la Asamblea Nacional aprobó, en 1977, el proyecto de ley sobre balance social. Se trata de una iniciativa que propone el uso de indicadores para medir la actividad de las empresas desde la óptica social (Server y Villalonga, 2005).

O en el Reino Unido, donde la Cámara de los Comunes aprobó en el 2002 la Corporate Responsability Act. Ley que afecta a todas las compañías que operan en territorio 
británico y establece nuevas obligaciones en materia de transparencia informativa (Server y Villalonga, 2008).

La implementación de una política pública en relación con la Responsabilidad Social Corporativa exige una normativización mínima que permita obtener una información fidedigna, objetiva, comparable y verificable. Además, también requiere de un marco de referencia que sustente la regulación sobre una estandarización variable (Vázquez, 2006).

Son diversas las iniciativas que en materia de responsabilidad social pueden impulsar las administraciones. Hemos indicado algunas (Vázquez, 2006):

- Incluir cláusulas sociales y medioambientales en la contratación y compra pública.

- Incorporar la Responsabilidad Social Corporativa como criterio de valor para la concesión de ayudas públicas.

- Generar un sistema de beneficios fiscales asociados al desarrollo de acciones de responsabilidad social.

- Crear instrumentos de deliberación y concertación inspirados en la responsabilidad social.

- Realizar acciones para difundir la responsabilidad social y para sensibilizar a las organizaciones en el desarrollo de acciones afines. 
- Participar activamente en organismos multilaterales con el fin de facilitar, incentivar y promover instrumentos y mecanismos que favorezcan una actuación responsable con independencia del entorno geográfico en el que operen las organizaciones. 


\subsection{LA RESPONSABILIDAD SOCIAL CORPORATIVA EN ESPAÑA}

\subsubsection{Estado de la Responsabilidad Social Corporativa en España}

Durante los primeros años del siglo XXI la Responsabilidad Social Corporativa ha adquirido relevancia y aceptación social en España.

Uno de los ámbitos en los que se refleja esta mayor importancia de la responsabilidad social es en la creación de espacios públicos de debate. Como es el caso del "Foro de Expertos en Responsabilidad Social de las Empresas", constituido el 17 de marzo de 2005, por iniciativa del Ministerio de Trabajo y Asuntos Sociales, con la participación de representantes de varios Ministerios y de expertos provenientes de grupos empresariales, organizaciones de la sociedad civil y de la Universidad (Foro de Expertos sobre RSE, 2007).

Otro aspecto en el que se refleja esta mayor relevancia de la Responsabilidad Social Corporativa es en la aparición de organismos implicados en el desarrollo de la Responsabilidad Social Corporativa. Hemos indicado algunos de los más representativos: 
Organismo

Objeto

Foro para la Evaluación de la Gestión Ética (Forética)

Observatorio de

Responsabilidad Social

Corporativa

\begin{tabular}{l|}
\hline Observatorio de Economía \\
Solidaria
\end{tabular}

Solidaria

Fundación Empresa y

Sociedad

-

\begin{tabular}{|l|}
\hline Fundación Entorno \\
\hline
\end{tabular}

Club de excelencia en sostenibilidad

\begin{tabular}{|l|l|} 
& \multicolumn{1}{|c|}{$\begin{array}{l}\text { excelencia de las empresas y al progreso } \\
\text { de la sociedad (Club de Excelencia en } \\
\text { Sostenibilidad, 2002). }\end{array}$} \\
\hline $\begin{array}{l}\text { Dirección } \\
\text { Asociación Española de }\end{array}$ & $\begin{array}{l}\text { Promover el estudio y la aplicación de la } \\
\text { ética en el ámbito de las organizaciones, } \\
\text { los negocios y la economía (Ética, Economía } \\
\text { y Dirección, 1987). }\end{array}$ \\
\hline $\begin{array}{l}\text { Administración de } \\
\text { Empresas }\end{array}$ & $\begin{array}{l}\text { Impulsar las buenas prácticas en gestión } \\
\text { empresarial (Asociación Española de } \\
\text { Contabilidad y Administración de Empresas, 1979). }\end{array}$ \\
\hline
\end{tabular}

Cuadro 11: Algunos de los organismos más representativos implicados en el desarrollo de la Responsabilidad Social Corporativa. Fuente: elaboración propia.
- Fomentar la cultura de la gestión ética y la responsabilidad social (Forética, 1999).

- Potenciar la responsabilidad social de las empresas en el núcleo de la sociedad (Observatorio de Responsabilidad Social Corporativa, 2004).

- Favorecer el desarrollo social, económico y sostenible a través de soluciones y herramientas (Observatorio de Economía Solidaria, 2004).

- Generar cambios relevantes para mejorar la realidad de las personas desfavorecidas (Fundación Empresa y Sociedad, 1995).

Trabajar con los líderes empresariales abordando los retos del desarrollo sostenible como oportunidades de negocio (Fundación Entorno, 1995).

- Impulsar la sostenibilidad, desde el ámbito empresarial, compartiendo y divulgando prácticas para contribuir a la excelencia de las empresas y al progreso de la sociedad (Club de Excelencia en Sostenibilidad, 2002). ética en el ámbito de las organizaciones, los negocios y la economía (Ética, Economía y Dirección, 1987).

Impulsar las buenas prácticas en gestión empresarial (Asociación Española de Contabilidad y Administración de Empresas, 1979).
Promover el estudio y la aplicación de la 
El impulso que se ha concedido a la formación especializada en responsabilidad social también denota el mayor interés por esta materia. Las universidades y escuelas de negocio han incluido la Responsabilidad Social Corporativa en sus programas de estudio 0 han incrementado el número de horas dedicadas a la materia (Mubabu, 2010).

Además también se han consolidado en el territorio nacional los sistemas de evaluación y reconocimiento de la orientación favorable hacia la responsabilidad social. Un ejemplo de este avance se encuentra en el ranking desarrollado por MERCO (2013), inspirado en el The World's Most Ethical Companies (Ethisphere Institute, 2013), para premiar la responsabilidad social en las empresas. 0 en el Informe Reporta, realizado anualmente por la agencia especializada en reputación corporativa Deva para evaluar el nivel de transparencia informativa que presentan las organizaciones (Informe Reporta, 2010).

Por otra parte España también se ha beneficiado en materia de responsabilidad social de los resultados favorables obtenidos por las ONG en España, que han generado un efecto "palanca". Su actuación sobre las empresas, directamente o a través de su capacidad de influencia sobre la sociedad y el gobierno, ha generado que las organizaciones desarrollen una actuación responsable de mayor calado que el que se habría obtenido si las ONG hubieran aplicado directamente sus recursos (Duran, 2005). 
También representa un indicador del avance de la responsabilidad social en territorio español la expansión del consumo responsable. Este consumo está caracterizado por valores característicos o afines a la responsabilidad social como la solidaridad, el respeto por los derechos humanos, el multiculturalismo o la ecología (Llopis, 2009).

Un ejemplo significativo de este tipo de consumo es el que hace referencia a las Inversiones Socialmente Responsables (ISR). Hasta hace muy poco tiempo este mercado ha sido anecdótico, tanto en volumen como en calidad de productos (Vázquez, 2006). Sin embargo ya es común en mercados maduros y altamente competitivos que las sociedades financieras, especialmente las cooperativas de crédito y las cajas de ahorro, ofrezcan productos especializados de este tipo (Dopacio, Valor y García, 2007).

Otro rasgo que también representa la relevancia que ha adquirido la responsabilidad en España es el desarrollo de grandes iniciativas de comunicación a favor de un desarrollo sostenible. Un ejemplo de iniciativas de este tipo se encuentra en la campaña "El Desarrollo Sostenible", desarrollada en el 2006 por la Fundación Entorno y 16 grandes empresas (Europa Press, 2006).

Por otra parte, la responsabilidad social también ha adquirido una considerable relevancia en el ámbito empresarial español, algo que algunos expertos (Duran, 2005) explican por las conexiones de redes de empresas y de cadenas de suministros. 
Las grandes empresas han presentado algunos aspectos positivos pero también otros mejorables.

Un aspecto que hemos destacado de la actuación en materia de responsabilidad social de las grandes organizaciones es el incremento de su publicación de memorias de sostenibilidad (Moneva y Ortas, 2009; Vaz, Fernández-Feijóo y Ruiz, 2012). Este aspecto refleja el interés de estas empresas por difundir su actuación social.

Además, las unidades organizativas que se ocupan de la responsabilidad social en las grandes empresas españolas se han integrado en las direcciones de reputación corporativa y han estado cercanas a su presidencia (Duran, 2005). Esto ha supuesto la concesión de un gran valor estratégico a la responsabilidad social pero, por otra parte, también ha implicado que los decisores sobre esta materia sufran un mayor desgaste.

Por otra parte, las organizaciones han apostado por la responsabilidad social como parte de la gestión del riesgo corporativo. La responsabilidad social se ha integrado en la dinámica de las organizaciones con el objetivo de evitar, en la medida de lo posible, las oscilaciones en los mercados de valores (Duran, 2005).

De todos modos también hemos indicado algunos aspectos en los que se podría mejorar la actuación de las grandes organizaciones en materia de responsabilidad social. 
Algunos investigadores han denunciado falta de transparencia en la comunicación. Algunos estudios han detectado carencias tanto en el nivel de transparencia que se ofrece como en la accesibilidad a la información que se produce (García, 2011). Otras investigaciones, como la desarrollada con empresas del Ibex 35 sobre derechos humanos (Cuesta, Valor y Holgado-Tello, 2011), concluyeron que la inmensa mayoría de las empresas no explicaban cuáles eran sus sistemas de gestión y sus procedimientos para asegurar un nivel de desempeño de los derechos humanos.

También se han declarado planteamientos distorsionados en el ámbito de la comunicación sobre la actuación realizada en materia de responsabilidad social. Se han dado casos de organizaciones que han indicado la realización de acciones sociales en beneficio de diferentes públicos (como los clientes, los proveedores o los colaboradores), cuando en realidad resultaban ser actuaciones necesarias para que las empresas desempeñaran su cometido (Hernández, 2011).

Además también se ha indicado que el compromiso con las exigencias en materia de responsabilidad social no ha sido ni generalizable ni satisfactorio. En el estudio realizado con las empresas del Ibex 35 sobre derechos humanos (Cuesta, Valor y Holgado-Tello, 2011) se demostró que la gestión realizada por las empresas en este campo no satisfacía las demandas de las sociedad. Aproximadamente la mitad de las empresas no les daba importancia y el resto 
de organizaciones se solía centrar en los resultados y no en los procesos.

En relación con la actuación de las PYMES en materia de responsabilidad social es necesario indicar que han desarrollado, como era de esperar, una actuación menor respecto a las grandes empresas. Este aspecto es lógico ya que las organizaciones de este tamaño no han manejado los elevados presupuestos que gestionan las grandes empresas.

De todos modos las PYMES han mostrado una receptividad favorable hacia la responsabilidad social porque la imagen corporativa ha influido en la competitividad de las PYMES al favorecer la llegada de clientes y trabajadores, en su mayor parte, de su área geográfica más próxima. Además, como hemos indicado en el bloque dedicado a las actitudes y la responsabilidad social, la Responsabilidad Social Corporativa de este tipo de empresas refleja, a menudo, los valores personales de quien ostenta la propiedad, lo que garantiza una implicación de la empresa en el campo de la responsabilidad social (Cox, 2009).

Estos aspectos explican los resultados de algunos estudios (Mubabu, 2010) que indican que las PYMES han desarrollado algunas prácticas de responsabilidad social, en mayor medida, que las grandes empresas: 
Prácticas en materia de responsabilidad social más desarrolladas por las PYMES que por las grandes empresas

- Definir de forma clara los valores y las normas de conducta de la empresa.

- Ofrecer oportunidades de formación para la gente de la comunidad (aprendizaje o prácticas para jóvenes o discapacitados).

- Ofrecer información clara y precisa sobre sus productos y actividades a sus clientes, proveedores, comunidad local, etc.

- Ofrecer un buen equilibrio entre la vida privada y el trabajo a sus empleados.

- Tomar medidas adecuadas para proporcionar suficiente protección a los empleados en materia de seguridad, salud y protección social.

Cuadro 12: Prácticas en materia de responsabilidad social más desarrolladas por las PYMES que por las grandes empresas. Fuente: Mubabu (2010).

Por otra parte también es necesario indicar que el desarrollo hacia la responsabilidad social no ha sido homogéneo en todos los sectores.

Hemos recogido resultados de investigaciones realizadas en dos sectores con alta repercusión social que reflejan esta disparidad en la implicación en materia de Responsabilidad Social Corporativa: medios de comunicación y universidades.

Los medios de comunicación han mostrado una insuficiente orientación hacia la responsabilidad social. Un estudio realizado en la comunicación desarrollada a través de la televisión, ha indicado que es necesaria una mejora en la orientación social de este medio que conlleve 
la adopción de criterios comunes para todas las cadenas (Delgado y Olarte, 2009).

Sin embargo se han experimentado avances significativos en la Universidad. La Responsabilidad Social Universitaria (RSU) no solo se ha ofrecido como contenido formativo sino que también se ha integrado en la institución. Este desarrollo se ha producido en la Universidad de Zaragoza, la Universidad Politécnica de Madrid, la Universidad de Andalucía o la Universidad de Santiago de Compostela en la que se creó un plan de sostenibilidad, incluyendo la responsabilidad social en los tres ejes principales de su estructura: docencia e investigación, planificación de la gestión y evaluación, y participación y sensibilización.

En relación con la colaboración de las empresas con los grupos de interés, hemos de catalogarla como deficiente. Se han realizado estudios que han demostrado que el trabajo conjunto de organizaciones y stakeholders para desarrollar instrumentos que permitan implantar y desarrollar la responsabilidad social en las empresas ha sido insuficiente (Duran, 2005).

Además también se ha denunciado que la existencia, desde el ámbito empresarial, de una orientación lucrativa hacia la responsabilidad social. Los criterios que han venido impulsando la inversión en responsabilidad social de 
las organizaciones españolas no han estado basados en el altruismo, sino en el retorno esperado de la inversión (García, 2011).

Esta realidad no se ha correspondido con las sugerencias de expertos en responsabilidad social, como Trillo (2010), para quienes la mejor inversión en responsabilidad social es la que se logra a través de las personas que integran las organizaciones. Su implicación en este tipo de políticas desde el convencimiento personal constituye un rasgo favorable de distinción en el mercado.

Por otra parte, se ha detectado una oposición a la creación de normas o sistemas de gestión empresarial en el esfera de la responsabilidad social en el ámbito empresarial. Las organizaciones han percibido las normas o sistemas de gestión como una imposición sobre el modo de actuación en su dinámica, por lo que han apoyado en mayor medida las guías orientadoras (Duran, 2005).

\subsubsection{Regulación de la Responsabilidad Social Corporativa en España}

Los dos modelos de informes sobre responsabilidad social con mayor aceptación internacional, el propuesto por el Global Reporting Initiative y el impulsado por Naciones Unidas, también han tenido presencia en España. 
Las organizaciones españolas que han utilizado las directrices propuestas por el Global Reporting Initiative (GRI) para la elaboración de sus memorias de sostenibilidad en el 2013 han sido 403 (Global Reporting Initiative, 2013b).

En España las Naciones Unidas también han promovido el Global Compact, pero en este caso a través de la Red Española de Pacto Mundial. El número de organizaciones participantes en el pacto en el 2012 ha sido de 2016, de las que 1382 han sido PYMES y 303 grandes empresas (Red Pacto Mundial España, 2013b, 30).

La red española, una de las primeras plataformas nacionales del Pacto Mundial, se ha constituido en un referente por diversos motivos. En primer lugar porque ha sido la red local con mayor número de firmantes. Además porque su modelo de gestión y su estructura organizativa ha sido de los más avanzados del Pacto Mundial. Por otra parte también ha destacado por el tipo de actividades y herramientas creadas para fomentar la implantación de los diez principios del Pacto Mundial entre las entidades firmantes. En este sentido ha sido reconocida como la red local con un funcionamiento más ejemplar e innovador en el desarrollo de herramientas para sus firmantes (Red Pacto Mundial España, 2013a).

En España también se han desarrollado modelos para la elaboración de los balances sociales dirigidos específicamente a las cooperativas. Como el desarrollado por HISPACOP (Confederación Española de Cooperativas de 
Consumidores y Usuarios) o el propuesto por la Organización Mundial del Trabajo (OIT), junto con la Asociación Nacional de Industriales (ANDI) y la Cámara Junior de Colombia Capítulo Antioquia $(\mathrm{JCl})$, en el que se contempló como una inversión, y no como un gasto, el dinero empleado en la responsabilidad social (Server y Villalonga, 2005).

En España también se han alcanzado una extensa cantidad de acuerdos de estandarización con la etiqueta de "normas", reflejo de la relevancia que ha adquirido la Responsabilidad Social Corporativa en España en el siglo XXI (Mozas y Puentes, 2010).

Una de las normas más destacadas ha sido la SGE21, desarrollada por Forética. En términos generales se trata de un sistema de gestión ética y socialmente responsable. Proporciona a la empresa un sistema enfocado a la integración voluntaria de sus preocupaciones sociales y medioambientales en las operaciones comerciales y en las relaciones con sus grupos de interés, de un modo flexible y compatible con las características de cada organización.

Otra norma con relevancia en el ámbito español es la UNE 165010:2009 EX desarrollada por AENOR. Este documento ofrece pautas para desarrollar una gestión ética y social de las empresas a través de herramientas como instrumentos financieros y éticos, sistemas de gestión de calidad y códigos éticos profesionales. 
En España también se han promulgado principios y recomendaciones en materia de responsabilidad social. Como ejemplo hemos señalado el "Marco Conceptual de la Responsabilidad Social Corporativa", diseñado por la Comisión de Responsabilidad Social Corporativa de la Asociación Española de Contabilidad y Administración de Empresas (AECA). Este marco teórico persigue ser un documento base, con enfoque práctico, para construir guías de actuación empresarial.

Además también se han desarrollado códigos de conducta empresarial vinculados al campo de la Responsabilidad Social Corporativa en el ámbito español.

Uno de ellos ha sido el Código Olivencia o Código de Buena Conducta (1998), que fue diseñado para garantizar un comportamiento más transparente del Consejo de Administración y una mejor defensa de los intereses de todos los accionistas (Velasco, Puentes y Vilar, 2010).

Otro ejemplo es el Libro Blanco sobre la Contabilidad de España (2002), creado para ofrecer reflexiones y recomendaciones respecto a la transparencia informativa y a los mecanismos de refuerzo y control de la información emitida por las empresas emisoras de los valores (Gonzalo, 2003).

Otro modelo de actuación lo constituye el Informe Aldama (2003), desarrollado para ofrecer criterios y pautas sobre el gobierno de las sociedades con vistas a aumentar la 
transparencia y la seguridad en los mercados (García y Suárez, 2005).

En España también se han impulsado iniciativas públicas para legislar la responsabilidad social, pero no han tenido el impacto social esperado.

Una de las razones que se han esgrimido para explicar esta situación es que las acciones han sido desarrolladas de manera descoordinada $y$, en muchas ocasiones, sin continuidad por parte de las diversas administraciones autonómicas y locales.

Además se han producido fuertes presiones en contra de cualquier indicio de normalización, estandarización, verificación o simples políticas públicas de incentivos, que hayan podido desembocar en una normalización mínima sobre la Responsabilidad Social Corporativa, por una parte del sector empresarial. $Y$ este rechazo se ha producido pese a que la mayor parte de los países vecinos han venido desarrollando políticas que favorecen la Responsabilidad Social Corporativa, y se ha dado un mandato claro por parte de la Comisión y el Parlamento Europeo para actuar en este sentido (Vázquez, 2006).

Entre las iniciativas desarrolladas en el ámbito español hemos destacado la Ley de Economía Sostenible (2011) y el Proyecto de Ley de Transparencia, Acceso a Ia Información Pública y Buen Gobierno (2013) al considerar que reflejan el esfuerzo por favorecer el desarrollo de la responsabilidad social que se realiza desde el Gobierno. 
La Ley de Economía Sostenible (2011) es un compendio regulatorio que afecta a los más diversos ámbitos económicos y sociales, y que tiene por objeto "introducir en el ordenamiento jurídico las reformas estructurales necesarias para crear condiciones que favorezcan un desarrollo económico sostenible".

Esta ley incide, de modo directo, en la promoción de la Responsabilidad Social Corporativa por parte de la Administración (tanto en empresas grandes como en PYMES), impulsa la autoevaluación (es decir, persigue que las empresas se conciencien sobre esta disciplina), fomenta la transparencia (en la que se exige indicar si la información difundida está avalada por una tercera parte), e implica a las empresas y entidades públicas (Diego, 2011):

Secciones de la Ley de Economía Sostenible (2011) que hacen referencia directamente a aspectos de responsabilidad social

\begin{tabular}{|l|l|}
\hline \multicolumn{1}{|c|}{ Sección } & \multicolumn{1}{c|}{ Contenido } \\
\hline & $\begin{array}{l}\text { Hace referencia a la promoción de la Responsabilidad } \\
\text { Social Corporativa por parte de la Administración } \\
\text { Pública, tanto en empresas grandes como en medianas } \\
\text { y pequeñas. }\end{array}$ \\
Artículo 39. & $\begin{array}{l}\text { Hace especial hincapié en la promoción de buenas } \\
\text { prácticas y en el análisis de los efectos de la } \\
\text { Punto 1. }\end{array}$ \\
$\begin{array}{l}\text { Responsabilidad Social Corporativa sobre la } \\
\text { competitividad. }\end{array}$ \\
$\begin{array}{l}\text { Indica que el Gobierno pondrá a disposición de las } \\
\text { empresas una herramienta de autoevaluación en } \\
\text { Responsabilidad Social Corporativa acorde con los } \\
\text { estándares internacionales en la materia. }\end{array}$ \\
\hline
\end{tabular}




\begin{tabular}{|c|c|}
\hline $\begin{array}{l}\text { Artículo } 39 . \\
\text { Punto } 2 .\end{array}$ & $\begin{array}{l}\text { Hace alusión a que el objetivo de esta herramienta es la } \\
\text { autoevaluación. } \\
\text { Indica que la empresa ha de informar sobre: } \\
\text { - } \text { - buensparencia en la gestión, } \\
\text { - compromiso con lo local y el medio ambiente, } \\
\text { - } \text { respeto a los derechos humanos, } \\
\text { - mejora de las relaciones laborales, } \\
\text { - integración de la mujer, } \\
\text { - igualdad efectiva entre mujeres y hombres, } \\
\text { - igualdad de oportunidades y accesibilidad universal } \\
\text { - de las personas con discapacidad, } \\
\text { - y consumo sostenible. }\end{array}$ \\
\hline $\begin{array}{l}\text { Artículo } 39 . \\
\text { Punto } 3 .\end{array}$ & $\begin{array}{l}\text { Alude a la posibilidad de que las empresas hagan } \\
\text { públicos sus resultados en materia de Responsabilidad } \\
\text { Social Corporativa a través de un informe. } \\
\text { Se deberá especificar si la información que contiene está } \\
\text { avalada o no por una tercera parte. }\end{array}$ \\
\hline $\begin{array}{l}\text { Artículo } 39 . \\
\text { Punto } 4 .\end{array}$ & $\begin{array}{l}\text { Expone la obligación del Gobierno de facilitar al Consejo } \\
\text { Estatal de Responsabilidad Social Corporativa los } \\
\text { recursos necesarios para que desarrolle sus funciones. }\end{array}$ \\
\hline Artículo 34. & $\begin{array}{l}\text { Hace referencia a que las sociedades mercantiles } \\
\text { estatales y las entidades públicas empresariales } \\
\text { adscritas a la Administración General del Estado } \\
\text { adaptarán sus planes estratégicos a la nueva ley en un } \\
\text { plazo máximo de un año a partir de su entrada en vigor, } \\
\text { de tal forma que contemplen: } \\
\text { - la elaboración de memorias de sostenibilidad, } \\
\text { - la orientación de la gestión medioambiental hacia el } \\
\text { EMAS (Eco-Management and Audit Scheme o } \\
\text { Reglamento Comunitario de Ecogestión y } \\
\text { Ecoauditoría -es un sistema de gestión ambiental } \\
\text { desarrollado por la Unión Europea-), } \\
\text { - y el favorecimiento de principios y prácticas de } \\
\text { Responsabilidad Social Corporativa, en especial } \\
\text { aquellos relativos a la promoción de: } \\
\text { · la integración de la mujer, } \\
\text { · la igualdad efectiva entre mujeres y hombres, } \\
\text { · y la plena integración de las personas con } \\
\text { discapacidad. }\end{array}$ \\
\hline
\end{tabular}

Cuadro 13: Secciones de la Ley de Economía Sostenible (2011) que hacen referencia directamente a aspectos de responsabilidad social. Fuente: elaboración propia. 
El Proyecto de Ley de Transparencia, Acceso a la Información Pública y Buen Gobierno (2013) ha formado parte, de acuerdo con el Director General de Trabajo Autónomo, Economía Social y Responsabilidad Social de las Empresas, Miguel Ángel García Martín, del Plan Nacional de Responsabilidad Social de las Empresas que se esperaba poner en marcha en 2013 por parte del ejecutivo español (Jaumà, 2013). 


\section{2 - ACTITUDES Y VALORES}





\subsection{DELIMITACIÓN TEÓRICA DE LAACTITUD}

\subsubsection{Concepto y características de la actitud}

Una definición clásica y orientadora de investigaciones posteriores es la de Allport $(1935,810)$, quien ha establecido que la actitud es "un estado mental y nervioso de disposición, adquirido a través de la experiencia para responder, que ejerce una influencia, directiva o dinámica, sobre las respuestas del individuo".

Esta definición ha puesto el acento en que las actitudes son disposiciones de comportamiento, por tanto se trata de predisposiciones habituales, que tienen un fundamento fisiológico en conexiones nerviosas determinadas y que se adquieren a través de la experiencia.

Posteriormente han aparecido definiciones en las que se ha concedido una mayor importancia al aspecto cognitivo de la atención, aunque manteniendo la idea de que las actitudes son predisposiciones de conducta y que, por tanto, actúan como fuerza del comportamiento humano.

Por ejemplo Rokeach ha propuesto que la actitud es "una organización de creencias relativamente permanentes que predisponen a responder de un modo preferencial ante un objeto o situación" (Rokeach, 1968, 112). 
También han aparecido definiciones en las que se ha destacado el carácter afectivo de la actitud.

Por ejemplo Triandis $(1997,2-3)$ ha sostenido que la actitud "es una idea cargada de emotividad que predispone una clase de acciones a una clase particular de situaciones".

Y Myers $(2011,675)$ ha indicado que las actitudes son "sentimientos, a menudo influidos por nuestras creencias, que predisponen nuestra reacción ante los objetos, las personas y los acontecimientos".

Con carácter general adoptaremos la definición que ha propuesto Pastor Ramos, para quien las actitudes son disposiciones relativamente estables, de los dinamismos psíquicos en su totalidad, hacia un objeto psicosocial cualquiera, sea real o ficticio (Pastor, 1978).

Destacamos de su propuesta el hecho de que las actitudes puedan estar asociadas a objetos intangibles.

De acuerdo con la literatura especializada las actitudes, como evaluaciones de prácticamente cualquier aspecto del mundo social, presentan rasgos específicos.

Por una parte las actitudes presentan un carácter ambivalente. Algunos investigadores han indicado que las evaluaciones que se realizan de objetos, temas, personas 0 eventos no son siempre uniformemente negativas o positivas y con frecuencia están mezcladas (Priester y Petty, 2001; Thompson, Zanna y Griffin, 1995). 
De acuerdo con este rasgo, la valoración de los líderes ante la Responsabilidad Social Corporativa puede no ser uniforme, ya que puede estar formada tanto por aspectos que se valoren de forma positiva, como por cuestiones que se valoren de manera negativa.

Otro aspecto característico de las actitudes es que, una vez que están formadas, son difíciles de cambiar. Para hacer referencia a este aspecto, algunos investigadores han utilizado el término "estabilidad" de la actitud, por tratarse de constructos relativamente estables en el tiempo y de una situación a otra (Llopis y Ballester, 2001).

Este rasgo de la actitud indica que una predisposición favorable hacia la responsabilidad social, en líderes vinculados a organizaciones que no desarrollan acciones en este ámbito, podría ser un buen indicador de que dichas acciones se realizarán en el futuro.

No obstante la fuerza de la estabilidad de la actitud hacia la responsabilidad social, especialmente ante posibles informaciones que la contravengan (como hemos indicado posteriormente en el apartado correspondiente al origen de las actitudes), está relacionada con su origen.

Se adquieren a través del aprendizaje. Aunque algunos autores (McGuire, 1969) han sugerido que las características genéticas y fisiológicas pueden contribuir a la formación de las actitudes, se ha dado muy poca importancia a los aspectos de formación de las actitudes 
que no sean aprendidos. En este sentido hemos asumido que las personas aprendemos a que nos gusten o nos desagraden todo tipo de cosas (Lamberth, 1989).

Este aspecto de la actitud, que se origine a través del aprendizaje, unido a la gran repercusión mediática que ha adquirido la Responsabilidad Social Corporativa desde finales del siglo XX, podría explicar la elevada aceptación que la mayoría de los líderes empresariales han venido mostrando hacia la responsabilidad social en los comienzos del siglo XXI.

Además el hecho de que las actitudes se aprendan nos ha permitido hipotetizar que de mantenerse el impulso mediático y de no agravarse la crisis económica vigente, podría seguir incrementándose en el futuro el grado de aceptación de la responsabilidad social en los líderes empresariales.

\subsubsection{Componentes de la actitud}

Se ha indicado que dentro de las actitudes existen tres componentes que forman parte del espacio de la actitud: cognitivo, afectivo y conductual (Campbell, 1963; Thurstone, 1928).

Para muchos investigadores estos tres componentes de la actitud están interrelacionados (Arnaw, 2010; Bohner y Wänke, 2002; Erwin, 2001; Johnson, Maio y Smith-McLallen, 
2005; Montané, Jariot y Rodríguez, 2007) constituyendo un todo (Llopis y Ballester, 2001).

De todos modos también hemos considerado que es necesario tener presente la indicación aportada por Eagly y Chaiken (1993; 1998; 2005; 2007), para quienes existen los tres componentes pero no como constitutivos de la actitud, sino como resultantes de una respuesta evaluativa global en la que aportan información a veces por separado y a veces de manera interactiva.

Hemos desarrollado a continuación aspectos específicos de cada uno de los tres componentes.

Se ha establecido que el componente cognitivo hace referencia a que las actitudes, en su dependencia de otras estructuras cognitivas superiores o más generales, manifiestan una dimensión cognitiva que implica un conocimiento de la realidad (Llopis y Ballester, 2001) y nutre las ideas y creencias de las personas (Gómez, Vidal, Fawaz y Ysern, 2002).

Sin esta dimensión las otras dos dimensiones carecerían de base para realizar la valoración, positiva o negativa, de la acción y de sus consecuencias (Llopis y Ballester, 2001).

En el ámbito de la Responsabilidad Social Corporativa hemos considerado que se trata de un componente esencial, al ser el que más presencia tiene en la empresa. La disposición favorable que los líderes han venido presentando 
hacia la responsabilidad social es deudora, en gran medida, de toda la información favorable sobre la responsabilidad social que los líderes empresariales han recibido en el ejercicio de su rol procedente de:

- La legislación favorable a la Responsabilidad Social Corporativa.

- Los organismos sin carácter legislativo que impulsan el desarrollo de la responsabilidad social desde todo tipo de ámbitos: derecho laboral, progreso europeo, contabilidad, sostenibilidad...

- Las instituciones que se dedican a la formación de directivos y profesionales de todo tipo, en las que ya es habitual encontrarse con bloques de materias especializadas en la responsabilidad social o en materias concretas que abordan este aspecto de modo exclusivo.

- Los clientes de las empresas, que trasladan directamente a las organizaciones la necesidad de que estas se responsabilicen de su posible impacto sobre el progreso social, económico y medioambiental.

- Los sectores empresariales, que desde las asociaciones de referencia, trasladan a las empresas asociadas la demanda de responsabilidad social que se exige a cada sector en concreto.

- Los proveedores sensibilizados con la responsabilidad social, que tienen interés en conocer las consecuencias sociales, 
medioambientales y económicas de la cadena de valor que impulsan.

- Los medios de comunicación, que trasladan el sentir de los principales actores involucrados en el fomento de la responsabilidad social.

- Y todos los grupos de interés con los que las organizaciones establecen algún tipo de diálogo y que están sensibilizados con el impacto de las empresas: lobbies, competidores, accionistas, comunidad local...

Se ha establecido que el componente afectivo muestra la dimensión del sentimiento de agrado o desagrado respecto al objeto de las actitudes. Hace referencia, por tanto, a los sentimientos y emociones de las personas (Gómez, Vidal, Fawaz y Ysern, 2002).

Los conocimientos y las creencias, aun siendo fundamentales, no son suficientes para explicar la predisposición a la conducta porque es necesaria una evaluación que determinará la posición afectiva frente a dichos contenidos. Su importancia en la configuración de la actitud es tal que este componente ha sido identificado por algunos autores como la misma actitud (Ajzen y Fishbein, 1980; Fishbein y Ajzen, 1975).

Hemos entendido que en el ámbito de la Responsabilidad Social Corporativa este componente es esencial porque implica que los líderes no solo acepten los presupuestos básicos de la Responsabilidad Social 
Corporativa sino que a nivel afectivo, auténtico motor actitudinal, estén a favor de su desarrollo.

De los diversos aspectos que tienen un peso importante en contra de que las organizaciones presenten una disposición afectiva hacia la responsabilidad social hemos destacado los siguientes:

- La visión clásica en el ámbito de la administración y dirección de empresas relacionada con que la única responsabilidad de las organizaciones es la maximización del beneficio. En el capítulo previo dedicado a la responsabilidad social hemos indicado que este ha sido un rasgo predominante en alguna de las etapas de la historia de la Responsabilidad Social Corporativa.

- La crisis económica que se ha producido desde finales de la primera década del siglo XXI, que ha impulsado a las organizaciones a contemplar la responsabilidad social como un aspecto de menor relevancia respecto a otros cuando, como hemos reflejado en el capítulo sobre responsabilidad social, se trata de un compromiso vital, según algunos expertos, para asegurar la viabilidad del progreso económico.

- El enorme peso de los valores materialistas en las sociedades occidentales, que ha reducido el impulso por contribuir a la conquista de beneficios sociales como en el caso, por 
ejemplo, de la atención a los grupos más desfavorecidos. No obstante, se han recogido indicios de que las organizaciones cada vez están más preocupadas por el bienestar de sus públicos internos aunque sería interesante profundizar en la naturaleza de la disposición con la que adoptan estas medidas: desde la preocupación por el bienestar de los colaboradores o desde el interés por aumentar su productividad.

- El gran arraigo de valores individualistas en las sociedades occidentales que fomentan una visión competitiva en el ámbito empresarial que, en muchos casos, colisiona frontalmente con el carácter colaborativo que caracteriza a muchas de las acciones propias de responsabilidad social.

Para estimular una evaluación más favorable de la Responsabilidad Social Corporativa por parte de los líderes empresariales hemos entendido que resultaría recomendable impulsar acciones que fomentasen una visión de su propia experiencia laboral que no estuviera asociada solo a su satisfacción profesional, sino también a su satisfacción personal. De este modo se favorecería la mayor aceptación de disposiciones colaborativas, que son esenciales para el desarrollo de acciones de responsabilidad social.

Además también hemos considerado que sería interesante ampliar el concepto "beneficio empresarial" a otros ámbitos esenciales que garantizan el desarrollo viable 
de una organización, como por ejemplo la felicidad de todos sus integrantes.

Por otra parte hemos entendido que el impulso de una gestión empresarial involucrada en el desarrollo personal, profesional, económico, social y medioambiental de todos los grupos de interés con los que una organización se relaciona también contribuiría a crear una disposición evaluativa más favorable en los líderes.

También hemos creído que sería interesante desarrollar acciones dirigidas a los líderes que favorecieran su comprensión de la Responsabilidad Social Corporativa como una inversión rentable, y no un como gasto, que debe integrarse en la estrategia de negocio de las organizaciones porque favorece su posición en el mercado.

La revisión de la literatura científica ha permitido concluir que el componente comportamental constituye la tendencia o disposición a actuar respecto a los referentes, es decir, en relación con los objetos, personas o situaciones objeto de la actitud (Llopis y Ballester, 2001).

Es, por tanto, el componente que da información sobre la disposición conductual de las personas (Gómez, Vidal, Fawaz y Ysern, 2002).

Lamberth ha indicado que el peso del componente comportamental en el valor de la actitud es menor que en el caso de los componentes cognitivo y afectivo (Lamberth, 1989). Esta es una de las razones que explican que la disposición comportamental asociada a las actitudes no 
siempre se manifieste. A veces se refleja en el comportamiento humano, pero a veces no (Fazio y RoskosEwoldson, 1994; Tesser, Martin y Cornell, 1996). Hemos revisado este aspecto en mayor profundidad en el apartado dedicado a las actitudes y a la conducta.

En materia de responsabilidad social, este componente aporta una explicación significativa del por qué la elevada aceptación de la Responsabilidad Social Corporativa por parte de los líderes empresariales, en muchos casos, no se ha traducido en el desarrollo de acciones de responsabilidad social en las organizaciones en las que estos desarrollan su labor.

Como hemos indicado, una disposición conductual favorable no siempre se traduciría en acciones de responsabilidad social porque el componente comportamental tiene un peso menor que el componente cognitivo y afectivo en el comportamiento. Además la aplicación de planteamientos sociales por parte de los líderes empresariales siempre estará en dependencia de otros factores externos a la propia actitud, como por ejemplo la existencia de una coyuntura económica favorable para el desarrollo de acciones en materia de responsabilidad social.

De todos modos una evaluación favorable de la responsabilidad social por parte de los líderes empresariales resulta ser un indicativo bastante fiable de que las organizaciones se involucrarán en acciones de 
Responsabilidad Social Corporativa, en un futuro, siempre que las circunstancias sean propicias.

\subsubsection{Funciones de la actitud}

En un sentido amplio de la funcionalidad, se ha indicado que las actitudes facilitan la adaptación al ambiente (Eagly \& Chaiken, 1998). Muchos autores han sostenido que esta capacidad general de la actitud, la de favorecer la adaptación del hombre al entorno en el que se encuentra, es su función más importante (Smith, Bruner y White, 1956; Kelman, 1961, 1980).

Desde este punto de vista la actitud juega un rol esencial en la supervivencia del hombre al facilitar su adaptación a su entorno. La actitud ordena la relación simbólica que las personas establecemos con nuestro entorno para que nuestro yo se encuentre confortable en el espacio que le rodea. En este sentido el rol adaptativo de la actitud es mucho más relevante en la infancia del ser humano, donde la familia se constituye en una institución poderosa en la formación de actitudes, que en su edad adulta. Aunque en la edad adulta la actitud sigue desempeñando un rol esencial para que las personas nos adaptemos a las nuevas situaciones con las que nos encontramos.

Una de las nuevas situaciones con las que se han encontrado los líderes organizacionales ha sido la Responsabilidad Social Corporativa. Ante la responsabilidad 
social los líderes empresariales han tenido, están teniendo y tendrán que mostrar preocupación, impensable hace algunas décadas, por aspectos que van más allá de la obtención de beneficios económicos. Desde el ámbito de responsabilidad social las empresas también tienen que ocuparse de otros aspectos asociados a la obtención de estos beneficios en los que puedan tener un mayor o menor grado de responsabilidad, como es el caso de las externalidades (efectos indirectos de las actividades de consumo o producción).

Los máximos responsables empresariales, para hacer frente a esta situación, han tenido que desarrollar una actitud adaptativa hacia la Responsabilidad Social Corporativa que les evite una posición de conflicto.

Además de la función adaptativa, que presenta un carácter más general en la actitud, los investigadores han indicado que las actitudes también presentan otras funciones más específicas: evaluativa, cognitiva, autoexpresión y autodefensa, y de motivación a causar buena impresión

La función evaluativa hace referencia a que las actitudes permiten clasificar como positivo o negativo, y de forma casi inmediata, todos los estímulos con los que las personas se encuentran (Ito, Larsen y Smith, 1998). Las personas tenemos actitudes hacia los objetos del mundo real, ya que así sabemos lo que es conveniente realizar o lo 
que es preferible evitar (Bolívar, 95). Es decir, las actitudes facilitan la orientación de las personas en el entorno (Smith, Bruner y White, 1956).

En un experimento de laboratorio, Chen y Bardh (1999) demostraron que las evaluaciones positivas y negativas sirven para orientar a las personas hacia la aproximación y el rechazo respectivamente.

Los participantes expuestos a palabras positivas respondieron más rápido cuando fueron aleccionados para presionar una palanca hacia ellos que cuando fueron instruidos para presionarla en sentido contrario, mientras que en los participantes expuestos a las palabras negativas se observó el patrón inverso.

En el ámbito de la Responsabilidad Social Corporativa esta función indica que la evaluación positiva de la responsabilidad social implica, en cierto modo, una predisposición comportamental favorable.

La función cognitiva hace alusión a que las actitudes parecen operar como esquemas, ya que matizan fuertemente las percepciones que se tienen sobre temas, personas, objetos y grupos a los cuales hacen referencia. Por ejemplo las personas vemos como más convincente y adecuada la información que ofrece soporte a las propias actitudes que la información que las refuta (Munro y Ditto, 1997).

De igual modo, los seres humanos percibimos a las fuentes que proporcionan evidencia contraria a los propios 
puntos de vista como altamente dudosas (Giner-Sorolla y Chaiken, 1994, 1997).

En relación a la Responsabilidad Social Corporativa esta función indica que si se pretende que los líderes están receptivos hacia las propuestas que los diferentes organismos y estamentos realicen sobre la responsabilidad social, es importante que los líderes dispongan de una actitud previa favorable hacia la Responsabilidad Social Corporativa.

La función de autoexpresión y autodefensa hace referencia, por una parte, a que las actitudes permiten expresar los valores centrales o creencias de las personas. Por ejemplo, si para una persona ser políticamente liberal es crucial para su autoidentidad, encontrará relevante tener actitudes proambientales que le permitan expresar sus creencias centrales (Shavitt, 1989, 1990).

Por otra parte también hace alusión a que las actitudes ayudan a la gente a protegerse de información no deseada acerca de ellos mismos (Katz, 1960). Es decir las actitudes permiten proteger al yo ante las situaciones de inseguridad, ansiedad o frustración que se presentan en la vida (Smith, Bruner y White, 1956). Un ejemplo de este aspecto se encuentra en el caso de las personas que afirman estar en contra del prejuicio. Al hacer tales afirmaciones estas personas se protegen de verse a sí mismas como personas altamente prejuiciadas, lo que en realidad son (Katz, 1960). 
En relación con la Responsabilidad Social Corporativa la autoexpresión indica que cuanto más centrales sean las creencias de los líderes empresariales relacionadas con la responsabilidad social, mayor necesidad tendrán de expresar dichas creencias a través de actitudes favorables. Este aspecto representa una aspiración poderosa en el intento de consolidar en los líderes empresariales una actitud favorable hacia la Responsabilidad Social Corporativa. Si se consiguiera que los líderes identificaran su autoidentidad con la responsabilidad social, sería mucho más probable que las actitudes favorables hacia la Responsabilidad Social Corporativa se tradujeran en acciones.

Una posible acción que se podría desarrollar en este sentido sería impulsar una redefinición del estatus de empresario de éxito, en la que esta visión se asocie con el rasgo de empresario cuyos proyectos conllevan un importante progreso social, económico y medioambiental.

En relación con la autodefensa, una forma de utilizar este rasgo en beneficio de la responsabilidad social sería asociar la Responsabilidad Social Corporativa con el desarrollo personal de todas las personas que integran las organizaciones. De este modo la responsabilidad social podría convertirse en un instrumento para favorecer una visión más amable de la información personal que, en cada caso particular, no se desea escuchar. 
La función de motivación a causar buena impresión hace alusión a que a menudo las personas desean causar una buena impresión en otros, y una forma de hacerlo es expresar el punto de vista "correcto" en la situación en la que se encuentren (Chaiken, Giner-Sorolla y Chen, 1996).

En la medida en que las actitudes cumplen en mayor grado esta función, causan un impacto más fuerte en el procesamiento de la información social (Nihenhuis, Manstead y Spears, 2001).

Para algunos autores está función se relaciona con la autoestima porque el hecho de expresar actitudes "correctas" ayuda a las personas a sentirse superiores a los demás (Shavitt, 1989, 1990). De este modo, la satisfacción de la deseabilidad social a través de la actitud contribuiría a mantener o realzar los sentimientos de confianza hacia uno mismo.

En relación con la Responsabilidad Social Corporativa esta función indica que cuanto más consolidada esté, socialmente, una visión favorable de la responsabilidad social mayor interés tendrán los líderes empresariales en mostrar su actitud positiva hacia la misma y en realizar acciones que demuestren que en su organización se están "haciendo bien las cosas" en relación con el orden social establecido sobre Responsabilidad Social Corporativa. 


\subsection{ENFOQUES TEÓRICOS SOBRE EL ORIGEN DE LA ACTITUD}

A comienzos del siglo XXI los psicólogos sociales están de acuerdo en que las actitudes son consecuencia del aprendizaje.

A continuación hemos comentado cuatro modelos que explican el origen de la actitud: condicionamiento clásico, condicionamiento instrumental, modelado y funcionalismo.

\subsubsection{Condicionamiento clásico}

Este planteamiento ha defendido que las actitudes se pueden aprender a través de la asociación. Cuando un estímulo anteriormente neutro (EC) se empareja con un estímulo positivo o negativo (EI), producirá por sí mismo, con el tiempo, la respuesta emocional (RC) (Lamberth, 1989). O, en otras palabras, cuando un estímulo sucede regularmente a otro, el que sucede primero puede convertirse pronto en una señal para el que ocurre después.

Por ejemplo un niño ve a su madre frunciendo el ceño y mostrando otros signos de desaprobación cada vez que la madre se encuentra con un miembro de un grupo étnico específico. Al principio el hijo es neutral hacia las personas que integran este grupo y sus características visibles, como 
el color de la piel o su acento. Después comienza a asociar estas claves con las reacciones emocionales negativas de la madre $y$, finalmente, el niño comienza a reaccionar negativamente frente a estos estímulos (Baron y Byrne, 2005).

En el ámbito de la responsabilidad social este tipo de condicionamiento es de gran interés para consolidar actitudes favorables hacia la Responsabilidad Social Corporativa.

Un ejemplo de actuación basada en el condicionamiento clásico sería que todos los organismos y entidades interesados en impulsar la responsabilidad social fomentaran que los "primeros pasos" de los líderes empresariales en materia de Responsabilidad Social Corporativa contribuyeran a mejorar su situación en el mercado, y a favorecer la posición de todos los grupos de interés con los que se relaciona la entidad.

Obrando de este modo se podría estar reforzando en estos líderes la percepción de que el camino para conseguir el éxito empresarial está en la responsabilidad social, incluso aunque no se perciba directamente el éxito económico de futuras actuaciones en materia de Responsabilidad Social Corporativa.

Dentro de este planteamiento sobre el origen de la actitud también se ha constatado que se pueden establecer 
asociaciones efectivas de modo inconsciente y a través de la imaginación

Los estudios han indicado que el "condicionamiento clásico" puede suceder incluso por debajo del nivel de atención consciente. A este tipo de formación de actitudes se le denomina "condicionamiento subliminal".

Se han realizado experimentos para comprobar este supuesto. Uno paradigmático es el desarrollado en los años 50 en un cine de Nueva Jersey el que se incluyeron los mensajes subliminales "¿Tienes hambre? Come palomitas y bebe Coca-Cola" durante la proyección de la película Picnic. En los días en los que los mensajes fueron incluidos las ventas de palomitas se incrementaron en un 58\% y las de Coca-Cola en un $18 \%$. De todos modos los resultados de este estudio, que en su época generaron mucho revuelo, no pudieron ser replicados (Saegert, 1979).

En otro de los muchos estudios que se han realizado sobre este tema se crearon dos grupos que visionaban fotografías de una persona realizando actividades cotidianas. En el visionado también se mostraban fotografías de forma muy rápida que inducían sentimientos positivos, en un grupo, y negativos, en otro. Posteriormente ambos grupos mostraron sus opiniones hacia el desconocido. Los que habían sido expuestos a fotografías positivas reflejaron actitudes más favorables (Krosnick, Betz, Jussim y Lynn, 1992). 
Este tipo de condicionamiento también puede influir en la percepción favorable de los líderes empresariales sobre la responsabilidad social.

Para que esto ocurriera sería necesario que el contexto en el que se inscribe toda la información sobre responsabilidad social que reciben los máximos responsables empresariales, contexto que no siempre puede ser percibido conscientemente, contenga los estímulos favorables que se pretendan asociar a la Responsabilidad Social Corporativa: bienestar social, alegría, éxito...

Por ejemplo si las noticias sobre responsabilidad social que apareciesen en televisión fueran comentadas por presentadores que desprendan una simpatía o alegría especial, fueran ubicadas en bloques con noticias positivas o aparecieran siempre en secciones de publicaciones periódicas en las que siempre compartieran espacio con otra información que despierte este tipo de sentimientos, entre otras posibilidades, es posible que también se estuviera influyendo en fomentar una actitud más favorable hacia la responsabilidad social.

Bandura (1965) también ha defendido que, dentro de este enfoque, se puede producir el condicionamiento por delegación, es decir, por participación imaginada en la experiencia de otras personas. Desde este punto de vista, no es necesario que una persona experimente por sí misma el proceso de condicionamiento, ya que puede establecer la asociación a través de la observación del proceso 
experimentado por otra persona en el que participa, de forma imaginada, a través de la identificación.

Por ejemplo, la mayoría de las personas no necesitamos que nos atropelle un coche para aprender que no se puede cruzar una calle con precaución cuando hay mucho tráfico. La observación de que otra persona ha sido atropellada, o incluso haber oído decir que alguien ha sido atropellado, puede ser suficiente para tomar precauciones.

Hemos considerado que en el ámbito de la responsabilidad social este proceso es de enorme interés para la formación de actitudes favorables hacia la Responsabilidad Social Corporativa.

Si los líderes empresariales que han alcanzado el éxito desarrollando políticas de responsabilidad social también hicieran un reconocimiento público del valor de dichas políticas, es posible que se fomentara, de forma inmediata, la percepción de que la responsabilidad social es un factor de éxito empresarial en otros líderes.

\subsubsection{Condicionamiento instrumental}

Las investigaciones científicas también han indicado que las actitudes pueden ser aprendidas con la ayuda de un refuerzo, caso de conductas deseadas, o un castigo, caso de conductas no deseadas.

En el condicionamiento clásico el estímulo neutro inicial (EC) y el estímulo positivo o negativo (EI) están emparejados sea cual sea la conducta de la persona, 
mientras que en el condicionamiento instrumental el refuerzo o castigo solo se da cuando la persona ha emitido una determinada respuesta (Lamberth, 1989).

Por tanto este planteamiento se basa en la idea de que los comportamientos seguidos por resultados positivos se ven fortalecidos y tienden a repetirse, mientras que los comportamientos seguidos de resultados negativos son debilitados y, al final, suprimidos.

Por ejemplo, los padres (y los adultos) juegan un rol moldeando las actitudes de los más jóvenes al recompensarles con sonrisas, aprobaciones o abrazos, gestos que establecen las posiciones que los niños entienden como correctas. Esta es la razón por la que los seres humanos de hasta diez años de edad expresan posiciones políticas, religiosas o sociales muy similares a las de su familia (Baron y Byrne, 2005).

En el ámbito de la responsabilidad social hemos entendido que el condicionamiento instrumental tiene una especial importancia en la infancia porque es en esta edad, como hemos indicado anteriormente, cuando los hijos aprenden las actitudes de los padres de modo habitual.

En este sentido, la infancia sería la etapa idónea de la vida para reforzar las actitudes prosociales de los futuros líderes empresariales porque el esfuerzo que es posible realizar en personas adultas para reforzar actitudes favorables a la Responsabilidad Social Corporativa no garantiza los mismos resultados que se podrían obtener en 
las personas más jóvenes, aunque no por ello es una opción que deba descartarse.

Hemos incorporado algunos de los refuerzos positivos que, de realizarse iniciativas con esta orientación, podrían favorecer la creación de una actitud más favorable hacia la Responsabilidad Social Corporativa en los líderes empresariales:

- Subvenciones concedidas desde la administración para el desarrollo de acciones de responsabilidad social de alto riesgo financiero pero elevado beneficio social.

- Reconocimientos y menciones especiales relevantes, realizadas por los principales organismos y entidades del sector, en relación con prácticas de responsabilidad social que hayan tenido un gran impacto en el progreso social, económico y medioambiental.

- Reducciones fiscales de la Administración para aquellas organizaciones que tengan políticas de responsabilidad social de gran impacto.

- Invitaciones a foros internacionales de networking, por parte de organismos 0 instituciones internacionales vinculadas con la responsabilidad social, a las que solo podrían asistir líderes de organizaciones que desarrollen políticas de responsabilidad social de gran impacto. 
De todos modos, la involucración de las empresas en actuaciones como las comentadas también podría estar motivada, exclusivamente, por la búsqueda de beneficios económicos o de imagen. En este caso, este tipo de acciones no estarían reforzando actitudes favorables a la responsabilidad social aunque sí estarían impulsando acciones de Responsabilidad Social Corporativa.

Tal y como hemos comentado anteriormente, el momento idóneo para que este tipo de disposiciones prosociales cristalizaran sería la infancia. En este sentido se podrían realizar acciones como, por ejemplo, concursos de cuentos escritos en los que se valoren los resultados positivos del trabajo cooperativo. O concursos de cuentos escenificados por Internet, en los que se dé especial importancia especialmente a la capacidad para empatizar con los diferentes actores y actrices participantes. 0 , por ejemplo, clases en el propio medio natural en las que se profundice en la importancia de la armonía entre todos los elementos que lo integran para que se mantenga el equilibrio. 


\subsubsection{Modelado}

La literatura científica también ha indicado que las actitudes pueden ser aprendidas a través de la observación. Este tipo de aprendizaje sucede cuando las personas adquieren nuevas formas de comportamiento, simplemente, a través de la contemplación de las acciones de los demás (Bandura, 1982; 1983; 1987; 1997).

En este sentido, no es necesario reforzar una conducta para que esta sea aprendida. Las personas adquirimos patrones de conducta, y las actitudes conexas a ellos, a través de la simple observación de un modelo y la puesta en marcha de unos procesos cognitivos de asimilación y reproducción de la información.

Por ejemplo, cuando los padres previenen a sus hijos en contra de cosas que hacen, como cuando encienden un cigarrillo, la evidencia indica que los hijos a menudo aprenden a realizar lo que sus padres hacen y no lo que dicen. Incluso la exposición a los medios de comunicación hace que muchas personas menores de treinta años, que no se cuestionan el contenido de lo que perciben en los medios, adquieran actitudes producto de la exposición a los mismos (Baron y Byrne, 2005).

Bandura y Walters (1982) han indicado que cuando una persona es sometida a la influencia del modelo es necesario que se desarrollen una serie de procesos para que dicho 
modelo se convierta en un marco de referencia: la atención al modelo, la retención de la información simbólica, la reproducción motora y la motivación para atraer, retener y reproducir la conducta observada. Hemos incorporado a continuación el cuadro 14 con algunos clave aspectos asociados a cada proceso:

\begin{tabular}{|l|l|}
\multicolumn{1}{|c|}{ Procesos } & \multicolumn{1}{c|}{ Algunos aspectos clave asociados } \\
\hline Atención al modelo & $\begin{array}{l}\text { Capacidades sensoriales y de observación. } \\
\text { Nivel de excitación. } \\
\text { Capacidad para procesar la información recibida. }\end{array}$ \\
\hline $\begin{array}{l}\text { Retención de la } \\
\text { información } \\
\text { simbólica }\end{array}$ & $\begin{array}{l}\text { Codificación simbólica. } \\
\text { Organización cognoscitiva. }\end{array}$ \\
\hline Repetición.
\end{tabular}

Cuadro 14: Procesos involucrados en el aprendizaje por observación. Fuente: Bandura y Walters (1982).

En el ámbito de la responsabilidad social, hemos entendido que el modelado es de gran relevancia para la formación y refuerzo de actitudes favorables a la Responsabilidad Social Corporativa, especialmente por su enorme potencial para favorecer el aprendizaje de este tipo de actitudes. 
En este sentido el mejor impulso que podría recibir la actitud a favor de la responsabilidad social sería que la conducta responsable se convirtiera, socialmente hablando, en un patrón social. Para conseguir este propósito se podrían realizar acciones dirigidas a reforzar el valor de esta disposición como las siguientes:

- Impulsar la presencia de empresarios con este perfil en las producciones de ficción que se realizan para cine y televisión.

- Fomentar el reconocimiento de este perfil a través de certámenes, premios o eventos que luego tengan una gran repercusión social. Por ejemplo se podría garantizar que las personas ganadoras tendrían encuentros con personalidades relevantes.

- Crear un grupo de asesoramiento en cuestiones de responsabilidad social, con acceso directo al Ministro de Economía, al que solo puedan pertenecer empresarios con reconocidas políticas de impacto en el ámbito de la Responsabilidad Social Corporativa y que tengan presencia gratuita y garantizada, con relativa frecuencia, en medios públicos de comunicación.

- Impulsar en el entorno formativo dirigido a directivos el estudio de referentes locales en el ámbito de la Responsabilidad Social Corporativa. Este tipo de estrategias podrían desarrollarse, por ejemplo, a través de congresos científicos en 
los que se impulsara el corpus sobre referentes de impacto local en el ámbito de la responsabilidad social.

Si además se vincularan este tipo de acciones a algunos de los procesos motivacionales externos indicados por Bandura y Walters (1982), es decir, si se combinaran el modelado y el condicionamiento instrumental en las estrategias que se planteen, seguramente se podrían mejorar los resultados a favor de la creación y la consolidación de una actitud favorable hacia la Responsabilidad Social Corporativa.

De todos modos, tal y como hemos comentado en el apartado precedente, lo idóneo es que la actitud prosocial se forjara en la infancia a través del ejemplo de padres y educadores. Es en esta época cuando puede obtener una mayor recompensa el esfuerzo por favorecer este tipo de actitudes.

Dentro de este planteamiento hemos entendido que sería de beneficio que las organizaciones desarrollaran, en su gran mayoría, políticas de responsabilidad social que estuvieran integradas en su modelo de negocio. De este modo, padres, educadores y otras personas del entorno de influencia de los más pequeños estarían mucho más sensibilizados con la responsabilidad social porque habitualmente verían actuaciones de este ámbito en su entorno laboral. Además, sin pretenderlo, podrían ejercer una influencia mayor en la formación de este tipo de actitudes en los más jóvenes. 


\subsubsection{Funcionalismo}

Este enfoque ha defendido que las actitudes, comprendidas como constructos o como rasgos de la personalidad, surgen para ajustar el funcionamiento del interior de las personas a las imposiciones del ambiente. En este sentido las teorías funcionalistas entroncan con la función más importante de las actitudes: facilitar la adaptación de las personas a su contexto.

Dentro de este enfoque hemos destacado la teoría de Kelman $(1961,1980)$, quien sostiene que hay tres tipos de actitudes según los motivos que están en su base y según los factores de su génesis.

Uno de los tipos son las actitudes de sumisión, que hacen referencia a que las personas cedemos ante las presiones del entorno y adecuamos nuestras actitudes a este para conseguir las consecuencias positivas derivadas de dicho ajuste.

Otro de los tipos son las actitudes de identificación, que hacen alusión a que las personas tenemos la tendencia a adoptar las actitudes que posee el ser humano ideal con el que nos identificamos.

El tercer tipo de actitudes sería las actitudes internalizadas, que hacen referencia a que las personas aceptamos las actitudes por exigencia de nuestro propio 
sistema de valores para que exista una congruencia entre actitudes, creencias y valores.

Además estos tipos de actitudes presentan dos características específicas en este planteamiento. Por una parte son dependientes, en su manifestación y en su permanencia, en relación con el modo en el que han sido aprendidas. Además cambian cuando dejan de desempeñar la función para la que se formaron, ya sea de sumisión, de identificación o de internalización.

En relación con la Responsabilidad Social Corporativa la teoría de Kelman $(1961,1980)$ tiene relevancia en la formación de actitudes favorables a la responsabilidad social, especialmente en el caso de las actitudes de identificación y en las actitudes internalizadas.

Las actitudes de identificación jugarían un rol relevante en la adquisición de actitudes favorables hacia la responsabilidad social si los líderes empresariales de referencia también fueran modélicos en el desarrollo de políticas de Responsabilidad Social Corporativa.

En este sentido, el desarrollo de acciones que impulsaran el prestigio social de este perfil profesional también fomentaría la formación de actitudes de identificación, próximas a la responsabilidad social, en otros líderes que tengan a aquellos como referencia.

La existencia de actitudes internalizadas favorables a la responsabilidad social en los líderes empresariales sería un indicador de un profundo arraigo de la responsabilidad 
social, ya que estaría asociada a creencias y valores. Hemos entendido que este proceso podría darse en un doble sentido.

Por un lado, fomentando el desarrollo de creencias y valores favorables hacia la responsabilidad social, ya que también se estarían generando actitudes afines a la Responsabilidad Social Corporativa. Una acción para fomentar el arraigo de este tipo de valores podría producirse con la presencia de rasgos prosociales en los héroes de los cuentos infantiles, aspecto que quizá podría fomentarse desde instancias educativas.

Por otro lado, fomentando el desarrollo de actitudes muy favorables hacia aspectos esenciales de la responsabilidad social porque también se podría estar motivando la formación de creencias y valores afines. Por ejemplo si la investigación científica confirmara que los líderes empresariales con altos índices de felicidad personal son los que dirigen las organizaciones más productivas, la aceptación de este hallazgo podría provocar que los líderes empresariales estuvieran más dispuestos a situar la búsqueda de su felicidad personal como un valor central en su vida. E, incluso, podrían llegar a situar este valor por encima de la búsqueda de rentabilidad en las organizaciones en las que desarrollan su labor. 


\subsubsection{Consideraciones finales sobre el origen de la actitud}

Hemos considerado importante destacar que, aunque las actitudes se aprenden, las que adquieren un mayor arraigo en la psique de las personas son las que se producen en la infancia.

En este sentido hay que apuntar que la actitud favorable hacia la Responsabilidad Social Corporativa no se adquiere en la infancia aunque, como hemos señalado, si hay ciertas disposiciones que sería deseable reforzar en esta etapa de la vida en los futuros líderes empresariales por su elevada implicación en la posterior disposición favorable hacia la responsabilidad social: actitud cooperativa, disposición prosocial, inteligencia emocional...

Otra forma de ejercer influencia en los futuros líderes empresariales sería consolidando este tipo de acciones en los ámbitos empresariales. Sería una manera de que este tipo de iniciativas también dejen su huella en los más pequeños, en mayor o menor medida, a través del contagio familiar.

De todos modos también hemos considerado que la actuación dirigida a impulsar una actitud favorable hacia la responsabilidad social en los adultos, especialmente la centrada en los líderes empresariales y altos directivos, también es positiva. Incluso contemplando que los altos cargos puedan aprovechar los esfuerzos que las diferentes 
instancias realicen para impulsar la responsabilidad social, fundamentalmente, en beneficio de la organización en la que trabajan.

Sea como fuere, hemos entendido que todo lo que suponga mayor presencia de la Responsabilidad Social Corporativa en la sociedad favorecerá que esta disposición empresarial se constituya en una demanda general, cada vez, más consolidada. 


\subsection{ACTITUDES Y CONDUCTA}

Como ha puesto de manifiesto LaPiere (1934) en el siglo XX al demostrar la gran distancia que existe entre lo que la gente dice y lo que realmente hace, las actitudes no siempre predicen la conducta.

Algunos autores han calificado la relación entre las actitudes y los comportamientos como débil por dos motivos (Campbell, 1963; Doob, 1947; Fishbein y Azjen, 1974; Hull, 1943; Thurstone, 1928):

\section{¿Por qué es débil la relación entre la actitud \\ y el comportamiento?}

- Cuando se identifican las actitudes individuales hacia un objeto solo se identifica la orientación general hacia el objeto.

- Para poder afirmar que una actitud conduce a un comportamiento concreto es necesario contemplar otros comportamientos específicos que tienen influencia, como las oportunidades o las normas.

Cuadro 15: ¿Por qué es débil la relación entre la actitud y el comportamiento? Fuente: Campbell (1963), Doob (1947), Fishbein y Azjen (1974), Hull (1943) y Thurstone (1928).

Eagly y Chaiken (1993) también han indicado que las relaciones entre las actitudes y el comportamiento solo son consistentes si se toman en consideración algunas variables.

Algunas investigaciones han indagado sobre el tipo de condiciones que hacen a las actitudes ser predictoras solo en algunos casos y han llegado a algunas conclusiones al 
respecto, como por ejemplo que la ambivalencia correlaciona negativamente con el carácter predictor de la actitud (Armitage y Conner, 2000).

Hemos indicado a continuación, agrupados en cuatro bloques, los principales factores de influencia que suponen que las actitudes se traduzcan en algún tipo de comportamiento: factores situacionales, factores actitudinales, factores relacionados con la capacidad de razonamiento ante una situación y factores comportamentales.

\subsubsection{Factores de influencia de las actitudes en el comportamiento}

Desde el siglo XX se han aportado evidencias de que las actitudes sí afectan a la conducta (Petty y Krosnick, 1995), aunque la fuerza de esta relación está determinada por un número de factores diversos relacionados con la propia situación y con otros aspectos específicos de las actitudes como los que proceden de las propias actitudes, los relacionados con la capacidad de razonamiento ante una situación y los vinculados con la influencia del comportamiento en las propias actitudes.

Se ha indicado que dentro de la situación existen dos aspectos de influencia. 
De una parte las restricciones situacionales dadas en unas condiciones concretas, que impiden a las actitudes ser expresadas en una conducta explícita por presiones de la propia situación (Ajzen y Fishbein, 1980; Fazio y RoskosEwoldsen, 1994).

Por ejemplo, en el caso de la Responsabilidad Social Corporativa, que una empresa no tenga una situación económica favorable para apoyar este tipo de iniciativas o, que los clientes de una organización no valoren los esfuerzos que esta realiza en materia de Responsabilidad Social Corporativa.

De otra parte la preferencia por situaciones en que las personas puedan involucrarse en conductas consistentes con sus propias actitudes. Aspecto que, asimismo, fortalece las actitudes a través de su expresión explícita (DeBono y Snyder, 1995).

En relación con la materia de esta investigación, este factor indica que los escenarios favorables para el desarrollo de la responsabilidad social serían especialmente atractivos para los líderes empresariales que tengan una actitud previa afín a la Responsabilidad Social Corporativa.

También existen factores de influencia dentro de las propias actitudes. En este sentido, es necesario considerar diversos aspectos dentro de las propias actitudes que influyen en su traducción en un comportamiento. 
Un aspecto relevante es el origen de la actitud. Existen importantes evidencias que indican que las actitudes formadas a través de la experiencia directa ejercen, a menudo, mayores efectos en la conducta que las actitudes formadas indirectamente. Una de las razones que, a priori, justifica este hecho es que son más fáciles de recordar (Baron y Byrne, 2005).

Este factor indica, en relación con la Responsabilidad Social Corporativa, que las experiencias en primera persona de los líderes empresariales en este campo son más influyentes en la formación de sus actitudes, si son experiencias positivas, que la información que los líderes puedan recibir a través de otras vías.

Otro aspecto relevante en la influencia de las actitudes en el comportamiento es la fuerza de la actitud. Hace referencia a que cuanto más fuerte sea una actitud mayor es su impacto en la conducta (Petkova, Ajzen y Driver, 1995).

El término fuerza incluye a varios factores que se encuentran interrelacionados (Krosnick, Boninger, Chuang, Berent y Carnot, 1993). Uno es la intensidad de la actitud, que hace referencia a cuan fuerte es la reacción emocional provocada por el objeto de la actitud. Otro es la importancia de la actitud, que hace alusión al grado en que una persona está preocupada a conciencia por su actitud y está personalmente implicada en ella (Krosnick, 1988). En este sentido, cuanto mayor sea el grado de interés 
concedido por una persona a su actitud, mayor será el impacto de la actitud en su conducta (Crano, 1995, 1997; Crano y Prislin, 1995). Otro es el conocimiento, que hace referencia a cuánto sabe una persona acerca del objeto de la actitud. Y otro es la accesibilidad, que hace alusión a la facilidad con la que se recuerda la actitud entre varias situaciones (Petty y Krosnick, 1995).

En relación con la Responsabilidad Social Corporativa, este factor indica que las actitudes favorables de los líderes empresariales hacia la responsabilidad social serán más poderosas si provocan una reacción emocional positiva intensa, responden al deseo de los líderes de tener una actitud favorable hacia la misma, surgen en líderes con una amplio conocimiento del ámbito de la Responsabilidad Social Corporativa y son memorables.

Un tercer aspecto concreto de las actitudes que ejerce influjo en la conducta es la especificidad de la actitud. Hace referencia a que la relación actitud-conducta es mayor cuando las actitudes y conductas son registradas al mismo nivel de especificidad (Fazio y Roskos-Ewoldsen, 1994). Por tanto, para conductas generales la influencia de actitudes menos específicas es mayor, y en los comportamientos más particulares las actitudes más concretas ejercen un mayor efecto.

En relación con el ámbito del que se ocupa esta investigación, la especificidad de la actitud aporta una guía de actuación interesante para incentivar el desarrollo de 
acciones de Responsabilidad Social Corporativa. En este sentido, sugiere adecuar la especificidad de los mensajes dirigidos a las personas que vayan a impulsar este tipo de acciones al grado de concreción implícito en la clase de conductas demandadas. Hemos incorporado dos ejemplos de referencia.

En el caso de un alto ejecutivo de una empresa que deba tomar decisiones estratégicas, es más interesante ofrecer información relacionada con la Responsabilidad Social Corporativa que tenga un carácter más global. Por ejemplo se podrían indicar claves para orientar socialmente la misión de su organización.

Cuando se trate de una persona encargada de la responsabilidad social de una organización de tamaño medio que no persigue comprometerse en políticas ambiciosas de responsabilidad social, sino que busca realizar actos de esta naturaleza con relativa frecuencia, lo más interesante es ofrecer información operativa. Por ejemplo, se podrían indicar pautas necesarias para realizar con éxito una campaña de marketing con causa asociada a alguna ONG.

Los expertos en el estudio de las actitudes y el comportamiento también han mencionado que es necesario contemplar otro aspecto que, asimismo, influye en los anteriormente comentados: la posibilidad de que exista capacidad para razonar ante una situación dada. 
Según la Teoría de la acción razonada, y una teoría posterior conocida como la Teoría de la conducta planeada (Ajzen y Fishbein, 1980; Ajzen, 1991), la decisión de actuar cuando existe oportunidad de razonar sigue un proceso en el que desempeñan un rol relevante diversos factores:

\begin{tabular}{|l|}
\hline $\begin{array}{c}\text { Factores que desempeñan un rol relevante } \\
\text { cuando existe oportunidad de razonar }\end{array}$ \\
\hline Variables externas que definen a la persona. \\
\hline Creencias conductuales. \\
\hline Creencias normativas o subjetivas. \\
\hline Actitudes conductuales. \\
\hline Normas subjetivas. \\
\hline - Intención de conducta. \\
\hline Control conductual percibido. \\
\hline Cuadro 16: Factores que desempeñan un rol relevante cuando existe oportunidad \\
de razonar. Fuente: Ajzen y Fishbein, (1980) y Ajzen (1991).
\end{tabular}

Las dos teorías han sido aplicadas con éxito para predecir el consumo de drogas, tales como la marihuana, el alcohol y el tabaco (Morojele y Sthephenson, 1994; Conner y McMillan, 1999). Además también han resultado ser válidas para anticipar el consumo de éxtasis (Orbell, Blair, Sherlock y Conner, 2001).

En relación con la responsabilidad social estas teorías sugieren que se podrían predecir las actuaciones en este campo si los líderes presentan creencias, actitudes y normas subjetivas favorables a la Responsabilidad Social Corporativa. Asimismo, la actitud sería predictiva si los líderes tienen motivación para actuar en esa dirección y se sienten identificados con la responsabilidad social como un 
rasgo que defina las preferencias de su personalidad y su comportamiento. Otro aspecto que también permitiría detectar una futura actuación favorable es que sientan que tendrán control conductual en el desarrollo de las futuras acciones de responsabilidad social.

También existe una teoría que explica el comportamiento de la actitud cuando las situaciones motivan una reacción inmediata y no hay, en primera instancia, capacidad de razonar. Se trata del Modelo del proceso 'de-la-actitud-a-la-conducta' (Fazio, 1989, Fazio y Roskos-Ewoldsen, 1994).

De acuerdo con esta propuesta, se produce una actuación a través de dos vías paralelas que desembocan en una definición de la situación que, a su vez, influye sobre la conducta. Por una parte la situación activa una actitud que influye espontáneamente sobre las percepciones de la misma. Por otra, el conocimiento que se posee sobre lo que es apropiado en la situación también es activado.

Ambas, la actitud y la información sobre lo que es apropiado o esperado, moldean la definición del evento y esta percepción es la que influye sobre la conducta (Bargh, 1997).

En relación con la responsabilidad social esta teoría sugiere que ante encuentros inesperados de situaciones en las que haya que tomar decisiones empresariales relacionadas con el ámbito de la Responsabilidad Social Corporativa, una percepción favorable de la responsabilidad 
puede motivar que la toma final de decisiones sea afín a la misma.

La revisión de la literatura científica también ha revelado que es necesario contemplar un cuarto factor que invierte la forma de contemplar el análisis que hemos venido realizando. Se trata, en este caso, del efecto del comportamiento en las propias actitudes. Existe un gran número de pruebas que demuestran que las actitudes siguen a la conducta (Myers, 2011).

Por ejemplo el cambio de actitud se puede producir a través del denominado "fenómeno del pie en la puerta o del primer paso" (Schein, 1953). Esta teoría defiende que cuando las personas aceptan realizar una acción pequeña en contra de su actitud están más dispuestas a realizar, posteriormente, una acción más grande que vaya en contra de su actitud. Es decir, la realización de este tipo de acciones provoca que la actitud hacia las mismas se vea modificada. Este proceso afecta tanto a las buenas como a las malas acciones (Freedman y Fraser, 1966).

En relación con la responsabilidad social, este fenómeno indica que los líderes que estén en contra de iniciativas en este campo pueden modificar su actitud si comienzan realizando pequeñas acciones favorables a la Responsabilidad Social Corporativa, como por ejemplo reciclar el papel de su organización. Estas acciones pueden 
conducir, con posterioridad, a iniciativas de mayor dimensión en favor de la responsabilidad social.

También hay investigaciones que han demostrado que el desempeño de un rol influye, finalmente, en las propias actitudes.

Se han realizados estudios de laboratorio en una prisión simulada y los resultados han verificado estos supuestos. De todos modos, los estudios sobre la influencia del rol en el cambio de actitudes también han indicado que no todas las personas modifican sus actitudes en este tipo de situaciones (Carnahan y McFarland, 2007; Haslam y Reicher, 2007; Zimbardo, 2007).

En relación con la responsabilidad social, estas investigaciones sugieren que la simulación del rol de líder a favor de la responsabilidad social también puede influir en la creación de actitudes afines a la Responsabilidad Social Corporativa.

Por ejemplo se podría favorecer la creación de actitudes favorables hacia la responsabilidad social a través de videojuegos dirigidos a futuros líderes empresariales en los que haya que poner en práctica esta destreza. 0 mediante campeonatos online orientados a jóvenes líderes empresariales en los que haya que utilizar habilidades de este tipo. 


\subsubsection{Inconsistencias entre las actitudes y el comportamiento}

La Teoría de la disonancia cognitiva ha revelado que cuando la conducta no es consistente con las actitudes o a la persona se le presentan dos actitudes inconsistentes, se experimenta un estado desagradable denominado “disonancia cognitiva” (Festinger, 1957).

La disonancia cognitiva presenta algunos rasgos característicos.

La disonancia cognitiva es una experiencia que, aun siendo universal (Heine y Lehman, 1997), está influida por los factores culturales.

Aunque todos los seres humanos nos sentimos incómodos por las inconsistencias entre las actitudes y la conducta, los factores culturales pueden influir en la intensidad de tales reacciones, las condiciones precisas en las que ocurren $\mathrm{y}$ en las estrategias utilizadas para reducirlas (Steele, Spencer y Lynch, 1993).

En relación con la responsabilidad social este rasgo indica que será más probable que los líderes tomen decisiones a favor de la responsabilidad social, cuando las disonancias se presenten, cuanto más favorables sean las 
culturas al desarrollo de iniciativas en el ámbito de la Responsabilidad Social Corporativa.

Un ejemplo de disonancia que se puede producir en el entorno actual para el líder empresarial español se encuentra en la demanda social de responsabilidad social frente a las dificultades económicas por las que están atravesando las organizaciones.

Otro aspecto característico de las disonancias es que su intensidad está influida, de modo inverso, por la fuerza de su fundamento. Es decir, de acuerdo con la teoría de la disonancia esta será mayor cuando se tengan pocas razones para implicarse en una discrepancia entre la actitud y la conducta. En este sentido produce, por tanto, más disonancia, ofrecer pequeñas recompensas individuales por realizar comportamientos contrarios a las actitudes que ofrecer recompensas mayores.

Esta predicción, que ha sido denominada por algunos psicólogos sociales como el "efecto menos-lleva a más" (Festinger y Carlsmith, 1959; Riess y Schlenker, 1977), ocurre cuando se dan algunas condiciones (Cooper y Scher, 1994) que hemos indicado en cuadro 17 "Condiciones que favorecen el efecto 'menos lleva a más'”: 


\section{Condiciones que favorecen el efecto "menos lleva a más"}

Cuando las personas puede escoger entre realizar o no la tarea discrepante con la actitud.

Cuando las personas creen que son personalmente responsables:

- tanto por el curso de acción escogido,

- como por los efectos negativos que se derivan de este.

Cuando las personas no perciben el pago que reciben por los servicios prestados como un soborno sino más bien como una recompensa.

Cuadro 17: Condiciones que favorecen el efecto "menos lleva a más". Fuente: Cooper y Scher (1994).

Esta dinámica puede ser interesante para impulsar el desarrollo de iniciativas de responsabilidad social en los líderes de las organizaciones que no realizan ningún tipo de actuación en este campo. En este sentido, si las instituciones y organizaciones que incentivan el desarrollo de acciones de Responsabilidad Social Corporativa ofrecieran pequeños incentivos a dichas organizaciones, es posible que obtuvieran mejores resultados para que finalmente dichas empresas se animasen a realizar este tipo de iniciativas que si prometieran grandes recompensas.

Otro rasgo propio de las disonancias cognitivas es su capacidad para motivar cambios beneficiosos en la persona. La disonancia puede ser de utilidad para generar cambios beneficiosos cuando es utilizada para provocar sentimientos de hipocresía, concretamente cuando las personas muestran públicamente algunas actitudes 0 comportamientos pero luego actúan de una manera inconsistente en relación con esas actitudes 0 
comportamientos (Gibbons, Eggleston y Benthin, 1997; Stone, Wiegand, Cooper y Aronson, 1997).

La efectividad de este proceso será mayor si las personas apoyan públicamente las conductas deseadas, son inducidas a pensar acerca de sus propios fallos al realizar dichas conductas y tienen acceso a medios directos para reducir su disonancia como cambiar su actitud, apoyar la conducta con más información o quitar importancia a la conducta. La utilización de medios indirectos para cambiar la conducta, como distraer la atención o implicarse en conductas evaluadas positivamente, no es favorable para reducir la disonancia (Aronson, Fried y Stone, 1991; Stone, Wiegand, Cooper y Aronson, 1997).

Este rasgo de la disonancia podría ser utilizado para fomentar el desarrollo de actitudes a favor de la responsabilidad social. Con este objetivo se podrían realizar encuentros en los que estuvieran presentes todos los grupos de interés que son afectados por las decisiones empresariales. La toma de conciencia, por parte de los máximos responsables empresariales, de los efectos menos favorables del comportamiento de las organizaciones en las que desempeñan su labor también podría impulsarles a manifestar públicamente una disposición negativa ante las actuaciones empresariales más nocivas para el progreso social, económico y medioambiental. En ambos casos se estaría favoreciendo el desarrollo de actitudes positivas hacia la responsabilidad social a través de la reducción de posibles disonancias cognitivas. 
Las estrategias que se pueden utilizar para modificar las disonancias son de dos tipos: directas e indirectas.

Dentro de las estrategias directas que pueden utilizarse es posible cambiar las actitudes o la conducta para hacerlas más consistentes entre ellas (Aronson, 1968; Festinger, 1957), reducir la disonancia cognitiva adquiriendo nueva información que apoye las actitudes o la conducta (Lipkus, Green, Feaganes y Sedikides, 2001) y trivializar las actitudes o la conducta calificándolas como poco importantes (Simon, Greenberg y Brehm, 1995).

De acuerdo con estas estrategias, un modo de hacer más consistente la actitud de los líderes empresariales hacia la responsabilidad social sería conseguir que consultasen información favorable sobre esta disciplina. Esta acción sería especialmente útil en el caso de los máximos responsables que tengan una visión de la Responsabilidad Social Corporativa más negativa.

Las estrategias indirectas que se pueden utilizar para reducir las disonancias son la autoafirmación, la restauración de las autoevaluaciones positivas que se encuentran amenazadas por la disonancia (Elliot y Devine, 1994; Tesser, Martin y Cornell, 1996) y el uso de cualquier cosa que disminuya el sentimiento negativo generado por la disonancia, como beber alcohol (Steele, Sounthwick y Critchlow, 1981) o implicarse en actividades recreativas 
para apartar la mente de la disonancia (Zanna y Aziza, 1976).

Tomando en consideración este tipo de estrategias en beneficio de la responsabilidad social, resultaría adecuado fomentar que los líderes empresariales no buscasen evadir su responsabilidad social autoafirmando su posición de rechazo o buscando medios de distracción.

En este sentido podría ser interesante desarrollar iniciativas que les conciencien de la relevancia de sus decisiones en el progreso social, económico y medioambiental. Además, también hemos considerado que sería interesante realizar acciones que fomentasen su destreza o su disfrute en el trabajo para que, de este modo, los máximos responsables organizacionales no evadan su responsabilidad en las resoluciones en curso en las que su empresa puede estar implicada en materia de responsabilidad social. 


\subsection{LA MEDICIÓN DE LAS ACTITUDES}

De acuerdo a la bibliografía revisada hemos entendido que la medición es la asignación de números a atributos o características de objetos 0 personas con normas preestablecidas. En este sentido, medir las características físicas de una persona resulta relativamente sencillo pero cuando se pretenden medir construcciones hipotéticas, como las actitudes, surge la dificultad de que estos constructos no son observables directamente sino inferibles de manifestaciones o conductas de las personas (Gómez, Vidal, Fawaz y Ysern, 2002).

La primera escala para medir cuantitativamente las actitudes, la Escala de Distancia Social, fue desarrollada por Bogardus en el año 1925.

Tal y como indican Garrido y Álvaro (2007), la aparición de esta primera escala planteó una revolución empírica en el ámbito de la psicología social porque, por una parte, creó entre los científicos de este ámbito la sensación de que esta disciplina alcanzaba un verdadero estatus científico y, por otra, aumento la aceptación de este concepto por parte de los psicólogos sociales.

En los inicios del siglo XXI los psicólogos sociales han medido las actitudes de diversas formas, que hemos agrupado en dos bloques. Por un lado hemos tratado las 
medidas directas de las actitudes, que son aquellas que utilizan la recogida de opiniones para medir las actitudes. $Y$ por otro las medidas indirectas de las actitudes, que son las que estudian la actitud a través de la conducta de las personas, sus respuestas fisiológicas u otros datos indirectos que pueden estar relacionados con el comportamiento de la actitud.

\subsubsection{Medidas directas de las actitudes}

Según la literatura existen muchas maneras de preguntar a una persona lo que cree pero cuatro son las técnicas de medición directa de actitudes más generalizadas: la escala tipo Likert, las medidas psicofísicas, el método del distanciamiento social y el diferencial semántico.

La escala tipo Likert es, probablemente, la medida de actitudes más utilizada (Lamberth, 1989).

El objetivo de la escala es situar a la persona en un continuo que va desde una actitud muy positiva a una actitud muy negativa hacia algo (Likert, 1932). Lo que se le pide a la persona es que exprese su grado de acuerdo o desacuerdo respecto a objeto, situación, persona... a través de la elección de diversas posibles respuestas en cada enunciado.

Un ejemplo de un enunciado podría ser: "Las casas de apuestas deberían estar limitadas a personas sin adicción al 
juego reconocida". Las posibles respuestas ante este enunciado podrían ser: "Muy de acuerdo", “De acuerdo", "No estoy seguro", "En desacuerdo" y "Muy en desacuerdo".

Para la elaboración de la escala, Likert ha ofrecido algunas pautas (1932). Considera que, en primer lugar, es necesario elaborar una amplia lista de enunciados que representan tanto actitudes negativas como positivas y que, posteriormente, deben ser presentados a una muestra de personas como si se tratara de la escala final. A continuación propone que se analicen las correlaciones entre los diferentes enunciados y se seleccionan aquellos que presentan una mayor correlación, con el objetivo de obtener una medida con gran consistencia interna.

Dentro de las medidas psicofísicas hemos destacado el enfoque psicofísico de Thurstone (1931), que también se basa en la evaluación afectiva de una persona respecto a un determinado tema. Thurstone usa el término "escala" para las medidas que utiliza, aunque suelen ir acompañadas del apelativo "experimental” (Clemente, 1992). Al igual que en la escala tipo Likert, el objetivo de este tipo de escalas también es situar a la persona en un continuo.

La pretensión de Thurstone (Thurstone y Chave, 1929) fue elaborar un conjunto de enunciados en el que, además de las posiciones extremas de las opiniones respecto a un tema, estuvieran presentes todos los puntos intermedios entre los extremos positivo y negativo del continuo en 
relación con ese tema. Thurstone buscaba que cada uno de los enunciados del conjunto representara distancias iguales en exactitud y se correspondiera con un determinado valor numérico. Cuando una persona cumplimentaba la escala se le pedía que eligiera los enunciados favorables con los que estaba de acuerdo. De este modo el valor numérico asociado en cada caso a los ítems seleccionados, determinaría el valor final de su actitud.

Para la elaboración de la escala, Thurstone ha ofrecido algunas indicaciones (1929). Indica que en primer término es necesario elaborar una relación de enunciados lo más amplia posible en la que hubiera afirmaciones representativas de las posiciones extremas que pueda adoptar la actitud, y afirmaciones relacionadas con todos los puntos intermedios entre los extremos positivo y negativo del continuo. A continuación se ha de pedir a un grupo de personas que clasificaran los enunciados en 11 categorías. Finalmente es posible construir la escala a partir de los enunciados que presenten mayor representatividad en cada punto del continuo.

Al ser un procedimiento de medida que hemos utilizado en esta investigación, hemos desarrollado con mayor detalle en el proceso seguido en el diseño de esta escala en el capítulo 5 dedicado a la metodología.

El método del distanciamiento social trata de medir empíricamente la voluntad de las personas, a través de una escala, para evaluar su disposición a relacionarse en 
determinadas actividades generales con algunos grupos concretos (Lamberth, 1989).

Cada elemento de la escala indica una voluntad de comprometerse en relaciones cada vez menos intensas. Para Bogardus la distancia social está en función de la distancia afectiva que existe entre los miembros de dos grupos (Bogardus, 1933). La escala original que propuso Bogardus (1933) para medir este aspecto es la siguiente:

1. Me casaría con él.

2. Le tendría como un amigo más.

3. Trabajaría con él en una oficina.

4. Admitiría a algunas familias en mi vecindad.

5. Le admitiría solamente como interlocutor.

6. Querría que viviese fuera de mi vecindad.

7. Querría que viviese fuera de mi país.

La escala de distancia social propuesta por Bogardus es acumulativa porque un acuerdo con cualquier enunciado implica un acuerdo con todos los puntos que hacen referencia a una relación menos intensa.

En el caso del diferencial semántico, el objetivo es evaluar la disposición afectiva de las personas respecto a una cuestión concreta.

El método fue elaborado originalmente por Osgoog, Suci y Tannenbaum (1957) bajo el supuesto de que es posible evaluar la disposición afectiva respecto a alguna cuestión concreta a través de adjetivos bipolares que 
representen puntuaciones extremas respecto a algo y admitan puntuaciones intermedias.

En la elaboración de este tipo de escalas se asignan los valores altos a las dimensiones agradables y los valores bajos a las dimensiones desagradables (Lamberth, 1989).

Para conocer el valor de la actitud en cada caso hay que calcular la suma o el promedio de las puntuaciones obtenidas en los diferentes ítems que componen la escala.

\subsubsection{Medidas indirectas de las actitudes}

En el ámbito de la psicología social también se han desarrollado mediciones de las actitudes a través de la observación de la conducta. Además también se han aportado planteamientos estratégicos y medidas fisiológicas para tratar de evitar los sesgos producidos por la percepción de la propia persona cuya actitud está siendo medida.

Las actitudes de las personas a menudo se reflejan en los comportamientos, por lo que los psicólogos sociales también utilizan las observaciones de la conducta para detectarlas (Smith y Mackie, 1997).

Por ejemplo, el tiempo dedicado por los líderes empresariales a revisar cuestiones relacionadas con novedades en el ámbito de la responsabilidad social podría ser indicativo del grado de afinidad que estos líderes sienten hacia esta materia. 
De todos modos la validez de las mediciones de las actitudes través de la observación, algo que también ocurre con las medidas directas, depende de la honestidad de las personas que contestan. Como ya hemos indicado en el bloque dedicado a las actitudes y al comportamiento, existen muchos factores que pueden impulsar un tipo de comportamiento en las personas que no se corresponda con las actitudes con las que está relacionado. Como por ejemplo la deseabilidad social, que puede impulsar comportamientos contrarios a las propias actitudes. Este es el motivo por el que también se han desarrollado medidas indirectas de las actitudes, como los planteamientos estratégicos y las medidas fisiológicas.

Dentro de los planteamientos estratégicos hemos destacado el anonimato, el desconocimiento del objeto de investigación y el detector falso.

El anonimato hace referencia a la regla que se sigue en casi todas las investigaciones de laboratorio sobre actitudes, con el objeto de evitar que los participantes teman ser identificados públicamente con una actitud concreta (Smith y Mackie, 1997).

El desconocimiento del objeto de investigación hace referencia a la utilización de mediciones que revelen sutilmente las actitudes sin que las personas lo adviertan. Este sistema ha sido puesto en práctica, de modo exitoso, interrogando a las personas investigadas sobre sucesos desconocidos de las vidas de personajes públicos para 
conocer su grado de afinidad hacia los mismos (Pratkanis, 1989).

Es posible que esta técnica se pueda utilizar para analizar la actitud hacia la responsabilidad social de líderes empresariales. En este caso se podría pedir a los máximos responsables que evaluaran algún rasgo de una persona que tuviera un comportamiento modélico en el campo de la Responsabilidad Social Corporativa.

El detector falso hace referencia a la utilización de un falso dispositivo en la evaluación de temas delicados, como el consumo de drogas o las prácticas de sexo seguro, para hacer creer a las personas que se están midiendo sus reacciones fisiológicas. Estas técnicas han sido utilizadas con éxito para aumentar la honestidad de las respuestas (Wech, Lundstrum y Moore, 1989).

También se han utilizado las medidas fisiológicas como medida indirecta de las actitudes.

Algunos expertos han indicado que no son recomendables para evaluar actitudes porque solo registran la activación, es decir, no indican la dirección de la actitud asociada a la elevación del ritmo cardiaco de una persona (Lamberth, 1989). Sin embargo se han desarrollado técnicas que permiten medir no solo la intensidad sino también la dirección de la actitud a través de respuestas fisiológicas.

Una de estas técnicas está basada en la electromiografía facial (EMG), que mide la actividad eléctrica de los músculos. 
Cacioppo, Petty, Losch y Kim (1986) realizaron un experimento basado en esta tecnología que permitió verificar que es posible detectar estados emocionales a través de las contracciones de diferentes grupos musculares. Por ejemplo la felicidad está más relacionada con los músculos asociados a la sonrisa y la tristeza está más vinculada con los músculos situados en el entrecejo.

Además, también demostraron que es posible realizar mediciones incluso cuando los estados emocionales no se detectan a simple vista. Como por ejemplo, cuando no se perciba una elevación de las comisuras de la boca o el entrecejo no se frunza. 


\subsection{ACTITUDES Y RESPONSABILIDAD SOCIAL CORPORATIVA}

De acuerdo a la documentación que se ha revisado, la actitud de los líderes empresariales hacia la responsabilidad social no es homogénea.

En estudios realizados en altos directivos de empresas, como el desarrollado con 505 CEOs en Argentina, existen actitudes proactivas frente a otras que presentan bajos niveles de responsabilidad social (Vázquez-Brust, ListonHeyes, Plaza-Úbeda y Burgos-Jiménez, 2010).

Las investigaciones han indicado que existen factores que influyen en la actitud de los líderes empresariales hacia la Responsabilidad Corporativa. Hemos tratado primero esos aspectos $y$, posteriomente, hemos incluido un bloque final con los factores de influencia que se han detectado en el caso español.

\subsubsection{Factores de influencia en las actitudes hacia la responsabilidad social}

Hemos agrupado los factores de influencia de las actitudes hacia la responsabilidad social en tres bloques: aquellos que están más asociados con el entorno en el que la organización desarrolla su actividad, los más próximos al 
perfil de la organización y los que hacen referencia a características del propio líder.

Dentro de los factores vinculados con el contexto en el que una organización desarrolla su actuación, hemos detectado tres aspectos que ejercen una especial influencia en la actitud de los líderes hacia la responsabilidad social: el grado de desarrollo de la economía en la que las organizaciones desarrollan su actividad, la competitividad del contexto en el que se enmarcan las empresas y la ubicación de las organizaciones en entornos rurales 0 urbanos.

Se han desarrollado investigaciones que han demostrado que el nivel de desarrollo de la economía de un país influye en la disposición de los líderes hacia la Responsabilidad Social Corporativa.

Por ejemplo Rusia, en la primera década del siglo XXI, ha sido un país en el que ha habido un débil entorno institucional, se ha producido un abuso de las leyes y la actuación del gobierno ha sido débil o no se ha respetado (Kuznetsov y Kuznetsova, 2003).

En este contexto los gerentes rusos han manifestado que no ven la Responsabilidad Social Corporativa como un aspecto determinante de la imagen pública de las empresas. Además también han indicado que supone un valor reducido a largo plazo para las compañías que estas se muestren responsables ante la sociedad. Por otra parte 
también han declarado que las actuaciones que responden a requerimientos legales estándar 0 al mínimo de responsabilidad social exigible a una compañía (como pagar los impuestos, crear empleo y respetar la ley) son actuaciones vinculadas al ámbito de la Responsabilidad Social Corporativa (Kutnesov, Kutnesova y Warren, 2009).

Esta falta de conciencia social también es impulsada por la situación precaria de la población activa en economías de bajo nivel de desarrollo. Por ejemplo en Cabo Verde, una economía en transición, la mayoría de la población activa ha indicado que asume la precariedad laboral y acepta lo que esto implica: empleos sin contrato, una remuneración inferior a la que corresponde en cada caso y un trabajo de una categoría profesional inferior a la pertenece el demandante (García y García, 2008).

Otro aspecto del contexto que influye en la actitud de los líderes hacia la responsabilidad social es su grado de competitividad.

En contra de lo que cabría inicialmente esperar, algunas investigaciones han indicado que la competitividad de un entorno no siempre garantiza el desarrollo de la responsabilidad social. La presencia de ese rasgo en el mercado puede influir, de forma negativa, en la percepción de la Responsabilidad Social Corporativa.

Baucus y Near (1991) han confirmado dos factores que pueden llevar a las pequeñas y medianas empresas a 
desarrollar conductas no éticas y fuera del marco legal: la presión del entorno y las oportunidades de negocio.

También se han realizado estudios para comprobar si la presencia de las organizaciones en entornos más urbanos o más rurales, ejerce algún tipo de influencia en la actitud de sus líderes hacia la responsabilidad social.

Hornsby, Kuratko, Naffziger, LaFollete y Hodgetts (1994) analizaron un conjunto de temas relacionados con la ética empresarial, comparando los empresarios urbanos con los de las zonas rurales. Concluyeron que los empresarios de áreas rurales están más preparados que los de las zonas urbanas, especialmente sobre temas de ética empresarial relacionados con el desarrollo de la empresa, dinero y evasión de impuestos, y toma de decisiones en la gestión.

En relación con el perfil de la organización se han realizado estudios que han indicado que tanto su tamaño como la existencia de culturas éticas en las empresas, influyen en la actitud de los líderes hacia la responsabilidad social.

De acuerdo a las investigaciones revisadas, el aspecto más determinante del perfil de la organización en la actitud del líder hacia la Responsabilidad Social Corporativa es su tamaño.

Algunos estudios han mostrado que el tamaño de una organización es un factor relevante para conocer la actitud 
de los líderes hacia la Responsabilidad Social Corporativa. Longenecker, McKinney y Moore (1989), y Payne y Joyner (2006) concluyeron que las percepciones de los empresarios de las pequeñas y medianas empresas sobre la Responsabilidad Social Corporativa se diferenciaban de las actitudes de los directivos de las grandes empresas o multinacionales.

Hemos citado algunos estudios que muestran que el mayor tamaño de la organización es un factor que discrimina negativamente en relación con la disposición hacia la Responsabilidad Social Corporativa.

Uno es el realizado por Bucar, Glas y Hisrich (2003), quienes presentaron un test de viñetas y escenarios simulados sobre la ética empresarial a empresarios de pequeñas y medianas empresas y directivos de grandes empresas de Eslovenia y Rusia. Sus análisis demuestran que los empresarios de pequeñas y medianas empresas tienen más actitudes éticas que los no empresarios o directivos de grandes empresas.

Otro estudio es el realizado por Brown y King (1982), quienes examinaron la opinión de diferentes sectores de la población sobre la ética empresarial de los empresarios de pequeñas y medianas empresas y la de los directivos de grandes empresas en Estados Unidos. Concluyeron que la mayoría de la población opina que los empresarios de pequeñas y medianas organizaciones tienen un nivel de ética empresarial elevado frente a los directivos de las grandes multinacionales. 
Otro de los trabajos que hemos destacado es el desarrollado por Longenecker, McKinney, y Moore (1989). Estos investigadores realizaron una revisión de algunos estudios y también llegaron a la misma conclusión: que los empresarios de pequeñas y medianas empresas presentan un nivel más alto en ética empresarial que los directivos y que los empleados de grandes empresas. De todos modos también indicaron que los investigadores debían mejorar sus instrumentos a la hora de realizar estudios comparativos sobre Responsabilidad Social Corporativa entre directivos de grandes organizaciones y máximos responsables de empresas pequeñas y medianas. El motivo es que algunas de las variables seleccionadas en estas herramientas sesgaban las respuestas que se habían obtenido.

En otra investigación Zu y Song (2008) constataron que los responsables empresariales que presentan una disposición más favorable hacia la responsabilidad social están presentes, entre otros factores, en compañías de tamaño pequeño.

También hemos considerado interesante indicar los resultados de algunos estudios no comparativos que se han realizado en 78 grandes empresas del listado de la revista Fortune. Estos resultados indican que, en un alto porcentaje, los directivos de grandes compañías tienen una disposición favorable hacia la Responsabilidad Social Corporativa (Post, Rahman y Rubow, 2011).

Estos últimos datos invitan a tomar con cautela los resultados de los estudios anteriormente indicados y a 
contemplar que, además del tamaño de las empresas, existen otros factores determinantes a la hora de prever la actitud de los líderes empresariales hacia la responsabilidad social.

También hemos encontrado estudios que han relacionado la existencia de dos factores, códigos éticos y formación en este campo, con organizaciones que intentan institucionalizar culturas éticas que favorezcan el desarrollo moral (Trevino y Nelson, 2004). Este tipo de acciones indicarían, por tanto, qué organizaciones demandan altos directivos próximos a la responsabilidad social.

Estos datos se corresponden con los resultados alcanzados por otras investigaciones que han indicado, tanto para entornos orientales como occidentales, que la cultura de las organizaciones ejerce una influencia significativa en las actitudes de los líderes empresariales hacia la ética de los negocios (Christie, Kwon, Stoeberl y Baumhart, 2003).

Además de estudios que ofrecen resultados sobre factores del entorno de las organizaciones y del perfil de la propia organización que inciden sobre la actitud de los máximos responsables empresariales hacia la responsabilidad social, también se han localizado trabajos sobre la influencia que ejercen características específicas del propio líder.

De los diversos estudios revisados, hemos destacado dos rasgos de los líderes más próximos a la responsabilidad 
social: la satisfacción laboral y la visión de la responsabilidad social como algo capaz de producir beneficios empresariales.

Los resultados de una encuesta con 313 profesionales de los negocios han indicado que la percepción favorable de la Responsabilidad Social Corporativa está relacionada, positivamente, con la satisfacción laboral que se experimenta (Valentine y Fleischman, 2008).

También hay estudios que indican que la percepción favorable de la responsabilidad social está influenciada por su visión cara a producir beneficios. En una investigación que se ha realizado sobre las creencias de los líderes de grandes instituciones financieras australianas (Lindorff y Peck, 2010), estos respondieron que la responsabilidad primaria de las empresas era maximizar su valor para satisfacer sus obligaciones fiduciarias con los accionistas.

En este contexto los líderes también han indicado que las actividades vinculadas con la responsabilidad social benefician financieramente a la organización y colaboran en la construcción de la sostenibilidad corporativa. Además también han manifestado que favorecen el compromiso y el rendimiento de los colaboradores. Por otra parte también han declarado que dichas acciones contribuyen a mejorar el capital social e incrementan la legitimidad de la organización (aunque la filantropía no se apoya a menos que sea un caso de negocio).

La vinculación de la visión favorable de la responsabilidad social condicionada a su potencial para producir beneficios también ha sido encontrada en el estudio 
desarrollado con directivos y máximos responsables de 83 empresas chinas (Zu y Song, 2008). En el análisis de los resultados alcanzados se indica que la verdadera naturaleza de las afirmaciones favorables a la Responsabilidad Social Corporativa podría estar más basada en la orientación al negocio que en la moralidad (p. 115).

\subsubsection{Factores de influencia en el caso español}

Existen estudios desarrollados en ámbito español que también han ofrecido resultados en relación con el contexto en el que las organizaciones realizan su actuación, con el perfil de las empresas y con características del propio líder.

En relación con el contexto se ha desarrollado una investigación con directivos de compañías españolas y británicas (Rodríguez, Menéndez y Martín-Castilla, 2007), en la que se ha concluido que para los directivos españoles la dimensión externa de la responsabilidad social es menos relevante que para los directivos británicos.

También hay trabajos sobre la influencia de algunas características de las organizaciones en la actitud de los líderes hacia la responsabilidad social. En relación con este aspecto se han encontrado estudios relacionados con la influencia del tamaño de las organizaciones, con la naturaleza de la propiedad de las empresas y con el tamaño edad de las empresas y su sector de actividad. 
En relación con el tamaño Mubabu (2010) ha comparado la percepción hacia la Responsabilidad Social Corporativa de los empresarios de las pequeñas y medianas empresas con la de los directivos de grandes empresas. Su estudio ha arrojado diferencias en la actitud ante la responsabilidad social de unos y otros.

Los empresarios de pequeñas y medianas organizaciones han mostrado una actitud más favorable hacia la responsabilidad social en algunas cuestiones.

En términos generales están más concienciados, sensibilizados, movilizados y comprometidos con la Responsabilidad Social Corporativa que los directivos.

Además consideran, en menor grado que los directivos de las grandes empresas y multinacionales, que existe un nivel de concienciación adecuado sobre Responsabilidad Social Corporativa. Es decir, entienden que hay una mayor necesidad de concienciación sobre este tema.

Por otra parte, resaltan en mayor grado que los directivos de grandes organizaciones, que las empresas son instituciones sociales y que, por tanto, deben actuar con los estándares que la sociedad establece.

En consonancia con la afirmación anterior sostienen, en un mayor grado que los directivos de las grandes organizaciones, que la producción eficiente de bienes y servicios no es lo único que la sociedad espera de la empresa. 
También consideran, en menor grado que los directivos de las grandes empresas, que en tiempos de crisis la responsabilidad social no es de interés prioritario para las empresas. Mubaru (2010) ha indicado que este aspecto refleja que la Responsabilidad Social Corporativa no es contemplada como un sinónimo de altruismo, sino que está motivada por razones empresariales.

Además destacan, en mayor medida que los directivos de las grandes empresas, el hecho de que el compromiso de su negocio con la responsabilidad social mejora la imagen pública de la organización. Es decir, los máximos responsables de empresas de menor tamaño consideran que la responsabilidad social mejora en mayor medida la reputación de su organización.

Por otro lado, los directivos de grandes organizaciones han mostrado una actitud más favorable hacia la responsabilidad social que los empresarios en algunas cuestiones.

Por una parte consideran, en menor grado que los empresarios, que ignorar la responsabilidad social puede suponer ventajas competitivas frente a los competidores.

Además manifiestan, en un grado mucho más elevado que los empresarios, que la organización en la que trabajan ha puesto en práctica un procedimiento para que se tomen las medidas adecuadas contra toda forma de discriminación y violación de los derechos humanos. En este sentido sería interesante verificar si el mayor tamaño 
de las empresas influye en la necesidad de crear procedimientos para fomentar el respeto a este tipo de derechos.

El estudio también ha indicado que los dos colectivos analizados han apoyado, de igual modo, que la política de responsabilidad social desarrollada por la empresa ayuda a equilibrar el poder social en la organización y a evitar cualquier conducta irresponsable o no ética.

Pese a los hallazgos encontradas en la investigación, el estudio no ha permitido afirmar que los empresarios tengan valores éticos y de responsabilidad social diferentes de los de los directivos. Mubaru (2010) ha indicado que el factor diferencial se debe a la percepción de la Responsabilidad Social Corporativa como un contrato tácito que la empresa establece con la comunidad donde se instala, que la obliga a generar valor añadido en forma de productos y servicios.

La visión de este contrato está motivada por aspectos diferentes para los empresariales y para los directivos, tal como hemos indicado a continuación en el cuadro 18 "Aspectos que motivan una percepción diferente en empresarios y directivos del contrato tácito que la empresa establece con su entorno": 


\section{Empresarios}

Directivos

- Elevada información inicial.

Ausencia de presión social (suelen ser empleados).

- Percepción de la empresa como "obra personal".

- Elevada presión social por la actuación responsable de la empresa.

- Familiaridad con la legislación en materias como:

- protección del medio ambiente,

- contratación de mano de obra,

- y obligaciones fiscales.

Cuadro 18: Aspectos que motivan una percepción diferente en empresarios y directivos del contrato tácito que la empresa establece con su entorno. Fuente: Mubaru (2010).

Los resultados de la investigación de Mubaru (2010) parecen indicar que la disposición hacia la responsabilidad social es similar en directivos y empresarios. Sin embargo, la interpretación que realiza de los resultados establece algunos matices diferenciales.

De acuerdo con Mubaru (2010) las actitudes hacia la responsabilidad social de los directivos parecen estar más influidas por la formación adquirida. Un estudio realizado con futuros gestores empresariales en España parece corroborar esta apreciación. En dicha investigación se ha concluido que este colectivo muestra preocupación por temas éticos y de responsabilidad social (Vázquez, Oliveira y Seabra, 2012)

Además el estudio de Mubabo (2010) también ha indicado que las actitudes de los empresarios de pequeñas y medianas organizaciones a favor de la Responsabilidad Social Corporativa parecen estar más influidas por la presión social. 
Los resultados de otras investigaciones, como el desarrollado por Godos y Fernández (2011) para evaluar la percepción de la responsabilidad social por parte de los altos directivos de empresas en España, no se corresponden con las conclusiones alcanzadas por Mubabu (2010).

En el estudio realizado por Godos y Fernández (2011) se ha concluido que los directivos que conceden mayor importancia a la responsabilidad social se encuentran en las empresas de mayor tamaño.

Otra característica de las organizaciones que parece tener incidencia en la actitud de los líderes empresariales que realizan su trabajo en el ámbito español hacia la responsabilidad social es la naturaleza de la propiedad de las organizaciones.

Déniz y Cabrera (2005) han estudiado la Responsabilidad Social Corporativa de las empresas familiares en España y han llegado a la conclusión de que estas organizaciones, en comparación con las no familiares, adoptan de manera informal un mayor comportamiento ético en sus actividades básicas aunque tengan escasos códigos éticos.

Otros aspectos de las empresas que también inciden en la disposición de los líderes hacia la responsabilidad social son la edad de las empresas y su sector de actividad. 
En una investigación desarrollada con directivos en España para evaluar su influjo en la implantación de la Responsabilidad Social Corporativa se concluyó que la edad de una empresa influye de forma positiva en las prácticas de responsabilidad social que desarrolla (Godos, Fernández y Martínez, 2010).

En otro trabajo realizado en directivos en España para evaluar su percepción de la responsabilidad social se ha concluido que el sector de actividad en el que una organización desarrolla su actividad influye en su orientación hacia la responsabilidad social (Godos, y Fernández, 2011). En esta investigación se constató que la responsabilidad social es un asunto de mayor trascendencia y utilidad económica para las empresas industriales que para el resto.

También se han localizado trabajos sobre características de los propios líderes que inciden en su actitud hacia la responsabilidad social.

En el estudio desarrollado con altos cargos en España para analizar su influencia en la implantación de la responsabilidad social se llegó a la conclusión de que la edad del alto cargo empresarial influye positiva $y$ significativamente en la subordinación de la ética y la responsabilidad social (Godos, Fernández y Martínez, 2010).

En la investigación realizada en España para evaluar la percepción de la responsabilidad por parte de los directivos 
de grandes organizaciones también se concluyó que aquellos que tienen menos edad otorgan más valor a la Responsabilidad Social Corporativa (Godos, y Fernández, 2011). 


\subsection{DELIMITACIÓN CONCEPTUAL DEL VALOR}

\subsubsection{Concepto de valor}

A pesar del amplio abanico histórico y multidisciplinario sobre la definición del término "valor", no ha existido consenso entre las distintas ciencias que han abordado su estudio.

Dentro de la propia psicología tampoco se ha dado una concordancia significativa sobre las diferentes comprensiones del concepto valor. A pesar de que algunos investigadores (Rokeach, 1973) ya habían indicado la necesidad de encontrar un concepto integrador del término.

$\mathrm{Ha}$ continuación hemos seleccionado las definiciones propuestas por algunos investigadores y hemos indicado, en cada caso, algunos rasgos que se destacan en los valores.

Kluckhohn $(1951,395)$ ha definido los valores como "una concepción, explícita o implícita, característica de un individuo o de un grupo, de los aspectos deseables que influyen en la selección de modos, medios y fines disponibles de acción".

En su exposición de contenidos este autor pone el énfasis en que los valores son productos abstractos que están contenidos en los procesos neuronales de las personas. 
Rokeach $(1973,5)$ ha establecido que "un valor es una creencia perdurable de un modo de conducta específico o fin en la vida, que es personal o socialmente preferible sobre otro modo de conducta o fin de existencia".

Este autor pone el acento en tres aspectos: su carácter perdurable, su vinculación con las necesidades y su tipología general (Rokeach, 1973).

Que los valores presentan perdurabilidad es un aspecto que Rokeach (1973) atribuye al proceso de socialización de la persona, donde los valores se van asimilando de forma aislada y contundente.

Rokeach (1973) también sostiene que los valores son transformaciones de las necesidades. Este tipo de transformaciones solo pueden ser realizadas por el hombre y, además, representan las demandas sociales e institucionales. Es decir, la sociedad socializa a las personas sobre el bien común a través de sus instituciones, haciendo que interioricen las concepciones compartidas sobre lo deseable.

Además también se destaca que existen dos tipos de valores (diferenciación tomada por Rokeach de autores previos) los valores terminales, que son fines y virtudes que las sociedades e individuos crean para sí mismos, y los valores instrumentales, aquellos que los actores y grupos consideran como medios para lograr fines.

Feather $(1992,111)$ ha definido los valores como "las condensaciones de experiencias acumuladas que capturan 
las cualidades abstractas de hechos pasados, y que tienen una cualidad normativa o de deber ser acerca de estas, funcionando como criterios o marcos de referencia contra los cuales pueden ser evaluadas las experiencias actuales (...). Pero no son estructuras abstractas nuevas, están atadas a nuestros sentimientos y pueden funcionar como motivadores generales".

En las definiciones previas se ha hecho alusión a dos componentes de los valores. De una parte al componente cognitivo, que hace referencia a la capacidad de los valores para facilitar una comprensión de la realidad. Y de otra al componente conativo, que hace alusión a la capacidad de los valores para impulsar un determinado modo de conducta. Aunque los autores precedentes sí aluden al carácter afectivo de los valores, es Feather el primero en hacer una referencia explícita a este componente.

Feather y Newton (1982) también destacan de los valores otros rasgos relacionados con la propuesta teórica de Feather: se trata de aspectos centrales de la personalidad que están estrechamente relacionados con el sentido propio del yo y que se ordenan de forma jerárquica o en un sistema de valores.

Para Locke $(1991,291)$ los valores son "aquello que la gente desea o considera benéfico para su bienestar, aunque la evidencia definitiva de los valores de una persona se manifiesta en sus acciones". 
En su exposición teórica sobre los valores, Locke ofrece diversas apreciaciones que matizan su definición.

Por una parte indica que los valores forman parte del descubrimiento que las personas necesitamos realizar para sobrevivir. Los seres humanos precisamos de un código de valores que guíe las acciones y la toma de decisiones. Si una persona no tuviera una jerarquía de valores, su acción quedaría continuamente paralizada, ya que no sería capaz de decidirse entre varias alternativas (Locke, 1991).

Además también observa que los valores conllevan una dimensión emocional. Esta dimensión emocional, ya indicada por Feather, es matizada por Locke (1984) al mencionar la intensidad del valor. En este sentido los valores determinan el grado de satisfacción que una persona puede experimentar sobre un objeto, evento o resultado asociado a un determinado valor, de acuerdo con su posición en la jerarquía de valores.

Locke (1991) también manifiesta que los valores pueden estar a un nivel consciente o inconsciente. Incluso en el caso de valores que se manifiesten en acciones.

Finalmente también destaca que las metas desempeñan un rol relevante en los valores. Locke indica que las metas permiten que los valores hagan referencia a su aplicación en situaciones específicas, y es tal su relevancia en los valores que reflejan el contenido de estos incluso cuando los valores se encuentran interiorizados a un nivel inconsciente. 
Hofstede $(1980,19)$ ha indicado que los valores son las tendencias generales a preferir ciertos estados o asuntos sobre otros.

Hofstede (1980) también ha señalado algunos aspectos de los valores. Por una pate ha indicado que se trata de sentimientos que tienen un lado positivo y otro negativo (Hofstede, 1980). Este autor, por tanto, establece con claridad la dirección que puede regir un valor. Además también ha manifestado que son la parte medular de una cultura y una de las primeras cosas que se aprenden de la misma (Hofstede, 1991). Se incorpora a la propuesta de Rokeach, por tanto, el carácter central de los valores en una cultura.

Ravlin y Meglino (1987) han definido los valores como "modos deseables de conducta, creencias sobre el modo en el que un individuo debería comportarse".

En su definición inciden en algunos de los aspectos tratados anteriormente, como en el carácter relativamente estable del valor (Ravlin y Meglino, 1989). Pese a no aportar novedad en su propuesta respecto a los autores previos, hemos incluido su definición entre las señaladas por su capacidad para sintetizar en pocas palabras un rasgo central que todos los autores destacan: la capacidad de los valores para orientar las decisiones.

Schwartz (1999a, 24-25) ha afirmado que los valores son "concepciones de lo deseable que guían la forma en que 
los actores sociales eligen sus acciones, evalúan a la gente y a los acontecimientos, y explican sus acciones y evaluaciones. En esta perspectiva los valores son metas transituacionales deseables, que varían en importancia y que sirven como principios guía en la vida de las personas".

De su definición del valor y de las reflexiones del propio Schwartz sobre su propuesta destacamos su hincapié en la capacidad del valor para expresar un objetivo motivacional (Schwartz, 1999a). Además también señalamos el potencial de los objetivos motivacionales que las personas poseen para construir una estructura exhaustiva y dinámica de validez universal sobre el valor (Schwartz, 1992).

Esta última apreciación ha sido una de las pretensiones del trabajo de este investigador. Hemos profundizado en su enfoque al tratar las tipologías de los valores, ya que hemos considerado que tiene implicaciones en el ámbito de la responsabilidad social. Concretamente, en la validez universal de los estudios sobre valores éticos.

Arciniega (2001) realizó un estudio teórico sobre el concepto de valor desde una perspectiva laboral. Definió los valores como "representaciones cognitivas de necesidades universales que se expresan a través de metas que trascienden a situaciones y objetos, y que se ordenan en una estructura dinámica con carácter jerárquico". 
Dado que esta definición ha sintetizado los rasgos más esenciales propuestos por los autores revisados, se ha tomado como referencia en la investigación.

\section{A continuación hemos incorporado el cuadro 19 con algunas de las características fundamentales que presentan los valores e información relevante asociada:}

\begin{tabular}{|c|c|}
\hline Características & Información relevante relacionada \\
\hline $\begin{array}{l}\text { 1. Son representaciones } \\
\text { cogntivas de } \\
\text { necesidades } \\
\text { universales que tienen } \\
\text { un carácter abstracto y } \\
\text { estable (Locke, 1991). }\end{array}$ & $\begin{array}{l}\text { El carácter cognitivo del valor y su carácter } \\
\text { estable permiten que el curso de actuación } \\
\text { siempre esté orientado por la conciencia. }\end{array}$ \\
\hline $\begin{array}{l}\text { 2. Trascienden las } \\
\text { situaciones y los } \\
\text { objetos específicos } \\
\text { aunque les dan sentido } \\
\text { (Ramió, 2005). }\end{array}$ & $\begin{array}{l}\text { Es decir, influyen sobre la percepción y las } \\
\text { actitudes. } \\
\text { Esto se produce porque expresan un objetivo } \\
\text { motivacional que ocupa un lugar central en el } \\
\text { sistema cognitivo de las personas. } \\
\text { El carácter motivacional de los valores presenta } \\
\text { dos atributos (Rand, 1966; Ravlin y Megglino, 1987): } \\
\text { - Contenido: lo que se quiere o valora. } \\
\text { - Intensidad: grado en que algo es querido o } \\
\text { valorado. }\end{array}$ \\
\hline $\begin{array}{l}\text { 3. Se ordenan de forma } \\
\text { jerárquica (MOW, 1987; } \\
\text { WOSY, 1989) } \\
\text { organizando los } \\
\text { principios que guían la } \\
\text { vida (Schwartz, 1999b). }\end{array}$ & $\begin{array}{l}\text { Este aspecto facilita la toma de decisiones ante } \\
\text { situaciones inciertas. } \\
\text { La jerarquía no es estática porque los valores } \\
\text { tienden a una estructura dinámica que permite } \\
\text { que cada valor pueda modificar su posición, o } \\
\text { incluso su presencia, en dicha jerarquía (Arciniega, } \\
\text { 2001). }\end{array}$ \\
\hline $\begin{array}{l}\text { 4. Son producto de la } \\
\text { socialización de las } \\
\text { personas. }\end{array}$ & $\begin{array}{l}\text { Este proceso permite la adopción de los valores } \\
\text { incluso de forma inconsciente. }\end{array}$ \\
\hline $\begin{array}{l}\text { 5. Solo son desarrollados } \\
\text { por los seres humanos } \\
\text { (Rokeach, 1973). }\end{array}$ & - Los animales carecen de la capacidad. \\
\hline
\end{tabular}

Cuadro 19: Características de los valores. Fuente: elaboración propia. 


\subsubsection{Diferencias entre los valores y las actitudes}

En la literatura sobre valores y actitudes se han encontrado afirmaciones como que los valores son una clase especial de actitudes (Levy y Guttman, 1976), aunque algunos autores ya han indicado que las actitudes son una función de los valores preexistentes en la persona, y, por tanto, valores y actitudes son constructos diferentes (Hofstede, 1998).

A continuación hemos indicado algunas de las diferencias más significativas que los expertos han señalado en relación a los valores y las actitudes.

En primer lugar se indica que los valores ocupan un lugar más central que las actitudes en la estructura cognitiva de las personas. Esta posición más central implica que los valores determinen las actitudes $y$ el comportamiento en los seres humanos (Arciniega, 2001).

Otro aspecto destacado que diferencia ambos constructos, es que el valor trasciende objetos y situaciones concretas mientras que las actitudes se centran de forma concreta en un objeto o situación. Esto es posible por la capacidad de las actitudes de expresar objetivos motivacionales (Schwartz, 1999a).

También es pertinente tener presente que las actitudes no poseen la capacidad que sí presentan los valores de ordenarse en una estructura dinámica de 
carácter jerárquico (Arciniega, 2001). En este sentido la relación que presentan las actitudes de una persona es más independiente que la que mantienen sus valores.

Otro rasgo diferencia valores y actitudes, es que los valores son estándares de referencia que permiten evaluar situaciones y objetos. Las actitudes no permiten realizar evaluaciones sobre el objeto al que hacen referencia mientras que el componente motivacional de los valores sí influye sobre la valencia que se asocia a cierto objeto o situación (Feather, 1992).

Además, ambos constructos presentan una clara diferenciación en su forma de relacionarse con las creencias. Mientras los valores son creencias únicas, la actitud hace referencia a la organización de un conjunto de creencias que están enfocadas hacia un objeto o situación particular (Serrano, 1984).

Por otra parte, un valor tiende a transformarse en norma de comportamiento gracias a su carácter relativamente estable, mientras este proceso no tiene por qué darse en el caso de las actitudes (Ravlin y Meglino, 1989). En el apartado que hemos dedicado a las actitudes y al comportamiento se ha profundizado en los factores que limitan la correspondencia entre ambos aspectos.

También es relevante destacar que aunque los dos constructos poseen los componentes cognitivo, afectivo y conativo, los valores se diferencian claramente de las actitudes por el lugar central que ocupan las creencias en 
su constitución. Posición que, como hemos indicado, transciende objetos y situaciones para ordenarse en estructuras dinámicas de carácter jerárquico (Arciniega, 2001). Mientras que en el caso de las actitudes ya habíamos indicado que el componente central, que había sido identificado por algunos autores como la misma actitud (Ajzen y Fishbein, 1980; Fishbein y Ajzen, 1975), es el afectivo. En este sentido, las actitudes se constituyen como una función de los valores ya que los valores orientan la comprensión, evaluación y disposición comportamental respecto a objetos, situaciones y personas. 


\subsection{TIPOLOGÍAS DE VALORES}

Tal y como hemos indicado en la definición del valor, este se ha estudiado desde diversas disciplinas y a través de distintos enfoques.

Hemos mencionado en este apartado algunos de los enfoques desde los que se ha estudiado el valor por su utilidad potencial en la discusión de los resultados de la investigación. Hemos agrupado estos enfoques en dos bloques.

Por una parte hemos incorporado el apartado "Enfoque filosófico" para revisar los tres clusters dominantes en el pensamiento occidental sobre el modo en el que los valores orientan el comportamiento (pragmático, intelectual y humano).

Por otra hemos desarrollado el apartado "Enfoque psicológico", para tratar algunas de las propuestas más relevantes que se han formulado para estudiar los valores.

\subsubsection{Enfoque filosófico}

La revisión de las filosofías dominantes en el pensamiento occidental ha revelado la existencia de tres clusters que representan tres maneras sobre cómo los valores orientan el comportamiento: pragmática, intelectual y humana (Boyatzis, Murphy y Wheeler, 1998). 
Una persona que presente una orientación pragmática en sus valores personales utiliza como referencias el utilitarismo, el consecuencialismo y el pragmatismo.

Desde estas filosofías un ser humano con orientación pragmática (Boyatzis, Murphy y Wheeler, 1998) evalúa las cosas, las actividades y la vida mediante el análisis de la utilidad que le proporcionan, comparando las "entradas" y las "salidas" (imputs y outputs).

Como resultado este planteamiento una persona resalta la cuantificación en la relación que establece con la vida (Boyatzis, 2002).

En la medida en que se asume que una persona juzga y puede controlar la utilidad que le proporcionan los imputs y los outputs de su vida, existe una tendencia a que el ser humano resalte el individualismo inherente en la persona.

La investigación sobre este enfoque ha demostrado que una persona pragmática está orientada de forma activa hacia nuevas situaciones y el aprendizaje (Kolb, 1984). Además también ha indicado que se trata de un ser humano con orientación hacia las metas y las acciones (Boyatzis, 1982, 1994, 1995), lo que se manifiesta en la relevancia que otorga a competencias como la orientación hacia la eficacia, la planificación, la iniciativa, la persuasión y la autoconfianza.

Los líderes empresariales que contemplan la responsabilidad social como un medio para satisfacer sus objetivos de mercado estarían enmarcados dentro de esta orientación. 
Una persona con una orientación intelectual utiliza como referencias el racionalismo y el misticismo.

Desde estas filosofías un ser humano con este tipo de orientación evalúa las cosas, actividades y la vida, en términos de su contribución a su conocimiento o su coherencia con un conjunto de principios abstractos (Boyatzis, Murphy y Wheeler, 1998).

Como resultado de este planteamiento, una persona muestra una tendencia hacia el pensamiento analítico o hacia la realización de evaluaciones comparativas en contraste con "un código de moralidad" (Boyatzis, 2002).

La investigación sobre este enfoque ha demostrado que una persona intelectual presenta una orientación abstracta hacia situaciones y aprendizajes nuevos, y tiene una tendencia a utilizar competencias relacionadas con el razonamiento analítico como el reconocimiento de pautas, el uso de conceptos y el desarrollo de teorías (Boyatzis, 2002).

Los líderes empresariales que conciben la responsabilidad social como una obligación moral que la empresa ha contraído con la sociedad estarían próximos a este planteamiento.

Una persona con orientación humana utiliza referencias como el humanismo, el comunitarismo y el colectivismo.

Tomando como base estas filosofías, una persona con este tipo de guía evalúa las cosas, las actividades y la vida 
en términos del impacto y efecto sobre las personas con quienes tiene una relación estrecha y sus relaciones con ellas (Boyatzis, Murphy y Wheeler, 1998).

La investigación sobre este enfoque ha demostrado que una persona que se asienta en este tipo de planteamientos filosóficos presenta una orientación concreta y reflexiva hacia situaciones y aprendizajes nuevos. Además también ha indicado que muestra una tendencia a utilizar competencias relacionadas con la gestión de las personas como la empatía, la dirección del grupo y la objetividad social (Boyatzis, 2002).

Los líderes empresariales que contemplan la responsabilidad social como una obligación de satisfacer las necesidades que contrae su organización en la relación que establece con sus grupos de interés, es decir como una posibilidad de mostrar sensibilidad social en el marco de la Responsabilidad Social Corporativa por dichos grupos (colaboradores, accionistas, proveedores, clientes...), estarían enmarcados dentro de esta orientación. 


\subsubsection{Enfoque psicológico}

Desde el inicio del estudio de los valores, los investigadores han buscado facetas o dimensiones que permitan clasificar a los valores con el objeto de facilitar la aplicación empírica de sus planteamientos.

Una de las primeras propuestas es la de Rokeach (1973), quien estableció los 36 valores del Rokeach Value Survey (RVS):

\section{Terminales}

Instrumentales

1. Amistad verdadera

2. Amor maduro

3. Respecto hacia uno mismo

4. Felicidad

5. Armonía interior

6. Igualdad

7. Libertad

8. Placer

9. Reconocimiento social

10. Sabiduría

11. Salvación

12. Seguridad familiar

13. Seguridad nacional

14. Sentido de logro

15. Un mundo hermoso

16. Un mundo en paz

17. Un mundo confortable

18. Una vida excitante
1. Alegría

2. Ambición

3. Capacidad de amar

4. Limpieza personal

5. Autocontrol

6. Competencia

7. Valentía

8. Cortesía

9. Honestidad

10. Imaginación

11. Independencia

12. Inteligencia

13. Amplitud de miras

14. Lógica

15. Obediencia

16. Disposición servicial

17. Responsabilidad

18. Capacidad de perdonar

Cuadro 20: Valores del Rokeach Value Survey (RVS). Fuente: Rokeach (1973). 
A partir del Rokeach Value Survey (RVS), Rokeach (1973) encontró siete factores subyacentes y bipolares en los valores:

\begin{tabular}{|c|}
\hline $\begin{array}{c}\text { Factores subyacentes y bipolares en los valores } \\
\text { del Rokeach Value Survey (RVS) }\end{array}$ \\
\hline gratificación inmediata versus retardada \\
\hline competencia versus moralidad religiosa \\
\hline autorestrición versus autoexpresión \\
\hline orientación social versus personal \\
\hline seguridad social versus familiar \\
\hline respeto versus amor
\end{tabular}

Cuadro 21: Factores subyacentes y bipolares en los valores del Rokeach Value Survey (RVS). Fuente: Rokeach (1973).

\section{Estos factores no fueron utilizados posteriormente} en los múltiples análisis con otras variables sociodemográficas realizados por Rokeach a causa de la baja varianza que explicaban, aunque en estudios posteriores (Johnston, 1995) se establecieron dos dimensiones subyacentes en los valores terminales e instrumentales: individualismo-logro y colectivismo-afiliación.

En relación con los valores propuestos por Rokeach (1973), parece darse una mayor proximidad a la responsabilidad social en algunos valores instrumentales. Este es el caso del valor "disposición servicial”, ya que la responsabilidad social se define, entre otros aspectos, por su atención a las necesidades de los grupos de interés. También hemos encontrado afinidad en el valor "responsabilidad", debido a que el quehacer empresarial propio de la responsabilidad social supone asumir los 
efectos causados por la actividad que desarrollan las organizaciones.

También hemos encontrado cercanía entre algunos de los valores terminales propuestos por Rokeach (1973) y la responsabilidad social. Este es el caso del valor "felicidad", que hemos entendido que emerge en la experiencia subjetiva de los líderes y de los colaboradores, a causa de la adecuada atención de las necesidades de los grupos de interés. También hemos entendido que existe proximidad con la Responsabilidad Social Corporativa con el valor "un mundo confortable", porque la Responsabilidad Social Corporativa se caracteriza, entre otros aspectos, por el respeto al medioambiente.

Además también nos parece que existe una relación directa entre la responsabilidad social tanto con uno de los factores mencionadas anteriormente, como con una de las dimensiones.

Vemos esta relación, en concreto, con el cuarto factor señalado por Rokeach (1973): la “orientación social versus personal". Hemos entendido que la Responsabilidad Social Corporativa se orienta específicamente hacia el primero de los polos de este factor por su preocupación por los grupos de interés, en particular, y por la sociedad, en general. También nos parece que existe proximidad entre la dimensión subyacente indicada por Johnston (1995) como “colectivismo-afiliación" y la Responsabilidad Social Corporativa, al considerar que esta disciplina se encuentra 
muy próxima al polo “colectivismo” por su preocupación por el adecuado progreso social.

Posteriormente Schwartz y Blisky (1987) realizaron una revisión de la literatura de necesidades, motivos sociales, demandas sociales y requerimientos funcionales de grupos sociales, para proponer una descripción conceptual de siete tipologías de valores o dominios motivacionales de valores. Las tipologías que propusieron fueron:

\begin{tabular}{|l|l|}
\hline \multicolumn{1}{|c|}{ Tipología } & \multicolumn{1}{c|}{ Definición } \\
\hline 1. Disfrute & $\begin{array}{l}\text { Necesidad básica de todo organismo de obtener } \\
\text { placer al satisfacer sus necesidades básicas. }\end{array}$ \\
\hline 2. Seguridad & $\begin{array}{l}\text { Necesidad básica de todo organismo de sobrevivir } \\
\text { y de evitar amenazas a su integridad. }\end{array}$ \\
\hline 3. Logro & $\begin{array}{l}\text { Necesidad básica de toda persona de desarrollar y } \\
\text { utilizar sus habilidades para obtener del entorno } \\
\text { físico y social aquellos recursos necesarios para } \\
\text { crecer. }\end{array}$ \\
\hline 4. Autodirección & $\begin{array}{l}\text { Deseo intrínseco que tienen las personas de: } \\
\text { explorar y de entender la realidad, } \\
\text { - y de experimentar por sí mismos que tienen } \\
\text { capacidad para controlar los eventos de forma } \\
\text { efectiva. }\end{array}$ \\
\hline 5. Prosocial & $\begin{array}{l}\text { Requerimiento de una actitud proactiva por parte } \\
\text { de los integrantes de los grupos sociales para que } \\
\text { el colectivo crezca. }\end{array}$ \\
\hline 7. Conformidad & $\begin{array}{l}\text { Consecución de objetivos en las personas con el } \\
\text { paso del tiempo y, no necesariamente, gracias al } \\
\text { trabajo y al esfuerzo (ejemplo: sabiduría). }\end{array}$ \\
\hline Madurez & $\begin{array}{l}\text { Necesidad de las personas de restringir sus } \\
\text { impulsos e inhibir ciertas acciones en pro del } \\
\text { correcto funcionamiento de la interacción social y } \\
\text { grupal. }\end{array}$ \\
\hline
\end{tabular}

Cuadro 22: Tipologías de valores o dominios motivacionales de valores. Fuente: Schwartz y Blisky (1987). 
La investigación desarrollada por los autores corroboró que los valores humanos pueden ser agrupados en dominios motivacionales que guardan una estructura dinámica. En dicha estructura verificaron cuatro contradicciones: (1) autodirección versus conformidad restrictiva, (2) logro versus seguridad, (3) logro versus prosocial y (4) disfrute versus prosocial.

De todos modos los autores también manifestaron que es necesario contemplar otros dominios motivacionales no examinados, como el de "autoridad", y depurar el de "seguridad" para que su propuesta tuviera mayor solidez.

Hemos entendido que la tipología "prosocial" presenta una mayor cercanía con la naturaleza de la Responsabilidad Social Corporativa, ya que teóricamente no existe en esta disciplina un interés lucrativo en la atención a los grupos de interés (Schwartz y Blisky, 1987). También hemos considerado destacable que el "logro" sea, en un caso, el otro eje del dominio motivacional en el que se enmarca esta tipología. En la esfera económica, el logro es el aspecto más comúnmente aceptado en relación con los fines que persiguen los líderes empresariales $y$, según el planteamiento de Schwartz y Blisky, sería opuesto a la preocupación altruista por los diversos colectivos con los que se relaciona una organización (que representa un rasgo central en la filosofía de la responsabilidad social). 
Bond (1988) también realizó investigaciones y encontró resultados que coincidían con las dimensiones encontradas por Schwartz y Blisky (1987).

Este investigador se propuso identificar dimensiones de variabilidad de los valores a nivel mundial. Realizó el estudio a partir de los datos de un trabajo previo (The Chinese Culture Connection, 1987) sobre una muestra de más de 2000 estudiantes universitarios de 22 países y utilizando el Cuestionario de Valores Chinos (The Chinese Culture Connection, 1987).

Bond encontró dos dimensiones subyacentes que explican tan solo el $13,8 \%$ de la varianza "integración social versus espiritualidad" y "reputación versus moralidad social".

En el polo positivo del factor "integración social versus espiritualidad" saturan los valores: "tolerancia hacia otros", “paciencia”, "armonía” y "persistencia”. Mientras en que en el polo negativo aparecen los valores: "piedad filial", "respeto por la tradición" y "sentido de superioridad social”.

En el polo positivo del factor "reputación versus moralidad social" se encuentran los valores: "protegiendo tu cara", "salud" y "reciprocidad de favores y regalos". Y en el polo opuesto emergen los valores: "manteniéndose uno mismo desinteresado y puro", "castidad en las mujeres" y "sentido de rectitud".

Bond destaca que el polo positivo de la primera dimensión, “integración social versus espiritualidad”, es 
similar a los dominios motivacionales "prosocial" y “madurez" encontrados por Schwartz y Blisky (1987), mientras que el polo negativo se solapa conceptualmente con el dominio motivacional "conformidad restrictiva" (Schwartz y Blisky, 1987).

En relación con la segunda dimensión, “reputación versus moralidad social", Bond indica la existencia de una relación parecida con el dominio motivacional de Schwartz y Blisky (1987) "autoridad social" en el polo positivo. Por otra parte, el polo negativo de la segunda dimensión, "moralidad social”, se relaciona, según Bond (1988), con el dominio motivacional "madurez" y, posiblemente, con "conformidad restrictiva".

Sus hallazgos han permitido otorgar validez a los dominios motivacionales conceptualizados por Schwartz y Blisky (1987).

En relación con la responsabilidad social es destacable que los hallazgos de Bond (1988) también han permitido otorgar validez universal a la orientación prosocial indicada por Schwartz y Blisky (1987), destacando asimismo el rol esencial que desempeña dentro de una de las dos dimensiones subyacentes en los valores.

Estas observaciones indican el elevado protagonismo de las motivaciones intrínsecas de la responsabilidad social en la estructura motivacional humana.

Años más tarde Schwartz (1992) decidió depurar las tipologías previamente confirmadas a través de la 
experimentación (Schwartz y Blisky, 1987, 1990) y robustecer las relaciones dinámicas que se habían propuesto. Schwartz incorporó tres nuevas tipologías de valores, propuso la existencia de una tipología adicional denominada inicialmente "espiritualidad" y redefinió algunas de las tipologías originales (madurez, prosocial y seguridad).

Las once tipologías que Schwartz propuso son (1992):

\begin{tabular}{|c|c|}
\hline Tipología & Definición \\
\hline 1. Autodirección & - Pensamiento y acción independientes. \\
\hline 2. Estimulación & $\begin{array}{l}\text { Necesidad de llevar a cabo una diversidad de } \\
\text { actividades estimulantes que permitan a la persona } \\
\text { mantener un nivel óptimo de activación. }\end{array}$ \\
\hline 3. Hedonismo & - Placer o sentido de gratificación para uno mismo. \\
\hline 4. Logro & $\begin{array}{l}\text { Demostración del éxito personal siendo } \\
\text { competente de acuerdo a los estándares sociales. }\end{array}$ \\
\hline 5. Autoridad & $\begin{array}{l}\text { Consecución de estatus social y prestigio, así como } \\
\text { de control y dominancia sobre personas y recursos } \\
\text { materiales. }\end{array}$ \\
\hline 6. Seguridad & $\begin{array}{l}\text { Seguridad, armonía y estabilidad de la sociedad, de } \\
\text { las relaciones personales y de la propia persona. }\end{array}$ \\
\hline 7. Conformidad & $\begin{array}{l}\text { Restricción de acciones, inclinaciones e impulsos: } \\
\text { - } \quad \text { que pudieran molestar o dañar a otros, } \\
\text { - y que supongan, por tanto, una violación de las } \\
\text { normas o expectativas sociales. }\end{array}$ \\
\hline 8. Tradición & $\begin{array}{l}\text { Respeto, compromiso y aceptación de las ideas } \\
\text { que la cultura o la religión de la persona imponen. }\end{array}$ \\
\hline 9. Religiosidad & $\begin{array}{l}\text { Dar significado y armonía interna a la vida de la } \\
\text { persona más allá de la intranscendencia cotidiana. }\end{array}$ \\
\hline 10. Benevolencia & $\begin{array}{l}\text { Preservación y mejoramiento del bienestar de la } \\
\text { gente con que la persona está en contacto } \\
\text { frecuentemente. }\end{array}$ \\
\hline 11. Universalismo & $\begin{array}{l}\text { Comprensión, tolerancia y protección del bienestar } \\
\text { de toda la gente y de la naturaleza. }\end{array}$ \\
\hline
\end{tabular}

Cuadro 23: Tipologías de valores. Fuente: Schwartz (1992). 
Experimentalmente la dimensión "religiosidad" no se pudo validar, y los análisis realizados descubrieron la existencia de tres contradicciones entre las diez tipologías restantes: (1) "autodirección” y “estimulación” versus "conformidad", "tradición” y "seguridad”, (2) “logro" y “autoridad" versus "benevolencia” y "universalismo", y (3) “hedonismo" versus "conformidad” y "tradición”.

A partir de las dos primeras contradicciones se deriva la posibilidad de agrupar nueve de las diez categorías indicadas en cuatro valores de orden superior: "apertura al cambio" (autodirección y estimulación), "conservación” (tradición, conformidad y seguridad), "autoengrandecimiento" (logro y autoridad) y "autotrascender" (universalismo y benevolencia).

Dado que la tipología "hedonismo" agrupa a valores que comparten los objetivos motivacionales de orden superior de "apertura al cambio" y "autoengrandecimiento", la teoría propone que su posición debe ser independiente e intermedia respecto al resto de tipologías.

En la propuesta teórica es importante tener presente que si bien el continuo de valores se divide en diez tipologías (las nueve integradas en los cuatro valores de orden superior y el hedonismo) y en cuatro valores de orden superior, la realidad es que se trata de un verdadero continuo con posibles solapamientos.

Los estudios realizados por el Schwartz (1992) y por Schwartz, Melech, Lehmann, Burgess y Harris (2001) para 
corroborar la validez de su planteamiento verificaron su propuesta.

Desde el punto de vista de la responsabilidad social el modelo presenta dos tipologías de valores que tienen mucha proximidad al planteamiento de la responsabilidad social. En primer lugar hemos destacado "benevolencia", al considerar que la preocupación por los grupos de interés está directamente asociada a la definición teórica de esta dimensión (preservación y mejoramiento del bienestar de la gente con que la persona está en contacto frecuentemente). También hemos encontrado coincidencia entre la Responsabilidad Social Corporativa y la tipología "universalismo", ya que el interés por mejorar la sociedad y el medioambiente están directamente relacionados con la concepción teórica de esta dimensión.

A las indicaciones anteriores hemos de añadir que estas tipologías se enmarcan dentro del cuarto valor de orden superior propuesto por Schwartz (1992), "autotrascender". Este aspecto indica, al igual que los estudios desarrollados por Bond, que en la estructura motivacional humana básica existe una destacada relevancia de las motivaciones propias de la responsabilidad social.

También hemos considerado importante destacar el hecho de que, al igual que en el caso de la propuesta de Bond, las investigaciones sobre la validez del planteamiento de Schwartz concedan carácter universal a algunos de los rasgos con mayor proximidad al perfil más característico de 
la responsabilidad social. Hemos encontrado esta coincidencia en las tipologías "benevolencia" y "universalismo" (comprensión, tolerancia y protección del bienestar de toda la gente y de la naturaleza). 


\subsection{VALORES Y RESPONSABILIDAD SOCIAL CORPORATIVA}

Dado el carácter guía de los valores personales en la orientación de la actitud hacia la Responsabilidad Social Corporativa, también hemos considerando pertinente hacer alusión a estudios en este campo.

En los estudios que se han revisado sobre valores y responsabilidad social se han encontrado diversos trabajos sobre este tema.

Estas investigaciones aportan información interesante sobre los factores que inciden en que los valores personales de los líderes se orienten hacia la responsabilidad social y sobre valores especialmente asociados a la Responsabilidad Social Corporativa.

Hemos clasificado los hallazgos encontrados en dos grupos: factores relacionados con la cultura empresarial y valores asociados a la responsabilidad social

En relación con la cultura empresarial, la literatura científica ha destacado que para que las empresas desarrollen una práctica coherente en materia de responsabilidad social resulta necesario que alineen sus actuaciones en el ámbito de la responsabilidad social con sus prioridades mercantiles. Es decir, que integren los 
valores próximos a la responsabilidad social en su modelo de negocio. Para algunos autores esto solo es posible si desarrollan una cultura flexible e innovadora centrada en la satisfacción de los grupos de interés (Castelló, 2003).

Por otra parte también se han encontrado estudios que indican, de modo específico, algunos aspectos de las organizaciones que inciden en la configuración de los valores éticos. En una investigación desarrollada en Taiwán y en EE.UU. (Blodgett, Lu, Rose y Vitell, 2001) se constató que la sensibilidad ética hacia los grupos de interés se estimula cuando se reduce de incertidumbre y disminuye cuando aumenta la distancia jerárquica, el individualismo y la masculinidad -aspecto este último asociado al materialismo (Hofstede, 1979, 1980, 1991)-. Estos datos parecen mostrar que las organizaciones cuyos valores más relevantes fomentan la preocupación por los demás y el colectivismo, presentan una mayor disposición a tratar con sensibilidad a sus grupos de interés.

De todos modos, la incidencia del entorno empresarial en los valores de los líderes próximos a la responsabilidad social es un ámbito incipiente en el que se esperan alcanzar muchas conclusiones en el futuro. Se ha constatado la existencia de un emergente campo de estudio que intenta establecer una relación entre los valores personales de los líderes y el desarrollo de marcos de trabajo éticos (Mudrack, 2007; Strautmanis, 2008). 
Respecto a los valores asociados a la responsabilidad social, Hemingway y Maclagan (2004) han indicado que la adopción de la responsabilidad social por parte de las organizaciones podría estar relacionada con un posible cambio en los valores personales de los líderes empresariales.

Esta dinámica se articula a partir de dos ejes (figura 23). Por una parte "motivación" (motive), que hace referencia a la motivación del líder, más orientada al ámbito comercial (strategic) o más centrada en un enfoque idealista y altruista (idealistic/altruistic). Por otra "locus de responsabilidad" (locus of responsability), que hace alusión a la motivación del líder, más centrada en su estatus individual (individual) o en la preocupación por todos los afectados en las actuaciones de la organización (corporate).

Hemos incorporado la figura 3 ("Un marco de trabajo para analizar la Responsabilidad Social Corporativa”), en la que se aprecia que los líderes que presentan un perfil más favorable hacia la responsabilidad social son quienes están más orientados hacia el altruismo y el idealismo, y muestran preocupación por aquellos afectados por la actuación organizacional: 


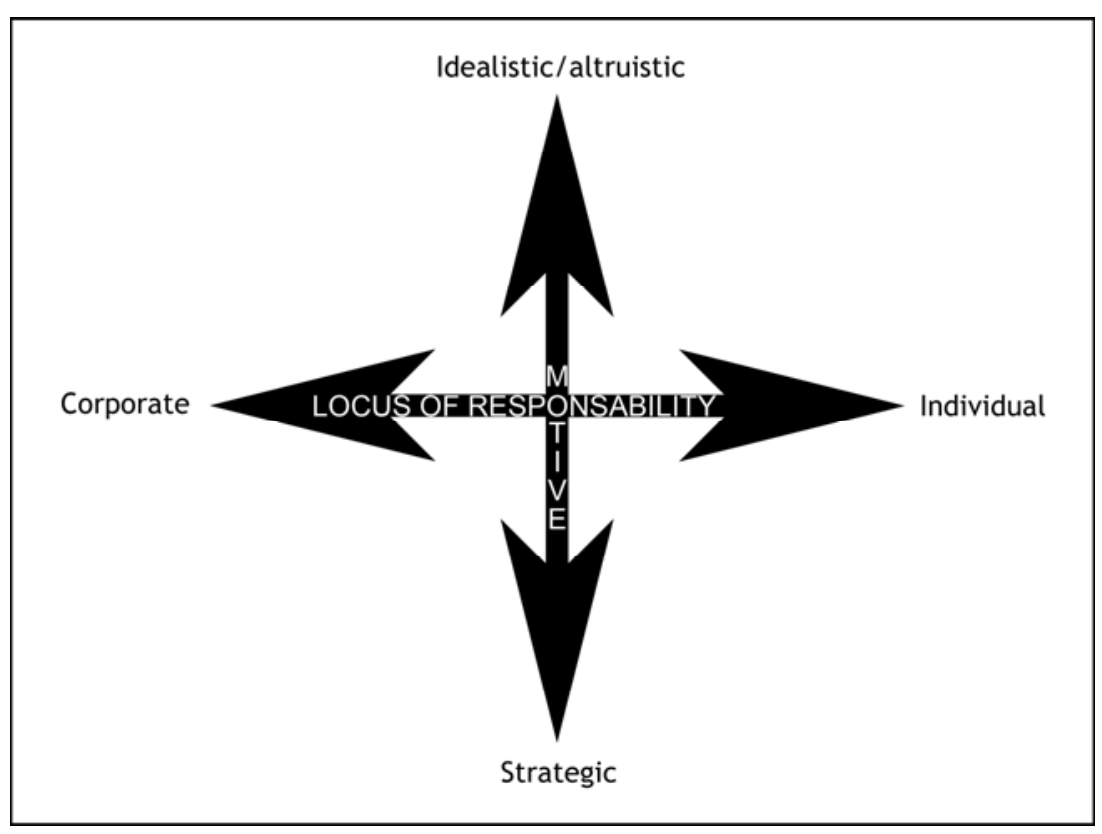

Figura 3: Un marco de trabajo para analizar la Responsabilidad Social Corporativa. Fuente: Hemingway y Maclagan (2004).

También hemos considerado pertinente indicar que, en contra de lo que habíamos sospechado inicialmente, la investigación académica no ha conseguido verificar la relación entre la religiosidad de las personas y su comportamiento ético o socialmente responsable.

Los resultados de los estudios realizados no son concluyentes (Ramasamy, Yeung y Au, 2010). Algunos investigadores (Brammer, Willimas y Zinkin, 2006) han destacado que los resultados que sí confirman esta relación solo están basados en pequeñas muestras y se centran fundamentalmente en la religión cristiana.

Guarda concordancia con estos resultados el hecho de que la tipología "religiosidad", indicada inicialmente por Schwartz (1992) para hacer referencia a la necesidad de dar significado y armonía interna a la vida más allá de la intranscendencia cotidiana, no se pudiera validar en su 
investigación como una tipología de valor con carácter mundial. 



\section{3 - LIDERAZGO: AYER, HOY Y MAÑANA}





\subsection{CONCEPTO DE LIDERAZGO}

La revisión del corpus científico sobre el concepto de liderazgo ha puesto de relieve que este puede comprenderse desde ópticas muy dispares.

Adoptando la propuesta de la Teoría Situacional II como enfoque metodológico en el estudio empírico, hemos entendido el liderazgo como la búsqueda de la excelencia a través de una relación óptima entre el nivel de desarrollo de una persona -aspecto variable en función de la combinación de su competencia y su grado de compromisosobre un objetivo específico o tarea, y el estilo de liderazgo que el líder provee -componente que varía en función del grado de presencia del comportamiento directivo y del comportamiento de apoyo en la conducta del líder- (Blanchard, 2001) 


\subsection{CARACTERÍSTICAS ASOCIADAS AL CONCEPTO DE LIDERAZGO}

Hasta finales del siglo XX muchos de los enfoques revisados sobre el liderazgo han reflejado una disparidad de criterios a la hora de abordar su estudio, variedad de orientaciones que también se ha visto reflejada en el objeto de su investigación: los rasgos del líder, las conductas del líder, la situación en la que el liderazgo se desarrolla, la percepción del liderazgo, la interacción entre los líderes y los colaboradores y la importancia de la identidad social en el establecimiento del liderazgo.

Esta disparidad de criterios también se ha manifestado en el examen que han realizado otros autores del liderazgo. Por ejemplo Bass ha hecho una revisión de la literatura científica sobre las diferentes definiciones que se han utilizado para definir el liderazgo en el primer capítulo de su libro The Bass Handbook of Leadership (2000). En dicho capítulo ha reunido más de 100 definiciones diferentes de liderazgo (Anexo 4) agrupadas en 20 categorías. Hemos indicado a continuación las tipologías utilizadas por Bass en la cuadro 24 "Categorías utilizadas por Bass para definir el liderazgo": 
Categorías utilizadas por Bass para definir el liderazgo

\begin{tabular}{|l|l|}
\hline $\begin{array}{l}\text { Rasgo de personalidad. } \\
\text { Posición central dentro de los } \\
\text { procesos de grupo. }\end{array}$ & Atribución. \\
\hline $\begin{array}{l}\text { Símbolo. } \\
\text { Estimulación intelectual. }\end{array}$ & $\begin{array}{l}\text { Iniciación de significado. } \\
\text { articula un colectivo. }\end{array}$ \\
\hline $\begin{array}{l}\text { Comportamiento persuasivo. } \\
\text { Influencia discrecional. }\end{array}$ & Ejercicio de la influencia. \\
\hline $\begin{array}{l}\text { Instrumento para el logro de un inducir conformidad. } \\
\text { objetivo. }\end{array}$ & - Efecto de la interacción. \\
\hline $\begin{array}{l}\text { Proceso. } \\
\text { Reconocimiento del líder por sus } \\
\text { seguidores. }\end{array}$ & $\begin{array}{l}\text { Combinación de elementos } \\
\text { interrelacionados. }\end{array}$ \\
\hline
\end{tabular}

Cuadro 24: Categorías utilizadas por Bass para definir el liderazgo. Fuente: Bass (2000).

Incluso hay autores que han indicado que es pertinente establecer una diferenciación entre el "líder", que hace referencia a la persona que influye en el compromiso de los integrantes de una organización, y los "directivos", que son aquellas personas que únicamente realizan las responsabilidades de su puesto y ejercen autoridad.

De todos modos también se ha verificado la existencia de un punto de vista opuesto que defiende un considerable solapamiento entre ambos términos. Esta concepción considera que se puede ser, al mismo tiempo, líder y directivo (Sánchez y Alonso del Amo, 2005). 
Nuestra revisión teórica ha permitido detectar algunos aspectos con cierto carácter general en el estudio científico del liderazgo.

Los diferentes trabajos revisados han reflejado que el liderazgo es un factor clave en el éxito de las organizaciones.

Además también podemos afirmar que el liderazgo es un fenómeno que se desarrolla en una situación determinada y a través de un proceso de comunicación que tiene lugar entre un líder y unos seguidores. En dicho proceso, el liderazgo se constituye es un fenómeno de influencia sobre el colectivo en el que se inscribe.

Aunque no existe una combinación de características personales que garanticen la eficacia en el liderazgo, ciertos rasgos presentes en diversos enfoques teóricos sí parecen favorecer el ejercicio de este rol: la flexibilidad, la competencia comunicativa capaz de motivar y transmitir una visión, las habilidades sociales para favorecer la construcción de un sentido colectivo, la capacidad para ganarse la confianza de los colaboradores y la capacidad para establecer objetivos atractivos.

Otro aspecto destacable del liderazgo es que es un tipo de comportamiento que desarrollan los máximos responsables de las organizaciones. Esta conducta se articula a través de dos ejes: las conductas orientadas hacia el desarrollo de las tareas por parte de los colaboradores, y las conductas orientadas a las relaciones humanas con los colaboradores. Además existen una serie de factores que 
inciden en que el comportamiento del líder más orientado a las tareas o más orientada a las relaciones sea más acertado. Estos aspectos son la capacidad de los colaboradores para desarrollar la tarea encomendada, su grado de compromiso con el cometido, el ambiente laboral y la cultura organizacional en la que se enmarca el liderazgo.

De todos modos, los colaboradores también parecen tener una gran influencia en la efectividad del liderazgo que se ejerce en un colectivo. Poseen capacidad para legitimar el rol de liderazgo que se desarrolla en una organización a través de su percepción del intercambio de contribuciones que establecen con el líder y de su visión de este como alguien prototípico del grupo. 


\subsection{MODELOS TEÓRICOS INICIALES}

\subsubsection{Consideraciones previas}

Para articular el planteamiento de nuestra investigación sobre los valores, el liderazgo y la actitud hacia la responsabilidad social de los líderes organizacionales y favorecer, al mismo tiempo, la interpretación de los resultados alcanzados en el estudio, hemos considerado necesario establecer un marco teórico desde el que concebir a las organizaciones y a los diferentes procesos que tienen lugar en ellas.

Entendemos por organización “la coordinación racional de las actividades de un cierto número de personas que intentan conseguir una finalidad y un objetivo común y explícito mediante la división de funciones y del trabajo, a través de una jerarquización de la autoridad y la responsabilidad" (Schein, 1978).

Para analizar los procesos organizacionales se ha venido denunciando la necesidad de superar el paradigma clásico de la psicología de las organizaciones. Este paradigma estaba basado en una concepción racional de la 
organización que resultaba ineficiente para el estudio de aquella (Benson, 1977).

Algunos autores ya habían indicado la necesidad de aproximarse a las organizaciones desde múltiples niveles de análisis en los que se pusiera el énfasis en los procesos (Bucher, 1970). Aunque solo desde el último tercio del siglo XX se ha comenzado a aceptar, desde un punto de vista pragmático, que de las propiedades y las leyes de interacción no es una cuestión trivial inferir las propiedades del todo (Simon, 1973).

Esta nueva visión del estudio de las organizaciones ha defendido su evaluación desde una "perspectiva integrada y global que considere las organizaciones en sus diferentes niveles (individual, grupal, organizacional e interorganizacional) sin reducir los niveles más complejos a una simple suma o agregado de evaluaciones tomadas en niveles inferiores" (Peiró, 1990, 248-249).

Este cambio en la orientación del esfuerzo por encontrar fórmulas efectivas para estudiar a las organizaciones ha tenido eco, también, en algunas instituciones y organismos preocupadas por las empresas. Por ejemplo el Instituto Nacional para la Seguridad y Salud Ocupacional (NIOSH) incorporó una nueva visión mucho más amplia que la visión precedente, centrada con carácter exclusivo en el control o en las características del puesto de trabajo. La nueva perspectiva incorporó una comprensión más amplia de "la experiencia laboral y de sus efectos sobre 
el bienestar de los trabajadores y el desempeño organizacional, añadiendo factores macro-organizacionales, tales como la cultura y el clima organizacionales, los valores centrales para la organización y los procedimientos y políticas" (Rodríguez, 2007).

En respuesta a este nuevo enfoque, la investigación centrada en mejorar la salud de las organizaciones también comenzó a dirigirse hacia intervenciones que estimulasen cambios en: la estructura organizacional, los procedimientos y políticas, y el clima y la cultura. El objetivo de estas intervenciones ha sido mejorar el bienestar de los trabajadores y el desempeño organizacional (Bennet, Cook y Pelletier, 2002; Rousseau, 2001; Sauter, Hurrell, Murphy y Levi, 2001).

Estos cambios se centraron en cuatro supuestos. En primer término en "la consideración de la organización como un sistema social abierto que tiene constantes transacciones con su entorno, mantiene su propia entidad y está compuesto de subsistemas que actúan de modo interrelacionado". En segundo lugar, en la constatación de que "la conducta organizacional ocurre siempre en un contexto". En tercer término, en "la consideración de la conducta organizacional en diferentes niveles (individual, grupal y organizacional) relacionados entre sí". Y en cuarto lugar, en "la apreciación de la organización como un fenómeno artificial de carácter complejo susceptible de diseño" (Peiró, 1990). 
Desde la perspectiva indicada también ha tenido pleno sentido el análisis de los diferentes grupos de poder en una organización.

Desde una concepción tradicional y liberal de la organización, el grupo constituyente, considerado fundamental, es el capital que pone los recursos económicos y asume los riesgos de la organización. En muchos casos el sistema legal ha establecido, además, que sea este grupo quien pueda crear la organización. Este grupo es denominado "accionistas" (stakeholders) (Peiró, 1999a).

También tienen un peso importante en la organización los directivos, aun no siendo los propietarios (Peiró, 1999a).

Un tercer grupo con poder en la organización es el formado por los colaboradores. Su existencia ha introducido una dialéctica bipolar capital-trabajo que ha implicado la emergencia de intereses con frecuencia contrapuestos, que han entrado en conflicto y que han sido, por tanto, objeto de negociación (Peiró, 1999a).

Una consideración más amplia de los grupos constituyentes, desde una concepción de "partenariado" (shareholders), ha incorporado a otros colectivos.

En este bloque se encuentran los órganos de decisión de la empresa, en los que tienen presencia los colaboradores (Peiró, 1999a).

También pertenece a esta grupo el Estado, que en ocasiones ha desempeñado un rol importante al participar 
en la propiedad de la organización o al ejercer gran influencia en la misma a través de la legislación (Peiró, 1999a).

Dentro de este bloque también tienen un peso importante los clientes. El motivo es que sus opiniones, preferencias, necesidades y demandas cada vez han adquirido más trascendencia en las decisiones organizacionales (Peiró, 1999a).

Otro grupo relevante en este conjunto es el formado por los proveedores. Como consecuencia de la puesta en práctica de estrategias organizativas de externalización (outsourcing), nuevos sistemas de aprovisionamiento que requieren una colaboración más estrecha, este colectivo ha adquirido cada vez un mayor protagonismo (Peiró, 1999a).

\begin{tabular}{|l|l|}
\hline Concepción tradicional y liberal & \multicolumn{1}{c|}{ Concepción más amplia } \\
\hline Accionistas (stakeholders). & $>$ Accionistas (stakeholders) \\
\hline Directivos. & $>$ Directivos. \\
\hline Colaboradores. & $>$ Colaboradores. \\
\hline & $>$ Órganos de decisión de la empresa. \\
\hline & $>$ Estado. \\
\hline & $>$ Clientes. \\
\hline & $>$ Proveedores. \\
\hline
\end{tabular}

Cuadro 25: Grupos de poder en una organización. Fuente: Peiró (1999a).

Schein ha sido uno de los primeros en concebir a la organización como una formación social compleja. Schein ha recogido algunos planteamientos precedentes -como la 
existencia de actividades complementarias 0 interdependientes en la organización (Katz y Kahn, 1966; 1978), la existencia de subsistemas dentro de la organización (Miller, 1978) o la constante relación de la organización con el entorno (Wexley y Yukul, 1977)- y ha planteado algunas consideraciones de relevancia sobre las organizaciones estrechamente relacionados con los planteamientos indicados previamente.

Shechein (1978) ha indicado que “...debemos concebir la organización como un sistema social abierto, lo que significa que se halla en una interacción constante con su medioambiente...”. Además también ha manifestado “...debemos concebir la organización como un sistema de múltiples propósitos o funciones que implican diversas interacciones entre la organización y el medio ambiente". Por otra parte Shechein (1978) también ha declarado que “...las organizaciones consisten en muchos subsistemas que se hallan en interacción dinámica entre sí...”. Además también ha defendido que “... (como) los subsistemas dependen mutuamente entre sí, los cambios en un subsistema es probable que afecten a la conducta de otros". Este autor también ha defendido que “...la organización existe en un medio ambiente dinámico que consta de otros sistemas, algunos más amplios y otros más estrechos...” y que “...los múltiples lazos entre la organización y su medio hacen difícil especificar claramente las fronteras de una organización dada... (por lo que) es 
mejor formular un concepto de organización en términos de procesos...” (Schein, 1978, 127-128).

Su enfoque ha dado lugar a la visión de la organización como un espacio tridimensional cuyo objetivo ha sido ofrecer una perspectiva de la organización que permita articular la óptica concreta de la carrera de las personas que la integran.

Esta propuesta ha defendido la existencia de tres tipos de movimientos distintos dentro de una organización. En primer término la dimensión vertical, que se corresponde con el aumento o disminución del rango o nivel de una persona dentro de una organización. En segundo lugar la dimensión radial, que hace referencia al aumento 0 disminución de la centralidad o inclusión de la persona dentro de la organización. Y finalmente la dimensión circunferencial, que se corresponde con el cambio en la función o área desempeñada en la organización (Schein, 1968, 1977).

\begin{tabular}{|c|}
\hline Dimensiones organizacionales \\
\hline Dimensión vertical (aumento o disminución de nivel). \\
\hline Dimensión radial (aumento o disminución de centralidad). \\
\hline Dimensión circunferencial (cambio en la función o área). \\
\hline
\end{tabular}

Cuadro 26: Dimensiones de la organización. Fuente: Schein $(1968,1977)$.

Otra propuesta centrada en la identificación de los aspectos relevantes de la organización y sus relaciones para facilitar su análisis ha sido la realizada por Kast y 
Rosenszweig (1979), que han caracterizado a las organizaciones como sistemas sociotécnicos a través de la distinción de cinco subsistemas: el estructural, el técnico, el psicosocial, el de los objetivos y valores, y el directivo.

Aunque se han formulado otros modelos, nos hemos detenido en realizar un análisis más detallado de dos de ellos por su vigencia y aceptación: el modelo Análisis del Sistema Humano (ASH) y el modelo Análisis Multifacético y de las Interdependencias en la Gestión Organizacional (AMIGO).

\subsubsection{El modelo Análisis del Sistema Humano} (ASH)

Otro modelo relevante que responde a la concepción de la organización como una organización social compleja es el ASH (Auditoría del Sistema Humano o el Análisis del Sistema Humano). El modelo ASH es una "unidad compuesta de partes interrelacionadas que responden a un Modelo 0 sistema de gestión de RRHH, que a su vez se compone de varios subsistemas, siendo él mismo un subsistema del mayor y más complejo Sistema Abierto que es la Organización” (Quijano y Navarro, 1999, 306).

El origen histórico del $\mathrm{ASH}$ se ha encontrado en la demanda realizada por la Unión Patronal Metalúrgica (UPM) 
de Cataluña a la Fundación Bosch i Gimpera de la Universidad de Barcelona para crear instrumentos que permitan diagnosticar o evaluar la Gestión Estratégica de Recursos Humanos en la pequeña y mediana empresa (Quijano y Navarro, 2009). Las razones que fundamentaron la atención de esta demanda y que, por tanto, han orientado el desarrollo del modelo se han relacionado con tres motivos principales: la búsqueda de la calidad en las organizaciones, la incertidumbre y la ambigüedad de los entornos laborales, y la mayor exigencia de efectividad a las organizaciones.

Como indicábamos, desde el siglo XX se ha concedido una mayor importancia a la conquista de calidad por parte de las organizaciones. Inicialmente el énfasis se puso en los productos de la organización para favorecer el incremento de la calidad. $Y$ posteriormente el acento se centró en mayor medida en el proceso de producción más que en el producto acabado (Shewhart, 1931).

Sin embargo los expertos en calidad pronto descubrieron que no era posible conseguir resultados excelentes en calidad si solo se aplicaban sus métodos a los procesos productivos. Por esta razón mostraron la necesidad de evaluar la calidad a través de una visión global de la organización que implicara a todos los departamentos y divisiones de la misma, y no solo a los implicados de modo directo en el proceso de producción. Este enfoque derivó, finalmente, en la perspectiva de la "calidad total" (Karatsu, 
1991) y en la concepción de la calidad como una estrategia y una política de dirección de la organización.

Otro motivo que impulsó el nacimiento del ASH ha sido la creciente incertidumbre y ambiguiedad del trabajo desarrollado por las personas en las organizaciones desde finales del s. XX por diversos motivos (como la virtualidad, la presión temporal o la elevada impredicibilidad del entorno, entre otros factores). Las organizaciones han precisado de herramientas para diseñar con acierto equipos que trabajen en grupo, de forma colaborativa o en red. Esta aspiración ha dado lugar al desarrollo de constructos clave que permitan entender el funcionamiento de los equipos de trabajo en el modelo ASH (Navarro, Quijano, Berger y Meneses, 2011).

También la globalización de la economía, la internacionalización de los mercados, la introducción de las nuevas tecnologías y el poder cada vez mayor de las asociaciones de consumidores desde finales del s. XX, han tenido influencia en la emergencia del modelo. Estos factores, que han obligado a las organizaciones de producción y servicios a comportarse de forma cada vez más efectiva para sobrevivir y desarrollarse en entornos altamente competitivos, también han motivado el desarrollo del ASH para ayudar a dichas empresas a alcanzar el éxito en el mercado (Quijano y Navarro, 1999).

Los objetivos del ASH son la evaluación de intangibles, la evaluación de la calidad en los modelos de excelencia, el 
diagnóstico y la intervención en el sistema humano de las organizaciones, y la investigación del comportamiento humano en las mismas.

Estos objetivos se persiguen con una visión integrada. El ASH aúna perspectivas de diversas disciplinas (psicología, psicología de las organizaciones, administración de empresas, sociología y antropología) que se han unificado en una propuesta sincrética de múltiples constructos relacionados (Quijano, Yepes, Berger y Romeo, 2008).

El modelo está formado, fundamentalmente, por tres componentes: un modelo teórico de comportamiento organizativo; una batería de instrumentos para la evaluación de distintos aspectos y dimensiones de la organización que resultan útiles para el diagnóstico y la intervención; y un sistema de control de gestión que permite seguir la evolución de la organización, desde la perspectiva de su sistema humano, el impacto de las decisiones de gestión sobre este sistema y su relación con los objetivos de negocio (Quijano, Cornejo, Yepes y Flores, 2005).

Las limitaciones que presenta el ASH están muy relacionadas con los objetivos que ha planteado el modelo.

El planteamiento teórico en el que está basado el ASH no describe ecuaciones matemáticas contrastadas entre las diferentes dimensiones y variables que lo componen, sin embargo sí permite proponer "micromodelos". Estos 
micromodelos son "relaciones más concretas y formales entre las distintas áreas y dimensiones de la organización" que permiten "contrastar empíricamente las relaciones hipotetizadas” (Quijano, Navarro, Yepes, Berger \& Romeo, 2008, 93).

Por tanto, el modelo impide establecer relaciones matemáticas exactas entre sus diferentes elementos constitutivos pero sí permite definir el tipo de relación que establecen grupos de elementos entre sí.

La dinámica del modelo teórico del ASH se basa en la interrelación que se produce entre dos entidades: la propia organización y el entorno.

A continuación hemos incorporado la figura 4, “Modelo ASH (Auditoría del Sistema Humano)" que, además del entorno, incorpora los elementos constitutivos de las principales dimensiones de análisis de la organización: estrategia, diseño, procesos psicológicos y psicosociales, y resultados. 


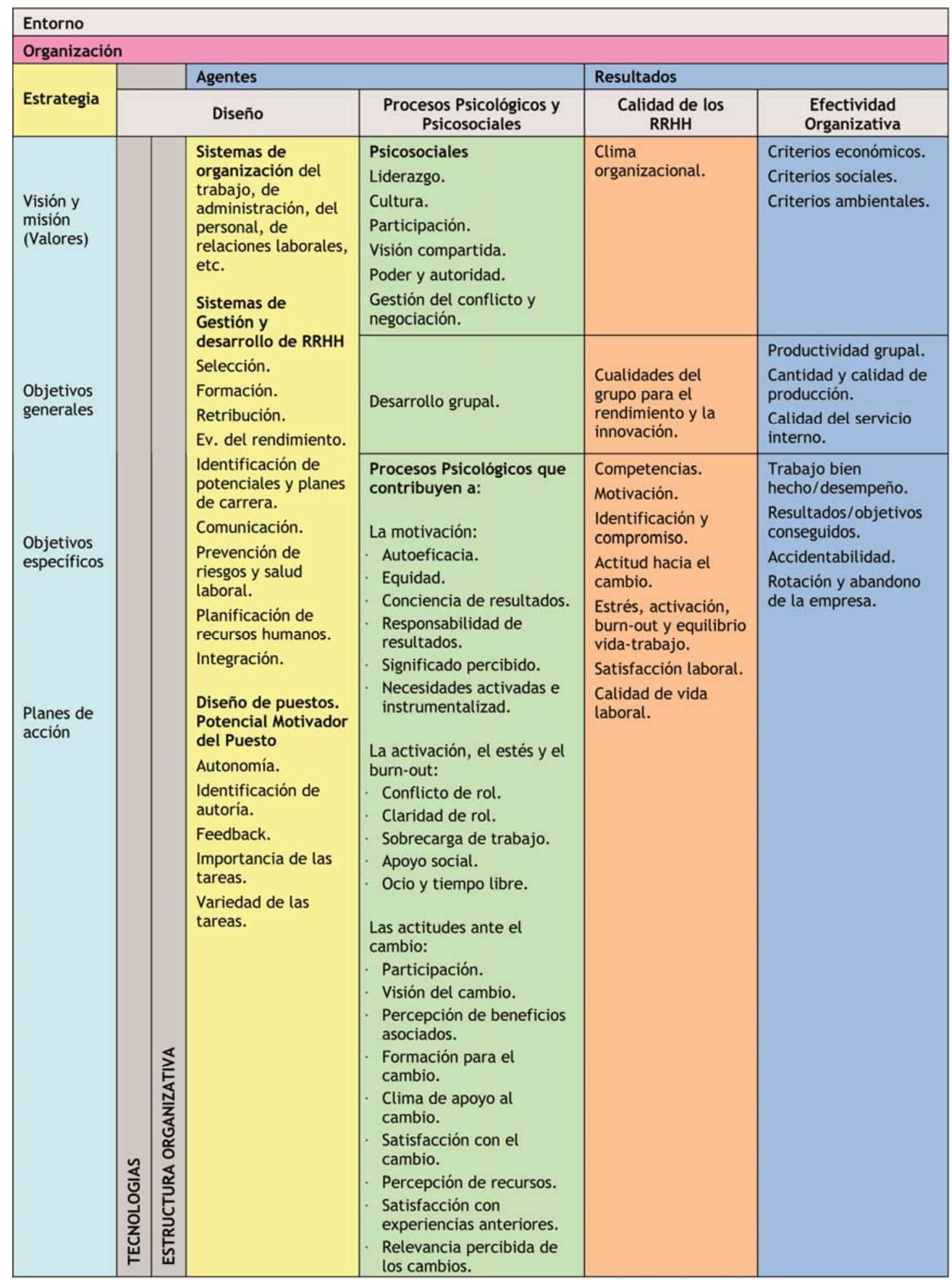

Figura 4: Modelo ASH (Auditoría del Sistema Humano).

Fuente: Quijano, Navarro, Yepes, Berger y Romeo (2008). 
La complejidad que presenta un estudio del entorno se ha simplificado en el ASH al considerar que está integrado por tres aspectos: la taxonomía de áreas del entorno, sus dimensiones y su textura (Quijano, Navarro, Yepes, Berger \& Romeo, 2008, 93).

El entorno de una organización está formado por áreas interrelacionadas que afectan a aquella de modo distinto y que, al ser consideradas por separado, permiten analizar el tipo de relación que dichas áreas establecen con otros aspectos de la organización. La taxonomía de áreas del entorno está integrada por: el entorno económico, el tecnológico, el político, el jurídico, el ecológico-proveedor de recursos naturales, el entorno del mercado laboral, el comercial o de mercados de producto/servicios, y el sociocultural o de valores sociales dominantes (Quijano y Navarro, 1999).

Las dimensiones han sido definidas por el ASH como las características comunes a diferentes áreas que resultan imprescindibles a la hora de realizar evaluaciones del entorno (Quijano y Navarro, 1999), ya que permiten determinar situaciones contingentes entre el entorno y las características organizativas. Las dimensiones son estabilidad, complejidad, hostilidad y percepción de la incertidumbre (Husenman, 1985).

La textura ha sido descrita por Husenman (1985) como un estado global de comportamiento del entorno derivado del carácter y combinación de sus dimensiones. Husenman ha propuesto cuatro tipos puros de textura 0 
comportamientos del entorno: entornos plácidos, flexibles, en ebullición o turbulentos.

Estas tipologías del entorno o perfiles, que se configuran a partir de las dimensiones, resultan útiles en el ASH para evaluar la adecuación entre el comportamiento organizativo y el entorno que lo rodea (Quijano y Navarro, 1999).

Para el ASH la organización, que se encuentra inmersa en el entorno, reaccionando ante él, adaptándose y configurándolo proactivamente al mismo tiempo, "se construye a sí misma y actúa" (Quijano Navarro, Yepes, Berger \& Romeo, 2008, 94).

En esta dinámica, el ASH ha planteado el análisis de cuatro dimensiones de la organización que es necesario analizar: la estrategia, el diseño, los procesos psicológicos y psicosociales, y los resultados (Quijano Navarro, Yepes, Berger \& Romeo, 2008, 94).

Thompson y Strickland (1994) han definido la estrategia como el conjunto de movimientos y enfoques que diseña la gerencia para conseguir que la organización tenga excelentes resultados. Es decir, es la respuesta dada por parte de la organización al entorno "después de analizarlo (en términos de amenazas y oportunidades) y de concienciar sus propios recursos para enfrentarlo" (Quijano Navarro, Yepes, Berger \& Romeo, 2008, 95). 
La estrategia consta de cinco componentes relacionados entre sí: desarrollar un concepto de negocio y una visión de hacia donde se necesita dirigir a la organización estableciendo una misión, transformar la misión en objetivos específicos de resultado, elaborar una estrategia que logre el resultado planeado, implantar y poner en práctica la estrategia seleccionada de manera eficiente y eficaz, y evaluar el resultado y revisar la situación para realizar los ajustes correctivos que sean necesarios (Thompson y Strickland, 1994).

En relación con la dimensión "diseño", el ASH contempla tres aspectos en esta dimensión: la tecnología, la estructura y los sistemas de dirección de personas.

El primero hace referencia a la tecnología que la organización adopta para alcanzar sus objetivos. En este sentido, existen diversos elementos relacionados con la tecnología que tienen una influencia relevante en el comportamiento organizativo en relación con este aspecto.

Uno de estos factores es la elección de una tecnología de producción de unidad, serie o proceso, lo que tiene repercusiones en la estructura organizativa en relación con la efectividad (Woodward, 1958, 1965).

Otro elemento relevante es la adopción de una tecnología analizable o no analizable y familiar o no familiar, ya que configura cuatro tipo de organizaciones (rutinaria, no rutinaria, ingeniería y oficio) con 
repercusiones muy diferentes en el comportamiento organizativo (Perrow, 1970).

Otra decisión importante es la que hace referencia a la incorporación o no de nuevas tecnologías en la organización (microelectrónica, informática, telecomunicaciones y la automatización). Es interesante tener presente que este aspecto, de acuerdo a algunos expertos, no ha tenido tanta influencia en la modificación de los puestos de trabajo como la gestión de recursos humanos o la gestión comercial (Munduate, 1985; 1994; Kavanagh, Gueutal \& Tannenbaum, 1990; Aragonés, 1997; Ferreiro y Tanco, 1997).

La estructura es otro elemento constitutivo del diseño. Viene determinada por decisiones adoptadas por la organización como las que tienen que ver con la tecnología, la distribución del poder, la necesidad de acercar la organización a su público, etc. (Quijano y Navarro, 1999).

Este conjunto de decisiones conducen a una forma de estructura más o menos plana, en red, por grupos de negocio descentralizados y de menor tamaño, virtual, etc. (Quijano y Navarro, 1999).

El tercer elemento que integra el diseño en el modelo $\mathrm{ASH}$, los sistemas de dirección de personas, son los responsables de la preparación, la integración y el compromiso de los recursos humanos de una organización (Quijano y Navarro, 1999).

En cierto sentido es posible considerar a estos sistemas como participantes de la estructura de una 
organización, en tanto establecen formas pautadas de gestionar y tratar la relación con las personas que se incorporan a la misma y trabajan en ella (Quijano y Navarro, 1999).

Dentro de este sistema existen tres subsistemas que, no obstante, han sido considerados prácticamente sinónimos por algunos autores: administración de personal, relaciones laborales, y gestión y desarrollo de recursos humanos, también denominado "dirección estratégica de personas" (Yoder y Heeneman, 1977; Dessler, 1988).

En el planteamiento teórico del ASH este último subsistema ha adquirido una especial relevancia por su función específica de integración y motivación del personal (Quijano, 2006).

Los autores del ASH han utilizado el término "calidad" en los sistemas de gestión de recursos humanos para hacer referencia a su capacidad para generar resultados favorables en los empleados y en los grupos, tanto para ellos mismos como para la organización. Concretamente esta calidad se haya relacionada con su capacidad para "captar, incorporar, retener y desarrollar personal competente y satisfecho con su vida laboral, eficaz y eficiente para conseguir los objetivos estratégicos de la organización en sus puestos de trabajo y en los grupos y equipos en los que participan” (Quijano Yepes, Berger y Romeo, 2008, 98). 
La segunda de las dimensiones de la organización que contempla el ASH, los procesos psicológicos y psicosociales, hace referencia a "aquellos fenómenos humanos individuales y grupales que, si bien en cierto modo son fruto y efecto de los sistemas de gestión, de la estructura, la estrategia y la tecnología, al mismo tiempo influyen sobre ellas y generan en las personas y en los grupos una manera de sentir, de hacer y de ser (calidad de los recursos humanos a nivel individual y grupal), que repercute en la tarea bien hecha y en la consecución de los objetivos estratégicos de la organización (efectividad organizativa)" (Quijano y Navarro, 1999, 317).

Algunos de los procesos psicológicos más importantes que tienen lugar a nivel individual son: autoeficiencia, percepción de equidad, claridad de rol, conflicto de rol, sobrecarga de trabajo, conciencia de resultados, conciencia de significación de trabajo y percepción de apoyo social (Quijano Yepes, Berger y Romeo, 2008).

Los procesos relevantes que hacen referencia a la relación entre las personas son los procesos psicosociales, que pueden ser intragrupales e intergrupales. Todos los procesos están interrelacionados aunque algunos presentan un carácter más globalizador que otros, como la cultura organizativa y los procesos de cambio organizativo (Quijano y Navarro, 1999).

En relación con la tercera dimensión de la organización que el ASH considera, la dimensión 
"resultados", está integrada por dos tipologías: resultados blandos y resultados duros o efectividad organizacional.

Los resultados blandos hacen referencia a la calidad que la dirección de recursos humanos espera obtener de las personas en cualquier organización.

La calidad de los recursos humanos, o resultados blandos, planteada por el ASH presenta componentes a nivel individual, grupal y organizativo.

A nivel individual el modelo no hace referencia a la calidad humana de las personas, al considerar que esta cuestión queda fuera de los objetivos que se persiguen. En este nivel el modelo plantea dos tipos de componentes: los supuestamente más relacionados de forma directa y lineal con los resultados de los personas para la organización (como la motivación, la identificación o el compromiso con la organización), y otros cuya relación respecto a esos resultados se expresa mejor con funciones matemáticas curvilíneas (como el estrés, la activación y burn-out o la satisfacción laboral).

A nivel grupal el ASH incluye el clima grupal y la adecuación de las cualidades grupales a la incertidumbre y exigencias de la tarea.

Y a nivel organizativo el ASH ha relacionado la calidad de los recursos humanos de la empresa con el clima organizativo $\mathrm{y}$, en cierto sentido, con todas las demás dimensiones (nivel de motivación global del personal de la 
empresa, de competencias, de estrés, etc.) (Quijano Yepes, Berger y Romeo, 2008).

En esta agregación de medidas para la autoevaluación de variables a nivel organizativo, el ASH ha planteado la evaluación de la autoeficacia a partir de la autoeficacia colectiva propuesta por Bandura $(1997,1998)$.

Una hipótesis básica del ASH es que la calidad de los recursos humanos de una organización se halla directamente relacionada con la efectividad organizativa. Pese a la coherencia de este planteamiento, ha llamado nuestra atención que un modelo que persigue la conquista de la excelencia en la dirección de las personas no haya contemplado la calidad humana de los colaboradores. Algunas de las nuevas corrientes de liderazgo que han emergido en el siglo XXI, han defendido que este aspecto está muy relacionado con la eficacia en el rol de liderazgo y con el desempeño de los colaboradores.

Los resultados duros hacen referencia a los resultados de las personas y los grupos para la organización.

Se basan en una serie de criterios comunes susceptibles de conformar diferentes formas de entender la efectividad organizativa por parte de cada organización.

Uno de estos parámetros está constituido por el resultado de la eficacia (outputs conseguidos/outputs esperados) y la eficiencia (outputs conseguidos/inputs utilizados) en la organización. 
Otro factor es la consideración de los modelos existentes más significativos (en el momento el que el ASH ha sido planteado) para disponer de una respuesta frente a las distintas formas de concebir y observar a la organización: como sistema racional (modelo de objetivos), como sistema abierto (modelo de sistemas) y como sistema político (modelo de componentes múltiples).

Otro aspecto es el que contempla la evaluación de la efectividad en tres niveles. Desde un plano individual, en el que se plantean criterios positivos (resultados y desempeño -trabajo bien hecho-). Desde una perspectiva grupal, en la que se considera la consecución de los objetivos de tarea o resultados conseguidos por los departamentos o grupos (como la productividad o calidad del servicio prestado a los clientes internos, entre otros). $Y$ desde un prisma organizativo, ya que el ASH contempla múltiples criterios agrupados en diversos apartados económicos (financieros, productivos y comerciales), sociales (internos y externos), ecológicos (cumplimiento de normas y aprovechamiento de energías) y otros -flexibilidad y captación de recursos- (Quijano y Navarro, 1999).

\subsubsection{El modelo AMIGO}

Otra propuesta que ha concebido la organización como una función social compleja es el modelo AMIGO (Análisis Multifacético para la Intervención y Gestión en las 
Organizaciones) (Peiró, 1999a, 2000; Peiró y Martínez-Tur, 2008).

En la dinámica de esta propuesta es central su comprensión de la organización a partir de un conjunto de componentes denominados “facetas". Estas entidades permiten una comprensión más adecuada de la realidad organizacional ya que favorecen el análisis de las relaciones que existen entre cada grupo y el sistema organizacional, así como de las interacciones entre los diferentes grupos (Peiró, 1999a).

A continuación hemos incorporado la figura 5 , modelo AMIGO (Análisis Multifacético para la Intervención y la Gestión Organizacional)", con los principales elementos o facetas que contempla la propuesta: las facetas estratégicas y paradigmáticas (como la misión, la visión y la cultura organizacional), las facetas duras (como el sistema de trabajo y la tecnología), las facetas blandas (como la gestión organizacional y el capital humano), las facetas de integración (como el ajuste y el contrato psicológico) y los resultados de la organización (Peiró, 1999; Peiró y MartínezTur, 2008). 


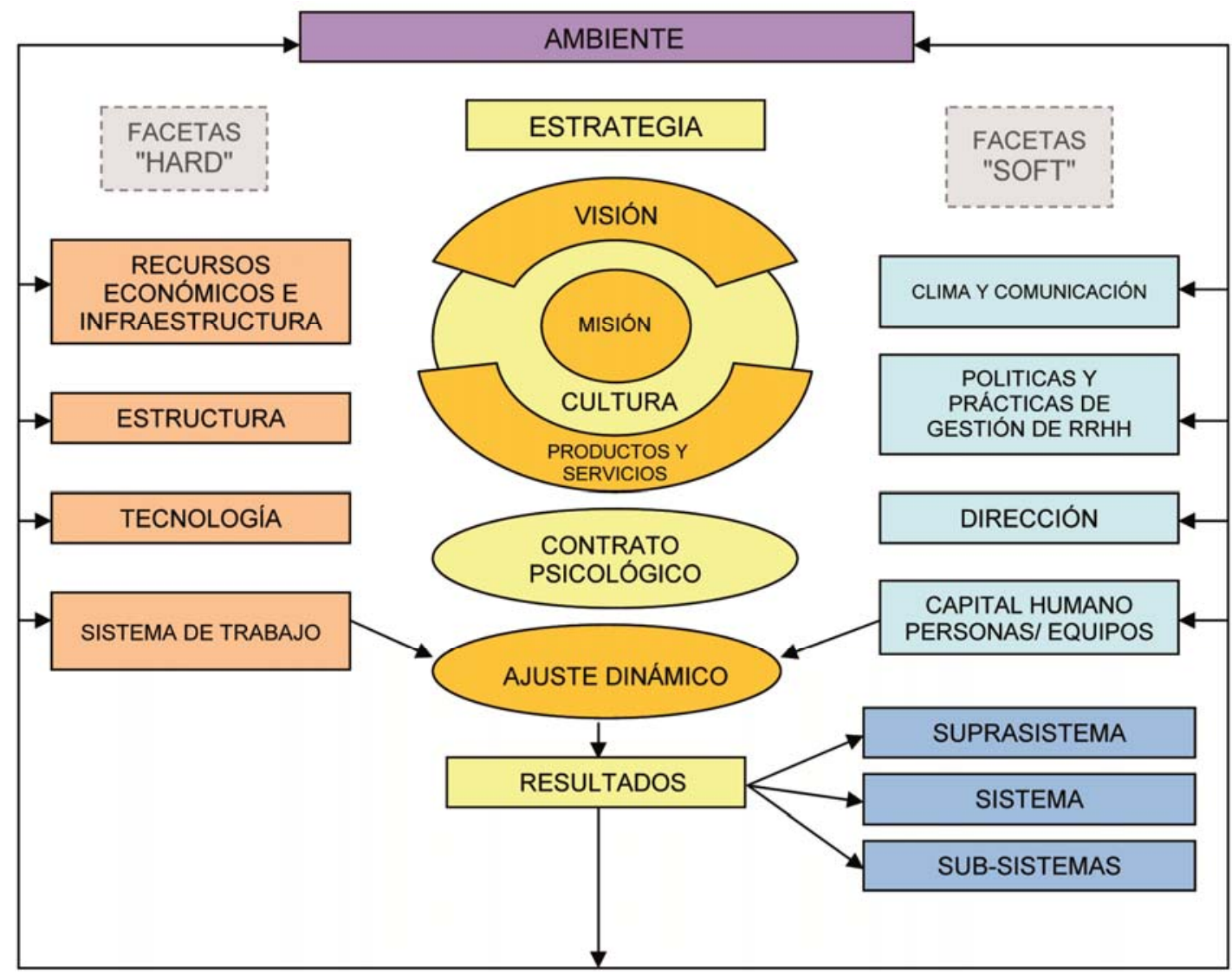

Figura 5: Modelo AMIGO (Análisis Multifacético para la Intervención y la Gestión Organizacional). Fuente: Peiró (2000).

Las facetas estratégicas y paradigmáticas que forman parte del modelo son misión, visión, estrategia, cultura organizacional, ambiente y productos y servicios.

La misión es elemento central de toda organización que da sentido a su existencia. Para su consecución es necesaria la configuración de una organización abierta a su entorno y capaz de interactuar con él. La misión de la organización es siempre un proyecto de futuro para dar respuesta a su ambiente tomando en consideración sus cambios (Peiró, 2003).

La visión es la manera de percibir el proyecto de la organización, considerando su desarrollo y el entorno donde 
opera (Peiró, 1999a). Ha de permitir una adecuada adaptación a su entorno gracias a la formulación de una estrategia adecuada (Peiró, 2003).

La estrategia es la expresión clara y determinada de los objetivos y metas a largo plazo (...), la adopción de cursos de acción y el reparto de recursos necesarios para llevar a cabo estas metas (Chandler, 1962). También se puede entender como "la orientación competitiva de una organización y de las decisiones necesarias para conseguir esa ventaja competitiva" (Peiró, 1999a, 4).

Las estrategias organizacionales pueden ser clasificadas de acuerdo con su respuesta ante entornos parecidos para alcanzar resultados similares en "defensora", "prospectora”, "analizadora” y "reactora” (Snow, 1978).

La estrategia defensora está basada en la identificación de un nicho de mercado en el que la organización pueda defender su posición de forma competitiva mediante la eficiencia. La estrategia prospectora se centra en la exploración de nuevos productos y oportunidades de mercado, y en el logro de las innovaciones necesarias para que la organización sea pionera en ella. La estrategia analizadora está basada en la búsqueda de nuevos mercados y productos, una vez que su viabilidad ha sido constatada. Y la estrategia reactora está caracterizada por la ausencia de las tres directrices anteriores. 
La cultura organizacional hace referencia al conjunto de creencias compartidas por las personas que integran una organización, así como los valores y expresiones en los que se manifiestan (Peiró, 1996b). Se entiende la cultura como un elemento constitutivo de la organización, algo que es, y no como algo que la organización tiene (Peiró, 1990).

El ambiente es el conjunto de elementos externos a la organización con los que esta mantiene o puede mantener relación y que en alguna medida son relevantes para dicha relación (Peiró, 1983-84). Para el modelo resulta clave anticipar el ambiente futuro, ya que es un factor crítico para la vida de la organización y el desarrollo de las personas que la integran (Peiró y Rodríguez, 2008). Cabe caracterizarlo en función de su grado de complejidad, su nivel de estabilidad frente a su nivel de dinamicidad, su predictibilidad, su grado de certidumbre o incertidumbre y su mayor o menor hostilidad hacia la organización (Peiró, 2003).

Con productos y servicios se hace referencia a "cualquier bien material, servicio o idea que posea un valor para el consumidor o usuario y sea susceptible de satisfacer una necesidad" (Santesmases, 1991). Son cada vez más conocidas las diferencias entre las organizaciones de servicios y las de producción en elementos que son esenciales para su funcionamiento, gestión, resultados y eficacia (Peiró, 2003). 
Las facetas duras (también llamadas hard) son los recursos (económicos) e infraestructura, la estructura, la tecnología y el sistema de trabajo.

Los recursos (económicos) e infraestructura son los elementos que condicionan el funcionamiento de una organización y el logro de su misión, así como las interacciones con su entorno (Peiró, 2003). Aunque son numerosos los recursos que pueden formar parte de una organización, estos se pueden clasificar en tres grandes grupos generales: recursos físicos, recursos humanos y recursos organizacionales (Barney, 1991).

La estructura es "el esquema formal de relaciones, comunicaciones, procesos de decisión, procedimientos y sistemas dentro de un conjunto de personas, unidades, factores materiales y funciones en vistas a la consecución de objetivos" mediante la diferenciación y división del trabajo, y la coordinación (Zerilli, 1985, 174).

En los años setenta se estableció una tipología con cinco grandes tipos de configuraciones: la estructura simple, la burocracia mecánica, la burocracia profesionalizada, la divisionalizada y la adhocracia (Mintzberg, 1988).

Cada uno de ellos permite entender el tipo de interacciones y relaciones que se dan en la organización, aunque sin reflejar la complejidad de la realidad que catalogan (Mintzberg, 1988).

Peiró (1987) ha indicado que desde el siglo XX cada vez están adquiriendo más protagonismo las estructuras 
organizativas que presentan formas de red o las planas, y la consideración de que las constantes interacciones y significados de los miembros de la organización tienen un peso importante en la estructura que la organización adopta finalmente.

En este sentido el propio Mintzberg (1991) también ha indicado otros dos tipos de configuraciones que pueden darse en las organizaciones: la ideológica y la política.

Peiró (2003) también ha hecho referencia a la ausencia de una preferencia por un tipo de estructura sobre otra en una organización, ya que su idoneidad dependerá de su grado de congruencia con el resto de componentes y de la de todos ellos con la misión de la organización.

La tecnología se define como las técnicas utilizadas que permiten a las organizaciones transformar inputs en outputs, contemplando que no solo se hace referencia a herramientas o hardware sino que también se incluye la tecnología del conocimiento (Peiró, 1983-84). Esta faceta tiene una gran implicación en el desempeño del trabajo, en la organización de los sistemas de trabajo y en la propia organización, tanto en su estructura como en su funcionamiento (Peiró, 1990).

El sistema de trabajo hace referencia a una combinación concreta de tareas, tecnología, conocimiento experto, estilos de dirección y procedimientos de trabajo que se entiende son determinantes de la manera en que el trabajo es organizado y dirigido, del modo en que los 
empleados viven la experiencia de trabajo y de cuál es su comportamiento (Beer, 1986).

Para el modelo AMIGO representa la faceta clave de este bloque ya que se supone que la tecnología, la estructura y la infraestructura y los recursos materiales de la organización contribuyen al funcionamiento eficaz y eficiente del sistema de trabajo (Peiró y Rodríguez, 2008).

Las facetas blandas (también denominadas soft) son comunicación y clima, prácticas y políticas de dirección de personas, gestión organizacional y capital humano.

La comunicación es un subsistema esencial de la organización que facilita "la transmisión, procesamiento de información y la interacción entre diversos agentes, individuales y colectivos internos y externos a la misma" (Peiró, 2003). Mientras el clima, ampliamente influido por la cultura, es el conjunto de percepciones compartidas que configuran la descripción y caracterización asumida por las personas que integran la organización (González-Roma y Peiró, 1999a).

Al hacer referencia al segundo componente de esta faceta es importante hacer constar que se trata de una variable de tipo cognitivo, en la que cada vez tienen más peso las dimensiones emocionales y afectivas que construyen el clima, entre otras vías, a través del contagio emocional (Rivera, 1992).

El equipo internacional de investigación de FOCUS (First Organizational Climate/Culture Unified Search) 
estableció cuatro dimensiones del clima en su herramienta de medición apoyándose en el Modelo de Valores Competitivos de Quinn y Rohrbaugh (1983): apoyo, orientación de reglas, orientación a metas e innovación.

Las políticas y prácticas de dirección de personas hacen referencia al conjunto de orientaciones y actuaciones que regulan las relaciones de las personas que integran una organización, que suele ser sensiblemente diferente en cada caso particular, tanto en la concepción global de las políticas de personal como en la articulación concreta de dichas políticas (Guest, 1994).

La gestión organizacional alude al hecho de que toda organización implica una adecuada combinación de funciones que contemplan la necesidad de un equilibrio entre la flexibilidad y el control, y entre la orientación externa e interna en la gestión de la organización. Estas funciones son: formular políticas, conseguir objetivos, integrar al personal y administrar (Peiró, 1996a).

La formulación de políticas es una función que hace referencia a la capacidad de la organización para adaptarse a su entorno mediante la innovación y a su capacidad para impactar en el mismo. Conseguir objetivos hace alusión a la conquista de un cierto orden que permita a la organización alcanzar sus objetivos. Integrar al personal implica hacer compatibles las funciones anteriores con otras dos: la coordinación e integración de las personas y la consecución de un buen clima social. Y administrar exige la búsqueda de un equilibrio en la administración de la organización entre 
la autoridad, el orden, la racionalidad y la coordinación interna.

El capital humano (personas y equipos) hace referencia al conjunto de recursos (competencias, conocimientos, aptitudes, actitudes, destrezas, habilidades, etc.) que los integrantes de una organización aportan para que esta logre su misión (Salanova, Prieto y Peiró, 1996 y Zorzona, Salanova y Peiró, 1996).

Es interesante considerar dos observaciones que algunos autores han formulado sobre el capital humano. Por una parte que las organizaciones intentan conseguir personas capaces de contribuir de forma significativa a la consecución de sus fines. $Y$ por otra que las diferentes agrupaciones de personas configuran, en el marco organizacional, una realidad de nivel colectivo que no se reduce a la mera agregación de los individuos y que introduce nuevos procesos de carácter psicosocial (Salanova, Prieto y Peiró, 1996 y Zorzona, Salanova y Peiró, 1996).

Debido a la importancia del componente humano, el capital humano es la faceta central de este bloque para el modelo AMIGO. El motivo es que el resto de facetas deben contribuir al mejor desempeño y desarrollo posible de las personas que integran una organización (Peiró y Rodríguez, 2008).

Las facetas de integración son el ajuste y el contrato psicológico. 
El ajuste hace referencia a la adaptación entre el capital humano (personas y grupos) y el sistema de trabajo de una organización. Habida cuenta de las transformaciones frecuentes en los puestos de trabajo y en las personas, este ajuste ha sido reconceptualizado poniendo énfasis en tres aspectos: la búsqueda de una sintonía razonable, la toma de conciencia del carácter dinámico que presenta la organización y la equifinalidad del ajuste (Hontangas y Peiró, 1996; Peiró, 2003).

La sintonía razonable hace referencia a la sintonía que se debe exigir a las formas que adoptan los diferentes componentes de la organización implicadas en cada ajuste concreto (sintonía que no debe entenderse como un ajuste perfecto ya que los componentes no son estáticos).

El carácter dinámico e interrelacionado que presenta la organización hace alusión a un aspecto concreto que es necesario tener en cuenta al considerar el ajuste. El modelo AMIGO contempla que las transformaciones y cambios en cualquier parte del sistema que la organización representa, desencadenados desde dentro o desde fuera del mismo, requieren cambios y adaptaciones en otros componentes para que el sistema mantenga su funcionalidad y eficacia.

La equifinalidad del ajuste hace referencia a la necesidad de considerar que, con frecuencia, existe más de una opción de ajuste satisfactorio entre dos o más componentes.

Las organizaciones más eficaces son las que logran una congruencia entre los distintos componentes y tienen 
alineada dicha configuración, al mismo tiempo, con la misión de la propia organización (Peiró, 1999a).

El contrato psicológico es el conjunto de compensaciones que la persona (o grupo, en cuyo caso se utiliza el término "contrato psicosocial") espera de la organización a cambio de sus contribuciones y conjunto de compensaciones que la organización espera de la persona a cambio de sus contribuciones. Es un factor relevante en el ajuste persona-puesto ya que los intercambios inciden sobre multitud de aspectos tales como la cultura, la estructura o la tecnología, etc. (Peiró, 2003).

Su acertada concreción permite reducir los riesgos de origen psicosocial (Gutiérrez, 2006). Estos riesgos se minimizan cuando el intercambio presenta dos características: ambas partes perciben como justo el intercambio de promesas y su cumplimiento, y el acuerdo está basado en la confianza y tiene una clara orientación al futuro (Peiró y Rodríguez, 2008).

El modelo AMIGO ha planteado que los resultados de la organización son una faceta con entidad propia, fundamentalmente por la amplia comprensión que el modelo concede al término "resultado". Para el modelo la concepción de resultados dista mucho de considerar como único indicador la producción o los beneficios económicos y el reparto de esos beneficios entre los propietarios de la organización. 
Los resultados suelen estar relacionados y ser valorados desde la misión que da razón a su existencia, aunque no se debe olvidar que los resultados son de carecer diverso (Peiró, 1999a).

Una complicación sobre la comprensión de los resultados resulta de la consideración del horizonte, a corto o a medio y largo plazo, desde el que se contempla su materialización (Peiró, 1999a). Un buen resultado en el corto plazo puede no serlo a largo plazo.

En este sentido un sistema ha de producir resultados para el supra-sistema, para el propio sistema y para los subsistemas que lo componen. Esto implica que el modelo AMIGO contemple que los resultados para una organización se dividan en tres categorías: resultados para el suprasistema, resultados para el sistema y resultados para los sub-sistemas.

Los resultados para el supra-sistema hacen alusión a que la organización ha de ser capaz de responder a las demandas del entorno (supra-sistema) produciendo resultados para la sociedad en su conjunto, los clientes, etc. (Peiró, 2003).

Los resultados para el sistema son los que están relacionados con la supervivencia, mejora y desarrollo de la organización como sistema (Peiró y Rodríguez, 2008).

Y los resultados para los sub-sistemas hacen referencia al hecho de que la organización ha de proporcionar resultados para los sub-sistemas y los diversos constituyentes -inversores, colaboradores, dirección, etc.- 
(Peiró, 2003). Estos resultados pueden ser de tres tipos: compensación, satisfacción de intereses y desarrollo de personas y grupos (Peiró y Rodríguez, 2008).

La elaboración de un modelo teórico resulta útil a la hora de investigar e intervenir en una organización. Hemos indicado a continuación las principales funciones del modelo teniendo presente dicha premisa (Peiró, 1999a).

La propuesta persigue constituirse en un marco orientador para el desarrollo de la evaluación, diagnóstico y auditoría (balance) organizacionales. El modelo AMIGO permite la formulación sistemática de la evaluación en cada una de las facetas y niveles que intervienen en la organización.

El modelo también busca constituirse en una aproximación relacional. Se trata de otra prestación del modelo: su utilidad a la hora de analizar una determinada faceta de la organización. Frente a una concepción elementalista o de unidades sustantivas que cifra la comprensión de cada ámbito de la organización en su análisis interno, el modelo AMIGO señala que ese análisis, aunque necesario, resulta insuficiente. La comprensión adecuada solo se producirá a partir del análisis de las relaciones con las otras facetas del modelo.

La propuesta también procura facilitar el análisis, la comprensión y la gestión de los cambios organizacionales. El modelo aporta también un análisis sistemático del cambio en las organizaciones. Estas experimentan constantes 
cambios más o menos rápidos, radicales y generalizados. Esos cambios, si superan determinados niveles-umbrales, desencadenan a su vez cambios en otras facetas de la propia organización que pueden buscar una adaptación o congruencia 0 , por el contrario, un mayor desajuste con los cambios ya ocurridos. El análisis de las "trayectorias" secuenciales o concurrentes así como su mayor o menor reciprocidad son elementos complejos en los que resulta válido el modelo AMIGO. Todos estos conocimientos son especialmente útiles a la hora de gestionar los cambios.

El modelo también permite orientar la planificación, implementación y valoración de las intervenciones organizacionales. El modelo AMIGO proporciona guías y orientaciones a la hora de intervenir en las organizaciones, tanto si esas intervenciones son reactivas ante cambios surgidos en alguna faceta de la organización o en su entorno como si son proactivas. En este punto, la distinción de las facetas duras y blandas permite prestar atención a las principales aproximaciones disciplinares del cambio organizacional.

Otro aspecto del modelo AMIGO que hemos considerado relevante a la hora de ofrecer pautas para interpretar los resultados de esta investigación es su concepción del cambio organizacional planificado.

El modelo ha planteado tres aproximaciones al cambio: el rediseño, el desarrollo y la transformación de las organizaciones (Peiró, 1999a). 
El rediseño plantea los cambios desde una visión fundamentalmente tecnocrática en las facetas hard del modelo, como la estructura, los recursos e infraestructuras, las innovaciones tecnológicas y los sistemas de trabajo (Peiró, 1999a).

Desde una perspectiva congruente, sus limitaciones se producen en la medida en la que estos cambios no se acompañen por cambios en las facetas soft como el clima, la gestión organizacional (o dirección) o las políticas y prácticas de dirección personal, además de cambios en la cultura organizacional (Peiró, 1999a).

El desarrollo organizacional, segundo aspecto que el modelo contempla en su aproximación al cambio, es la disciplina que aborda el cambio a través de la modificación de la cultura organizacional (Alonso, 1994).

Franch y Bell definen el desarrollo organizacional como "un esfuerzo a largo plazo para mejorar los procesos de renovación y de solución de problemas de una organización, particularmente a través de una gestión de la cultura organizacional más eficaz y colaborativa (con especial énfasis en la cultura de los equipos de trabajo formales) con la asistencia de un agente de cambio, o catalizador, y el uso de la teoría y la tecnología de la ciencia comportamental aplicada, incluyendo la investigación mediante la acción” (Franch y Bell, 1978, 15).

Esta área de conocimiento ha elaborado un amplio repertorio de técnicas centrado en uno o varios niveles de la 
organización: individual, de equipo, departamental y organizacional (Peiró, 1999a).

De todos modos los cambios que, a su vez, también implican cambios en otras facetas soft solo serán eficaces, desde una visión congruente, si van acompañadas por cambios en las facetas hard.

La transformación en las organizaciones, tercer aspecto contemplado, persigue considerar de forma conjunta las facetas hard y soft para afrontar las crisis que las organizaciones experimentan con mayor índice de éxito.

Gestionar adecuadamente la dialéctica que se crea entre ambas facetas para prevenir el declive organizacional (Nutt y Backoff, 1995) también implica una gestión adecuada de la dialéctica entre el rediseño y el desarrollo organizacional. Es frecuente que el rediseño en situaciones de declive (reducción de tamaño, reconversiones, etc.) resulte conflictivo y provoque la aparición de resistencias. De todas formas es en ese tipo de situaciones cuando resulta más necesaria la revitalización de las facetas soft.

El reto que plantea el modelo es crear una nueva plataforma, a partir de cambios congruentes en las diversas facetas, para afrontar las nuevas actuaciones.

Así pues, "los cambios pueden surgir en algunas facetas del modelo $y$, para ser eficaces, han de ir desencadenando otros cambios en otras facetas del sistema". Si la organización carece de estrategias proactivas los cambios arrancan del entorno. Si la organización posee 
estrategias proactivas el cambio se inicia en la propia organización y debe implicar a otras facetas desde una óptica congruente (Peiró, 1999a, 11).

Las razones que han motivado la elección del Modelo AMIGO como referente en el marco teórico de la investigación son diversas.

En primer lugar porque se trata de un modelo que posee mayor actualidad que los mencionados anteriormente, aunque el ASH también es un modelo reciente.

Además el modelo AMIGO se ha desarrollado (al igual que el $\mathrm{ASH}$ ) en el ámbito español (que es donde hemos realizado el trabajo).

Otro aspecto que hemos considerado es el hecho de que el modelo presenta un contexto europeo, además de entender que acoge con mayor acierto los nuevos planteamientos que desde el ámbito de la Psicología de las Organizaciones se venían demandando a los modelos de evaluación e intervención en las organizaciones, especialmente en lo que hace referencia a la necesidad de plasmar en un diseño eficiente el carácter complejo que representa la organización.

También hemos confiado en la gran coherencia interna que ofrece el modelo, reflejada en sus categorías constitutivas (facetas estratégicas y paradigmáticas, facetas duras, facetas blandas, facetas de integración y resultados organizacionales) y en el modelo dialéctico que las 
relaciona. Este aspecto nos ha permitido contemplar los resultados de la investigación a partir de las facetas constructivas del modelo y de su interrelación.

Por otra parte la visión integral y relacional de la organización que ofrece el modelo AMIGO también nos ha permitido tener la posibilidad de hipotetizar a partir de los resultados del estudio. En este sentido nos ha permitido valorar, desde un planteamiento proactivo, sobre los posibles efectos derivados de actuaciones específicas en algunas de las facetas del modelo a partir de los resultados que hemos alcanzado en la investigación.

Este aspecto ha sido especialmente interesante en el caso de la faceta que hace referencia a los resultados para el supra-sistema, ya que se corresponde con los beneficios que la sociedad recibe como consecuencia de las actuaciones organizacionales en el ámbito de la Responsabilidad Social Corporativa. 


\subsection{ENFOQUES TEÓRICOS EN EL ESTUDIO DEL LIDERAZGO}

Tomando en consideración que en la historia siempre han existido líderes, ha sido a lo largo del siglo XX y en el vigente siglo XXI cuando los científicos sociales han profundizado en la comprensión y en el desarrollo del liderazgo.

El estudio científico del liderazgo se inició, desde una perspectiva muy próxima al management, en la época de la Revolución Industrial. En este momento histórico se trató de teorizar sobre el tipo de liderazgo más adecuado para estimular la productividad entre los trabajadores que poseían una habilidad particular en un área concreta. Los principios de la gestión científica propuestos por Taylor (1911), centrados en el análisis de la tarea, guiaron el ejercicio del liderazgo en el ámbito laboral de 1900 a 1930. Taylor defendió la necesidad de vincular la prosperidad del empresario a la prosperidad del empleado para conseguir colaboradores motivados a un bajo coste de producción.

Posteriormente otros investigadores comenzaron a considerar que la clave en el éxito de las organizaciones podría estar más relacionada con la calidad de las relaciones humanas que las personas desarrollan en su 
ámbito laboral, que con la búsqueda de su propia prosperidad (Giffin, 2011).

Los estudios dirigidos por Mayo en la Western Electric de Hawthorne, a finales de la década de los 30, demostraron que las relaciones humanas establecidas entre los colaboradores y la comunicación con los operarios elevaba el nivel de la productividad (Mayo, 1933). Descubrimiento accidental que no había sido incluido inicialmente en el diseño de la investigación (Pozo, 1997).

Mayo llegó a la conclusión de que no solo era importante mejorar el diseño de las tareas para mejorar la producción, sino que también era fundamental incentivar los aspectos humanos del trabajo (García, 2006).

Este autor llegó a manifestar que la pertenencia a los grupos informales, frente a los formales, era lo que en realidad motivaba a los trabajadores a acudir al trabajo cada día (Mayo, 1943).

Las diversas formas en las que es posible entender el concepto de liderazgo desde un punto de vista científico, son reflejo de los diversos enfoques teóricos y metodológicos desarrollados desde entonces.

Hemos utilizado la clasificación propuesta por Sánchez y Alonso del Amo (2005) a la hora de abordar los diferentes enfoques centrados en el estudio del liderazgo.

En primer lugar hemos tratado los enfoques teóricos centrados en el líder, que analizan tanto los rasgos del líder como su conducta. 
A continuación hemos desarrollado los enfoques contingentes, que contemplan la importancia de la situación en el estudio del liderazgo. Dentro de esta orientación se enmarca la teoría que hemos utilizado en el estudio empírico del liderazgo.

En el siguiente apartado nos hemos encargado de los enfoques teóricos centrados en los seguidores, que profundizan en la percepción del líder por parte de los seguidores.

En un cuarto bloque hemos tratado los enfoques teóricos que toman en consideración la interacción líderseguidores, que analizan el liderazgo a partir del intercambio que establecen líder y colaboradores.

$Y$ finalmente hemos incluido el bloque "nuevas teorías sobre liderazgo", en el que se tratan las propuestas centradas en el estudio de algunos rasgos específicos del líder y en la importancia de la identidad social en la constitución del liderazgo. Además también se incluyen en este apartado algunas de las últimas perspectivas que se han utilizado en el estudio del liderazgo, haciendo especial hincapié en las iniciativas que se ocupan de las nuevas tecnologías y en las centradas en la esfera humana del colaborador. 


\subsubsection{Enfoques centrados en el líder}

En este grupo se han incluido todas aquellas aproximaciones centradas exclusivamente en la figura del líder a la hora de abordar el estudio del liderazgo. Se trata de propuestas que analizan fundamentalmente sus atributos personales y sus conductas, con independencia de la situación en la que se ejerce el liderazgo o de los seguidores.

Hemos tratado en primer lugar las propuestas que se encargan del estudio de los rasgos del líder en el ejercicio del liderazgo y, a continuación, las teorías que se centran en el estudio de la importancia de la conducta del líder en el ejercicio de su rol.

Los temas que fueron abordados inicialmente en la literatura científica sobre el liderazgo se centraron en identificar las características específicas del líder que eran esenciales para favorecer su ejercicio con éxito. Este enfoque ha sido conocido como la Teoría de los Rasgos, y parte del supuesto de que es posible identificar a las personas que tienen potencial para el ejercicio del liderazgo.

Este objetivo respondía a la creencia popular de que los líderes presentaban características específicas que les distinguían de los demás. Esta fue la atribución que fundamentó la Teoría del Gran Hombre, presente durante la 
primera mitad del s. XX, y que constituyó un antecedente de la Teoría de los Rasgos (García, 2006).

Uno de los primeros trabajos realizados para conocer los rasgos de los líderes fue el de Terman (1904), centrado en la descripción de los alumnos líderes durante los recreos por parte de los profesores.

La búsqueda del descubrimiento de los rasgos de los líderes también condujo a Stogdill (1948) a revisar 104 estudios sobre rasgos, realizados desde 1904 a 1948, para descubrir a aquellos que convertían a una persona en líder.

Otro autor relevante que realizó estudios sobre los rasgos de los líderes fue Mann (1959), quien examinó 75 investigaciones.

La mayoría de los trabajos realizados antes de los años 60 investigaron las cualidades de niños y estudiantes, analizando el liderazgo en situaciones informales y sin evaluar su eficacia. Sin embargo estos trabajos permitieron alcanzar alguna conclusión relevante. Por ejemplo Stogdill indicó que no existía una combinación de rasgos que hicieran líder a una persona, aunque las diferencias individuales eran importantes para identificar líderes efectivos o emergentes, ya que la gran diversidad de situaciones en las que los líderes actúan hacía poco probable encontrar algún rasgo que fuera predictor universal (Sánchez y Alonso del Amo, 2005). 
Con posterioridad Stogdill (1974) revisó los estudios analizados y nuevas investigaciones realizadas en adultos y en organizaciones formales. En los 163 estudios supervisados analizó, en algunos casos, el surgimiento del líder y, en otros, su eficacia.

Stogdill (1974) indicó que la personalidad de los líderes no se había tenido en cuenta en anteriores revisiones de las investigaciones y destacó, entre otros rasgos, los siguientes: la actividad del líder, su motivación de logro o sus habilidades personales.

Yukl (1981) sostuvo, sin embargo, que muchas de las características indicadas por Stogdill no eran rasgos sino habilidades. Aspecto que impidió corroborar las posibles relaciones existentes entre los rasgos de la personalidad y la efectividad del líder (Pervin, 1984).

Siguiendo a García, hemos indicado las críticas realizadas por otros autores (Yukl y Van Fleet, 1992; Sánchez Santa-Bárbara, 1998; Rodríguez Fernández, Sánchez Santa-Bárbara, Zarco Martín y Martín Quirós, 2004) a los estudios citados que se han centrado fundamentalmente en su carácter metodológico.

Una de las observaciones señaladas hace referencia a que no fuera posible realizar una comparación de los resultados obtenidos por los diversos estudios para establecer un conjunto de rasgos diferenciadores con carácter universal (a pesar del aumento progresivo de la lista de rasgos asociados al liderazgo como consecuencia del creciente número de investigaciones). El motivo se hallaba 
en que los estudios bien carecían de una definición de rasgo, bien aportaban una definición del mismo claramente deficiente.

Otra observación está relacionada con el hecho de que aunque se encontraron diferencias entre los líderes y los no líderes, no fue posible establecer una relación consistente entre los rasgos de los líderes y el éxito en el ejercicio del liderazgo.

También se denunció que si la modificación de rasgos de personalidad para formar un líder implicaba cambios en su personalidad, esta podría ser una acción discutible desde un punto de vista ético.

A pesar de las críticas recibidas, el estudio de los rasgos psicológicos que aumentan la probabilidad de éxito de los líderes nunca se abandonó por completo. La revisión de algunos aspectos del enfoque (como un mayor desarrollo teórico y una mayor importancia concedida a la situación en el análisis y la ejecución del comportamiento) ha posibilitado que desde la década de los 70 se aporten datos más consistentes, aunque sin garantizar que la tenencia de determinados rasgos garantice la eficacia en el ejercicio del liderazgo (Gil y Rodríguez, 2003).

De todos modos, se han indicado rasgos que han permitido presuponer el tipo de persona que con mayor probabilidad podría ocupar una posición de liderazgo (Gil y Rodríguez, 2003). La investigación desarrollada desde la década de los 70 se ha centrado en los siguientes rasgos: 


\begin{tabular}{|c|c|c|c|}
\hline Rasgo & Definición & $\begin{array}{l}\text { Otros rasgos } \\
\text { asociados }\end{array}$ & $\begin{array}{l}\text { Habilidades } \\
\text { relacionadas }\end{array}$ \\
\hline $\begin{array}{c}\text { Motivación de logro } \\
\text { (Sánchez y Alonso del Amo, 2005; } \\
\text { Yukl, 1994). }\end{array}$ & $\begin{array}{c}\text { “Orientación a establecer } \\
\text { objetivos desafiantes e } \\
\text { invertir los esfuerzos } \\
\text { necesarios para } \\
\text { conseguirlos". }\end{array}$ & $\begin{array}{l}\text { Ambicioso, } \\
\text { enérgico, } \\
\text { persistente, } \\
\text { y tolerante frente } \\
\text { al estrés (Yukl, } \\
\text { 1994). }\end{array}$ & \\
\hline $\begin{array}{l}\text { Motivación para influir en } \\
\text { los demás } \\
\text { (Sánchez y Alonso del Amo, 2005). }\end{array}$ & $\begin{array}{l}\text { "Interés por adquirir estatus } \\
\text { y poder en el grupo y ejercer } \\
\text { un impacto en los demás". }\end{array}$ & $\begin{array}{l}\text { Dominante, } \\
\text { y deseo de asumir } \\
\text { responsabilidades } \\
\text { (Yukl, 1994). }\end{array}$ & $\begin{array}{l}\text { Facilidad de } \\
\text { palabra, } \\
\text { y capacidad } \\
\text { persuasiva } \\
\text { (Yukl, 1994). }\end{array}$ \\
\hline $\begin{array}{c}\text { Conocimientos } \\
\text { (Sánchez y Alonso del Amo, 2005). }\end{array}$ & $\begin{array}{c}\text { "Aspectos relevantes y } \\
\text { necesarios para el } \\
\text { funcionamiento del grupo". }\end{array}$ & & $\begin{array}{l}\text { Conocimiento } \\
\text { de las tareas } \\
\text { grupales (Yukl, } \\
\text { 1994). }\end{array}$ \\
\hline $\begin{array}{c}\text { Competencia cognitiva } \\
\text { (Sánchez y Alonso del Amo, 2005). }\end{array}$ & $\begin{array}{l}\text { "Nivel óptimo de complejidad } \\
\text { cognitiva, con facilidad para } \\
\text { integrar e interpretar grandes } \\
\text { cantidades de información". }\end{array}$ & $\begin{array}{l}\text { Inteligente, } \\
\text { y con habilidades } \\
\text { conceptuales (Yukl, } \\
\text { 1994). }\end{array}$ & \\
\hline $\begin{array}{c}\text { Competencia social } \\
\text { (Sánchez y Alonso del Amo, 2005). }\end{array}$ & $\begin{array}{l}\text { "Habilidades sociales para } \\
\text { ejercer la influencia } \\
\text { interpersonal típica en los } \\
\text { procesos de liderazgo". }\end{array}$ & & $\begin{array}{l}\text { Ser } \\
\text { diplomático y } \\
\text { discreto, } \\
\text { y tener } \\
\text { habilidades } \\
\text { sociales (Yukl, } \\
\text { 1994). }\end{array}$ \\
\hline $\begin{array}{c}\text { Auto-confianza } \\
\text { (Sánchez y Alonso del Amo, 2005). } \\
\text { Confiado } \\
\text { (Yukl, 1994) }\end{array}$ & $\begin{array}{c}\text { "Confianza en las propias } \\
\text { competencias". }\end{array}$ & $\begin{array}{l}\text { Decidido, } \\
\text { y seguro (Yukl, } \\
\text { 1994). }\end{array}$ & \\
\hline $\begin{array}{c}\text { Fiabilidad } \\
\text { (Sánchez y Alonso del Amo, 2005). }\end{array}$ & $\begin{array}{l}\text { "Ser una persona de } \\
\text { confianza para sus } \\
\text { seguidores". }\end{array}$ & & \\
\hline $\begin{array}{c}\text { Flexibilidad } \\
\text { (Sánchez y Alonso del Amo, 2005). } \\
\text { Versatilidad y flexibilidad } \\
\text { (Kirpatrick y Locke, 1984). }\end{array}$ & $\begin{array}{l}\text { "Adaptabilidad a las } \\
\text { situaciones". }\end{array}$ & & \\
\hline \multicolumn{4}{|l|}{$\begin{array}{c}\text { Asertivo y cooperativo } \\
\text { (Yukl, 1994). }\end{array}$} \\
\hline $\begin{array}{c}\text { Creativo y organizado } \\
\text { (Yukl, 1994). }\end{array}$ & & & \\
\hline
\end{tabular}

Cuadro 27: Rasgos y habilidades asociadas en los que se ha centrado el trabajo de investigación desde la década de los 70 del siglo XX. Fuente: Elaboración propia.

\section{Algunos investigadores (Angulo, 2013, 181) han}


rasgos, especialmente desde los años 90 del siglo XX, se ha debido a la ausencia de una "sociedad culta, formada en valores humanos y justa". Esta carencia es la que ha legitimado el auge de liderazgos populistas, que han presentado un trasfondo carismático, con el único objetivo de maximizar el beneficio para las organizaciones.

A causa de los decepcionantes resultados obtenidos en la década de los 40 y debido al auge que en ese momento tenía la orientación conductual, algunos estudios se centraron en el análisis de la conducta del líder.

El trabajo de investigación que se inició en este campo constituye el denominado "enfoque conductual" en la literatura científica.

Hemos indicado algunos estudios precedentes, las aportaciones de los dos principales grupos de investigación y una propuesta que se encontraría a mitad de camino entre este enfoque conductual y el estudiado a continuación, el enfoque contingente.

Aunque el avance en la investigación dentro del "enfoque conductual" se centró en dos universidades, hay dos investigaciones previas que son consideradas como precedentes.

Por una parte el estudio de laboratorio desarrollado por Bales (1950). Este autor observó cómo se relacionaban personas que previamente no se conocían entre sí y que tenían que resolver problemas. 
Las conductas de los integrantes del grupo durante el proceso de interacción fueron estructuradas por Bales en doce categorías constituyentes del denominado API (Análisis del Proceso de Interacción).

Las doce categorías identificadas se clasificaron haciendo referencia a tres tipos diferentes de conducta:

\begin{tabular}{|c|c|}
\hline Tipo de conducta & Explicación de la conducta \\
\hline $\begin{array}{c}\text { Socio-emocional } \\
\text { positiva }\end{array}$ & $\begin{array}{l}\text { Hace referencia a conductas } \\
\text { emocionales afectivas con carga } \\
\text { positiva. }\end{array}$ \\
\hline $\begin{array}{c}\text { Socio-emocional } \\
\text { negativa }\end{array}$ & $\begin{array}{l}\text { Hace alusión a conductas } \\
\text { emocionales afectivas con carga } \\
\text { negativa. }\end{array}$ \\
\hline Socio-operativa & - Alude a conductas de actuación. \\
\hline
\end{tabular}

Cuadro 28: Tipos diferentes de conducta. Fuente: Bales (1950).

Por otra, el estudio de laboratorio desarrollado por Bales y Slater (1955) sugirió la existencia de dos tipos de líderes, los líderes socio-emocionales y los líderes de tarea, cuya actuación se iniciaba en cada caso por una conducta diferente.

Los líderes socio-emocionales iniciaban su comportamiento con las conductas socio-emocionales positivas y de intercambio de información, y los líderes orientados a la tarea comenzaban su comportamiento con conductas de tarea.

Además Bales y Slater indicaron que una misma persona no ejercía al mismo tiempo ambos tipos de conducta por dos motivos. En primer lugar porque es poco 
frecuente que un líder tenga capacidad para realizar las dos funciones. El segundo motivo se encuentra en la inhibición que provoca el tipo de respuesta que el líder recibe de sus seguidores, sobre cada uno de los dos tipos posibles de conducta. Si se trata de un líder de tarea generalmente va a producir hostilidad entre los integrantes del grupo y estos le expresarán conductas socio-emocionales negativas. Pero si se trata de un líder socio-emocional, recibirá generalmente conductas socio-emocionales negativas.

Estos antecedentes motivaron el desarrollo del núcleo de la investigación dentro del enfoque conductual, casi de forma simultánea, en dos universidades: la Universidad de Ohio y la Universidad de Michigan.

Los grupos de investigación de las dos universidades, en consonancia con los estudios previos, situaron la descripción del comportamiento del líder en dos categorías: atención a la tarea y atención a las relaciones personales.

El objetivo del grupo de Ohio fue conocer qué tipos de conductas favorecen un mejor ejercicio de liderazgo en los grupos de trabajo.

En el primero de los dos estudios realizados en esta universidad, bajo la dirección de Hemphill (1956) y Fleishman (1951), se diseñó un primer cuestionario para evaluar qué tipo de conductas estaban más asociadas al rendimiento del grupo de acuerdo a las percepciones de los 
colaboradores (Leader Behavior Description Questionnaire -LBDQ-), y un segundo cuestionario para recoger las impresiones del propio líder (Leadership Opinion Questionnaire -LOQ-).

Los investigadores recogieron más de 1800 muestras de conductas de líder, que posteriormente redujeron a 150 (Sánchez y Alonso del Amo, 2005).

El análisis factorial de las respuestas indicó que los subordinados percibían la conducta de su supervisor en términos de dos dimensiones o conductas de su comportamiento que eran independientes entre sí (Johns \& Moser, 1989; García, 2006): iniciación de estructura y consideración.

Iniciación de estructura hace referencia a la conducta del líder que se dirige a la tarea y a la estructuración de las actividades de los seguidores para la consecución de los objetivos.

Mientras consideración alude a la conducta del líder que estaba más orientada a los aspectos socio-emocionales, como sus expectativas, sentimientos y necesidades, con objeto de establecer una confianza mutua.

En el segundo grupo de estudios, realizados, entre otros, por Korman (1966), Fleishman y Hunt (1973) y Kerr, Schriesheim, Murphy y Stogdill (1974), se analizaron las repercusiones del ejercicio de cada una de las dos dimensiones en las organizaciones. 
Los líderes muy valorados por la dimensión “iniciación a la estructura" eran también muy valorados por su productividad, pero en sus equipos de trabajo también existían elevadas tasas de absentismo y de reclamaciones, y bajos índices de satisfacción laboral.

Y los líderes muy valorados en la dimensión “consideración” ejercían su rol en grupos bastante cohesionados, con escasa frecuencia de bajas, con reducido absentismo laboral y con altos índices de satisfacción laboral.

Los resultados obtenidos en estas investigaciones sobre la repercusión organizacional de los dos tipos de conducta fueron similares a los alcanzados en otros estudios (Korman, 1966; Schriesheim, 1974).

Como crítica a los resultados alcanzados, algunos autores han denunciado que las dos dimensiones no pueden ser tratadas como elementos independientes.

Blake y Mouton (1982) han indicado que el grado de consideración con que se exprese el líder y las conductas previas de consideración que se hayan podido desarrollar entre el líder y el colaborador influyen en la respuesta de este.

Smith y Peterson (1990), en una revisión de una investigación de simulación de roles realizada con alumnos (Lowin, Hrapchack y Kavanagh, 1969), también constataron que la respuesta a un determinado líder no solo dependía de 
su conducta de consideración sino también de su conducta de iniciación de estructura.

Fleishman (1998) ha indicado que es necesario realizar el análisis de las dos dimensiones del modelo desde la interacción, y no como dimensiones separadas, ya que la interacción parece ser más la norma que la excepción. De todos modos el modelo ha contemplado que aunque ambas conductas parecen presentar un carácter independiente, los líderes también pueden exhibir conductas asociadas a alguna de las dos dimensiones, a ambas al mismo tiempo o a ninguna (Sánchez y Alonso del Amo, 2005).

El grupo de Michigan también se centró en el conocimiento de las conductas más relacionadas con la efectividad en el ejercicio del liderazgo. Con este objetivo los investigadores Katz, Maccoby y Morse (1950) y Likert (1961), entre otros, identificaron dos estilos de conducta del líder asociados a la efectividad en grupos de personas procedentes de diferentes sectores: conducta orientada a la producción y conducta orientada a las relaciones.

La conducta orientada a la producción pone el énfasis en la orientación a la producción. El líder la utiliza cuando establece las tareas necesarias para la consecución de los objetivos. Mientras la conducta orientada a las relaciones pone el énfasis en las relaciones humanas. Es ejercida por el líder cuando comparte sus decisiones y toma en consideración tanto las necesidades, como el desarrollo individual de cada colaborador (Giffin, 2011). 
Se desarrollaron diversos estudios para tratar de verificar la eficacia asociada a las dos conductas de liderazgo, entre los que hemos citado dos: el realizado por Morse y Reimer (1956) y el realizado por Likert (1961).

Morse y Reimer (1956) analizaron los efectos que cada estilo de liderazgo tenía sobre el grupo y sobre el rendimiento. Sus resultados indicaron que los estilos de liderazgo centrados en las personas obtenían, por término medio, resultados más favorables en el grupo de trabajo que los estilos de liderazgo centrados en la producción.

Sus resultados también indicaron que el tiempo era una variable discriminatoria sobre el rendimiento. El estilo de liderazgo centrado en la producción obtenía mejores resultados en el corto plazo, mientras que el estilo de liderazgo centrado en las personas obtenía mejores resultados en el largo plazo (Weinert, 1985).

Likert (1961) realizó una investigación con gerentes que conseguían una alta producción. Indicó que aquellos que utilizaban estilos de liderazgo centrados en los empleados obtenían mejores resultados que los gerentes que utilizaban estilos de liderazgo centrados en la producción. Sus conclusiones evidenciaron que los líderes menos centrados en la supervisión favorecían el aumento de su productividad, aunque estos resultados no fueron corroborados por otros estudios (García, 2006). 
En términos generales esta línea de investigación ha puesto de manifiesto que el estilo de dirección centrado en las relaciones es mucho más favorable que el orientado a la producción si se persiguen objetivos a largo plazo, aunque este último estilo puede ser más recomendable para periodos cortos de tiempo.

El trabajo desarrollado por el grupo de Michigan ha recibido diversas críticas.

Se ha denunciado que no tuvo en cuenta la situación en la que se desempeña el liderazgo (Byrman, 1996; Gil, 2003 y Rodríguez, Sánchez, Zarco y Martín, 2004).

Además también se ha declarado que contemplara que los líderes pueden tener comportamientos en los que exhiban, al mismo tiempo, los dos estilos de liderazgo. Las investigaciones realizadas por Blake y Mouton (1964) indicaron que los directivos rendían mejor cuando utilizaban, de manera simultánea, una elevada atención a las personas y a la producción.

También se ha manifestado que el grupo de trabajo no estableció con claridad la distinción entre las actitudes y las conductas a la hora de analizar los estilos de liderazgo. De acuerdo con Hersey y Blanchard (1982) las dimensiones que ha utilizado el modelo no eran realmente conductas observadas sino actitudes mostradas, ya se trate de un interés por las personas o de una preferencia por la producción y la tarea. 
El modelo planteado por Tannenbaum y Schmidt (1958, 1973) se encuentra a mitad de camino entre las teorías basadas en la conducta del líder y las teorías que también consideran la situación en la que se ejerce el liderazgo, que hemos tratado en el siguiente apartado.

Esta teoría propuso la existencia de un continuo entre las conductas democráticas, orientadas a las personas, y las conductas autoritarias, centradas en las tareas. La elección de un estilo de liderazgo, dentro de ese continuo, vendría determinada por las características de la propia situación, por la evaluación que el líder hace de la misma, por sus atributos personales y por la capacitación de los integrantes del grupo.

\subsubsection{Enfoques contingentes}

Los enfoques anteriores, centrados en el estudio de los rasgos psicológicos y en el comportamiento, no han sido determinantes a la hora de evaluar la eficacia del ejercicio de liderazgo. El motivo, de acuerdo a algunos planteamientos, se encuentra en que no han contemplado la influencia de un tercer factor: las condiciones en las que el liderazgo se desarrolla. Estas condiciones pueden provocar que un líder muy efectivo en una situación específica resulte inefectivo en otra.

El nuevo enfoque, denominado "enfoque situacional", ha sostenido que el acierto en el ejercicio del liderazgo depende, en gran medida, del contexto. 
Algunos autores han indicado que este enfoque ha dado lugar a una perspectiva interaccionista en el estudio del liderazgo, ya que analiza como adecuar el estilo de liderazgo a cada situación a partir de los rasgos psicológicos y las conductas de los actores, y las características de las situaciones específicas (Sánchez y Alonso del Amo, 2005).

Se han desarrollado diversas teorías que han contemplado la variable situacional como eje central para mejorar la eficacia en el ejercicio del liderazgo.

A continuación exponemos las aproximaciones más representativas: el Modelo Contingente de Fiedler, la Teoría de Liderazgo Situacional o de Ciclo de Vida de Hersey y Blanchard, y la Teoría del Camino-Meta de House.

Se desarrolla en mayor medida la propuesta de Hersey y Blanchard, la Teoría del Liderazgo Situacional, ya que se ha tomado como referente para analizar el estilo del liderazgo en esta investigación.

De acuerdo al Modelo Contingente planteado por Fiedler, existen tres variables cuya interactividad determina la cualidad de una situación y su potencial para favorecer la efectividad en el liderazgo desarrollado por el líder (Fiedler, 1964, 1967).

La primera variable es la que hace referencia a la relación personal del líder con los integrantes del grupo (relaciones líder-miembros). Se trata de la variable más determinante en la influencia del líder sobre el grupo 
(Fiedler y Chemers, 1985), aspecto que se ve enfatizado porque el líder tiene dificultad para cambiar el tipo de relación que establece con su grupo (Fiedler (1972). En esta propuesta teórica, al contrario que en otros modelos situacionales, se espera que el líder adapte la situación a su estilo para que este sea efectivo (Rodríguez, Sánchez, Zarco y Martín, 2004). Este último aspecto parece ir en contra de uno de los rasgos más destacados por los investigadores que han abordado las cualidades idóneas del líder: su flexibilidad.

La segunda variable es la que hace alusión al grado de estructuración de la tarea que ha sido asignada al grupo (grado de estructuración de la tarea). Para Fiedler y sus colegas es la segunda variable en importancia sobre la influencia que el líder ejerce en el grupo (Fiedler y Chemers, 1985).

La tercera variable considerada hace referencia al poder y autoridad concedidos a quien desempeña el rol de líder (posición de poder).

El modelo ha sostenido que las tres variables son dependientes y que el tipo de relación que establecen determina el grado de "favorabilidad" de una situación concreta para el ejercicio del liderazgo (Giffing, 2011). Fiedler definió la "favorabilidad” como "el grado en el que la situación permite al líder ejercer influencia sobre el grupo" (Fiedler, 1967, 13). De acuerdo con este 
planteamiento el modelo contempla ocho tipos de situaciones a través de la relación de las tres variables:

\begin{tabular}{|c|c|c|c|c|c|c|c|c|}
\hline $\begin{array}{c}\text { Categoría } \\
\begin{array}{c}\text { Relaciones } \\
\text { líder-miembros }\end{array}\end{array}$ & Buenas & Buenas & Buenas & Buenas & Pobres & Pobres & Pobres & Pobres \\
\hline $\begin{array}{c}\text { Estructura } \\
\text { de la tarea }\end{array}$ & Alta & Alta & Baja & Baja & Alta & Alta & Baja & Baja \\
\hline $\begin{array}{c}\text { Poder } \\
\text { del puesto }\end{array}$ & Fuerte & Débil & Fuerte & Débil & Fuerte & Débil & Fuerte & Débil \\
\hline
\end{tabular}

Cuadro 29: Relación entre poder del puesto, estructura de tarea y relaciones entre el líder y los miembros. Fuente: Fiedler y Chemers (1985).

La situación más favorable para el líder, según el Modelo Contingente de Fiedler, sería la que corresponde a la categoría "I": buenas relaciones entre el líder y sus seguidores, alta estructuración de las tareas y fuerte posición de poder.

Fiedler intentó profundizar en la capacidad del modelo para predecir "favorabilidad" del ejercicio del liderazgo en las diversas situaciones que contempla. En este sentido Fiedler relacionó el rendimiento del grupo, la escala de situaciones indicada en el Cuadro 29 y los resultados del programa de investigación desarrollado en 1953 para predecir la efectividad del liderazgo a partir de la medición del rasgo Least Preferred Co-worker (LPC) -“compañero de trabajo menos preferido"-. Este programa de investigación clasificó a los líderes con una puntuación alta, si estaban orientados a las relaciones o con una puntuación baja, si estaban orientados a las tareas (Fiedler y Chemers, 1985).

Los resultados de la correlación de estos datos mostraron que los líderes orientados a las tareas resultaban 
ser más eficientes en las situaciones más favorables o más desfavorables. También reflejaron que los líderes orientados a las relaciones personales se desenvolvían mejor en situaciones medianamente favorables. Por otra parte también indicaron que no se producía una preferencia por un estilo de liderazgo en situaciones que no eran moderadamente favorables ni se encontraban en los extremos de "favorabilidad" (Fiedler y Chemers, 1985).

La teoría propuesta por Fiedler ha contribuido al estudio del liderazgo dentro del enfoque situacional, especialmente por haber considerado que existen múltiples variables que influyen en su efectividad (Giffing, 2011).

No obstante el modelo también ha recibido algunas críticas.

Por una parte, por el carácter especulativo de la propuesta (Sánchez, 2002) y por la reducida explicación de los elementos que la integran (Yukl, 1998). Esta denuncia ha sido especialmente acentuada en relación con el Least Preferred Co-worker (LPC). Inicialmente Fiedler sostuvo que el LPC hacía referencia a un rasgo estable y difícil de modificar de la personalidad (García, 2006). Sin embargo la revisión de la fiabilidad en los estudios realizados con el LPC arrojó una gran variabilidad en los resultados (Rice, 1978). Como consecuencia Fiedler planteó que la puntuación del LPC reflejaba, únicamente, la posición del líder en una jerarquía de motivos (Fiedler, 1978). 
Por otra parte también se ha criticado la validez del modelo. Aunque hay estudios que han corroborado, parcial o totalmente, las tesis de la teoría (Wienert, 1985) otros trabajos han denunciado la capacidad limitada de predicción del modelo. Pese a que predice de forma acertada el estilo de liderazgo idóneo para situaciones muy desfavorables y muy favorables, con niveles bajos de LPC, y pronostica de manera atinada el estilo de liderazgo para situaciones intermedias de "favorabilidad", no pronostica de manera acertada el estilo de liderazgo en niveles que no se encuentren en los extremos de "favorabilidad" y que no sean moderadamente favorables (Smith y Peterson, 1990).

En respuesta a algunas de estas críticas Fiedler y García (1987) plantearon una renovación del modelo a través de su Teoría de los Recursos Cognitivos, donde profundizaron en el estudio de la influencia de algunas habilidades cognitivas de los líderes (como la inteligencia o la experiencia) en el rendimiento de colaboradores en diversas situaciones: estrés interpersonal, apoyo grupal y complejidad de las tareas.

Sánchez y Alonso del Amo (2005) han indicado que sería necesario realizar más estudios que contemplaran las diversas combinaciones de las variables implicadas en el modelo, para que la propuesta obtenga un mayor respaldo.

El segundo modelo revisado, la Teoría del Liderazgo Situacional o de Ciclo de Vida, parte de la idea central de 
que la efectividad del liderazgo se consigue mediante el ajuste entre el estilo de liderazgo puesto en práctica por el líder con el nivel de preparación del colaborador.

Hemos clasificado la información sobre este modelo en cuatro bloques: el que hace referencia al origen, denominación y relevancia de la teoría, el que hace alusión a las influencias de la Teoría del Liderazgo Situacional, el referido al enfoque teórico del Liderazgo Situacional II y un cuarto bloque en el que hemos tratado las críticas que ha recibido la propuesta.

En su origen (1969), en el que la teoría fue llamada Teoría del Ciclo Vital del Liderazgo (Hersey y Blanchard, 1969b), el modelo perseguía facilitar el cambio en el estilo de liderazgo que los padres necesitaban conforme sus hijos crecían desde la infancia, pasando por la adolescencia, hasta la edad adulta. Se consideraba que "un niño necesita un estilo de liderazgo diferente del que precisa un adolescente $\mathrm{y}$, con certeza, un estilo diferente del adecuado cuando ya es un joven adulto" (Blanchard, Zigarmi y Nelson, 1993, 22).

Desde entonces el modelo ha experimentado diversas modificaciones (1972, 1974, 1977, 1982, 1988 y 1996), en algunos casos con colaboradores (1979 y 1998), con el fin de mejorar la propuesta inicial.

A partir de la segunda edición de la publicación de la teoría (1972) sus autores comenzaron a utilizar la expresión Teoría del Liderazgo Situacional (TLS). Y en posteriores 
revisiones pasó a denominarse Teoría Situacional II -TLS II(Blanchard, Zigarmi y Zigarmi, 1985).

El modelo ha tenido gran aceptación en la industria y las empresas de mayor éxito en los Estados Unidos lo emplean para entrenar a sus mandos (Sánchez y Rodríguez, 2010).

En relación con las influencias del modelo, el trabajo inicial de Hersey y Blanchard estaba orientado a edificarse sobre las principales aportaciones científicas de liderazgo alcanzadas hasta entonces (Hersey y Blanchard, 1969a):

\begin{tabular}{|c|c|c|}
\hline Autores & \multicolumn{1}{|c|}{ Influencia } & $\begin{array}{c}\text { Implicación en la Teoría } \\
\text { del Liderazgo Situacional }\end{array}$ \\
\hline $\begin{array}{c}\text { Lewin, Lippitt y } \\
\text { White (1960) }\end{array}$ & $\begin{array}{c}\text { Diferencias existentes entre el } \\
\text { liderazgo autocrático, } \\
\text { democrático y el dejar hacer. }\end{array}$ & $\begin{array}{c}\text { Concreción de los estilos } \\
\text { de liderazgo. }\end{array}$ \\
\hline $\begin{array}{c}\text { Tannenbaum y } \\
\text { Schmidt (1958) }\end{array}$ & Liderazgo como un continuo. & $\begin{array}{c}\text { Existencia de relación entre } \\
\text { los estilos de liderazgo. }\end{array}$ \\
\hline $\begin{array}{c}\text { Stogdill, } \\
\text { Halpin (1957) }\end{array}$ & $\begin{array}{l}\text { Liderazgo como un modelo de } \\
\text { dos dimensiones: "iniciación a } \\
\text { la estructura" y }\end{array}$ & $\begin{array}{l}\text { Concreción de los cuatro } \\
\text { estilos de liderazgo del } \\
\text { modelo. }\end{array}$ \\
\hline Konsideración". & $\begin{array}{l}\text { Posible relación curvilínea, } \\
\text { más que lineal, entre } \\
\text { "iniciación de estructura", } \\
\text { "consideración" y otras } \\
\text { variables. }\end{array}$ & $\begin{array}{l}\text { Relación no lineal entre la } \\
\text { iniciación a la estructura, la } \\
\text { consideración y otras } \\
\text { variables. }\end{array}$ \\
\hline
\end{tabular}

Cuadro 30: Algunas influencias de la Teoría del Liderazgo Situacional. Fuente: elaboración propia.

Otra influencia importante de la Teoría del Liderazgo Situacional fue la Rejilla Gerencial desarrollada por Blake y Mouton (1964) que, para algunos autores (Blanchard, Zigarmi y Nelson, 1993), supuso una evolución de la 
propuesta inicial del grupo de Ohio. Blake y Mouton cambiaron las dimensiones de "iniciación a la estructura" y "consideración" por "preocupación por la producción" o "preocupación por las personas", y desarrollaron un programa de gestión que se volvió muy popular.

El grupo de Ohio también ejerció influencia en la Teoría del Liderazgo Situacional en su decisión de elegir el comportamiento del líder como objeto de estudio. Esta herencia estuvo especialmente motivada porque el grupo de Ohio consideraba que el mejor estilo de liderazgo equivalía a una alta preocupación por las personas y a una alta preocupación por la producción. También ejerció influjo su defensa de la interdependencia de los dos tipos de comportamiento (Blake y Mouton, 1982).

La formulación inicial de la Teoría del Liderazgo Situacional también fue deudora del trabajo de Fiedler (1967), padre de la Teoría de la Contingencia, que sugirió la existencia de tres variables clave que determinaban que una situación específica fuera favorable para un líder: su relación personal con los integrantes de su equipo, el grado de estructura de la tarea asignada a su grupo, y el poder y la autoridad que su posición le proveía. En relación con esta herencia algunos autores han indicado que las relaciones líder-miembros son análogas a los conceptos sobre las relaciones presentados en teorías previas, mientras que la estructura de tarea y la posición de poder, que miden aspectos relacionados con la situación, parecen estar 
asociados con conceptos de tarea (Blanchard, Zigarmi y Nelson, 1993).

De Fiedler y Chemers (Fiedler, 1978; Fiedler y Chemers, 1985), Hersey y Blanchard recogieron la indicación de que el estilo de liderazgo de una persona refleja su estructura motivacional y sus necesidades básicas. Es decir, la manera en que un directivo se comporta con sus colaboradores en el ámbito laboral muestra su prioridad: centrarse en las tareas o en las relaciones. Solo cuando está satisfecha una de las dos necesidades, el líder atenderá la otra (Sánchez y Rodríguez, 2010).

Otro autor cuyo trabajo influyó en la propuesta inicial de Hersey y Blanchard fue Reddin (1967). Fue el primero en añadir una dimensión de efectividad a las dimensiones de preocupación por la tarea y preocupación por las relaciones de los modelos actitudinales iniciales, como la Rejilla Gerencial. Algunos autores han indicado que su trabajo fue una evolución de la Rejilla Gerencial, aunque Redding sugirió que no había un estilo de liderazgo idóneo (Blanchard, Zigarmi y Nelson, 1993). Su propuesta influyó ampliamente a Hersey y Blanchard, especialmente a través de su Modelo de Efectividad Tridimensional del Líder también conocido como Teoría Tridimensional del Estilo de Dirección (Sánchez y Rodríguez, 2010).

En relación con la efectividad, también destacamos la herencia de las cinco bases de poder propuestas por French y Raven (1959) y la base de poder "información" de Raven y Kruglanski (1975). Las dos formulaciones representaron una 
herencia importante en los supuestos que fundamentaron la efectividad del estilo de liderazgo en una situación dada dentro de la Teoría del Liderazgo Situacional.

Otra herencia importante recibida por la Teoría del Liderazgo Situacional es el concepto de "madurez" y su conceptualización como un continuo, tomado de Argyris (1957, 1962 y 1964). Este autor examinó qué efectos tienen las prácticas organizacionales en el comportamiento y en el desarrollo personal dentro del entorno organizacional. Estableció dos polos, inmadurez y madurez, para describir cómo evoluciona una personalidad "sana" en un contexto organizacional a través de siete cambios:

\begin{tabular}{|l|l|}
\hline \multicolumn{1}{|c|}{ Inmaduro } & \multicolumn{1}{|c|}{ Maduro } \\
\hline Pasivo. & $>$ Activo. \\
\hline Dependencia. & $>\begin{array}{l}\text { Capaz de comportarse de } \\
\text { muchas formas. }\end{array}$ \\
\hline Intereses erráticos y superficiales. & $>\begin{array}{l}\text { Intereses más profundos y más } \\
\text { fuertes. }\end{array}$ \\
\hline Perspectiva a corto plazo. & $>\begin{array}{l}\text { Perspectiva a largo plazo (pasado } \\
\text { y futuro). }\end{array}$ \\
\hline Posición subordinada. & $>$\begin{tabular}{l} 
Posición igual o superior. \\
\hline Falta de conocimiento de sí \\
mismo.
\end{tabular} \\
\hline
\end{tabular}

Cuadro 31: Continuo inmaduro-maduro en la evolución de una persona en un entorno organizacional. Fuente: Argyris (1957, 1962 y 1964).

El enfoque teórico del Liderazgo Situacional II ha mantenido gran parte de los planteamientos del enfoque teórico propuesto por el Liderazgo Situacional, aunque ha 
presentado algunas modificaciones que indicamos a continuación.

El Liderazgo Situacional II se ha basado en la búsqueda de la excelencia a través de una relación óptima entre el nivel de desarrollo de una persona -aspecto variable en función de la combinación de su competencia y su grado de compromiso- sobre un objetivo específico o tarea, y el estilo de liderazgo que el líder provee -componente que varía en función del grado de presencia en la conducta del líder del comportamiento directivo y del comportamiento de apoyo- (Blanchard, 2001).

Los supuestos que han fundamentado el Liderazgo Situacional II son diversos. Para tratar este aspecto se ha estructurado la exposición de los contenidos del siguiente modo: algunas consideraciones sobre el nuevo rol del líder contemporáneo, aspectos clave relacionados con el estilo de liderazgo propuesto por la Teoría Situacional II, su concepción del nivel de desarrollo, el objetivo del Liderazgo Situacional II y los instrumentos que utiliza.

El modelo ha intentado adaptarse al hecho de que el rol del líder haya cambiado drásticamente en los últimos años del siglo $\mathrm{XX}$.

En el pasado el líder era más visto como un “jefe”, pero desde finales del s. XX los líderes han empezado a ser considerados como compañeros de sus colaboradores. Han pasado del rol de evaluación y juicio propio de "ordenar y controlar", al rol de asegurar la responsabilidad en el 
desarrollo de las tareas a través del apoyo, del impulso y del ánimo.

En relación con este nuevo contexto el Liderazgo Situacional II ha intentado abrirse a la comunicación. En este sentido el modelo ha tratado de incrementar la calidad y la frecuencia de las conversaciones para proveer a los colaboradores de un liderazgo efectivo que les permita alcanzar el nivel más alto de rendimiento (Blanchard, 2001).

El estilo de liderazgo es, para el modelo, el patrón de comportamiento que utiliza el líder.

Este patrón es solo una percepción del propio líder sobre su estilo de liderazgo, pero no es necesariamente el modo en el que estilo de liderazgo es percibido por los colaboradores.

Los estudios han mostrado que este patrón de comportamiento se articula a partir de dos componentes básicos: directivo y de apoyo (Blanchard, 2001). El comportamiento directivo, que desarrolla competencia en los colaboradores, se concentra en el "qué" y en el "cómo" e implica mostrar a las personas qué hay que hacer, cómo y cuándo; realizar un seguimiento del rendimiento y proveer una retroalimentación frecuente sobre los resultados. El comportamiento de apoyo, que estimula el compromiso en los colaboradores, se centra en desarrollar la iniciativa y el compromiso individual, $y$ en desarrollar actitudes $y$ sentimientos positivos hacia el objetivo o la tarea. Ejemplos 
válidos de comportamiento de apoyo son escuchar, incentivar la solución personal de los problemas y animar e involucrar a los otros en la toma de decisiones.

De acuerdo con los dos componentes anteriores, el modelo ha planteado la existencia de cuatro estilos de liderazgo diferentes según la dirección y el apoyo que el líder ofrece, y de acuerdo con la implicación de los colaboradores en la toma de decisiones -aunque en todos ellos el líder clarifica las expectativas y los objetivos, observa y revisa el rendimiento de los colaboradores y ofrece algún tipo de retroalimentación-: directivo o directing, persuasivo o de impulso o consultivo o coaching, de apoyo o participativo o supporting y delegativo o delegating (Blanchard, 2001).

El estilo directivo o directing (S1) consiste en utilizar un alto comportamiento directivo y un bajo comportamiento de apoyo. En este estilo el líder provee de instrucciones específicas acerca de las tareas que se deben acometer y cómo se deben afrontar, y supervisa de cerca el rendimiento de los colaboradores. La mayoría de las decisiones de este estilo son tomadas por el líder. Las actuaciones que caracterizan este estilo directivo son: definir, planificar y priorizar, orientar, enseñar, realizar seguimiento y retroalimentar.

El estilo persuasivo o de impulso o consultivo 0 coaching (S2) se basa en un alto comportamiento directivo y un alto comportamiento de apoyo. En este tipo de estilo 
el líder explica las decisiones, solicita sugerencias, elogia los progresos y acompaña el alcance directo de la tarea; y toma en cuenta las consideraciones de los colaboradores aunque las decisiones finales son realizadas por el propio líder. El modo de actuación que define este estilo directivo son: explorar y preguntar, explicar y clarificar, reorientar, compartir feedback, animar y elogiar.

El estilo de apoyo o participativo o supporting (S3) consiste en proveer un bajo comportamiento directivo y un alto comportamiento de apoyo. Un líder que utiliza este tipo de estilo escucha, anima y facilita la propia toma de decisiones y de solución de problemas. Los modos de conducta que más identifican este directivo son preguntar y escuchar, tranquilizar, colaborar, incentivar la propia confianza en la solución de los problemas, fomentar la retroalimentación y apreciar. Hemos considerado que este es un estilo de liderazgo más característico en líderes afines a la responsabilidad social porque el desarrollo de actuaciones en este ámbito precisa, en muchos casos, de una disposición colaborativa con otros actores implicados.

El estilo delegativo o delegating (S4) consiste en una combinación de bajo comportamiento directivo y bajo comportamiento de apoyo. El líder impulsa al colaborador a actuar de forma independiente, y le provee de los recursos apropiados para realizar el trabajo. En este estilo la mayoría de las decisiones son tomadas por los colaboradores. Los comportamientos que más definen este tipo de actuación por parte del líder son: mostrar confianza 
y permisividad, ratificar, facultar, afirmar, mostrar reconocimiento y estimular el desarrollo de desafíos. Hemos entendido que el estilo delegativo tiene un gran protagonismo en los líderes más próximos a la responsabilidad social porque no sería posible realizar acciones de responsabilidad social sin la posibilidad de delegar responsabilidades en los colectivos con los que se colabora en el desarrollo de dichas acciones. Además implicarse en iniciativas de Responsabilidad Social Corporativa supone, en muchos casos, vincularse a proyectos que representan un desafío y cuyo retorno de resultados no se garantiza.

A continuación hemos incorporado la figura 6 con los cuatro estilos de liderazgo propuestos por el modelo:

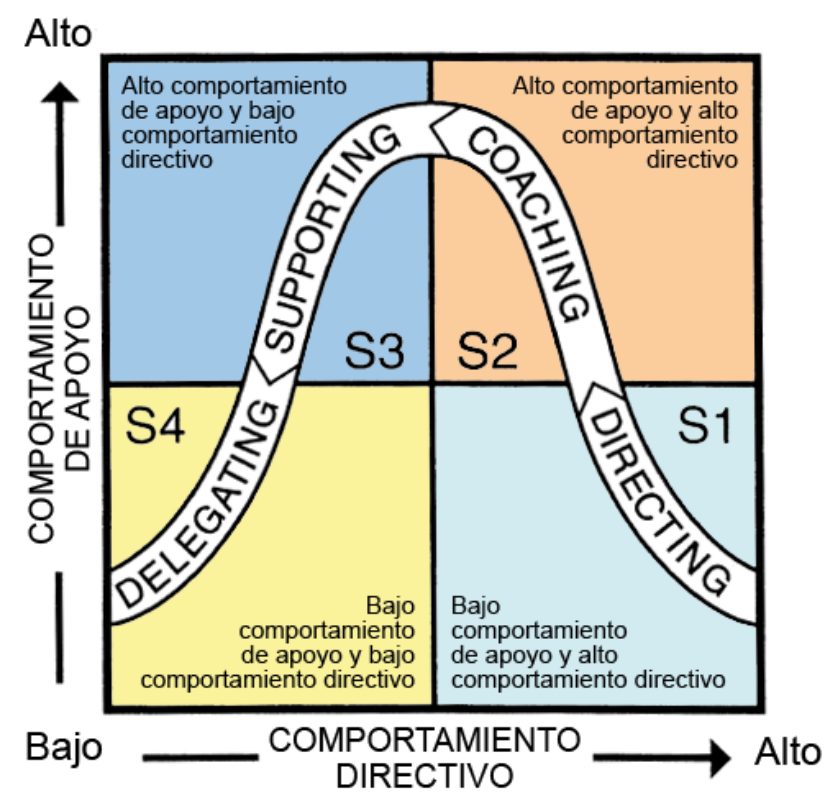

Figura 6: Estilos de liderazgo. Teoría del Liderazgo Situacional II. Fuente: Blanchard, Zigarmi y Nelson (1993).

Otro aspecto relevante dentro del enfoque teórico del Liderazgo Situacional II es el nivel de desarrollo de una persona en una organización. Para el modelo este nivel de 
desarrollo está representado por una combinación de dos factores: competencia y compromiso. La competencia representa el conocimiento y la habilidad que una persona posee a la hora de afrontar un objetivo o tarea. Mientras el compromiso resulta de la combinación de la motivación, entendida como un nivel de interés y entusiasmo en relación con una asignación, y de la confianza, concebida como la seguridad que una persona posee a la hora de afrontar un objetivo o tarea.

Estos factores han determinado cuatro niveles de desarrollo posibles que se pueden ubicar dentro de un continuo. Este continuo representa el trayecto que sigue una persona hasta que es capaz de producir resultados de forma independiente dentro de un objetivo o tarea concreta, ya que no existe un nivel general de desarrollo absoluto. Estos niveles son el principiante entusiasmado o the Enthusiastic Beginner, el que aprende desilusionado, o the Disillusioned Learner, el capaz pero cauto o the Capable but Cautious Performer y el que consigue depender solo de sí mismo o the Self-Reliant Achiever (Blanchard, 2001).

El nivel "principiante entusiasmado" 0 the Enthusiastic Beginner (D1) se caracteriza por un nivel bajo de competencia y un nivel alto de compromiso. Es propio de personas en nuevas tareas que presentan poca o ninguna experiencia y, en la mayoría de los casos, entusiasmo y disposición para aprender. Algunos rasgos que caracterizan a las personas que se encuentran en este nivel son los 
siguientes: ilusionado, inexperto, curioso, poco diestro, optimista, con ganas de aprender, feliz y entusiasta.

El nivel "el que aprende desilusionado" o the Disillusioned Learner (D2) se caracteriza por un nivel de competencia que se encuentra entre bajo y moderado, y un nivel bajo de compromiso. Es propio de personas que hace poco tiempo han comenzado una nueva tarea y suelen experimentar un periodo de desilusión. La decepción ocurre cuando un trabajo es diferente o más difícil de lo que habían esperado, desilusión que causa una disminución del nivel de compromiso. Quienes se encuentran en este nivel se sienten abrumados, confusos, desmotivados, desmoralizados, frustrados, desilusionados, deprimidos y con destellos de competencia.

El nivel "el capaz pero cauto" o the Capable but Cautious Performer (D3) se caracteriza por un alto nivel de competencia y un nivel de compromiso variable. Es propio de personas que superan la fase de desilusión y adquieren las habilidades que necesitan, aunque a través de una fase de indecisión en la que se cuestionan si pueden realizar bien la tarea por sí mismos. Aunque su líder pueda decirles que son competentes ellos no se sienten seguros porque carecen de confianza en su propia capacidad. En este sentido alternan sentimientos de competencia y duda, causados por un compromiso variable que fluctúa entre la excitación y la inseguridad. Los colaboradores que se encuentran en este nivel se caracterizan por ser autocríticos, cautos, 
dubitativos, capaces, participativos, inseguros, indecisos y apáticos.

El nivel "el que consigue depender solo de sí mismo" o the Self-Reliant Achiever (D4) se caracteriza por un alto nivel de competencia y compromiso. Se trata de personas que han alcanzado este nivel gracias a una adecuada dosis de dirección y apoyo. Los rasgos que más identifican a las personas que se encuentran en este nivel son: con confianza justificada, competentes consistentemente, capaces de inspirar a otros, expertos, autónomos, seguros, hábiles e independientes.

El aumento del nivel desarrollo de un colaborador respecto a una tarea $\mathrm{u}$ objetivo mediante un progreso secuencial de cuatro niveles ha sido llamado "el ciclo del desarrollo". Pero Blanchard (2001) también contempla que este proceso pueda tomar una dirección inversa, lo que ha denominado "el ciclo regresivo".

Esto se produce cuando un colaborador se encuentra en un nivel de rendimiento menor del que previamente había demostrado, lo que implica que el líder deba ajustar su comportamiento con estilos de liderazgo ya utilizados previamente para adecuarse al nivel de desarrollo actual del colaborador (Blanchard, 2001).

De acuerdo con la teoría, los cambios en el estilo de liderazgo para adecuarse a los diferentes niveles de desarrollo del colaborador deben ser de uno en uno, ya sea hacia delante o hacia atrás. Por ejemplo cuando un colaborador que "consigue depender solo de sí mismo" 
ofrece un nivel de rendimiento menor porque está experimentado una crisis familiar o porque hay rumores de una posible compra de la compañía, el líder podría pasar del estilo "delegativo" (delegating) a un estilo "de apoyo" (supporting), pero no podría pasar directamente a un estilo "persuasivo o de impulso" (coaching) aunque finalmente fuera el estilo que adoptara una vez que se hubiera diagnosticado adecuadamente la causa del problema (Blanchard, 2001).

A continuación hemos incorporado la figura 7 que muestra la progresión del nivel de desarrollo que ha propuesto el modelo:

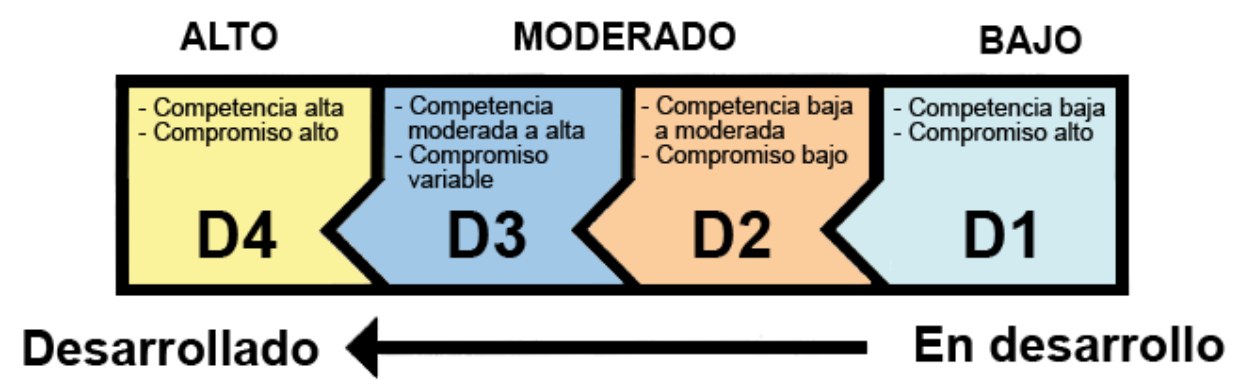

Figura 7: Nivel de desarrollo del colaborador. Teoría del Liderazgo Situacional II. Fuente: Blanchard (2001).

En cuanto al cuarto elemento al que hemos dedicado un especial hincapié en el estudio de los fundamentos teóricos del modelo, el objetivo que se persigue con la aplicación de los planteamientos del Liderazgo Situacional II, la propuesta defiende la utilización del estilo de liderazgo más apropiado para un objetivo o tarea específica tomando en consideración el nivel de desarrollo de cada persona. Esto significa que no existe un estilo de liderazgo idóneo ya que este variará en función del nivel de 
desarrollo que una tarea u objetivo específicos puedan exigir en cada caso concreto. Si las personas están sobresupervisadas o infra-supervisadas, de acuerdo con su nivel de desarrollo y tomando en consideración la tarea $u$ objetivo encomendado, se producirá un impacto negativo en su desarrollo.

De acuerdo con este planteamiento existe un estilo de liderazgo (directivo o directing, persuasivo o de impulso o coaching, de apoyo o supporting, delegativo o delegating) que resulta más apropiado para cada nivel de desarrollo (Blanchard, 2001).

El estilo directivo es especialmente idóneo para "el principiante entusiasmado" porque el alto comportamiento directivo facilita el conocimiento de la tarea y el desarrollo de las habilidades que el colaborador necesita, y no es necesario un alto comportamiento de apoyo porque el colaborador está entusiasmado.

El estilo consultivo resulta más adecuado para "el que aprende desilusionado" ya que el alto comportamiento directivo facilita la adquisición de las competencias, y el alto comportamiento de apoyo evita que el compromiso se resienta.

El estilo participativo es más idóneo para "el capaz pero cauto" porque presenta un compromiso variable que incentiva la utilización de un alto comportamiento de apoyo para reforzar la confianza débil y los problemas derivados de la reducción de la confianza, y solo necesita un bajo 
estilo directivo, ya que en este nivel la competencia va de moderada a alta.

El estilo delegativo resulta especialmente aconsejable para "el que consigue depender solo de sí mismo". Un colaborador altamente competente y altamente comprometido solo necesita un estilo de liderazgo de bajo apoyo y dirección.

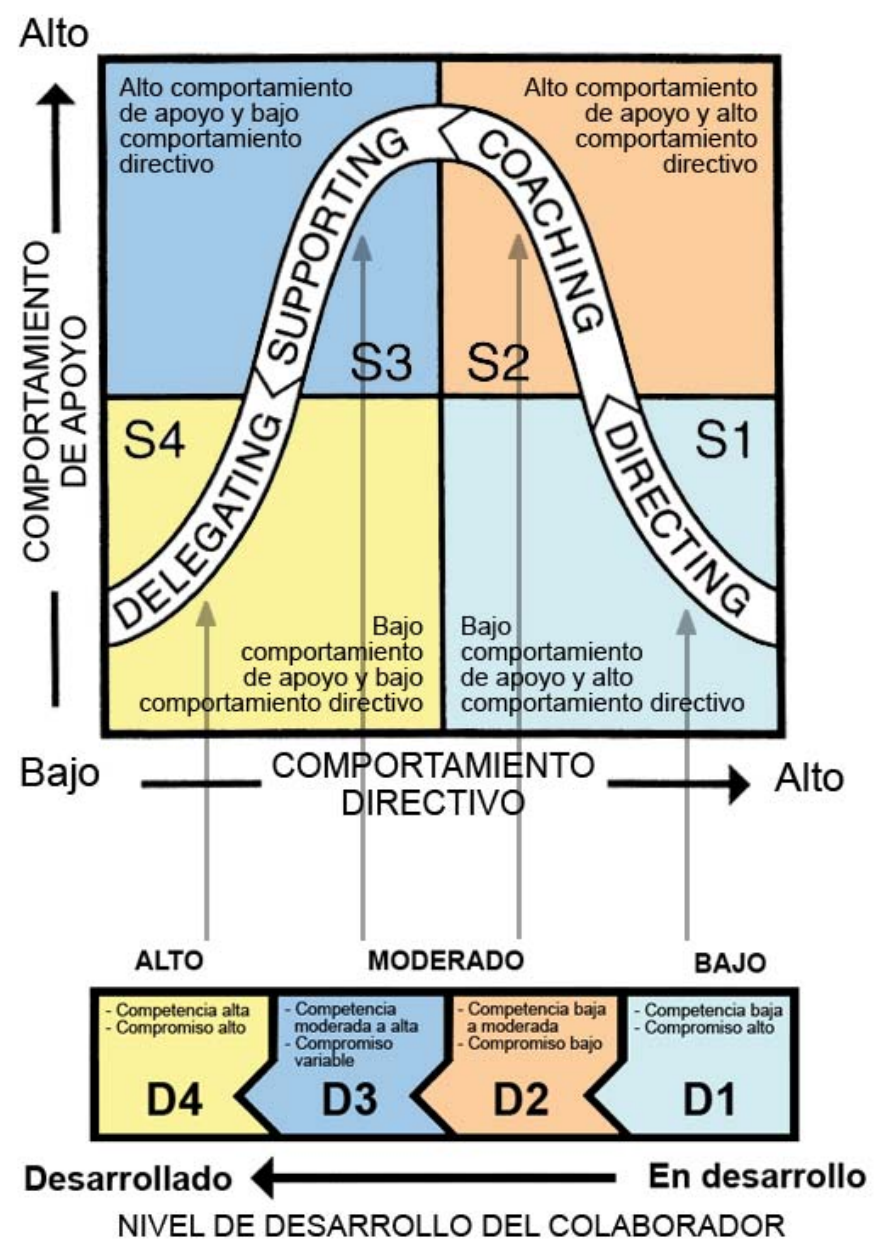

Figura 8: Cruce entre el estilo de liderazgo apropiado al nivel de desarrollo del colaborador. Teoría del Liderazgo Situacional II. Fuente: Blanchard (2001).

Sobre estas líneas se ha incorporado la figura 8, "Cruce entre el estilo de liderazgo apropiado al nivel de desarrollo del colaborador", que muestra las relaciones más adecuadas en cada caso entre los estilos de liderazgo 
(directivo, consultivo, participativo y delegativo) y los niveles de desarrollo del colaborador (desde un nivel inferior bajo caracterizado por una competencia baja y un compromiso alto hasta un nivel alto de desarrollo alto caracterizado por unos niveles de competencia y compromiso altos).

Como los colaboradores que coordina un líder se mueven de un nivel de desarrollo al siguiente, en cada objetivo o tarea específica el líder debería cambiar su propio estilo para proveer un estilo de liderazgo efectivo (Blanchard, 2001).

Los datos empíricos recogidos de la aplicación del enfoque propuesto por la Teoría Situacional II (Zigarmi, Edeburn y Blanchard, 1997) han indicado que el $54 \%$ de los líderes tienden a usar solo un estilo, el 35\% dos, el 10\% tres y el $1 \%$ los cuatro. Para ser realmente efectivos los líderes tendrían que, de acuerdo con la Teoría Situacional II, aprender a ser flexibles y usar los cuatro estilos (Blanchard, 2001).

Para facilitar la adecuación entre el estilo de liderazgo más apropiado al grado de desarrollo en el que se encuentra cada colaborador, el Liderazgo Situacional II es deudor del planteamiento elaborado para el Liderazgo Situacional I. Hersey, Blanchard y Natemayer (1979, p. 420) indicaron que el grado de desarrollo en el que el colaborador se encuentra no solo dicta qué estilo de liderazgo tiene la probabilidad más alta de éxito, "sino que también determina la base de poder que debería emplear el líder para inducir la 
obediencia o influir en el comportamiento". A continuación hemos incluido la figura 9 con las bases de poder contempladas en el Liderazgo Situacional I:
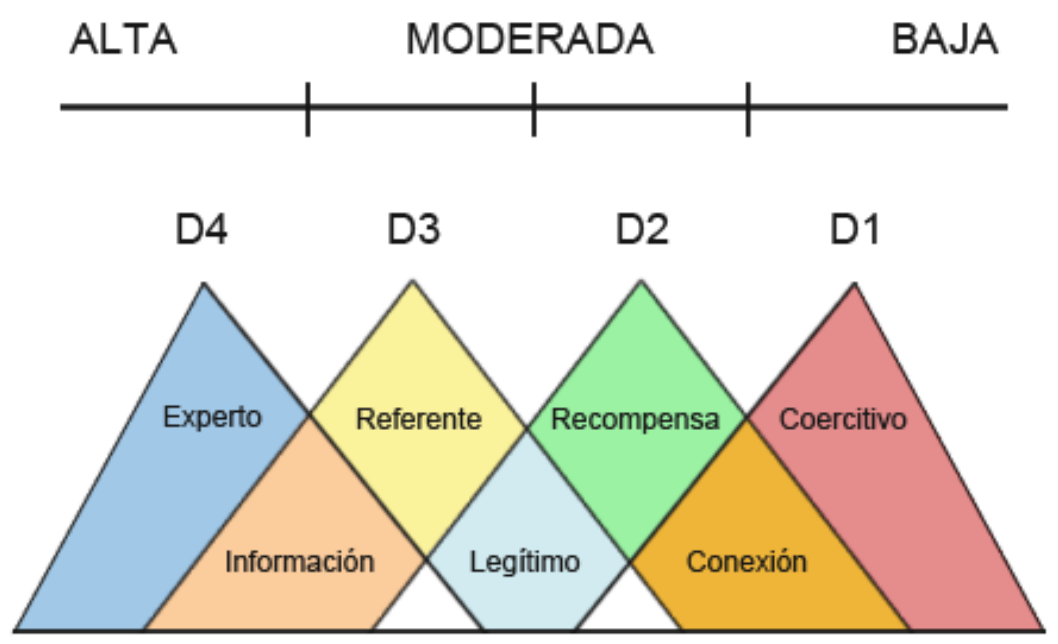

Figura 9: Bases de poder descritas para distintos niveles de desarrollo. Teoría del Liderazgo Situacional I. Fuente: Hersey y Blanchard (1982).

En el Liderazgo Situacional I se consideró un acierto (Hersey y Blanchard, 1982a) la inclusión no solo del poder sino también de la percepción del poder, ya que "es la percepción de los otros acerca del poder del líder lo que da al líder la capacidad de inducir la obediencia o influir en el comportamiento" (p. 186).

Tratamos ahora a continuación el quinto elemento abordado en la revisión de los aspectos teóricos del modelo, los instrumentos que ha utilizado.

Inicialmente Hersey y Blanchard (1974) desarrollaron el LASI, Leader Adaptability and Style Inventory, que en 1977 pasó a denominarse LEAD, Leader Effectiveness And Adaptability Description (1977). Este instrumento se 
diseñó para evaluar la percepción del comportamiento del líder, especialmente respecto al estilo del líder, el rango de estilos, y la adaptabilidad del estilo (Sánchez y Rodríguez, 2010).

Se trata de una herramienta que presenta 12 situaciones empresariales en las que el líder debe escoger una de las cuatro posibles soluciones que se presentan. Este instrumento tiene dos versiones, una para ser contestada por el líder y otra para que otras personas (superiores, iguales o colaboradores) determinen esos mismos valores sobre el estilo del líder. Hemos entendido que recoger las opiniones de las personas cercanas al líder refuerza la validez de los resultados alcanzados en el diagnóstico.

La herramienta también se ha acompañado de una escala de madurez, que debe contestar el líder para determinar el nivel de madurez de cada colaborador y el nivel de desarrollo exigido para cada tarea u objetivo concreto de su trabajo. Es un instrumento que consta de ocho escalas y mide las dos dimensiones que integran el nivel de desarrollo del colaborador.

Además, a las dos herramientas anteriores se les ha acompañado del perfil de percepción del poder. Se trata de un instrumento de 21 pares de afirmaciones de elección forzosa que describen cada una de las siete bases de poder y qué recogen las razones por las que los colaboradores hacen lo que su líder les sugiere o quiere que hagan. De este instrumento se han desarrollado dos versiones según 
sea el propio líder u otras personas (superiores, iguales o colaboradores) quienes contesten.

La revisión de la Teoría Situacional (Blanchard, Hambleton, Zigarmi y Forsyth, 1982), que se inició con un cambio en la forma de pensar de Blanchard y sus colegas, condujo a la creación de un instrumento llamado LBA (Leader Behavior Analysis) que poco tiempo después derivó en la herramienta LBA II.

Este instrumento ha ampliado el número de situaciones empresariales contempladas respecto al LEAD, de 12 se han pasado a 20, manteniéndose el formato de cuatro posibles opciones de respuesta en cada situación planteada. En cada caso, el líder debe escoger la que considere más apropiada.

El cuestionario ha sido reforzado con otra herramienta opcional, LBA II - other, dirigida a los colaboradores y superiores del líder (Blanchar, Zigarmi y Zigarmi, 1985).

El LBA II permite conocer la flexibilidad y la efectividad en el ejercicio del liderazgo. La flexibilidad es entendida como la capacidad del líder para utilizar los cuatro estilos de liderazgo específicos que la Teoría Situacional II ha planteado en las situaciones laborales que describe. Y la efectividad hace referencia a la capacidad del líder para adoptar el estilo de liderazgo más idóneo en cada situación, tomando en consideración la competencia y el compromiso que son necesarios en los colaboradores para realizar adecuadamente las tareas implicadas en cada caso. 
Esta efectividad, según el grado de adecuación del estilo de liderazgo seleccionado a la competencia y al compromiso que requiere la situación, se considera excelente, buena, justa o pobre.

Se han realizado estudios sobre la validez (Zigarmi, Edeburn \& Blanchard, 1991) del instrumento. También se han realizado análisis de la fiabilidad del LBA II que han mostrado unos coeficientes de fiabilidad que van de 0.54 a 0.86, con un valor medio de 0.74 (Zigarmi, Edeburn \& Blanchard, 1995).

Aunque los investigadores habían encontrado problemas de fiabilidad con el LEAD y su escala producía resultados que generaban desconfianza, el uso del test desde mediados de los años 80 del siglo XX ha mostrado una consistencia interna de 0.75 (Donovan, 2003).

Además del origen del modelo, de sus influencias y de su enfoque teórico, también hemos recogido en un bloque final las distintas críticas que ha recibido. Para facilitar la revisión de las conclusiones alcanzadas, hemos tratado en primer lugar las críticas más favorables, a continuación las más desfavorables y finalmente hemos incorporado unas consideraciones finales sobre las críticas al modelo

Siguiendo a García (2006), algunas investigaciones han confirmado la validez del modelo de Liderazgo Situacional, especialmente en determinadas situaciones de formación y de educación de los directivos (Hersey, Angelini y 
Carakushansky, 1982). Otros trabajos también han aprobado la validez del modelo, al menos de forma parcial (Vecchio, 1987; Fernández y Vecchio, 1997). Y otras investigaciones también han verificado, en términos generales, el modelo de la Teoría Situacional aunque no han llegado a establecer una relación causal definitiva entre las principales variables implicadas (Hambleton y Gumpert, 1982; Norris y Vecchio, 1992).

También se ha defendido la gran aplicabilidad del modelo de la Teoría del Liderazgo Situacional (Menárguez, 1999) y se ha recomendado su utilización en el estudio del liderazgo dentro de la Administración Pública (Sánchez, 1996), concretamente en medios sanitarios hospitalarios (Myrick, Bushardt y Cadenhead, 1988; Adams, 1990). En este sentido Galvao, Trevizan, Sawada y Mendes (1997) han indicado que este modelo resulta ideal en el ámbito de la enfermería.

Sin embargo también existen otros trabajos que no han mostrado datos favorables al modelo propuesto por la Teoría Situacional.

Sus indicaciones han servido de guía, en algunos casos, para orientar las sucesivas revisiones que se han realizado del modelo.

Hemos tratado en primer lugar las críticas relacionadas con aspectos teóricos del modelo $\mathrm{y}$, a continuación, las críticas que se han centrado en la efectividad de la propuesta. 
Las críticas teóricas que ha recibido el modelo han hecho especial incidencia en el concepto "madurez", en principios que el modelo no satisface y en la relación que establecen las variables que contempla.

Se han realizado críticas centradas en la fuerte ambigüedad del concepto de madurez de los colaboradores, término que pasó a denominarse "desarrollo" en la Teoría Situacional II.

Generó confusión el paso sin justificar por los autores (Sánchez y Rodríguez, 2010) de la consideración de la variable "madurez" como un constructo unidimensional (Hersey y Blanchard, 1977) a un constructo compuesto por dos componentes separados: madurez psicológica 0 motivación y madurez para el puesto o capacidad (Hersey y Blanchard, 1982).

Además, en la presentación de la madurez en 1982 no se explicó adecuadamente la evolución de la madurez entre los niveles intermedios en la Teoría del Liderazgo Situacional. Es coherente que la madurez baja implique baja capacidad y baja motivación, y también es coherente que la madurez alta implique alta capacidad y alta motivación, pero no quedó suficientemente clara la evolución de la madurez en los dos momentos intermedios. Nicholls (1985) indicó que la diferente evolución teórica de los componentes de la madurez en la Teoría Situacional invalidaba este concepto porque dicha evolución no estaba justificada. Nicholls (1985) entendía que la Teoría de 
Liderazgo Situacional nunca explicaba por qué la motivación aparecía, desaparecía y reaparecía conforme aumentaba el nivel de madurez.

En este sentido Blank, Weitzel y Green (1990) corroboraron que la madurez de los propios colaboradores no conducía a moderar la relación entre las conductas de dirección y las de apoyo.

De todos modos es necesario tener presente que dos aspectos revisados en la Teoría de Liderazgo Situacional II han sido el establecimiento del grado de desarrollo de cada uno de los dos componentes de la madurez y la evolución establecida entre los mismos.

El modelo también ha recibido críticas relacionadas con ciertos principios que la teoría no satisface. Nicholls (1985) ha propuesto un nuevo enfoque para el modelo en el que se deberían satisfacer tres principios que no se cumplían en el modelo propuesto por la Teoría Situacional:

\begin{tabular}{|c|c|}
\hline Principio & Explicación \\
\hline $\begin{array}{l}\text { 1. Principio de } \\
\text { consistencia }\end{array}$ & $\begin{array}{l}\text { Es necesaria una conexión entre el estilo del líder en la } \\
\text { supervisión de una tarea específica y el grado de } \\
\text { competencia y compromiso de los colaboradores que la } \\
\text { desarrollan. }\end{array}$ \\
\hline $\begin{array}{l}\text { 2. Principio de } \\
\text { continuidad }\end{array}$ & $\begin{array}{l}\text { La evolución del nivel de desarrollo en los colaboradores } \\
\text { no debe producir saltos entre los niveles de competencia y } \\
\text { de compromiso. }\end{array}$ \\
\hline $\begin{array}{l}\text { 3. Principio de } \\
\text { conformidad }\end{array}$ & $\begin{array}{l}\text { Se debe satisfacer la siguiente correspondencia: "si un } \\
\text { colaborador con bajo nivel de competencia requiere un } \\
\text { estilo de alta dirección, un colaborador con bajo nivel de } \\
\text { compromiso requeriría un estilo de alta relación". }\end{array}$ \\
\hline
\end{tabular}

Cuadro 32: Principios no satisfechos por la Teoría del Liderazgo Situacional. Fuente: Nicholls (1985). 
Respecto al primero de los principios a los que hace alusión Nicholls, se ha denunciado que la curva con forma de campana que relaciona ambos conceptos da un cierto aire de validez matemática a la conexión arbitraria entre el nivel de desarrollo y los cuadrantes de matriz asociados a cada estilo de liderazgo. Algo que no está justificado científicamente.

En este sentido Graeff (1983) ya había denunciado que la propuesta de relación curvilínea entre iniciación de estructura, consideración y otras variables, heredada de Korman (1966), ha sido interpretada de forma errónea por Hersey y Blanchard, ya que la aportación de Korman no implica que las dos dimensiones del comportamiento del líder interactúen con el desarrollo del colaborador.

En relación con el segundo de los principios a los que hace referencia Nicholls (1985), el principio de continuidad, el investigador indica que el modelo no justifica por qué el avance del estilo persuasivo, que implica alta tarea y alta relación, al estilo de apoyo, que implica alta tarea y baja relación, suponen que en un caso el líder deba emplear alta relación con personas motivadas y en el otro deba emplear también alta relación con personas poco motivada. Nicholls ha entendido que esta incongruencia puede estar asociada a los saltos entre los niveles de competencia y compromiso sustentados por el modelo.

En cuanto al tercero de los principios a los que alude Nicholls (1985), el principio de conformidad, el autor indica que el modelo propuesto por la Teoría del Liderazgo 
Situacional prescribe el estilo directivo, que implica alta tarea, como el apropiado para personas con baja capacidad. Sin embargo no plantea la utilización de un estilo de alta relación para personas con baja motivación, incongruencia que se producía en el primer nivel de desarrollo del líder en la propuesta de la Teoría Situacional.

Nicholls (1986a, 1986b) aportó un modelo que cumple con los principios indicados. Su propuesta sugiere que un líder debe iniciar el ejercicio de su rol con un estilo de alta tarea y alta relación ante una persona o grupo con poca capacidad y poca motivación. Desde esta situación el líder debe avanzar, de forma progresiva, hacia el estilo de baja tarea y baja relación. Si el grupo o la persona desarrolla primero la motivación y luego la capacidad, el líder debe concentrarse en la tarea. Pero si el grupo o la persona desarrollan primero la capacidad y luego la motivación, el líder debe centrarse en la capacidad.

La modificación de la evolución de los dos componentes del "desarrollo" en la propuesta actual de la Teoría de Liderazgo Situacional II ha transformado las relaciones entre esta variable y los estilos de liderazgo (Blanchard, 2001). En esta versión de la teoría la justificación de la evolución del desarrollo tiene una fundamentación teórica más rigurosa y se puede considerar que las demandas de Nicholls, relacionadas con los principios de conformidad y continuidad, se han satisfecho. 
También se ha denunciado que la Teoría del Liderazgo Situacional I y II (Graeff, 1997, p.164) carecían de un "buen fundamento teórico en la relación hipotética entre las variables".

Sobre esta valoración Hersey y Blanchard (1988a, 1993) y Hersey, Blanchard y Johnson (1996) han indicado que el modelo del liderazgo situacional no es una teoría, ya que en realidad se trata de "un modelo práctico que puede ser usado por gerentes, personal de ventas, profesores 0 padres".

Hemos entendido que la respuesta aportada por los autores del modelo no satisface la crítica planteada. Además, atender adecuadamente esta objeción permitiría aportar más solidez al modelo y favorecer su mejora.

También se han realizado críticas relacionadas con efectividad de la Teoría del Liderazgo Situacional. Vecchio (1987), al intentar probar la efectividad del líder, indicó que los resultados del modelo solo se mantenían en relación con cierto tipo de colaboradores. Asimismo Sánchez (2000), en el estudio que realizó para evaluar el modelo entre personas con y sin función de mando, manifestó no haber encontrado diferencias significativas en los estilos de dirección y en la efectividad al comparar los mandos y los subordinados.

Además las investigaciones centradas en verificar la adecuación de determinados estilos de liderazgo a las bases de poder a las que teóricamente estaban asociadas en la 
Teoría del Liderazgo Situacional, no han confirmado el supuesto que sustenta la relación entre dichas bases de poder con los niveles de desarrollo y los estilos de liderazgo a los que están asociados (García y Sánchez, 2005). En ambos casos se corroboró la relación entre el estilo directivo, asociado al nivel de desarrollo denominado "el principiante entusiasmado" (D1), con la base de poder coercitivo y la relación entre el estilo de apoyo, asociado al nivel de desarrollo llamado "el capaz pero cauto" (D2), con la base de poder referente, pero en el resto de casos no se obtuvieron los resultados esperados.

Como consideración final sobre las críticas recibidas por el modelo hemos incorporado la opinión de Vroom y Jago (1990, p. 63) porque entendemos que refleja el gran valor del modelo y una deficiencia que comparten varios críticos. Para estos autores la escasez de investigaciones que han respaldado la propuesta la limitan aunque, por otra parte, los investigadores han reconocido el gran atractivo del modelo, su difusión entre los directivos (Vecchio, 1987; Sánchez y González, 1998; De Miguel, Fernández y Rico, 1997) y su gran aplicabilidad (Menárguez, 1999).

Hemos considerado que sería deseable que el modelo propuesto por la Teoría del Liderazgo Situacional II fuera más utilizado en investigaciones en el ámbito español. De este modo sería posible disponer de más datos contextualizados para verificar la validez y la fiabilidad de 
una aproximación al liderazgo con éxito en el ámbito empresarial.

En esta investigación hemos seleccionado el modelo propuesto por la Teoría Situacional II para analizar el estilo de liderazgo de los líderes.

Un aspecto que ha motivado esta elección se encuentra en que el modelo contemple la existencia de estilos de liderazgo muy respaldados en la literatura científica sobre el liderazgo. Este aspecto ha permitido valorar la importancia de cada estilo de liderazgo en relación con el resto de variables contempladas en este estudio y, en especial medida, con la actitud del líder ante la responsabilidad social.

Además el modelo teórico ha planteado la adecuación del estilo de liderazgo al nivel de capacidad y motivación de los colaboradores. Al tratarse de una investigación en la que se ha estudiado la responsabilidad social, hemos considerado relevante que estuvieran presentes los aspectos motivaciones del colaborador, de algún modo, en el análisis de la eficacia del liderazgo ejercido en las organizaciones.

Otra cuestión que ha influido en la elección del modelo es el hecho de que, hasta el momento, haya sido muy respetado en el ámbito organizacional y que sea en este contexto en el que hemos realizado la investigación. 
La Teoría del Camino-Meta fue desarrollada por House (1971) a partir de las propuestas de Georgopoulos, Mahoney y Jones (1957) y de Evans (1970). Y fue posteriormente revisada por House y Dessler (1974) y por House y Mitchell (1974).

Su planteamiento se basó en el supuesto de que los líderes son capaces de motivar a sus seguidores para que rindan mejor y para que aumenten su grado de satisfacción. Un aspecto clave para conseguir este propósito es que logren articular con mucha claridad los objetivos y el modo de alcanzarlos (Giffing, 2011).

El modelo, muy influido por los planteamientos de la escuela de Ohio, estableció que existían dos posibles vías de actuación para alcanzar los objetivos: incrementar la valoración de las recompensas de los colaboradores o clarificar el camino a seguir para alcanzarlas (Giffing, 2011). Para escoger la vía adecuada en el establecimiento de los objetivos, el modelo planteó la necesidad de analizar las características de los colaboradores y el ambiente laboral (García y Sánchez, 2005).

A continuación hemos incorporado la figura 38, “Aspectos situacionales de análisis en la Teoría del CaminoMeta", con las características de los colaboradores que contempla el modelo y con los aspectos críticos que considera relevantes en el ambiente laboral: 


\begin{tabular}{|l|l|}
\multicolumn{1}{|c|}{ Colaboradores } & \multicolumn{1}{c|}{ Ambiente laboral } \\
\hline $\begin{array}{l}\text { Confianza en sus } \\
\text { propias capacidades }\end{array}$ & $\begin{array}{l}\text { Grado en el que las tareas están } \\
\text { estructuradas o son mecánicas }\end{array}$ \\
\hline $\begin{array}{l}\text { Locus de control y } \\
\text { necesidades de estima }\end{array}$ & $\begin{array}{l}\text { Grado de formalización que la organización } \\
\text { impone por medio de reglas }\end{array}$ \\
\hline Afiliación & $\begin{array}{l}\text { Procedimientos y descripciones de los } \\
\text { puestos de trabajo }\end{array}$ \\
\hline Autonomía & $\begin{array}{l}\text { Relaciones que existen entre los } \\
\text { colaboradores del grupo }\end{array}$ \\
\hline Responsabilidad & \\
\hline
\end{tabular}

Cuadro 33: Aspectos situacionales de análisis en la Teoría del Camino-Meta.

Fuente: García y Sánchez (2005).

De acuerdo con este planteamiento, el diagnóstico previo y el establecimiento de la vía de actuación más adecuada para alcanzar los objetivos tienen gran influencia en la elección del estilo de liderazgo más idóneo (Castro y Nader, 2004).

En este sentido el modelo plantea que las posibles conductas que un líder puede desarrollar se agrupan en cuatro estilos diferenciados: estilo de apoyo, estilo directivo, estilo participativo y estilo orientado a metas (García y Sánchez, 2005).

El estilo de apoyo se caracteriza porque el líder manifiesta preocupación por el bienestar y las necesidades de los subordinados, es amable y accesible, es considerado, crea un clima amistoso y trata a sus colaboradores como iguales.

El estilo directivo es el que desarrolla el líder que indica a sus colaboradores que se espera que hagan, les guía, les indica sus niveles de rendimiento y los plazos de 
ejecución, establece sus objetivos y les pide que sigan las normas y los reglamentos establecidos.

El estilo participativo es el que aplica el líder cuando consulta con sus colaboradores las decisiones sobre sus actividades de trabajo, sus plazos de ejecución y sus objetivos del trabajo; persigue pedirles su opinión y sus sugerencias, les permite su participación en la toma de decisiones y tiene en cuenta sus puntos de vista.

El estilo orientado a metas está representado por comportamientos de liderazgo en los que se tiende a establecer objetivos que supongan un reto para buscar la mejora en el rendimiento de los colaboradores, se hace hincapié en conseguir un rendimiento excelente, y se muestra confianza en que los colaboradores serán capaces de alcanzar altos niveles de rendimiento.

House y Mitchell (1974) plantearon que un mismo líder podía utilizar uno, algunos o todos los estilos que la teoría propone de acuerdo a cada situación. La efectividad de los líderes vendría determinada por su habilidad para adaptar su estilo a la situación o a las necesidades de sus colaboradores.

Hemos considerado que el planteamiento de la Teoría del Camino-Meta guarda mucha similitud con el planteamiento de la Teoría del Liderazgo Situacional en los estilos de liderazgo que propone (que presentan cierto paralelismo con los planteados en el modelo situacional), en los ejes que articulan los estilos de liderazgo que expresa (dirección y consulta) y en su comprensión de la efectividad 
en el ejercicio del liderazgo (centrada en la adecuación del estilo a la situación o las necesidades de los colaboradores).

La teoría ha recibido muchas críticas por considerarse una teoría incompleta, ya que no describe todas las situaciones que pueden darse. De todos modos la investigación desarrollada apoya la propuesta de que los líderes eficaces motivan a los empleados a mejorar su rendimiento clarificando la forma de conseguir sus recompensas o actuando para incrementarlas (Sánchez y Alonso del Amo, 2005).

Wooford y Liska (1993), en un metaanálisis que ha compilado 120 investigaciones derivadas de la Teoría del Camino Meta, encontraron que las características del trabajo influían decisivamente en los estilos del liderazgo ejercidos y en el rendimiento de los colaboradores. De acuerdo a los estudios, algunas de las características situacionales que estaban especialmente implicadas en el rendimiento de los colaboradores eran el grado de autonomía y la estructura de la tarea.

\subsubsection{Enfoques centrados en los seguidores}

Los enfoques centrados en los seguidores se han articulado a partir de la Teoría del Procesamiento de la Información (Lord, Foti y De Vader, 1984) y de las teorías implícitas asumidas por líderes y colaboradores, contemplando, al mismo tiempo, la influencia del contexto en el que estos procesos se desarrollan. 
En el procesamiento de la información que determina los rasgos idóneos del liderazgo, las Teorías Implícitas del Liderazgo (Lord, 1985; Lord, Foti y De Vader, 1984; Lord, Foti y Phillips, 1982; Lord y Maher, 1991; Phillips, 1984; Schyns y Meindl, 2005) han tenido una especial relevancia, ya que representan los esquemas cognitivos que definen los rasgos y los comportamientos que los seguidores esperan de los líderes (Kenney, Schwartz-Kenney, \& Blascovich, 1996; Lord \& Maher, 1991; Weick, 1995).

A continuación se han indicado algunas de las características esenciales de los aspectos teóricos fundamentales de las Teorías Implícitas del Liderazgo, mencionando en algunos casos investigaciones asociadas.

Un aspecto representativo de estos planteamientos es que la formación de los esquemas cognitivos y de los comportamientos esperados en la mente de las personas se produce a partir de procesos de socialización y de experiencias pasadas con líderes, en los que los colaboradores desarrollaron asunciones sobre qué rasgos y habilidades caracterizaban a un líder ideal en un ámbito específico. Estas estructuras cognitivas o esquemas, se almacenan en la memoria y se activan cuando los colaboradores interactúan con una persona que ocupa una posición de liderazgo para definir sus atributos y los comportamientos que esperan (Kenney, Schwartz-Kenney y Blascovich, 1996): 
Otro rasgo de estas teorías es que las estructuras cognitivas, una vez formadas, persisten en el tiempo moldeando las percepciones, las interpretaciones y el comportamiento de los integrantes en una organización determinada (Jelinek, Smircich y Hirsch, 1983).

Además estos esquemas pueden no estar relacionados directamente con la realidad, ya que responden a una visión de la misma construida por el colaborador socialmente (Gioia, Thomas, Clark \& Chittipeddi, 1994).

Otro aspecto característico de las propuestas implícitas es que las representaciones mentales configuran lo que fue denominado por Phillips (1984) como prototipo, es decir, una concepción abstracta de la persona más representativa o de las características más ampliamente compartidas de una categoría cognitiva dada. En este sentido hemos considerado interesante destacar un aspecto por su posible relación con conductas más centradas en el desarrollo personal de los colaboradores o en el progreso social. En algunos estudios transculturales diseñados para describir las concepciones implícitas de los líderes efectivos concluyeron se establecieron seis conductas esperadas por los colaboradores que se indican en el cuadro 34 (Hanges, 2004; Hanges y Dickson, 2004): 


\begin{tabular}{|c|} 
Conductas de liderazgo esperadas \\
por los colaboradores en las Teorías Implícitas \\
\hline Liderazgo carismático o basado en valores. \\
\hline Orientado hacia sí mismo. \\
\hline Liderazgo con orientación humana. \\
\hline Orientado hacia el grupo. \\
\hline Liderazgo participativo. \\
\hline Liderazgo autónomo. \\
\hline
\end{tabular}

Cuadro 34: Conductas de liderazgo esperadas por los colaboradores en las Teorías Implícitas. Fuente: Hanges (2004) y Hanges y Dickson (2004).

Algunas investigaciones posteriores (Castro, 2006) han mostrado dificultad a la hora de confirmar las dimensiones "liderazgo con orientación humana" y “liderazgo autónomo". Resultado que puede explicarse porque el objetivo de los estudios transculturales ha sido comparar sociedades y no organizaciones.

Otro rasgo representativo de las teorías implícitas es su clasificación de los esquemas mentales en atributos "prototípicos o positivos" y "antiprototípicos o negativos" (Lord, Foti y De Vader, 1984).

También es destacable de estos planteamientos implícitos que se hayan centrado en el análisis de los procesos preceptúales subyacentes al liderazgo y no en la efectividad real del mismo (Lord y Allinger, 1995). De acuerdo a esta aproximación, la esencia del liderazgo descansaría más en el propio colaborador que en los rasgos individuales del líder (Lord y Maher, 1991). 
El enfoque también ha presentado una tipología en los colaboradores. De acuerdo a la Teoría del Procesamiento de la Información, es factible encontrar diferencias entre colaboradores novatos y expertos. Los primeros suelen categorizar a los líderes basándose en un ejemplo prototípico, como puede ser un líder famoso o conocido. Mientras que el proceso que siguen los colaboradores expertos es distinto. A medida que van tomando contacto con líderes reales, su estructura representacional se enriquece y acceden a un proceso más abstracto, que se corresponde con el que caracteriza a los expertos en un ámbito del conocimiento (Brewer, 1988; Rosch, 1978).

En estas teorías también ha recibido una especial consideración la cultura porque discrimina las percepciones individuales que los colaboradores atribuyen a un líder efectivo. Mientras en las culturas "transaccionales" predomina especialmente un tipo de líder orientado hacia el cumplimiento de las normas y con un estilo más directivo, en las culturas "transformacionales" el prototipo de líder es más participativo, más democrático y con una elevada preocupación por el colaborador (Castro y Lupano, 2005).

También se ha indicado que el contexto en el que el liderazgo se desarrolla puede alterar los atributos o comportamientos esperados de un líder por parte de sus seguidores (Castro y Lupano, 2005).

Por otra parte el modelo ha sostenido que el propio líder también cuenta con un repertorio de representaciones mentales sobre los comportamientos que 
espera de los colaboradores que, a su vez, moldean la relación que establece con ellos (Dweck, Chiu y Hong, 1995; Gervey, Chiu, Hong y Dweck, 1999).

Aunque las Teorías Implícitas del Liderazgo han adquirido mucha relevancia en el final del siglo $X X$ y comienzos del XXI, su creciente desarrollo no se ha correspondido con una cantidad muy representativa de trabajos que respalden el planteamiento general de este constructo (Castro y Fernández, 2006). Y esto a pesar del gran atractivo que, a priori, representan en el estudio de la eficacia en el ejercicio del liderazgo, ya que permiten conocer aspectos relevantes que utilizan los colaboradores en su establecimiento de los rasgos prototípicos del líder.

De todos modos las Teorías Implícitas del Liderazgo son un buen marco de referencia para evitar en el análisis del ejercicio del liderazgo sesgos perceptivos y atributivos, o procesos de categorización incompletos o inadecuados (Sánchez, 2002).

Además, las aportaciones teóricas de las Teorías Implícitas del Liderazgo favorecen la detección de desviaciones en la medida del liderazgo y el desarrollo de nuevas teorías que expliquen cómo los colaboradores perciben el modo en que los líderes gestionan el significado de los acontecimientos (Avolio, Sosik, Jung y Berson, 2003). 


\subsubsection{Enfoques que toman en consideración la interacción líder-seguidores}

En este enfoque las teorías han puesto el énfasis en el intercambio que persigue una satisfacción mutua de objetivos y necesidades, tanto por parte del líder como por parte de los seguidores.

Dentro este enfoque, la teoría más relevante es la Teoría de Intercambio Líder-Miembro también conocida como Leader-Member Exchange (LMX) e introducida originalmente como Modelo de Enlace Diádico Vertical o Vertical Dyad Linkage Model (Dansereau, Graen y Haga, 1975).

La base fundamental de la Teoría de Intercambio Líder-Miembro es que los líderes desarrollan relaciones de intercambio exclusivas con cada colaborador. En estas relaciones continuamente se negocia el rol del colaborador y la propia calidad de la relación que se establece (Dienesch \& Liden, 1986; Gerstner \& Day, 1997; Graen y Scandura, 1987; Graen y Uhl-Bien, 1995).

Las diferentes relaciones que ambas partes establecen se pueden integrar dentro de dos posibilidades. Por una parte en una relación de intercambio de alta calidad con el 
líder, que se caracteriza por que tanto líder como el colaborador tienen confianza, respeto mutuo y simpatía (Dansereau, Graen y Haga, 1975). Por otra en una relación en la que los colaboradores no son considerados dentro del círculo más cercano del líder pero en la que ellos mismos tampoco se consideran a sí mismos como pertenecientes a él (Graen y Uhl-Bien, 1995).

De acuerdo con la teoría, el proceso a través del cual se desarrolla la relación de intercambio se inicia a través de una oferta inicial del líder, que es correspondida por el seguidor. La relación continúa con una serie de contribuciones recíprocas: acciones positivas que ambas partes desarrollan para fortalecer la relación a través de la satisfacción de las necesidades de la otra parte. El límite hasta el que cada una de las partes está dispuesta a satisfacer las necesidades de la otra se alcanza cuando ambas partes perciben un equilibrio en la relación de intercambio. Hasta entonces la relación no se estabilizará y podrá bien deteriorarse, situación que se produce cuando una parte percibe que la otra contribuye en menor medida $y$, en consecuencia, reduce su nivel de contribución, o bien prosperar, momento en el que una parte percibe que la otra contribuye en mayor grado y decide aumentar su propia aportación (Dienesch \& Liden, 1986; Gertner y Day, 1997; Graen, 2003; Graen y Scandura, 1987; Graen y Schiemann, 1978; Graen y Uhl-Bien, 1995). 
El resultado que se alcanza a través de la relación de intercambio puede ser de dos tipos:

\begin{tabular}{|l|l|}
\multicolumn{1}{|c|}{$\begin{array}{c}\text { Relaciones satisfactorias } \\
\text { y estables }\end{array}$} & $\begin{array}{c}\text { Relaciones insatisfactorias } \\
\text { e inestables }\end{array}$ \\
\begin{tabular}{|l|l|} 
Una parte percibe las \\
contribuciones como similares \\
(Buunk, Doosje, Jans \& Hopstaken, \\
1993).
\end{tabular} & $\begin{array}{l}\text { Las partes advierten una carencia } \\
\text { de reciprocidad, que se } \\
\text { experimenta a través de } \\
\text { sentimientos negativos (Walster, } \\
\text { Walster \& Berscheid, 1978). }\end{array}$ \\
\hline $\begin{array}{l}\text { Una parte percibe que la otra } \\
\text { parte contribuye más (Buunk, } \\
\text { Doosje, Jans \& Hopstaken, 1993). }\end{array}$ & $\begin{array}{l}\text { Las partes consideran que han } \\
\text { contribuido mucho a la relación } \\
\text { (Walster, Walster \& Berscheid, 1978). }\end{array}$ \\
\hline
\end{tabular}

Cuadro 35: Claves para alcanzar un resultado satisfactorio o insatisfactorio en la relación de acuerdo a la Teoría del Intercambio Líder-Miembro. Fuente: elaboración propia.

Las investigaciones desarrolladas en diferentes países y culturas (Anseel y Lievens, 2007; Erdogan, Liden y Kraimer, 2006; Schyns, Paul, Mohr y Blank, 2005) han mostrado que cuando la relación de intercambio es de alta calidad los colaboradores trabajan más duro (Basu \& Green, 1997; Duchon, Green \& Taber; 1986), rinden mejor (Graen, Novak, y Sommerkamp, 1982; Mayfield y Mayfield, 1998), experimentan más satisfacción con el líder (Graen y Cashman, 1975; Scandura y Graen, 1984) y están menos predispuestos a abandonar su equipo de trabajo o su organización (Scandura y Graen, 1984; Vecchio \& Norris, 1996).

La versión más reciente de la teoría ha sugerido que los líderes efectivos tratan a todos los colaboradores del mismo modo y consiguen que cada colaborador perciba que 
es un miembro importante del equipo, y no alguien de segundo nivel (Sánchez y Alonso del Amo, 2005).

\subsubsection{Nuevas teorías sobre liderazgo}

A partir de la década de los 80 surgió un renovado interés por el liderazgo. Hemos agrupado las principales teorías revisadas que han surgido desde entonces en seis grupos: liderazgo carismático, liderazgo transformacional, enfoque de la identidad social, liderazgo integrador, liderazgo y nuevas tecnologías, y liderazgo y desarrollo humano.

Dentro del grupo “liderazgo carismático" se han integrado las teorías que han compartido la visión del carisma como el resultado de las percepciones de los seguidores.

En estos modelos, las percepciones están influenciadas por los rasgos y conductas del líder, el contexto de la situación y las necesidades colectivas e individuales de los seguidores.

Dentro de este enfoque hemos destacado dos teorías: la Teoría del Liderazgo Carismático y la Teoría Atribucional del Carisma.

La Teoría del Liderazgo Carismático fue formulada inicialmente por House (1977), quien identificó cómo se comportan los líderes carismáticos, en qué se diferencian de 
otras personas y las condiciones en las que es más probable que surjan líderes carismáticos.

House planteó que el líder carismático presenta características que pueden agruparse en tres categorías: personales, comportamentales y situacionales (Sánchez y Alonso del Amo, 2005).

Los rasgos personales más destacados del líder carismático son poseer algunos niveles de autoconfianza, dominio sobre los demás, fuerte convicción en la rectitud moral de sus creencias y una alta necesidad de influir en los otros.

El comportamiento del líder carismático se identifica por su capacidad para modelar su rol a través de su compromiso público con valores y creencias importantes, su capacidad para construir una imagen que favorezca en los colaboradores la creación de su percepción como dotados, su capacidad para articular metas a través de una visión o misión compartida, su capacidad para demostrar altas expectativas en sus colaboradores y confianza en su habilidad para lograr e inducir estados emocionales y cognitivos consistentes con las conductas necesarias que faciliten la consecución de la meta.

Y las condiciones del contexto en las que es más favorable el liderazgo carismático son aquellas muy estresantes y las que fomentan la expresión de los objetivos en términos ideológicos.

Una nueva versión de esta teoría (Shamir, House y Arthur, 1993) intentó explicar los mecanismos psicológicos a 
través de los cuales los líderes carismáticos ejercen influencia.

El supuesto del que los autores partieron en la reformulación de la teoría es que los líderes carismáticos son capaces de lograr sus objetivos gracias a su habilidad para asociar el autoconcepto del colaborador con los objetivos y las experiencias colectivas relacionadas con las metas organizacionales. Este proceso de transformación se produce a través de cuatro vías: el cambio de las percepciones del colaborador acerca de la naturaleza de la labor que se ha de realizar, la capacidad para ofrecer una visión atractiva del futuro, la habilidad para desarrollar un profundo sentido de identidad colectiva entre los seguidores y el fomento de un sentimiento de autoeficacia tanto en el plano individual como colectivo (Molero, 2002).

La principal herramienta de la que dispone el líder para influir sobre el autoconcepto de sus colaboradores son los contenidos de su mensaje o visión, que suele hacer referencia a valores y justificaciones morales, la identidad e historia colectivas y a un proyecto de futuro consistente con dicha historia (Shamir, Arthur y House, 1994).

Se ha indicado que no es necesaria la existencia de una situación de crisis para que un líder carismático sea realmente eficaz, aunque este tipo de situaciones favorecen la aparición de un líder que sea capaz de interpretar la crisis y ofrecer estrategias creíbles para enfrentarse a ella de modo exitoso (Sánchez y Alonso del Amo, 2005). Se trata de escenarios propicios para que un líder se convierta en un 
símbolo capaz de evocar, con su visión, el modo en el que las personas que forman parte de un entorno social determinado otorguen significado y dirección a sus vidas (House y Shamir, 1993).

Hemos considerado que el contexto actual de la economía española es favorable para la emergencia de este tipo de comportamientos de liderazgo, especialmente en colectivos en los que las personas presenten autoconceptos con bajos niveles de confianza personal para afrontar el incierto futuro.

La Teoría Atribucional del Carisma fue formulada por Conger y Kanugo (1987) y se basa en el supuesto de que el carisma es un fenómeno atribucional que se realiza por los colaboradores a partir de las características y los comportamientos del líder, y la importancia que los colaboradores conceden a la visión o proyecto de futuro que formula el líder.

A continuación hemos incorporado el cuadro 36, "Características del líder que contribuyen a que se le atribuya carisma", con algunos de los rasgos personales y conductuales más relevantes que contribuyen a que los colaboradores atribuyan carisma al líder: 


\section{Características del líder que contribuyen}

a que se le atribuya carisma

- Capacidad para proponer una meta o visión que se aparte de lo habitualmente establecido.

- Capacidad para utilizar métodos no convencionales e innovadores a la hora de alcanzar dicha meta.

- Capacidad para evaluar de modo realista los recursos y las limitaciones del entorno para que se produzca un cambio.

- Capacidad para articular y transmitir la visión.

- Capacidad para dar ejemplo a los colaboradores asumiendo riesgos personales en el cumplimiento de la visión.

- Capacidad para mostrar sensibilidad hacia las necesidades de sus colaboradores.

Cuadro 36: Características del líder que contribuyen a que se le atribuya carisma. Fuente: Molero (2002).

De acuerdo con Conger (1999), el proceso a través del cual el líder carismático es capaz de conducir a la organización desde un estado actual a otro futuro se desarrolla a través de tres etapas.

En un primer momento los líderes carismáticos realizan una evaluación realista del entorno que les permite detectar cuáles son las necesidades no satisfechas tanto por parte de los seguidores, como por parte de la organización.

A continuación, y partiendo de los resultados de la evaluación, los líderes carismáticos formulan y transmiten un proyecto de futuro o visión que es capaz de ilusionar a los seguidores. Para que produzca la atribución de carisma es necesario que esta visión rompa el status quo establecido (para que ilusione a los seguidores y facilite la 
atribución de carisma) y sea percibida por los colaboradores como algo que puede lograrse (Conger y Kanungo, 1987).

Finalmente los líderes consiguen que los seguidores adquieran confianza en su visión y estén dispuestos a desarrollarla. Los recursos que el líder carismático utiliza para alcanzar este objetivo son su ejemplo y la asunción de riesgos y compromisos personales.

El modelo de Conger puede aplicarse perfectamente para explicar el cambio de la cultura organizacional, ya que el líder carismático primero formula una visión o proyecto de futuro que rompe con el status quo (la cultura preexistente) y, a continuación, consigue que los miembros de la organización asuman como propia dicha visión (Molero, 2002).

Algunos estudios realizados para verificar la Teoría Atribucional del Carisma se han traducido en un apoyo limitado a la misma (Howell y Higgins, 1990).

Hemos entendido que, en el ámbito de la responsabilidad social, esta teoría puede explicar el comportamiento de culturas organizacionales orientadas a favor de esta disciplina que han sido promovidas, en su origen, por un líder. Este sería el caso de un máximo responsable que revitalice su colectivo a través de una nueva visión que transforme, a través de un proyecto claro y alcanzable, un comportamiento organizacional reactivo en una actuación implicada en el progreso saludable de su entorno. 
El segundo grupo de teorías, las que hemos agrupado en la etiqueta "liderazgo transformacional", dan respuesta a planteamientos teóricos previos desarrollados con anterioridad a este enfoque. Estas propuestas defendían una concepción del liderazgo en las organizaciones como un proceso de intercambios dirigido a la satisfacción de los intereses propios. Este proceso fue denominado por Burns (1978) como liderazgo transaccional, en contraposición al liderazgo transformacional desarrollado por los líderes que animan a sus colaboradores a trascender sus propios intereses en beneficio de la misión organizacional, consiguiendo que los colaboradores alcancen unos niveles de rendimientos mayores de lo esperado.

Con el objetivo de diferenciar estos dos tipos de liderazgo, Bass (1985) realizó un estudio con 70 ejecutivos para verificar si existían líderes transformacionales. El análisis de la investigación derivó en la concreción de dos factores que caracterizan a los líderes transaccionales (recompensa contingente y gestión por excepción activa), un factor que caracteriza al liderazgo de evitación pasiva (laissez-faire) y tres factores que caracterizan a los líderes transformacionales: carisma, estimulación intelectual y consideración individualizada. El carisma implica que el líder provea a los colaboradores de un sentido de propósito que ilusione, sea un modelo en el rendimiento y la moral, y facilite la identificación de los colaboradores con la visión que comunica. La estimulación intelectual supone fomentar en los colaboradores el pensamiento crítico y la 
creatividad. Y la consideración individualizada implica que el líder comprenda las necesidades individuales de los seguidores y se comprometa a favorecer su desarrollo.

Posteriormente la mayoría de los autores que han revisado el modelo han denominado al factor "carisma" como "influencia idealizada" (Bass, 1998; Bass y Steidlmeier, 1999) y han introducido un cuarto factor adicional en el liderazgo transformacional, "motivación inspiradora" (Avolio y Bass, 1991; Bass, 1998; Sosik, Potosky y Jung, 2002), que hace referencia a la capacidad de los líderes transformacionales para generar entusiasmo, ánimo, optimismo y el comportamiento deseado a través de la comunicación, con fluidez y confianza, de una visión de futuro alcanzable, y la utilización de símbolos que orienten el esfuerzo de los colaboradores (Yukl, 2002).

Se han indicado diversos efectos asociados al ejercicio de este tipo de liderazgo. Uno de ellos es que estimula a iguales y colaboradores para que consideren los problemas desde nuevas perspectivas. Además, aspecto asociado al efecto indicado, permite que los colaboradores dispongan de margen de libertad para desafiar el status quo vigente (Avolio, Bass y Jung, 1999).

Por otra parte este estilo también favorece que los colaboradores tomen conciencia de la visión que se comunica (Avolio y Bass, 1991). En este sentido algunos estudios han demostrado que el liderazgo transformacional aumenta los niveles de identificación con la organización (Fiol, Harris y House, 1999). 
También se ha destacado que el liderazgo transformacional motiva a los colaboradores para que vayan más allá de sus propios intereses y tengan en cuenta las necesidades del grupo (Avolio y Bass, 1991). En este sentido algunos expertos han indicado este tipo de liderazgo favorece el aumento de los niveles de compromiso (Vallejo, 2007).

Además también se ha indicado que este estilo permite a los colaboradores aumentar su satisfacción (Fiol, Harris y House, 1999).

Para algunos autores el liderazgo transformacional ha sido considerado como carismático (de hecho muchos autores emplean indistintamente ambos términos) aunque para Bass el líder carismático no tiene por qué, necesariamente, ser transformacional.

A continuación hemos incluido el cuadro 37, "Características comunes y diferencias entre líderes carismáticos y transformacionales" que muestra las características comunes de ambos estilos, los rasgos específicos de los líderes carismáticos y los aspectos más característicos de los líderes transformacionales: 


\begin{tabular}{|c|c|c|}
\hline $\begin{array}{c}\text { Características } \\
\text { comunes de líderes } \\
\text { carismáticos y } \\
\text { transformacionales }\end{array}$ & $\begin{array}{l}\text { Características específicas } \\
\text { de líderes carismáticos }\end{array}$ & $\begin{array}{c}\text { Características } \\
\text { específicas de líderes } \\
\text { transformacionales }\end{array}$ \\
\hline $\begin{array}{l}\text { Habilidad en tareas } \\
\text { importantes para el } \\
\text { grupo. }\end{array}$ & $\begin{array}{l}\text { Ser percibido como } \\
\text { extraordinario por los } \\
\text { seguidores que son } \\
\text { dependientes del líder. }\end{array}$ & $\begin{array}{l}\text { Inspirar y facultar } \\
\text { (empowerment) a los } \\
\text { colaboradores. }\end{array}$ \\
\hline $\begin{array}{l}\text { Expresividad } \\
\text { emocional }\end{array}$ & $\begin{array}{l}\text { Pueden encontrarse en } \\
\text { cualquier organización. }\end{array}$ & $\begin{array}{l}\text { Es raro encontrar a los } \\
\text { líderes carismáticos en } \\
\text { una organización. }\end{array}$ \\
\hline Auto-confianza. & $\begin{array}{l}\text { Pueden encontrarse en } \\
\text { cualquier nivel } \\
\text { organizacional. }\end{array}$ & $\begin{array}{l}\text { Aparecen cuando la } \\
\text { autoridad formal ha } \\
\text { fracasado en la gestión } \\
\text { de una crisis. }\end{array}$ \\
\hline - Autodeterminación. & $\begin{array}{l}\text { Las respuestas que los } \\
\text { colaboradores dan al líder } \\
\text { carismático suelen } \\
\text { polarizarse, ser amado por } \\
\text { unos y odiado por otros. }\end{array}$ & $\begin{array}{l}\text { Las reacciones a los } \\
\text { líderes } \\
\text { transformacionales no } \\
\text { son extremas. }\end{array}$ \\
\hline $\begin{array}{l}\text { Convicción en las } \\
\text { creencias propias. }\end{array}$ & & \\
\hline
\end{tabular}

Cuadro 37: Características comunes y diferencias entre líderes carismáticos y transformacionales. Fuente: Bass (1990).

También hemos indicado algunas de las deficiencias formuladas al planteamiento transformacional. Se ha declarado que existe una alta intercorrelación entre las cuatro conductas transformacionales. Además también se ha indicado que la medición de procesos de influencia subyacentes relacionados con el liderazgo transformacional y transaccional es deficiente, ya que la herramienta que se utiliza para la obtención de la información, el Multifactor Leadeship Questionnaire (MLQ), solo mide conductas. Por otra parte también se ha denunciado el escaso interés por los aspectos emocionales (Sánchez y Alonso del Amo, 2005). Esta última crítica resulta un tanto sorprendente 
para un modelo que fomenta aspectos como la motivación o la inspiración para que los colaboradores mejoren su rendimiento pero, por otra parte, también parece indicar un camino de progreso para la teoría bastante definido.

El tercer grupo de propuestas contemporáneas se han agrupado en la denominación "enfoque de la identidad social". Las teorías de este planteamiento se han basado en el supuesto de que los procesos de liderazgo se fundamentan en el sentido de pertenencia compartido entre los colaboradores que forman parte de un grupo. Esta identidad social constituye la prototipicalidad del líder del grupo y juega, al mismo tiempo, un rol esencial en la eficacia del liderazgo (Hogg, 2001).

Dentro de esta perspectiva la teoría más relevante ha sido el Modelo de Identidad Social del Liderazgo Organizacional (SIMOL) (Van Knippenberg y Hogg, 2003), que sugiere que los integrantes más prototípicos de un grupo son los que tienen más probabilidades de emerger como líderes y ser percibidos como líderes eficaces por el resto de componentes del colectivo.

El Modelo de Identidad Social del Liderazgo Organizacional basa su propuesta en dos ideas centrales. Por una parte en que los integrantes del grupo están más abiertos a dejarse influenciar por los líderes prototípicos (Knippenberg, Lossie, \& Wilke, 1994). Además también defiende que los líderes que más se aproximan al prototipo del grupo es más probable que sean percibidos como más 
interesados en que el grupo alcance los intereses que tenga establecidos (Giessner, Sleebos, \& Van Knippenberg, 2003; Van Knippenberg \& Van Knippenberg, 2005).

A la hora de tratar la eficacia del líder, el modelo ha propuesto que los integrantes de un grupo tendrán más posibilidades de convertirse en líderes efectivos si presentan credenciales prototípicas (Moriano, Topa y Lévy, 2009). También ha planteado que es necesario un nivel mínimo de identificación de los seguidores con el grupo para que la prototipicalidad suponga eficacia en el rol de liderazgo. A partir de este mínimo, cuanto más se incremente el nivel de identificación grupal más se incrementarán los efectos derivados de la prototipicalidad del líder (Ullrich, Christ, Van Dick, 2009). El modelo también ha defendido que los líderes también pueden ser eficaces, independientemente de su prototipicalidad, cuando su motivación orientada al grupo se muestre por medio de actitudes, como el compromiso con el grupo, y conductas encaminadas al propio grupo, como arriesgarse en situaciones personales en beneficio del colectivo (Haslam et al., 2001).

Se han realizado diversas aportaciones que refuerzan la validez del modelo. En este sentido la percepción de mayor eficacia en aquellos líderes más prototípicos tiene un amplio apoyo empírico (Hogg \& Van Knippenberg, 2003; Van Knippenberg \& Hogg, 2003; Van Knippenberg, Van Knippenberg, De Cremer y Hogg, 2004). 
Además varios estudios también han dado apoyo a la hipótesis de interacción entre prototipicidad e identificación a la hora de predecir la eficacia del liderazgo (Fielding \& Hogg, 1997; Hains, Hogg, \& Duck, 1997; Hogg, Hains, \& Mason, 1998; Platow, Reid, \& Andrew, 1998; Platow \& Van Knippenberg, 2001).

Por otra parte, también se han desarrollado investigaciones (Moriano, Topa y Levy, 2009) que han verificado que la prototipicidad afecta de forma significativa a la eficacia percibida y al esfuerzo extra de los integrantes del grupo.

Hemos considerado que el modelo refuerza el rol del líder afín a la responsabilidad social en entornos cuyos colaboradores presenten predisposiciones favorables hacia ese ámbito. Entendemos que un rasgo de dichos contextos podría ser el contacto directo entre los integrantes de una organización y los grupos de interés afectados. De este modo es más probable que emerja una demanda de liderazgo próximo a la Responsabilidad Social Corporativa en los colaboradores.

El cuarto grupo de teorías presentadas son las que hemos denominado con la etiqueta "liderazgo integrador". Pese a la intensa investigación científica desarrollada en el campo del liderazgo desde mediados del siglo XX, en realidad se tiene poca certeza sobre el modo en el que el liderazgo cambia a las personas, grupos, organizaciones y colectivos más amplios (Yukl, 1999). Y esto a pesar de que 
algunos autores han atribuido entre un 20\% y un $40 \%$ de la efectividad de las organizaciones al rol de liderazgo desarrollado por los altos ejecutivos (Ireland y Hit, 1999).

Desde los años 90 del siglo XX ha existido un interés por favorecer el desarrollo del liderazgo a través de nuevas perspectivas (Avolio, Sosik, Jung y Berson, 2003) entre las que destacamos tres: el liderazgo a través de las culturas, el liderazgo como un fenómeno multinivel y el liderazgo como una fusión de enfoques.

La investigación del liderazgo a través de las culturas ha recibido un renovado impulso, especialmente, por el estudio desarrollado por House y sus colegas sobre la efectividad del comportamiento organizacional y el liderazgo global, conocido como el proyecto Global Leadership and Organizacional Behavior Effectiveness 0 proyecto GLOBE (Lowe y Gardner, 2000).

En su origen fue concebido como un proyecto de investigación internacional sobre liderazgo aunque posteriormente también se ha preocupado por otros aspectos de las culturas nacionales y organizacionales. $\mathrm{El}$ proyecto GLOBE ha tomado como modelo la propuesta de Hofstede (1980) sobre las dimensiones de las culturas nacionales aunque ha ampliado su modelo de 5 dimensiones a 18. El proyecto recoge datos de máximos responsables de casi 1000 organizaciones locales de 62 países, con un gran esfuerzo por superar la visión etnocéntrica de las iniciativas de este tipo (Hofstede, 2006). 
Esta perspectiva ha tenido una especial relevancia para las organizaciones que se dirigen, al mismo tiempo, a diferentes entornos culturales.

También ha recibido un importante impulso la concepción del liderazgo como un fenómeno multinivel, al considerar en su estudio diferentes niveles de análisis.

Esta visión ha cambiado la conceptualización de cómo el liderazgo es definido, medido y contextualizado (Brass, 2001; House y Aditya, 1997; Zaccaro y Klimoski, 2001).

En los comienzos del siglo XXI se ha contemplado un amplio rango de constructos en el estudio del liderazgo, tales como (Avolio, Sosik, Jung y Berson, 2003):

Constructos contemplados en el estudio del liderazgo como fenómeno multinivel

- La naturaleza y el nivel de cambio.

El medio a través del que los líderes y seguidores interactúan.

- Las culturas en las que el liderazgo se inscribe.

- La organización en la que el liderazgo se desarrolla.

- El grupo de trabajo.

- La red de trabajo.

Cuadro 38: Constructos contemplados en el estudio del liderazgo como fenómeno multinivel. Fuente: Avolio, Sosik, Jung y Berson (2003).

El esfuerzo por favorecer la investigación del liderazgo para estimular su eficacia, también ha impulsado la integración de diferentes enfoques.

Autores como Avolio (2007) han lamentado la carencia de una integración de las diferentes teorías y constructos, 
especialmente porque los expertos en liderazgo han tendido a crear nuevas teorías sobre esta disciplina sin intentar comparar y contrastar la validez de las teorías existentes.

Una de las razones indicadas para explicar por qué el desarrollo teórico de los diferentes enfoques no ha estado bien integrado es por su diferente comprensión de la efectividad en el ejercicio del liderazgo (Avolio, Sosik, Jung y Berson, 2003).

Sin embargo algunas propuestas combinadas, como la desarrollada por Derue, Nahrgang, Wellman y Humphrey (2011), que ha relacionado con éxito el enfoque basado en los rasgos y el centrado en el comportamiento a partir de un meta-análisis de la literatura del liderazgo, han demostrado la validez de la integración de perspectivas.

En quinto lugar hemos tratado las teorías que han vinculado el liderazgo con las nuevas tecnologías en el grupo “liderazgo y nuevas tecnologías".

Hemos desarrollado un bloque específico porque las nuevas tecnologías de la información, especialmente por su gran valor estratégico, han supuesto una nueva oportunidad de favorecer la eficacia en el ejercicio del liderazgo desarrollado en las organizaciones (Avolio, Kahai y Dodge, 2000).

Una de las ventajas asociadas al ejercicio del liderazgo a través de las nuevas tecnologías, también conocido como "e-leadership", es que favorece la 
efectividad de la organización al mejorar su capacidad para alinear el liderazgo y los sistemas de información basados en las nuevas tecnologías (Trist, 1993). Esto es posible porque tanto la tecnología como el liderazgo deben interactuar de un modo favorable, y porque el liderazgo es clave para promover adaptaciones favorables a los cambios tecnológicos (Avolio, Kahai y Dodge, 2000).

Además este estilo de liderazgo permite que las organizaciones desarrollen nuevas actuaciones en el mercado. El e-leadeship favorece la creación de estrategias centradas en el consumidor, lo que puede convertir a este en parte del propio sistema de liderazgo de las organizaciones (Avolio, Sosik, Jung y Berson, 2003).

Algunos expertos también han planteado que el eleadership presenta algunos riesgos. Entre ellos, hemos destacado el hecho de que la flexibilidad adicional que las nuevas tecnologías ofrecen también puede suponer un factor de riesgo (Lurey y Raisinghani, 2001) porque los equipos que trabajan de forma virtual pueden experimentar un impacto negativo en su sentido de responsabilidad y en su grado de compromiso (Caballer, Gracia, y Peiró, 2005; Golden y Veiga, 2008; Pillis y Furumo, 2007) fundamentalmente por la distancia espacial entre los colaboradores y los líderes (Watt, 2007), la pérdida de interacción social intrínseca a esas relaciones distantes (Koh, Kim, Butler y Bock, 2007) y las posibles diferencias 
culturales existentes si no se producen interacciones muy frecuentes (Anawati \& Craig, 2006).

También es necesario tener en cuenta que el trabajo desarrollado en entornos virtuales puede llegar a provocar que, en algunos casos, los colaboradores se sientan legitimados para trabajar en contra de los intereses que persigue la propia organización (Salas, 2009).

Hemos considerado que este tipo de liderazgo puede favorecer el impulso de la responsabilidad social en las organizaciones en las que exista, a través de los nuevos canales de comunicación que ofrece Internet, una fuerte presencia de consumidores afines a la actuación social.

En sexto lugar hemos tratado un último conjunto de teorías agrupadas bajo la denominación “liderazgo y desarrollo humano", al considerar que otra esfera en la que el liderazgo más se ha desarrollado es la que ha puesto un especial énfasis en el trato con los colaboradores.

Hemos considerado que estas propuestas podrían estar relacionadas con el auge de la responsabilidad social en las últimas décadas debido, de modo especial, a que uno de los ámbitos de ocupación de la Responsabilidad Social Corporativa es la defensa de los derechos humanos.

Hemos hecho una selección de las diversas teorías y propuestas desarrolladas dentro de este enfoque que hemos agrupado en tres bloques: el denominado "liderazgo 
respetuoso", el catalogado como "liderazgo de servicio" y el que hemos denominado como "liderazgo transcendente".

En relación con el primer bloque, es interesante destacar lo que ha sido denominado por algunos autores como liderazgo respetuoso (Van Quaquebeke y Eckloff, 2010).

Este tipo de liderazgo se constituye a partir de la satisfacción del deseo de las personas de ser tratadas con respeto por los demás, tanto en su vida privada como en su trabajo (Mason, 1994; Van Quaquebeke y Brodbeck, 2008).

Hay datos que indican que cuando las personas se sienten respetadas en el trabajo, especialmente por las autoridades de la organización, se producen los siguientes efectos (Boezeman y Ellemers, 2008; Lind y Tyler, 1988; Simon y Stürmer, 2003; Tyler y Blazer, 2000; Tyler y Lind, 1992; Tyler, Boeckmann, Smith y Huo, 1997): están más satisfechas, se identifican en mayor grado con el colectivo del que forman parte y se esfuerzan en beneficio del mismo.

Pese a los efectos positivos que la investigación ha constatado en relación con este estilo de liderazgo, los expertos han indicado que esta experiencia es actualmente rara en el lugar de trabajo (Van Quaquebeke y Brodbeck, 2008).

Entronca con el planteamiento anterior el liderazgo de servicio, que ha sido propuesto inicialmente por 
Greenleaf (1977) al hacer referencia al líder que está más orientado a servir a los demás que a satisfacer las necesidades y creencias centradas en su ego (p. 27).

La propuesta de Greenleaf derivó en un cuerpo creciente de literatura alrededor del constructo y en el desarrollo de estudios empíricos (Dennos, 2004; Dennis y Winston, 2003; Laub, 2005; Winston, 2004).

En las frecuentes discusiones teóricas sobre el liderazgo de servicio se han contemplado tres modelos: el de Spears (1998), que destaca diez características en el lidreazgo de servicio, el de Russell y Stone (2002), que ofrece nueve rasgos distintivos del liderazgo de servicio, y el de Page y Wong (2000), que indica seis tipologías en las que se han agrupado las características asociadas al liderazgo de servicio.

La propuesta de Spears (1998), cuadro 39, ofrece las siguientes características como definitorias del liderazgo de servicio:

\begin{tabular}{|l|l|}
\hline \multicolumn{2}{|c|}{ Características del liderazgo de servicio (Spears) } \\
\hline Escucha. & Empatía. \\
\hline Despierto. & Persuasivo. \\
\hline Comprometido. & Previsor \\
\hline $\begin{array}{l}\text { Orientado a la salud de los } \\
\text { demás. }\end{array}$ & $\begin{array}{l}\text { Con capacidad de } \\
\text { administración. }\end{array}$ \\
\hline $\begin{array}{l}\text { Con capacidad para } \\
\text { expresar conceptos y } \\
\text { provocar imágenes } \\
\text { mentales. }\end{array}$ & $\begin{array}{l}\text { Con capacidad para reforzar } \\
\text { el espíritu colectivo. }\end{array}$ \\
\hline
\end{tabular}

Cuadro 39: Características del liderazgo de servicio (Spears). Fuente: Spears (1998). 
El modelo de Russell y Stone (2002), se basa en los siguientes nueve atributos funcionales interrelacionados, cualidades operativas y características distintivas que pueden ser observados en los líderes:

\begin{tabular}{|l|l|}
\hline \multicolumn{2}{|c|}{$\begin{array}{c}\text { Atributos, cualidades y características } \\
\text { observadas en el liderazgo de servicio }\end{array}$} \\
\hline Visionario. & - Honesto. \\
\hline Íntegro. & - Pionero. \\
\hline Flexible. & - Con vocación de servicio. \\
\hline $\begin{array}{l}\text { Persona en quien se puede } \\
\text { confiar. }\end{array}$ & - Preocupado por los demás. \\
\hline $\begin{array}{l}\text { Con capacidad para conferir } \\
\text { un sentimiento de capacidad } \\
\text { a los otros. }\end{array}$ & \\
\hline
\end{tabular}

Cuadro 40: Atributos, cualidades y características observadas en el liderazgo de servicio. Fuente: Russell y Stone (2002).

El modelo de Page y Wong (2000), identifica 62 características del liderazgo de servicio agrupadas en seis áreas:

\section{Características del liderazgo de servicio (Page y Wong)}

- Valoración de las personas.

Fomento del desarrollo personal.

Manifestación de autenticidad.

Liderazgo compartido.

Construcción del sentido de comunidad.

Liderazgo de apoyo.

Cuadro 41: Características del liderazgo de servicio (Page y Wong). Fuente: Page y Wong (2000).

Destacamos la relación encontrada entre algunas características del liderazgo de servicio, como la capacidad 
para conferir un sentimiento de capacidad a los otros, con algunos rasgos propios del liderazgo transformacional. En este sentido sería interesante realizar una investigación para conocer si existen rasgos actitudinales que compartan ambos modelos, como por ejemplo, la preocupación por los demás.

Hemos entendido que los modelos propuestos pueden tener una alta incidencia en el comportamiento de las organizaciones que se implican en acciones de responsabilidad social sin esperar ningún retorno de valor, exceptuando la satisfacción por el servicio social prestado.

Finalmente hemos desarrollado el bloque liderazgo transformador para hacer referencia a los planteamientos que persiguen, con especial vigor, que el colaborador vaya más allá de su propio interés en el ejercicio del liderazgo.

Dentro de este apartado, en el que también estarían incluidas las teorías que vinculan el liderazgo con aspectos espirituales, hemos destacado la propuesta de Covey (1990). Su planteamiento, sin estar fundamentado en datos empíricos, ha tenido una extraordinaria aceptación empresarial.

Covey (1990), quien también ha realizado aportaciones científicas dentro del campo del liderazgo de servicio (Greenleaf, Spears y Covey, 2002), ha defendido en su Best Seller "Los 7 hábitos de la gente altamente efectiva" -más de 15 millones de copias vendidas en treinta 
idiomas- (Aplei News, 2012) que el liderazgo efectivo está basado en siete hábitos:

\begin{tabular}{|c|c|}
\hline Hábito & Definición \\
\hline 1. Sea proactivo & - Asumir la responsabilidad sobre la vida personal. \\
\hline $\begin{array}{l}\text { 2. Empiece con un fin en } \\
\text { mente }\end{array}$ & $\begin{array}{l}\text { Contemplar la vida como un todo en el que cada } \\
\text { momento contribuye de modo significativo a la } \\
\text { visión que cada uno quiera otorgar a su existencia. }\end{array}$ \\
\hline $\begin{array}{l}\text { 3. Establezca lo primero } \\
\text { lo primero }\end{array}$ & Desarrollar la capacidad para tomar decisiones. \\
\hline 4. Pensar en ganar/ganar & $\begin{array}{l}\text { Procurar el beneficio mutuo en todas las } \\
\text { interacciones humanas. }\end{array}$ \\
\hline $\begin{array}{l}\text { 5. Procure primero } \\
\text { comprender, y } \\
\text { después ser } \\
\text { comprendido }\end{array}$ & $\begin{array}{l}\text { Tomarse el tiempo necesario para comprender un } \\
\text { problema en profundidad antes de solucionarlo. }\end{array}$ \\
\hline 6. La sinergia & $\begin{array}{l}\text { Aplicar del principio "el todo es mayor que la suma } \\
\text { de las partes" en todas las interacciones sociales } \\
\text { con el objetivo de favorecer la cooperación creativa. }\end{array}$ \\
\hline 7. Afile la sierra & $\begin{array}{l}\text { Cuidarse cultivando las cuatro dimensiones de la } \\
\text { naturaleza: física, espiritual, mental y } \\
\text { social/emocional. }\end{array}$ \\
\hline
\end{tabular}

Cuadro 42: Los 7 hábitos de la gente altamente efectiva. Fuente: Covey (1990).

Posteriormente Covey (2005) indicó un octavo hábito que hace referencia a la necesidad de que las personas encuentren su voz interior e inspiren a los demás a que encuentren la suya a través del ejercicio del liderazgo $(p$. 116). Con "voz" Covey hace referencia a (p. 19) la "voz" de un espíritu humano que define como lleno de esperanza y de inteligencia, fuerte por naturaleza y con un potencial inagotable para servir al bien común. Pero también hace referencia al "alma de las organizaciones" que sobrevivirán, prosperarán y tendrán un impacto profundo en el futuro del mundo. 
El planteamiento de Covey representa una nueva corriente de propuestas orientadas hacia un liderazgo organizacional que entronca con el desarrollo de los valores humanos en las organizaciones (Vilaseca, 2010) y que, en muchos casos, carece de un enfoque científico en el estudio del liderazgo.

De todos modos la elevada aceptación empresarial de este corpus divulgativo y su tiempo de vigencia en el mercado parecen aconsejar su consideración como propuesta teórica en el ejercicio del liderazgo.

Además también hemos entendido que el desarrollo de la sensibilidad humana en el líder, algo que conlleva la aplicación de este tipo de modelos, también favorece que el máximo responsable tenga una predisposición a promover acciones de responsabilidad social en las organizaciones 
PARTE II:

ESTUDIO EMPÍRICO 

4 - OBJETIVOS 

Dentro de la diversidad de variables que pueden estar implicadas, este estudio se ha centrado en algunos rasgos de los líderes organizacionales, concretamente en su estilo de liderazgo, su actitud ante la Responsabilidad Social Corporativa y sus "valores" personales.

Con ello se ha pretendido comprobar si los líderes que aplican políticas de Responsabilidad Social Corporativa comparten, en alguna medida, una actitud similar hacia la responsabilidad social y presentan características personales comunes.

Además también hemos intentado verificar si los líderes que impulsan actuaciones en este ámbito han utilizado un estilo de liderazgo similar, ya compartan o no una actitud parecida hacia la Responsabilidad Social Corporativa o ciertos "valores".

La revisión bibliográfica realizada ha permitido constatar la preocupación existente en la comunidad científica por profundizar en el estudio de la Responsabilidad Social Corporativa.

Existe un elevado número de revistas de prestigio que se encargan del estudio de la responsabilidad social, generalmente con una perspectiva internacional.

Además, la preocupación científica sobre esta cuestión también se manifiesta por la alta presencia de contenidos sobre responsabilidad social en revistas internacionales centradas en el ámbito de la gestión y de los negocios. Hay una creciente atención de temas afines a este ámbito, como 
la ética o la atención a los grupos de interés, y una demanda de información científica concreta sobre la responsabilidad social (gran parte de los estudios que se realizan tienen una orientación empírica).

No obstante también hemos verificado, como consecuencia del trabajo de revisión de fuentes secundarias que hemos desarrollado, que la investigación en el ámbito de la responsabilidad social presenta algunas carencias.

Una de estas deficiencias reside en el hecho de que el grueso de la investigación científica sobre esta cuestión se realiza en países económicamente desarrollados. Además los estudios que generalizan sus resultados en realidad suelen hacer referencia, exclusivamente, a los países más ricos.

En contraste con las cuestiones indicadas, existe una carencia de investigación en los países en los que la responsabilidad social es más necesaria (África, Europa Central y del Este, Asia Central y del Sur, Latinoamérica y Oriente Medio) porque tienen elevados niveles de pobreza, presentan degradación medioambiental y necesitan mejorar su gobernanza institucional.

Contemplando el ámbito geográfico como factor de incidencia en la puesta en marcha de este tipo de prácticas, las investigaciones también han indicado que el desarrollo económico del país es un factor discriminante para el desarrollo de acciones de responsabilidad social.

De todos modos el aspecto que más incide en el impulso de este tipo de prácticas, por encima del territorio 
en el que las organizaciones operan, es el tamaño de las empresas.

Los datos científicos también han permitido conocer los estilos de liderazgo que pueden tener una mayor incidencia en el desarrollo de políticas de Responsabilidad Social Corporativa en las organizaciones. Veamos algunas aportaciones de los modelos revisados.

Hemos considerado que la Teoría del Liderazgo Situacional II favorece el impulso de la responsabilidad social. Esta propuesta defiende que el líder contemple al colaborador como un compañero y no como un subordinado, disposición que favorece la calidad de la relación que ambos establecen y que tiene implicaciones positivas, por tanto, en las relaciones que los máximos responsables establecen con sus públicos internos.

También hemos entendido que el planteamiento defendido por algunas teorías del enfoque contingente en el estudio del liderazgo, que procura tomar en consideración las motivaciones del colaborador, también fomenta la puesta en práctica de iniciativas de Responsabilidad Social Corporativa por parte de las organizaciones. La mayor sensibilidad mostrada hacia los integrantes de una empresa favorece la implicación de este grupo de interés en actuaciones de responsabilidad social.

Por otra parte también hemos argüido que la existencia de una demanda de liderazgo con orientación humana por parte de los seguidores, estimula el desarrollo 
de iniciativas de Responsabilidad Social Corporativa. De acuerdo a las Teorías Implícitas de Liderazgo son los esquemas mentales de los colaboradores los que impulsan un determinado tipo de liderazgo en las organizaciones (propuesta que también se ve respaldada por el enfoque de la identidad social en las teorías del (iderazgo). Esta demanda se produce de modo especial, de acuerdo a las Teorías Implícitas de Liderazgo, en las culturas organizacionales transformacionales. En este tipo de liderazgo se demanda un estilo de liderazgo más participativo y democrático de lo habitual, y con elevada preocupación por el colaborador.

Hemos considerado que las culturas que demandan este estilo de dirección son más proclives al impulso de acciones de responsabilidad porque desarrollan un mayor grado de sensibilidad hacia todos los grupos de interés.

También hemos entendido que la puesta en práctica de comportamientos de liderazgo transformacionales tiene una influencia positiva en la esfera de la responsabilidad social. Hemos considerado que este tipo de conductas fomentan el desarrollo de culturas organizacionales orientadas favorablemente hacia la responsabilidad social, especialmente, porque estimulan un clima positivo que mejora la atención a los grupos de interés.

Además hemos supuesto que el mayor protagonismo de los consumidores afines a la responsabilidad social en las empresas que utilizan las nuevas tecnologías como canales 
de comunicación también tiene incidencia en la Responsabilidad Social Corporativa. Tal como propone el eleadership, el consumidor se ha convertido en parte del propio sistema de liderazgo en las organizaciones que utilizan estos canales en el ámbito de la comunicación. Hemos considerado que la existencia de rasgos favorables a la responsabilidad social en los consumidores incentiva acciones, vinculadas al ámbito de la Responsabilidad Social Corporativa, en las empresas en las que aquellos tengan incidencia.

También hemos argüido que el impulso por desarrollar estilos de liderazgo que respeten los derechos humanos, como el propuesto por el liderazgo respetuoso, estimula la responsabilidad social en las organizaciones. Hemos entendido que la consideración asociada a este modo de actuación, que incide en la deferencia hacia los grupos de interés, fomenta el desarrollo de culturas favorables a la Responsabilidad Social Corporativa.

Otro aspecto asociado de modo favorable a la responsabilidad social es el fomento de la cultura de servicio, impulsada por comportamientos de dirección como el liderazgo de servicio. Hemos considerado que la orientación del liderazgo hacia la satisfacción de las necesidades de los colaboradores impulsa, asimismo, la preocupación por atender las necesidades de otros grupos de interés.

Un último aspecto que hemos destacado del liderazgo asociado a la responsabilidad social está representado por el 
auge de los estilos de liderazgo que procuran desarrollar todo el potencial interior de los líderes, como el propuesto por Covey. Hemos entendido que estos comportamientos directos también están implicados en el desarrollo de acciones de responsabilidad social por parte de las organizaciones, ya que estimulan la sensibilidad de los máximos responsables empresariales hacia los grupos de interés con los que se relacionan.

Asimismo el material revisado también ha permitido conocer aspectos relevantes que facilitan el desarrollo de actitudes favorables hacia la responsabilidad social en los líderes de las organizaciones. Hemos indicado a continuación los aspectos más destacados.

Un primer rasgo influyente es el desarrollo de la economía en la que las empresas realizan su actividad. En este sentido cuanto mayor sea el grado de progreso económico, más se favorece el desarrollo de actitudes afines a la responsabilidad social.

Otro aspecto que tiene incidencia en la actitud de los máximos cargos hacia la responsabilidad social es el tamaño de las empresas. No obstante, no todos los estudios han indicado que la dimensión de una organización se correlacione de forma directa y positiva con la existencia de actitudes afines a la Responsabilidad Social Corporativa.

También es un factor de influencia la edad de una empresa. Las investigaciones han indicado que las organizaciones con más historia son más proclives a 
incentivar en sus líderes el desarrollo de actitudes favorables hacia la responsabilidad social.

La presencia de las organizaciones en el sector industrial también es un rasgo que tiene incidencia en la disposición de los máximos responsables de las organizaciones. Los estudios han indicado que existe una mayor implicación en la responsabilidad social por parte de las empresas que se enmarcan en este sector empresarial respecto a las que se circunscriben en otros ámbitos.

También incide en la actitud favorable de los líderes frente a la responsabilidad social el hecho de que las culturas organizacionales estén orientadas hacia la ética. Como se podría presuponer, este tipo de culturas demandan directivos con un perfil afín a esta orientación.

Otro factor de incidencia es la satisfacción laboral que el líder experimenta. Los datos han indicado que este aspecto se correlaciona de forma directa y positiva con una percepción favorable de la responsabilidad social.

La percepción por parte del líder de que la responsabilidad social es capaz de producir beneficios para su organización también es un aspecto que influye en su actitud. Esta visión favorable de la responsabilidad social se ve reforzada por la existencia de estudios que respaldan su potencial para generar valor para la empresa. Hay investigaciones que han indicado que la actuación en el ámbito de la Responsabilidad Social Corporativa aumenta la legitimidad de las organizaciones y estimula el compromiso y el rendimiento de los colaboradores. 
La edad del líder también es un rasgo de incidencia en su predisposición hacia la Responsabilidad Social Corporativa. Los datos han revelado que la juventud favorece la adopción de una actitud favorable hacia la responsabilidad social.

Los trabajos analizados también han permitido conocer aspectos que estimulan el desarrollo de valores personales afines a la responsabilidad social en los líderes empresariales. Veamos algunos de los hallazgos encontrados.

El hecho de que la cultura de una organización sea flexible e innovadora tiene incidencia en los valores de los líderes. Cuando las empresas tienen este tipo de cultura, mejora la predisposición de los líderes para atender de un modo más satisfactorio a sus grupos de interés.

También es un factor de incidencia que la incertidumbre en los entornos de trabajo sea reducida, y la distancia jerárquica, el individualismo y la masculinidad (aspecto asociado al materialismo) tengan poco protagonismo. Las culturas en las que los valores dominantes premian el colectivismo y la preocupación por los demás son más proclives a desarrollar un trato más sensible hacia los grupos de interés.

Otro aspecto, en cierta medida bastante lógico, que favorece el desarrollo de valores próximos a la responsabilidad social es que los líderes muestren preocupación por los demás y se sientan más atraídos por 
el altruismo y el idealismo que por el ámbito comercial. Los valores próximos a esta doble orientación favorecen el estímulo por atender las necesidades de los grupos de interés y la defensa de un planteamiento estratégico a largo plazo (aspecto este último que es muy relevante para integrar la responsabilidad social de forma efectiva en la cultura corporativa).

Sin embargo ha quedado pendiente determinar si los líderes de las organizaciones que aplican políticas de Responsabilidad Social Corporativa han presentado algún denominador común -en lo que a estilo de liderazgo, actitud ante la Responsabilidad Social Corporativa y valores personales se refiere-, y si estos rasgos han estado asociados, de algún modo, con sus características sociodemográficas o con aspectos de las organizaciones a las que están vinculados, tales como su tamaño o su sector de actividad.

Las cuestiones planteadas han implicado el diseño y la selección de herramientas para obtener información sobre el estilo de liderazgo, la actitud ante la Responsabilidad Social Corporativa y los "valores" personales de líderes organizaciones con objeto de verificar dichos supuestos.

Dentro de las posibles aplicaciones de los resultados de la investigación, se ha planteado la obtención de directrices educativas que puedan favorecer una disposición proactiva en los futuros líderes de las organizaciones hacia la Responsabilidad Social Corporativa. 
Además también se ha previsto que el descubrimiento de posibles aspectos comunes en los líderes que aplican políticas de Responsabilidad Social Corporativa facilitará, para las organizaciones que deseen impulsar este ámbito, el reclutamiento de los perfiles profesionales más idóneos.

\subsection{OBJETIVO GENERAL}

El objetivo general de este trabajo ha sido descubrir si existe algún tipo de relación entre tres rasgos de los líderes de organizaciones que actúan en España -su actitud ante la responsabilidad social, su estilo de liderazgo y sus "valores" personales-, y la realización de acciones de Responsabilidad Social Corporativa por parte de las organizaciones en las que desempeñan su labor.

\subsection{OBJETIVOS ESPECÍFICOS}

A partir del objetivo general se han establecido once objetivos específicos que han articulado el planteamiento de la investigación.

De estos once objetivos, cinco están relacionados con tres rasgos psicológicos de los líderes: su actitud hacia la Responsabilidad Social Corporativa, su estilo de liderazgo y la presencia de ciertos "valores" en su personalidad. 
Otro objetivo está relacionado con dos características de las organizaciones: el desarrollo de acciones de responsabilidad social y su impulso por formar a sus colaboradores en esta disciplina.

De los objetivos restantes, tres están asociados con la actitud de los líderes frente a la responsabilidad social y con tres características de las organizaciones a las que estos están vinculados: su sector de actividad, su tamaño y el hecho de que realicen o no actividades de responsabilidad social.

Y dos objetivos están relacionados con la actitud hacia la responsabilidad social de los líderes y con algunas de sus características demográficas como son su edad y su sexo.

A continuación hemos indicado los objetivos específicos, agrupados tal y como se ha señalado con anterioridad.

\subsubsection{Relativos a aspectos de los líderes}

1. Conocer la actitud de los líderes de las organizaciones que desempeñan su labor en España hacia la Responsabilidad Social Corporativa.

2. Evaluar el estilo de liderazgo "directivo", “consultivo”, “participativo” y "delegativo” en los líderes organizacionales que desarrollan su actividad en el ámbito español. 
3. Conocer si existe alguna relación entre la actitud hacia la responsabilidad social de los líderes organizacionales que desempeñan su labor en España y el estilo de liderazgo "directivo", “consultivo", "participativo” y "delegativo".

4. Evaluar los "valores" "practicidad", "resultados", "variedad", “decisión”, “orden y método" y "metas" en los líderes organizacionales que realizan su labor en el ámbito español.

5. Descubrir si existe alguna relación entre la actitud hacia la Responsabilidad Social Corporativa de los líderes organizacionales que desempeñan su rol en España y los "valores” "practicidad”, "resultados”, "variedad”, “decisión”, “orden y método" y "metas".

\subsubsection{Relacionados con el perfil de la organización}

1. Conocer si las organizaciones que forman a sus colaboradores en responsabilidad social están más implicadas en el desarrollo de acciones en este ámbito. 
4.2.3. Vinculados con el perfil de la organización y la actitud de los líderes frente a la responsabilidad social

1. Conocer si el sector de actividad en el que actúan las organizaciones en España tiene algún tipo de relación con la actitud de sus líderes hacia la Responsabilidad Social Corporativa.

2. Conocer si el tamaño de las organizaciones en España tiene algún tipo de relación con la actitud de sus líderes hacia la Responsabilidad Social Corporativa.

3. Conocer si el desarrollo de acciones de Responsabilidad Social Corporativa por parte de las organizaciones en España tiene algún tipo de relación con la actitud de sus líderes hacia la Responsabilidad Social Corporativa.

\subsubsection{Asociados a características demográficas de los líderes y a su actitud frente a la responsabilidad social}

1. Descubrir si la edad de los líderes de las organizaciones que operan en el ámbito español 
tiene algún tipo de relación con su actitud hacia la Responsabilidad Social Corporativa.

2. Conocer si el sexo de los líderes organizacionales que actúan en España tiene algún tipo de relación con su actitud hacia la Responsabilidad Social Corporativa. 


\section{5 - METODOLOGÍA}





\subsection{DISEÑO METODOLÓGICO}

Arnau señala $(1995,27)$ que el diseño metodológico de una investigación debe atender a dos aspectos fundamentales: los objetivos básicos y las características de los datos obtenidos. Ambos han sido tenidos en cuenta a la hora de seleccionar tanto el método como el diseño de la investigación.

El objetivo general perseguido por esta investigación ha sido descubrir si existe una relación entre tres rasgos de los líderes organizacionales que actúan en España (su actitud hacia la responsabilidad social, su estilo de liderazgo y sus "valores" personales) y la realización de acciones de Responsabilidad Social Corporativa por parte de las organizaciones en las que aquellos desempeñan su labor.

Dado que el objetivo general de la investigación no ha permitido la manipulación ni de la variable dependiente ni de las independientes, se ha seleccionado un método selectivo o no experimental (García, Quintanilla, Garriga, Fontes, Pérez-Llantada y Sarriá, 2003).

Este tipo de estrategia de investigación contempla el análisis de las variables en situaciones menos controladas que las que ofrecen los diseños experimentales. 
Dentro del método no experimental se ha elegido una metodología cuantitativa, ya que hemos entendido que se adecúa en mayor grado al enfoque de la investigación: más centrado en conocer la presencia de ciertos rasgos específicos en los líderes y en las organizaciones que en profundizar en cualidades asociadas a dichos aspectos.

De todos modos, hemos sido conscientes de que la utilización de una metodología cuantitativa también presenta algunas desventajas como "la tendencia a considerar a los sujetos como seres estáticos y descontextualizados, los numerosos problemas que plantean los procedimientos psicométricos y la pretendida objetividad de las propiedades psicométricas en que se sustentan" (Diego, 1988, 88).

Las herramientas utilizadas para recoger la información a través del enfoque cuantitativo han sido el ARS19, escala de Thurstone que ha sido diseñada ad hoc para medir la actitud de los líderes ante la responsabilidad social, el SPV de Gordon, cuestionario que ha permitido evaluar los valores personales, y el LBA II, cuestionario que ha posibilitado el estudio del liderazgo. Las tres herramientas han sido desarrolladas en el apartado 5.5 de este capítulo.

En el marco de la metodología selectiva hemos optado por un diseño ex post facto porque la investigación ha recogido datos que ya han ocurrido. Además también ha sido un factor influyente el hecho de que la recogida de 
datos a través de una metodología cuantitativa se haya realizado con carácter transversal, es decir, se ha realizado en un momento dado y en una sola medición. Por otra parte también hemos tenido en cuenta en la elección de este tipo de diseño que permita establecer relaciones concomitantes entre las variables ya que, en este caso, es el único tipo de relaciones que hemos podido analizar. Al no ser posible manipular las variables no hemos conseguido establecer entre las mismas relaciones de causa y efecto (Diego \& Diego, 1990).

En la elección de este tipo de diseño también han estado muy presentes las palabras de León y Montero (1997, 324) cuando indica que al escoger un diseño, el investigador debe "conocer muy bien los riesgos que asume para amortiguarlos en la medida de lo posible".

Uno de estas posibles contingencias es que se trata de un diseño con menor control de variables (Diego \& Diego, 1990). Por este motivo el rigor y la exigencia deben aumentar a la hora de recoger los datos a través de los instrumentos seleccionados. Teniendo en consideración esta objeción, se ha trabajado con extrema pulcritud en la recogida de la información. Además resulta fundamental recurrir a diversas fuentes de información para enriquecer y dar mayor fiabilidad a los datos de modo que se compense, en cierta medida, el menor control sobre las variables estudiadas. En relación con este aspecto, se ha contrastado la información recogida a través de fuentes primarias con 
todos los datos previos recabados a través de fuentes documentales y estadísticas.

Otro aspecto importante que debe considerarse en los diseños ex post facto es la necesidad de contar con una muestra amplia y representativa que dé validez a la investigación para que, de este modo, sea posible analizar la covariación entre las variables y se compense que se trata de un estudio a posteriori (Diego \& Diego, 1990).

Si se pretende estudiar la relación entre las variables, conviene que sus rangos estén suficientemente representados. En respuesta a esta exigencia, el trabajo de campo no se ha finalizado hasta que no se han encontrado grupos suficientemente representativos en los tres segmentos relacionados con el tamaño de las organizaciones que forman parte del universo objeto de estudio. Por otra parte también se ha puesto un especial cuidado en que los grupos que integran la variable "sexo" hayan tenido una adecuada presencia en la muestra final.

Además, como hemos indicado anteriormente, una muestra amplia, y más dada la imposibilidad de asignación aleatoria en este estudio, puede compensar las limitaciones inherentes a todo estudio a posteriori. Esta cuestión se ha considerado satisfecha ya que, finalmente, se han realizado 189 entrevistas estructuradas en profundidad.

El diseño ex post facto parte del presupuesto de que debe, como se ha mencionado, haber una relación concomitante entre las variables. Es decir, que deben 
encontrarse significativamente correlacionadas las variables independientes (antecedente o predictora) y la variable dependiente (consecuente o efecto).

Sin embargo, quizás por el peso del modelo experimental o por el afán de vincular causalmente los fenómenos, en ocasiones el diseño correlacional también pretende ser causal, a pesar de que solo se alcance a dibujar un panorama amplio y diversificado de todos los posibles antecedentes de un hecho, y el tipo de asociación entre este hecho y sus antecedentes no esté probado de modo empírico.

Aunque en este estudio nos hemos limitado a indicar posibles variables asociadas al desarrollo de acciones de Responsabilidad Social Corporativa en las organizaciones donde los líderes desempeñan su labor, entendemos que la investigación también se puede contemplar como prospectiva, en cierta medida, si se interpreta la edad como una variable predictora.

El diseño ha estudiado la actitud ante la Responsabilidad Social Corporativa, el estilo de liderazgo y los "valores" personales de los líderes de organizaciones que actúan en España en un momento concreto. La reducción a un momento concreto, y que no se trate de un diseño longitudinal (Sierra, 2008), tiene el inconveniente de haber impedido la comparación de información registrada en diferentes periodos de tiempo.

De todos modos hemos considerado que el estudio sí presenta algún valor predictivo, aunque este se haya 
realizado únicamente en un momento puntual. El registro de los datos a través de diversas variables no solo ha permitido explicar la relación de estas con las variables dependientes, sino que también ha permitido conocer cómo cambian las diversas variables estudiadas en función de la edad del líder del que se recoge la información. 


\subsection{HIPÓTESIS}

Los objetivos específicos que se han indicado anteriormente han llevado a concretar las siguientes hipótesis de trabajo:

1. Hipótesis 1: Los líderes que tienen una actitud más favorable hacia la responsabilidad social están vinculados a organizaciones que tienen una política de Responsabilidad Social Corporativa más definida.

2. Hipótesis 2: Los líderes que tienen una actitud más favorable hacia la Responsabilidad Social Corporativa utilizan un estilo de liderazgo que presenta preferencia por los estilos "participativo" y "delegativo".

3. Hipótesis 3: Los líderes que tienen una actitud más favorable hacia la Responsabilidad Social Corporativa presentan una puntuación más elevada en los "valores" personales "resultados" y "practicidad".

4. Hipótesis 4: Las organizaciones que impulsan la formación de sus colaboradores en materia de responsabilidad social están más implicadas en la realización de acciones en este ámbito.

5. Hipótesis 5: Las organizaciones que actúan en el sector servicios, supuestamente más sensibilizadas 
con el trato personal, presentan líderes con una actitud más favorable hacia la Responsabilidad Social Corporativa.

6. Hipótesis 6: Las organizaciones de gran tamaño, supuestamente más preocupadas por su reputación corporativa, presentan líderes con una actitud más favorable hacia la Responsabilidad Social Corporativa.

7. Hipótesis 7: La edad de los líderes de las organizaciones no resulta un factor indicativo de cómo de favorable es su actitud hacia la Responsabilidad Social Corporativa.

8. Hipótesis 8: El sexo de los líderes de las organizaciones no es un factor indicativo de cómo de favorable es su actitud hacia la Responsabilidad Social Corporativa.

9. Hipótesis 9: El estilo de liderazgo participativo, de acuerdo a lo que hemos medido los responsables de la investigación, está más asociado a la flexibilidad de estilo que al resto de estilos de liderazgo. 


\subsection{VARIABLES}

Inicialmente hemos agrupado las variables consideradas en la investigación en tres categorías: de identificación o control, predictoras o independientes y de criterio o dependientes.

No obstante, desde un punto de vista metodológico, hemos considerado que las variables de identificación revisten carácter de predictoras en la investigación porque pueden tener influencia en la realización de acciones de Responsabilidad Social Corporativa por parte de las organizaciones.

\subsubsection{Variables independientes}

La descripción conceptual y operacional de las variables independientes se ha realizado atendiendo al aspecto al que hacen referencia: la organización o al líder.

En relación con el líder se han establecido como variables independientes el sexo, la edad, el liderazgo, los "valores" del líder y la actitud de este frente a la responsabilidad social. Además también se ha incorporado una pregunta de control dentro de un cuestionario relacionada con la actitud del máximo responsable empresarial frente a la responsabilidad social. 
Sexo. Una de las variables que tradicionalmente se ha considerado como identificadora de una muestra. En esta investigación ha sido susceptible de tener poder discriminante en relación con la realización de acciones de Responsabilidad Social Corporativa por parte de las organizaciones. Ha tomado los valores “mujer" y "hombre”.

Edad. Otra de las variables que tradicionalmente se ha considerado como identificadora de una muestra. En esta investigación ha sido susceptible de poder discriminante en relación con la realización de acciones de Responsabilidad Social Corporativa por parte de las organizaciones. Ha tomado los valores: “de 20 a 30 años”, “de 31 a 40 años”, “de 41 a 50 años”, “de 51 a 60 años” y “más de 65 años”.

Liderazgo. El LBA II, herramienta utilizada en la recogida de información sobre liderazgo, plantea la necesidad de elegir uno de los siguientes cuatro estilos de liderazgo en cada una de las 20 situaciones que plantea: directivo, comportamiento altamente directivo y que requiere poco apoyo, consultivo, comportamiento altamente directivo y que requiere mucho apoyo, participativo, comportamiento de alto apoyo que requiere poca dirección, y delegativo, comportamiento de poco apoyo y que requiere baja dirección.

Estas elecciones han permitido medir cuatro aspectos del liderazgo. En primer lugar el estilo de liderazgo primario, que hace referencia al estilo o estilos más seleccionados. En segundo lugar el estilo de liderazgo secundario, que alude al estilo o estilos más seleccionados 
en segundo lugar. En tercer lugar la flexibilidad en el estilo de liderazgo, que hace alusión a la capacidad del líder para utilizar diversos estilos de liderazgo. La flexibilidad de estilo ha tomado el valor de $\mathbf{0}$, que equivale a una mínima flexibilidad y a la selección de un mismo estilo para cada una de las veinte situaciones que se presentan, a 30 , que se corresponde con una máxima flexibilidad y a la selección de los cuatro estilos específicos de liderazgo en el mismo número de ocasiones (cinco). $Y$ en cuarto lugar la efectividad en el estilo del liderazgo, que indica la capacidad del líder para adoptar el estilo de liderazgo más idóneo en cada situación de acuerdo a la competencia del colaborador (conocimiento y habilidad que posee a la hora de afrontar un objetivo o tarea), y a su compromiso, entendido como una combinación de su motivación, nivel de interés y entusiasmo, y de su confianza, seguridad a la hora de afrontar un objetivo o tarea.

Esta efectividad se considera “excelente”, “buena”, "justa" o "pobre" según el grado de correspondencia de la elección realizada con el estilo de liderazgo más idóneo en cada situación, de acuerdo a la competencia y el compromiso que requiere en cada caso. La efectividad ha tomado el valor de 20, que equivale a una mínima efectividad en el ejercicio del liderazgo, a 80 , que se corresponde con una máxima efectividad en el desarrollo del liderazgo.

Valores personales del líder. El SPV, herramienta utilizada en la recogida de información sobre esta variable, 
mide "valores" que no requieren necesariamente para su satisfacción de interacciones directas con otros ni, en general, del comportamiento de los demás (Gordon, 2010); es decir, el marco teórico de la herramienta sostiene que el comportamiento personal puede ser suficiente para evaluar los "valores" característicos de un líder de acuerdo a la importancia relativa que concede a diversas actividades. Es importante hacer mención a que los "valores" que utiliza Gordon para construir su escala fueron formulados en una época (Gordon, 1960) en la que el concepto “valor" difiere del vigente en la actualidad. No obstante hemos considerado que su planteamiento satisface los requisitos exigidos por la investigación porque no invalida su poder psicométrico, aunque en el marco teórico actual se trate más bien de competencias genéricas, rasgos de personalidad y características comportamentales.

A la hora de evaluar la forma en que los líderes prefieren afrontar sucesos de la vida cotidiana o las tareas laborales, el SPV excluye comportamientos patológicos, delictivos y otros claramente desviados (Gordon, 2010).

Los "valores" que mide el SPV y que han sido estudiados en la investigación son seis: practicidad, resultados, variedad, decisión, metas y orden y método.

Uno es practicidad, asociado a la persona que quiere conseguir lo mejor de su dinero, cuidar de sus propiedades 0 pertenencias y sacarle fruto, y hacer cosas que le den beneficio. Ha tomado el valor de 0 , como practicidad 
mínima, a 30, como valor que refleja una máxima practicidad.

Otro es resultados, e indica que la persona prefiere afrontar problemas difíciles, tener un trabajo complicado al que enfrentarse, abordar algo importante tratando de encontrar la perfección, superarse constantemente y hacer un trabajo excelente en cualquier cosa que intente. Ha tomado el valor de 0 a 30.

Un tercer "valor" estudiado es variedad, que hace referencia a la persona que valora hacer cosas que sean nuevas y diferentes, tener experiencias variadas, visitar lugares extraños o inusuales y tener la experiencia de riesgo. Ha tomado el valor de 0 a 30 .

Un cuarto "valor" es decisión, que alude a la persona que prefiere las convicciones fuertes y firmes, tomar decisiones rápidamente, ir directamente al tema, hacer que su posición sea clara, y llegar a una decisión y mantenerse en ella. Ha tomado el valor de 0 a 28.

Otro es metas, que hace referencia a la persona que prefiere tener una meta definida hacia la que trabajar, mantenerse en un problema hasta que esté resuelto, dirigir el esfuerzo propio hacia objetivos bien delimitados y conocer con precisión en qué uno está pensando. Ha tomado el valor de 0 a 30.

Y el último valor es orden y método, que describe a la persona que desea tener hábitos de trabajo bien organizados, colocar sus cosas en el lugar correcto, ser una 
persona ordenada, tener un enfoque sistemático en sus actividades y hacer las cosas de acuerdo a un plan. Ha tomado el valor de 0 a 32.

Actitud del líder frente a la Responsabilidad Social Corporativa. Se ha diseñado una escala de Thurstone con la colaboración de diversos jueces para medir, a través de 19 juicios sobre las organizaciones y la Responsabilidad Social Corporativa, cómo de favorable es la actitud del líder hacia la Responsabilidad Social Corporativa a partir de su posición favorable o desfavorable en cada uno de los ítems. La escala ha tomado el valor de 0 , que corresponde a la actitud más desfavorable, a 8,6 , que indica la actitud más favorable.

Pregunta de control. Dentro del SPV se ha introducido una pregunta de control para verificar la validez de los resultados de la investigación relacionados con la actitud manifestada por los líderes hacia la responsabilidad social.

En dicha pregunta, como en el resto del SPV, el líder ha tenido que elegir dos enunciados, de tres posibles, que representaran lo más importante y lo menos importante en relación con la cuestión planteada. De este modo han indicado el orden de importancia concedido a tres ítems: "conseguir que mi organización sea rentable", "desarrollar políticas de responsabilidad social en mi organización" y “conseguir que mi organización sea líder en el mercado”. 
En relación con la organización, se han contemplado como variables independientes el sector en el que la organización realiza su actividad y su tamaño.

Sector de actividad de la organización. Hace referencia al sector en el que las organizaciones operan. Ha tomado los valores: "servicios (en el que se incluye el comercio)", “construcción" e “industria”.

Tamaño de la organización. Hace referencia al tamaño de la organización en función del número de empleados que la integran. Ha tomado los valores "pequeña (1-9 integrantes)", “mediana (10-250 integrantes)" y "grande" (más de 250 integrantes)".

\subsubsection{Variables dependientes}

Este estudio presentó como variable dependiente la realización de acciones de Responsabilidad Social Corporativa por parte de la organización. Dentro de estas acciones también se han registrado, de forma independiente, las horas dedicadas a la formación de los públicos internos en materia de responsabilidad social por parte de la organización.

Realización de acciones de Responsabilidad Social Corporativa por parte de la organización. Con esta variable se ha pretendido conocer si la organización realiza acciones de Responsabilidad Social Corporativa y, en caso afirmativo, el grado de integración de dichas acciones 
dentro de una política de Responsabilidad Social Corporativa en la organización. Ha tomado los valores: “no” y "sí”. En caso de respuesta afirmativa se solicitaba indicar si se trataba de acciones puntuales, de acciones frecuentes que no formaban parte de una política definida de Responsabilidad Social Corporativa o de acciones integradas dentro de una política de actuación definida en el marco de la Responsabilidad Social Corporativa.

Dedicación de horas de formación al año a la responsabilidad social. Hace referencia al tiempo que cada organización dedica a formar a sus integrantes en materia de Responsabilidad Social Corporativa. Ha tomado los valores: "no" y "sí". En caso de respuesta afirmativa, se ha solicitado una estimación del número de horas anuales que la organización de procedencia del líder invierte en la formación encuadra en el ámbito de la responsabilidad social. 


\subsection{PROCEDIMIENTO}

Inicialmente se ha realizado una revisión de fuentes documentales que, además de facilitar el desarrollo del marco teórico de la investigación, ha permitido orientar la formación de un criterio idóneo para seleccionar los instrumentos más adecuados en la medición de cada una de las variables.

A continuación se han recogido datos de líderes organizacionales a través de los tres instrumentos seleccionados, el LBA II, el ARS19 y el SPV, con objeto de conocer su estilo de liderazgo, sus actitudes ante la Responsabilidad Social Corporativa y sus valores personales.

Desde el comienzo del trabajo de campo, la realización de las entrevistas se ha acogido a los criterios establecidos por ADEMO (Asociación Española de Estudios de Mercado y Opinión) y al Código $\mathrm{CCl}$ Esomar para la realización de estudios de mercado y sociológicos. Asimismo, se ha garantizado el anonimato y la confidencialidad de las respuestas, de acuerdo con la Ley Orgánica 15/1999, de 13 de diciembre, de Protección de Datos de Carácter Personal.

El proceso de recogida de datos se ha iniciado en diciembre de 2011 y ha finalizado en junio de 2013. 
Cuando ha comenzado la recogida de datos ha existido un desencanto generalizado en las empresas. Tanto los trabajadores como los gestores estaban volviendo a planteamientos anteriores.

Los autores de la investigación entienden que, considerando el momento en el han sido recogidos los datos sobre responsabilidad social, se ha producido una contingencia que ha afectado al modo de concebir esta materia por parte de los líderes organizacionales que han sido entrevistados.

La selección de los líderes se ha realizado a través de una selección muestral aleatoria. Inicialmente se ha intentado establecer una muestra al azar representativa de los diferentes sectores en análisis (industria, servicios y construcción). Sin embargo las dificultades encontradas en cada caso han derivado en que hayamos elaborado una muestra, que se puede calificar de incidental, y en la que se ha procurado que el tamaño y, en menor medida, el sexo, hayan estado suficientemente representados.

Los datos se han recogido a través de una entrevista estructurada $y$, en mínimos casos, mediante el correo electrónico (en el anexo 5 hemos incorporado el cuadernillo de recogida de información utilizado en las entrevistas).

Los datos han sido recogidos de líderes de empresas ubicadas en España. Algunas provincias han tenido una especial representación en la investigación (Castilla y León, 
Aragón, Madrid, Galicia y Asturias) por contar con un mayor número de líderes empresariales próximos a personas cercanas a los responsables de la investigación.

La recogida de datos ha supuesto un proceso muy laborioso y complicado que ha seguido la pauta de actuación que detallamos a continuación.

En primer lugar se ha acudido a actos a los que han asistido los líderes empresariales, en dichos eventos se ha buscado una posición preferente en los descansos y en su finalización. En dichos actos se ha entrado en contacto con líderes a través de una presentación personal, en la que se ha entregado una tarjeta indicativa del rol laboral de profesor universitario de uno de los responsables del estudio. Además se ha presentado la investigación como un proyecto de $\mathrm{I}+\mathrm{D}+\mathrm{i}$ desarrollado conjuntamente por la Universidad de Valladolid y la Universidad San Jorge, en el que se ha ofrecido la posibilidad de participar.

Dado el número de ítems considerados en el diseño de la entrevista, 218, no ha sido posible realizar la misma en el momento de presentación del estudio (el tiempo mínimo en el que ha sido realizada una entrevista en todo el proceso de recogida de información ha sido 25 minutos, siendo lo habitual entre 40 y 60 minutos), y lo que se ha buscado es concertar un encuentro personal.

Pese a los esfuerzos, el índice de respuesta obtenido a través de esta vía ha sido prácticamente nulo. 
También se ha optado por presentar la investigación directamente en las organizaciones en las que ha sido posible contactar con el máximo responsable. En dicho encuentro se ha indicado que la participación en la investigación le permitiría disponer de datos estratégicos clave como resultado del estudio (como las tendencias actuales en responsabilidad social o el perfil de los líderes frente a la Responsabilidad Social Corporativa).

Tanto en la elaboración de listados de empresas medianas y grandes con las que entrar en contacto, como en la difusión de la oferta para participar en el estudio han colaborado algunas instituciones aragonesas (como la Confederación de Empresarios de Zaragoza, la Confederación de Empresarios de Aragón o la Fundación Basilio Paraíso de Zaragoza).

En el caso de las empresas pequeñas se han utilizado algunos refuerzos para motivar la participación en la investigación dado que su disposición inicial a participar en el estudio fue prácticamente nula. En este sentido se ha tratado de insistir, cuando se había detectado inicialmente una mínima disposición favorable, e incluso, en algunos casos, se ha comprado algún tipo de producto o servicio para incentivar la participación del líder en el estudio. En alguna ocasión, en la que se había comprado algún producto, el líder incluso rechazó realizar la entrevista una vez que esta hubo comenzado (a pesar de que siempre se ofrecía la posibilidad de continuar la recogida de información en otro momento). Un argumento que hemos 
esgrimido a la hora de evaluar este tipo de actuaciones ha sido que los líderes organizacionales no han tenido plena confianza en el carácter confidencial de los datos que suministraban.

Los esfuerzos realizados por esta vía han dado un fruto reducido en las empresas pequeñas, y prácticamente nulo en las empresas medianas y grandes.

Otra alternativa que se ha utilizado para recoger datos ha sido acceder a líderes empresariales a los que se conocía con anterioridad al diseño del estudio. El índice de respuesta obtenido por esta vía ha sido moderadamente satisfactorio.

También se ha explorado la posibilidad de contactar con líderes empresariales a través de personas cercanas a estos.

El protocolo de actuación seguido en este caso ha comenzado con la elaboración de un listado de contactos personales con posibilidades de tener acceso a líderes empresariales. A continuación hemos intentado acceder a estas personas, a través del teléfono o por correo electrónico, para conocer, en cada caso, el número de líderes organizacionales a los que pueden tener acceso. El siguiente paso ha sido concretar los datos del líder, los de su organización y la forma de hacer referencia a la persona que había facilitado el acceso al líder. Finalmente hemos 
contactado con la empresa utilizando la información recabada.

Esta es la vía que ha permitido la realización del mayor número de entrevistas en el caso de los líderes de pequeñas empresas, de bastantes entrevistas de máximos responsables en las organizaciones medianas y de algunos líderes de empresas grandes.

En relación con los resultados alcanzados por este último modo de actuación, hemos de indicar que el hecho de que el líder adquiriera un compromiso con alguien cercano ha sido uno de los factores clave a la hora de satisfacer los requerimientos del trabajo de campo exigidos por esta investigación. De todos modos cerrar la participación del líder en la investigación solo fue posible, en algunos casos, a través de regalos o comidas.

Como estrategia final, se realizó una presentación de la investigación en grandes empresas con una política de responsabilidad social reconocida.

De acuerdo con este modo de proceder hemos elaborado una base de datos de empresas con una política de responsabilidad social en marcha, a través de la información publicada por la Red Española de Pacto Mundial. A continuación hemos indagado a través del teléfono y de Internet para conocer los datos de contacto de los líderes empresariales. El siguiente paso ha sido enviar un sobre por correo postal dirigido al líder empresarial en el 
que, además de una tarjeta personal, hemos aportado una carta de presentación del estudio en la que hemos reconocido la política de responsabilidad social que desarrolla su organización y hemos indicado que su empresa ha sido seleccionada para participar en el estudio. Finalmente hemos contactado con el máximo responsable de la organización para verificar si había recibido la documentación y para concertar un encuentro en el que realizar la entrevista.

Esta vía ha permitido la realización de bastantes entrevistas de líderes de empresas grandes. El índice de respuesta que hemos obtenido por esta vía ha estado próximo al $5 \%$ sobre el total de envíos postales realizados. 


\subsection{INSTRUMENTOS}

Los instrumentos de recogida de información, como ya hemos mencionado, han sido una escala para conocer la actitud hacia la Responsabilidad Social Corporativa por parte de los máximos responsables organizacionales (ARS19), un cuestionario para conocer sus valores personales (SPV) y un cuestionario para conocer su estilo de liderazgo (LBA II).

\subsubsection{Escala ARS19}

El instrumento para conocer la actitud de los líderes organizacionales ante la Responsabilidad Social Corporativa es una escala de Thurstone creada ad hoc. Se trata de una escala de actitudes experimentales integrada por juicios, cada uno de los cuales tiene un valor o puntuación que ha sido establecido experimentalmente con ayuda de un equipo de jueces (Sierra, 2008).

Hemos tratado, en primer lugar, diversos aspectos relacionados con la escala (algunos supuestos teóricos que exige asumir su utilización, ciertos aspectos fundamentales que es necesario considerar en su diseño y el rango final de valores posibles en la escala que hemos construido). Al final del apartado hemos incorporado algunas aportaciones sobre 
las críticas que se han formulado en relación con la utilización de este tipo de escalas.

La utilización de una escala de Thurstone para medir la actitud ha exigido la asunción de varios supuestos (Thurstone, 1976, 263-268).

En primer término nos ha exigido adoptar una forma de entender la actitud y la opinión. El concepto de "actitud" como un conjunto de inclinaciones 0 sentimientos, prejuicios o tendenciosidades, nociones preconcebidas, ideas, temores y convicciones de un líder respecto a la responsabilidad social. Y el concepto de “opinión” como la expresión verbal de una actitud del líder frente a la Responsabilidad Social Corporativa.

En segundo lugar nos ha obligado a aceptar que las opiniones no son datos confiables para orientarse respecto a las tendencias subjetivas y preferencias que configuran la actitud de una líder hacia la responsabilidad social, ya que el máximo responsable ha podido mentir. Por tanto se han utilizado sus opiniones solo en su carácter de índice de su actitud hacia la responsabilidad social. $Y$ hemos tenido que aceptar que ha existido una discrepancia, algo así como un error de medición, entre la opinión del líder y la actitud que se ha inferido.

Por otra parte también hemos tenido que asumir que la verdad se infiere solo a partir de la relativa coherencia de diversos índices, ya que nunca se la conoce directamente. Hemos intentado hacer frente a esta 
objeción midiendo de dos modos la actitud del líder hacia la responsabilidad social. Por un lado hemos postulado una variable de actitud que ha participado del carácter de continuo abstracto. $\mathrm{Y}$ por otro hemos hallado un índice que posea coherencia interna para evaluar la actitud del líder hacia la responsabilidad social.

Además también hemos tenido presente que medir la actitud de un líder tal como se manifiesta al aceptar o rechazar opiniones sobre la responsabilidad social no ha implicado que el líder, necesariamente, actúe de acuerdo con las opiniones que ha apoyado. Se supone que es importante conocer lo que los líderes dicen creer en la medición de actitudes, aun cuando su conducta no sea coherente con las opiniones que han sustentado.

Sea como fuere hemos otorgado validez a la medición porque se ha medido, al menos, la actitud que los líderes desean que les adjudiquen los demás. $\mathrm{Y}$ hemos utilizado la escala en una situación en la que ha sido razonable esperar que los líderes digan la verdad acerca de sus convicciones u opiniones hacia la responsabilidad social, ya que la presión sobre la actitud medida en los espacios cerrados en los que se han realizado la gran mayoría de las entrevistas ha sido mínima.

También hemos dado por sentado que las actitudes de las personas están sujetas al cambio. Es decir, hemos contemplado que la actitud de un líder respecto a la Responsabilidad Social Corporativa puede variar de un día para otro, aunque las variaciones también pueden 
atribuirse, parcialmente, a errores en las mediciones. En este sentido se ha asumido un error estándar de medición en la información recogida a través de la escala ARS19 y en las fluctuaciones de la actitud del líder hacia la responsabilidad social.

Por otra parte ha sido necesario que la medición implicara un continuo lineal de alguna clase para evitar que las opiniones que puedan dar los líderes sean multidimensionales. En la práctica hemos solucionado esta objeción con el concepto de escala que permite evaluar las actitudes a través de juicios del tipo “más o menos”, en un determinado continuo (explícito o implícito) y dentro de unos límites (que han sido los que han establecido los extremos de las mediciones).

De acuerdo a los supuestos anteriores, la actitud de un líder hacia la responsabilidad social ha quedado representada por medio de "un punto en el continuo de actitud". Aunque teóricamente la cantidad de actitudes que pueden representarse a lo largo de dicha escala serían infinitas, en términos prácticos la actitud no es más que una cierta extensión o sector de estrechos límites dentro de la escala (Thurstone, 1976, 271).

Para identificar las distintas actitudes hacia la responsabilidad social ha sido necesario utilizar un conjunto de opiniones como puntos de demarcación entre los distintos segmentos o intervalos de la escala. De este modo la escala final ha consistido en una serie de enunciados de 
opinión, cada uno de los cuales ha recibido una posición específica (Thurstone, 1976, 274).

En la construcción de la escala de actitudes se han tenido en cuenta los requisitos indicados por Thurstone (1976, 278-281).

En este sentido se ha elaborado una amplia lista de enunciados representativos de actitudes hacia la responsabilidad social que cubran, en la medida de lo posible, todas las graduaciones de un extremo a otro de la escala en relación con la actitud de los líderes hacia la Responsabilidad Social Corporativa y que manifiesten una especial atención a los enunciados neutros.

Además se han redactado los enunciados teniendo presentes los criterios prácticos aportados por Thurstone: ser lo más breves posible, para que los líderes no se fatiguen; que permitan apoyarse o rechazarse según concuerden o no con la actitud del líder, salvo algunos enunciados que serán formulados de tal modo que el lector no pueda expresar su apoyo o rechazo definitivo por ellos; tener la cualidad de que su aceptación o rechazo indique algo de la actitud del líder hacia la Responsabilidad Social Corporativa reduciendo, en lo posible, el juicio personal al mínimo; y evitar enunciados que contengan dos argumentos.

Posteriormente hemos seleccionado los enunciados que pueden ubicarse en la escala. El conjunto inicial de ítems seleccionados en la escala ARS19 ha sido 33, de los que 11 han sido considerados como juicios negativos hacia la Responsabilidad Social Corporativa, 11 han sido 
catalogados como juicios neutros respecto a la responsabilidad social y 11 han sido seleccionados por suponer que respondían a una visión positiva de la Responsabilidad Social Corporativa.

Otro requisito importante que también hemos respetado para dotar de validez al instrumento ha sido solicitar a 10 jueces preseleccionados que ordenaran los enunciados en nueve posiciones. Estas cubrían desde las opiniones más intensamente positivas, hasta las más intensamente negativas.

A continuación hemos construido la escala a partir de los enunciados que fueron ubicados por todos los jueces, en cada caso, en tres posiciones contiguas. El número de ítems que han satisfecho este criterio ha sido 19.

Además, en la construcción final de la escala ARS19 se ha tenido presente la directriz específica indicada por Thurstone relacionada con la pretensión de que el instrumento sea efectivo hacia los extremos, es decir, que los enunciados de la escala trasciendan bastante en ambas direcciones.

Para calcular la puntuación que ha obtenido cada líder en la escala hemos sumado los valores de las proposiciones que ha aceptado y hallado su media (Sierra, 2008). El valor final de cada ítem ha sido determinado por la media de las puntuaciones otorgadas por los jueces (Thurstone, 1976).

El espectro de opiniones que los líderes han apoyado en cada caso ha conducido al establecimiento de su actitud 
hacia la Responsabilidad Social Corporativa, valoración que se ha correspondido con el siguiente rango: 0 , que ha representado la actitud más desfavorable, a 8,6, que se ha correspondido con la actitud más favorable.

Las puntuaciones asignadas a los ítems de la escala también han permitido determinar la tolerancia en la actitud hacia la Responsabilidad Social Corporativa. Este cálculo se ha realizado a través de la "desviación estándar de los valores de escala" de los enunciados que cada líder ha apoyado (Thurstone, 1976, 289).

Una de las críticas principales que se han formulado a las escalas de tipo Thurstone es que la valoración hecha por los jueces puede no ser adecuada para el grupo al que se aplique finalmente la escala (Sierra, 2008, 377).

Esta objeción se ha procurado satisfacer seleccionando un grupo de jueces multidisciplinar en el que también han estado presentes líderes organizacionales (experto en investigación de mercados y organizaciones, experto en psicología y consumo, experto en Responsabilidad Social Corporativa y ONG's, empresario con políticas definidas de Responsabilidad Social Corporativa, experta en relaciones públicas, empresario que realiza acciones de Responsabilidad Social Corporativa, experto en economía y dirección empresarial, experto en administración y dirección de empresas, y dos expertas en reputación corporativa). 
Otra de las críticas que se han realizado a este tipo de escalas de actitudes es que no discriminan a las personas que alcanzan una misma puntuación cuando los ítems que han aceptado han sido distintos (Sierra, 2008, 377).

Hemos asumido esta objeción como una limitación, sin embargo hemos considerado que este hecho no ha afectado a los objetivos de esta investigación porque la escala ha permitido cuantificar la actitud de los líderes respecto a la responsabilidad social.

Además hemos considerado que esta limitación ha sido compensada, en parte, con la información cualitativa que este tipo de escalas sí ofrecen. En concreto con la posibilidad de conocer la heterogeneidad de la actitud del líder hacia la responsabilidad social a través del cálculo de las desviaciones estándar que se han obtenido en cada caso (Thurstone, 1976).

\subsubsection{Cuestionario SPV}

El cuestionario que ha sido seleccionado para conocer los valores de los líderes es el Cuestionario de Valores Personales o Survey of Personal Values (SPV), en su cuarta edición, desarrollado por L.V. Gordon en 1967.

La adaptación española ha sido realizada por $\mathrm{N}$. Seisdedos, con la colaboración de F. Abad, y el Departamento de I+D de TEA Ediciones en 1996 (Gordon, 2010). 
El SPV ha permitido evaluar los siguientes "valores" en el líder: practicidad, resultados, variedad, decisión, metas y orden y método. Como ya hemos indicado en la descripción de las variables, esta medida sigue los estándares y el rigor debido que permiten respaldar su utilización en base a su poder psicométrico. De todos modos se ha de tener presente la evolución del concepto "valores", que en la actualidad y en Europa hace referencia a "representaciones cognitivas de necesidades universales que se expresan a través de metas que trascienden a situaciones y objetos, y que se ordenan en una estructura dinámica con carácter jerárquico" (Arciniega, 2001).

En relación con este planteamiento, Gordon ofrece unas definiciones de los valores inexactas en el contexto científico actual. En la aproximación vigente sus valores serían considerados más propiamente competencias genéricas, rasgos de personalidad y características comportamentales. No obstante hecha esta aclaración, seguiremos adelante con la nomenclatura de Gordon sin detenernos más en la discrepancia ya que su propuesta resulta interesante para el estudio.

Hemos tratado a continuación algunos aspectos relevantes relacionados con la construcción del instrumento y otras consideraciones sobre la adaptación española del SPV. 
Algunas consideraciones que se han tenido en cuenta en el desarrollo de la herramienta han sido (Gordon, 2010, 11):

1. Concebirse para investigar la forma en la que las personas prefieren afrontar los sucesos de la vida cotidiana o las tareas laborales.

2. Centrarse en el campo de aplicación de las conductas llamadas normales; por lo tanto, se excluyeron los comportamientos patológicos, delictivos y otros claramente desviados.

3. Considerar dimensiones que presenten un razonable grado de variabilidad de respuestas en diversos subgrupos de la población. De acuerdo con este planteamiento, los contenidos han tenido que ser importantes, al menos, para una proporción significativa de esos subgrupos. Para lograr este objetivo se han utilizado muestras variadas en la construcción del instrumento.

4. Partir de teorías e investigaciones previas más destacadas en diferentes entornos para la inclusión de los constructos. En concreto el SPV ha revisado los factores aislados en los análisis de Guilford, Christensen, Bond y Sutton (1954) y Guildford, Frick y Merrifield (1957); el esquema de valores ideado por White (1951) y las dimensiones de valor-trabajo de Money (1941). 
5. Conseguir simplicidad en la descripción y la medida de cada constructo, para lo que se ha procurado que cada uno de los aspectos incluidos sea razonablemente independiente del resto. Para satisfacer este criterio se ha empleado el análisis factorial y se ha obtenido una estructura ortogonal en la que los elementos del test han estado claramente relacionados con cada dimensión. En las revisiones posteriores necesarias para determinar las escalas, el criterio más importante para la selección de un elemento ha sido que éste tuviera un elevado grado de relación con una sola de las dimensiones establecidas.

6. Atender a la importancia relativa que la persona atribuye a cada uno de los valores estudiados, teniendo presente que habían sido considerados, en conjunto, favorable y socialmente aceptables. Por este motivo fue especialmente indicado el uso del formato de elección forzosa para la selección de las respuestas.

En su desarrollo inicial la herramienta ha estado compuesta por siete constructos hipotéticos: "practicidad", “resultados”, “variedad”, “decisión”, “orden y método”, “metas” y “comprensión”.

Este último, que aludía a la valoración de los conocimientos y al desarrollo intelectual, ha sido finalmente descartado tras el análisis factorial realizado a las 
respuestas dadas por una muestra de universitarios a las siete escalas iniciales de 175 elementos (Gordon, 2010, 13).

En cuanto al proceso de selección de triadas para evaluar los constructos, se ha obtenido un índice de deseabilidad social en cada elemento de la primera edición experimental y se han reunido dichos ítems formando tríadas; en cada tríada se han representado distintos factores $y$, en la medida de lo posible, se ha procurado que sus elementos hayan sido equivalentes en cuanto a deseabilidad social.

Esa edición y sucesivas han sido aplicadas a escolares de enseñanza media, a estudiantes universitarios y a adultos profesionales.

En cada revisión, las tríadas se han organizado de modo que proporcionaran un mayor equilibrio en las preferencias por los “valores", así como una optimización de las correlaciones de cada elemento con su escala respectiva en distintas muestras.

Finalmente se han seleccionado las tríadas que demostraron una adecuada capacidad discriminativa (es decir, todos sus elementos contribuían a la fiabilidad de sus respectivas escalas) en todas las distintas muestras analizadas (Gordon, 2010).

En la adaptación española se ha perseguido el objetivo de medir unos "valores" que sean significativos y 
discriminativos en amplios segmentos de la población y en los que no influya significativamente su deseabilidad social.

Por ello se ha procurado descubrir si se mantenía la misma significación y capacidad discriminativa de los elementos que en la población estadounidense.

Con este objetivo se han cuidado los aspectos de traducción de los elementos para que resultaran comprensibles y semánticamente significativos en relación con la variable que representaban (Gordon, 2010, 13).

Además también se ha realizado un estudio de la deseabilidad social para observar si se conseguía un equilibrio en las elecciones de las alternativas de respuesta a los diferentes elementos de cada tríada, a parte de los estudios de fiabilidad y validez que suelen realizarse en las adaptaciones (Gordon, 2010, 13).

Para la fiabilidad del instrumento en su versión española (Gordon, 2010) se ha empleado una muestra de aspirantes de ingreso a la universidad de 3.039 personas, de las que un $49 \%$ han sido varones. Los resultados han sido:

\begin{tabular}{|l|c|c|c|c|c|c|}
\hline \multirow{2}{*}{ Escala } & \multicolumn{2}{c|}{ Coeficientes } & \multicolumn{3}{c|}{ Relaciones entre los elementos } \\
\cline { 2 - 7 } & Alfa & $\begin{array}{c}\text { Dos } \\
\text { mitades }\end{array}$ & Media & Mínima & Máxima & Rango \\
\hline P (Practicidad) & 0,59 & 0,60 & 0,008 & $-0,07$ & 0,40 & 0,48 \\
\hline A (Resultados) & 0,58 & 0,63 & 0,008 & $-0,10$ & 0,31 & 0,42 \\
\hline V (Variedad) & 0,87 & 0,87 & 0,32 & 0,15 & 0,49 & 0,33 \\
\hline D (Decisión) & 0,58 & 0,56 & 0,09 & $-0,06$ & 0,37 & 0,43 \\
\hline O (Orden y método) & 0,75 & 0,77 & 0,15 & $-0,06$ & 0,42 & 0,49 \\
\hline G (Metas) & 0,73 & 0,74 & 0,15 & $-0,08$ & 0,42 & 0,50 \\
\hline
\end{tabular}

Cuadro 43: Coeficiente de fiabilidad y relaciones entre los elementos del SPV (N=2.399). Fuente: Gordon (2010). 
Estos resultados han sugerido diversas cuestiones (Gordon, 2010, 21-22).

En primer lugar que "variedad" (V), “orden" (O) y "metas" $(G)$ son las escalas más fiables, con índices superiores a 0,70 .

Además también indican que los coeficientes son solo moderadamente altos en todas las escalas (al menos superiores a 0,55). De todos modos es necesario tener en cuenta el reducido número de elementos utilizado para la obtención de los índices (16 en la escala “orden”, 14 en "decisiones" y 15 en las demás escalas) y que son medidas de "valores" desde el prisma planteado por Gordon (1960), es decir, aspectos de la personalidad más inestables que los aptitudinales.

Por otra parte las relaciones entre los elementos, que han sido indicadas a través de la cohesión o consistencia interna de cada elemento con todos los demás mediante dos coeficientes, han sugerido una homogeneidad moderada en las escalas. Su rango total va desde $-0,10$ a 0,49 y, agrupados todos los elementos de cada escala, el resultado es siempre positivo.

Es también un dato satisfactorio del SPV el hecho de que casi todos los elementos han contribuido significativamente a la fiabilidad de la escala (las excepciones observadas se tratan precisamente en aquellos elementos que menos han correlacionado con el resto de los de su escala). En el supuesto de una eliminación de estos 
elementos poco satisfactorios la ganancia en fiabilidad no supera las dos centésimas.

Aunque los datos estadounidenses no son directamente extrapolables a las muestras españolas (sus coeficientes han sido algo menores), el tamaño de los índices obtenidos en ambas culturas (americana y española) han sugerido que las personas que cumplimentan el SPV son consistentes en sus respuestas y de manera similar en las dos poblaciones, aunque estas tengan una estructura diferente de valores (Gordon, 2010, 23).

Este es un aspecto relevante del SPV si se contemplaran futuras extrapolaciones de los resultados obtenidos en este estudio con líderes españoles al contexto norteamericano, o se realizaran comparaciones entre ambos contextos utilizando esta medida.

En cuanto al estudio de la deseabilidad social del SPV, esta se ha calculado a través de la media de respuesta de cada elemento (que puede oscilar entre 0 y 2 puntos).

Una vez calculada se ha obtenido la media de las medias de los elementos de cada escala. En dicho cálculo se observa que dichos promedios se sitúan alrededor del ámbito de la media (entre 0,70 y 1,30 ), lo cual parece indicar que ninguna de las seis escalas del SPV destaca por su deseabilidad social. Además también muestra que el valor medio más bajo aparece en la escala "variedad" (V), 0,69, y el más alto en la escala "metas" (G), 1,29 (Gordon, 2010). 
En la siguiente tabla pueden observarse los resultados de este análisis:

\begin{tabular}{|l|c|c|c|c|c|c|c|c|}
\hline \multirow{2}{*}{ Escala } & \multicolumn{4}{|c|}{ Valores medios } & \multicolumn{5}{c|}{ Desviaciones típicas } \\
\cline { 2 - 10 } & Media & Mínimo & Máximo & Rango & Media & Mínima & Máxima & Rango \\
\hline P (Practicidad) & 0,88 & 0,60 & 1,36 & 0,76 & 0,73 & 0,63 & 0,81 & 0,18 \\
\hline A (Resultados) & 1,05 & 0,14 & 1,77 & 1,63 & 0,73 & 0,40 & 0,84 & 0,44 \\
\hline V (Variedad) & 0,69 & 0,38 & 1,08 & 0,70 & 0,73 & 0,59 & 0,82 & 0,23 \\
\hline D (Decisión) & 1,17 & 0,54 & 1,56 & 1,02 & 0,76 & 0,66 & 0,84 & 0,18 \\
\hline O (Orden y método) & 0,91 & 0,52 & 1,30 & 0,78 & 0,76 & 0,59 & 0,85 & 0,26 \\
\hline G (Metas) & 1,29 & 0,90 & 1,60 & 0,70 & 0,74 & 0,59 & 0,84 & 0,25 \\
\hline
\end{tabular}

Cuadro 44: Análisis de los elementos del SPV (N=2.399). Fuente: Gordon (2010).

En relación con la capacidad discriminativa del SPV se observa que, si se atiende la variabilidad de los elementos, es aceptable dado el escaso rango de variación (entre 0 y 2).

Las medias de los índices del cuadro 44 (primera columna de la mitad izquierda) son mayores de 0,68 y el índice más bajo se encuentra en la escala de "resultados" (A), con 0,14 , pero no hay elementos poco discriminativos por tener una variabilidad baja (Gordon, 2010, 23).

En lo referido al estudio de correlaciones entre variables realizado entre las diferentes escalas del SPV para una muestra de adolescentes $(\mathrm{N}=3.047$, de los que 1.571 son mujeres y 1.476 varones) y de adultos $(\mathrm{N}=618)$, no se han observado diferencias importantes entre ambos sexos.

Tal y como se había comprobado en la muestra original estadounidense de adultos, se ha advertido una cierta configuración bidimensional (dos ejes) en las escalas que ya había sido indicada por Gordon. 
El autor de la herramienta ha indicado que uno de los ejes tiene en un extremo a la "variedad" (V), polo etiquetado por Gordon como "Fluidez", y en el otro a “orden y método" y "metas", denominado por Gordon como “Organización". Este eje estaría relacionado con la socialización de las personas (grado en que estas se amoldan al orden y siguen unas metas prefijadas).

El segundo de los ejes del modelo tipológico de Gordon tiene en un extremo a la escala "practicidad", polo definido como "Seguridad", y en el otro a la variable “resultados" y a "decisión", polo denominado por Gordon como "Desafío". Este eje tendría que ver con el grado en que una persona tiende a plantearse problemas e inclinarse hacia el reto por el placer mismo que le proporciona la actividad (Gordon, 2010, 27).

Aunque los análisis factoriales de los componentes principales (rotación oblicua) y el estudio para analizar el efecto del sesgo provocado por la concurrencia de dos variables en una misma triada, ambos realizados en España, no reconocen los significados de las dimensiones superiores de una forma suficientemente clara, sí se podría suponer la existencia de una estructura general bidimensional y unas características personales asociadas a cada extremo de los ejes (Gordon, 2010, 28): 


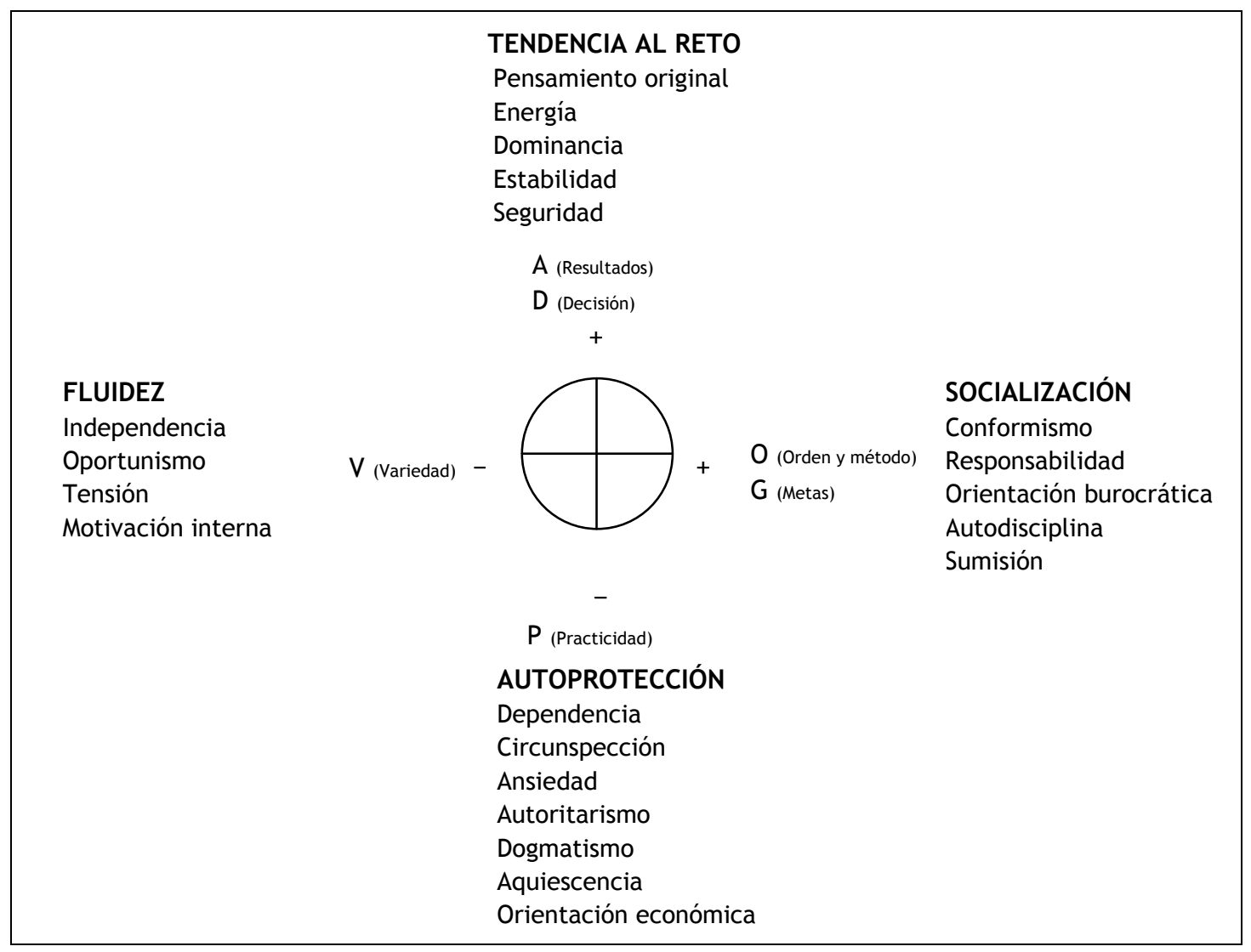

Figura 10: Estructura bidimensional subyacente en el SPV. Fuente: Gordon (2010).

En cuanto a la validez del SPV es pertinente realizar observaciones sobre su validez de contenido y sobre su validez de constructo (Gordon, 2010, 30-43).

Respecto a su validez de contenido se ha intentado que los elementos del cuestionario surgieran de la literatura psicológica y fueran significativos (discriminativos) en diferentes muestras. De todos modos también habría sido deseable que en la adaptación española se hubiera recurrido al juicio de expertos (Gordon, 2010).

Respecto a la validez de constructo esta se ha analizado, en primer lugar, a través de su relación con otras 
variables $^{2}$ en una muestra de adolescentes -Test de Matrices Progresivas de Raven, Test de Flexibilidad Cognitiva y Cuestionario de Valores Interpersonales (SIV) ${ }^{3}$-, en una muestra de adultos -versión reducida del Test de Aptitudes Diferenciales (DAT) ${ }^{4}$, Cuestionario de Valores Interpersonales (SIV) y Perfil e Inventario de Personalidad $(P P G-I P G)^{5}-y$ en otra muestra de adolescentes -prueba factorial de inteligencia (IGF, nivel medio), una de tipo espacial (Rotación de Figuras Macizas) y otra de razonamiento mecánico (DAT-MR) -.

El conjunto de índices de correlación estudiados ha sugerido que las relaciones entre el SPV y las medidas aptitudinales son prácticamente nulas entre los adolescentes.

Además ha indicado que en la muestra de adultos hay pequeñas relaciones negativas con la variable "orden", sobre todo en aptitud numérica $(-0,20)$.

También ha reflejado que existe otra variable del SPV implicada también en lo aptitudinal aunque en menor grado, "resultados", con quien correlaciona positivamente. Las relaciones menores se han dado entre el "razonamiento

\footnotetext{
${ }^{2}$ Los cuadros con los resultados estadísticos del estudio de la validez sobre la relación del SPV con otras variables se encuentran en el anexo 6 "Tablas de validez del SPV".

${ }^{3}$ Valores estudiados por el SIV (Cuestionario de Valores Interpersonales): S (Estímulo), C (Conformidad), R (Reconocimiento), I (Independencia), B (Benevolencia) y L (Liderazgo).

${ }^{4}$ Capacidades analizadas por el DAT (Test de Aptitudes Diferenciales): VR (Razonamiento verbal), AR (Razonamiento abstracto), NA (Aptitud numérica) y SR (Relaciones espaciales).

${ }^{5}$ Rasgos estudiados por el PPG-IPG (Perfil e Inventario de Personalidad): Asc (Ascendencia), Res (Responsabilidad), Est (Estabilidad emocional), Soc (Sociabilidad), Cau (Cautela), Ori (Originalidad), Com (Comprensión) y Vit (Vitalidad).
} 
espacial” y "variedad" (en sentido positivo) y "metas" (en sentido negativo).

Además, de acuerdo a los resultados, también parece confirmarse la existencia de relaciones significativas con medidas de personalidad (especialmente en la muestra de adultos). No son de gran tamaño pero algunas han alcanzado un índice moderadamente alto. De todos modos, hay que destacar que los valores han resultado ser bastantes independientes de los rasgos de personalidad y que el uso de los dos instrumentos (SPV y PPG-IPG) proporcionó informaciones complementarias (Gordon, 2010).

\begin{tabular}{|c|c|c|}
\hline Rasgo & Definición & Conexiones \\
\hline Ascendencia & $\begin{array}{l}\text { Persona que no se } \\
\text { amolda a las presiones } \\
\text { del grupo ni deja que } \\
\text { los demás tomen las } \\
\text { decisiones por ellas. }\end{array}$ & $\begin{array}{l}\text { Se relaciona negativamente con } \\
\text { "practicidad". } \\
\text { Tiene una vinculación positiva } \\
\text { con "decisión". }\end{array}$ \\
\hline Cautela & $\begin{array}{l}\text { Persona precavida que } \\
\text { considera } \\
\text { cuidadosamente todos } \\
\text { los detalles antes de } \\
\text { tomar una decisión. }\end{array}$ & $\begin{array}{l}\text { Se relaciona bastante con todas } \\
\text { las escalas del SPV } \\
\text { (exceptuando "practicidad" y } \\
\text { "resultados"). } \\
\text { L Las personas precavidas } \\
\text { puntúan bajo en: } \\
\text { - "variedad" (no les gusta la } \\
\text { experiencia del riesgo). } \\
\text { - y en "decisiones" (evitan } \\
\text { tomar una decisión rápida). } \\
\text { Ofrecen puntuaciones altas en } \\
\text { "orden" y "metas". }\end{array}$ \\
\hline Originalidad & $\begin{array}{l}\text { Persona que prefiere } \\
\text { trabajar en tareas } \\
\text { difíciles y se preocupa } \\
\text { por la adquisición de } \\
\text { conocimientos. }\end{array}$ & $\begin{array}{l}\text { Rasgo propio de personas que } \\
\text { puntúan bajo en "practicidad". } \\
\text { También es característico de } \\
\text { personas que puntúan alto en } \\
\text { "resultados". }\end{array}$ \\
\hline
\end{tabular}

Cuadro 45: Rasgos de personalidad que muestran conexiones significativas con las escalas del SPV. Fuente: Gordon (2010). 
En el cuadro 45 hemos indicado tres rasgos de personalidad (ascendencia, cautela y originalidad) y las conexiones significativas que han mostrado, de acuerdo al análisis desarrollado, con escalas del SPV.

El análisis que se ha realizado entre los dos instrumentos de medida de valores (SPV y SIV) aplicados en adolescentes y adultos, ha indicado que los índices son moderadamente bajos y apuntan a una discreta independencia de ambos test (aspecto razonable, ya que los dos instrumentos están especialmente diseñados para medir rasgos complementarios y no solapados de la conducta). Aunque hay múltiples relaciones significativas, estas son de tamaño moderadamente bajo si se exceptúa que la "conformidad" del SIV (hacer lo socialmente correcto) se relaciona negativamente con "variedad" (-43) y positivamente con "orden y método" (38), y que la "independencia" del SIV (actuar según el propio criterio) se relaciona positivamente con "variedad" (28) y negativamente con “orden y método" (-29) (Gordon, 2010).

A pesar de las divergencias encontradas en las diferentes muestras, parece evidente que la estructura bidimensional del modelo de Gordon es aplicable a las muestras españolas. 
La validez de constructo también se ha revisado a través de un análisis factorial del SPV con otras variables ${ }^{6}$. Gordon afirma que "las escalas pueden ser consideradas como categorías fiables y muy definidas desde el punto de vista factorial", ya que el SPV fue construido con la ayuda del análisis factorial de varias muestras (Gordon, 2010, 35).

\begin{tabular}{|c|c|}
\hline Dimensiones & Variables implicadas \\
\hline $\begin{array}{l}\text { Dimensión general } \\
\text { de inteligencia }\end{array}$ & $\begin{array}{l}\text { Mayor relación positiva con "razonamiento abstracto", aunque } \\
\text { también guarda correspondencia con "razonamiento verbal" y } \\
\text { "relaciones espaciales". } \\
\text { - En un menor grado también se relaciona positivamente con la } \\
\text { "responsabilidad", con la "estabilidad emocional" y con la } \\
\text { "originalidad". } \\
\text { - Correlaciona negativamente con la "conformidad". }\end{array}$ \\
\hline $\begin{array}{c}\text { Socialización o } \\
\text { conformidad con la } \\
\text { cultura frente a la } \\
\text { fluidez }\end{array}$ & $\begin{array}{l}\text { Mayor relación positiva con los "valores" "metas", el "orden" y } \\
\text { el "conformismo" y con los rasgos "cautela", "responsabilidad" } \\
\text { y "estabilidad emocional". } \\
\text { Correlaciona negativamente con "variedad" y muy } \\
\text { negativamente con "independencia". }\end{array}$ \\
\hline $\begin{array}{l}\text { Estabilidad de tipo } \\
\text { extravertido que } \\
\text { influye en algunos } \\
\text { de los valores } \\
\text { interpersonales }\end{array}$ & $\begin{array}{l}\text { Mayor relación positiva con los rasgos "sociable", } \\
\text { "ascendencia", "comprensión", "originalidad" y "estabilidad } \\
\text { emocional". } \\
\text { - Alta relación positiva con los "valores" "liderazgo" y } \\
\text { "benevolencia". } \\
\text { - Correlaciona negativamente con "independencia". }\end{array}$ \\
\hline Dependencia & $\begin{array}{l}\text { - Mayor relación positiva con "reconocimiento" y "estímulo". } \\
\text { Correlaciona negativamente con "independencia", } \\
\text { "conformidad" y "estabilidad emocional". }\end{array}$ \\
\hline Amabilidad & $\begin{array}{l}\text { - Mayor relación positiva con "benevolencia" y "comprensión". } \\
\text { - Correlación negativa con "liderazgo" y "reconocimiento". }\end{array}$ \\
\hline Socialización & $\begin{array}{l}\text { - Mayor relación positiva con "metas" y "comprensión". } \\
\text { - Correlación negativa con "resultados" y "vitalidad". }\end{array}$ \\
\hline $\begin{array}{l}\text { Tendencia al } \\
\text { desafío }\end{array}$ & $\begin{array}{l}\text { Mayor relación positiva con "decisión". } \\
\text { Correlación negativa con los "valores" personales de } \\
\text { "practicidad" y "orden". }\end{array}$ \\
\hline
\end{tabular}

Cuadro 46: Dimensiones factoriales del SPV y otras medidas y variables implicadas. Fuente: Gordon (2010).

${ }^{6}$ Los cuadros con los resultados estadísticos del estudio de la validez a partir del análisis factorial realizado del SPV con otras variables se encuentran en el anexo 6 "Tablas de validez del SPV". 
En la adaptación española, las seis escalas del SPV se han analizado factorialmente junto a otras medidas de valores, personalidad y aptitudes: el Cuestionario de Valores Interpersonales (SIV), el Perfil e Inventario de Personalidad (PPG-IPG) y el Test de Aptitudes Diferenciales (DAT). Las dimensiones ${ }^{7}$ obtenidas en dicho análisis y los factores implicados en cada uno se muestran en el cuadro precedente (46).

\subsubsection{Cuestionario LBA II}

El cuestionario que ha sido seleccionado para analizar el estilo de liderazgo de los máximos responsables empresariales es el LBA II.

El LBA (Leader Behavior Analysis) ha sido originariamente creado por Kenneth $\mathrm{H}$. Blanchard, Ronald K. Hambleton, Drea Zigarmi y Douglas Forsyth (1982) dentro del nuevo enfoque de la Teoría Situacional.

Una revisión de dicho instrumento, denominado LBA II, se ha correspondido con la presentación de la nueva orientación de la teoría denominada Teoría Situacional II (Blanchard, Zigarmi y Zigarmi, 1985; Carew, Parisi-Carew y Blanchard, K.H. 1986).

Inicialmente Hersey y Blanchard (1974) han desarrollado el LASI, Leader Adaptability and Style

\footnotetext{
${ }^{7}$ Las dimensiones han sido etiquetadas con números romanos en las tablas que los contemplan del anexo 6.
} 
Inventory, que en 1977 pasó a denominarse LEAD, Leader Effectiveness And Adaptability Description (1977). Este instrumento se ha diseñado para evaluar la percepción del comportamiento del líder, especialmente respecto al estilo del líder, el rango de estilos y la adaptabilidad del estilo (Sánchez y Rodríguez, 2010).

Se trata de una herramienta que presenta 12 situaciones empresariales en las que el líder debe escoger, en cada caso, una de las cuatro posibles soluciones que se presentan. Este instrumento tiene dos versiones: una para ser contestada por el líder y otra para que otras personas (superiores, iguales o colaboradores) determinaran esos mismos valores sobre el estilo del líder.

La herramienta también se acompaña de una escala de madurez que debe contestar el líder para determinar tanto el nivel de madurez de cada colaborador, como el nivel de desarrollo exigido para cada tarea u objetivo concreto de su trabajo. Es una herramienta que consta de ocho escalas y que mide las dos dimensiones que integran el nivel de desarrollo del colaborador (Sánchez y Rodríguez, 2010).

Además, a los dos instrumentos anteriores se les acompaña del perfil de percepción del poder. Se trata de una herramienta de 21 pares de afirmaciones de elección forzosa que describen cada una las siete bases de poder del líder (de acuerdo a la Teoría Situacional) y que recogen las razones por las que los colaboradores hacen lo que su líder les sugiere o quiere que hagan. 
De este último instrumento existen dos versiones según sea el propio líder u otras personas (superiores, iguales 0 colaboradores) quienes contesten este herramienta (Sánchez y Rodríguez, 2010).

En 1985 el LBA II ha ampliado el número de situaciones empresariales contempladas respecto al LEAD, de 12 se han pasado a 20, manteniéndose el formato de cuatro posibles opciones de respuesta en cada pregunta, entre las que el líder debe escoger la que considere más idónea para cada situación empresarial presentada (Blanchard, Zigarmi y Zigarmi, 1985).

El cuestionario ha sido reforzado con otra herramienta opcional, el LBA Il-other, dirigida a los colaboradores y superiores del líder (Blanchard, Zigarmi y Zigarmi, 1985).

Para analizar los diferentes tipos de líder en los que se enmarca la propuesta teórica que sustenta el LBA II, la herramienta estudia la utilización de cuatro estilos de liderazgo por parte del líder: directivo (comportamiento altamente directivo y que requiere poco apoyo), consultivo (comportamiento altamente directivo y que requiere mucho apoyo), participativo (comportamiento de alto apoyo que requiere poca dirección) y delegativo (comportamiento de poco apoyo y que requiere baja dirección).

Además también evalúa cuatro aspectos relacionados con la mayor o menor utilización de los estilos de liderazgo que hemos indicado. El LBA II permite obtener información 
sobre el estilo de liderazgo primario (estilo o estilos más utilizados), el estilo de liderazgo secundario (estilo o estilos más puestos en práctica en segundo lugar), la flexibilidad en el estilo de liderazgo (capacidad del líder para utilizar diversos estilos de liderazgo) y la efectividad en el estilo del liderazgo (capacidad del líder para adoptar el estilo de liderazgo más idóneo en cada situación).

Los criterios que permiten definir la idoneidad de las situaciones son la competencia del colaborador (conocimiento y habilidad que posee a la hora de afrontar un objetivo o tarea) y el compromiso del colaborador.

El compromiso es entendido como una combinación de dos aspectos: la motivación (nivel de interés y entusiasmo que posee el colaborador) y la confianza (seguridad a la hora de afrontar un objetivo o tarea).

Esta efectividad se considera "excelente", "buena”, "justa" o "pobre" según se corresponda la elección del estilo específico de liderazgo, en cada caso, con la competencia y el compromiso que resultan más idóneos en cada situación que plantea el LBA II.

Se han realizado investigaciones para verificar la validez del instrumento (Zigarmi, Edeburn \& Blanchard, 1991).

También se han desarrollado análisis de la fiabilidad del LBA II mediante seis estudios que han mostrado unos coeficientes de fiabilidad que van de 0.54 a 0.86 , con un valor medio de 0.74 (Zigarmi, Edeburn \& Blanchard, 1995). 
Aunque los investigadores habían encontrado problemas de fiabilidad con el LEAD y la escala había producido resultados que generaban desconfianza, el uso del test desde mediados de los años 80 del siglo XX ha mostrado una consistencia interna de 0.75 (Donovan, 2003). 


\subsection{POBLACIÓN}

El universo del estudio ha estado integrado por máximos responsables $y$, en algunos casos, altos directivos próximos a la responsabilidad social, de 20 o más años de edad, que están vinculados a organizaciones pequeñas (1 a 9 integrantes), medianas (10 a 250 integrantes) y grandes (más de 250 integrantes) que actúan en el mercado español, y que ejercen su labor en los sectores servicios (en el que se ha incluido el comercio), construcción e industria.

De acuerdo a los datos de Estructura y Demografía Empresarial establecidos por el Directorio Central de Empresas (Instituto Nacional de Estadística, 2012), en el año 2011 ha habido en España 214.992 empresas vinculadas al sector industria, de las que 32.225 han tenido 10 o más integrantes. Es decir, las empresas medianas y grandes de este sector han representado en el año 2011 el 15\%.

Además los datos también han indicado que en el 2011 han existido 462.402 empresas asociadas al sector de la construcción, de las que 19.086 han tenido 10 o más integrantes. Por tanto, las empresas medianas y grandes en el sector construcción han supuesto el $4,1 \%$ del tejido empresarial. 
La información estadística también ha indicado que se han registrado 773.657 empresas dedicadas al comercio en el 2011, de las que 25.985 tenían 10 o más integrantes. Es decir, las empresas medianas y grandes de este sector en el año 2011 han representado el 3,35\%.

De estos datos hemos concluido que el sector más representado en el tejido empresarial es el comercio (la suma del total de empresas del sector construcción e industria no llega al total de empresas dedicadas al comercio). En esta investigación hemos incluido el sector comercio dentro de la categoría "servicios".

También hemos deducido que el sector con menor número de empresas es el dedicado a la industria, aunque es el que presenta un mayor número de PYMES.

Por otra parte también hemos entendido que los datos indican que la gran mayoría del tejido empresarial español está formado por pequeñas empresas, de modo especial en el sector construcción $(95,9 \%)$ y en el sector comercio $(96,65 \%)$.

En cuanto al sexo de los máximos responsables y altos directivos de empresas (de acuerdo con los datos ofrecidos por el Ministerio de Sanidad, Servicios Sociales e Igualdad sobre la población activa según el tipo de ocupación) en el año 2012 el 30\% de las mujeres ha desempeñado el rol de “Directores y gerentes” (Instituto de la Mujer, 2012). 
Estos datos se han correspondido a los obtenidos en otros estudios (Gran Thorton, 2012, 5), que han indicado que las mujeres ocupan el $\mathbf{2 4 \%}$ de los cargos directivos en las empresas españolas de 100 a 500 integrantes. 


\subsection{MUESTRA}

A la hora de seleccionar la muestra - a pesar de las limitaciones, económicas, temporales, situacionales y geográficas que ha habido que atender- hemos seguido un criterio que permita garantizar su representatividad, tal y como hemos indicado en el apartado 5.4 (Procedimiento).

La muestra final ha estado integrada por 189 máximos responsables y altos directivos de empresas. Hemos considerado que se trata de número de entrevistas satisfactorio para contrastar las hipótesis de investigación.

A continuación hemos presentado la muestra en función de diversas variables.

\subsubsection{Sexo}

\begin{tabular}{|l|c|c|}
\hline & Casos & Porcentaje (\%) \\
\hline Mujer & 68 & 36 \\
\hline Hombre & 121 & 64 \\
\hline TOTAL & 189 & 100 \\
\hline
\end{tabular}

Cuadro 47: Sexo de la muestra.

Tal como refleja el cuadro 47, las mujeres que han formado parte de la muestra han sido 68 y los hombres que han participado en el estudio han sido 121.

Estos datos han significado que el $64 \%$ la muestra haya estado integrada por hombres y el $36 \%$ por mujeres. 
Se ha considerado que el hecho de que un 36\% de la muestra sean mujeres (68 casos en números absolutos), ha permitido satisfacer las exigencias de la investigación en relación con la variable "sexo" para realizar comparaciones entre hombres y mujeres. De acuerdo a los estudios consultados (Instituto de la Mujer, 2012; Gran Thorton, 2012), las mujeres en puestos directivos y de gerencia se encuentran por debajo de ese porcentaje a comienzos de la segunda década del XXI.

De todos modos, tal como habíamos esperado, el acceso a mujeres que respondan al rol de líder en la fase de recogida de información ha resultado más complicado a medida que ha aumentado el tamaño de las empresas.

\subsubsection{Edad}

A continuación hemos mostrado las franjas de edad en el siguiente gráfico (gráfico 1):

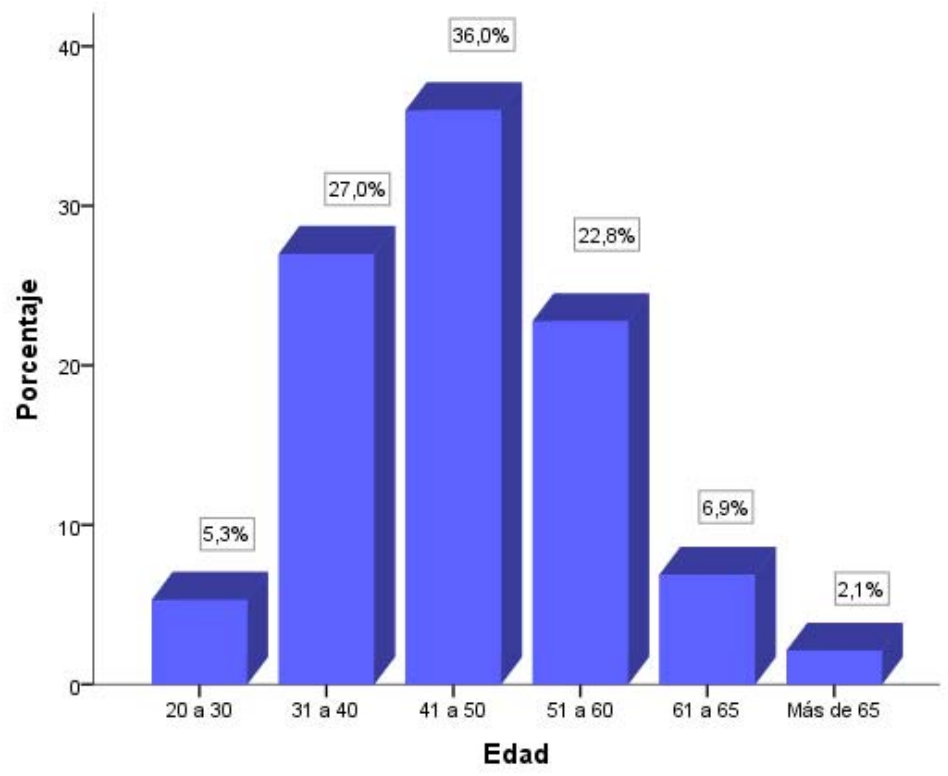

Gráfico 1: Edad de la muestra. 
De acuerdo con esta variable, los líderes con más protagonismo en la muestra son los que se encuentran entre los 31 y los 60 años, 162 personas. Este grupo, que supone el $85,8 \%$ de la muestra, hemos considerado que representa adecuadamente a los líderes más numerosos del ámbito empresarial.

Las franjas menos representadas en la muestra han sido la de 20 a 30 años, con 10 máximos responsables (un 5,3\% de la muestra), y la de más de 65 años, con 4 líderes (un 2,1\% de la muestra).

En la recogida de datos siempre se ha comprobado que el líder empresarial haya estado ejerciendo su rol en el momento de realización de la entrevista. En este sentido se ha descartado la colaboración de líderes recientemente retirados que se han ofrecido a participar en el estudio.

\subsubsection{Sector de procedencia}

\begin{tabular}{|l|c|c|}
\hline & Casos & Porcentaje (\%) \\
\hline Servicios (incluye comercio) & 141 & 74,6 \\
\hline Construcción & 14 & 7,4 \\
\hline Industria & 34 & 18,0 \\
\hline TOTAL & 189 & 100,0 \\
\hline
\end{tabular}

Cuadro 48: Sector de procedencia de la muestra.

Tal y como muestra el cuadro 48, el sector de actividad más representado en la muestra ha sido servicios $(74,6 \%)$, datos que se han correspondido con el mayor peso del ámbito comercial en el tejido empresarial español. 
El sector industria (34 líderes procedentes de este ámbito) ha estado menos representado (no alcanza al 20\% del total de la muestra) y los líderes de empresas pertenecientes al sector construcción han tenido una baja representatividad en la investigación (solo 14 líderes de este ámbito han accedido a realizar la entrevista). Esta menor representación de máximos responsables en estos dos últimos sectores de actividad, de modo especial en el ámbito de la construcción, ha venido motivada por la dificultad para seleccionar a líderes de pequeñas empresas procedentes de dichos sectores que estuvieran dispuestos a realizar la entrevista.

\subsubsection{Tamaño de las empresas}

Hemos incorporado el gráfico 2 para mostrar la distribución del tamaño de las organizaciones de procedencia de los líderes:

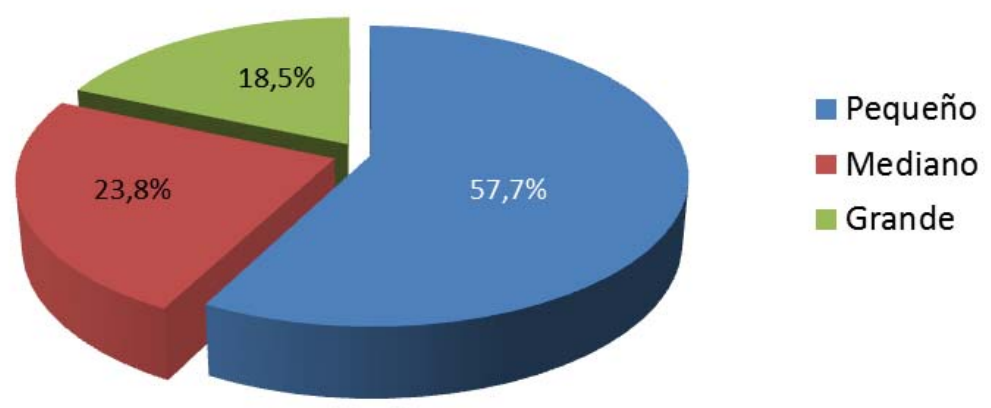

Gráfico 2: Tamaño de las empresas de la muestra. 
El tamaño más representado en la muestra $(57,7 \%)$ ha sido el de los líderes de las empresas pequeñas, organizaciones de 1 a 9 integrantes, con 109 casos.

Las empresas medianas, de 10 a 250 integrantes, han tenido una presencia en la muestra de casi el $24 \%$. En total han participado en la investigación 45 líderes de organizaciones procedentes de este tamaño empresarial.

La dificultad para conseguir líderes de empresas medianas, especialmente por la extensión de la entrevista y por el escaso tiempo disponible de los máximos cargos, ha sido un aspecto relevante al considerar que 45 líderes de organizaciones medianas constituyen un número suficientemente representativo para contrastar las hipótesis de la investigación.

Los líderes de empresas grandes, organizaciones de más de 250 integrantes, que han realizado la entrevista han sido 35 . Este número ha representado un $18,5 \%$ de la muestra.

Los problemas encontrados en las empresas medianas se han incrementado en el caso de las empresas grandes. A los inconvenientes anteriormente indicados se ha sumado, en muchos casos, la negativa de los máximos responsables empresariales a participar en procesos de recogida y análisis de información. Estos hechos han tenido incidencia al entender que 35 líderes de organizaciones grandes suponen 
un número suficientemente representativo para contrastar las hipótesis de la investigación.

La representación conjunta de las empresas medianas y grandes en la muestra ha sido del 42,3\% (80 líderes de los dos tamaños empresariales han participado en la investigación).

\subsubsection{Realización de acciones y formación sobre Responsabilidad Social Corporativa en las empresas}

En este caso también hemos incorporado un gráfico (gráfico 3) para mostrar la realización de acciones de responsabilidad por parte de las empresas de la muestra.

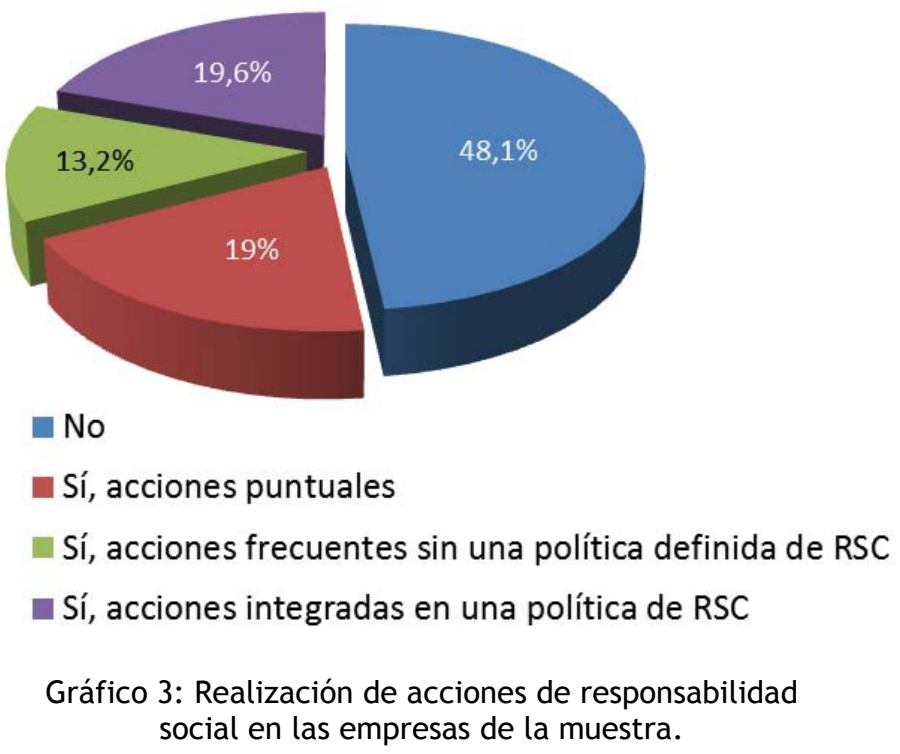

En primer término, algo que refleja claramente el gráfico, hemos destacado que casi la mitad de las 
organizaciones $(48,1 \%)$ no han realizado ningún tipo de acción de responsabilidad social (este porcentaje equivale a 91 empresas en términos absolutos). De todos modos este dato también ha indicado que más de la mitad de las empresas de la muestra (51,9\%, lo que supone 98 empresas) se ha implicado en algún tipo de acción vinculada a la Responsabilidad Social Corporativa. Dato que, teniendo en cuenta el momento económicamente difícil en el que se ha recogido la información, ha reflejado la importancia concedida a esta materia por parte de las organizaciones.

Si se realiza una valoración de los datos en función del grado de integración de las acciones de responsabilidad social en una política definida de Responsabilidad Social Corporativa, solo el 19\% de los líderes (37 empresas en términos absolutos) han manifestado que su organización tiene una política establecida en este ámbito.

El 32,8\% de los líderes (61 empresas) ha indicado que sus empresas realizan acciones de responsabilidad social, de modo frecuente o puntual, sin que estas se encuentren incluidas dentro de una política definida.

Estos datos han mostrado, en términos generales, que las organizaciones están sensibilizadas con la realización de acciones de responsabilidad social.

A continuación hemos incorporado el cuadro 49, que indica las empresas de la muestra que dedican horas a formar a sus colaboradores en esta materia: 


\begin{tabular}{|l|c|c|}
\hline & Casos & Porcentaje (\%) \\
\hline Forman en responsabilidad social & 39 & 20,6 \\
\hline No forman en responsabilidad social & 150 & 79,4 \\
\hline
\end{tabular}

Cuadro 49: Formación en responsabilidad social en las empresas de la muestra.

Los datos muestran que la gran mayoría de las organizaciones de procedencia de los líderes entrevistados, casi el $80 \%$, no dedican horas de formación a la responsabilidad social entre sus colaboradores.

Por otra parte hemos considerado que es un dato positivo que algo más de un $20 \%$ de las empresas hayan estado sensibilizando a sus colaboradores sobre aspectos relacionados con la responsabilidad social (o que hayan realizado acciones formativas enmarcadas en esta disciplina), teniendo presente que el proceso de recogida de datos se ha realizado en un momento de desencanto generalizado en el ámbito económico. Hemos entendido que este dato indica la existencia de un grado, aunque reducido al menos consolidado, de preocupación por sensibilizar a los colaboradores de las empresas en materia de Responsabilidad Social Corporativa.

A continuación hemos incorporado el gráfico 4 que muestra, de modo visual, el número de horas dedicadas a la formación en responsabilidad social dentro de las empresas de la muestra que han venido impulsando este tipo de acciones (39 casos): 


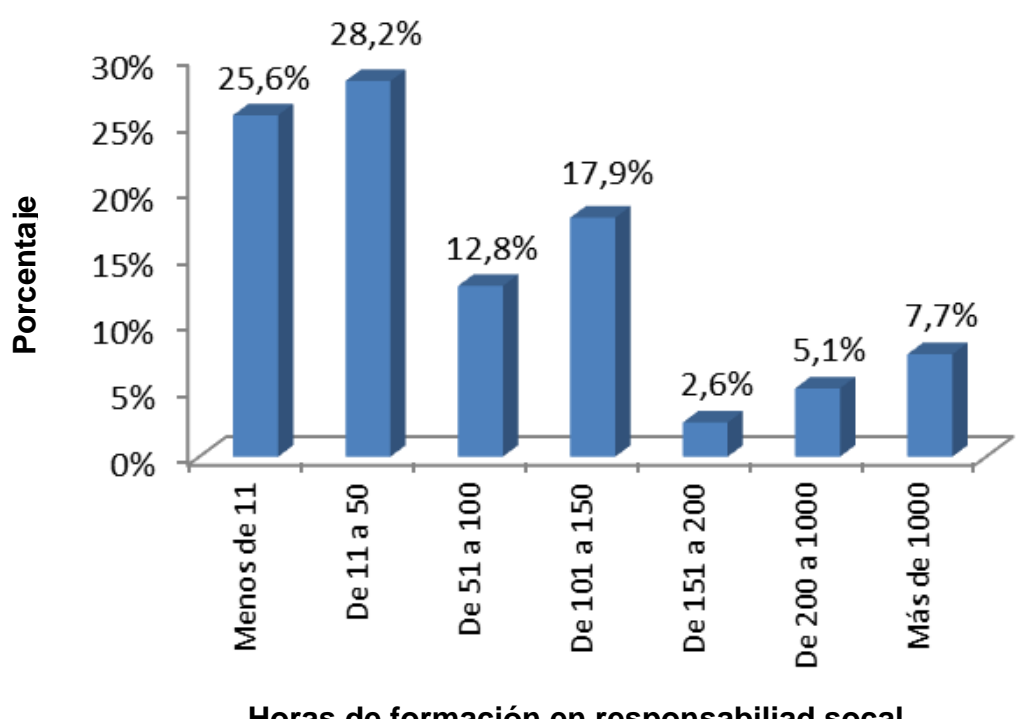

Horas de formación

Gráfico 4: Horas dedicadas a la formación en responsabilidad social en las empresas de la muestra.

Los datos han mostrado que más de la mitad de las organizaciones que realizan acciones de este tipo $(53,8 \%)$ han dedicado 50 o menos horas a la formación en responsabilidad social.

Además también han indicado que un $46,7 \%$ de las empresas han invertido 51 o más horas a formar en responsabilidad social a sus colaboradores. Hemos entendido que este número más elevado de horas dedicadas anualmente a acciones formativas encuadradas en el ámbito de la responsabilidad social indica la preocupación empresarial por concienciar a sus trabajadores en esta materia. De todos modos casi el $85 \%$ (84,5\%) de las empresas no han superado las 150 horas anuales dedicadas a acciones formativas sobre responsabilidad social.

En la recogida de datos, no todos los líderes entrevistados han compartido el mismo criterio en el cálculo 
de las horas de formación en responsabilidad social impulsadas por su organización.

En algunos casos los líderes solo han incluido las horas formativas que habían sido costeadas por sus organizaciones, ya sea de modo parcial o total, y en otros casos consideraron, además, las acciones que no habían sido pagadas por las empresas.

En relación con el contenido de dicha formación, aspecto que ha influido en el cálculo anual de horas dedicadas a la formación en responsabilidad social en cada caso, los líderes también han discrepado. La gran mayoría de los máximos responsables empresariales solo han contemplado los ámbitos de actuación más específicos de la responsabilidad social (medioambiental y social). Sin embargo los líderes también han incluido, en algún otro caso, las acciones formativas dirigidas a los colaboradores que estaban más directamente relacionadas con su desempeño profesional. 


\subsection{ANÁLISIS DE DATOS}

Durante el tiempo dedicado al desarrollo de las entrevistas, hemos ido aplicando la plantilla de corrección del cuestionario LBA II a los datos recabados sobre liderazgo y hemos realizado la corrección en línea del SPV.

Posteriormente hemos diseñado un archivo con el programa de cálculo SPSS 19 que permitiera introducir todos los datos de cada variable contemplada en el estudio.

Finalmente, una vez preparado el archivo, hemos incorporado todos los datos de la investigación y los hemos tratado estadísticamente a través del programa de cálculo SPSS 19. 
6 - RESULTADOS 

En este capítulo se han expuesto los resultados alcanzados en relación con los objetivos y las hipótesis planteadas. Han sido muchos los datos vinculados con las variables estudiadas que se han obtenido.

Hemos mostrado, en primer lugar, la información general referida a la actitud ante la responsabilidad social, a los "valores" personales y al liderazgo de los máximos responsables empresariales. Además, en este primer bloque, también hemos incluido los datos obtenidos sobre sexo, edad, sector, tamaño, liderazgo y "valores", en relación con actitud de los líderes organizacionales hacia la Responsabilidad Social Corporativa y con el comportamiento socialmente responsable en sus organizaciones de origen (tanto en términos genéricos como en relación con la actuación formativa de dichas organizaciones encuadrada en el ámbito de la responsabilidad social).

A continuación hemos reflejado los resultados comparativos a partir del sexo de los líderes, su edad, su liderazgo, el sector de las organizaciones en las que desempeñan su labor y el tamaño de dichas organizaciones, tomando en consideración en cada caso tanto la actitud hacia la Responsabilidad Social Corporativa de los máximos dirigentes empresariales como la conducta de su organización de procedencia en el ámbito de la responsabilidad social.

Finalmente hemos realizado un análisis de la medida mediante diversas revisiones de las relaciones entre las variables. 


\subsection{RESULTADOS GENERALES}

\subsubsection{Actitud ante la Responsabilidad Social Corporativa}

Tal y como se indicó en el apartado dedicado a las variables, el rango del valor que puede tomar la actitud en la escala ARS 19 va de 0, valor mínimo, a 8,6, valor máximo.

\begin{tabular}{|c|c|c|c|}
\hline Mínimo & Máximo & Media & Desv. típica \\
\hline 3,86 & 8,13 & 7,2043 & 1,05294 \\
\hline
\end{tabular}

Cuadro 50: Máximo, mínimo, media y desviación típica de la actitud.

En el cuadro 50 hemos indicado algunas medidas significativas registradas en el estudio sobre la actitud. En relación con los datos alcanzados hemos incorporado algunas consideraciones.

La media del valor de la actitud hacia la responsabilidad social de los líderes que han participado en la investigación ha sido alta $(7,2)$, lo que ha reflejado la existencia de una elevada sensibilidad hacia la responsabilidad social en la dirección empresarial.

El valor mínimo obtenido en el estudio $(3,86)$ ha indicado que existe una mínima concienciación en relación con la materia incluso en aquellos líderes que han 
presentado una actitud más negativa hacia la responsabilidad social.

La desviación estándar de los valores de la muestra en relación con la actitud hacia la responsabilidad social ha sido de 1,05. Este registro indica que la media es muy representativa y que, por tanto, refleja una sólida disposición favorable hacia la Responsabilidad Social Corporativa en los líderes empresariales.

Para profundizar en los datos recabados hemos realizado una segmentación del valor medio que la actitud ha recibido:

\begin{tabular}{|c|c|}
\hline Valor de la actitud & Porcentaje (\%) \\
\hline $\mathbf{0} \mathbf{a}<\mathbf{4}$ &, 5 \\
\hline $\mathbf{4} \mathbf{a}<\mathbf{5}$ & 3,7 \\
\hline $\mathbf{5} \mathbf{a}<\mathbf{6}$ & 12,2 \\
\hline $\mathbf{6} \mathbf{a}<\mathbf{7}$ & 16,4 \\
\hline $\mathbf{7} \mathbf{a} \mathbf{8}$ & 47,6 \\
\hline$>\mathbf{8}$ & 19,6 \\
\hline Total & 100 \\
\hline
\end{tabular}

Cuadro 51: Valor segmentado de la actitud hacia la responsabilidad social.

Los datos del cuadro 51 indican que la actitud hacia la responsabilidad social de tres cuartas partes de los líderes $(76,2 \%)$ se encuentra en tres segmentos de su valor medio: “5 a <6", “6 a <7", y “7 a 8".

Además los datos también reflejan que casi el $50 \%$ de los líderes $(47,6 \%)$ se han encontrado en el segmento "7 a 8”. Este es el segmento de puntuaciones más representado en la muestra. De todos modos también es relevante la 
representatividad de los segmentos superior e inferior al "7 a 8", indicativos de una actitud hacia la responsabilidad social favorable (segmento “6 a <7") y extremadamente favorable (segmento ">8"), ya que han supuesto un $36 \%$ de la muestra.

Esta disposición positiva frente a la responsabilidad social también se ve reflejada en el hecho de que casi dos tercios de los líderes $(67,2 \%)$ han mostrado una actitud que se encuentra en los segmentos "7 a 8 " y ">8".

Hemos entendido que la gran presión social que se ha producido desde finales del siglo XX por fomentar una disposición favorable hacia la responsabilidad social en la alta dirección de las empresas se ha visto reflejada en la información recabada en el estudio, tal como muestra el gráfico 5:

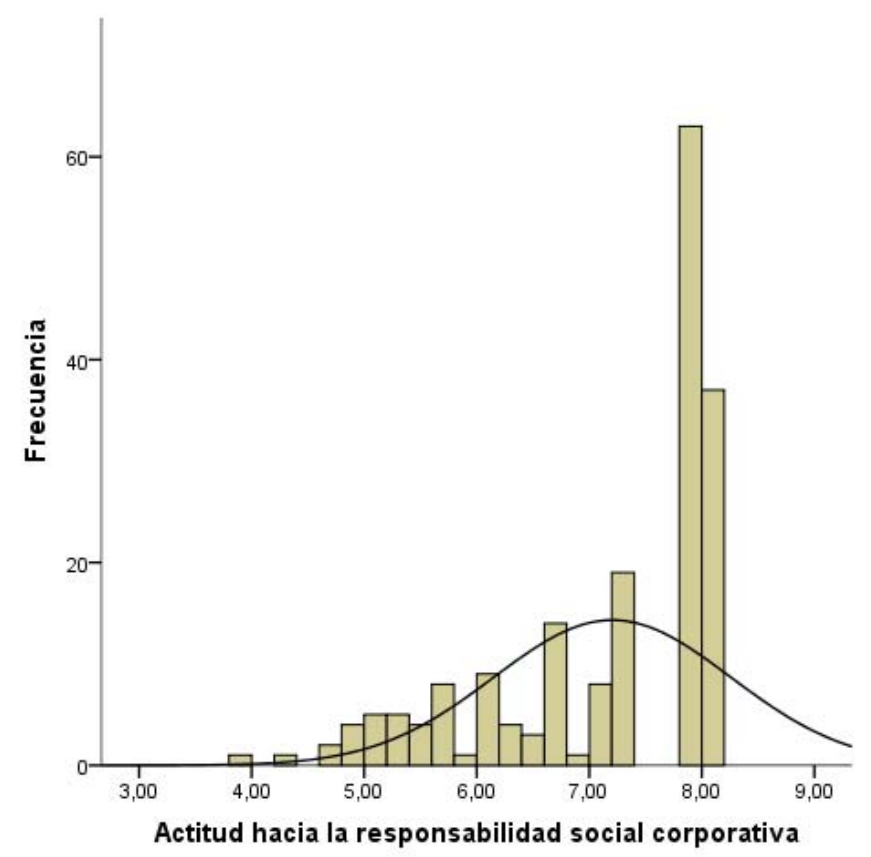

Gráfico 5: Histograma de las puntuaciones de la actitud hacia la responsabilidad social. 
También hemos valorado en este apartado la actitud de los líderes hacia las organizaciones en función de su comportamiento socialmente responsable, considerando tanto el desarrollo genérico de este tipo de acciones (gráfico 6) como contemplando como el impulso de acciones formativas, dirigidas a públicos internos, enmarcadas en el ámbito de la responsabilidad social (cuadro 53).

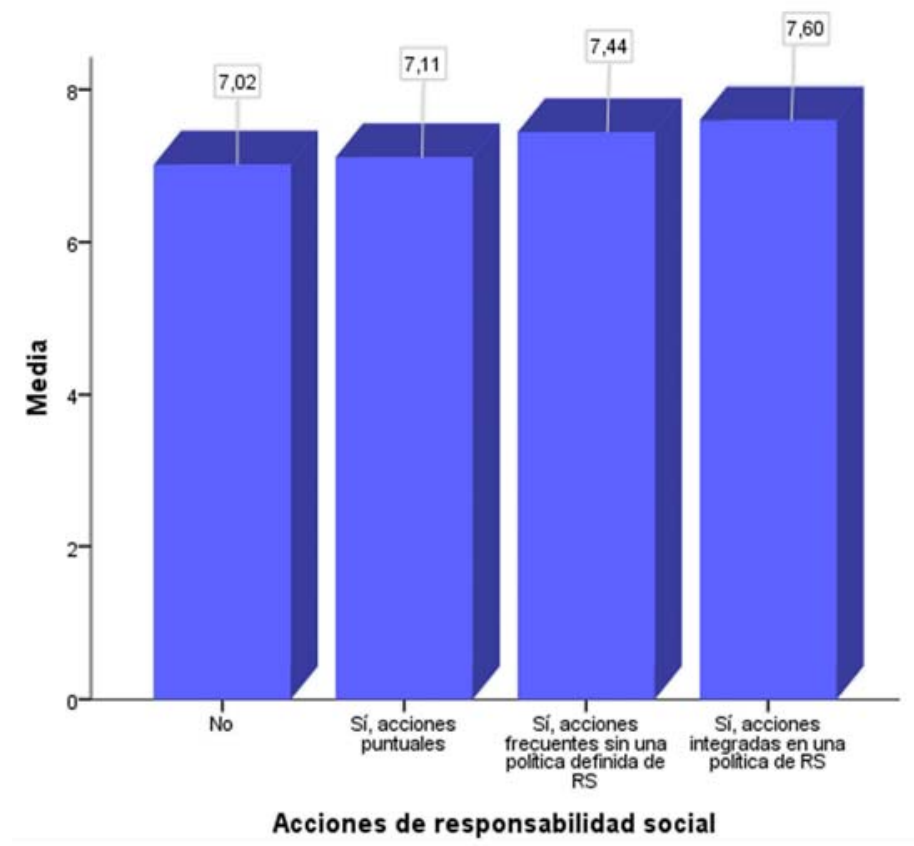

Gráfico 6: Actitud hacia la responsabilidad social y acciones de responsabilidad social.

Antes de hacer una valoración del gráfico 8 hemos aplicado ANOVA de un factor a los datos para verificar si existen diferencias estadísticamente significativas entre los diversos grupos considerados.

\begin{tabular}{|l|r|r|r|c|c|}
\hline & Suma de cuadrados & gl & Media cuadrática & F & Sig. \\
\hline Inter-grupos & 10,591 & 3 & 3,530 & 3,301 &, 022 \\
\hline Intra-grupos & 197,840 & 185 & 1,069 & & \\
\hline Total & 208,431 & 188 & & & \\
\hline
\end{tabular}

Cuadro 52: Tabla ANOVA de actitud hacia la responsabilidad social, factor Realización de Acciones de Responsabilidad Social. 
La información que ofrece el cuadro 52 indica que existen diferencias estadísticamente significativas entre los diversos grupos muestrales considerados porque el coeficiente de significación es menor de 0,05 $(0,022)$.

Según muestra el gráfico 8 , la actitud de los líderes empresariales hacia la responsabilidad social es mayor a medida que es más intenso el comportamiento socialmente responsable de su organización de origen.

Estos datos indican que existe una correspondencia entre ambos aspectos y que el grado de afinidad de los líderes hacia la responsabilidad, pese a la aceptación favorable que esta disciplina presenta en los máximos responsables organizacionales con independencia del comportamiento socialmente responsable de sus organizaciones de origen, parece ser un factor de influencia en el mayor grado de apuesta empresarial por la responsabilidad social.

\begin{tabular}{|l|r|r|r|r|}
\hline $\begin{array}{l}\text { Horas de formación en } \\
\text { responsabilidad social }\end{array}$ & Media & Máximo & Mínimo & Desv. típ. \\
\hline Menos de 11 & 7,2877 & 8,03 & 4,85 & 1,04418 \\
\hline De 11 a 50 & 7,7155 & 8,12 & 6,20 &, 60329 \\
\hline De 51 a 100 & 7,7175 & 8,10 & 7,24 &, 43442 \\
\hline De 101 a 150 & 7,1599 & 8,10 & 6,20 &, 86010 \\
\hline De 151 a 200 & 8,0000 & 8,00 & 8,00 & \\
\hline De 201 a 1000 & 7,0556 & 7,38 & 6,73 &, 45569 \\
\hline Más de 1000 & 8,0238 & 8,07 & 8,00 &, 04124 \\
\hline Total & 7,5035 & 8,12 & 4,85 &, 76661 \\
\hline
\end{tabular}

Cuadro 53: Medidas estadísticas de actitud hacia la responsabilidad social según formación en responsabilidad social. 
Hemos aplicado ANOVA de un factor en la información del cuadro 53, antes de analizarla, para verificar la posible existencia de diferencias estadísticamente significativas entre los diversos grupos muestrales considerados.

\begin{tabular}{|l|r|r|r|c|c|}
\hline & Suma de cuadrados & gl & Media cuadrática & F & Sig. \\
\hline Inter-grupos & 3,475 & 6 &, 579 &, 983 &, 453 \\
\hline Intra-grupos & 18,857 & 32 &, 589 & & \\
\hline Total & 22,332 & 38 & & & \\
\hline
\end{tabular}

Cuadro 54: Tabla ANOVA de actitud hacia la responsabilidad social, factor Formación en Responsabilidad Social.

La prueba de ANOVA (cuadro 54) indica que no existen diferencias estadísticamente significativas entre los diversos grupos muestrales contemplados (el coeficiente de significación es 0,453$)$.

En la valoración de la información que ofrece el cuadro 53 no hemos considerado, por su escasa representatividad (solo se ha recabado información de un líder), el grupo muestral de líderes procedentes de organizaciones que han impulsado acciones de responsabilidad social de 151 a 200 horas de duración.

Los datos indican que en la formación empresarial de corta extensión (entre 1 y 100 horas anuales), la actitud de los líderes de dichas organizaciones a favor de la Responsabilidad Social Corporativa se acentúa cuando los cursos superan las 11 horas. Los líderes procedentes de organizaciones que invierten menos de 11 horas en dichas acciones presentan una media en su actitud hacia la 
responsabilidad social de 7,28, mientras los máximos responsables cuyo origen son empresas que impulsan acciones de 11 a 50 horas de extensión y los líderes de organización vinculados a empresas que desarrollan acciones de 51 a 100 horas presentan una media en su actitud pro responsabilidad social de 7,71 en ambos casos.

Además también reflejan que las organizaciones que impulsan acciones de formación de elevada extensión (más de 1000 horas anuales), sus máximos responsables presentan una disposición más favorable hacia la responsabilidad social que la que presentan los líderes de organizaciones que desarrollan acciones de extensión menor.

Los máximos dirigentes procedentes de empresas que impulsan acciones de extensión intermedia (de 101 a 150 horas y de 201 a 1000 horas) han presentado la menor actitud hacia la responsabilidad social de todos los grupos considerados (su media ha sido, respectivamente, 7,16 y 7,05).

Los datos sobre la actitud hacia la responsabilidad social y el desarrollo de acciones formativas encuadradas en este ámbito han reflejado dos aspectos destacados: que la actitud de los líderes se acentúa cuando las iniciativas de formación de corta extensión promovidas por las empresas incrementan su duración y que la disposición de los líderes a favor de la responsabilidad social es muy intensa cuando las organizaciones se involucran en cursos de gran extensión. 
Como hemos indicado en el capítulo 5 (Metodología), en las preguntas del cuestionario sobre valores personales se han introducido tres ítems de control para filtrar los resultados obtenidos a través de la escala ARS 19.

El líder debía decidir, según la importancia que concediera a cada enunciado, el orden de los tres ítems que estaban integrados en la misma triada y que hacían referencia a: la búsqueda de rentabilidad por parte de su organización, el desarrollo de políticas de responsabilidad social y la persecución de liderazgo en el mercado.

En relación con el primer ítem, "Conseguir que mi organización sea rentable", los datos han sido:

\begin{tabular}{|l|c|}
\hline & Porcentaje (\%) \\
\hline Negativo & 7,9 \\
\hline Neutro & 27,5 \\
\hline Positivo & 64,6 \\
\hline TOTAL & 100 \\
\hline
\end{tabular}

Cuadro 55: Valoración concedida al ítem

“Conseguir que mi organización sea rentable".

Como muestran los datos, dos tercios de los líderes $(64,6 \%)$ han considerado que conseguir que su organización sea rentable es, dentro las tres alternativas, la prioridad más importante.

En un principio nos ha sorprendido que algunos líderes hayan situado este ítem en último lugar. Hemos entendido que uno de los motivos que han explicado este comportamiento, se encuentra en el hecho de que algunas de las organizaciones a las que los líderes representaban 
eran empresas fuertemente asentadas en el mercado y que, por tanto, ya asumían la capacidad para obtener rentabilidad como un rasgo de su organización consolidado.

En relación con el segundo ítem, "Desarrollar políticas de responsabilidad social en mi organización", los datos han sido:

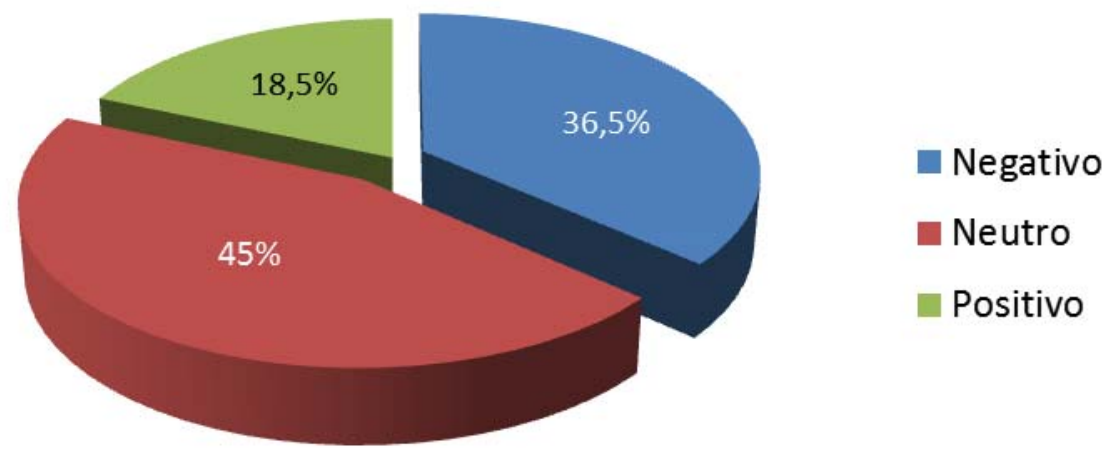

Gráfico 7: Valoración concedida al ítem "Desarrollar políticas de responsabilidad social en mi organización”.

Como muestra el gráfico 7 , el desarrollo de políticas de responsabilidad social en la empresa ha sido el ítem más valorado por casi un $20 \%$ de los líderes $(18,5 \%)$. Los datos recabados indican que ha sido elegido como segunda opción, descartando por tanto el liderazgo o la rentabilidad en la empresa, por un $36,5 \%$.

Los datos obtenidos con la pregunta de control sobre el ítem relacionado con la Responsabilidad Social Corporativa no han sido tan favorables como los obtenidos con la escala ARS 19 en relación con la actitud hacia la responsabilidad social de los máximos responsables empresariales aunque, en ambos casos, los registros son positivos. En la pregunta de control casi 2 de cada 3 líderes 
$(63,5 \%)$ han situado la responsabilidad social como una opción prioritaria o importante, observación en la que hemos de tener en cuenta que la selección de este ítem como segunda opción implicaba que se descartara bien la búsqueda de rentabilidad o bien la persecución de liderazgo en el mercado.

A la hora de comparar los datos de la escala ARS 19 con las puntuaciones obtenidas por el ítem "Desarrollar políticas de responsabilidad social en mi organización", hemos tenido presente que el sesgo también está justificado por la diferente medición que realiza cada instrumento. En el caso del ARS 19, se trata de una escala creada ad hoc para medir la actitud hacia la responsabilidad social de una forma precisa. Mientras que en el método de elección forzosa del ítem más valorado y el menos valorado en relación con tres opciones de respuesta, representa una medida muy general de la responsabilidad social que además ha estado limitada por la inclusión de dos alternativas de respuesta previamente establecidas en la triada.

Hemos entendido que estas consideraciones han condicionado la comparación objetiva de la información obtenida con ambas medidas.

En relación con el tercer ítem, "Conseguir que mi organización sea líder en el mercado", los datos se han mostrado en el cuadro 56: 


\begin{tabular}{|l|c|}
\hline & Porcentaje (\%) \\
\hline Negativo & 55,6 \\
\hline Neutro & 27,5 \\
\hline Positivo & 16,9 \\
\hline TOTAL & 100 \\
\hline
\end{tabular}

Cuadro 56: Valoración concedida al ítem "Conseguir que mi organización sea líder en el mercado".

Tal como muestra el cuadro 56 , solo el $16,9 \%$ de los líderes ha indicado que su primera opción es liderar el mercado con su organización, y más de la mitad ha situado esta preferencia como última alternativa.

Estos datos han indicado que para las empresas es mucho más prioritaria la búsqueda de rentabilidad en el mercado que de liderazgo aunque, aspecto al que hemos hecho referencia en los comentarios del primer ítem de control "Conseguir que mi organización sea rentable", algunas de las empresas de procedencia de los líderes ya disfrutaban de una posición de liderazgo consolidada en el mercado cuando se produjo la recogida de la información.

En la comparación conjunta de los datos registrados en los tres ítems es destacable que los líderes hayan concedido más importancia al desarrollo de acciones de responsabilidad social en su organización $(18,5 \%)$, que a la búsqueda de liderazgo en el mercado $(16,9 \%)$.

Estos datos han guardado correspondencia con los alcanzados con la escala ARS 19. 


\subsubsection{Valores de los líderes empresariales}

A través del cuestionario SPV se han evaluado seis "valores": "metas" (presenta un mínimo de 0 y un máximo de 30), "variedad" (tiene un mínimo de 0 y un máximo de 30), “decisión" (presenta un mínimo de 0 y un máximo de 28), "orden y método" (muestra un mínimo de 0 y un máximo de 32), "resultados" (tiene un mínimo de 0 y un máximo de 30) y "practicidad" (presenta un mínimo de 0 y un máximo de 30).

Los datos han sido los siguientes:

\begin{tabular}{|l|r|r|r|r|r|r|}
\hline & Practicidad & Resultados & Variedad & Decisión & $\begin{array}{c}\text { Orden y } \\
\text { Método }\end{array}$ & Metas \\
\hline Media & 13,70 & 14,80 & 8,31 & 16,62 & 16,21 & 20,15 \\
\hline Mediana & 14,00 & 15,00 & 7,00 & 17,00 & 16,00 & 20,00 \\
\hline Mínimo & 4 & 2 & 0 & 5 & 5 & 6 \\
\hline Máximo & 27 & 26 & 26 & 26 & 29 & 30 \\
\hline Desv. típ. & 4,197 & 3,907 & 5,632 & 4,203 & 5,321 & 4,644 \\
\hline Curtosis &,- 038 &, 806 &, 148 &,- 296 &,- 613 &,- 202 \\
\hline Asimetría &, 143 &,- 151 &, 850 &,- 256 &, 029 &,- 393 \\
\hline
\end{tabular}

Cuadro 57: Resultados de medidas estadísticas sobre los “valores”.

Según muestra el cuadro 57 existe un "valor" que ha recibido una puntuación media mayor (metas), dos que se encuentra en un segundo nivel medio de importancia (decisión y orden y método), dos que se sitúan en un tercer nivel de relevancia (practicidad y resultados) y un "valor" que ha registrado una trascendencia menor (variedad). 
Hemos comentado a continuación la información recabada en cada caso y hemos realizado una síntesis final sobre el perfil de los "valores" del líder en función de los datos alcanzados.

El "valor", de los seis estudiados, que ha recibido una puntuación más alta por los líderes, con bastante diferencia respecto al resto, ha sido la competencia genérica "metas". Hace referencia a tener una meta definida hacia la que trabajar, mantenerse en un problema hasta que este esté resuelto, dirigir el esfuerzo propio hacia objetivos bien delimitados y conocer con precisión en qué uno está pensando.

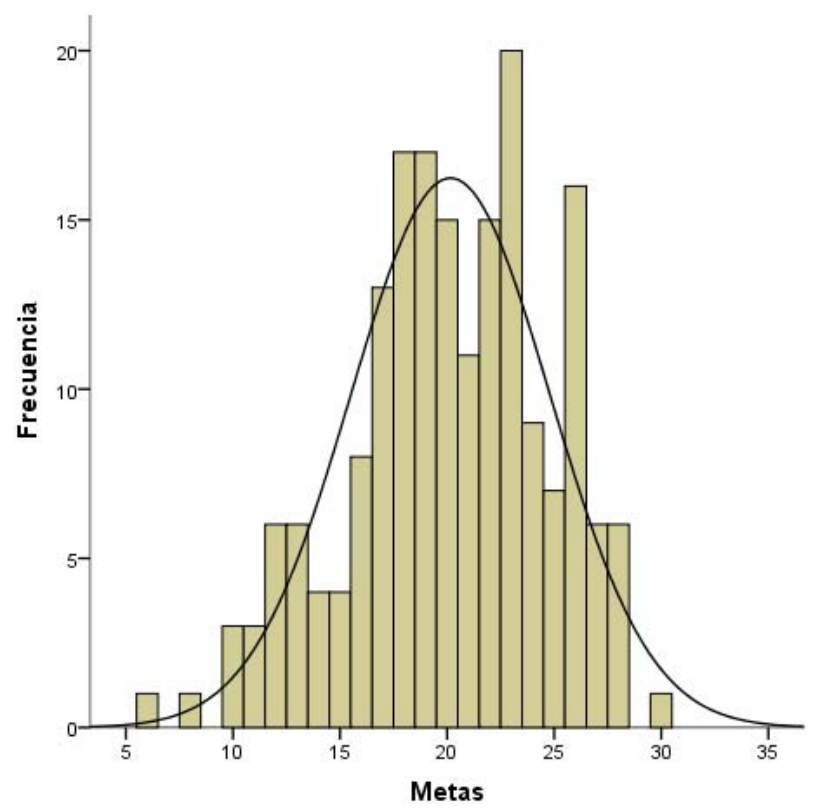

Gráfico 8: Histograma de las puntuaciones del “valor" “metas”.

Tal como refleja el gráfico 8 , la media de la competencia genérica "metas" $(20,15)$ indica la gran 
importancia que los líderes conceden a la disposición de objetivos perfectamente definidos en su actividad.

En el ámbito de la responsabilidad social hemos considerado que la competencia genérica "metas" es relevante para aquellos líderes que entienden la Responsabilidad Social Corporativa como una orientación hacia la que la empresa debe dirigirse.

"Variedad" es el rasgo de personalidad cuya media $(8,31)$ ha recibido, con bastante claridad, una puntuación menor respecto al resto de aspectos evaluados.

Hace referencia a la preferencia por hacer cosas que sean nuevas y diferentes, tener experiencias variadas, visitar lugares extraños o inusuales y tener la experiencia de riesgo.

En contraposición con los datos alcanzados en la competencia genérica "metas", hemos interpretado la información de "variedad" como un rechazo de los líderes a dedicar tiempo a actividades que no estén encaminadas a un fin productivo previamente definido.

A continuación hemos incorporado el gráfico 9, "Histograma de las puntuaciones del 'valor' 'variedad", con la distribución de frecuencias de los datos alcanzados por esta variable en los líderes empresariales entrevistados: 


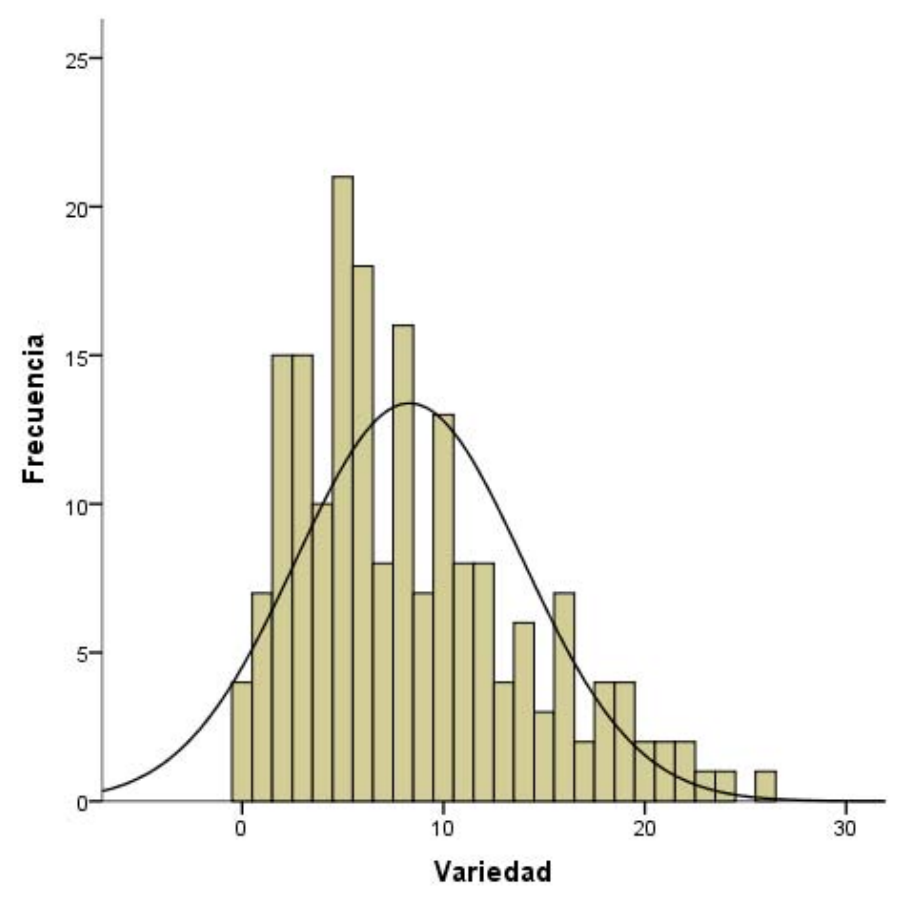

Gráfico 9: Histograma de las puntuaciones del "valor” “variedad”.

Aun siendo la desviación típica de "variedad" la mayor de las alcanzadas por todos las seis aspectos analizados $(5,632)$, hemos entendido que el resultado medio registrado por "variedad" es representativo como puntaje medio más reducido. La asimetría de la distribución de variedad $(0,850)$ indica que ha habido una mayor presencia de líderes por debajo de la media de "variedad" en la distribución.

En relación con la responsabilidad social, hemos entendido que el rasgo de personalidad "variedad" es relevante para los líderes que conciben el impulso de acciones en este ámbito como una actividad exótica o como algo que aporta diversidad a la dinámica empresarial.

La información alcanzada por el rasgo de personalidad "decisión" muestra que ha registrado la segunda media más alta $(16,62)$ de los seis aspectos evaluados. La fortaleza de 
este dato se ha visto reforzada por tratarse de la variable que ha podido obtener una menor puntuación máxima (la puntuación más elevada que puede alcanzar es 28 ).

"Decisión" hace referencia a una preferencia por las convicciones fuertes y firmes, por tomar decisiones rápidamente, por ir directamente al tema, por hacer que la posición personal sea clara, y por llegar a una decisión y mantenerse en ella.

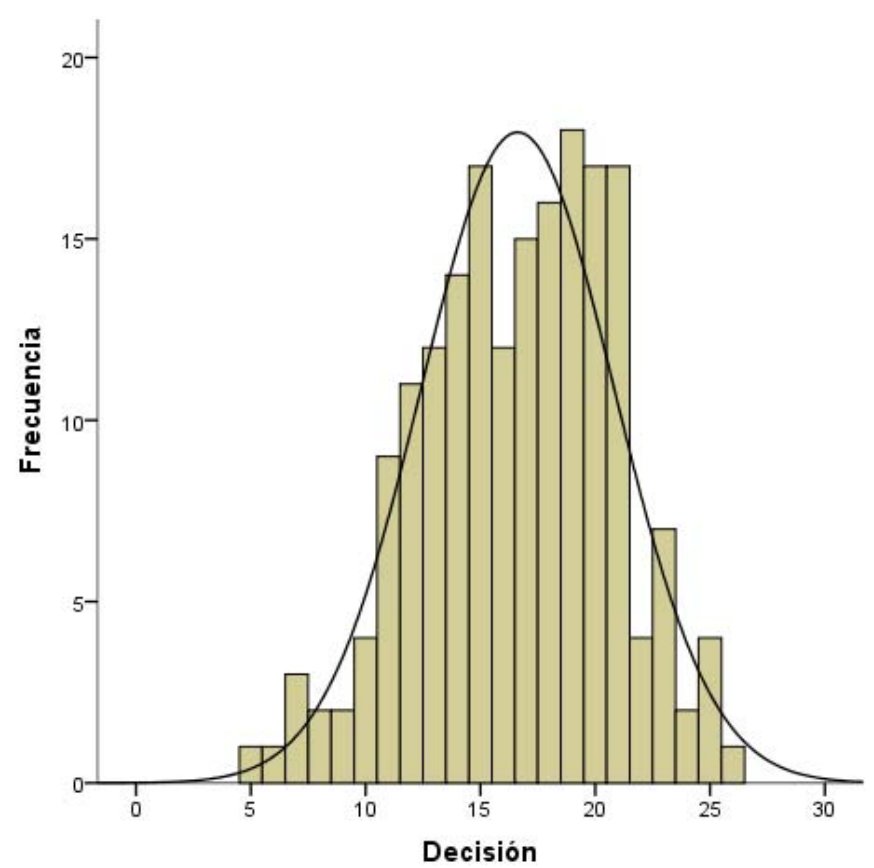

Gráfico 10: Histograma de las puntuaciones del "valor” “decisión”.

Según refleja el gráfico 10 , los datos han estado concentrados (la desviación típica ha sido 4,203) alrededor del puntaje medio $(16,62)$.

Hemos interpretado estos datos como una preferencia en el modo de alcanzar los objetivos delimitados por parte del líder, la firmeza.

En relación con la responsabilidad social, hemos entendido que el rasgo de personalidad “decisión" es 
relevante para los líderes que consideran que la Responsabilidad Social Corporativa representa una filosofía de trabajo claramente definida.

La característica comportamental "orden y método" ha conseguido la tercera media más alta de los seis aspectos analizados $(16,62)$. Resultado que se ve matizado por el hecho de que es el "valor" que ha permitido alcanzar una mayor puntuación (su puntaje máximo es 32 ).

"Orden y método" hace referencia al deseo de tener hábitos de trabajo bien organizados, colocar las cosas en el lugar correcto, ser una persona ordenada, tener un enfoque sistemático en las actividades y hacer las cosas de acuerdo a un plan.

Esta característica comportamental ha obtenido una desviación típica por encima de los 5 puntos $(5,321)$. Se trata de la segunda desviación típica más elevada después del rasgo de personalidad "variedad". Por este motivo hemos de tomar la media de "orden y método", aun siendo representativa, con cierta cautela al tratarse de una distribución con una leve curtosis $(-, 0613)$.

Las consideraciones indicadas se constatan visualmente en el gráfico 11: 


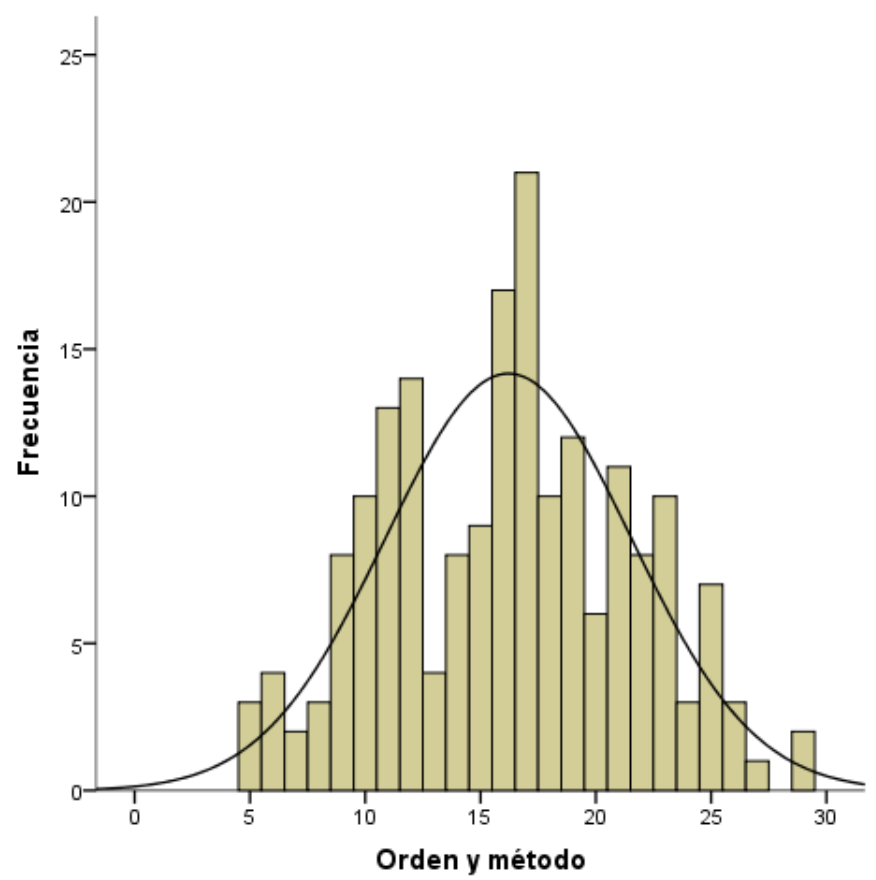

Gráfico 11: Histograma de las puntuaciones del "valor” “orden y método".

Hemos interpretado esta información también como otro matiz, no completamente generalizable, que caracteriza la manera en la que los líderes se enfrentan a la persecución de sus objetivos: el carácter metódico.

En relación con la responsabilidad social, hemos entendido que la característica comportamental "orden y método" es menos relevante para los líderes que valoran positivamente la responsabilidad social. De todos modos hemos considerado que la característica comportamental “orden y método" sí podría estar relacionada, al igual que ocurre con el rasgo de personalidad "decisión” (aunque en este caso en una menor medida), con una comprensión de la Responsabilidad Social Corporativa como una filosofía de trabajo.

La competencia genérica "resultados" ha alcanzado una puntuación media de 14,80. 
"Resultados" hace referencia a la preferencia por afrontar problemas difíciles, tener un trabajo complicado al que enfrentarse, abordar algo importante tratando de encontrar la perfección, superarse constantemente y hacer un trabajo excelente en cualquier cosa que se intente.

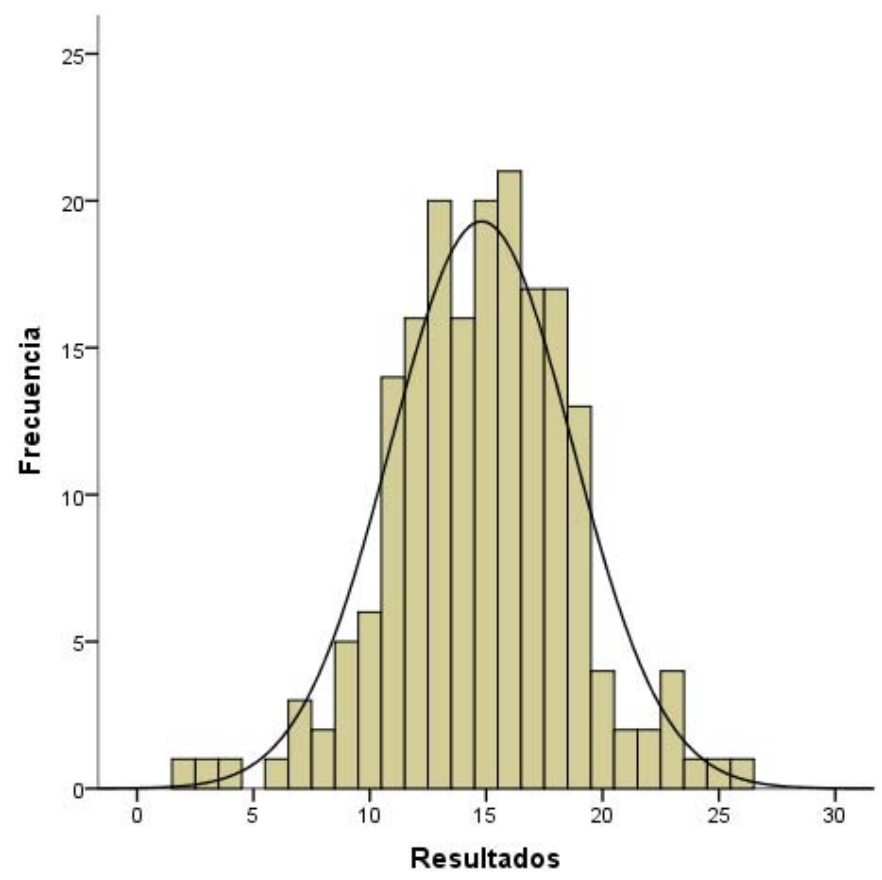

Gráfico 12: Histograma de las puntuaciones del "valor" "resultados”.

La distribución de las puntuaciones obtenidas en "resultados" ha mostrado la alta representatividad del puntaje medio de esta competencia genérica $(14,80)$. Aspecto que se ve reforzado por tratarse de la distribución que ha presentado la menor desviación típica $(3,907)$. Este resultado ha guardado correspondencia con el leve carácter leptocúrtico de la distribución (la curtosis de la distribución es 0,806$)$.

Hemos interpretado estos datos bajo la hipótesis de que el líder ha buscado la excelencia en su trabajo, siempre que fuera posible, pero teniendo presente que la búsqueda 
de la misma no resultara un obstáculo para afrontar los objetivos previamente establecidos de modo satisfactorio. Además, hemos entendido que los datos indican que esta búsqueda de la calidad está asociada a la firmeza del líder y a su carácter metódico.

En relación con la responsabilidad social, hemos considerado que la competencia genérica "resultados" es relevante para los líderes que conciben la Responsabilidad Social Corporativa como un reto que debe afrontar la empresa.

La media del rasgo de personalidad "practicidad" ha sido la quinta media más alta de todos los "valores" $(13,70)$, aunque a una distancia de más de 5 puntos respecto a la menor valoración media registrada por "variedad" $(8,31)$.

"Practicidad" hace referencia al deseo de conseguir lo mejor del dinero, a cuidar de propiedades o pertenencias y sacarle fruto, y a hacer cosas que den beneficio.

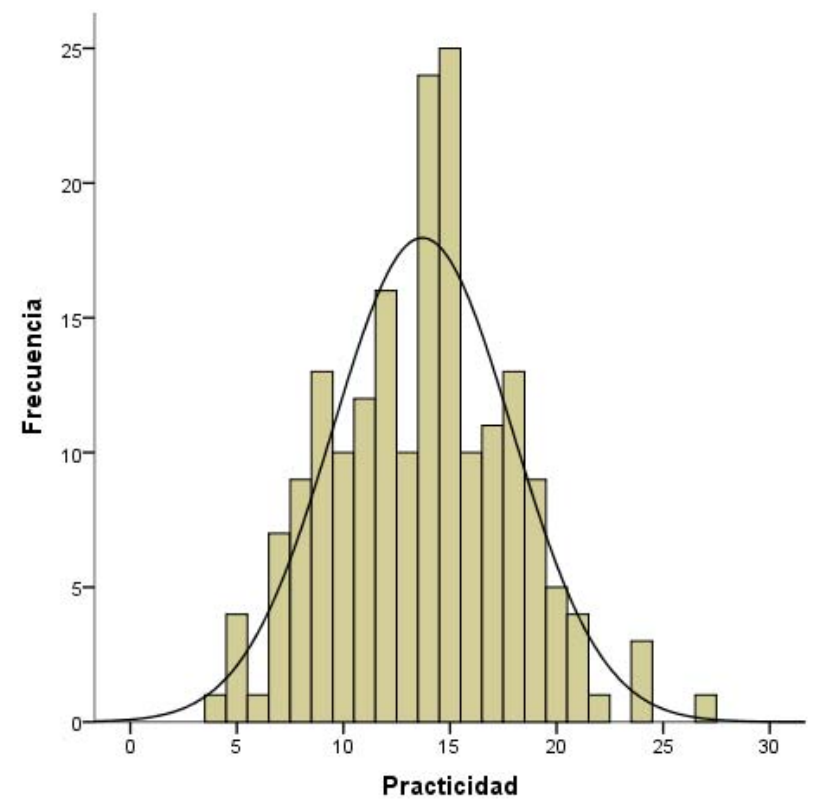

Gráfico 13: Histograma de las puntuaciones del “valor” “practicidad”. 
Como refleja el gráfico 13, se trata de una distribución bastante normal (los valores de curtosis y asimetría están próximos a 0) con una media representativa (la desviación típica ha sido levemente superior a 4, concretamente 4,197, la penúltima desviación típica de todos los "valores").

Hemos interpretado este resultado como un matiz de segundo nivel con cierta importancia que filtra los objetivos que los líderes persiguen.

En este sentido hemos considerado que la puntuación obtenida ha sido indicativa de que los máximos responsables de las empresas valoran, aunque no de modo exclusivo, la persecución de objetivos prácticos, tangibles y que se traduzcan en algún tipo de beneficio.

Hemos entendido que practicidad es un rasgo de personalidad importante en la consideración positiva de la responsabilidad social por parte de los líderes siempre que se dé una condición: que las acciones de Responsabilidad Social Corporativa generen algún tipo de valor para la empresa.

La lectura de los datos nos ha permitido establecer el perfil del líder a partir de los aspectos analizados. En este sentido se trata de un máximo responsable que concede, por encima del resto de aspectos estudiados, una especial importancia a la realización de tareas que se dirijan a objetivos perfectamente definidos. 
Asimismo el líder también valora, aunque en menor medida, que sus tareas se traduzcan en algún tipo de beneficio.

Otro aspecto característico del máximo responsable empresarial es su rechazo por aquellas actividades cuyo resultado es incierto, algo en cierto sentido bastante lógico en un entorno económico en el que prima la obtención de logros.

Los datos también han indicado que el líder, en el ejercicio de su rol, presenta un carácter metódico. Además, persigue mantenerse con firmeza en sus decisiones y busca la excelencia siempre y cuando esta no interfiera en la persecución de objetivos que ya se encuentran previamente establecidos.

A partir de la información obtenida también hemos supuesto que los líderes más afines a la responsabilidad social conciben esta disciplina como una orientación hacia la que la empresa debe dirigirse, como un "rumbo" que orienta la trayectoria empresarial.

Además los máximos responsables empresariales no están atraídos por la responsabilidad social a no ser que esta represente una actividad productiva o genere algún tipo de valor para su organización.

Algunos de los datos también permiten entender que los líderes conciben la responsabilidad social, en cierto sentido, como una filosofía de trabajo claramente definida y 
consideran que esta representa un reto que la empresa debe afrontar.

\subsubsection{Liderazgo}

Hemos dedicado este apartado a mostrar la información alcanzada en relación con los estilos de liderazgo que el líder aplica, el estilo más utilizado o estilo primario, el segundo estilo más utilizado o estilo secundario y la flexibilidad y la efectividad de su liderazgo. Además hemos incorporado unas consideraciones finales sobre el liderazgo basadas en los datos que se han revisado.

Los estilos de liderazgo que el líder ha podido seleccionar en cada una de las situaciones planteadas en la entrevista son los siguientes: "directivo" (comportamiento altamente directivo que requiere poco apoyo), "consultivo" (comportamiento altamente directivo que supone mucho apoyo), "participativo" (comportamiento de alto apoyo que requiere poca dirección) y "delegativo" (comportamiento de poco apoyo que supone baja dirección). En todos los casos el valor mínimo que ha podido alcanzar cada estilo de liderazgo es 0 y el valor máximo 20. 


\begin{tabular}{|l|c|c|c|c|}
\hline & $\begin{array}{c}\text { Estilo directivo } \\
\text { (alta dirección y } \\
\text { poco apoyo) }\end{array}$ & $\begin{array}{c}\text { Estilo consultivo } \\
\text { (alta dirección y } \\
\text { mucho apoyo) }\end{array}$ & $\begin{array}{c}\text { Estilo participativo } \\
\text { (alto apoyo y poca } \\
\text { dirección) }\end{array}$ & $\begin{array}{c}\text { Estilo delegativo } \\
\text { (poco apoyo y baja } \\
\text { dirección) }\end{array}$ \\
\hline Media & 2,54 & 6,49 & 7,74 & 3,21 \\
\hline Mediana & 2,00 & 7,00 & 8,00 & 3,00 \\
\hline Mínimo & 0 & 0 & 1 & 0 \\
\hline Máximo & 9 & 14 & 15 & 14 \\
\hline Desv. típ. & 2,041 & 2,707 & 3,013 & 1,977 \\
\hline Curtosis &,- 201 &,- 202 &,- 506 & 4,381 \\
\hline Asimetría &, 682 &, 041 &, 195 & 1,316 \\
\hline
\end{tabular}

Cuadro 58: Resultados de medidas estadísticas sobre los estilos de liderazgo.

De acuerdo a los valores de la media que muestra el cuadro 58, los datos globales han reflejado una polaridad en la elección de los estilos de liderazgo.

Por un lado los estilos "participativo" y "consultivo", que han presentado, en el primer caso, la media más alta $(7,74) \mathrm{y}$, en el segundo caso, la segunda media más alta $(6,46)$.

Por otro, los estilos “directivo" y “delegativo". En relación con el estilo "directivo", ha registrado la media más baja $(2,51)$. Y en el caso del estilo "delegativo" su media ha sido sensiblemente superior $(3,21)$, pero también muy reducida en relación con los estilos "participativo" y "consultivo". Esta lectura se ve reforzada por el hecho de que la distribución del estilo "delegativo" presenta una asimetría positiva $(1,316)$, por lo que gran parte de los valores registrados en este estilo se han situado debajo de su valor medio. 


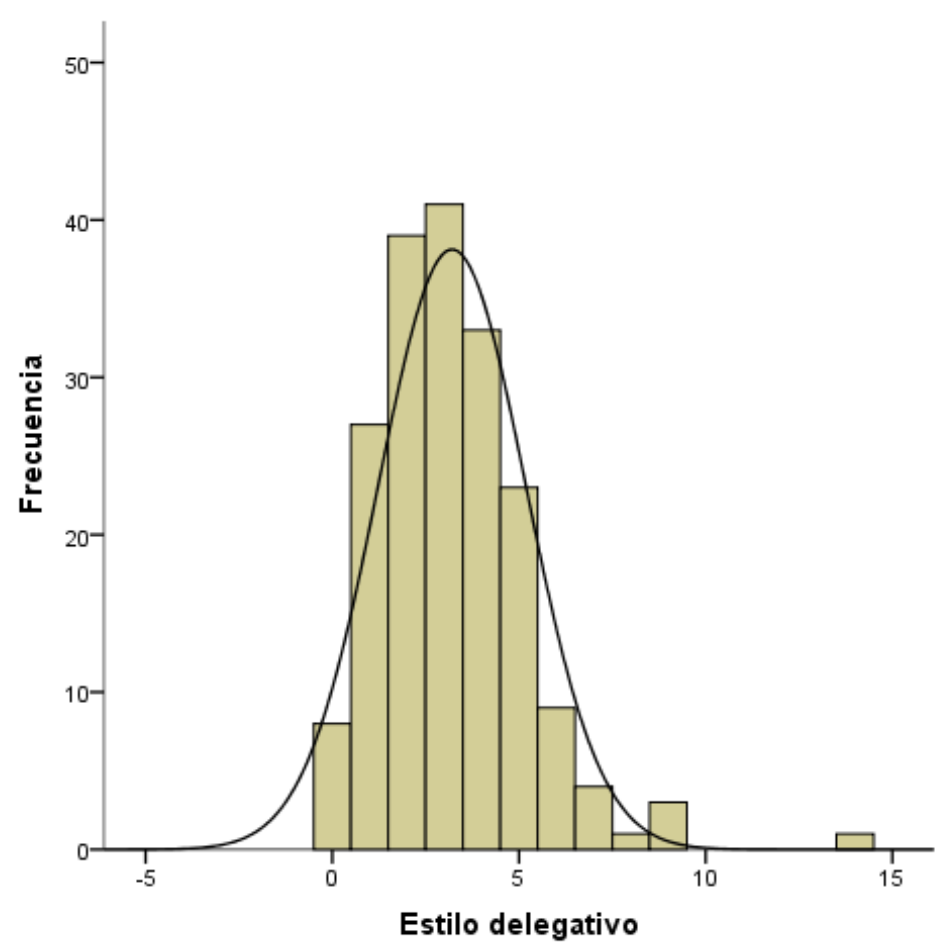

Gráfico 14: Histograma de las puntuaciones del estilo “delegativo”.

El grafico 14 refleja, tal y como veníamos indicando, la elevada concentración de valores por debajo del puntaje medio del estilo de liderazgo "delegativo" $(3,21)$.

En la lectura de los datos relacionados con el estilo de liderazgo primario hemos tenido en cuenta que un mismo líder ha podido seleccionar más de un estilo preferente.

El estilo más utilizado por los líderes, de acuerdo con los datos mostrados en el gráfico 15 incorporado a continuación, ha sido el estilo "participativo" (alto apoyo y poca dirección). Este ha sido el estilo principal para casi 6 de cada 10 líderes $(57,7 \%)$. 


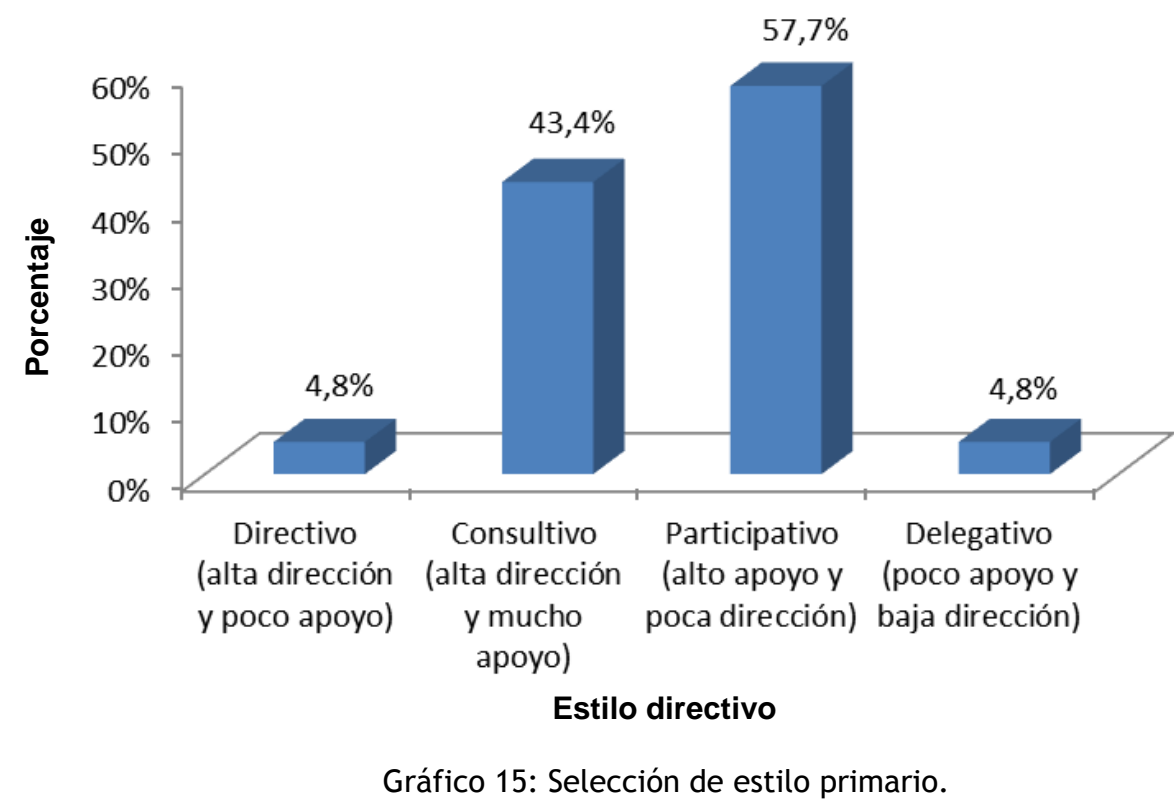

El segundo estilo más utilizado como primera opción ha sido el estilo "consultivo" (alta dirección y mucho apoyo), considerado el estilo más relevante para algo más del $40 \%$ de la muestra $(43,4 \%)$.

Los estilos "directivo" (alta dirección y poco apoyo) y "delegativo" (poco apoyo y baja dirección) han sido poco elegidos como estilos preferentes. En cada caso no llegan a representar al $5 \%$ de la muestra $(4,8 \%)$.

Los datos reflejan de nuevo, por tanto, la polaridad que comentábamos al principio del apartado. Además también indican que los líderes han optado en su relación con los colaboradores, como primera opción, por un estilo de liderazgo en el que estuvieran siempre presentes las directrices o las indicaciones $y$, en función de las circunstancias, se incorporara o no el apoyo.

Al igual que en el estilo primario, en la lectura de los datos sobre el estilo secundario también hemos 
considerado que un mismo líder ha podido seleccionar más de un estilo como segunda opción. La información alcanzada en relación con el segundo estilo preferente ha sido:

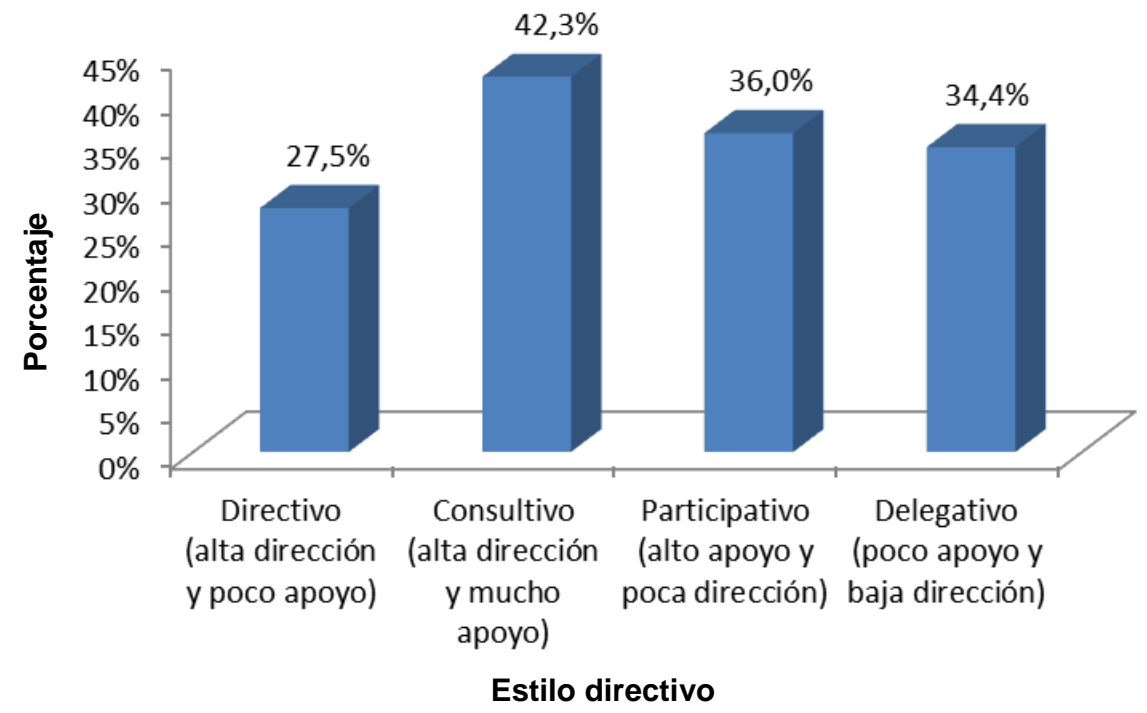

Gráfico 16: Selección de estilo secundario.

Tal como muestra el gráfico 16, la selección del estilo secundario por parte de los líderes ha estado mucho más repartida que la elección del estilo primario.

En este caso el estilo más seleccionado como segunda opción no ha sido el "participativo" sino el "consultivo" (alta dirección y mucho apoyo), elegido por poco más del $40 \%$ de los líderes entrevistados. De todos modos la distancia respecto al estilo secundario más seleccionado en segundo lugar (estilo participativo, elegido por el 36\% de los líderes), en tercer lugar (estilo delegativo, seleccionado por el $34 \%$ ) e incluso en cuarto lugar (estilo directivo, elegido por el $27,5 \%)$, es bastante reducida.

Aunque los dos primeros estilos secundarios escogidos por los líderes son los mismos que dos los primeros estilos 
primarios más utilizados, el peso del estilo "participativo" como estilo secundario se ha reducido considerablemente respecto al estilo primario (del $57,7 \%$ como estilo primario ha pasado al $36 \%$ como estilo secundario).

También hemos considerado destacable que casi un $70 \%$ de los líderes $(67,2 \%)$ muestra preferencia por utilizar más de un estilo secundario.

En la interpretación de los datos hemos entendido que estos indican que los líderes han sido mucho más flexibles en la elección del estilo secundario que en la elección del estilo primario. Aspecto que se ve reforzado por el elevado número de líderes que han seleccionado más de un estilo secundario como segunda opción (76 líderes).

También hemos considerado que este dato refleja una tendencia interesante: cuando los líderes consolidan la utilización de un estilo primario están más dispuestos a adaptar el siguiente estilo de liderazgo a la competencia y al compromiso de los colaboradores.

En cuanto a la flexibilidad y la efectividad de estilo hemos recordado, en primer término, a qué hacen referencia antes de mostrar la información recabada.

La flexibilidad hace alusión a la utilización de más de un estilo de liderazgo en el desarrollo de este rol (su puntaje va de 0 a 30). Y la efectividad de estilo hace referencia a la elección del estilo de liderazgo más idóneo para la situación que se presenta (esta variable puede tomar un valor que va de 20 a 80 ). 
Hemos indicado a continuación las medidas estadísticas más representativas en relación con la efectividad y la flexibilidad de estilo:

\begin{tabular}{|l|c|c|}
\hline & Flexibilidad de estilo & Efectividad de estilo \\
\hline Media & 19,24 & 55,96 \\
\hline Mínimo & 10 & 43 \\
\hline Máximo & 28 & 68 \\
\hline Desv. típica & 4,264 & 5,331 \\
\hline
\end{tabular}

Cuadro 59: Medidas estadísticas sobre la flexibilidad y la efectividad del estilo de liderazgo.

Los datos de las medias mostrados por el cuadro 16 guardan cierta correspondencia si consideramos los valores máximos y mínimos que puede tomar cada variable.

Los líderes han presentado, en términos generales, una flexibilidad de estilo por encima del valor medio que puede tomar esta variable (15 puntos). Esta puntuación media alcanzada $(19,24)$ muestra una significativa flexibilidad por parte de los líderes en el ejercicio del liderazgo.

De todos modos, tal como refleja visualmente el gráfico 17 (incorporado tras estas líneas), no todos los líderes han mostrado una flexibilidad moderada o elevada: 


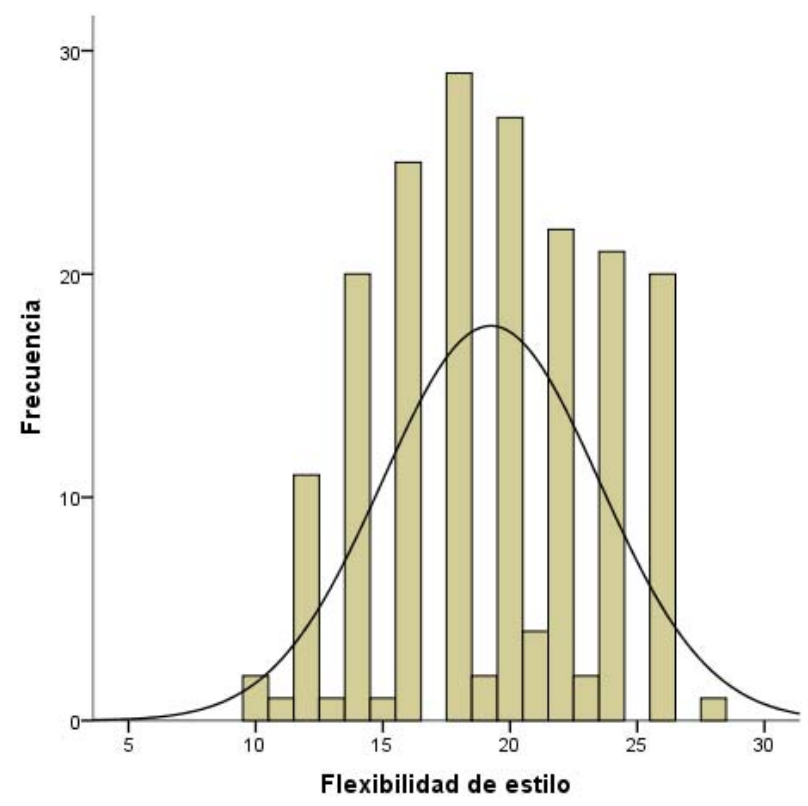

Gráfico 17: Histograma de la flexibilidad de estilo.

El gráfico 17 muestra que la flexibilidad es un rasgo muy disperso en la distribución (aspecto que también refleja la desviación típica alcanzada, 4,264).

Hemos entendido que estos datos evidencian una falta de correspondencia entre el marco teórico propuesto por el Liderazgo Situacional, en el que se contempla que es favorable para el ejercicio del liderazgo utilizar diferentes estilos, y el hecho de que los líderes no utilicen varios estilos de liderazgo de modo generalizado.

Los datos nos han empujado a entender que muchos líderes no consideran un acierto la utilización de varios estilos de liderazgo en el desempeño de su rol.

En cuanto a los datos sobre efectividad de estilo, no se ha producido una correspondencia exacta con los obtenidos en relación con la flexibilidad.

Aunque de nuevo el valor de la media en la efectividad de estilo es alto $(55,96)$, los valores están 
mucho menos dispersos (la desviación típica es, en proporción, mucho más reducida que en la distribución de la flexibilidad, 5,331). Estas observaciones se ven reflejadas en el gráfico 18:

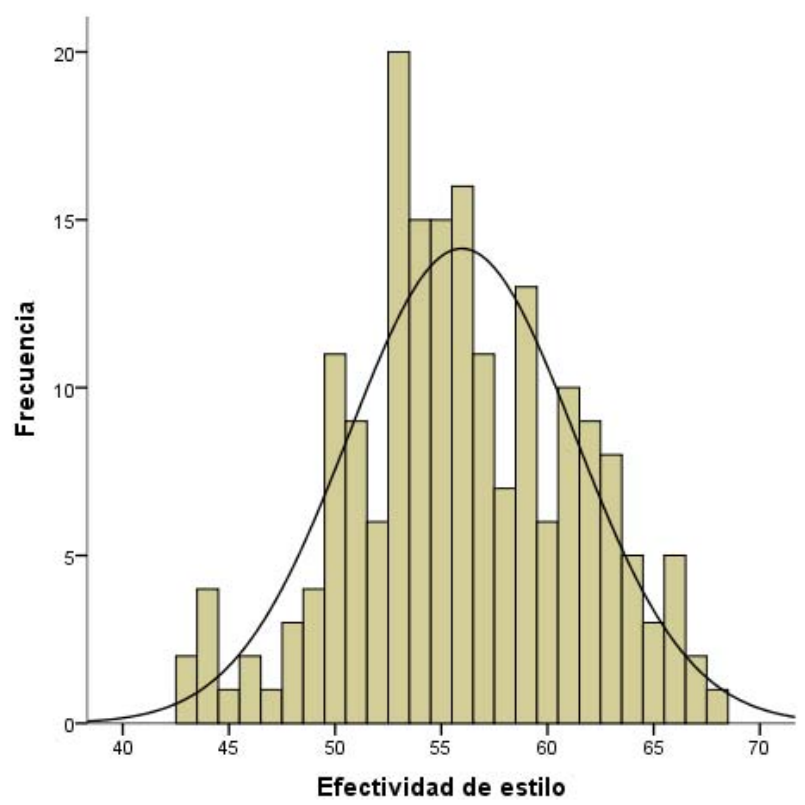

Gráfico 18: Histograma de la efectividad de estilo.

El gráfico 18 muestra lo que ya han indicado los valores estadísticos obtenidos: que los datos están mucho menos dispersos en esta variable y que hay, por tanto, una concentración de líderes alrededor del valor medio de la efectividad bastante mayor que en el caso de la flexibilidad.

Esta conclusión nos ha conducido a calificar la efectividad de los líderes en el ejercicio del liderazgo como moderadamente alta (valoración que también se ve reforzada por el valor mínimo de la distribución, 43, que ya se encuentra por encima de la media teórica de la escala, $40)$. 
Hemos interpretado estos datos sobre efectividad de modo literal. Hemos entendido que reflejan la habilidad de los líderes para adecuar su estilo de liderazgo a los rasgos del colaborador, tomando en consideración las situaciones que este debe afrontar.

De todos modos, hemos supuesto que la efectividad podría ser más elevada si los líderes incrementaran su flexibilidad de estilo y por tanto, se familiarizasen con comportamientos de liderazgo que no suelen a utilizar.

Teniendo presente la información registrada, hemos incorporado unas consideraciones finales sobre el estilo de liderazgo.

Los líderes en España muestran una preferencia por un tipo de conducta con sus colaboradores en el desempeño de su rol: orientan y, en ocasiones, ofrecen apoyo. En ambos casos, los datos han indicado que el líder muestra preferencia por realizar un seguimiento de los colaboradores, ya sea con un cariz solo racional o también con implicaciones emocionales.

El patrón seguido en el estilo de liderazgo primario no se ha correspondido con el utilizado en el estilo de liderazgo secundario. En este segundo caso los máximos responsables empresariales son mucho más permeables a adaptar su estilo de liderazgo a la competencia y al compromiso que muestran los colaboradores. Por tanto los líderes usan, de un modo bastante equitativo, una amplia gama de estilos de liderazgo como opción secundaria. 
En relación con la flexibilidad de estilo, hay líderes que muestran una predisposición favorable a la utilización de diversos estilos de liderazgo en el ejercicio de su rol aunque no se trata de un rasgo generalizable. Hemos entendido que un aspecto que impulsaría una mayor representatividad en el valor concedido a esta variable sería que más líderes aceptaran que la utilización de varios estilos de dirección favorece su desempeño.

Por otra parte, los líderes presentan una destacada habilidad para adaptar su estilo de liderazgo a los rasgos psicológicos del colaborador considerando, al mismo tiempo, su cometido. De todos modos hemos supuesto que los líderes podrían incrementar su acierto en la elección del estilo de liderazgo más idóneo para cada situación si se familiarizasen con estilos de liderazgo que no utilizan con frecuencia.

\subsubsection{Sexo y Responsabilidad Social Corporativa}

Hemos tratado, en primer término, la relación entre el sexo del líder y su actitud hacia la Responsabilidad Social Corporativa. A continuación hemos desarrollado el vínculo entre el sexo del líder y el comportamiento socialmente responsable de su organización de origen, en primer término de forma genérica y, a continuación, haciendo referencia a las acciones formativas dirigidas a públicos internos que se enmarcan dentro de la responsabilidad social. 


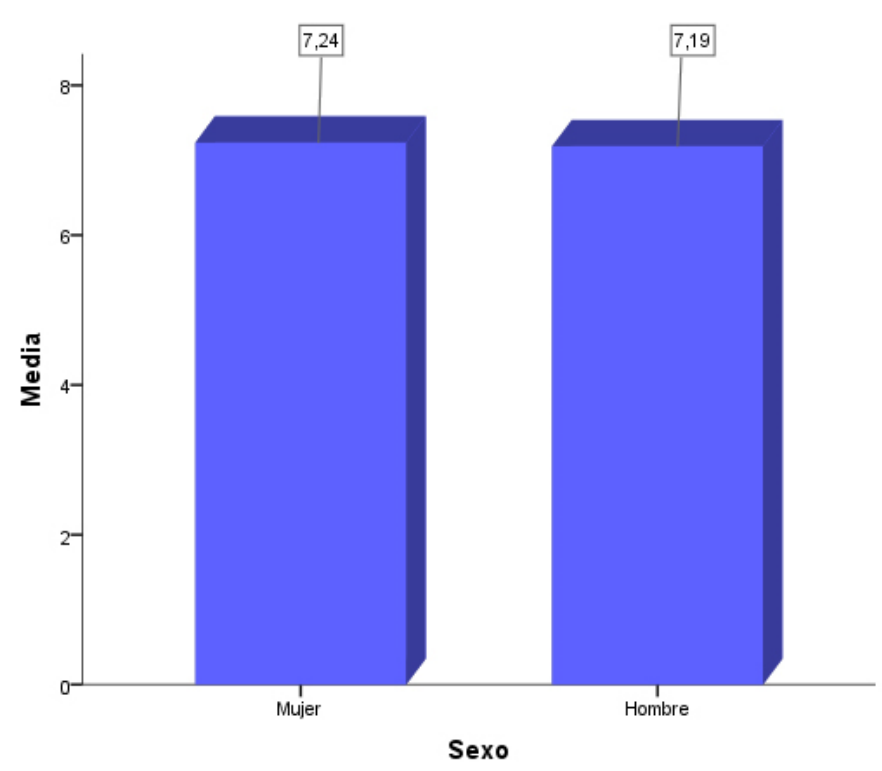

Gráfico 19: Actitud hacia la responsabilidad social según sexo.

Antes de valorar la información del gráfico 18, hemos aplicado ANOVA de un factor a los datos para verificar si existen diferencias estadísticamente significativas entre los dos grupos muestrales (cuadro 60):

\begin{tabular}{|l|c|c|c|c|c|}
\hline & Suma de cuadrados & gl & Media cuadrática & F & Sig. \\
\hline Inter-grupos & 16,894 & 80 &, 211 &, 856 &, 767 \\
\hline Intra-grupos & 26,640 & 108 &, 247 & & \\
\hline Total & 43,534 & 188 & & & \\
\hline
\end{tabular}

Cuadro 60: Tabla ANOVA de sexo, factor Actitud hacia la Responsabilidad Social.

La información que ofrece el cuadro 60 indica que no existen diferencias estadísticamente significativas entre el grupo muestral de las líderes y el de los máximos responsables (el coeficiente de significación es 0,767 ).

La información que ofrece el grafico 18 muestra que la actitud hacia la responsabilidad social no está condicionada por el sexo. 
Ambos grupos muestran una media prácticamente idéntica en su actitud hacia la responsabilidad social, levemente superior en el caso de las líderes femeninas.

En relación con los datos sobre sexo y acciones de responsabilidad social, hemos incorporado el cuadro 61:

\begin{tabular}{|c|c|c|c|c|c|}
\hline & & & & xo & \\
\hline & & & Mujer & Hombre & Fiar \\
\hline & & $\%$ dentro de acciones & $37,4 \%$ & $62,6 \%$ & $100,0 \%$ \\
\hline & TNO & $\%$ dentro de sexo & $50,0 \%$ & $47,1 \%$ & $48,1 \%$ \\
\hline & & $\%$ dentro de acciones & $50,0 \%$ & $50,0 \%$ & $100,0 \%$ \\
\hline Acciones & 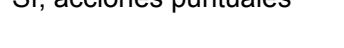 & $\%$ dentro de sexo & $26,5 \%$ & $14,9 \%$ & $19,0 \%$ \\
\hline social & Sí, acciones frecuentes & $\%$ dentro de acciones & $28,0 \%$ & $72,0 \%$ & $100,0 \%$ \\
\hline & de RS & $\%$ dentro de sexo & $10,3 \%$ & $14,9 \%$ & $13,2 \%$ \\
\hline & Sí, acciones integradas en & $\%$ dentro de acciones & $24,3 \%$ & $75,7 \%$ & $100,0 \%$ \\
\hline & una política de RS & $\%$ dentro de sexo & $13,2 \%$ & $23,1 \%$ & $19,6 \%$ \\
\hline & TOTAL & $\%$ dentro de acciones & $36,0 \%$ & $64,0 \%$ & $100,0 \%$ \\
\hline & & $\%$ dentro de sexo & $100,0 \%$ & $100,0 \%$ & $100,0 \%$ \\
\hline
\end{tabular}

Cuadro 61: Tabla de contingencia de realización de acciones de responsabilidad social y sexo.

El cuadro 61 muestra que, con independencia del sexo, prácticamente 1 de cada 2 líderes $(47,1 \%$ en el caso de los hombres y $50 \%$ en el caso de las mujeres), están vinculados a organizaciones que no realizan ningún tipo de actuación en materia de responsabilidad social.

Los datos también reflejan que existe una tendencia decreciente en la presencia del sexo femenino en la cúpula de las organizaciones a medida que aumenta la intensidad del comportamiento socialmente responsable de las empresas. De todos modos esta tendencia no se ha mantenido al pasar de las organizaciones que han desarrollado acciones frecuentes a las que las han realizado 
acciones dentro de una política establecida de Responsabilidad Social Corporativa. En este último caso, la presencia de líderes femeninas en relación con el total de mujeres de la muestra poblacional ha pasado del $10,3 \%$ en las empresas que realizan acciones frecuentes sin una política definida, al $13,2 \%$ en las organizaciones en las que todas las iniciativas en esta materia están integradas dentro de una política definida de responsabilidad social.

En el caso del sexo masculino no se ha registrado esta tendencia. Comparte con el sexo femenino una mayor presencia en las organizaciones que no realizan ningún tipo de iniciativa $(47,1 \%$ del total de líderes masculinos de la muestra) pero su protagonismo en las empresas con acciones puntuales de responsabilidad social es más reducido que en el caso de las mujeres $(14,9 \%$ del total de máximos responsables masculinos).

También es diferente la presencia de máximos dirigentes masculinos, respecto a las líderes femeninas, en las empresas con políticas establecidas de Responsabilidad Social Corporativa. Mientras que el $13,2 \%$ del total de mujeres está presente en este tipo de empresas, en el caso de los hombres es el 23,1\% de este grupo muestral el que ha declarado trabajar en empresas con una política reconocida de responsabilidad social. Estos datos indican que casi uno de cada cuatro líderes masculinos está vinculado a organizaciones con una política definida de responsabilidad social. 
En cuanto a las organizaciones que realizan acciones formativas asociadas a la responsabilidad social según el sexo de los líderes, los datos se han mostrado en el gráfico 20:

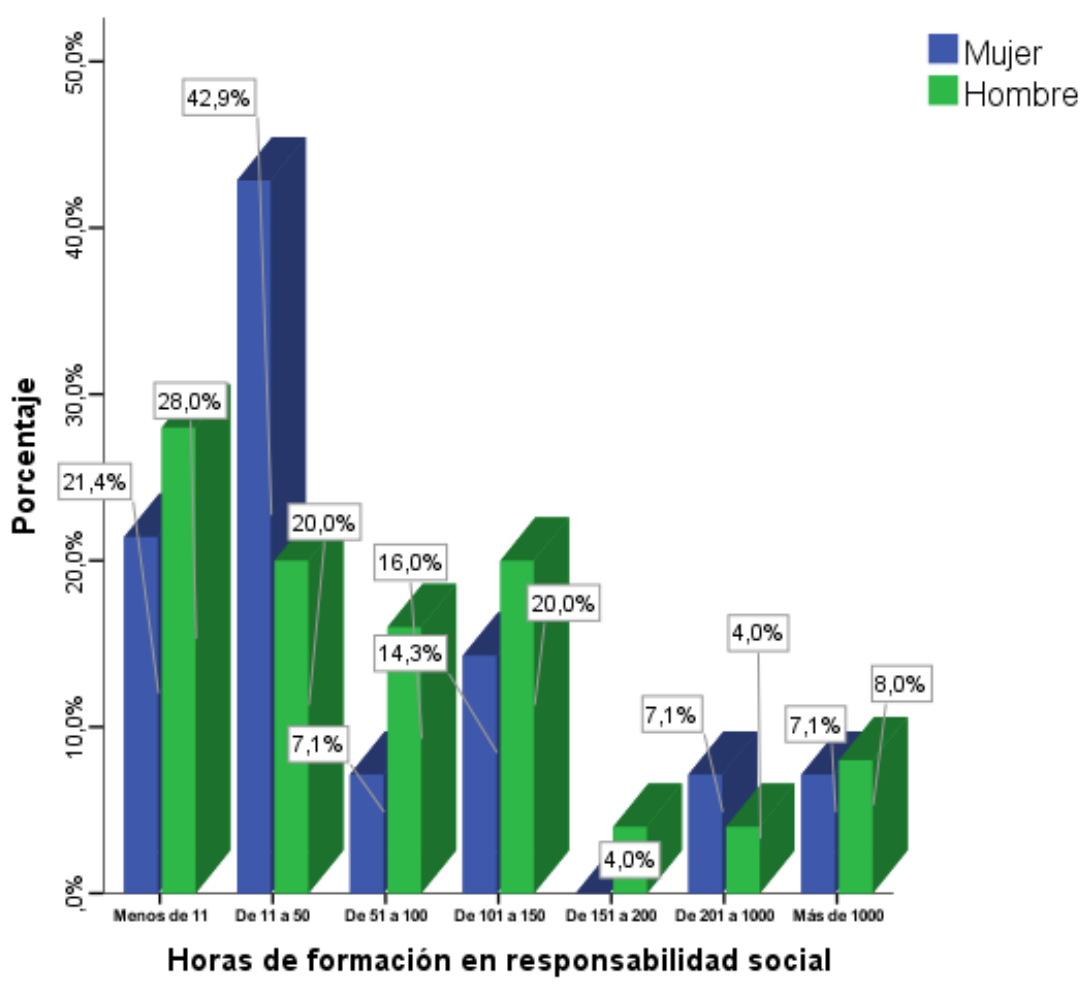

Gráfico 20: Formación en responsabilidad social según sexo.

El gráfico 20 muestra que no hay diferencias significativas en ambos sexos dentro de las empresas que dedican más de 150 horas a formar a sus colaboradores a través de acciones enmarcadas en el ámbito de la responsabilidad social.

Sin embargo, si parece existir una diferencia significativa en la presencia de líderes femeninas dentro de las organizaciones que realizan acciones formativas de 50 o menos horas. En este caso la presencia de líderes masculinos (48\%) es sensiblemente inferior a la de sus homónimas femeninas $(64,3 \%)$. 
Asimismo también existe una leve diferencia en el sexo del líder dentro de las organizaciones que dedican menos de 11 horas a ofrecer formación sobre responsabilidad social a sus colaboradores. En este caso hay una mayor presencia de máximos responsables de género masculino: $28 \%$ frente a $21,4 \%$. Esta disparidad también se produce en el caso de las organizaciones que realizan acciones formativas de 51 a 150 horas de extensión. En estas empresas se han registrado un $36 \%$ de máximos responsables masculinos frente a un $21,4 \%$ de líderes femeninas.

Las políticas de formación de personal son una de las prácticas internas de responsabilidad social más consolidadas en las empresas porque conllevan ventajas tanto para la empresa como para los colaboradores (Curto, 2012).

La guía para la elaboración de memorias que ofrece el Global Reporting Initiative (Global Reporting Initiative, 2011) incorpora el apartado "Formación y sensibilización", dentro de la "Dimensión ambiental", para que la empresa especifique los procedimientos relacionados con la formación y la sensibilización relativos a aspectos ambientales.

Además también establece, dentro de la "Dimensión social", tres indicadores del desempeño de prácticas laborales y de ética en el trabajo, en los que se inscribe la formación y la educación en al ámbito de la sostenibilidad. 
Se indican a continuación los contenidos mencionados en el cuadro 62:

Contenidos solicitados por el Global Reporting Initiative sobre formación interna para la elaboración de memorias de sostenibilidad

- Especificar los procedimientos relacionados con la formación y la sensibilización relativos a aspectos ambientales.

Promedio de horas de formación al año por empleado, desglosado por sexo y por categoría de empleado (indicador LA10).

- Programas de gestión de habilidades y de formación continua que fomenten la empleabilidad de los trabajadores y les apoyen en la gestión del final de sus carreras profesionales (indicador LA11).

- Porcentaje de empleados que reciben evaluaciones regulares del desempeño y de desarrollo profesional desglosado por sexo (indicador LA12).

Cuadro 62: Indicadores del Global Reporting Initiative sobre formación interna para la elaboración de memorias de sostenibilidad. Fuente: Global Reporting Initiative (2011).

Como se desprende de la revisión de la información del cuadro 62, la formación interna en materia de responsabilidad social no solo hace referencia a la sensibilización de los públicos internos en aspectos afines a la responsabilidad social sino también a la capacitación técnica del colaborador en relación con su desempeño específico. Además, contempla que a la hora de acceder a estas iniciativas formativas no se discrimine a unos integrantes de las organizaciones frente a otras.

En la memoria de responsabilidad social presentada por Accenture al Global Reporting Initiative en relación con el ejercicio del 2012, la empresa ha indicado el desarrollo de diversas iniciativas para favorecer la capacitación de sus colaboradores. Se ofrece un listado de las mismas, extraído 
de su "Informe de responsabilidad empresarial", en el cuadro 63:

Acciones de formación de Accenture en España (2012) en públicos internos indicadas en su informe de responsabilidad empresarial

\begin{tabular}{|c|c|}
\hline $\begin{array}{l}\text { Centro de Alto Rendimiento } \\
\text { (CAR) en Madrid }\end{array}$ & $\begin{array}{l}\text { Certificado como Centro Regional de } \\
\text { Formación para Europa. }\end{array}$ \\
\hline Programa FormAcción & $\begin{array}{l}\text { Diseñado para potenciar la participación } \\
\text { activa de sus profesionales en su propio } \\
\text { desarrollo. }\end{array}$ \\
\hline $\begin{array}{l}\text { Herramienta de formación } \\
\text { 'online' myLearning }\end{array}$ & $\begin{array}{l}\text { Creada para ofrecer a sus profesionales } \\
\text { el curso que mejor se adecue a sus } \\
\text { necesidades profesionales. }\end{array}$ \\
\hline Programas estrella & $\begin{array}{l}\text { Accenture indica los siguientes: } \\
\text { - Subvención del } 100 \% \text { de las clases de } \\
\text { inglés. } \\
\text { - 'Masters in Company' en el IE } \\
\text { Business School. } \\
\text { - Acuerdos con escuelas de negocios. } \\
\text { - Escuela de Creatividad. } \\
\text { - Certificaciones para capacitar a sus } \\
\text { profesionales en habilidades } \\
\text { especializadas y diferenciadoras. }\end{array}$ \\
\hline
\end{tabular}

Cuadro 63 Acciones de formación de Accenture en España (2012) en públicos internos indicadas en su informe de responsabilidad empresarial. Fuente: Global Reporting Initiative (2013c).

La información del cuadro 63 indica el compromiso de Accenture por responder a las exigencias de formación interna en el ámbito de la responsabilidad social.

En esta memoria, las acciones están más centradas en mejorar la cualificación profesional de los colaboradores que en su sensibilización sobre aspectos medioambientales o sociales relacionados, de algún modo, con las actividades que la organización desarrolla. 


\subsubsection{Edad y Responsabilidad Social Corporativa}

La edad de los líderes se ha agrupado en tres nuevas franjas de edad más diferenciadas (menos de 40 años, de 41 a 60 años y más de 60 años) para aumentar la representatividad de los grupos de edad en la lectura de los datos.

En lo que respecta a la información sobre la edad y la actitud de los líderes hacia la responsabilidad social, hemos incorporado el gráfico 21:

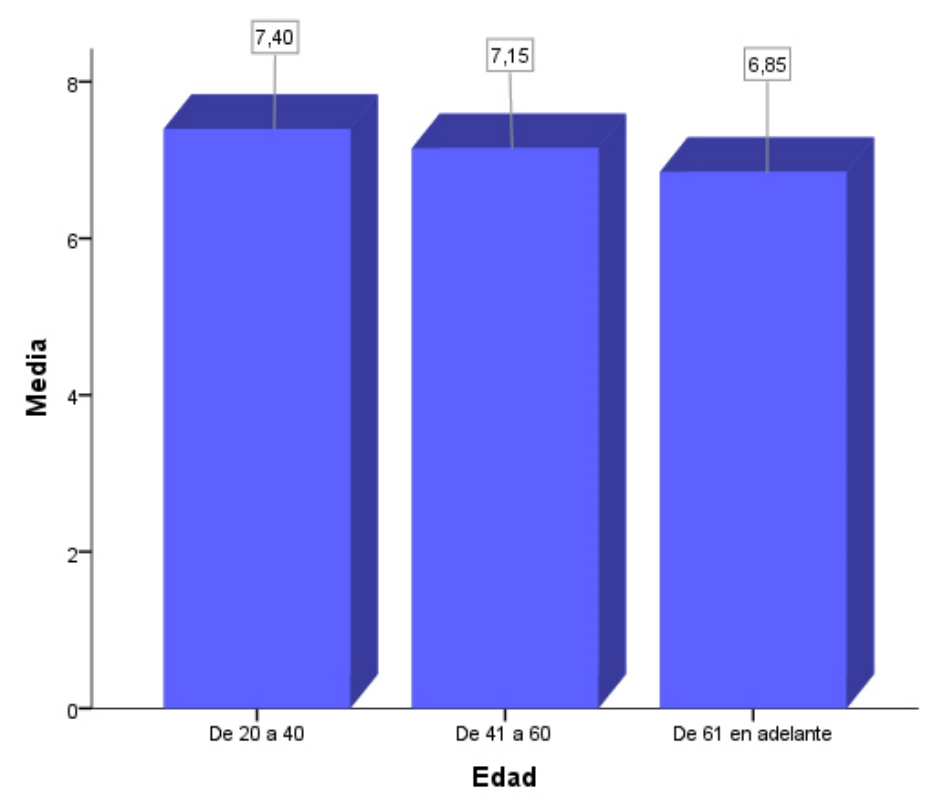

Gráfico 21: Actitud hacia la responsabilidad social y edad.

Antes de hacer una valoración de la información que ofrece el gráfico 21 hemos aplicado ANOVA de un factor en los datos a los que alude dicho gráfico. 


\begin{tabular}{|l|r|r|r|c|c|}
\hline & Suma de cuadrados & gl & Media cuadrática & F & Sig. \\
\hline Inter-grupos & 28,159 & 80 &, 352 &, 960 &, 573 \\
\hline Intra-grupos & 39,598 & 108 &, 367 & & \\
\hline Total & 67,757 & 188 & & & \\
\hline
\end{tabular}

Cuadro 64: Tabla ANOVA de edad, factor Actitud hacia la Responsabilidad Social.

El coeficiente de significación del cuadro $64(0,573)$ indica que no existen diferencias estadísticamente significativas entre los grupos muestrales considerados.

La información que ofrece el gráfico 20 muestra que a pesar de que todos los líderes presentan una actitud favorable hacia la Responsabilidad Social Corporativa, el incremento de la edad parece ser un factor que reduce el grado de la disposición positiva hacia la responsabilidad social.

En los líderes de 20 a 40 años la actitud media es de 7,4 , en los de 41 a 60 años 7,15, y en los de más de 60 años 6,85 . Es decir, se ha registrado una media de más de medio punto de diferencia $(0,55)$ entre la actitud media del grupo de los líderes más jóvenes y el de los más mayores.

Se incorpora a continuación el gráfico 22, "Realización de acciones de responsabilidad social y edad", con la información recabada sobre la edad de los líderes y la realización de acciones de responsabilidad social por parte de las organizaciones en las que desempeñan su labor los máximos responsables empresariales. 


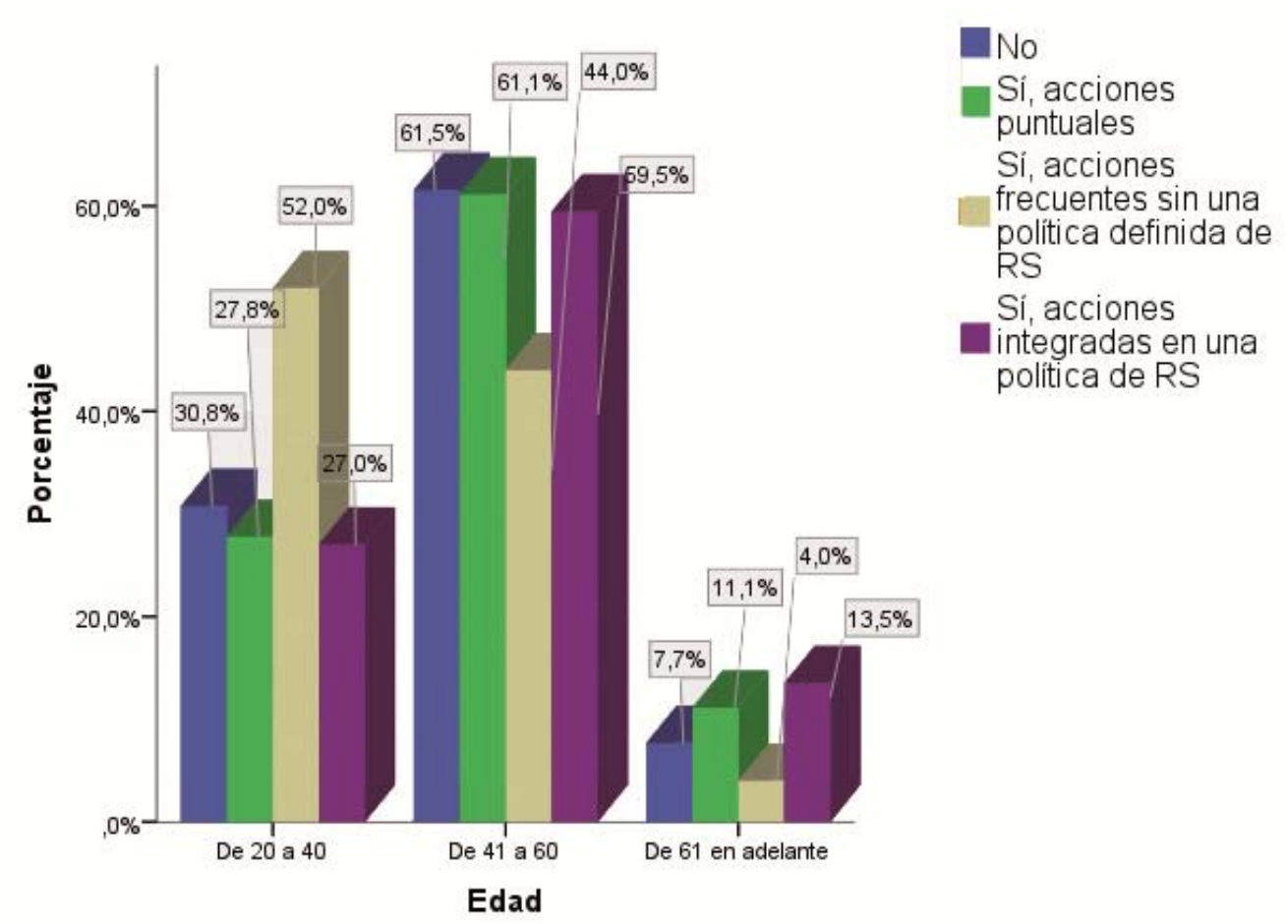

Gráfico 22: Realización de acciones de responsabilidad social y edad.

Tal y como muestra el gráfico 22, los líderes de 41 a 60 años tienen un especial protagonismo en todos los tipos de comportamiento empresarial analizado excepto en el caso de las organizaciones que desarrollan acciones frecuentes de responsabilidad social, donde los líderes de 20 a 40 años tienen mayor presencia (52\%) que los máximos responsables de 41 a 60 años (44\%).

De todos modos los líderes de 20 a 40 años también muestran una presencia significativa en las organizaciones que no desarrollan ningún tipo de actuación en materia de responsabilidad social $(30,8 \%)$, las que desarrollan acciones puntuales $(27,8 \%)$ y las que impulsan acciones dentro de una política definida de responsabilidad social (27\%).

Los líderes de más de 60 años tienen una presencia reducida en todos los casos aunque es significativo que su 
protagonismo sea un poco mayor en las organizaciones que desarrollan acciones de responsabilidad social integradas en una política definida $(13,5 \%)$. Es el único grupo que muestra una cierta tendencia a tener mayor presencia, propensión que no se mantiene en los líderes más mayores cuyo origen son empresas que realizan acciones frecuentes, a medida que aumenta la actuación de su organización de procedencia en materia de responsabilidad social.

Al considerar todas las opciones de comportamiento empresarial casi uno de cada dos líderes, con independencia de su edad, se encuentra en empresas inactivas en lo que respecta a su conducta socialmente responsable $(45,9 \%$ de los líderes de 20 a 40 años, 50,5\% de los de 41 a 60 años y el 41,2\% de los de más de 60 años).

En relación con la edad de los líderes y el desarrollo de acciones formativas enmarcadas en el ámbito de la responsabilidad social dentro las empresas a las que los líderes están vinculados, hemos incorporado más adelante el cuadro 65.

En la lectura de los datos del cuadro 65 no hemos considerado, por su escasa representatividad, aquellos grupos muestrales en los que solo se ha recogido información de un líder.

Los datos del cuadro 65 indican que en las organizaciones que desarrollan acciones formativas de menos de 11 horas de duración, la presencia de líderes de 20 a 40 años y de 41 a 60 años está repartida (en cada caso 
representan el $50 \%$ de los líderes que proceden de las empresas que invierten menos de 11 horas en formar a sus públicos internos sobre responsabilidad social).

\begin{tabular}{|c|c|c|c|c|c|c|}
\hline & & & \multicolumn{3}{|c|}{ Edad } & \multirow[b]{2}{*}{ Total } \\
\hline & & & De 20 a 40 & De 41 a 60 & $\begin{array}{l}\text { De } 61 \text { en } \\
\text { adelante }\end{array}$ & \\
\hline \multirow{14}{*}{$\begin{array}{l}\text { Horas de } \\
\text { formación en } \\
\text { resp. social }\end{array}$} & \multirow{2}{*}{ Menos de 11} & $\%$ dentro de horas & $50,0 \%$ & $50,0 \%$ & $0,0 \%$ & $100,0 \%$ \\
\hline & & $\%$ dentro de edad & $41,7 \%$ & $20,8 \%$ & $0,0 \%$ & $25,6 \%$ \\
\hline & \multirow{2}{*}{ De 11 a 50} & $\%$ dentro de horas & $27,3 \%$ & $54,5 \%$ & $18,2 \%$ & $100,0 \%$ \\
\hline & & $\%$ dentro de edad & $25,0 \%$ & $25,0 \%$ & $66,7 \%$ & $28,2 \%$ \\
\hline & \multirow{2}{*}{ De 51 a 100} & $\%$ dentro de horas & $20,0 \%$ & $80,0 \%$ & $0,0 \%$ & $100,0 \%$ \\
\hline & & $\%$ dentro de edad & $8,3 \%$ & $16,7 \%$ & $0,0 \%$ & $12,8 \%$ \\
\hline & \multirow{2}{*}{ De 101 a 150} & $\%$ dentro de horas & $14,3 \%$ & $71,4 \%$ & $14,3 \%$ & $100,0 \%$ \\
\hline & & $\%$ dentro de edad & $8,3 \%$ & $20,8 \%$ & $33,3 \%$ & $17,9 \%$ \\
\hline & \multirow{2}{*}{ De 151 a 200} & $\%$ dentro de horas & $0,0 \%$ & $100,0 \%$ & $0,0 \%$ & $100,0 \%$ \\
\hline & & $\%$ dentro de edad & $0,0 \%$ & $4,2 \%$ & $0,0 \%$ & $2,6 \%$ \\
\hline & \multirow{2}{*}{ De 201 a 1000} & $\%$ dentro de horas & $50,0 \%$ & $50,0 \%$ & $0,0 \%$ & $100,0 \%$ \\
\hline & & $\%$ dentro de edad & $8,3 \%$ & $4,2 \%$ & $0,0 \%$ & $5,1 \%$ \\
\hline & \multirow{2}{*}{ Más de 1000} & $\%$ dentro de horas & $33,3 \%$ & $66,7 \%$ & $0,0 \%$ & $100,0 \%$ \\
\hline & & $\%$ dentro de edad & $8,3 \%$ & $8,3 \%$ & $0,0 \%$ & $7,7 \%$ \\
\hline \multirow{2}{*}{\multicolumn{2}{|c|}{ TOTAL }} & $\%$ dentro de horas & $30,8 \%$ & $61,5 \%$ & $7,7 \%$ & $100,0 \%$ \\
\hline & & $\%$ dentro de edad & $100,0 \%$ & $100,0 \%$ & $100,0 \%$ & $100,0 \%$ \\
\hline
\end{tabular}

Cuadro 65: Tabla de contingencia de formación en responsabilidad social y edad.

Sin embargo en los líderes procedentes de organizaciones que dedican entre 11 y 50 horas a acciones formativas enmarcadas en el ámbito de la responsabilidad social, el protagonismo de los líderes de 41 a 60 años sobre los de 20 a 40 años es mayor (54,5\% frente al $27,3 \%$ ).

En el resto de grupos muestrales contemplados en los que las horas dedicadas a acciones formativas sobre responsabilidad social superan las 50 horas, la presencia de los líderes de 41 a 60 años es muy destacada.

Considerando la muestra total de líderes de 20 a 40 años, el $66,7 \%$ se encuentran en las organizaciones que 
dedican 50 horas o menos a las acciones formativas mientras que el total de líderes de 41 a 60 años se reparte de forma más equitativa en las diferentes opciones de formación organizacional contempladas. Este dato parece indicar que los líderes de 41 a 60 años son más propensos a impulsar acciones formativas de mayor extensión.

En lo que respecta a los líderes de más de 60 años, solo tienen una presencia significativa en las empresas que dedican entre 11 y 50 horas a acciones de formación encuadradas en el ámbito de la responsabilidad social. Estos líderes representan el 18,2\% en este grupo muestral.

\subsubsection{Sector y Responsabilidad Social Corporativa}

Hemos incorporado, en primer término, el grafico 23 para mostrar los datos de la actitud de los líderes hacia la responsabilidad social según su sector de procedencia.

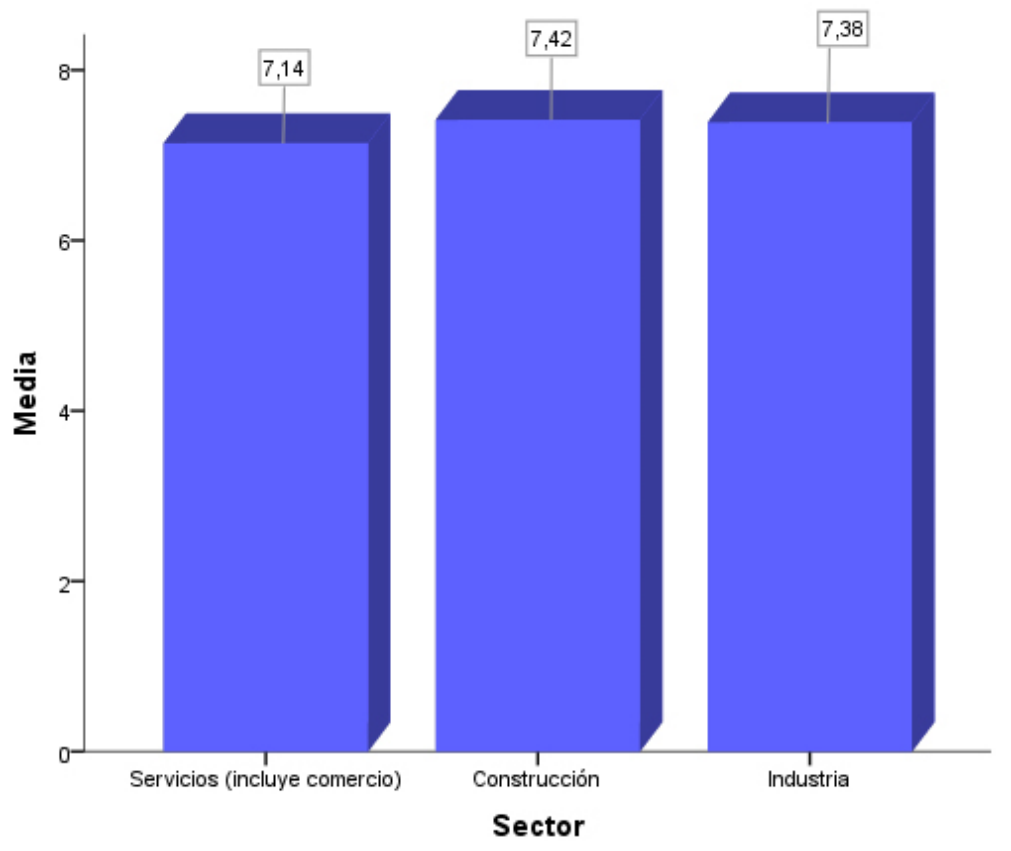

Gráfico 23: Actitud hacia la responsabilidad social y edad. 
Antes de comentar la información visual del gráfico 22 hemos aplicado ANOVA de un factor en los datos sobre los grupos muestrales que componen dicha población.

\begin{tabular}{|l|r|r|r|c|c|}
\hline & Suma de cuadrados & \multicolumn{1}{|c|}{ gl } & Media cuadrática & F & Sig. \\
\hline Inter-grupos & 42,217 & 80 &, 528 &, 815 &, 832 \\
\hline Intra-grupos & 69,920 & 108 &, 647 & & \\
\hline Total & 112,138 & 188 & & & \\
\hline
\end{tabular}

Cuadro 66: Tabla ANOVA de sector, factor Actitud hacia la Responsabilidad Social.

La información que ofrece el cuadro 66 indica que no existen diferencias estadísticamente significativas entre los diversos grupos muestrales (el coeficiente de significación es 0,832 ).

El gráfico 22 muestra que en los sectores industria $(7,38)$ y construcción $(7,42)$ la actitud media es levemente superior a la registrada por los líderes del sector servicios, donde también se incluye al comercio $(7,14)$.

Los datos descriptivos sobre el sector de las organizaciones de procedencia de los líderes empresariales entrevistados y el desarrollo de acciones de responsabilidad social se indican en el cuadro 67 "Tabla de contingencia de realización de acciones de responsabilidad social y sector": 


\begin{tabular}{|c|c|c|c|c|c|c|}
\hline & & & \multicolumn{3}{|c|}{ Sector } & \multirow[b]{2}{*}{ TOTAL } \\
\hline & & & $\begin{array}{l}\text { Servicios } \\
\text { (incluye } \\
\text { comercio) }\end{array}$ & Construcción & Industria & \\
\hline \multirow{9}{*}{$\begin{array}{l}\text { Acciones } \\
\text { de resp. } \\
\text { Social }\end{array}$} & \multirow{3}{*}{ No } & Casos & 69 & 10 & 12 & 91 \\
\hline & & $\%$ dentro de acciones & $75,8 \%$ & $11,0 \%$ & $13,2 \%$ & $100,0 \%$ \\
\hline & & $\%$ dentro de sector & $48,6 \%$ & $71,4 \%$ & $36,4 \%$ & $48,1 \%$ \\
\hline & \multirow{2}{*}{$\mathrm{Si}$, acciones puntuales } & $\%$ dentro de acciones & $80,6 \%$ & $5,6 \%$ & $13,9 \%$ & $100,0 \%$ \\
\hline & & $\%$ dentro de sector & $20,4 \%$ & $14,3 \%$ & $15,2 \%$ & $19,0 \%$ \\
\hline & \multirow{2}{*}{$\begin{array}{l}\mathrm{Si} \text {, acciones } \\
\text { frecuentes sin una } \\
\text { política definida de RS }\end{array}$} & $\%$ dentro de acciones & $72,0 \%$ & $4,0 \%$ & $24,0 \%$ & $100,0 \%$ \\
\hline & & $\%$ dentro de sector & $12,7 \%$ & $7,1 \%$ & $18,2 \%$ & $13,2 \%$ \\
\hline & \multirow{2}{*}{$\begin{array}{l}\text { Si, acciones } \\
\text { integradas en una } \\
\text { política de RS }\end{array}$} & $\%$ dentro de acciones & $70,3 \%$ & $2,7 \%$ & $27,0 \%$ & $100,0 \%$ \\
\hline & & $\%$ dentro de sector & $18,3 \%$ & $7,1 \%$ & $30,3 \%$ & $19,6 \%$ \\
\hline \multirow{2}{*}{\multicolumn{2}{|c|}{ TOTAL }} & $\%$ dentro de acciones & $75,1 \%$ & $7,4 \%$ & $17,5 \%$ & $100,0 \%$ \\
\hline & & $\%$ dentro de sector & $100,0 \%$ & $100,0 \%$ & $100,0 \%$ & $100,0 \%$ \\
\hline
\end{tabular}

Cuadro 67: Tabla de contingencia de realización de acciones de responsabilidad social y sector.

El cuadro 67 muestra que en los tres sectores de procedencia de los líderes (servicios, construcción e industria) el mayor protagonismo de la muestra se encuentra en los líderes procedentes de empresas que no impulsan ningún tipo de iniciativa vinculada con la responsabilidad social. Este aspecto es especialmente destacado en el caso de las organizaciones del sector de la construcción, donde el $71,4 \%$ de las empresas de este ámbito de actividad no han registrado ningún tipo de actuación en materia de Responsabilidad Social Corporativa.

En función de la información aportada por los líderes parece existir una menor tendencia a la realización de acciones de responsabilidad social en las empresas del sector de la construcción, lo que podría incidir en el desempeño de los líderes en este ámbito. De todos modos sería necesario realizar una investigación con una muestra más amplia para poder generalizar esta observación. 
Por el contrario, los datos reflejan la existencia de una mayor tendencia a la realización de acciones de responsabilidad social en las empresas industriales (casi dos de cada tres empresas realizan acciones en este campo). Este resultado se corresponde con el obtenido en otras investigaciones (Godos y Fernández, 2011).

En relación con los datos registrados sobre el sector en el que las organizaciones desarrollan su actividad y el número de horas que dedican a formar a sus colaboradores a través de cursos encuadrados en el ámbito de la responsabilidad social, tal como muestra el gráfico 24 todos los sectores dedican prácticamente menos de 150 horas a este cometido:

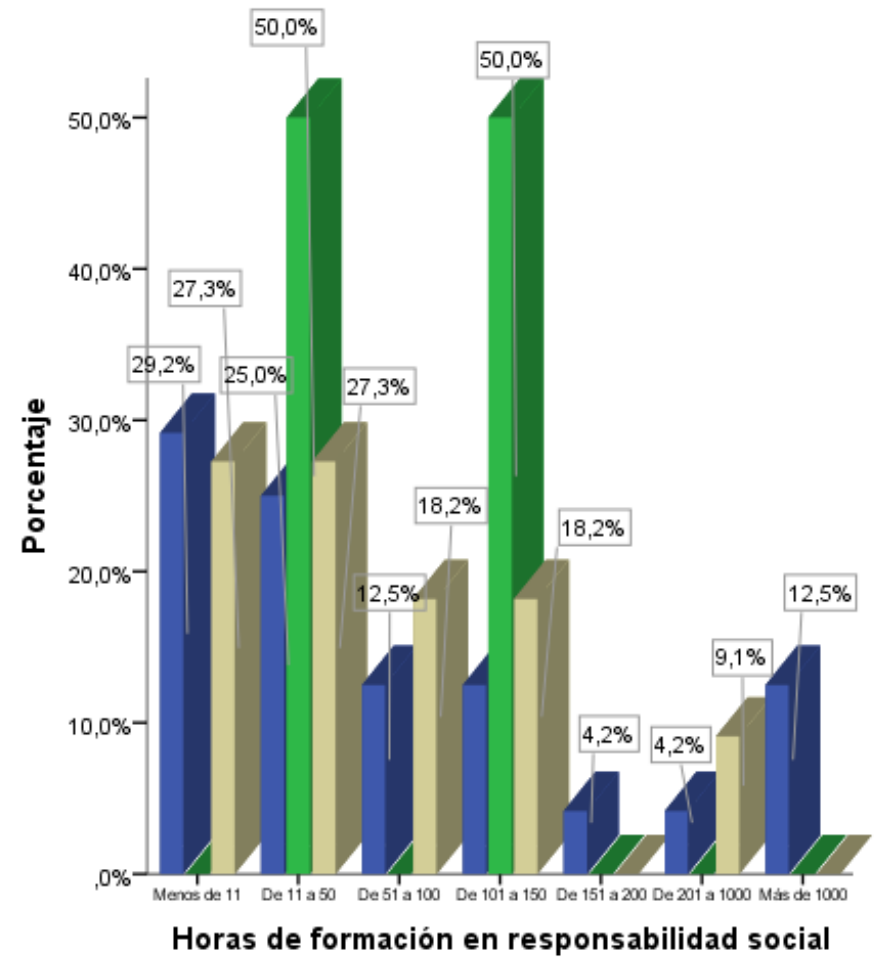


La pauta indicada se rompe de un modo leve en el sector servicios, en el que algo más de una de cada cinco empresas (21\%) dedica más de 150 horas a mejorar los conocimientos sobre Responsabilidad Social Corporativa de sus públicos internos. También se ha registrado una organización del sector industria $(9,1 \%$ del peso relativo en este sector) que invierte más de 200 horas a formar a sus colaboradores en responsabilidad social. Ambos sectores también comparten una cierta tendencia decreciente a medida que aumenta el número de horas dedicadas a sensibilizar a sus públicos internos en cuestiones de Responsabilidad Social Corporativa.

En el sector construcción solo se han registrado cuatro casos de empresas que impulsan este tipo de acciones a las que dedican entre 11 y 150 horas.

\subsubsection{Tamaño y Responsabilidad Social Corporativa}

A continuación incorporamos el cuadro 68 con datos sobre la actitud de los líderes hacia la responsabilidad social según el tamaño de sus organizaciones de origen:

\begin{tabular}{|l|c|r|r|r|}
\hline Tamaño & Media & Mínimo & Máximo & Desv. típ. \\
\hline Pequeño & 7,0845 & 3,86 & 8,13 & 1,11040 \\
\hline Mediano & 7,1458 & 4,39 & 8,10 & 1,06398 \\
\hline Grande & 7,6528 & 5,40 & 8,12 &, 70090 \\
\hline TOTAL & 7,2043 & 3,86 & 8,13 & 1,05294 \\
\hline
\end{tabular}

Cuadro 68: Medidas estadísticas sobre el tamaño y la actitud hacia la responsabilidad social. 
Antes de revisar la información del cuadro 68, hemos aplicado ANOVA de un factor a los datos a los que hace referencia para comprobar si existen diferencias estadísticamente significativas entre los diversos grupos que integran la muestra poblacional.

\begin{tabular}{|l|r|r|r|c|c|}
\hline & Suma de cuadrados & gl & Media cuadrática & F & Sig. \\
\hline Inter-grupos & 39,531 & 80 &, 494 &, 707 &, 948 \\
\hline Intra-grupos & 75,495 & 108 &, 699 & & \\
\hline Total & 115,026 & 188 & & & \\
\hline
\end{tabular}

Cuadro 69: Tabla ANOVA de tamaño, factor Actitud hacia la Responsabilidad Social.

De acuerdo con los datos que ofrece el cuadro 69 (el coeficiente de significación es igual a 0,948 ) no existen diferencias significativas, desde el punto de vista estadístico, entre los diversos grupos muestrales contemplados.

La información que ofrece el cuadro 68 indica que el tamaño de la organización es un aspecto que tiene incidencia en la actitud de los líderes organizacionales hacia la Responsabilidad Social Corporativa.

Además también muestra que a medida que crece el tamaño empresarial, la actitud favorable hacia la responsabilidad social también se incrementa. De manera muy leve al pasar de los máximos responsables de organizaciones pequeñas (su actitud media es 7,08) a medianas (presentan una actitud media de 7,14), y de manera más pronunciada (algo más de medio punto) al 
pasar de los líderes de empresas medianas a los de organizaciones grandes (su actitud media es 7,65 ).

En lo que se refiere a la realización de acciones de responsabilidad social en las empresas en función de su tamaño, hemos incorporado el gráfico 25:

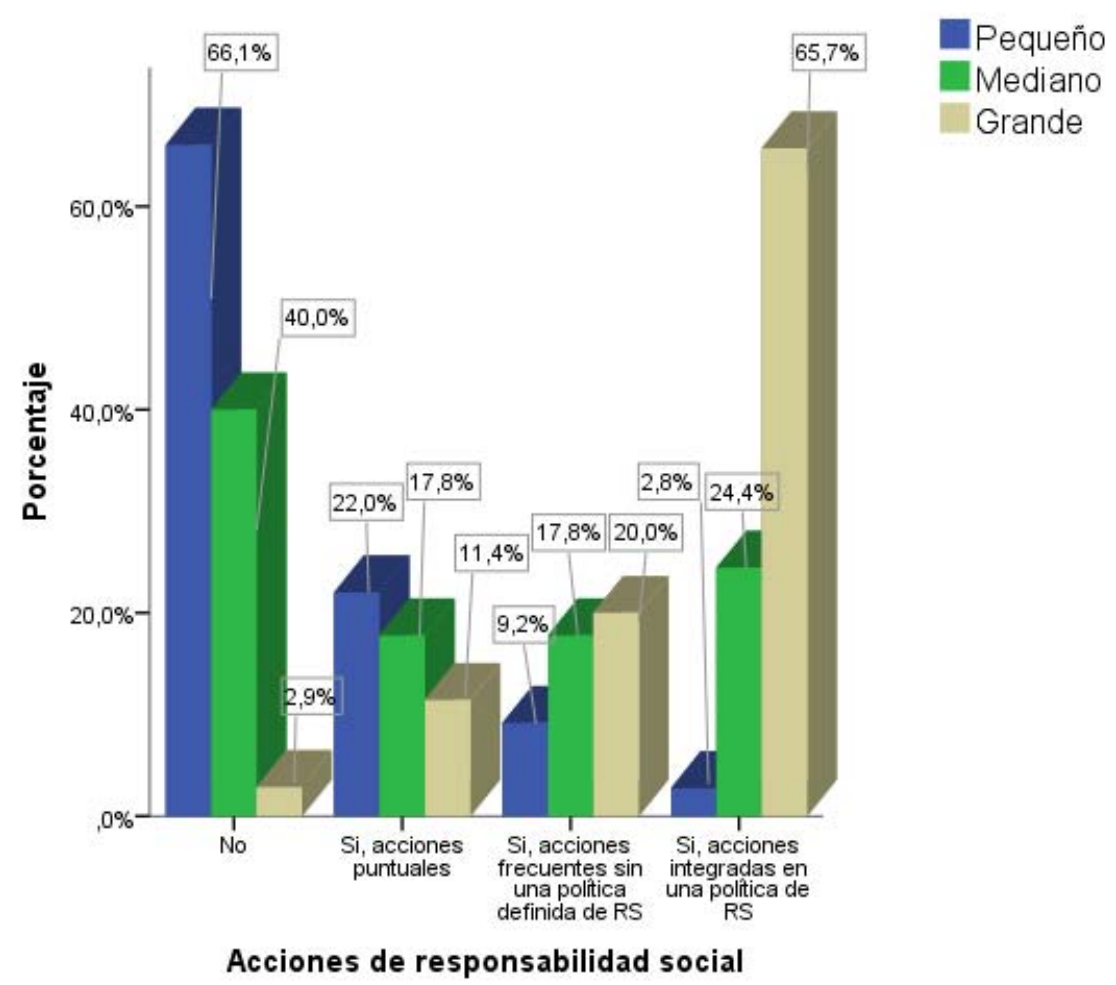

Gráfico 25: Realización de acciones de responsabilidad social y tamaño.

Según muestra el gráfico 25 se ha constatado una tendencia inversa en las empresas de la muestra entre la intensidad de su comportamiento socialmente responsable y su tamaño.

Mientras que 2 de cada 3 organizaciones pequeñas no realizan acciones de responsabilidad social $(66,1 \%)$ y menos de 1 de cada 4 realizan acciones puntuales, esta tendencia decreciente se equilibra y termina siendo ascendente en el caso de las empresas medianas. En las organizaciones de 
este tamaño, algo más de 1 de cada 3 (35,6\%) realizan acciones puntuales 0 frecuentes de responsabilidad social y 1 de cada 4 empresas medianas impulsan iniciativas dentro de una política establecida de responsabilidad social.

En el caso de las organizaciones grandes, la gran mayoría $(85,7 \%)$ desarrollan acciones frecuentes de responsabilidad social o las impulsan dentro de una política de actuación definida. En este último caso se encuentran prácticamente 2 de cada 3 organizaciones grandes $(65,7 \%)$.

En relación con la formación en responsabilidad social para los públicos internos de las organizaciones según su tamaño, los datos recabados a través de las entrevistas figuran en el cuadro 70:

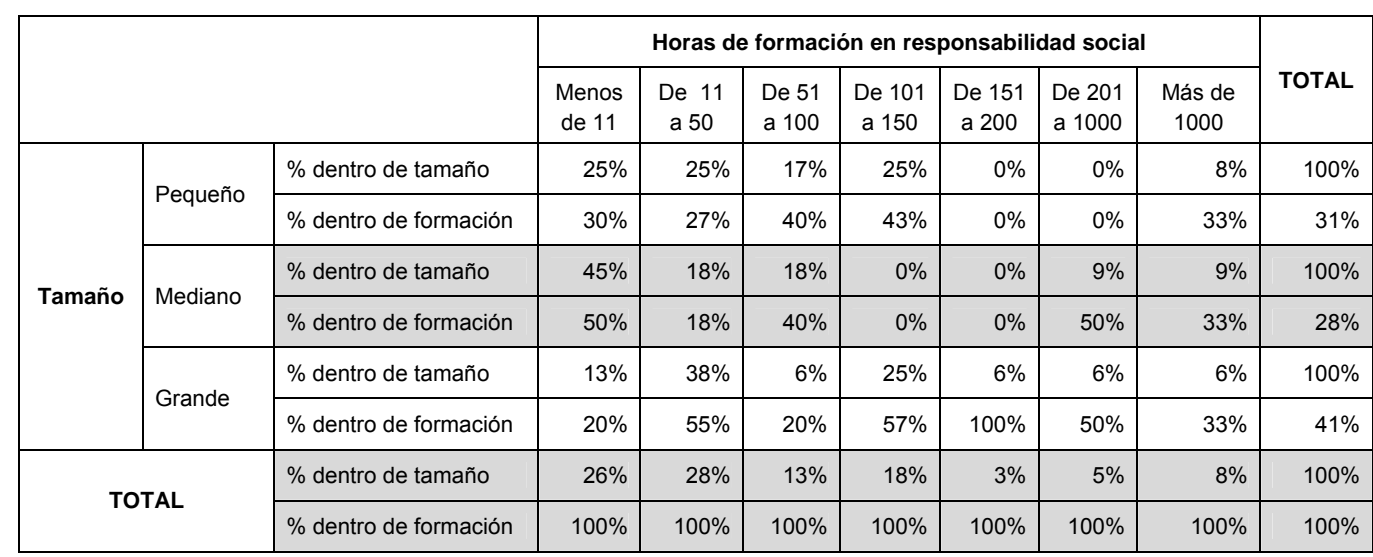

Cuadro 70: Tabla de contingencia de tamaño y horas dedicadas a la formación en responsabilidad social en empresas que realizan este tipo de formación.

La información del cuadro 70 indica que el tamaño empresarial no es un factor tan crítico en el desarrollo de acciones formativas en materia de responsabilidad social por parte de las organizaciones como el desarrollo de acciones de responsabilidad social. 
Se han recogido datos de líderes procedentes de empresas pequeñas que dedican entre 11 a 150 horas a formar a sus públicos internos en esta materia e incluso una organización que dedica más de 1000 horas a esta cuestión. En este último caso se trata de una consultora pequeña que se dedica a asesorar en el ámbito de la Responsabilidad Social Corporativa. De todos modos, debido a la naturaleza de la actividad de esta empresa, no se trata de un dato representativo.

En cuanto a las empresas medianas, su mayor protagonismo se ha registrado en las organizaciones que dedican 100 o menos horas a sensibilizar a sus públicos internos en responsabilidad social $(81 \%$ de las empresas medianas). Además, su presencia entre las organizaciones que dedican más de $\mathbf{2 0 0}$ horas a formar a sus colaboraciones en Responsabilidad Social Corporativa es prácticamente anecdótica (2 casos).

Tampoco existe la correspondencia que ya hemos visto entre las organizaciones de tamaño grande y la realización de acciones de responsabilidad social al considerar el desarrollo de acciones formativas sobre esta materia. Aunque hay líderes de empresas grandes que han indicado que sus organizaciones dedican desde 11 horas a más de 1000 horas a sensibilizar a sus colaboradores en Responsabilidad Social Corporativa, el porcentaje más elevado de empresas grandes se encuentra en las organizaciones que dedican 150 o menos horas a formar a sus públicos internos en responsabilidad social (82\%). 
Estos datos han indicado que el mayor tamaño de las empresas no parece influir en que dediquen más horas a formar a sus colaboradores sobre Responsabilidad Social Corporativa aunque las empresas grandes sí parecen estar más comprometidas con este tipo de iniciativas. Esto se constata al contemplar que en la muestra general del estudio las empresas grandes han representado el 18,5\% del tamaño muestral, mientras en la muestra de organizaciones que impulsan acciones de formación en responsabilidad social para públicos internos han supuesto el $41 \%$.

Las políticas de formación de personal son una de las prácticas internas de responsabilidad social más consolidadas en las empresas porque conllevan ventajas tanto para la empresa, sea cual sea su tamaño, como para los colaboradores. Por ejemplo este tipo de actuaciones potencian la flexibilidad funcional de los colaboradores, es decir, su capacidad para adaptarse a otras tareas (Curto, 2012).

Sin embargo también hemos entendido que este tipo de acciones, que mejoran la preparación de los colaboradores para investigar dentro de su campo de actuación (Delgado, 2012), tienen más demanda en las empresas grandes por tratarse de organizaciones que requieren un mayor grado de especialización. Consideración que guardaría correspondencia con los datos registrados en el estudio. 


\subsubsection{Liderazgo y Responsabilidad Social \\ Corporativa}

Hemos segmentado el valor de la media de la actitud hacia la responsabilidad social en 6 grupos para facilitar su revisión conjunta con los datos obtenidos sobre liderazgo.

\begin{tabular}{|c|c|c|c|c|c|c|c|}
\hline \multicolumn{2}{|c|}{$\begin{array}{l}\text { Actitud hacia la } \\
\text { responsabilidad social }\end{array}$} & \multirow{2}{*}{$\begin{array}{c}\begin{array}{c}\text { Estilo } \\
\text { directivo } \\
\text { (alta dirección y } \\
\text { poco apoyo) }\end{array} \\
2,00\end{array}$} & \multirow{2}{*}{$\begin{array}{c}\begin{array}{c}\text { Estilo } \\
\text { consultivo } \\
\text { (alta dirección y } \\
\text { mucho apoyo) }\end{array} \\
12,00 \\
\end{array}$} & \multirow{2}{*}{$\begin{array}{r}\begin{array}{c}\text { Estilo } \\
\text { participativo } \\
\text { (alto apoyo y } \\
\text { poca dirección) }\end{array} \\
6,00\end{array}$} & \multirow{2}{*}{$\begin{array}{c}\begin{array}{c}\text { Estilo } \\
\text { delegativo } \\
\text { (poco apoyo y } \\
\text { baja dirección) }\end{array} \\
, 00\end{array}$} & \multirow{2}{*}{$\begin{array}{r}\text { Flexibilidad } \\
14,00\end{array}$} & \multirow{2}{*}{$\begin{array}{r}\text { Efectividad } \\
57,00 \\
\end{array}$} \\
\hline \multirow{4}{*}{$0 a<4$} & Media & & & & & & \\
\hline & Mínimo & 2 & 12 & 6 & 0 & 14 & 57 \\
\hline & Máximo & 2 & 12 & 6 & 0 & 14 & 57 \\
\hline & Desv. típ. & . & . & . & . & . & . \\
\hline \multirow{4}{*}{$4 a<5$} & Media & 3,43 & 6,00 & 7,57 & 3,00 & 21,86 & 54,14 \\
\hline & Mínimo & 0 & 4 & 5 & 1 & 12 & 44 \\
\hline & Máximo & 6 & 9 & 13 & 7 & 26 & 62 \\
\hline & Desv. típ. & 2,440 & 1,633 & 2,573 & 2,082 & 5,113 & 6,094 \\
\hline \multirow{4}{*}{$5 a<6$} & Media & 3,74 & 5,65 & 6,61 & 4,00 & 20,74 & 55,35 \\
\hline & Mínimo & 0 & 0 & 1 & 1 & 10 & 44 \\
\hline & Máximo & 8 & 10 & 15 & 14 & 26 & 66 \\
\hline & Desv. típ. & 2,320 & 2,790 & 3,299 & 2,876 & 4,614 & 5,749 \\
\hline \multirow{4}{*}{$6 a<7$} & Media & 2,87 & 6,87 & 7,39 & 2,87 & 19,65 & 55,13 \\
\hline & Mínimo & 0 & 1 & 1 & 0 & 10 & 45 \\
\hline & Máximo & 7 & 11 & 15 & 6 & 26 & 63 \\
\hline & Desv. típ. & 2,012 & 2,078 & 3,422 & 1,628 & 4,325 & 4,380 \\
\hline \multirow{4}{*}{7 a 8} & Media & 2,17 & 6,76 & 8,02 & 3,03 & 18,69 & 56,28 \\
\hline & Mínimo & 0 & 1 & 1 & 0 & 12 & 43 \\
\hline & Máximo & 7 & 13 & 14 & 9 & 28 & 67 \\
\hline & Desv. típ. & 1,844 & 2,691 & 2,983 & 1,666 & 3,985 & 5,230 \\
\hline \multirow{4}{*}{$>8$} & Media & 2,27 & 6,00 & 8,11 & 3,54 & 18,97 & 56,59 \\
\hline & Mínimo & 0 & 1 & 4 & 0 & 11 & 43 \\
\hline & Máximo & 9 & 14 & 14 & 9 & 26 & 68 \\
\hline & Desv. típ. & 2,023 & 3,109 & 2,558 & 2,142 & 4,272 & 6,021 \\
\hline \multirow{4}{*}{ TOTAL } & Media & 2,54 & 6,49 & 7,74 & 3,21 & 19,24 & 55,96 \\
\hline & Mínimo & 0 & 0 & 1 & 0 & 10 & 43 \\
\hline & Máximo & 9 & 14 & 15 & 14 & 28 & 68 \\
\hline & Desv. típ. & 2,041 & 2,707 & 3,013 & 1,977 & 4,264 & 5,331 \\
\hline
\end{tabular}

Cuadro 71: Medidas estadísticas sobre la actitud hacia la responsabilidad social y el liderazgo.

Antes de comentar los datos del cuadro 71 hemos aplicado ANOVA de un factor en la muestra poblacional para comprobar si existen diferencias estadísticamente significativas entre los diversos grupos poblacionales. 


\begin{tabular}{|l|l|r|r|r|c|c|}
\hline \multicolumn{2}{|c|}{} & Suma de cuadrados & gl & Media cuadrática & F & Sig. \\
\hline \multirow{4}{*}{ Estilo directivo } & Inter-grupos & 57,522 & 5 & 11,504 & 2,902 &, 015 \\
\cline { 2 - 8 } & Intra-grupos & 725,430 & 183 & 3,964 & & \\
\cline { 2 - 8 } & Total & 782,952 & 188 & & & \\
\hline \multirow{4}{*}{ Estilo consultivo } & Inter-grupos & 67,915 & 5 & 13,583 & 1,898 &, 097 \\
\cline { 2 - 8 } & Intra-grupos & 1309,323 & 183 & 7,155 & \\
\cline { 2 - 8 } & Total & 1377,238 & 188 & & & \\
\hline \multirow{4}{*}{ Estilo delegativo } & Inter-grupos & 48,702 & 5 & 9,740 & 1,075 &, 376 \\
\cline { 2 - 8 } & Intra-grupos & 1658,071 & 183 & 9,060 & & \\
\cline { 2 - 8 } & Total & 1706,772 & 188 & & & \\
\hline & Inter-grupos & 35,379 & 5 & 7,076 & 1,851 &, 105 \\
\cline { 2 - 8 } & Intra-grupos & 699,573 & 183 & 3,823 & & \\
\cline { 2 - 8 } & Total & 734,952 & 188 & & & \\
\hline \multirow{5}{*}{ Efectividad } & Inter-grupos & 162,154 & 5 & 32,431 & 1,822 &, 110 \\
\cline { 2 - 8 } & Intra-grupos & 3256,651 & 183 & 17,796 & & \\
\cline { 2 - 8 } & Total & 3418,804 & 188 & & & \\
\hline & Inter-grupos & 78,208 & 5 & 15,642 &, 544 &, 743 \\
\cline { 2 - 8 } & Intra-grupos & 5264,533 & 183 & 28,768 & & \\
\cline { 2 - 8 } & Total & 5342,741 & 188 & & & \\
\hline
\end{tabular}

Cuadro 72: Tabla ANOVA de liderazgo, factor Actitud hacia la Responsabilidad Social.

La información que nos ofrece el cuadro 72 indica que existen diferencias estadísticamente significativas entre los diversos grupos muestrales en relación con "estilo directivo" (su coeficiente de significación es 0,015 ).

En la revisión de los datos que ofrece el cuadro 71 no hemos considerado, por su escasa representatividad, aquellos casos en los que solo hemos recogido información de un líder (en este caso, el que ha registrado una actitud que se encuentra entre 0 y 4 ).

Hemos indicado, en primer lugar, las observaciones que hacen referencia a los cinco grupos muestrales considerados, ya sea porque afecten a todos los grupos o porque revelen ciertas tendencias presentes en la mayoría de ellos. 
A continuación hemos señalado algunos resultados puntuales alcanzados en grupos muestrales concretos.

Los datos del cuadro 71 indican que el estilo directivo parece tender a perder relevancia en el rol del líder, pese a ser un estilo con poco peso en sus decisiones, a medida que se incrementa el valor medio de la actitud del líder a favor de la responsabilidad social. La valoración media del estilo directivo en los líderes del segmento " $4<5$ " es 3,43 , mientras que los líderes que han valorado la actitud entre 7 y 8 han registrado 2,17 como puntaje medio en este estilo.

Además la información que aporta el cuadro 71 también permite observar que en todos los líderes, sea cual sea su actitud hacia la responsabilidad social, su estilo de liderazgo primario es el participativo y su estilo de liderazgo secundario es el consultivo.

Por otra parte el estilo participativo parece ganar protagonismo en el ejercicio del liderazgo a media que el líder presenta una actitud más favorable hacia la responsabilidad social. Los líderes cuya actitud media se encuentra en el segmento "5 a <6" han obtenido una puntuación media en el estilo participativo de 6,61, mientras que los máximos responsables que han registrado un valor medio de su actitud mayor de 8 han obtenido una puntuación media de 8,11 en el estilo participativo.

Asimismo también parece existir una tendencia a que la flexibilidad sea más reducida en el rol de liderazgo a medida que la actitud hacia la responsabilidad social es más 
favorable. La flexibilidad media en los líderes que han valorado la actitud, como promedio, entre 4 y 5 ha sido 21,86, mientras que los máximos responsables ubicados en el segmento de valor de la actitud "7 a 8" han registrado una puntuación media de 18,69en la flexibilidad.

También parece darse un incremento en la efectividad del liderazgo del máximo responsable organizacional a medida que presenta una disposición más favorable hacia la Responsabilidad Social Corporativa. El valor medio de la efectividad en los líderes cuya actitud media se ha encontrado entre 4 y 5 ha sido 54,14, mientras que los máximos responsables que han registrado una actitud media mayor de 8 han presentado una efectividad media de 56,59.

En cuanto a datos de grupos poblacionales concretos, hemos destacado dos aspectos.

En primer lugar que en el grupo de líderes cuya actitud media se encuentra en el segmento " 5 a $<6$ ", el estilo consultivo ha registrado su puntuación media más reducida $(5,65)$ y el estilo participativo también $(6,61)$.

En segundo lugar que en los líderes que han mostrado una actitud media hacia la responsabilidad social situada en el segmento de valor "6 a <7", el estilo consultivo ha obtenido su puntuación media más alta $(6,87)$ aunque los líderes del segmento de valor medio de la actitud "7 a 8" también han presentado una puntación media elevada en el estilo consultivo $(6,76)$. 
En lo que respecta al liderazgo y al desarrollo de acciones de responsabilidad social por parte de las empresas de procedencia de los líderes entrevistados, hemos incorporado el cuadro 73 a continuación con los datos obtenidos.

\begin{tabular}{|c|c|c|c|c|c|c|c|}
\hline \multicolumn{2}{|c|}{ Acciones de resp. social } & \multirow{2}{*}{$\begin{array}{r}\begin{array}{c}\text { Estilo } \\
\text { directivo } \\
\text { (alta dirección } \\
\text { y poco apoyo) }\end{array} \\
3,07\end{array}$} & \multirow{2}{*}{$\begin{array}{c}\begin{array}{c}\text { Estilo } \\
\text { consultivo } \\
\text { (alta dirección y } \\
\text { mucho apoyo) }\end{array} \\
6,29\end{array}$} & \multirow{2}{*}{$\begin{array}{r}\begin{array}{c}\text { Estilo } \\
\text { participativo } \\
\text { (alto apoyo y } \\
\text { poca dirección) }\end{array} \\
6,88\end{array}$} & \multirow{2}{*}{$\begin{array}{r}\begin{array}{c}\text { Estilo } \\
\text { delegativo } \\
\text { (poco apoyo y } \\
\text { baja dirección) }\end{array} \\
3,63\end{array}$} & \multirow{2}{*}{$\begin{array}{l}\text { Efectividad } \\
54,74\end{array}$} & \multirow{2}{*}{$\begin{array}{r}\text { Flexibilidad } \\
20,34\end{array}$} \\
\hline \multirow{6}{*}{ No } & Media & & & & & & \\
\hline & Desv. típ. & 2,169 & 2,810 & 2,863 & 2,234 & 5,297 & 4,264 \\
\hline & Mínimo & 0 & 0 & 1 & 0 & 43 & 11 \\
\hline & Máximo & 9 & 14 & 14 & 14 & 67 & 26 \\
\hline & Suma & 279 & 572 & 626 & 330 & 4981 & 1851 \\
\hline & Mediana & 3,00 & 6,00 & 7,00 & 3,00 & 55,00 & 21,00 \\
\hline \multirow{6}{*}{$\begin{array}{l}\text { Sí, acciones } \\
\text { puntuales }\end{array}$} & Media & 2,28 & 6,44 & 8,44 & 2,83 & 55,17 & 19,22 \\
\hline & Desv. típ. & 1,632 & 2,261 & 2,761 & 1,424 & 5,218 & 3,921 \\
\hline & Mínimo & 0 & 1 & 4 & 0 & 43 & 10 \\
\hline & Máximo & 8 & 11 & 15 & 5 & 66 & 26 \\
\hline & Suma & 82 & 232 & 304 & 102 & 1986 & 692 \\
\hline & Mediana & 2,00 & 7,00 & 8,00 & 3,00 & 54,50 & 18,00 \\
\hline \multirow{6}{*}{$\begin{array}{l}\text { Sí, acciones } \\
\text { frecuentes } \\
\text { sin una } \\
\text { política } \\
\text { definida de } \\
\text { resp. social }\end{array}$} & Media & 1,92 & 6,80 & 8,48 & 2,76 & 57,72 & 17,08 \\
\hline & Desv. típ. & 2,040 & 2,915 & 2,988 & 2,006 & 4,542 & 3,487 \\
\hline & Mínimo & 0 & 1 & 3 & 0 & 48 & 12 \\
\hline & Máximo & 7 & 13 & 14 & 9 & 66 & 24 \\
\hline & Suma & 48 & 170 & 212 & 69 & 1443 & 427 \\
\hline & Mediana & 1,00 & 7,00 & 9,00 & 3,00 & 59,00 & 18,00 \\
\hline \multirow{6}{*}{$\begin{array}{l}\text { Sí, acciones } \\
\text { integradas } \\
\text { en una } \\
\text { política de } \\
\text { resp. social }\end{array}$} & Media & 1,92 & 6,84 & 8,65 & 2,84 & 58,57 & 18,03 \\
\hline & Desv. típ. & 1,785 & 2,754 & 3,155 & 1,555 & 4,947 & 4,317 \\
\hline & Mínimo & 0 & 1 & 3 & 0 & 51 & 10 \\
\hline & Máximo & 6 & 13 & 15 & 6 & 68 & 28 \\
\hline & Suma & 71 & 253 & 320 & 105 & 2167 & 667 \\
\hline & Mediana & 2,00 & 7,00 & 8,00 & 3,00 & 58,00 & 18,00 \\
\hline \multirow{6}{*}{ TOTAL } & Media & 2,54 & 6,49 & 7,74 & 3,21 & 55,96 & 19,24 \\
\hline & Desv. típ. & 2,041 & 2,707 & 3,013 & 1,977 & 5,331 & 4,264 \\
\hline & Mínimo & 0 & 0 & 1 & 0 & 43 & 10 \\
\hline & Máximo & 9 & 14 & 15 & 14 & 68 & 28 \\
\hline & Suma & 480 & 1227 & 1462 & 606 & 10577 & 3637 \\
\hline & Mediana & 2,00 & 7,00 & 8,00 & 3,00 & 56,00 & 20,00 \\
\hline
\end{tabular}

Cuadro 73: Medidas estadísticas de liderazgo según realización de acciones de responsabilidad social.

Hemos incluido en dicho cuadro medidas estadísticas sobre liderazgo dentro de cada una de las cuatro 
posibilidades que podía presentar la organización en relación con el desarrollo de acciones de responsabilidad social: no realiza ningún tipo de acción, desarrolla acciones puntuales, realiza acciones frecuentes e impulsa iniciativas integradas dentro de una política definida de responsabilidad social.

Estas tres últimas opciones (actuación puntual, frecuente o integrada en una política) representan una disposición activa ante la responsabilidad social frente a la primera opción (inacción), que se corresponde con organizaciones que no desarrollan ningún tipo de iniciativa en el ámbito de la Responsabilidad Social Corporativa.

Los datos del cuadro 73 reflejan algunas variaciones significativas en la importancia que los líderes conceden a algunos estilos de liderazgo de acuerdo con la actuación de su organización de origen en materia de responsabilidad social, aunque en todos los casos los estilos más utilizados son dos: el consultivo y el participativo. También ofrecen algunas variaciones destacadas en los valores medios alcanzados por la flexibilidad y la efectividad de estilo en las diversas opciones contempladas.

Antes de revisar los datos con mayor profundidad hemos aplicado ANOVA de un factor (cuadro 74) para ver si existen diferencias estadísticamente significativas entre los cuatro grupos muestrales en relación con las variables contempladas. 


\begin{tabular}{|l|l|r|r|r|r|c|}
\hline \multicolumn{2}{|c|}{} & Suma de cuadrados & gl & Media cuadrática & F & Sig. \\
\hline \multirow{3}{*}{$\begin{array}{l}\text { Estilo } \\
\text { directivo }\end{array}$} & Inter-grupos & 51,529 & 3 & 17,176 & 4,344 &, 006 \\
\cline { 2 - 8 } & Intra-grupos & 731,423 & 185 & 3,954 & & \\
\cline { 2 - 8 } & Total & 782,952 & 188 & & & \\
\hline \multirow{3}{*}{$\begin{array}{l}\text { Estilo } \\
\text { consultivo }\end{array}$} & Inter-grupos & 10,751 & 3 & 3,584 &, 485 &, 693 \\
\cline { 2 - 8 } & Intra-grupos & 1366,487 & 185 & 7,386 & & \\
\cline { 2 - 8 } & Total & 1377,238 & 188 & & & \\
\hline \multirow{3}{*}{$\begin{array}{l}\text { Estilo } \\
\text { participativo }\end{array}$} & Inter-grupos & 129,541 & 3 & 43,180 & 5,065 &, 002 \\
\cline { 2 - 8 } & Intra-grupos & 1577,232 & 185 & 8,526 & & \\
\cline { 2 - 8 } & Total & 1706,772 & 188 & & & \\
\hline \multirow{3}{*}{$\begin{array}{l}\text { Estilo } \\
\text { delegativo }\end{array}$} & Inter-grupos & 31,069 & 3 & 10,356 & 2,722 &, 046 \\
\cline { 2 - 8 } & Intra-grupos & 703,884 & 185 & 3,805 & & \\
\cline { 2 - 8 } & Total & 734,952 & 188 & & & \\
\hline \multirow{3}{*}{$\begin{array}{l}\text { Flexibilidad de } \\
\text { estilo }\end{array}$} & Inter-grupos & 281,329 & 3 & 93,776 & 5,529 &, 001 \\
\cline { 2 - 8 } & Intra-grupos & 3137,475 & 185 & 16,959 & & \\
\cline { 2 - 8 } & Total & 3418,804 & 188 & & & \\
\hline \multirow{2}{*}{$\begin{array}{l}\text { Efectividad de } \\
\text { estilo }\end{array}$} & Inter-grupos & 487,949 & 3 & 162,650 & 6,198 &, 000 \\
\cline { 2 - 8 } & Intra-grupos & 4854,791 & 185 & 26,242 & & \\
\cline { 2 - 8 } & Total & 5342,741 & 188 & & & \\
\hline
\end{tabular}

Cuadro 74: Tabla ANOVA de liderazgo, factor Realización de Acciones de Responsabilidad Social.

Los datos del cuadro 74 muestran la existencia de diferencias estadísticamente significativas entre los diversos grupos muestrales (el coeficiente de significación en los 5 casos está por debajo de 0,05).

A continuación hemos realizado una lectura de los datos significativos en relación con las cuatro opciones posibles de actuación empresarial en materia de responsabilidad social (cuadro 73).

En los líderes que están vinculados a organizaciones en las que no se desarrolla ningún tipo iniciativa sobre responsabilidad social hay dos estilos preferentes (el consultivo y el participativo) cuyas medias son 6,29 y 6,88 respectivamente, y dos estilos (directivo y delegativo), cuya relevancia para los líderes se reduce a prácticamente la 
mitad (sus medias son, respectivamente 3,07 y 3,63). Estos líderes presentan la efectividad media de estilo más baja $(55,74)$, de los cuatro tipos de comportamiento empresarial contemplados, y la flexibilidad media más alta $(20,34)$.

En el resto de grupos muestrales, atendiendo al comportamiento socialmente responsable de su organización de origen, se repite la misma pauta en los estilos de liderazgo aunque con alguna variación que se mantiene tanto para los líderes procedentes de empresas que realizan acciones puntuales, como para los vinculados a organizaciones que desarrollan acciones frecuentes y como para los que ejercen su rol de máximo responsable en empresas con políticas definidas de responsabilidad social.

En los tres casos el comportamiento que tiene menos presencia es el estilo directivo, ya que su media es la menor en los tres grupos. El segundo estilo que presenta una media menor es el delegativo, que muestra un aumento ligeramente mayor en su valor medio (el aumento oscila entre el medio punto y casi el punto dependiendo del tipo de comportamiento socialmente responsable que se considere). $Y$ en cuanto a los estilos consultivo y participativo, este último es el más utilizado en los tres grupos y con mayor relevancia que en las empresas inactivas desde el punto de vista de la responsabilidad social (la media del estilo participativo en todos los casos es entre un punto y medio y dos mayor). 
En cuando a la efectividad y flexibilidad de estilo en los líderes vinculados a organizaciones que presentan algún tipo de comportamiento empresarial, la efectividad va aumentando a medida que se incrementa la intensidad en el comportamiento socialmente responsable de la organización (55,17 para los líderes procedentes de organizaciones que impulsan acciones puntuales, 57,72 para los que proceden de empresas que desarrollan acciones frecuentes y 58,57 para los que están vinculados a organizaciones que tienen una política de responsabilidad social) y la flexibilidad va descendiendo (19,22 para los líderes que trabajan en organizaciones que desarrollan iniciativas puntuales, 17,08 para los que están vinculados a empresas que impulsan iniciativas frecuentes y 18,03 para que los que proceden de organizaciones que tienen una política definida de Responsabilidad Social Corporativa).

Los datos reflejan que en las organizaciones que desarrollan algún tipo de iniciativa sobre responsabilidad social existe un mayor protagonismo del estilo participativo, más centrado en el apoyo y menos en la dirección, en el comportamiento del líder. También indican que el estilo directivo, donde el comportamiento de liderazgo se apoya menos en la dirección y se centra más en el apoyo, tiene algo menos de presencia en la conducta del líder procedente de este tipo de organizaciones. Esta reducción del protagonismo también se produce en el estilo delegativo, caracterizado por un escaso apoyo y baja dirección, aunque en menor medida. 
Asimismo los datos también muestran que a medida que crece el comportamiento responsable de una organización se reduce la flexibilidad de liderazgo y aumenta la efectividad de sus máximos cargos en su rol.

En relación con los datos sobre el desarrollo de acciones formativas enmarcadas en el ámbito de la responsabilidad social y el liderazgo, hemos incorporado dos gráficos.

En primer lugar hemos incluido los datos sobre los estilos de liderazgo en cada uno de las diferentes franjas de duración consideradas en las acciones formativas (gráfico 26) y, en segundo término, hemos incorporado los datos sobre la efectividad y la flexibilidad media de los líderes empresariales en dichas franjas (gráfico 27).

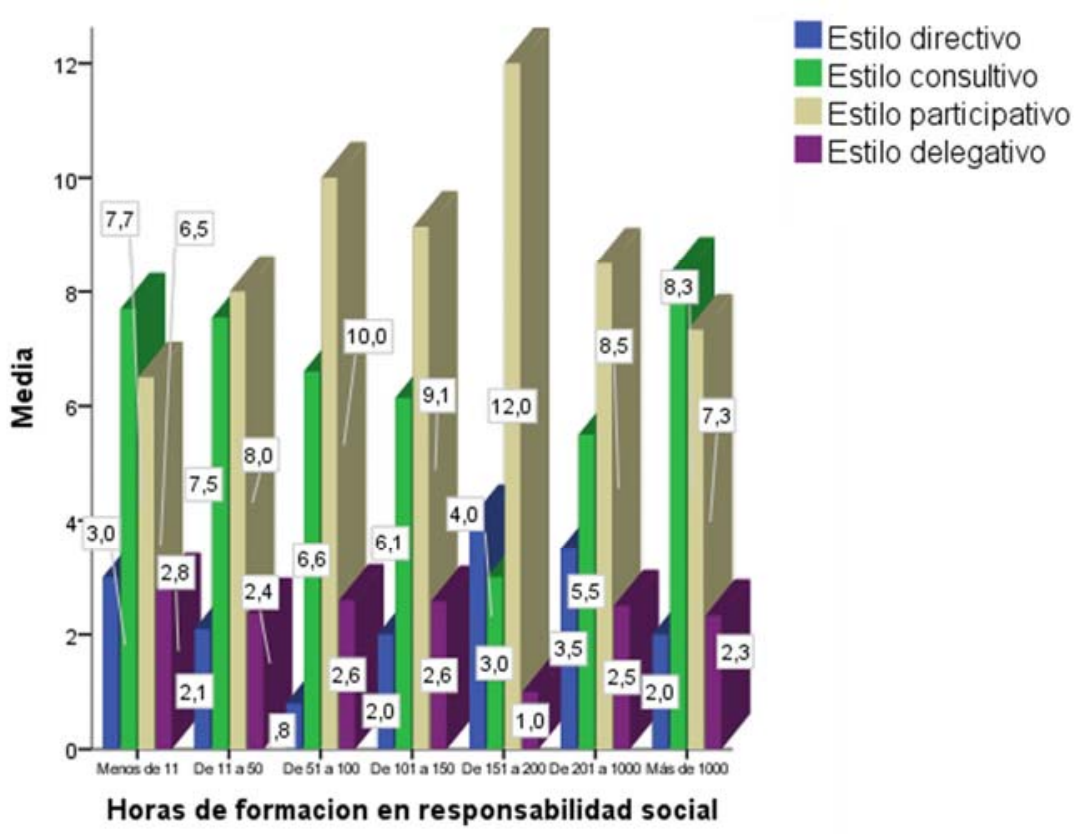

Gráfico 26: Formación en responsabilidad social según estilo de liderazgo. 
Tal y como muestra el gráfico 26, existen ligeras variaciones en el valor medio de los estilos de liderazgo, un poco más pronunciadas en algún caso, para los diferentes grupos de empresas según las horas que dedican a la formación en responsabilidad social.

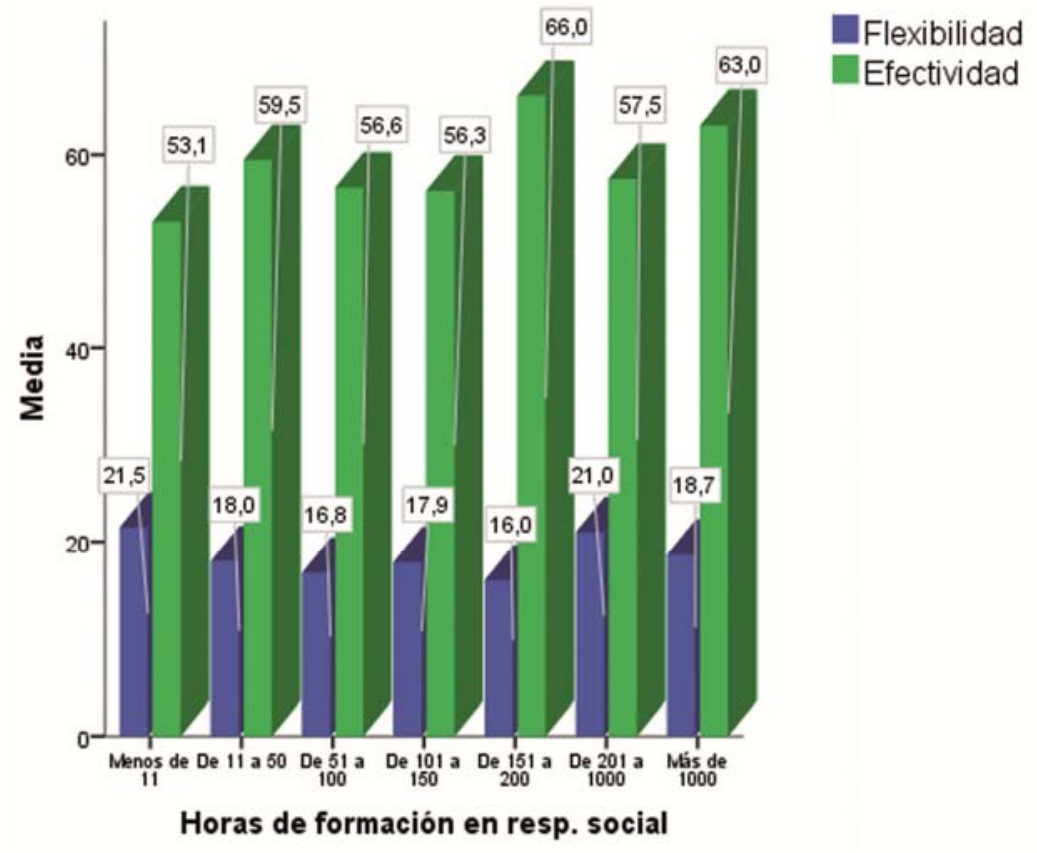

Gráfico 27: Formación en responsabilidad social según flexibilidad y efectividad de liderazgo.

El gráfico 27 también muestra, en ciertos casos, algunas variaciones leves.

Antes de hacer una valoración de la información reflejada en los gráficos 26 y 27 , hemos aplicado ANOVA de un factor en los datos (cuadro 72) para verificar si es posible comparar las medias de los diferentes grupos muestrales según las horas de formación en responsabilidad social.

Los datos estadísticos del cuadro 75, incorporado a continuación, muestran la existencia de diferencias estadísticamente significativas entre la "efectividad de 
estilo" (coeficiente de significación 0,004) y el resto de grupos muestrales en relación con el número de horas de formación en responsabilidad social.

\begin{tabular}{|l|l|r|r|r|r|r|}
\hline \multicolumn{2}{|c|}{} & Suma de cuadrados & gl & Media cuadrática & F & Sig. \\
\hline \multirow{3}{*}{$\begin{array}{l}\text { Estilo } \\
\text { directivo }\end{array}$} & Inter-grupos & 23,227 & 6 & 3,871 & 1,315 &, 279 \\
\cline { 2 - 8 } & Intra-grupos & 94,209 & 32 & 2,944 & & \\
\cline { 2 - 8 } & Total & 117,436 & 38 & & & \\
\hline \multirow{4}{*}{$\begin{array}{l}\text { Estilo } \\
\text { consultivo }\end{array}$} & Inter-grupos & 39,846 & 6 & 6,641 & 1,634 &, 170 \\
\cline { 2 - 8 } & Intra-grupos & 130,051 & 32 & 4,064 & & \\
\cline { 2 - 8 } & Total & 169,897 & 38 & & & \\
\hline \multirow{3}{*}{$\begin{array}{l}\text { Estilo } \\
\text { participativo }\end{array}$} & Inter-grupos & 68,553 & 6 & 11,426 & 1,720 &, 148 \\
\cline { 2 - 8 } & Intra-grupos & 212,524 & 32 & 6,641 & & \\
\cline { 2 - 8 } & Total & 281,077 & 38 & & & \\
\hline \multirow{3}{*}{$\begin{array}{l}\text { Estilo } \\
\text { delegativo }\end{array}$} & Inter-grupos & 3,517 & 6 &, 586 &, 253 &, 955 \\
\cline { 2 - 8 } & Intra-grupos & 74,226 & 32 & 2,320 & & \\
\cline { 2 - 8 } & Total & 77,744 & 38 & & & \\
\hline \multirow{3}{*}{$\begin{array}{l}\text { Flexibilidad de } \\
\text { estilo }\end{array}$} & Inter-grupos & 123,535 & 6 & 20,589 & 1,305 &, 283 \\
\cline { 2 - 8 } & Intra-grupos & 504,824 & 32 & 15,776 & & \\
\cline { 2 - 8 } & Total & 628,359 & 38 & & & \\
\hline \multirow{3}{*}{$\begin{array}{l}\text { Efectividad de } \\
\text { estilo }\end{array}$} & Inter-grupos & 410,167 & 6 & 68,361 & 4,045 &, 004 \\
\cline { 2 - 8 } & Intra-grupos & 540,756 & 32 & 16,899 & & \\
\cline { 2 - 8 } & Total & 950,923 & 38 & & & \\
\hline
\end{tabular}

Cuadro 75: Tabla ANOVA de liderazgo, factor Horas de Formación en Responsabilidad Social.

Una vez realizada la prueba de ANOVA hemos revisado la información de los gráficos 26 y 27.

En lectura de los datos los dos gráficos (26 y 27) no hemos considerado los grupos muestrales en los que solo se ha recabado información de un líder. Este hecho se ha dado en las empresas que ofrecen formación de 151 a 200 horas y en las que dedican a este tipo de actuaciones entre 201 a 1000 horas. 
Al igual que ocurría en el análisis sobre acciones de Responsabilidad Social Corporativa y liderazgo, en todos los grupos siempre se ha registrado una mayor relevancia de dos estilos (consultivo y participativo) y una menor incidencia de dos estilos (directivo y delegativo). Sin embargo los datos sobre efectividad y flexibilidad de estilo no guardan el mismo paralelismo.

En relación con el estilo directivo (alta dirección y poco apoyo) el número de horas dedicadas a la formación en responsabilidad social parece no afectar a la utilización de este estilo (la media del estilo para los líderes cuyas organizaciones dedican entre 11 a 50 horas es 2,09 y la de los cuyas empresas dedican más de 1000 horas es 2 ). Aunque la media del estilo directivo se reduce en los 5 líderes que están vinculados a organizaciones que dedican entre 51 a 100 horas (la media en este grupo es 0,80 ), en el resto de casos se mantiene entre 3 y 2 .

En lo que respecta a los estilos consultivo (alta dirección y mucho apoyo) y participativo (alto apoyo y poca dirección) tienen puntuaciones próximas (son los dos estilos con medias más elevadas en todos los casos) aunque su presencia en el comportamiento del líder presenta una cierta tendencia inversa.

En el estilo consultivo, su media decrece ligeramente a medida que aumenta el número de horas dedicadas a la formación (de 7,70 en los líderes cuyo origen son organizaciones que dedican menos de 11 horas a acciones formativas pasa a 6,14 en los máximos responsables 
procedentes de empresas que invierten de 151 a 200 horas) y finalmente aumenta cuando se hace referencia a los líderes cuyas organizaciones dedican a la formación específica en materia de responsabilidad social un elevado número de horas dedicadas (la media del estilo consultivo en este último caso es de 8,33 ).

Mientras en el estilo participativo su media aumenta ligeramente a medida que se incrementa el número de horas que las empresas de origen de los líderes dedican a la formación sobre Responsabilidad Social Corporativa (pasa de 6,50 en los líderes vinculados a organizaciones que dedican menos de 11 horas a 10 en los máximos responsables que proceden de empresas que invierten entre 51 a 100 horas a este tipo de iniciativas) y finalmente decrece cuando el número de horas que destinan las organizaciones de procedencia de los líderes es muy elevado (la media de este estilo directivo en los máximos responsable que proceden de empresas que dedican más de 1000 horas a la formación de públicos internos en materia de responsabilidad social es $7,33)$.

El comportamiento de estos dos últimos estilos en los grupos muestrales parece indicar que en las organizaciones en las que existe una implicación media en acciones formativas sobre responsabilidad el estilo liderazgo del máximo responsable organizacional suele ser el participativo (alto apoyo y poca dirección), mientras que en las empresas en las que se dedican pocas o muchas horas a la formación de públicos internos encuadradas en el ámbito de la 
responsabilidad social, el estilo primario parece ser el consultivo (alta dirección y mucho apoyo).

Finalmente en el caso del estilo delegativo (poco apoyo y baja dirección) su media, como ocurre con el estilo directivo, se mantiene más o menos estable sin que se vea afectada porque la empresa de la que procede el líder dedique más o menos horas a la formación enmarcada en el ámbito de la responsabilidad social.

En cuanto a la efectividad de estilo, existe una gran diferencia en los dos extremos contemplados (acciones formativas de poca duración y de gran duración) que guarda la misma lógica que existe entre la efectividad y las acciones de responsabilidad social.

En la opción asociada a una menor implicación en acciones formativas de responsabilidad social (empresas que dedican menos de 11 horas a este tipo de iniciativas) los líderes han registrado una efectividad media de 53,10, y en los líderes procedentes de organizaciones que dedican más de 1000 horas a acciones de formación enmarcadas en el ámbito de la responsabilidad social los máximos responsables empresariales han obtenido un puntaje medio de 63. Sin embargo, en este caso, no se mantiene la misma tendencia creciente que se registraba cuando analizamos el comportamiento socialmente responsable de las organizaciones y la efectividad de estilo de sus líderes. Por ejemplo la segunda puntuación más alta $(59,45)$ es la que corresponde a los líderes procedentes de empresas que 
dedican entre 11 y 50 horas a acciones formativas sobre responsabilidad social.

En lo que respecta a la flexibilidad de estilo, tampoco se repite la tendencia decreciente que se registraba en al analizar el comportamiento socialmente responsable de la organización (la flexibilidad tiende a perder relevancia a medida que se intensifica la actuación responsable de la organización de procedencia del máximo responsable). En este caso también existe un decrecimiento en las tres primeras opciones contempladas (21,50 para los líderes procedentes de empresas que dedican menos de 11 horas a formación enmarcada en el ámbito de la responsabilidad social, 18 para los que están vinculados a organizaciones que invierten entre 11 y 50 horas en acciones formativas y 16,80 para los líderes asociados a empresas que desarrollan acciones de formación de 51 a 100 horas). Sin embargo esta tendencia decreciente no se mantiene en los grupos muestrales que se corresponden con un mayor número de horas dedicadas a iniciativas de formación: los líderes que proceden de empresas que invierten entre 101 y 150 horas a acciones formativas encuadradas en el ámbito de la Responsabilidad Social Corporativa presentan una flexibilidad media de 17,86 y los que están vinculados a organizaciones que dedican más de 1000 horas a este tipo de acciones formativas han registrado una flexibilidad media de 18,67. 


\subsubsection{Valores y Responsabilidad Social}

\section{Corporativa}

Al igual que en el apartado precedente, hemos segmentado el valor de la actitud hacia la responsabilidad social de los líderes empresariales para realizar una lectura conjunta de dicho aspecto junto con los rasgos de personalidad, competencias genéricas y características comportamentales analizados.

Incorporamos a continuación el cuadro 76 con información estadística sobre las variables mencionadas.

\begin{tabular}{|c|c|c|c|c|c|c|c|}
\hline \multicolumn{2}{|c|}{$\begin{array}{c}\text { Actitud hacia la } \\
\text { responsabilidad social }\end{array}$} & \multirow{2}{*}{$\begin{array}{r}\text { Practicidad } \\
21,00\end{array}$} & \multirow{2}{*}{$\begin{array}{r}\text { Resultados } \\
17,00\end{array}$} & \multirow{2}{*}{$\begin{array}{r}\text { Variedad } \\
7,00\end{array}$} & \multirow{2}{*}{$\begin{array}{r}\text { Decisión } \\
20,00\end{array}$} & \multirow{2}{*}{$\begin{array}{r}\text { Orden y método } \\
12,00\end{array}$} & \multirow{2}{*}{$\begin{array}{r}\text { Metas } \\
10,00\end{array}$} \\
\hline \multirow{4}{*}{$0 a<4$} & Media & & & & & & \\
\hline & Mínimo & 21 & 17 & 7 & 20 & 12 & 10 \\
\hline & Máximo & 21 & 17 & 7 & 20 & 12 & 10 \\
\hline & Desv. típ. & . & . & . & & . & \\
\hline \multirow{4}{*}{$4 a<5$} & Media & 15,14 & 14,14 & 8,14 & 16,29 & 16,86 & 19,43 \\
\hline & Mínimo & 13 & 7 & 4 & 11 & 10 & 13 \\
\hline & Máximo & 18 & 17 & 20 & 26 & 26 & 24 \\
\hline & Desv. típ. & 2,410 & 3,388 & 5,429 & 4,957 & 5,521 & 4,117 \\
\hline \multirow{4}{*}{$5 a<6$} & Media & 13,57 & 14,65 & 8,70 & 16,00 & 16,61 & 20,48 \\
\hline & Mínimo & 7 & 7 & 2 & 10 & 9 & 14 \\
\hline & Máximo & 22 & 19 & 19 & 21 & 26 & 26 \\
\hline & Desv. típ. & 3,776 & 3,393 & 4,487 & 3,075 & 4,793 & 3,246 \\
\hline \multirow{4}{*}{$6 a<7$} & Media & 14,16 & 14,55 & 8,32 & 16,97 & 16,29 & 19,10 \\
\hline & Mínimo & 5 & 9 & 0 & 12 & 6 & 10 \\
\hline & Máximo & 24 & 23 & 22 & 25 & 27 & 28 \\
\hline & Desv. típ. & 4,344 & 3,161 & 6,085 & 3,851 & 5,442 & 5,294 \\
\hline \multirow{4}{*}{7 a 8} & Media & 13,42 & 14,88 & 8,71 & 16,80 & 15,81 & 20,26 \\
\hline & Mínimo & 4 & 2 & 0 & 7 & 5 & 6 \\
\hline & Máximo & 24 & 25 & 24 & 25 & 29 & 30 \\
\hline & Desv. típ. & 4,036 & 4,053 & 6,008 & 4,430 & 5,538 & 4,843 \\
\hline \multirow{4}{*}{$>8$} & Media & 13,62 & 15,00 & 7,14 & 16,24 & 16,84 & 21,00 \\
\hline & Mínimo & 6 & 4 & 0 & 5 & 5 & 11 \\
\hline & Máximo & 27 & 26 & 26 & 24 & 25 & 28 \\
\hline & Desv. típ. & 4,901 & 4,637 & 5,138 & 4,536 & 5,172 & 4,157 \\
\hline \multirow{4}{*}{ TOTAL } & Media & 13,70 & 14,80 & 8,31 & 16,62 & 16,21 & 20,15 \\
\hline & Mínimo & 4 & 2 & 0 & 5 & 5 & 6 \\
\hline & Máximo & 27 & 26 & 26 & 26 & 29 & 30 \\
\hline & Desv. típ. & 4,197 & 3,907 & 5,632 & 4,203 & 5,321 & 4,644 \\
\hline
\end{tabular}

Cuadro 76: Medidas estadísticas de "valores" según actitud hacia la responsabilidad social. 
Antes de realizar una lectura de la información que ofrece el cuadro 76 hemos aplicado ANOVA de un factor sobre los datos para verificar la existencia de diferencias estadísticamente significativas entre los grupos muestrales.

\begin{tabular}{|c|c|c|c|c|c|c|}
\hline & & Suma de cuadrados & gl & Media cuadrática & $\mathbf{F}$ & Sig. \\
\hline \multirow{3}{*}{ Valor numérico } & Inter-grupos & 82,046 & 5 & 16,409 & ,930 & ,463 \\
\hline & Intra-grupos & 3229,361 & 183 & 17,647 & & \\
\hline & Total & 3311,407 & 188 & & & \\
\hline \multirow{3}{*}{ Resultados } & Inter-grupos & 12,349 & 5 & 2,470 & , 158 & ,977 \\
\hline & Intra-grupos & 2857,408 & 183 & 15,614 & & \\
\hline & Total & 2869,757 & 188 & & & \\
\hline \multirow{3}{*}{ Variedad } & Inter-grupos & 70,887 & 5 & 14,177 & , 440 & ,820 \\
\hline & Intra-grupos & 5893,314 & 183 & 32,204 & & \\
\hline & Total & 5964,201 & 188 & & & \\
\hline \multirow{3}{*}{ Decisión } & Inter-grupos & 32,964 & 5 & 6,593 & ,367 & ,871 \\
\hline & Intra-grupos & 3287,607 & 183 & 17,965 & & \\
\hline & Total & 3320,571 & 188 & & & \\
\hline \multirow{3}{*}{ Orden y método } & Inter-grupos & 53,414 & 5 & 10,683 & ,371 & ,868 \\
\hline & Intra-grupos & 5269,538 & 183 & 28,795 & & \\
\hline & Total & 5322,952 & 188 & & & \\
\hline \multirow{3}{*}{ Metas } & Inter-grupos & 171,265 & 5 & 34,253 & 1,614 & , 158 \\
\hline & Intra-grupos & 3883,285 & 183 & 21,220 & & \\
\hline & Total & 4054,550 & 188 & & & \\
\hline
\end{tabular}

Cuadro 77: Tabla ANOVA de valores, factor Actitud hacia la Responsabilidad Social.

El cuadro 77 muestra que no existen diferencias estadísticamente significativas entre los diversos grupos muestrales contemplados en el cuadro 76.

En relación con la lectura de la información que ofrece el cuadro 76 no hemos tenido en cuenta, por su baja representatividad (solo se he recabado información de un líder), al grupo muestral que corresponde al segmento de valoración media de la actitud " 0 a $<4$ ". 
Hemos incorporado inicialmente algunas consideraciones que hacen referencia a todos los grupos muestrales considerados $y$, posteriormente, hemos realizado algunas indicaciones específicas sobre ciertos grupos.

En todos los grupos muestrales en los que hemos dividido la muestra del estudio a partir de diversos segmentos del valor de la actitud, la competencia genérica "metas" es, de los seis aspectos considerados, el que ha recibido una mayor puntuación media en todos los grupos. Este resultado indica que, independientemente del grado de disposición favorable que los líderes tengan hacia la responsabilidad social, los máximos responsables empresariales valoran muy especialmente tener una meta definida en la que trabajar, mantenerse en un problema hasta que este sea resuelto, dirigir el esfuerzo propio hacia objetivos bien delimitados y conocer con precisión en qué están pensando.

Además la competencia genérica "resultados" muestra una leve tendencia creciente a media que se incrementa la disposición favorable de los líderes hacia la Responsabilidad Social Corporativa (su puntuación media aumenta de 14,14 a 15).

En los segmentos en los que la sintonía entre la disposición y la responsabilidad corporativa es menor ("4 a $<5$ " y "5 a <6"), el rasgo de personalidad "practicidad" $(15,14)$ y la característica comportamental "orden y 
método" $(16,86)$ han registrado sus puntuaciones medias más altas.

En el grupo muestral en el que la actitud hacia la responsabilidad social se encuentra en el segmento "7 a 8", el rasgo de personalidad "practicidad" $(13,42)$ y la característica comportamental “orden y método" $(15,81)$ han registrado su valor medio mínimo mientras que el rasgo de personalidad "variedad" $(8,71)$ ha obtenido su mayor valor medio (aunque el puntaje medio de "variedad" es prácticamente el mismo que se ha registrado en el segmento de valor de la actitud " $5 \mathrm{a}<6$ ").

En el grupo en el que se encuentran los líderes que han mostrado una actitud más favorable hacia la responsabilidad social (">8"), la competencia genérica “metas" ha obtenido su puntuación más alta (21).

A continuación hemos revisado los datos obtenidos sobre los "valores" de los líderes y el desarrollo de acciones de responsabilidad social en las organizaciones en las que desarrollan su labor.

Antes de hacer una lectura de la información recabada sobre la disposición a actuar en el ámbito de la responsabilidad social de las organizaciones y los "valores" de sus líderes, hemos aplicado ANOVA de un factor (cuadro 75) para revisar la posible existencia de diferencias estadísticamente significativas entre los diversos grupos muestrales (practicidad, resultados, variedad, decisión, 
metas y orden y método) a partir de la actuación de las organizaciones en materia de responsabilidad social.

\begin{tabular}{|c|c|c|c|c|c|c|}
\hline & & Suma de cuadrados & gl & Media cuadrática & $\mathbf{F}$ & Sig. \\
\hline \multirow{3}{*}{ Practicidad } & Inter-grupos & 236,772 & 3 & 78,924 & 4,749 & ,003 \\
\hline & Intra-grupos & 3074,636 & 185 & 16,620 & & \\
\hline & Total & 3311,407 & 188 & & & \\
\hline \multirow{3}{*}{ Resultados } & Inter-grupos & 6,856 & 3 & 2,285 & ,148 & ,931 \\
\hline & Intra-grupos & 2862,901 & 185 & 15,475 & & \\
\hline & Total & 2869,757 & 188 & & & \\
\hline \multirow{3}{*}{ Variedad } & Inter-grupos & 79,442 & 3 & 26,481 & 832 & ,478 \\
\hline & Intra-grupos & 5884,759 & 185 & 31,810 & & \\
\hline & Total & 5964,201 & 188 & & & \\
\hline \multirow{3}{*}{ Decisión } & Inter-grupos & 45,522 & 3 & 15,174 & 857 & ,464 \\
\hline & Intra-grupos & 3275,050 & 185 & 17,703 & & \\
\hline & Total & 3320,571 & 188 & & & \\
\hline \multirow{3}{*}{$\begin{array}{l}\text { Orden y } \\
\text { método }\end{array}$} & Inter-grupos & 40,179 & 3 & 13,393 & ,469 & ,704 \\
\hline & Intra-grupos & 5282,774 & 185 & 28,556 & & \\
\hline & Total & 5322,952 & 188 & & & \\
\hline \multirow{3}{*}{ Metas } & Inter-grupos & 69,526 & 3 & 23,175 & 1,076 & ,361 \\
\hline & Intra-grupos & 3985,025 & 185 & 21,541 & & \\
\hline & Total & 4054,550 & 188 & & & \\
\hline
\end{tabular}

Cuadro 78: Tabla ANOVA de los valores personales, factor Realización de Acciones de Responsabilidad Social.

La información que ofrece el cuadro 78 sobre el coeficiente de significación indica la existencia de diferencias estadísticamente significativas entre los diversos grupos muestrales en relación con "practicidad" (su coeficiente de significación es 0,003).

A continuación hemos realizado una lectura de los datos que muestra el gráfico 28 "Realización de acciones de responsabilidad social y valores" incorporado más adelante.

De acuerdo a la información que ofrece el gráfico 28 , el rasgo de personalidad "practicidad" es, de los aspectos 
estudiados en el líder, el que presenta una variación más directa a medida que aumenta la implicación de la organización en materia de responsabilidad social.

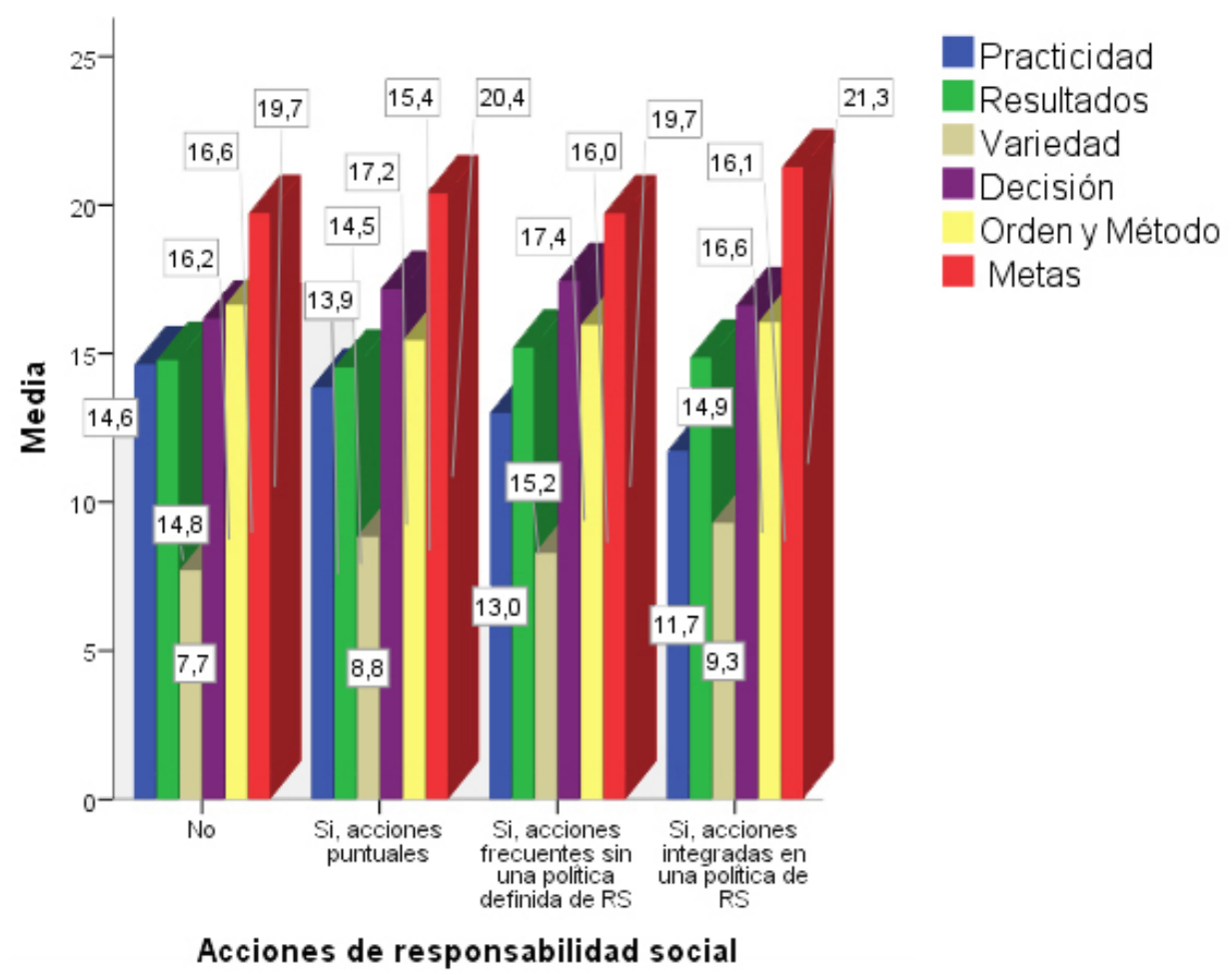

Gráfico 28: Realización de acciones de responsabilidad social y "valores”.

Mientras que en las organizaciones que no desarrollan ningún tipo de iniciativa en este ámbito el puntaje medio del líder en "practicidad" es 14,64, este va descendiendo progresivamente hasta un valor medio de 11,73 en los máximos responsables vinculados a organizaciones con políticas de actuación definidas en Responsabilidad Social Corporativa. Los datos indican que el incremento de la actuación de la organización en materia de responsabilidad social parece estar asociado, en cierta medida, a una reducción de las metas materialistas y de la búsqueda de beneficios en el líder a corto plazo. 
La competencia genérica "resultados" presenta un comportamiento estable excepto en los líderes vinculados a las organizaciones que desarrollan acciones frecuentes, donde su valor medio ha sido ligeramente mayor $(15,20)$.

En cuanto al rasgo de personalidad "variedad", también se produce un aumento de su valor medio a medida que crece la implicación de la organización en actuaciones socialmente responsables, aunque esta progresión ascendente no se mantiene al pasar de las puntuaciones de los líderes procedentes de organizaciones que realizan acciones puntuales a las de los máximos responsables procedentes de empresas que realizan acciones frecuentes. De todos modos el puntaje de medio de "variedad" aumenta desde 7,70, caso de los líderes procedentes de empresas que no desarrollan ningún tipo de iniciativa en el ámbito de la Responsabilidad Social Corporativa, a 9,30, caso de los máximos responsables vinculados a organizaciones con una política de actuación definida en responsabilidad social. Estos datos indican que, frente a los máximos responsables vinculados a organizaciones que no desarrollan ningún tipo de actuación en materia de Responsabilidad Social Corporativa, los líderes procedentes de organizaciones con políticas establecidas de responsabilidad social parecen tener más afinidad con el desarrollo de nuevas actividades que rompan su rutina.

En cuanto al rasgo de personalidad "decisión", aumenta ligeramente su valor medio en los líderes que están vinculados a organizaciones que realizan acciones 
puntuales o frecuentes $(17,17$ y 17,44 respectivamente), frente al promedio que ha obtenido "decisión" en los máximos responsables que desarrollan su labor en organizaciones que no realizan ningún tipo de actuación en materia de responsabilidad social o que la desarrollan integrada en una política definida (16,18 y 16,62 en cada caso).

La característica comportamental "orden y método" ha registrado un valor medio ligeramente menor en los líderes que desarrollan acciones frecuentes y puntuales, especialmente en este último caso $(15,44)$.

Y en cuanto a la competencia genérica "metas", al igual que ocurría con "variedad", su valor medio ha crecido desde un 19,73 en los líderes vinculados a organizaciones que no desarrollan ningún tipo de actuación en materia de Responsabilidad Social Corporativa, a 21,27 en los máximos responsables vinculados a organizaciones con una política de actuación definida en este ámbito. Sin embargo, se ha registrado una ligera disminución en su valor medio al pasar de los líderes procedentes de organizaciones que realizan acciones puntuales $(20,39)$ a los máximos responsables de empresas que impulsan iniciativas de Responsabilidad Social Corporativa de modo habitual $(19,72)$. Estos datos indican que los líderes vinculados a organizaciones con políticas definidas de responsabilidad social presentan, respecto a los máximos responsables vinculados al resto de organizaciones contempladas, mayor preferencia por objetivos bien definidos en los que centrar su esfuerzo. 
En relación con la información recabada sobre metas, resultados, practicidad, decisión, variedad $y$ orden $y$ método, y el desarrollo de acciones formativas enmarcadas en el ámbito de la responsabilidad social por parte de organizaciones en las que los líderes entrevistados desarrollan labor, hemos incorporado el cuadro 80 con diversas medidas estadísticas.

Antes de comentar los resultados de las medidas estadísticas sobre las variables indicadas, hemos aplicado ANOVA de un factor a los grupos muestrales considerados en este caso para comprobar si existen diferencias estadísticamente significativas entre los mismos (cuadro 79).

\begin{tabular}{|c|c|c|c|c|c|c|}
\hline & & Suma de cuadrados & gl & Media cuadrática & $\mathbf{F}$ & Sig. \\
\hline \multirow{3}{*}{ Practicidad } & Inter-grupos & 96,892 & 6 & 16,149 & 1,007 & ,438 \\
\hline & Intra-grupos & 513,006 & 32 & 16,031 & & \\
\hline & Total & 609,897 & 38 & & & \\
\hline \multirow{3}{*}{ Resultados } & Inter-grupos & 49,573 & 6 & 8,262 & ,452 & 838 \\
\hline & Intra-grupos & 585,094 & 32 & 18,284 & & \\
\hline & Total & 634,667 & 38 & & & \\
\hline \multirow{3}{*}{ Variedad } & Inter-grupos & 126,906 & 6 & 21,151 &, 520 & ,780 \\
\hline & Intra-grupos & 1302,017 & 32 & 40,688 & & \\
\hline & Total & 1428,923 & 38 & & & \\
\hline \multirow{3}{*}{ Decisión } & Inter-grupos & 225,961 & 6 & 37,660 & 1,616 & 175 \\
\hline & Intra-grupos & 745,732 & 32 & 23,304 & & \\
\hline & Total & 971,692 & 38 & & & \\
\hline \multirow{3}{*}{ Orden y método } & Inter-grupos & 112,949 & 6 & 18,825 &, 793 &, 582 \\
\hline & Intra-grupos & 759,717 & 32 & 23,741 & & \\
\hline & Total & 872,667 & 38 & & & \\
\hline \multirow{3}{*}{ Valor numérico } & Inter-grupos & 101,619 & 6 & 16,936 & ,686 & 662 \\
\hline & Intra-grupos & 789,817 & 32 & 24,682 & & \\
\hline & Total & 891,436 & 38 & & & \\
\hline
\end{tabular}

Cuadro 79: Tabla ANOVA de los valores personales, factor Horas de Formación en Responsabilidad Social. 
Los coeficientes de significación del cuadro 79 indican que no existen diferencias estadísticamente significativas entre los grupos muestrales contemplados.

\begin{tabular}{|c|c|c|c|c|c|c|c|}
\hline \multicolumn{2}{|c|}{ Horas de formación en resp. social } & \multirow{2}{*}{$\begin{array}{r}\text { Practicidad } \\
13,30 \\
\end{array}$} & \multirow{2}{*}{\begin{tabular}{|r|} 
Resultados \\
14,50 \\
\end{tabular}} & \multirow{2}{*}{\begin{tabular}{|r|} 
Variedad \\
9,00 \\
\end{tabular}} & \multirow{2}{*}{\begin{tabular}{|r|} 
Decisión \\
16,00 \\
\end{tabular}} & \multirow{2}{*}{$\begin{array}{r}\begin{array}{c}\text { Orden y } \\
\text { método }\end{array} \\
15,90 \\
\end{array}$} & \multirow{2}{*}{$\begin{array}{r}\text { Metas } \\
21,30 \\
\end{array}$} \\
\hline \multirow{6}{*}{ Menos de 11} & Media & & & & & & \\
\hline & Mediana & 13,50 & 14,00 & 7,00 & 16,50 & 16,50 & 22,50 \\
\hline & Mínimo & 8 & 7 & 4 & 9 & 8 & 12 \\
\hline & Máximo & 18 & 22 & 19 & 21 & 21 & 27 \\
\hline & Desv. típ. & 3,529 & 4,577 & 5,207 & 3,771 & 3,872 & 4,523 \\
\hline & Suma & 133 & 145 & 90 & 160 & 159 & 213 \\
\hline \multirow{6}{*}{ De 11 a 50} & Media & 13,27 & 15,45 & 8,18 & 18,82 & 14,18 & 19,82 \\
\hline & Mediana & 11,00 & 16,00 & 8,00 & 20,00 & 11,00 & 20,00 \\
\hline & Mínimo & 8 & 10 & 1 & 8 & 9 & 12 \\
\hline & Máximo & 27 & 21 & 18 & 25 & 21 & 25 \\
\hline & Desv. típ. & 5,551 & 3,328 & 5,288 & 6,274 & 4,813 & 4,400 \\
\hline & Suma & 146 & 170 & 90 & 207 & 156 & 218 \\
\hline \multirow{6}{*}{ De 51 a 100} & Media & 12,40 & 15,40 & 12,00 & 18,00 & 14,80 & 17,40 \\
\hline & Mediana & 13,00 & 14,00 & 10,00 & 19,00 & 12,00 & 19,00 \\
\hline & Mínimo & 9 & 12 & 3 & 10 & 8 & 6 \\
\hline & Máximo & 15 & 19 & 21 & 23 & 25 & 26 \\
\hline & Desv. típ. & 2,191 & 3,362 & 6,819 & 5,000 & 7,050 & 7,335 \\
\hline & Suma & 62 & 77 & 60 & 90 & 74 & 87 \\
\hline \multirow{6}{*}{ De 101 a 150} & Media & 10,86 & 16,00 & 6,57 & 17,71 & 17,43 & 21,43 \\
\hline & Mediana & 10,00 & 15,00 & 4,00 & 20,00 & 17,00 & 20,00 \\
\hline & Mínimo & 8 & 9 & 0 & 12 & 11 & 14 \\
\hline & Máximo & 15 & 26 & 22 & 21 & 25 & 28 \\
\hline & Desv. típ. & 2,340 & 5,831 & 7,913 & 4,152 & 5,224 & 5,028 \\
\hline & Suma & 76 & 112 & 46 & 124 & 122 & 150 \\
\hline \multirow{6}{*}{ De 151 a 200} & Media & 14,00 & 12,00 & 10,00 & 22,00 & 9,00 & 23,00 \\
\hline & Mediana & 14,00 & 12,00 & 10,00 & 22,00 & 9,00 & 23,00 \\
\hline & Mínimo & 14 & 12 & 10 & 22 & 9 & 23 \\
\hline & Máximo & 14 & 12 & 10 & 22 & 9 & 23 \\
\hline & Desv. típ. & . & . & . & . & . & . \\
\hline & Suma & 14 & 12 & 10 & 22 & 9 & 23 \\
\hline \multirow{6}{*}{ De 201 a 1000} & Media & 7,00 & 19,00 & 6,00 & 23,00 & 13,00 & 20,50 \\
\hline & Mediana & 7,00 & 19,00 & 6,00 & 23,00 & 13,00 & 20,50 \\
\hline & Mínimo & 5 & 15 & 6 & 21 & 12 & 19 \\
\hline & Máximo & 9 & 23 & 6 & 25 & 14 & 22 \\
\hline & Desv. típ. & 2,828 & 5,657 & ,000 & 2,828 & 1,414 & 2,121 \\
\hline & Suma & 14 & 38 & 12 & 46 & 26 & 41 \\
\hline \multirow{6}{*}{ Más de 1000} & Media & 11,33 & 14,67 & 11,33 & 11,67 & 17,33 & 23,67 \\
\hline & Mediana & 12,00 & 15,00 & 8,00 & 12,00 & 19,00 & 24,00 \\
\hline & Mínimo & 7 & 13 & 3 & 9 & 13 & 19 \\
\hline & Máximo & 15 & 16 & 23 & 14 & 20 & 28 \\
\hline & Desv. típ. & 4,041 & 1,528 & 10,408 & 2,517 & 3,786 & 4,509 \\
\hline & Suma & 34 & 44 & 34 & 35 & 52 & 71 \\
\hline \multirow{5}{*}{ TOTAL } & Mediana & 12,00 & 15,00 & 8,00 & 19,00 & 16,00 & 21,00 \\
\hline & Mínimo & 5 & 7 & 0 & 8 & 8 & 6 \\
\hline & Máximo & 27 & 26 & 23 & 25 & 25 & 28 \\
\hline & Desv. típ. & 4,006 & 4,087 & 6,132 & 5,057 & 4,792 & 4,843 \\
\hline & Suma & 479 & 598 & 342 & 684 & 598 & 803 \\
\hline
\end{tabular}

Cuadro 80: Medidas estadísticas de "valores" personales según formación en responsabilidad social. 
Previamente hemos incluido el cuadro 80 con los datos de algunas medidas estadísticas en cada una de las opciones contempladas sobre horas de formación invertidas en materia de responsabilidad social.

En la lectura de los datos del cuadro 80 hemos descartado, por su baja representatividad, la que procede de los líderes de organizaciones que dedican de 151 a 200 horas a impartir formación a sus colaboradores enmarcada en el ámbito de la responsabilidad social (solo se han registrado datos de un máximo responsable).

Las puntuaciones medias obtenidas por el rasgo de personalidad "practicidad" tienden a decrecer a medida que aumenta el número de horas que la empresa dedica a formar y a sensibilizar a sus públicos internos en responsabilidad social (el valor medio de 13,30 en los máximos responsables de organizaciones que dedican menos de 11 horas a la formación se reduce a 10,86 en los líderes de las empresas que dedican de 101 a 150 horas). Estos datos guardan correspondencia con los obtenidos por los líderes cuando hemos tomado en consideración la actuación de la organización en materia de responsabilidad social y los "valores" de los líderes. No consideramos en esta tendencia el leve aumento del valor medio de "practicidad" $(11,33)$ en el último grupo muestral (empresas que dedican más de 1000 horas a la formación).

La competencia genérica "resultados" presenta un valor medio bastante próximo en todos los grupos muestrales excepto en el grupo de los líderes cuyas 
organizaciones invierten de 101 a 150 horas a la formación encuadrada en la responsabilidad social (16), donde el promedio es ligeramente más elevado, y en el grupo muestral de líderes cuyas empresas dedican a este tipo de acciones formativas de 201 a 1000 horas (19), donde el valor medio es significativamente mayor.

El rasgo de personalidad "variedad" presenta un comportamiento bastante inestable al comparar su valor medio en los diferentes grupos muestrales (es 6,57 en las organizaciones que dedican a formación entre 101 y 150 horas y es 12 en las organizaciones que dedican entre 51 y 100 horas). Esta tendencia no se producía al estudiar la variación media de este rasgo, se mantenía bastante estable, en relación con los diversos grupos de líderes procedentes de empresas con una actuación diferente en materia de responsabilidad social.

En cuanto al rasgo de personalidad “decisión” hemos encontrado la misma tendencia que se producía a la hora de analizar la actuación en materia de responsabilidad social y los "valores" de los líderes. En las opciones extremas, menos de 11 horas y más de 1000 horas dedicadas a la formación, los valores medios son un poco más reducidos que en el resto de casos (16 y 11,67 respectivamente).

En cuanto a la característica comportamental "orden y método", de nuevo se produce la misma tendencia que se registraba al estudiar la actuación en materia de responsabilidad social de las organizaciones y los "valores" de sus líderes. El valor medio es ligeramente menor en los 
máximos responsables vinculados a organizaciones que invierten de 11 a 50 horas $(14,18), 51$ a 100 horas $(14,80)$ y 201 a 1000 horas (13) que el que presentan los máximos responsables que proceden de organizaciones que dedican menos de 11 horas $(15,90)$ y más de 1000 horas $(17,33)$. Los máximos responsables procedentes de organizaciones que dedican entre 101 a 150 horas (su media en "orden y método" es 17,43) representan una excepción a la tendencia indicada.

En relación con la competencia genérica "metas", la puntuación media de esta competencia genérica no sigue la misma tónica que cuando se consideraba el aumento de la implicación de la organización en actuaciones de responsabilidad social (en ese caso se producía una tendencia ascendente no progresiva). Su mayor valor medio se ha registrado en el grupo de líderes cuyas organizaciones dedican entre 51 y 100 horas a acciones formativas sobre responsabilidad social $(17,40)$ y el puntaje medio más elevado ha sido obtenido por los líderes cuyas organizaciones dedican más de 1000 horas a iniciativas de formación enmarcadas en la disciplina de la Responsabilidad Social Corporativa. De todos modos es destacable de "metas" que en todos los grupos muestrales, excepto en el de los líderes cuyo origen son organizaciones que invierten entre 201 y 1000 horas a formación sobre responsabilidad social, es el aspecto que recibe una mayor valoración media de los seis analizados. 


\subsection{RESULTADOS COMPARATIVOS}

\subsubsection{Sexo, edad y Responsabilidad Social Corporativa}

En primer lugar hemos incluido los datos que hacen referencia al sexo de los líderes, a su edad y a su actitud hacia la responsabilidad social.

\begin{tabular}{|c|l|r|r|r|r|}
\hline Sexo & \multicolumn{1}{|c|}{ Edad } & \multicolumn{1}{c|}{ Media } & Mínimo & Máximo & Desv. típ. \\
\hline \multirow{4}{*}{ Mujer } & De 20 a 40 & 7,5309 & 4,39 & 8,13 &, 9354 \\
\cline { 2 - 6 } & De 41 a 60 & 7,1675 & 3,86 & 8,07 & 1,1055 \\
\cline { 2 - 6 } & De 61 en adelante & 6,2400 & 5,12 & 7,96 &, 9389 \\
\cline { 2 - 6 } & Total & 7,2353 & 3,86 & 8,13 & 1,0714 \\
\hline \multirow{4}{*}{ Hombre } & De 20 a 40 & 7,2861 & 4,81 & 8,12 &, 9662 \\
\cline { 2 - 6 } & De 41 a 60 & 7,1454 & 4,63 & 8,10 & 1,0567 \\
\cline { 2 - 6 } & De 61 en adelante & 7,1801 & 4,76 & 8,12 & 1,2739 \\
\cline { 2 - 6 } & Total & 7,1869 & 4,63 & 8,12 & 1,0465 \\
\hline \multirow{4}{*}{ Total } & De 20 a 40 & 7,3985 & 4,39 & 8,13 &, 9523 \\
\cline { 2 - 6 } & De 41 a 60 & 7,1522 & 3,86 & 8,10 & 1,0669 \\
\cline { 2 - 6 } & De 61 en adelante & 6,8483 & 4,76 & 8,12 & 1,2264 \\
\cline { 2 - 6 } & Total & 7,2043 & 3,86 & 8,13 & 1,0529 \\
\hline
\end{tabular}

Cuadro 81: Medidas estadísticas de edad, sexo y actitud hacia la responsabilidad social.

Antes de revisar los datos del cuadro 81 hemos aplicado ANOVA para verificar si existen diferencias estadísticamente significativas entre los diversos grupos muestrales que integran dicha muestra poblacional. 


\begin{tabular}{|l|l|r|r|r|c|c|}
\hline \multicolumn{2}{|c|}{} & Suma de cuadrados & gl & Media cuadrática & F & Sig. \\
\hline \multirow{4}{*}{ Sexo } & Inter-grupos & 16,894 & 80 &, 211 &, 856 &, 767 \\
\cline { 2 - 8 } & Intra-grupos & 26,640 & 108 &, 247 & & \\
\cline { 2 - 8 } & Total & 43,534 & 188 & & & \\
\hline \multirow{4}{*}{ Edad } & Inter-grupos & 28,159 & 80 &, 352 &, 960 &, 573 \\
\cline { 2 - 8 } & Intra-grupos & 39,598 & 108 &, 367 & & \\
\cline { 2 - 8 } & Total & 67,757 & 188 & & & \\
\hline
\end{tabular}

Cuadro 82: Tabla ANOVA de la edad y el sexo, factor Actitud hacia la Responsabilidad Social.

Los coeficientes de significación del grupo muestral sexo $(0,767)$ y edad $(0,573)$ indican que no existen diferencias estadísticamente significativas entre los diversos grupos muestrales que integran la muestra poblacional (cuadro 82).

Los datos del cuadro 81 reflejan la existencia de variaciones en la actitud de los hombres y de las mujeres hacia la responsabilidad social considerando su edad.

En las mujeres los tres segmentos de edad considerados (20 a 40 años, 41 a 60 años y más de 61 años) están bastante diferenciados. El primer segmento de edad (20 a 40 años) muestra una actitud media hacia la responsabilidad social $(7,53)$ casi 0,4 puntos más alta que la que ha obtenido el segmento de 41 a 60 años $(7,16)$. Y este último grupo de líderes muestra una actitud casi un punto superior a la de las líderes de 61 años en adelante $(6,24)$.

En los hombres no existen estas diferencias tan marcadas entre los diversos grupos muestrales y las actitudes medias están bastante próximas. De todos modos es destacable que aunque los líderes de 20 a 40 años presentan una actitud media más favorable hacia la 
responsabilidad social $(7,28)$, el segundo grupo con una actitud media mayor no es el de los máximos responsables de 41 a 60 años $(7,14)$ sino el de los líderes de 61 años en adelante $(7,18)$.

Estos datos indican que la edad es una variable más discriminativa, en relación con la actitud hacia la responsabilidad, en las mujeres que en los hombres.

Incorporamos a continuación el gráfico 29 para comprobar, de modo visual, posibles asociaciones en la variación de la edad y la actitud hacia la responsabilidad social en hombres y mujeres:

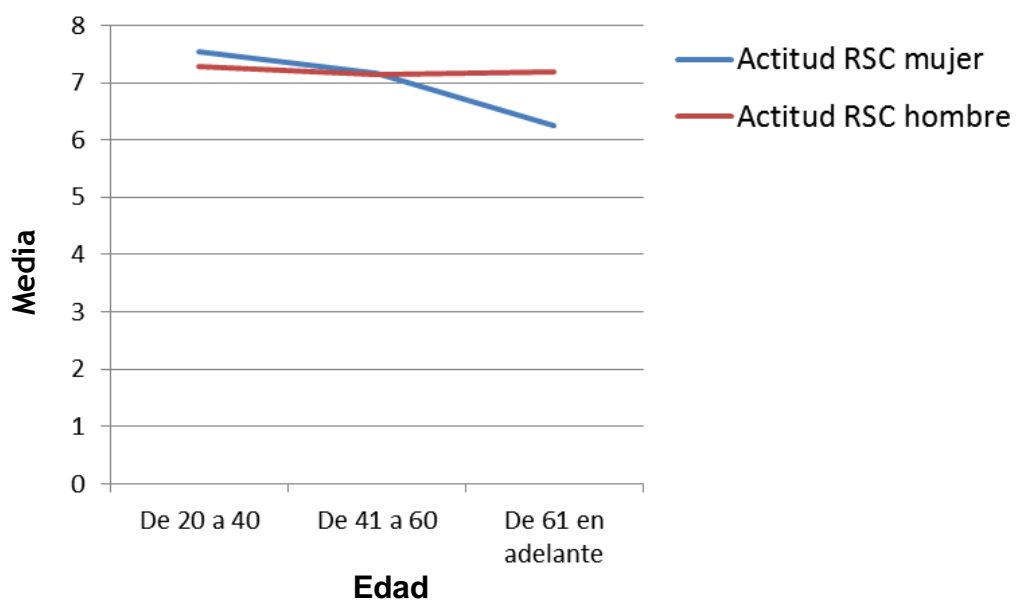

Gráfico 29: Edad, sexo y actitud hacia la responsabilidad social.

Tal y como muestra el gráfico 29 , el incremento de la edad de las líderes parece estar asociado a una pérdida de disposición favorable hacia la responsabilidad social. Esta asociación no parece darse en el caso de los hombres, ya que los máximos responsables no ven alterada su actitud hacia la responsabilidad social con el aumento de su edad. 
A continuación hemos revisado los datos sobre sexo, edad y comportamiento responsable de la organización. Primero de forma genérica y luego en relación con las acciones formativas desarrolladas en este campo.

\begin{tabular}{|c|c|c|c|c|c|c|c|}
\hline \multirow{2}{*}{\multicolumn{4}{|c|}{ Sexo }} & \multicolumn{3}{|c|}{ Edad } & \multirow{3}{*}{$\begin{array}{l}\text { TOTAL } \\
100,0 \%\end{array}$} \\
\hline & & & & \multirow{2}{*}{\begin{tabular}{r|} 
De 20 a 40 \\
$35,3 \%$
\end{tabular}} & \multirow{2}{*}{\begin{tabular}{r|} 
De 41 a 60 \\
$58,8 \%$
\end{tabular}} & \multirow{2}{*}{$\begin{array}{r}\begin{array}{l}\text { De } 61 \text { en } \\
\text { adelante }\end{array} \\
5,9 \%\end{array}$} & \\
\hline \multirow{10}{*}{ Mujer } & \multirow{8}{*}{$\begin{array}{l}\text { Acciones de } \\
\text { resp. social }\end{array}$} & \multirow{2}{*}{ No } & $\%$ dentro de acciones & & & & \\
\hline & & & $\%$ dentro de edad & $42,9 \%$ & $58,8 \%$ & $33,3 \%$ & $50,0 \%$ \\
\hline & & \multirow{2}{*}{ Sí, acciones puntuales } & $\%$ dentro de acciones & $38,9 \%$ & $50,0 \%$ & $11,1 \%$ & $100,0 \%$ \\
\hline & & & $\%$ dentro de edad & $25,0 \%$ & $26,5 \%$ & $33,3 \%$ & $26,5 \%$ \\
\hline & & \multirow{2}{*}{$\begin{array}{l}\text { Sí, acciones frecuentes } \\
\text { sin una política definida } \\
\text { de RS }\end{array}$} & $\%$ dentro de acciones & $71,4 \%$ & $28,6 \%$ & $0,0 \%$ & $100,0 \%$ \\
\hline & & & $\%$ dentro de edad & $17,9 \%$ & $5,9 \%$ & $0,0 \%$ & $10,3 \%$ \\
\hline & & \multirow{2}{*}{$\begin{array}{l}\text { Sí, acciones integradas } \\
\text { en una política de RS }\end{array}$} & $\%$ dentro de acciones & $44,4 \%$ & $33,3 \%$ & $22,2 \%$ & $100,0 \%$ \\
\hline & & & $\%$ dentro de edad & $14,3 \%$ & $8,8 \%$ & $33,3 \%$ & $13,2 \%$ \\
\hline & \multirow{2}{*}{\multicolumn{2}{|c|}{ Total }} & $\%$ dentro de acciones & $41,2 \%$ & $50,0 \%$ & $8,8 \%$ & $100,0 \%$ \\
\hline & & & $\%$ dentro de edad & $100,0 \%$ & $100,0 \%$ & $100,0 \%$ & $100,0 \%$ \\
\hline \multirow{10}{*}{ Hombre } & \multirow{8}{*}{$\begin{array}{l}\text { Acciones de } \\
\text { resp. social }\end{array}$} & \multirow{2}{*}{ No } & $\%$ dentro de acciones & $28,1 \%$ & $63,2 \%$ & $8,8 \%$ & $100,0 \%$ \\
\hline & & & $\%$ dentro de edad & $48,5 \%$ & $46,8 \%$ & $45,5 \%$ & $47,1 \%$ \\
\hline & & \multirow{2}{*}{ Sí, acciones puntuales } & $\%$ dentro de acciones & $16,7 \%$ & $72,2 \%$ & $11,1 \%$ & $100,0 \%$ \\
\hline & & & $\%$ dentro de edad & $9,1 \%$ & $16,9 \%$ & $18,2 \%$ & $14,9 \%$ \\
\hline & & \multirow{2}{*}{$\begin{array}{l}\text { Sí, acciones frecuentes } \\
\text { sin una política definida } \\
\text { de RS }\end{array}$} & $\%$ dentro de acciones & $44,4 \%$ & $50,0 \%$ & $5,6 \%$ & $100,0 \%$ \\
\hline & & & $\%$ dentro de edad & $24,2 \%$ & $11,7 \%$ & $9,1 \%$ & $14,9 \%$ \\
\hline & & \multirow{2}{*}{$\begin{array}{l}\text { Sí, acciones integradas } \\
\text { en una política de RS }\end{array}$} & $\%$ dentro de acciones & $21,4 \%$ & $67,9 \%$ & $10,7 \%$ & $100,0 \%$ \\
\hline & & & $\%$ dentro de edad & $18,2 \%$ & $24,7 \%$ & $27,3 \%$ & $23,1 \%$ \\
\hline & \multirow{2}{*}{\multicolumn{2}{|c|}{ Total }} & $\%$ dentro de acciones & $27,3 \%$ & $63,6 \%$ & $9,1 \%$ & $100,0 \%$ \\
\hline & & & $\%$ dentro de edad & $100,0 \%$ & $100,0 \%$ & $100,0 \%$ & $100,0 \%$ \\
\hline \multirow{10}{*}{ TOTAL } & \multirow{8}{*}{$\begin{array}{l}\text { Acciones de } \\
\text { resp. social }\end{array}$} & \multirow{2}{*}{ No } & $\%$ dentro de acciones & $30,8 \%$ & $61,5 \%$ & $7,7 \%$ & $100,0 \%$ \\
\hline & & & $\%$ dentro de edad & $45,9 \%$ & $50,5 \%$ & $41,2 \%$ & $48,1 \%$ \\
\hline & & \multirow{2}{*}{ Sí, acciones puntuales } & $\%$ dentro de acciones & $27,8 \%$ & $61,1 \%$ & $11,1 \%$ & $100,0 \%$ \\
\hline & & & $\%$ dentro de edad & $16,4 \%$ & $19,8 \%$ & $23,5 \%$ & $19,0 \%$ \\
\hline & & \multirow{2}{*}{$\begin{array}{l}\text { Sí, acciones frecuentes } \\
\text { sin una política definida } \\
\text { de RS }\end{array}$} & $\%$ dentro de acciones & $52,0 \%$ & $44,0 \%$ & $4,0 \%$ & $100,0 \%$ \\
\hline & & & $\%$ dentro de edad & $21,3 \%$ & $9,9 \%$ & $5,9 \%$ & $13,2 \%$ \\
\hline & & \multirow{2}{*}{$\begin{array}{l}\text { Sí, acciones integradas } \\
\text { en una política de RS }\end{array}$} & $\%$ dentro de acciones & $27,0 \%$ & $59,5 \%$ & $13,5 \%$ & $100,0 \%$ \\
\hline & & & $\%$ dentro de edad & $16,4 \%$ & $19,8 \%$ & $29,4 \%$ & $19,6 \%$ \\
\hline & \multirow{2}{*}{\multicolumn{2}{|c|}{ Total }} & $\%$ dentro de acciones & $32,3 \%$ & $58,7 \%$ & $9,0 \%$ & $100,0 \%$ \\
\hline & & & $\%$ dentro de edad & $100,0 \%$ & $100,0 \%$ & $100,0 \%$ & $100,0 \%$ \\
\hline
\end{tabular}

Cuadro 83: Tabla de contingencia de realización de acciones de responsabilidad social, sexo y edad.

Los datos del cuadro 83 reflejan que las mujeres que están vinculadas a empresas que no realizan ningún tipo de actuación socialmente responsable tienen, en su mayoría, entre 20 y 60 años (94,1\%). Además estas líderes de 20 a 60 años tienen mayor presencia en las empresas que no desarrollan ningún tipo de iniciativa responsable (42,9\% para 
las líderes de 20 a 40 años y 58,8\% para las líderes de 41 a 60 años) que en las sí la impulsan, ya sea de modo puntual, frecuente o integrada en una política de Responsabilidad Social Corporativa.

En el caso de los hombres, los líderes de 20 a 60 años también tienen más protagonismo dentro de las empresas que no realizan ningún tipo de actuación, especialmente en el caso de los líderes de 41 a 60 años (63,2\%). Además los máximos responsables de 41 a 60 años también son mayoría considerando todos los tipos de organizaciones, sea cual sea su comportamiento en el ámbito de la responsabilidad social (48,5\% en los líderes de 20 a 40 años y 45,8\% en los líderes de 41 a 60 años).

Si consideramos al mismo tiempo las tres conductas empresariales afines a la responsabilidad social (acciones puntuales, habituales e integradas en una política definida) vemos que en el caso de las mujeres, las líderes que tienen entre 41 y 60 años tienen un mayor protagonismo que el resto de segmentos de edad en las organizaciones que impulsan acciones puntuales de responsabilidad social (50\%). Sin embargo, en las empresas que desarrollan acciones frecuentes o tienen una actuación responsable integrada en una política definida, las líderes más representadas son las que se encuentran entre los 20 y los 40 años $(71,4 \%$ en las empresas que impulsan acciones habituales y $44,4 \%$ en las organizaciones que cuentan con una política definida de responsabilidad social). De todos modos también se ha registrado una presencia de líderes de 
otras edades en las empresas que impulsan iniciativas dentro una política de responsabilidad social predefinida ( 3 casos en las líderes de 41 a 60 años y 2 casos en las líderes de 61 o más años).

En el caso de los hombres no se repite la misma tónica al contemplar, en conjunto, las organizaciones que desarrollan alguno de los tres tipos activos de comportamiento socialmente responsable. Al igual que en el sexo femenino, los datos de los hombres han indicado que existe una mayor presencia de líderes de 41 a 60 años en organizaciones que impulsan acciones de responsabilidad social de modo puntual (72,2\%). Sin embargo, en las organizaciones que desarrollan acciones frecuentes de Responsabilidad Social Corporativa, los líderes con mayor presencia son los de 41 a 60 años (50\%) seguidos por los de 20 a 40 años (44\%). Otro dato dispar es el que hemos obtenido en el caso de las organizaciones que desarrollan acciones de responsabilidad social dentro de una política. En este último caso los líderes con mayor protagonismo son los de 41 a 60 años (67,9\%), a mucha distancia de los líderes de 20 a 40 años (21,4\%). En este último tipo de organizaciones también es destacable la presencia de líderes de más 60 años (se han registrado 3 casos).

Los datos indican, por tanto, que algo más de 4 de cada 10 líderes se encuentran, con independencia de su sexo y de su edad, en organizaciones que no impulsan ningún tipo de iniciativa en el ámbito de la responsabilidad social. 
Además también muestran que en las empresas que presentan un comportamiento más afín a la responsabilidad social, ya sea porque realicen acciones de forma frecuente o las desarrollen integradas en una política definida, existe una diferencia en el sexo de los líderes al considerar su edad. Mientras que las mujeres de 20 a 40 años tienen mayor protagonismo en este tipo de organizaciones, en el caso de los hombres, los líderes de 41 a 60 tienen una mayor presencia en estas empresas.

Hemos incorporado a continuación el gráfico 30, "Sexo, edad y acciones de responsabilidad social" para evaluar, de modo visual, si existe algún tipo de relación entre el sexo y la edad de los líderes, y el desarrollo de acciones de Responsabilidad Social Corporativa por parte de las organizaciones en las que desempeñan su labor. En los gráficos incluidos para evaluar tendencias en la variación de las variables hemos contemplado todos los grupos muestrales aunque tengan una baja representatividad.

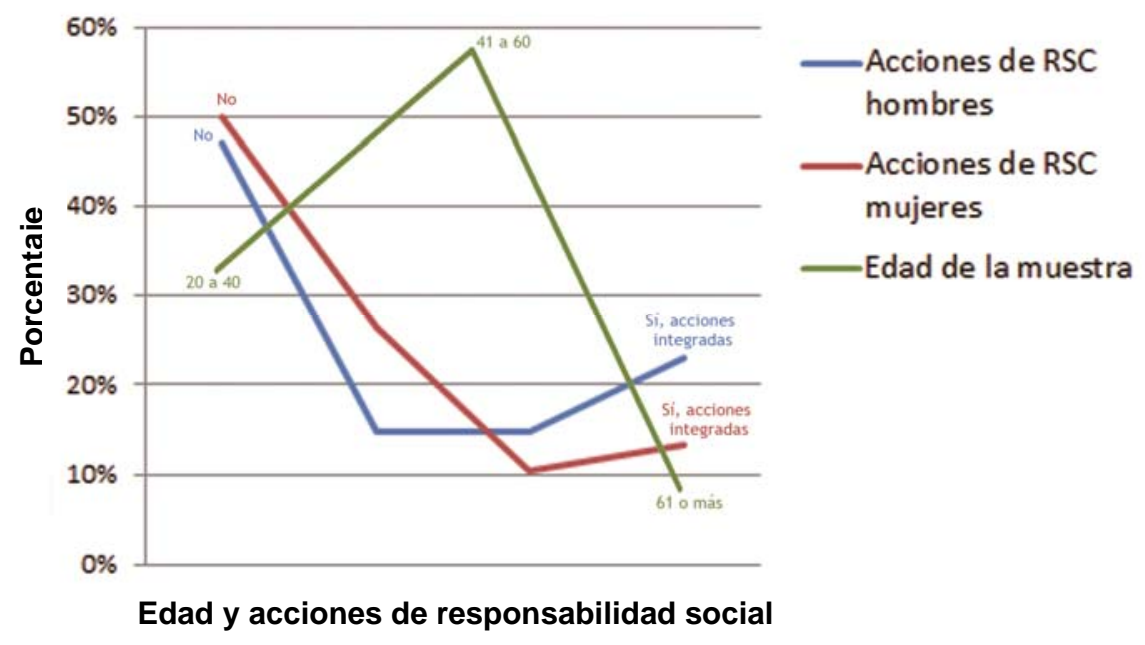

Gráfico 30: Sexo, edad y acciones de responsabilidad social. 
El gráfico 30 parece mostrar que existe un cierto comportamiento inverso entre la evolución del comportamiento de las empresas en materia de responsabilidad social y la edad de los líderes de la muestra, con independencia de su sexo.

Las organizaciones que no realizan acciones de responsabilidad social son mayoría. Su protagonismo en la muestra decrece a medida que aumenta su implicación en acciones de este tipo. Esta tendencia se revierte en el caso de las organizaciones que desarrollan actuaciones dentro de una política definida.

En cuanto a la edad, los datos registrados indican que a medida que los líderes van alcanzando los 40 años su protagonismo en la dirección de las organizaciones crece. Esta tendencia es opuesta cuando los líderes alcanzan los 61 años, momento a partir del cual comienza a reducirse su presencia en la dirección de las organizaciones.

Más adelante hemos incorporado el cuadro 84 con los datos sobre el sexo del líder, su edad y la formación enmarcada en el ámbito de la responsabilidad social por parte de las empresas en las que los líderes desarrollan su labor.

Aunque la muestra de líderes que proceden de organizaciones que imparten formación encuadrada en el ámbito de la responsabilidad social no es muy amplia (39 casos), el cuadro 84 indica una cierta concentración de líderes en algunas franjas de edad y en algunos de los 
segmentos contemplados en relación con las horas que las organizaciones dedican a la formación en responsabilidad social.

\begin{tabular}{|c|c|c|c|c|c|c|c|}
\hline \multirow{2}{*}{\multicolumn{4}{|c|}{ Sexo }} & \multicolumn{3}{|c|}{ Edad } & \multirow{3}{*}{$\begin{array}{l}\text { Total } \\
100,0 \%\end{array}$} \\
\hline & & & & \multirow{2}{*}{$\begin{array}{r}\text { De } 20 \text { a } 40 \\
66,7 \%\end{array}$} & \multirow{2}{*}{$\begin{array}{r}\text { De } 41 \text { a } 60 \\
33,3 \%\end{array}$} & \multirow{2}{*}{$\begin{array}{r}\text { De } 61 \text { en adelante } \\
0,0 \%\end{array}$} & \\
\hline \multirow{14}{*}{ Mujer } & \multirow{12}{*}{$\begin{array}{l}\text { Horas de } \\
\text { formación en } \\
\text { responsabilidad } \\
\text { social }\end{array}$} & \multirow{2}{*}{ Menos de 11} & $\%$ dentro de horas & & & & \\
\hline & & & $\%$ dentro de edad & $28,6 \%$ & $16,7 \%$ & $0,0 \%$ & $21,4 \%$ \\
\hline & & \multirow{2}{*}{ De 11 a 50} & $\%$ dentro de horas & $33,3 \%$ & $50,0 \%$ & $16,7 \%$ & $100,0 \%$ \\
\hline & & & $\%$ dentro de edad & $28,6 \%$ & $50,0 \%$ & $100,0 \%$ & $42,9 \%$ \\
\hline & & \multirow{2}{*}{ De 51 a 100} & $\%$ dentro de horas & $0,0 \%$ & $100,0 \%$ & $0,0 \%$ & $100,0 \%$ \\
\hline & & & $\%$ dentro de edad & $0,0 \%$ & $16,7 \%$ & $0,0 \%$ & $7,1 \%$ \\
\hline & & \multirow{2}{*}{ De 101 a 150} & $\%$ dentro de horas & $50,0 \%$ & $50,0 \%$ & $0,0 \%$ & $100,0 \%$ \\
\hline & & & $\%$ dentro de edad & $14,3 \%$ & $16,7 \%$ & $0,0 \%$ & $14,3 \%$ \\
\hline & & \multirow{2}{*}{ De 201 a 1000} & $\%$ dentro de horas & $100,0 \%$ & $0,0 \%$ & $0,0 \%$ & $100,0 \%$ \\
\hline & & & $\%$ dentro de edad & $14,3 \%$ & $0,0 \%$ & $0,0 \%$ & $7,1 \%$ \\
\hline & & \multirow{2}{*}{ Más de 1000} & $\%$ dentro de horas & $100,0 \%$ & $0,0 \%$ & $0,0 \%$ & $100,0 \%$ \\
\hline & & & $\%$ dentro de edad & $14,3 \%$ & $0,0 \%$ & $0,0 \%$ & $7,1 \%$ \\
\hline & \multirow{2}{*}{\multicolumn{2}{|c|}{ Total }} & $\%$ dentro de horas & $50,0 \%$ & $42,9 \%$ & $7,1 \%$ & $100,0 \%$ \\
\hline & & & $\%$ dentro de edad & $100,0 \%$ & $100,0 \%$ & $100,0 \%$ & $100,0 \%$ \\
\hline \multirow{16}{*}{ Hombre } & \multirow{14}{*}{$\begin{array}{l}\text { Horas de } \\
\text { formación en } \\
\text { responsabilidad } \\
\text { social }\end{array}$} & \multirow{2}{*}{ Menos de 11} & $\%$ dentro de horas & $42,9 \%$ & $57,1 \%$ & $0,0 \%$ & $100,0 \%$ \\
\hline & & & $\%$ dentro de edad & $60,0 \%$ & $22,2 \%$ & $0,0 \%$ & $28,0 \%$ \\
\hline & & \multirow{2}{*}{ De 11 a 50} & $\%$ dentro de horas & $20,0 \%$ & $60,0 \%$ & $20,0 \%$ & $100,0 \%$ \\
\hline & & & $\%$ dentro de edad & $20,0 \%$ & $16,7 \%$ & $50,0 \%$ & $20,0 \%$ \\
\hline & & \multirow{2}{*}{ De 51 a 100} & $\%$ dentro de horas & $25,0 \%$ & $75,0 \%$ & $0,0 \%$ & $100,0 \%$ \\
\hline & & & $\%$ dentro de edad & $20,0 \%$ & $16,7 \%$ & $0,0 \%$ & $16,0 \%$ \\
\hline & & \multirow{2}{*}{ De 101 a 150} & $\%$ dentro de horas & $0,0 \%$ & $80,0 \%$ & $20,0 \%$ & $100,0 \%$ \\
\hline & & & $\%$ dentro de edad & $0,0 \%$ & $22,2 \%$ & $50,0 \%$ & $20,0 \%$ \\
\hline & & De 151 a 200 & $\%$ dentro de horas & $0,0 \%$ & $100,0 \%$ & $0,0 \%$ & $100,0 \%$ \\
\hline & & De 151 a 200 & $\%$ dentro de edad & $0,0 \%$ & $5,6 \%$ & $0,0 \%$ & $4,0 \%$ \\
\hline & & De 201 a 1000 & $\%$ dentro de horas & $0,0 \%$ & $100,0 \%$ & $0,0 \%$ & $100,0 \%$ \\
\hline & & De 201 a 1000 & $\%$ dentro de edad & $0,0 \%$ & $5,6 \%$ & $0,0 \%$ & $4,0 \%$ \\
\hline & & Más de 1000 & $\%$ dentro de horas & $0,0 \%$ & $100,0 \%$ & $0,0 \%$ & $100,0 \%$ \\
\hline & & ivias de tou & $\%$ dentro de edad & $0,0 \%$ & $11,1 \%$ & $0,0 \%$ & $8,0 \%$ \\
\hline & & & $\%$ dentro de horas & $20,0 \%$ & $72,0 \%$ & $8,0 \%$ & $100,0 \%$ \\
\hline & & & $\%$ dentro de edad & $100,0 \%$ & $100,0 \%$ & $100,0 \%$ & $100,0 \%$ \\
\hline & & Menos de 11 & $\%$ dentro de horas & $50,0 \%$ & $50,0 \%$ & $0,0 \%$ & $100,0 \%$ \\
\hline & & IVienos de 11 & $\%$ dentro de edad & $41,7 \%$ & $20,8 \%$ & $0,0 \%$ & $25,6 \%$ \\
\hline & & De 11 a 50 & $\%$ dentro de horas & $27,3 \%$ & $54,5 \%$ & $18,2 \%$ & $100,0 \%$ \\
\hline & & De it a so & $\%$ dentro de edad & $25,0 \%$ & $25,0 \%$ & $66,7 \%$ & $28,2 \%$ \\
\hline & & De 51 a 100 & $\%$ dentro de horas & $20,0 \%$ & $80,0 \%$ & $0,0 \%$ & $100,0 \%$ \\
\hline & & De & $\%$ dentro de edad & $8,3 \%$ & $16,7 \%$ & $0,0 \%$ & $12,8 \%$ \\
\hline & formación en & De 101 a 150 & $\%$ dentro de horas & $14,3 \%$ & $71,4 \%$ & $14,3 \%$ & $100,0 \%$ \\
\hline TOTAL & responsabilidad & De 101 a 150 & $\%$ dentro de edad & $8,3 \%$ & $20,8 \%$ & $33,3 \%$ & $17,9 \%$ \\
\hline 10IAL & & & $\%$ dentro de horas & $0,0 \%$ & $100,0 \%$ & $0,0 \%$ & $100,0 \%$ \\
\hline & & De 151 a 200 & $\%$ dentro de edad & $0,0 \%$ & $4,2 \%$ & $0,0 \%$ & $2,6 \%$ \\
\hline & & De 201 a 1000 & $\%$ dentro de horas & $50,0 \%$ & $50,0 \%$ & $0,0 \%$ & $100,0 \%$ \\
\hline & & De 201 d i touo & $\%$ dentro de edad & $8,3 \%$ & $4,2 \%$ & $0,0 \%$ & $5,1 \%$ \\
\hline & & Más de 1000 & $\%$ dentro de horas & $33,3 \%$ & $66,7 \%$ & $0,0 \%$ & $100,0 \%$ \\
\hline & & Tidas de ivou & $\%$ dentro de edad & $8,3 \%$ & $8,3 \%$ & $0,0 \%$ & $7,7 \%$ \\
\hline & & & $\%$ dentro de horas & $30,8 \%$ & $61,5 \%$ & $7,7 \%$ & $100,0 \%$ \\
\hline & & & $\%$ dentro de edad & $100,0 \%$ & $100,0 \%$ & $100,0 \%$ & $100,0 \%$ \\
\hline
\end{tabular}

Cuadro 84: Tabla de contingencia de formación en responsabilidad social, sexo y edad.

Según el cuadro 84, las líderes femeninas que tienen entre 20 a 40 años muestran una mayor presencia en las organizaciones que dedican de 1 a 11 horas a la formación enmarcada en el ámbito de la responsabilidad social 
$(66,7 \%)$. Mientras que en las organizaciones que invierten entre 11 a 50 horas a la formación en responsabilidad social, la presencia mayoritaria es la de las líderes de 41 a 60 años (50\%) aunque las máximas dirigentes femeninas de 20 a 40 años también tienen un protagonismo destacable $(33,3 \%)$.

En cuanto a los máximos responsables masculinos, los líderes de 20 a 40 años tienen menos protagonismo que en el caso de sus homónimas femeninas. En las organizaciones que dedican entre 1 y 11 horas a la formación enmarcada en el ámbito de la responsabilidad social, ya es más elevada la presencia de líderes de 41 a 60 años $(57,1 \%)$ que la de líderes de 20 a 40 años (42,9\%). En el resto de opciones contempladas, también es mayor el protagonismo de los máximos responsables de 41 a 60 años. Aunque en algunos segmentos su presencia es poco representativa por el reducido número de casos registrados, destacamos la que se ha producido en las empresas que dedican a la formación enmarcada en el ámbito de la responsabilidad social de 11 a 50 horas (60\%), de 51 a 100 horas (75\%) y de 101 a 150 horas $(80 \%)$.

Los datos también indican la mínima presencia de líderes de 61 o más años que, con independencia del sexo, impulsan acciones formativas enmarcadas en el ámbito de la responsabilidad social (un caso registrado en el sexo femenino y dos en el masculino). También reflejan que hay un mayor protagonismo de líderes masculinos de 41 a 60 años que femeninos en las organizaciones que invierten horas en formación interna y en sensibilizar a sus 
colaboradores en aspectos ecológicos y ambientales asociados a su ámbito de actividad (72\% en el caso de los hombres frente a un $42,9 \%$ en el caso de las mujeres).

La información aportada por el cuadro 84 refleja que la formación encuadrada en el ámbito de la responsabilidad social es impulsada, a pequeña escala (50 o menos horas dedicadas a la formación) por líderes de ambos sexos de 20 a 60 años. En lo que podríamos denominar escala "media” (organizaciones que dedican de 51 a 150 horas dedicadas a la formación enmarcada en el ámbito de la responsabilidad social), la presencia de los líderes masculinos de 41 a 60 años es mayoritaria.

Hemos incluido a continuación el gráfico 31 para mostrar la evolución del sexo en función de la edad y de la formación impartida por las organizaciones de origen de los líderes en materia de responsabilidad social, con objeto de contemplar alguna posible tendencia global en la variación de las variables:

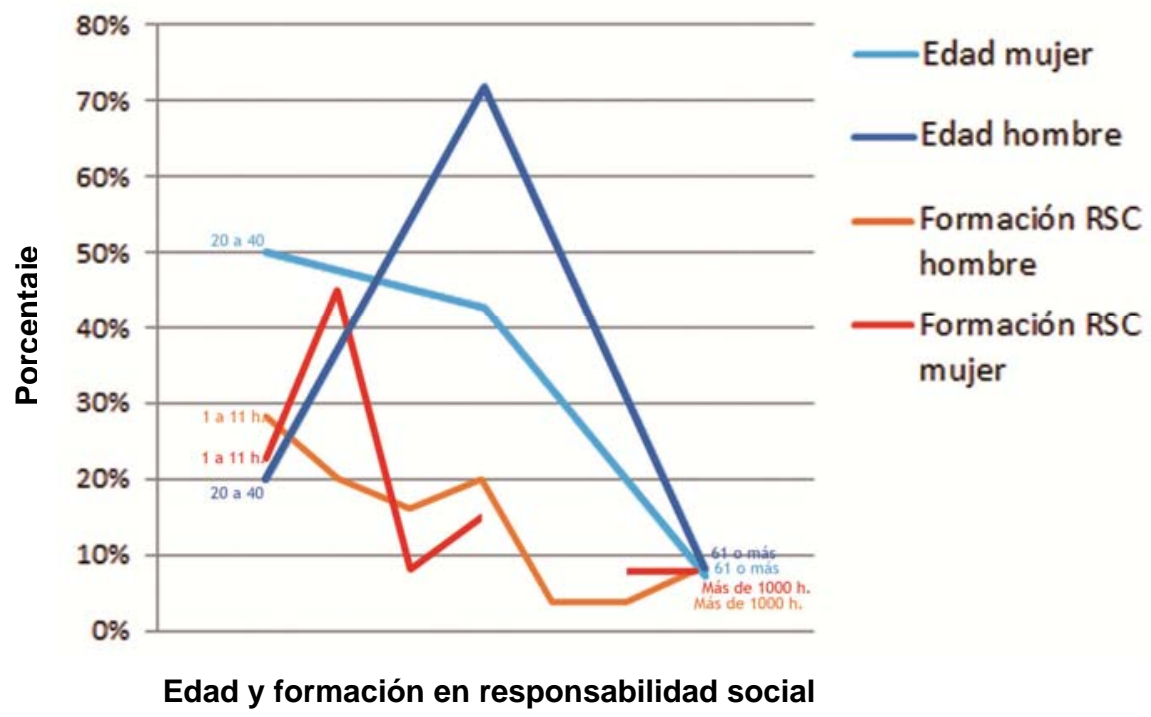

Gráfico 31: Sexo, edad y formación en responsabilidad social. 
Los datos del gráfico 31 indican que a medida que aumenta el número de horas que las organizaciones dedican a acciones formativas sobre responsabilidad social disminuye su presencia en la muestra, al igual que también se reduce la presencia de líderes femeninas en la investigación a medida que avanza su edad. Esta tendencia no se ha producido en el caso de los máximos responsables masculinos.

También existe una tendencia decreciente al contemplar la edad de los máximos responsables entrevistados, con independencia de su sexo, a partir de los 60 años. Los máximos responsables de 61 o más años parecen tender a registrar una menor presencia en la cúpula directiva de organizaciones que impulsan acciones formativas de responsabilidad social. Presencia reducida que guarda cierta correspondencia con el menor protagonismo de empresas según aumenta el número de horas que dedican a iniciativas de formación sobre responsabilidad social.

\subsubsection{Sexo, sector y Responsabilidad Social Corporativa}

En primer lugar incorporamos los datos sobre el sexo de los líderes, su sector de procedencia y su actitud hacia la Responsabilidad Social Corporativa. 


\begin{tabular}{|l|l|r|r|r|r|}
\hline Sexo & \multicolumn{1}{|c|}{ Sector } & \multicolumn{1}{c|}{ Media } & \multicolumn{1}{c|}{ Mínimo } & \multicolumn{1}{c|}{ Máximo } & Desv. típ. \\
\hline \multirow{4}{*}{ Mujer } & Servicios (incluye comercio) & 7,1541 & 3,86 & 8,13 & 1,13173 \\
\cline { 2 - 6 } & Construcción & 7,6029 & 6,78 & 8,03 &, 71276 \\
\cline { 2 - 6 } & Industria & 7,6765 & 6,78 & 8,10 &, 51075 \\
\cline { 2 - 6 } & Total & 7,2353 & 3,86 & 8,13 & 1,07138 \\
\hline \multirow{4}{*}{ Hombre } & Servicios (incluye comercio) & 7,1333 & 4,63 & 8,12 & 1,05742 \\
\cline { 2 - 6 } & Construcción & 7,3649 & 5,25 & 8,03 & 1,00840 \\
\cline { 2 - 6 } & Industria & 7,2910 & 5,00 & 8,12 & 1,05015 \\
\cline { 2 - 6 } & Total & 7,1869 & 4,63 & 8,12 & 1,04651 \\
\hline \multirow{4}{*}{ Total } & Servicios (incluye comercio) & 7,1416 & 3,86 & 8,13 & 1,08394 \\
\cline { 2 - 6 } & Construcción & 7,4159 & 5,25 & 8,03 &, 93308 \\
\cline { 2 - 6 } & Industria & 7,3844 & 5,00 & 8,12 &, 95516 \\
\cline { 2 - 6 } & Total & 7,2043 & 3,86 & 8,13 & 1,05294 \\
\hline
\end{tabular}

Cuadro 85: Medidas estadísticas de sector, sexo y actitud hacia la responsabilidad social.

Antes de realizar una valoración de la información que ofrece el cuadro 85 hemos aplicado ANOVA de un factor en los datos para comprobar si los grupos muestrales que componen el grupo poblacional presentan diferencias estadísticamente significativas.

\begin{tabular}{|l|l|r|r|r|r|r|}
\hline \multicolumn{2}{|c|}{} & Suma de cuadrados & gl & Media cuadrática & F & \multicolumn{1}{c|}{ Sig. } \\
\hline \multirow{4}{*}{ Sexo } & Inter-grupos & 16,894 & 80 &, 211 &, 856 &, 767 \\
\cline { 2 - 8 } & Intra-grupos & 26,640 & 108 &, 247 & & \\
\cline { 2 - 8 } & Total & 43,534 & 188 & & & \\
\hline \multirow{4}{*}{ Sector } & Inter-grupos & 42,217 & 80 &, 528 &, 815 &, 832 \\
\cline { 2 - 8 } & Intra-grupos & 69,920 & 108 &, 647 & & \\
\cline { 2 - 8 } & Total & 112,138 & 188 & & & \\
\hline
\end{tabular}

Cuadro 86: Tabla ANOVA del sector y el sexo, factor Horas de Formación en Responsabilidad Social.

Los datos que ofrece el cuadro 86 muestra que no existen diferencias estadísticamente significativas entre los grupos muestrales considerados (el coeficiente de significación es mayor de 0,05 en ambos casos). 
La información que ofrece el cuadro 85 indica que, prácticamente, no existen diferencias en la actitud hacia la responsabilidad social en hombres y en mujeres en el sector servicios (la actitud media de las mujeres en ese sector es 7,15 y la de los hombres 7,13 ).

También existe un cierto paralelismo en la actitud que presentan los hombres y las mujeres en los dos sectores con una actitud media mayor (construcción e industria), ya que los promedios están bastantes próximos en cada sexo. De todos modos la actitud en estos dos sectores es un poco más favorable en las mujeres que en los hombres (prácticamente 0,3 puntos de diferencia en cada uno de los dos ámbitos de actividad). Además, el sector con una media más alta en cada caso es diferente: en las líderes femeninas el ámbito industrial (su media es 7,67 ) y en los máximos responsables el sector construcción (su puntuación media es 7,36).

Si consideramos ambos sexos es destacable que en los dos sectores que muestran una actitud media mayor, el sector construcción con un valor medio de 7,41 y el sector industria con una puntuación media de 7,38, las mujeres presenten una actitud favorable hacia la Responsabilidad Social Corporativa un poco superior a los hombres.

Hemos incluido a continuación el gráfico 32 para comprobar, de modo visual, si es posible contemplar alguna asociación entre las variables estudiadas. 


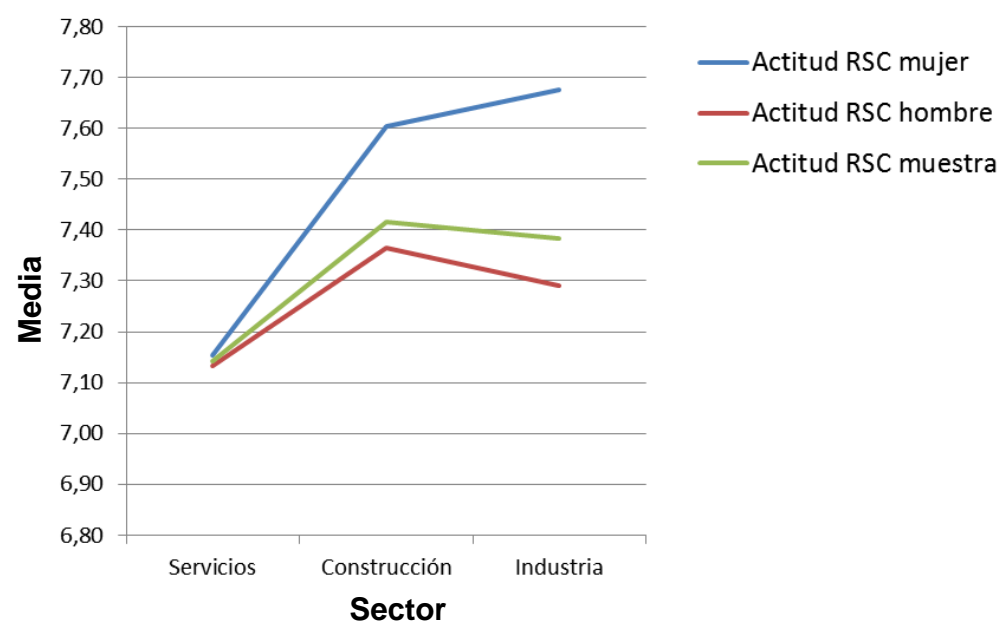

Gráfico 32: Sexo, sector y actitud hacia la responsabilidad social.

La información del gráfico 32 indica que ambos sexos presentan una actitud hacia la responsabilidad social muy similar en el sector servicios. Además también refleja que la actitud media tiende a ser mayor en los líderes de ambos sexos en el ámbito de la construcción que en el sector servicios, aunque más elevada en las mujeres. Y que estas diferencias tienden a hacerse mayores en el ámbito de la industria, donde la actitud de los máximos responsables masculinos decrece y la de las líderes femeninas alcanza su valor máximo.

En relación con el comportamiento socialmente responsable de la organización, al igual que en el apartado previo, hemos realizado en primer lugar un análisis de la relación existente entre el sexo de los líderes, su sector de procedencia y la actuación en materia responsable de su organización de origen.

A continuación hemos revisado las relaciones existentes entre el sexo de los líderes y su sector de procedencia pero, en este caso, hemos relacionado estos 
datos con las acciones formativas de la empresa a la que el máximo responsable está vinculado que puedan encuadrarse en el ámbito de la responsabilidad social.

Hemos incorporado a continuación el cuadro 87 con los datos recabados sobre el sexo de los líderes que han participado en el estudio, el comportamiento genérico de su empresa de procedencia en el ámbito de la responsabilidad social y el sector de su organización:

\begin{tabular}{|c|c|c|c|c|c|c|c|}
\hline \multirow{2}{*}{ Sexo } & & & & \multicolumn{3}{|c|}{ Sector } & \multirow{3}{*}{$\begin{array}{l}\text { Total } \\
100,0 \%\end{array}$} \\
\hline & & & & \multirow{2}{*}{$\begin{array}{r}\begin{array}{l}\text { Servicios } \\
\text { (incluye } \\
\text { comercio) }\end{array} \\
88,2 \%\end{array}$} & \multirow{2}{*}{$\begin{array}{r}\text { Construcción } \\
2,9 \%\end{array}$} & \multirow{2}{*}{$\begin{array}{r}\text { Industria } \\
8,8 \%\end{array}$} & \\
\hline \multirow{10}{*}{ Mujer } & \multirow{8}{*}{$\begin{array}{l}\text { Acciones de } \\
\text { responsabilidad } \\
\text { social }\end{array}$} & \multirow{2}{*}{ No } & $\%$ dentro de acciones & & & & \\
\hline & & & $\%$ dentro de sector & $52,6 \%$ & $33,3 \%$ & $37,5 \%$ & $50,0 \%$ \\
\hline & & \multirow{2}{*}{ Sí, acciones puntuales } & $\%$ dentro de acciones & $83,3 \%$ & $5,6 \%$ & $11,1 \%$ & $100,0 \%$ \\
\hline & & & $\%$ dentro de sector & $26,3 \%$ & $33,3 \%$ & $25,0 \%$ & $26,5 \%$ \\
\hline & & \multirow{2}{*}{$\begin{array}{l}\text { Sí, acciones } \\
\text { frecuentes sin una } \\
\text { política definida de RS }\end{array}$} & $\%$ dentro de acciones & $71,4 \%$ & $14,3 \%$ & $14,3 \%$ & $100,0 \%$ \\
\hline & & & $\%$ dentro de sector & $8,8 \%$ & $33,3 \%$ & $12,5 \%$ & $10,3 \%$ \\
\hline & & \multirow{2}{*}{$\begin{array}{l}\text { Sí, acciones } \\
\text { integradas en una } \\
\text { política de RS }\end{array}$} & $\%$ dentro de acciones & $77,8 \%$ & $0,0 \%$ & $22,2 \%$ & $100,0 \%$ \\
\hline & & & $\%$ dentro de sector & $12,3 \%$ & $0,0 \%$ & $25,0 \%$ & $13,2 \%$ \\
\hline & \multirow{2}{*}{\multicolumn{2}{|c|}{ Total }} & $\%$ dentro de acciones & $83,8 \%$ & $4,4 \%$ & $11,8 \%$ & $100,0 \%$ \\
\hline & & & $\%$ dentro de sector & $100,0 \%$ & $100,0 \%$ & $100,0 \%$ & $100,0 \%$ \\
\hline \multirow{10}{*}{ Hombre } & \multirow{8}{*}{$\begin{array}{l}\text { Acciones de } \\
\text { responsabilidad } \\
\text { social }\end{array}$} & \multirow{2}{*}{ No } & $\%$ dentro de acciones & $68,4 \%$ & $15,8 \%$ & $15,8 \%$ & $100,0 \%$ \\
\hline & & & $\%$ dentro de sector & $45,9 \%$ & $81,8 \%$ & $36,0 \%$ & $47,1 \%$ \\
\hline & & \multirow{2}{*}{ Sí, acciones puntuales } & $\%$ dentro de acciones & $77,8 \%$ & $5,6 \%$ & $16,7 \%$ & $100,0 \%$ \\
\hline & & & $\%$ dentro de sector & $16,5 \%$ & $9,1 \%$ & $12,0 \%$ & $14,9 \%$ \\
\hline & & \multirow{2}{*}{$\begin{array}{l}\text { Sí, acciones } \\
\text { frecuentes sin una } \\
\text { política definida de RS }\end{array}$} & $\%$ dentro de acciones & $72,2 \%$ & $0,0 \%$ & $27,8 \%$ & $100,0 \%$ \\
\hline & & & $\%$ dentro de sector & $15,3 \%$ & $0,0 \%$ & $20,0 \%$ & $14,9 \%$ \\
\hline & & \multirow{2}{*}{$\begin{array}{l}\text { Sí, acciones } \\
\text { integradas en una } \\
\text { política de RS }\end{array}$} & $\%$ dentro de acciones & $67,9 \%$ & $3,6 \%$ & $28,6 \%$ & $100,0 \%$ \\
\hline & & & $\%$ dentro de sector & $22,4 \%$ & $9,1 \%$ & $32,0 \%$ & $23,1 \%$ \\
\hline & \multirow{2}{*}{\multicolumn{2}{|c|}{ Total }} & $\%$ dentro de acciones & $70,2 \%$ & $9,1 \%$ & $20,7 \%$ & $100,0 \%$ \\
\hline & & & $\%$ dentro de sector & $100,0 \%$ & $100,0 \%$ & $100,0 \%$ & $100,0 \%$ \\
\hline \multirow{10}{*}{ TOTAL } & \multirow{8}{*}{$\begin{array}{l}\text { Acciones de } \\
\text { responsabilidad } \\
\text { social }\end{array}$} & \multirow{2}{*}{ No } & $\%$ dentro de acciones & $75,8 \%$ & $11,0 \%$ & $13,2 \%$ & $100,0 \%$ \\
\hline & & & $\%$ dentro de sector & $48,6 \%$ & $71,4 \%$ & $36,4 \%$ & $48,1 \%$ \\
\hline & & \multirow{2}{*}{ Sí, acciones puntuales } & $\%$ dentro de acciones & $80,6 \%$ & $5,6 \%$ & $13,9 \%$ & $100,0 \%$ \\
\hline & & & $\%$ dentro de sector & $20,4 \%$ & $14,3 \%$ & $15,2 \%$ & $19,0 \%$ \\
\hline & & \multirow{2}{*}{$\begin{array}{l}\text { Sí, acciones } \\
\text { frecuentes sin una } \\
\text { política definida de RS }\end{array}$} & $\%$ dentro de acciones & $72,0 \%$ & $4,0 \%$ & $24,0 \%$ & $100,0 \%$ \\
\hline & & & $\%$ dentro de sector & $12,7 \%$ & $7,1 \%$ & $18,2 \%$ & $13,2 \%$ \\
\hline & & \multirow{2}{*}{$\begin{array}{l}\text { Sí, acciones } \\
\text { integradas en una } \\
\text { política de RS }\end{array}$} & $\%$ dentro de acciones & $70,3 \%$ & $2,7 \%$ & $27,0 \%$ & $100,0 \%$ \\
\hline & & & $\%$ dentro de sector & $18,3 \%$ & $7,1 \%$ & $30,3 \%$ & $19,6 \%$ \\
\hline & \multirow{2}{*}{\multicolumn{2}{|c|}{ Total }} & $\%$ dentro de acciones & $75,1 \%$ & $7,4 \%$ & $17,5 \%$ & $100,0 \%$ \\
\hline & & & $\%$ dentro de sector & $100,0 \%$ & $100,0 \%$ & $100,0 \%$ & $100,0 \%$ \\
\hline
\end{tabular}

Cuadro 87: Tabla de contingencia de realización de acciones de responsabilidad social, sexo y sector. 
Los datos indican que existe un comportamiento bastante similar tanto en los líderes masculinos como en las líderes femeninas.

En el caso de las mujeres existe una mayor presencia de líderes que proceden del sector servicios en todos los tipos de comportamiento empresarial contemplados: la organización no realiza ningún tipo de actuación $(88,2 \%)$, desarrolla iniciativas puntuales $(83,3 \%)$, frecuentes $(71,4 \%)$ - las impulsa pero dentro de una política definida de Responsabilidad Social Corporativa $(77,8 \%)$.

Este mayor protagonismo de las líderes de este sector era esperable porque está mucho más representado que el resto, sin embargo es destacable que de los dos sectores con menos presencia en la muestra femenina (construcción e industria) solo el sector industria tenga presencia de líderes en todos los tipos de actuación responsable.

También es destacable que mientras el $52,6 \%$ de las mujeres del sector servicios están vinculadas a empresas que no impulsan ningún tipo de iniciativa en materia responsable, solo el $37,5 \%$ de las líderes del sector industria se encuentran en la misma situación. No hemos realizado esta comparativa con el sector construcción por el reducido número de casos registrados en este ámbito de actividad (3).

En cuanto a los hombres se mantiene el mismo patrón. Se ha producido una mayor presencia de máximos responsables del sector servicios en todas las opciones 
contempladas en relación con la actuación responsable: la empresa no realiza ningún tipo de iniciativa $(68,4 \%)$, las desarrolla muy esporádicamente $(77,8 \%)$, las impulsa habitualmente $(72,2 \%)$ o las ejecuta pero dentro de una política previamente establecida sobre responsabilidad social $(67,9 \%)$.

En los máximos responsables masculinos también contábamos, como en el caso de las líderes femeninas, con que el sector servicios estuviera más representado que el resto, aunque en esta muestra los sectores industria y construcción han estado mejor representados. Aunque el número de líderes masculinos sea mayor en estos dos últimos ámbitos de actividad se mantiene la misma inercia que en las líderes femeninas: el sector industria tiene presencia destacada respecto al sector servicios en todos los tipos de comportamiento empresarial socialmente responsable -en este caso con bastante distancia respecto a los datos registrados sobre comportamiento puntual $(16,7 \%$ frente a $5,6 \%)$, frecuente $(27,8 \%$ frente a $0 \%)$ o integrado en una política definida $(28,3 \%$ frente a $3,6 \%)$-.

Al igual que en el caso de las mujeres, el mayor porcentaje de hombres del sector servicios está vinculado a empresas que no impulsan ningún tipo de iniciativa socialmente responsable $(45,9 \%)$, porcentaje que es mucho más elevado en el caso de los líderes procedentes del sector construcción $(81,8 \%)$. De igual modo que ha sucedido en las líderes femeninas, los máximos responsables del sector industria tienen una menor presencia en las organizaciones 
que no realizan ningún tipo de acción responsable $(36,6 \%)$ que la que presentan los máximos responsables del sector servicios $(45,9 \%)$.

Los datos indican, por tanto, que el sector construcción, con independencia del sexo, presenta un comportamiento socialmente responsable menos destacado que el sector industria.

A continuación hemos incorporado el grafico 33, "Sexo, sector y acciones de responsabilidad social", para revisar visualmente si existe algún tipo de asociación en la variación del sexo, el sector y la actuación organizacional en materia de responsabilidad social:

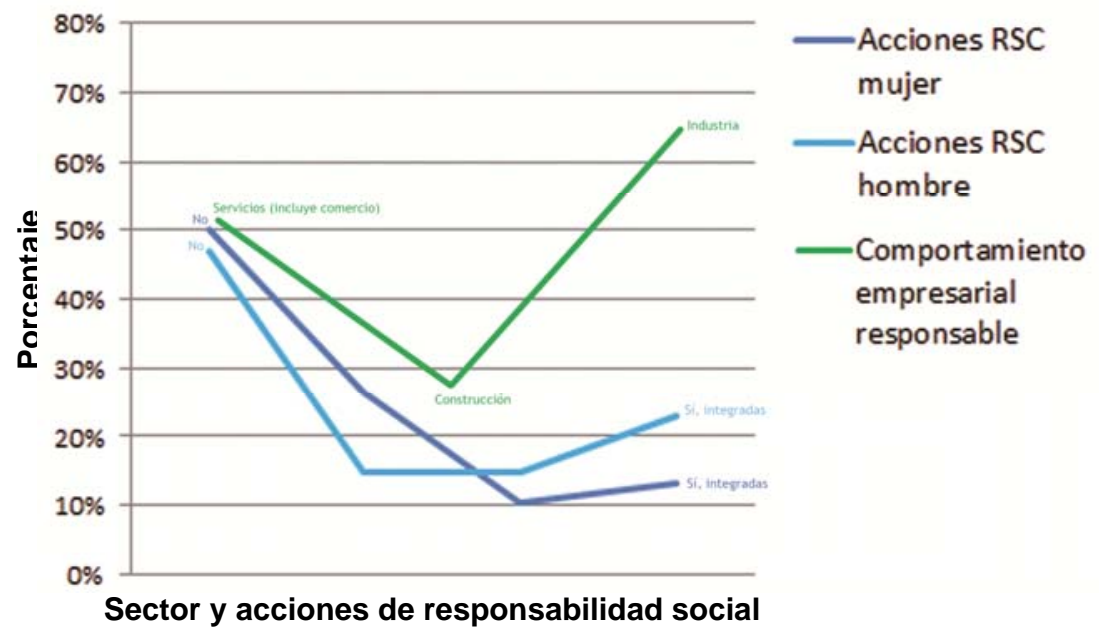

Gráfico 33: Sexo, sector y acciones de responsabilidad social.

Los datos del gráfico 33 indican que el comportamiento del líder en materia responsable es bastante similar, con independencia de que quien lidere las organizaciones sea un hombre o una mujer. 
Hemos incorporado la línea "Comportamiento empresarial responsable" que hace referencia, exclusivamente, a los líderes de los sectores servicios, industria y construcción que impulsan iniciativas en el marco de la Responsabilidad Social Corporativa, ya sean estas puntuales, frecuentes o integradas en una política definida.

La inclusión de esta línea permite hipotetizar una posible relación entre el crecimiento leve de las acciones responsables desde la tercera opción contemplada en intensidad de comportamiento responsable (acciones frecuentes) hacia la cuarta (acciones integradas) y la mayor presencia de los líderes en el sector servicios y, especialmente, en el sector industria.

A continuación hemos incluido el cuadro 88, "Tabla de contingencia de formación en responsabilidad social, sexo y sector", para facilitar la revisión de los datos que hacen referencia al sexo del líder y a su sector de procedencia pero contemplando, en este caso, el comportamiento de la organización de procedencia del líder en relación con sus acciones formativas encuadras en el ámbito de la responsabilidad social.

Los datos del cuadro 88 indican que hay cierta similitud si tomamos como referencia el sexo, aunque también existen matices diferenciales en las organizaciones según el sexo del líder. 


\begin{tabular}{|c|c|c|c|c|c|c|c|}
\hline \multirow{2}{*}{\multicolumn{4}{|c|}{ Sexo }} & \multicolumn{3}{|c|}{ Sector } & \multirow{3}{*}{$\begin{array}{c}\text { Total } \\
100,0 \% \\
\end{array}$} \\
\hline & & & & \multirow{2}{*}{$\begin{array}{c}\begin{array}{c}\text { Servicios } \\
\text { (incluye comercio) }\end{array} \\
66,7 \% \\
\end{array}$} & \multirow{2}{*}{$\begin{array}{r}\text { Construcción } \\
0,0 \% \\
\end{array}$} & \multirow{2}{*}{$\begin{array}{r}\text { Industria } \\
33,3 \% \\
\end{array}$} & \\
\hline \multirow{14}{*}{ Mujer } & \multirow{12}{*}{$\begin{array}{l}\text { Horas de } \\
\text { formación en } \\
\text { responsabilidad } \\
\text { social }\end{array}$} & \multirow{2}{*}{ Menos de 11} & $\%$ dentro horas de formación & & & & \\
\hline & & & $\%$ dentro de sector & $22,2 \%$ & $0,0 \%$ & $33,3 \%$ & $21,4 \%$ \\
\hline & & \multirow{2}{*}{ De 11 a 50} & $\%$ dentro horas de formación & $83,3 \%$ & $16,7 \%$ & $0,0 \%$ & $100,0 \%$ \\
\hline & & & $\%$ dentro de sector & $55,6 \%$ & $50,0 \%$ & $0,0 \%$ & $42,9 \%$ \\
\hline & & \multirow{2}{*}{ De 51 a 100} & $\%$ dentro horas de formación & $0,0 \%$ & $0,0 \%$ & $100,0 \%$ & $100,0 \%$ \\
\hline & & & $\%$ dentro de sector & $0,0 \%$ & $0,0 \%$ & $33,3 \%$ & $7,1 \%$ \\
\hline & & \multirow{2}{*}{ De 101 a 150} & $\%$ dentro horas de formación & $0,0 \%$ & $50,0 \%$ & $50,0 \%$ & $100,0 \%$ \\
\hline & & & $\%$ dentro de sector & $0,0 \%$ & $50,0 \%$ & $33,3 \%$ & $14,3 \%$ \\
\hline & & \multirow{2}{*}{ De 201 a 1000} & $\%$ dentro horas de formación & $100,0 \%$ & $0,0 \%$ & $0,0 \%$ & $100,0 \%$ \\
\hline & & & $\%$ dentro de sector & $11,1 \%$ & $0,0 \%$ & $0,0 \%$ & $7,1 \%$ \\
\hline & & \multirow{2}{*}{ Más de 1000} & $\%$ dentro horas de formación & $100,0 \%$ & $0,0 \%$ & $0,0 \%$ & $100,0 \%$ \\
\hline & & & $\%$ dentro de sector & $11,1 \%$ & $0,0 \%$ & $0,0 \%$ & $7,1 \%$ \\
\hline & \multirow{2}{*}{\multicolumn{2}{|c|}{ Total }} & $\%$ dentro horas de formación & $64,3 \%$ & $14,3 \%$ & $21,4 \%$ & $100,0 \%$ \\
\hline & & & $\%$ dentro de sector & $100,0 \%$ & $100,0 \%$ & $100,0 \%$ & $100,0 \%$ \\
\hline \multirow{16}{*}{ Hombre } & \multirow{14}{*}{$\begin{array}{l}\text { Horas de } \\
\text { formación en } \\
\text { responsabilidad } \\
\text { social }\end{array}$} & \multirow{2}{*}{ Menos de 11} & $\%$ dentro horas de formación & $71,4 \%$ & $0,0 \%$ & $28,6 \%$ & $100,0 \%$ \\
\hline & & & $\%$ dentro de sector & $33,3 \%$ & $0,0 \%$ & $25,0 \%$ & $28,0 \%$ \\
\hline & & \multirow{2}{*}{ De 11 a 50} & $\%$ dentro horas de formación & $20,0 \%$ & $20,0 \%$ & $60,0 \%$ & $100,0 \%$ \\
\hline & & & $\%$ dentro de sector & $6,7 \%$ & $50,0 \%$ & $37,5 \%$ & $20,0 \%$ \\
\hline & & \multirow{2}{*}{ De 51 a 100} & $\%$ dentro horas de formación & $75,0 \%$ & $0,0 \%$ & $25,0 \%$ & $100,0 \%$ \\
\hline & & & $\%$ dentro de sector & $20,0 \%$ & $0,0 \%$ & $12,5 \%$ & $16,0 \%$ \\
\hline & & \multirow{2}{*}{ De 101 a 150} & $\%$ dentro horas de formación & $60,0 \%$ & $20,0 \%$ & $20,0 \%$ & $100,0 \%$ \\
\hline & & & $\%$ dentro de sector & $20,0 \%$ & $50,0 \%$ & $12,5 \%$ & $20,0 \%$ \\
\hline & & De 151 a 200 & $\%$ dentro horas de formación & $100,0 \%$ & $0,0 \%$ & $0,0 \%$ & $100,0 \%$ \\
\hline & & DE TST a $\angle 00$ & $\%$ dentro de sector & $6,7 \%$ & $0,0 \%$ & $0,0 \%$ & $4,0 \%$ \\
\hline & & De 201 a 1000 & $\%$ dentro horas de formación & $0,0 \%$ & $0,0 \%$ & $100,0 \%$ & $100,0 \%$ \\
\hline & & De 201 a & $\%$ dentro de sector & $0,0 \%$ & $0,0 \%$ & $12,5 \%$ & $4,0 \%$ \\
\hline & & Más de 1000 & $\%$ dentro horas de formación & $100,0 \%$ & $0,0 \%$ & $0,0 \%$ & $100,0 \%$ \\
\hline & & Tias he toro & $\%$ dentro de sector & $13,3 \%$ & $0,0 \%$ & $0,0 \%$ & $8,0 \%$ \\
\hline & & & $\%$ dentro horas de formación & $60,0 \%$ & $8,0 \%$ & $32,0 \%$ & $100,0 \%$ \\
\hline & & & $\%$ dentro de sector & $100,0 \%$ & $100,0 \%$ & $100,0 \%$ & $100,0 \%$ \\
\hline & & Menos de 11 & $\%$ dentro horas de formación & $70,0 \%$ & $0,0 \%$ & $30,0 \%$ & $100,0 \%$ \\
\hline & & S & $\%$ dentro de sector & $29,2 \%$ & $0,0 \%$ & $27,3 \%$ & $25,6 \%$ \\
\hline & & Re 11 a 50 & $\%$ dentro horas de formación & $54,5 \%$ & $18,2 \%$ & $27,3 \%$ & $100,0 \%$ \\
\hline & & DE TI a SO & $\%$ dentro de sector & $25,0 \%$ & $50,0 \%$ & $27,3 \%$ & $28,2 \%$ \\
\hline & & De 51 a 100 & $\%$ dentro horas de formación & $60,0 \%$ & $0,0 \%$ & $40,0 \%$ & $100,0 \%$ \\
\hline & & De Sid t To & $\%$ dentro de sector & $12,5 \%$ & $0,0 \%$ & $18,2 \%$ & $12,8 \%$ \\
\hline & formación en & De 101 a 150 & $\%$ dentro horas de formación & $42,9 \%$ & $28,6 \%$ & $28,6 \%$ & $100,0 \%$ \\
\hline TOTAL & $\begin{array}{l}\text { responsabilidad } \\
\text { social }\end{array}$ & De to ta & $\%$ dentro de sector & $12,5 \%$ & $50,0 \%$ & $18,2 \%$ & $17,9 \%$ \\
\hline TUIAL & & De 151 a 200 & $\%$ dentro horas de formación & $100,0 \%$ & $0,0 \%$ & $0,0 \%$ & $100,0 \%$ \\
\hline & & DE TJI a $\angle U 0$ & $\%$ dentro de sector & $4,2 \%$ & $0,0 \%$ & $0,0 \%$ & $2,6 \%$ \\
\hline & & De 201 a 1000 & $\%$ dentro horas de formación & $50,0 \%$ & $0,0 \%$ & $50,0 \%$ & $100,0 \%$ \\
\hline & & De 20 i a & $\%$ dentro de sector & $4,2 \%$ & $0,0 \%$ & $9,1 \%$ & $5,1 \%$ \\
\hline & & Más de 1000 & $\%$ dentro horas de formación & $100,0 \%$ & $0,0 \%$ & $0,0 \%$ & $100,0 \%$ \\
\hline & & Mids de inou & $\%$ dentro de sector & $12,5 \%$ & $0,0 \%$ & $0,0 \%$ & $7,7 \%$ \\
\hline & & & $\%$ dentro horas de formación & $61,5 \%$ & $10,3 \%$ & $28,2 \%$ & $100,0 \%$ \\
\hline & & & $\%$ dentro de sector & $100,0 \%$ & $100,0 \%$ & $100,0 \%$ & $100,0 \%$ \\
\hline
\end{tabular}

Cuadro 88: Tabla de contingencia de formación en responsabilidad social, sexo y sector.

En el caso de las mujeres la muestra ha sido muy reducida (solo se han registrado 14 casos) de los que 9 (64,3\% de la muestra de líderes femeninas) son del sector servicios. La concentración de estas líderes se encuentra dentro de las empresas que dedican menos de 11 horas a 
acciones formativas (el $66,7 \%$ si contemplamos todos los sectores en esa franja de horas) y en las que invierten entre 11 y 50 horas (el 83,3\% al considerar de nuevo a las organizaciones de los tres sectores que dedican entre $11 \mathrm{y}$ 50 horas). Las líderes del sector servicios cuyas empresas dedican entre 1 y 50 horas a la formación encuadrada en el ámbito de la responsabilidad social son el $77,8 \%$ del total de líderes de este sector.

En relación a los hombres, también existe una concentración de líderes en las empresas del sector servicios aunque en este caso su presencia significativa se amplía hasta las empresas que dedican 150 horas a la formación encuadrada en el ámbito de la responsabilidad social $(71,4 \%$ en el caso de las empresas que dedican menos de 11 horas, $75 \%$ en las que invierten entre 51 y 100 horas y $60 \%$ en las que dedican entre 101 y 150 horas a formación sobre responsabilidad social). De todos modos, en el caso de los hombres también existe una presencia destacada de líderes del sector industria (el $28,6 \%$ de líderes en las empresas que dedican entre 1 y 11 horas a formación son de este sector y el $60 \%$ en las organizaciones que invierten entre 11 y 50 horas en cursos enmarcados en el ámbito de la responsabilidad social).

Los datos parecen indicar que en las empresas del sector industria lideradas por hombres hay una mayor dedicación de horas dirigidas a formar en materia de Responsabilidad Social Corporativa. Además también reflejan que en las empresas del sector servicios la 
presencia de los hombres parece favorecer la extensión de los cursos impartidos.

A continuación hemos incorporado el gráfico 34 con la variación de los datos sobre el sector de procedencia de los líderes, considerando su sexo, y sobre las horas de formación en materia de responsabilidad social que impulsan sus organizaciones de origen.

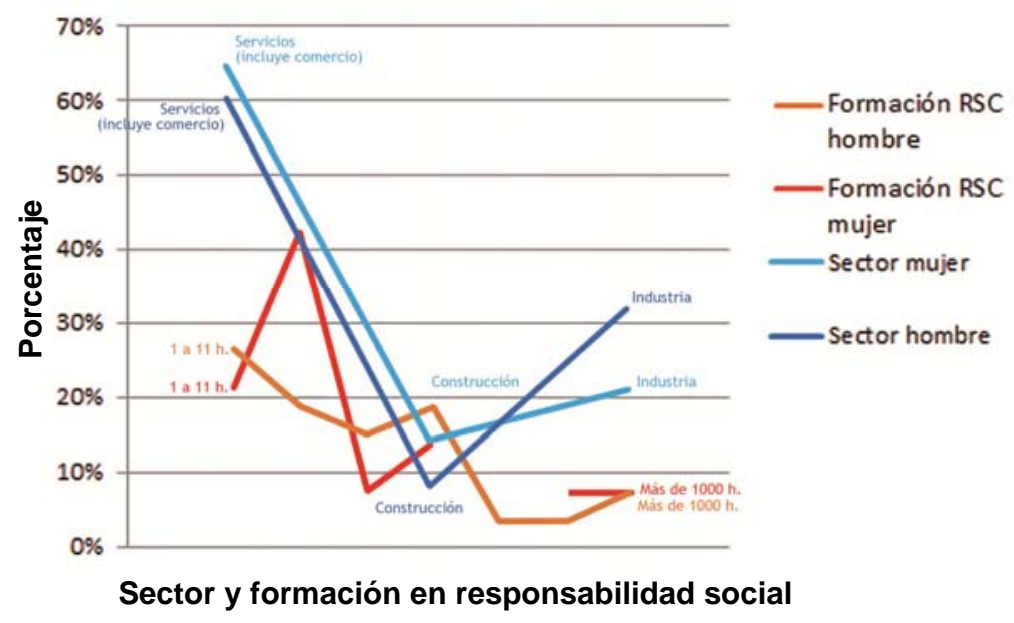

Gráfico 34: Sexo, sector y formación de responsabilidad social.

Los datos indican que a medida que se incrementan las horas que las organizaciones dedican a impartir formación encuadrada en el ámbito de la responsabilidad social, disminuye el número de empresas. La información que ofrece el gráfico 34 no evidencia la existencia de relaciones entre las horas de formación y el sector, exceptuando quizá el hecho de que la mayor presencia en la muestra de líderes masculinos procedentes de empresas que dedican más de 1000 horas a formación en materia de responsabilidad social, respecto a los máximos responsables de 
organizaciones que dedican entre 201 y 1000 horas, se corresponda con un mayor protagonismo en la muestra del estudio de hombres del sector industrial.

\subsubsection{Sexo, tamaño y Responsabilidad Social Corporativa}

Hemos revisado, en primer lugar, los datos sobre el tamaño de las organizaciones de procedencia de los líderes, el sexo de los máximos responsables y su actitud hacia la Responsabilidad Social Corporativa (cuadro 89).

\begin{tabular}{|l|l|l|r|r|r|}
\hline Sexo & Tamaño & Media & Mínimo & Máximo & Desv. típ. \\
\hline \multirow{4}{*}{ Mujer } & Pequeño & 7,1542 & 3,86 & 8,13 & 1,09537 \\
\cline { 2 - 6 } & Mediano & 7,0989 & 4,39 & 8,03 & 1,25393 \\
\cline { 2 - 6 } & Grande & 7,7209 & 6,20 & 8,10 &, 57627 \\
\cline { 2 - 6 } & Total & 7,2353 & 3,86 & 8,13 & 1,07138 \\
\hline \multirow{4}{*}{ Hombre } & Pequeño & 7,0374 & 4,63 & 8,12 & 1,12646 \\
\cline { 2 - 6 } & Mediano & 7,1648 & 5,00 & 8,10 &, 99842 \\
\cline { 2 - 6 } & Grande & 7,6215 & 5,40 & 8,12 &, 76064 \\
\cline { 2 - 6 } & Total & 7,1869 & 4,63 & 8,12 & 1,04651 \\
\hline \multirow{4}{*}{ TOTAL } & Pequeño & 7,0845 & 3,86 & 8,13 & 1,11040 \\
\cline { 2 - 6 } & Mediano & 7,1458 & 4,39 & 8,10 & 1,06398 \\
\cline { 2 - 6 } & Grande & 7,6528 & 5,40 & 8,12 &, 70090 \\
\cline { 2 - 6 } & Total & 7,2043 & 3,86 & 8,13 & 1,05294 \\
\hline
\end{tabular}

Cuadro 89: Medidas estadísticas de tamaño, sexo y actitud hacia la responsabilidad social.

Antes de realizar una revisión de la información que ofrece el cuadro 89, hemos aplicado a los datos ANOVA de un factor para verificar si existen diferencias estadísticamente significativas entre los diversos grupos muestrales contemplados (cuadro 90). 


\begin{tabular}{|l|l|r|r|r|c|c|}
\hline \multicolumn{2}{|c|}{} & Suma de cuadrados & gl & Media cuadrática & F & Sig. \\
\hline \multirow{4}{*}{ Sexo } & Inter-grupos & 16,894 & 80 &, 211 &, 856 &, 767 \\
\cline { 2 - 8 } & Intra-grupos & 26,640 & 108 &, 247 & & \\
\cline { 2 - 8 } & Total & 43,534 & 188 & & & \\
\hline \multirow{4}{*}{ Tamaño } & Inter-grupos & 39,531 & 80 &, 494 &, 707 &, 948 \\
\cline { 2 - 8 } & Intra-grupos & 75,495 & 108 &, 699 & & \\
\cline { 2 - 8 } & Total & 115,026 & 188 & & & \\
\hline
\end{tabular}

Cuadro 90: Tabla ANOVA del tamaño y el sexo, factor Actitud hacia la Responsabilidad Social.

La información que aporta el cuadro 90 indica que no existen diferencias estadísticamente significativas entre los grupos muestrales considerados ya que, en ambos casos, los coeficientes de significación $(0,767$ y 0,948$)$ son superiores a 0,05 .

Los datos del cuadro 89 indican que tanto en el caso de las líderes femeninas (presentan una actitud media de 7,72 ) como en el caso de los líderes masculinos (muestran una actitud media de 7,62 ), el hecho de que procedan de organizaciones grandes influye en su mayor actitud media hacia la responsabilidad social. Actitud que es levemente superior en las líderes femeninas respecto a los máximos responsables masculinos (0,1 puntos de diferencia).

En relación con la actitud de los líderes masculinos y femeninos en las empresas pequeñas y medianas, ambos sexos muestran una actitud muy similar aunque en el caso de las mujeres su actitud más reducida no se ha registrado en aquellas líderes vinculadas a empresas pequeñas (estas han presentado una actitud media de 7,15 ) sino en las que proceden de organizaciones medianas (han mostrado una actitud media de 7,09). 
La menor actitud media en los hombres se ha registrado en los líderes cuyo origen son empresas pequeñas $(7,03)$, mientras que aquellos que proceden de organizaciones medianas han presentado una actitud media mayor en algo más de 0,1 puntos $(7,16)$.

Debajo de estas líneas hemos incorporado el gráfico 35 para verificar, de modo visual, si es posible establecer algún tipo de asociación en la variación del tamaño empresarial y de la actitud de los líderes hacia la responsabilidad social considerando el sexo de los máximos responsables.

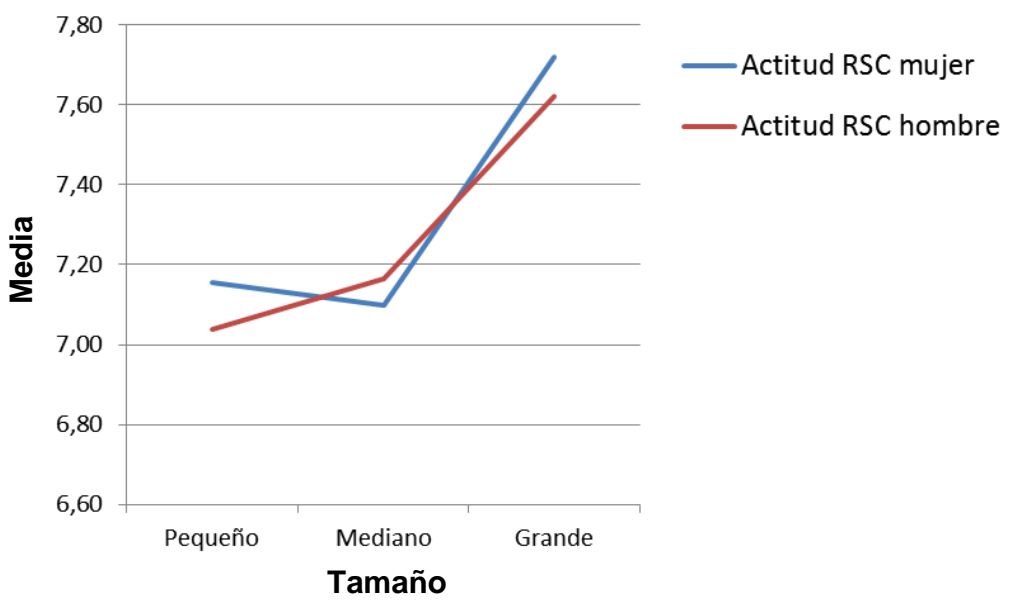

Gráfico 35: Sexo, tamaño y actitud hacia la responsabilidad social.

La información que ofrece el gráfico 35 indica que a medida que aumenta el tamaño de las empresas de origen de los líderes también se intensifica su actitud positiva hacia la responsabilidad social si su sexo es masculino, ya que la actitud de las mujeres a favor de la responsabilidad social, inicialmente, decrece. Sin embargo al centrar la lectura de la información visual que ofrece el gráfico 35 en 
las empresas medianas y grandes, la disposición de las mujeres hacia la responsabilidad social crece en mayor medida que la de los hombres.

A continuación hemos realizado un análisis de los datos relacionados con el sexo de los líderes entrevistados, el tamaño de sus organizaciones de origen y el comportamiento socialmente responsable de sus empresas de procedencia, desde un punto de vista genérico, en este ámbito (cuadro 91).

\begin{tabular}{|c|c|c|c|c|c|c|c|}
\hline \multirow{2}{*}{\multicolumn{4}{|c|}{ Sexo }} & \multicolumn{3}{|c|}{ Tamaño } & \multirow{3}{*}{$\begin{array}{c}\text { Total } \\
100,0 \%\end{array}$} \\
\hline & & & & \multirow{2}{*}{$\begin{array}{r}\text { Pequeño } \\
70,6 \%\end{array}$} & \multirow{2}{*}{$\frac{\text { Mediano }}{26,5 \%}$} & \multirow{2}{*}{$\begin{array}{r}\text { Grande } \\
2,9 \%\end{array}$} & \\
\hline \multirow{10}{*}{ Mujer } & \multirow{8}{*}{$\begin{array}{l}\text { Acciones } \\
\text { de resp. } \\
\text { social }\end{array}$} & \multirow{2}{*}{ No } & $\%$ dentro de acciones & & & & \\
\hline & & & $\%$ dentro de tamaño & $54,5 \%$ & $69,2 \%$ & $9,1 \%$ & $50,0 \%$ \\
\hline & & \multirow{2}{*}{ Sí, acciones puntuales } & $\%$ dentro de acciones & $77,8 \%$ & $16,7 \%$ & $5,6 \%$ & $100,0 \%$ \\
\hline & & & $\%$ dentro de tamaño & $31,8 \%$ & $23,1 \%$ & $9,1 \%$ & $26,5 \%$ \\
\hline & & \multirow{2}{*}{$\begin{array}{l}\text { Sí, acciones frecuentes sin } \\
\text { una política definida de RS }\end{array}$} & $\%$ dentro de acciones & $71,4 \%$ & $14,3 \%$ & $14,3 \%$ & $100,0 \%$ \\
\hline & & & $\%$ dentro de tamaño & $11,4 \%$ & $7,7 \%$ & $9,1 \%$ & $10,3 \%$ \\
\hline & & \multirow{2}{*}{$\begin{array}{l}\text { Sí, acciones integradas en } \\
\text { una política de RS }\end{array}$} & $\%$ dentro de acciones & $11,1 \%$ & $0,0 \%$ & $88,9 \%$ & $100,0 \%$ \\
\hline & & & $\%$ dentro de tamaño & $2,3 \%$ & $0,0 \%$ & $72,7 \%$ & $13,2 \%$ \\
\hline & \multirow{2}{*}{\multicolumn{2}{|c|}{ Total }} & $\%$ dentro de acciones & $64,7 \%$ & $19,1 \%$ & $16,2 \%$ & $100,0 \%$ \\
\hline & & & $\%$ dentro de tamaño & $100,0 \%$ & $100,0 \%$ & $100,0 \%$ & $100,0 \%$ \\
\hline \multirow{10}{*}{ Hombre } & \multirow{8}{*}{$\begin{array}{l}\text { Acciones } \\
\text { de resp. } \\
\text { social }\end{array}$} & \multirow{2}{*}{ No } & $\%$ dentro de acciones & $84,2 \%$ & $15,8 \%$ & $0,0 \%$ & $100,0 \%$ \\
\hline & & & $\%$ dentro de tamaño & $73,8 \%$ & $28,1 \%$ & $0,0 \%$ & $47,1 \%$ \\
\hline & & \multirow{2}{*}{ Sí, acciones puntuales } & $\%$ dentro de acciones & $55,6 \%$ & $27,8 \%$ & $16,7 \%$ & $100,0 \%$ \\
\hline & & & $\%$ dentro de tamaño & $15,4 \%$ & $15,6 \%$ & $12,5 \%$ & $14,9 \%$ \\
\hline & & \multirow{2}{*}{$\begin{array}{l}\text { Sí, acciones frecuentes sin } \\
\text { una política definida de RS }\end{array}$} & $\%$ dentro de acciones & $27,8 \%$ & $38,9 \%$ & $33,3 \%$ & $100,0 \%$ \\
\hline & & & $\%$ dentro de tamaño & $7,7 \%$ & $21,9 \%$ & $25,0 \%$ & $14,9 \%$ \\
\hline & & \multirow{2}{*}{$\begin{array}{l}\text { Sí, acciones integradas en } \\
\text { una política de RS }\end{array}$} & $\%$ dentro de acciones & $7,1 \%$ & $39,3 \%$ & $53,6 \%$ & $100,0 \%$ \\
\hline & & & $\%$ dentro de tamaño & $3,1 \%$ & $34,4 \%$ & $62,5 \%$ & $23,1 \%$ \\
\hline & \multirow{2}{*}{\multicolumn{2}{|c|}{ Total }} & $\%$ dentro de acciones & $53,7 \%$ & $26,4 \%$ & $19,8 \%$ & $100,0 \%$ \\
\hline & & & $\%$ dentro de tamaño & $100,0 \%$ & $100,0 \%$ & $100,0 \%$ & $100,0 \%$ \\
\hline \multirow{10}{*}{ TOTAL } & \multirow{8}{*}{$\begin{array}{l}\text { Acciones } \\
\text { de resp. } \\
\text { social }\end{array}$} & \multirow{2}{*}{ No } & $\%$ dentro de acciones & $79,1 \%$ & $19,8 \%$ & $1,1 \%$ & $100,0 \%$ \\
\hline & & & $\%$ dentro de tamaño & $66,1 \%$ & $40,0 \%$ & $2,9 \%$ & $48,1 \%$ \\
\hline & & \multirow{2}{*}{ Sí, acciones puntuales } & $\%$ dentro de acciones & $66,7 \%$ & $22,2 \%$ & $11,1 \%$ & $100,0 \%$ \\
\hline & & & $\%$ dentro de tamaño & $22,0 \%$ & $17,8 \%$ & $11,4 \%$ & $19,0 \%$ \\
\hline & & \multirow{2}{*}{$\begin{array}{l}\text { Sí, acciones frecuentes sin } \\
\text { una política definida de RS }\end{array}$} & $\%$ dentro de acciones & $40,0 \%$ & $32,0 \%$ & $28,0 \%$ & $100,0 \%$ \\
\hline & & & $\%$ dentro de tamaño & $9,2 \%$ & $17,8 \%$ & $20,0 \%$ & $13,2 \%$ \\
\hline & & \multirow{2}{*}{$\begin{array}{l}\text { Sí, acciones integradas en } \\
\text { una política de RS }\end{array}$} & $\%$ dentro de acciones & $8,1 \%$ & $29,7 \%$ & $62,2 \%$ & $100,0 \%$ \\
\hline & & & $\%$ dentro de tamaño & $2,8 \%$ & $24,4 \%$ & $65,7 \%$ & $19,6 \%$ \\
\hline & & \multirow{2}{*}{ Total } & $\%$ dentro de acciones & $57,7 \%$ & $23,8 \%$ & $18,5 \%$ & $100,0 \%$ \\
\hline & & & $\%$ dentro de tamaño & $100,0 \%$ & $100,0 \%$ & $100,0 \%$ & $100,0 \%$ \\
\hline
\end{tabular}

Cuadro 91: Tabla de contingencia de realización de acciones de responsabilidad social, sexo y tamaño. 
Los datos del cuadro 91 muestran aspectos comunes y diferenciados en relación con el tamaño y la actuación responsable de las organizaciones cuando tomamos en consideración el sexo de sus líderes.

En el caso de las líderes femeninas existe una mayor presencia de las mujeres procedentes de empresas pequeñas dentro de las organizaciones que no realizan ningún tipo de actuación responsable (70\%), desarrollan iniciativas de manera puntual $(77,8 \%)$ y las impulsan de modo frecuente $(71,4 \%)$. Sin embargo, en el caso de las organizaciones que realizan acciones de Responsabilidad Social Corporativa integradas en una política definida, las líderes más representadas son las que proceden de empresas grandes $(88,9 \%)$. Este dato es especialmente significativo dado que en el grupo muestral femenino solo hay un $16,2 \%$ de líderes femeninas cuyo origen son empresas grandes, frente al 19,1\% que procede de organizaciones de dimensión mediana y al $64,7 \%$ que está vinculado a empresas de tamaño pequeño.

La mayor presencia de las mujeres de la muestra (50\%) se ha producido en las empresas que no realizan ningún tipo de actuación responsable. En este tipo de organizaciones no solo tienen protagonismo las líderes procedentes de organizaciones pequeñas $(54,5 \%$ de todas las líderes procedentes de empresas de tamaño pequeño) sino también las que proceden de empresas de tamaño mediano $(69,2 \%$ 
de todas las líderes cuyo origen son organizaciones de dimensión mediana que han participado en el estudio).

Respecto a los líderes masculinos también se ha registrado un mayor protagonismo de máximos responsables que proceden de empresas pequeñas dentro de las organizaciones que no realizan ninguna acción de responsabilidad social (84,2\%) y los que están vinculados a empresas que impulsan iniciativas puntuales (55,6\%). Sin embargo, algo que no ocurría en el caso de las líderes femeninas, los máximos responsables de empresas medianas $(39,3 \%)$ y grandes $(33,3 \%)$ tienen un mayor protagonismo que los líderes de las empresas pequeñas $(27,8 \%)$ dentro de las organizaciones que desarrollan iniciativas frecuentes. Esta tendencia se acrecienta en las empresas que promueven iniciativas integradas en una política establecida de Responsabilidad Social Corporativa. En este caso la presencia de líderes masculinos de empresas medianas es levemente mayor $(39,4 \%)$ pero es aún más elevado el protagonismo de los máximos responsables procedentes de organizaciones grandes $(53,6 \%)$.

Otro aspecto distinto a la hora de contemplar el sexo de los líderes es la mayor presencia de comportamientos responsables (puntuales, frecuentes e integrados en una política definida) en las empresas medianas lideradas por hombres $(71,9 \%)$ frente a las que registran este comportamiento y están conducidas por mujeres (30,8\%). La presencia mayoritaria de líderes masculinos procedentes de 
empresas pequeñas dentro de las organizaciones que no realizan ningún tipo de actuación $(73,8 \%$ de todos los líderes masculinos procedentes de empresas pequeñas) y el protagonismo destacado de máximos responsables masculinos procedentes de organizaciones grandes dentro de las empresas que desarrollan iniciativas integradas en una política definida $(53,6 \%)$, presentan paralelismo con los datos registrados en las líderes femeninas.

A continuación hemos incorporado el gráfico 36 para comprobar si, visualmente, es posible detectar algún tipo de asociación en la variación del tamaño de las organizaciones y en su actuación socialmente responsable, considerando el sexo de los máximos dirigentes empresariales:

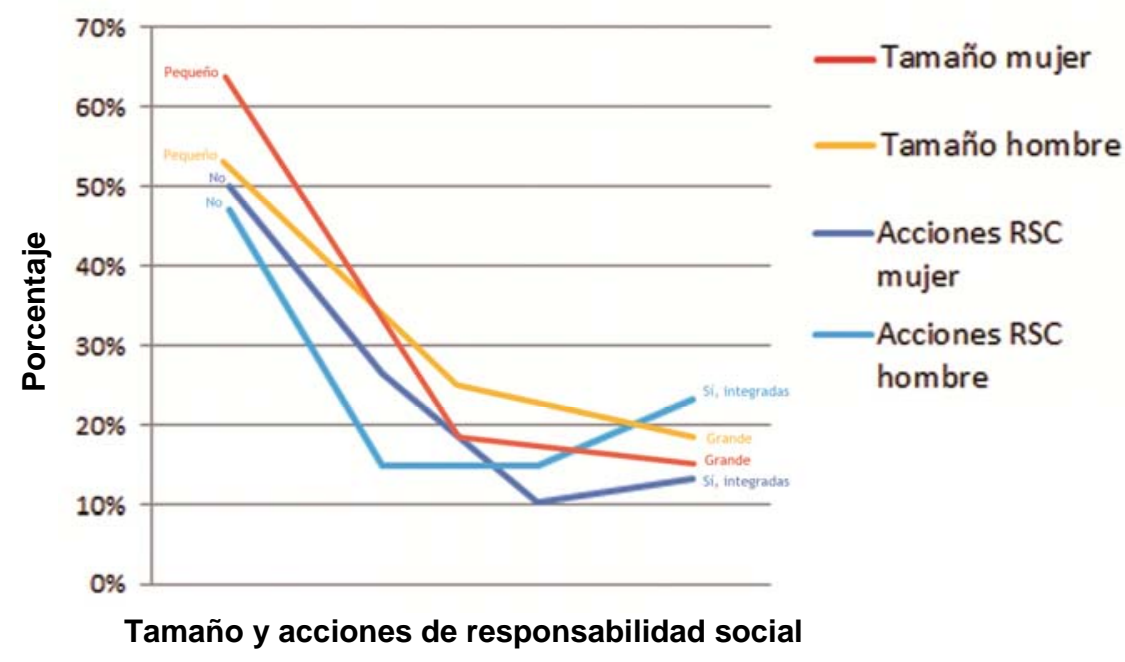

Gráfico 36: Sexo, tamaño y acciones de responsabilidad social.

Los datos del gráfico 36 indican que existe una asociación entre el aumento del tamaño de las organizaciones y la mayor implicación de las empresas en el desarrollo de acciones de responsabilidad social, tanto en 
las organizaciones lideradas por mujeres como en las empresas dirigidas por hombres.

A continuación hemos revisado el sexo del líder, el tamaño organizacional y la formación responsable.

\begin{tabular}{|c|c|c|c|c|c|c|c|}
\hline \multirow{2}{*}{\multicolumn{4}{|c|}{ Sexo }} & \multicolumn{3}{|c|}{ Tamaño } & \multirow{3}{*}{$\begin{array}{l}\text { Total } \\
100,0 \% \\
\end{array}$} \\
\hline & & & & \multirow{2}{*}{$\begin{array}{r}\text { Pequeño } \\
33,3 \% \\
\end{array}$} & \multirow{2}{*}{\begin{tabular}{|r|} 
Mediano \\
$33,3 \%$
\end{tabular}} & \multirow{2}{*}{$\begin{array}{r}\text { Grande } \\
33,3 \%\end{array}$} & \\
\hline \multirow{14}{*}{ Mujer } & \multirow{12}{*}{$\begin{array}{l}\text { Horas de formación } \\
\text { en responsabilidad } \\
\text { social }\end{array}$} & \multirow{2}{*}{ Menos de 11} & $\%$ dentro de horas de formación & & & & \\
\hline & & & $\%$ dentro de tamaño & $16,7 \%$ & $100,0 \%$ & $14,3 \%$ & $21,4 \%$ \\
\hline & & \multirow{2}{*}{ De 11 a 50} & $\%$ dentro de horas de formación & $50,0 \%$ & $0,0 \%$ & $50,0 \%$ & $100,0 \%$ \\
\hline & & & $\%$ dentro de tamaño & $50,0 \%$ & $0,0 \%$ & $42,9 \%$ & $42,9 \%$ \\
\hline & & \multirow{2}{*}{ De 51 a 100} & $\%$ dentro de horas de formación & $100,0 \%$ & $0,0 \%$ & $0,0 \%$ & $100,0 \%$ \\
\hline & & & \% dentro de tamaño & $16,7 \%$ & $0,0 \%$ & $0,0 \%$ & $7,1 \%$ \\
\hline & & \multirow{2}{*}{ De 101 a 150} & $\%$ dentro de horas de formación & $50,0 \%$ & $0,0 \%$ & $50,0 \%$ & $100,0 \%$ \\
\hline & & & $\%$ dentro de tamaño & $16,7 \%$ & $0,0 \%$ & $14,3 \%$ & $14,3 \%$ \\
\hline & & \multirow{2}{*}{ De 201 a 1000} & $\%$ dentro de horas de formación & $0,0 \%$ & $0,0 \%$ & $100,0 \%$ & $100,0 \%$ \\
\hline & & & $\%$ dentro de tamaño & $0,0 \%$ & $0,0 \%$ & $14,3 \%$ & $7,1 \%$ \\
\hline & & \multirow{2}{*}{ Más de 1000} & $\%$ dentro de horas de formación & $0,0 \%$ & $0,0 \%$ & $100,0 \%$ & $100,0 \%$ \\
\hline & & & $\%$ dentro de tamaño & $0,0 \%$ & $0,0 \%$ & $14,3 \%$ & $7,1 \%$ \\
\hline & \multirow{2}{*}{\multicolumn{2}{|c|}{ Total }} & $\%$ dentro de horas de formación & $42,9 \%$ & $7,1 \%$ & $50,0 \%$ & $100,0 \%$ \\
\hline & & & $\%$ dentro de tamaño & $100,0 \%$ & $100,0 \%$ & $100,0 \%$ & $100,0 \%$ \\
\hline \multirow{16}{*}{ Hombre } & \multirow{14}{*}{$\begin{array}{l}\text { Horas de formación } \\
\text { en responsabilidad } \\
\text { social }\end{array}$} & \multirow{2}{*}{ Menos de 11} & $\%$ dentro de horas de formación & $28,6 \%$ & $57,1 \%$ & $14,3 \%$ & $100,0 \%$ \\
\hline & & & \% dentro de tamaño & $33,3 \%$ & $40,0 \%$ & $11,1 \%$ & $28,0 \%$ \\
\hline & & \multirow{2}{*}{ De 11 a 50} & $\%$ dentro de horas de formación & $0,0 \%$ & $40,0 \%$ & $60,0 \%$ & $100,0 \%$ \\
\hline & & & $\%$ dentro de tamaño & $0,0 \%$ & $20,0 \%$ & $33,3 \%$ & $20,0 \%$ \\
\hline & & \multirow{2}{*}{ De 51 a 100} & $\%$ dentro de horas de formación & $25,0 \%$ & $50,0 \%$ & $25,0 \%$ & $100,0 \%$ \\
\hline & & & $\%$ dentro de tamaño & $16,7 \%$ & $20,0 \%$ & $11,1 \%$ & $16,0 \%$ \\
\hline & & \multirow{2}{*}{ De 101 a 150} & $\%$ dentro de horas de formación & $40,0 \%$ & $0,0 \%$ & $60,0 \%$ & $100,0 \%$ \\
\hline & & & \% dentro de tamaño & $33,3 \%$ & $0,0 \%$ & $33,3 \%$ & $20,0 \%$ \\
\hline & & & $\%$ dentro de horas de formación & $0,0 \%$ & $0,0 \%$ & $100,0 \%$ & $100,0 \%$ \\
\hline & & De 151 a 200 & $\%$ dentro de tamaño & $0,0 \%$ & $0,0 \%$ & $11,1 \%$ & $4,0 \%$ \\
\hline & & De 201 a 1000 & $\%$ dentro de horas de formación & $0,0 \%$ & $100,0 \%$ & $0,0 \%$ & $100,0 \%$ \\
\hline & & De 201 a 1000 & \% dentro de tamaño & $0,0 \%$ & $10,0 \%$ & $0,0 \%$ & $4,0 \%$ \\
\hline & & & $\%$ dentro de horas de formación & $50,0 \%$ & $50,0 \%$ & $0,0 \%$ & $100,0 \%$ \\
\hline & & Más de 1000 & $\%$ dentro de tamaño & $16,7 \%$ & $10,0 \%$ & $0,0 \%$ & $8,0 \%$ \\
\hline & & & $\%$ dentro de horas de formación & $24,0 \%$ & $40,0 \%$ & $36,0 \%$ & $100,0 \%$ \\
\hline & lot & & $\%$ dentro de tamaño & $100,0 \%$ & $100,0 \%$ & $100,0 \%$ & $100,0 \%$ \\
\hline & & & $\%$ dentro de horas de formación & $30,0 \%$ & $50,0 \%$ & $20,0 \%$ & $100,0 \%$ \\
\hline & & Menos de 11 & $\%$ dentro de tamaño & $25,0 \%$ & $45,5 \%$ & $12,5 \%$ & $25,6 \%$ \\
\hline & & م 50 & $\%$ dentro de horas de formación & $27,3 \%$ & $18,2 \%$ & $54,5 \%$ & $100,0 \%$ \\
\hline & & De $T 1$ a so & $\%$ dentro de tamaño & $25,0 \%$ & $18,2 \%$ & $37,5 \%$ & $28,2 \%$ \\
\hline & & & $\%$ dentro de horas de formación & $40,0 \%$ & $40,0 \%$ & $20,0 \%$ & $100,0 \%$ \\
\hline & & De 51 a 100 & $\%$ dentro de tamaño & $16,7 \%$ & $18,2 \%$ & $6,3 \%$ & $12,8 \%$ \\
\hline & Horas de formación & & $\%$ dentro de horas de formación & $42,9 \%$ & $0,0 \%$ & $57,1 \%$ & $100,0 \%$ \\
\hline & $\begin{array}{l}\text { en responsabilldad } \\
\text { social }\end{array}$ & De 101 a 150 & \% dentro de tamaño & $25,0 \%$ & $0,0 \%$ & $25,0 \%$ & $17,9 \%$ \\
\hline TOTAL & & مח2 a 151 م" & $\%$ dentro de horas de formación & $0,0 \%$ & $0,0 \%$ & $100,0 \%$ & $100,0 \%$ \\
\hline & & De 151 a 200 & \% dentro de tamaño & $0,0 \%$ & $0,0 \%$ & $6,3 \%$ & $2,6 \%$ \\
\hline & & & $\%$ dentro de horas de formación & $0,0 \%$ & $50,0 \%$ & $50,0 \%$ & $100,0 \%$ \\
\hline & & De 201 a 1000 & $\%$ dentro de tamaño & $0,0 \%$ & $9,1 \%$ & $6,3 \%$ & $5,1 \%$ \\
\hline & & & $\%$ dentro de horas de formación & $33,3 \%$ & $33,3 \%$ & $33,3 \%$ & $100,0 \%$ \\
\hline & & Más de 1000 & $\%$ dentro de tamaño & $8,3 \%$ & $9,1 \%$ & $6,3 \%$ & $7,7 \%$ \\
\hline & & & $\%$ dentro de horas de formación & $30,8 \%$ & $28,2 \%$ & $41,0 \%$ & $100,0 \%$ \\
\hline & & & \% dentro de tamaño & $100,0 \%$ & $100,0 \%$ & $100,0 \%$ & $100,0 \%$ \\
\hline
\end{tabular}

Cuadro 92: Tabla de contingencia de formación en responsabilidad social, sexo y tamaño.

El cuadro 92 indica que también existe cierta similitud, tomando como referencia el sexo del líder, a la hora de valorar el desarrollo de acciones formativas por 
parte de las organizaciones enmarcadas en el ámbito de las Responsabilidad Social Corporativa en empresas pequeñas, medianas y grandes.

En el caso de las líderes femeninas, el mayor protagonismo se encuentra en las organizaciones que dedican entre 1 y 50 horas a la formación ( 9 de los 14 casos que integran la muestra de organizaciones dirigidas por líderes femeninas se encuentran en esta franja de horas de formación). Además el tamaño no parece ser un factor discriminante en las empresas que impulsan acciones formativas de menos de 51 horas (se ha registrado una pequeña, una mediana y una grande que dedican entre 1 y 11 horas a acciones formativas y se han recabado datos de 3 pequeñas y de 3 grandes que invierten entre 11 y 50 horas en este tipo de acciones).

En cuanto a las empresas lideradas por hombres, también se ha registrado una presencia mayoritaria de máximos responsables de empresas que dedican 50 o menos horas a impartir formación enmarcada en el ámbito de la responsabilidad social (12 empresas de las 25 que integran la muestra están incluidas en los grupos muestrales "Menos de 11" y “De 11 a 50"). De todos modos, los máximos responsables masculinos también tienen presencia en las empresas que dedican de 51 a 100 horas (4 casos) y las que invierten entre 101 a 150 horas (5 casos). Al igual que ocurría en las empresas dirigidas por mujeres, el tamaño de las organizaciones gobernadas por hombres no es un rasgo que discrimine el desarrollo de acciones formativas 
encuadradas en el ámbito de la Responsabilidad Social Corporativa (en la muestra de empresas dirigidas por hombres que invierten horas en formación hay 6 pequeñas, 10 medianas y 9 grandes).

Por tanto, los datos indican que ni el tamaño de las organizaciones ni el sexo de los líderes condicionan el desarrollo de acciones formativas por parte de las empresas encuadradas en el ámbito de la responsabilidad social. De todos modos, los líderes masculinos sí parecen promover iniciativas formativas de mayor duración que no tienen correspondencia en el caso de las organizaciones dirigidas por mujeres.

A continuación incorporamos el gráfico 37 para revisar, de modo visual, si existe algún tipo de asociación en la variación de las horas dedicadas a la formación en materia de responsabilidad social por parte de las organizaciones y su tamaño, tomando en consideración el sexo de sus gobernantes:

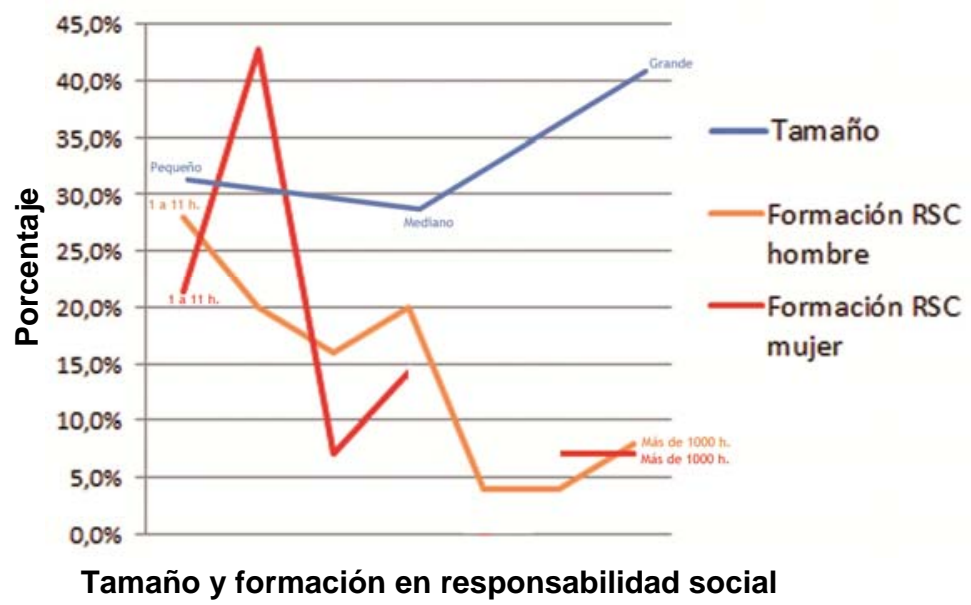

Gráfico 37: Sexo, tamaño y formación en responsabilidad social. 
El gráfico 37 muestra que cuanto más aumenta el número de horas dedicadas a la formación en materia de responsabilidad social por parte de las empresas, más se reduce el número de organizaciones que impulsan este tipo de iniciativas.

También refleja que cuando las empresas pasan de un tamaño mediano a uno grande, se incrementa el número de organizaciones que realizan acciones formativas de responsabilidad social.

En conclusión podríamos indicar que el aumento del tamaño de las empresas y el incremento de las horas que estas dedican a la formación encuadrada en el ámbito de la responsabilidad social presentan una cierta asociación inversa.

\subsubsection{Sexo, liderazgo y Responsabilidad Social Corporativa}

En relación con el sexo de los líderes, sus estilos de liderazgo, su efectividad en el desempeño de su rol, su flexibilidad de liderazgo y su actitud hacia la Responsabilidad Social Corporativa hemos incorporado el cuadro 93.

Antes de revisar los datos del cuadro 93, hemos aplicado en los mismos ANOVA de un factor para verificar si existen diferencias estadísticamente significativas en los 


\section{grupos muestrales que integran la muestra poblacional (cuadro 94).}

\begin{tabular}{|c|c|c|c|c|c|c|c|c|}
\hline \multicolumn{2}{|l|}{ Sexo } & $\begin{array}{l}\text { Actitud hacia la } \\
\text { resp. social }\end{array}$ & $\begin{array}{c}\text { Estilo } \\
\text { directivo }\end{array}$ & $\begin{array}{c}\text { Estilo } \\
\text { consultivo }\end{array}$ & $\begin{array}{c}\text { Estilo } \\
\text { participativo }\end{array}$ & $\begin{array}{c}\text { Estilo } \\
\text { delegativo }\end{array}$ & Flexibilidad & Efectividad \\
\hline \multirow{4}{*}{ Mujer } & Media & 7,2353 & 2,56 & 6,50 & 7,85 & 2,90 & 19,21 & 55,15 \\
\hline & Mínimo & 3,86 & 0 & 1 & 3 & 0 & 10 & 44 \\
\hline & Máximo & 8,13 & 9 & 13 & 15 & 7 & 26 & 67 \\
\hline & Desv. típ. & 1,07138 & 2,133 & 2,629 & 2,898 & 1,667 & 4,273 & 5,146 \\
\hline \multirow{4}{*}{ Hombre } & Media & 7,1869 & 2,53 & 6,49 & 7,67 & 3,38 & 19,26 & 56,42 \\
\hline & Mínimo & 4,63 & 0 & 0 & 1 & 0 & 10 & 43 \\
\hline & Máximo & 8,12 & 7 & 14 & 15 & 14 & 28 & 68 \\
\hline & Desv. típ. & 1,04651 & 1,996 & 2,760 & 3,086 & 2,118 & 4,277 & 5,399 \\
\hline \multirow{4}{*}{ Total } & Media & 7,2043 & 2,54 & 6,49 & 7,74 & 3,21 & 19,24 & 55,96 \\
\hline & Mínimo & 3,86 & 0 & 0 & 1 & 0 & 10 & 43 \\
\hline & Máximo & 8,13 & 9 & 14 & 15 & 14 & 28 & 68 \\
\hline & Desv. típ. & 1,05294 & 2,041 & 2,707 & 3,013 & 1,977 & 4,264 & 5,331 \\
\hline
\end{tabular}

Cuadro 93: Medidas estadísticas de liderazgo, sexo y actitud hacia la responsabilidad social.

Hemos incorporado debajo de estas líneas los resultados de la prueba de ANOVA de un factor (cuadro 94):

\begin{tabular}{|c|c|c|c|c|c|c|}
\hline & & Suma de cuadrados & gl & Media cuadrática & $\mathbf{F}$ & Sig. \\
\hline \multirow{3}{*}{ Sexo } & Inter-grupos & 16,894 & 80 & 211 & 856 & ,767 \\
\hline & Intra-grupos & 26,640 & 108 & ,247 & & \\
\hline & Total & 43,534 & 188 & & & \\
\hline \multirow{3}{*}{ Estilo directivo } & Inter-grupos & 460,904 & 80 & 5,761 & 1,932 & 001 \\
\hline & Intra-grupos & 322,049 & 108 & 2,982 & & \\
\hline & Total & 782,952 & 188 & & & \\
\hline \multirow{3}{*}{ Estilo consultivo } & Inter-grupos & 542,014 & 80 & 6,775 & ,876 &, 732 \\
\hline & Intra-grupos & 835,224 & 108 & 7,734 & & \\
\hline & Total & 1377,238 & 188 & & & \\
\hline \multirow{3}{*}{ Estilo participativo } & Inter-grupos & 758,724 & 80 & 9,484 & 1,080 & ,352 \\
\hline & Intra-grupos & 948,049 & 108 & 8,778 & & \\
\hline & Total & 1706,772 & 188 & & & \\
\hline \multirow{3}{*}{ Estilo delegativo } & Inter-grupos & 361,062 & 80 & 4,513 & 1,304 & 099 \\
\hline & Intra-grupos & 373,890 & 108 & 3,462 & & \\
\hline & Total & 734,952 & 188 & & & \\
\hline \multirow{3}{*}{ Flexibilidad } & Inter-grupos & 1712,188 & 80 & 21,402 & 1,354 &, 071 \\
\hline & Intra-grupos & 1706,617 & 108 & 15,802 & & \\
\hline & Total & 3418,804 & 188 & & & \\
\hline \multirow{3}{*}{ Efectividad } & Inter-grupos & 2304,729 & 80 & 28,809 & 1,024 &, 450 \\
\hline & Intra-grupos & 3038,012 & 108 & 28,130 & & \\
\hline & Total & 5342,741 & 188 & & & \\
\hline
\end{tabular}

Cuadro 94: Tabla ANOVA del tamaño y el sexo, factor Actitud hacia la Responsabilidad Social. 
Los datos del cuadro 94 revelan la existencia de diferencias estadísticamente significativas entre los diversos grupos muestrales en relación con "estilo directivo" (su coeficiente de significación es 0,001).

La información que ofrece el cuadro 93 indica que, al igual que ocurre en la actitud hacia la responsabilidad social, las diferencias entre las diversas variables contempladas en relación con el liderazgo son mínimas en casi todos los casos.

En el estilo directivo (2,56), consultivo $(6,5)$ y participativo $(7,85)$, las mujeres han alcanzado una puntuación media un poco más alta aunque prácticamente igual que la que han registrado los hombres $(2,53 ; 6,49$ y 7,67 respectivamente). Esta dinámica se invierte en el caso de la flexibilidad de estilo, donde la media es mínimamente inferior en las mujeres $(19,21)$ que en los hombres $(19,26)$.

Lo que sí ha arrojado algo de diferencia entre ambos sexos es el estilo delegativo y la efectividad. La puntuación media del estilo delegativo ha sido un poco más elevada en los hombres $(3,38)$ que en las mujeres $(2,9)$. Con la efectividad se ha mantenido la misma tónica, la puntuación media de esta variable ha sido un poco más elevada en los hombres $(56,42)$ que en las mujeres $(55,15)$.

También hemos incorporado el cuadro 95, con el valor medio de la actitud segmentado, para comprobar posibles tendencias en la variación de los datos sobre liderazgo. 


\begin{tabular}{|c|c|c|c|c|c|c|c|c|}
\hline Sexo & $\begin{array}{r}\text { Actitc } \\
\text { res }\end{array}$ & $\begin{array}{l}\text { d hacia la } \\
\text { social }\end{array}$ & $\begin{array}{c}\text { Estilo } \\
\text { directivo }\end{array}$ & $\begin{array}{c}\text { Estilo } \\
\text { consultivo }\end{array}$ & $\begin{array}{c}\text { Estilo } \\
\text { participativo }\end{array}$ & $\begin{array}{c}\text { Estilo } \\
\text { delegativo }\end{array}$ & Flexibilidad & Efectividad \\
\hline \multirow{14}{*}{ Mujer } & \multirow{2}{*}{$0 a<4$} & Media & 2,00 & 12,00 & 6,00 & ,00 & 14,00 & 57,00 \\
\hline & & Desv. típ. & & & & & & \\
\hline & \multirow{2}{*}{$4 a<5$} & Media & 4,50 & 5,50 & 7,00 & 3,00 & 24,50 & 54,00 \\
\hline & & Desv. típ. & ,707 & 2,121 & ,000 & 1,414 & 2,121 &, 000 \\
\hline & \multirow{2}{*}{$5 a<6$} & Media & 3,86 & 5,57 & 7,43 & 3,14 & 20,29 & 54,29 \\
\hline & & Desv. típ. & 2,673 & 3,505 & 3,867 & 1,676 & 6,047 & 7,342 \\
\hline & \multirow{2}{*}{$6 a<7$} & Media & 2,20 & 6,90 & 8,80 & 2,10 & 18,70 & 55,50 \\
\hline & & Desv. típ. & 1,549 & 1,729 & 2,936 & 1,287 & 4,423 & 3,837 \\
\hline & \multirow{2}{*}{7 a 8} & Media & 2,32 & 6,89 & 7,86 & 2,89 & 18,73 & 55,57 \\
\hline & & Desv. típ. & 2,069 & 2,601 & 3,093 & 1,560 & 4,234 & 4,970 \\
\hline & \multirow{2}{*}{$>8$} & Media & 2,55 & 5,09 & 7,55 & 3,73 & 20,09 & 54,00 \\
\hline & & Desv. típ. & 2,505 & 2,166 & 1,864 & 2,054 & 2,587 & 6,293 \\
\hline & \multirow{2}{*}{ Total } & Media & 2,56 & 6,50 & 7,85 & 2,90 & 19,21 & 55,15 \\
\hline & & Desv. típ. & 2,133 & 2,629 & 2,898 & 1,667 & 4,273 & 5,146 \\
\hline \multirow{12}{*}{ Hombre } & \multirow{2}{*}{$4 a<5$} & Media & 3,00 & 6,20 & 7,80 & 3,00 & 20,80 & 54,20 \\
\hline & & Desv. típ. & 2,828 & 1,643 & 3,114 & 2,449 & 5,762 & 7,463 \\
\hline & \multirow{2}{*}{$5 a<6$} & Media & 3,69 & 5,69 & 6,25 & 4,38 & 20,94 & 55,81 \\
\hline & & Desv. típ. & 2,243 & 2,549 & 3,088 & 3,243 & 4,057 & 5,115 \\
\hline & \multirow{2}{*}{$6 a<7$} & Media & 3,19 & 6,86 & 6,71 & 3,24 & 20,10 & 54,95 \\
\hline & & Desv. típ. & 2,159 & 2,265 & 3,495 & 1,670 & 4,312 & 4,695 \\
\hline & \multirow{2}{*}{7 a 8} & Media & 2,06 & 6,66 & 8,13 & 3,13 & 18,66 & 56,77 \\
\hline & & Desv. típ. & 1,680 & 2,773 & 2,929 & 1,744 & 3,843 & 5,395 \\
\hline & \multirow{2}{*}{$>8$} & Media & 2,15 & 6,38 & 8,35 & 3,46 & 18,50 & 57,69 \\
\hline & & Desv. típ. & 1,826 & 3,395 & 2,799 & 2,213 & 4,777 & 5,669 \\
\hline & \multirow{2}{*}{ Total } & Media & 2,53 & 6,49 & 7,67 & 3,38 & 19,26 & 56,42 \\
\hline & & Desv. típ. & 1,996 & 2,760 & 3,086 & 2,118 & 4,277 & 5,399 \\
\hline \multirow{14}{*}{ TOTAL } & \multirow{2}{*}{$0 a<4$} & Media & 2,00 & 12,00 & 6,00 &, 00 & 14,00 & 57,00 \\
\hline & & Desv. típ. & & & & . & . & \\
\hline & \multirow{2}{*}{$4 a<5$} & Media & 3,43 & 6,00 & 7,57 & 3,00 & 21,86 & 54,14 \\
\hline & & Desv. típ. & 2,440 & 1,633 & 2,573 & 2,082 & 5,113 & 6,094 \\
\hline & \multirow{2}{*}{$5 a<6$} & Media & 3,74 & 5,65 & 6,61 & 4,00 & 20,74 & 55,35 \\
\hline & & Desv. típ. & 2,320 & 2,790 & 3,299 & 2,876 & 4,614 & 5,749 \\
\hline & \multirow{2}{*}{$6 a<7$} & Media & 2,87 & 6,87 & 7,39 & 2,87 & 19,65 & 55,13 \\
\hline & & Desv. típ. & 2,012 & 2,078 & 3,422 & 1,628 & 4,325 & 4,380 \\
\hline & \multirow{2}{*}{7 a 8} & Media & 2,17 & 6,76 & 8,02 & 3,03 & 18,69 & 56,28 \\
\hline & & Desv. típ. & 1,844 & 2,691 & 2,983 & 1,666 & 3,985 & 5,230 \\
\hline & \multirow{2}{*}{$>8$} & Media & 2,27 & 6,00 & 8,11 & 3,54 & 18,97 & 56,59 \\
\hline & & Desv. típ. & 2,023 & 3,109 & 2,558 & 2,142 & 4,272 & 6,021 \\
\hline & \multirow{2}{*}{ Total } & Media & 2,54 & 6,49 & 7,74 & 3,21 & 19,24 & 55,96 \\
\hline & & Desv. típ. & 2,041 & 2,707 & 3,013 & 1,977 & 4,264 & 5,331 \\
\hline
\end{tabular}

Cuadro 95: Medidas estadísticas de liderazgo, sexo y actitud hacia la responsabilidad social.

La información que ofrece el cuadro 95 indica que parecen existir dos tendencias en la variación de los datos sobre liderazgo en los hombres a medida que se incrementa el valor medio de su actitud hacia la responsabilidad social.

La flexibilidad de los líderes masculinos tiende a decrecer a medida que su actitud hacia la Responsabilidad Social Corporativa se intensifica: decrece de 20,94 en el 
segmento de valor de la actitud " 5 a $<6$ " a 18,5, en el segmento de valor de la actitud ">8".

Además su efectividad también parece tender a aumentar, la progresión creciente no se da en todos los segmentos, a medida que se incrementa su disposición favorable hacia la responsabilidad social: crece de 54,20 en el segmento de valor de la actitud " 4 a $<5$ " a 57,69 en el segmento de mayor valor medio de la actitud (">8").

Debajo de estas líneas, hemos incorporado los gráficos 38 y 39 para comprobar, de modo visual, si existe algún tipo de asociación en la variación de la actitud y del resto de variables de liderazgo contempladas:

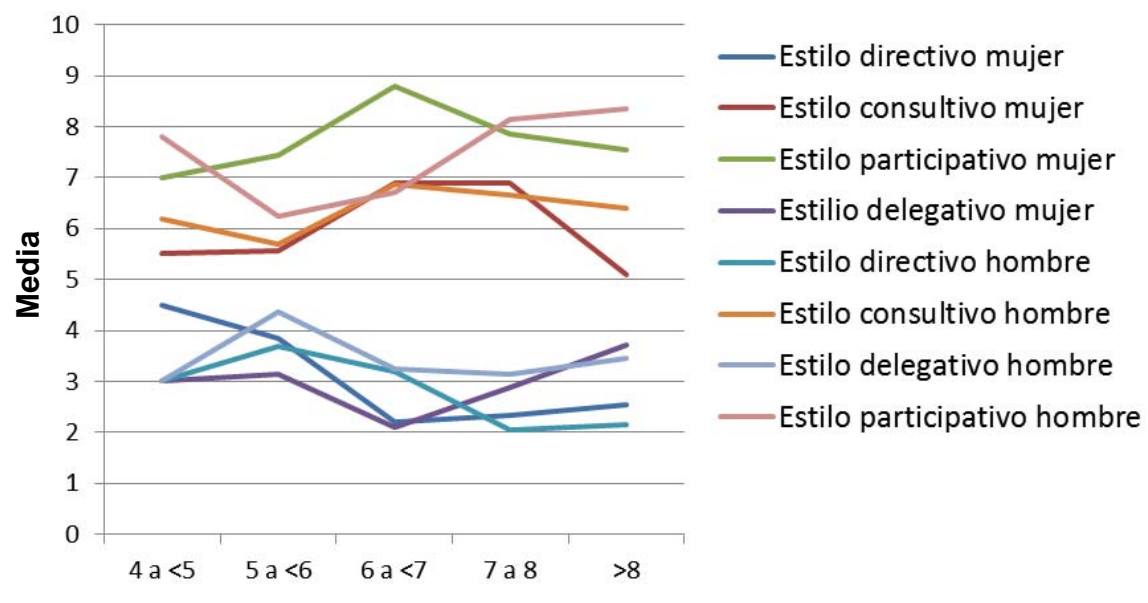

Actitud hacia la responsabilidad social

Gráfico 38: Sexo, estilos de liderazgo y actitud hacia la responsabilidad social.

El gráfico 38 muestra una cierta tendencia decreciente en el estilo directivo, tanto en hombres como en mujeres, a medida que aumenta su actitud a favor de la responsabilidad social. 


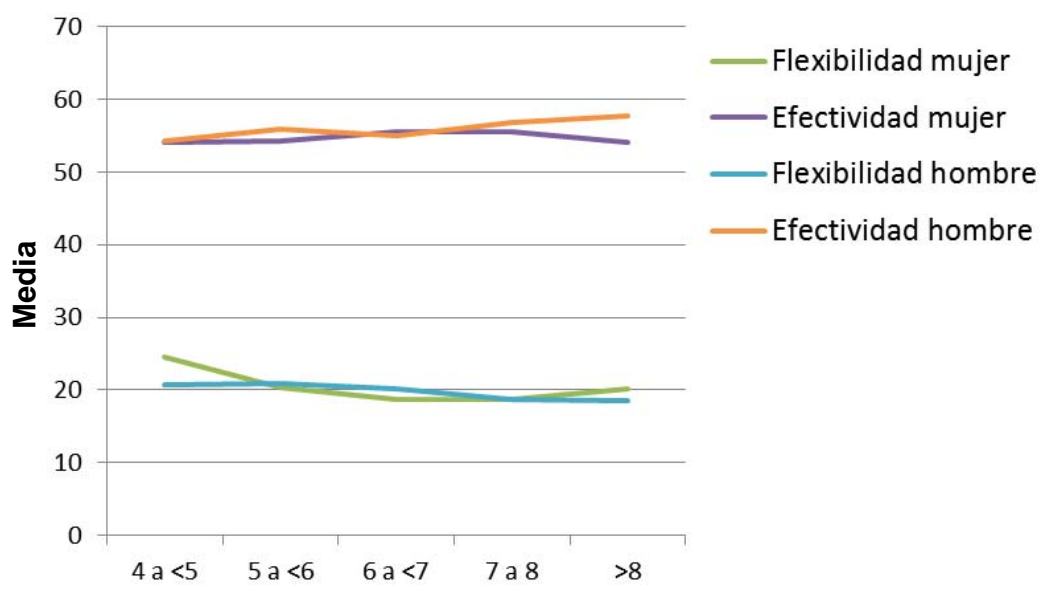

Actitud hacia la responsabilidad social

Gráfico 39: Sexo, flexibilidad, efectividad y actitud hacia la responsabilidad social.

El gráfico 39 refleja una leve tendencia creciente en la efectividad de los hombres y una mínima tendencia decreciente en la flexibilidad de los líderes masculinos según se acrecienta su actitud a favor de la responsabilidad social.

A continuación hemos revisado la relación entre el sexo de los máximos responsables, su liderazgo y la Responsabilidad Social Corporativa que impulsan sus organizaciones de origen.

En primer lugar, como en los apartados previos, hemos relacionado el sexo de los líderes y su liderazgo con el grado de actuación socialmente responsable de la empresa de la que proceden (cuadro 96). En segundo lugar también hemos revisado la relación entre el sexo y el liderazgo de los máximos responsables pero contemplando, en este caso, las horas de formación asociadas a la responsabilidad social que impulsan sus organizaciones de origen. 


\begin{tabular}{|c|c|c|c|c|c|c|c|c|}
\hline Sexo & \multicolumn{2}{|c|}{ Acciones de resp. social } & $\begin{array}{c}\text { Estilo } \\
\text { directivo }\end{array}$ & $\begin{array}{c}\text { Estilo } \\
\text { consultivo }\end{array}$ & $\begin{array}{c}\text { Estilo } \\
\text { participativo }\end{array}$ & $\begin{array}{c}\text { Estilo } \\
\text { delegativo }\end{array}$ & Flexibilidad & Efectividad \\
\hline \multirow{10}{*}{ Mujer } & \multirow{2}{*}{ No } & Media & 3,06 & 6,47 & 7,06 & 3,06 & 20,41 & 53,85 \\
\hline & & Desv. típ. & 2,159 & 2,884 & 2,269 & 1,890 & 4,342 & 5,211 \\
\hline & \multirow{2}{*}{ Sí, acciones puntuales } & Media & 1,89 & 5,89 & 9,44 & 2,78 & 17,89 & 55,39 \\
\hline & & Desv. típ. & 1,875 & 2,398 & 2,935 & 1,396 & 4,028 & 4,754 \\
\hline & \multirow{2}{*}{$\begin{array}{l}\text { Sí, acciones frecuentes } \\
\text { sin una política definida } \\
\text { de RS }\end{array}$} & Media & 2,29 & 7,43 & 8,14 & 2,14 & 16,86 & 55,71 \\
\hline & & Desv. típ. & 2,628 & 2,299 & 3,716 & 1,215 & 4,140 & 3,546 \\
\hline & \multirow{2}{*}{$\begin{array}{l}\text { Sí, acciones integradas } \\
\text { en una política de RS }\end{array}$} & Media & 2,22 & 7,11 & 7,44 & 3,11 & 19,11 & 59,11 \\
\hline & & Desv. típ. & 1,986 & 2,315 & 3,432 & 1,616 & 3,586 & 5,207 \\
\hline & \multirow{2}{*}{ Total } & Media & 2,56 & 6,50 & 7,85 & 2,90 & 19,21 & 55,15 \\
\hline & & Desv. típ. & 2,133 & 2,629 & 2,898 & 1,667 & 4,273 & 5,146 \\
\hline \multirow{10}{*}{ Hombre } & \multirow{2}{*}{ No } & Media & 3,07 & 6,18 & 6,77 & 3,96 & 20,30 & 55,26 \\
\hline & & Desv. típ. & 2,195 & 2,785 & 3,179 & 2,368 & 4,255 & 5,324 \\
\hline & \multirow{2}{*}{ Sí, acciones puntuales } & Media & 2,67 & 7,00 & 7,44 & 2,89 & 20,56 & 54,94 \\
\hline & & Desv. típ. & 1,283 & 2,029 & 2,229 & 1,491 & 3,417 & 5,775 \\
\hline & \multirow{2}{*}{$\begin{array}{l}\text { Sí, acciones frecuentes } \\
\text { sin una política definida } \\
\text { de RS }\end{array}$} & Media & 1,78 & 6,56 & 8,61 & 3,00 & 17,17 & 58,50 \\
\hline & & Desv. típ. & 1,833 & 3,148 & 2,768 & 2,223 & 3,330 & 4,731 \\
\hline & \multirow{2}{*}{$\begin{array}{l}\text { Sí, acciones integradas } \\
\text { en una política de RS }\end{array}$} & Media & 1,82 & 6,75 & 9,04 & 2,75 & 17,68 & 58,39 \\
\hline & & Desv. típ. & 1,744 & 2,914 & 3,024 & 1,555 & 4,530 & 4,947 \\
\hline & \multirow{2}{*}{ Total } & Media & 2,53 & 6,49 & 7,67 & 3,38 & 19,26 & 56,42 \\
\hline & & Desv. típ. & 1,996 & 2,760 & 3,086 & 2,118 & 4,277 & 5,399 \\
\hline \multirow{10}{*}{ TOTAL } & \multirow{2}{*}{ Sí, acciones puntuales } & Media & 3,07 & 6,29 & 6,88 & 3,63 & 20,34 & 54,74 \\
\hline & & Desv. típ. & 2,169 & 2,810 & 2,863 & 2,234 & 4,264 & 5,297 \\
\hline & \multirow{2}{*}{$\begin{array}{l}\text { Sí, acciones frecuentes } \\
\text { sin una política definida } \\
\text { de RS }\end{array}$} & Media & 2,28 & 6,44 & 8,44 & 2,83 & 19,22 & 55,17 \\
\hline & & Desv. típ. & 1,632 & 2,261 & 2,761 & 1,424 & 3,921 & 5,218 \\
\hline & \multirow{2}{*}{$\begin{array}{l}\text { Sí, acciones integradas } \\
\text { en una política de RS }\end{array}$} & Media & 1,92 & 6,80 & 8,48 & 2,76 & 17,08 & 57,72 \\
\hline & & Desv. típ. & 2,040 & 2,915 & 2,988 & 2,006 & 3,487 & 4,542 \\
\hline & \multirow{2}{*}{ Total } & Media & 1,92 & 6,84 & 8,65 & 2,84 & 18,03 & 58,57 \\
\hline & & Desv. típ. & 1,785 & 2,754 & 3,155 & 1,555 & 4,317 & 4,947 \\
\hline & \multirow{2}{*}{ Sí, acciones puntuales } & Media & 2,54 & 6,49 & 7,74 & 3,21 & 19,24 & 55,96 \\
\hline & & Desv. típ. & 2,041 & 2,707 & 3,013 & 1,977 & 4,264 & 5,331 \\
\hline
\end{tabular}

Cuadro 96: Medidas estadísticas sobre acciones de responsabilidad social, sexo y liderazgo.

Antes de hacer una lectura de los datos estadísticos sobre acciones de responsabilidad social, sexo de los líderes y liderazgo que figuran en el cuadro 96, hemos aplicado ANOVA de un factor (cuadro 97) en los grupos muestrales analizados para comprobar si existen diferencias estadísticamente significativas entre los mismos. 


\begin{tabular}{|c|c|c|c|c|c|c|}
\hline & & Suma de cuadrados & gl & Media cuadrática & $\mathbf{F}$ & Sig. \\
\hline \multirow{3}{*}{ Sexo } & Inter-grupos & 1,387 & 3 & 462 & 2,029 & 111 \\
\hline & Intra-grupos & 42,148 & 185 & 228 & & \\
\hline & Total & 43,534 & 188 & & & \\
\hline \multirow{3}{*}{$\begin{array}{l}\text { Estilo } \\
\text { directivo }\end{array}$} & Inter-grupos & 51,529 & 3 & 17,176 & 4,344 & ,006 \\
\hline & Intra-grupos & 731,423 & 185 & 3,954 & & \\
\hline & Total & 782,952 & 188 & & & \\
\hline \multirow{3}{*}{$\begin{array}{l}\text { Estilo } \\
\text { consultivo }\end{array}$} & Inter-grupos & 10,751 & 3 & 3,584 & 485 & 693 \\
\hline & Intra-grupos & 1366,487 & 185 & 7,386 & & \\
\hline & Total & 1377,238 & 188 & & & \\
\hline \multirow{3}{*}{$\begin{array}{l}\text { Estilo } \\
\text { participativo }\end{array}$} & Inter-grupos & 129,541 & 3 & 43,180 & 5,065 & ,002 \\
\hline & Intra-grupos & 1577,232 & 185 & 8,526 & & \\
\hline & Total & 1706,772 & 188 & & & \\
\hline \multirow{3}{*}{$\begin{array}{l}\text { Estilo } \\
\text { delegativo }\end{array}$} & Inter-grupos & 31,069 & 3 & 10,356 & 2,722 & ,046 \\
\hline & Intra-grupos & 703,884 & 185 & 3,805 & & \\
\hline & Total & 734,952 & 188 & & & \\
\hline \multirow{3}{*}{$\begin{array}{l}\text { Flexibilidad de } \\
\text { estilo }\end{array}$} & Inter-grupos & 281,329 & 3 & 93,776 & 5,529 & ,001 \\
\hline & Intra-grupos & 3137,475 & 185 & 16,959 & & \\
\hline & Total & 3418,804 & 188 & & & \\
\hline \multirow{3}{*}{$\begin{array}{l}\text { Efectividad de } \\
\text { estilo }\end{array}$} & Inter-grupos & 487,949 & 3 & 162,650 & 6,198 &, 000 \\
\hline & Intra-grupos & 4854,791 & 185 & 26,242 & & \\
\hline & Total & 5342,741 & 188 & & & \\
\hline
\end{tabular}

Cuadro 97: Tabla ANOVA de sexo y liderazgo, factor Realización de Acciones de Responsabilidad Social.

La información que aporta el cuadro 97 sobre el coeficiente de significación muestra que existen diferencias estadísticamente significativas entre los diversos grupos muestrales en relación con el "estilo directivo" (coeficiente de significación 0,006), con el "estilo participativo" (coeficiente de significación 0,002), con el "estilo delegativo" (coeficiente de significación 0,046), con la "flexibilidad de estilo" (coeficiente de significación 0,001) y con la "efectividad de estilo" (coeficiente de significación 0,000).

Los datos del cuadro 96 indican resultados bastante similares para los hombres y las mujeres sobre su liderazgo, 
tomando en consideración el comportamiento socialmente responsable de sus organizaciones de origen.

En el caso de las líderes femeninas, mantienen los mismos tipos de estilos de liderazgo primario (participativo) y secundario (consultivo) sea la cual el grado de actuación de su organización de origen en materia de responsabilidad social. De todos modos, existen algunas variaciones significativas al contemplar distintos comportamientos organizacionales socialmente responsables.

El estilo consultivo es menos utilizado por las líderes vinculadas a empresas que desarrollan acciones puntuales de responsabilidad social (su media es de 5,89 ) que por el resto de líderes. Y el estilo participativo es más utilizado por las líderes en las organizaciones que realizan algún tipo de actuación responsable, especialmente en las organizaciones que desarrollan acciones frecuentes $(8,14)$ y sobre todo en las que impulsan acciones puntuales $(9,44)$.

En cuanto a su flexibilidad, el registro más alto se encuentra en las líderes que proceden de organizaciones inactivas desde el punto de vista de la responsabilidad social $(20,41)$. Sin embargo en la efectividad de estilo la puntuación más baja la obtienen las líderes que proceden de organizaciones que no impulsan ningún tipo de acción responsable $(53,85)$, valor que va ascendiendo a medida que aumenta el grado de intensidad de la actuación responsable de la organización (alcanza su valor máximo de 59,11 en las líderes cuyo origen son organizaciones que desarrollan 
acciones de Responsabilidad Social Corporativa dentro de una política definida).

En cuanto a los líderes masculinos, se han registrado unos datos bastantes similares. Mantienen también el mismo estilo primario (participativo) y secundario (consultivo) en todos los tipos posibles de comportamiento empresarial y, como en el caso de las mujeres, también presentan algunas variaciones significativas. El estilo consultivo registra el valor más bajo en el comportamiento nulo desde el punto de vista de la responsabilidad social $(6,18)$, aunque no existe una gran distancia entre el valor medio del estilo consultivo respecto al registrado en los líderes procedentes de organizaciones que desarrollan acciones puntuales (7), frecuentes $(6,56)$ e integradas en una política definida $(6,75)$. En el estilo primario, el participativo, este presenta una valoración mayor a medida que aumenta el grado de intensidad en la conducta socialmente responsable de las organizaciones de origen de los líderes. Pasa de un valor medio de 6,77 en los líderes procedentes de organizaciones inactivas desde el punto de vista de la responsabilidad social, a un valor medio de 9,04 en los máximos responsables cuyo origen son empresas con políticas definidas en materia de Responsabilidad Social Corporativa. En el caso de los hombres, el estilo participativo experimenta un mayor protagonismo en el rol de liderazgo a medida que aumenta la intensidad de la conducta socialmente responsable de su organización de procedencia. 
En cuanto a la flexibilidad de estilo, los líderes masculinos que presentan las puntuaciones más altas son aquellos que proceden de organizaciones que no impulsan ningún tipo de actividad $(20,30)$ o que las desarrollan de manera puntual $(20,56)$, y los que muestran las valoraciones más bajas son los vinculados a organizaciones que ejecutan acciones de responsabilidad social con frecuencia $(17,17) 0$ las impulsan dentro de una política establecida $(17,68)$. Estos datos presentan una tendencia inversa a la hora de evaluar la efectividad en el liderazgo. Esta es más baja en los líderes cuyo origen son organizaciones inactivas en materia de responsabilidad social $(55,26)$ o empresas que realizan iniciativas puntuales $(54,94)$, que en los que están asociados a organizaciones que impulsan acciones frecuentes $(58,50)$ o las realizan dentro de una política previamente definida de responsabilidad social $(58,90)$.

Los datos indican que la mayor implicación de las organizaciones en una actuación responsable parece estar asociada a un estilo de dirección menos variado (especialmente en los máximos responsables masculinos) pero más efectivo (en los líderes de ambos sexos).

Hemos incluido a continuación los gráficos 40 y 41 para revisar, visualmente, posibles asociaciones en la variación del comportamiento socialmente responsable de las organizaciones y en el liderazgo de sus máximos responsables, considerando su sexo. 


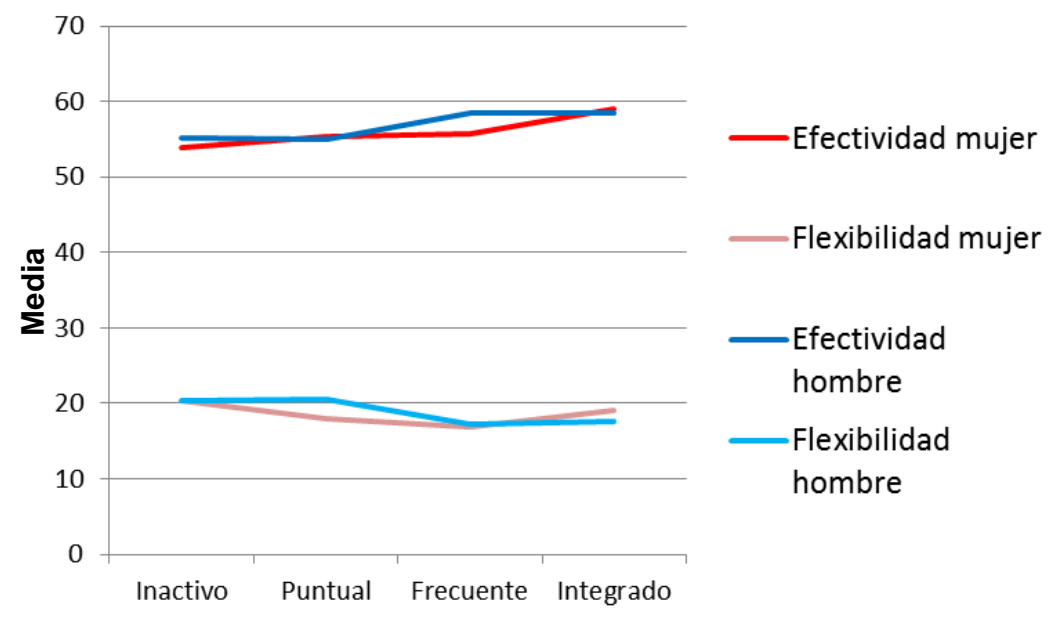

Comportamiento socialmente responsable

Gráfico 40: Sexo, efectividad, flexibilidad y acciones de responsabilidad social.

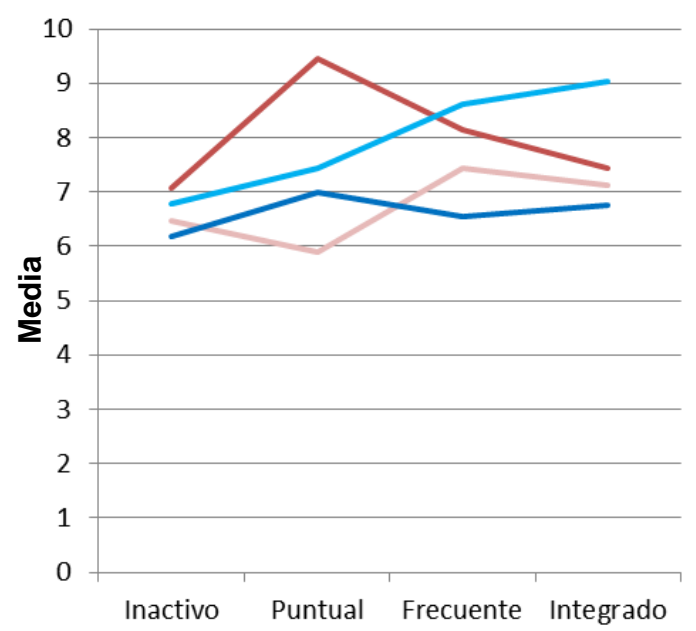

Estilo partipativo mujer

Estilo consultivo mujer

Estilo participativo hombre

Estilo consultivo hombre

Comportamiento socialmente responsable

Gráfico 41: Sexo, estilo de liderazgo y acciones de responsabilidad social.

El grafico 40 muestra que a medida que crece el comportamiento empresarial socialmente responsable parece aumentar la efectividad del liderazgo con independencia del sexo y, al mismo tiempo, reducirse la flexibilidad del liderazgo. De todos modos esta última tendencia no está tan presente en la flexibilidad de las líderes femeninas. 
Por otra parte, el gráfico 41 refleja que a medida que se incrementa la intensidad de la conducta empresarial socialmente responsable, los líderes masculinos conceden más importancia al estilo de liderazgo participativo (alto apoyo y poca dirección).

En el gráfico 41 también parece existir una cierta correspondencia entre la importancia concedida al estilo consultivo, en el caso de los máximos responsables masculinos, a medida que se acentúa la actuación socialmente responsable de su organización de origen. Aunque, en este caso, el incremento del protagonismo del estilo consultivo a medida que aumenta el comportamiento de la organización en materia de responsabilidad social, no es constante.

A continuación hemos revisado la relación entre el liderazgo y el sexo de los líderes, y las horas de formación dedicada a la responsabilidad social que ha sido declarada por los líderes entrevistados.

Antes de revisar los datos registrados sobre la formación enmarcada en el ámbito de la responsabilidad social, el sexo de los máximos responsables empresariales y el liderazgo, hemos aplicado ANOVA de un factor para descubrir si existen diferencias estadísticamente significativas entre los grupos muestrales estudiados. Hemos incorporado en el cuadro 98 los resultados obtenidos tras este análisis estadístico. 


\begin{tabular}{|c|c|c|c|c|c|c|}
\hline & & Suma de cuadrados & gl & Media cuadrática & $\mathbf{F}$ & Sig. \\
\hline \multirow{3}{*}{ Sexo } & Inter-grupos & ,752 & 6 & ,125 & ,488 & ,813 \\
\hline & Intra-grupos & 8,223 & 32 & ,257 & & \\
\hline & Total & 8,974 & 38 & & & \\
\hline \multirow{3}{*}{ Estilo directivo } & Inter-grupos & 23,227 & 6 & 3,871 & 1,315 & 279 \\
\hline & Intra-grupos & 94,209 & 32 & 2,944 & & \\
\hline & Total & 117,436 & 38 & & & \\
\hline \multirow{3}{*}{$\begin{array}{l}\text { Estilo } \\
\text { consultivo }\end{array}$} & Inter-grupos & 39,846 & 6 & 6,641 & 1,634 & 170 \\
\hline & Intra-grupos & 130,051 & 32 & 4,064 & & \\
\hline & Total & 169,897 & 38 & & & \\
\hline \multirow{3}{*}{$\begin{array}{l}\text { Estilo } \\
\text { participativo }\end{array}$} & Inter-grupos & 68,553 & 6 & 11,426 & 1,720 & 148 \\
\hline & Intra-grupos & 212,524 & 32 & 6,641 & & \\
\hline & Total & 281,077 & 38 & & & \\
\hline \multirow{3}{*}{$\begin{array}{l}\text { Estilo } \\
\text { delegativo }\end{array}$} & Inter-grupos & 3,517 & 6 &, 586 & ,253 & ,955 \\
\hline & Intra-grupos & 74,226 & 32 & 2,320 & & \\
\hline & Total & 77,744 & 38 & & & \\
\hline \multirow{3}{*}{$\begin{array}{l}\text { Flexibilidad de } \\
\text { estilo }\end{array}$} & Inter-grupos & 123,535 & 6 & 20,589 & 1,305 & 283 \\
\hline & Intra-grupos & 504,824 & 32 & 15,776 & & \\
\hline & Total & 628,359 & 38 & & & \\
\hline \multirow{3}{*}{$\begin{array}{l}\text { Efectividad de } \\
\text { estilo }\end{array}$} & Inter-grupos & 410,167 & 6 & 68,361 & 4,045 & ,004 \\
\hline & Intra-grupos & 540,756 & 32 & 16,899 & & \\
\hline & Total & 950,923 & 38 & & & \\
\hline
\end{tabular}

Cuadro 98: Tabla ANOVA sexo y liderazgo, factor Horas de Formación en Responsabilidad Social.

La información que ofrece el cuadro 98 indica que existen diferencias estadísticamente significativas entre los diversos grupos muestrales en relación con "efectividad de estilo" (su coeficiente de significación es 0,004 ).

Algunas de las opciones empresariales contempladas en el cuadro 99, incorporado en la página siguiente, en relación con el número de horas que las organizaciones dedican a la formación enmarcada en el ámbito de la responsabilidad social han estado poco representadas. 


\begin{tabular}{|c|c|c|c|c|c|c|c|c|}
\hline Sexo & \multicolumn{2}{|c|}{ Horas de formación en resp. social } & $\begin{array}{c}\text { Estilo } \\
\text { directivo }\end{array}$ & $\begin{array}{c}\text { Estilo } \\
\text { consultivo }\end{array}$ & $\begin{array}{c}\text { Estilo } \\
\text { participativo }\end{array}$ & $\begin{array}{c}\text { Estilo } \\
\text { delegativo }\end{array}$ & Flexibilidad & Efectividad \\
\hline \multirow{14}{*}{ Mujer } & \multirow{2}{*}{ Menos de 11} & Media & 1,67 & 7,33 & 7,67 & 3,33 & 19,67 & 55,00 \\
\hline & & Desv. típ. & 2,082 & 1,528 & 3,055 & 2,309 & 3,512 & 1,732 \\
\hline & \multirow{2}{*}{ De 11 a 50} & Media & 2,17 & 7,33 & 8,50 & 2,00 & 17,67 & 58,17 \\
\hline & & Desv. típ. & 2,137 & 1,633 & 2,881 & 1,095 & 2,658 & 4,622 \\
\hline & \multirow{2}{*}{ De 51 a 100} & Media & 2,00 & 8,00 & 7,00 & 3,00 & 20,00 & 50,00 \\
\hline & & Desv. típ. & & & & & & \\
\hline & \multirow{2}{*}{ De 101 a 150} & Media & 1,50 & 7,50 & 7,50 & 3,00 & 19,50 & 54,00 \\
\hline & & Desv. típ. & ,707 & 2,121 & ,707 & 2,828 & 4,950 & 2,828 \\
\hline & \multirow{2}{*}{ De 201 a 1000} & Media & 3,00 & 4,00 & 9,00 & 4,00 & 22,00 & 60,00 \\
\hline & & Desv. típ. & 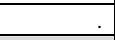 & & . & . & & \\
\hline & \multirow{2}{*}{ Más de 1000} & Media & 2,00 & 8,00 & 9,00 & 1,00 & 16,00 & 67,00 \\
\hline & & Desv. típ. & & & & & & \\
\hline & \multirow{2}{*}{ Total } & Media & 2,00 & 7,21 & 8,14 & 2,57 & 18,71 & 57,07 \\
\hline & & Desv. típ. & 1,617 & 1,626 & 2,248 & 1,604 & 2,972 & 4,938 \\
\hline \multirow{16}{*}{ Hombre } & \multirow{2}{*}{ Menos de 11} & Media & 3,57 & 7,86 & 6,00 & 2,57 & 22,29 & 52,29 \\
\hline & & Desv. típ. & ,976 & 1,574 & 1,291 & ,787 & 3,352 & 1,799 \\
\hline & \multirow{2}{*}{ De 11 a 50} & Media & 2,00 & 7,80 & 7,40 & 2,80 & 18,40 & 61,00 \\
\hline & & Desv. típ. & 1,732 & 3,347 & 3,050 & 1,643 & 5,177 & 5,196 \\
\hline & \multirow{2}{*}{ De 51 a 100} & Media &, 50 & 6,25 & 10,75 & 2,50 & 16,00 & 58,25 \\
\hline & & Desv. típ. &, 577 & ,957 & 2,872 & 1,915 & 4,320 & 4,425 \\
\hline & \multirow{2}{*}{ De 101 a 150} & Media & 2,20 & 5,60 & 9,80 & 2,40 & 17,20 & 57,20 \\
\hline & & Desv. típ. & 2,490 & 2,793 & 3,421 & 1,140 & 5,933 & 4,550 \\
\hline & \multirow{2}{*}{ De 151 a 200} & Media & 4,00 & 3,00 & 12,00 & 1,00 & 16,00 & 66,00 \\
\hline & & Desv. típ. & & & 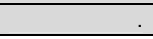 & (2) & & \\
\hline & \multirow{2}{*}{ De 201 a 1000} & Media & 4,00 & 7,00 & 8,00 & 1,00 & 20,00 & 55,00 \\
\hline & & Desv. típ. & . & 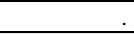 & . & . & . & \\
\hline & \multirow{2}{*}{ Más de 1000} & Media & 2,00 & 8,50 & 6,50 & 3,00 & 20,00 & 61,00 \\
\hline & & Desv. típ. & 2,828 & ,707 & ,707 & 2,828 &, 000 & 2,828 \\
\hline & \multirow{2}{*}{ Total } & Media & 2,40 & 6,96 & 8,16 & 2,48 & 18,96 & 57,32 \\
\hline & & Desv. típ. & 1,848 & 2,371 & 2,996 & 1,358 & 4,623 & 5,137 \\
\hline \multirow{16}{*}{ TOTAL } & \multirow{2}{*}{ Menos de 11} & Media & 3,00 & 7,70 & 6,50 & 2,80 & 21,50 & 53,10 \\
\hline & & Desv. típ. & 1,563 & 1,494 & 1,958 & 1,317 & 3,440 & 2,132 \\
\hline & \multirow{2}{*}{ De 11 a 50} & Media & 2,09 & 7,55 & 8,00 & 2,36 & 18,00 & 59,45 \\
\hline & & Desv. típ. & 1,868 & 2,423 & 2,864 & 1,362 & 3,795 & 4,865 \\
\hline & 100 & Media &, 80 & 6,60 & 10,00 & 2,60 & 16,80 & 56,60 \\
\hline & De 51 a 100 & Desv. típ. & ,837 & 1,140 & 3,000 & 1,673 & 4,147 & 5,320 \\
\hline & & Media & 2,00 & 6,14 & 9,14 & 2,57 & 17,86 & 56,29 \\
\hline & De 101 a 150 & Desv. típ. & 2,082 & 2,610 & 3,024 & 1,512 & 5,367 & 4,192 \\
\hline & م 2151 a 151 & Media & 4,00 & 3,00 & 12,00 & 1,00 & 16,00 & 66,00 \\
\hline & $0 e 151$ a $<00$ & Desv. típ. & & & & . & & \\
\hline & & Media & 3,50 & 5,50 & 8,50 & 2,50 & 21,00 & 57,50 \\
\hline & De 201 a 1000 & Desv. típ. & ,707 & 2,121 & ,707 & 2,121 & 1,414 & 3,536 \\
\hline & Más de 1000 & Media & 2,00 & 8,33 & 7,33 & 2,33 & 18,67 & 63,00 \\
\hline & Mlas de 1000 & Desv. típ. & 2,000 &, 577 & 1,528 & 2,309 & 2,309 & 4,000 \\
\hline & & Media & 2,26 & 7,05 & 8,15 & 2,51 & 18,87 & 57,23 \\
\hline & Total & Desv. típ. & 1,758 & 2,114 & 2,720 & 1,430 & 4,066 & 5,002 \\
\hline
\end{tabular}

Cuadro 99: Medidas estadísticas sobre formación en responsabilidad social, sexo y liderazgo.

Por este motivo no hemos considerado en el análisis de los datos del cuadro 99 aquellos grupos muestrales en los que solo se ha recabado información de un líder ("De 51 a 100", de "201 a 1000" y "Más de 1000" en el caso de las líderes femeninas, y “151 a 200” y “De 201 a 1000” en el caso de los máximos responsables masculinos). 
Los datos del cuadro 99 guardan cierta similitud al ser comparados si tomamos como referencia el sexo de los líderes.

En el caso de las mujeres, sea cual sea el número de horas que su organización dedica a acciones formativas encuadradas en al ámbito de la responsabilidad social, el estilo primario es siempre el participativo y el estilo secundario el consultivo. De todos modos las líderes procedentes de organizaciones que invierten entre $101 \mathrm{y}$ 150 horas han concedido la misma importancia al estilo participativo y al consultivo, ya que en ambos casos su valor medio es 7,5. Las valoraciones más bajas de ambos estilos se encuentran en las líderes que proceden de organizaciones que dedican entre 1 y 11 horas a formación enmarcada en el ámbito de la responsabilidad social (se ha registrado una media de 7,33 en el estilo consultivo y de 7,67 en el estilo participativo).

En relación con la flexibilidad de estilo no se ha registrado una tendencia uniforme a medida que ha aumentado el número de horas que las empresas de origen de las líderes dedican a la formación encuadrada en el ámbito de la responsabilidad social (el valor medio más bajo en la flexibilidad, 17,67, se ha obtenido por el grupo muestral intermedio “De 11 a 50" horas).

En la efectividad de estilo tampoco se ha registrado una línea de variación constante en la puntuación alcanzada por los líderes a medida que se ha incrementado la duración 
de las acciones formativas por parte de sus organizaciones de origen (su valor medio más alto, 58,17 , se ha producido en el grupo muestral intermedio "De 11 a 50" horas).

En referencia a los hombres, no en todos los casos en los que ha habido una representación mínima de líderes (más de un líder) el estilo participativo ha sido siempre el estilo primario. En las empresas que dedican menos horas a la formación encuadrada en materia de responsabilidad social (la media del estilo ha sido 7,86 ), en las que invierten de 11 a 50 horas (la media registrada por el estilo consultivo ha sido 7,8) y en las que dedican más de 1000 (el estilo consultivo ha obtenido una media de 8,5 ), el estilo primario ha sido el consultivo. De todos modos el estilo participativo es elegido de manera preferente y destacada respecto al estilo consultivo en las organizaciones que invierten entre 51 y 100 horas acciones formativas (su valor medio ha sido 10,75 frente al 6,25 que ha registrado el estilo consultivo) y las que dedican entre 101 a 150 horas (su media ha sido 9,8 frente al 5,6 que ha obtenido el estilo consultivo).

En cuanto a la flexibilidad de estilo parece existir una cierta tendencia decreciente en sus puntuaciones medias a medida que aumenta el número de horas que las organizaciones dedican a la formación enmarcada en el ámbito de la responsabilidad social. Decrece de 22,29 en los líderes procedentes de organizaciones que dedican menos de 11 horas a acciones formativas a 16 en los líderes que proceden de empresas que invierten entre 51 y 100 horas. 
De todos modos esta tendencia no es constante e, incluso, se han registrado dos casos de líderes procedentes de organizaciones que dedican más de 1000 horas a acciones formativas encuadradas en el ámbito de la responsabilidad social que han registrado una efectividad media de 20.

En lo que se refiere a la efectividad de estilo, tampoco se aprecia una tendencia en los valores medios obtenidos por los líderes procedentes de las diferentes tipologías de empresas contempladas. Aunque el valor mínimo registrado corresponde a los líderes cuyo origen son organizaciones que dedican menos de 11 horas $(52,29)$, los máximos responsables vinculados a organizaciones que invierten entre 11 y 50 horas han registrado un valor medio de 61. La independencia de la efectividad en relación con el número de horas que las organizaciones dedican a acciones formativas sobre responsabilidad social también se refleja en que 61 ha sido el valor registrado en los líderes de organizaciones que dedican más de 1000 horas a la formación encuadrada en la esfera de la Responsabilidad Social Corporativa.

A continuación hemos incorporado el gráfico 42 para contemplar, de modo visual, posibles variaciones en la flexibilidad y la efectividad del liderazgo teniendo presente, al mismo tiempo, el sexo de los máximos responsables empresariales y las horas de formación que sus empresas de origen invierten en materia de responsabilidad social. 


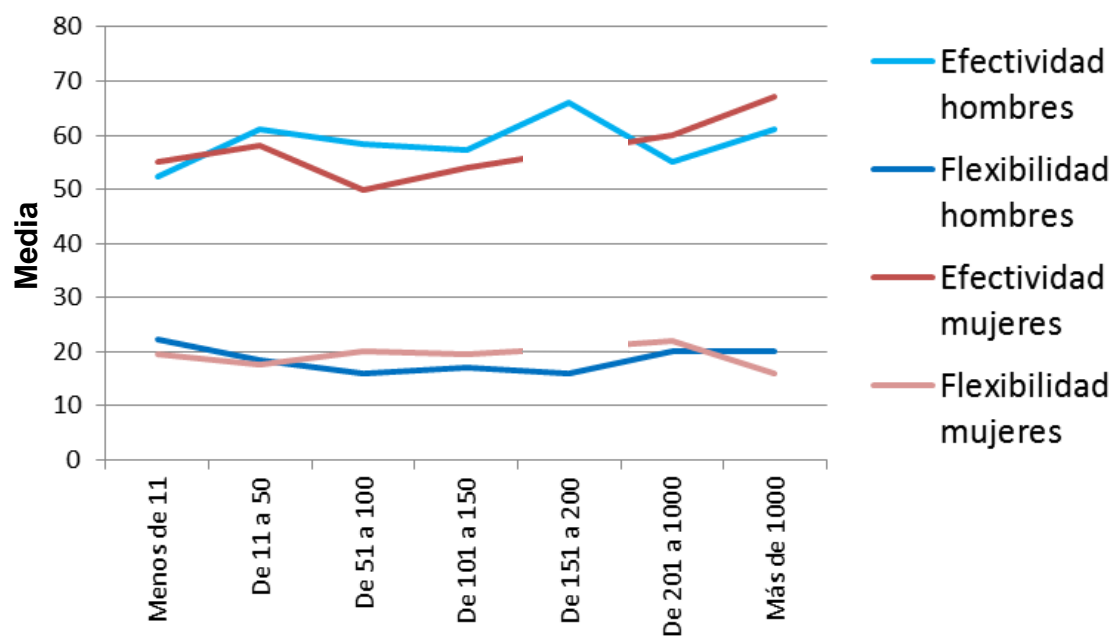

Formación en responsabilidad social

Gráfico 42: Sexo, efectividad, flexibilidad y formación en responsabilidad social.

En el gráfico 42 no parece darse algún tipo de asociación entre el aumento de las horas que las empresas dedican a la formación en materia de responsabilidad social y la flexibilidad de estilo considerando el sexo del líder.

De todos modos el gráfico 42 sí parece indicar que en el caso de los hombres, se ejerce un liderazgo más efectivo a medida que se incrementan las horas que las organizaciones dedican a la formación enmarcada en el ámbito de la Responsabilidad Social Corporativa.

\subsubsection{Sexo, valores y Responsabilidad Social Corporativa}

Hemos revisado, en primer lugar, los datos sobre las competencias genéricas, los rasgos de personalidad y las características comportamentales estudiadas y el sexo de 
los líderes en relación con su actitud hacia la

\section{Responsabilidad Social Corporativa.}

Antes de revisar la información recabada, hemos aplicado ANOVA de un factor en los datos para comprobar si existen diferencias estadísticamente significativas entre los diversos grupos muestrales contemplados.

\begin{tabular}{|c|c|c|c|c|c|c|}
\hline & & Suma de cuadrados & gl & Media cuadrática & $\mathrm{F}$ & Sig. \\
\hline \multirow{3}{*}{ Sexo } & Inter-grupos & 16,894 & 80 & ,211 & ,856 & ,767 \\
\hline & Intra-grupos & 26,640 & 108 & ,247 & & \\
\hline & Total & 43,534 & 188 & & & \\
\hline \multirow{3}{*}{ Practicidad } & Inter-grupos & 1402,026 & 80 & 17,525 & ,991 &, 513 \\
\hline & Intra-grupos & 1909,381 & 108 & 17,679 & & \\
\hline & Total & 3311,407 & 188 & & & \\
\hline \multirow{3}{*}{ Resultados } & Inter-grupos & 1395,917 & 80 & 17,449 & 1,279 & , 117 \\
\hline & Intra-grupos & 1473,839 & 108 & 13,647 & & \\
\hline & Total & 2869,757 & 188 & & & \\
\hline \multirow{3}{*}{ Variedad } & Inter-grupos & 2907,734 & 80 & 36,347 & 1,284 &, 113 \\
\hline & Intra-grupos & 3056,467 & 108 & 28,301 & & \\
\hline & Total & 5964,201 & 188 & & & \\
\hline \multirow{3}{*}{ Decisión } & Inter-grupos & 1367,343 & 80 & 17,092 & ,945 & ,602 \\
\hline & Intra-grupos & 1953,229 & 108 & 18,085 & & \\
\hline & Total & 3320,571 & 188 & & & \\
\hline \multirow{3}{*}{ Orden y método } & Inter-grupos & 2731,090 & 80 & 34,139 & 1,423 & ,044 \\
\hline & Intra-grupos & 2591,862 & 108 & 23,999 & & \\
\hline & Total & 5322,952 & 188 & & & \\
\hline \multirow{3}{*}{ Metas } & Inter-grupos & 1606,850 & 80 & 20,086 & 886 & ,714 \\
\hline & Intra-grupos & 2447,700 & 108 & 22,664 & & \\
\hline & Total & 4054,550 & 188 & & & \\
\hline
\end{tabular}

Cuadro 100: Tabla ANOVA de los “valores" y el sexo, factor Actitud hacia la Responsabilidad Social.

Los resultados del cuadro 100 muestran la existencia de diferencias estadísticamente significativas entre los diversos grupos muestrales en relación con "orden y método" (su coeficiente de significación es 0,044).

Hemos incluido debajo de estas líneas el cuadro 101 con algunas medidas estadísticas sobre los rasgos de 
personalidad, las características comportamentales y las competencias genéricas consideradas en el estudio, junto con la actitud de los líderes hacia la responsabilidad, desglosando los datos en función del sexo del líder.

\begin{tabular}{|l|l|r|r|r|r|r|r|r|}
\hline \multicolumn{2}{|c|}{ Sexo } & Practicidad & Resultados & Variedad & Decisión & $\begin{array}{c}\text { Orden y } \\
\text { método }\end{array}$ & Metas & $\begin{array}{c}\text { Actitud hacia } \\
\text { la resp. social }\end{array}$ \\
\hline \multirow{4}{*}{ Mujer } & Media & 13,96 & 15,25 & 8,94 & 16,97 & 14,93 & 19,71 & 7,2353 \\
\cline { 2 - 10 } & Mínimo & 7 & 6 & 0 & 6 & 5 & 6 & 3,86 \\
\cline { 2 - 10 } & Máximo & 21 & 25 & 22 & 25 & 25 & 28 & 8,13 \\
\cline { 2 - 10 } & Desv. típ. & 3,903 & 3,826 & 5,962 & 4,164 & 4,888 & 4,960 & 1,07138 \\
\hline \multirow{4}{*}{ Hombre } & Media & 13,56 & 14,55 & 7,95 & 16,42 & 16,93 & 20,40 & 7,1869 \\
\cline { 2 - 10 } & Mínimo & 4 & 2 & 0 & 5 & 5 & 10 & 4,63 \\
\cline { 2 - 9 } & Máximo & 27 & 26 & 26 & 26 & 29 & 30 & 8,12 \\
\cline { 2 - 10 } & Desv. típ. & 4,363 & 3,945 & 5,431 & 4,228 & 5,438 & 4,458 & 1,04651 \\
\hline \multirow{3}{*}{ TOTAL } & Media & 13,70 & 14,80 & 8,31 & 16,62 & 16,21 & 20,15 & 7,2043 \\
\cline { 2 - 9 } & Mínimo & 4 & 2 & 0 & 5 & 5 & 6 & 3,86 \\
\cline { 2 - 9 } & Máximo & 27 & 26 & 26 & 26 & 29 & 30 & 8,13 \\
\cline { 2 - 9 } & Desv. típ. & 4,197 & 3,907 & 5,632 & 4,203 & 5,321 & 4,644 & 1,05294 \\
\hline
\end{tabular}

Cuadro 101: Medidas estadísticas de "valores", sexo y actitud hacia la responsabilidad social.

La información que muestra el cuadro 101 indica la existencia de una leve diferencia en la actitud hacia la responsabilidad social de ambos sexos a favor de la mujer $(7,23)$, resultado en que podría tener incidencia la competencia genérica “metas" $y$, especialmente, la característica comportamental “orden y método" (cuyas medias registradas en los hombres son significativamente más altas, 20,40 y 16,93 respectivamente), y el rasgo de personalidad "variedad" (cuya puntuación media es más destacada en las mujeres, 8,94).

El siguiente cuadro (102) permite verificar posibles variaciones asociadas al incremento de la actitud: 


\begin{tabular}{|c|c|c|c|c|c|c|c|c|}
\hline Sexo & \multicolumn{2}{|c|}{ Actitud hacia la resp. social } & Practicidad & Resultados & Variedad & Decisión & Orden y & Metas \\
\hline \multirow{14}{*}{ Mujer } & \multirow{2}{*}{$0 \mathrm{a}<4$} & Media & 21,00 & 17,00 & 7,00 & 20,00 & 12,00 & 10,00 \\
\hline & & Desv. típ. & & & & & . & \\
\hline & \multirow{2}{*}{$4 a<5$} & Media & 17,50 & 10,00 & 12,50 & 15,50 & 16,00 & 18,50 \\
\hline & & Desv. típ. & ,707 & 4,243 & 10,607 & ,707 & 7,071 & 7,778 \\
\hline & \multirow{2}{*}{$5 a<6$} & Media & 12,14 & 15,43 & 8,43 & 18,00 & 14,29 & 21,71 \\
\hline & & Desv. típ. & 4,100 & 3,409 & 4,315 & 2,160 & 2,984 & 2,430 \\
\hline & \multirow{2}{*}{$6 a<7$} & Media & 13,70 & 14,10 & 10,80 & 16,30 & 15,90 & 19,20 \\
\hline & & Desv. típ. & 3,401 & 3,957 & 7,300 & 3,561 & 4,533 & 6,529 \\
\hline & \multirow{2}{*}{7 a 8} & Media & 14,32 & 15,54 & 8,95 & 17,08 & 14,35 & 19,54 \\
\hline & & Desv. típ. & 3,473 & 3,355 & 6,128 & 4,639 & 5,277 & 5,069 \\
\hline & \multirow{2}{*}{$>8$} & Media & 12,82 & 16,00 & 7,09 & 16,55 & 16,45 & 20,55 \\
\hline & & Desv. típ. & 5,135 & 5,158 & 4,721 & 4,655 & 4,987 & 3,267 \\
\hline & \multirow{2}{*}{ Total } & Media & 13,96 & 15,25 & 8,94 & 16,97 & 14,93 & 19,71 \\
\hline & & Desv. típ. & 3,903 & 3,826 & 5,962 & 4,164 & 4,888 & 4,960 \\
\hline & \multirow{2}{*}{$4 a<5$} & Media & 14,20 & 15,80 & 6,40 & 16,60 & 17,20 & 19,80 \\
\hline & & Desv. típ. & 2,168 & ,837 & 1,673 & 6,025 & 5,718 & 3,114 \\
\hline & \multirow{2}{*}{$5 a<6$} & Media & 14,19 & 14,31 & 8,81 & 15,13 & 17,63 & 19,94 \\
\hline & & Desv. típ. & 3,582 & 3,439 & 4,694 & 3,052 & 5,149 & 3,473 \\
\hline & \multirow{2}{*}{$6 a<7$} & Media & 14,38 & 14,76 & 7,14 & 17,29 & 16,48 & 19,05 \\
\hline & & Desv. típ. & 4,790 & 2,791 & 5,199 & 4,027 & 5,921 & 4,780 \\
\hline & \multirow{2}{*}{7 a 8} & Media & 12,79 & 14,42 & 8,55 & 16,60 & 16,83 & 20,75 \\
\hline & & Desv. típ. & 4,307 & 4,448 & 5,976 & 4,312 & 5,536 & 4,661 \\
\hline & \multirow{2}{*}{$>8$} & Media & 13,96 & 14,58 & 7,15 & 16,12 & 17,00 & 21,19 \\
\hline & & Desv. típ. & 4,862 & 4,438 & 5,394 & 4,572 & 5,337 & 4,526 \\
\hline & \multirow{2}{*}{ Total } & Media & 13,56 & 14,55 & 7,95 & 16,42 & 16,93 & 20,40 \\
\hline & & Desv. típ. & 4,363 & 3,945 & 5,431 & 4,228 & 5,438 & 4,458 \\
\hline \multirow{14}{*}{ TOTAL } & \multirow{2}{*}{$0 a<4$} & Media & 21,00 & 17,00 & 7,00 & 20,00 & 12,00 & 10,00 \\
\hline & & Desv. típ. & & & & . & . & \\
\hline & \multirow{2}{*}{$4 a<5$} & Media & 15,14 & 14,14 & 8,14 & 16,29 & 16,86 & 19,43 \\
\hline & & Desv. típ. & 2,410 & 3,388 & 5,429 & 4,957 & 5,521 & 4,117 \\
\hline & \multirow{2}{*}{$5 a<6$} & Media & 13,57 & 14,65 & 8,70 & 16,00 & 16,61 & 20,48 \\
\hline & & Desv. típ. & 3,776 & 3,393 & 4,487 & 3,075 & 4,793 & 3,246 \\
\hline & \multirow{2}{*}{$6 a<7$} & Media & 14,16 & 14,55 & 8,32 & 16,97 & 16,29 & 19,10 \\
\hline & & Desv. típ. & 4,344 & 3,161 & 6,085 & 3,851 & 5,442 & 5,294 \\
\hline & \multirow{2}{*}{7 a 8} & Media & 13,42 & 14,88 & 8,71 & 16,80 & 15,81 & 20,26 \\
\hline & & Desv. típ. & 4,036 & 4,053 & 6,008 & 4,430 & 5,538 & 4,843 \\
\hline & \multirow{2}{*}{$>8$} & Media & 13,62 & 15,00 & 7,14 & 16,24 & 16,84 & 21,00 \\
\hline & & Desv. típ. & 4,901 & 4,637 & 5,138 & 4,536 & 5,172 & 4,157 \\
\hline & \multirow{2}{*}{ Total } & Media & 13,70 & 14,80 & 8,31 & 16,62 & 16,21 & 20,15 \\
\hline & & Desv. típ. & 4,197 & 3,907 & 5,632 & 4,203 & 5,321 & 4,644 \\
\hline
\end{tabular}

Cuadro 102: Medidas estadísticas de "valores", sexo y actitud hacia la responsabilidad social.

La información del cuadro 102 permite advertir que, en el caso de las líderes femeninas, parece darse una cierta tendencia decreciente (la tendencia no se mantiene en el grupo que corresponden al segmento de la actitud " $5 \mathrm{a}<6$ ") en el rasgo de personalidad "variedad" (su media pasa de 12,5 a 7,09) a medida que se intensifica su actitud hacia la responsabilidad social. 
Este resultado parece indicar que la preferencia por abrir el ámbito de las actividades, encontrarse en situaciones nuevas y diferentes, y disfrutar de trabajos que no se desarrollan dentro de una rutina decrece a medida que aumenta la disposición de las líderes femeninas a favor de la Responsabilidad Social Corporativa.

Además el cuadro 102 también refleja que en los máximos responsables masculinos, la competencia genérica "resultados" y la característica comportamental "orden y método" tienden a mantenerse estables aunque varíe su actitud hacia la responsabilidad social.

Es decir, que los retos que permiten la iniciativa personal en los que el esfuerzo individual es recompensado y la preferencia por desarrollar actividades o planificarlas tanto como sea posible, parecen ser independientes de la actitud de los hombres hacia la responsabilidad social.

A continuación hemos incorporado los gráficos 43 y 44 para comprobar posibles asociaciones en las variaciones de las variables estudiadas en función del sexo de los líderes.

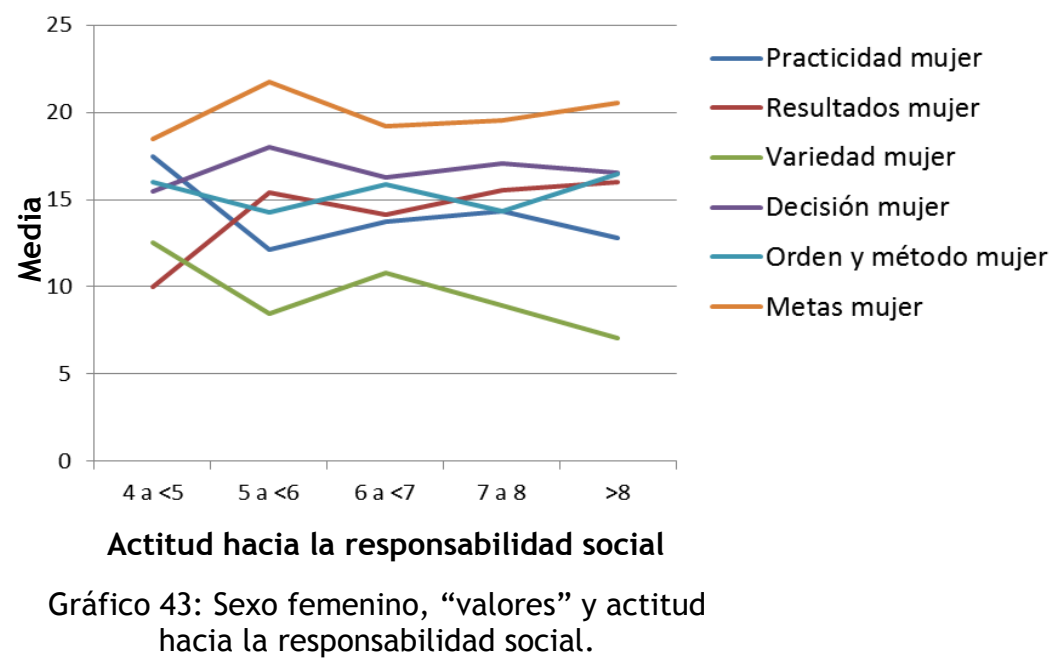


La información del gráfico 43 refleja que a medida que la actitud hacia la responsabilidad social de las líderes femeninas se incrementa, parece producirse una pérdida de relevancia del rasgo de personalidad "variedad".

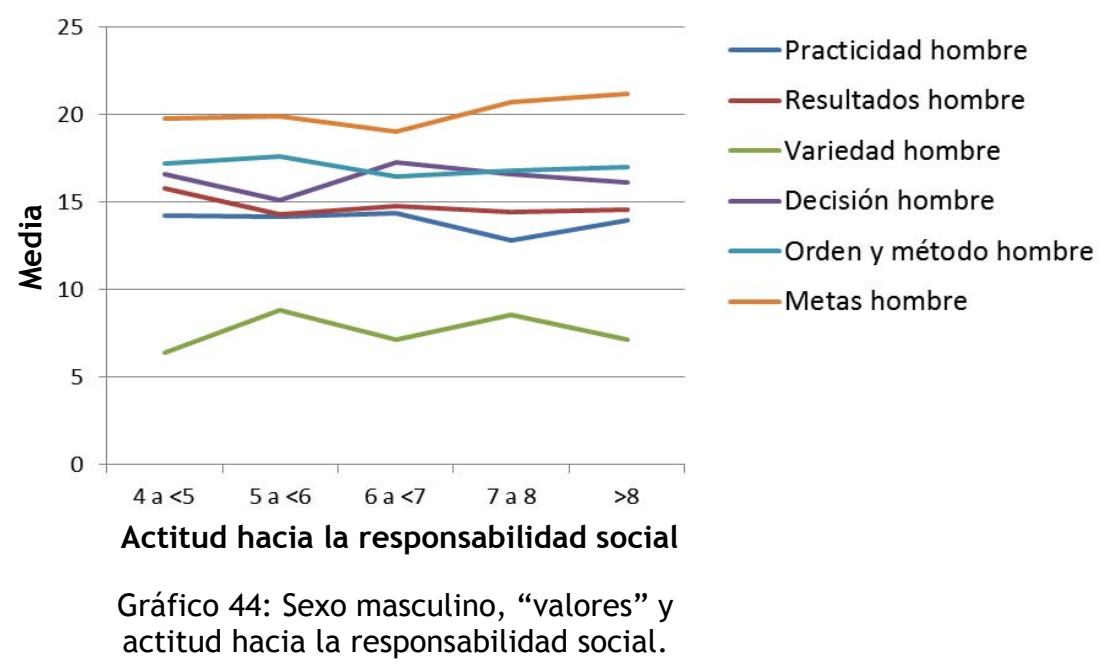

En el gráfico 44 se advierte que el rasgo de personalidad "decisión" y la característica comportamental “orden y método" tienden a comportarse de forma estable ante variaciones de los máximos responsables empresariales en su actitud hacia la Responsabilidad Social Corporativa.

A continuación hemos incorporado el cuadro 103 con los datos sobre el sexo de los líderes y las características comportamentales, los rasgos de personalidad y las competencias genéricas contempladas en el estudio, junto con el comportamiento socialmente responsable de las organizaciones de procedencia de los máximos responsables empresariales. 


\begin{tabular}{|c|c|c|c|c|c|c|c|c|}
\hline Sexo & \multicolumn{2}{|c|}{ Acciones de responsabilidad social } & Practicidad & Resultados & Variedad & Decisión & $\begin{array}{l}\text { Orden y } \\
\text { método }\end{array}$ & Metas \\
\hline \multirow{10}{*}{ Mujer } & \multirow{2}{*}{ No } & Media & 14,82 & 15,18 & 8,79 & 16,44 & 14,94 & 19,38 \\
\hline & & Desv. típ. & 4,026 & 3,672 & 6,139 & 3,791 & 4,658 & 4,465 \\
\hline & \multirow{2}{*}{ Sí, acciones puntuales } & Media & 13,50 & 15,22 & 9,28 & 17,61 & 14,39 & 19,89 \\
\hline & & Desv. típ. & 3,746 & 3,828 & 6,182 & 3,616 & 4,552 & 6,009 \\
\hline & \multirow{2}{*}{$\begin{array}{l}\text { Sí, acciones frecuentes } \\
\text { sin una política definida } \\
\text { de RS }\end{array}$} & Media & 11,43 & 17,86 & 10,00 & 19,14 & 13,57 & 18,00 \\
\hline & & Desv. típ. & 1,988 & 3,891 & 5,132 & 5,815 & 6,241 & 3,606 \\
\hline & \multirow{2}{*}{$\begin{array}{l}\text { Sí, acciones integradas } \\
\text { en una política definida } \\
\text { de RS }\end{array}$} & Media & 13,56 & 13,56 & 8,00 & 16,00 & 17,00 & 21,89 \\
\hline & & Desv. típ. & 4,304 & 3,909 & 6,245 & 5,050 & 5,500 & 5,372 \\
\hline & \multirow{2}{*}{ Total } & Media & 13,96 & 15,25 & 8,94 & 16,97 & 14,93 & 19,71 \\
\hline & & Desv. típ. & 3,903 & 3,826 & 5,962 & 4,164 & 4,888 & 4,960 \\
\hline \multirow{10}{*}{ Hombre } & \multirow{2}{*}{ No } & Media & 14,53 & 14,54 & 7,05 & 16,02 & 17,65 & 19,93 \\
\hline & & Desv. típ. & 4,339 & 3,991 & 4,397 & 4,134 & 5,150 & 4,114 \\
\hline & \multirow{2}{*}{ Sí, acciones puntuales } & Media & 14,22 & 13,83 & 8,39 & 16,72 & 16,50 & 20,89 \\
\hline & & Desv. típ. & 4,532 & 4,579 & 5,832 & 3,908 & 5,874 & 4,714 \\
\hline & \multirow{2}{*}{$\begin{array}{l}\text { Sí, acciones frecuentes } \\
\text { sin una política definida } \\
\text { de RS }\end{array}$} & Media & 13,61 & 14,17 & 7,61 & 16,78 & 16,89 & 20,39 \\
\hline & & Desv. típ. & 4,231 & 3,348 & 4,245 & 4,506 & 4,825 & 5,226 \\
\hline & \multirow{2}{*}{$\begin{array}{l}\text { Sí, acciones integradas } \\
\text { en una política definida } \\
\text { de RS }\end{array}$} & Media & 11,14 & 15,29 & 9,71 & 16,82 & 15,75 & 21,07 \\
\hline & & Desv. típ. & 3,608 & 3,857 & 7,287 & 4,579 & 6,114 & 4,578 \\
\hline & \multirow{2}{*}{ Total } & Media & 13,56 & 14,55 & 7,95 & 16,42 & 16,93 & 20,40 \\
\hline & & Desv. típ. & 4,363 & 3,945 & 5,431 & 4,228 & 5,438 & 4,458 \\
\hline \multirow{10}{*}{ TOTAL } & \multirow{2}{*}{ No } & Media & 14,64 & 14,78 & 7,70 & 16,18 & 16,64 & 19,73 \\
\hline & & Desv. típ. & 4,205 & 3,867 & 5,154 & 3,993 & 5,118 & 4,232 \\
\hline & \multirow{2}{*}{ Sí, acciones puntuales } & Media & 13,86 & 14,53 & 8,83 & 17,17 & 15,44 & 20,39 \\
\hline & & Desv. típ. & 4,114 & 4,219 & 5,940 & 3,738 & 5,289 & 5,347 \\
\hline & \multirow{2}{*}{$\begin{array}{l}\text { Sí, acciones frecuentes } \\
\text { sin una política definida } \\
\text { de RS }\end{array}$} & Media & 13,00 & 15,20 & 8,28 & 17,44 & 15,96 & 19,72 \\
\hline & & Desv. típ. & 3,830 & 3,819 & 4,532 & 4,900 & 5,342 & 4,878 \\
\hline & \multirow{2}{*}{$\begin{array}{l}\text { Sí, acciones integradas } \\
\text { en una política definida } \\
\text { de RS }\end{array}$} & Media & 11,73 & 14,86 & 9,30 & 16,62 & 16,05 & 21,27 \\
\hline & & Desv. típ. & 3,870 & 3,888 & 7,003 & 4,639 & 5,921 & 4,718 \\
\hline & \multirow{2}{*}{ Total } & Media & 13,70 & 14,80 & 8,31 & 16,62 & 16,21 & 20,15 \\
\hline & & Desv. típ. & 4,197 & 3,907 & 5,632 & 4,203 & 5,321 & 4,644 \\
\hline
\end{tabular}

Cuadro 103: Medidas estadísticas sobre acciones de responsabilidad social, sexo y "valores".

Antes de revisar los datos del cuadro 104 hemos aplicado ANOVA de un factor para verificar la posible existencia de diferencias estadísticamente significativas entre los diversos grupos muestrales contemplados.

La información que ofrece el cuadro 104 (incluido tras estas líneas) indica que existen, desde un punto de vista estadístico, diferencias significativas entre los diversos grupos muestrales en relación con "practicidad" (su coeficiente de significación es de 0,003). 


\begin{tabular}{|c|c|c|c|c|c|c|}
\hline & & Suma de cuadrados & gl & Media cuadrática & $\mathbf{F}$ & Sig. \\
\hline \multirow{3}{*}{ Sexo } & Inter-grupos & 1,387 & 3 & 462 & 2,029 & ,111 \\
\hline & Intra-grupos & 42,148 & 185 & ,228 & & \\
\hline & Total & 43,534 & 188 & & & \\
\hline \multirow{3}{*}{ Practicidad } & Inter-grupos & 236,772 & 3 & 78,924 & 4,749 & ,003 \\
\hline & Intra-grupos & 3074,636 & 185 & 16,620 & & \\
\hline & Total & 3311,407 & 188 & & & \\
\hline \multirow{3}{*}{ Resultados } & Inter-grupos & 6,856 & 3 & 2,285 & 148 & 931 \\
\hline & Intra-grupos & 2862,901 & 185 & 15,475 & & \\
\hline & Total & 2869,757 & 188 & & & \\
\hline \multirow{3}{*}{ Variedad } & Inter-grupos & 79,442 & 3 & 26,481 & ,832 & ,478 \\
\hline & Intra-grupos & 5884,759 & 185 & 31,810 & & \\
\hline & Total & 5964,201 & 188 & & & \\
\hline \multirow{3}{*}{ Decisión } & Inter-grupos & 45,522 & 3 & 15,174 & ,857 & ,464 \\
\hline & Intra-grupos & 3275,050 & 185 & 17,703 & & \\
\hline & Total & 3320,571 & 188 & & & \\
\hline \multirow{3}{*}{ Orden y método } & Inter-grupos & 40,179 & 3 & 13,393 & ,469 & ,704 \\
\hline & Intra-grupos & 5282,774 & 185 & 28,556 & & \\
\hline & Total & 5322,952 & 188 & & & \\
\hline \multirow{3}{*}{ Metas } & Inter-grupos & 69,526 & 3 & 23,175 & 1,076 & 361 \\
\hline & Intra-grupos & 3985,025 & 185 & 21,541 & & \\
\hline & Total & 4054,550 & 188 & & & \\
\hline
\end{tabular}

Cuadro 104: Tabla ANOVA de sexo y valores, factor Realización de Acciones de Responsabilidad Social.

Una vez aplicado ANOVA de un factor a los datos (cuadro 104) hemos revisado la información que ofrece el cuadro 103. Si contemplamos el sexo de los líderes, los datos sobre "valores" de los máximos responsables empresariales y el comportamiento socialmente responsable de sus organizaciones de origen presentan algunos aspectos diferenciados.

En relación con las mujeres, solo existe un "valor" medio con una puntuación más alta en las líderes que proceden de organizaciones que no realizan ningún tipo de actuación en materia de responsabilidad social que en el 
resto de grupos muestrales contemplados. Se trata del rasgo de personalidad "practicidad" (media 14,82).

En el resto de casos las medias más altas y más bajas de cada "valor" se encuentran en las mujeres que están vinculadas a organizaciones que desarrollan acciones de responsabilidad social de modo frecuente o tienen una política establecida en este campo. En ninguno de los casos se aprecia una tendencia creciente o decreciente en las puntuaciones medias de las competencias genéricas, rasgos de personalidad y características comportamentales analizadas.

También hemos destacado una situación que se da en las mujeres pero no se produce en los hombres. Para las líderes femeninas la competencia genérica "metas" es el aspecto más importante, de los seis evaluados, en todos los grupos muestrales excepto en uno: las mujeres que proceden de organizaciones que desarrollan acciones de Responsabilidad Social Corporativa de modo frecuente. En este último grupo muestral, la puntuación media más elevada la recibe el rasgo de personalidad "decisión" $(19,14)$.

En cuanto a las puntuaciones medias registradas por los hombres, hay resultados bastante similares aunque los datos también ofrecen algunas diferencias en relación con los resultados obtenidos por las líderes femeninas.

Los máximos responsables masculinos cuyo origen son organizaciones con una conducta más intensa, en referencia 
a su actuación a favor de la responsabilidad social, no concentran los valores máximos y mínimos de las competencias genéricas, rasgos de personalidad y características comportamentales estudiados. En este caso, estos registros se encuentran en los líderes que proceden de organizaciones que no realizan ningún tipo de iniciativa socialmente responsable (medias máximas para "practicidad" -14,53- y “orden y método" -17,65- y mínimas para "variedad" -7,05-, “decisión" -16,02- y “metas" -19,93-), que desarrollan acciones puntuales (valor medio máximo para "variedad" -8,39- y mínimo para "resultados" -13,83-) y que cuentan con una política definida de Responsabilidad Social Corporativa (valores medios máximos para "resultados" -15,29-, “decisión" -16,82- y "metas" -21,07- y mínimos para "practicidad" $-11,14-y$ “orden y método" -17,75-).

Otro aspecto que diferencia a los datos registrados por los hombres de los de las mujeres es que en el caso de los hombres sí se aprecian tendencias de variación a medida que aumenta el comportamiento socialmente responsable en sus organizaciones de origen. En el caso del rasgo de personalidad "practicidad", este reduce progresivamente su peso medio a medida que aumenta el comportamiento socialmente responsable de las organizaciones de procedencia de los líderes (pasa de un 14,53 a un 11,14). También se aprecian tendencias de crecimiento 0 decrecimiento en otros dos aspectos evaluados, aunque en estos casos las variaciones no mantienen esa tónica en las 
cuatro tipos de comportamiento socialmente responsable contemplados. Hacemos referencia a la característica comportamental "orden y método", que presenta una tendencia a disminuir su relevancia a medida que aumenta el comportamiento socialmente responsable de la organización a la que el líder está vinculado (el valor medio máximo es de 17,65 y el mínimo es de 15,75) y a la competencia genérica "metas" que tiende a aumentar su importancia a medida que crece la intensidad en el comportamiento socialmente responsable de la organización de procedencia del líder (el valor medio mínimo de esta competencia es 19,93 y el máximo 21,07 ).

A continuación hemos incorporado los gráficos 45 y 46 para comprobar visualmente posibles asociaciones en la variación de las variables estudiadas.

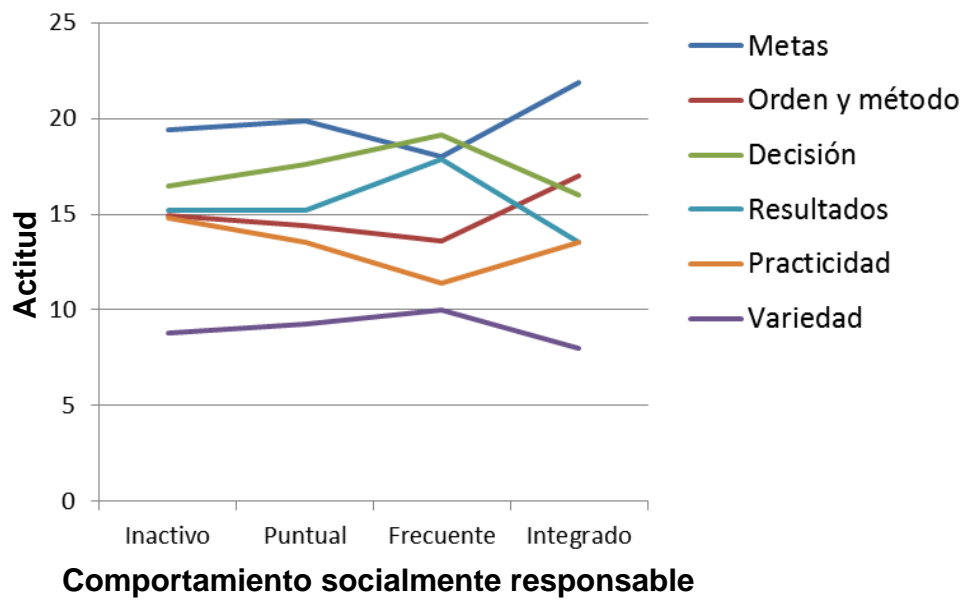

Gráfico 45: Valores y acciones de responsabilidad social en el sexo femenino.

En el gráfico superior (45) contemplamos la variación de las competencias genéricas, rasgos de personalidad y características comportamentales en las mujeres a medida 
que crece el comportamiento socialmente responsable de las organizaciones.

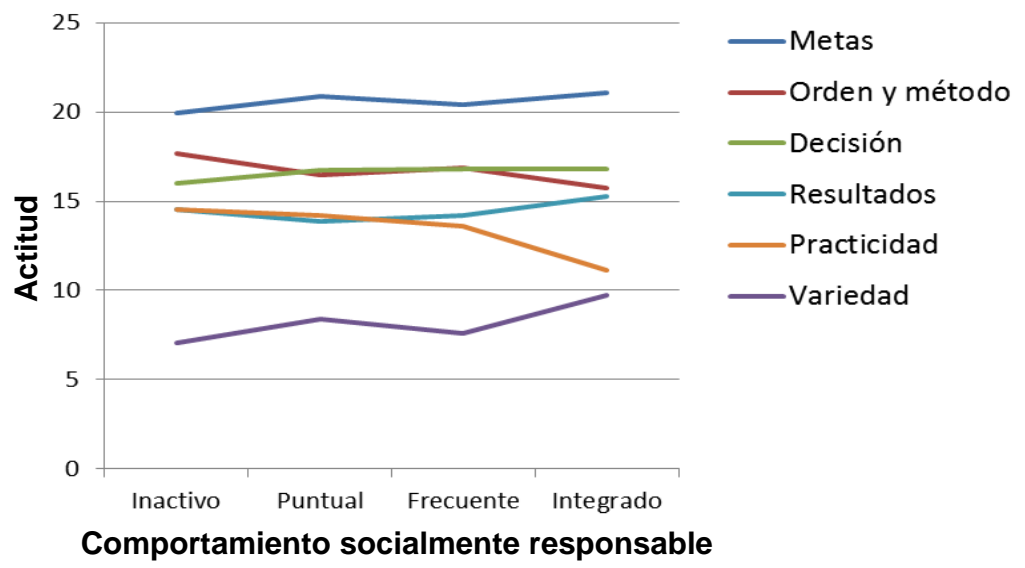

Gráfico 46: Valores y acciones de responsabilidad social en el sexo masculino.

En el gráfico 46 se muestran las tendencias de variación de “metas", “decisión”, “resultados”, "practicidad", "variedad" y "orden y método" a medida que se incrementa la actuación en materia de Responsabilidad Social Corporativa de las empresas de procedencia de los líderes masculinos.

Los gráficos indican que en el caso de las mujeres (gráfico 45) resulta complicado advertir algún cambio en sus rasgos de personalidad, sus características comportamentales y sus competencias genéricas asociado al crecimiento de la actuación socialmente responsable de sus empresas de procedencia.

En cambio en el caso de los hombres, los datos indican que a medida que crece la conducta socialmente responsable de las organizaciones de origen de los líderes tiende a aumentar ligeramente la competencia genérica 
“metas” y de forma más marcada (aunque no progresiva) el rasgo de personalidad "variedad".

Por otra parte, el aumento de la intensidad en el comportamiento organizacional socialmente responsable parece estar asociado en los hombres a una reducción del rasgo de personalidad "practicidad" (reducción especialmente marcada en el paso de los líderes que proceden de organizaciones que desarrollan acciones frecuentes a los que proceden de empresas con una política definida) y de la característica comportamental "orden y método".

En cuanto al rasgo de personalidad "decisión" parece no verse afectado, en el caso de los líderes masculinos, por el hecho de que sus organizaciones de origen tengan o no tengan un comportamiento socialmente responsable en cualquiera de las opciones que se han considerado.

A continuación mostramos los datos sobre las competencias genéricas, los rasgos de personalidad, las características comportamentales y el sexo de los líderes pero asociando los datos, en este caso, con el número de horas que las organizaciones de procedencia de los líderes dedican a acciones formativas que pueden encuadrarse en el ámbito de la Responsabilidad Social Corporativa (cuadro 105: "Medidas estadísticas sobre formación en responsabilidad social, sexo y valores"). 


\begin{tabular}{|c|c|c|c|c|c|c|c|c|}
\hline Sexo & Horas de form & esp. social & Practicidad & Resultados & Variedad & Decisión & $\begin{array}{l}\text { Orden y } \\
\text { método }\end{array}$ & Metas \\
\hline \multirow{14}{*}{ Mujer } & \multirow{2}{*}{ Menos de 11} & Media & 15,33 & 15,00 & 9,33 & 15,00 & 16,00 & 19,33 \\
\hline & & Desv. típ. & 3,786 & 7,000 & 8,386 & 5,568 & 4,583 & 6,429 \\
\hline & \multirow{2}{*}{ De 11 a 50} & Media & 11,33 & 15,00 & 9,83 & 21,50 & 13,00 & 19,33 \\
\hline & & Desv. típ. & 3,445 & 3,347 & 5,456 & 3,332 & 5,177 & 4,546 \\
\hline & \multirow{2}{*}{ De 51 a 100} & Media & 13,00 & 19,00 & 21,00 & 21,00 & 10,00 & 6,00 \\
\hline & & Desv. típ. & & & . & & & \\
\hline & \multirow{2}{*}{ De 101 a 150} & Media & 9,00 & 10,00 & 13,00 & 16,50 & 18,00 & 23,50 \\
\hline & & Desv. típ. & 1,414 & 1,414 & 12,728 & 6,364 & 9,899 & 6,364 \\
\hline & \multirow{2}{*}{ De 201 a 1000} & Media & 9,00 & 23,00 & 6,00 & 21,00 & 12,00 & 19,00 \\
\hline & & Desv. típ. & & & & & & \\
\hline & \multirow{2}{*}{ Más de 1000} & Media & 15,00 & 15,00 & 8,00 & 9,00 & 19,00 & 24,00 \\
\hline & & Desv. típ. & & & & & & \\
\hline & \multirow{2}{*}{ Total } & Media & 12,07 & 15,14 & 10,57 & 18,43 & 14,50 & 19,29 \\
\hline & & Desv. típ. & 3,540 & 4,688 & 6,836 & 5,258 & 5,302 & 5,954 \\
\hline \multirow{16}{*}{ Hombre } & \multirow{2}{*}{ Menos de 11} & Media & 12,43 & 14,29 & 8,86 & 16,43 & 15,86 & 22,14 \\
\hline & & Desv. típ. & 3,309 & 3,861 & 4,140 & 3,207 & 3,934 & 3,761 \\
\hline & \multirow{2}{*}{ De 11 a 50} & Media & 15,60 & 16,00 & 6,20 & 15,60 & 15,60 & 20,40 \\
\hline & & Desv. típ. & 7,057 & 3,606 & 4,868 & 7,797 & 4,450 & 4,669 \\
\hline & \multirow{2}{*}{ De 51 a 100} & Media & 12,25 & 14,50 & 9,75 & 17,25 & 16,00 & 20,25 \\
\hline & & Desv. típ. & 2,500 & 3,109 & 5,315 & 5,439 & 7,528 & 4,193 \\
\hline & \multirow{2}{*}{ De 101 a 150} & Media & 11,60 & 18,40 & 4,00 & 18,20 & 17,20 & 20,60 \\
\hline & & Desv. típ. & 2,302 & 5,030 & 4,950 & 3,834 & 4,025 & 4,980 \\
\hline & \multirow{2}{*}{ De 151 a 200} & Media & 14,00 & 12,00 & 10,00 & 22,00 & 9,00 & 23,00 \\
\hline & & Desv. típ. & & & & & & \\
\hline & \multirow{2}{*}{ De 201 a 1000} & Media & 5,00 & 15,00 & 6,00 & 25,00 & 14,00 & 22,00 \\
\hline & & Desv. típ. & & & & & & \\
\hline & \multirow{2}{*}{ Más de 1000} & Media & 9,50 & 14,50 & 13,00 & 13,00 & 16,50 & 23,50 \\
\hline & & Desv. típ. & 3,536 & 2,121 & 14,142 & 1,414 & 4,950 & 6,364 \\
\hline & \multirow{2}{*}{ Total } & Media & 12,40 & 15,44 & 7,76 & 17,04 & 15,80 & 21,32 \\
\hline & & Desv. típ. & 4,311 & 3,809 & 5,592 & 4,979 & 4,528 & 4,049 \\
\hline \multirow{16}{*}{ TOTAL } & \multirow{2}{*}{ Menos de 11} & Media & 13,30 & 14,50 & 9,00 & 16,00 & 15,90 & 21,30 \\
\hline & & Desv. típ. & 3,529 & 4,577 & 5,207 & 3,771 & 3,872 & 4,523 \\
\hline & \multirow{2}{*}{ De 11 a 50} & Media & 13,27 & 15,45 & 8,18 & 18,82 & 14,18 & 19,82 \\
\hline & & Desv. típ. & 5,551 & 3,328 & 5,288 & 6,274 & 4,813 & 4,400 \\
\hline & \multirow{2}{*}{ De 51 a 100} & Media & 12,40 & 15,40 & 12,00 & 18,00 & 14,80 & 17,40 \\
\hline & & Desv. típ. & 2,191 & 3,362 & 6,819 & 5,000 & 7,050 & 7,335 \\
\hline & 150 & Media & 10,86 & 16,00 & 6,57 & 17,71 & 17,43 & 21,43 \\
\hline & De 101 a 150 & Desv. típ. & 2,340 & 5,831 & 7,913 & 4,152 & 5,224 & 5,028 \\
\hline & م 20151 ב 151 & Media & 14,00 & 12,00 & 10,00 & 22,00 & 9,00 & 23,00 \\
\hline & De 151 a $\angle 00$ & Desv. típ. & & & & & & \\
\hline & & Media & 7,00 & 19,00 & 6,00 & 23,00 & 13,00 & 20,50 \\
\hline & De 201 a 1000 & Desv. típ. & 2,828 & 5,657 &, 000 & 2,828 & 1,414 & 2,121 \\
\hline & Mác de 1000 & Media & 11,33 & 14,67 & 11,33 & 11,67 & 17,33 & 23,67 \\
\hline & IMlas de 1000 & Desv. típ. & 4,041 & 1,528 & 10,408 & 2,517 & 3,786 & 4,509 \\
\hline & Total & Media & 12,28 & 15,33 & 8,77 & 17,54 & 15,33 & 20,59 \\
\hline & Iotal & Desv. típ. & 4,006 & 4,087 & 6,132 & 5,057 & 4,792 & 4,843 \\
\hline
\end{tabular}

Cuadro 105: Medidas estadísticas sobre formación en responsabilidad social, sexo y valores.

Antes de realizar una lectura de la información del cuadro 105 hemos aplicado ANOVA de un factor en los datos (cuadro 106) para constatar si existen diferencias estadísticamente significativas entre los diferentes grupos muestrales que componen dicha muestra poblacional. 


\begin{tabular}{|c|c|c|c|c|c|c|}
\hline & & Suma de cuadrados & gl & Media cuadrática & $\mathbf{F}$ & Sig. \\
\hline \multirow{3}{*}{ Sexo } & Inter-grupos & ,752 & 6 & 125 & 488 & 813 \\
\hline & Intra-grupos & 8,223 & 32 & 257 & & \\
\hline & Total & 8,974 & 38 & & & \\
\hline \multirow{3}{*}{ Practicidad } & Inter-grupos & 96,892 & 6 & 16,149 & 1,007 & ,438 \\
\hline & Intra-grupos & 513,006 & 32 & 16,031 & & \\
\hline & Total & 609,897 & 38 & & & \\
\hline \multirow{3}{*}{ Resultados } & Inter-grupos & 49,573 & 6 & 8,262 & ,452 & 838 \\
\hline & Intra-grupos & 585,094 & 32 & 18,284 & & \\
\hline & Total & 634,667 & 38 & & & \\
\hline \multirow{3}{*}{$\begin{array}{c}\text { Valor } \\
\text { numérico }\end{array}$} & Inter-grupos & 126,906 & 6 & 21,151 &, 520 & ,789 \\
\hline & Intra-grupos & 1302,017 & 32 & 40,688 & & \\
\hline & Total & 1428,923 & 38 & & & \\
\hline \multirow{3}{*}{ Decisión } & Inter-grupos & 225,961 & 6 & 37,660 & 1,616 & 175 \\
\hline & Intra-grupos & 745,732 & 32 & 23,304 & & \\
\hline & Total & 971,692 & 38 & & & \\
\hline \multirow{3}{*}{$\begin{array}{l}\text { Orden y } \\
\text { método }\end{array}$} & Inter-grupos & 112,949 & 6 & 18,825 & ,793 & ,582 \\
\hline & Intra-grupos & 759,717 & 32 & 23,741 & & \\
\hline & Total & 872,667 & 38 & & & \\
\hline \multirow{3}{*}{ Metas } & Inter-grupos & 101,619 & 6 & 16,936 & 686 & 662 \\
\hline & Intra-grupos & 789,817 & 32 & 24,682 & & \\
\hline & Total & 891,436 & 38 & & & \\
\hline
\end{tabular}

Cuadro 106: Tabla ANOVA de sexo y valores, factor Horas de Formación en Responsabilidad Social.

Los datos del cuadro 106 muestran que no existen diferencias estadísticamente significativas entre los diversos grupos muestrales contemplados, ya que en ningún caso el coeficiente de significación es inferior a 0,05.

Por razones de representatividad en el análisis de la información que aporta el cuadro 105 solo hemos considerado aquellos grupos muestrales que cuentan con, al menos, dos líderes.

En la exposición de las observaciones sugeridas tras la lectura de los datos del cuadro 105 hemos agrupado los datos por sexos. 
En el caso de las líderes femeninas la característica comportamental, rasgo de personalidad o competencia genérica más relevante en todos los casos es "metas", aunque hay una excepción (que no se repite en el caso de los máximos responsables masculinos) dentro de las líderes que proceden de organizaciones que dedican entre 11 y 50 horas a acciones formativas enmarcadas en el ámbito de la responsabilidad. En este último caso el aspecto más destacado ha sido el rasgo de personalidad "decisión" (media 21,50).

En las mujeres se aprecian dos tendencias decrecientes a medida que sus organizaciones de procedencia aumentan el número de horas que dedican a acciones formativas enmarcadas en el ámbito de la Responsabilidad Social Corporativa en el rasgo de personalidad "practicidad" (su valor medio desciende de 15,33 a 9) y en la competencia genérica "resultados" (su valor medio se reduce de 15 a 10). Asimismo también se detectan tendencias crecientes en el rasgo de personalidad "variedad" (su valor medio asciende de 9,33 a 13) y en la competencia genérica "metas" (su valor medio se incrementa de 19,33 a 23,50).

En el caso de los máximos responsables masculinos no se perciben tendencias decrecientes o crecientes en ninguno de los rasgos de personalidad, las competencias genéricas, y las características comportamentales contempladas. 
Es destacable que los líderes que están vinculados a organizaciones que impulsan más de 1000 horas a formación encuadrada en el ámbito de la responsabilidad social presenten dos valores medios máximos y dos mínimos. Los máximos se han registrado en el rasgo de personalidad "variedad" (la media es 13) y en la competencia genérica "metas" (la media es 23,50), y los mínimos en los rasgos de personalidad "practicidad" $(9,5)$ y “decisión” $(13)$.

También es destacable que algunos valores medios máximos y mínimos se hayan obtenido por los líderes que proceden de organizaciones que impulsan acciones formativas de responsabilidad social en la franja de 51 a 100 horas (un comportamiento intermedio en relación a las acciones formativas dentro de las opciones contempladas). Los valores medios máximos se han registrado en la competencia genérica "resultados" (su valor medio ha sido 18,40), el rasgo de personalidad “decisión" $(18,20)$ y la característica comportamental “orden y método" $(17,20)$. El valor medio mínimo se ha registrado en el rasgo de personalidad "variedad" (4).

Hemos incluido tras estas líneas los gráficos 47 y 48 para comprobar, visualmente, si es posible establecer algún tipo de asociación en las variaciones de las variables contempladas a medida que aumenta el número de horas que las organizaciones dedican a acciones formativas encuadradas en el ámbito de la responsabilidad social. Hemos incorporado en dichos gráficos los datos de los 
grupos muestrales en los que solo se ha registrado información de un líder, al considerar que pueden aportar valor en la detención de tendencias.

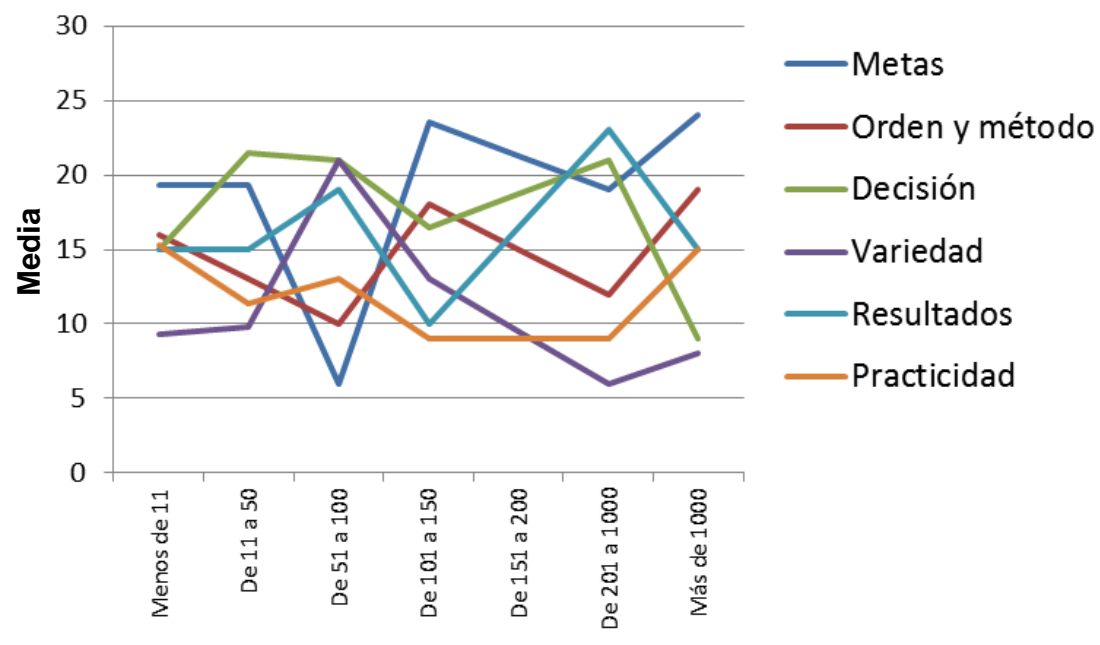

Formación en responsabilidad social

Gráfico 47: Valores y formación en responsabilidad social en el sexo femenino.

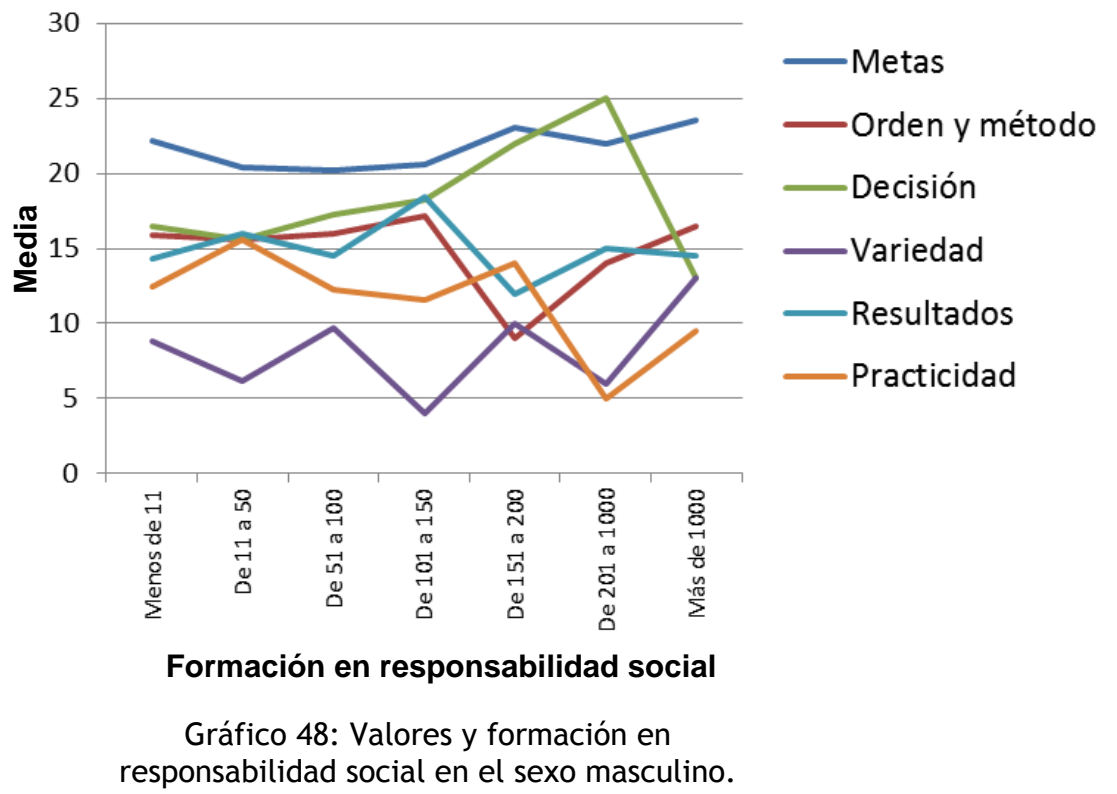

En los datos que muestra el gráfico 47 no parece advertirse algún tipo de asociación en la evolución de los rasgos de personalidad, las competencias genéricas y los rasgos comportamentales de las líderes femeninas a medida 
que aumenta el número de horas que sus organizaciones de origen dedican a la formación enmarcada en el ámbito de la responsabilidad social.

En cambio, en los datos sobre máximos responsables masculinos que refleja el gráfico 48 sí es posible detectar un cierto carácter creciente (no siempre se mantiene) en la competencia genérica "metas" a medida que la organización de procedencia del líder incrementa el número de horas de formación en materia de responsabilidad social. También parece darse (no siempre se produce) un aumento del valor medio del rasgo de personalidad “decisión" según aumenta el tiempo dedicado por la empresa a acciones formativas enmarcadas en el ámbito de la responsabilidad social.

\subsubsection{Edad, sector y Responsabilidad Social Corporativa}

Como en los apartados precedentes, hemos revisado en primer lugar los datos sobre el sexo de los líderes y el sector en el que estos desarrollan su actividad junto con la actitud que presentan hacia la Responsabilidad Social Corporativa los máximos responsables empresariales (cuadro 107). 


\begin{tabular}{|l|l|r|r|r|r|}
\hline Sector & \multicolumn{1}{|c|}{ Edad } & Media & Mínimo & Máximo & Desv. típ. \\
\hline \multirow{4}{*}{ Servicios } & De 20 a 40 & 7,3182 & 4,39 & 8,13 &, 97458 \\
\cline { 2 - 6 } & De 41 a 60 & 7,1466 & 3,86 & 8,08 & 1,09524 \\
\cline { 2 - 6 } & De 61 en adelante & 6,3179 & 4,76 & 8,03 & 1,17960 \\
\cline { 2 - 6 } & Total & 7,1416 & 3,86 & 8,13 & 1,08394 \\
\hline \multirow{4}{*}{ Construcción } & De 20 a 40 & 7,0833 & 5,25 & 8,00 & 1,58771 \\
\cline { 2 - 6 } & De 41 a 60 & 7,4572 & 5,79 & 8,03 &, 78787 \\
\cline { 2 - 6 } & De 61 en adelante & 8,0000 & 8,00 & 8,00 & \\
\cline { 2 - 6 } & Total & 7,4159 & 5,25 & 8,03 &, 93308 \\
\hline \multirow{5}{*}{ Total } & De 20 a 40 & 7,9404 & 7,27 & 8,10 &, 25472 \\
\cline { 2 - 6 } & De 41 a 60 & 7,0157 & 5,00 & 8,10 & 1,08431 \\
\cline { 2 - 6 } & De 61 en adelante & 7,7848 & 6,75 & 8,12 &, 58011 \\
\cline { 2 - 6 } & Total & 7,3844 & 5,00 & 8,12 &, 95516 \\
\hline & De 20 a 40 & 7,3985 & 4,39 & 8,13 &, 95226 \\
\cline { 2 - 6 } & De 41 a 60 & 7,1522 & 3,86 & 8,10 & 1,06686 \\
\cline { 2 - 6 } & De 61 en adelante & 6,8483 & 4,76 & 8,12 & 1,22644 \\
\cline { 2 - 6 } & Total & 7,2043 & 3,86 & 8,13 & 1,05294 \\
\hline
\end{tabular}

Cuadro 107: Medidas estadísticas de sector, edad y actitud hacia la responsabilidad social.

Antes de revisar la información que ofrece el cuadro 107 hemos aplicado ANOVA de un factor para comprobar si existen diferencias estadísticamente significativas entre los grupos muestrales considerados.

\begin{tabular}{|l|l|r|r|r|c|c|}
\hline \multicolumn{2}{|c|}{} & Suma de cuadrados & gl & Media cuadrática & F & Sig. \\
\hline \multirow{4}{*}{ Edad } & Inter-grupos & 28,159 & 80 &, 352 &, 960 &, 573 \\
\cline { 2 - 8 } & Intra-grupos & 39,598 & 108 &, 367 & & \\
\cline { 2 - 8 } & Total & 67,757 & 188 & & & \\
\hline \multirow{3}{*}{ Sector } & Inter-grupos & 42,217 & 80 &, 528 &, 815 &, 832 \\
\cline { 2 - 8 } & Intra-grupos & 69,920 & 108 &, 647 & & \\
\cline { 2 - 8 } & Total & 112,138 & 188 & & & \\
\hline
\end{tabular}

Cuadro 108: Tabla ANOVA sector y edad, factor Actitud hacia la Responsabilidad Social.

La información que ofrece el cuadro 108 muestra que no existen diferencias estadísticamente significativas entre los grupos muestrales que integran la muestra poblacional ya que, en ningún caso, el coeficiente de significación es inferior a 0,05. 
En relación con la información que ofrece el cuadro 107, los líderes de 20 a 40 años son los que han obtenido la mayor puntación media en la actitud hacia la responsabilidad social en los sectores servicios $(7,31)$ e industria $(7,94)$. Mientras que en el sector construcción la actitud media más elevada a favor de la responsabilidad social ha sido registrada por los líderes de 41 a 60 años $(7,45)$. No hemos considerado en este último sector, por su baja representatividad, la puntuación media en la actitud hacia la responsabilidad social de los líderes de más de 60 años, ya que solo se ha registrado un caso (su actitud media ha sido 8$)$.

En el sector servicios y en el sector construcción parece darse un comportamiento inverso en relación actitud hacia la Responsabilidad Social Corporativa al considerar la edad de los líderes. Mientras que en el sector servicios la actitud hacia la responsabilidad social decrece a medida que se incrementa la edad (se reduce de 7,31 en los líderes de 20 a 40 años a 6,31 en los máximos responsables de 61 y más años), en el sector construcción la actitud tiende a intensificarse a medida que crece la edad (aumenta de 7,08 en los líderes de 20 a 40 años a 7,45 en los máximos responsables de 41 a 60 años).

En sector industria los líderes de 61 y más años han registrado un valor medio en su actitud $(7,78)$ muy cercano al de los máximos responsables de 20 a 40 años $(7,94)$, y con una diferencia significativa respecto a los líderes de 41 a 60 años (cuya puntuación media en la actitud ha sido 7,01). 
Además también es destacable que la actitud media de los líderes de 61 años en adelante del sector industria haya alcanzado una puntuación por encima del punto y medio más alta que la que han obtenido los líderes de más de 60 años del sector servicios $(6,31)$.

A continuación hemos incorporado el gráfico 49 para revisar, de modo visual, posibles asociaciones en la variación de la edad y la actitud hacia la responsabilidad social en los líderes de cada uno de los tres sectores contemplados.

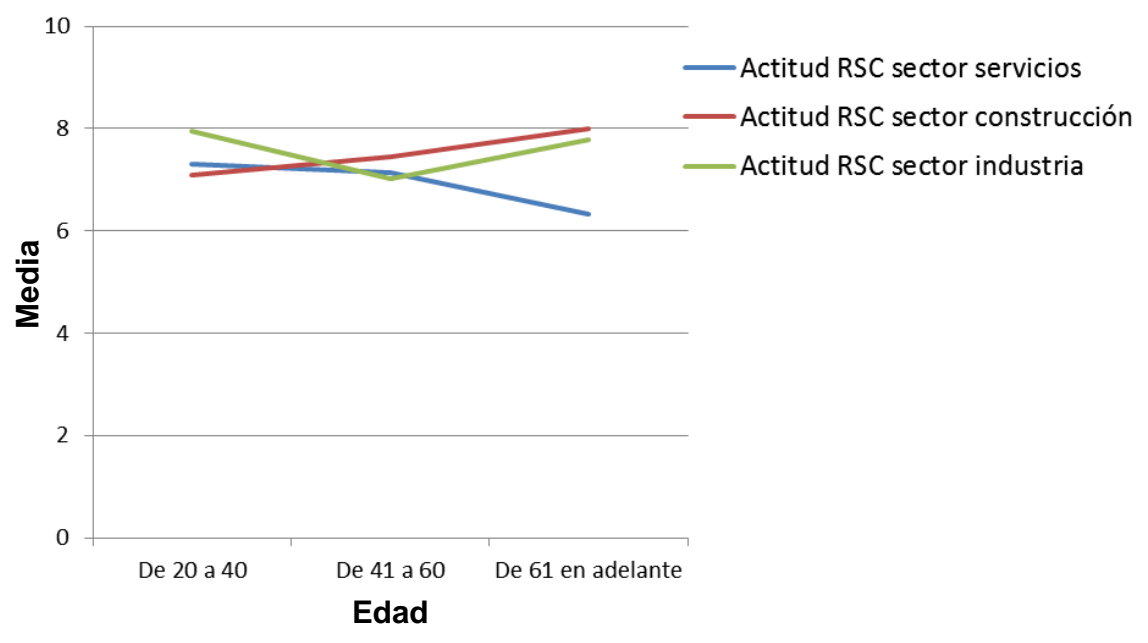

Gráfico 49: Sector, edad y actitud hacia la responsabilidad social.

El gráfico 49 refleja el comportamiento inverso antes indicado en los sectores servicios y construcción en relación con la actitud a favor de la responsabilidad social. Mientras que en el sector servicios la actitud de los líderes decrece a medida que crece su edad, en el sector construcción su actitud positiva hacia la Responsabilidad Social Corporativa aumenta según se incrementa su edad. 


\begin{tabular}{|c|c|c|c|c|c|c|c|}
\hline \multirow{2}{*}{\multicolumn{4}{|c|}{ Sector }} & \multicolumn{3}{|c|}{ Edad } & \multirow{3}{*}{$\begin{array}{l}\text { Total } \\
100,0 \% \\
\end{array}$} \\
\hline & & & & \multirow{2}{*}{\begin{tabular}{r|} 
De 20 a 40 \\
$33,3 \%$ \\
\end{tabular}} & \multirow{2}{*}{\begin{tabular}{|r|} 
De 41 a 60 \\
$59,4 \%$ \\
\end{tabular}} & \multirow{2}{*}{\begin{tabular}{|r|} 
De 61 en adelante \\
$7,2 \%$ \\
\end{tabular}} & \\
\hline \multirow{10}{*}{$\begin{array}{l}\text { Servicios } \\
\text { (incluye } \\
\text { comercio) }\end{array}$} & \multirow{8}{*}{$\begin{array}{l}\text { Acciones } \\
\text { de resp. } \\
\text { social }\end{array}$} & \multirow{2}{*}{ No } & $\%$ dentro de acciones & & & & \\
\hline & & & $\%$ dentro de edad & $46,9 \%$ & $50,0 \%$ & $45,5 \%$ & $48,6 \%$ \\
\hline & & \multirow{2}{*}{ Sí, acciones puntuales } & $\%$ dentro de acciones & $27,6 \%$ & $65,5 \%$ & $6,9 \%$ & $100,0 \%$ \\
\hline & & & $\%$ dentro de edad & $16,3 \%$ & $23,2 \%$ & $18,2 \%$ & $20,4 \%$ \\
\hline & & \multirow{2}{*}{$\begin{array}{l}\text { Sí, acciones frecuentes sin } \\
\text { una política definida de RS }\end{array}$} & $\%$ dentro de acciones & $66,7 \%$ & $27,8 \%$ & $5,6 \%$ & $100,0 \%$ \\
\hline & & & $\%$ dentro de edad & $24,5 \%$ & $6,1 \%$ & $9,1 \%$ & $12,7 \%$ \\
\hline & & \multirow{2}{*}{$\begin{array}{l}\text { Sí, acciones integradas en } \\
\text { una política de RS }\end{array}$} & $\%$ dentro de acciones & $23,1 \%$ & $65,4 \%$ & $11,5 \%$ & $100,0 \%$ \\
\hline & & & $\%$ dentro de edad & $12,2 \%$ & $20,7 \%$ & $27,3 \%$ & $18,3 \%$ \\
\hline & \multirow{2}{*}{\multicolumn{2}{|c|}{ Total }} & $\%$ dentro de acciones & $34,5 \%$ & $57,7 \%$ & $7,7 \%$ & $100,0 \%$ \\
\hline & & & $\%$ dentro de edad & $100,0 \%$ & $100,0 \%$ & $100,0 \%$ & $100,0 \%$ \\
\hline \multirow{10}{*}{ Construcción } & \multirow{8}{*}{$\begin{array}{l}\text { Acciones } \\
\text { de resp. } \\
\text { social }\end{array}$} & \multirow{2}{*}{ No } & $\%$ dentro de acciones & $30,0 \%$ & $70,0 \%$ & $0,0 \%$ & $100,0 \%$ \\
\hline & & & $\%$ dentro de edad & $100,0 \%$ & $70,0 \%$ & $0,0 \%$ & $71,4 \%$ \\
\hline & & \multirow{2}{*}{ Sí, acciones puntuales } & $\%$ dentro de acciones & $0,00 \%$ & $50,00 \%$ & $50,00 \%$ & $100,00 \%$ \\
\hline & & & $\%$ dentro de edad & $0,00 \%$ & $10,00 \%$ & $100,00 \%$ & $14,29 \%$ \\
\hline & & \multirow{2}{*}{$\begin{array}{l}\text { Sí, acciones frecuentes sin } \\
\text { una política definida de RS }\end{array}$} & $\%$ dentro de acciones & $0,00 \%$ & $100,00 \%$ & $0,00 \%$ & $100,00 \%$ \\
\hline & & & $\%$ dentro de edad & $0,00 \%$ & $10,00 \%$ & $0,00 \%$ & $7,14 \%$ \\
\hline & & \multirow{2}{*}{\begin{tabular}{|l|} 
Sí, acciones integradas en \\
una política de RS \\
\end{tabular}} & $\%$ dentro de acciones & $0,00 \%$ & $100,00 \%$ & $0,00 \%$ & $100,00 \%$ \\
\hline & & & $\%$ dentro de edad & $0,00 \%$ & $10,00 \%$ & $0,00 \%$ & $7,14 \%$ \\
\hline & \multirow{2}{*}{\multicolumn{2}{|c|}{ Total }} & $\%$ dentro de acciones & $21,4 \%$ & $71,4 \%$ & $7,1 \%$ & $100,0 \%$ \\
\hline & & & $\%$ dentro de edad & $100,0 \%$ & $100,0 \%$ & $100,0 \%$ & $100,0 \%$ \\
\hline \multirow{10}{*}{ Industria } & \multirow{8}{*}{$\begin{array}{l}\text { Acciones } \\
\text { de resp. } \\
\text { social }\end{array}$} & \multirow{2}{*}{ No } & $\%$ dentro de acciones & $16,7 \%$ & $66,7 \%$ & $16,7 \%$ & $100,0 \%$ \\
\hline & & & $\%$ dentro de edad & $22,2 \%$ & $42,1 \%$ & $40,0 \%$ & $36,4 \%$ \\
\hline & & \multirow{2}{*}{ Sí, acciones puntuales } & $\%$ dentro de acciones & $40,0 \%$ & $40,0 \%$ & $20,0 \%$ & $100,0 \%$ \\
\hline & & & $\%$ dentro de edad & $22,2 \%$ & $10,5 \%$ & $20,0 \%$ & $15,2 \%$ \\
\hline & & Sí, acciones frecuentes sin & $\%$ dentro de acciones & $16,7 \%$ & $83,3 \%$ & $0,0 \%$ & $100,0 \%$ \\
\hline & & una política definida de RS & $\%$ dentro de edad & $11,1 \%$ & $26,3 \%$ & $0,0 \%$ & $18,2 \%$ \\
\hline & & Sí, acciones integradas en & $\%$ dentro de acciones & $40,0 \%$ & $40,0 \%$ & $20,0 \%$ & $100,0 \%$ \\
\hline & & una política de RS & $\%$ dentro de edad & $44,4 \%$ & $21,1 \%$ & $40,0 \%$ & $30,3 \%$ \\
\hline & Total & & $\%$ dentro de acciones & $27,3 \%$ & $57,6 \%$ & $15,2 \%$ & $100,0 \%$ \\
\hline & Iotal & & $\%$ dentro de edad & $100,0 \%$ & $100,0 \%$ & $100,0 \%$ & $100,0 \%$ \\
\hline & & $\mathrm{No}$ & $\%$ dentro de acciones & $30,8 \%$ & $61,5 \%$ & $7,7 \%$ & $100,0 \%$ \\
\hline & & INO & $\%$ dentro de edad & $45,9 \%$ & $50,5 \%$ & $41,2 \%$ & $48,1 \%$ \\
\hline & & Sí acciones nuntuales & $\%$ dentro de acciones & $27,8 \%$ & $61,1 \%$ & $11,1 \%$ & $100,0 \%$ \\
\hline & Acciones & SI, acciones puminales & $\%$ dentro de edad & $16,4 \%$ & $19,8 \%$ & $23,5 \%$ & $19,0 \%$ \\
\hline TOTAL & social & Sí, acciones frecuentes sin & $\%$ dentro de acciones & $52,0 \%$ & $44,0 \%$ & $4,0 \%$ & $100,0 \%$ \\
\hline TUIAL & & una política definida de RS & $\%$ dentro de edad & $21,3 \%$ & $9,9 \%$ & $5,9 \%$ & $13,2 \%$ \\
\hline & & & $\%$ dentro de acciones & $27,0 \%$ & $59,5 \%$ & $13,5 \%$ & $100,0 \%$ \\
\hline & & una política de RS & $\%$ dentro de edad & $16,4 \%$ & $19,8 \%$ & $29,4 \%$ & $19,6 \%$ \\
\hline & Total & & $\%$ dentro de acciones & $32,3 \%$ & $58,7 \%$ & $9,0 \%$ & $100,0 \%$ \\
\hline & Iotal & & $\%$ dentro de edad & $100,0 \%$ & $100,0 \%$ & $100,0 \%$ & $100,0 \%$ \\
\hline
\end{tabular}

Cuadro 109: Tabla de contingencia de realización de acciones de responsabilidad social, sector y edad.

En la tabla superior hemos incorporado los datos sobre la edad de los líderes y su sector de procedencia, en relación con la actuación genérica en el ámbito de la responsabilidad social de las organizaciones a las que aquellos están vinculados (cuadro 109). Posteriormente, como en los apartados precedentes, hemos realizado el mismo análisis pero contemplando, en este caso, las horas de formación dedicadas a la responsabilidad social. 
Si tomamos como referencia el sector de procedencia de los líderes entrevistados, la información que ofrece el cuadro 109 presenta algunas diferencias significativas en relación con la edad de los líderes y el desarrollo de acciones de responsabilidad social. En la lectura de los datos no hemos tenido en cuenta aquellos grupos muestrales en los que solo se ha obtenido información de un líder.

En relación con los líderes procedentes del sector servicios, hay dos grupos con un especial protagonismo dentro de las opciones contempladas. En las organizaciones que no desarrollan ningún tipo de actividad vinculada con la responsabilidad social, las que desarrollan acciones puntuales en este ámbito y las que tienen una política definida de Responsabilidad Social Corporativa el líder más representado en cada grupo es el que tiene entre 41 y 60 años $(59,4 \%, 65,5 \%$ y $65,4 \%$ de los líderes asociados a cada uno de los tipos de comportamiento empresarial indicados en el sector servicios respectivamente con independencia de su edad). En las empresas que impulsan acciones frecuentes, el líder con mayor presencia en la muestra es el que tiene entre 20 y 40 años (el 66,7\% de los líderes procedentes de las empresas que realizan acciones de responsabilidad social de forma habitual en este sector).

En cuanto a los líderes procedentes del sector construcción, solo se encuentran suficientemente representadas las organizaciones que no realizan ningún tipo de actuación en el ámbito de la responsabilidad social. En estas organizaciones el líder mayoritario (70\% de los líderes 
vinculados a este tipo de empresas) tiene entre 41 y 60 años.

En relación con los máximos responsables del sector industria, los datos revelan la presencia de dos grupos con un especial protagonismo. En las organizaciones que no realizan ningún tipo de actuación socialmente responsable el líder con más presencia tiene entre 41 y 60 años $(66,7 \%)$, al igual que ocurre en las organizaciones que impulsan acciones frecuentes no integradas en una política definida $(83,3 \%)$. En cuanto a las empresas que desarrollan acciones puntuales y las que cuentan con una política de responsabilidad social definida, el líder mayoritario es el que tiene entre 20 y 60 años (el $80 \%$ de los líderes de ese tipo de organizaciones).

A continuación hemos incorporado el gráfico 50 para evaluar visualmente si existe algún tipo de asociación en la variación de la edad de los líderes y el comportamiento socialmente responsable de sus empresas de procedencia dentro de cada sector:

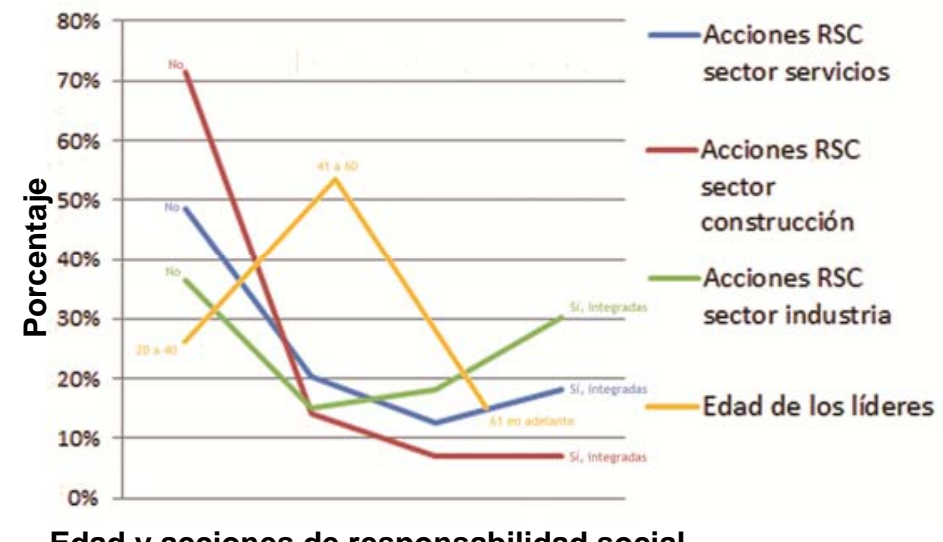

Edad y acciones de responsabilidad social

Gráfico 50: Edad, sector y acciones de responsabilidad social. 
La información del gráfico 50 indica que el comportamiento responsable en los tres sectores es similar. En los tres ámbitos es mayoritaria la presencia de líderes cuyas organizaciones no desarrollan acciones de responsabilidad social. A medida que aumenta el comportamiento responsable de las empresas de procedencia de los máximos responsables, las organizaciones tienden a decrecer y mantenerse estables (sector construcción) o a decrecer y a aumentar en menor (sector servicios) o mayor grado (sector construcción).

La conducta responsable de las empresas guarda una cierta correspondencia inversa con la edad de los líderes, cuya presencia en la muestra es creciente hasta los 41 a 60 años y luego es muy decreciente de los 61 años en adelante.

A continuación hemos incorporado el cuadro 110 con datos sobre la edad de los líderes, las horas que sus organizaciones de origen dedican a la formación enmarcada en el ámbito de la responsabilidad social y el sector en el que las organizaciones desarrollan su actividad (sectores servicios, construcción e industria). En la lectura de los datos no hemos considerado, por su baja representatividad, aquellos grupos muestrales en los que solo ha sido posible recabar información de un líder.

En el sector servicios destaca especialmente la presencia de líderes de 41 a 60 años $(71,4 \%$ en las organizaciones que dedican menos de 11 horas a formación sobre responsabilidad social, $66,7 \%$ en las que invierten 


\section{entre 51 y 100 horas, el $100 \%$ en las que dedican entre 101 y}

\section{0 horas y $66,7 \%$ en las que invierten más de 1000 horas).}

\begin{tabular}{|c|c|c|c|c|c|c|c|}
\hline \multirow{2}{*}{\multicolumn{4}{|c|}{ Sector }} & \multicolumn{3}{|c|}{ Edad } & \multirow{3}{*}{$\begin{array}{l}\text { Total } \\
100,0 \%\end{array}$} \\
\hline & & & & \multirow{2}{*}{$\begin{array}{r}\text { De } 20 \text { a } 40 \\
28,6 \% \\
\end{array}$} & \multirow{2}{*}{$\begin{array}{r}\text { De } 41 \text { a } 60 \\
71,4 \%\end{array}$} & \multirow{2}{*}{$\begin{array}{r}\text { De } 61 \text { en adelante } \\
0,0 \% \\
\end{array}$} & \\
\hline \multirow{16}{*}{$\begin{array}{l}\text { Servicios } \\
\text { (incluye } \\
\text { comercio) }\end{array}$} & \multirow{14}{*}{$\begin{array}{l}\text { Horas de } \\
\text { formación en resp. } \\
\text { social }\end{array}$} & \multirow{2}{*}{ Menos de 11} & $\%$ dentro de horas & & & & \\
\hline & & & $\%$ dentro de edad & $25,0 \%$ & $33,3 \%$ & $0,0 \%$ & $29,2 \%$ \\
\hline & & \multirow{2}{*}{ De 11 a 50} & $\%$ dentro de horas & $50,0 \%$ & $33,3 \%$ & $16,7 \%$ & $100,0 \%$ \\
\hline & & & $\%$ dentro de edad & $37,5 \%$ & $13,3 \%$ & $100,0 \%$ & $25,0 \%$ \\
\hline & & \multirow{2}{*}{ De 51 a 100} & $\%$ dentro de horas & $33,3 \%$ & $66,7 \%$ & $0,0 \%$ & $100,0 \%$ \\
\hline & & & $\%$ dentro de edad & $12,5 \%$ & $13,3 \%$ & $0,0 \%$ & $12,5 \%$ \\
\hline & & \multirow{2}{*}{ De 101 a 150} & $\%$ dentro de horas & $0,0 \%$ & $100,0 \%$ & $0,0 \%$ & $100,0 \%$ \\
\hline & & & $\%$ dentro de edad & $0,0 \%$ & $20,0 \%$ & $0,0 \%$ & $12,5 \%$ \\
\hline & & \multirow{2}{*}{ De 151 a 200} & $\%$ dentro de horas & $0,0 \%$ & $100,0 \%$ & $0,0 \%$ & $100,0 \%$ \\
\hline & & & $\%$ dentro de edad & $0,0 \%$ & $6,7 \%$ & $0,0 \%$ & $4,2 \%$ \\
\hline & & \multirow{2}{*}{ De 201 a 1000} & $\%$ dentro de horas & $100,0 \%$ & $0,0 \%$ & $0,0 \%$ & $100,0 \%$ \\
\hline & & & $\%$ dentro de edad & $12,5 \%$ & $0,0 \%$ & $0,0 \%$ & $4,2 \%$ \\
\hline & & \multirow{2}{*}{ Más de 1000} & $\%$ dentro de horas & $33,3 \%$ & $66,7 \%$ & $0,0 \%$ & $100,0 \%$ \\
\hline & & & $\%$ dentro de edad & $12,5 \%$ & $13,3 \%$ & $0,0 \%$ & $12,5 \%$ \\
\hline & Total & & $\%$ dentro de horas & $33,3 \%$ & $62,5 \%$ & $4,2 \%$ & $100,0 \%$ \\
\hline & Total & & $\%$ dentro de edad & $100,0 \%$ & $100,0 \%$ & $100,0 \%$ & $100,0 \%$ \\
\hline \multirow{6}{*}{ Construcción } & \multirow{4}{*}{$\begin{array}{l}\text { Horas de } \\
\text { formación en resp. } \\
\text { social }\end{array}$} & \multirow{2}{*}{ De 11 a 50} & $\%$ dentro de horas & $0,0 \%$ & $100,0 \%$ & $0,0 \%$ & $100,0 \%$ \\
\hline & & & $\%$ dentro de edad & $0,0 \%$ & $66,7 \%$ & $0,0 \%$ & $50,0 \%$ \\
\hline & & \multirow{2}{*}{ De 101 a 150} & $\%$ dentro de horas & $0,0 \%$ & $50,0 \%$ & $50,0 \%$ & $100,0 \%$ \\
\hline & & & $\%$ dentro de edad & $0,0 \%$ & $33,3 \%$ & $100,0 \%$ & $50,0 \%$ \\
\hline & Total & & $\%$ dentro de horas & $0,0 \%$ & $75,0 \%$ & $25,0 \%$ & $100,0 \%$ \\
\hline & Total & & $\%$ dentro de edad & $0,0 \%$ & $100,0 \%$ & $100,0 \%$ & $100,0 \%$ \\
\hline & & Menes de 11 & $\%$ dentro de horas & $100,0 \%$ & $0,0 \%$ & $0,0 \%$ & $100,0 \%$ \\
\hline & & MIVITUS Me II & $\%$ dentro de edad & $75,0 \%$ & $0,0 \%$ & $0,0 \%$ & $27,3 \%$ \\
\hline & & De 11 a 50 & $\%$ dentro de horas & $0,0 \%$ & $66,7 \%$ & $33,3 \%$ & $100,0 \%$ \\
\hline & & De T1 a so & $\%$ dentro de edad & $0,0 \%$ & $33,3 \%$ & $100,0 \%$ & $27,3 \%$ \\
\hline & Horas de & De 51 a 100 & $\%$ dentro de horas & $0,0 \%$ & $100,0 \%$ & $0,0 \%$ & $100,0 \%$ \\
\hline Industria & social & De Si a TOU & $\%$ dentro de edad & $0,0 \%$ & $33,3 \%$ & $0,0 \%$ & $18,2 \%$ \\
\hline & & De 101 a 150 & $\%$ dentro de horas & $50,0 \%$ & $50,0 \%$ & $0,0 \%$ & $100,0 \%$ \\
\hline & & De 101 a 150 & $\%$ dentro de edad & $25,0 \%$ & $16,7 \%$ & $0,0 \%$ & $18,2 \%$ \\
\hline & & De 201 a 1000 & $\%$ dentro de horas & $0,0 \%$ & $100,0 \%$ & $0,0 \%$ & $100,0 \%$ \\
\hline & & De 201 a 1000 & $\%$ dentro de edad & $0,0 \%$ & $16,7 \%$ & $0,0 \%$ & $9,1 \%$ \\
\hline & Total & & $\%$ dentro de horas & $36,4 \%$ & $54,5 \%$ & $9,1 \%$ & $100,0 \%$ \\
\hline & Total & & $\%$ dentro de edad & $100,0 \%$ & $100,0 \%$ & $100,0 \%$ & $100,0 \%$ \\
\hline & & Menos de 11 & $\%$ dentro de horas & $50,0 \%$ & $50,0 \%$ & $0,0 \%$ & $100,0 \%$ \\
\hline & & IVlenos de 11 & $\%$ dentro de edad & $41,7 \%$ & $20,8 \%$ & $0,0 \%$ & $25,6 \%$ \\
\hline & & De 11 a 50 & $\%$ dentro de horas & $27,3 \%$ & $54,5 \%$ & $18,2 \%$ & $100,0 \%$ \\
\hline & & ve 11 a so & $\%$ dentro de edad & $25,0 \%$ & $25,0 \%$ & $66,7 \%$ & $28,2 \%$ \\
\hline & & De 51 a 100 & $\%$ dentro de horas & $20,0 \%$ & $80,0 \%$ & $0,0 \%$ & $100,0 \%$ \\
\hline & & De 51 a 100 & $\%$ dentro de edad & $8,3 \%$ & $16,7 \%$ & $0,0 \%$ & $12,8 \%$ \\
\hline & Horas de & 150 & $\%$ dentro de horas & $14,3 \%$ & $71,4 \%$ & $14,3 \%$ & $100,0 \%$ \\
\hline TOTAL & social & De Tula & $\%$ dentro de edad & $8,3 \%$ & $20,8 \%$ & $33,3 \%$ & $17,9 \%$ \\
\hline TUIAL & & De 151 a 200 & $\%$ dentro de horas & $0,0 \%$ & $100,0 \%$ & $0,0 \%$ & $100,0 \%$ \\
\hline & & DE IJ a 200 & $\%$ dentro de edad & $0,0 \%$ & $4,2 \%$ & $0,0 \%$ & $2,6 \%$ \\
\hline & & Re 201 a 1000 & $\%$ dentro de horas & $50,0 \%$ & $50,0 \%$ & $0,0 \%$ & $100,0 \%$ \\
\hline & & De $\angle 01$ a 1000 & $\%$ dentro de edad & $8,3 \%$ & $4,2 \%$ & $0,0 \%$ & $5,1 \%$ \\
\hline & & Más de 1000 & $\%$ dentro de horas & $33,3 \%$ & $66,7 \%$ & $0,0 \%$ & $100,0 \%$ \\
\hline & & IVids de inov & $\%$ dentro de edad & $8,3 \%$ & $8,3 \%$ & $0,0 \%$ & $7,7 \%$ \\
\hline & Total & & $\%$ dentro de horas & $30,8 \%$ & $61,5 \%$ & $7,7 \%$ & $100,0 \%$ \\
\hline & Total & & $\%$ dentro de edad & $100,0 \%$ & $100,0 \%$ & $100,0 \%$ & $100,0 \%$ \\
\hline
\end{tabular}

Cuadro 110: Tabla de contingencia de formación en responsabilidad social, sector y edad. 
En el sector servicios los líderes de 41 a 60 años también presentan un protagonismo significativo en las empresas que invierten entre 11 y 50 horas (33\%). De todos modos, los líderes de 20 a 40 años tienen una presencia mayoritaria en las organizaciones que invierten entre 11 y 50 horas (50\%) y significativa en las organizaciones que impulsan acciones formativas de 51 a 100 horas enmarcadas en el ámbito de la responsabilidad social (33\%). Los líderes de este sector están concentrados, fundamentalmente, en las organizaciones que dedican 150 o menos horas a la formación en Responsabilidad Social Corporativa.

En cuanto al sector industria, de los cuatro casos registrados tres se han producido en los líderes de 41 a 60 . Y los cuatro casos de los que se ha recabado información se encuentran dentro de las empresas que dedican entre $11 \mathrm{y}$ 150 horas a formación encuadrada en el ámbito de la responsabilidad social.

En lo que respecta al sector industria, 10 de los 11 casos registrados se encuentran en la organizaciones que dedican 150 o menos horas a acciones formativas enmarcadas en la disciplina de la responsabilidad social. Como vemos, se mantiene la misma tendencia que en el sector servicios. En cuanto a las edades con mayor presencia en este sector, de nuevo se repite el protagonismo de los dos segmentos de edad indicados en el sector servicios. Para las organizaciones que dedican entre 11 y 50 horas a la formación encuadrada en el ámbito de la 
responsabilidad social y las que invierten entre 51 y 100 horas el líder mayoritario es el que tiene entre 41 y 60 años $(66,7 \%$ y $100 \%$ respectivamente). $Y$ en el caso de las empresas que invierten menos de 11 horas a formación en responsabilidad social dentro del sector industria, el líder con mayor presencia es el que tiene entre 20 y 40 años (100\% de los líderes procedentes de organizaciones que dedican menos de 11 horas a iniciativas formativas sobre responsabilidad social).

A continuación hemos incorporado el gráfico 51 para revisar, visualmente, si existe algún tipo de asociación en la variación de la edad y de las horas que las empresas dedican a la formación enmarcada en el ámbito de la Responsabilidad Social Corporativa dentro de los sectores analizados.

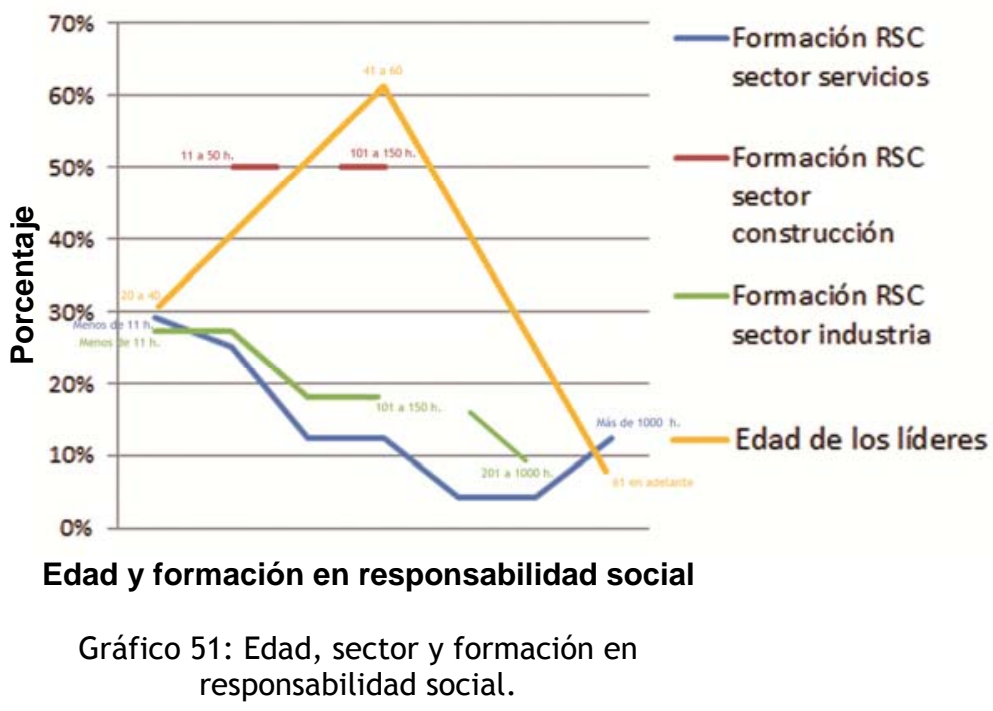

Los datos del gráfico 51 también parecen indicar, al igual que ocurría cuando hemos revisado el comportamiento responsable de las organizaciones en relación con la edad de 
sus líderes dentro de cada sector de actividad, que existe una cierta tendencia inversa entre la variación de la edad de los líderes entrevistados y de las horas que sus organizaciones de origen dedican a acciones formativas integradas en el ámbito de la Responsabilidad Social Corporativa (aunque en este caso los datos del sector construcción no son representativos y no hay presencia de líderes en todos los segmentos empresariales considerados en el sector industria).

\subsubsection{Edad, tamaño y Responsabilidad Social Corporativa}

En primer lugar hemos incorporado los datos sobre la edad de los líderes, el tamaño de sus organizaciones de procedencia y su actitud hacia la Responsabilidad Social Corporativa (cuadro 111).

\begin{tabular}{|c|c|c|c|c|c|}
\hline Tamaño & Edad & Media & Mínimo & Máximo & Desv. típ. \\
\hline \multirow{4}{*}{ Pequeño } & De 20 a 40 & 7,3472 & 4,81 & 8,13 & ,98531 \\
\hline & De 41 a 60 & 7,0245 & 3,86 & 8,08 & 1,11077 \\
\hline & De 61 en adelante & 6,6517 & 4,76 & 8,03 & 1,36233 \\
\hline & Total & 7,0845 & 3,86 & 8,13 & 1,11040 \\
\hline \multirow{4}{*}{ Mediano } & De 20 a 40 & 7,2229 & 4,39 & 8,10 & 1,10793 \\
\hline & De 41 a 60 & 7,1118 & 5,00 & 8,10 & 1,07205 \\
\hline & De 61 en adelante & 6,7500 & 6,75 & 6,75 & \\
\hline & Total & 7,1458 & 4,39 & 8,10 & 1,06398 \\
\hline \multirow{4}{*}{ Grande } & De 20 a 40 & 7,8237 & 7,27 & 8,10 & ,33188 \\
\hline & De 41 a 60 & 7,6465 & 5,40 & 8,07 & ,76772 \\
\hline & De 61 en adelante & 7,3005 & 6,20 & 8,12 & 1,00618 \\
\hline & Total & 7,6528 & 5,40 & 8,12 & ,70090 \\
\hline \multirow{4}{*}{ TOTAL } & De 20 a 40 & 7,3985 & 4,39 & 8,13 & 95226 \\
\hline & De 41 a 60 & 7,1522 & 3,86 & 8,10 & 1,06686 \\
\hline & De 61 en adelante & 6,8483 & 4,76 & 8,12 & 1,22644 \\
\hline & Total & 7,2043 & 3,86 & 8,13 & 1,05294 \\
\hline
\end{tabular}

Cuadro 111: Medidas estadísticas de tamaño, edad y actitud hacia la responsabilidad social. 
Antes de revisar los datos del cuadro 111 hemos aplicado ANOVA de un factor en la muestra poblacional para verificar si existen diferencias estadísticamente significativas entre los diversos grupos muestrales contemplados.

\begin{tabular}{|l|l|r|r|r|c|c|}
\hline \multicolumn{2}{|c|}{} & Suma de cuadrados & gl & Media cuadrática & F & Sig. \\
\hline \multirow{4}{*}{ Edad } & Inter-grupos & 28,159 & 80 &, 352 &, 960 &, 573 \\
\cline { 2 - 8 } & Intra-grupos & 39,598 & 108 &, 367 & & \\
\cline { 2 - 8 } & Total & 67,757 & 188 & & & \\
\hline \multirow{4}{*}{ Tamaño } & Inter-grupos & 39,531 & 80 &, 494 &, 707 &, 948 \\
\cline { 2 - 8 } & Intra-grupos & 75,495 & 108 &, 699 & & \\
\cline { 2 - 8 } & Total & 115,026 & 188 & & & \\
\hline
\end{tabular}

Cuadro 112: Tabla ANOVA tamaño y edad, factor Actitud hacia la Responsabilidad Social.

La información que ofrece el cuadro 112 indica que no existen diferencias estadísticamente significativas entre los grupos muestrales que integran la muestra poblacional (sus coeficientes de significación son superiores a 0,05).

En la revisión de la información que ofrece el cuadro 111 no hemos considerado, por su escaso valor representativo, los grupos muestrales en los que solo se ha recabado información de un líder.

En todos los tamaños empresariales contemplados, el incremento de la edad del líder ha supuesto una reducción de su actitud media hacia la Responsabilidad Social Corporativa. En las empresas pequeñas la puntuación media de la actitud de los máximos responsables ha decrecido de 7,34 (líderes de 20 a 40 años) a 6,65 (máximos responsables de más de 60 años). En las medianas de 7,22 (máximos 
responsables de 20 a 40 años) a 7,11 (líderes de 20 a 40 años). Y en las empresas grandes de 7,87 (líderes de 20 a 40 años) a 7,3 (máximos responsables de 61 años en adelante).

Hay cierta proximidad en las puntuaciones medias de la actitud que se ha registrado en los líderes de empresas pequeñas y medianas, mientras que los líderes de las empresas grandes han obtenido la mayor puntuación media de todas las franjas de edad: 7,87 en los líderes de 20 a 40 años (frente al 7,22 y 7,34 en los máximos responsables de empresas medianas y pequeñas respectivamente de esa edad), 7,64 en los máximos responsables de 41 a 60 años (frente al 7,11 y 7,02 en los líderes de 40 a 60 años de empresas medianas y de organizaciones pequeñas en cada caso) y 7,3 en los líderes de más de 60 años (frente a 7,08 en los máximos responsables de las empresas pequeñas de 61 años en adelante).

Hemos incorporado el siguiente gráfico para detectar visualmente posibles asociaciones entre las variables:

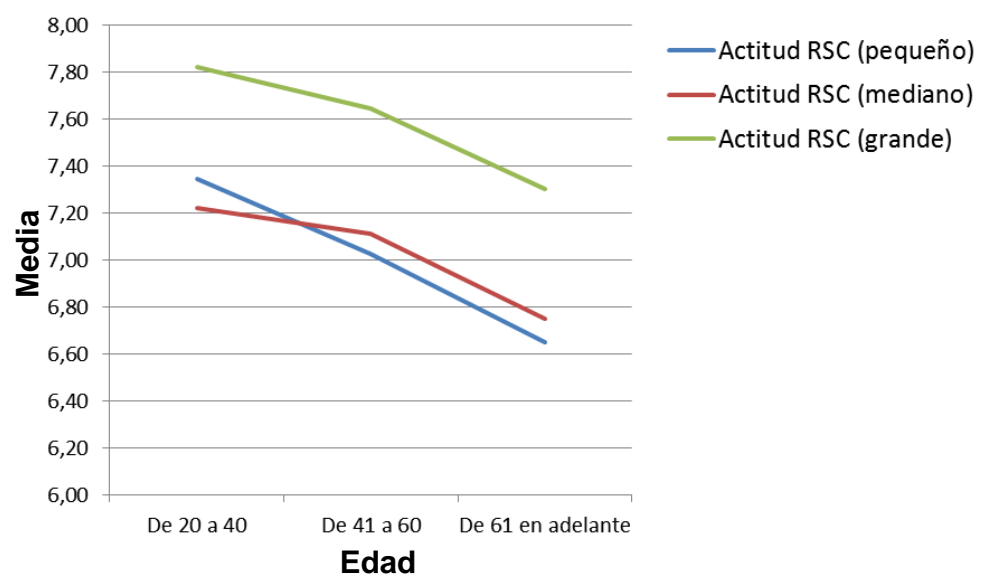

Gráfico 52: Edad, tamaño, edad y actitud hacia la responsabilidad social. 
La información visual que ofrece el gráfico 50 muestra que, independientemente del tamaño de la organización de procedencia del líder, a medida que se incrementa la edad del máximo responsable se reduce su disposición a favor de la Responsabilidad Social Corporativa.

A continuación hemos revisado, en primer lugar, los datos sobre la edad de los líderes, el tamaño de las empresas y su comportamiento socialmente responsable (cuadro 113).

La información que aporta el cuadro 113 muestra cierta similitud al comparar los tres tamaños empresariales estudiados. De todos modos también es posible advertir algunas diferencias en el comportamiento de las variables analizadas. Hemos descartado en la lectura de los datos, por su escasa representatividad, aquellos grupos muestrales en los que solo se ha recabado información de un líder.

En las organizaciones pequeñas los líderes de 41 a 60 años son mayoría en todos los tipos de comportamiento socialmente responsable $(59,7 \%$ en el caso de las empresas que no desarrollan ningún tipo de iniciativa, $70,8 \%$ en las que impulsan acciones esporádicas y $100 \%$ en las que desarrollan acciones integradas en una política de responsabilidad social) excepto en el caso de las empresas que desarrollan acciones de responsabilidad social de modo frecuente, donde el $70 \%$ de los líderes de este tipo de organizaciones tienen de 20 a 40 años. 


\begin{tabular}{|c|c|c|c|c|c|c|c|}
\hline \multirow{2}{*}{\multicolumn{4}{|c|}{ Tamaño }} & \multicolumn{3}{|c|}{ Edad } & \multirow{3}{*}{$\begin{array}{l}\text { Total } \\
100,0 \% \\
\end{array}$} \\
\hline & & & & \multirow{2}{*}{$\begin{array}{r}\text { De } 20 \text { a } 40 \\
31,9 \% \\
\end{array}$} & \multirow{2}{*}{$\begin{array}{r}\text { De } 41 \text { a } 60 \\
59,7 \%\end{array}$} & \multirow{2}{*}{$\begin{array}{r}\begin{array}{l}\text { De } 61 \text { en } \\
\text { adelante }\end{array} \\
8,3 \%\end{array}$} & \\
\hline \multirow{10}{*}{ Pequeño } & \multirow{8}{*}{$\begin{array}{l}\text { Acciones } \\
\text { de resp. } \\
\text { social }\end{array}$} & \multirow{2}{*}{ No } & $\%$ dentro de acciones & & & & \\
\hline & & & $\%$ dentro de edad & $69,7 \%$ & $66,2 \%$ & $54,5 \%$ & $66,1 \%$ \\
\hline & & \multirow{2}{*}{ Sí, acciones puntuales } & $\%$ dentro de acciones & $12,5 \%$ & $70,8 \%$ & $16,7 \%$ & $100,0 \%$ \\
\hline & & & $\%$ dentro de edad & $9,1 \%$ & $26,2 \%$ & $36,4 \%$ & $22,0 \%$ \\
\hline & & \multirow{2}{*}{$\begin{array}{l}\text { Sí, acciones frecuentes sin } \\
\text { una política definida de RS }\end{array}$} & $\%$ dentro de acciones & $70,0 \%$ & $20,0 \%$ & $10,0 \%$ & $100,0 \%$ \\
\hline & & & $\%$ dentro de edad & $21,2 \%$ & $3,1 \%$ & $9,1 \%$ & $9,2 \%$ \\
\hline & & \multirow{2}{*}{$\begin{array}{l}\text { Sí, acciones integradas en } \\
\text { una política de RS }\end{array}$} & $\%$ dentro de acciones & $0,0 \%$ & $100,0 \%$ & $0,0 \%$ & $100,0 \%$ \\
\hline & & & $\%$ dentro de edad & $0,0 \%$ & $4,6 \%$ & $0,0 \%$ & $2,8 \%$ \\
\hline & \multirow{2}{*}{\multicolumn{2}{|c|}{ Total }} & $\%$ dentro de acciones & $30,3 \%$ & $59,6 \%$ & $10,1 \%$ & $100,0 \%$ \\
\hline & & & $\%$ dentro de edad & $100,0 \%$ & $100,0 \%$ & $100,0 \%$ & $100,0 \%$ \\
\hline \multirow{10}{*}{ Mediano } & \multirow{8}{*}{$\begin{array}{l}\text { Acciones } \\
\text { de resp. } \\
\text { social }\end{array}$} & \multirow{2}{*}{ No } & $\%$ dentro de acciones & $22,2 \%$ & $72,2 \%$ & $5,6 \%$ & $100,0 \%$ \\
\hline & & & $\%$ dentro de edad & $23,5 \%$ & $48,1 \%$ & $100,0 \%$ & $40,0 \%$ \\
\hline & & \multirow{2}{*}{ Sí, acciones puntuales } & $\%$ dentro de acciones & $50,0 \%$ & $50,0 \%$ & $0,0 \%$ & $100,0 \%$ \\
\hline & & & $\%$ dentro de edad & $23,5 \%$ & $14,8 \%$ & $0,0 \%$ & $17,8 \%$ \\
\hline & & \multirow{2}{*}{$\begin{array}{l}\text { Sí, acciones frecuentes sin } \\
\text { una política definida de RS }\end{array}$} & $\%$ dentro de acciones & $50,0 \%$ & $50,0 \%$ & $0,0 \%$ & $100,0 \%$ \\
\hline & & & $\%$ dentro de edad & $23,5 \%$ & $14,8 \%$ & $0,0 \%$ & $17,8 \%$ \\
\hline & & \multirow{2}{*}{$\begin{array}{l}\text { Sí, acciones integradas en } \\
\text { una política de RS }\end{array}$} & $\%$ dentro de acciones & $45,5 \%$ & $54,5 \%$ & $0,0 \%$ & $100,0 \%$ \\
\hline & & & $\%$ dentro de edad & $29,4 \%$ & $22,2 \%$ & $0,0 \%$ & $24,4 \%$ \\
\hline & \multirow{2}{*}{\multicolumn{2}{|c|}{ Total }} & $\%$ dentro de acciones & $37,8 \%$ & $60,0 \%$ & $2,2 \%$ & $100,0 \%$ \\
\hline & & & $\%$ dentro de edad & $100,0 \%$ & $100,0 \%$ & $100,0 \%$ & $100,0 \%$ \\
\hline \multirow{10}{*}{ Grande } & \multirow{8}{*}{$\begin{array}{l}\text { Acciones } \\
\text { de resp. } \\
\text { social }\end{array}$} & \multirow{2}{*}{ No } & $\%$ dentro de acciones & $100,0 \%$ & $0,0 \%$ & $0,0 \%$ & $100,0 \%$ \\
\hline & & & $\%$ dentro de edad & $9,1 \%$ & $0,0 \%$ & $0,0 \%$ & $2,9 \%$ \\
\hline & & \multirow{2}{*}{ Sí, acciones puntuales } & $\%$ dentro de acciones & $75,0 \%$ & $25,0 \%$ & $0,0 \%$ & $100,0 \%$ \\
\hline & & & $\%$ dentro de edad & $27,3 \%$ & $5,3 \%$ & $0,0 \%$ & $11,4 \%$ \\
\hline & & Sí, acciones frecuentes sin & $\%$ dentro de acciones & $28,6 \%$ & $71,4 \%$ & $0,0 \%$ & $100,0 \%$ \\
\hline & & una política definida de RS & $\%$ dentro de edad & $18,2 \%$ & $26,3 \%$ & $0,0 \%$ & $20,0 \%$ \\
\hline & & Sí, acciones integradas en & $\%$ dentro de acciones & $21,7 \%$ & $56,5 \%$ & $21,7 \%$ & $100,0 \%$ \\
\hline & & una política de RS & $\%$ dentro de edad & $45,5 \%$ & $68,4 \%$ & $100,0 \%$ & $65,7 \%$ \\
\hline & Total & & $\%$ dentro de acciones & $31,4 \%$ & $54,3 \%$ & $14,3 \%$ & $100,0 \%$ \\
\hline & TOtal & & $\%$ dentro de edad & $100,0 \%$ & $100,0 \%$ & $100,0 \%$ & $100,0 \%$ \\
\hline & & $\mathrm{No}$ & $\%$ dentro de acciones & $30,8 \%$ & $61,5 \%$ & $7,7 \%$ & $100,0 \%$ \\
\hline & & TNO & $\%$ dentro de edad & $45,9 \%$ & $50,5 \%$ & $41,2 \%$ & $48,1 \%$ \\
\hline & & Sí acciones nuntuales & $\%$ dentro de acciones & $27,8 \%$ & $61,1 \%$ & $11,1 \%$ & $100,0 \%$ \\
\hline & & i, actionies purituares & $\%$ dentro de edad & $16,4 \%$ & $19,8 \%$ & $23,5 \%$ & $19,0 \%$ \\
\hline TOTAL & social & Sí, acciones frecuentes sin & $\%$ dentro de acciones & $52,0 \%$ & $44,0 \%$ & $4,0 \%$ & $100,0 \%$ \\
\hline & & una política definida de RS & $\%$ dentro de edad & $21,3 \%$ & $9,9 \%$ & $5,9 \%$ & $13,2 \%$ \\
\hline & & Sí, acciones integradas en & $\%$ dentro de acciones & $27,0 \%$ & $59,5 \%$ & $13,5 \%$ & $100,0 \%$ \\
\hline & & una política de RS & $\%$ dentro de edad & $16,4 \%$ & $19,8 \%$ & $29,4 \%$ & $19,6 \%$ \\
\hline & Total & & $\%$ dentro de acciones & $32,3 \%$ & $58,7 \%$ & $9,0 \%$ & $100,0 \%$ \\
\hline & Total & & $\%$ dentro de edad & $100,0 \%$ & $100,0 \%$ & $100,0 \%$ & $100,0 \%$ \\
\hline
\end{tabular}

Cuadro 113: Tabla de contingencia de acciones de responsabilidad social, tamaño y edad.

En las empresas medianas se repite la misma tendencia dominante. El líder de 41 a 60 años tiene una presencia destacada en las empresas que no realizan ningún tipo de iniciativa $(72,2 \%)$, las que impulsan acciones puntuales $(50 \%)$, las que desarrollan iniciativas de forma frecuente $(50 \%)$ y las que cuentan con una política definida de Responsabilidad Social Corporativa (54,5). De todos modos, en las empresas medianas la presencia de líderes de 
20 a 40 años es mayor: el 50\% en las empresas que impulsan acciones puntuales y en las organizaciones que desarrollan acciones frecuentes, y el $45,5 \%$ en las organizaciones que cuentan con una política de responsabilidad social definida.

En las organizaciones grandes los líderes de 41 a 60 años vuelven a tener una presencia destacada. En el caso de las empresas que desarrollan acciones frecuentes representan el $71,4 \%$ de los líderes procedentes de este tipo de organizaciones y en las empresas que impulsan acciones de Responsabilidad Social Corporativa enmarcadas en una política definida de responsabilidad social suponen el 56,6\%. En las organizaciones que realizan acciones puntuales los líderes con más protagonismo tienen entre 20 y 40 años (75\%).

A continuación hemos incorporado el gráfico 53 para revisar, de modo visual, si existe algún tipo de asociación en la variación del comportamiento responsable y de la edad de los líderes dentro de cada tamaño empresarial:

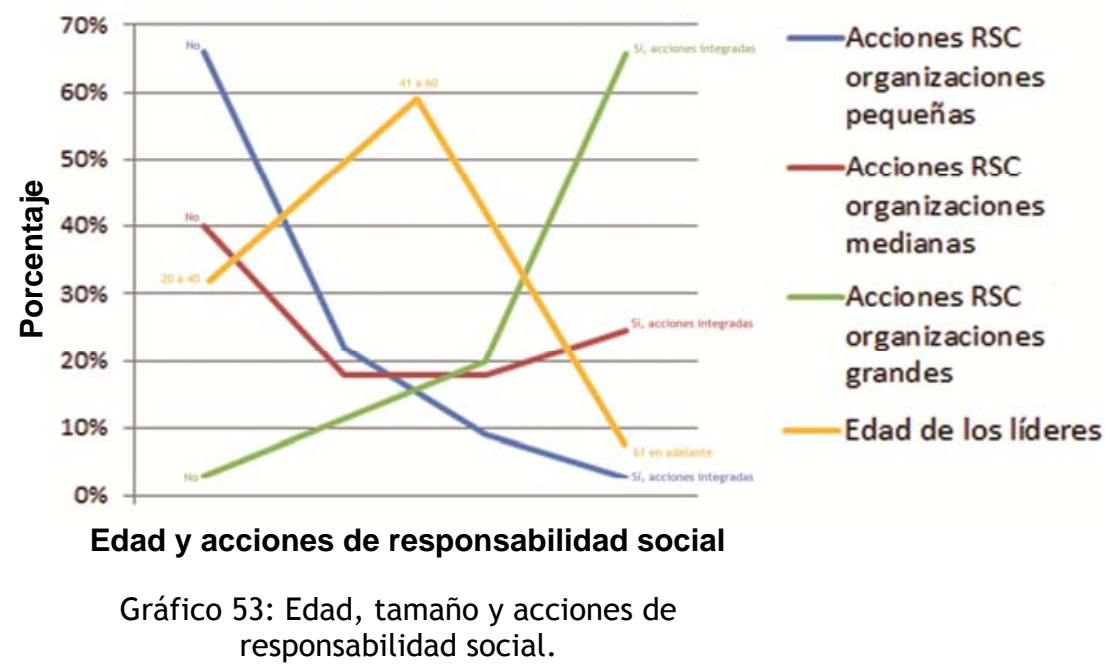


La información que aporta el gráfico 53 indica que la variación de la edad de los líderes del estudio presenta un comportamiento inverso, en cierta medida, en relación con la actuación socialmente responsable de las empresas medianas. La edad tiende a crecer primero para luego disminuir y las empresas medianas que no realizan ningún tipo de actuación socialmente responsable tienden, en primera instancia, a reducirse y finalmente a aumentar cuando su actuación es más intensa desde el punto de vista de la responsabilidad social.

Con las organizaciones grandes parece darse un cierto paralelismo en el crecimiento del número de empresas que se comportan socialmente de forma responsable y el aumento de los líderes de 60 o menos años en las organizaciones.

En las empresa pequeñas se aprecia un cierto paralelismo entre la reducción de su presencia en la muestra a medida que aumenta su comportamiento responsable y el protagonismo en el estudio de los líderes de mayor edad (a partir de los 60 años es muy pequeño).

A continuación hemos revisado los datos sobre la edad de líderes, el tamaño de las organizaciones y el desarrollo de acciones formativas enmarcadas en el ámbito de la responsabilidad social.

En la revisión de los datos (cuadro 114) no hemos considerado, por su reducida representatividad, aquellos 


\section{grupos muestrales en los que solo se ha obtenido información de un líder.}

\begin{tabular}{|c|c|c|c|c|c|c|c|}
\hline \multirow{2}{*}{\multicolumn{4}{|c|}{ Tamaño }} & \multicolumn{3}{|c|}{ Edad } & \multirow{3}{*}{$\begin{array}{l}\text { Total } \\
100,0 \%\end{array}$} \\
\hline & & & & \multirow{2}{*}{$\begin{array}{r}\text { De } 20 \text { a } 40 \\
0,0 \%\end{array}$} & \multirow{2}{*}{$\begin{array}{r}\text { De } 41 \text { a } 60 \\
100,0 \% \\
\end{array}$} & \multirow{2}{*}{$\begin{array}{r}\text { De } 61 \text { en adelante } \\
0,0 \%\end{array}$} & \\
\hline \multirow{12}{*}{ Pequeño } & \multirow{10}{*}{$\begin{array}{l}\text { Horas de } \\
\text { formación en } \\
\text { resp. social }\end{array}$} & \multirow{2}{*}{ Menos de 11} & $\%$ dentro de acciones & & & & \\
\hline & & & $\%$ dentro de edad & $0,0 \%$ & $33,3 \%$ & $0,0 \%$ & $25,0 \%$ \\
\hline & & \multirow{2}{*}{ De 11 a 50} & $\%$ dentro de acciones & $66,7 \%$ & $33,3 \%$ & $0,0 \%$ & $100,0 \%$ \\
\hline & & & $\%$ dentro de edad & $100,0 \%$ & $11,1 \%$ & $0,0 \%$ & $25,0 \%$ \\
\hline & & \multirow{2}{*}{ De 51 a 100} & $\%$ dentro de acciones & $0,0 \%$ & $100,0 \%$ & $0,0 \%$ & $100,0 \%$ \\
\hline & & & $\%$ dentro de edad & $0,0 \%$ & $22,2 \%$ & $0,0 \%$ & $16,7 \%$ \\
\hline & & \multirow{2}{*}{ De 101 a 150} & $\%$ dentro de acciones & $0,0 \%$ & $66,7 \%$ & $33,3 \%$ & $100,0 \%$ \\
\hline & & & $\%$ dentro de edad & $0,0 \%$ & $22,2 \%$ & $100,0 \%$ & $25,0 \%$ \\
\hline & & \multirow{2}{*}{ Más de 1000} & $\%$ dentro de acciones & $0,0 \%$ & $100,0 \%$ & $0,0 \%$ & $100,0 \%$ \\
\hline & & & $\%$ dentro de edad & $0,0 \%$ & $11,1 \%$ & $0,0 \%$ & $8,3 \%$ \\
\hline & \multirow{2}{*}{\multicolumn{2}{|c|}{ Total }} & $\%$ dentro de acciones & $16,7 \%$ & $75,0 \%$ & $8,3 \%$ & $100,0 \%$ \\
\hline & & & $\%$ dentro de edad & $100,0 \%$ & $100,0 \%$ & $100,0 \%$ & $100,0 \%$ \\
\hline \multirow{12}{*}{ Mediano } & \multirow{10}{*}{$\begin{array}{l}\text { Horas de } \\
\text { formación en } \\
\text { resp. social }\end{array}$} & Menes de 11 & $\%$ dentro de acciones & $80,0 \%$ & $20,0 \%$ & $0,0 \%$ & $100,0 \%$ \\
\hline & & IVIenos de 11 & $\%$ dentro de edad & $80,0 \%$ & $16,7 \%$ & $0,0 \%$ & $45,5 \%$ \\
\hline & & & $\%$ dentro de acciones & $0,0 \%$ & $100,0 \%$ & $0,0 \%$ & $100,0 \%$ \\
\hline & & De 11 a 50 & $\%$ dentro de edad & $0,0 \%$ & $33,3 \%$ & $0,0 \%$ & $18,2 \%$ \\
\hline & & & $\%$ dentro de acciones & $50,0 \%$ & $50,0 \%$ & $0,0 \%$ & $100,0 \%$ \\
\hline & & De 51 a 100 & $\%$ dentro de edad & $20,0 \%$ & $16,7 \%$ & $0,0 \%$ & $18,2 \%$ \\
\hline & & 1000 1 201 & $\%$ dentro de acciones & $0,0 \%$ & $100,0 \%$ & $0,0 \%$ & $100,0 \%$ \\
\hline & & De 201 a 1000 & $\%$ dentro de edad & $0,0 \%$ & $16,7 \%$ & $0,0 \%$ & $9,1 \%$ \\
\hline & & Mác de 1000 & $\%$ dentro de acciones & $0,0 \%$ & $100,0 \%$ & $0,0 \%$ & $100,0 \%$ \\
\hline & & Mlas de 1000 & $\%$ dentro de edad & $0,0 \%$ & $16,7 \%$ & $0,0 \%$ & $9,1 \%$ \\
\hline & & & $\%$ dentro de acciones & $45,5 \%$ & $54,5 \%$ & $0,0 \%$ & $100,0 \%$ \\
\hline & Total & & $\%$ dentro de edad & $100,0 \%$ & $100,0 \%$ & $0,0 \%$ & $100,0 \%$ \\
\hline & & Menos de 11 & $\%$ dentro de acciones & $50,0 \%$ & $50,0 \%$ & $0,0 \%$ & $100,0 \%$ \\
\hline & & Menos de 11 & $\%$ dentro de edad & $20,0 \%$ & $11,1 \%$ & $0,0 \%$ & $12,5 \%$ \\
\hline & & & $\%$ dentro de acciones & $16,7 \%$ & $50,0 \%$ & $33,3 \%$ & $100,0 \%$ \\
\hline & & De T1 a so & $\%$ dentro de edad & $20,0 \%$ & $33,3 \%$ & $100,0 \%$ & $37,5 \%$ \\
\hline & & 100 & $\%$ dentro de acciones & $0,0 \%$ & $100,0 \%$ & $0,0 \%$ & $100,0 \%$ \\
\hline & & De 51 a 100 & $\%$ dentro de edad & $0,0 \%$ & $11,1 \%$ & $0,0 \%$ & $6,3 \%$ \\
\hline & Horas de & 1010150 & $\%$ dentro de acciones & $25,0 \%$ & $75,0 \%$ & $0,0 \%$ & $100,0 \%$ \\
\hline Grande & resp. social & De 101 a 150 & $\%$ dentro de edad & $20,0 \%$ & $33,3 \%$ & $0,0 \%$ & $25,0 \%$ \\
\hline Grande & & ח0 1510101 & $\%$ dentro de acciones & $0,0 \%$ & $100,0 \%$ & $0,0 \%$ & $100,0 \%$ \\
\hline & & De 151 a 200 & $\%$ dentro de edad & $0,0 \%$ & $11,1 \%$ & $0,0 \%$ & $6,3 \%$ \\
\hline & & 1001010 & $\%$ dentro de acciones & $100,0 \%$ & $0,0 \%$ & $0,0 \%$ & $100,0 \%$ \\
\hline & & De 201 a 1000 & $\%$ dentro de edad & $20,0 \%$ & $0,0 \%$ & $0,0 \%$ & $6,3 \%$ \\
\hline & & Mác de 1000 & $\%$ dentro de acciones & $100,0 \%$ & $0,0 \%$ & $0,0 \%$ & $100,0 \%$ \\
\hline & & IVias de 1000 & $\%$ dentro de edad & $20,0 \%$ & $0,0 \%$ & $0,0 \%$ & $6,3 \%$ \\
\hline & Total & & $\%$ dentro de acciones & $31,3 \%$ & $56,3 \%$ & $12,5 \%$ & $100,0 \%$ \\
\hline & lotal & & $\%$ dentro de edad & $100,0 \%$ & $100,0 \%$ & $100,0 \%$ & $100,0 \%$ \\
\hline & & Menos de 11 & $\%$ dentro de acciones & $50,0 \%$ & $50,0 \%$ & $0,0 \%$ & $100,0 \%$ \\
\hline & & Menos de 11 & $\%$ dentro de edad & $41,7 \%$ & $20,8 \%$ & $0,0 \%$ & $25,6 \%$ \\
\hline & & م 11 a 50 & $\%$ dentro de acciones & $27,3 \%$ & $54,5 \%$ & $18,2 \%$ & $100,0 \%$ \\
\hline & & De traso & $\%$ dentro de edad & $25,0 \%$ & $25,0 \%$ & $66,7 \%$ & $28,2 \%$ \\
\hline & & 100 & $\%$ dentro de acciones & $20,0 \%$ & $80,0 \%$ & $0,0 \%$ & $100,0 \%$ \\
\hline & & De 51 a 100 & $\%$ dentro de edad & $8,3 \%$ & $16,7 \%$ & $0,0 \%$ & $12,8 \%$ \\
\hline & Horas de & 150 & $\%$ dentro de acciones & $14,3 \%$ & $71,4 \%$ & $14,3 \%$ & $100,0 \%$ \\
\hline ТОтА & $\begin{array}{l}\text { formacion en } \\
\text { resp. social }\end{array}$ & De 101 a 150 & $\%$ dentro de edad & $8,3 \%$ & $20,8 \%$ & $33,3 \%$ & $17,9 \%$ \\
\hline IOIAL & & 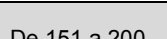 & $\%$ dentro de acciones & $0,0 \%$ & $100,0 \%$ & $0,0 \%$ & $100,0 \%$ \\
\hline & & De 151 a 200 & $\%$ dentro de edad & $0,0 \%$ & $4,2 \%$ & $0,0 \%$ & $2,6 \%$ \\
\hline & & 1000 & $\%$ dentro de acciones & $50,0 \%$ & $50,0 \%$ & $0,0 \%$ & $100,0 \%$ \\
\hline & & De 201 a 1000 & $\%$ dentro de edad & $8,3 \%$ & $4,2 \%$ & $0,0 \%$ & $5,1 \%$ \\
\hline & & Móc de 1000 & $\%$ dentro de acciones & $33,3 \%$ & $66,7 \%$ & $0,0 \%$ & $100,0 \%$ \\
\hline & & Inias de 1000 & $\%$ dentro de edad & $8,3 \%$ & $8,3 \%$ & $0,0 \%$ & $7,7 \%$ \\
\hline & Total & & $\%$ dentro de acciones & $30,8 \%$ & $61,5 \%$ & $7,7 \%$ & $100,0 \%$ \\
\hline & lotal & & $\%$ dentro de edad & $100,0 \%$ & $100,0 \%$ & $100,0 \%$ & $100,0 \%$ \\
\hline
\end{tabular}

Cuadro 114: Tabla de contingencia de formación en responsabilidad social, tamaño y edad. 
Hemos realizado la lectura de la información del cuadro 114 agrupando los datos sobre edad y formación en responsabilidad social según el tamaño de las empresas de procedencia de los líderes.

En las organizaciones pequeñas se produce la misma tónica que cuando hemos revisado la edad, el tamaño de las organizaciones y el desarrollo de acciones de responsabilidad social. En este caso hay una mayoría de líderes de 41 a 60 años en cuatro de los cinco grupos contemplados: el $100 \%$ de los líderes en las empresas que dedican menos de 11 horas, en las que invierten entre 51 y 100 horas y en las que destinan más de 1000 horas a formación encuadrada en la disciplina "responsabilidad social", y el $66,7 \%$ en las organizaciones que dedican entre 101 y 150 horas a este tipo de formación. Los líderes de 20 a 40 años son mayoría en las organizaciones que impulsan acciones formativas de 11 a 50 horas.

En las empresas medianas que dedican menos de 11 horas a formación en materia de responsabilidad social un $80 \%$ de los líderes tiene entre 20 y 40 años, y en las organizaciones que invierten entre 11 y 50 horas en ese tipo de formación el $100 \%$ de los máximos responsables tiene entre 41 y 60 años.

Dentro de las organizaciones grandes existe un protagonismo de los líderes de 41 a 60 años. En las empresas que destinan entre 11 y 50 horas a acciones formativas encuadradas en el ámbito de la responsabilidad social son mayoría los líderes de 41 a 60 años (50\%) aunque los 
máximos responsables de más de 60 años también tienen una presencia destacada (33\%). En las organizaciones que dedican entre 101 y 150 horas a iniciativas formativas sobre responsabilidad social, los líderes con más presencia son los que tienen entre 41 y 60 años (75\%).

Hemos incluido el grafico 54 a continuación para contemplar, de modo visual, si existe algún tipo de asociación en la variación de los datos sobre la edad de los líderes, el tamaño de las empresas y las horas que estas dedican a la formación enmarcada en el ámbito de la responsabilidad social.

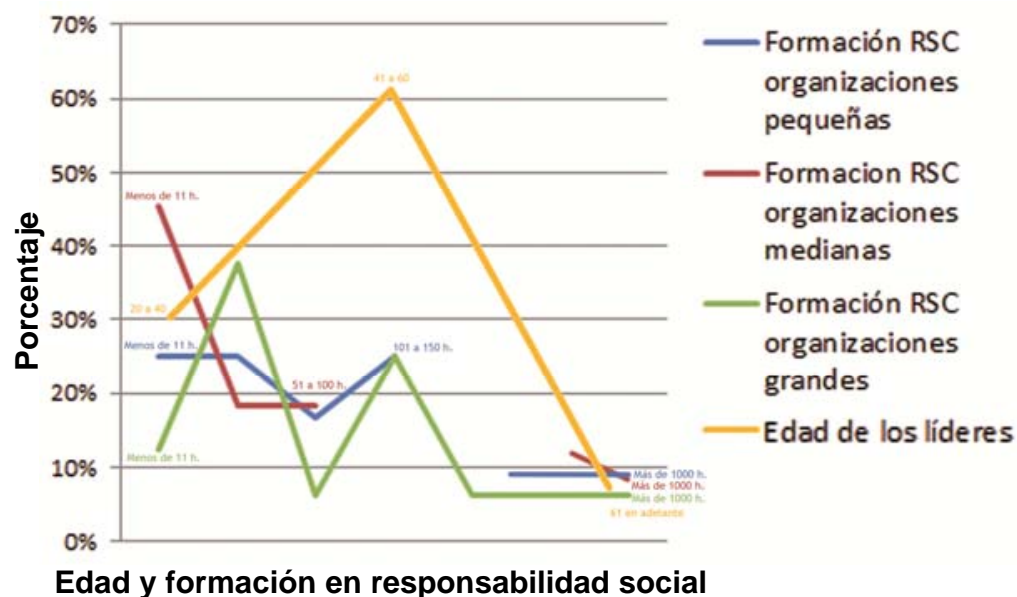

Gráfico 54: Edad, tamaño y formación en responsabilidad social.

El gráfico 54 no parece revelar alguna asociación directa en la variación del tamaño de las organizaciones, de la formación integrada en el ámbito de la responsabilidad social que está dirigida a sus públicos internos y de la edad de sus líderes. 
En términos generales, en algunos sectores no se han registrado datos en todas las opciones contempladas sobre horas dedicadas a la formación sobre responsabilidad social, parece existir una cierta relación entre el incremento de edad de los líderes (a partir de los 60 años su presencia en la muestra es muy reducida) y la presencia cada vez menor de organizaciones en la muestra a medida que incrementan el número de horas que dedican a sus actuaciones formativas encuadradas en la responsabilidad social.

\subsubsection{Edad, liderazgo y Responsabilidad Social Corporativa}

Hemos revisado, en primer término, los datos que hacen referencia a la edad de los líderes y a su liderazgo, junto con su actitud hacia la Responsabilidad Social Corporativa.

\begin{tabular}{|c|c|c|c|c|c|c|c|c|}
\hline \multicolumn{2}{|l|}{ Edad } & $\begin{array}{l}\text { Actitud hacia la } \\
\text { resp. social }\end{array}$ & $\begin{array}{c}\text { Estilo } \\
\text { directivo }\end{array}$ & $\begin{array}{c}\begin{array}{c}\text { Estilo } \\
\text { consultivo }\end{array} \\
\end{array}$ & \begin{tabular}{|c|} 
Estilo \\
participativo
\end{tabular} & \begin{tabular}{|c|}
$\begin{array}{c}\text { Estilo } \\
\text { delegativo }\end{array}$ \\
\end{tabular} & Flexibilidad & Efectividad \\
\hline \multirow{4}{*}{ De 20 a 40} & Media & 7,3985 & 2,80 & 6,36 & 7,43 & 3,34 & 19,61 & 55,67 \\
\hline & Mínimo & 4,39 & 0 & 2 & 1 & 0 & 12 & 44 \\
\hline & Máximo & 8,13 & 9 & 13 & 14 & 8 & 28 & 67 \\
\hline & Desv. típ. & ,95226 & 2,264 & 2,702 & 3,243 & 1,750 & 4,298 & 5,606 \\
\hline \multirow{4}{*}{ De 41 a 60} & Media & 7,1522 & 2,53 & 6,65 & 7,69 & 3,12 & 19,31 & 56,17 \\
\hline & Mínimo & 3,86 & 0 & 0 & 1 & 0 & 10 & 43 \\
\hline & Máximo & 8,10 & 8 & 14 & 15 & 14 & 26 & 67 \\
\hline & Desv. típ. & 1,06686 & 1,911 & 2,699 & 2,786 & 2,135 & 4,229 & 5,157 \\
\hline \multirow{4}{*}{$\begin{array}{l}\text { De } 61 \text { en } \\
\text { adelante }\end{array}$} & Media & 6,8483 & 1,65 & 5,94 & 9,12 & 3,29 & 17,53 & 55,65 \\
\hline & Mínimo & 4,76 & 0 & 1 & 3 & 1 & 10 & 46 \\
\hline & Máximo & 8,12 & 5 & 11 & 15 & 7 & 26 & 68 \\
\hline & Desv. típ. & 1,22644 & 1,869 & 2,839 & 3,389 & 1,724 & 4,215 & 5,700 \\
\hline \multirow{4}{*}{ TOTAL } & Media & 7,2043 & 2,54 & 6,49 & 7,74 & 3,21 & 19,24 & 55,96 \\
\hline & Mínimo & 3,86 & 0 & 0 & 1 & 0 & 10 & 43 \\
\hline & Máximo & 8,13 & 9 & 14 & 15 & 14 & 28 & 68 \\
\hline & Desv. típ. & 1,05294 & 2,041 & 2,707 & 3,013 & 1,977 & 4,264 & 5,331 \\
\hline
\end{tabular}

Cuadro 115: Medidas estadísticas de liderazgo, edad y actitud hacia la responsabilidad social. 
Antes de analizar la información que ofrece el cuadro 115, hemos aplicado ANOVA de un factor en la muestra poblacional para comprobar si existen diferencias estadísticamente significativas entre los diversos grupos muestrales que se han considerado.

\begin{tabular}{|c|c|c|c|c|c|c|}
\hline & & Suma de cuadrados & gl & Media cuadrática & $\mathbf{F}$ & Sig. \\
\hline \multirow{3}{*}{ Edad } & Inter-grupos & 28,159 & 80 & 352 & ,960 & ,573 \\
\hline & Intra-grupos & 39,598 & 108 & ,367 & & \\
\hline & Total & 67,757 & 188 & & & \\
\hline \multirow{3}{*}{ Estilo directivo } & Inter-grupos & 460,904 & 80 & 5,761 & 1,932 & ,001 \\
\hline & Intra-grupos & 322,049 & 108 & 2,982 & & \\
\hline & Total & 782,952 & 188 & & & \\
\hline \multirow{3}{*}{ Estilo consultivo } & Inter-grupos & 542,014 & 80 & 6,775 & 876 & ,732 \\
\hline & Intra-grupos & 835,224 & 108 & 7,734 & & \\
\hline & Total & 1377,238 & 188 & & & \\
\hline \multirow{3}{*}{ Estilo participativo } & Inter-grupos & 758,724 & 80 & 9,484 & 1,080 & ,352 \\
\hline & Intra-grupos & 948,049 & 108 & 8,778 & & \\
\hline & Total & 1706,772 & 188 & & & \\
\hline \multirow{3}{*}{ Estilo delegativo } & Inter-grupos & 361,062 & 80 & 4,513 & 1,304 & ,099 \\
\hline & Intra-grupos & 373,890 & 108 & 3,462 & & \\
\hline & Total & 734,952 & 188 & & & \\
\hline \multirow{3}{*}{ Flexibilidad } & Inter-grupos & 1712,188 & 80 & 21,402 & 1,354 & ,071 \\
\hline & Intra-grupos & 1706,617 & 108 & 15,802 & & \\
\hline & Total & 3418,804 & 188 & & & \\
\hline \multirow{3}{*}{ Efectividad } & Inter-grupos & 2304,729 & 80 & 28,809 & 1,024 & ,450 \\
\hline & Intra-grupos & 3038,012 & 108 & 28,130 & & \\
\hline & Total & 5342,741 & 188 & & & \\
\hline
\end{tabular}

Cuadro 116: Tabla ANOVA liderazgo y edad, factor Actitud hacia la Responsabilidad Social.

La información que ofrece el cuadro 116 indica que existen diferencias estadísticamente significativas entre los diversos grupos muestrales en relación con "estilo directivo" (su coeficiente de significación es 0,001 ).

Los datos que muestra el cuadro 115 indican que en el grupo en el que se ha registrado una actitud hacia la responsabilidad social más favorable, el de los líderes de 20 
a 40 años, también se ha obtenido la puntuación media más alta en el estilo directivo (aunque su media, 2,80, indica que este estilo tiene poco peso en las decisiones de los líderes), la puntuación media más baja en el estilo participativo (aun siendo una media que indica que este estilo tiene incidencia en las decisiones de los líderes, 7,43 ) y el grado de flexibilidad más alto en los tres segmentos de edad contemplados (la media de la flexibilidad de estilo de estos líderes ha sido 19,61).

Los líderes de 41 a 60 años, cuya actitud media es levemente inferior a la del grupo anterior $(7,15)$, han obtenido la media más alta en el estilo consultivo $(6,65)$ y en el estilo delegativo $(3,12)$ dentro de los tres segmentos de edad considerados. Además también han registrado la puntuación media más elevada en efectividad $(56,17)$ en relación con los tres grupos muestrales.

Los líderes de 61 años en adelante, que han obtenido la menor puntuación media en actitud $(6,84)$, también han registrado la puntuación media más baja en el estilo directivo $(1,65)$, en el estilo consultivo $(5,94)$ y en la flexibilidad de estilo $(17,53)$. Por el contrario, han obtenido el puntaje medio más alto en el estilo participativo $(9,12)$, lo que indica que en su estilo de liderazgo el apoyo es más relevante y la dirección menos. Estos líderes también han obtenido una puntuación media cercana a la máxima alcanzada en los tres grupos en el estilo delegativo $(3,29)$ y en la efectividad de estilo $(55,65)$. 
Considerando los tres grupos muestrales al mismo tiempo se constata que a medida que avanza la edad de los líderes y decrece su disposición a favor de la responsabilidad social, también se reduce la importancia que otorgan al estilo directivo (su media decrece de 2,8 a $1,65)$ y de la flexibilidad de estilo (su puntuación media se reduce de 19,61 a 17,53) y aumenta la importancia concedida al estilo participativo, alto apoyo y poca dirección, ya que su media aumenta de 7,43 a 9,12.

Además también se verifica que sea cual sea la actitud y la edad del líder, su estilo de liderazgo primario es el participativo (con mayor peso, como hemos indicado, en los líderes de 61 años en adelante) y su estilo de liderazgo secundario es el consultivo (alta dirección y mucho apoyo).

A continuación hemos incorporado el cuadro 117, con el valor de actitud segmentado, para detectar posibles variaciones en el liderazgo asociadas a cambios de actitud.

El cuadro 117 indica que en los líderes de 20 a 40 años, los más afines a la responsabilidad social, el estilo directivo parece perder relevancia a medida que su actitud responsable se intensifica (su valor medio pasa de 5,5 en los líderes del segmento "4 a <5" a 2,36 en los máximos responsables del segmento “7 a <8”). Además también parece reducirse su flexibilidad a medida que su actitud pro responsabilidad social es más favorable (su flexibilidad media se reduce de 26 en los máximos responsables del segmento " 4 a $<5$ " a 18,64 en los líderes del segmento "7 a 
$<8$ "). Sin embargo su efectividad tiende a aumentar a medida que se acentúa su actitud responsable (su valor medio aumenta de 49 en los líderes del segmento " $4 \mathrm{a}<5$ " a 57,09 en los máximos responsables del segmento "7 a >8”).

\begin{tabular}{|c|c|c|c|c|c|c|c|c|}
\hline Edad & $\begin{array}{l}\text { Actitu } \\
\text { res! }\end{array}$ & $\begin{array}{l}\text { hacia la } \\
\text { social }\end{array}$ & $\begin{array}{c}\text { Estilo } \\
\text { directivo }\end{array}$ & $\begin{array}{c}\text { Estilo } \\
\text { consultivo }\end{array}$ & $\begin{array}{c}\text { Estilo } \\
\text { participativo }\end{array}$ & $\begin{array}{c}\text { Estilo } \\
\text { delegativo }\end{array}$ & Flexibilidad & Efectividad \\
\hline \multirow{12}{*}{ De 20 a 40} & \multirow{2}{*}{$4 a<5$} & Media & 5,50 & 5,00 & 6,00 & 3,50 & 26,00 & 49,00 \\
\hline & & Desv. típ. & ,707 & 1,414 & 1,414 & ,707 &, 000 & 7,071 \\
\hline & \multirow{2}{*}{$5 a<6$} & Media & 4,40 & 5,60 & 5,60 & 4,40 & 22,00 & 54,60 \\
\hline & & Desv. típ. & 2,702 & 2,302 & 3,715 & 2,608 & 3,162 & 8,764 \\
\hline & \multirow{2}{*}{$6 a<7$} & Media & 3,43 & 7,29 & 6,14 & 3,14 & 20,29 & 55,57 \\
\hline & & Desv. típ. & 2,507 & 1,890 & 2,854 & 1,952 & 4,231 & 5,563 \\
\hline & \multirow{2}{*}{7 a 8} & Media & 2,36 & 6,85 & 7,67 & 3,06 & 18,64 & 57,09 \\
\hline & & Desv. típ. & 2,104 & 2,991 & 3,506 & 1,638 & 4,520 & 5,083 \\
\hline & \multirow{2}{*}{$>8$} & Media & 2,57 & 5,21 & 8,36 & 3,71 & 19,79 & 53,71 \\
\hline & & Desv. típ. & 2,174 & 2,293 & 2,560 & 1,684 & 3,534 & 4,811 \\
\hline & \multirow{2}{*}{ Total } & Media & 2,80 & 6,36 & 7,43 & 3,34 & 19,61 & 55,67 \\
\hline & & Desv. típ. & 2,264 & 2,702 & 3,243 & 1,750 & 4,298 & 5,606 \\
\hline \multirow{14}{*}{ De 41 a 60} & \multirow{2}{*}{$0 a<4$} & Media & 2,00 & 12,00 & 6,00 &, 00 & 14,00 & 57,00 \\
\hline & & Desv. típ. & & & & . & . & \\
\hline & \multirow{2}{*}{$4 a<5$} & Media & 3,25 & 6,75 & 8,25 & 1,75 & 20,25 & 57,50 \\
\hline & & Desv. típ. & 2,217 & 1,708 & 3,202 & ,957 & 6,021 & 4,655 \\
\hline & \multirow{2}{*}{$5 a<6$} & Media & 3,87 & 6,00 & 5,87 & 4,27 & 21,67 & 56,47 \\
\hline & & Desv. típ. & 2,134 & 2,854 & 2,232 & 3,105 & 4,135 & 4,470 \\
\hline & \multirow{2}{*}{$6 a<7$} & Media & 2,95 & 6,95 & 7,47 & 2,63 & 19,53 & 54,63 \\
\hline & & Desv. típ. & 1,810 & 2,272 & 3,470 & 1,535 & 4,247 & 4,284 \\
\hline & \multirow{2}{*}{7 a 8} & Media & 2,08 & 6,66 & 8,23 & 3,04 & 18,81 & 55,92 \\
\hline & & Desv. típ. & 1,719 & 2,526 & 2,607 & 1,754 & 3,798 & 5,320 \\
\hline & \multirow{2}{*}{$>8$} & Media & 2,21 & 6,53 & 7,84 & 3,37 & 18,68 & 57,84 \\
\hline & & Desv. típ. & 1,903 & 3,470 & 2,500 & 2,565 & 4,762 & 6,094 \\
\hline & \multirow{2}{*}{ Total } & Media & 2,53 & 6,65 & 7,69 & 3,12 & 19,31 & 56,17 \\
\hline & & Desv. típ. & 1,911 & 2,699 & 2,786 & 2,135 & 4,229 & 5,157 \\
\hline \multirow{12}{*}{$\begin{array}{l}\text { De } 61 \text { en } \\
\text { adelante }\end{array}$} & \multirow{2}{*}{$4 a<5$} & Media &, 00 & 5,00 & 8,00 & 7,00 & 20,00 & 51,00 \\
\hline & & Desv. típ. & . & & & & . & \\
\hline & \multirow{2}{*}{$5 a<6$} & Media & 2,00 & 4,00 & 12,00 & 2,00 & 14,00 & 51,00 \\
\hline & & Desv. típ. & 2,646 & 3,606 & 2,646 & 1,732 & 4,000 & 5,568 \\
\hline & $60<7$ & Media & 1,80 & 6,00 & 8,80 & 3,40 & 19,20 & 56,40 \\
\hline & 0 a $<1$ & Desv. típ. & 2,049 & 1,581 & 4,025 & 1,673 & 5,586 & 3,362 \\
\hline & 7 ค 8 & Media & 1,75 & 7,25 & 8,25 & 2,75 & 17,50 & 54,25 \\
\hline & 10 & Desv. típ. & 1,258 & 2,872 & 3,594 &, 500 & 1,000 & 5,500 \\
\hline & $>8$ & Media & 1,50 & 6,25 & 8,50 & 3,75 & 17,50 & 60,75 \\
\hline & $>8$ & Desv. típ. & 2,380 & 4,031 & 3,416 & 1,708 & 4,726 & 6,344 \\
\hline & Total & Media & 1,65 & 5,94 & 9,12 & 3,29 & 17,53 & 55,65 \\
\hline & Tolal & Desv. típ. & 1,869 & 2,839 & 3,389 & 1,724 & 4,215 & 5,700 \\
\hline & $00<1$ & Media & 2,00 & 12,00 & 6,00 &, 00 & 14,00 & 57,00 \\
\hline & $d d^{2}$ & Desv. típ. & & & & & & \\
\hline & $4 a<5$ & Media & 3,43 & 6,00 & 7,57 & 3,00 & 21,86 & 54,14 \\
\hline & $4 d<0$ & Desv. típ. & 2,440 & 1,633 & 2,573 & 2,082 & 5,113 & 6,094 \\
\hline & $5 a<6$ & Media & 3,74 & 5,65 & 6,61 & 4,00 & 20,74 & 55,35 \\
\hline & $5 a<0$ & Desv. típ. & 2,320 & 2,790 & 3,299 & 2,876 & 4,614 & 5,749 \\
\hline TOTAI & $60<7$ & Media & 2,87 & 6,87 & 7,39 & 2,87 & 19,65 & 55,13 \\
\hline IOIAL & 0 a $<1$ & Desv. típ. & 2,012 & 2,078 & 3,422 & 1,628 & 4,325 & 4,380 \\
\hline & 7 ค 8 & Media & 2,17 & 6,76 & 8,02 & 3,03 & 18,69 & 56,28 \\
\hline & $1 \mathrm{~d} 0$ & Desv. típ. & 1,844 & 2,691 & 2,983 & 1,666 & 3,985 & 5,230 \\
\hline & $>8$ & Media & 2,27 & 6,00 & 8,11 & 3,54 & 18,97 & 56,59 \\
\hline & $>8$ & Desv. típ. & 2,023 & 3,109 & 2,558 & 2,142 & 4,272 & 6,021 \\
\hline & Total & Media & 2,54 & 6,49 & 7,74 & 3,21 & 19,24 & 55,96 \\
\hline & Tolal & Desv. típ. & 2,041 & 2,707 & 3,013 & 1,977 & 4,264 & 5,331 \\
\hline
\end{tabular}

Cuadro 117: Medidas estadísticas de liderazgo, edad y actitud hacia la responsabilidad social. 
En el caso de los líderes de 41 a 60 años, de acuerdo a la información aportada por el cuadro 117, también parecen presentar una menor flexibilidad de estilo a medida que su actitud a favor de la responsabilidad social se intensifica (su valor medio decrece de 21,67 en los máximos responsables del segmento "5 a <6" a 18,68 en los líderes del segmento “>8”). Estos máximos responsables también presentan unas medias bastante próximas en el estilo consultivo en todos los segmentos, lo que es indicativo de que este estilo (secundario en todos los casos excepto en el segmento " $5 \mathrm{a}$ $<6$ " donde es el estilo primario) parece no verse afectado por cambios en la disposición de los líderes hacia la responsabilidad social. 0 , en otras palabras, que sea cual sea la actitud socialmente responsable, las directrices y el apoyo siempre están presentes en el estilo de dirección.

En los máximos responsables de más de 61 años se ha registrado, como en los líderes de 20 a 40 años, un aumento de su efectividad de estilo a medida que se ha intensificado su actitud a favor de la responsabilidad social (el valor medio de la efectividad aumenta de 51 en los líderes del segmento " 4 a <5” a 60,75 en los máximos responsables del grupo muestral “ $>8$ ").

Hemos incorporado a continuación los gráficos 55,56 , 57 y 58 para revisar, de modo visual, las asociaciones indicadas en la variación de los aspectos analizados del liderazgo y de la actitud hacia la responsabilidad social por grupos de edad. 


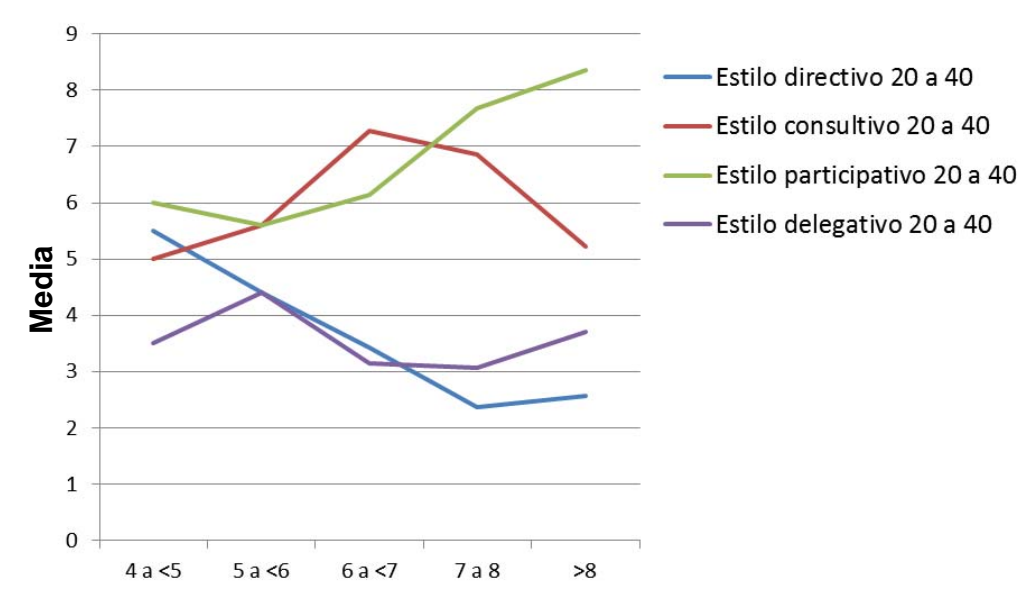

Actitud hacia la responsabilidad social

Gráfico 55: Liderazgo, 20 a 40 años y actitud hacia la responsabilidad social.

El gráfico 55 permite contemplar cómo a medida que se intensifica la actitud de los líderes de 20 a 40 años hacia la responsabilidad social, parece tender a decrecer la importancia que conceden al estilo directivo (alta dirección y poco apoyo) y a aumentar la relevancia que otorgan al estilo participativo (alto apoyo y poca dirección).

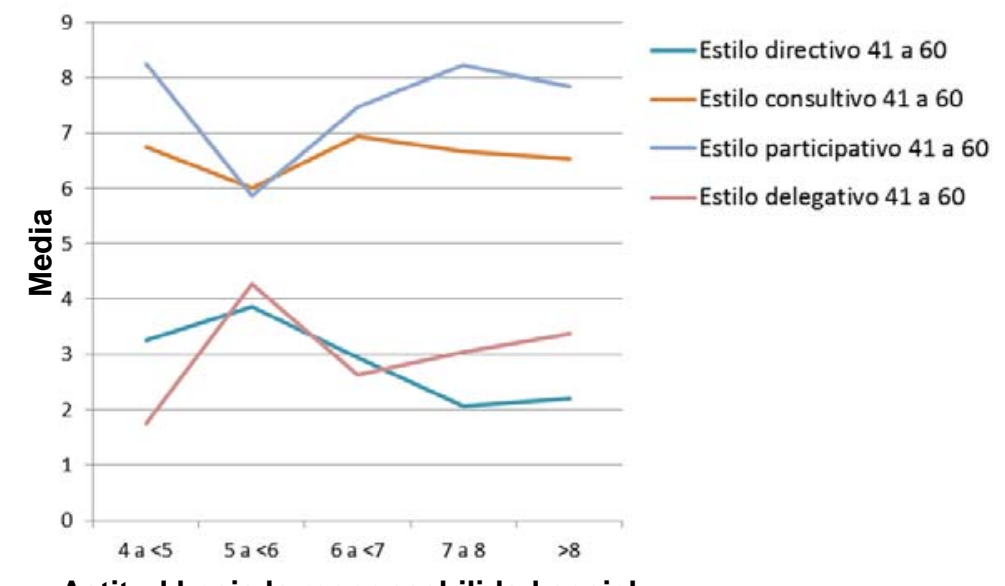

Actitud hacia la responsabilidad social

Gráfico 56: Liderazgo, 41 a 60 años y actitud hacia la responsabilidad social.

El gráfico 56 permite advertir una cierta tendencia decreciente en el estilo directivo de los máximos 
responsables de 41 a 60 años según aumenta su actitud a favor de la responsabilidad social.

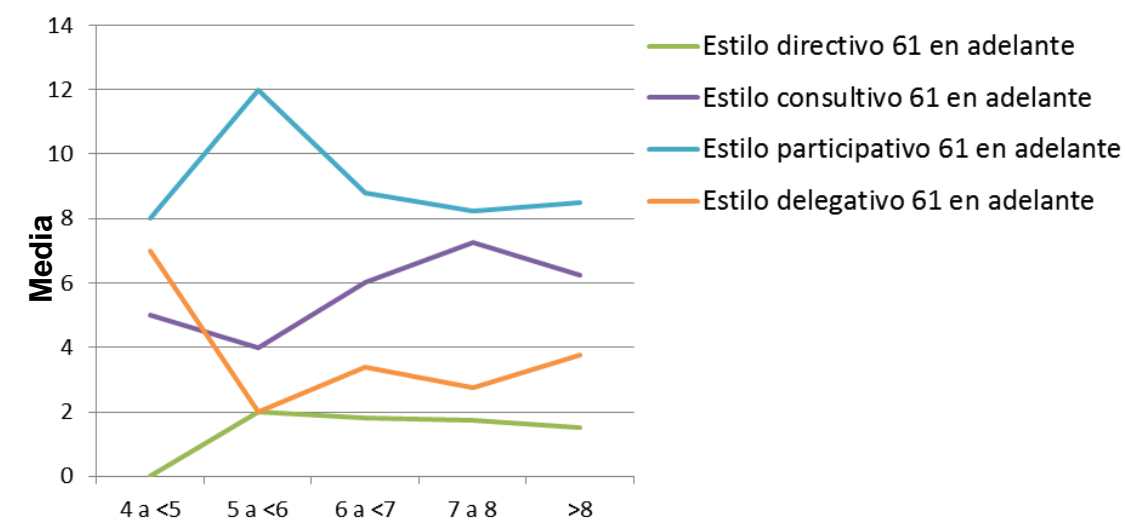

Actitud hacia la responsabilidad social

Gráfico 57: Liderazgo, 61 años en adelante y actitud hacia la responsabilidad social.

El gráfico 57 no permite atisbar, con claridad, asociaciones entre los estilos de liderazgo y la actitud hacia la responsabilidad en los máximos responsables de más de 61 años. Quizá existe una cierta tendencia creciente en el estilo consultivo a media que se intensifica la disposición de los líderes a favor de la Responsabilidad Social Corporativa.

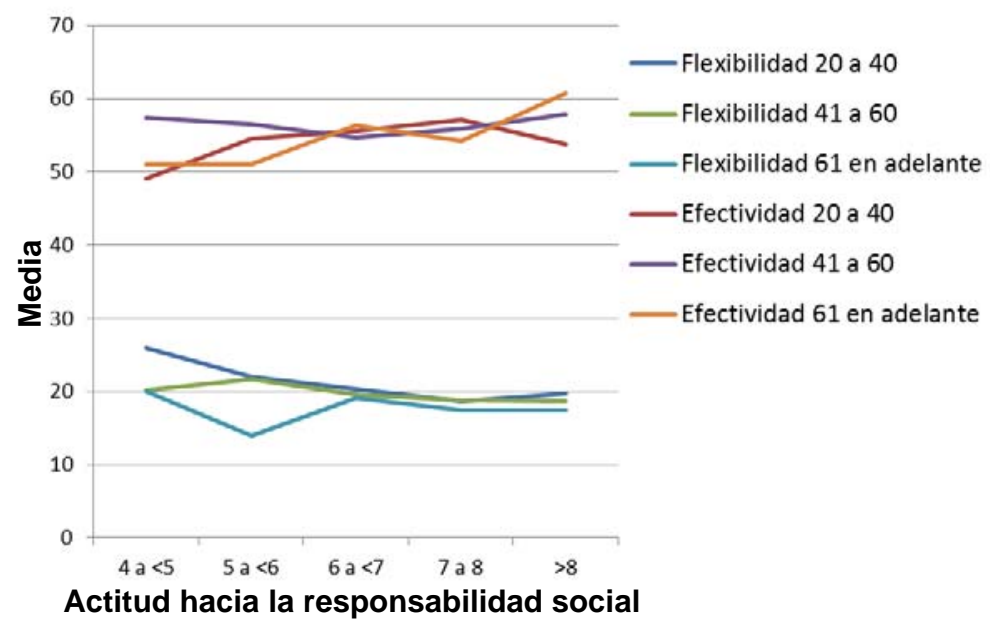

Gráfico 58: Efectividad, flexibilidad, edad y actitud hacia la responsabilidad social. 
El gráfico 58 permite advertir que la efectividad de estilo tiende a aumentar a medida que se intensifica la actitud a favor de la responsabilidad social (en mayor medida en los líderes de 20 a 40 años y de 61 en adelante).

También permite advertir que, en términos generales, la flexibilidad tiende a reducirse a medida que aumenta la afinidad por la Responsabilidad Social Corporativa (en menor grado en los líderes de más de 60 años).

\begin{tabular}{|c|c|c|c|c|c|c|c|c|}
\hline Edad & Acciones de resp. so & & $\begin{array}{c}\text { Estilo } \\
\text { directivo }\end{array}$ & $\begin{array}{c}\text { Estilo } \\
\text { consultivo }\end{array}$ & $\begin{array}{c}\text { Estilo } \\
\text { participativo }\end{array}$ & $\begin{array}{c}\text { Estilo } \\
\text { delegativo }\end{array}$ & Flexibilidad & Efectividad \\
\hline \multirow{10}{*}{ De 20 a 40} & \multirow{2}{*}{ No } & Media & 3,54 & 5,54 & 6,86 & 4,00 & 21,04 & 53,11 \\
\hline & & Desv. típ. & 2,411 & 2,617 & 3,407 & 1,764 & 4,256 & 5,486 \\
\hline & \multirow{2}{*}{ Sí, acciones puntuales } & Media & 2,00 & 6,30 & 9,00 & 2,70 & 18,80 & 58,90 \\
\hline & & Desv. típ. & 1,247 & 2,312 & 2,708 & 1,337 & 3,676 & 4,508 \\
\hline & \multirow{2}{*}{$\begin{array}{l}\text { Sí, acciones frecuentes sin una } \\
\text { política definida de RS }\end{array}$} & Media & 2,23 & 7,92 & 7,69 & 2,08 & 16,85 & 58,31 \\
\hline & & Desv. típ. & 2,555 & 2,532 & 3,449 & 1,320 & 3,826 & 4,820 \\
\hline & \multirow{2}{*}{$\begin{array}{l}\text { Sí, acciones integradas en una } \\
\text { política de RS }\end{array}$} & Media & 2,30 & 6,70 & 7,10 & 3,80 & 20,00 & 56,20 \\
\hline & & Desv. típ. & 1,829 & 2,908 & 2,846 & 1,619 & 4,190 & 5,051 \\
\hline & \multirow{2}{*}{ Total } & Media & 2,80 & 6,36 & 7,43 & 3,34 & 19,61 & 55,67 \\
\hline & & Desv. típ. & 2,264 & 2,702 & 3,243 & 1,750 & 4,298 & 5,606 \\
\hline \multirow{10}{*}{ De 41 a 60} & \multirow{2}{*}{ No } & Media & 2,95 & 6,59 & 6,82 & 3,45 & 20,11 & 55,84 \\
\hline & & Desv. típ. & 2,031 & 2,903 & 2,580 & 2,441 & 4,297 & 5,162 \\
\hline & \multirow{2}{*}{ Sí, acciones puntuales } & Media & 2,64 & 6,82 & 7,64 & 2,91 & 20,18 & 53,91 \\
\hline & & Desv. típ. & 1,761 & 2,085 & 2,460 & 1,571 & 3,647 & 4,869 \\
\hline & \multirow{2}{*}{$\begin{array}{l}\text { Sí, acciones frecuentes sin una } \\
\text { política definida de RS }\end{array}$} & Media & 1,73 & 5,91 & 9,09 & 3,27 & 17,64 & 56,55 \\
\hline & & Desv. típ. & 1,272 & 2,809 & 2,166 & 2,370 & 3,202 & 4,108 \\
\hline & \multirow{2}{*}{$\begin{array}{l}\text { Sí, acciones integradas en una } \\
\text { política de RS }\end{array}$} & Media & 1,77 & 7,00 & 9,27 & 2,41 & 17,23 & 59,09 \\
\hline & & Desv. típ. & 1,744 & 2,743 & 3,042 & 1,501 & 4,320 & 4,810 \\
\hline & \multirow{2}{*}{ Total } & Media & 2,53 & 6,65 & 7,69 & 3,12 & 19,31 & 56,17 \\
\hline & & Desv. típ. & 1,911 & 2,699 & 2,786 & 2,135 & 4,229 & 5,157 \\
\hline \multirow{10}{*}{$\begin{array}{l}\text { De } 61 \text { en } \\
\text { adelante }\end{array}$} & \multirow{2}{*}{ No } & Media & 2,14 & 6,86 & 7,43 & 3,57 & 19,43 & 52,43 \\
\hline & & Desv. típ. & 2,116 & 2,545 & 3,047 & 2,299 & 4,276 & 3,359 \\
\hline & \multirow{2}{*}{ Sí, acciones puntuales } & Media & 1,00 & 4,75 & 11,50 & 2,75 & 15,00 & 52,75 \\
\hline & & Desv. típ. & 1,155 & 2,872 & 2,517 & ,957 & 3,830 & 4,992 \\
\hline & \multirow{2}{*}{$\begin{array}{l}\text { Sí, acciones frecuentes sin una } \\
\text { política definida de RS }\end{array}$} & Media &, 00 & 2,00 & 12,00 & 6,00 & 14,00 & 63,00 \\
\hline & & Desv. típ. & & & & & & \\
\hline & \multirow{2}{*}{$\begin{array}{l}\text { Sí, acciones integradas en una } \\
\text { política de RS }\end{array}$} & Media & 1,80 & 6,40 & 9,00 & 2,80 & 17,60 & 61,00 \\
\hline & & Desv. típ. & 2,168 & 3,050 & 3,808 & ,837 & 4,099 & 4,301 \\
\hline & \multirow{2}{*}{ Total } & Media & 1,65 & 5,94 & 9,12 & 3,29 & 17,53 & 55,65 \\
\hline & & Desv. típ. & 1,869 & 2,839 & 3,389 & 1,724 & 4,215 & 5,700 \\
\hline \multirow{10}{*}{ TOTAL } & \multirow{2}{*}{ No } & Media & 3,07 & 6,29 & 6,88 & 3,63 & 20,34 & 54,74 \\
\hline & & Desv. típ. & 2,169 & 2,810 & 2,863 & 2,234 & 4,264 & 5,297 \\
\hline & \multirow{2}{*}{ Sí, acciones puntuales } & Media & 2,28 & 6,44 & 8,44 & 2,83 & 19,22 & 55,17 \\
\hline & & Desv. típ. & 1,632 & 2,261 & 2,761 & 1,424 & 3,921 & 5,218 \\
\hline & \multirow{2}{*}{$\begin{array}{l}\text { Sí, acciones frecuentes sin una } \\
\text { política definida de RS }\end{array}$} & Media & 1,92 & 6,80 & 8,48 & 2,76 & 17,08 & 57,72 \\
\hline & & Desv. típ. & 2,040 & 2,915 & 2,988 & 2,006 & 3,487 & 4,542 \\
\hline & \multirow{2}{*}{$\begin{array}{l}\text { Sí, acciones integradas en una } \\
\text { política de RS }\end{array}$} & Media & 1,92 & 6,84 & 8,65 & 2,84 & 18,03 & 58,57 \\
\hline & & Desv. típ. & 1,785 & 2,754 & 3,155 & 1,555 & 4,317 & 4,947 \\
\hline & \multirow{2}{*}{ Total } & Media & 2,54 & 6,49 & 7,74 & 3,21 & 19,24 & 55,96 \\
\hline & & Desv. típ. & 2,041 & 2,707 & 3,013 & 1,977 & 4,264 & 5,331 \\
\hline
\end{tabular}

Cuadro 118: Medidas estadísticas sobre acciones en responsabilidad social, liderazgo y edad. 
Sobre estas líneas hemos incorporado los datos sobre la edad de los líderes, su liderazgo y el comportamiento socialmente responsable de las organizaciones de las que proceden (cuadro 118).

Antes de revisar los datos del cuadro 118 hemos realizado ANOVA de un factor entre los diferentes grupos muestrales para comprobar si existen diferencias estadísticamente significativas entre los mismos.

\begin{tabular}{|c|c|c|c|c|c|c|}
\hline & & Suma de cuadrados & gl & Media cuadrática & $\mathbf{F}$ & Sig. \\
\hline \multirow{3}{*}{ Edad } & Inter-grupos & 2,038 & 3 & 679 & 1,913 & ,129 \\
\hline & Intra-grupos & 65,718 & 185 & ,355 & & \\
\hline & Total & 67,757 & 188 & & & \\
\hline \multirow{3}{*}{$\begin{array}{l}\text { Estilo } \\
\text { directivo }\end{array}$} & Inter-grupos & 51,529 & 3 & 17,176 & 4,344 & ,006 \\
\hline & Intra-grupos & 731,423 & 185 & 3,954 & & \\
\hline & Total & 782,952 & 188 & & & \\
\hline \multirow{3}{*}{$\begin{array}{l}\text { Estilo } \\
\text { consultivo }\end{array}$} & Inter-grupos & 10,751 & 3 & 3,584 & 485 & 693 \\
\hline & Intra-grupos & 1366,487 & 185 & 7,386 & & \\
\hline & Total & 1377,238 & 188 & & & \\
\hline \multirow{3}{*}{$\begin{array}{l}\text { Estilo } \\
\text { participativo }\end{array}$} & Inter-grupos & 129,541 & 3 & 43,180 & 5,065 & ,002 \\
\hline & Intra-grupos & 1577,232 & 185 & 8,526 & & \\
\hline & Total & 1706,772 & 188 & & & \\
\hline \multirow{3}{*}{$\begin{array}{l}\text { Estilo } \\
\text { delegativo }\end{array}$} & Inter-grupos & 31,069 & 3 & 10,356 & 2,722 & 046 \\
\hline & Intra-grupos & 703,884 & 185 & 3,805 & & \\
\hline & Total & 734,952 & 188 & & & \\
\hline \multirow{3}{*}{$\begin{array}{l}\text { Flexibilidad de } \\
\text { estilo }\end{array}$} & Inter-grupos & 281,329 & 3 & 93,776 & 5,529 & ,001 \\
\hline & Intra-grupos & 3137,475 & 185 & 16,959 & & \\
\hline & Total & 3418,804 & 188 & & & \\
\hline \multirow{3}{*}{$\begin{array}{l}\text { Efectividad de } \\
\text { estilo }\end{array}$} & Inter-grupos & 487,949 & 3 & 162,650 & 6,198 &, 000 \\
\hline & Intra-grupos & 4854,791 & 185 & 26,242 & & \\
\hline & Total & 5342,741 & 188 & & & \\
\hline
\end{tabular}

Cuadro 119: Tabla ANOVA de edad y liderazgo, factor Realización de Acciones de Responsabilidad Social.

Los coeficientes de significación indicados en el cuadro 119 muestran que hay diferencias estadísticas significativas entre los diversos grupos muestrales en relación con "efectividad de estilo" $(0,000)$, “flexibilidad de 
estilo" $(0,001)$, “estilo delegativo" $(0,046)$, “estilo participativo" $(0,002)$ y "estilo directivo" $(0,006)$.

En el análisis de los datos que ofrece el cuadro 118 no hemos tenido en cuenta, por su baja representatividad, los grupos en los que únicamente se ha recabado información de un líder. Hemos realizado la lectura de los datos agrupando las observaciones por edades.

En los líderes de 20 a 40 años el estilo primario es el participativo en tres de los cuatro grupos contemplados: en los líderes procedentes de organizaciones que no realizan ningún tipo de actuación en el ámbito de la responsabilidad social la media registrada ha sido 6,86 , en los vinculados a empresas que realizan acciones puntuales el puntaje medio alcanzado por el estilo ha sido 9 y en los asociados a organizaciones que tienen una política definida de responsabilidad social el valor medio del estilo ha sido 7,10. En estos tres grupos el estilo secundario de los líderes ha sido el consultivo mientras que el estilo primario en los máximos responsables que proceden de empresas que impulsan acciones frecuentes sin una política definida ha sido el consultivo (ha registrado un valor medio de 6,70 ).

En cuanto a la flexibilidad de estilo, ha alcanzado la puntuación media más alta en los líderes vinculados a organizaciones que no realizan ningún tipo de actuación en materia de responsabilidad social $(21,04)$ y el valor medio más reducido en los máximos responsables de empresas que 
impulsan acciones frecuentes sin una política definida (su valor medio ha sido 16,85 ).

En el caso de la efectividad, y al contrario que en la flexibilidad, el valor medio más reducido se ha registrado en los líderes procedentes de empresas que no desarrollan ningún tipo de comportamiento socialmente responsable (su efectividad media ha sido 53,11). La efectividad más alta se ha registrado en los líderes procedentes de empresas que desarrollan acciones puntuales (su valor medio ha sido $58,90)$ aunque los máximos responsables procedentes de organizaciones que desarrollan acciones frecuentes han registrado un valor medio bastante cercano $(58,31)$.

En los líderes de 41 a 60 años se han producido algunas diferencias significativas. El estilo participativo es el estilo primario en todos los grupos muestrales sea cual sea el comportamiento socialmente responsable de la organización de procedencia del líder. Su valor medio ha sido 6,82 en las organizaciones que no impulsan ningún tipo de acción, 7,64 en las que desarrollan acciones puntuales, 9,09 en las que ponen en marcha iniciativas de manera habitual y 9,27 en las que realizan acciones dentro de una política definida. Como vemos, a medida que se ha intensificado el comportamiento socialmente responsable de las empresas ha crecido la importancia que los líderes conceden al estilo participativo (mucho apoyo y poca dirección). En los cuatro tipos de conducta socialmente responsable analizada el estilo secundario ha sido el consultivo, que ha obtenido una 
puntuación media más reducida en los líderes procedentes de empresas que desarrollan acciones frecuentes sin contar con una política definida $(5,91)$.

En relación con la flexibilidad de estilo se aprecia una cierta tendencia decreciente al pasar de los líderes procedentes de organizaciones que no realizan ningún tipo de actuación o que realizan acciones puntuales (las puntuaciones medias de estilo han sido 20,11 y 20,18 respectivamente) a los que están vinculados a empresas que desarrollan iniciativas en el ámbito de la responsabilidad social de modo frecuente o las impulsan integradas en una política definida (el puntaje medio obtenido por la flexibilidad ha sido 17,64 y 17,23 en cada caso respectivo).

En cuanto a la efectividad de estilo, su valor medio ha sido creciente en las organizaciones que presentan algún tipo de comportamiento socialmente responsable a medida que este se ha intensificado. Los líderes procedentes de organizaciones que impulsan acciones de modo ocasional han registrado una efectividad media de 53,91 mientras el valor medio de la efectividad ha sido 59,09 en los líderes cuyo origen son organizaciones con una política definida de responsabilidad social.

En relación con los líderes de 61 o más años, el estilo primario ha sido el participativo y el secundario el consultivo en las tres opciones contempladas (inacción, acciones puntuales y actuación integrada dentro de una política definida). Destaca especialmente la distancia del 
valor medio de ambos estilos en los máximos responsables que proceden de empresas que desarrollan acciones puntuales $(6,75)$ aunque la diferencia también es significativa en los líderes procedentes de organizaciones con una política establecida de responsabilidad social $(2,6)$.

En cuanto a la flexibilidad, el valor medio más alto se ha registrado en los líderes procedentes de organizaciones que no impulsan ningún tipo de acción en materia de Responsabilidad Social Corporativa $(19,43)$. En el caso de la efectividad ha ocurrido al revés, el valor medio más alto se ha producido en los máximos responsables vinculados a organizaciones que desarrollan acciones dentro de una política definida (61).

A continuación hemos incluido los gráficos 59 y 60 para comprobar, de modo visual, si existe algún tipo de asociación en la variación de la edad de los líderes, los aspectos de liderazgo evaluados y el comportamiento socialmente responsable de su organización de procedencia.

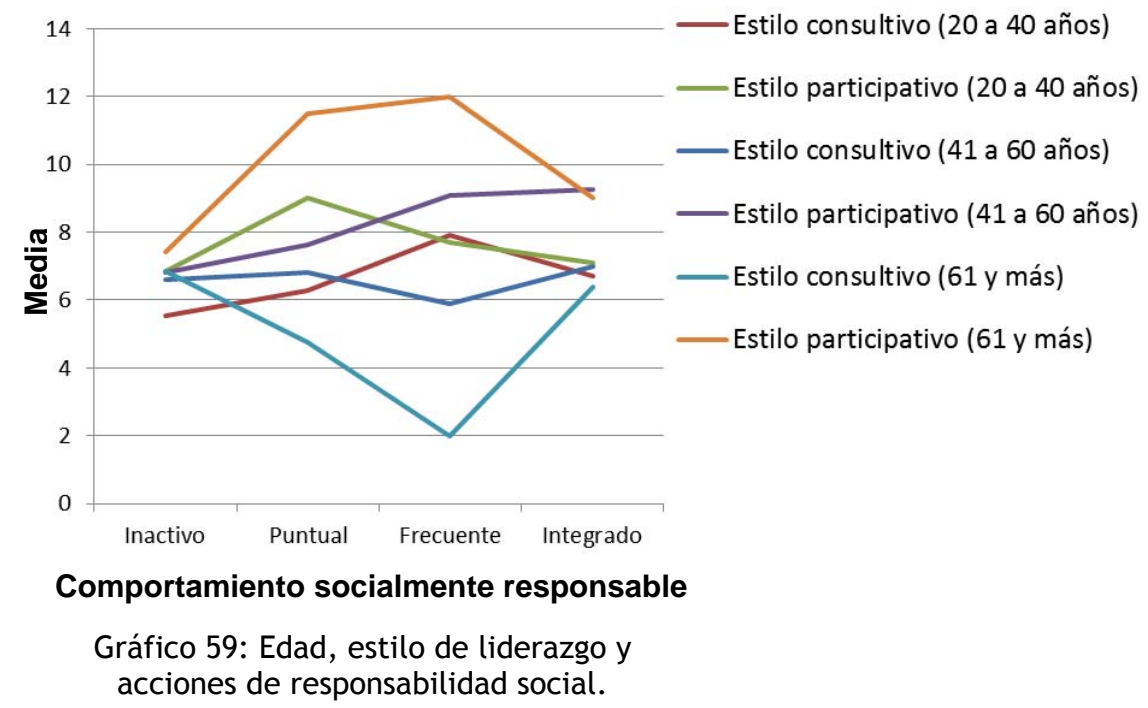


Los datos del gráfico 59 indican que, en términos generales, hay una cierta tendencia a apoyarse en mayor grado en los estilos participativo y consultivo a medida que se intensifica el comportamiento socialmente responsable de la organización. De todos modos el estilo consultivo y el estilo participativo no siguen esta tónica en los líderes de más de 60 años al considerar las conductas organizacionales intermedias sobre Responsabilidad Social Corporativa. El estilo consultivo es propenso a decrecer cuando la organización desarrolla acciones puntuales para crecer finalmente, y el estilo participativo tiende a crecer cuando la organización desarrolla acciones puntuales o frecuentes para, finalmente, decrecer.

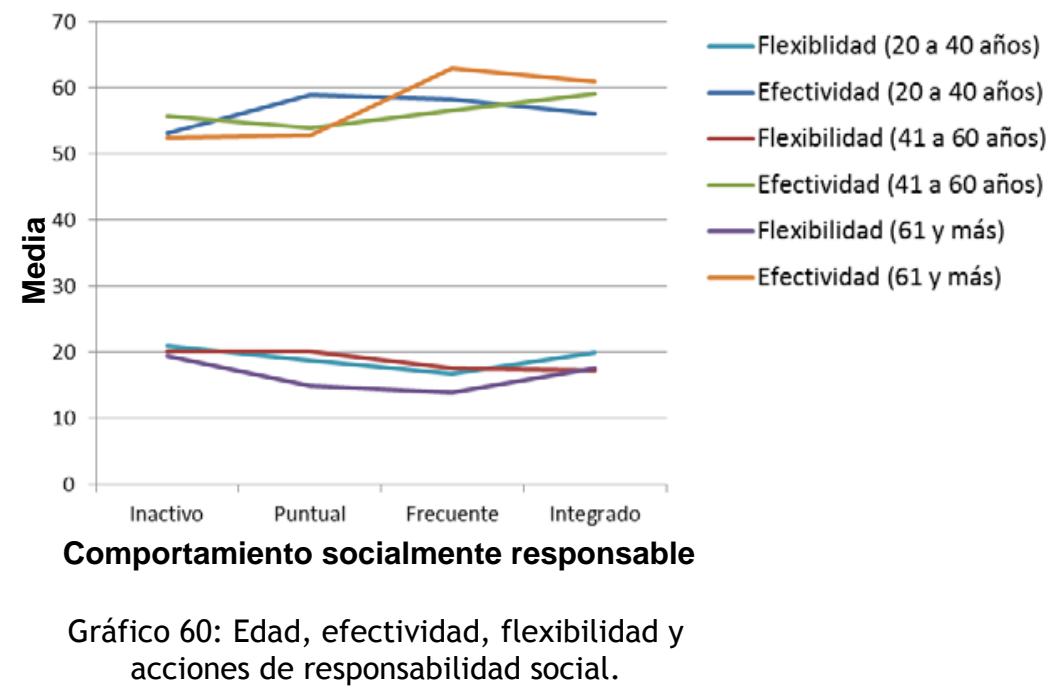

La información visual del gráfico 60 indica que la edad no afecta a la flexibilidad y a la efectividad en el ejercicio del liderazgo. En términos generales la efectividad tiende a aumentar ligeramente a medida que se eleva el nivel de responsabilidad social de la organización y la flexibilidad 


\section{parece mantenerse más o menos estable aunque se intensifique el comportamiento social.}

\begin{tabular}{|c|c|c|c|c|c|c|c|c|}
\hline Edad & $\begin{array}{l}\text { Horas de for } \\
\text { responsabil }\end{array}$ & $\begin{array}{l}\text { ción en } \\
\text { d social }\end{array}$ & $\begin{array}{c}\text { Estilo } \\
\text { directivo }\end{array}$ & $\begin{array}{l}\text { Estilo } \\
\text { consultivo }\end{array}$ & $\begin{array}{c}\text { Estilo } \\
\text { participativo }\end{array}$ & $\begin{array}{c}\text { Estilo } \\
\text { delegativo }\end{array}$ & Flexibilidad & Efectividad \\
\hline \multirow{14}{*}{ De 20 a 40} & \multirow{2}{*}{ Menos de 11} & Media & 2,60 & 7,40 & 6,80 & 3,20 & 21,20 & 53,80 \\
\hline & & Desv. típ. & 2,074 & 1,517 & 2,683 & 1,789 & 4,382 & 2,588 \\
\hline & \multirow{2}{*}{ De 11 a 50} & Media & 3,00 & 10,33 & 5,00 & 1,67 & 16,67 & 57,33 \\
\hline & & Desv. típ. & 2,646 & 2,309 & 2,646 & 1,155 & 3,055 & 4,163 \\
\hline & \multirow{2}{*}{ De 51 a 100} & Media & 1,00 & 7,00 & 7,00 & 5,00 & 22,00 & 55,00 \\
\hline & & Desv. típ. & & & . & . & . & \\
\hline & \multirow{2}{*}{ De 101 a 150} & Media & 1,00 & 6,00 & 7,00 & 5,00 & 23,00 & 52,00 \\
\hline & & Desv. típ. & & & & & & \\
\hline & \multirow{2}{*}{ De 201 a 1000} & Media & 3,00 & 4,00 & 9,00 & 4,00 & 22,00 & 60,00 \\
\hline & & Desv. típ. & . & . & . & . & . & \\
\hline & \multirow{2}{*}{ Más de 1000} & Media & 2,00 & 8,00 & 9,00 & 1,00 & 16,00 & 67,00 \\
\hline & & Desv. típ. & & & . & . & . & \\
\hline & \multirow{2}{*}{ Total } & Media & 2,42 & 7,75 & 6,75 & 3,00 & 19,92 & 56,25 \\
\hline & & Desv. típ. & 1,832 & 2,301 & 2,379 & 1,758 & 3,919 & 4,712 \\
\hline \multirow{16}{*}{ De 41 a 60} & \multirow{2}{*}{ Menos de 11} & Media & 3,40 & 8,00 & 6,20 & 2,40 & 21,80 & 52,40 \\
\hline & & Desv. típ. & 894 & 1,581 & 1,095 & ,548 & 2,683 & 1,517 \\
\hline & \multirow{2}{*}{ De 11 a 50} & Media & 1,50 & 7,17 & 8,67 & 2,67 & 18,33 & 58,67 \\
\hline & & Desv. típ. & 837 & ,983 & 1,633 & 1,633 & 3,670 & 4,590 \\
\hline & \multirow{2}{*}{ De 51 a 100} & Media &, 75 & 6,50 & 10,75 & 2,00 & 15,50 & 57,00 \\
\hline & & Desv. típ. & ,957 & 1,291 & 2,872 & 1,155 & 3,416 & 6,055 \\
\hline & \multirow{2}{*}{ De 101 a 150} & Media & 2,20 & 6,00 & 9,60 & 2,20 & 16,80 & 57,80 \\
\hline & & Desv. típ. & 2,490 & 3,162 & 3,507 & 1,304 & 5,933 & 4,025 \\
\hline & \multirow{2}{*}{ De 151 a 200} & Media & 4,00 & 3,00 & 12,00 & 1,00 & 16,00 & 66,00 \\
\hline & & Desv. típ. & & & . & . & . & \\
\hline & \multirow{2}{*}{ De 201 a 1000} & Media & 4,00 & 7,00 & 8,00 & 1,00 & 20,00 & 55,00 \\
\hline & & Desv. típ. & & & . & . & . & \\
\hline & \multirow{2}{*}{ Más de 1000} & Media & 2,00 & 8,50 & 6,50 & 3,00 & 20,00 & 61,00 \\
\hline & & Desv. típ. & 2,828 & ,707 & ,707 & 2,828 &, 000 & 2,828 \\
\hline & \multirow{2}{*}{ Total } & Media & 2,17 & 6,92 & 8,63 & 2,29 & 18,38 & 57,25 \\
\hline & & Desv. típ. & 1,711 & 1,998 & 2,683 & 1,301 & 4,116 & 4,839 \\
\hline \multirow{6}{*}{$\begin{array}{l}\text { De } 61 \text { en } \\
\text { adelante }\end{array}$} & 0 & Media & 2,50 & 4,50 & 10,50 & 2,50 & 19,00 & 65,00 \\
\hline & De il a & Desv. típ. & 3,536 & ,707 & 3,536 & ,707 & 7,071 & 4,243 \\
\hline & 0 & Media & 2,00 & 7,00 & 9,00 & 2,00 & 18,00 & 53,00 \\
\hline & De ivid 150 & Desv. típ. & . & . & . & . & . & . \\
\hline & Toto & Media & 2,33 & 5,33 & 10,00 & 2,33 & 18,67 & 61,00 \\
\hline & Iotal & Desv. típ. & 2,517 & 1,528 & 2,646 & ,577 & 5,033 & 7,550 \\
\hline & Menes de 11 & Media & 3,00 & 7,70 & 6,50 & 2,80 & 21,50 & 53,10 \\
\hline & Menos de 11 & Desv. típ. & 1,563 & 1,494 & 1,958 & 1,317 & 3,440 & 2,132 \\
\hline & 50 & Media & 2,09 & 7,55 & 8,00 & 2,36 & 18,00 & 59,45 \\
\hline & De 11 a 50 & Desv. típ. & 1,868 & 2,423 & 2,864 & 1,362 & 3,795 & 4,865 \\
\hline & 1010 & Media & 80 & 6,60 & 10,00 & 2,60 & 16,80 & 56,60 \\
\hline & De 51 a 100 & Desv. típ. & ,837 & 1,140 & 3,000 & 1,673 & 4,147 & 5,320 \\
\hline & 150 & Media & 2,00 & 6,14 & 9,14 & 2,57 & 17,86 & 56,29 \\
\hline TOTA1 & De 101 a 150 & Desv. típ. & 2,082 & 2,610 & 3,024 & 1,512 & 5,367 & 4,192 \\
\hline IOIAL & م200 0151 مת & Media & 4,00 & 3,00 & 12,00 & 1,00 & 16,00 & 66,00 \\
\hline & De 151 a 200 & Desv. típ. & & & . & . & . & \\
\hline & 1000 ב 201 & Media & 3,50 & 5,50 & 8,50 & 2,50 & 21,00 & 57,50 \\
\hline & De 201 a 1000 & Desv. típ. & ,707 & 2,121 & ,707 & 2,121 & 1,414 & 3,536 \\
\hline & Mác do 1000 & Media & 2,00 & 8,33 & 7,33 & 2,33 & 18,67 & 63,00 \\
\hline & Mas de 1000 & Desv. típ. & 2,000 & ,577 & 1,528 & 2,309 & 2,309 & 4,000 \\
\hline & Total & Media & 2,26 & 7,05 & 8,15 & 2,51 & 18,87 & 57,23 \\
\hline & Total & Desv. típ. & 1,758 & 2,114 & 2,720 & 1,430 & 4,066 & 5,002 \\
\hline
\end{tabular}

Cuadro 120: Medidas estadísticas sobre formación en responsabilidad social, liderazgo y edad. 
Sobre estas líneas hemos incorporado (cuadro 120) los datos sobre la edad de los líderes, su liderazgo y el desarrollo de acciones formativas encuadradas en el ámbito de la responsabilidad social por parte de sus organizaciones de origen.

Antes de realizar una lectura de la información del cuadro 120 hemos aplicado ANOVA de un factor a los grupos muestrales analizados para ver si existen diferencias entre los mismos que sean estadísticamente significativas (cuadro 121).

\begin{tabular}{|c|c|c|c|c|c|c|}
\hline & & Suma de cuadrados & gl & Media cuadrática & $\mathbf{F}$ & Sig. \\
\hline \multirow{3}{*}{ Edad } & Inter-grupos & 1,547 & 6 & ,258 & ,725 & 632 \\
\hline & Intra-grupos & 11,376 & 32 & ,355 & & \\
\hline & Total & 12,923 & 38 & & & \\
\hline \multirow{3}{*}{$\begin{array}{l}\text { Estilo } \\
\text { directivo }\end{array}$} & Inter-grupos & 23,227 & 6 & 3,871 & 1,315 & 279 \\
\hline & Intra-grupos & 94,209 & 32 & 2,944 & & \\
\hline & Total & 117,436 & 38 & & & \\
\hline \multirow{3}{*}{$\begin{array}{l}\text { Estilo } \\
\text { consultivo }\end{array}$} & Inter-grupos & 39,846 & 6 & 6,641 & 1,634 & , 170 \\
\hline & Intra-grupos & 130,051 & 32 & 4,064 & & \\
\hline & Total & 169,897 & 38 & & & \\
\hline \multirow{3}{*}{$\begin{array}{l}\text { Estilo } \\
\text { participativo }\end{array}$} & Inter-grupos & 68,553 & 6 & 11,426 & 1,720 & 148 \\
\hline & Intra-grupos & 212,524 & 32 & 6,641 & & \\
\hline & Total & 281,077 & 38 & & & \\
\hline \multirow{3}{*}{$\begin{array}{l}\text { Estilo } \\
\text { delegativo }\end{array}$} & Inter-grupos & 3,517 & 6 &, 586 & ,253 & ,955 \\
\hline & Intra-grupos & 74,226 & 32 & 2,320 & & \\
\hline & Total & 77,744 & 38 & & & \\
\hline \multirow{3}{*}{$\begin{array}{l}\text { Flexibilidad de } \\
\text { estilo }\end{array}$} & Inter-grupos & 123,535 & 6 & 20,589 & 1,305 & ,283 \\
\hline & Intra-grupos & 504,824 & 32 & 15,776 & & \\
\hline & Total & 628,359 & 38 & & & \\
\hline \multirow{3}{*}{$\begin{array}{l}\text { Efectividad de } \\
\text { estilo }\end{array}$} & Inter-grupos & 410,167 & 6 & 68,361 & 4,045 & ,004 \\
\hline & Intra-grupos & 540,756 & 32 & 16,899 & & \\
\hline & Total & 950,923 & 38 & & & \\
\hline
\end{tabular}

Cuadro 121: Tabla ANOVA de la edad y del liderazgo, factor Horas de Formación en Responsabilidad Social.

La prueba de ANOVA de un factor (cuadro 121) indica que existen diferencias estadísticamente significativas entre los diversos grupos muestrales que se han contemplado en 
relación con "efectividad de estilo" (el coeficiente de significación ha sido 0,04$)$.

A continuación hemos realizado una lectura de la información que ofrece el cuadro 120. Hemos descartado los casos en los que la representatividad ha sido mínima porque solo se han recabado datos de un líder. En la exposición de las observaciones hemos agrupado las consideraciones en función de la edad de los máximos responsables.

En los líderes de 20 a 40 años el estilo primario es el consultivo en los dos grupos muestrales revisados: los líderes procedentes de empresas que invierten menos de 11 horas han obtenido una puntuación media de 7,40 y los máximos responsables vinculados a organizaciones que dedican entre 11 y 50 horas a actuaciones formativas sobre responsabilidad social han registrado un valor medio en el estilo consultivo de 10,33. En ambos casos el liderazgo secundario ha sido el participativo. Este hecho (que el liderazgo participativo no sea el estilo primario en ninguno de los grupos muestrales contemplados) no se había producido al revisar la edad, el liderazgo y la conducta organizacional socialmente responsable.

En los líderes de esta franja de edad se registra un comportamiento inverso en la puntuación media que han obtenido en flexibilidad y efectividad de estilo. La flexibilidad media más alta se ha producido en los líderes que proceden de organizaciones que dedican menos de 11 
horas a acciones formativas encuadradas en el ámbito de la responsabilidad social $(21,20)$, mientras que la efectividad más elevada se ha registrado en los máximos responsables vinculados a empresas que dedican entre 11 y 50 horas a iniciativas de formación enmarcadas en la etiqueta “Responsabilidad Social Corporativa” $(57,33)$.

En los líderes de 41 a 60 años, en tres de los cinco casos contemplados el estilo participativo ha sido el estilo primario: en los líderes que proceden de organizaciones que dedican menos de 11 horas acciones formativas de responsabilidad social (su valor medio ha sido 8,67 ), en los que están asociados a empresas que dedican entre 51 y 100 horas (el puntaje medio del estilo ha sido 10,75) y en los que están vinculados a organizaciones que dedican entre 101 y 150 horas a este tipo de iniciativas (el valor medio en este caso ha sido 9,60). En dos casos, que responden a los dos extremos dentro de la duración de las acciones formativas, el estilo consultivo ha sido el estilo primario: en los líderes que está vinculados a organizaciones que invierten menos de 11 horas en acciones formativas enmarcadas en el ámbito de la responsabilidad social y en los que proceden de organizaciones que dedican más de 1000 horas a este tipo de iniciativas.

En cuanto a la flexibilidad de estilo, el valor medio más alto $(21,8)$ se ha registrado en los líderes procedentes de organizaciones que destinan menos de 11 horas a acciones formativas de responsabilidad social (resultado en 
consonancia con el obtenido por los otros dos grupos de edad) y el valor medio más bajo $(15,5)$ en los líderes asociados a empresas que invierten entre 51 y 100 horas en acciones formativas circunscritas a la responsabilidad social.

En cuanto a la efectividad de estilo, la puntuación media más alta se ha alcanzado en los líderes vinculados a organizaciones que invierten más de 1000 horas en acciones integradas en el ámbito de la responsabilidad social (61). Y la puntuación media más baja se ha registrado en los líderes procedentes de organizaciones que dedican menos de 11 horas a este tipo de acciones formativas $(52,4)$.

En lo que se refiere a los líderes de más de 60 años se ha revisado un grupo: el de los máximos responsables procedentes de empresas que invierten entre 11 y 50 horas en acciones formativas asociadas a la responsabilidad social. Su estilo primario ha sido el participativo (ha registrado un valor medio de 10,50$)$ y su estilo secundario ha sido el consultivo (ha obtenido un puntaje medio de 4,50).

La flexibilidad media de estilo ha sido de 19, puntuación que se encuentra dentro de los guarismos contemplados en los otros grupos de edad, y la efectividad media de estilo ha sido 65, la más alta en cualquiera de las procedencias empresariales revisadas dentro de los tres grupos de edad.

A continuación hemos incluido el gráfico 61 para facilitar la revisión visual de posibles asociaciones en la 
variación de la edad, el liderazgo y las horas de formación que las organizaciones de procedencia de los líderes dedican a la responsabilidad social.

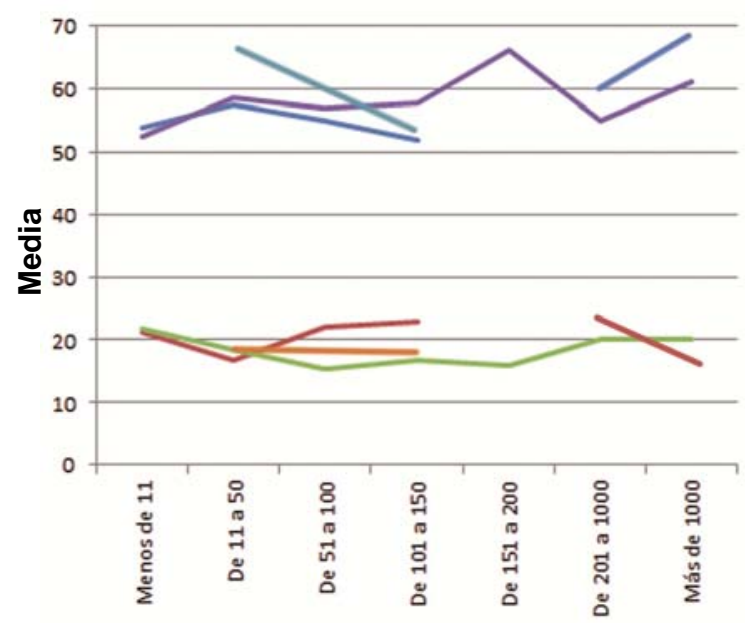

Formación en responsabilidad social

Gráfico 61: Edad, efectividad, flexibilidad y formación en responsabilidad social.
-Efectividad (20 a 40 años)

—Flexibilidad (20 a 40 años)

-Flexibilidad (41 a 60 años)

-Efectividad (41 a 60 años)

—Flexibilidad (61 y más)

—Efectividad (61 y más)

Solo se han recabado datos en todas categorías empresariales contempladas por parte de los líderes de 41 a 60 años, lo que limita la interpretación de la información. Las líneas que informan sobre la flexibilidad de los líderes parecen indicar que, en términos generales, la flexibilidad de los líderes se mantiene estable aunque las organizaciones incrementen el número de horas que dedican a acciones formativas enmarcadas en el ámbito de la responsabilidad social.

Por otra parte parece advertirse un leve aumento de la efectividad de los máximos responsables empresariales en el ejercicio del liderazgo, a medida que se incrementa el número de horas que sus organizaciones de origen destinan a acciones de formación vinculadas al ámbito de la responsabilidad social. 


\subsubsection{Edad, valores y Responsabilidad Social}

\section{Corporativa}

Como en los apartados precedentes hemos revisado en primer lugar la actitud de los líderes empresariales hacia la Responsabilidad Social Corporativa, su edad y las competencias genéricas, los rasgos de personalidad y las características comportamentales que hemos analizado en los máximos responsables empresariales. A continuación hemos abordado el estudio de las variables indicadas pero remplazando la actitud por el comportamiento socialmente responsable de la organización y por la actuación formativa de la empresa en materia de responsabilidad social.

Hemos incluido debajo de estas líneas el cuadro 122 con los resultados de algunas medidas estadísticas utilizadas en el estudio de las variables señaladas inicialmente.

\begin{tabular}{|c|c|c|c|c|c|c|c|c|}
\hline \multicolumn{2}{|l|}{ Edad } & $\begin{array}{l}\text { Actitud hacia } \\
\text { la resp. social }\end{array}$ & Practicidad & Resultados & Variedad & Decisión & $\begin{array}{l}\text { Orden y } \\
\text { método }\end{array}$ & Metas \\
\hline \multirow{4}{*}{ De 20 a 40} & Media & 7,3985 & 13,44 & 15,93 & 8,89 & 16,48 & 16,03 & 19,23 \\
\hline & Mínimo & 4,39 & 5 & 8 & 0 & 6 & 5 & 8 \\
\hline & Máximo & 8,13 & 21 & 25 & 24 & 25 & 29 & 28 \\
\hline & Desv. típ. & ,95226 & 3,757 & 3,741 & 6,034 & 4,463 & 5,782 & 5,025 \\
\hline \multirow{4}{*}{ De 41 a 60} & Media & 7,1522 & 14,00 & 14,20 & 8,20 & 16,58 & 16,14 & 20,54 \\
\hline & Mínimo & 3,86 & 4 & 2 & 0 & 5 & 5 & 6 \\
\hline & Máximo & 8,10 & 27 & 26 & 26 & 26 & 27 & 30 \\
\hline & Desv. típ. & 1,06686 & 4,355 & 4,006 & 5,503 & 4,115 & 5,284 & 4,425 \\
\hline \multirow{4}{*}{$\begin{array}{l}\text { De } 61 \text { en } \\
\text { adelante }\end{array}$} & Media & 6,8483 & 12,71 & 14,71 & 6,94 & 17,41 & 17,29 & 20,94 \\
\hline & Mínimo & 4,76 & 5 & 10 & 0 & 12 & 11 & 11 \\
\hline & Máximo & 8,12 & 21 & 20 & 18 & 25 & 23 & 26 \\
\hline & Desv. típ. & 1,22644 & 4,661 & 3,016 & 4,968 & 3,954 & 3,738 & 4,380 \\
\hline \multirow{4}{*}{ TOTAL } & Media & 7,2043 & 13,70 & 14,80 & 8,31 & 16,62 & 16,21 & 20,15 \\
\hline & Mínimo & 3,86 & 4 & 2 & 0 & 5 & 5 & 6 \\
\hline & Máximo & 8,13 & 27 & 26 & 26 & 26 & 29 & 30 \\
\hline & Desv. típ. & 1,05294 & 4,197 & 3,907 & 5,632 & 4,203 & 5,321 & 4,644 \\
\hline
\end{tabular}

Cuadro 122: Medidas estadísticas de "valores", edad y actitud hacia la responsabilidad social. 
Antes de revisar la información que ofrece el cuadro 122 hemos aplicado ANOVA de un factor en la muestra poblacional para revisar si existen diferencias estadísticamente significativas entre los diversos muestrales considerados (cuadro 123).

\begin{tabular}{|c|c|c|c|c|c|c|}
\hline & & Suma de cuadrados & gl & Media cuadrática & $\mathrm{F}$ & Sig. \\
\hline \multirow{3}{*}{ Edad } & Inter-grupos & 28,159 & 80 & ,352 & ,960 & ,573 \\
\hline & Intra-grupos & 39,598 & 108 & ,367 & & \\
\hline & Total & 67,757 & 188 & & & \\
\hline \multirow{3}{*}{ Practicidad } & Inter-grupos & 1402,026 & 80 & 17,525 & ,991 &, 513 \\
\hline & Intra-grupos & 1909,381 & 108 & 17,679 & & \\
\hline & Total & 3311,407 & 188 & & & \\
\hline \multirow{3}{*}{ Resultados } & Inter-grupos & 1395,917 & 80 & 17,449 & 1,279 & 117 \\
\hline & Intra-grupos & 1473,839 & 108 & 13,647 & & \\
\hline & Total & 2869,757 & 188 & & & \\
\hline \multirow{3}{*}{ Variedad } & Inter-grupos & 2907,734 & 80 & 36,347 & 1,284 & ,113 \\
\hline & Intra-grupos & 3056,467 & 108 & 28,301 & & \\
\hline & Total & 5964,201 & 188 & & & \\
\hline \multirow{3}{*}{ Decisión } & Inter-grupos & 1367,343 & 80 & 17,092 & ,945 & 602 \\
\hline & Intra-grupos & 1953,229 & 108 & 18,085 & & \\
\hline & Total & 3320,571 & 188 & & & \\
\hline \multirow{3}{*}{ Orden y método } & Inter-grupos & 2731,090 & 80 & 34,139 & 1,423 & ,044 \\
\hline & Intra-grupos & 2591,862 & 108 & 23,999 & & \\
\hline & Total & 5322,952 & 188 & & & \\
\hline \multirow{3}{*}{ Metas } & Inter-grupos & 1606,850 & 80 & 20,086 & ,886 & ,714 \\
\hline & Intra-grupos & 2447,700 & 108 & 22,664 & & \\
\hline & Total & 4054,550 & 188 & & & \\
\hline
\end{tabular}

Cuadro 123: Tabla ANOVA de edad y "valores", factor Actitud hacia la Responsabilidad Social.

Los resultados de dicho análisis (incorporados al cuadro 123 que se encuentra encima de estas líneas) indican la existencia de diferencias estadísticamente significativas entre los diferentes grupos muestrales en relación con “orden y método". Su coeficiente de significación ha sido inferior a 0,05, concretamente 0,044. 
Hemos revisado, a continuación, los datos del cuadro 122.

Los líderes de 20 a 40 años, quienes presentan la disposición más favorable hacia la responsabilidad social de los tres grupos muestrales contemplados, han obtenido la mayor puntuación media en el rasgo de personalidad “practicidad" $(13,44)$, la competencia genérica "resultados" $(15,93)$ y el rasgo de personalidad "variedad" $(8,89)$. Además han presentado las medias más bajas en el rasgo de personalidad “decisión” $(16,48)$, en la característica comportamental "orden y método" $(16,03)$ y en la competencia genérica "metas" $(19,23)$. Es posible que estos resultados puedan ofrecer, en alguna medida, algún tipo de explicación a la mayor afinidad que presentan los líderes de 20 a 40 años hacia la responsabilidad social. Especialmente por la búsqueda de retos (resultados) que puede suponer el desarrollo de acciones de responsabilidad social, y por la preferencia por ampliar el ámbito de actividades laborales (variedad) que suelen representar las actuaciones socialmente responsables.

En los líderes de 41 a 60 años, la competencia genérica resultados ha obtenido su menor puntuación media $(14,20)$.

Y en los máximos responsables de más de 61 años, los que presentan la actitud más débil hacia la responsabilidad social, los rasgos de personalidad "practicidad" $(12,71)$ y "variedad" $(6,94)$ han registrado sus puntaciones más reducidas, mientras que han obtenido la mayor puntuación 
media el rasgo de personalidad "decisión" $(17,41)$, la característica comportamental “orden y método" $(17,29)$ y la competencia genérica “metas" $(20,94)$.

Contemplando al mismo tiempo los tres grupos muestrales se comprueba que en todos ellos "metas" ha sido, de los aspectos analizados, el que ha obtenido una puntuación media más alta.

Además también existe una tendencia decreciente en el rasgo de personalidad "variedad" a medida que aumenta la edad de los líderes (pasa de 8,89 en los líderes de 20 a 40 años a 6,94 en los máximos responsables de más de 60 años).

Por otra parte se han detectado tres tendencias crecientes, paralelas al incremento de la edad de los líderes. Este hecho se ha producido en el rasgo de personalidad "decisión" (aumenta de 16,48 a 17,41), la característica comportamental "orden y método" (crece de 16,03 a 17,29) y la competencia genérica “metas" (amplía su valor medio de 19,23 a 20,94).

A continuación hemos incluido, de nuevo, datos estadísticos sobre la edad, las competencias genéricas estudiadas, los rasgos de personalidad considerados y las características comportamentales contempladas pero considerando, en este caso, el valor medio de la actitud hacia la responsabilidad social segmentado. El objetivo ha sido detectar posibles tendencias en la variación de las variables estudiadas a medida que la intensidad de la 


\section{actitud a favor de la responsabilidad social se acrecienta}

(cuadro 124).

\begin{tabular}{|c|c|c|c|c|c|c|c|c|}
\hline Edad & $\begin{array}{r}\text { Actitu } \\
\text { resp }\end{array}$ & $\begin{array}{l}\text { hacia la } \\
\text { social }\end{array}$ & Practicidad & Resultados & Variedad & Decisión & $\begin{array}{l}\text { Orden y } \\
\text { método }\end{array}$ & Metas \\
\hline \multirow{12}{*}{ De 20 a 40} & \multirow{2}{*}{$4 a<5$} & Media & 18,00 & 15,00 & 13,00 & 13,00 & 13,50 & 17,50 \\
\hline & & Desv. típ. & ,000 & 2,828 & 9,899 & 2,828 & 3,536 & 6,364 \\
\hline & \multirow{2}{*}{$5 a<6$} & Media & 14,00 & 14,00 & 11,80 & 17,60 & 14,40 & 18,20 \\
\hline & & Desv. típ. & 1,414 & 3,317 & 7,294 & 2,702 & 4,561 & 2,588 \\
\hline & \multirow{2}{*}{$6 a<7$} & Media & 15,86 & 14,71 & 7,86 & 16,29 & 16,00 & 17,86 \\
\hline & & Desv. típ. & 2,545 & 2,215 & 5,080 & 3,200 & 5,859 & 6,012 \\
\hline & \multirow{2}{*}{7 a 8} & Media & 13,24 & 16,64 & 9,58 & 17,00 & 14,88 & 18,97 \\
\hline & & Desv. típ. & 3,825 & 3,943 & 6,596 & 4,969 & 6,163 & 5,382 \\
\hline & \multirow{2}{*}{$>8$} & Media & 11,86 & 15,71 & 6,14 & 15,43 & 19,71 & 21,14 \\
\hline & & Desv. típ. & 4,036 & 4,046 & 3,060 & 4,398 & 4,196 & 4,167 \\
\hline & \multirow{2}{*}{ Total } & Media & 13,44 & 15,93 & 8,89 & 16,48 & 16,03 & 19,23 \\
\hline & & Desv. típ. & 3,757 & 3,741 & 6,034 & 4,463 & 5,782 & 5,025 \\
\hline \multirow{14}{*}{ De 41 a 60} & \multirow{2}{*}{$0 a<4$} & Media & 21,00 & 17,00 & 7,00 & 20,00 & 12,00 & 10,00 \\
\hline & & Desv. típ. & & & & & & \\
\hline & \multirow{2}{*}{$4 a<5$} & Media & 14,25 & 13,25 & 6,75 & 17,25 & 18,50 & 20,00 \\
\hline & & Desv. típ. & 1,893 & 4,193 & 1,500 & 5,965 & 6,758 & 4,082 \\
\hline & \multirow{2}{*}{$5 a<6$} & Media & 13,20 & 15,13 & 8,00 & 15,60 & 16,80 & 21,27 \\
\hline & & Desv. típ. & 3,877 & 3,523 & 3,024 & 3,180 & 5,031 & 3,432 \\
\hline & \multirow{2}{*}{$6 a<7$} & Media & 14,00 & 14,68 & 8,58 & 16,89 & 16,11 & 19,26 \\
\hline & & Desv. típ. & 4,372 & 3,728 & 6,727 & 3,900 & 5,666 & 5,075 \\
\hline & \multirow{2}{*}{7 a 8} & Media & 13,58 & 13,68 & 8,45 & 16,49 & 16,32 & 21,08 \\
\hline & & Desv. típ. & 4,263 & 3,797 & 5,500 & 4,121 & 5,291 & 4,314 \\
\hline & \multirow{2}{*}{$>8$} & Media & 15,37 & 14,47 & 7,63 & 16,95 & 14,84 & 20,42 \\
\hline & & Desv. típ. & 5,123 & 5,243 & 6,610 & 4,859 & 5,091 & 4,350 \\
\hline & \multirow{2}{*}{ Total } & Media & 14,00 & 14,20 & 8,20 & 16,58 & 16,14 & 20,54 \\
\hline & & Desv. típ. & 4,355 & 4,006 & 5,503 & 4,115 & 5,284 & 4,425 \\
\hline \multirow{12}{*}{$\begin{array}{l}\text { De } 61 \text { en } \\
\text { adelante }\end{array}$} & \multirow{2}{*}{$4 a<5$} & Media & 13,00 & 16,00 & 4,00 & 19,00 & 17,00 & 21,00 \\
\hline & & Desv. típ. & & . & & & . & \\
\hline & \multirow{2}{*}{$5 a<6$} & Media & 14,67 & 13,33 & 7,00 & 15,33 & 19,33 & 20,33 \\
\hline & & Desv. típ. & 6,658 & 3,512 & 4,359 & 3,215 & 3,215 & 1,528 \\
\hline & $60<7$ & Media & 12,40 & 13,80 & 8,00 & 18,20 & 17,40 & 20,20 \\
\hline & $0 \mathrm{a}<1$ & Desv. típ. & 6,066 & 2,049 & 5,874 & 4,970 & 4,930 & 5,975 \\
\hline & 7 . 8 & Media & 12,75 & 16,25 & 5,00 & 19,25 & 16,75 & 20,00 \\
\hline & 1 a 8 & Desv. típ. & 3,304 & 3,096 & 7,394 & 3,775 & 2,062 & 5,831 \\
\hline & $>8$ & Media & 11,50 & 15,00 & 8,25 & 15,75 & 16,25 & 23,25 \\
\hline & 0 & Desv. típ. & 4,509 & 4,243 & 2,500 & 3,862 & 4,992 & 3,096 \\
\hline & Total & Media & 12,71 & 14,71 & 6,94 & 17,41 & 17,29 & 20,94 \\
\hline & Iotal & Desv. típ. & 4,661 & 3,016 & 4,968 & 3,954 & 3,738 & 4,380 \\
\hline & $0<<4$ & Media & 21,00 & 17,00 & 7,00 & 20,00 & 12,00 & 10,00 \\
\hline & $0<<4$ & Desv. típ. & & . & . & & . & \\
\hline & $4 a<5$ & Media & 15,14 & 14,14 & 8,14 & 16,29 & 16,86 & 19,43 \\
\hline & & Desv. típ. & 2,410 & 3,388 & 5,429 & 4,957 & 5,521 & 4,117 \\
\hline & $5 a<6$ & Media & 13,57 & 14,65 & 8,70 & 16,00 & 16,61 & 20,48 \\
\hline & $5 d<0$ & Desv. típ. & 3,776 & 3,393 & 4,487 & 3,075 & 4,793 & 3,246 \\
\hline TOTAI & $6 a<7$ & Media & 14,16 & 14,55 & 8,32 & 16,97 & 16,29 & 19,10 \\
\hline 10TAL & 0 a $<1$ & Desv. típ. & 4,344 & 3,161 & 6,085 & 3,851 & 5,442 & 5,294 \\
\hline & 708 & Media & 13,42 & 14,88 & 8,71 & 16,80 & 15,81 & 20,26 \\
\hline & 1 a & Desv. típ. & 4,036 & 4,053 & 6,008 & 4,430 & 5,538 & 4,843 \\
\hline & $>8$ & Media & 13,62 & 15,00 & 7,14 & 16,24 & 16,84 & 21,00 \\
\hline & 38 & Desv. típ. & 4,901 & 4,637 & 5,138 & 4,536 & 5,172 & 4,157 \\
\hline & & Media & 13,70 & 14,80 & 8,31 & 16,62 & 16,21 & 20,15 \\
\hline & rotal & Desv. típ. & 4,197 & 3,907 & 5,632 & 4,203 & 5,321 & 4,644 \\
\hline
\end{tabular}

Cuadro 124: Medidas estadísticas de "valores", edad y actitud hacia la responsabilidad social. 
La información del cuadro 124 muestra que los líderes de 41 a 60 años y de 61 años en adelante, presentan un menor valor medio en la característica comportamental "orden y método" a medida que crece la puntuación media que han registrado en la actitud hacia la responsabilidad social.

En el primer grupo el valor medio de "orden y método" decrece de 18,5 en el segmento " 4 a $<5$ " a 14,84 en el segmento “>8”, y en el segundo de 19,33 en el segmento " $4 \mathrm{a}<5$ " a 16,25 en el segmento “ $>8$ ".

Hemos entendido que, en ambos grupos muestrales, la aproximación a la responsabilidad social en el ámbito empresarial por parte de los líderes pueda estar asociada a una menor importancia concedida a la planificación y a la automatización en el desempeño de su rol.

Hemos incluido a continuación los gráficos 62,63 y 64 para revisar, de modo visual, las posibles asociaciones en las variables estudiadas dentro de cada grupo de edad.

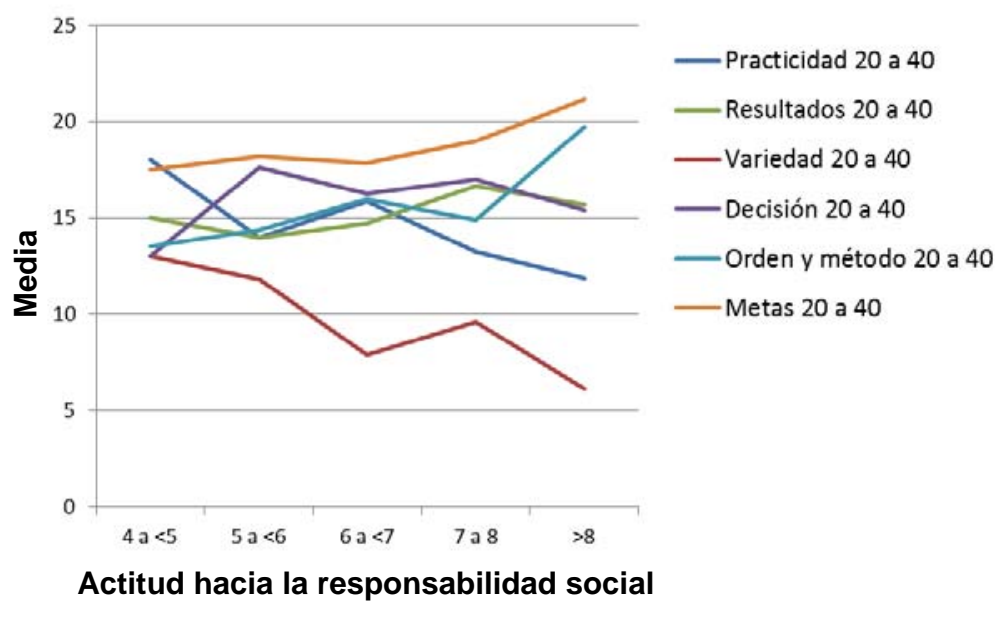

Gráfico 62: "Valores", 20 a 40 años y actitud hacia la responsabilidad social. 
El gráfico 62 muestra que los líderes de 20 a 40 años parecen prestar una menor importancia a realizar actividades laborales diferentes o que no se corresponden con una rutina, a medida que se intensifica su actitud hacia la responsabilidad social.

Asimismo también indica que estos líderes parecen otorgar más valor a la orientación hacia objetivos bien delimitados (metas) y hacia el enfoque sistemático de su actividad (orden y método) a medida que crece su afinidad hacia la Responsabilidad Social Corporativa.

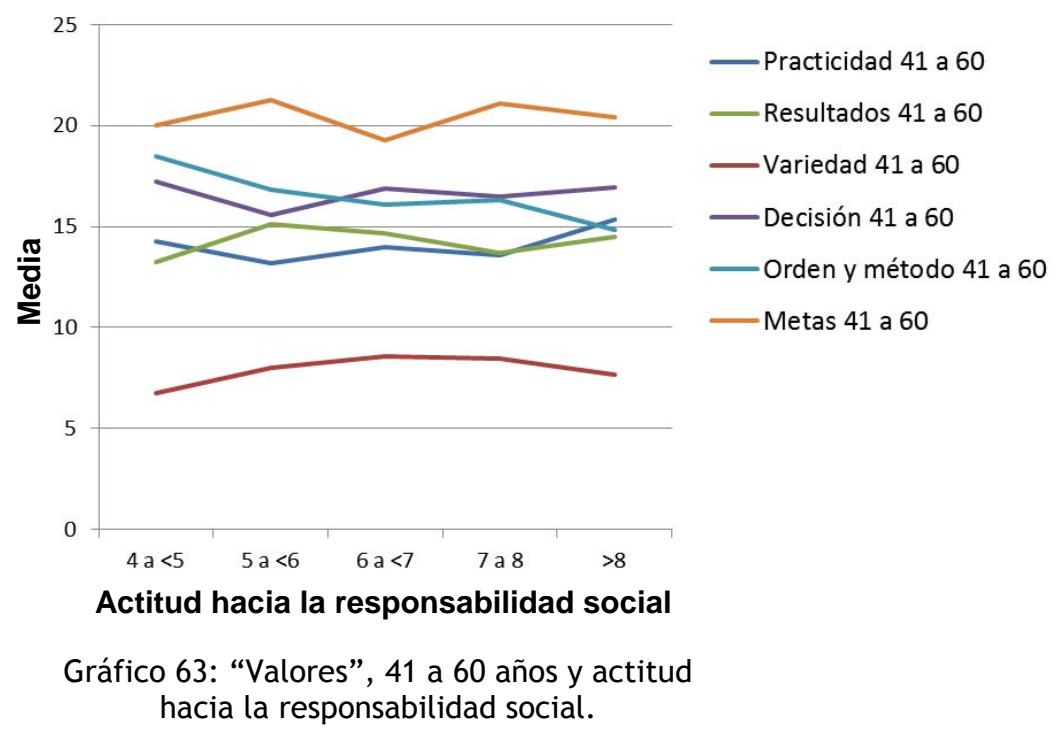

El gráfico 63, sobre los líderes de 41 a 60 años, no permite detectar tendencias en la variación de las variables salvo, quizás, que la competencia genérica "resultados" y el rasgo de personalidad "practicidad" tienden a mantenerse estables ante variaciones en la actitud de los máximos responsables hacia la responsabilidad social. 


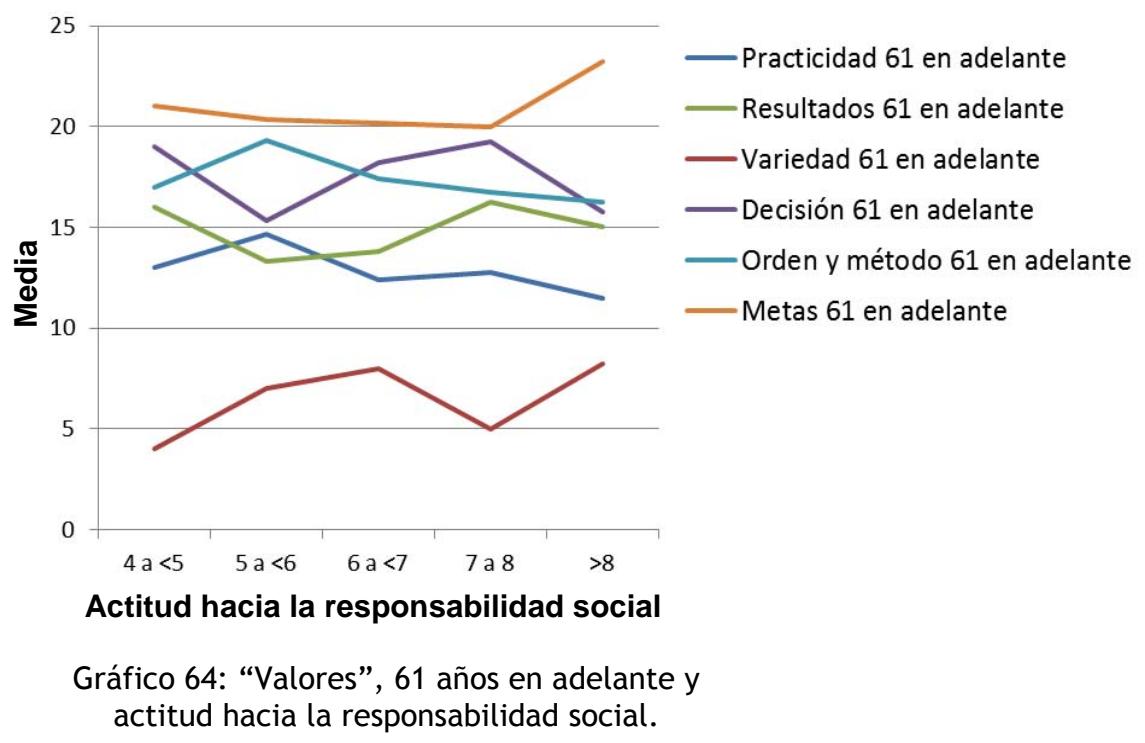

En relación con los líderes de más de 60 años, el gráfico 64 permite detectar una cierta tendencia decreciente en el rasgo de personalidad "practicidad" a medida que se intensifica la actitud de los máximos responsables a favor de la responsabilidad social.

En relación con la característica comportamental "orden y método" se aprecia, desde el segmento "5 a <6", una tendencia a perder relevancia a media que se eleva la afinidad de los líderes hacia la responsabilidad social.

A continuación hemos revisado los datos que hacen referencia a las competencias genéricas, los rasgos de personalidad y las características comportamentales estudiadas en los líderes y a su edad. En un primer momento hemos revisado estos datos considerando el comportamiento socialmente responsable de las organizaciones de origen del líder $\mathrm{y}$, en segundo lugar, teniendo presente la formación sobre responsabilidad social impulsada en dichas empresas. 


\begin{tabular}{|c|c|c|c|c|c|c|c|c|}
\hline Edad & \multicolumn{2}{|c|}{ Acciones de responsabilidad social } & Practicidad & Resultados & Variedad & Decisión & $\begin{array}{l}\text { Orden y } \\
\text { método }\end{array}$ & Metas \\
\hline \multirow{10}{*}{ De 20 a 40} & \multirow{2}{*}{ No } & Media & 13,89 & 16,07 & 7,82 & 16,18 & 16,32 & 19,71 \\
\hline & & Desv. típ. & 4,122 & 3,651 & 6,171 & 3,692 & 4,738 & 4,697 \\
\hline & \multirow{2}{*}{ Sí, acciones puntuales } & Media & 13,20 & 16,50 & 11,30 & 17,40 & 14,20 & 18,40 \\
\hline & & Desv. típ. & 3,994 & 3,629 & 6,865 & 5,190 & 7,391 & 5,816 \\
\hline & \multirow{2}{*}{$\begin{array}{l}\text { Sí, acciones frecuentes sin } \\
\text { una política definida de RS }\end{array}$} & Media & 12,85 & 16,69 & 8,92 & 18,38 & 14,31 & 18,08 \\
\hline & & Desv. típ. & 2,734 & 4,171 & 5,361 & 4,942 & 5,633 & 4,499 \\
\hline & \multirow{2}{*}{$\begin{array}{l}\text { Sí, acciones integradas en } \\
\text { una política de RS }\end{array}$} & Media & 13,20 & 14,00 & 9,40 & 13,90 & 19,30 & 20,20 \\
\hline & & Desv. típ. & 3,994 & 3,399 & 5,719 & 4,306 & 6,201 & 6,070 \\
\hline & \multirow{2}{*}{ Total } & Media & 13,44 & 15,93 & 8,89 & 16,48 & 16,03 & 19,23 \\
\hline & & Desv. típ. & 3,757 & 3,741 & 6,034 & 4,463 & 5,782 & 5,025 \\
\hline \multirow{10}{*}{ De 41 a 60} & \multirow{2}{*}{ No } & Media & 14,82 & 14,07 & 7,50 & 16,20 & 16,88 & 19,98 \\
\hline & & Desv. típ. & 4,336 & 3,893 & 4,533 & 4,321 & 5,491 & 3,975 \\
\hline & \multirow{2}{*}{ Sí, acciones puntuales } & Media & 14,68 & 13,59 & 8,55 & 16,95 & 15,32 & 20,82 \\
\hline & & Desv. típ. & 4,087 & 4,447 & 5,378 & 3,078 & 4,325 & 5,288 \\
\hline & \multirow{2}{*}{$\begin{array}{l}\text { Sí, acciones frecuentes sin } \\
\text { una política definida de RS }\end{array}$} & Media & 13,36 & 13,82 & 7,45 & 16,73 & 17,27 & 21,36 \\
\hline & & Desv. típ. & 5,065 & 2,714 & 3,671 & 4,962 & 4,474 & 5,025 \\
\hline & \multirow{2}{*}{$\begin{array}{l}\text { Sí, acciones integradas en } \\
\text { una política de RS }\end{array}$} & Media & 11,55 & 15,32 & 10,00 & 17,09 & 14,50 & 21,27 \\
\hline & & Desv. típ. & 3,515 & 4,390 & 8,024 & 4,219 & 5,780 & 4,399 \\
\hline & \multirow{2}{*}{ Total } & Media & 14,00 & 14,20 & 8,20 & 16,58 & 16,14 & 20,54 \\
\hline & & Desv. típ. & 4,355 & 4,006 & 5,503 & 4,115 & 5,284 & 4,425 \\
\hline \multirow{10}{*}{$\begin{array}{l}\text { De } 61 \text { en } \\
\text { adelante }\end{array}$} & \multirow{2}{*}{ No } & Media & 16,14 & 15,29 & 8,86 & 16,00 & 16,00 & 17,71 \\
\hline & & Desv. típ. & 3,288 & 3,546 & 6,067 & 2,582 & 3,742 & 4,386 \\
\hline & \multirow{2}{*}{ Sí, acciones puntuales } & Media & 11,00 & 14,75 & 4,25 & 17,75 & 19,25 & 23,00 \\
\hline & & Desv. típ. & 3,916 & 3,202 & 4,349 & 3,862 & 2,630 & 3,559 \\
\hline & \multirow{2}{*}{$\begin{array}{l}\text { Sí, acciones frecuentes sin } \\
\text { una política definida de RS }\end{array}$} & Media & 11,00 & 11,00 & 9,00 & 13,00 & 23,00 & 23,00 \\
\hline & & Desv. típ. & & . & . & & . & \\
\hline & \multirow{2}{*}{$\begin{array}{l}\text { Sí, acciones integradas en } \\
\text { una política de RS }\end{array}$} & Media & 9,60 & 14,60 & 6,00 & 20,00 & 16,40 & 23,40 \\
\hline & & Desv. típ. & 4,775 & 2,408 & 3,674 & 4,950 & 3,715 & 2,702 \\
\hline & \multirow{2}{*}{ Total } & Media & 12,71 & 14,71 & 6,94 & 17,41 & 17,29 & 20,94 \\
\hline & & Desv. típ. & 4,661 & 3,016 & 4,968 & 3,954 & 3,738 & 4,380 \\
\hline \multirow{10}{*}{ TOTAL } & \multirow{2}{*}{ No } & Media & 14,64 & 14,78 & 7,70 & 16,18 & 16,64 & 19,73 \\
\hline & & Desv. típ. & 4,205 & 3,867 & 5,154 & 3,993 & 5,118 & 4,232 \\
\hline & \multirow{2}{*}{ Sí, acciones puntuales } & Media & 13,86 & 14,53 & 8,83 & 17,17 & 15,44 & 20,39 \\
\hline & & Desv. típ. & 4,114 & 4,219 & 5,940 & 3,738 & 5,289 & 5,347 \\
\hline & \multirow{2}{*}{$\begin{array}{l}\text { Sí, acciones frecuentes sin } \\
\text { una política definida de RS }\end{array}$} & Media & 13,00 & 15,20 & 8,28 & 17,44 & 15,96 & 19,72 \\
\hline & & Desv. típ. & 3,830 & 3,819 & 4,532 & 4,900 & 5,342 & 4,878 \\
\hline & \multirow{2}{*}{$\begin{array}{l}\text { Sí, acciones integradas en } \\
\text { una política de RS }\end{array}$} & Media & 11,73 & 14,86 & 9,30 & 16,62 & 16,05 & 21,27 \\
\hline & & Desv. típ. & 3,870 & 3,888 & 7,003 & 4,639 & 5,921 & 4,718 \\
\hline & Total & Media & 13,70 & 14,80 & 8,31 & 16,62 & 16,21 & 20,15 \\
\hline & Tuar & Desv. típ. & 4,197 & 3,907 & 5,632 & 4,203 & 5,321 & 4,644 \\
\hline
\end{tabular}

Cuadro 125: Medidas estadísticas sobre acciones en responsabilidad social, valores y edad.

Antes de proceder a revisar los datos del cuadro 125 hemos aplicado ANOVA de un factor (hemos incorporado la información en la página siguiente) para comprombar si existen diferencias estadísticamente significativas entre los diversos grupos muestrales contemplados (cuadro 126). 


\begin{tabular}{|c|c|c|c|c|c|c|}
\hline & & Suma de cuadrados & gl & Media cuadrática & $\mathbf{F}$ & Sig. \\
\hline \multirow{3}{*}{ Edad } & Inter-grupos & 2,038 & 3 & 679 & 1,913 & 129 \\
\hline & Intra-grupos & 65,718 & 185 & 355 & & \\
\hline & Total & 67,757 & 188 & & & \\
\hline \multirow{3}{*}{ Practicidad } & Inter-grupos & 236,772 & 3 & 78,924 & 4,749 & ,003 \\
\hline & Intra-grupos & 3074,636 & 185 & 16,620 & & \\
\hline & Total & 3311,407 & 188 & & & \\
\hline \multirow{3}{*}{ Resultados } & Inter-grupos & 6,856 & 3 & 2,285 & , 148 & ,931 \\
\hline & Intra-grupos & 2862,901 & 185 & 15,475 & & \\
\hline & Total & 2869,757 & 188 & & & \\
\hline \multirow{3}{*}{ Variedad } & Inter-grupos & 79,442 & 3 & 26,481 & ,832 & ,478 \\
\hline & Intra-grupos & 5884,759 & 185 & 31,810 & & \\
\hline & Total & 5964,201 & 188 & & & \\
\hline \multirow{3}{*}{ Decisión } & Inter-grupos & 45,522 & 3 & 15,174 & 857 & ,464 \\
\hline & Intra-grupos & 3275,050 & 185 & 17,703 & & \\
\hline & Total & 3320,571 & 188 & & & \\
\hline \multirow{3}{*}{ Orden y método } & Inter-grupos & 40,179 & 3 & 13,393 & ,469 & ,704 \\
\hline & Intra-grupos & 5282,774 & 185 & 28,556 & & \\
\hline & Total & 5322,952 & 188 & & & \\
\hline \multirow{3}{*}{ Metas } & Inter-grupos & 69,526 & 3 & 23,175 & 1,076 & ,361 \\
\hline & Intra-grupos & 3985,025 & 185 & 21,541 & & \\
\hline & Total & 4054,550 & 188 & & & \\
\hline
\end{tabular}

Cuadro 126: Tabla ANOVA de edad y valores, factor Realización de Acciones de Responsabilidad Social.

Los datos del cuadro 126 revelan la existencia de diferencias estadísticamente significativas entre los diversos grupos muestrales en relación con "practicidad" (su coeficiente de significación ha sido 0,003).

En la lectura de la información que ofrece el cuadro 125 no hemos considerado, por su baja representatividad, aquellos grupos muestrales en los que solo se ha recabado información de un líder.

Hemos realizado la revisión de los datos sobre "valores" y comportamiento socialmente responsable de las organizaciones agrupando la información a partir de los segmentos de edad considerados en la revisión de los datos: 20 a 40 años, 41 a 60 y más de 61. 
En los líderes de 20 a 40 años procedentes de organizaciones que no desarrollan ninguna acción de responsabilidad social, solo se ha registrado un "valor" con una puntuación media mayor que en el resto de comportamientos socialmente responsables considerados. Se trata del rasgo de personalidad "practicidad" (su valor medio ha sido 13,89). En el resto de conductas de responsabilidad social contempladas se encuentran las puntuaciones máximas alcanzadas por cada "valor".

En ninguno de los cuatro tipos de comportamientos socialmente responsables considerados se observan tendencias crecientes o decrecientes en las puntuaciones medias de los "valores". Sí es destacable que en uno de los cuatro casos el "valor" con mayor importancia no sea la competencia genérica “metas" (que es el "valor" con mayor puntaje medio en los líderes de 41 y 60 años y en los máximos responsables de 61 o más años sea cual sea el comportamiento socialmente responsable de su organización de origen) sino el rasgo de personalidad "decisión", que ha registrado un valor medio de 18,38 en los líderes procedentes de empresas que impulsan acciones de responsabilidad social de modo frecuente pero sin contar con una política definida.

En los líderes asociados a empresas que cuentan con una política establecida de responsabilidad social, además de la competencia genérica "metas" la característica comportamental "orden y método" ha mostrado ser relevante (su media ha sido 19,30). 
En los máximos responsables de 41 a 60 años procedentes de organizaciones que no presentan ningún tipo de actuación socialmente responsable sucede lo mismo que ocurre en los líderes de 20 a 40 años vinculados a este tipo de empresas: el único "valor" que ha alcanzado una puntuación media mayor en los líderes procedentes de las organizaciones inactivas en el ámbito de la responsabilidad social que en el resto de empresas contempladas ha sido el rasgo de personalidad "practicidad" (su valor medio ha alcanzado la puntuación 14,82).

En los tres comportamientos organizacionales más afines a la responsabilidad social figuran las medias máximas alcanzados por los líderes en el resto de "valores". Es destacable que en aquellos que proceden de empresas con una política establecida de responsabilidad social se encuentren tres "valores" con la puntuación media más alta: “resultados" (15,32), “variedad” (10) y “decisión” $(17,09)$.

En las puntuaciones medias obtenidas en las competencias genéricas, rasgos de personalidad $y$ características comportamentales por los líderes de 41 a 60 años se observan dos tendencias a medida que se intensifica la actuación de las organizaciones en materia de responsabilidad social. El rasgo de personalidad "practicidad" tiene cada vez menos peso (su valor medio decrece de 14,82 a 11,55 ) y el rasgo de personalidad "decisión" cobra cada vez una leve mayor relevancia (su puntuación media pasa de 16,20 a 17,09). 
En los líderes de 61 o más años se produce de nuevo la misma situación que en los dos grupos de edad previos. Los máximos responsables procedentes de organizaciones que no impulsan ningún tipo de iniciativa en el ámbito de la responsabilidad social conceden mayor importancia al rasgo de personalidad "practicidad" (su puntuación media ha sido $16,14)$ respecto a los otros dos tipos de origen organizacional considerados en el líder de esta franja de edad (organizaciones que impulsan acciones frecuentes y empresas que cuentan con una política de responsabilidad social). Sin embargo en los líderes procedentes de las empresas que no desarrollan ningún tipo de actuación en materia de responsabilidad social la competencia genérica "resultados" también ha alcanzado la puntuación media más elevada $(15,29)$.

En los máximos responsables procedentes de organizaciones que cuentan con una política definida de responsabilidad social se ha registrado el mayor valor medio, además de en la competencia genérica "metas" $(23,40)$, en el rasgo de personalidad “decisión” (20). En ambos casos se trata de las puntuaciones medias más elevadas en "metas" y en "decisión", considerando los líderes de todas las franjas de edad.

En los líderes de 61 o más años se aprecian dos tendencias crecientes y dos decrecientes a medida que el comportamiento socialmente responsable de las organizaciones se intensifica. Las tendencias decrecientes se dan en el rasgo de personalidad "practicidad" (su valor 
medio pasa de 16,14 a 9,60) y en la competencia genérica "resultados" (su puntuación media decrece levemente de 15,29 a 14,60). Las tendencias crecientes se producen en el rasgo de personalidad "decisión" (su valor medio crece de 16 a 20) y en la competencia genérica "metas" (su puntuación media pasa de 17,71 a 23,40).

A continuación incorporamos los gráficos 65, 66 y 67 para revisar visualmente la evolución de los valores en los segmentos de edad considerados (20 a 40 años, 41 a 60 años y más de 60 años) y teniendo presente, al mismo tiempo, el comportamiento socialmente responsable de sus organizaciones de origen.

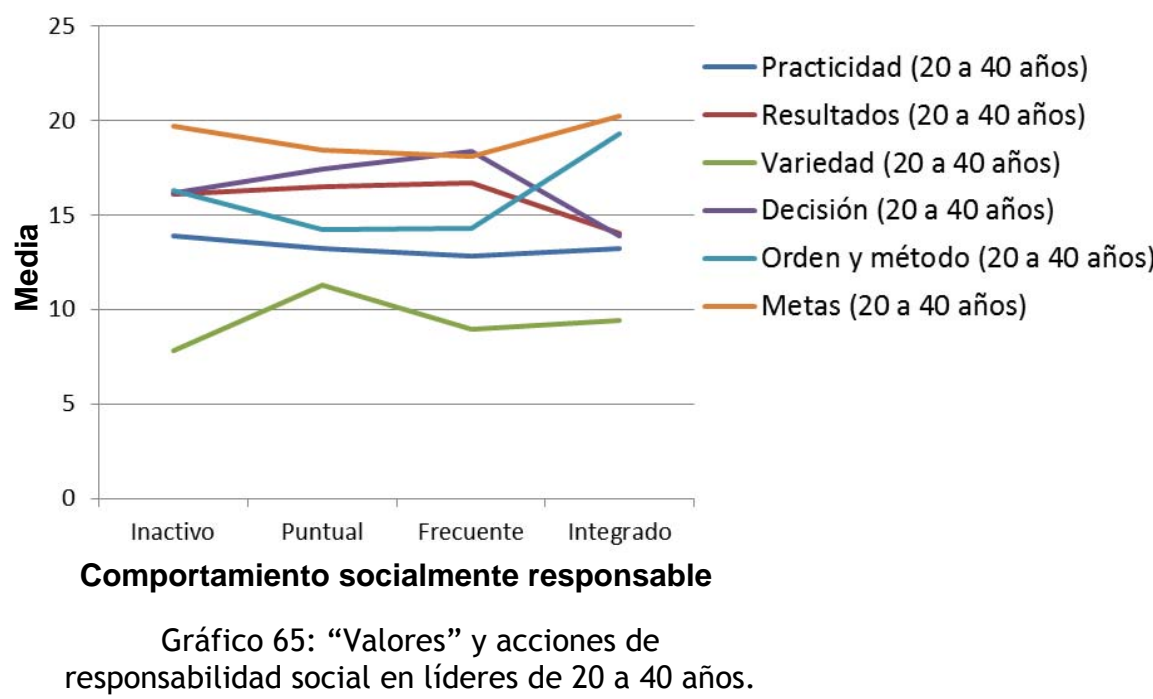

En los máximos responsables de 20 a 40 años (gráfico 65) el rasgo de personalidad "variedad", en términos generales, tiende a ganar importancia a medida que se intensifica el comportamiento socialmente responsable de 
la organización, mientras el rasgo de personalidad "practicidad" va reduciendo su relevancia.

El resto de "valores" no presenta una tendencia más o menos constante a medida que se incrementa la actuación social de la organización de procedencia del líder.

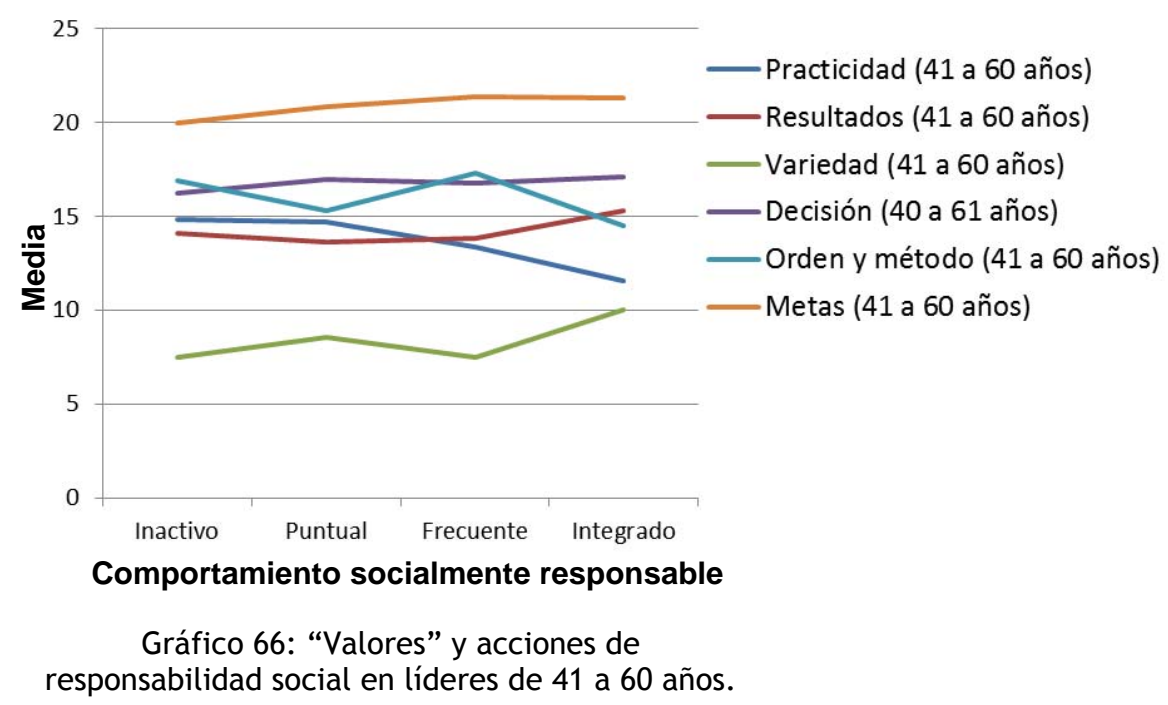

En los líderes de 40 a 61 años (gráfico 66) el rasgo de personalidad "variedad", en términos generales, y la competencia genérica "metas" presentan una tendencia a cobrar más relevancia a medida que se incrementa la implicación de las empresas de procedencia del líder en el ámbito de la responsabilidad social.

El rasgo de personalidad "practicidad" tiende a disminuir a medida que se intensifica el comportamiento socialmente responsable de las organizaciones. Y el rasgo de personalidad "decisión" parece mantenerse estable sea cual sea la conducta socialmente responsable de la empresa de procedencia del líder. 


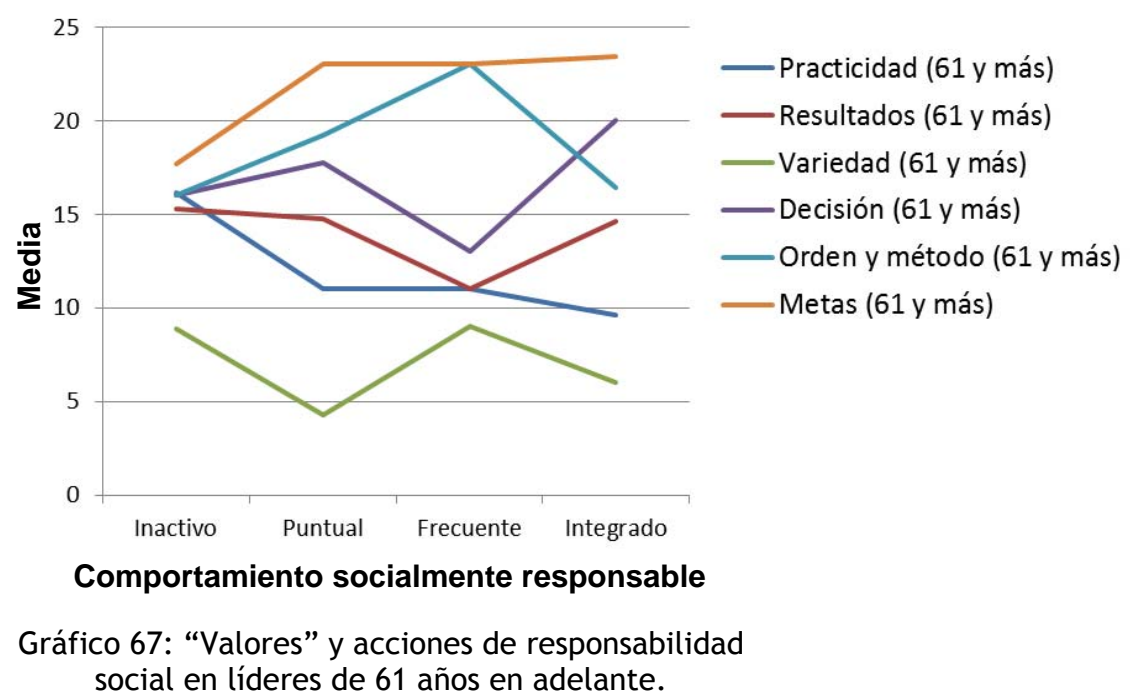

En cuanto a los líderes de más de 61 años (gráfico 67), la competencia genérica "metas" tiende a cobrar más relevancia a medida que se intensifica el comportamiento socialmente responsable de las organizaciones. En los líderes de esta edad el rasgo de personalidad "variedad" no muestra, en términos generales, la tendencia creciente a aumentar su importancia que se aprecia en los líderes del resto de edades contempladas a medida que crece la implicación de las organizaciones en el ámbito de la responsabilidad social.

A continuación hemos revisado los datos sobre la edad de los líderes y las competencias genéricas, los rasgos de personalidad y las características comportamentales estudiadas pero considerando, en este caso, la formación de las organizaciones de procedencia de los líderes enmarcada en el ámbito de la responsabilidad social. 


\begin{tabular}{|c|c|c|c|c|c|c|c|c|}
\hline Edad & Horas de form & tión en resp. social & Practicidad & Resultados & Variedad & Decisión & $\begin{array}{l}\text { Orden y } \\
\text { método }\end{array}$ & Metas \\
\hline \multirow{14}{*}{ De 20 a 40} & \multirow{2}{*}{ Menos de 11} & Media & 11,80 & 15,40 & 9,80 & 17,40 & 15,20 & 20,40 \\
\hline & & Desv. típ. & 3,768 & 3,578 & 6,760 & 4,827 & 2,049 & 5,683 \\
\hline & \multirow{2}{*}{ De 11 a 50} & Media & 10,33 & 17,00 & 7,67 & 24,67 & 12,00 & 18,33 \\
\hline & & Desv. típ. & 3,215 & 1,732 & 6,506 &, 577 & 4,359 & 5,686 \\
\hline & \multirow{2}{*}{ De 51 a 100} & Media & 13,00 & 12,00 & 10,00 & 10,00 & 25,00 & 20,00 \\
\hline & & Desv. típ. & & & & & & \\
\hline & \multirow{2}{*}{ De 101 a 150} & Media & 10,00 & 11,00 & 4,00 & 12,00 & 25,00 & 28,00 \\
\hline & & Desv. típ. & & . & & & & \\
\hline & \multirow{2}{*}{ De 201 a 1000} & Media & 9,00 & 23,00 & 6,00 & 21,00 & 12,00 & 19,00 \\
\hline & & Desv. típ. & & & & & & \\
\hline & \multirow{2}{*}{ Más de 1000} & Media & 15,00 & 15,00 & 8,00 & 9,00 & 19,00 & 24,00 \\
\hline & & Desv. típ. & . & . & & & & \\
\hline & \multirow{2}{*}{ Total } & Media & 11,42 & 15,75 & 8,33 & 17,75 & 16,08 & 20,67 \\
\hline & & Desv. típ. & 3,088 & 3,720 & 5,280 & 6,166 & 5,160 & 5,033 \\
\hline \multirow{16}{*}{ De 41 a 60} & \multirow{2}{*}{ Menos de 11} & Media & 14,80 & 13,60 & 8,20 & 14,60 & 16,60 & 22,20 \\
\hline & & Desv. típ. & 2,864 & 5,683 & 3,701 & 1,949 & 5,320 & 3,421 \\
\hline & \multirow{2}{*}{ De 11 a 50} & Media & 14,83 & 15,00 & 9,33 & 16,83 & 14,67 & 18,83 \\
\hline & & Desv. típ. & 6,555 & 4,050 & 5,645 & 6,616 & 4,926 & 3,545 \\
\hline & \multirow{2}{*}{ De 51 a 100} & Media & 12,25 & 16,25 & 12,50 & 20,00 & 12,25 & 16,75 \\
\hline & & Desv. típ. & 2,500 & 3,202 & 7,767 & 2,582 & 4,787 & 8,302 \\
\hline & \multirow{2}{*}{ De 101 a 150} & Media & 11,40 & 16,60 & 8,40 & 18,40 & 16,00 & 19,20 \\
\hline & & Desv. típ. & 2,608 & 6,580 & 8,792 & 3,975 & 4,899 & 3,962 \\
\hline & \multirow{2}{*}{ De 151 a 200} & Media & 14,00 & 12,00 & 10,00 & 22,00 & 9,00 & 23,00 \\
\hline & & Desv. típ. & & . & & & & \\
\hline & \multirow{2}{*}{ De 201 a 1000} & Media & 5,00 & 15,00 & 6,00 & 25,00 & 14,00 & 22,00 \\
\hline & & Desv. típ. & & & & & & \\
\hline & \multirow{2}{*}{ Más de 1000} & Media & 9,50 & 14,50 & 13,00 & 13,00 & 16,50 & 23,50 \\
\hline & & Desv. típ. & 3,536 & 2,121 & 14,142 & 1,414 & 4,950 & 6,364 \\
\hline & \multirow{2}{*}{ Total } & Media & 12,79 & 15,08 & 9,63 & 17,46 & 14,83 & 19,96 \\
\hline & & Desv. típ. & 4,403 & 4,462 & 6,566 & 4,709 & 4,724 & 4,823 \\
\hline \multirow{6}{*}{$\begin{array}{l}\text { De } 61 \text { en } \\
\text { adelante }\end{array}$} & م 50 & Media & 13,00 & 14,50 & 5,50 & 16,00 & 16,00 & 25,00 \\
\hline & De II & Desv. típ. & 5,657 & 3,536 & 3,536 & 5,657 & 7,071 &, 000 \\
\hline & 1010150 & Media & 9,00 & 18,00 &, 00 & 20,00 & 17,00 & 26,00 \\
\hline & De tola 100 & Desv. típ. & & . & & & & \\
\hline & Total & Media & 11,67 & 15,67 & 3,67 & 17,33 & 16,33 & 25,33 \\
\hline & Tulaí & Desv. típ. & 4,619 & 3,215 & 4,041 & 4,619 & 5,033 & ,577 \\
\hline & Menec de 11 & Media & 13,30 & 14,50 & 9,00 & 16,00 & 15,90 & 21,30 \\
\hline & Tivitus de t & Desv. típ. & 3,529 & 4,577 & 5,207 & 3,771 & 3,872 & 4,523 \\
\hline & $011=50$ & Media & 13,27 & 15,45 & 8,18 & 18,82 & 14,18 & 19,82 \\
\hline & De t a d a & Desv. típ. & 5,551 & 3,328 & 5,288 & 6,274 & 4,813 & 4,400 \\
\hline & 510100 & Media & 12,40 & 15,40 & 12,00 & 18,00 & 14,80 & 17,40 \\
\hline & DE SI A TOU & Desv. típ. & 2,191 & 3,362 & 6,819 & 5,000 & 7,050 & 7,335 \\
\hline & 150101 & Media & 10,86 & 16,00 & 6,57 & 17,71 & 17,43 & 21,43 \\
\hline TOTA & De ivi a TOU & Desv. típ. & 2,340 & 5,831 & 7,913 & 4,152 & 5,224 & 5,028 \\
\hline TUTAL & 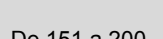 & Media & 14,00 & 12,00 & 10,00 & 22,00 & 9,00 & 23,00 \\
\hline & De IJI a 200 & Desv. típ. & & . & & & & \\
\hline & 1000 ב 201 م" & Media & 7,00 & 19,00 & 6,00 & 23,00 & 13,00 & 20,50 \\
\hline & Dezol a tous & Desv. típ. & 2,828 & 5,657 & ,000 & 2,828 & 1,414 & 2,121 \\
\hline & Mác de 1000 & Media & 11,33 & 14,67 & 11,33 & 11,67 & 17,33 & 23,67 \\
\hline & IVids de ivou & Desv. típ. & 4,041 & 1,528 & 10,408 & 2,517 & 3,786 & 4,509 \\
\hline & Total & Media & 12,28 & 15,33 & 8,77 & 17,54 & 15,33 & 20,59 \\
\hline & Tulai & Desv. típ. & 4,006 & 4,087 & 6,132 & 5,057 & 4,792 & 4,843 \\
\hline
\end{tabular}

Cuadro 127: Medidas estadísticas sobre formación en responsabilidad social, valores y edad. 
Antes de revisar la información del cuadro 127 hemos realizado ANOVA de un factor (cuadro 128) para comprobar si existen diferencias estadísticamente significativas entre los diversos grupos muestrales considerados.

\begin{tabular}{|c|c|c|c|c|c|c|}
\hline & & Suma de cuadrados & gl & Media cuadrática & $\mathbf{F}$ & Sig. \\
\hline \multirow{3}{*}{ Edad } & Inter-grupos & 1,547 & 6 & 258 & ,725 & ,632 \\
\hline & Intra-grupos & 11,376 & 32 & ,355 & & \\
\hline & Total & 12,923 & 38 & & & \\
\hline \multirow{3}{*}{ Practicidad } & Inter-grupos & 96,892 & 6 & 16,149 & 1,007 & ,438 \\
\hline & Intra-grupos & 513,006 & 32 & 16,031 & & \\
\hline & Total & 609,897 & 38 & & & \\
\hline \multirow{3}{*}{ Resultados } & Inter-grupos & 49,573 & 6 & 8,262 & ,452 & ,838 \\
\hline & Intra-grupos & 585,094 & 32 & 18,284 & & \\
\hline & Total & 634,667 & 38 & & & \\
\hline \multirow{3}{*}{ Variedad } & Inter-grupos & 126,906 & 6 & 21,151 &, 520 & ,789 \\
\hline & Intra-grupos & 1302,017 & 32 & 40,688 & & \\
\hline & Total & 1428,923 & 38 & & & \\
\hline \multirow{3}{*}{ Decisión } & Inter-grupos & 225,961 & 6 & 37,660 & 1,616 & ,175 \\
\hline & Intra-grupos & 745,732 & 32 & 23,304 & & \\
\hline & Total & 971,692 & 38 & & & \\
\hline \multirow{3}{*}{ Orden y método } & Inter-grupos & 112,949 & 6 & 18,825 &, 793 &, 582 \\
\hline & Intra-grupos & 759,717 & 32 & 23,741 & & \\
\hline & Total & 872,667 & 38 & & & \\
\hline \multirow{3}{*}{ Metas } & Inter-grupos & 101,619 & 6 & 16,936 & ,686 & ,662 \\
\hline & Intra-grupos & 789,817 & 32 & 24,682 & & \\
\hline & Total & 891,436 & 38 & & & \\
\hline
\end{tabular}

Cuadro 128: Tabla ANOVA de edad y valores, factor Horas de Formación en Responsabilidad Social.

La información que ofrece el cuadro 128 indica que no existen diferencias estadísticamente significativas entre los diversos grupos muestrales considerados ya que, en ningún caso, el coeficiente de significación está por debajo de 0,05 .

En la lectura de los datos del cuadro 127 no hemos tenido en cuenta, por su reducida representatividad, a los 
grupos muestrales en los que solo se ha obtenido información de un líder.

Hemos realizado el análisis agrupando la información a partir de los segmentos de edad indicados en el cuadro 127.

En los líderes de 20 a 40 años se han revisado los datos de los máximos responsables procedentes de empresas que dedican menos de 11 horas y de 11 a 50 horas a acciones formativas enmarcadas en el ámbito de la responsabilidad social.

Las puntaciones medias más elevadas registradas en los "valores" analizados se alternan en los dos grupos señalados: la competencia genérica "metas" (su puntuación media ha sido 20,40 ) en los líderes vinculados a organizaciones que dedican menos de 11 horas a formación encuadrada en el ámbito de la responsabilidad social y el rasgo de personalidad “decisión” $(24,67)$ en los máximos responsables vinculados a organizaciones que dedican entre 11 y 50 horas a este tipo de formación.

En los líderes de 41 a 60 años procedentes de organizaciones que dedican la cantidad mínima de horas contemplada a acciones de responsabilidad social (menos de 11) hay dos "valores" que han obtenido una puntación máxima: se trata del rasgo de personalidad "practicidad" (ha registrado un valor medio de 14,80 ) y la característica comportamental "orden y método" (ha alcanzado un valor medio de 16,60). 
Y en los máximos responsables de 41 a 60 años vinculados a organizaciones en los que existe la mayor implicación contemplada en las acciones de formación enmarcadas en el ámbito de la responsabilidad social (las que invierten más de 1000 horas a este tipo de iniciativas) el rasgo de personalidad "variedad" ha alcanzado su valor medio máximo (13) al igual que la competencia genérica “metas" $(23,50)$.

En los líderes de 41 a 60 años se ha producido una cierta tendencia decreciente (no se mantiene en todos los casos considerados) del rasgo de personalidad "practicidad" a medida que la organización aumenta el número de horas dirigidas a formación enmarcada en el ámbito de la responsabilidad social. Esta tendencia también se producía en los líderes de esta franja al considerar el comportamiento socialmente responsable de las organizaciones, la edad de los líderes y las competencias genéricas, rasgos de personalidad y características comportamentales analizadas.

En lo que respecta a los líderes de 61 años en adelante solo hemos considerado los datos de los máximos responsables procedentes de organizaciones que dedican entre 11 y 50 horas a acciones formativas encuadradas en la disciplina de la Responsabilidad Social Corporativa.

La puntuación media más alta en estos líderes ha sido registrada por la competencia genérica “metas” (25) y, en segundo orden de importancia, se han situado la 
característica comportamental “orden y método" (16) y el rasgo de personalidad "decisión” (16).

Hemos incluido a continuación los gráficos 68 y 69 para contemplar, visualmente, si es posible advertir algún tipo de asociación entre: la variación de los datos sobre las horas de formación que las organizaciones de origen de los líderes dedican a acciones enmarcadas en el ámbito de la responsabilidad social, las competencias genéricas analizadas, los rasgos de personalidad contemplados y las características comportamentales consideradas en los líderes de 20 a 40 años y en los máximos responsables de 41 a 60 años.

Como en el resto de revisiones visuales, hemos incluido en los gráficos todos los grupos muestrales aunque presenten una baja representatividad.

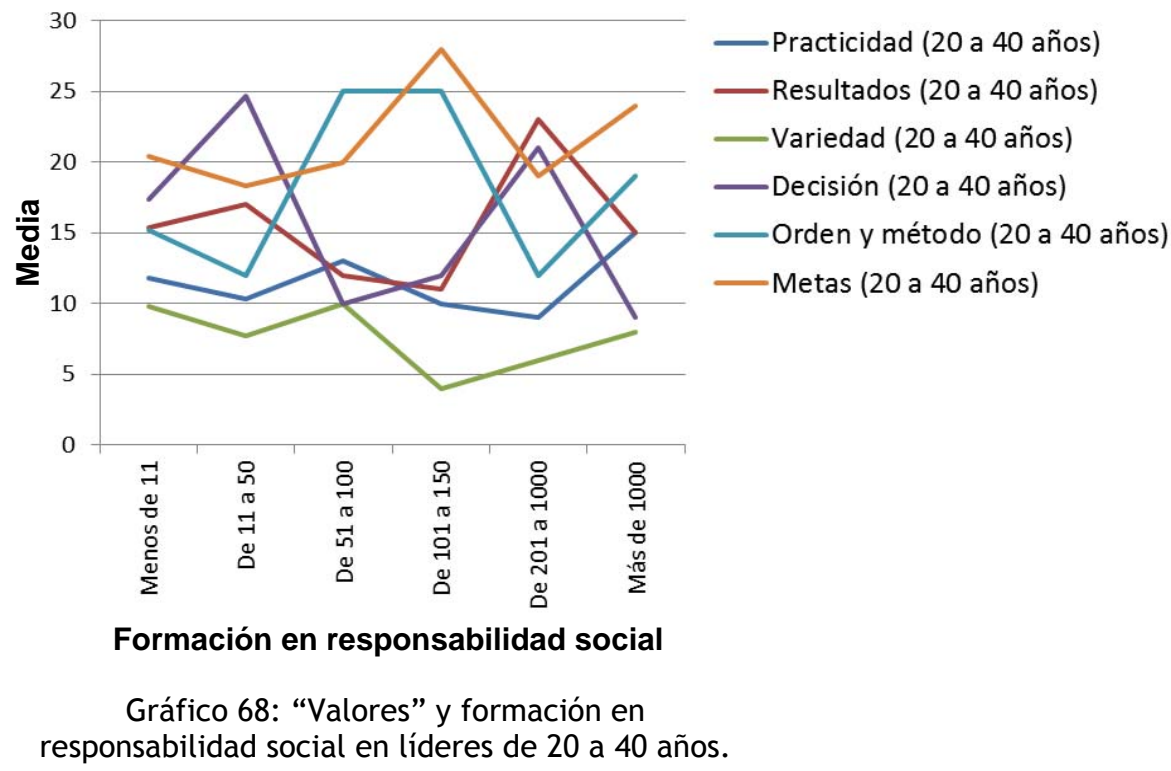


El grafico 68 muestra que las líneas visuales de "practicidad”, “resultados”, “variedad”, “decisión”, "metas" y "orden y método" no presentan variaciones constantes a medida que las organizaciones de procedencia de los líderes de 20 a 40 años aumentan el número de horas que dedican a acciones formativas enmarcadas en el ámbito de la responsabilidad social.

Existe una cierta tendencia a no registrar una gran variación en sus valores medios en los rasgos de personalidad "variedad" y "decisión" a medida que la organización aumenta el tiempo invertido en acciones de formación encuadradas en el ámbito de Responsabilidad Social Corporativa.

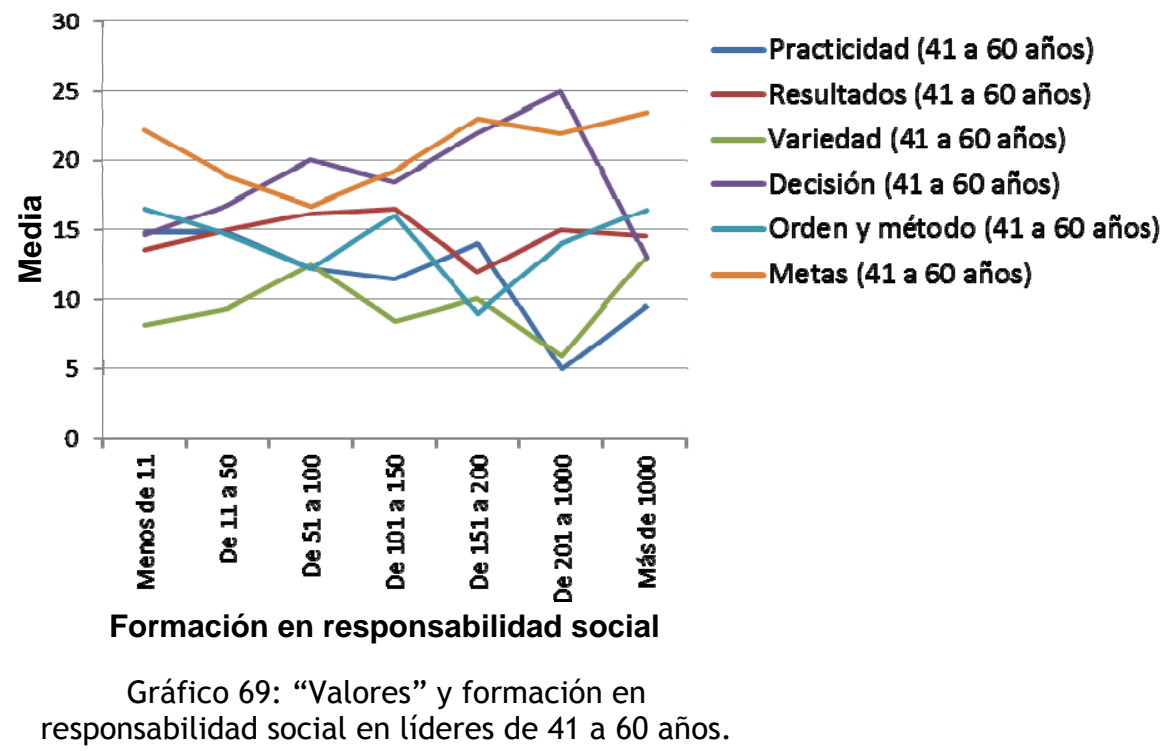

En el gráfico 69 se aprecia en los líderes de 41 a 60 años una cierta tendencia creciente, en algunas franjas consideradas decrece, en el rasgo de personalidad “decisión" y en la competencia genérica "metas" a medida que la organización de procedencia de los máximos 
responsables dedica más horas a formar a sus públicos internos en aspectos afines a la responsabilidad social.

También se percibe en los líderes de 41 a 60 años una cierta tendencia decreciente en el rasgo "practicidad", a medida que su empresa de origen dedica más horas a acciones formativas enmarcadas en el ámbito de la responsabilidad social.

La competencia genérica "resultados" parece presentar una relevancia constante en los máximos responsables de 41 a 60 que no se ve afectada por variaciones en el número de horas que las organizaciones a las que los líderes están vinculados dedican a acciones de formación asociadas a la Responsabilidad Social Corporativa.

\subsubsection{Sector, tamaño y Responsabilidad Social Corporativa}

\begin{tabular}{|l|l|r|r|r|r|}
\hline Sector & Tamaño & Media & Mínimo & Máximo & Desv. típ. \\
\hline \multirow{4}{*}{$\begin{array}{l}\text { Servicios } \\
\text { incluye comercio }\end{array}$} & Pequeño & 7,0315 & 3,86 & 8,13 & 1,14114 \\
\cline { 2 - 6 } & Mediano & 7,1277 & 4,39 & 8,10 & 1,09708 \\
\cline { 2 - 6 } & Grande & 7,6114 & 6,20 & 8,07 &, 65141 \\
\cline { 2 - 6 } & Total & 7,1416 & 3,86 & 8,13 & 1,08394 \\
\hline \multirow{4}{*}{ Construcción } & Pequeño & 7,2536 & 5,25 & 8,03 & 1,05262 \\
\cline { 2 - 6 } & Mediano & 7,7619 & 7,26 & 8,03 &, 43737 \\
\cline { 2 - 6 } & Grande & 8,0000 & 8,00 & 8,00 & \\
\cline { 2 - 6 } & Total & 7,4159 & 5,25 & 8,03 &, 93308 \\
\hline \multirow{5}{*}{ Totustusia } & Pequeño & 7,4275 & 5,56 & 8,03 &, 84379 \\
\cline { 2 - 6 } & Mediano & 7,0370 & 5,00 & 8,10 & 1,09683 \\
\cline { 2 - 6 } & Grande & 7,6997 & 5,40 & 8,12 &, 83159 \\
\cline { 2 - 6 } & Total & 7,3844 & 5,00 & 8,12 &, 95516 \\
\hline \multirow{5}{*}{} & Pequeño & 7,0845 & 3,86 & 8,13 & 1,11040 \\
\cline { 2 - 6 } & Mediano & 7,1458 & 4,39 & 8,10 & 1,06398 \\
\cline { 2 - 6 } & Grande & 7,6528 & 5,40 & 8,12 &, 70090 \\
\cline { 2 - 6 } & Total & 7,2043 & 3,86 & 8,13 & 1,05294 \\
\hline
\end{tabular}

Cuadro 129: Medidas estadísticas de sector, tamaño y actitud hacia la responsabilidad social. 
En la página anterior hemos incorporado los datos sobre el sector de actividad del líder, el tamaño de su organización y su actitud hacia la Responsabilidad Social Corporativa (cuadro 129).

Antes de revisar la información que ofrece el cuadro 129 hemos aplicado ANOVA de un factor en la muestra poblacional para comprobar si existen diferencias estadísticamente significativas entre los diversos grupos muestrales contemplados (cuadro 130).

\begin{tabular}{|l|l|r|r|r|c|c|}
\hline \multicolumn{2}{|c|}{} & Suma de cuadrados & gl & Media cuadrática & F & Sig. \\
\hline \multirow{4}{*}{ Sector } & Inter-grupos & 42,217 & 80 &, 528 &, 815 &, 832 \\
\cline { 2 - 8 } & Intra-grupos & 69,920 & 108 &, 647 & & \\
\cline { 2 - 8 } & Total & 112,138 & 188 & & & \\
\hline \multirow{4}{*}{ Tamaño } & Inter-grupos & 39,531 & 80 &, 494 &, 707 &, 948 \\
\cline { 2 - 8 } & Intra-grupos & 75,495 & 108 &, 699 & & \\
\cline { 2 - 8 } & Total & 115,026 & 188 & & & \\
\hline
\end{tabular}

Cuadro 130: Tabla ANOVA de sector y tamaño, factor Actitud hacia la Responsabilidad Social.

Los resultados de la prueba de ANOVA (cuadro 130) indican que no hay diferencias estadísticamente significativas entre los grupos muestrales que integran la muestra poblacional (en ningún caso el coeficiente de significación es inferior a 0,05).

En la lectura de los datos del cuadro 129 no hemos considerado el grupo muestral del sector construcción "grande" por su escasa representatividad (solo se ha recabado información de un líder).

En los sectores servicios y construcción el aumento del tamaño de la organización de procedencia del líder supone 
un incremento de su actitud a favor de la responsabilidad social. En las empresas del sector servicios la actitud media de los máximos responsables aumenta de 7,03 (en los líderes cuyo origen son empresas pequeñas) a 7,61 (en los máximos responsables asociados de empresas grandes). En las organizaciones del sector construcción, la puntuación media de la actitud de los máximos responsables crece de 7,25 (valor registrado en los líderes procedentes de empresas pequeñas) a 7,76 (puntuación media registrada por los líderes vinculados a empresas grandes).

Esta tendencia no se ha mantenido en el sector industria. En este ámbito de actividad mercantil, la menor actitud media se ha producido en los líderes procedentes de empresas medianas $(7,03)$, seguidos por los de empresas pequeñas $(7,42)$ y a continuación se han situado los que proceden de empresas grandes $(7,69)$.

Si comparamos la actitud media registrada por los líderes vinculados a organizaciones pequeñas, la puntuación media más alta la reciben los líderes del sector industria $(7,42)$ seguidos por los del sector construcción $(7,25)$ y finalmente se sitúan los del sector servicios $(7,03)$.

En relación con los líderes procedentes de empresas medianas, los líderes del sector construcción han registrado una actitud media más elevada que la que han obtenido los máximos responsables del sector servicios e industria $(7,76)$.

En cuanto a los líderes de las empresas grandes, los procedentes del sector servicios e industria han obtenido 
una puntuación muy similar en su actitud media $(7,61$ y 7,69 respectivamente).

Hemos incorporado a continuación el gráfico 70 para verificar, de modo visual, posibles asociaciones en la variación del tamaño empresarial y de la actitud hacia la responsabilidad social de los líderes dentro de cada sector empresarial.

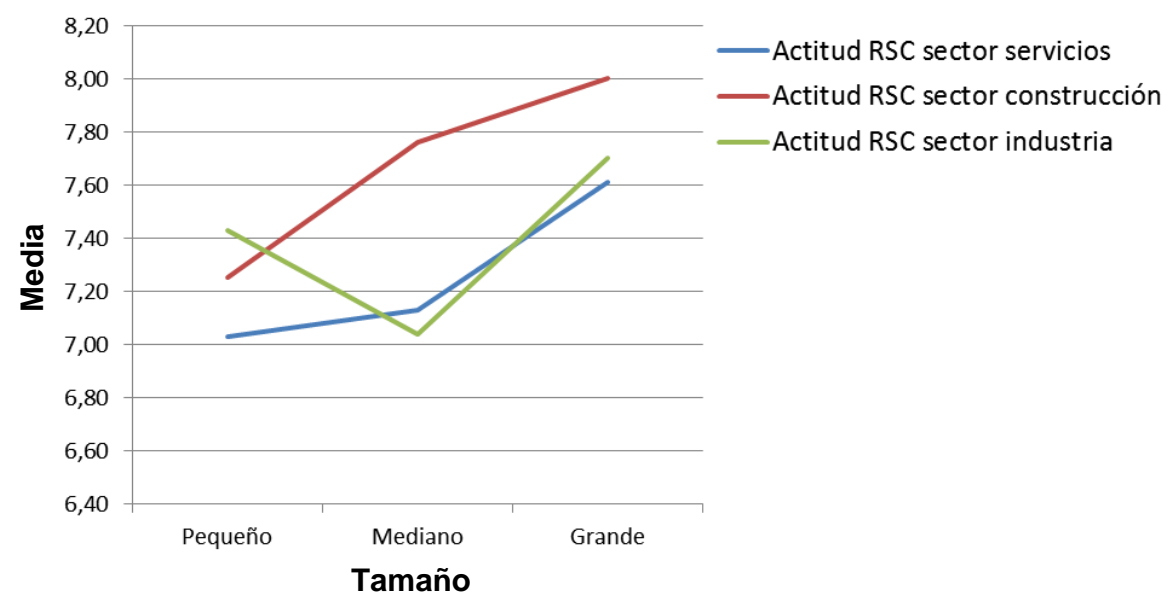

Gráfico 70: Sector, tamaño y actitud hacia la responsabilidad social.

El gráfico 70 muestra como en los sectores servicios y construcción, el tamaño parece ser un factor discriminante en relación con la actitud de sus líderes empresariales hacia la responsabilidad social. A medida que crece el tamaño de las organizaciones que operan en estos entornos, aumenta la actitud afín de sus máximos dirigentes hacia la responsabilidad social.

A continuación revisamos los datos que hacen referencia al sector de procedencia de los líderes 
(industria, construcción y comercio -donde se incluye también al sector servicios-) y al tamaño de sus organizaciones de origen (grande, mediano y pequeño), junto con el comportamiento socialmente responsable de la empresa de origen del máximo responsable (cuadro 128).

\begin{tabular}{|c|c|c|c|c|c|c|c|}
\hline \multirow{2}{*}{\multicolumn{4}{|c|}{ Sector }} & \multicolumn{3}{|c|}{ Tamaño } & \multirow{3}{*}{$\begin{array}{l}\text { Total } \\
100,0 \%\end{array}$} \\
\hline & & & & \multirow{2}{*}{$\begin{array}{r}\text { Pequeño } \\
84,1 \%\end{array}$} & \multirow{2}{*}{$\begin{array}{r}\text { Mediano } \\
15,9 \%\end{array}$} & \multirow{2}{*}{$\begin{array}{r}\text { Grande } \\
0,0 \%\end{array}$} & \\
\hline \multirow{10}{*}{$\begin{array}{l}\text { Servicios } \\
\text { (incluye } \\
\text { comercio) }\end{array}$} & \multirow{8}{*}{$\begin{array}{l}\text { Acciones de } \\
\text { resp. social }\end{array}$} & \multirow{2}{*}{ No } & $\%$ dentro de acciones & & & & \\
\hline & & & $\%$ dentro de tamaño & $64,4 \%$ & $36,7 \%$ & $0,0 \%$ & $48,6 \%$ \\
\hline & & \multirow{2}{*}{ Sí, acciones puntuales } & $\%$ dentro de acciones & $69,0 \%$ & $17,2 \%$ & $13,8 \%$ & $100,0 \%$ \\
\hline & & & $\%$ dentro de tamaño & $22,2 \%$ & $16,7 \%$ & $18,2 \%$ & $20,4 \%$ \\
\hline & & \multirow{2}{*}{$\begin{array}{l}\text { Sí, acciones frecuentes sin } \\
\text { una política definida de RS }\end{array}$} & $\%$ dentro de acciones & $50,0 \%$ & $38,9 \%$ & $11,1 \%$ & $100,0 \%$ \\
\hline & & & $\%$ dentro de tamaño & $10,0 \%$ & $23,3 \%$ & $9,1 \%$ & $12,7 \%$ \\
\hline & & \multirow{2}{*}{$\begin{array}{l}\text { Sí, acciones integradas en } \\
\text { una política de RS }\end{array}$} & $\%$ dentro de acciones & $11,5 \%$ & $26,9 \%$ & $61,5 \%$ & $100,0 \%$ \\
\hline & & & $\%$ dentro de tamaño & $3,3 \%$ & $23,3 \%$ & $72,7 \%$ & $18,3 \%$ \\
\hline & \multirow{2}{*}{\multicolumn{2}{|c|}{ Total }} & $\%$ dentro de acciones & $63,4 \%$ & $21,1 \%$ & $15,5 \%$ & $100,0 \%$ \\
\hline & & & $\%$ dentro de tamaño & $100,0 \%$ & $100,0 \%$ & $100,0 \%$ & $100,0 \%$ \\
\hline \multirow{10}{*}{ Construcción } & \multirow{8}{*}{$\begin{array}{l}\text { Acciones de } \\
\text { resp. social }\end{array}$} & \multirow{2}{*}{ No } & $\%$ dentro de acciones & $80,0 \%$ & $20,0 \%$ & $0,0 \%$ & $100,0 \%$ \\
\hline & & & $\%$ dentro de tamaño & $80,0 \%$ & $66,7 \%$ & $0,0 \%$ & $71,4 \%$ \\
\hline & & \multirow{2}{*}{ Sí, acciones puntuales } & $\%$ dentro de acciones & $100,0 \%$ & $0,0 \%$ & $0,0 \%$ & $100,0 \%$ \\
\hline & & & $\%$ dentro de tamaño & $20,0 \%$ & $0,0 \%$ & $0,0 \%$ & $14,3 \%$ \\
\hline & & \multirow{2}{*}{$\begin{array}{l}\text { Sí, acciones frecuentes sin } \\
\text { una politica definida de RS }\end{array}$} & $\%$ dentro de acciones & $0,0 \%$ & $0,0 \%$ & $100,0 \%$ & $100,0 \%$ \\
\hline & & & $\%$ dentro de tamaño & $0,0 \%$ & $0,0 \%$ & $100,0 \%$ & $7,1 \%$ \\
\hline & & \multirow{2}{*}{$\begin{array}{l}\text { Sí, acciones integradas en } \\
\text { una política de RS }\end{array}$} & $\%$ dentro de acciones & $0,0 \%$ & $100,0 \%$ & $0,0 \%$ & $100,0 \%$ \\
\hline & & & $\%$ dentro de tamaño & $0,0 \%$ & $33,3 \%$ & $0,0 \%$ & $7,1 \%$ \\
\hline & \multirow{2}{*}{\multicolumn{2}{|c|}{ Total }} & $\%$ dentro de acciones & $71,4 \%$ & $21,4 \%$ & $7,1 \%$ & $100,0 \%$ \\
\hline & & & $\%$ dentro de tamaño & $100,0 \%$ & $100,0 \%$ & $100,0 \%$ & $100,0 \%$ \\
\hline \multirow{10}{*}{ Industria } & \multirow{8}{*}{$\begin{array}{l}\text { Acciones de } \\
\text { resp. social }\end{array}$} & \multirow{2}{*}{ No } & $\%$ dentro de acciones & $50,0 \%$ & $41,7 \%$ & $8,3 \%$ & $100,0 \%$ \\
\hline & & & $\%$ dentro de tamaño & $66,7 \%$ & $41,7 \%$ & $8,3 \%$ & $36,4 \%$ \\
\hline & & \multirow{2}{*}{ Sí, acciones puntuales } & $\%$ dentro de acciones & $40,0 \%$ & $60,0 \%$ & $0,0 \%$ & $100,0 \%$ \\
\hline & & & $\%$ dentro de tamaño & $22,2 \%$ & $25,0 \%$ & $0,0 \%$ & $15,2 \%$ \\
\hline & & Sí, acciones frecuentes sin & $\%$ dentro de acciones & $16,7 \%$ & $16,7 \%$ & $66,7 \%$ & $100,0 \%$ \\
\hline & & una política definida de RS & $\%$ dentro de tamaño & $11,1 \%$ & $8,3 \%$ & $33,3 \%$ & $18,2 \%$ \\
\hline & & Sí, acciones integradas en & $\%$ dentro de acciones & $0,0 \%$ & $30,0 \%$ & $70,0 \%$ & $100,0 \%$ \\
\hline & & una política de RS & $\%$ dentro de tamaño & $0,0 \%$ & $25,0 \%$ & $58,3 \%$ & $30,3 \%$ \\
\hline & Total & & $\%$ dentro de acciones & $27,3 \%$ & $36,4 \%$ & $36,4 \%$ & $100,0 \%$ \\
\hline & Total & & $\%$ dentro de tamaño & $100,0 \%$ & $100,0 \%$ & $100,0 \%$ & $100,0 \%$ \\
\hline & & $\mathrm{No}$ & $\%$ dentro de acciones & $79,1 \%$ & $19,8 \%$ & $1,1 \%$ & $100,0 \%$ \\
\hline & & No & $\%$ dentro de tamaño & $66,1 \%$ & $40,0 \%$ & $2,9 \%$ & $48,1 \%$ \\
\hline & & Sí accinnes nuntuales & $\%$ dentro de acciones & $66,7 \%$ & $22,2 \%$ & $11,1 \%$ & $100,0 \%$ \\
\hline & Acciones de & Sl, acciones puntuales & $\%$ dentro de tamaño & $22,0 \%$ & $17,8 \%$ & $11,4 \%$ & $19,0 \%$ \\
\hline & resp. social & Sí, acciones frecuentes sin & $\%$ dentro de acciones & $40,0 \%$ & $32,0 \%$ & $28,0 \%$ & $100,0 \%$ \\
\hline TOTAL & & una política definida de RS & $\%$ dentro de tamaño & $9,2 \%$ & $17,8 \%$ & $20,0 \%$ & $13,2 \%$ \\
\hline & & Sí, acciones integradas en & $\%$ dentro de acciones & $8,1 \%$ & $29,7 \%$ & $62,2 \%$ & $100,0 \%$ \\
\hline & & una política de RS & $\%$ dentro de tamaño & $2,8 \%$ & $24,4 \%$ & $65,7 \%$ & $19,6 \%$ \\
\hline & & & $\%$ dentro de acciones & $57,7 \%$ & $23,8 \%$ & $18,5 \%$ & $100,0 \%$ \\
\hline & Iotal & & $\%$ dentro de tamaño & $100,0 \%$ & $100,0 \%$ & $100,0 \%$ & $100,0 \%$ \\
\hline
\end{tabular}

Cuadro 131: Tabla de contingencia de acciones de responsabilidad social, tamaño y sector.

En la lectura de los datos del cuadro 131 no hemos considerado, por su escasa representatividad, aquellos 
grupos muestrales que solo han registrado información de un líder.

A continuación hemos realizado una revisión de la información, agrupando las consideraciones a partir del sector de procedencia del líder.

En el sector servicios las empresas mayoritarias en los comportamientos organizacionales menos responsables son las pequeñas: el $84,1 \%$ de las empresas que no realizan ningún tipo de actuación y el $69 \%$ de las organizaciones que impulsan iniciativas puntuales de responsabilidad social. En las empresas que desarrollan acciones frecuentes las empresas pequeñas siguen teniendo la presencia más destacada (50\%), aunque el protagonismo de las organizaciones medianas también es llamativo (38,9\%). En el caso de las organizaciones que cuentan con una política definida de Responsabilidad Social Corporativa, las empresas grandes $(61,5 \%)$ tienen una mayor presencia. De todos modos en este último grupo también es significativa la presencia de empresas medianas (26,9\%).

En el sector construcción hay un protagonismo muy destacado de las empresas pequeñas en los dos grupos contemplados en el análisis: en el de las empresas que no desarrollan ningún tipo de actuación socialmente responsable (80\%) y en el de las organizaciones que impulsan acciones puntuales (100\%).

En el sector industria hay una cierta similitud con el sector servicios, aunque no se repite el mismo patrón. En las organizaciones que no presentan ningún tipo de 
comportamiento socialmente responsable las empresas pequeñas son las más numerosas (50\%), aunque la presencia de organizaciones medianas también es destacada $(41,7 \%)$. En las empresas que desarrollan acciones puntuales se invierte la tendencia: las organizaciones con mayor protagonismo son las medianas (60\%) aunque las pequeñas también tienen una presencia significativa (40\%). En los dos grupos que hacen alusión a una conducta socialmente responsable más intensa las empresas grandes tienen una mayor presencia: $66,7 \%$ en el caso de las organizaciones que desarrollan acciones frecuentes y $70 \%$ en el caso de las empresas que cuentan con una política de Responsabilidad Social Corporativa. En este último grupo las organizaciones medianas también tienen una presencia significativa (30\%).

Hemos incluido a continuación los gráficos 70 y 71 con objeto de revisar visualmente si existe algún tipo de asociación en la variación del tamaño de las empresas y de su comportamiento socialmente responsable dentro de cada sector.

El gráfico 71 muestra como a medida que aumenta el comportamiento responsable de las empresas decrece el número de organizaciones del sector construcción, tiende a reducirse en el sector servicios y decrece para finalmente aumentar en el sector industria. 


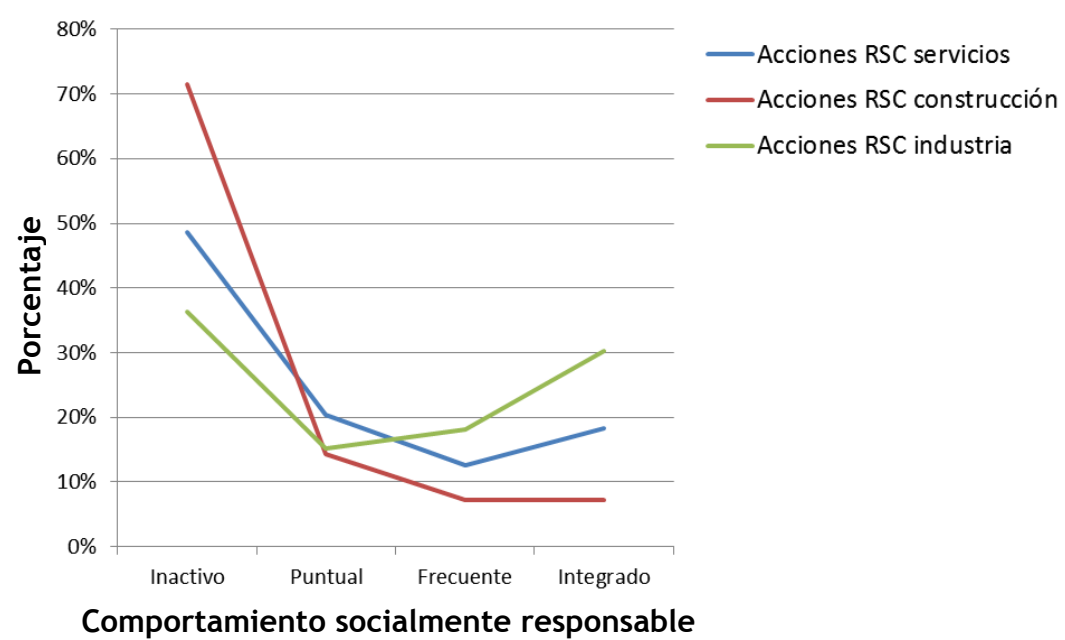

Gráfico 71: Sector y acciones de responsabilidad social.

Los datos del gráfico 71 revelan cierta asociación con la información visual del gráfico 72 incorporada más abajo.

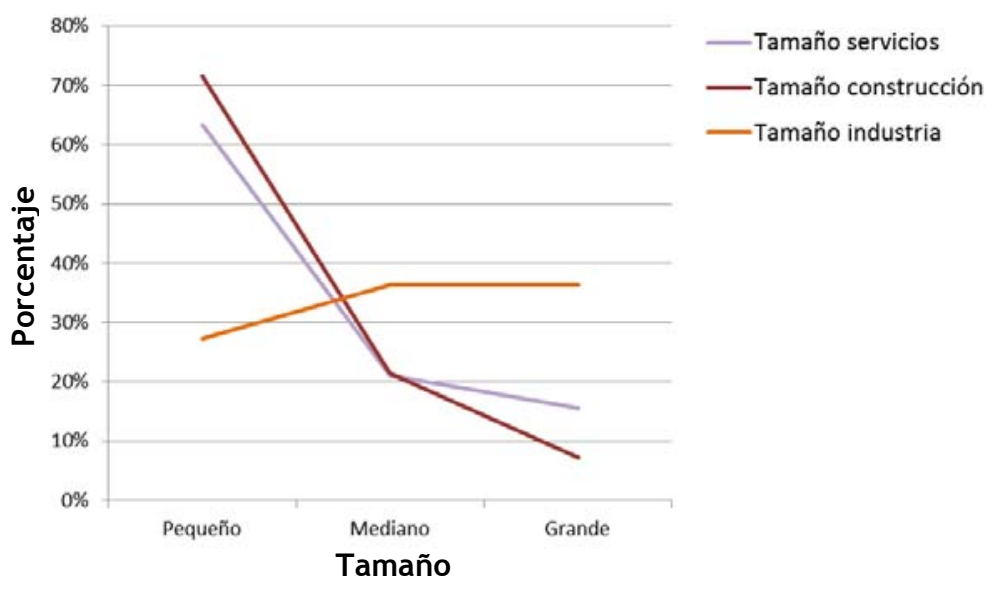

Gráfico 72: Sector y tamaño.

El gráfico 72 muestra como el tamaño empresarial parece ser bastante indicativo del tipo de comportamiento socialmente responsable de las empresas (gráfico 71). En los sectores servicios y construcción, donde hay más presencia de empresas pequeñas que medianas y más protagonismo de organizaciones medianas que grandes, la correspondencia visual entre ambos gráficos refleja una conducta 
organizacional responsable menos intensa. Mientras que en las empresas del sector construcción, donde hay más organizaciones medianas y grandes que pequeñas, existen comportamientos socialmente responsables más acentuados.

A continuación revisamos los datos sobre el tamaño de las organizaciones y su sector de actividad pero contemplando, en este caso, las horas de formación enmarcadas en el ámbito de la responsabilidad social que las organizaciones dirigen a sus públicos internos.

En la lectura de los datos del cuadro 132, incorporando más adelante, no hemos considerado, por su reducida representatividad, los grupos muestrales en los que solo se han obtenido datos de un líder.

Hemos agrupado la revisión de la información a partir de los sectores de actividad contemplados en el estudio.

En el sector servicios las empresas pequeñas tienen más presencia que el resto en las organizaciones que dedican menos de 11 horas a acciones formativas de responsabilidad social (42,9\%), aunque en este tipo de organizaciones también es destacado el protagonismo de las empresas medianas $(28,6 \%)$ y grandes $(28,6 \%)$. En las organizaciones que dedican de 11 a 50 horas a actuaciones de formación, la mayor presencia corresponde, a partes iguales, a las organizaciones pequeñas y grandes $(50 \%$ de las empresas en cada caso). 


\begin{tabular}{|c|c|c|c|c|c|c|c|}
\hline \multirow{2}{*}{\multicolumn{4}{|c|}{ Sector }} & \multicolumn{3}{|c|}{ Tamaño } & \multirow{3}{*}{$\begin{array}{c}\text { Total } \\
100,0 \%\end{array}$} \\
\hline & & & & \multirow{2}{*}{$\begin{array}{r}\text { Pequeño } \\
42,9 \%\end{array}$} & \multirow{2}{*}{$\begin{array}{r}\text { Mediano } \\
28,6 \%\end{array}$} & \multirow{2}{*}{$\begin{array}{r}\text { Grande } \\
28,6 \%\end{array}$} & \\
\hline \multirow{16}{*}{$\begin{array}{l}\text { Servicios } \\
\text { (incluye } \\
\text { comercio) }\end{array}$} & \multirow{14}{*}{$\begin{array}{l}\text { Horas de } \\
\text { formación en } \\
\text { resp. social }\end{array}$} & \multirow{2}{*}{ Menos de 11} & $\%$ dentro de horas de formación & & & & \\
\hline & & & $\%$ dentro de tamaño & $33,3 \%$ & $40,0 \%$ & $20,0 \%$ & $29,2 \%$ \\
\hline & & \multirow{2}{*}{ De 11 a 50} & $\%$ dentro de horas de formación & $50,0 \%$ & $0,0 \%$ & $50,0 \%$ & $100,0 \%$ \\
\hline & & & $\%$ dentro de tamaño & $33,3 \%$ & $0,0 \%$ & $30,0 \%$ & $25,0 \%$ \\
\hline & & \multirow{2}{*}{ De 51 a 100} & $\%$ dentro de horas de formación & $33,3 \%$ & $66,7 \%$ & $0,0 \%$ & $100,0 \%$ \\
\hline & & & $\%$ dentro de tamaño & $11,1 \%$ & $40,0 \%$ & $0,0 \%$ & $12,5 \%$ \\
\hline & & \multirow{2}{*}{ De 101 a 150} & $\%$ dentro de horas de formación & $33,3 \%$ & $0,0 \%$ & $66,7 \%$ & $100,0 \%$ \\
\hline & & & $\%$ dentro de tamaño & $11,1 \%$ & $0,0 \%$ & $20,0 \%$ & $12,5 \%$ \\
\hline & & \multirow{2}{*}{ De 151 a 200} & $\%$ dentro de horas de formación & $0,0 \%$ & $0,0 \%$ & $100,0 \%$ & $100,0 \%$ \\
\hline & & & $\%$ dentro de tamaño & $0,0 \%$ & $0,0 \%$ & $10,0 \%$ & $4,2 \%$ \\
\hline & & \multirow{2}{*}{ De 201 a 1000} & $\%$ dentro de horas de formación & $0,0 \%$ & $0,0 \%$ & $100,0 \%$ & $100,0 \%$ \\
\hline & & & $\%$ dentro de tamaño & $0,0 \%$ & $0,0 \%$ & $10,0 \%$ & $4,2 \%$ \\
\hline & & \multirow{2}{*}{ Más de 1000} & $\%$ dentro de horas de formación & $33,3 \%$ & $33,3 \%$ & $33,3 \%$ & $100,0 \%$ \\
\hline & & & $\%$ dentro de tamaño & $11,1 \%$ & $20,0 \%$ & $10,0 \%$ & $12,5 \%$ \\
\hline & Total & & $\%$ dentro de horas de formación & $37,5 \%$ & $20,8 \%$ & $41,7 \%$ & $100,0 \%$ \\
\hline & TOlal & & $\%$ dentro de tamaño & $100,0 \%$ & $100,0 \%$ & $100,0 \%$ & $100,0 \%$ \\
\hline \multirow{6}{*}{ Construcción } & \multirow{4}{*}{$\begin{array}{l}\text { Horas de } \\
\text { formación en } \\
\text { resp. social }\end{array}$} & \multirow{2}{*}{ De 11 a 50} & $\%$ dentro de horas de formación & $0,0 \%$ & $50,0 \%$ & $50,0 \%$ & $100,0 \%$ \\
\hline & & & $\%$ dentro de tamaño & $0,0 \%$ & $100,0 \%$ & $100,0 \%$ & $50,0 \%$ \\
\hline & & \multirow{2}{*}{ De 101 a 150} & $\%$ dentro de horas de formación & $100,0 \%$ & $0,0 \%$ & $0,0 \%$ & $100,0 \%$ \\
\hline & & & $\%$ dentro de tamaño & $100,0 \%$ & $0,0 \%$ & $0,0 \%$ & $50,0 \%$ \\
\hline & Total & & $\%$ dentro de horas de formación & $50,0 \%$ & $25,0 \%$ & $25,0 \%$ & $100,0 \%$ \\
\hline & TOlal & & $\%$ dentro de tamaño & $100,0 \%$ & $100,0 \%$ & $100,0 \%$ & $100,0 \%$ \\
\hline & & Menoc de 11 & $\%$ dentro de horas de formación & $0,0 \%$ & $100,0 \%$ & $0,0 \%$ & $100,0 \%$ \\
\hline & & (2) & $\%$ dentro de tamaño & $0,0 \%$ & $60,0 \%$ & $0,0 \%$ & $27,3 \%$ \\
\hline & & & $\%$ dentro de horas de formación & $0,0 \%$ & $33,3 \%$ & $66,7 \%$ & $100,0 \%$ \\
\hline & & De ti a d & $\%$ dentro de tamaño & $0,0 \%$ & $20,0 \%$ & $40,0 \%$ & $27,3 \%$ \\
\hline & Horas de & $51=100$ & $\%$ dentro de horas de formación & $50,0 \%$ & $0,0 \%$ & $50,0 \%$ & $100,0 \%$ \\
\hline Inductria & resp. social & DE S d T TOU & $\%$ dentro de tamaño & $100,0 \%$ & $0,0 \%$ & $20,0 \%$ & $18,2 \%$ \\
\hline 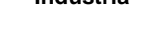 & & 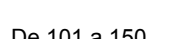 & $\%$ dentro de horas de formación & $0,0 \%$ & $0,0 \%$ & $100,0 \%$ & $100,0 \%$ \\
\hline & & De tol a ivo & $\%$ dentro de tamaño & $0,0 \%$ & $0,0 \%$ & $40,0 \%$ & $18,2 \%$ \\
\hline & & ח 10010 & $\%$ dentro de horas de formación & $0,0 \%$ & $100,0 \%$ & $0,0 \%$ & $100,0 \%$ \\
\hline & & De 201 a 1000 & $\%$ dentro de tamaño & $0,0 \%$ & $20,0 \%$ & $0,0 \%$ & $9,1 \%$ \\
\hline & Totat $>$ & & $\%$ dentro de horas de formación & $9,1 \%$ & $45,5 \%$ & $45,5 \%$ & $100,0 \%$ \\
\hline & Tulai & & $\%$ dentro de tamaño & $100,0 \%$ & $100,0 \%$ & $100,0 \%$ & $100,0 \%$ \\
\hline & & Menec de 11 & $\%$ dentro de horas de formación & $30,0 \%$ & $50,0 \%$ & $20,0 \%$ & $100,0 \%$ \\
\hline & & iventios de ti & $\%$ dentro de tamaño & $25,0 \%$ & $45,5 \%$ & $12,5 \%$ & $25,6 \%$ \\
\hline & & D 11 = 50 & $\%$ dentro de horas de formación & $27,3 \%$ & $18,2 \%$ & $54,5 \%$ & $100,0 \%$ \\
\hline & & De II a d ov & $\%$ dentro de tamaño & $25,0 \%$ & $18,2 \%$ & $37,5 \%$ & $28,2 \%$ \\
\hline & & $80-10100$ & $\%$ dentro de horas de formación & $40,0 \%$ & $40,0 \%$ & $20,0 \%$ & $100,0 \%$ \\
\hline & & Levia & $\%$ dentro de tamaño & $16,7 \%$ & $18,2 \%$ & $6,3 \%$ & $12,8 \%$ \\
\hline & Horas de & R 101 150 & $\%$ dentro de horas de formación & $42,9 \%$ & $0,0 \%$ & $57,1 \%$ & $100,0 \%$ \\
\hline Tatal & resp. social & De ivia & $\%$ dentro de tamaño & $25,0 \%$ & $0,0 \%$ & $25,0 \%$ & $17,9 \%$ \\
\hline 10tai & & חم2 ב 151 م ח & $\%$ dentro de horas de formación & $0,0 \%$ & $0,0 \%$ & $100,0 \%$ & $100,0 \%$ \\
\hline & & De & $\%$ dentro de tamaño & $0,0 \%$ & $0,0 \%$ & $6,3 \%$ & $2,6 \%$ \\
\hline & & 1000 & $\%$ dentro de horas de formación & $0,0 \%$ & $50,0 \%$ & $50,0 \%$ & $100,0 \%$ \\
\hline & & De 201 a 1000 & $\%$ dentro de tamaño & $0,0 \%$ & $9,1 \%$ & $6,3 \%$ & $5,1 \%$ \\
\hline & & Más de 1000 & $\%$ dentro de horas de formación & $33,3 \%$ & $33,3 \%$ & $33,3 \%$ & $100,0 \%$ \\
\hline & & ivids ue tovo & $\%$ dentro de tamaño & $8,3 \%$ & $9,1 \%$ & $6,3 \%$ & $7,7 \%$ \\
\hline & Total 20 & & $\%$ dentro de horas de formación & $30,8 \%$ & $28,2 \%$ & $41,0 \%$ & $100,0 \%$ \\
\hline & Torai & & $\%$ dentro de tamaño & $100,0 \%$ & $100,0 \%$ & $100,0 \%$ & $100,0 \%$ \\
\hline
\end{tabular}

Cuadro 132: Tabla de contingencia de formación en responsabilidad social, tamaño y sector. 
En los otros tres casos considerados dentro del sector servicios en el cuadro 132 (empresas que invierten entre 51 y 100 horas, 101 a 150 horas y más de 1000 horas), las empresas con mayor presencia son las medianas y las grandes, aunque también se ha registrado el caso de una empresa pequeña que invierte más de 1000 horas a este tipo de formación (no es un caso representativo ya que se trata de una empresa que se dedica a la consultoría en el campo de la responsabilidad social).

En el sector construcción, los dos casos registrados en las empresas que destinan de 11 a 50 horas a acciones formativas enmarcadas en el ámbito de la responsabilidad social son una empresa mediana y una grande. En las empresas que dedican entre 101 y 150 horas a este tipo de acciones formativas, los dos líderes de los que se ha recabado información procedían de empresas pequeñas.

En lo que respecta al sector industria las empresas grandes tienen mayor presencia. Aunque en las organizaciones que dedican menos de 11 horas a acciones formativas son mayoría las empresas medianas (100\%) y en las que invierten entre 50 y 100 horas se ha registrado dos casos que corresponden a una empresa grande y una pequeña, en las que destinan entre 11 y 50 horas a actuaciones de formación destacan las organizaciones grandes $(66,7 \%)$ al igual que en el caso de las empresas que destinan entre 101 y 150 horas a este tipo de iniciativas formativas (100\%). 
A continuación hemos incluido el gráfico 73 para revisar posibles asociaciones entre la variación del tamaño empresarial dentro de cada sector y las horas que las organizaciones dedican a acciones formativas enmarcadas en el ámbito de la responsabilidad social.

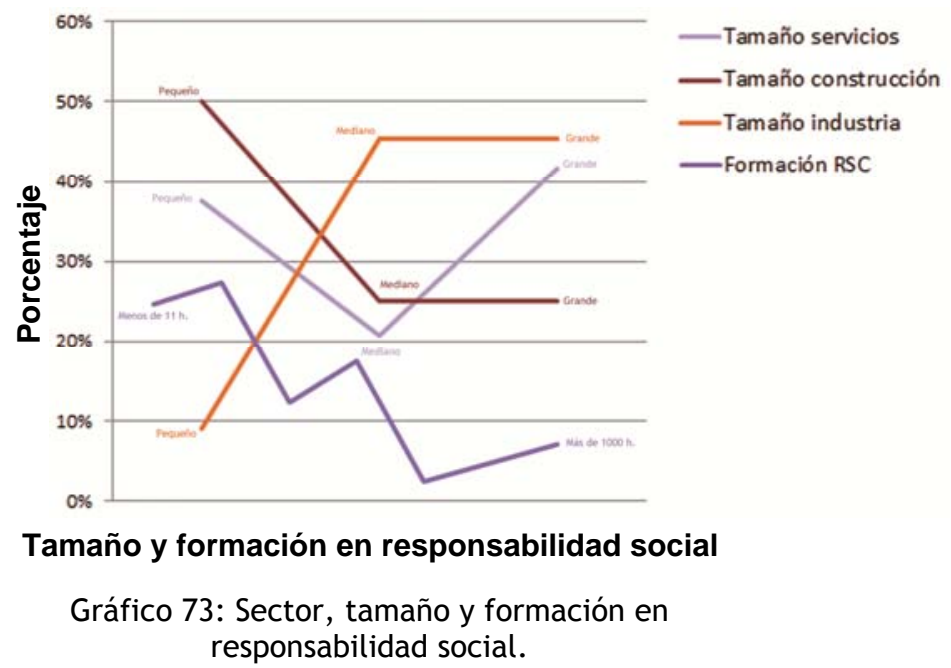

De acuerdo con la información visual que aporta el gráfico 73 parece existir una cierta asociación en la menor presencia de organizaciones del sector construcción y servicios, en el paso de la dimensión "pequeña" a "mediana", y la reducción del número de empresas a medida que estas incrementan las horas que dedican a acciones formativas enmarcadas en el ámbito de la responsabilidad social.

Asimismo también parece haber una cierta relación en el aumento de la dimensión de las organizaciones del sector industria, al pasar de las empresas pequeñas a medianas, y la tendencia decreciente del número de organizaciones a medida que las empresas incrementan la extensión de sus iniciativas formativas sobre responsabilidad social. 


\subsubsection{Sector, liderazgo y Responsabilidad Social Corporativa}

Junto con el sector de procedencia del máximo responsable empresarial, sus estilos de liderazgo, su flexibilidad de estilo y su eficacia de estilo hemos revisado en primer término, como en los apartados precedentes, su actitud hacia la Responsabilidad Social Corporativa.

Antes de analizar la información sobre las variables indicadas, hemos aplicado ANOVA de un factor en la muestra poblacional (cuadro 133) para comprobar si existen diferencias estadísticamente significativas entre los grupos contemplados.

\begin{tabular}{|c|c|c|c|c|c|c|}
\hline & & Suma de cuadrados & gl & Media cuadrática & $\mathbf{F}$ & Sig. \\
\hline \multirow{3}{*}{ Sector } & Inter-grupos & 42,217 & 80 & ,528 & ,815 & 832 \\
\hline & Intra-grupos & 69,920 & 108 & ,647 & & \\
\hline & Total & 112,138 & 188 & & & \\
\hline \multirow{3}{*}{ Estilo directivo } & Inter-grupos & 460,904 & 80 & 5,761 & 1,932 & 001 \\
\hline & Intra-grupos & 322,049 & 108 & 2,982 & & \\
\hline & Total & 782,952 & 188 & & & \\
\hline \multirow{3}{*}{ Estilo consultivo } & Inter-grupos & 542,014 & 80 & 6,775 & 876 & ,732 \\
\hline & Intra-grupos & 835,224 & 108 & 7,734 & & \\
\hline & Total & 1377,238 & 188 & & & \\
\hline \multirow{3}{*}{ Estilo participativo } & Inter-grupos & 758,724 & 80 & 9,484 & 1,080 & ,352 \\
\hline & Intra-grupos & 948,049 & 108 & 8,778 & & \\
\hline & Total & 1706,772 & 188 & & & \\
\hline \multirow{3}{*}{ Estilo delegativo } & Inter-grupos & 361,062 & 80 & 4,513 & 1,304 & 099 \\
\hline & Intra-grupos & 373,890 & 108 & 3,462 & & \\
\hline & Total & 734,952 & 188 & & & \\
\hline \multirow{3}{*}{ Flexibilidad } & Inter-grupos & 1712,188 & 80 & 21,402 & 1,354 & 071 \\
\hline & Intra-grupos & 1706,617 & 108 & 15,802 & & \\
\hline & Total & 3418,804 & 188 & & & \\
\hline \multirow{3}{*}{ Efectividad } & Inter-grupos & 2304,729 & 80 & 28,809 & 1,024 & , 450 \\
\hline & Intra-grupos & 3038,012 & 108 & 28,130 & & \\
\hline & Total & 5342,741 & 188 & & & \\
\hline
\end{tabular}

Cuadro 133: Tabla ANOVA de sector y liderazgo, factor Actitud hacia la Responsabilidad Social. 
La información aportada la prueba de ANOVA de un factor indica que existen diferencias estadísticamente significativas ente los diversos grupos muestrales en relación con "estilo directivo" (su coeficiente de significación es menor de 0,001).

Hemos incorporado a continuación el cuadro 134 con los datos sobre el sector de procedencia del líder, su liderazgo y su actitud hacia la Responsabilidad Social Corporativa.

\begin{tabular}{|c|c|c|c|c|c|c|c|c|}
\hline \multicolumn{2}{|l|}{ Sector } & $\begin{array}{l}\text { Actitud hacia } \\
\text { la resp. social }\end{array}$ & $\begin{array}{c}\text { Estilo } \\
\text { directivo }\end{array}$ & $\begin{array}{c}\text { Estilo } \\
\text { consultivo }\end{array}$ & $\begin{array}{c}\text { Estilo } \\
\text { participativo }\end{array}$ & $\begin{array}{c}\text { Estilo } \\
\text { delegativo }\end{array}$ & Flexibilidad & Efectividad \\
\hline \multirow{4}{*}{$\begin{array}{l}\text { Servicios } \\
\text { (incluye } \\
\text { comercio) }\end{array}$} & Media & 7,1416 & 2,61 & 6,43 & 7,75 & 3,19 & 19,32 & 55,73 \\
\hline & Mínimo & 3,86 & 0 & 0 & 1 & 0 & 10 & 43 \\
\hline & Máximo & 8,13 & 9 & 13 & 15 & 14 & 26 & 67 \\
\hline & Desv. típ. & 1,08394 & 2,052 & 2,756 & 3,007 & 1,996 & 4,252 & 5,455 \\
\hline \multirow{4}{*}{ Construcción } & Media & 7,4159 & 2,93 & 6,93 & 6,14 & 4,00 & 20,57 & 54,86 \\
\hline & Mínimo & 5,25 & 1 & 3 & 1 & 1 & 16 & 43 \\
\hline & Máximo & 8,03 & 7 & 11 & 11 & 8 & 26 & 66 \\
\hline & Desv. típ. & ,93308 & 2,093 & 2,303 & 2,905 & 1,922 & 3,056 & 5,586 \\
\hline \multirow{4}{*}{ Industria } & Media & 7,3844 & 2,06 & 6,58 & 8,36 & 2,94 & 18,33 & 57,42 \\
\hline & Mínimo & 5,00 & 0 & 2 & 3 & 0 & 11 & 48 \\
\hline & Máximo & 8,12 & 7 & 14 & 14 & 9 & 28 & 68 \\
\hline & Desv. típ. & ,95516 & 1,952 & 2,705 & 2,924 & 1,886 & 4,661 & 4,493 \\
\hline \multirow{4}{*}{ TOTAL } & Media & 7,2043 & 2,54 & 6,49 & 7,74 & 3,21 & 19,24 & 55,96 \\
\hline & Mínimo & 3,86 & 0 & 0 & 1 & 0 & 10 & 43 \\
\hline & Máximo & 8,13 & 9 & 14 & 15 & 14 & 28 & 68 \\
\hline & Desv. típ. & 1,05294 & 2,041 & 2,707 & 3,013 & 1,977 & 4,264 & 5,331 \\
\hline
\end{tabular}

Cuadro 134: Medidas estadísticas de liderazgo, sector y actitud hacia la responsabilidad social.

La información que ofrece el cuadro 134 indica que los líderes del sector que han registrado una actitud media más alta, los del sector construcción $(7,41)$, también han obtenido la mayor puntuación media en el estilo consultivo $(6,93)$, en el estilo delegativo (4) y en la flexibilidad de estilo $(20,57)$. Estos máximos responsables, sin embargo, 
han registrado el valor medio más reducido en el estilo participativo $(6,14)$ y en la efectividad $(54,86)$. Es destacable que los líderes de este sector sean los únicos para los que el estilo consultivo, y no el participativo, sea el estilo primario.

Los máximos responsables del sector industria han obtenido una actitud media muy próxima a la mostrada por los líderes del sector construcción $(7,38)$. Estos líderes también han registrado la media más elevada en el estilo participativo $(8,36)$ y en la efectividad de estilo $(57,42)$. Por el contrario, han obtenido la puntuación media menor en los estilos directivo $(2,06)$ y delegativo $(2,94)$, y en la flexibilidad de estilo $(18,33)$.

Los líderes que han registrado una media más reducida en la actitud hacia la responsabilidad social, los del sector servicios $(7,14)$, han obtenido el valor más alto en la media del estilo directivo $(2,61)$. Excepto en este último aspecto y en la actitud, las medias del resto de variables contempladas se han situado entre las obtenidas por los líderes de los otros dos sectores.

Hemos incluido a continuación el cuadro 135 en el que de nuevo se contempla el sector y el liderazgo pero, en este caso, hemos incorporado el valor medio de la actitud hacia la responsabilidad social segmentado para contemplar posibles tendencias en su variación en relación con las variables de liderazgo dentro de cada sector. 


\begin{tabular}{|c|c|c|c|c|c|c|c|c|}
\hline Sector & $\begin{array}{r}\text { Actitu } \\
\text { resp }\end{array}$ & $\begin{array}{l}\text { d hacia la } \\
\text {. social }\end{array}$ & $\begin{array}{c}\text { Estilo } \\
\text { directivo }\end{array}$ & $\begin{array}{c}\text { Estilo } \\
\text { consultivo }\end{array}$ & $\begin{array}{c}\text { Estilo } \\
\text { participativo }\end{array}$ & $\begin{array}{c}\text { Estilo } \\
\text { delegativo }\end{array}$ & Flexibilidad & Efectividad \\
\hline \multirow{14}{*}{$\begin{array}{l}\text { Servicios } \\
\text { (incluye } \\
\text { comercio) }\end{array}$} & \multirow{2}{*}{$0 a<4$} & Media & 2,00 & 12,00 & 6,00 & , 00 & 14,00 & 57,00 \\
\hline & & Desv. típ. & & . & . & . & & \\
\hline & \multirow{2}{*}{$4 a<5$} & Media & 4,00 & 6,00 & 6,67 & 3,33 & 23,50 & 52,83 \\
\hline & & Desv. típ. & 2,098 & 1,789 & 1,033 & 2,066 & 2,950 & 5,492 \\
\hline & \multirow{2}{*}{$5 a<6$} & Media & 3,94 & 5,41 & 6,71 & 3,94 & 20,82 & 54,65 \\
\hline & & Desv. típ. & 2,249 & 3,063 & 3,274 & 3,071 & 4,953 & 6,314 \\
\hline & \multirow{2}{*}{$6 a<7$} & Media & 3,00 & 6,60 & 7,48 & 2,92 & 19,68 & 55,36 \\
\hline & & Desv. típ. & 2,121 & 2,121 & 3,641 & 1,579 & 4,423 & 4,663 \\
\hline & \multirow{2}{*}{7 a 8} & Media & 2,06 & 6,79 & 8,11 & 3,01 & 18,53 & 55,90 \\
\hline & & Desv. típ. & 1,710 & 2,750 & 2,932 & 1,765 & 3,851 & 5,400 \\
\hline & \multirow{2}{*}{$>8$} & Media & 2,57 & 5,78 & 8,04 & 3,57 & 19,39 & 57,13 \\
\hline & & Desv. típ. & 2,273 & 3,059 & 2,567 & 1,996 & 4,272 & 5,841 \\
\hline & \multirow{2}{*}{ Total } & Media & 2,61 & 6,43 & 7,75 & 3,19 & 19,32 & 55,73 \\
\hline & & Desv. típ. & 2,052 & 2,756 & 3,007 & 1,996 & 4,252 & 5,455 \\
\hline \multirow{10}{*}{ Construcción } & \multirow{2}{*}{$5 a<6$} & Media & 4,00 & 7,00 & 3,00 & 6,00 & 21,50 & 59,50 \\
\hline & & Desv. típ. & 2,828 & 2,828 & 2,828 & 2,828 & ,707 & ,707 \\
\hline & \multirow{2}{*}{$6 a<7$} & Media & 2,00 & 9,00 & 6,50 & 2,50 & 19,00 & 55,50 \\
\hline & & Desv. típ. &, 000 & , 000 & 2,121 & 2,121 & 4,243 & ,707 \\
\hline & \multirow{2}{*}{7 a 8} & Media & 2,86 & 7,29 & 6,14 & 3,71 & 20,43 & 56,43 \\
\hline & & Desv. típ. & 2,545 & 2,138 & 2,854 & 1,254 & 3,155 & 5,094 \\
\hline & \multirow{2}{*}{$>8$} & Media & 3,00 & 4,67 & 8,00 & 4,33 & 21,33 & 47,67 \\
\hline & & Desv. típ. & 1,732 & 2,082 & 3,000 & 2,517 & 4,163 & 4,041 \\
\hline & \multirow{2}{*}{ Total } & Media & 2,93 & 6,93 & 6,14 & 4,00 & 20,57 & 54,86 \\
\hline & & Desv. típ. & 2,093 & 2,303 & 2,905 & 1,922 & 3,056 & 5,586 \\
\hline \multirow{12}{*}{ Industria } & \multirow{2}{*}{$4 a<5$} & Media &, 00 & 6,00 & 13,00 & 1,00 & 12,00 & 62,00 \\
\hline & & Desv. típ. & & . & . & & & \\
\hline & \multirow{2}{*}{$5 a<6$} & Media & 2,75 & 6,00 & 8,00 & 3,25 & 20,00 & 56,25 \\
\hline & & Desv. típ. & 2,872 & 1,633 & 2,944 & 2,062 & 4,899 & 3,775 \\
\hline & \multirow{2}{*}{$6 a<7$} & Media & 2,50 & 7,50 & 7,25 & 2,75 & 19,75 & 53,50 \\
\hline & & Desv. típ. & 1,915 & 1,732 & 2,986 & 2,217 & 4,924 & 3,697 \\
\hline & \multirow{2}{*}{7 a 8} & Media & 2,38 & 6,31 & 8,54 & 2,77 & 18,62 & 58,23 \\
\hline & & Desv. típ. & 2,181 & 2,750 & 3,178 & 1,235 & 5,059 & 4,146 \\
\hline & $>0$ & Media & 1,45 & 6,82 & 8,27 & 3,27 & 17,45 & 57,91 \\
\hline & $>0$ & Desv. típ. & 1,293 & 3,459 & 2,687 & 2,494 & 4,180 & 5,069 \\
\hline & Total & Media & 2,06 & 6,58 & 8,36 & 2,94 & 18,33 & 57,42 \\
\hline & Tordal & Desv. típ. & 1,952 & 2,705 & 2,924 & 1,886 & 4,661 & 4,493 \\
\hline & $0><4$ & Media & 2,00 & 12,00 & 6,00 &, 00 & 14,00 & 57,00 \\
\hline & $0 \mathrm{~d}<4$ & Desv. típ. & & . & & & & \\
\hline & $4 a<5$ & Media & 3,43 & 6,00 & 7,57 & 3,00 & 21,86 & 54,14 \\
\hline & $4 a-0$ & Desv. típ. & 2,440 & 1,633 & 2,573 & 2,082 & 5,113 & 6,094 \\
\hline & $5 a<6$ & Media & 3,74 & 5,65 & 6,61 & 4,00 & 20,74 & 55,35 \\
\hline & $3 d<0$ & Desv. típ. & 2,320 & 2,790 & 3,299 & 2,876 & 4,614 & 5,749 \\
\hline & $6 a<7$ & Media & 2,87 & 6,87 & 7,39 & 2,87 & 19,65 & 55,13 \\
\hline TOTAL & $0 \mathrm{~d}<1$ & Desv. típ. & 2,012 & 2,078 & 3,422 & 1,628 & 4,325 & 4,380 \\
\hline & 7 ค 8 & Media & 2,17 & 6,76 & 8,02 & 3,03 & 18,69 & 56,28 \\
\hline & $1 \mathrm{do}$ & Desv. típ. & 1,844 & 2,691 & 2,983 & 1,666 & 3,985 & 5,230 \\
\hline & $>8$ & Media & 2,27 & 6,00 & 8,11 & 3,54 & 18,97 & 56,59 \\
\hline & $>0$ & Desv. típ. & 2,023 & 3,109 & 2,558 & 2,142 & 4,272 & 6,021 \\
\hline & Tat & Media & 2,54 & 6,49 & 7,74 & 3,21 & 19,24 & 55,96 \\
\hline & Tolal & Desv. típ. & 2,041 & 2,707 & 3,013 & 1,977 & 4,264 & 5,331 \\
\hline
\end{tabular}

Cuadro 135: Medidas estadísticas de liderazgo, sector y actitud hacia la responsabilidad social. 
En la lectura de los datos del cuadro 135 no hemos contemplado, por su escasa representatividad, aquellos grupos muestrales en los que solo se ha recabado información de un líder.

En el sector servicios existe una cierta tendencia a que el estilo participativo adquiera protagonismo a medida que se incrementa la actitud favorable de los líderes hacia la responsabilidad social (su valor medio crece de 6,67 en el segmento “4 a <5" a 8,11 en el segmento "7 a 8"). Además también se aprecia que según se incrementa dicha afinidad hacia la responsabilidad social, también se incrementa la efectividad en el liderazgo de los máximos responsables (su media aumenta de 52,83 en el segmento " 4 a $<5$ " a 57,13 en el segmento ">8"). Por el contrario, se percibe una cierta tendencia decreciente en la flexibilidad de estilo de estos líderes a medida que se intensifica su disposición favorable hacia la responsabilidad social (su puntuación media en esta variable decrece de 23,5 en los líderes del segmento " 4 a $<5$ " a 18,53 en los máximos responsables del segmento "7 a 8").

En el sector construcción se aprecia una cierta tendencia creciente en el estilo participativo a medida que se intensifica, de modo favorable, la actitud de los líderes hacia la responsabilidad social (su valor medio crece de 3 en los líderes del segmento " 5 a $<6$ " a 8 en los máximos responsables del segmento ">8").

En el sector industria se han observado dos tendencias decrecientes a medida que aumenta la actitud de los 
máximos responsables a favor de la responsabilidad social. Se trata del estilo directivo (pasa de 2,75 en el segmento " 5 a <6" a 1,45 en el segmento ">8") y de la efectividad de estilo (decrece de 20 en el grupo muestral “5 a $<6$ ” a 17,45 en los líderes del segmento “>8”).

Hemos incorporado a continuación los gráficos 74,75 , 76 y 77 para revisar, visualmente, las tendencias de variación asociadas entre la actitud y el liderazgo dentro de cada sector.

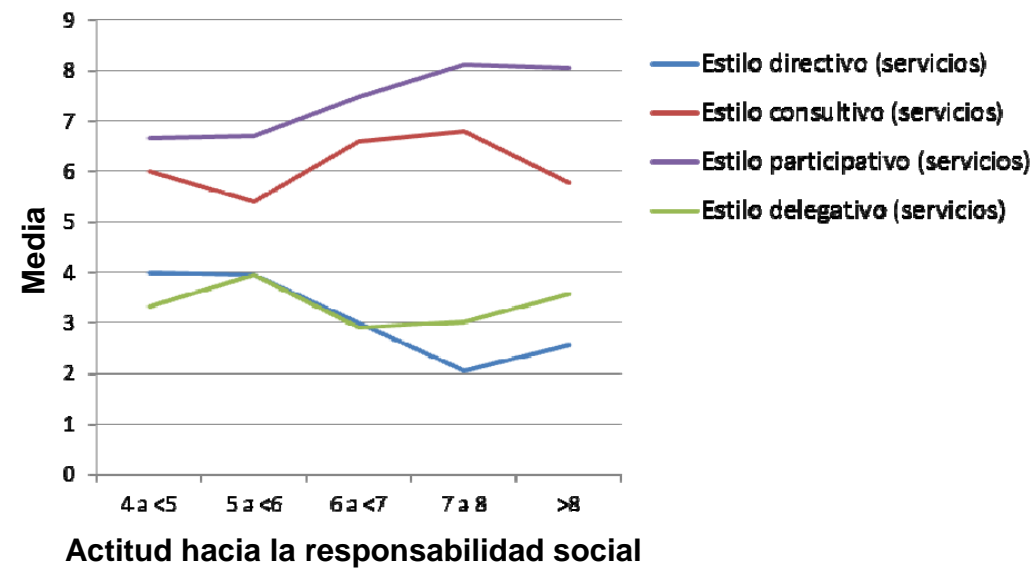

Gráfico 74: Sector servicios, estilos de liderazgo y actitud hacia la responsabilidad social.

En el gráfico 74 sobre el sector servicios se aprecia una tendencia creciente la importancia concedida al estilo participativo a medida que el líder aumenta la actitud a favor de la responsabilidad social.

Además también parece darse una cierta tendencia decreciente en el estilo directivo asociada al aumento de la actitud positiva del máximo dirigente empresarial hacia la Responsabilidad Social Corporativa. 


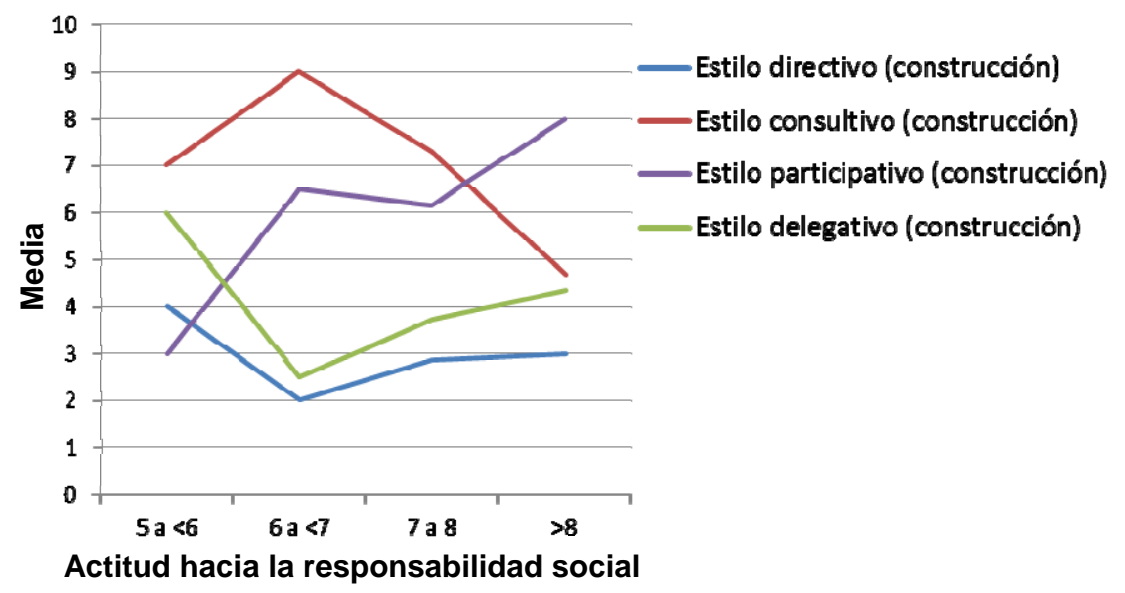

Gráfico 75: Sector construcción, estilos de liderazgo y actitud hacia la responsabilidad social.

En el gráfico 75 sobre el sector construcción parece registrarse una tendencia creciente en el estilo participativo y una cierta tendencia decreciente en el estilo consultivo, a medida que se intensifica la disposición afín del líder hacia la Responsabilidad Social Corporativa.

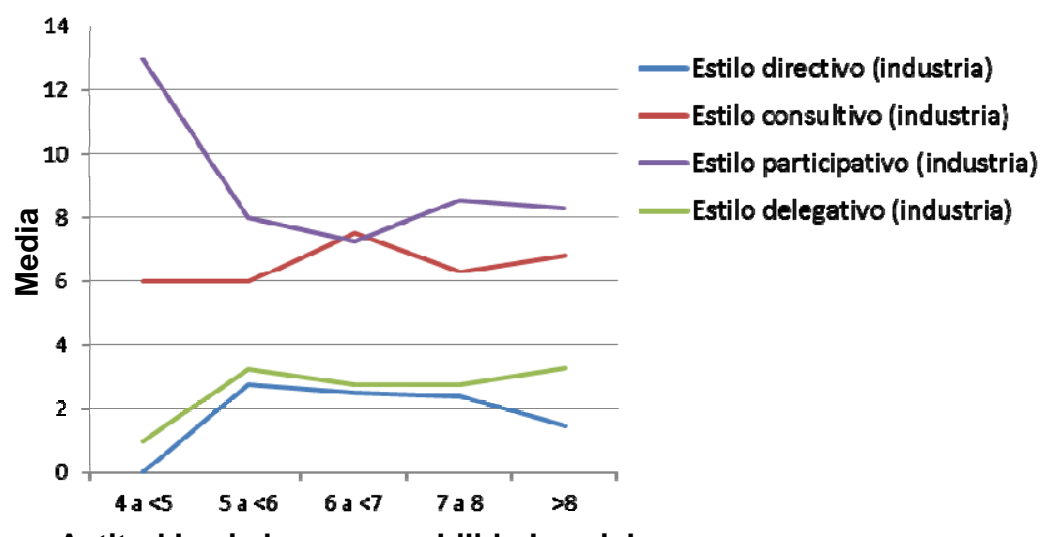

Actitud hacia la responsabilidad social

Gráfico 76: Sector industria, estilos de liderazgo y actitud hacia la responsabilidad social.

En el gráfico 76 del sector industria parece producirse una leve tendencia decreciente en el estilo directivo del máximo responsable empresarial a medida que aumenta su actitud favorable hacia la responsabilidad social. 


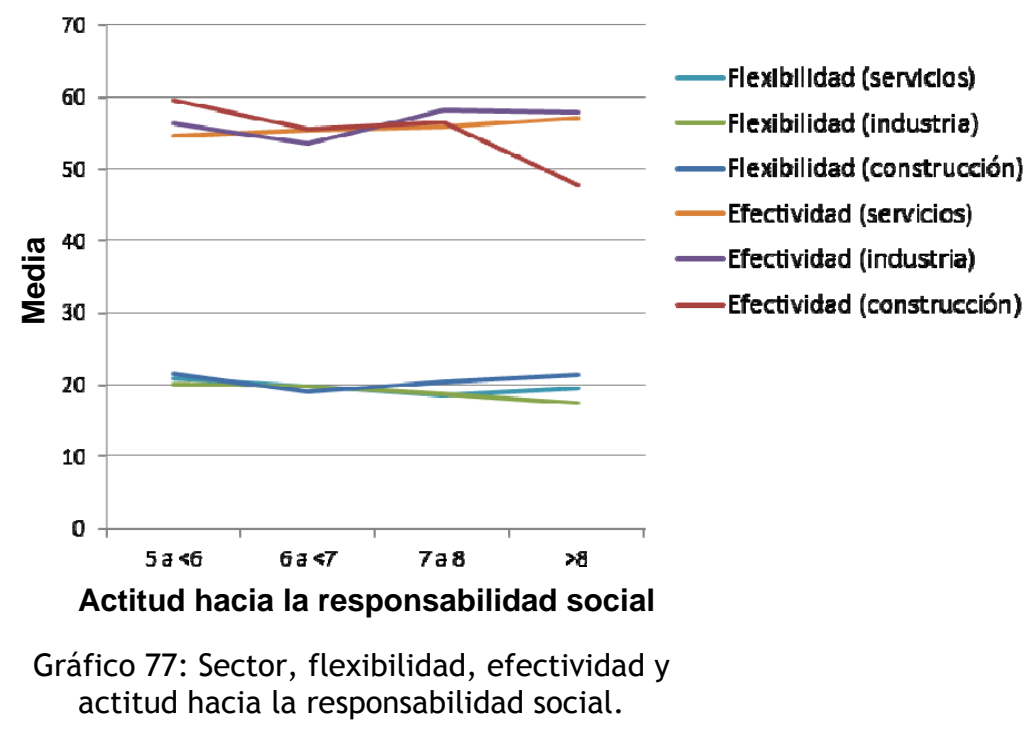

En el gráfico 77 se aprecia una leve tendencia creciente en la efectividad del líder del sector servicios e industria, a media que crece su actitud a favor de la Responsabilidad Social Corporativa.

A continuación hemos procedido a revisar los datos sobre el sector de procedencia de las organizaciones, el estilo de liderazgo de los líderes, su efectividad, su flexibilidad y el comportamiento socialmente responsable de sus organizaciones de origen.

En segundo término, como en los apartados precedentes, hemos analizado los datos sobre el sector de actividad de las empresas y el liderazgo pero contemplando, en este caso, las horas de formación enmarcadas en el ámbito de la responsabilidad social que han sido invertidas por las organizaciones. 


\begin{tabular}{|c|c|c|c|c|c|c|c|c|}
\hline Sector & Acciones de resp. & cial & $\begin{array}{c}\text { Estilo } \\
\text { directivo }\end{array}$ & $\begin{array}{c}\text { Estilo } \\
\text { consultivo }\end{array}$ & $\begin{array}{c}\text { Estilo } \\
\text { participativo }\end{array}$ & $\begin{array}{c}\text { Estilo } \\
\text { delegativo }\end{array}$ & Flexibilidad & Efectividad \\
\hline \multirow{10}{*}{$\begin{array}{l}\text { Servicios } \\
\text { (incluye } \\
\text { comercio) }\end{array}$} & \multirow{2}{*}{ No } & Media & 3,14 & 6,12 & 6,94 & 3,62 & 20,54 & 54,62 \\
\hline & & Desv. típ. & 2,144 & 2,731 & 2,695 & 2,327 & 4,192 & 5,396 \\
\hline & \multirow{2}{*}{ Sí, acciones puntuales } & Media & 2,34 & 6,31 & 8,45 & 2,90 & 19,31 & 55,14 \\
\hline & & Desv. típ. & 1,758 & 2,362 & 2,923 & 1,472 & 4,218 & 5,611 \\
\hline & \multirow{2}{*}{$\begin{array}{l}\text { Sí, acciones frecuentes sin } \\
\text { una política definida de RS }\end{array}$} & Media & 2,33 & 7,11 & 8,06 & 2,44 & 17,28 & 57,22 \\
\hline & & Desv. típ. & 2,249 & 3,066 & 3,171 & 1,617 & 3,723 & 5,071 \\
\hline & \multirow{2}{*}{$\begin{array}{l}\text { Sí, acciones integradas en } \\
\text { una política de RS }\end{array}$} & Media & 1,69 & 6,92 & 8,88 & 2,88 & 17,54 & 58,31 \\
\hline & & Desv. típ. & 1,594 & 3,006 & 3,327 & 1,558 & 3,797 & 4,856 \\
\hline & \multirow{2}{*}{ Total } & Media & 2,61 & 6,43 & 7,75 & 3,19 & 19,32 & 55,73 \\
\hline & & Desv. típ. & 2,052 & 2,756 & 3,007 & 1,996 & 4,252 & 5,455 \\
\hline \multirow{10}{*}{ Construcción } & \multirow{2}{*}{ No } & Media & 3,40 & 6,70 & 5,40 & 4,50 & 21,20 & 54,30 \\
\hline & & Desv. típ. & 2,319 & 2,627 & 3,062 & 1,900 & 3,120 & 6,325 \\
\hline & \multirow{2}{*}{ Sí, acciones puntuales } & Media & 2,00 & 8,00 & 8,50 & 1,50 & 17,00 & 54,50 \\
\hline & & Desv. típ. & ,000 & 1,414 & ,707 & ,707 & 1,414 & 2,121 \\
\hline & \multirow{2}{*}{$\begin{array}{l}\text { Sí, acciones frecuentes sin } \\
\text { una política definida de RS }\end{array}$} & Media & 1,00 & 6,00 & 9,00 & 4,00 & 20,00 & 55,00 \\
\hline & & Desv. típ. & & & & & & \\
\hline & \multirow{2}{*}{$\begin{array}{l}\text { Sí, acciones integradas en } \\
\text { una política de RS }\end{array}$} & Media & 2,00 & 8,00 & 6,00 & 4,00 & 22,00 & 61,00 \\
\hline & & Desv. típ. & . & . & & . & . & \\
\hline & \multirow{2}{*}{ Total } & Media & 2,93 & 6,93 & 6,14 & 4,00 & 20,57 & 54,86 \\
\hline & & Desv. típ. & 2,093 & 2,303 & 2,905 & 1,922 & 3,056 & 5,586 \\
\hline \multirow{10}{*}{ Industria } & \multirow{2}{*}{ No } & Media & 2,33 & 6,92 & 7,75 & 2,92 & 18,50 & 55,75 \\
\hline & & Desv. típ. & 2,229 & 3,476 & 3,415 & 1,782 & 5,248 & 3,934 \\
\hline & \multirow{2}{*}{ Sí, acciones puntuales } & Media & 2,00 & 6,60 & 8,40 & 3,00 & 19,60 & 55,60 \\
\hline & & Desv. típ. & 1,225 & 1,949 & 2,608 & 1,225 & 2,608 & 4,037 \\
\hline & \multirow{2}{*}{$\begin{array}{l}\text { Sí, acciones frecuentes sin } \\
\text { una política definida de RS }\end{array}$} & Media & ,83 & 6,00 & 9,67 & 3,50 & 16,00 & 59,67 \\
\hline & & Desv. típ. & ,753 & 2,757 & 2,503 & 3,017 & 2,828 & 2,160 \\
\hline & \multirow{2}{*}{$\begin{array}{l}\text { Sí, acciones integradas en } \\
\text { una política de RS }\end{array}$} & Media & 2,50 & 6,50 & 8,30 & 2,60 & 18,90 & 59,00 \\
\hline & & Desv. típ. & 2,273 & 2,224 & 2,830 & 1,647 & 5,587 & 5,598 \\
\hline & \multirow{2}{*}{ Total } & Media & 2,06 & 6,58 & 8,36 & 2,94 & 18,33 & 57,42 \\
\hline & & Desv. típ. & 1,952 & 2,705 & 2,924 & 1,886 & 4,661 & 4,493 \\
\hline \multirow{10}{*}{ TOTAL } & \multirow{2}{*}{ No } & Media & 3,07 & 6,29 & 6,88 & 3,63 & 20,34 & 54,74 \\
\hline & & Desv. típ. & 2,169 & 2,810 & 2,863 & 2,234 & 4,264 & 5,297 \\
\hline & \multirow{2}{*}{ Sí, acciones puntuales } & Media & 2,28 & 6,44 & 8,44 & 2,83 & 19,22 & 55,17 \\
\hline & & Desv. típ. & 1,632 & 2,261 & 2,761 & 1,424 & 3,921 & 5,218 \\
\hline & \multirow{2}{*}{$\begin{array}{l}\text { Sí, acciones frecuentes sin } \\
\text { una política definida de RS }\end{array}$} & Media & 1,92 & 6,80 & 8,48 & 2,76 & 17,08 & 57,72 \\
\hline & & Desv. típ. & 2,040 & 2,915 & 2,988 & 2,006 & 3,487 & 4,542 \\
\hline & \multirow{2}{*}{$\begin{array}{l}\text { Sí, acciones integradas en } \\
\text { una política de RS }\end{array}$} & Media & 1,92 & 6,84 & 8,65 & 2,84 & 18,03 & 58,57 \\
\hline & & Desv. típ. & 1,785 & 2,754 & 3,155 & 1,555 & 4,317 & 4,947 \\
\hline & \multirow{2}{*}{ Total } & Media & 2,54 & 6,49 & 7,74 & 3,21 & 19,24 & 55,96 \\
\hline & & Desv. típ. & 2,041 & 2,707 & 3,013 & 1,977 & 4,264 & 5,331 \\
\hline
\end{tabular}

Cuadro 136: Medidas estadísticas sobre acciones de responsabilidad social, liderazgo y sector.

Antes de revisar los datos del cuadro 136 hemos realizado ANOVA de un factor (cuadro 137) en los diferentes grupos muestrales considerados para verificar si existen diferencias estadísticamente significativas entre los mismos. 


\begin{tabular}{|c|c|c|c|c|c|c|}
\hline & & Suma de cuadrados & gl & Media cuadrática & $\mathbf{F}$ & Sig. \\
\hline \multirow{3}{*}{ Estilo directivo } & Inter-grupos & 51,529 & 3 & 17,176 & 4,344 &, 006 \\
\hline & Intra-grupos & 731,423 & 185 & 3,954 & & \\
\hline & Total & 782,952 & 188 & & & \\
\hline \multirow{3}{*}{ Estilo consultivo } & Inter-grupos & 10,751 & 3 & 3,584 & ,485 & 693 \\
\hline & Intra-grupos & 1366,487 & 185 & 7,386 & & \\
\hline & Total & 1377,238 & 188 & & & \\
\hline \multirow{3}{*}{ Estilo participativo } & Inter-grupos & 129,541 & 3 & 43,180 & 5,065 & ,002 \\
\hline & Intra-grupos & 1577,232 & 185 & 8,526 & & \\
\hline & Total & 1706,772 & 188 & & & \\
\hline \multirow{3}{*}{ Estilo delegativo } & Inter-grupos & 31,069 & 3 & 10,356 & 2,722 &, 046 \\
\hline & Intra-grupos & 703,884 & 185 & 3,805 & & \\
\hline & Total & 734,952 & 188 & & & \\
\hline \multirow{3}{*}{ Flexibilidad } & Inter-grupos & 281,329 & 3 & 93,776 & 5,529 &, 001 \\
\hline & Intra-grupos & 3137,475 & 185 & 16,959 & & \\
\hline & Total & 3418,804 & 188 & & & \\
\hline \multirow{3}{*}{ Efectividad } & Inter-grupos & 487,949 & 3 & 162,650 & 6,198 &, 000 \\
\hline & Intra-grupos & 4854,791 & 185 & 26,242 & & \\
\hline & Total & 5342,741 & 188 & & & \\
\hline \multirow{3}{*}{ Sector } & Inter-grupos & 1,520 & 3 & ,507 & 847 & 470 \\
\hline & Intra-grupos & 110,618 & 185 &, 598 & & \\
\hline & Total & 112,138 & 188 & & & \\
\hline
\end{tabular}

Cuadro 137 Tabla ANOVA de liderazgo y sector, factor Realización de Acciones de Responsabilidad Social.

Los datos de cuadro 137 revelan la existencia de diferencias estadísticamente significativas entre los distintos grupos muestrales con la excepción de "estilo consultivo" (su coeficiente de significación es 0,693 ) y de "sector" (su coeficiente de significación es 0,470 ).

En la lectura de la información que ofrece el cuadro 136 no hemos considerado, debido a su baja representatividad, a los grupos muestrales en los únicamente hemos recogido información de un máximo responsable. Hemos agrupado las observaciones sobre la información de dicho cuadro en función del sector de procedencia de los líderes. 
En el sector servicios el estilo de liderazgo primario en los cuatro casos de comportamiento socialmente responsable considerados ha sido el participativo y el estilo secundario, también en las cuatro opciones contempladas, ha sido el consultivo. Las medias del estilo participativo han sido más altas en los líderes procedentes de organizaciones que desarrollan algún tipo de actuación socialmente responsable: 8,45 en los máximos responsables procedentes organizaciones que realizan acciones puntuales, 8,06 en los que proceden de empresas que impulsan acciones frecuentes y 8,88 en los que están vinculados a empresas que cuentan con una política definida de Responsabilidad Social Corporativa. También es destacable, en relación con los estilos de liderazgo, que la media del estilo directivo ha reducido levemente su valor a medida que se ha intensificado el comportamiento socialmente responsable de la empresa de origen del líder.

En cuanto a la flexibilidad y efectividad de estilo, han tenido un comportamiento inverso en los líderes de este sector.

La flexibilidad ha mostrado una cierta tendencia decreciente a medida que se ha intensificado el comportamiento socialmente responsable de las empresas de origen del líder: de una media de 20,54 en los máximos responsables de organizaciones que no realizan ningún tipo de actuación socialmente responsable se ha pasado a una media de 17,28 y 17,54 en los líderes procedentes de 
empresas que impulsan acciones frecuentes o que cuentan con una política de responsabilidad social respectivamente.

La efectividad media ha registrado un mínimo en los máximos responsables vinculados a organizaciones que no impulsan ningún tipo de actuación en materia de responsabilidad social $(54,62)$. Este valor mínimo ha ido ascendiendo a medida que las empresas de origen de los líderes han intensificado su comportamiento responsable hasta alcanzar un máximo de 58,31 en los máximos responsables asociados a empresas que cuentan con una política definida de Responsabilidad Social Corporativa.

En el sector construcción solo hemos revisado los datos de los líderes procedentes de empresas que no desarrollan ningún tipo de iniciativa en materia de responsabilidad social y de los máximos responsables vinculados a organizaciones que impulsan acciones puntuales. En los líderes de empresas inactivas, en relación con su comportamiento socialmente responsable, el estilo primario ha sido el consultivo (con un valor medio de 6,70) y el estilo secundario ha sido el participativo (con un puntaje medio de 5,40). De todos modos ha sido significativa la puntuación media que ha alcanzado el estilo delegativo $(4,5)$ y son destacables las medias bajas registradas en los estilos primarios y secundarios. En los líderes procedentes de organizaciones que impulsan acciones puntuales, los estilos primario y secundario han sido el participativo y el consultivo respectivamente con unas medias muy superiores 
al resto de estilos considerados (8,5 el estilo participativo y 8 el estilo consultivo).

En cuanto a la flexibilidad y la efectividad de estilo se mantiene la tendencia inversa comentada en el sector servicios, aunque en este caso el crecimiento de la efectividad es más leve. La flexibilidad registra su valor medio máximo en los líderes vinculados a organizaciones que no realizan ningún tipo de actuación en materia de responsabilidad social $(21,20)$, y la efectividad alcanza su puntuación media más alta en los máximos responsables procedentes de organizaciones que desarrollan acciones puntuales de Responsabilidad Social Corporativa $(54,50)$.

En el sector industria se repite la tónica indicada en el sector servicios en relación con los estilos de liderazgo. En todos los casos el estilo primario es el participativo y el secundario el consultivo. Además de nuevo el estilo participativo alcanza valores medios más altos en los líderes procedentes de organizaciones que desarrollan iniciativas en el campo de la responsabilidad social, ya sea de forma puntual (su media ha sido 8,40), frecuente (su valor medio ha sido 9,67) o dentro de una política (su puntuación media ha sido 8,30).

En relación con la efectividad de los líderes en este sector, se mantiene un cierto incremento en el valor medio de su efectividad a medida que se intensifica el comportamiento socialmente responsable de su empresa de origen (hay casi cuatro puntos de diferencia entre las 
medias de los líderes procedentes de empresas que carecen de un comportamiento socialmente responsable o que impulsan acciones puntuales respecto a los que desarrollan su rol en empresas que realizan acciones frecuentes o que cuentan con una política definida de responsabilidad social.

En cuanto a la efectividad, no se ha producido la tendencia contemplada en otros sectores. Su valor medio máximo se ha registrado en los líderes procedentes de organizaciones que desarrollan acciones puntuales de responsabilidad social $(19,6)$ y el mínimo en los máximos dirigentes vinculados a empresas que impulsan acciones frecuentes de Responsabilidad Social Corporativa (16).

Hemos incorporado debajo los gráficos 78 y 79 para realizar una comprobación visual sobre posibles asociaciones en las variaciones registradas en la efectividad, la efectividad y los estilos de liderazgo primario y secundario dentro de cada sector, a medida que las organizaciones intensifican su comportamiento socialmente responsable.

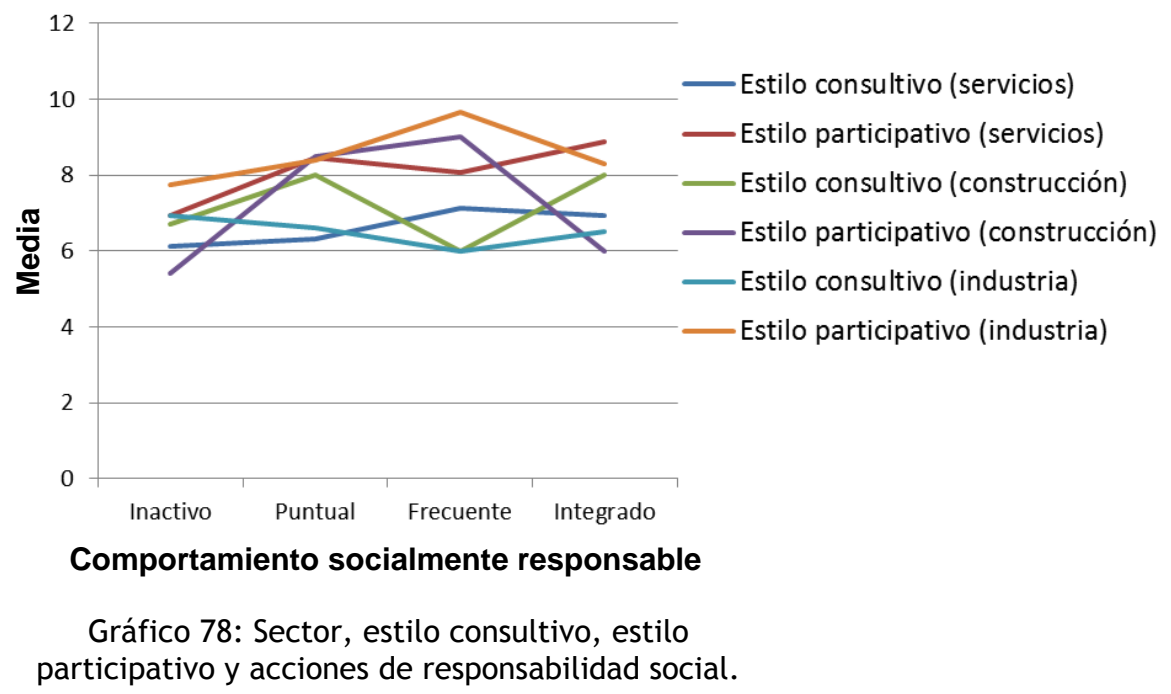


El gráfico 78 muestra que, en términos generales (el estilo participativo en el sector de la construcción y el consultivo en el sector industria no siguen la tónica que mencionamos a continuación), los estilos participativo (alto apoyo y poca dirección) y consultivo (alta dirección y mucho apoyo) tienden a cobrar más relevancia para los líderes a medida que se intensifica el comportamiento socialmente responsable de sus organizaciones de procedencia.

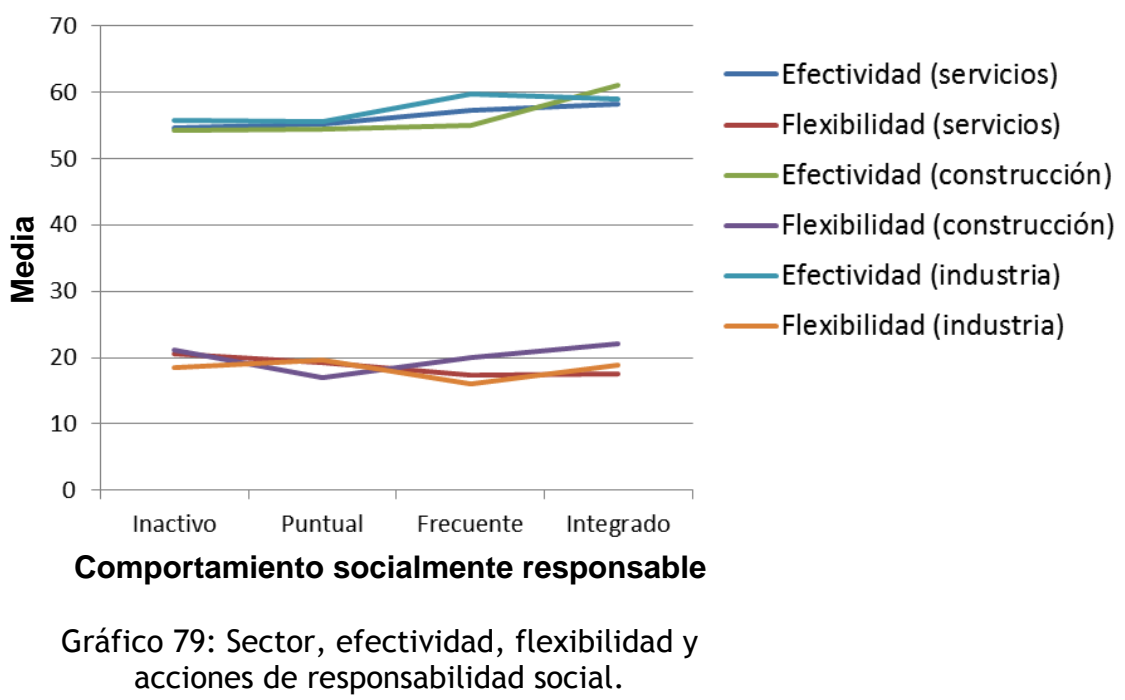

El gráfico 79 refleja un incremento de la efectividad de los líderes de todos los sectores contemplados a medida que las organizaciones incrementan su compromiso en materia de responsabilidad social. La flexibilidad, en términos generales, tiende a permanecer constante.

Si consideramos de manera conjunta las observaciones alcanzadas al revisar ambos gráficos podemos concluir que los estilos consultivo y participativo y la efectividad parecen presentar, en líneas generales, un comportamiento bastante 


\section{similar en relación con la conducta socialmente responsable}

\section{de las organizaciones.}

\begin{tabular}{|c|c|c|c|c|c|c|c|c|}
\hline Sector & $\begin{array}{l}\text { Horas de fc } \\
\text { resp. }\end{array}$ & $\begin{array}{l}\text { ación en } \\
\text { iial }\end{array}$ & $\begin{array}{c}\text { Estilo } \\
\text { directivo }\end{array}$ & $\begin{array}{c}\text { Estilo } \\
\text { consultivo }\end{array}$ & $\begin{array}{c}\text { Estilo } \\
\text { participativo }\end{array}$ & $\begin{array}{c}\text { Estilo } \\
\text { delegativo }\end{array}$ & Flexibilidad & Efectividad \\
\hline \multirow{16}{*}{$\begin{array}{l}\text { Servicios } \\
\text { (incluye } \\
\text { comercio) }\end{array}$} & \multirow{2}{*}{ Menos de 11} & Media & 2,86 & 8,00 & 6,29 & 2,86 & 21,29 & 52,29 \\
\hline & & Desv. típ. & 1,464 & 1,414 & 1,254 & 1,464 & 2,360 & 1,704 \\
\hline & \multirow{2}{*}{ De 11 a 50} & Media & 2,17 & 8,50 & 7,50 & 1,83 & 16,67 & 58,33 \\
\hline & & Desv. típ. & 2,137 & 2,665 & 3,619 & ,753 & 2,733 & 4,502 \\
\hline & \multirow{2}{*}{ De 51 a 100} & Media & ,67 & 6,33 & 10,67 & 2,33 & 16,00 & 57,33 \\
\hline & & Desv. típ. & ,577 & 1,155 & 3,512 & 2,309 & 5,292 & 4,933 \\
\hline & \multirow{2}{*}{ De 101 a 150} & Media & 3,00 & 4,67 & 9,67 & 2,67 & 18,00 & 59,00 \\
\hline & & Desv. típ. & 3,000 & 3,512 & 4,726 & 1,528 & 8,000 & 5,196 \\
\hline & \multirow{2}{*}{ De 151 a 200} & Media & 4,00 & 3,00 & 12,00 & 1,00 & 16,00 & 66,00 \\
\hline & & Desv. típ. & & & & & & \\
\hline & \multirow{2}{*}{ De 201 a 1000} & Media & 3,00 & 4,00 & 9,00 & 4,00 & 22,00 & 60,00 \\
\hline & & Desv. típ. & & & & & & \\
\hline & \multirow{2}{*}{ Más de 1000} & Media & 2,00 & 8,33 & 7,33 & 2,33 & 18,67 & 63,00 \\
\hline & & Desv. típ. & 2,000 &, 577 & 1,528 & 2,309 & 2,309 & 4,000 \\
\hline & \multirow{2}{*}{ Total } & Media & 2,38 & 7,17 & 8,04 & 2,42 & 18,54 & 57,50 \\
\hline & & Desv. típ. & 1,837 & 2,496 & 3,085 & 1,472 & 4,054 & 5,209 \\
\hline \multirow{6}{*}{ Construcción } & \multirow{2}{*}{ De 11 a 50} & Media & 1,50 & 7,00 & 7,50 & 4,00 & 21,00 & 58,00 \\
\hline & & Desv. típ. & ,707 & 1,414 & 2,121 &, 000 & 1,414 & 4,243 \\
\hline & \multirow{2}{*}{ De 101 a 150} & Media & 2,00 & 8,00 & 8,50 & 1,50 & 17,00 & 54,50 \\
\hline & & Desv. típ. &, 000 & 1,414 & ,707 &, 707 & 1,414 & 2,121 \\
\hline & \multirow{2}{*}{ Total } & Media & 1,75 & 7,50 & 8,00 & 2,75 & 19,00 & 56,25 \\
\hline & & Desv. típ. &, 500 & 1,291 & 1,414 & 1,500 & 2,582 & 3,403 \\
\hline \multirow{13}{*}{ Industria } & \multirow{2}{*}{ Menos de 11} & Media & 3,33 & 7,00 & 7,00 & 2,67 & 22,00 & 55,00 \\
\hline & & Desv. típ. & 2,082 & 1,732 & 3,464 & 1,155 & 6,000 & 2,000 \\
\hline & \multirow{2}{*}{ De 11 a 50} & Media & 2,33 & 6,00 & 9,33 & 2,33 & 18,67 & 62,67 \\
\hline & & Desv. típ. & 2,309 & 2,000 & 1,528 & 2,082 & 6,110 & 6,110 \\
\hline & \multirow{2}{*}{ De 51 a 100} & Media & 1,00 & 7,00 & 9,00 & 3,00 & 18,00 & 55,50 \\
\hline & & Desv. típ. & 1,414 & 1,414 & 2,828 &, 000 & 2,828 & 7,778 \\
\hline & \multirow{3}{*}{ De 101 a 150} & Casos & 2 & 2 & 2 & 2 & 2 & 2 \\
\hline & & Media &, 50 & 6,50 & 9,00 & 3,50 & 18,50 & 54,00 \\
\hline & & Desv. típ. & ,707 &, 707 & 2,828 & 2,121 & 6,364 & 2,828 \\
\hline & \multirow{2}{*}{ De 201 a 1000} & Media & 4,00 & 7,00 & 8,00 & 1,00 & 20,00 & 55,00 \\
\hline & & Desv. típ. & . & & . & & . & \\
\hline & Total & Media & 2,18 & 6,64 & 8,45 & 2,64 & 19,55 & 57,00 \\
\hline & TOldil & Desv. típ. & 1,940 & 1,362 & 2,339 & 1,433 & 4,719 & 5,348 \\
\hline & Menec de 11 & Media & 3,00 & 7,70 & 6,50 & 2,80 & 21,50 & 53,10 \\
\hline & Tienos de it & Desv. típ. & 1,563 & 1,494 & 1,958 & 1,317 & 3,440 & 2,132 \\
\hline & Rn 11050 & Media & 2,09 & 7,55 & 8,00 & 2,36 & 18,00 & 59,45 \\
\hline & De 11 a so & Desv. típ. & 1,868 & 2,423 & 2,864 & 1,362 & 3,795 & 4,865 \\
\hline & Dn $51=100$ & Media & ,80 & 6,60 & 10,00 & 2,60 & 16,80 & 56,60 \\
\hline & De d T & Desv. típ. & ,837 & 1,140 & 3,000 & 1,673 & 4,147 & 5,320 \\
\hline & 150 & Media & 2,00 & 6,14 & 9,14 & 2,57 & 17,86 & 56,29 \\
\hline TOTAI & De ivi a IJO & Desv. típ. & 2,082 & 2,610 & 3,024 & 1,512 & 5,367 & 4,192 \\
\hline TUIAL & م20 ב 151 & Media & 4,00 & 3,00 & 12,00 & 1,00 & 16,00 & 66,00 \\
\hline & De 151 a 200 & Desv. típ. & . & & . & & . & \\
\hline & 1001010 & Media & 3,50 & 5,50 & 8,50 & 2,50 & 21,00 & 57,50 \\
\hline & De 201 a 1000 & Desv. típ. & ,707 & 2,121 & ,707 & 2,121 & 1,414 & 3,536 \\
\hline & Mós do 1000 & Media & 2,00 & 8,33 & 7,33 & 2,33 & 18,67 & 63,00 \\
\hline & IVIas de 1000 & Desv. típ. & 2,000 & ,577 & 1,528 & 2,309 & 2,309 & 4,000 \\
\hline & & Media & 2,26 & 7,05 & 8,15 & 2,51 & 18,87 & 57,23 \\
\hline & TOlai & Desv. típ. & 1,758 & 2,114 & 2,720 & 1,430 & 4,066 & 5,002 \\
\hline
\end{tabular}

Cuadro 138: Medidas estadísticas sobre formación en responsabilidad social, liderazgo y sector. 
En la página precedente (cuadro 138) hemos incorporado la información sobre el sector de procedencia de los líderes, su liderazgo y las horas de formación enmarcadas en el ámbito de la responsabilidad social que las organizaciones de procedencia de los máximos responsables empresariales destinan a sus públicos internos.

Antes de proceder a la lectura de los datos del cuadro 138, hemos aplicado ANOVA de un factor (cuadro 139) para determinar si existen diferencias estadísticamente significativas entre los diferentes grupos muestrales que integran el cuadro 138.

\begin{tabular}{|l|l|r|r|r|r|c|}
\hline \multicolumn{2}{|c|}{} & Suma de cuadrados & gl & Media cuadrática & F & Sig. \\
\hline \multirow{4}{*}{ Estilo directivo } & Inter-grupos & 23,227 & 6 & 3,871 & 1,315 &, 279 \\
\cline { 2 - 7 } & Intra-grupos & 94,209 & 32 & 2,944 & & \\
\cline { 2 - 8 } & Total & 117,436 & 38 & & & \\
\hline \multirow{4}{*}{ Estilo consultivo } & Inter-grupos & 39,846 & 6 & 6,641 & 1,634 &, 170 \\
\cline { 2 - 8 } & Intra-grupos & 130,051 & 32 & 4,064 & & \\
\cline { 2 - 8 } & Total & 169,897 & 38 & & & \\
\hline \multirow{4}{*}{ Estilo participativo delegativo } & Inter-grupos & 68,553 & 6 & 11,426 & 1,720 &, 148 \\
\cline { 2 - 8 } & Intra-grupos & 212,524 & 32 & 6,641 & & \\
\cline { 2 - 8 } & Total & 281,077 & 38 & & & \\
\hline \multirow{4}{*}{ Flexibilidad } & Inter-grupos & 3,517 & 6 &, 586 &, 253 &, 955 \\
\cline { 2 - 8 } & Intra-grupos & 74,226 & 32 & 2,320 & & \\
\cline { 2 - 8 } & Total & 77,744 & 38 & & & \\
\hline \multirow{5}{*}{ Efectividad } & Inter-grupos & 123,535 & 6 & 20,589 & 1,305 &, 283 \\
\cline { 2 - 8 } & Intra-grupos & 504,824 & 32 & 15,776 & & \\
\cline { 2 - 8 } & Total & 628,359 & 38 & & & \\
\hline \multirow{5}{*}{ Sector } & Inter-grupos & 410,167 & 6 & 68,361 & 4,045 &, 004 \\
\cline { 2 - 8 } & Intra-grupos & 540,756 & 32 & 16,899 & & \\
\cline { 2 - 8 } & Total & 950,923 & 38 & & & \\
\hline & Inter-grupos & 2,428 & 6 &, 405 &, 459 &, 834 \\
\cline { 2 - 8 } & Intra-grupos & 28,239 & 32 &, 882 & & \\
\cline { 2 - 8 } & Total & 30,667 & 38 & & & \\
\hline
\end{tabular}

Cuadro 139: Tabla ANOVA de liderazgo y sector, factor Horas de Formación en Responsabilidad Social.

Tal como indica el cuadro 139 existen diferencias estadísticamente significativas entre los diversos grupos 
muestrales en relación con "efectividad", ya que es el único grupo cuyo coeficiente de significación ha estado por debajo del valor 0,05 (su coeficiente de significación ha sido 0,004).

En la lectura de los datos del cuadro 138 no hemos contemplado, al igual que en las ocasiones precedentes, los grupos muestrales en los que solo se ha obtenido información de un máximo responsable por la baja representatividad de esta información.

En la revisión de los datos del cuadro 138 hemos agrupado las diversas consideraciones en función de los sectores contemplados.

En el sector servicios los estilos consultivo y participativo han sido los estilos de liderazgo primario y secundario de los máximos responsables empresariales en los cinco tipos de organizaciones de procedencia consideradas.

En las organizaciones del sector servicios que impulsan acciones formativas de menos de 11 horas, de 11 a 50 horas y de más de 1000 horas, el estilo primario ha sido el consultivo (las medias registradas por los líderes han sido 8 , 8,50 y 8,33 respectivamente). En cambio, en las empresas que dedican a este tipo de acciones de 51 a 100 horas y de 101 a 150 horas, el estilo primario ha sido el participativo (ha alcanzado unos valores medios de 10,67 y de 9,67). 
En relación con la flexibilidad de los líderes de este sector, su valor medio máximo se ha producido en aquellos que proceden de empresas que invierten menos de 11 horas en acciones formativas enmarcadas en el ámbito de la responsabilidad social $(21,29)$ y su valor mínimo en los vinculados a organizaciones que destinan entre 51 y 100 horas (16) a dichas acciones.

Aunque en la flexibilidad no ha sido posible advertir una cierta tendencia en la progresión de su valor medio a medida que se ha incrementado el número de horas que las organizaciones de procedencia de los líderes destinan a acciones formativas encuadradas en el ámbito de la responsabilidad social, en la efectividad sí se ha registrado una cierta tendencia creciente (no se mantiene en todos los casos) en su valor medio a medida que las empresas han aumentado las horas dedicadas a formación en materia de responsabilidad social. Su mínima puntuación media se ha producido en los líderes procedentes de organizaciones que dedican menos de 11 horas a acciones formativas enmarcadas en el ámbito de la responsabilidad social $(52,29)$ y su valor medio más alto en los máximos responsable que vinculados a empresas que destinan a este tipo de acciones más de 1000 horas.

En el sector construcción se ha revisado información de dos grupos muestrales: líderes procedentes de organizaciones que destinan entre 11 y 50 horas a acciones formativas y máximos responsables procedentes de 
empresas que invierten entre 101 y 150 horas a dichas iniciativas. En ambos casos el estilo primario ha sido el participativo (las medias registradas por el líder han sido 7,50 en las empresas que dedican entre 11 y 50 horas a formación y 8,50 en las que destinan de 101 a 150 horas) y también en ambos casos el estilo secundario ha sido el consultivo (su puntuación media ha sido 7 en los líderes procedentes de organizaciones que invierten entre 11 y 50 horas y 8 en los vinculados a empresas que destinan entre 101 y 150$)$.

En cuanto a la flexibilidad y la efectividad de estilo en los líderes de este sector, sus valores medios más altos se han registrado en los máximos responsables vinculados a empresas que dedican entre 11 y 50 horas a iniciativas de formación que están encuadradas en el ámbito de la Responsabilidad Social Corporativa.

En el sector industria el estilo primario ha sido el participativo en todos los grupos muestrales revisados aunque en un caso el estilo consultivo también ha sido el estilo primario (el valor medio de ambos estilos ha sido 7 en los líderes procedente de empresas que dedican menos de 11 horas a acciones de formación sobre responsabilidad social). En los otros tres grupos muestrales considerados (máximos responsables procedentes de empresas que dedican entre 11 y 50 horas, entre 51 y 100 horas y entre 101 y 150 horas a acciones formativas enmarcadas en el ámbito de la responsabilidad social) el estilo consultivo del 
líder ha sido el secundario (su valor medio ha estado entre 6 y 7).

En cuanto a la flexibilidad y la efectividad de liderazgo en los máximos responsables de este sector, no se advierten tendencias crecientes o decrecientes en ninguna de las dos variables a medida que aumenta el número de horas que las organizaciones de procedencia de los líderes destinan a la responsabilidad social. El valor medio máximo de la flexibilidad se ha registrado en los líderes cuyo origen son empresas que dedican menos de 11 horas a acciones formativas de responsabilidad social (22) y su valor mínimo en las organizaciones que invierten entre 51 y 100 (18). En lo que respecta a la efectividad, su puntuación media más elevada se ha registrado en los líderes asociados a organizaciones que destinan entre 11 y 50 horas a formación encuadrada en el ámbito de la responsabilidad social $(62,67)$ y su valor medio más reducido en los máximos responsables procedentes de empresas que destinan a este tipo de acciones formativas entre 101 y 150 horas (54).

A continuación hemos incorporado el gráfico 80 y 81 para revisar alguna posible asociación en la variación de los estilos consultivo y participativo a medida que las empresas de procedencia de los líderes aumentan el número de horas que dedican a acciones formativas enmarcadas en el ámbito de la responsabilidad social dentro de los sectores servicios e industria, y considerando, asimismo, la efectividad y la flexibilidad registrada por los líderes. 


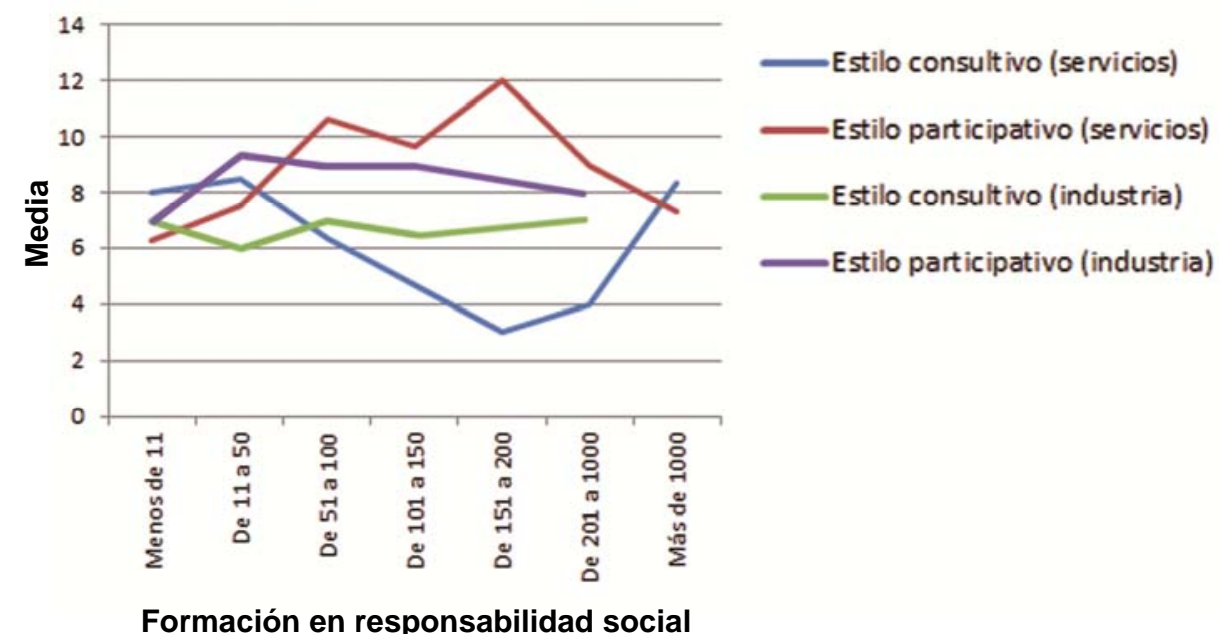

Formación en responsabilidad socia

Gráfico 80: Sector, estilo consultivo, estilo participativo y formación en responsabilidad social.

El gráfico 80 revela que en el sector servicios los estilos participativo y consultivo parecen presentar un cierto comportamiento inverso a medida que crece el número de horas que las empresas dedican a acciones de formación en responsabilidad social. En el sector industria, sin embargo, los estilos participativo y consultivo no parecen verse afectados el incremento en la duración de las iniciativas formativas impulsadas por las organizaciones.

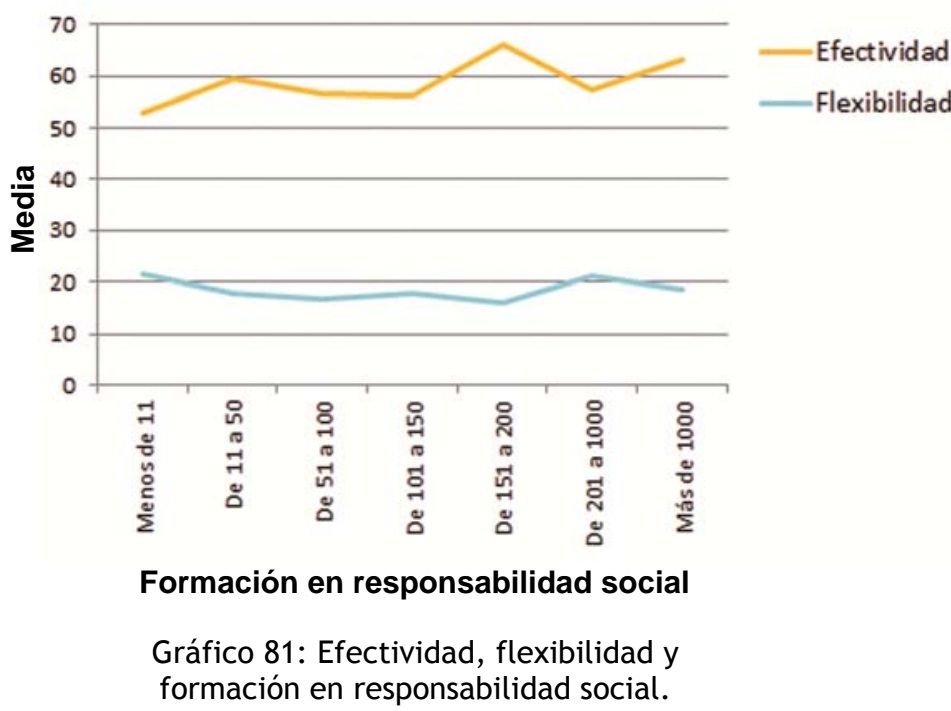


El gráfico 81 muestra que tanto la flexibilidad y la efectividad de los líderes no se ven afectadas por el incremento de las horas que las organizaciones dedican a acciones de formación encuadradas en el ámbito de la Responsabilidad Social Corporativa y, por tanto, presentan un comportamiento similar al que registran los estilos participativo y consultivo en el sector industria a medida que aumentan las horas que las empresas dedican a iniciativas de formación enmarcadas en el ámbito de la responsabilidad social.

\subsubsection{Sector, valores y Responsabilidad Social Corporativa}

Hemos revisado en primer lugar los datos sobre el sector de procedencia de los líderes empresariales, sobre las competencias genéricas, rasgos de personalidad y características comportamentales consideradas en el estudio, y sobre su actitud hacia la responsabilidad social.

Hemos analizado, posteriormente, de nuevo los datos pero contemplando en este caso el comportamiento socialmente responsable de la organización de procedencia de los líderes en vez de su disposición hacia la Responsabilidad Social Corporativa. Primero de forma genérica y después en relación con las acciones formativas impulsadas por las empresas de procedencia de los máximos dirigentes en materia de responsabilidad social. 


\begin{tabular}{|c|c|c|c|c|c|c|c|c|}
\hline \multicolumn{2}{|l|}{ Sector } & $\begin{array}{l}\text { Actitud hacia la } \\
\text { resp. social }\end{array}$ & Practicidad & Resultados & Variedad & Decisión & $\begin{array}{l}\text { Orden y } \\
\text { método }\end{array}$ & Metas \\
\hline \multirow{4}{*}{$\begin{array}{l}\text { Servicios } \\
\text { (incluye } \\
\text { comercio) }\end{array}$} & Media & 7,1416 & 13,72 & 14,75 & 8,20 & 16,41 & 16,63 & 20,18 \\
\hline & Mínimo & 3,86 & 4 & 3 & 0 & 5 & 5 & 8 \\
\hline & Máximo & 8,13 & 24 & 26 & 26 & 25 & 29 & 30 \\
\hline & Desv. típ. & 1,08394 & 4,052 & 3,887 & 5,685 & 4,121 & 5,531 & 4,741 \\
\hline \multirow{4}{*}{ Construcción } & Media & 7,4159 & 13,14 & 14,21 & 8,14 & 17,64 & 14,79 & 21,43 \\
\hline & Mínimo & 5,25 & 8 & 6 & 0 & 8 & 9 & 14 \\
\hline & Máximo & 8,03 & 20 & 19 & 22 & 23 & 21 & 26 \\
\hline & Desv. típ. & ,93308 & 3,613 & 4,042 & 6,323 & 4,106 & 3,556 & 3,368 \\
\hline \multirow{4}{*}{ Industria } & Media & 7,3844 & 13,88 & 15,30 & 8,85 & 17,09 & 15,00 & 19,48 \\
\hline & Mínimo & 5,00 & 5 & 2 & 1 & 6 & 5 & 6 \\
\hline & Máximo & 8,12 & 27 & 25 & 21 & 26 & 25 & 28 \\
\hline & Desv. típ. & ,95516 & 5,067 & 4,004 & 5,233 & 4,605 & 4,822 & 4,678 \\
\hline \multirow{4}{*}{ TOTAL } & Media & 7,2043 & 13,70 & 14,80 & 8,31 & 16,62 & 16,21 & 20,15 \\
\hline & Mínimo & 3,86 & 4 & 2 & 0 & 5 & 5 & 6 \\
\hline & Máximo & 8,13 & 27 & 26 & 26 & 26 & 29 & 30 \\
\hline & Desv. típ. & 1,05294 & 4,197 & 3,907 & 5,632 & 4,203 & 5,321 & 4,644 \\
\hline
\end{tabular}

Cuadro 140: Medidas estadísticas de sector, “valores” y actitud hacia la responsabilidad social.

Antes de revisar la información del cuadro 140 hemos aplicado ANOVA de un factor en la muestra poblacional.

\begin{tabular}{|c|c|c|c|c|c|c|}
\hline & & Suma de cuadrados & gl & Media cuadrática & $\mathbf{F}$ & Sig. \\
\hline \multirow{3}{*}{ Sector } & Inter-grupos & 42,217 & 80 & 528 & 815 & 832 \\
\hline & Intra-grupos & 69,920 & 108 & 647 & & \\
\hline & Total & 112,138 & 188 & & & \\
\hline \multirow{3}{*}{ Practicidad } & Inter-grupos & 1402,026 & 80 & 17,525 & 991 & ,513 \\
\hline & Intra-grupos & 1909,381 & 108 & 17,679 & & \\
\hline & Total & 3311,407 & 188 & & & \\
\hline \multirow{3}{*}{ Resultados } & Inter-grupos & 1395,917 & 80 & 17,449 & 1,279 & 117 \\
\hline & Intra-grupos & 1473,839 & 108 & 13,647 & & \\
\hline & Total & 2869,757 & 188 & & & \\
\hline \multirow{3}{*}{ Variedad } & Inter-grupos & 2907,734 & 80 & 36,347 & 1,284 & 113 \\
\hline & Intra-grupos & 3056,467 & 108 & 28,301 & & \\
\hline & Total & 5964,201 & 188 & & & \\
\hline \multirow{3}{*}{ Decisión } & Inter-grupos & 1367,343 & 80 & 17,092 & ,945 & 602 \\
\hline & Intra-grupos & 1953,229 & 108 & 18,085 & & \\
\hline & Total & 3320,571 & 188 & & & \\
\hline \multirow{3}{*}{ Orden y método } & Inter-grupos & 2731,090 & 80 & 34,139 & 1,423 & ,044 \\
\hline & Intra-grupos & 2591,862 & 108 & 23,999 & & \\
\hline & Total & 5322,952 & 188 & & & \\
\hline \multirow{3}{*}{ Metas } & Inter-grupos & 1606,850 & 80 & 20,086 & 886 & ,714 \\
\hline & Intra-grupos & 2447,700 & 108 & 22,664 & & \\
\hline & Total & 4054,550 & 188 & & & \\
\hline
\end{tabular}

Cuadro 141: Tabla ANOVA de sector y “valores”, factor Actitud hacia la Responsabilidad Social. 
Los resultados de la prueba de ANOVA de un factor (cuadro 141) indican la existencia de diferencias estadísticamente significativas entre los diversos grupos muestrales considerados en relación con "orden y método" (su coeficiente de significación es menor de 0,05, concretamente 0,44$)$.

Una vez realizada la prueba de ANOVA hemos revisado la información que ofrece el cuadro 140.

Los líderes del sector construcción, cuya actitud media ha sido la más alta de los tres sectores, también han presentado la mayor puntuación media en el rasgo de personalidad “decisión" $(17,64)$ y en la competencia genérica "metas" $(21,43)$. En este último aspecto los máximos responsables han registrado una media de más de un punto de diferencia respecto a los otros dos sectores. Esta diferencia expresa una mayor relevancia en la búsqueda de objetivos bien delimitados por parte de los líderes de este sector, lo que podría tener alguna incidencia en su mayor actitud media a favor de la responsabilidad social.

Los máximos dirigentes del ámbito de la construcción también han obtenido las puntuaciones medias más reducidas en los rasgos de personalidad "practicidad" $(13,14)$ y “variedad" $(8,14)$, y en la característica comportamental “orden y método" $(14,79)$.

Los líderes procedentes del sector industria, que han alcanzado la segunda puntuación media en la actitud a favor 
de la responsabilidad social $(7,38)$, han registrado el mayor valor medio en los rasgos de personalidad "practicidad" $(13,88)$ y "variedad" $(8,85)$, y las medias más reducidas en las competencias genéricas "resultados" $(15,30)$ y “metas" $(19,48)$.

Los máximos responsables cuyo origen es el sector servicios, cuya actitud media ha sido inferior a la de los otros dos sectores $(7,14)$, han registrado el menor valor medio en el rasgo de personalidad "decisión" $(16,41)$ y las puntuaciones medias más altas en la competencia genérica "resultados" $(14,75)$ y en la característica comportamental “orden y método" $(16,63)$. El valor alcanzado en este último aspecto se destaca del obtenido por los líderes de los otros dos sectores.

Hemos incorporado a continuación el cuadro 142, con el valor medio de la actitud segmentado, para revisar si existen tendencias asociadas dentro de cada sector en la variación de la actitud hacia la Responsabilidad Social Corporativa y en los rasgos de personalidad, características comportamentales y competencias genéricas analizadas.

Los datos del cuadro 142 indican que en el sector servicios existe una leve tendencia creciente en la competencia genérica "resultados" a medida que se incrementa la actitud de los líderes hacia la responsabilidad social (su valor medio crece de 13,83 en el segmento " 4 a $<5$ " a 14,87 en el grupo muestral “7 a 8"). 


\begin{tabular}{|c|c|c|c|c|c|c|c|c|}
\hline Sector & $\begin{array}{r}\text { Actite } \\
\text { res }\end{array}$ & $\begin{array}{l}\text { d hacia la } \\
\text { social }\end{array}$ & Practicidad & Resultados & Variedad & Decisión & $\begin{array}{l}\text { Orden y } \\
\text { método }\end{array}$ & Metas \\
\hline \multirow{14}{*}{$\begin{array}{l}\text { Servicios } \\
\text { (incluye } \\
\text { comercio) }\end{array}$} & \multirow{2}{*}{$0 a<4$} & Media & 21,00 & 17,00 & 7,00 & 20,00 & 12,00 & 10,00 \\
\hline & & Desv. típ. & & & & & & \\
\hline & \multirow{2}{*}{$4 a<5$} & Media & 15,50 & 13,83 & 8,17 & 14,67 & 18,00 & 19,83 \\
\hline & & Desv. típ. & 2,429 & 3,601 & 5,947 & 2,733 & 5,060 & 4,355 \\
\hline & \multirow{2}{*}{$5 a<6$} & Media & 13,24 & 14,12 & 8,00 & 16,29 & 17,35 & 21,00 \\
\hline & & Desv. típ. & 3,474 & 3,333 & 4,402 & 3,293 & 5,049 & 3,102 \\
\hline & \multirow{2}{*}{$6 a<7$} & Media & 14,56 & 14,84 & 8,04 & 16,64 & 16,44 & 18,84 \\
\hline & & Desv. típ. & 3,990 & 3,287 & 5,905 & 3,558 & 5,723 & 5,684 \\
\hline & \multirow{2}{*}{7 a 8} & Media & 13,34 & 14,87 & 8,69 & 16,50 & 16,27 & 20,36 \\
\hline & & Desv. típ. & 4,003 & 3,956 & 5,909 & 4,532 & 5,616 & 4,761 \\
\hline & \multirow{2}{*}{$>8$} & Media & 13,52 & 14,87 & 7,09 & 16,26 & 17,22 & 21,04 \\
\hline & & Desv. típ. & 4,766 & 4,911 & 5,938 & 4,413 & 5,862 & 4,269 \\
\hline & \multirow{2}{*}{ Total } & Media & 13,72 & 14,75 & 8,20 & 16,41 & 16,63 & 20,18 \\
\hline & & Desv. típ. & 4,052 & 3,887 & 5,685 & 4,121 & 5,531 & 4,741 \\
\hline \multirow{10}{*}{ Construcción } & \multirow{2}{*}{$5 a<6$} & Media & 13,50 & 15,00 & 15,00 & 14,50 & 13,50 & 18,50 \\
\hline & & Desv. típ. & ,707 & 5,657 & 5,657 & ,707 & 6,364 & 6,364 \\
\hline & \multirow{2}{*}{$6 a<7$} & Media & 9,50 & 11,00 & 13,00 & 21,50 & 15,00 & 20,00 \\
\hline & & Desv. típ. & 2,121 & 2,828 & 12,728 & ,707 & 5,657 & 1,414 \\
\hline & \multirow{2}{*}{7 a 8} & Media & 13,71 & 16,00 & 5,57 & 16,71 & 15,29 & 22,29 \\
\hline & & Desv. típ. & 3,200 & 3,055 & 4,237 & 4,923 & 3,592 & 3,352 \\
\hline & \multirow{2}{*}{$>8$} & Media & 14,00 & 11,67 & 6,33 & 19,33 & 14,33 & 22,33 \\
\hline & & Desv. típ. & 6,000 & 5,132 & 3,215 & 2,082 & 2,082 & 2,082 \\
\hline & \multirow{2}{*}{ Total } & Media & 13,14 & 14,21 & 8,14 & 17,64 & 14,79 & 21,43 \\
\hline & & Desv. típ. & 3,613 & 4,042 & 6,323 & 4,106 & 3,556 & 3,368 \\
\hline \multirow{12}{*}{ Industria } & \multirow{2}{*}{$4 a<5$} & Media & 13,00 & 16,00 & 8,00 & 26,00 & 10,00 & 17,00 \\
\hline & & Desv. típ. & . & & & & & \\
\hline & \multirow{2}{*}{$5 a<6$} & Media & 15,00 & 16,75 & 8,50 & 15,50 & 15,00 & 19,25 \\
\hline & & Desv. típ. & 6,055 & 2,630 & 2,082 & 3,000 & 2,449 & 2,500 \\
\hline & \multirow{2}{*}{$6 a<7$} & Media & 14,00 & 14,50 & 7,75 & 16,75 & 16,00 & 20,25 \\
\hline & & Desv. típ. & 6,633 & 1,291 & 4,646 & 5,679 & 4,690 & 4,272 \\
\hline & \multirow{2}{*}{7 a 8} & Media & 13,69 & 14,31 & 10,54 & 18,46 & 13,62 & 18,62 \\
\hline & & Desv. típ. & 4,837 & 5,105 & 6,972 & 3,431 & 5,752 & 5,709 \\
\hline & $>8$ & Media & 13,73 & 16,18 & 7,45 & 15,36 & 16,73 & 20,55 \\
\hline & -0 & Desv. típ. & 5,405 & 3,763 & 3,882 & 5,163 & 4,197 & 4,525 \\
\hline & Tatal & Media & 13,88 & 15,30 & 8,85 & 17,09 & 15,00 & 19,48 \\
\hline & Total & Desv. típ. & 5,067 & 4,004 & 5,233 & 4,605 & 4,822 & 4,678 \\
\hline & $0>4$ & Media & 21,00 & 17,00 & 7,00 & 20,00 & 12,00 & 10,00 \\
\hline & $0 a<4$ & Desv. típ. & & & & & & \\
\hline & $4=5$ & Media & 15,14 & 14,14 & 8,14 & 16,29 & 16,86 & 19,43 \\
\hline & $4 a<5$ & Desv. típ. & 2,410 & 3,388 & 5,429 & 4,957 & 5,521 & 4,117 \\
\hline & $5 a<6$ & Media & 13,57 & 14,65 & 8,70 & 16,00 & 16,61 & 20,48 \\
\hline & $5 a<b$ & Desv. típ. & 3,776 & 3,393 & 4,487 & 3,075 & 4,793 & 3,246 \\
\hline TOTAІ & $6 a<7$ & Media & 14,16 & 14,55 & 8,32 & 16,97 & 16,29 & 19,10 \\
\hline TUIAL & $6 a<1$ & Desv. típ. & 4,344 & 3,161 & 6,085 & 3,851 & 5,442 & 5,294 \\
\hline & 7 ? 8 & Media & 13,42 & 14,88 & 8,71 & 16,80 & 15,81 & 20,26 \\
\hline & 100 & Desv. típ. & 4,036 & 4,053 & 6,008 & 4,430 & 5,538 & 4,843 \\
\hline & $>8$ & Media & 13,62 & 15,00 & 7,14 & 16,24 & 16,84 & 21,00 \\
\hline & $>0$ & Desv. típ. & 4,901 & 4,637 & 5,138 & 4,536 & 5,172 & 4,157 \\
\hline & & Media & 13,70 & 14,80 & 8,31 & 16,62 & 16,21 & 20,15 \\
\hline & Total & Desv. típ. & 4,197 & 3,907 & 5,632 & 4,203 & 5,321 & 4,644 \\
\hline
\end{tabular}

Cuadro 142: Medidas estadísticas de sector, “valores” y actitud hacia la responsabilidad social. 
En el sector construcción los datos del cuadro 142 también han permitido detectar una tendencia creciente en la competencia genérica "metas" a medida que se intensifica la actitud afín del líder hacia la Responsabilidad Social Corporativa (su valor medio aumenta de 18,5 en el segmento " 5 a $<6$ " a 22,33 en el grupo muestral " >8").

En el sector industria parece producirse una cierta tendencia decreciente en el rasgo de personalidad "practicidad" a medida que la actitud del máximo responsable a favor de la responsabilidad social es mayor (su puntuación media se reduce de 15 en el grupo muestral " 5 a $<6$ " a 13,69 en el segmento "7 a 8").

A continuación hemos incluido los gráficos 82,83 y 84 para comprobar, de modo visual, posibles tendencias asociadas al incremento de la responsabilidad social en la variación de las características comportamentales, de las competencias genéricas y de los rasgos de personalidad analizados en el estudio dentro de cada sector.

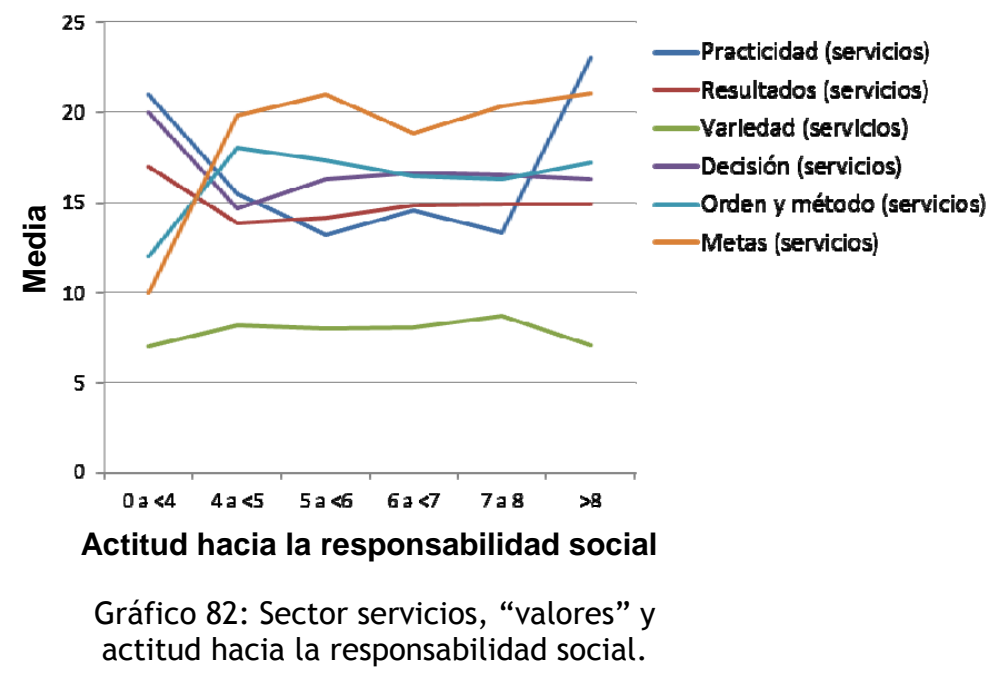


El gráfico 82 permite comprobar el leve crecimiento experimentado por la competencia genérica "resultados" a partir de que el valor medio de la actitud del líder del sector servicios a favor de la responsabilidad social es superior a 4.

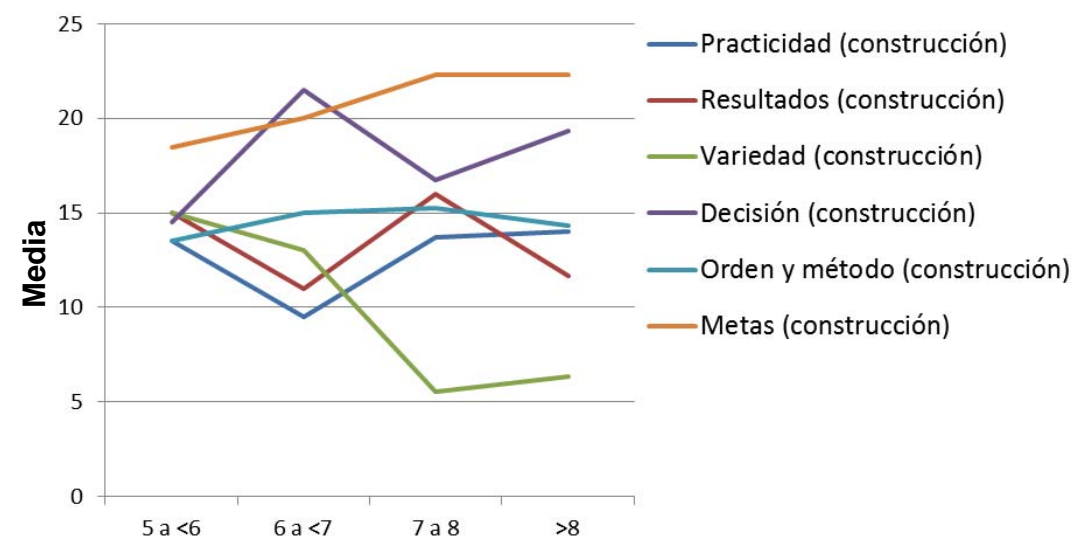

Actitud hacia la responsabilidad social

Gráfico 83: Sector construcción, "valores” y actitud hacia la responsabilidad social.

El gráfico 83 permite verificar una tendencia decreciente en el rasgo de personalidad "variedad" y una tendencia creciente en la competencia genérica "metas" a medida que la actitud del líder a favor de la responsabilidad social del líder del sector construcción se intensifica.

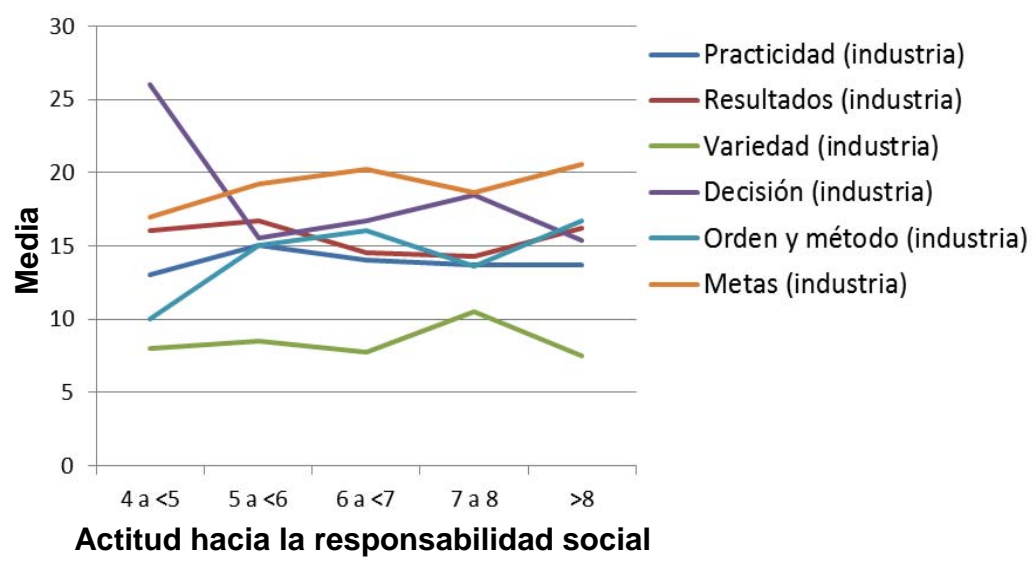

Gráfico 84: Sector industria, "valores” y actitud hacia la responsabilidad social. 
En el gráfico 84 se observa como existe una cierta tendencia decreciente en el rasgo de personalidad "practicidad" a medida que aumenta la actitud del líder del sector industria a favor de la responsabilidad social (tendencia manifiesta desde el valor 5 de la actitud).

A continuación hemos revisado los datos sobre las competencias genéricas, los rasgos de personalidad y las características comportamentales analizadas en el estudio, sobre el sector de procedencia de los líderes organizacionales y sobre la actuación en el ámbito de la Responsabilidad Social Corporativa de las empresas de procedencia de los máximos dirigentes.

Como en los apartados precedentes, hemos desglosado el análisis del comportamiento socialmente responsable de las organizaciones en dos aspectos: el comportamiento genérico propiamente dicho (que revisamos en primer lugar) y las horas que las empresas dedican a acciones formativas integradas en el ámbito de la responsabilidad social.

Antes de revisar la información, hemos aplicado ANOVA de un factor a la primera muestra poblacional para comprobar la posible existencia de diferencias estadísticamente significativas entre sus grupos muestrales.

La información que ofrece el cuadro 143, incorporado a continuación, indica la existencia de diferencias estadísticamente significativas entre los diferentes grupos 
muestrales en relación con "practicidad" (su coeficiente de significación ha sido 0,003 ).

\begin{tabular}{|c|c|c|c|c|c|c|}
\hline & & Suma de cuadrados & gl & Media cuadrática & $\mathbf{F}$ & Sig. \\
\hline \multirow{3}{*}{ Sector } & Inter-grupos & 1,520 & 3 & ,507 & ,847 & ,470 \\
\hline & Intra-grupos & 110,618 & 185 & ,598 & & \\
\hline & Total & 112,138 & 188 & & & \\
\hline \multirow{3}{*}{ Practicidad } & Inter-grupos & 236,772 & 3 & 78,924 & 4,749 & ,003 \\
\hline & Intra-grupos & 3074,636 & 185 & 16,620 & & \\
\hline & Total & 3311,407 & 188 & & & \\
\hline \multirow{3}{*}{ Resultados } & Inter-grupos & 6,856 & 3 & 2,285 & 148 & 931 \\
\hline & Intra-grupos & 2862,901 & 185 & 15,475 & & \\
\hline & Total & 2869,757 & 188 & & & \\
\hline \multirow{3}{*}{ Variedad } & Inter-grupos & 79,442 & 3 & 26,481 & ,832 & ,478 \\
\hline & Intra-grupos & 5884,759 & 185 & 31,810 & & \\
\hline & Total & 5964,201 & 188 & & & \\
\hline \multirow{3}{*}{ Decisión } & Inter-grupos & 45,522 & 3 & 15,174 & 857 & 464 \\
\hline & Intra-grupos & 3275,050 & 185 & 17,703 & & \\
\hline & Total & 3320,571 & 188 & & & \\
\hline \multirow{3}{*}{ Orden y método } & Inter-grupos & 40,179 & 3 & 13,393 & ,469 & 704 \\
\hline & Intra-grupos & 5282,774 & 185 & 28,556 & & \\
\hline & Total & 5322,952 & 188 & & & \\
\hline \multirow{3}{*}{ Metas } & Inter-grupos & 69,526 & 3 & 23,175 & 1,076 & 361 \\
\hline & Intra-grupos & 3985,025 & 185 & 21,541 & & \\
\hline & Total & 4054,550 & 188 & & & \\
\hline
\end{tabular}

Cuadro 143: Tabla ANOVA de "valores" y sector, factor Realización de Acciones de Responsabilidad Social.

Una vez realizada la prueba de ANOVA (cuadro 143) hemos revisado la información del cuadro 144 que se encuentra a continuación.

En el análisis de los datos del cuadro 144 no hemos contemplado los grupos muestrales en los que únicamente se ha recogido información de un líder.

Hemos revisado el estudio de los datos agrupando las consideraciones por sectores de actividad (servicios -en el que se incluye el comercio-, construcción e industria). 


\begin{tabular}{|c|c|c|c|c|c|c|c|c|}
\hline Sector & \multicolumn{2}{|c|}{ Acciones de resp. social } & Practicidad & Resultados & Variedad & Decisión & $\begin{array}{l}\text { Orden y } \\
\text { método }\end{array}$ & Metas \\
\hline \multirow{10}{*}{$\begin{array}{l}\text { Servicios } \\
\text { (incluye } \\
\text { comercio) }\end{array}$} & \multirow{2}{*}{ No } & Media & 14,70 & 14,86 & 7,49 & 16,04 & 17,07 & 19,62 \\
\hline & & Desv. típ. & 4,181 & 3,687 & 5,332 & 3,976 & 5,317 & 4,515 \\
\hline & \multirow{2}{*}{ Sí, acciones puntuales } & Media & 14,34 & 14,28 & 8,55 & 16,59 & 15,69 & 20,83 \\
\hline & & Desv. típ. & 4,064 & 4,309 & 5,061 & 3,896 & 5,664 & 5,141 \\
\hline & \multirow{2}{*}{$\begin{array}{l}\text { Sí, acciones frecuentes sin } \\
\text { una política definida de RS }\end{array}$} & Media & 12,50 & 14,61 & 7,67 & 17,17 & 17,17 & 20,33 \\
\hline & & Desv. típ. & 2,749 & 3,583 & 4,485 & 4,817 & 5,415 & 4,802 \\
\hline & \multirow{2}{*}{$\begin{array}{l}\text { Sí, acciones integradas en } \\
\text { una política de RS }\end{array}$} & Media & 11,27 & 15,08 & 10,04 & 16,65 & 16,12 & 20,85 \\
\hline & & Desv. típ. & 3,317 & 4,279 & 7,571 & 4,372 & 6,141 & 4,921 \\
\hline & \multirow{2}{*}{ Total } & Media & 13,72 & 14,75 & 8,20 & 16,41 & 16,63 & 20,18 \\
\hline & & Desv. típ. & 4,052 & 3,887 & 5,685 & 4,121 & 5,531 & 4,741 \\
\hline \multirow{10}{*}{ Construcción } & \multirow{2}{*}{ No } & Media & 14,30 & 14,00 & 7,60 & 17,50 & 14,70 & 21,30 \\
\hline & & Desv. típ. & 3,368 & 4,243 & 5,275 & 2,991 & 3,199 & 3,529 \\
\hline & \multirow{2}{*}{ Sí, acciones puntuales } & Media & 8,50 & 13,50 & 11,00 & 20,50 & 14,00 & 22,50 \\
\hline & & Desv. típ. & ,707 & 6,364 & 15,556 & ,707 & 4,243 & 4,950 \\
\hline & \multirow{2}{*}{$\begin{array}{l}\text { Sí, acciones frecuentes sin } \\
\text { una política definida de RS }\end{array}$} & Media & 10,00 & 17,00 & 6,00 & 23,00 & 11,00 & 23,00 \\
\hline & & Desv. típ. & & . & & & & \\
\hline & \multirow{2}{*}{$\begin{array}{l}\text { Sí, acciones integradas en } \\
\text { una política de RS }\end{array}$} & Media & 14,00 & 15,00 & 10,00 & 8,00 & 21,00 & 19,00 \\
\hline & & Desv. típ. & . & . & . & . & & \\
\hline & \multirow{2}{*}{ Total } & Media & 13,14 & 14,21 & 8,14 & 17,64 & 14,79 & 21,43 \\
\hline & & Desv. típ. & 3,613 & 4,042 & 6,323 & 4,106 & 3,556 & 3,368 \\
\hline \multirow{10}{*}{ Industria } & \multirow{2}{*}{ No } & Media & 14,58 & 15,00 & 9,00 & 15,83 & 15,75 & 19,00 \\
\hline & & Desv. típ. & 5,213 & 4,786 & 4,090 & 4,859 & 5,065 & 2,730 \\
\hline & \multirow{2}{*}{ Sí, acciones puntuales } & Media & 13,20 & 16,40 & 9,60 & 19,20 & 14,60 & 17,00 \\
\hline & & Desv. típ. & 3,962 & 3,209 & 8,081 & 1,643 & 3,647 & 6,403 \\
\hline & \multirow{2}{*}{$\begin{array}{l}\text { Sí, acciones frecuentes sin } \\
\text { una política definida de RS }\end{array}$} & Media & 15,00 & 16,67 & 10,50 & 17,33 & 13,17 & 17,33 \\
\hline & & Desv. típ. & 6,099 & 4,676 & 4,680 & 5,465 & 4,215 & 5,046 \\
\hline & \multirow{2}{*}{$\begin{array}{l}\text { Sí, acciones integradas en } \\
\text { una política de RS }\end{array}$} & Media & 12,70 & 14,30 & 7,30 & 17,40 & 15,40 & 22,60 \\
\hline & & Desv. típ. & 5,208 & 3,020 & 5,559 & 4,904 & 5,680 & 4,326 \\
\hline & \multirow{2}{*}{ Total } & Media & 13,88 & 15,30 & 8,85 & 17,09 & 15,00 & 19,48 \\
\hline & & Desv. típ. & 5,067 & 4,004 & 5,233 & 4,605 & 4,822 & 4,678 \\
\hline \multirow{10}{*}{ TOTAL } & \multirow{2}{*}{ No } & Media & 14,64 & 14,78 & 7,70 & 16,18 & 16,64 & 19,73 \\
\hline & & Desv. típ. & 4,205 & 3,867 & 5,154 & 3,993 & 5,118 & 4,232 \\
\hline & \multirow{2}{*}{ Sí, acciones puntuales } & Media & 13,86 & 14,53 & 8,83 & 17,17 & 15,44 & 20,39 \\
\hline & & Desv. típ. & 4,114 & 4,219 & 5,940 & 3,738 & 5,289 & 5,347 \\
\hline & \multirow{2}{*}{$\begin{array}{l}\text { Sí, acciones frecuentes sin } \\
\text { una política definida de RS }\end{array}$} & Media & 13,00 & 15,20 & 8,28 & 17,44 & 15,96 & 19,72 \\
\hline & & Desv. típ. & 3,830 & 3,819 & 4,532 & 4,900 & 5,342 & 4,878 \\
\hline & \multirow{2}{*}{$\begin{array}{l}\text { Sí, acciones integradas en } \\
\text { una política de RS }\end{array}$} & Media & 11,73 & 14,86 & 9,30 & 16,62 & 16,05 & 21,27 \\
\hline & & Desv. típ. & 3,870 & 3,888 & 7,003 & 4,639 & 5,921 & 4,718 \\
\hline & Total & Media & 13,70 & 14,80 & 8,31 & 16,62 & 16,21 & 20,15 \\
\hline & Tial & Desv. típ. & 4,197 & 3,907 & 5,632 & 4,203 & 5,321 & 4,644 \\
\hline
\end{tabular}

Cuadro 144: Medidas estadísticas sobre acciones de responsabilidad social, "valores” y sector.

En el sector servicios existen dos "valores" que han registrado su valor medio más alto dentro de los líderes procedentes de empresas inactivas desde el punto de vista de la responsabilidad social: el rasgo de personalidad "practicidad" $(14,70)$ y la competencia genérica “resultados" (14,86). En los líderes procedentes de estas organizaciones también se han dado tres puntuaciones medias mínimas: los rasgos de personalidad "variedad" 
$(7,49)$ y "decisión" $(16,04)$ y la competencia genérica “metas" $(19,62)$.

En el resto de comportamientos socialmente responsables posibles dentro de este sector se ha registrado la puntuación media más alta en la característica comportamental “orden y método" $(15,69)$ dentro de los máximos responsables procedentes de organizaciones que impulsan ocasionalmente acciones de responsabilidad social, en el rasgo de personalidad “decisión" $(17,17)$ dentro de los líderes vinculados a empresas que desarrollan acciones de responsabilidad social de modo frecuente, y en el rasgo de personalidad "variedad" $(10,04)$ y la competencia genérica “metas" $(20,85)$ dentro de los máximos responsables procedentes de organizaciones que cuentan con una política reconocida de Responsabilidad Social Corporativa.

En los líderes asociados a empresas que cuentan con una política de responsabilidad social establecida también se han registrado dos valores medios mínimos: el rasgo de personalidad "practicidad" $(11,27)$ y la competencia genérica "resultados" $(15,08)$.

En los cuatro tipos de comportamiento socialmente responsable considerados, la competencia genérica "metas" ha sido la que ha obtenido el valor medio más alto. Este aspecto indica que, sea cual sea la actuación de la organización en materia de responsabilidad social, los líderes del sector servicios valoran el hecho de disponer de objetivos perfectamente definidos, orientarse a las tareas y 
restringir la amplitud de sus actividades hasta que estas se finalicen.

En el sector servicios la importancia concedida por los líderes al rasgo de personalidad "practicidad" ha ido decreciendo a medida que ha aumentado el comportamiento socialmente responsable de sus organizaciones de origen. Esta tendencia parece indicar que a medida que las empresas se implican en este tipo de acciones los líderes de este sector están menos centrados en las metas materiales y otorgan menos preferencia a las cosas prácticas, útiles a corto plazo o económicamente ventajosas.

En los datos de los grupos muestrales revisados en el sector construcción, los líderes procedentes de organizaciones que no desarrollan ningún tipo de actuación en materia de responsabilidad social han registrado las puntuaciones medias máximas en el rasgo de personalidad "practicidad" $(14,30)$, en la competencia genérica "resultados" (14) y en la características comportamental “orden y método" $(14,70)$.

Dentro de los máximos responsables vinculados a organizaciones que impulsan acciones puntuales, se han producido las puntuaciones medias más altas en los rasgos de personalidad "variedad" (11) y "decisión" $(20,50)$ y en la competencia genérica “metas" $(22,50)$. Esta competencia genérica es, de los aspectos analizados, el que ha obtenido 
el valor medio más alto en los líderes procedentes de los dos grupos muestrales revisados.

En cuanto al sector industria, los máximos responsables vinculados a organizaciones que no impulsan ningún tipo de actuación en materia de responsabilidad social han registrado la puntuación media más elevada en el rasgo de personalidad "practicidad" $(14,58)$ y en la característica comportamental “orden y método" $(15,75)$.

En los líderes procedentes de organizaciones que promueven acciones de responsabilidad social de modo puntual, el rasgo de personalidad "decisión" ha registrado su valor medio más elevado $(19,20)$.

En los máximos responsables vinculados a organizaciones que desarrollan acciones de responsabilidad social frecuentemente, la competencia genérica "resultados" $(16,67)$ y el rasgo de personalidad "variedad" $(10,50)$ han obtenido su valor medio más alto.

En los líderes procedentes de organizaciones que cuentan con una política establecida de responsabilidad social, la competencia genérica "metas" ha registrado su mayor valor medio $(22,60)$. En este grupo muestral también hemos destacado tres puntuaciones medias mínimas en los rasgos de personalidad "practicidad" $(12,70)$ y "variedad" $(7,30)$, y en la competencia genérica "resultados" $(14,30)$.

En tres de los cuatro tipos de comportamiento socialmente responsable considerados la competencia genérica "metas" ha obtenido, de los seis aspectos 
contemplados en cada caso, el valor medio más alto, aunque en el grupo de los líderes cuyas organizaciones desarrollan acciones frecuentes de responsabilidad social comparte su especial relevancia con el rasgo de personalidad “decisión” (17,33). En los máximos responsables cuyo origen son empresas que desarrollan acciones puntuales, el aspecto que ha obtenido el valor medio más alto, de los seis analizados en el estudio, es el rasgo de personalidad “decisión” $(19,20)$.

A continuación hemos incorporado los gráficos 85 y 86 para contemplar, visualmente, posibles asociaciones en la variación del valor medio de los valores a medida que se incrementa el comportamiento socialmente responsable de las organizaciones, dentro de los sectores servicios y construcción.

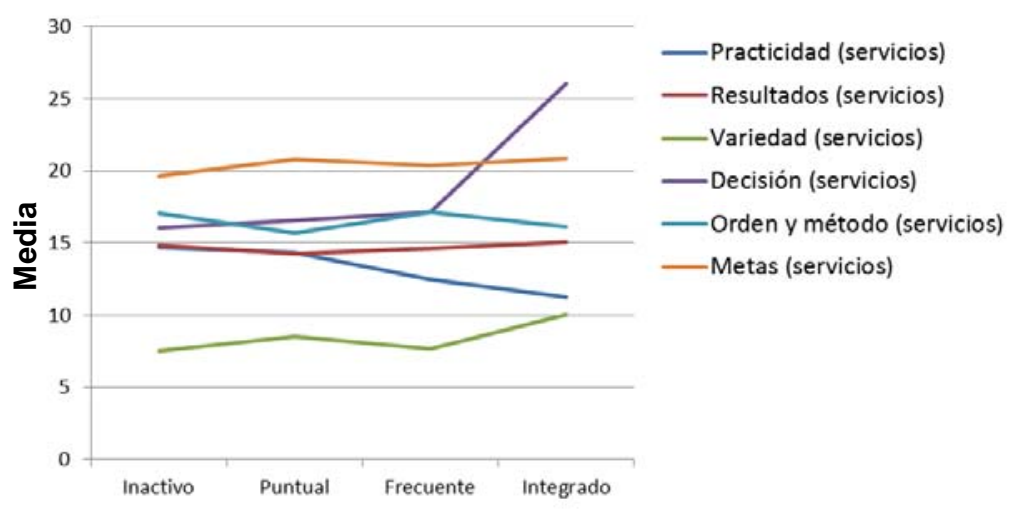

Comportamiento socialmente responsable

Gráfico 85: "Valores", sector servicios y acciones de responsabilidad social.

La información que ofrece el gráfico 85 indica que a medida que se incrementa el comportamiento socialmente responsable en las organizaciones del sector servicios, el 
rasgo de personalidad "variedad" tiende (no siempre gana en relevancia) a cobrar algo más de importancia en el líder y el rasgo de personalidad "practicidad" va perdiendo peso.

Además también muestra que para los máximos responsables vinculados a organizaciones con una política reconocida de responsabilidad social el rasgo de personalidad "decisión” tiene una especial importancia.

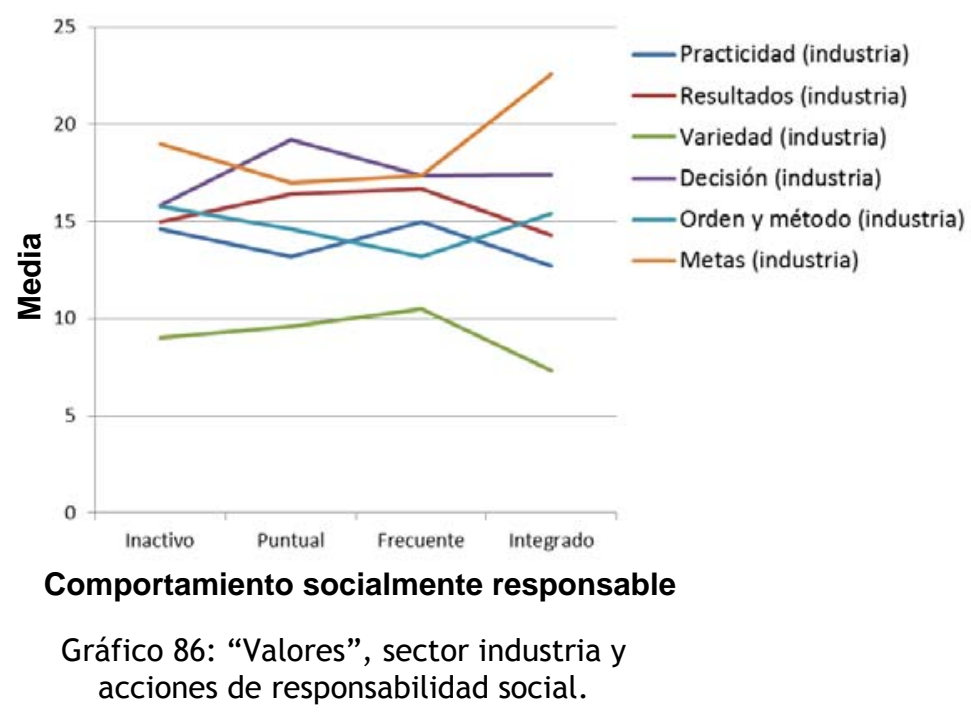

El gráfico (86) sobre el sector industria muestra que la competencia genérica "metas" es más importante para los máximos cargos en los polos de comportamiento socialmente relevante (inacción y política establecida), mientras que la competencia genérica "resultados" es más relevante para los líderes en las conductas empresariales intermedias (acciones puntuales y frecuentes).

El gráfico también indica que el rasgo de personalidad "variedad" tiene menos relevancia para los máximos dirigentes vinculados a organizaciones que cuentan con una política definida de responsabilidad social. 
Considerando ambos gráficos al mismo tiempo (85 y 86) vemos que el único aspecto, de los seis contemplados, que tiene un comportamiento similar en ambos sectores es la característica comportamental “orden y método", que tiende a mantenerse estable aunque aumente la implicación de la organización en materia de responsabilidad social.

A continuación hemos realizado el análisis del sector y los “valores" pero considerando, en este caso, la formación enmarcada en el ámbito de la Responsabilidad Social Corporativa.

Antes de revisar los datos hemos aplicado ANOVA de un factor (cuadro 145) para verificar si existen diferencias estadísticamente significativas entre los diversos grupos muestrales.

\begin{tabular}{|c|c|c|c|c|c|c|}
\hline & & Suma de cuadrados & gl & Media cuadrática & $\mathbf{F}$ & Sig. \\
\hline \multirow{3}{*}{ Sector } & Inter-grupos & 2,428 & 6 & ,405 & ,459 & 834 \\
\hline & Intra-grupos & 28,239 & 32 & ,882 & & \\
\hline & Total & 30,667 & 38 & & & \\
\hline \multirow{3}{*}{ Practicidad } & Inter-grupos & 96,892 & 6 & 16,149 & 1,007 & ,438 \\
\hline & Intra-grupos & 513,006 & 32 & 16,031 & & \\
\hline & Total & 609,897 & 38 & & & \\
\hline \multirow{3}{*}{ Resultados } & Inter-grupos & 49,573 & 6 & 8,262 & 452 & 838 \\
\hline & Intra-grupos & 585,094 & 32 & 18,284 & & \\
\hline & Total & 634,667 & 38 & & & \\
\hline \multirow{3}{*}{ Variedad } & Inter-grupos & 126,906 & 6 & 21,151 & ,520 & ,789 \\
\hline & Intra-grupos & 1302,017 & 32 & 40,688 & & \\
\hline & Total & 1428,923 & 38 & & & \\
\hline \multirow{3}{*}{ Decisión } & Inter-grupos & 225,961 & 6 & 37,660 & 1,616 & 175 \\
\hline & Intra-grupos & 745,732 & 32 & 23,304 & & \\
\hline & Total & 971,692 & 38 & & & \\
\hline \multirow{3}{*}{ Orden y método } & Inter-grupos & 112,949 & 6 & 18,825 & ,793 & ,582 \\
\hline & Intra-grupos & 759,717 & 32 & 23,741 & & \\
\hline & Total & 872,667 & 38 & & & \\
\hline \multirow{3}{*}{ Metas } & Inter-grupos & 101,619 & 6 & 16,936 & 686 & 662 \\
\hline & Intra-grupos & 789,817 & 32 & 24,682 & & \\
\hline & Total & 891,436 & 38 & & & \\
\hline
\end{tabular}

Cuadro 145: Tabla ANOVA de "valores" y sector, factor Horas de Formación en Responsabilidad Social. 
Los datos del cuadro 145 indican que no existen diferencias estadísticamente significativas en ninguno de los grupos muestrales considerados ya que, en ningún caso, el coeficiente de significación registrado ha sido inferior al valor 0,05 .

Una vez revisadas las diferencias estadísticamente significativas entre los grupos muestrales (cuadro 145) hemos procedido a analizar la información que ofrece el cuadro 146 (incorporado en la página siguiente). En dicho análisis no hemos tenido en cuenta, por su escasa representatividad, aquellos grupos muestrales en los que únicamente hemos obtenido información de un líder.

Hemos realizado el análisis de los datos agrupando las consideraciones por sectores empresariales.

En el sector servicios, los líderes han registrado la puntuación media más alta del rasgo de personalidad "practicidad" $(14,86)$ en las organizaciones que destinan menos de 11 horas a acciones formativas enmarcadas en el ámbito de la responsabilidad social. Los máximos responsables procedentes de estas empresas también han registrado la puntuación media mínima en la competencia genérica "resultados" $(14,14)$. 


\begin{tabular}{|c|c|c|c|c|c|c|c|c|}
\hline Sector & \multicolumn{2}{|c|}{ Horas de formación en resp. social } & Practicidad & Resultados & Variedad & Decisión & $\begin{array}{l}\text { Orden y } \\
\text { método }\end{array}$ & Metas \\
\hline \multirow{16}{*}{$\begin{array}{l}\text { Servicios } \\
\text { (incluye } \\
\text { comercio) }\end{array}$} & \multirow{2}{*}{ Menos de 11} & Media & 14,86 & 14,14 & 9,43 & 14,71 & 16,00 & 20,86 \\
\hline & & Desv. típ. & 2,911 & 5,398 & 5,255 & 3,817 & 4,690 & 4,811 \\
\hline & \multirow{2}{*}{ De 11 a 50} & Media & 11,17 & 14,83 & 9,00 & 21,67 & 14,00 & 19,33 \\
\hline & & Desv. típ. & 3,545 & 3,251 & 6,450 & 3,445 & 5,292 & 4,546 \\
\hline & \multirow{2}{*}{ De 51 a 100} & Media & 11,33 & 14,67 & 9,67 & 15,33 & 17,33 & 21,67 \\
\hline & & Desv. típ. & 2,082 & 3,786 & 6,506 & 4,726 & 8,622 & 3,786 \\
\hline & \multirow{2}{*}{ De 101 a 150} & Media & 11,33 & 20,33 & 5,67 & 19,67 & 15,67 & 17,33 \\
\hline & & Desv. típ. & 1,155 & 5,508 & 6,028 & 2,309 & 4,163 & 3,055 \\
\hline & \multirow{2}{*}{ De 151 a 200} & Media & 14,00 & 12,00 & 10,00 & 22,00 & 9,00 & 23,00 \\
\hline & & Desv. típ. & & & & & & \\
\hline & \multirow{2}{*}{ De 201 a 1000} & Media & 9,00 & 23,00 & 6,00 & 21,00 & 12,00 & 19,00 \\
\hline & & Desv. típ. & & & & . & & \\
\hline & \multirow{2}{*}{ Más de 1000} & Media & 11,33 & 14,67 & 11,33 & 11,67 & 17,33 & 23,67 \\
\hline & & Desv. típ. & 4,041 & 1,528 & 10,408 & 2,517 & 3,786 & 4,509 \\
\hline & \multirow{2}{*}{ Total } & Media & 12,33 & 15,50 & 9,00 & 17,33 & 15,33 & 20,50 \\
\hline & & Desv. típ. & 3,185 & 4,568 & 5,934 & 4,824 & 4,993 & 4,232 \\
\hline \multirow{6}{*}{ Construcción } & \multirow{2}{*}{ De 11 a 50} & Media & 12,00 & 16,00 & 8,00 & 15,50 & 16,00 & 21,00 \\
\hline & & Desv. típ. & 2,828 & 1,414 & 2,828 & 10,607 & 7,071 & 2,828 \\
\hline & \multirow{2}{*}{ De 101 a 150} & Media & 8,50 & 13,50 & 11,00 & 20,50 & 14,00 & 22,50 \\
\hline & & Desv. típ. & ,707 & 6,364 & 15,556 & ,707 & 4,243 & 4,950 \\
\hline & \multirow{2}{*}{ Total } & Media & 10,25 & 14,75 & 9,50 & 18,00 & 15,00 & 21,75 \\
\hline & & Desv. típ. & 2,630 & 4,031 & 9,292 & 6,782 & 4,899 & 3,403 \\
\hline \multirow{12}{*}{ Industria } & \multirow{2}{*}{ Menos de 11} & Media & 9,67 & 15,33 & 8,00 & 19,00 & 15,67 & 22,33 \\
\hline & & Desv. típ. & 1,528 & 2,309 & 6,083 & 1,000 & 1,155 & 4,509 \\
\hline & \multirow{2}{*}{ De 11 a 50} & Media & 18,33 & 16,33 & 6,67 & 15,33 & 13,33 & 20,00 \\
\hline & & Desv. típ. & 8,083 & 5,033 & 5,132 & 7,572 & 4,041 & 6,245 \\
\hline & \multirow{2}{*}{ De 51 a 100} & Media & 14,00 & 16,50 & 15,50 & 22,00 & 11,00 & 11,00 \\
\hline & & Desv. típ. & 1,414 & 3,536 & 7,778 & 1,414 & 1,414 & 7,071 \\
\hline & \multirow{2}{*}{ De 101 a 150} & Media & 12,50 & 12,00 & 3,50 & 12,00 & 23,50 & 26,50 \\
\hline & & Desv. típ. & 3,536 & 1,414 & ,707 & ,000 & 2,121 & 2,121 \\
\hline & 1000 a 201 & Media & 5,00 & 15,00 & 6,00 & 25,00 & 14,00 & 22,00 \\
\hline & DezUI a I000 & Desv. típ. & . & & & . & & \\
\hline & Total & Media & 12,91 & 15,18 & 8,00 & 17,82 & 15,45 & 20,36 \\
\hline & Toldil & Desv. típ. & 5,787 & 3,219 & 5,916 & 5,437 & 4,762 & 6,622 \\
\hline & M 11 & Media & 13,30 & 14,50 & 9,00 & 16,00 & 15,90 & 21,30 \\
\hline & 19 & Desv. típ. & 3,529 & 4,577 & 5,207 & 3,771 & 3,872 & 4,523 \\
\hline & R 11 a 50 & Media & 13,27 & 15,45 & 8,18 & 18,82 & 14,18 & 19,82 \\
\hline & a & Desv. típ. & 5,551 & 3,328 & 5,288 & 6,274 & 4,813 & 4,400 \\
\hline & D 51 : 100 & Media & 12,40 & 15,40 & 12,00 & 18,00 & 14,80 & 17,40 \\
\hline & De 51 व & Desv. típ. & 2,191 & 3,362 & 6,819 & 5,000 & 7,050 & 7,335 \\
\hline & 150 & Media & 10,86 & 16,00 & 6,57 & 17,71 & 17,43 & 21,43 \\
\hline TOTAL & 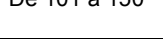 & Desv. típ. & 2,340 & 5,831 & 7,913 & 4,152 & 5,224 & 5,028 \\
\hline TUTAL & 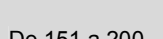 & Media & 14,00 & 12,00 & 10,00 & 22,00 & 9,00 & 23,00 \\
\hline & De is a & Desv. típ. & & & & & & \\
\hline & 1000 מ 201 & Media & 7,00 & 19,00 & 6,00 & 23,00 & 13,00 & 20,50 \\
\hline & Dezula ivou & Desv. típ. & 2,828 & 5,657 & ,000 & 2,828 & 1,414 & 2,121 \\
\hline & Mác de 1000 & Media & 11,33 & 14,67 & 11,33 & 11,67 & 17,33 & 23,67 \\
\hline & Tivas he tous & Desv. típ. & 4,041 & 1,528 & 10,408 & 2,517 & 3,786 & 4,509 \\
\hline & Tatal & Media & 12,28 & 15,33 & 8,77 & 17,54 & 15,33 & 20,59 \\
\hline & Trar & Desv. típ. & 4,006 & 4,087 & 6,132 & 5,057 & 4,792 & 4,843 \\
\hline
\end{tabular}

Cuadro 146: Medidas estadísticas sobre formación en responsabilidad social, "valores” y sector. 
En los grupos muestrales que corresponden a posiciones intermedias en el sector servicios en el cuadro 146, en relación con el número de horas que las organizaciones invierten en formación de responsabilidad social dirigida a públicos internos, tres de los aspectos analizados han obtenido su valor medio máximo: el rasgo de personalidad “decisión" $(21,67)$ en líderes procedentes de organizaciones que destinan a esta formación específica entre 11 y 50 horas, la característica comportamental “orden y método" $(17,33)$ en los máximos responsables vinculados a empresas que invierten entre 51 y 100 horas en acciones formativas enmarcadas en el ámbito de la responsabilidad social y la competencia genérica "resultados" $(20,33)$ dentro de los líderes cuyo origen son organizaciones que destinan de 101 a 150 horas a este tipo de iniciativas.

En los máximos responsables que ejercen su rol en organizaciones que dedican más de 1000 horas a formar a sus públicos internos en el ámbito de la responsabilidad social, el rasgo de personalidad "variedad" $(11,33)$, la característica comportamental "orden y método" $(17,33)$ y la competencia genérica "metas" $(23,67)$ han obtenido sus puntuaciones medias más altas. Por el contrario, la característica comportamental “orden y método" ha registrado su valor medio más reducido.

En tres de los cinco tipos de comportamiento formativo considerados en el ámbito de la responsabilidad social la competencia genérica "metas" ha sido, de los seis 
aspectos considerados en cada caso, el más valorado mientras que en dos casos (organizaciones que destinan 11 a 50 horas a acciones formativas y las que dedican entre $101 \mathrm{y}$ 150 horas) el rasgo de personalidad “decisión” ha sido el aspecto que ha obtenido una puntuación media más alta ( 21,67 y 19,67 respectivamente).

En el sector construcción se han considerado dos grupos muestrales.

En los líderes procedentes de empresas que destinan entre 11 y 50 horas a acciones de formación encuadradas en el ámbito de la responsabilidad social, el rasgo de personalidad "practicidad" (12), la competencia genérica "resultados" (16) y la característica comportamental "orden y método" (16) han obtenido su valor medio más alto.

En los máximos responsables cuyo origen son organizaciones que invierten entre 101 y 150 horas a acciones de formación que se enmarcan en el ámbito de la Responsabilidad Social Corporativa, los rasgos de personalidad “variedad" (11) y “decisión" $(20,5)$ y la competencia genérica "metas" $(22,5)$ han registrado sus puntuaciones medias máximas.

En los dos grupos muestrales la competencia genérica "metas" ha sido el aspecto, de los seis evaluados en el estudio, que ha obtenido una puntación media mayor.

En el sector de la industria se han considerado cuatro grupos muestrales. 
En los líderes procedentes de organizaciones que invierten menos de 11 horas a acciones de formación afines a la Responsabilidad Social Corporativa, el rasgo de personalidad "practicidad" ha obtenido su valor medio más reducido $(9,67)$.

En los máximos responsables vinculados a organizaciones que dedican entre 11 y 50 horas, el rasgo de personalidad "practicidad" ha registrado su puntuación media más alta dentro de los cuatro grupos contemplados $(18,33)$.

En los líderes asociados a organizaciones que destinan de 51 a 100 horas a acciones formativas encuadradas en el ámbito de la responsabilidad social, los rasgos de personalidad “decisión" (22) y "variedad" $(15,5)$ y la competencia genérica "resultados" $(16,5)$ han obtenido sus valores medios más altos.

$Y$ en los máximos responsables de empresas que dedican entre 101 y 150 horas a acciones de formación de responsabilidad social, la competencia genérica "metas" $(26,5)$ y la característica comportamental "orden y método" $(23,5)$ han registrado su valor medio máximo dentro de este sector. En los líderes procedentes de estas organizaciones los rasgos de personalidad "variedad” $(3,5)$ y “decisión” $(12)$ y la competencia genérica "resultados" (12) han obtenido sus valores medios mínimos contemplando los cuatro grupos de comportamiento formativo revisados.

En tres de los cuadro grupos muestrales considerados la competencia genérica "metas" ha obtenido, teniendo 
presente los seis aspectos estudiados en cada caso, la puntuación media más alta. Mientras en los líderes procedentes de organizaciones que destinan entre 51 y 100 horas a formación enmarcada en el ámbito de la Responsabilidad Social Corporativa la competencia genérica "resultados" ha sido la que ha obtenido, dentro de los seis aspectos analizados, el valor medio más alto $(16,50)$.

Hemos incorporado a continuación los gráficos 87 y 88 para revisar la variación de las competencias genéricas, los rasgos de personalidad y las características comportamentales estudiadas dentro de los sectores servicios e industria, considerando las horas que las organizaciones invierten en formación enmarcada en el ámbito de la responsabilidad social.

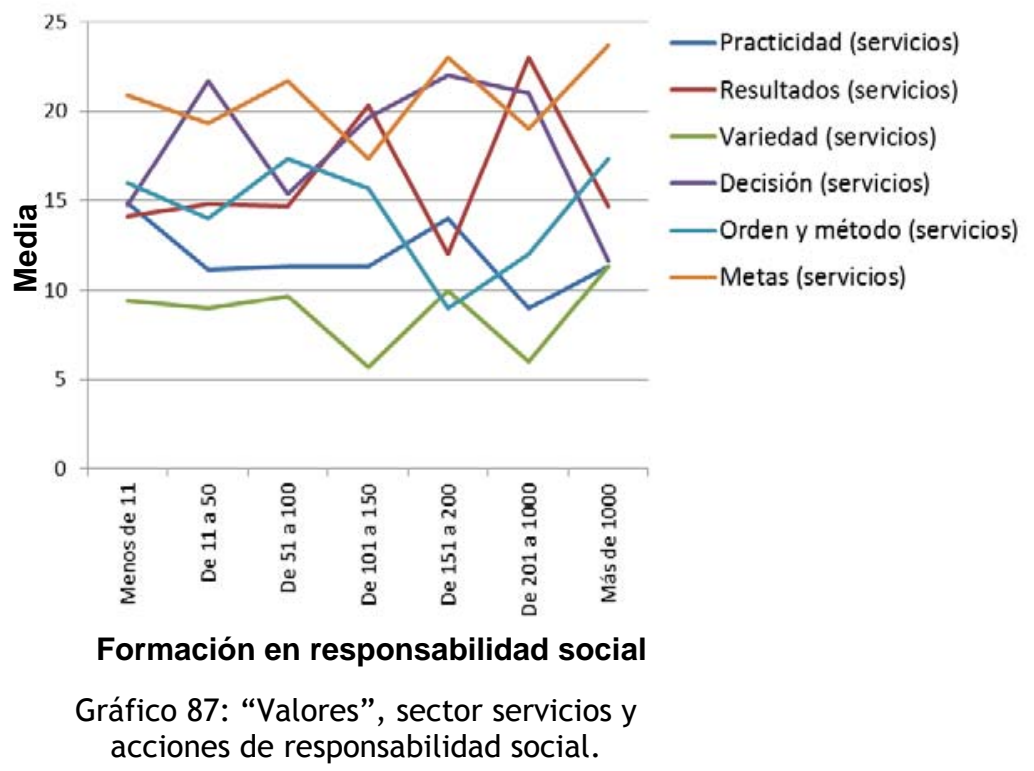

La información que ofrece el gráfico 87 sobre el sector servicios muestra que el rasgo de personalidad "variedad" 
tiende a mantenerse estable en los líderes aunque las organizaciones varíen el número de horas que dedican a acciones formativas encuadradas en el campo de la responsabilidad social.

También refleja que la competencia genérica "metas" tiende a aumentar ligeramente en los máximos dirigentes a medida que las empresas incrementan las horas que dedican a acciones formativas sobre Responsabilidad Social Corporativa, al contrario de lo que ocurre con el rasgo de personalidad "practicidad" que tiende a perder protagonismo.

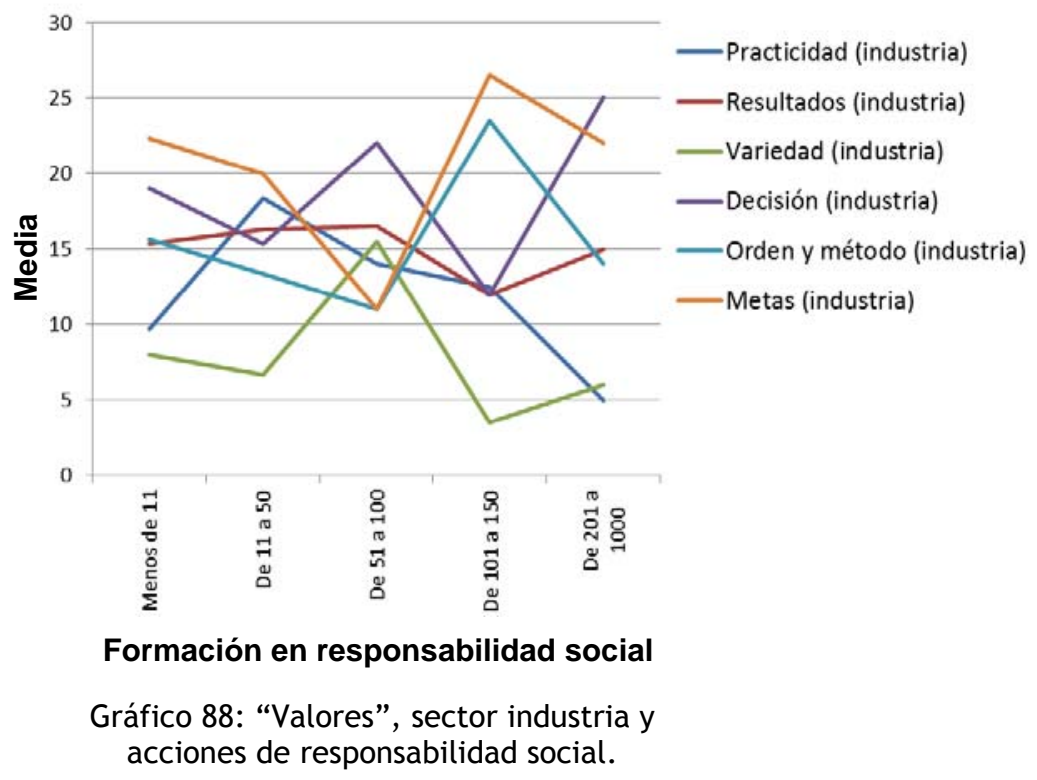

El gráfico 88 muestra que la competencia genérica "resultados" tiende a permanecer invariable en los máximos responsables del sector industria aunque se incrementen las horas que sus organizaciones de origen dedican a acciones formativas sobre responsabilidad social.

Además también revela que cuando las organizaciones invierten de 11 horas en adelante a formación sobre 
responsabilidad social, el rasgo de personalidad "practicidad" tiende a perder relevancia en los líderes. Esta pérdida de importancia es paulatinamente menor a medida que las empresas incrementan las horas que dedican a acciones de formación enmarcadas en el ámbito de la Responsabilidad Social Corporativa.

La tendencia, en términos generales, a que la "practicidad" pierda peso en las decisiones de los líderes a medida que sus organizaciones aumentan el número de horas que dedican a acciones formativas enmarcadas en el ámbito de la responsabilidad social parece ser común en los sectores industria y servicios.

\subsubsection{Tamaño, liderazgo y Responsabilidad Social Corporativa}

\begin{tabular}{|c|c|c|c|c|c|c|c|c|}
\hline \multicolumn{2}{|l|}{ Tamaño } & $\begin{array}{l}\text { Actitud hacia } \\
\text { la resp. social }\end{array}$ & $\begin{array}{c}\text { Estilo } \\
\text { directivo }\end{array}$ & $\begin{array}{c}\text { Estilo } \\
\text { consultivo }\end{array}$ & $\begin{array}{c}\text { Estilo } \\
\text { participativo }\end{array}$ & $\begin{array}{c}\text { Estilo } \\
\text { delegativo }\end{array}$ & Flexibilidad & Efectividad \\
\hline \multirow{4}{*}{ Pequeño } & Media & 7,0845 & 2,86 & 6,39 & 7,35 & 3,28 & 19,62 & 54,91 \\
\hline & Mínimo & 3,86 & 0 & 0 & 1 & 0 & 10 & 43 \\
\hline & Máximo & 8,13 & 9 & 14 & 15 & 14 & 26 & 67 \\
\hline & Desv. típ. & 1,11040 & 2,175 & 2,835 & 3,080 & 2,081 & 4,255 & 5,327 \\
\hline \multirow{4}{*}{ Mediano } & Media & 7,1458 & 2,29 & 6,56 & 8,20 & 3,18 & 19,11 & 55,96 \\
\hline & Mínimo & 4,39 & 0 & 1 & 2 & 0 & 12 & 43 \\
\hline & Máximo & 8,10 & 7 & 13 & 14 & 9 & 28 & 66 \\
\hline & Desv. típ. & 1,06398 & 1,866 & 2,510 & 3,079 & 1,862 & 4,687 & 4,903 \\
\hline \multirow{4}{*}{ Grande } & Media & 7,6528 & 1,86 & 6,71 & 8,34 & 3,03 & 18,23 & 59,26 \\
\hline & Mínimo & 5,40 & 0 & 2 & 3 & 0 & 12 & 51 \\
\hline & Máximo & 8,12 & 6 & 13 & 13 & 9 & 26 & 68 \\
\hline & Desv. típ. & ,70090 & 1,611 & 2,596 & 2,578 & 1,823 & 3,614 & 4,598 \\
\hline \multirow{4}{*}{ TOTAL } & Media & 7,2043 & 2,54 & 6,49 & 7,74 & 3,21 & 19,24 & 55,96 \\
\hline & Mínimo & 3,86 & 0 & 0 & 1 & 0 & 10 & 43 \\
\hline & Máximo & 8,13 & 9 & 14 & 15 & 14 & 28 & 68 \\
\hline & Desv. típ. & 1,05294 & 2,041 & 2,707 & 3,013 & 1,977 & 4,264 & 5,331 \\
\hline
\end{tabular}

Cuadro 147: Medidas estadísticas de sector, “valores” y actitud hacia la responsabilidad social. 
En la página previa hemos incluido el cuadro 147 con datos sobre el tamaño de la organización de procedencia del líder, su liderazgo y su actitud hacia la responsabilidad social.

Antes de proceder a la revisión de la información que ofrece el cuadro 147 hemos aplicado ANOVA de un factor a la muestra poblacional para conocer si existen diferencias estadísticamente significativas entre los diversos grupos muestrales considerados (cuadro 148).

\begin{tabular}{|c|c|c|c|c|c|c|}
\hline & & Suma de cuadrados & gl & Media cuadrática & $\mathbf{F}$ & Sig. \\
\hline \multirow{3}{*}{ Tamaño } & Inter-grupos & 39,531 & 80 & ,494 & ,707 & 948 \\
\hline & Intra-grupos & 75,495 & 108 & 699 & & \\
\hline & Total & 115,026 & 188 & & & \\
\hline \multirow{3}{*}{ Estilo directivo } & Inter-grupos & 460,904 & 80 & 5,761 & 1,932 & 001 \\
\hline & Intra-grupos & 322,049 & 108 & 2,982 & & \\
\hline & Total & 782,952 & 188 & & & \\
\hline \multirow{3}{*}{ Estilo consultivo } & Inter-grupos & 542,014 & 80 & 6,775 & ,876 & ,732 \\
\hline & Intra-grupos & 835,224 & 108 & 7,734 & & \\
\hline & Total & 1377,238 & 188 & & & \\
\hline \multirow{3}{*}{ Estilo participativo } & Inter-grupos & 758,724 & 80 & 9,484 & 1,080 & ,352 \\
\hline & Intra-grupos & 948,049 & 108 & 8,778 & & \\
\hline & Total & 1706,772 & 188 & & & \\
\hline \multirow{3}{*}{ Estilo delegativo } & Inter-grupos & 361,062 & 80 & 4,513 & 1,304 & ,099 \\
\hline & Intra-grupos & 373,890 & 108 & 3,462 & & \\
\hline & Total & 734,952 & 188 & & & \\
\hline \multirow{3}{*}{ Flexibilidad } & Inter-grupos & 1712,188 & 80 & 21,402 & 1,354 & 071 \\
\hline & Intra-grupos & 1706,617 & 108 & 15,802 & & \\
\hline & Total & 3418,804 & 188 & & & \\
\hline \multirow{3}{*}{ Efectividad } & Inter-grupos & 2304,729 & 80 & 28,809 & 1,024 & ,450 \\
\hline & Intra-grupos & 3038,012 & 108 & 28,130 & & \\
\hline & Total & 5342,741 & 188 & & & \\
\hline
\end{tabular}

Cuadro 148: Tabla ANOVA de sector y "valores", factor Actitud hacia la Responsabilidad Social.

Los resultados de la prueba de ANOVA (cuadro 148) indican la existencia de diferencias estadísticamente significativas entre los diversos grupos muestrales en 
relación con "estilo directivo" (su coeficiente de significación es 0,001$)$.

En relación con la información que ofrece el cuadro 147, en el que la actitud media más reducida corresponde a los líderes procedentes de empresas pequeñas $(7,08)$ y la más alta a los máximos responsables de organizaciones grandes $(7,65)$, es destacable que todos los valores medios extremos del resto de variables estudiadas se han situado en los tamaños empresariales grande y pequeño. En este sentido podemos advertir diversas tendencias en los datos a medida que se incrementa el tamaño empresarial.

Algunas variables de liderazgo reducen su importancia. El estilo directivo decrece a medida que aumenta el tamaño empresarial (su puntuación media se reduce de 2,86 en los líderes procedentes de organizaciones grandes a 1,86 en los vinculados a organizaciones pequeñas). La misma tendencia se manifiesta en el estilo delegativo (su valor medio se reduce de 3,28 a 3,03 ) y en la flexibilidad de estilo (su puntuación media disminuye de 19,62 a 18,23).

Otras variables, sin embargo, aumentan su valor a medida que crece el tamaño empresarial y la afinidad hacia la Responsabilidad Social Corporativa. Este es el caso del estilo consultivo (su valor medio aumenta de 6,39 a 6,71), del estilo participativo (su puntuación media se incrementa de 7,35 y a 8,34 ) y de la efectividad (cuya media crece de 54,91 a 59,26). El incremento de la media de la efectividad 


\section{en los líderes de empresas grandes, quienes han obtenido}

\section{también una mayor puntuación media, es remarcable.}

\begin{tabular}{|c|c|c|c|c|c|c|c|c|}
\hline Tamaño & $\begin{array}{l}\text { Actit } \\
\text { res }\end{array}$ & $\begin{array}{l}\text { d hacia la } \\
\text { o. social }\end{array}$ & $\begin{array}{c}\text { Estilo } \\
\text { directivo }\end{array}$ & $\begin{array}{c}\text { Estilo } \\
\text { consultivo }\end{array}$ & $\begin{array}{c}\text { Estilo } \\
\text { participativo }\end{array}$ & $\begin{array}{c}\text { Estilo } \\
\text { delegativo }\end{array}$ & Flexibilidad & Efectividad \\
\hline \multirow{14}{*}{ Pequeño } & \multirow{2}{*}{$0 \mathrm{a}<4$} & Media & 2,00 & 12,00 & 6,00 &, 00 & 14,00 & 57,00 \\
\hline & & Desv. típ. & & & & . & & \\
\hline & \multirow{2}{*}{$4 a<5$} & Media & 3,80 & 6,40 & 6,60 & 3,20 & 23,00 & 52,60 \\
\hline & & Desv. típ. & 2,280 & 1,673 & 1,140 & 2,280 & 3,000 & 6,107 \\
\hline & \multirow{2}{*}{$5 a<6$} & Media & 3,93 & 4,73 & 6,80 & 4,53 & 20,20 & 54,93 \\
\hline & & Desv. típ. & 2,549 & 2,963 & 3,649 & 3,292 & 4,931 & 6,497 \\
\hline & \multirow{2}{*}{$6 a<7$} & Media & 3,00 & 7,05 & 7,15 & 2,80 & 19,65 & 55,45 \\
\hline & & Desv. típ. & 2,026 & 2,373 & 3,617 & 1,576 & 4,648 & 4,359 \\
\hline & \multirow{2}{*}{7 a 8} & Media & 2,47 & 6,69 & 7,65 & 3,16 & 19,33 & 54,63 \\
\hline & & Desv. típ. & 2,052 & 2,616 & 3,018 & 1,736 & 3,955 & 4,662 \\
\hline & \multirow{2}{*}{$>8$} & Media & 2,68 & 5,95 & 7,47 & 3,26 & 19,32 & 55,53 \\
\hline & & Desv. típ. & 2,212 & 3,407 & 2,716 & 1,881 & 4,204 & 6,963 \\
\hline & \multirow{2}{*}{ Total } & Media & 2,86 & 6,39 & 7,35 & 3,28 & 19,62 & 54,91 \\
\hline & & Desv. típ. & 2,175 & 2,835 & 3,080 & 2,081 & 4,255 & 5,327 \\
\hline \multirow{12}{*}{ Mediano } & \multirow{2}{*}{$4 a<5$} & Media & 2,50 & 5,00 & 10,00 & 2,50 & 19,00 & 58,00 \\
\hline & & Desv. típ. & 3,536 & 1,414 & 4,243 & 2,121 & 9,899 & 5,657 \\
\hline & \multirow{2}{*}{$5 a<6$} & Media & 3,71 & 7,29 & 5,86 & 3,14 & 22,57 & 55,71 \\
\hline & & Desv. típ. & 1,799 & 1,380 & 2,673 & 1,676 & 3,599 & 4,461 \\
\hline & \multirow{2}{*}{$6 a<7$} & Media & 4,00 & 6,50 & 6,00 & 3,50 & 22,33 & 53,00 \\
\hline & & Desv. típ. & 1,549 & ,837 & 2,530 & 2,168 & 2,658 & 4,817 \\
\hline & \multirow{2}{*}{7 a 8} & Media & 1,63 & 6,68 & 9,00 & 2,68 & 17,47 & 57,05 \\
\hline & & Desv. típ. & 1,571 & 2,730 & 3,018 & 1,565 & 4,623 & 5,873 \\
\hline & \multirow{2}{*}{$>8$} & Media & 1,55 & 6,18 & 9,18 & 4,00 & 18,00 & 55,45 \\
\hline & & Desv. típ. & 1,368 & 3,401 & 2,523 & 2,236 & 4,000 & 2,876 \\
\hline & \multirow{2}{*}{ Total } & Media & 2,29 & 6,56 & 8,20 & 3,18 & 19,11 & 55,96 \\
\hline & & Desv. típ. & 1,866 & 2,510 & 3,079 & 1,862 & 4,687 & 4,903 \\
\hline \multirow{10}{*}{ Grande } & \multirow{2}{*}{$5 a<6$} & Media & 1,00 & 8,00 & 9,00 & 2,00 & 16,00 & 59,00 \\
\hline & & Desv. típ. & & & & & . & \\
\hline & \multirow{2}{*}{$6 a<7$} & Media & 1,00 & 6,60 & 10,00 & 2,40 & 16,40 & 56,40 \\
\hline & & Desv. típ. & 1,225 & 2,074 & 2,449 & 1,140 & 2,191 & 3,912 \\
\hline & \multirow{2}{*}{7 a 8} & Media & 1,95 & 6,95 & 8,00 & 3,05 & 18,32 & 59,27 \\
\hline & & Desv. típ. & 1,463 & 2,935 & 2,812 & 1,618 & 3,286 & 4,516 \\
\hline & $>8$ & Media & 2,29 & 5,86 & 8,14 & 3,57 & 19,57 & 61,29 \\
\hline & $>8$ & Desv. típ. & 2,289 & 1,952 & 1,773 & 2,820 & 5,224 & 5,155 \\
\hline & Total & Media & 1,86 & 6,71 & 8,34 & 3,03 & 18,23 & 59,26 \\
\hline & Iotal & Desv. típ. & 1,611 & 2,596 & 2,578 & 1,823 & 3,614 & 4,598 \\
\hline & $0 a<4$ & Media & 2,00 & 12,00 & 6,00 &, 00 & 14,00 & 57,00 \\
\hline & $0 a<4$ & Desv. típ. & . & & & . & . & \\
\hline & & Media & 3,43 & 6,00 & 7,57 & 3,00 & 21,86 & 54,14 \\
\hline & $4 a<5$ & Desv. típ. & 2,440 & 1,633 & 2,573 & 2,082 & 5,113 & 6,094 \\
\hline & & Media & 3,74 & 5,65 & 6,61 & 4,00 & 20,74 & 55,35 \\
\hline & $5 a<b$ & Desv. típ. & 2,320 & 2,790 & 3,299 & 2,876 & 4,614 & 5,749 \\
\hline & & Media & 2,87 & 6,87 & 7,39 & 2,87 & 19,65 & 55,13 \\
\hline TOTAL & 6 a $<1$ & Desv. típ. & 2,012 & 2,078 & 3,422 & 1,628 & 4,325 & 4,380 \\
\hline & & Media & 2,17 & 6,76 & 8,02 & 3,03 & 18,69 & 56,28 \\
\hline & 7 a 8 & Desv. típ. & 1,844 & 2,691 & 2,983 & 1,666 & 3,985 & 5,230 \\
\hline & $>0$ & Media & 2,27 & 6,00 & 8,11 & 3,54 & 18,97 & 56,59 \\
\hline & $>8$ & Desv. típ. & 2,023 & 3,109 & 2,558 & 2,142 & 4,272 & 6,021 \\
\hline & Total & Media & 2,54 & 6,49 & 7,74 & 3,21 & 19,24 & 55,96 \\
\hline & Iotal & Desv. típ. & 2,041 & 2,707 & 3,013 & 1,977 & 4,264 & 5,331 \\
\hline
\end{tabular}

Cuadro 149: Medidas estadísticas de sector, “valores” y actitud hacia la responsabilidad social. 
Previamente hemos incluido el cuadro 149 de nuevo con los datos sobre tamaño, liderazgo y actitud hacia la responsabilidad pero, en esta ocasión, segmentando las puntuaciones medias de la actitud para detectar posibles tendencias en las variables de liderazgo a medida que se intensifica la actitud de los líderes dentro de cada sector a favor de la responsabilidad social.

Los datos que ofrece el cuadro 149 indican que en los líderes vinculados a empresas pequeñas, la flexibilidad de su liderazgo es menor a media que se acentúa su disposición positiva hacia la responsabilidad social (la media de la flexibilidad se reduce de 23 en el segmento de valor " 4 a $<5$ " a 19,32 en el grupo muestral “>8”). Además, los máximos responsables de este tamaño empresarial también parecen conceder la misma importancia al estilo participativo (alto apoyo y poca dirección) aunque varíe la intensidad de su actitud hacia la responsabilidad social.

En los líderes procedentes de empresas grandes se detectan cuatro tendencias crecientes al pasar del segmento de la actitud "6 a <7" al segmento ">8" (no hemos contemplado el segmento "6 a $<7$ " por su baja representatividad): en el estilo directivo (su valor medio crece de 1 a 2,29), en el estilo delegativo (su puntuación media aumenta de 2,4 a 3,57 ), en la flexibilidad de estilo (su media se incrementa de 16,40 a 19,57) y en la efectividad de estilo (su valor medio aumenta de 56,4 a $61,29)$. 
Es destacable que mientras en los líderes procedentes de empresas pequeñas la mayor intensidad en su actitud afín a la responsabilidad social supone una tendencia a reducir su flexibilidad de estilo, en los máximos responsables de las empresas grandes ocurre al contrario.

Hemos incorporado tras estas líneas los gráficos 89,90 y 91 para comprobar de modo visual las tendencias de variación entre las variables estudiadas dentro de cada tamaño empresarial.

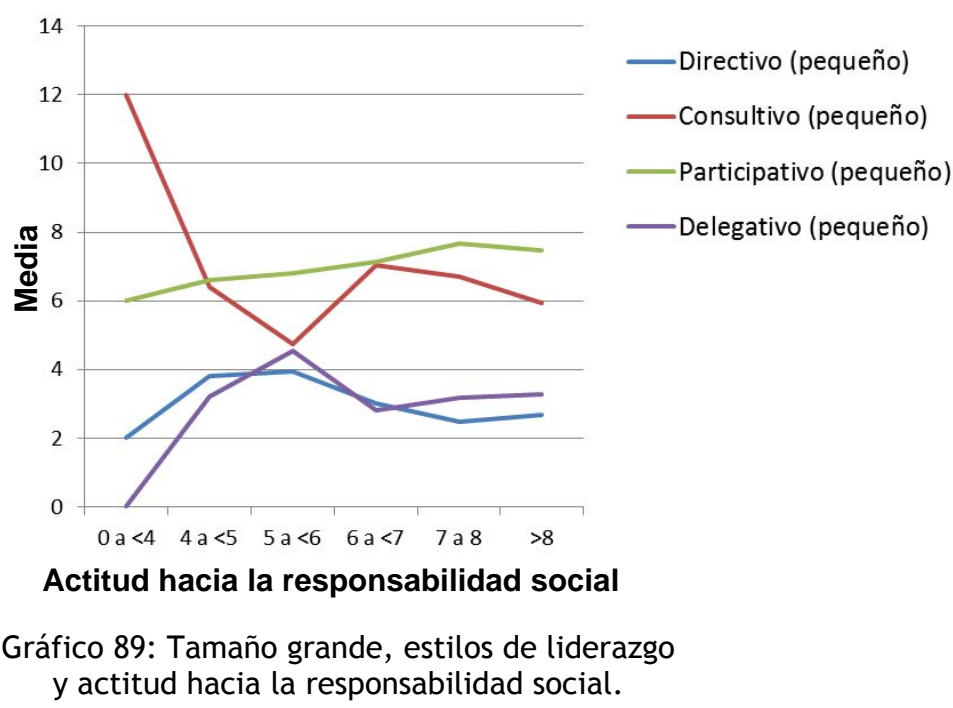

El gráfico 89 muestra que a medida que la actitud de los líderes de las empresas pequeñas a favor de la responsabilidad social es mayor, la importancia que conceden al estilo delegativo también aumenta. 


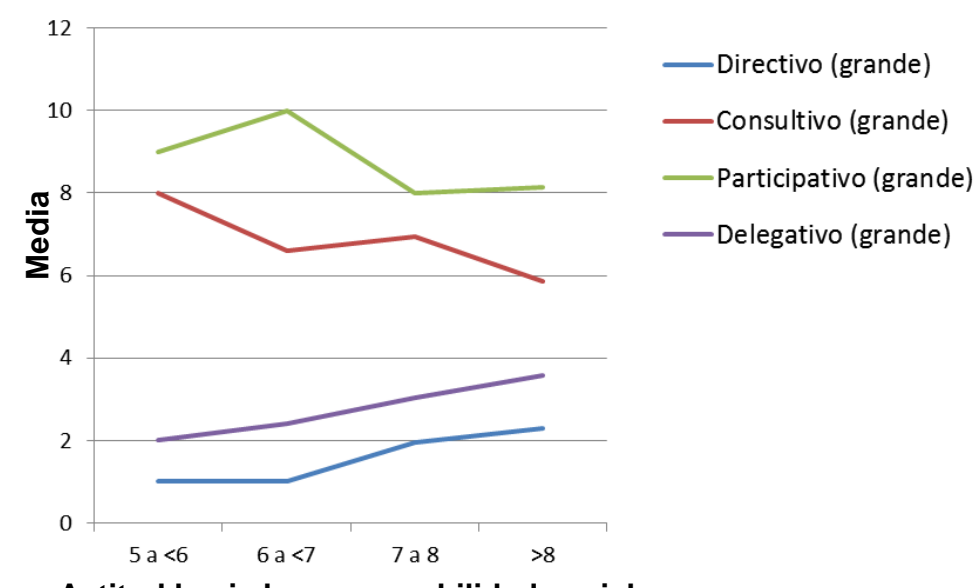

Actitud hacia la responsabilidad social

Gráfico 90: Tamaño pequeño, estilos de liderazgo y actitud hacia la responsabilidad social.

El gráfico 90 indica que cuando crece la afinidad de los líderes de las empresas grandes hacia la Responsabilidad Social Corporativa también aumenta la relevancia que conceden al estilo delegativo y directivo, y se reduce la que otorgan al estilo consultivo.

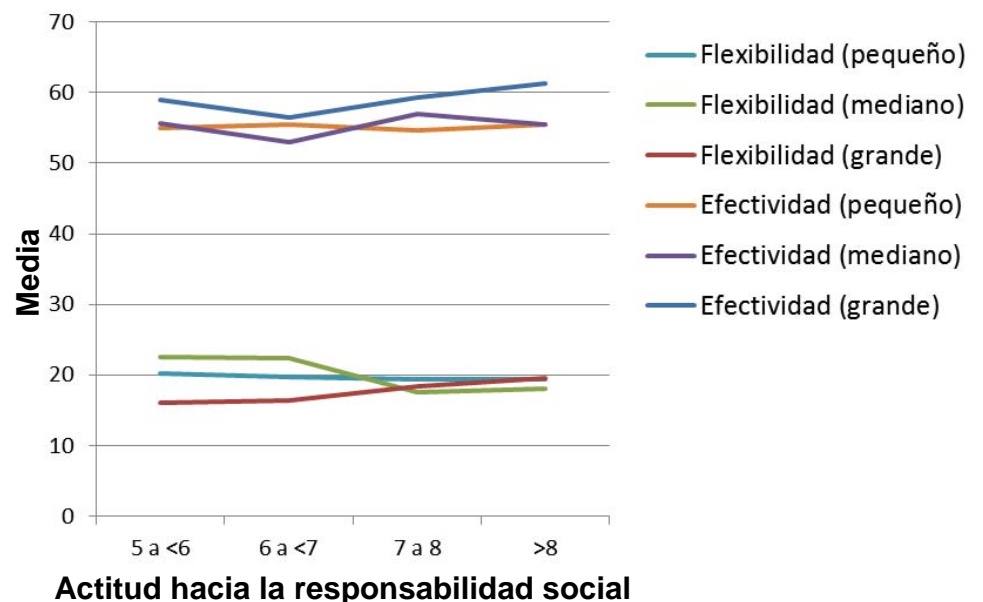

Gráfico 91: Tamaño, flexibilidad, efectividad y actitud hacia la responsabilidad social.

El gráfico 91 refleja una cierta tendencia creciente en la efectividad y la flexibilidad de estilo de los líderes procedentes de organizaciones grandes a medida que aumenta su actitud a favor de la responsabilidad social. 
Por el contario, los líderes de las empresas pequeñas parecen mostrar una leve tendencia decreciente en su flexibilidad de estilo según se intensifica su disposición positiva hacia la responsabilidad social.

A continuación hemos realizado el análisis de los datos sobre liderazgo y tamaño empresarial considerando, de modo genérico, el comportamiento socialmente responsable de las organizaciones.

\begin{tabular}{|c|c|c|c|c|c|c|c|c|}
\hline Tamaño & Acciones de resp. & ocial & $\begin{array}{c}\text { Estilo } \\
\text { directivo }\end{array}$ & $\begin{array}{c}\text { Estilo } \\
\text { consultivo }\end{array}$ & $\begin{array}{c}\text { Estilo } \\
\text { participativo }\end{array}$ & $\begin{array}{c}\text { Estilo } \\
\text { delegativo }\end{array}$ & Flexibilidad & Efectividad \\
\hline \multirow{10}{*}{ Pequeño } & \multirow{2}{*}{ No } & Media & 3,17 & 6,26 & 6,76 & 3,63 & 20,44 & 54,64 \\
\hline & & Desv. típ. & 2,175 & 2,945 & 2,909 & 2,267 & 4,212 & 5,567 \\
\hline & \multirow{2}{*}{ Sí, acciones puntuales } & Media & 2,21 & 6,71 & 8,42 & 2,67 & 18,58 & 53,75 \\
\hline & & Desv. típ. & 1,744 & 2,510 & 2,781 & 1,373 & 3,752 & 4,204 \\
\hline & \multirow{2}{*}{$\begin{array}{l}\mathrm{Si} \text {, acciones frecuentes } \sin \\
\text { una política definida de RS }\end{array}$} & Media & 2,30 & 6,90 & 8,30 & 2,50 & 16,80 & 58,80 \\
\hline & & Desv. típ. & 2,869 & 2,767 & 3,743 & 1,780 & 3,553 & 4,733 \\
\hline & \multirow{2}{*}{$\begin{array}{l}\text { Sí, acciones integradas en } \\
\text { una política de RS }\end{array}$} & Media & 2,67 & 5,33 & 9,67 & 2,33 & 17,67 & 57,67 \\
\hline & & Desv. típ. & 2,309 & 3,786 & 4,619 & 1,528 & 6,807 & 4,726 \\
\hline & \multirow{2}{*}{ Total } & Media & 2,86 & 6,39 & 7,35 & 3,28 & 19,62 & 54,91 \\
\hline & & Desv. típ. & 2,175 & 2,835 & 3,080 & 2,081 & 4,255 & 5,327 \\
\hline \multirow{10}{*}{ Mediano } & \multirow{2}{*}{ No } & Media & 2,72 & 6,33 & 7,28 & 3,67 & 19,94 & 54,83 \\
\hline & & Desv. típ. & 2,218 & 2,351 & 2,782 & 2,223 & 4,684 & 4,176 \\
\hline & \multirow{2}{*}{ Sí, acciones puntuales } & Media & 2,25 & 6,25 & 8,38 & 3,13 & 20,25 & 56,88 \\
\hline & & Desv. típ. & 1,581 & 1,488 & 3,378 & 1,553 & 4,464 & 6,999 \\
\hline & \multirow{2}{*}{$\begin{array}{l}\text { Sí, acciones frecuentes sin } \\
\text { una política definida de RS }\end{array}$} & Media & 2,25 & 6,00 & 9,25 & 2,50 & 17,75 & 55,25 \\
\hline & & Desv. típ. & 1,488 & 3,024 & 2,493 & 1,604 & 4,464 & 5,064 \\
\hline & \multirow{2}{*}{$\begin{array}{l}\text { Sí, acciones integradas en } \\
\text { una política de RS }\end{array}$} & Media & 1,64 & 7,55 & 8,82 & 2,91 & 17,91 & 57,64 \\
\hline & & Desv. típ. & 1,690 & 2,979 & 3,656 & 1,578 & 5,108 & 4,178 \\
\hline & \multirow{2}{*}{ Total } & Media & 2,29 & 6,56 & 8,20 & 3,18 & 19,11 & 55,96 \\
\hline & & Desv. típ. & 1,866 & 2,510 & 3,079 & 1,862 & 4,687 & 4,903 \\
\hline \multirow{10}{*}{ Grande } & \multirow{2}{*}{ No } & Media & 2,00 & 7,00 & 8,00 & 3,00 & 20,00 & 60,00 \\
\hline & & Desv. típ. & & & & & & \\
\hline & \multirow{2}{*}{ Sí, acciones puntuales } & Media & 2,75 & 5,25 & 8,75 & 3,25 & 21,00 & 60,25 \\
\hline & & Desv. típ. & 1,258 & 1,893 & 1,708 & 1,708 & 3,830 & 3,096 \\
\hline & \multirow{2}{*}{$\begin{array}{l}\text { Sí, acciones frecuentes sin } \\
\text { una política definida de RS }\end{array}$} & Media & 1,00 & 7,57 & 7,86 & 3,43 & 16,71 & 59,00 \\
\hline & & Desv. típ. & ,577 & 3,207 & 2,478 & 2,760 & 2,360 & 2,646 \\
\hline & \multirow{2}{*}{$\begin{array}{l}\text { Sí, acciones integradas en } \\
\text { una política de RS }\end{array}$} & Media & 1,96 & 6,70 & 8,43 & 2,87 & 18,13 & 59,13 \\
\hline & & Desv. típ. & 1,821 & 2,548 & 2,842 & 1,604 & 3,794 & 5,405 \\
\hline & \multirow{2}{*}{ Total } & Media & 1,86 & 6,71 & 8,34 & 3,03 & 18,23 & 59,26 \\
\hline & & Desv. típ. & 1,611 & 2,596 & 2,578 & 1,823 & 3,614 & 4,598 \\
\hline \multirow{10}{*}{ TOTAL } & \multirow{2}{*}{ No } & Media & 3,07 & 6,29 & 6,88 & 3,63 & 20,34 & 54,74 \\
\hline & & Desv. típ. & 2,169 & 2,810 & 2,863 & 2,234 & 4,264 & 5,297 \\
\hline & \multirow{2}{*}{ Sí, acciones puntuales } & Media & 2,28 & 6,44 & 8,44 & 2,83 & 19,22 & 55,17 \\
\hline & & Desv. típ. & 1,632 & 2,261 & 2,761 & 1,424 & 3,921 & 5,218 \\
\hline & \multirow{2}{*}{$\begin{array}{l}\text { Sí, acciones frecuentes sin } \\
\text { una política definida de RS }\end{array}$} & Media & 1,92 & 6,80 & 8,48 & 2,76 & 17,08 & 57,72 \\
\hline & & Desv. típ. & 2,040 & 2,915 & 2,988 & 2,006 & 3,487 & 4,542 \\
\hline & \multirow{2}{*}{$\begin{array}{l}\text { Sí, acciones integradas en } \\
\text { una política de RS }\end{array}$} & Media & 1,92 & 6,84 & 8,65 & 2,84 & 18,03 & 58,57 \\
\hline & & Desv. típ. & 1,785 & 2,754 & 3,155 & 1,555 & 4,317 & 4,947 \\
\hline & \multirow{2}{*}{ Total } & Media & 2,54 & 6,49 & 7,74 & 3,21 & 19,24 & 55,96 \\
\hline & & Desv. típ. & 2,041 & 2,707 & 3,013 & 1,977 & 4,264 & 5,331 \\
\hline
\end{tabular}

Cuadro 150: Medidas estadísticas sobre acciones de responsabilidad social, liderazgo y tamaño. 
Antes de revisar el cuadro 150 hemos aplicado ANOVA de un factor en los datos (cuadro 151) para comprobar si existen diferencias estadísticamente significativas entre los diversos grupos muestrales considerados.

La información que ofrece el cuadro 151 muestra que hay diferencias estadísticamente significativas entre los diversos grupos muestrales en relación con "tamaño" (tiene un coeficiente de significación de 0,000), "estilo directivo" (presenta un coeficiente de significación de 0,006), "estilo participativo" (ha registrado un coeficiente de significación de 0,002), "estilo delegativo" (presenta un coeficiente de significación de 0,046), "flexibilidad" (tiene un coeficiente de significación de 0,001) y "efectividad" (presenta un coeficiente de significación de 0,000).

\begin{tabular}{|l|l|r|r|r|r|c|}
\hline \multicolumn{2}{|c|}{} & Suma de cuadrados & gl & Media cuadrática & F & Sig. \\
\hline \multirow{4}{*}{ Tamaño } & Inter-grupos & 48,704 & 3 & 16,235 & 45,285 &, 000 \\
\cline { 2 - 8 } & Intra-grupos & 66,322 & 185 &, 358 & & \\
\cline { 2 - 8 } & Total & 115,026 & 188 & & & \\
\hline \multirow{4}{*}{ Estilo directivo } & Inter-grupos & 51,529 & 3 & 17,176 & 4,344 &, 006 \\
\cline { 2 - 8 } & Intra-grupos & 731,423 & 185 & 3,954 & & \\
\cline { 2 - 8 } & Total & 782,952 & 188 & & & \\
\hline \multirow{4}{*}{ Estilo consultivo participativo } & Inter-grupos & 10,751 & 3 & 3,584 &, 485 &, 693 \\
\cline { 2 - 8 } & Intra-grupos & 1366,487 & 185 & 7,386 & & \\
\cline { 2 - 8 } & Total & 1377,238 & 188 & & & \\
\hline & Inter-grupos & 129,541 & 3 & 43,180 & 5,065 &, 002 \\
\cline { 2 - 8 } & Intra-grupos & 1577,232 & 185 & 8,526 & & \\
\cline { 2 - 8 } & Total & 1706,772 & 188 & & & \\
\hline \multirow{4}{*}{ Estilo delegativo } & Inter-grupos & 31,069 & 3 & 10,356 & 2,722 &, 046 \\
\cline { 2 - 8 } & Intra-grupos & 703,884 & 185 & 3,805 & & \\
\cline { 2 - 8 } & Total & 734,952 & 188 & & & \\
\hline \multirow{5}{*}{ Flexibilidad } & Inter-grupos & 281,329 & 3 & 93,776 & 5,529 &, 001 \\
\cline { 2 - 8 } & Intra-grupos & 3137,475 & 185 & 16,959 & & \\
\cline { 2 - 8 } & Total & 3418,804 & 188 & & & \\
\hline \multirow{5}{*}{ Efectividad } & Inter-grupos & 487,949 & 3 & 162,650 & 6,198 &, 000 \\
\cline { 2 - 8 } & Intra-grupos & 4854,791 & 185 & 26,242 & & \\
\cline { 2 - 8 } & Total & 5342,741 & 188 & & & \\
\hline
\end{tabular}

Cuadro 151: Tabla ANOVA de liderazgo y tamaño, factor Realización de Acciones de Responsabilidad Social. 
Una vez realizada la prueba de ANOVA hemos procedido a revisar los datos que ofrece el cuadro 150. En esta lectura no hemos considerado, por su baja representatividad, aquellos casos en los que solo se han recogido datos de un líder.

Aunque en todas las dimensiones consideradas siempre el estilo participativo ha sido el primario y el estilo consultivo el secundario, hemos agrupado la lectura de la información del cuadro 150 de acuerdo con el tamaño empresarial para enriquecer la revisión.

En las empresas pequeñas se ha apreciado una cierta tendencia creciente en la media obtenida por los líderes en el estilo participativo a medida que se ha acentuado la actuación responsable de sus empresas de origen. Esta tendencia es especialmente acuciada al pasar de los líderes procedentes de empresas inactivas $(6,76)$, desde el punto de vista del comportamiento socialmente responsable, a los líderes vinculados a empresas que desarrollan acciones de forma puntual $(8,42)$, frecuente $(8,30)$ o que cuentan con una política definida de Responsabilidad Social Corporativa $(9,67)$.

También se ha registrado una tendencia decreciente en la importancia que el máximo dirigente concede al estilo delegativo al incrementarse la intensidad del comportamiento socialmente responsable de su empresa de origen. Su media pasa de 3,63 en los líderes que proceden de organizaciones que no desarrollan ninguna iniciativa en 
materia de responsabilidad social a 2,33 en los máximos responsables que están vinculados a organizaciones que cuentan con una política definida de Responsabilidad Social Corporativa.

En las empresas pequeñas, el valor medio máximo de la flexibilidad se ha producido en los líderes cuyo origen son empresas inactivas desde el punto de vista de la responsabilidad social.

En cuanto a la efectividad, su puntuación media más elevada se ha registrado en los máximos responsables procedentes de organizaciones que impulsan acciones de Responsabilidad Social Corporativa de modo frecuente. También es destacable que los líderes procedentes de empresas que no realizan ningún tipo de iniciativa $(54,64)$ o que impulsan actuaciones esporádicamente $(53,75)$ presenten una efectividad media más baja que aquellos vinculados a organizaciones que desarrollan iniciativas de modo frecuente $(58,30)$ o que cuentan con una política establecida de Responsabilidad Social Corporativa $(57,67)$.

En las empresas medianas, los líderes han registrado una puntuación media más alta en el estilo participativo cuando han procedido de organizaciones que desarrollan algún tipo de actuación socialmente responsable. Mientras la puntuación media del estilo participativo en los máximos responsables de las empresas inactivas, desde el punto de vista de la responsabilidad social, es 7,28 , en las organizaciones con actuaciones puntuales $(8,38)$, frecuentes 
$(9,25)$ o integradas en una política específica $(8,82)$ los líderes registran un valor medio más alto.

Los máximos dirigentes de las empresas medianas presentan una cierta tendencia decreciente, en la importancia que conceden al estilo directivo, a medida que se intensifica el comportamiento socialmente responsable de su organización de origen. El estilo directivo reduce su valor medio de 2,72 en las empresas inactivas, desde el punto de vista de la responsabilidad social, a 1,64 en las organizaciones que disponen de una política definida de responsabilidad social.

En cuanto a la flexibilidad, ha obtenido los valores medios más altos en los líderes procedentes de empresas que no desarrollan ningún tipo de actuación sobre responsabilidad social $(19,94)$ y en los que están vinculados a organizaciones que impulsan acciones de Responsabilidad Social Corporativa de modo puntual $(20,25)$.

En relación con la efectividad de los líderes procedentes de empresas medianas, esta ha registrado su valor medio mínimo en aquellos cuyo origen son organizaciones inactivas desde el punto de vista de la responsabilidad social $(54,83)$ y su puntuación media más alta en los máximos responsables procedentes de empresas que cuentan con una política definida de Responsabilidad Social Corporativa $(57,64)$.

En cuanto a las empresas grandes, en las tres opciones contempladas (las que hacen referencia algún tipo de 
comportamiento afín a la responsabilidad social) es destacable que los valores medios más altos en efectividad $(60,25)$ y en flexibilidad $(21)$ se han producido en los líderes procedentes de organizaciones que desarrollan iniciativas puntuales. De todos modos los máximos responsables vinculados a organizaciones que impulsan actuaciones frecuentes de responsabilidad social o que cuentan con una política definida en ese campo han obtenido una efectividad media (59 y 59,13 en cada caso respectivamente) bastante próxima a la de los líderes cuyo origen son empresas que realizan acciones de forma esporádica.

A continuación hemos incorporado los gráfico 92 y 93 para comprobar, visualmente, posibles asociaciones en la variación de algunos de los aspectos contemplados en el liderazgo a medida que se intensifica el comportamiento socialmente responsable de las organizaciones y teniendo presente, al mismo tiempo, su tamaño empresarial.

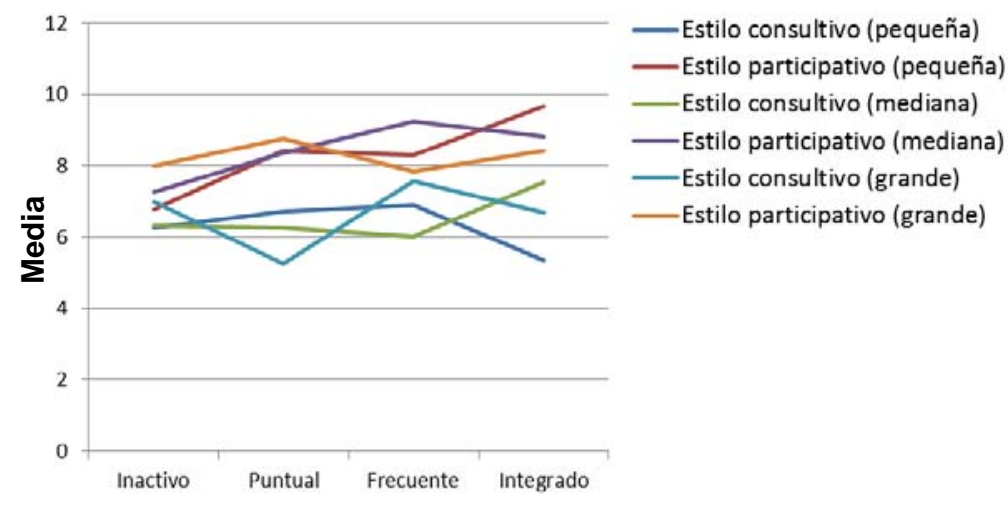

Comportamiento socialmente responsable

Gráfico 92: Tamaño, estilo consultivo, estilo participativo y acciones de responsabilidad social. 
La información visual que ofrece el gráfico 92 permite observar que, en general, los estilos consultivo y participativo en todos los tamaños empresariales, excepto en el caso del estilo consultivo en las empresas pequeñas, parecen cobrar una leve mayor importancia en el ejercicio del rol de liderazgo del máximo responsable empresarial a medida que se intensifica el comportamiento socialmente responsable de su organización de procedencia.

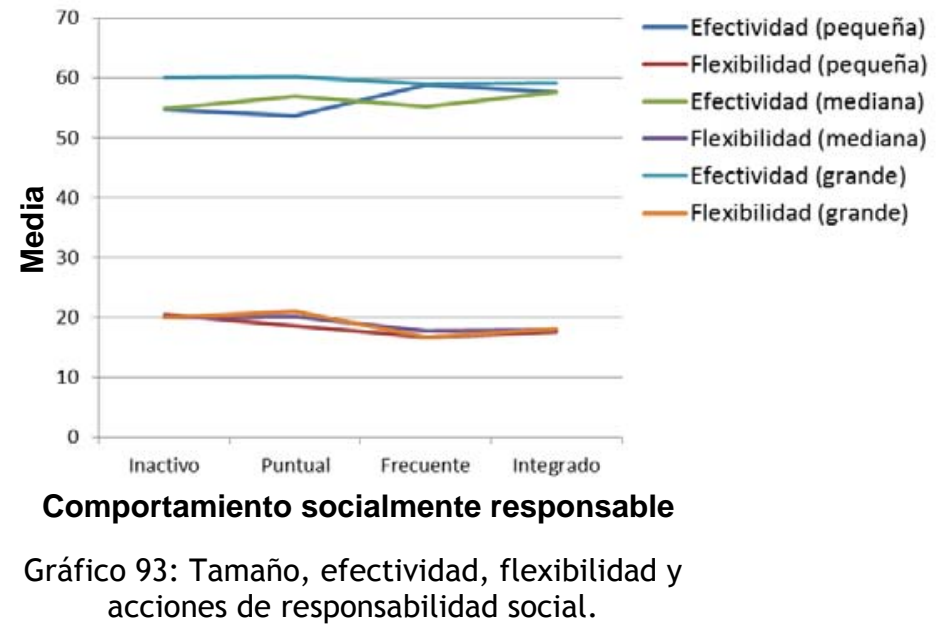

El grafico 93 muestra que la efectividad de los líderes tiende a aumentar levemente en las empresas pequeñas y medianas a medida que se incrementa la actuación socialmente responsable de las organizaciones (en las empresas grandes tiende a permanecer estable).

También refleja que, con independencia del tamaño empresarial, la flexibilidad de los máximos responsables tiende a reducirse ligeramente a medida que su organización de procedencia intensifica su comportamiento socialmente responsable. 


\begin{tabular}{|c|c|c|c|c|c|c|c|c|}
\hline Tamaño & \multicolumn{2}{|c|}{ Horas de formación en resp. social } & $\begin{array}{c}\text { Estilo } \\
\text { directivo }\end{array}$ & $\begin{array}{c}\text { Estilo } \\
\text { consultivo }\end{array}$ & $\begin{array}{c}\text { Estilo } \\
\text { participativo }\end{array}$ & $\begin{array}{c}\text { Estilo } \\
\text { delegativo }\end{array}$ & Flexibilidad & Efectividad \\
\hline \multirow{12}{*}{ Pequeño } & \multirow{2}{*}{ Menos de 11} & Media & 3,67 & 7,67 & 6,33 & 2,33 & 22,33 & 52,33 \\
\hline & & Desv. típ. &, 577 & 2,082 & 1,155 & ,577 & 2,082 & 2,082 \\
\hline & \multirow{2}{*}{ De 11 a 50} & Media & 3,67 & 8,33 & 6,67 & 1,33 & 18,67 & 56,33 \\
\hline & & Desv. típ. & 2,082 & 1,155 & 2,309 &, 577 & 2,309 & 4,933 \\
\hline & \multirow{2}{*}{ De 51 a 100} & Media & 1,50 & 7,50 & 9,00 & 2,00 & 17,00 & 52,00 \\
\hline & & Desv. típ. & ,707 & ,707 & 2,828 & 1,414 & 4,243 & 2,828 \\
\hline & \multirow{2}{*}{ De 101 a 150} & Media & 1,33 & 5,67 & 10,67 & 2,33 & 14,67 & 55,00 \\
\hline & & Desv. típ. & 1,155 & 4,163 & 3,786 & 1,528 & 4,163 & 1,732 \\
\hline & \multirow{2}{*}{ Más de 1000} & Media & 4,00 & 8,00 & 7,00 & 1,00 & 20,00 & 63,00 \\
\hline & & Desv. típ. & . & . & & . & . & \\
\hline & \multirow{2}{*}{ Total } & Media & 2,75 & 7,33 & 8,00 & 1,92 & 18,42 & 54,83 \\
\hline & & Desv. típ. & 1,603 & 2,309 & 2,828 & ,996 & 3,895 & 4,041 \\
\hline \multirow{12}{*}{ Mediano } & \multirow{2}{*}{ Menos de 11} & Media & 3,40 & 7,20 & 6,80 & 2,60 & 22,00 & 53,60 \\
\hline & & Desv. típ. & 1,517 & 1,304 & 2,683 & ,894 & 4,472 & 2,608 \\
\hline & \multirow{2}{*}{ De 11 a 50} & Media & 1,50 & 7,00 & 7,50 & 4,00 & 21,00 & 58,50 \\
\hline & & Desv. típ. & ,707 & 1,414 & 2,121 &, 000 & 1,414 & 3,536 \\
\hline & \multirow{2}{*}{ De 51 a 100} & Media &, 50 & 6,00 & 10,50 & 3,00 & 17,00 & 59,00 \\
\hline & & Desv. típ. & ,707 & 1,414 & 4,950 & 2,828 & 7,071 & 5,657 \\
\hline & \multirow{2}{*}{ De 201 a 1000} & Media & 4,00 & 7,00 & 8,00 & 1,00 & 20,00 & 55,00 \\
\hline & & Desv. típ. & & & & & . & \\
\hline & \multirow{2}{*}{ Más de 1000} & Media &, 00 & 9,00 & 6,00 & 5,00 & 20,00 & 59,00 \\
\hline & & Desv. típ. & . & . & & . & . & \\
\hline & \multirow{2}{*}{ Total } & Media & 2,27 & 7,09 & 7,64 & 3,00 & 20,55 & 56,09 \\
\hline & & Desv. típ. & 1,794 & 1,300 & 2,838 & 1,483 & 4,108 & 3,754 \\
\hline \multirow{16}{*}{ Grande } & Menes de 11 & Media & 1,00 & 9,00 & 6,00 & 4,00 & 19,00 & 53,00 \\
\hline & Mienos de 11 & Desv. típ. & 1,414 & ,000 & 1,414 & 2,828 & 1,414 & 1,414 \\
\hline & 50 & Media & 1,50 & 7,33 & 8,83 & 2,33 & 16,67 & 61,33 \\
\hline & De Tl a so & Desv. típ. & 1,761 & 3,204 & 3,371 & 1,366 & 4,502 & 4,967 \\
\hline & 100 & Media & ,00 & 6,00 & 11,00 & 3,00 & 16,00 & 61,00 \\
\hline & De ol d ivo & Desv. típ. & . & . & & . & . & \\
\hline & 150 & Media & 2,50 & 6,50 & 8,00 & 2,75 & 20,25 & 57,25 \\
\hline & De 101 a 150 & Desv. típ. & 2,646 & 1,291 & 2,160 & 1,708 & 5,315 & 5,500 \\
\hline & חم2 ב 151 م م & Media & 4,00 & 3,00 & 12,00 & 1,00 & 16,00 & 66,00 \\
\hline & De 151 a 200 & Desv. típ. & . & . & & . & . & \\
\hline & Re 201 a 1000 & Media & 3,00 & 4,00 & 9,00 & 4,00 & 22,00 & 60,00 \\
\hline & De 201 d 1000 & Desv. típ. & & & & & & \\
\hline & Mác de 1000 & Media & 2,00 & 8,00 & 9,00 & 1,00 & 16,00 & 67,00 \\
\hline & Mias de 1000 & Desv. típ. & . & . & & . & . & \\
\hline & Total 19 & Media & 1,88 & 6,81 & 8,63 & 2,63 & 18,06 & 59,81 \\
\hline & Toldi & Desv. típ. & 1,857 & 2,482 & 2,655 & 1,586 & 4,074 & 5,419 \\
\hline & Menes de 11 & Media & 3,00 & 7,70 & 6,50 & 2,80 & 21,50 & 53,10 \\
\hline & Ivienos de II & Desv. típ. & 1,563 & 1,494 & 1,958 & 1,317 & 3,440 & 2,132 \\
\hline & R 11 - 50 & Media & 2,09 & 7,55 & 8,00 & 2,36 & 18,00 & 59,45 \\
\hline & De Tl a so & Desv. típ. & 1,868 & 2,423 & 2,864 & 1,362 & 3,795 & 4,865 \\
\hline & De 51 a 100 & Media &, 80 & 6,60 & 10,00 & 2,60 & 16,80 & 56,60 \\
\hline & & Desv. típ. & ,837 & 1,140 & 3,000 & 1,673 & 4,147 & 5,320 \\
\hline & 150 & Media & 2,00 & 6,14 & 9,14 & 2,57 & 17,86 & 56,29 \\
\hline TOTAI & De 101 a 150 & Desv. típ. & 2,082 & 2,610 & 3,024 & 1,512 & 5,367 & 4,192 \\
\hline TUIAL & חم2 20151 مח & Media & 4,00 & 3,00 & 12,00 & 1,00 & 16,00 & 66,00 \\
\hline & De 151 a 200 & Desv. típ. & & . & & . & . & \\
\hline & De 201 a 1000 & Media & 3,50 & 5,50 & 8,50 & 2,50 & 21,00 & 57,50 \\
\hline & De 201 a 1000 & Desv. típ. & ,707 & 2,121 & ,707 & 2,121 & 1,414 & 3,536 \\
\hline & Mác de 1000 & Media & 2,00 & 8,33 & 7,33 & 2,33 & 18,67 & 63,00 \\
\hline & IVtas de 1000 & Desv. típ. & 2,000 &, 577 & 1,528 & 2,309 & 2,309 & 4,000 \\
\hline & Total & Media & 2,26 & 7,05 & 8,15 & 2,51 & 18,87 & 57,23 \\
\hline & Total & Desv. típ. & 1,758 & 2,114 & 2,720 & 1,430 & 4,066 & 5,002 \\
\hline
\end{tabular}

Cuadro 152: Medidas estadísticas sobre formación en responsabilidad social, liderazgo y tamaño. 
Previamente hemos incluido los datos sobre liderazgo y tamaño pero considerando, en este caso, la formación sobre responsabilidad social desarrollada por las organizaciones de procedencia de los líderes (cuadro 152).

Antes de proceder a revisar y comentar la información que ofrece el cuadro 152, hemos aplicado ANOVA de un factor en los datos para comprobar si existen diferencias estadísticamente significativas entre los diversos grupos muestrales considerados (cuadro 153).

\begin{tabular}{|c|c|c|c|c|c|c|}
\hline & & Suma de cuadrados & gl & Media cuadrática & $\mathbf{F}$ & Sig. \\
\hline \multirow{3}{*}{ Tamaño } & Inter-grupos & 2,351 & 6 & ,392 & ,497 & 806 \\
\hline & Intra-grupos & 25,239 & 32 & ,789 & & \\
\hline & Total & 27,590 & 38 & & & \\
\hline \multirow{3}{*}{ Estilo directivo } & Inter-grupos & 23,227 & 6 & 3,871 & 1,315 &, 279 \\
\hline & Intra-grupos & 94,209 & 32 & 2,944 & & \\
\hline & Total & 117,436 & 38 & & & \\
\hline \multirow{3}{*}{ Estilo consultivo } & Inter-grupos & 39,846 & 6 & 6,641 & 1,634 & 170 \\
\hline & Intra-grupos & 130,051 & 32 & 4,064 & & \\
\hline & Total & 169,897 & 38 & & & \\
\hline \multirow{3}{*}{ Estilo participativo } & Inter-grupos & 68,553 & 6 & 11,426 & 1,720 & 148 \\
\hline & Intra-grupos & 212,524 & 32 & 6,641 & & \\
\hline & Total & 281,077 & 38 & & & \\
\hline \multirow{3}{*}{ Estilo delegativo } & Inter-grupos & 3,517 & 6 &, 586 &, 253 &, 955 \\
\hline & Intra-grupos & 74,226 & 32 & 2,320 & & \\
\hline & Total & 77,744 & 38 & & & \\
\hline \multirow{3}{*}{ Flexibilidad } & Inter-grupos & 123,535 & 6 & 20,589 & 1,305 & ,283 \\
\hline & Intra-grupos & 504,824 & 32 & 15,776 & & \\
\hline & Total & 628,359 & 38 & & & \\
\hline \multirow{3}{*}{ Efectividad } & Inter-grupos & 410,167 & 6 & 68,361 & 4,045 &, 004 \\
\hline & Intra-grupos & 540,756 & 32 & 16,899 & & \\
\hline & Total & 950,923 & 38 & & & \\
\hline
\end{tabular}

Cuadro 153: Tabla ANOVA de liderazgo y tamaño, factor Horas de Formación en Responsabilidad Social.

Los resultados de la prueba de ANOVA de un factor (cuadro 153) han revelado que hay diferencias estadísticamente significativas entre los diversos grupos 
muestrales en relación con "efectividad" (su coeficiente de significación ha sido 0,004).

Una vez comprobada la existencia de diferencias estadísticamente significativas entre los datos hemos revisado la información que ofrece el cuadro 152.

En el análisis de la información del cuadro 152 no hemos considerado, por su baja representatividad, aquellos grupos muestrales en los que solo hemos obtenido información de un líder.

Aunque todos los líderes comparten la preferencia por los estilos consultivo y participativo, hemos revisado los datos según el tamaño de las empresas de procedencia de los líderes para profundizar en el estudio de los datos.

En las empresas pequeñas, los líderes que proceden de aquellas organizaciones que invierten menos horas en acciones formativas encuadradas en el ámbito de la responsabilidad social presentan el mismo estilo primario, el estilo consultivo. Los valores medios que ha registrado el estilo consultivo en estos casos son: 7,67 (en los máximos responsables procedentes de empresas que dedican menos de 11 horas a acciones formativas) y 8,33 (en los líderes cuyo origen son empresas que invierten entre 11 y 50 horas en este tipo de actuaciones).

En cambio, los máximos responsables que están vinculados a organizaciones que dedican de 51 a 150 horas a formación para públicos internos encuadrada en el ámbito 
de la responsabilidad social han ubicado al estilo participativo como estilo primario. Ha alcanzado un valor medio de 9 en los líderes cuyo origen son empresas que impulsan acciones de 51 a 100 horas y 10,67 en los máximos responsables que proceden de organizaciones que destinan entre 101 y 150 horas a dichas acciones.

En cuanto a la flexibilidad, los líderes han registrado una puntuación media menor a medida que las organizaciones han aumentado el número de horas que dedican a la formación encuadrada en el campo de la responsabilidad social (decrece de 22,33 en los máximos responsables de empresas que dedican menos de 11 horas a este tipo de acciones a 14,67 en los líderes vinculados a organizaciones que invierten entre 101 y 150 horas).

En cuanto a la efectividad, ha registrado un valor medio más alto en los máximos responsables procedentes de organizaciones que invierten entre 11 y 50 horas en acciones formativas afines a la responsabilidad social.

En las empresas medianas hemos contemplado tres grupos muestrales. Los líderes procedentes de organizaciones que invierten menos de 11 horas en acciones de formación sobre Responsabilidad Social Corporativa han registrado como estilo primario el consultivo (su valor medio ha sido 7,20). En los otros dos grupos contemplados el estilo primario ha sido el participativo: su valor medio ha sido 7,5 en los líderes cuyo origen son empresas que dedican entre 11 y 50 horas a iniciativas de formación enmarcadas en el 
ámbito de la responsabilidad social, y 10,50 en los máximos responsables que proceden de organizaciones que destinan entre 51 y 100 horas a dichas acciones.

En los líderes procedentes de empresas de esta dimensión intermedia se han detectado tres tendencias en la variación de los estilos de liderazgo que guardan correspondencia con el aumento de las horas que las organizaciones de origen del líder destinan a acciones formativas sobre responsabilidad social. Los estilos directivo y consultivo tienen a perder relevancia a medida que se incrementan las horas de las acciones formativas (pasan, respectivamente, de 3,4 a 0,5 y de 7,2 a 6) y el estilo participativo tiende a ganar peso (aumenta de 6,8 a 10,5).

En lo que se refiere a la efectividad y la flexibilidad de estilo de los líderes, también guardan una correlación con el aumento de las horas que las organizaciones dedican a acciones de formación integradas en el ámbito de la responsabilidad social. La flexibilidad tiende a reducirse a medida que crecen las horas de las acciones formativas (su valor medio decrece de 22 a 17) y la efectividad tiende a aumentar a medida que se incrementan las horas de los cursos sobre responsabilidad social (pasa de 53,6 a 59).

En las empresas grandes solo se han considerado dos grupos muestrales: líderes procedentes de empresas que destinan entre 11 y 50 horas a acciones formativas enmarcadas en el ámbito de la responsabilidad social, y máximos responsables procedentes de empresas que 
invierten de 101 a 150 horas. En ambos grupos el estilo primario ha sido el participativo (su valor medio ha sido 8,83 en los líderes procedentes de organizaciones que impulsan acciones de 11 a 50 horas y 8 para los vinculados a empresas que dedican entre 101 y 150 horas a dichas iniciativas).

En cuanto a la efectividad media más elevada, esta se ha registrado en los líderes procedentes de organizaciones grandes que invierten entre 11 y 50 horas en acciones formativas $(61,33)$. Mientras que la flexibilidad media más alta se ha producido en los líderes cuyo origen son empresas que dedican a formación de 101 a 150 horas $(20,25)$.

A continuación hemos incorporado los gráficos 94 y 95 para contemplar de manera visual posibles asociaciones en la variación de los estilos participativo y consultivo, de la efectividad y la flexibilidad, y de las horas que las organizaciones invierten en acciones formativas de responsabilidad social en las empresas pequeñas, medianas y grandes.

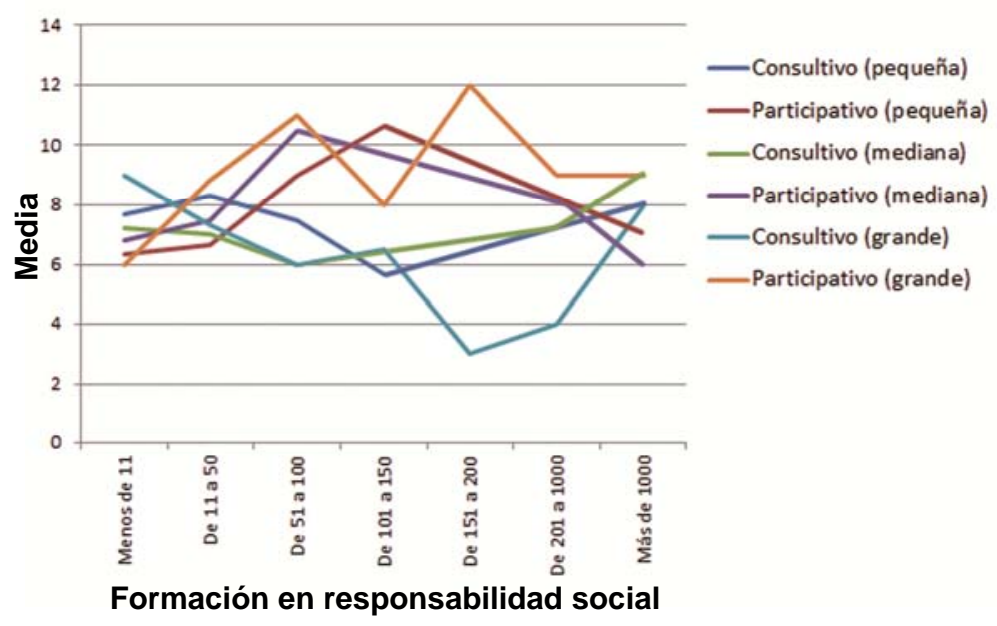

Gráfico 94: Tamaño, estilo consultivo, estilo participativo y formación en responsabilidad social. 
El gráfico 94 muestra que los estilos participativo y consultivo en los líderes procedentes de las empresas grandes, medianas y pequeñas tienden a experimentar un comportamiento inverso a medida que se incrementan las horas que las organizaciones de procedencia de los líderes dedican a acciones de formación enmarcadas en el ámbito de la responsabilidad social.

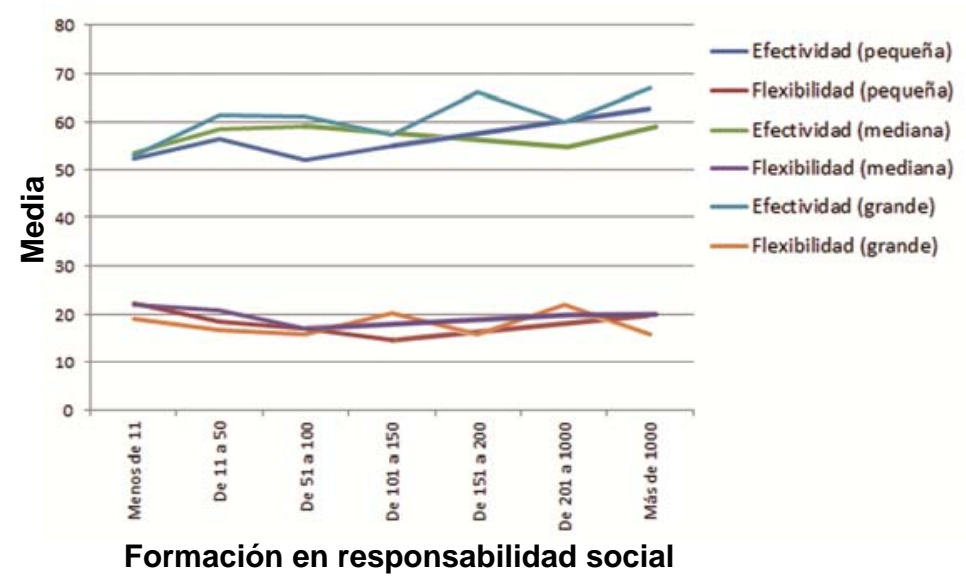

Gráfico 95: Tamaño, efectividad, flexibilidad y formación en responsabilidad social.

Los datos del gráfico 95 también tienden a reflejar un comportamiento similar en los líderes procedentes de los tres tamaños empresariales considerados. A medida que las organizaciones incrementan el número de horas que destinan a acciones formativas encuadradas en el ámbito de la responsabilidad social, la efectividad de los líderes tiende a incrementarse, ligeramente, y su flexibilidad a permanecer constante. 


\subsubsection{Tamaño, valores y Responsabilidad Social Corporativa}

Hemos tratado, inicialmente, los datos sobre las competencias genéricas, los rasgos de personalidad y las características comportamentales analizadas en el estudio junto con el tamaño de las organizaciones de procedencia de los líderes y su actitud hacia la Responsabilidad Social Corporativa.

Posteriormente hemos revisado los rasgos de personalidad, las características comportamentales y las competencias genéricas estudiadas, junto con el tamaño de las organizaciones, pero considerando el comportamiento socialmente responsable de las empresas de procedencia de los líderes. Primero tratando su actuación genérica y luego la específica en el campo formativo.

\begin{tabular}{|c|c|c|c|c|c|c|c|c|}
\hline \multicolumn{2}{|l|}{ Tamaño } & $\begin{array}{l}\text { Actitud hacia la } \\
\text { resp. social }\end{array}$ & Practicidad & Resultados & Variedad & Decisión & $\begin{array}{l}\text { Orden y } \\
\text { método }\end{array}$ & Metas \\
\hline \multirow{4}{*}{ Pequeño } & Media & 7,0845 & 14,29 & 14,72 & 7,50 & 16,32 & 16,96 & 19,95 \\
\hline & Mínimo & 3,86 & 4 & 2 & 0 & 5 & 6 & 6 \\
\hline & Máximo & 8,13 & 24 & 25 & 22 & 25 & 27 & 28 \\
\hline & Desv. típ. & 1,11040 & 3,968 & 4,027 & 5,156 & 3,889 & 5,000 & 4,764 \\
\hline \multirow{4}{*}{ Mediano } & Media & 7,1458 & 13,29 & 13,96 & 10,09 & 16,89 & 15,20 & 20,09 \\
\hline & Mínimo & 4,39 & 5 & 3 & 3 & 8 & 5 & 10 \\
\hline & Máximo & 8,10 & 27 & 19 & 26 & 26 & 29 & 30 \\
\hline & Desv. típ. & 1,06398 & 4,879 & 3,529 & 5,676 & 4,108 & 5,888 & 4,284 \\
\hline \multirow{4}{*}{ Grande } & Media & 7,6528 & 12,40 & 16,14 & 8,54 & 17,20 & 15,14 & 20,86 \\
\hline & Mínimo & 5,40 & 5 & 10 & 0 & 6 & 5 & 10 \\
\hline & Máximo & 8,12 & 21 & 26 & 24 & 25 & 29 & 28 \\
\hline & Desv. típ. & ,70090 & 3,672 & 3,735 & 6,550 & 5,201 & 5,287 & 4,772 \\
\hline \multirow{4}{*}{ TOTAL } & Media & 7,2043 & 13,70 & 14,80 & 8,31 & 16,62 & 16,21 & 20,15 \\
\hline & Mínimo & 3,86 & 4 & 2 & 0 & 5 & 5 & 6 \\
\hline & Máximo & 8,13 & 27 & 26 & 26 & 26 & 29 & 30 \\
\hline & Desv. típ. & 1,05294 & 4,197 & 3,907 & 5,632 & 4,203 & 5,321 & 4,644 \\
\hline
\end{tabular}

Cuadro 154: Medidas estadísticas de tamaño, “valores” y actitud hacia la responsabilidad social. 
Antes de revisar la información del cuadro 154 hemos aplicado ANOVA de un factor en los datos para comprobar si existen diferencias estadísticamente significativas entre los diversos grupos que integran la muestra poblacional (cuadro 155).

Los resultados de dicha prueba, incorporados a continuación, revelan la existencia de diferencias estadísticamente significativas entre los diversos grupos muestrales en relación con "orden y método" (su coeficiente de significación es 0,044).

\begin{tabular}{|c|c|c|c|c|c|c|}
\hline & & Suma de cuadrados & gl & Media cuadrática & $\mathbf{F}$ & Sig. \\
\hline \multirow{3}{*}{ Tamaño } & Inter-grupos & 39,531 & 80 & 494 & 707 & 948 \\
\hline & Intra-grupos & 75,495 & 108 & 699 & & \\
\hline & Total & 115,026 & 188 & & & \\
\hline \multirow{3}{*}{ Practicidad } & Inter-grupos & 1402,026 & 80 & 17,525 & 991 & ,513 \\
\hline & Intra-grupos & 1909,381 & 108 & 17,679 & & \\
\hline & Total & 3311,407 & 188 & & & \\
\hline \multirow{3}{*}{ Resultados } & Inter-grupos & 1395,917 & 80 & 17,449 & 1,279 & 117 \\
\hline & Intra-grupos & 1473,839 & 108 & 13,647 & & \\
\hline & Total & 2869,757 & 188 & & & \\
\hline \multirow{3}{*}{ Variedad } & Inter-grupos & 2907,734 & 80 & 36,347 & 1,284 & 113 \\
\hline & Intra-grupos & 3056,467 & 108 & 28,301 & & \\
\hline & Total & 5964,201 & 188 & & & \\
\hline \multirow{3}{*}{ Decisión } & Inter-grupos & 1367,343 & 80 & 17,092 & 945 & 602 \\
\hline & Intra-grupos & 1953,229 & 108 & 18,085 & & \\
\hline & Total & 3320,571 & 188 & & & \\
\hline \multirow{3}{*}{ Orden y método } & Inter-grupos & 2731,090 & 80 & 34,139 & 1,423 & ,044 \\
\hline & Intra-grupos & 2591,862 & 108 & 23,999 & & \\
\hline & Total & 5322,952 & 188 & & & \\
\hline \multirow{3}{*}{ Metas } & Inter-grupos & 1606,850 & 80 & 20,086 & 886 & ,714 \\
\hline & Intra-grupos & 2447,700 & 108 & 22,664 & & \\
\hline & Total & 4054,550 & 188 & & & \\
\hline
\end{tabular}

Cuadro 155: Tabla ANOVA de tamaño y "valores", factor Actitud hacia la Responsabilidad Social.

Una vez realizada la prueba de ANOVA en la muestra poblacional, hemos pasado a revisar los datos del cuadro 154. 
En consonancia con la actitud creciente de los líderes a medida que se incrementa el tamaño empresarial de su organización de procedencia, se comportan el rasgo de personalidad "decisión" (su media crece de 16,96 en los máximos responsables vinculados a empresas pequeñas a 17,2 en los líderes procedentes de organizaciones grandes) y la competencia genérica "metas" (su media se incrementa de 19,95 en los máximos responsables cuyo origen son empresas pequeñas a 20,86 en los líderes de organizaciones grandes).

El incremento de la actitud asociado al aumento del tamaño empresarial también guarda correspondencia inversa con el rasgo de personalidad "variedad" (su media decrece de 14,20 en los máximos responsables de empresas pequeñas a 12,40 en los líderes de organizaciones grandes) y con la característica comportamental “orden y método" (su media registra un valor de 16,96 en los máximos responsables de empresas pequeñas que se reduce a 15,14 en los líderes de empresas grandes).

Además de estas tendencias, los líderes procedentes de organizaciones pequeñas han registrado el valor medio más bajo en el rasgo de personalidad "variedad" $(7,5)$ y los máximos responsables vinculados a organizaciones medianas en la competencia genérica “resultados" $(13,96)$. Además estos últimos líderes han obtenido la media más alta en el rasgo de personalidad "variedad" $(10,09)$. Los máximos dirigentes de empresas grandes también han obtenido, además de forma destacada respecto a los otros dos grupos 


\section{muestrales, la media más alta en la competencia genérica}

\section{"resultados" $(16,14)$.}

\begin{tabular}{|c|c|c|c|c|c|c|c|c|}
\hline Tamaño & $\begin{array}{r}\text { Actitu } \\
\text { res }\end{array}$ & $\begin{array}{l}\text { hacia la } \\
\text { social }\end{array}$ & Practicidad & Resultados & Variedad & Decisión & $\begin{array}{l}\text { Orden y } \\
\text { método }\end{array}$ & Metas \\
\hline \multirow{14}{*}{ Pequeño } & \multirow{2}{*}{$0 \mathrm{a}<4$} & Media & 21,00 & 17,00 & 7,00 & 20,00 & 12,00 & 10,00 \\
\hline & & Desv. típ. & & & & & & \\
\hline & \multirow{2}{*}{$4 a<5$} & Media & 15,00 & 14,00 & 5,80 & 14,60 & 19,40 & 21,20 \\
\hline & & Desv. típ. & 2,345 & 4,000 & 1,483 & 3,050 & 4,159 & 3,114 \\
\hline & \multirow{2}{*}{$5 a<6$} & Media & 13,53 & 14,73 & 8,40 & 15,80 & 17,40 & 20,13 \\
\hline & & Desv. típ. & 3,226 & 3,173 & 5,040 & 3,098 & 4,983 & 3,159 \\
\hline & \multirow{2}{*}{$6 a<7$} & Media & 14,80 & 14,15 & 7,35 & 16,30 & 17,50 & 19,60 \\
\hline & & Desv. típ. & 3,722 & 3,407 & 5,815 & 3,278 & 5,453 & 5,335 \\
\hline & \multirow{2}{*}{7 a 8} & Media & 14,55 & 14,80 & 7,98 & 16,76 & 16,04 & 19,51 \\
\hline & & Desv. típ. & 3,974 & 4,282 & 5,588 & 4,361 & 5,192 & 5,160 \\
\hline & \multirow{2}{*}{$>8$} & Media & 13,16 & 15,21 & 6,16 & 15,89 & 18,05 & 21,53 \\
\hline & & Desv. típ. & 4,845 & 4,871 & 4,031 & 4,081 & 4,062 & 3,991 \\
\hline & \multirow{2}{*}{ Total } & Media & 14,29 & 14,72 & 7,50 & 16,32 & 16,96 & 19,95 \\
\hline & & Desv. típ. & 3,968 & 4,027 & 5,156 & 3,889 & 5,000 & 4,764 \\
\hline \multirow{12}{*}{ Mediano } & \multirow{2}{*}{$4 a<5$} & Media & 15,50 & 14,50 & 14,00 & 20,50 & 10,50 & 15,00 \\
\hline & & Desv. típ. & 3,536 & 2,121 & 8,485 & 7,778 & ,707 & 2,828 \\
\hline & \multirow{2}{*}{$5 a<6$} & Media & 14,00 & 14,14 & 9,00 & 16,86 & 15,14 & 20,86 \\
\hline & & Desv. típ. & 5,164 & 4,180 & 3,651 & 3,132 & 4,670 & 3,716 \\
\hline & \multirow{2}{*}{$6 a<7$} & Media & 15,00 & 14,83 & 10,83 & 17,83 & 12,83 & 16,50 \\
\hline & & Desv. típ. & 5,831 & 2,137 & 5,456 & 4,665 & 2,483 & 5,541 \\
\hline & \multirow{2}{*}{7 a 8} & Media & 11,16 & 13,95 & 10,53 & 15,84 & 16,53 & 21,84 \\
\hline & & Desv. típ. & 3,655 & 3,965 & 5,882 & 3,760 & 6,628 & 3,270 \\
\hline & \multirow{2}{*}{$>8$} & Media & 15,18 & 13,27 & 8,91 & 17,55 & 15,09 & 19,45 \\
\hline & & Desv. típ. & 5,546 & 3,495 & 6,580 & 4,503 & 6,789 & 4,180 \\
\hline & \multirow{2}{*}{ Total } & Media & 13,29 & 13,96 & 10,09 & 16,89 & 15,20 & 20,09 \\
\hline & & Desv. típ. & 4,879 & 3,529 & 5,676 & 4,108 & 5,888 & 4,284 \\
\hline \multirow{10}{*}{ Grande } & \multirow{2}{*}{$5 a<6$} & Media & 11,00 & 17,00 & 11,00 & 13,00 & 15,00 & 23,00 \\
\hline & & Desv. típ. & . & . & & . & . & \\
\hline & \multirow{2}{*}{$6 a<7$} & Media & 10,60 & 15,80 & 9,20 & 18,60 & 15,60 & 20,20 \\
\hline & & Desv. típ. & 3,782 & 3,347 & 8,044 & 5,128 & 6,877 & 4,868 \\
\hline & \multirow{2}{*}{7 a 8} & Media & 12,86 & 15,86 & 8,77 & 17,73 & 14,68 & 20,55 \\
\hline & & Desv. típ. & 3,681 & 3,523 & 6,907 & 5,082 & 5,366 & 5,068 \\
\hline & $>8$ & Media & 12,43 & 17,14 & 7,00 & 15,14 & 16,29 & 22,00 \\
\hline & $>0$ & Desv. típ. & 3,952 & 5,146 & 5,354 & 5,900 & 4,855 & 4,509 \\
\hline & Total & Media & 12,40 & 16,14 & 8,54 & 17,20 & 15,14 & 20,86 \\
\hline & TOlal & Desv. típ. & 3,672 & 3,735 & 6,550 & 5,201 & 5,287 & 4,772 \\
\hline & $0 \Omega<4$ & Media & 21,00 & 17,00 & 7,00 & 20,00 & 12,00 & 10,00 \\
\hline & 0 a 4 & Desv. típ. & . & . & . & . & & \\
\hline & $40<5$ & Media & 15,14 & 14,14 & 8,14 & 16,29 & 16,86 & 19,43 \\
\hline & $4 a<5$ & Desv. típ. & 2,410 & 3,388 & 5,429 & 4,957 & 5,521 & 4,117 \\
\hline & $50<6$ & Media & 13,57 & 14,65 & 8,70 & 16,00 & 16,61 & 20,48 \\
\hline & $3 a<0$ & Desv. típ. & 3,776 & 3,393 & 4,487 & 3,075 & 4,793 & 3,246 \\
\hline TOTAI & $60<7$ & Media & 14,16 & 14,55 & 8,32 & 16,97 & 16,29 & 19,10 \\
\hline IUIAL & 0 a $<1$ & Desv. típ. & 4,344 & 3,161 & 6,085 & 3,851 & 5,442 & 5,294 \\
\hline & 708 & Media & 13,42 & 14,88 & 8,71 & 16,80 & 15,81 & 20,26 \\
\hline & 1 a 0 & Desv. típ. & 4,036 & 4,053 & 6,008 & 4,430 & 5,538 & 4,843 \\
\hline & $>0$ & Media & 13,62 & 15,00 & 7,14 & 16,24 & 16,84 & 21,00 \\
\hline & $>8$ & Desv. típ. & 4,901 & 4,637 & 5,138 & 4,536 & 5,172 & 4,157 \\
\hline & & Media & 13,70 & 14,80 & 8,31 & 16,62 & 16,21 & 20,15 \\
\hline & & Desv. típ. & 4,197 & 3,907 & 5,632 & 4,203 & 5,321 & 4,644 \\
\hline
\end{tabular}

Cuadro 156: Medidas estadísticas de tamaño, “valores” y actitud hacia la responsabilidad social. 
En la página previa hemos incluido el cuadro 156 con datos, nuevamente, sobre los rasgos de personalidad, las competencias genéricas y las características comportamentales consideradas en el estudio junto con el tamaño de las organizaciones de procedencia de los líderes. Sin embargo, en este caso, hemos considerado el valor medio de la actitud por segmentos para detectar posibles asociaciones con el resto de variables analizadas dentro de cada tamaño empresarial.

Los datos del cuadro 156 muestran que los líderes procedentes de empresas medianas presentan cierta tendencia a reducir el valor que otorgan a la competencia genérica "resultados" a medida que se intensifica su actitud a favor de la responsabilidad social, es decir, conceden menos importancia a la perfección y a los retos a medida que se intensifica su actitud a favor de la responsabilidad social (su valor medio decrece de 14,5 en el segmento " 4 a $<5$ " a 13,27 en el grupo muestral " $>8$ ").

En los líderes vinculados a las organizaciones grandes también hemos detectado algunas tendencias asociadas al aumento de su actitud a favor de la responsabilidad social. Las competencias genéricas "resultados" (su media pasa de 15,8 en el segmento " 6 a $<7$ " a 17,14 en el grupo muestral “>8) y "metas" (su puntuación media aumenta de 20,2 en el grupo muestral " 6 a $<7$ " a 22 en el segmento ">8") tienden a crecer y los rasgos de personalidad "variedad" (su valor medio se reduce de 9,2 en el segmento “6 a $<7$ " a 7 en el 
grupo muestral “>8”) y "decisión” (su media pasa de 18,6 en el grupo muestral " 6 a $<7$ " a 15,14 en el segmento de valor de la actitud “>8”) a perder importancia.

A continuación hemos incorporado los gráficos 96 y 97 para revisar, de modo visual, posibles tendencias de asociación entre las variables en los líderes de empresas medianas y grandes.

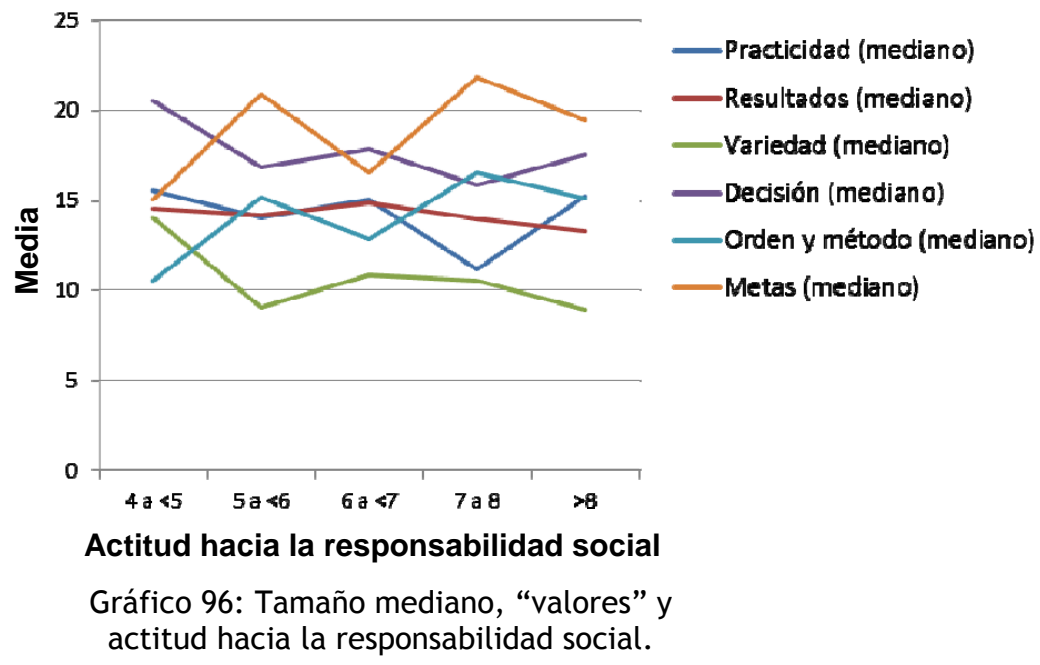

El gráfico 96 muestra como a medida que aumenta la actitud afín a la responsabilidad de los líderes de las empresas medianas, los rasgos de personalidad "decisión" y "variedad" y la competencia genérica "resultados" parecen tender a perder importancia para los máximos cargos.

Asimismo también parece apreciarse que la competencia genérica "metas" y la característica comportamental “orden y método" tienden a ser más relevantes a medida que crece la actitud favorable del máximo dirigente hacia la responsabilidad social. 


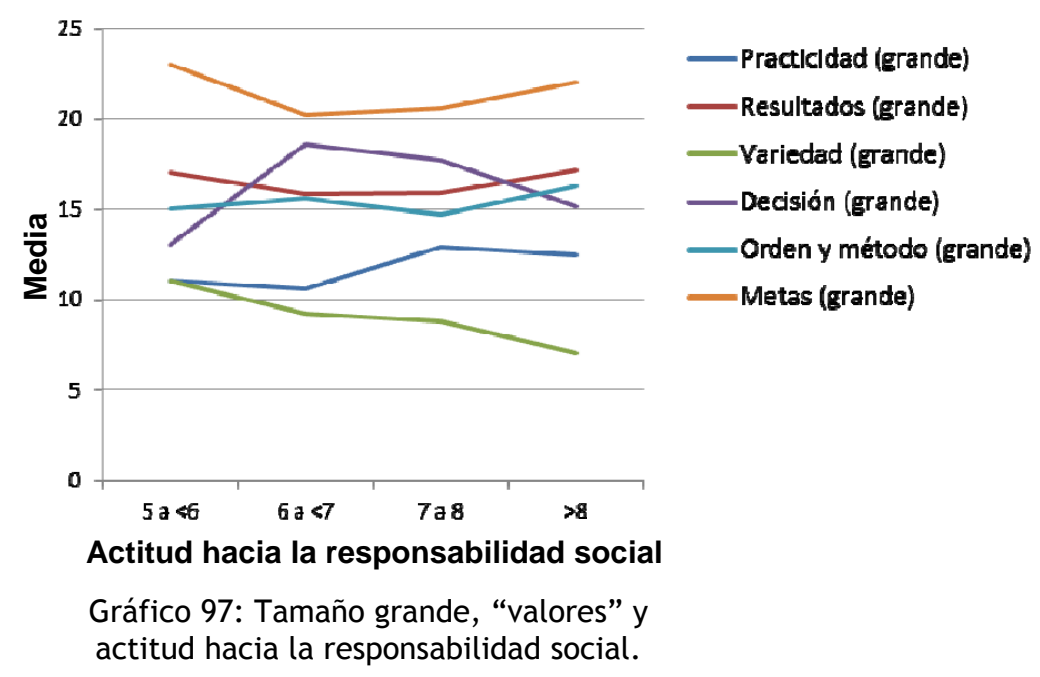

En cuanto al gráfico 97, refleja como a medida que la disposición a favor de la responsabilidad social se intensifica en el líder también parece reducirse la importancia que concede al rasgo de personalidad "variedad" y aumentar la relevancia que otorga al rasgo de personalidad "practicidad".

A continuación revisamos los rasgos de personalidad, las características comportamentales y las competencias genéricas consideradas en el estudio junto con el tamaño de las organizaciones pero considerando, en este caso, el comportamiento socialmente responsable, de modo genérico, de las organizaciones de procedencia de los líderes.

Hemos incorporado tras estas líneas el cuadro 157 ("Medidas estadísticas sobre acciones en responsabilidad social, 'valores' y tamaño”) con los datos sobre las variables mencionadas. 


\begin{tabular}{|c|c|c|c|c|c|c|c|c|}
\hline Tamaño & \multicolumn{2}{|c|}{ Acciones de resp. social } & Practicidad & Resultados & Variedad & Decisión & $\begin{array}{l}\text { Orden y } \\
\text { método }\end{array}$ & Metas \\
\hline \multirow{10}{*}{ Pequeño } & \multirow{2}{*}{ No } & Media & 14,50 & 14,74 & 7,01 & 15,88 & 17,50 & 20,03 \\
\hline & & Desv. típ. & 3,989 & 4,101 & 4,895 & 3,827 & 4,803 & 4,370 \\
\hline & \multirow{2}{*}{ Sí, acciones puntuales } & Media & 14,46 & 14,33 & 8,17 & 17,17 & 15,75 & 20,04 \\
\hline & & Desv. típ. & 4,413 & 3,279 & 5,866 & 3,422 & 4,590 & 5,835 \\
\hline & \multirow{2}{*}{$\begin{array}{l}\text { Sí, acciones frecuentes sin } \\
\text { una política definida de RS }\end{array}$} & Media & 12,80 & 16,50 & 10,30 & 17,30 & 15,10 & 18,00 \\
\hline & & Desv. típ. & 2,700 & 4,859 & 5,165 & 5,334 & 7,125 & 4,619 \\
\hline & \multirow{2}{*}{$\begin{array}{l}\text { Sí, acciones integradas en } \\
\text { una política de RS }\end{array}$} & Media & 13,00 & 11,67 & 4,33 & 17,00 & 20,00 & 24,00 \\
\hline & & Desv. típ. & 3,606 & 4,163 & 1,155 & 3,606 & 1,000 & 4,000 \\
\hline & \multirow{2}{*}{ Total } & Media & 14,29 & 14,72 & 7,50 & 16,32 & 16,96 & 19,95 \\
\hline & & Desv. típ. & 3,968 & 4,027 & 5,156 & 3,889 & 5,000 & 4,764 \\
\hline \multirow{10}{*}{ Mediano } & \multirow{2}{*}{ No } & Media & 15,06 & 14,83 & 10,22 & 17,94 & 13,06 & 18,56 \\
\hline & & Desv. típ. & 5,150 & 2,936 & 5,547 & 3,670 & 5,023 & 3,634 \\
\hline & \multirow{2}{*}{ Sí, acciones puntuales } & Media & 12,75 & 13,25 & 9,63 & 16,75 & 15,13 & 22,50 \\
\hline & & Desv. típ. & 3,732 & 5,701 & 4,565 & 2,712 & 4,883 & 3,024 \\
\hline & \multirow{2}{*}{$\begin{array}{l}\text { Sí, acciones frecuentes sin } \\
\text { una política definida de RS }\end{array}$} & Media & 13,88 & 12,50 & 7,13 & 15,50 & 18,63 & 21,13 \\
\hline & & Desv. típ. & 5,866 & 2,449 & 2,748 & 4,276 & 3,889 & 6,034 \\
\hline & \multirow{2}{*}{$\begin{array}{l}\text { Sí, acciones integradas en } \\
\text { una política de RS }\end{array}$} & Media & 10,36 & 14,09 & 12,36 & 16,27 & 16,27 & 20,09 \\
\hline & & Desv. típ. & 3,202 & 3,113 & 7,527 & 5,424 & 7,964 & 4,085 \\
\hline & \multirow{2}{*}{ Total } & Media & 13,29 & 13,96 & 10,09 & 16,89 & 15,20 & 20,09 \\
\hline & & Desv. típ. & 4,879 & 3,529 & 5,676 & 4,108 & 5,888 & 4,284 \\
\hline \multirow{10}{*}{ Grande } & \multirow{2}{*}{ No } & Media & 17,00 & 17,00 & 12,00 & 6,00 & 19,00 & 19,00 \\
\hline & & Desv. típ. & & . & & & . & \\
\hline & \multirow{2}{*}{ Sí, acciones puntuales } & Media & 12,50 & 18,25 & 11,25 & 18,00 & 14,25 & 18,25 \\
\hline & & Desv. típ. & 2,646 & 5,123 & 9,287 & 7,394 & 10,308 & 5,679 \\
\hline & \multirow{2}{*}{$\begin{array}{l}\text { Sí, acciones frecuentes sin } \\
\text { una política definida de RS }\end{array}$} & Media & 12,29 & 16,43 & 6,71 & 19,86 & 14,14 & 20,57 \\
\hline & & Desv. típ. & 2,430 & 1,272 & 4,680 & 4,488 & 2,410 & 3,505 \\
\hline & \multirow{2}{*}{$\begin{array}{l}\text { Sí, acciones integradas en } \\
\text { una política de RS }\end{array}$} & Media & 12,22 & 15,65 & 8,48 & 16,74 & 15,43 & 21,48 \\
\hline & & Desv. típ. & 4,156 & 4,052 & 6,755 & 4,535 & 5,089 & 5,062 \\
\hline & \multirow{2}{*}{ Total } & Media & 12,40 & 16,14 & 8,54 & 17,20 & 15,14 & 20,86 \\
\hline & & Desv. típ. & 3,672 & 3,735 & 6,550 & 5,201 & 5,287 & 4,772 \\
\hline \multirow{10}{*}{ TOTAL } & \multirow{2}{*}{ No } & Media & 14,64 & 14,78 & 7,70 & 16,18 & 16,64 & 19,73 \\
\hline & & Desv. típ. & 4,205 & 3,867 & 5,154 & 3,993 & 5,118 & 4,232 \\
\hline & \multirow{2}{*}{ Sí, acciones puntuales } & Media & 13,86 & 14,53 & 8,83 & 17,17 & 15,44 & 20,39 \\
\hline & & Desv. típ. & 4,114 & 4,219 & 5,940 & 3,738 & 5,289 & 5,347 \\
\hline & \multirow{2}{*}{$\begin{array}{l}\text { Sí, acciones frecuentes sin } \\
\text { una política definida de RS }\end{array}$} & Media & 13,00 & 15,20 & 8,28 & 17,44 & 15,96 & 19,72 \\
\hline & & Desv. típ. & 3,830 & 3,819 & 4,532 & 4,900 & 5,342 & 4,878 \\
\hline & \multirow{2}{*}{$\begin{array}{l}\text { Sí, acciones integradas en } \\
\text { una política de RS }\end{array}$} & Media & 11,73 & 14,86 & 9,30 & 16,62 & 16,05 & 21,27 \\
\hline & & Desv. típ. & 3,870 & 3,888 & 7,003 & 4,639 & 5,921 & 4,718 \\
\hline & Toto & Media & 13,70 & 14,80 & 8,31 & 16,62 & 16,21 & 20,15 \\
\hline & lotal & Desv. típ. & 4,197 & 3,907 & 5,632 & 4,203 & 5,321 & 4,644 \\
\hline
\end{tabular}

Cuadro 157: Medidas estadísticas sobre acciones en responsabilidad social, “valores” y tamaño.

Antes de revisar los datos del cuadro 157 hemos aplicado ANOVA de un factor para verificar si existen diferencias significativas, desde el punto de vista estadístico, entre los diferentes grupos muestrales que integran dicho cuadro. 


\begin{tabular}{|c|c|c|c|c|c|c|}
\hline & & Suma de cuadrados & gl & Media cuadrática & $\mathbf{F}$ & Sig. \\
\hline \multirow{3}{*}{ Tamaño } & Inter-grupos & 48,704 & 3 & 16,235 & 45,285 &, 000 \\
\hline & Intra-grupos & 66,322 & 185 & ,358 & & \\
\hline & Total & 115,026 & 188 & & & \\
\hline \multirow{3}{*}{ Practicidad } & Inter-grupos & 236,772 & 3 & 78,924 & 4,749 & ,003 \\
\hline & Intra-grupos & 3074,636 & 185 & 16,620 & & \\
\hline & Total & 3311,407 & 188 & & & \\
\hline \multirow{3}{*}{ Resultados } & Inter-grupos & 6,856 & 3 & 2,285 & 148 & ,931 \\
\hline & Intra-grupos & 2862,901 & 185 & 15,475 & & \\
\hline & Total & 2869,757 & 188 & & & \\
\hline \multirow{3}{*}{ Variedad } & Inter-grupos & 79,442 & 3 & 26,481 & 832 & ,478 \\
\hline & Intra-grupos & 5884,759 & 185 & 31,810 & & \\
\hline & Total & 5964,201 & 188 & & & \\
\hline \multirow{3}{*}{ Decisión } & Inter-grupos & 45,522 & 3 & 15,174 & 857 & ,464 \\
\hline & Intra-grupos & 3275,050 & 185 & 17,703 & & \\
\hline & Total & 3320,571 & 188 & & & \\
\hline \multirow{3}{*}{ Orden y método } & Inter-grupos & 40,179 & 3 & 13,393 & ,469 & ,704 \\
\hline & Intra-grupos & 5282,774 & 185 & 28,556 & & \\
\hline & Total & 5322,952 & 188 & & & \\
\hline \multirow{3}{*}{ Metas } & Inter-grupos & 69,526 & 3 & 23,175 & 1,076 & ,361 \\
\hline & Intra-grupos & 3985,025 & 185 & 21,541 & & \\
\hline & Total & 4054,550 & 188 & & & \\
\hline
\end{tabular}

Cuadro 158: Tabla ANOVA de "valores” y tamaño, factor Realización de Acciones de Responsabilidad Social.

La información que ofrece el cuadro 158 revela la existencia de diferencias estadísticamente significativas entre los diversos grupos en relación con "tamaño" (su coeficiente de significación es 0,000) y "practicidad" (el coeficiente de significación que presenta es 0,003).

Hemos agrupado las consideraciones sobre la información que ofrece el cuadro 157 en función del tamaño de la organización de procedencia del líder. No obstante hacemos mención aquí, de forma global, al protagonismo preferente que tiene la competencia genérica "metas" ya que en todos los grupos muestrales es, de los seis aspectos estudiados, el que tiene un mayor valor medio. Este dato indica que la relevancia de la definición clara de los 
objetivos que se persiguen en el trabajo, la orientación a la tarea y la reducción de la amplitud de las actividades para poder facilitar su finalización es independiente de la dimensión de la organización de procedencia del líder.

Como en los apartados precedentes no hemos considerado, por su baja representatividad, aquellos grupos muestrales en los que solo existe información de un líder.

Los máximos dirigentes cuyo origen son empresas pequeñas que no desarrollan ningún tipo de actuación socialmente responsable solo registran la puntuación media máxima en el rasgo de personalidad "practicidad" $(14,50)$. También es destacable que el rasgo de personalidad “decisión” registre en estos líderes su valor medio mínimo $(15,88)$.

El resto de los valores medios más altos, en relación con los aspectos estudiados, se ha registrado en los líderes que proceden de organizaciones que impulsan actuaciones de responsabilidad social de modo frecuente y en los que están vinculados a empresas que cuentan con una política específica de Responsabilidad Social Corporativa. En el primer grupo muestral han registrado su valor medio más alto los rasgos de personalidad "variedad" $(10,3)$ y “decisión" $(17,3)$, y la competencia genérica "resultados" $(16,5)$. En el segundo grupo muestral los que han obtenido una puntuación media mayor han sido la característica comportamental "orden y método" (20) y la competencia genérica "metas" (24). 
En los líderes cuyo origen son empresas que tienen una política de responsabilidad social constituida, la competencia genérica "resultados" $(11,67)$ y el rasgo de personalidad "variedad" han obtenido su puntuación media más baja.

En los máximos responsables procedentes de empresas pequeñas se ha producido una cierta tendencia descendente en la relevancia otorgada al rasgo de personalidad "practicidad" a medida que se ha intensificado el comportamiento socialmente responsable de la organización de origen del líder. Los máximos responsables procedentes de empresas inactivas $(14,5)$ y que desarrollan acciones puntuales $(14,46)$ han registrado unas puntuaciones medias mayores que los máximos responsables de organizaciones que desarrollan acciones frecuentes $(12,80)$ y que cuentan con una política definida de responsabilidad social (13).

Los líderes de las organizaciones pequeñas también han obtenido un valor medio diferente en el rasgo de personalidad "decisión" según sea el comportamiento socialmente responsable de su organización de origen (aunque en este caso cualquier conducta empresarial a favor de la responsabilidad incrementa dicho valor). En los líderes procedentes de empresas inactivas, su puntuación media ha sido 15,88 y en los líderes vinculados a organizaciones que impulsan acciones puntuales $(17,17)$, frecuentes $(17,3)$ y que las desarrollan dentro de una política (17), sus puntuaciones medias son más elevadas. 
En los líderes procedentes de empresas medianas que no impulsan ningún tipo de iniciativa en el campo de la responsabilidad social se han registrado las tres puntuaciones medias más elevadas en los rasgos de personalidad “practicidad” $(15,06)$ y “decisión" $(17,94)$, y en la competencia genérica "resultados" $(14,83)$.

La competencia genérica "metas" ha obtenido su puntuación media más alta en los máximos responsables procedentes de empresas medianas que impulsan acciones puntuales $(22,5)$.

En los líderes que proceden de empresas que desarrollan acciones frecuentes la característica comportamental "orden y método" ha obtenido su puntuación media más alta $(18,63)$.

Los máximos responsables cuyo origen son organizaciones que cuentan con una política definida de responsabilidad social han obtenido su puntuación media más alta en el rasgo de personalidad "variedad" $(12,36)$. En estos líderes, el rasgo de personalidad "practicidad" ha registrado su valor medio mínimo $(10,36)$. Este rasgo de personalidad ha tendido a perder relevancia (esta reducción de importancia no se da en todos los grupos muestrales) a medida que se ha incrementado la actuación socialmente responsable de la organización de la que procede el líder.

En las organizaciones grandes, los líderes cuyo origen son empresas que impulsan acciones puntuales han registrado las puntuaciones medias más altas en los rasgos 
de personalidad "practicidad" $(12,5)$ y "variedad" $(11,25)$, y en la competencia genérica "resultados" $(18,25)$.

En el caso de máximos responsables que proceden de organizaciones que desarrollan acciones frecuentes, el rasgo de personalidad "decisión" ha obtenido su puntuación media más elevada $(19,86)$.

En los líderes cuyo origen son organizaciones con una política definida de Responsabilidad Social Corporativa se han registrado dos puntuaciones medias más altas. Se trata de la característica comportamental "orden y método" $(15,43)$ y de la competencia genérica “metas" $(21,48)$. El rasgo de personalidad "practicidad", aun no habiendo obtenido su valor medio más alto, ha registrado una puntuación media elevada $(12,22)$.

La competencia genérica "resultados" $(15,65)$ y el rasgo de personalidad "decisión" $(16,74)$ han obtenido sus puntuaciones medias más bajas en los líderes procedentes de empresas que cuentan con una política establecida de responsabilidad social.

En los máximos responsables de empresas grandes se ha registrado una tendencia creciente y una decreciente en dos de los aspectos estudiados a medida que la organización ha intensificado su actuación socialmente responsable. La competencia genérica "resultados" tiende a perder relevancia (pasa de un valor medio de 18,25 en los líderes cuyas empresas desarrollan acciones puntuales a 15,65 en los que proceden de organizaciones que cuentan con una política definida) y la competencia genérica "metas" tiende 
a ganar en importancia (su media crece desde un 18,25 en los líderes cuyo origen son organizaciones que impulsan acciones puntuales a 21,48 en los máximos responsables asociados a empresas con política reconocida de responsabilidad social).

A continuación incorporamos los gráficos 98, 99 y 100 para revisar visualmente si es posible advertir algún tipo de asociación en la variación de las competencias genéricas, los rasgos de personalidad y las características comportamentales a medida que la organización intensifica su comportamiento socialmente responsable y considerando, al mismo tiempo, su tamaño empresarial.

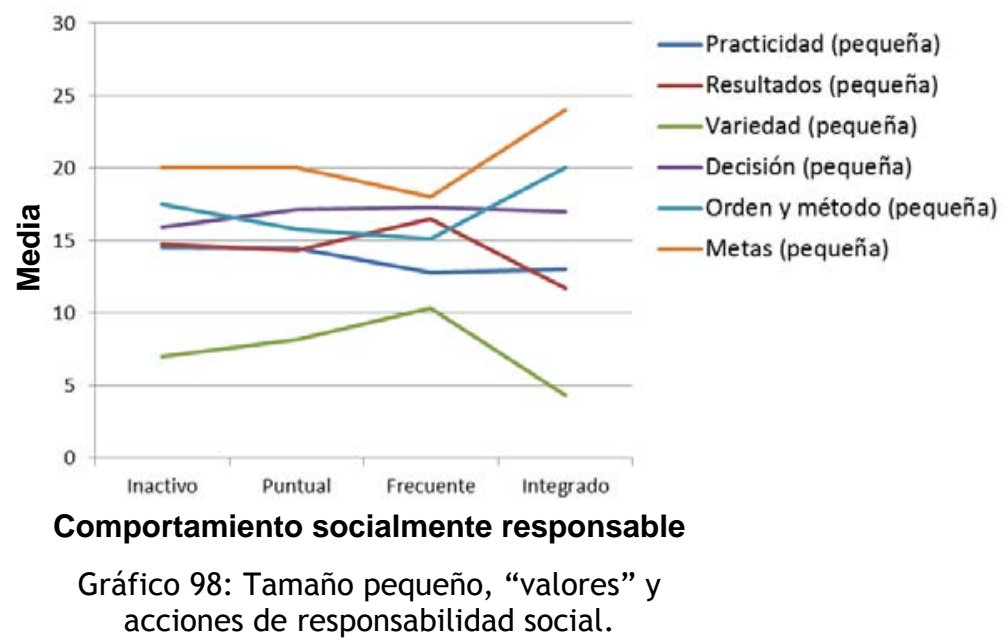

La información visual del gráfico 98 muestra que el rasgo de personalidad "practicidad" tiende a perder importancia a medida que la empresa pequeña de origen del líder intensifica su comportamiento socialmente responsable. 
El gráfico 98 también indica que el rasgo de personalidad "variedad" tiende a perder relevancia cuando los líderes proceden de organizaciones que cuentan con una política definida de responsabilidad social, mientras que con la competencia genérica "metas" ocurre al contrario (cobra más importancia en los líderes vinculados a organizaciones pequeñas con políticas establecidas de Responsabilidad Social Corporativa).

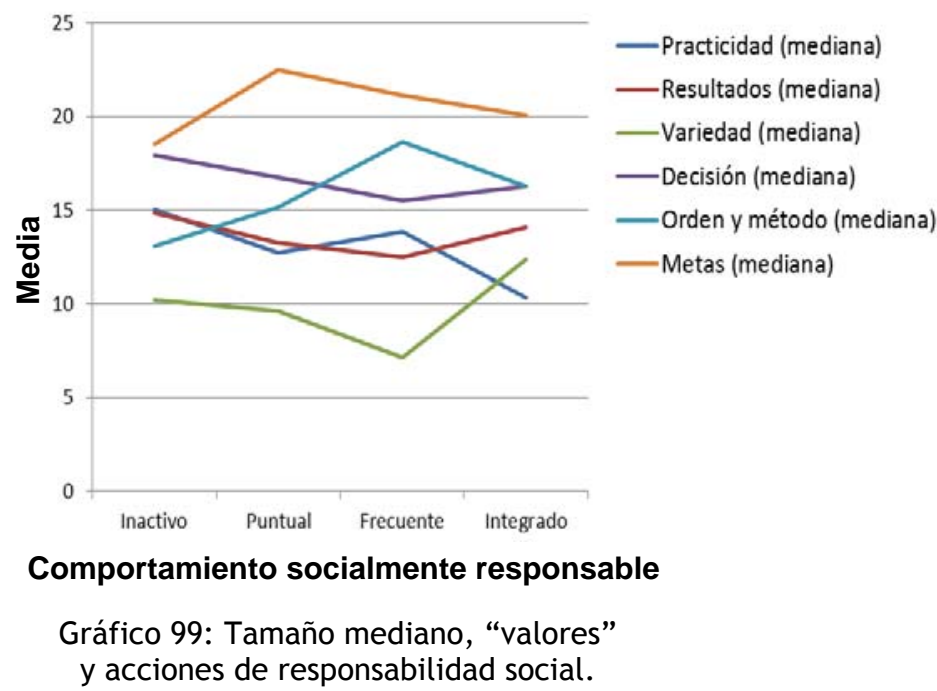

El gráfico 99 muestra como en las empresas medianas el rasgo de personalidad "practicidad" también tiende a perder relevancia en los líderes a medida que sus organizaciones de origen incrementan su actuación responsable.

La competencia genérica "metas" muestra una cierta tendencia a perder relevancia (no manifiesta en los líderes procedentes de empresas inactivas desde el punto de vista de la responsabilidad social) a medida que la organización intensifica su comportamiento socialmente responsable. 
También se aprecia una cierta tendencia (no presente en todos los tipos de comportamiento empresarial contemplados) a que adquiera mayor importancia la característica comportamental "orden y método" a medida que la organización de procedencia del líder intensifica su quehacer en materia de responsabilidad social.

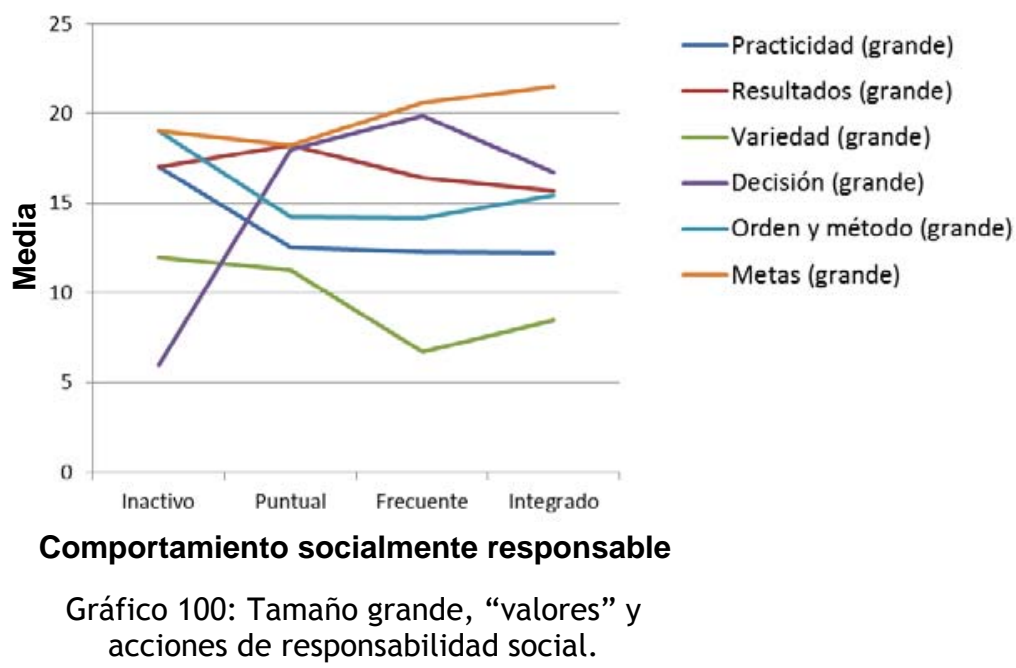

El gráfico 100 refleja como la competencia genérica "metas", en los líderes procedentes de empresas grandes, tiende (la tendencia no se da en todos los tipos de conducta socialmente responsable contemplados) a cobrar más importancia a medida que la organización acentúa su comportamiento afín a la Responsabilidad Social Corporativa.

Asimismo el rasgo de personalidad "variedad" y la competencia genérica "resultados", en este último caso como en los líderes vinculados a empresas medianas y pequeñas, tienden a perder peso en las decisiones del líder a medida que su organización de origen se involucra en mayor grado en acciones de responsabilidad social. 


\begin{tabular}{|c|c|c|c|c|c|c|c|c|}
\hline Tamaño & \multicolumn{2}{|c|}{ Horas de formación en resp. social } & Practicidad & Resultados & Variedad & Decisión & $\begin{array}{l}\text { Orden y } \\
\text { método }\end{array}$ & Metas \\
\hline \multirow{12}{*}{ Pequeño } & \multirow{2}{*}{ Menos de 11} & Media & 16,33 & 11,33 & 9,33 & 14,00 & 15,33 & 23,67 \\
\hline & & Desv. típ. & 1,155 & 4,509 & 4,509 & 2,000 & 6,658 & 2,517 \\
\hline & \multirow{2}{*}{ De 11 a 50} & Media & 13,00 & 15,00 & 10,67 & 22,33 & 12,33 & 16,67 \\
\hline & & Desv. típ. & 4,583 & 4,583 & 3,055 & 4,619 & 4,933 & 4,163 \\
\hline & \multirow{2}{*}{ De 51 a 100} & Media & 12,50 & 16,00 & 12,00 & 19,00 & 14,50 & 16,00 \\
\hline & & Desv. típ. &, 707 & 4,243 & 12,728 & 2,828 & 6,364 & 14,142 \\
\hline & \multirow{2}{*}{ De 101 a 150} & Media & 9,00 & 14,00 & 9,00 & 20,67 & 15,67 & 21,67 \\
\hline & & Desv. típ. & 1,000 & 4,583 & 11,533 &, 577 & 4,163 & 3,786 \\
\hline & \multirow{2}{*}{ Más de 1000} & Media & 12,00 & 13,00 & 3,00 & 14,00 & 20,00 & 28,00 \\
\hline & & Desv. típ. & & & & & & \\
\hline & \multirow{2}{*}{ Total } & Media & 12,67 & 13,83 & 9,50 & 18,58 & 14,92 & 20,50 \\
\hline & & Desv. típ. & 3,420 & 3,996 & 7,052 & 4,252 & 4,870 & 6,403 \\
\hline \multirow{12}{*}{ Mediano } & \multirow{2}{*}{ Menos de 11} & Media & 11,20 & 13,80 & 7,00 & 18,40 & 17,00 & 22,60 \\
\hline & & Desv. típ. & 2,588 & 2,683 & 4,528 & 2,702 & 2,449 & 3,209 \\
\hline & \multirow{2}{*}{ De 11 a 50} & Media & 20,50 & 13,00 & 10,50 & 9,00 & 19,50 & 16,00 \\
\hline & & Desv. típ. & 9,192 & 2,828 & ,707 & 1,414 & 2,121 & 4,243 \\
\hline & \multirow{2}{*}{ De 51 a 100} & Media & 11,00 & 15,50 & 13,00 & 14,50 & 16,50 & 19,50 \\
\hline & & Desv. típ. & 2,828 & 4,950 & 4,243 & 6,364 & 12,021 & ,707 \\
\hline & \multirow{2}{*}{ De 201 a 1000} & Media & 5,00 & 15,00 & 6,00 & 25,00 & 14,00 & 22,00 \\
\hline & & Desv. típ. & & & & & & \\
\hline & \multirow{2}{*}{ Más de 1000} & Media & 7,00 & 16,00 & 23,00 & 12,00 & 13,00 & 19,00 \\
\hline & & Desv. típ. & & . & . & & . & \\
\hline & \multirow{2}{*}{ Total } & Media & 11,91 & 14,27 & 10,09 & 16,00 & 16,73 & 20,45 \\
\hline & & Desv. típ. & 5,856 & 2,687 & 5,907 & 5,477 & 4,585 & 3,588 \\
\hline \multirow{16}{*}{ Grande } & Menos de 11 & Media & 14,00 & 21,00 & 13,50 & 13,00 & 14,00 & 14,50 \\
\hline & vienos de it & Desv. típ. & 5,657 & 1,414 & 7,778 & 5,657 & 2,828 & 3,536 \\
\hline & & Media & 11,00 & 16,50 & 6,17 & 20,33 & 13,33 & 22,67 \\
\hline & De $T 1$ a su & Desv. típ. & 3,033 & 2,881 & 6,432 & 4,590 & 4,633 & 2,582 \\
\hline & 100 a 51 e م" & Media & 15,00 & 14,00 & 10,00 & 23,00 & 12,00 & 16,00 \\
\hline & De 51 a 100 & Desv. típ. & & & & & & \\
\hline & De 101 a 150 & Media & 12,25 & 17,50 & 4,75 & 15,50 & 18,75 & 21,25 \\
\hline & De ivi is 150 & Desv. típ. & 2,062 & 6,856 & 5,123 & 4,359 & 6,131 & 6,397 \\
\hline & De 151 a 200 & Media & 14,00 & 12,00 & 10,00 & 22,00 & 9,00 & 23,00 \\
\hline & De 101 a $\angle 00$ & Desv. típ. & & . & . & & . & \\
\hline & De 201 a 1000 & Media & 9,00 & 23,00 & 6,00 & 21,00 & 12,00 & 19,00 \\
\hline & De 201 a 1000 & Desv. típ. & & $\cdot$ & & & . & \\
\hline & Más de 1000 & Media & 15,00 & 15,00 & 8,00 & 9,00 & 19,00 & 24,00 \\
\hline & IVlas de 1000 & Desv. típ. & & . & & & . & \\
\hline & Total & Media & 12,25 & 17,19 & 7,31 & 17,81 & 14,69 & 20,75 \\
\hline & Total & Desv. típ. & 3,000 & 4,415 & 5,618 & 5,369 & 4,976 & 4,553 \\
\hline & Menos de 11 & Media & 13,30 & 14,50 & 9,00 & 16,00 & 15,90 & 21,30 \\
\hline & IVIenos de 11 & Desv. típ. & 3,529 & 4,577 & 5,207 & 3,771 & 3,872 & 4,523 \\
\hline & م 50 & Media & 13,27 & 15,45 & 8,18 & 18,82 & 14,18 & 19,82 \\
\hline & De 11 a so & Desv. típ. & 5,551 & 3,328 & 5,288 & 6,274 & 4,813 & 4,400 \\
\hline & De 51 a 100 & Media & 12,40 & 15,40 & 12,00 & 18,00 & 14,80 & 17,40 \\
\hline & De 51 a 100 & Desv. típ. & 2,191 & 3,362 & 6,819 & 5,000 & 7,050 & 7,335 \\
\hline & 150 & Media & 10,86 & 16,00 & 6,57 & 17,71 & 17,43 & 21,43 \\
\hline TOTAL & De 101 a 150 & Desv. típ. & 2,340 & 5,831 & 7,913 & 4,152 & 5,224 & 5,028 \\
\hline 1OTAL & De 151 a 200 & Media & 14,00 & 12,00 & 10,00 & 22,00 & 9,00 & 23,00 \\
\hline & De 101 a 200 & Desv. típ. & & . & & & . & \\
\hline & De 201 a 1000 & Media & 7,00 & 19,00 & 6,00 & 23,00 & 13,00 & 20,50 \\
\hline & De $\angle 01$ a 1000 & Desv. típ. & 2,828 & 5,657 & ,000 & 2,828 & 1,414 & 2,121 \\
\hline & Más de 1000 & Media & 11,33 & 14,67 & 11,33 & 11,67 & 17,33 & 23,67 \\
\hline & 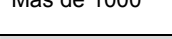 & Desv. típ. & 4,041 & 1,528 & 10,408 & 2,517 & 3,786 & 4,509 \\
\hline & Total & Media & 12,28 & 15,33 & 8,77 & 17,54 & 15,33 & 20,59 \\
\hline & Total & Desv. típ. & 4,006 & 4,087 & 6,132 & 5,057 & 4,792 & 4,843 \\
\hline
\end{tabular}

Cuadro 159: Medidas estadísticas sobre formación en responsabilidad social, "valores" y tamaño. 
En la página previa hemos incorporado el cuadro 159 con datos sobre las horas que las organizaciones dedican a acciones de formación enmarcadas en el ámbito de la responsabilidad social y su tamaño, además de la que hace referencia a las competencias genéricas, los rasgos de personalidad y las características comportamentales analizadas en los líderes.

Antes de proceder a la revisión de la información que ofrece el cuadro 159 hemos aplicado ANOVA de un factor para verificar si existen diferencias estadísticamente significativas entre los diversos grupos muestrales considerados (cuadro 160).

\begin{tabular}{|c|c|c|c|c|c|c|}
\hline & & Suma de cuadrados & gl & Media cuadrática & $\mathbf{F}$ & Sig. \\
\hline \multirow{3}{*}{ Tamaño } & Inter-grupos & 2,351 & 6 & 392 & 497 & ,806 \\
\hline & Intra-grupos & 25,239 & 32 & ,789 & & \\
\hline & Total & 27,590 & 38 & & & \\
\hline \multirow{3}{*}{ Practicidad } & Inter-grupos & 96,892 & 6 & 16,149 & 1,007 & ,438 \\
\hline & Intra-grupos & 513,006 & 32 & 16,031 & & \\
\hline & Total & 609,897 & 38 & & & \\
\hline \multirow{3}{*}{ Resultados } & Inter-grupos & 49,573 & 6 & 8,262 & ,452 & ,838 \\
\hline & Intra-grupos & 585,094 & 32 & 18,284 & & \\
\hline & Total & 634,667 & 38 & & & \\
\hline \multirow{3}{*}{ Variedad } & Inter-grupos & 126,906 & 6 & 21,151 & ,520 & 789 \\
\hline & Intra-grupos & 1302,017 & 32 & 40,688 & & \\
\hline & Total & 1428,923 & 38 & & & \\
\hline \multirow{3}{*}{ Decisión } & Inter-grupos & 225,961 & 6 & 37,660 & 1,616 & ,175 \\
\hline & Intra-grupos & 745,732 & 32 & 23,304 & & \\
\hline & Total & 971,692 & 38 & & & \\
\hline \multirow{3}{*}{ Orden y método } & Inter-grupos & 112,949 & 6 & 18,825 & ,793 &, 582 \\
\hline & Intra-grupos & 759,717 & 32 & 23,741 & & \\
\hline & Total & 872,667 & 38 & & & \\
\hline \multirow{3}{*}{ Metas } & Inter-grupos & 101,619 & 6 & 16,936 & 686 & 662 \\
\hline & Intra-grupos & 789,817 & 32 & 24,682 & & \\
\hline & Total & 891,436 & 38 & & & \\
\hline
\end{tabular}

Cuadro 160: Tabla ANOVA de "valores" y tamaño, factor Horas de Formación en Responsabilidad Social. 
Los coeficientes de significación que aporta el cuadro 160 indican que no existen diferencias estadísticamente significativas entre los diversos grupos muestrales contemplados ya que en ningún caso el coeficiente de significación es inferior a 0,05.

En la revisión de la información que ofrece el cuadro 159 no hemos considerado, por su baja representatividad, aquellos grupos muestrales en los que únicamente hemos recabado información de un líder.

Hemos agrupado las observaciones sobre la lectura de los datos del cuadro 159 en función de la dimensión de las organizaciones.

En los líderes cuyo origen son organizaciones pequeñas que dedican menos de 11 horas a acciones formativas enmarcadas en el ámbito de la responsabilidad social el rasgo de personalidad "practicidad" $(16,33)$ y la competencia genérica “metas" $(23,67)$ han registrado su valor medio más alto en relación con los cuatro grupos muestrales considerados.

En los máximos responsables que proceden de organizaciones que dedican entre 11 y 50 horas a acciones de formación sobre responsabilidad social, el rasgo de personalidad "decisión" ha obtenido su puntuación media más elevada.

En los líderes vinculados a organizaciones pequeñas que invierten entre 51 y 100 horas a acciones formativas 
encuadras en el ámbito de la responsabilidad, la competencia genérica "resultados" (16) y el rasgo de personalidad "variedad" (12) han registrado su puntuación media más alta.

En cuanto a los líderes que proceden de organizaciones que invierten de 101 a 150 horas a acciones de formación afines a la responsabilidad social, la característica comportamental "orden y método" ha registrado su valor medio más elevado $(15,67)$ y los rasgos de personalidad "practicidad" (9) y "variedad" (9) han obtenido su valor medio más reducido.

En dos de los cuatro grupos la competencia genérica "metas" ha sido el aspecto, de los seis evaluados, con un mayor valor medio y en los otros dos grupos, el rasgo de personalidad "decisión" ha sido el que ha recibido una puntuación media más elevada de los seis considerados en cada caso.

Los líderes de las empresas pequeñas han tendido (no siempre se ha reducido su valor medio) a conceder menos relevancia al rasgo de personalidad "practicidad" a medida que sus organizaciones de origen han incrementado la duración de sus acciones formativas dirigidas a públicos internos sobre responsabilidad social (su valor medio pasa de 16,33 a 9).

En los máximos responsables empresariales procedentes de organizaciones medianas que dedican menos de 11 horas a acciones de formación sobre responsabilidad 
social, el rasgo de personalidad "decisión" $(18,4)$ y la competencia genérica "metas" $(22,6)$ han obtenido su puntuación media más alta.

En los líderes procedentes de empresas medianas que dedican entre 51 y 100 horas a acciones formativas, el rasgo de personalidad "practicidad" $(20,5)$ y la característica comportamental "orden y método" $(19,5)$ han registrado su valor medio más alto.

Y en los máximos responsables cuyo origen ha sido las organizaciones que dedican de 51 a 100 horas a acciones formativas, la competencia genérica "resultados" $(15,5)$ y el rasgo de personalidad "variedad" (13) han obtenido su valor medio mayor mientras que el rasgo de personalidad "practicidad" (11) y la característica comportamental "orden y método" $(16,5)$ han registrado su valor medio más reducido.

En dos de los tres grupos muestrales el aspecto, de los seis contemplados en cada caso, que ha recibido una mayor valoración media ha sido la competencia genérica "metas" y en un caso el rasgo de personalidad "practicidad".

Los datos también han indicado que el rasgo de personalidad "variedad" tiende a ganar relevancia en los líderes a medida que sus organizaciones incrementan la duración de las acciones formativas enmarcadas en el ámbito de la responsabilidad social (su valor medio aumenta de 7 a 13). 
En los máximos responsables de organizaciones grandes hemos contemplado tres grupos muestrales. En los que proceden de empresas que dedican un menor número de horas a acciones formativas sobre responsabilidad social, (menos de 11 horas y de 11 a 50 horas) los rasgos de personalidad "practicidad" (14), “variedad" $(13,5)$ y “decisión" $(20,33), \quad$ y las competencias genéricas "resultados" (21) y "metas" $(22,67)$ han obtenido su puntuación media más elevada.

En los líderes procedentes de empresas que destinan entre 101 a 150 horas a las acciones formativas afines a la Responsabilidad Social Corporativa, la característica comportamental "orden y método" ha obtenido su puntuación media más alta $(18,75)$ y el rasgo de personalidad "variedad" $(4,75)$ su valor medio más reducido.

En dos de los tres grupos muestrales contemplados la competencia genérica "metas", en relación con los seis aspectos contemplados en cada caso, es el que ha registrado un mayor valor medio. En el otro grupo esta valoración media más alta ha sido obtenida por la competencia genérica "resultados".

Hemos incorporado a continuación los gráficos 101 y 102 para revisar de modo visual posibles asociaciones en la variación de los rasgos de personalidad, las competencias genéricas y las características comportamentales consideradas a medida que las organizaciones de 
procedencia de los líderes aumentan el número de horas que dedican a acciones formativas y considerando, al mismo tiempo, el tamaño de las empresas.

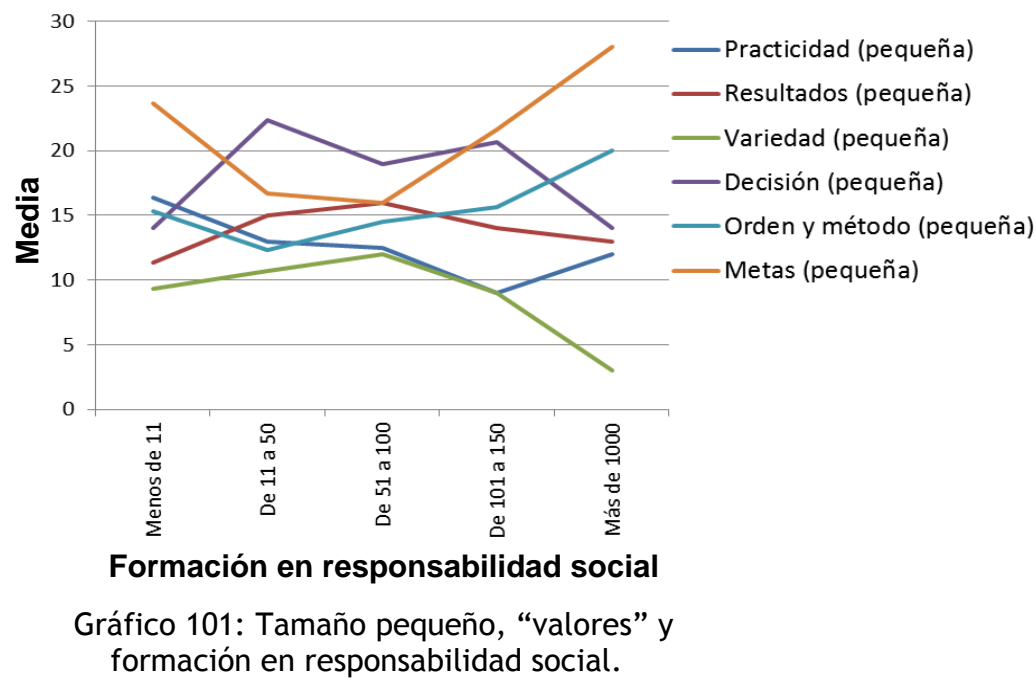

El gráfico 101 revela que el rasgo de personalidad "practicidad" tiende a perder relevancia en los líderes a medida que las organizaciones pequeñas aumentan el número de horas que dedican a acciones formativas.

Además también muestra que la característica comportamental "orden y método" tiende a adquirir más importancia en los máximos responsables a medida que la formación en materia de responsabilidad social se intensifica, mientras que el rasgo de personalidad "variedad" tiende a perder relevancia en los líderes según va aumentando la duración de los cursos de formación, enmarcados en el ámbito de la responsabilidad social, que las empresas pequeñas dirigen a sus públicos internos. 


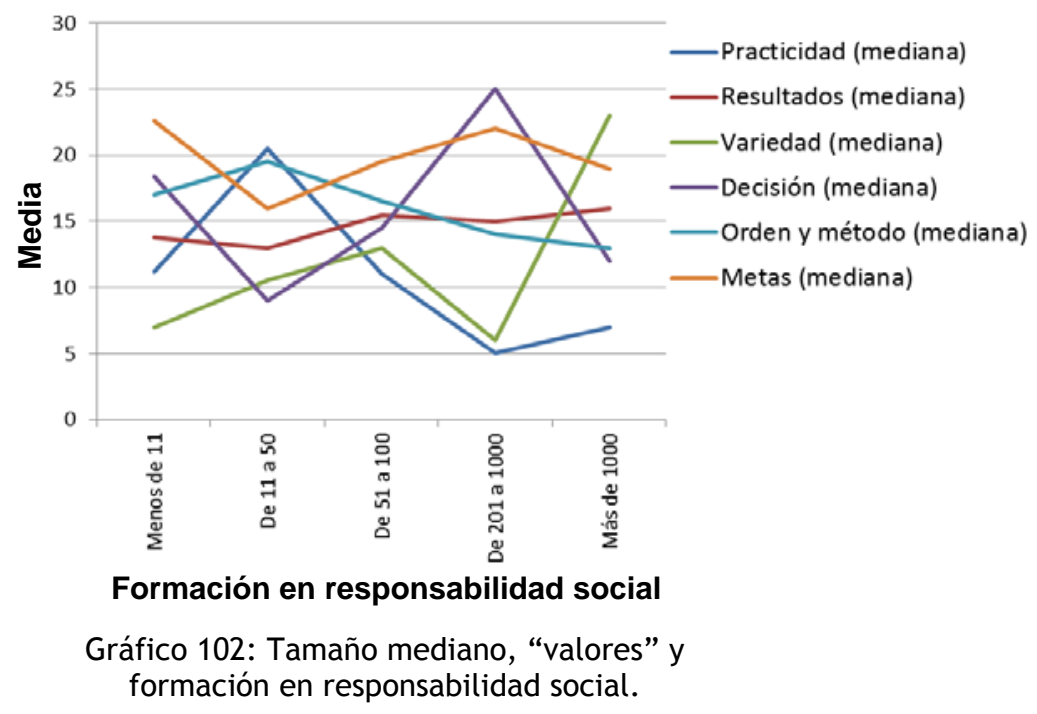

El gráfico 102 también muestra que el rasgo de personalidad "practicidad" tiende a perder importancia en el líder según se incrementa las horas de las acciones formativas encuadradas en el ámbito de la Responsabilidad Social Corporativa que impulsan las empresas medianas.

Además, la competencia genérica “resultados" tiende a adquirir más relevancia en los máximos dirigentes a medida que la formación sobre responsabilidad social es más extensa en las organizaciones medianas, mientras que la característica comportamental "orden y método" tiende a perder importancia para los líderes a medida que aumentan las horas dedicadas a las acciones formativas.

\subsubsection{Liderazgo, valores y Responsabilidad Social Corporativa}

En primer lugar hemos revisado los datos sobre el liderazgo de los máximos responsables empresariales junto 
con las competencias genéricas, los rasgos de personalidad y las características comportamentales contempladas en el estudio considerado, al mismo tiempo, la actitud de los líderes empresariales hacia la Responsabilidad Social Corporativa (cuadro 161). Hemos utilizado el valor segmentado de la media de la actitud con objeto de advertir posibles tendencias asociadas a la modificación de la actitud en el resto de variables.

\begin{tabular}{|c|c|c|c|c|c|c|c|c|c|c|c|c|c|}
\hline \multicolumn{2}{|c|}{$\begin{array}{l}\text { Actitud hacia la } \\
\text { resp. social }\end{array}$} & \multirow{2}{*}{$\begin{array}{r}\text { Practicidad } \\
21,00\end{array}$} & \multirow{2}{*}{\begin{tabular}{|r|} 
Resultados \\
17,00 \\
\end{tabular}} & \multirow{2}{*}{\begin{tabular}{|r|} 
Variedad \\
7,00 \\
\end{tabular}} & \multirow{2}{*}{$\begin{array}{r}\text { Decisión } \\
20,00\end{array}$} & \multirow{2}{*}{$\begin{array}{r}\begin{array}{r}\text { Orden y } \\
\text { método }\end{array} \\
12,00 \\
\end{array}$} & \multirow{2}{*}{$\begin{array}{c}\text { Metas } \\
10,00\end{array}$} & \multirow{2}{*}{$\begin{array}{r}\begin{array}{c}\text { Estilo } \\
\text { directivo }\end{array} \\
2,00 \\
\end{array}$} & \multirow{2}{*}{$\begin{array}{r}\begin{array}{c}\text { Estilo } \\
\text { consultivo }\end{array} \\
12,00 \\
\end{array}$} & \multirow{2}{*}{$\begin{array}{r}\begin{array}{c}\text { Estilo } \\
\text { participativo }\end{array} \\
6,00 \\
\end{array}$} & \multirow{2}{*}{$\begin{array}{r}\begin{array}{c}\text { Estilo } \\
\text { delegativo }\end{array} \\
, 00\end{array}$} & \multirow{2}{*}{\begin{tabular}{|r|} 
Flexibilidad \\
14,00 \\
\end{tabular}} & \multirow{2}{*}{$\begin{array}{r}\text { Efectividad } \\
57,00 \\
\end{array}$} \\
\hline \multirow{4}{*}{$0 a<4$} & Media & & & & & & & & & & & & \\
\hline & Mínimo & 21 & 17 & 7 & 20 & 12 & 10 & 2 & 12 & 6 & 0 & 14 & 57 \\
\hline & Máximo & 21 & 17 & 7 & 20 & 12 & 10 & 2 & 12 & 6 & 0 & 14 & 57 \\
\hline & Desv. típ. & & & & & & & & & & & & \\
\hline \multirow{4}{*}{$4 a<5$} & Media & 15,14 & 14,14 & 8,14 & 16,29 & 16,86 & 19,43 & 3,43 & 6,00 & 7,57 & 3,00 & 21,86 & 54,14 \\
\hline & Mínimo & 13 & 7 & 4 & 11 & 10 & 13 & 0 & 4 & 5 & 1 & 12 & 44 \\
\hline & Máximo & 18 & 17 & 20 & 26 & 26 & 24 & 6 & 9 & 13 & 7 & 26 & 62 \\
\hline & Desv. típ. & 2,410 & 3,388 & 5,429 & 4,957 & 5,521 & 4,117 & 2,440 & 1,633 & 2,573 & 2,082 & 5,113 & 6,094 \\
\hline \multirow{4}{*}{$5 a<6$} & Media & 13,57 & 14,65 & 8,70 & 16,00 & 16,61 & 20,48 & 3,74 & 5,65 & 6,61 & 4,00 & 20,74 & 55,35 \\
\hline & Mínimo & 7 & 7 & 2 & 10 & 9 & 14 & 0 & 0 & 1 & 1 & 10 & 44 \\
\hline & Máximo & 22 & 19 & 19 & 21 & 26 & 26 & 8 & 10 & 15 & 14 & 26 & 66 \\
\hline & Desv. tip. & 3,776 & 3,393 & 4,487 & 3,075 & 4,793 & 3,246 & 2,320 & 2,790 & 3,299 & 2,876 & 4,614 & 5,749 \\
\hline \multirow{4}{*}{$6 a<7$} & Media & 14,16 & 14,55 & 8,32 & 16,97 & 16,29 & 19,10 & 2,87 & 6,87 & 7,39 & 2,87 & 19,65 & 55,13 \\
\hline & Mínimo & 5 & 9 & 0 & 12 & 6 & 10 & 0 & 1 & 1 & 0 & 10 & 45 \\
\hline & Máximo & 24 & 23 & 22 & 25 & 27 & 28 & 7 & 11 & 15 & 6 & 26 & 63 \\
\hline & Desv. típ. & 4,344 & 3,161 & 6,085 & 3,851 & 5,442 & 5,294 & 2,012 & 2,078 & 3,422 & 1,628 & 4,325 & 4,380 \\
\hline \multirow{4}{*}{7 a 8} & Media & 13,42 & 14,88 & 8,71 & 16,80 & 15,81 & 20,26 & 2,17 & 6,76 & 8,02 & 3,03 & 18,69 & 56,28 \\
\hline & Mínimo & 4 & 2 & 0 & 7 & 5 & 6 & 0 & 1 & 1 & 0 & 12 & 43 \\
\hline & Máximo & 24 & 25 & 24 & 25 & 29 & 30 & 7 & 13 & 14 & 9 & 28 & 67 \\
\hline & Desv. típ. & 4,036 & 4,053 & 6,008 & 4,430 & 5,538 & 4,843 & 1,844 & 2,691 & 2,983 & 1,666 & 3,985 & 5,230 \\
\hline \multirow{4}{*}{$>8$} & Media & 13,62 & 15,00 & 7,14 & 16,24 & 16,84 & 21,00 & 2,27 & 6,00 & 8,11 & 3,54 & 18,97 & 56,59 \\
\hline & Mínimo & 6 & 4 & 0 & 5 & 5 & 11 & 0 & 1 & 4 & 0 & 11 & 43 \\
\hline & Máximo & 27 & 26 & 26 & 24 & 25 & 28 & 9 & 14 & 14 & 9 & 26 & 68 \\
\hline & Desv. típ. & 4,901 & 4,637 & 5,138 & 4,536 & 5,172 & 4,157 & 2,023 & 3,109 & 2,558 & 2,142 & 4,272 & 6,021 \\
\hline \multirow{4}{*}{ TOTAL } & Media & 13,70 & 14,80 & 8,31 & 16,62 & 16,21 & 20,15 & 2,54 & 6,49 & 7,74 & 3,21 & 19,24 & 55,96 \\
\hline & Mínimo & 4 & 2 & 0 & 5 & 5 & 6 & 0 & 0 & 1 & 0 & 10 & 43 \\
\hline & Máximo & 27 & 26 & 26 & 26 & 29 & 30 & 9 & 14 & 15 & 14 & 28 & 68 \\
\hline & Desv. tip. & 4,197 & 3,907 & 5,632 & 4,203 & 5,321 & 4,644 & 2,041 & 2,707 & 3,013 & 1,977 & 4,264 & 5,331 \\
\hline
\end{tabular}

Cuadro 161: Medidas estadísticas de liderazgo, “valores” y actitud hacia la responsabilidad social

Antes de hacer una valoración de la información que ofrece el cuadro 161 hemos aplicado ANOVA de un factor en los datos para verificar si existen diferencias 


\section{estadísticamente significativas entre los diversos grupos que componen la muestra poblacional (cuadro 162).}

\begin{tabular}{|c|c|c|c|c|c|c|}
\hline & & Suma de cuadrados & gl & Media cuadrática & $\mathbf{F}$ & Sig. \\
\hline \multirow{3}{*}{ Practicidad } & Inter-grupos & 82,046 & 5 & 16,409 & ,930 & ,463 \\
\hline & Intra-grupos & 3229,361 & 183 & 17,647 & & \\
\hline & Total & 3311,407 & 188 & & & \\
\hline \multirow{3}{*}{ Resultados } & Inter-grupos & 12,349 & 5 & 2,470 & ,158 & ,977 \\
\hline & Intra-grupos & 2857,408 & 183 & 15,614 & & \\
\hline & Total & 2869,757 & 188 & & & \\
\hline \multirow{3}{*}{ Variedad } & Inter-grupos & 70,887 & 5 & 14,177 & ,440 & ,820 \\
\hline & Intra-grupos & 5893,314 & 183 & 32,204 & & \\
\hline & Total & 5964,201 & 188 & & & \\
\hline \multirow{3}{*}{ Decisión } & Inter-grupos & 32,964 & 5 & 6,593 & ,367 & ,871 \\
\hline & Intra-grupos & 3287,607 & 183 & 17,965 & & \\
\hline & Total & 3320,571 & 188 & & & \\
\hline \multirow{3}{*}{ Orden y método } & Inter-grupos & 53,414 & 5 & 10,683 & ,371 & ,868 \\
\hline & Intra-grupos & 5269,538 & 183 & 28,795 & & \\
\hline & Total & 5322,952 & 188 & & & \\
\hline \multirow{3}{*}{ Metas } & Inter-grupos & 171,265 & 5 & 34,253 & 1,614 & , 158 \\
\hline & Intra-grupos & 3883,285 & 183 & 21,220 & & \\
\hline & Total & 4054,550 & 188 & & & \\
\hline \multirow{3}{*}{ Estilo directivo } & Inter-grupos & 57,522 & 5 & 11,504 & 2,902 & ,015 \\
\hline & Intra-grupos & 725,430 & 183 & 3,964 & & \\
\hline & Total & 782,952 & 188 & & & \\
\hline \multirow{3}{*}{ Estilo consultivo } & Inter-grupos & 67,915 & 5 & 13,583 & 1,898 & ,097 \\
\hline & Intra-grupos & 1309,323 & 183 & 7,155 & & \\
\hline & Total & 1377,238 & 188 & & & \\
\hline \multirow{3}{*}{$\begin{array}{l}\text { Estilo } \\
\text { participativo }\end{array}$} & Inter-grupos & 48,702 & 5 & 9,740 & 1,075 & ,376 \\
\hline & Intra-grupos & 1658,071 & 183 & 9,060 & & \\
\hline & Total & 1706,772 & 188 & & & \\
\hline \multirow{3}{*}{ Estilo delegativo } & Inter-grupos & 35,379 & 5 & 7,076 & 1,851 & , 105 \\
\hline & Intra-grupos & 699,573 & 183 & 3,823 & & \\
\hline & Total & 734,952 & 188 & & & \\
\hline \multirow{3}{*}{ Flexibilidad } & Inter-grupos & 162,154 & 5 & 32,431 & 1,822 & , 110 \\
\hline & Intra-grupos & 3256,651 & 183 & 17,796 & & \\
\hline & Total & 3418,804 & 188 & & & \\
\hline \multirow{3}{*}{ Efectividad } & Inter-grupos & 78,208 & 5 & 15,642 &, 544 & ,743 \\
\hline & Intra-grupos & 5264,533 & 183 & 28,768 & & \\
\hline & Total & 5342,741 & 188 & & & \\
\hline
\end{tabular}

Cuadro 162: Tabla ANOVA de liderazgo y "valores", factor Actitud hacia la Responsabilidad Social.

La información que ofrece el cuadro 162 muestra la existencia de diferencias estadísticamente significativas 
entre los diversos grupos muestrales en relación con "estilo directivo" (su coeficiente de significación es 0,015 ).

A continuación hemos revisado la información que ofrece el cuadro 160 sin tomar en consideración, por su escasa representatividad, al grupo muestral en el que la actitud hacia la responsabilidad social ha registrado un valor medio situado en el segmento " $0 \mathrm{a}<4$ ".

Se han registrado dos tendencias que guardan correspondencia, en mayor o menor medida, con el incremento de la actitud de los líderes hacia la responsabilidad social.

Una se ha producido en la competencia genérica "resultados", cuyo valor medio crece ligeramente, no de forma progresiva, a medida que se intensifica la disposición del líder a favor de la responsabilidad social (su puntuación media decrece de 14,14 en el grupo poblacional " 4 a $<5$ " a 15 en el segmento de valor de la actitud "7 a 8").

Otra en la efectividad de estilo, cuyo valor medio tiene tendencia a aumentar a medida que la actitud favorable del máximo dirigente hacia la responsabilidad social es más alta (su valor medio crece de 54,14 en el segmento " $4 \mathrm{a}<5$ " a 56,59 en el grupo poblacional “>8”).

También hemos destacado en los segmentos que representan una actitud favorable hacia la responsabilidad social menos intensa ("4 $a<5$ " y "5 $a<6$ ") los rasgos de 
personalidad “practicidad" $(15,14)$ y “decisión” $(16,86)$ porque han registrado su media mayor, así como el estilo directivo $(3,74)$. Mientras que el rasgo de personalidad “decisión" (16) y los estilos consultivo $(5,65)$ y participativo $(6,61)$ han obtenido su puntuación media más baja.

En los segmentos que representan una actitud más alta hacia la responsabilidad social (7 a 8 " y “>8”), el rasgo de personalidad "practicidad" $(13,42)$, la característica comportamental "orden y método" $(15,81)$ y el estilo directivo $(2,17)$ han registrado su media más reducida contemplando todos los grupos muestrales. Por el contrario, el rasgo de personalidad "variedad" $(8,71)$, la competencia genérica "metas" (21) y el estilo participativo $(8,11)$ han obtenido sus medias más altas. En consecuencia el aumento de la preferencia por hacer cosas nuevas y diferentes, la mayor predilección por disponer de objetivos perfectamente definidos y el incremento de la preferencia por un estilo directivo en el que predomine el apoyo podrían ser indicativos de una disposición favorable hacia la responsabilidad social.

Tras estas líneas hemos incorporado los gráficos 103 y 104 para contemplar, de modo visual, las posibles asociaciones existentes entre el liderazgo, las competencias genéricas, las características comportamentales y los rasgos de personalidad estudiados, y el aumento de la disposición favorable hacia la Responsabilidad Social Corporativa. 

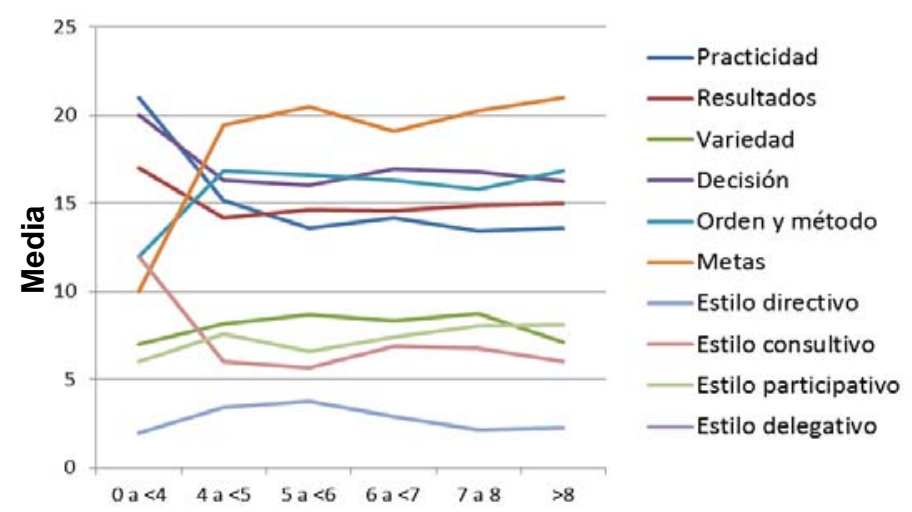

Actitud hacia la responsabilidad social

Gráfico 103: “Valores” y estilos de liderazgo y actitud hacia la responsabilidad social.

El grafico 103 parece revelar que existe una cierta tendencia creciente en la competencia genérica "metas" y un leve incremento en el rasgo de personalidad "resultados" y en el estilo participativo, a medida que se intensifica la actitud del líder a favor de la responsabilidad social.

Asimismo, el rasgo de personalidad "practicidad" parece mostrar una cierta tendencia a perder importancia a medida que aumenta la actitud del líder a favor de la responsabilidad social.

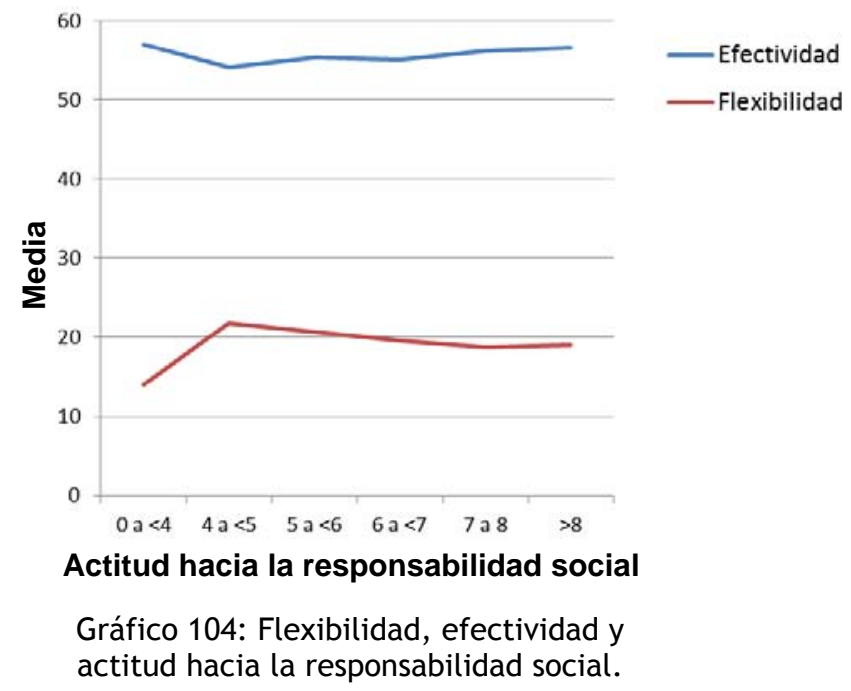


El grafico 104 muestra cómo la efectividad del liderazgo tiende a aumentar y su flexibilidad a disminuir a medida que la actitud del líder a favor de la responsabilidad social es más elevada.

En definitiva, los gráficos 103 y 104 parecen mostrar que en la competencia genérica “metas", en el rasgo de personalidad "resultados" y en el estilo participativo existe una tendencia a adquirir relevancia a medida que crece la actitud a favor de la responsabilidad social del líder. Por el contrario, el rasgo de personalidad "practicidad" y la flexibilidad de estilo tienden a reducir su importancia a medida que es más intensa la actitud del máximo dirigente a favor de la Responsabilidad Social Corporativa.

En lo que hace referencia al comportamiento socialmente responsable de la organización revisamos en primer lugar, como en los apartados precedentes, los datos más generales sobre la conducta responsable de la empresa, el estilo de liderazgo de sus máximos dirigentes, su flexibilidad de estilo, su efectividad de estilo y los resultados registrados sobre las competencias genéricas, los rasgos de personalidad y las características comportamentales contemplados en el estudio.

Antes de proceder a la revisión de los datos hemos aplicado ANOVA de un factor en la muestra poblacional para verificar si existen diferencias estadísticamente significativas entre los diversos grupos muestrales contemplados (cuadro 163). 


\begin{tabular}{|c|c|c|c|c|c|c|}
\hline & & Suma de cuadrados & gl & Media cuadrática & $\mathrm{F}$ & Sig. \\
\hline \multirow{3}{*}{ Practicidad } & Inter-grupos & 236,772 & 3 & 78,924 & 4,749 & 003 \\
\hline & Intra-grupos & 3074,636 & 185 & 16,620 & & \\
\hline & Total & 3311,407 & 188 & & & \\
\hline \multirow{3}{*}{ Resultados } & Inter-grupos & 6,856 & 3 & 2,285 & , 148 & 931 \\
\hline & Intra-grupos & 2862,901 & 185 & 15,475 & & \\
\hline & Total & 2869,757 & 188 & & & \\
\hline \multirow{3}{*}{ Variedad } & Inter-grupos & 79,442 & 3 & 26,481 & ,832 & ,478 \\
\hline & Intra-grupos & 5884,759 & 185 & 31,810 & & \\
\hline & Total & 5964,201 & 188 & & & \\
\hline \multirow{3}{*}{ Valor numérico } & Inter-grupos & 45,522 & 3 & 15,174 & ,857 & ,464 \\
\hline & Intra-grupos & 3275,050 & 185 & 17,703 & & \\
\hline & Total & 3320,571 & 188 & & & \\
\hline \multirow{3}{*}{ Orden y método } & Inter-grupos & 40,179 & 3 & 13,393 & ,469 & ,704 \\
\hline & Intra-grupos & 5282,774 & 185 & 28,556 & & \\
\hline & Total & 5322,952 & 188 & & & \\
\hline \multirow{3}{*}{ Metas } & Inter-grupos & 69,526 & 3 & 23,175 & 1,076 &, 361 \\
\hline & Intra-grupos & 3985,025 & 185 & 21,541 & & \\
\hline & Total & 4054,550 & 188 & & & \\
\hline \multirow{3}{*}{ Estilo directivo } & Inter-grupos & 51,529 & 3 & 17,176 & 4,344 &, 006 \\
\hline & Intra-grupos & 731,423 & 185 & 3,954 & & \\
\hline & Total & 782,952 & 188 & & & \\
\hline \multirow{3}{*}{ Estilo consultivo } & Inter-grupos & 10,751 & 3 & 3,584 &, 485 & 693 \\
\hline & Intra-grupos & 1366,487 & 185 & 7,386 & & \\
\hline & Total & 1377,238 & 188 & & & \\
\hline \multirow{3}{*}{ Estilo participativo } & Inter-grupos & 129,541 & 3 & 43,180 & 5,065 &, 002 \\
\hline & Intra-grupos & 1577,232 & 185 & 8,526 & & \\
\hline & Total & 1706,772 & 188 & & & \\
\hline \multirow{3}{*}{ Estilo delegativo } & Inter-grupos & 31,069 & 3 & 10,356 & 2,722 & ,046 \\
\hline & Intra-grupos & 703,884 & 185 & 3,805 & & \\
\hline & Total & 734,952 & 188 & & & \\
\hline \multirow{3}{*}{ Flexibilidad } & Inter-grupos & 281,329 & 3 & 93,776 & 5,529 & ,001 \\
\hline & Intra-grupos & 3137,475 & 185 & 16,959 & & \\
\hline & Total & 3418,804 & 188 & & & \\
\hline \multirow{3}{*}{ Efectividad } & Inter-grupos & 487,949 & 3 & 162,650 & 6,198 & 000 \\
\hline & Intra-grupos & 4854,791 & 185 & 26,242 & & \\
\hline & Total & 5342,741 & 188 & & & \\
\hline
\end{tabular}

Cuadro 163: Tabla ANOVA de "valores" y liderazgo, factor Realización de Acciones de Responsabilidad Social.

Los resultados del cuadro 163 revelan la existencia de diferencias estadísticamente significativas entre los diversos grupos muestrales en relación con "practicidad" (su coeficiente de significación es 0,003), "estilo directivo" (presenta un coeficiente de significación de 0,006), “estilo participativo" (tiene un coeficiente de significación de 
0,002), "estilo delegativo" (su coeficiente de significación es 0,046), “flexibilidad" (presenta un coeficiente de significación de 0,001) y "efectividad" (su coeficiente de significación es 0,000).

\begin{tabular}{|c|c|c|c|c|c|c|c|c|c|c|c|c|c|}
\hline \multicolumn{2}{|c|}{ Acciones de resp. social } & \multirow{2}{*}{$\begin{array}{r}\text { Practicidad } \\
14,64\end{array}$} & \multirow{2}{*}{$\begin{array}{r}\text { Resultados } \\
14,78\end{array}$} & \multirow{2}{*}{$\begin{array}{r}\text { Variedad } \\
7,70\end{array}$} & \multirow{2}{*}{\begin{tabular}{|r|} 
Decisión \\
16,18
\end{tabular}} & \multirow{2}{*}{\begin{tabular}{|c|}
$\begin{array}{c}\text { Orden y } \\
\text { método }\end{array}$ \\
16,64
\end{tabular}} & \multirow{2}{*}{$\begin{array}{l}\text { Metas } \\
19,73\end{array}$} & \multirow{2}{*}{\begin{tabular}{r|}
$\begin{array}{c}\text { Estilo } \\
\text { directivo }\end{array}$ \\
3,07
\end{tabular}} & \multirow{2}{*}{$\begin{array}{r}\begin{array}{c}\text { Estilo } \\
\text { consultivo }\end{array} \\
6,29\end{array}$} & \multirow{2}{*}{\begin{tabular}{|r|}
$\begin{array}{c}\text { Estilo } \\
\text { participativo }\end{array}$ \\
6,88
\end{tabular}} & \multirow{2}{*}{$\begin{array}{r}\begin{array}{c}\text { Estilo } \\
\text { delegativo }\end{array} \\
3,63\end{array}$} & \multirow{2}{*}{$\begin{array}{r}\text { Flexibilidad } \\
20,34\end{array}$} & \multirow{2}{*}{$\begin{array}{r}\text { Efectividad } \\
54,74\end{array}$} \\
\hline & Media & & & & & & & & & & & & \\
\hline & Desv. típ. & 4,205 & 3,867 & 5,154 & 3,993 & 5,118 & 4,232 & 2,169 & 2,810 & 2,863 & 2,234 & 4,264 & 5,297 \\
\hline \multirow{2}{*}{$\begin{array}{l}\text { Sí, acciones } \\
\text { puntuales }\end{array}$} & Media & 13,86 & 14,53 & 8,83 & 17,17 & 15,44 & 20,39 & 2,28 & 6,44 & 8,44 & 2,83 & 19,22 & 55,17 \\
\hline & Desv. típ. & 4,114 & 4,219 & 5,940 & 3,738 & 5,289 & 5,347 & 1,632 & 2,261 & 2,761 & 1,424 & 3,921 & 5,218 \\
\hline \multirow{2}{*}{$\begin{array}{l}\text { Sí, acciones } \\
\text { frecuentes sin una } \\
\text { política definida de } \\
\text { RS }\end{array}$} & Media & 13,00 & 15,20 & 8,28 & 17,44 & 15,96 & 19,72 & 1,92 & 6,80 & 8,48 & 2,76 & 17,08 & 57,72 \\
\hline & Desv. típ. & 3,830 & 3,819 & 4,532 & 4,900 & 5,342 & 4,878 & 2,040 & 2,915 & 2,988 & 2,006 & 3,487 & 4,542 \\
\hline \multirow{2}{*}{$\begin{array}{l}\text { Sí, acciones } \\
\text { integradas en una } \\
\text { política de RS }\end{array}$} & Media & 11,73 & 14,86 & 9,30 & 16,62 & 16,05 & 21,27 & 1,92 & 6,84 & 8,65 & 2,84 & 18,03 & 58,57 \\
\hline & Desv. típ. & 3,870 & 3,888 & 7,003 & 4,639 & 5,921 & 4,718 & 1,785 & 2,754 & 3,155 & 1,555 & 4,317 & 4,947 \\
\hline \multirow{2}{*}{ TOTAL } & Media & 13,70 & 14,80 & 8,31 & 16,62 & 16,21 & 20,15 & 2,54 & 6,49 & 7,74 & 3,21 & 19,24 & 55,96 \\
\hline & Desv. típ. & 4,197 & 3,907 & 5,632 & 4,203 & 5,321 & 4,644 & 2,041 & 2,707 & 3,013 & 1,977 & 4,264 & 5,331 \\
\hline
\end{tabular}

Cuadro 164: Medidas estadísticas sobre acciones de responsabilidad social, “valores” y liderazgo.

En relación con los datos que ofrece el cuadro 164 incorporado más arriba, hemos indicado, en primer lugar, los aspectos comunes que comparten los líderes procedentes de los cuatro tipos posibles de comportamiento socialmente responsable contemplados en sus empresas de procedencia, así como las tendencias en las que se ven afectados todos o la mayoría de los grupos muestrales.

A continuación hemos tratado los aspectos específicos más destacados que hacen referencia a los líderes en cada uno de los tipos de conducta socialmente responsable considerados.

En relación a las competencias genéricas, rasgos de personalidad y características comportamentales analizadas, todos los líderes, sea cual sea el 
comportamiento socialmente responsable de sus organizaciones de origen, otorgan una mayor relevancia a la competencia genérica "metas" dentro de los seis "valores" analizados.

Además el rasgo de personalidad "practicidad" tiende a perder peso en las decisiones de los líderes a medida que se intensifica el comportamiento socialmente responsable de las empresas de procedencia de los máximos dirigentes (su valor medio decrece de 14,64 a 11,73).

En cuanto a los estilos de liderazgo, en todos los grupos muestrales los estilos participativo y consultivo son los estilos primario y secundario respectivamente. Además ambos estilos tienden a ganar importancia a medida que se incrementa la actuación socialmente responsable de la organización de procedencia del líder: la media del estilo participativo crece de 6,88 a 8,65 (siendo significativamente más alta en los grupos donde existe algún tipo de comportamiento socialmente responsable) y la media del estilo consultivo aumenta de 6,29 a 6,84.

En relación con los estilos, también es destacable que el estilo directivo, aun siendo un estilo con poco peso en las decisiones del líder, tiende a perder relevancia a medida que las organizaciones de procedencia de los líderes incrementan sus actuaciones responsables hasta que son frecuentes o cuentan con una política específica en este campo (su media decrece de 3,07 a 1,92).

En cuento a la flexibilidad y la efectividad, estas presentan un comportamiento inverso a medida que 
aumenta el compromiso organizacional con la Responsabilidad Social Corporativa. La flexibilidad parece tender a disminuir a medida que se intensifica dicho comportamiento (su media decrece de 20,34 en los líderes vinculados a empresas inactivas desde el punto de vista de la responsabilidad social a 17,08 en los máximos responsables procedentes de organizaciones que desarrollan acciones frecuentes), mientras que con la efectividad ocurre al contrario ya que su puntuación media crece de 54,74 a 58,57 a medida que se intensifica la actuación de la organización de origen del máximo cargo en materia de responsabilidad social.

En los líderes procedentes de empresas que no impulsan ningún tipo de iniciativa desde el punto de vista de la responsabilidad social el rasgo de personalidad "practicidad" ha obtenido su valor medio más alto $(14,64)$ así como la característica comportamental "orden y método" (16,64). Por el contrario, los rasgos de personalidad “variedad" $(7,7)$ y “decisión” $(16,18)$ han recibido sus puntuaciones medias más reducidas. También destaca en este grupo muestral la media registrada por los líderes en el estilo delegativo $(3,63)$ que es, al menos, medio punto más alta que la que presenta el mismo estilo en el resto de grupos muestrales.

En los máximos responsables de organizaciones que desarrollan acciones puntuales la competencia genérica "resultados" $(14,53)$ y la característica comportamental 
"orden y método" $(15,44)$ han obtenido su puntuación media más reducida considerando los cuatro grupos muestrales.

En el grupo de los líderes que proceden de empresas que impulsan acciones de responsabilidad social de modo frecuente, la competencia genérica "resultados" $(15,2)$ y el rasgo de personalidad "decisión" $(17,44)$ han registrado su puntuación media más alta en los cuatro grupos contemplados.

En los máximos responsables vinculados a organizaciones que cuentan con una política de Responsabilidad Social Corporativa, el rasgo de personalidad “variedad" $(9,3)$ y la competencia genérica “metas" $(21,27)$ han obtenido su puntaje medio mayor, mientras que el rasgo de personalidad "practicidad" ha registrado su puntuación media menor $(11,73)$. En este grupo también es destacable que la flexibilidad media ha sido casi un punto más alta que en el grupo de líderes cuyo origen son empresas que impulsan acciones de responsabilidad social de modo frecuente.

A continuación hemos incorporado los gráficos 105 y 106 para evaluar, de modo visual, posibles asociaciones en la variación de los rasgos de personalidad, competencias genéricas y características comportamentales estudiadas, considerando también los aspectos analizados del liderazgo, a medida que se intensifica el comportamiento socialmente responsable en las organizaciones. 


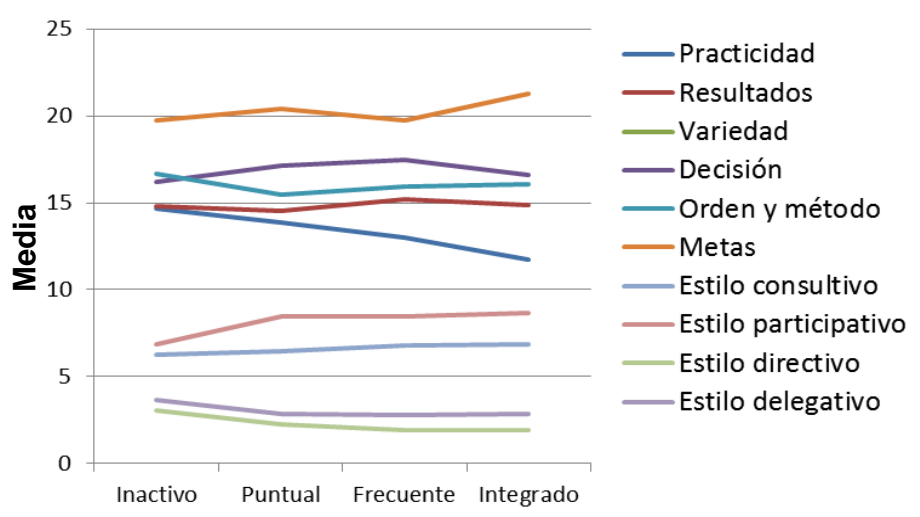

Comportamiento socialmente responsable

Gráfico 105: "Valores”, estilos de liderazgo y acciones de responsabilidad social.

El gráfico 105 muestra como el rasgo de personalidad "practicidad" y los estilos directivo y delegativo tienden a perder relevancia a medida que las organizaciones intensifican su comportamiento socialmente responsable, mientras que los estilos consultivo y participativo $\mathrm{y}$, en menor medida, la competencia genérica “metas" tienden a cobrar más importancia para el líder cuando la empresa intensifica su conducta a favor de la responsabilidad social.

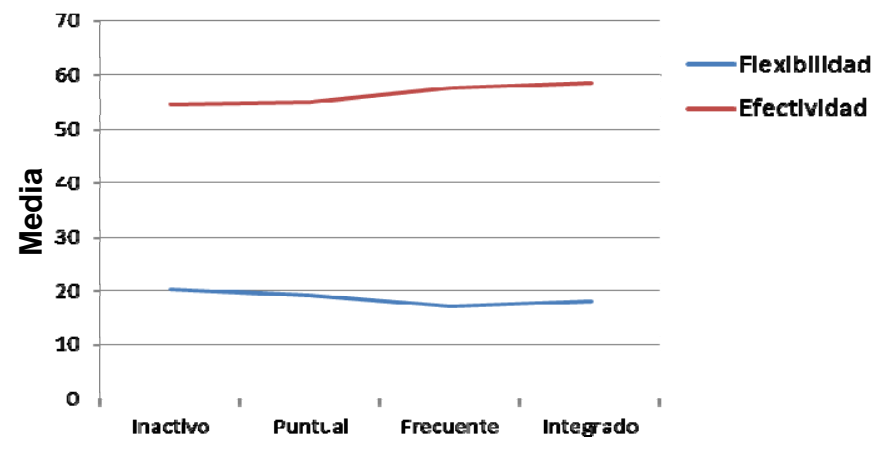

Comportamiento socialmente responsable

Gráfico 106: Flexibilidad, efectividad y acciones de responsabilidad social.

El gráfico 106 refleja, de modo visual, como a medida que aumenta la actuación responsable en las organizaciones 
de procedencia de los líderes, estos tienden a ser menos flexibles y más efectivos.

Es posible que el incremento de la efectividad y la reducción de la flexibilidad en los líderes, a medida que aumenta la intensidad del comportamiento responsable de sus organizaciones de procedencia, tengan algún tipo de incidencia en las asociaciones comentadas en el gráfico 105.

A continuación realizamos una valoración del comportamiento socialmente responsable de la organización en materia formativa, junto con el liderazgo de sus máximos responsables, y considerando al mismo tiempo las competencias genéricas, las características comportamentales y los rasgos de personalidad analizados en el estudio (cuadro 165).

\begin{tabular}{|c|c|c|c|c|c|c|c|c|c|c|c|c|c|}
\hline \multicolumn{2}{|c|}{$\begin{array}{l}\text { Horas de formación en } \\
\text { resp. social }\end{array}$} & \multirow{2}{*}{$\begin{array}{r}\text { Practicidad } \\
13,30\end{array}$} & \multirow{2}{*}{$\begin{array}{r}\text { Resultados } \\
14,50\end{array}$} & \multirow{2}{*}{$\begin{array}{r}\text { Variedad } \\
9,00\end{array}$} & \multirow{2}{*}{$\begin{array}{r}\text { Decisión } \\
16,00\end{array}$} & \multirow{2}{*}{$\begin{array}{r}\begin{array}{c}\text { Orden y } \\
\text { método }\end{array} \\
15,90\end{array}$} & \multirow{2}{*}{\begin{tabular}{c|} 
Metas \\
21,30
\end{tabular}} & \multirow{2}{*}{$\begin{array}{r}\begin{array}{c}\text { Estilo } \\
\text { directivo }\end{array} \\
3,00\end{array}$} & \multirow{2}{*}{$\begin{array}{r}\begin{array}{c}\text { Estilo } \\
\text { consultivo }\end{array} \\
7,70\end{array}$} & \multirow{2}{*}{$\begin{array}{r}\begin{array}{c}\text { Estilo } \\
\text { participativo }\end{array} \\
6,50\end{array}$} & \multirow{2}{*}{$\begin{array}{r}\begin{array}{c}\text { Estilo } \\
\text { delegativo }\end{array} \\
2,80\end{array}$} & \multirow{2}{*}{$\begin{array}{r}\text { Flexibilidad } \\
21,50\end{array}$} & \multirow{2}{*}{$\begin{array}{r}\text { Efectividad } \\
53,10\end{array}$} \\
\hline & Media & & & & & & & & & & & & \\
\hline Tientios de $1 \mathrm{t}$ & Desv. tip. & 3,529 & 4,577 & 5,207 & 3,771 & 3,872 & 4,523 & 1,563 & 1,494 & 1,958 & 1,317 & 3,440 & 2,132 \\
\hline \multirow{2}{*}{ De 11 a 50} & Media & 13,27 & 15,45 & 8,18 & 18,82 & 14,18 & 19,82 & 2,09 & 7,55 & 8,00 & 2,36 & 18,00 & 59,45 \\
\hline & Desv. tip. & 5,551 & 3,328 & 5,288 & 6,274 & 4,813 & 4,400 & 1,868 & 2,423 & 2,864 & 1,362 & 3,795 & 4,865 \\
\hline \multirow{2}{*}{ De 51 a 100} & Media & 12,40 & 15,40 & 12,00 & 18,00 & 14,80 & 17,40 & ,80 & 6,60 & 10,00 & 2,60 & 16,80 & 56,60 \\
\hline & Desv. tip. & 2,191 & 3,362 & 6,819 & 5,000 & 7,050 & 7,335 & ,837 & 1,140 & 3,000 & 1,673 & 4,147 & 5,320 \\
\hline \multirow{2}{*}{ De 101 a 150} & Media & 10,86 & 16,00 & 6,57 & 17,71 & 17,43 & 21,43 & 2,00 & 6,14 & 9,14 & 2,57 & 17,86 & 56,29 \\
\hline & Desv. tip. & 2,340 & 5,831 & 7,913 & 4,152 & 5,224 & 5,028 & 2,082 & 2,610 & 3,024 & 1,512 & 5,367 & 4,192 \\
\hline \multirow{2}{*}{ De 151 a 200} & Media & 14,00 & 12,00 & 10,00 & 22,00 & 9,00 & 23,00 & 4,00 & 3,00 & 12,00 & 1,00 & 16,00 & 66,00 \\
\hline & Desv. tip. & & & & & & & & . & & & & \\
\hline \multirow{2}{*}{ De 201 a 1000} & Media & 7,00 & 19,00 & 6,00 & 23,00 & 13,00 & 20,50 & 3,50 & 5,50 & 8,50 & 2,50 & 21,00 & 57,50 \\
\hline & Desv. típ. & 2,828 & 5,657 &, 000 & 2,828 & 1,414 & 2,121 & ,707 & 2,121 & 707 & 2,121 & 1,414 & 3,536 \\
\hline \multirow{2}{*}{ Más de 1000} & Media & 11,33 & 14,67 & 11,33 & 11,67 & 17,33 & 23,67 & 2,00 & 8,33 & 7,33 & 2,33 & 18,67 & 63,00 \\
\hline & Desv. tip. & 4,041 & 1,528 & 10,408 & 2,517 & 3,786 & 4,509 & 4,041 & 1,528 & 10,408 & 2,517 & 3,786 & 4,509 \\
\hline \multirow{2}{*}{ TOTAL } & Media & 12,28 & 15,33 & 8,77 & 17,54 & 15,33 & 20,59 & 12,28 & 15,33 & 8,77 & 17,54 & 15,33 & 20,59 \\
\hline & Desv. tip. & 1,758 & 2,114 & 2,720 & 1,430 & 4,066 & 5,002 & 4,006 & 4,087 & 6,132 & 5,057 & 4,792 & 4,843 \\
\hline
\end{tabular}

Cuadro 165: Medidas estadísticas sobre formación en responsabilidad social, “valores” y liderazgo.

Antes de realizar una lectura de los datos del cuadro 165 hemos aplicado ANOVA de un factor en dicha 
información para comprobar si existen diferencias estadísticamente significativas entre los diversos grupos muestrales contemplados (cuadro 166).

\begin{tabular}{|c|c|c|c|c|c|c|}
\hline & & Suma de cuadrados & gl & Media cuadrática & $\mathbf{F}$ & Sig. \\
\hline \multirow{3}{*}{ Practicidad } & Inter-grupos & 96,892 & 6 & 16,149 & 1,007 & ,438 \\
\hline & Intra-grupos & 513,006 & 32 & 16,031 & & \\
\hline & Total & 609,897 & 38 & & & \\
\hline \multirow{3}{*}{ Resultados } & Inter-grupos & 49,573 & 6 & 8,262 & ,452 & ,838 \\
\hline & Intra-grupos & 585,094 & 32 & 18,284 & & \\
\hline & Total & 634,667 & 38 & & & \\
\hline \multirow{3}{*}{ Variedad } & Inter-grupos & 126,906 & 6 & 21,151 & ,520 & ,789 \\
\hline & Intra-grupos & 1302,017 & 32 & 40,688 & & \\
\hline & Total & 1428,923 & 38 & & & \\
\hline \multirow{3}{*}{ Decisión } & Inter-grupos & 225,961 & 6 & 37,660 & 1,616 & , 175 \\
\hline & Intra-grupos & 745,732 & 32 & 23,304 & & \\
\hline & Total & 971,692 & 38 & & & \\
\hline \multirow{3}{*}{ Orden y método } & Inter-grupos & 112,949 & 6 & 18,825 & ,793 &, 582 \\
\hline & Intra-grupos & 759,717 & 32 & 23,741 & & \\
\hline & Total & 872,667 & 38 & & & \\
\hline \multirow{3}{*}{ Metas } & Inter-grupos & 101,619 & 6 & 16,936 & ,686 & ,662 \\
\hline & Intra-grupos & 789,817 & 32 & 24,682 & & \\
\hline & Total & 891,436 & 38 & & & \\
\hline \multirow{3}{*}{ Estilo directivo } & Inter-grupos & 23,227 & 6 & 3,871 & 1,315 & ,279 \\
\hline & Intra-grupos & 94,209 & 32 & 2,944 & & \\
\hline & Total & 117,436 & 38 & & & \\
\hline \multirow{3}{*}{ Estilo consultivo } & Inter-grupos & 39,846 & 6 & 6,641 & 1,634 & , 170 \\
\hline & Intra-grupos & 130,051 & 32 & 4,064 & & \\
\hline & Total & 169,897 & 38 & & & \\
\hline \multirow{3}{*}{$\begin{array}{l}\text { Estilo } \\
\text { participativo }\end{array}$} & Inter-grupos & 68,553 & 6 & 11,426 & 1,720 & , 148 \\
\hline & Intra-grupos & 212,524 & 32 & 6,641 & & \\
\hline & Total & 281,077 & 38 & & & \\
\hline \multirow{3}{*}{ Estilo delegativo } & Inter-grupos & 3,517 & 6 & ,586 & ,253 & ,955 \\
\hline & Intra-grupos & 74,226 & 32 & 2,320 & & \\
\hline & Total & 77,744 & 38 & & & \\
\hline \multirow{3}{*}{ Flexibilidad } & Inter-grupos & 123,535 & 6 & 20,589 & 1,305 & ,283 \\
\hline & Intra-grupos & 504,824 & 32 & 15,776 & & \\
\hline & Total & 628,359 & 38 & & & \\
\hline \multirow{3}{*}{ Efectividad } & Inter-grupos & 410,167 & 6 & 68,361 & 4,045 &, 004 \\
\hline & Intra-grupos & 540,756 & 32 & 16,899 & & \\
\hline & Total & 950,923 & 38 & & & \\
\hline
\end{tabular}

Cuadro 166: Tabla ANOVA de "valores" y liderazgo, Horas de Formación en Responsabilidad Social.

Los resultados del cuadro 166 revelan la existencia de diferencias estadísticamente significativas entre los diversos 
grupos muestrales en relación con "efectividad" (su coeficiente de significación es 0,004).

En el análisis de la información que ofrece el cuadro 165 no hemos contemplado, por su escasa representatividad, aquellos grupos muestrales en los que solo se ha registrado información de un líder.

Hemos indicado, en primer término, la información que hace referencia a aspectos generales del cuadro $165 \mathrm{y}$, a continuación, hemos mencionado aspectos destacables de algunos de los grupos muestrales.

En todos los líderes, sea cual sea el número de horas que sus organizaciones de origen destinan a acciones formativas encuadradas en el ámbito de la responsabilidad social, la competencia genérica "metas" ha sido el "valor" que ha obtenido una puntuación media más alta dentro de los rasgos de personalidad, competencias genéricas y características comportamentales estudiadas. En esta observación no se contempla una excepción: los líderes vinculados a empresas que destinan a sus cursos de formación sobre responsabilidad social de 201 a 1000 horas, en los que el rasgo de personalidad “decisión” ha obtenido una puntuación media mayor (23).

En los líderes cuyas organizaciones dedican el menor número de horas a acciones formativas enmarcadas en el ámbito de la responsabilidad social, la competencia 
genérica "resultados" ha registrado su valor medio menor $(14,5)$, así como el estilo de liderazgo participativo $(6,5)$ y la efectividad $(53,1)$. Por el contrario, la flexibilidad ha obtenido su puntuación media más alta en estos líderes $(21,5)$.

En los máximos responsables vinculados a organizaciones que destinan entre 51 y 100 horas a acciones de formación sobre responsabilidad social, el rasgo de personalidad "variedad" (12) ha registrado su valor medio más alto así como el estilo participativo (10).

En los líderes cuyo origen son empresas que destinan entre 201 y 1000 horas a acciones de formación encuadradas en el ámbito de la responsabilidad social el rasgo de personalidad “decisión" (23) y la competencia genérica "resultados" (19) han registrado su valor medio más elevado. Al contrario, estos máximos dirigentes han obtenido su puntación media más baja en el estilo consultivo $(5,5)$ así como en los rasgos de personalidad “practicidad” (7) y “variedad” (6), y en la característica comportamental “orden y método" (13).

En los máximos responsables cuyo origen son organizaciones que desarrollan acciones de formación cuya duración supera las 1000 horas, el rasgo de personalidad "practicidad" $(11,33)$ ha obtenido su puntuación media más elevada así como la característica comportamental "orden y método" $(17,33)$, la competencia genérica “metas” $(23,67)$, el estilo consultivo $(8,33)$ y la efectividad $(63)$. En estos 
líderes, el rasgo de personalidad "decisión" $(11,67)$ ha registrado su valor medio más reducido.

Hemos incluido a continuación los gráficos 107 y 108 para verificar de manera visual si es posible percibir algún tipo de asociación en la variación de las competencias genéricas, los rasgos de personalidad y las características comportamentales que hemos analizado considerando, al mismo tiempo, el liderazgo y la actuación formativa en materia de responsabilidad social por parte de las organizaciones de procedencia de los líderes.

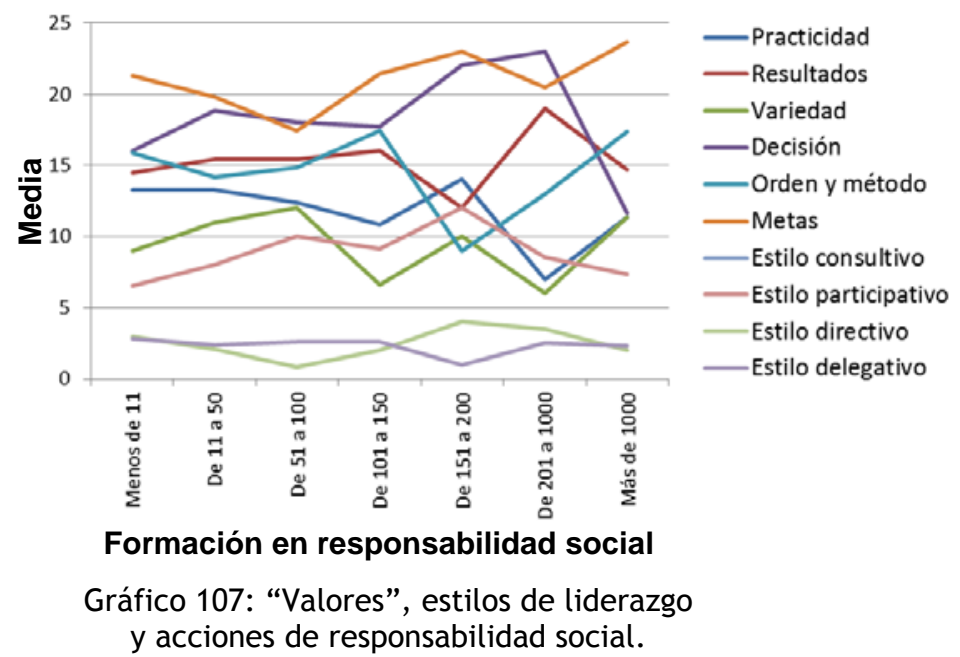

La información que ofrece el gráfico 107 muestra como a medida que se incrementan las horas que las organizaciones invierten en acciones de formación enmarcadas en el ámbito de la responsabilidad social no se aprecia una tendencia de variación constante en las otras variables consideradas excepto, en parte, en la competencia genérica "metas", cuya relevancia para el 
líder tiende a aumentar a medida que las empresas incrementan la duración de las iniciativas formativas enmarcadas en el ámbito de la responsabilidad social.

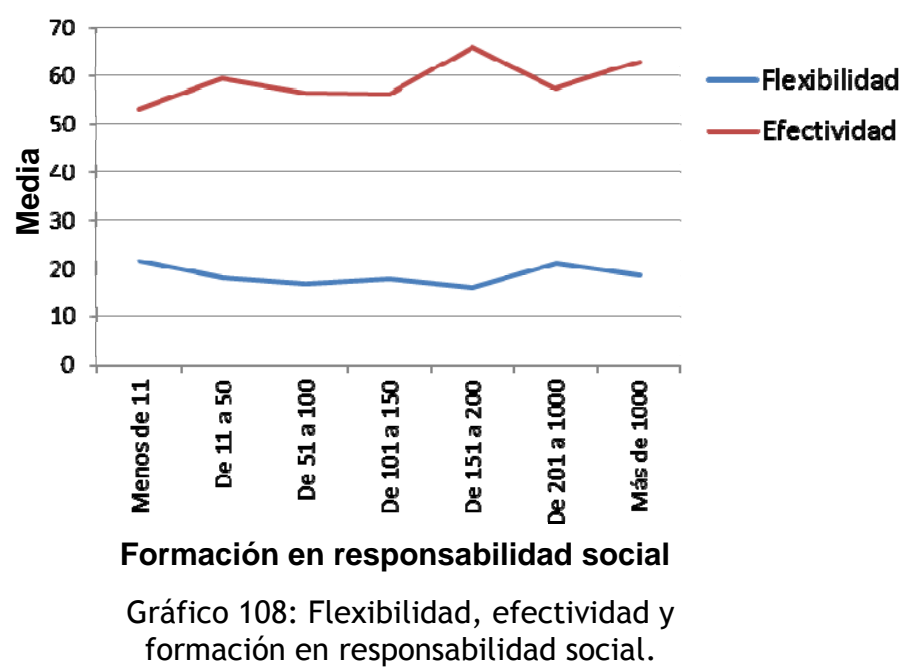

El gráfico 108 permite observar como el liderazgo de los máximos responsables parece volverse más efectivo según aumentan las horas que las organizaciones invierten en acciones formativas sobre Responsabilidad Social Corporativa.

En este sentido la competencia genérica "metas" y la efectividad de estilo parecen estar asociadas, de forma positiva, al incremento de la formación afín a la responsabilidad social que las organizaciones de procedencia de los líderes dirigen a sus públicos internos. 


\subsection{REVISIÓN DE LA MEDIDA}

\subsubsection{Relación entre los valores personales}

\begin{tabular}{|l|l|r|r|r|r|r|r|}
\hline & & Practicidad & Resultados & Variedad & Decisión & Orden y método & Metas \\
\hline \multirow{3}{*}{ Practicidad } & Cor. de Pearson & 1 &,- 149 &, 012 &,- 395 &,- 136 &,- 282 \\
\cline { 2 - 9 } & Sig. (bilateral) & &, 041 &, 875 &, 000 &, 062 &, 000 \\
\hline \multirow{3}{*}{ Resultados } & Cor. de Pearson &,- 149 & 1 &,- 028 &, 238 &,- 432 &,- 323 \\
\cline { 2 - 9 } & Sig. (bilateral) &, 041 & &, 705 &, 001 &, 000 &, 000 \\
\hline \multirow{3}{*}{ Variedad } & Cor. de Pearson &, 012 &,- 028 & 1 &,- 119 &,- 446 &,- 538 \\
\cline { 2 - 9 } & Sig. (bilateral) &, 875 &, 705 & &, 103 &, 000 &, 000 \\
\hline \multirow{3}{*}{ Decisión } & Cor. de Pearson &,- 395 &, 238 &,- 119 & 1 &,- 422 &,- 083 \\
\cline { 2 - 9 } & Sig. (bilateral) &, 000 &, 001 &, 103 & &, 000 &, 256 \\
\hline \multirow{3}{*}{ Orden y método } & Cor. de Pearson &,- 136 &,- 432 &,- 446 &,- 422 & 1 &, 226 \\
\cline { 2 - 8 } & Sig. (bilateral) &, 062 &, 000 &, 000 &, 000 &,- 000 &, 002 \\
\hline \multirow{2}{*}{ Metas } & Cor. de Pearson &,- 282 &,- 323 &,- 538 &,- 083 &, 226 & 1 \\
\cline { 2 - 8 } & Sig. (bilateral) &, 000 &, 000 &, 000 &, 256 &, 002 & \\
\hline
\end{tabular}

Cuadro 167: Correlaciones bivariadas entre “valores” personales.

El análisis de las correlaciones entre las competencias genéricas, la característica comportamental y los rasgos de personalidad considerados en el estudio (cuadro 167) ha permitido detectar relaciones intensas entre las variables (mayores del valor +5 o menores del valor -5 ) y también establecer entre las mismas otras correlaciones de menor intensidad (entre los valores 3 y 5 o entre los valores -3 y $-5)$.

La relación más intensa, e inversa en este caso $(-0,538)$, se ha dado entre el rasgo de personalidad "variedad" y la característica comportamental "metas". 
Hemos considerado que esta relación indica que los líderes orientados hacia objetivos muy definidos tienen preferencia por centrarse en dichas tareas antes que ampliar el ámbito de sus actividades, y que los máximos responsables que muestran preferencia por romper su rutina y ampliar el abanico de sus cometidos tratan de evitar que su esfuerzo se centre, de modo exclusivo, en tareas bien delimitadas.

Las correlaciones también han permitido establecer otras relaciones de menor intensidad e inversas entre algunas de las variables estudiadas.

Una de estas relaciones es la que se ha producido entre el rasgo de personalidad "practicidad" y “decisión" $(-0,395)$. Se trata de una relación inversa que ha resultado, en cierto sentido, sorprendente ya que esperábamos encontrar una correlación directa entre ambas variables. Habíamos supuesto que los líderes más centrados en la utilidad de sus tareas tendrían preferencia, en cierto grado, por la toma rápida de decisiones. Sin embargo los datos han indicado, en alguna medida, que el líder que prefiere centrarse en actividades útiles a corto plazo no suele tomar decisiones rápidas y con firmeza.

Otra de estas relaciones inversas se ha registrado entre la competencia genérica "resultados" y la característica comportamental “orden y método" (-432). Hemos entendido que esta correspondencia indica que cuanto menos metódico es el líder más orientado está, en 
cierto grado, a la superación y a la búsqueda de la perfección en sus cometidos.

También se ha registrado una correlación entre las competencias genéricas "metas" y "resultados" (-323). De nuevo se ha tratado de una relación, en cierto sentido, no esperada. Habíamos supuesto que los líderes que tienen más preferencia, en alguna medida, por centrarse en objetivos bien delimitados serían más proclives a la búsqueda de la excelencia en cualquier tarea de la que se ocuparan.

Otra relación entre las variables es la que se ha producido entre el rasgo de personalidad "variedad" y la característica comportamental “orden y método" (-446). Esta correspondencia manifiesta que cuanta más preferencia por hacer cosas nuevas y diferentes presenta el líder, este tiende a ser menos metódico, en cierto grado, en la resolución de sus tareas.

La última correlación menos intensa que hemos detectado es la que se ha producido entre el rasgo de personalidad "decisión” y la característica comportamental “orden y método" (-442). Esta correspondencia indica que cuanta más preferencia muestra un líder por tomar decisiones rápidamente e ir directamente al tema que debe afrontar, tiene menos tendencia, en alguna medida, a ser ordenado y tener hábitos de trabajo muy definidos. 


\subsubsection{Relaciones entre los estilos de liderazgo}

\begin{tabular}{|c|c|c|c|c|c|}
\hline & & $\begin{array}{l}\text { Estilo directivo } \\
\text { (alta dirección y } \\
\text { poco apoyo) }\end{array}$ & $\begin{array}{l}\text { Estilo consultivo } \\
\text { (alta dirección y } \\
\text { mucho apoyo) }\end{array}$ & $\begin{array}{l}\text { Estilo participativo } \\
\text { (alto apoyo y poca } \\
\text { dirección) }\end{array}$ & $\begin{array}{c}\text { Estilo delegativo } \\
\text { (poco apoyo y baja } \\
\text { dirección) }\end{array}$ \\
\hline \multirow{2}{*}{$\begin{array}{c}\text { Estilo } \\
\text { directivo }\end{array}$} & Correlación de Pearson & 1 &,- 085 &,- 593 &,- 019 \\
\hline & Sig. (bilateral) & & ,245 &, 000 & 800 \\
\hline \multirow{2}{*}{$\begin{array}{c}\text { Estilo } \\
\text { consultivo }\end{array}$} & Correlación de Pearson &,- 085 & 1 &,- 459 &,- 477 \\
\hline & Sig. (bilateral) & ,245 & & ,000 &, 000 \\
\hline \multirow{2}{*}{$\begin{array}{c}\text { Estilo } \\
\text { participativo }\end{array}$} & Correlación de Pearson &,- 593 &,- 459 & 1 &,- 202 \\
\hline & Sig. (bilateral) & ,000 &, 000 & &, 005 \\
\hline \multirow{2}{*}{$\begin{array}{c}\text { Estilo } \\
\text { delegativo }\end{array}$} & Correlación de Pearson &,- 019 &,- 477 &,- 202 & 1 \\
\hline & Sig. (bilateral) & ,800 &, 000 &, 005 & \\
\hline
\end{tabular}

Cuadro 168: Correlaciones bivariadas entre estilos de liderazgo.

Los datos del cuadro 168 han permitido establecer una relación intensa e inversa entre el estilo directivo y participativo $(-0,593)$. Es una correlación muy lógica porque hace referencia a estilos de dirección inversos: en un caso con alta dirección y poco apoyo, y en otro con mucho impulso motivacional y poca instrucción.

El análisis de las correlaciones también ha permitido detectar otras dos relaciones de menor intensidad e inversas.

Una es la que se ha registrado entre el estilo consultivo y participativo $(-0,459)$. Se trata de los estilos secundario y primario utilizados por los líderes que han participado en la investigación. La comprensión de la correspondencia inversa podría explicarse por el contenido que no comparten ambos estilos directivos: la disposición a dar directrices a los colaboradores. Mientras en el estilo 
consultivo están presentes las indicaciones y la preocupación emocional del colaborador, en el estilo participativo pierde protagonismo el primero de estos dos aspectos y el máximo responsable centra su actuación en impulsar la motivación del colaborador.

Otra correlación es la que se ha producido entre el estilo consultivo y delegativo $(-0,477)$. Hemos considerado que también se trata de una relación muy lógica porque hace referencia a dos estilos de liderazgo inversos: en un caso con alto peso de la dirección y mucho apoyo (consultivo), y en otro con poca instrucción y reducido impulso (delegativo).

\subsubsection{Relación entre la flexibilidad y el estilo de liderazgo}

\begin{tabular}{|r|l|r|r|r|r|}
\hline \multicolumn{2}{|c|}{} & $\begin{array}{c}\text { Estilo } \\
\text { directivo } \\
\text { (alta dirección } \\
\text { y poco apoyo) }\end{array}$ & $\begin{array}{c}\text { Estilo } \\
\text { consultivo } \\
\text { (alta dirección y } \\
\text { mucho apoyo) }\end{array}$ & $\begin{array}{c}\text { Estilo } \\
\text { participativo } \\
\text { (alto apoyo y poca } \\
\text { dirección) }\end{array}$ & $\begin{array}{c}\text { Estilo } \\
\text { delegativo } \\
\text { (poco apoyo y } \\
\text { baja dirección) }\end{array}$ \\
\hline \multirow{2}{*}{ Flexibilidad } & Correlación de Pearson &, 661 &,- 101 &,- 588 &, 332 \\
\cline { 2 - 6 } & Sig. (bilateral) &, 000 &, 168 &, 000 &, 000 \\
\hline
\end{tabular}

Cuadro 169: Correlaciones bivariadas entre estilos de liderazgo y flexibilidad.

El análisis de las correlaciones entre la flexibilidad y los estilos de liderazgo (cuadro 169) ha permitido establecer una relación intensa y dos de menor intensidad entre las variables consideradas.

La relación más intensa y de tipo directo, es la que se ha registrado entre el estilo directivo y la flexibilidad $(0,661)$. Hemos interpretado que esta fuerte correlación 
indica que los líderes que utilizan en mayor medida el estilo directivo precisan, en mayor grado que el resto de líderes, de la utilización de otros estilos de liderazgo para desempeñar con eficacia su rol. Es posible que el desgaste que puede suponer para el colaborador la utilización preferente de un estilo centrado en las instrucciones, sobre todo con colaboradores cuya estabilidad emocional no sea plenamente satisfactoria, pueda requerir la utilización de otros estilos de liderazgo en los que haya más preocupación emocional por la persona (consultivo y participativo) o mayor libertad (delegativo).

De una intensidad algo menor, aunque también alta y en este caso de tipo inverso, se ha producido una correlación entre el estilo participativo y la flexibilidad $(-0,588)$. Hemos entendido que este resultado indica que los líderes más propensos a centrarse en el apoyo emocional son menos proclives a utilizar otros estilos de liderazgo. Hemos considerado que esta correspondencia refleja que los líderes que utilizan en mayor medida el estilo participativo precisan, en menor grado que el resto de líderes, de la utilización de otros estilos de liderazgo para desempeñar con eficacia su rol.

La última relación registrada entre el estilo delegativo y la flexibilidad es más débil que las dos anteriores y directa $(-0,332)$. Hemos supuesto que esta correspondencia indica que el líder más dispuesto a “dejar hacer” presenta, en cierto grado, menos predisposición por utilizar otros estilos de liderazgo. 0 , en otras palabras, que el estilo de liderazgo 
delegativo parece inhibir, en cierta medida, la utilización de otros estilos de liderazgo.

\subsubsection{Relación entre la efectividad y el estilo de liderazgo}

\begin{tabular}{|c|l|r|r|r|r|}
\hline \multicolumn{2}{|c|}{} & $\begin{array}{c}\text { Estilo } \\
\text { directivo } \\
\text { (alta dirección } \\
\text { y poco apoyo) }\end{array}$ & $\begin{array}{c}\text { Estilo } \\
\text { consultivo } \\
\text { (alta dirección y } \\
\text { mucho apoyo) }\end{array}$ & $\begin{array}{c}\text { Estilo } \\
\text { participativo } \\
\text { (alto apoyo y poca } \\
\text { dirección) }\end{array}$ & $\begin{array}{c}\text { Estilo } \\
\text { delegativo } \\
\text { (poco apoyo y } \\
\text { baja dirección) }\end{array}$ \\
\hline \multirow{2}{*}{ Efectividad } & Correlación de Pearson &,- 171 &, 053 &, 174 &,- 186 \\
\cline { 2 - 7 } & Sig. (bilateral) &, 018 &, 473 &, 017 &, 010 \\
\hline
\end{tabular}

Cuadro 170: Correlaciones bivariadas entre estilos de liderazgo y efectividad.

La información que muestra el cuadro 170 no ha permitido establecer relaciones significativas entre la efectividad y el estilo directivo.

\subsubsection{Relación entre la flexibilidad y la efectividad en el estilo de liderazgo}

\begin{tabular}{|l|l|r|r|}
\hline \multicolumn{2}{|c|}{} & Flexibilidad de estilo & Efectividad de estilo \\
\hline \multirow{3}{*}{ Flexibilidad de estilo } & Correlación de Pearson & 1 &,- 217 \\
\cline { 2 - 4 } & Sig. (bilateral) & &, 003 \\
\hline \multirow{2}{*}{ Efectividad de estilo } & Correlación de Pearson &,- 217 & 1 \\
\cline { 2 - 4 } & Sig. (bilateral) &, 003 & \\
\hline
\end{tabular}

Cuadro 171: Correlaciones bivariadas entre flexibilidad y efectividad en el ejercicio del liderazgo.

Los datos del cuadro 171 no han revelado la existencia de relaciones de intensidad alta o moderada entre la efectividad y la flexibilidad en el ejercicio del liderazgo. 
Se ha registrado una leve correlación (de 2 a 3 y de -2 $y-3)$, en este caso inversa, entre ambas variables $(-0,217)$ que también se ha reflejado en los resultados de la investigación. Al analizar la relación entre el liderazgo y la responsabilidad social, veíamos como a medida que se intensificaba la actitud de los líderes a favor de la responsabilidad social también tendía a producirse una reducción de su flexibilidad de estilo y un aumento de su eficacia en el ejercicio del liderazgo. Es decir, ambas variables parecen mostrar un cierto comportamiento inverso.

\subsubsection{Relaciones entre la actitud y los valores personales}

\begin{tabular}{|c|l|r|r|r|r|r|r|}
\hline \multicolumn{2}{|c|}{} & Practicidad & Resultados & Variedad & Decisión & $\begin{array}{c}\text { Orden y } \\
\text { método }\end{array}$ & Metas \\
\hline $\begin{array}{c}\text { Actitud hacia } \\
\text { la RS }\end{array}$ & Correlación de Pearson &,- 086 &, 033 &,- 050 &, 022 &,- 004 &, 097 \\
\cline { 2 - 8 } & Sig. (bilateral) &, 241 &, 649 &, 498 &, 759 &, 953 &, 182 \\
\hline
\end{tabular}

Cuadro 172: Correlaciones bivariadas entre "valores" personales y actitud hacia la responsabilidad social.

La información del cuadro 172 sobre el estudio de correlaciones entre la actitud hacia la responsabilidad social y las competencias genéricas consideradas en la investigación (metas y resultados), los rasgos de personalidad contemplados (practicidad, decisión y variedad) y la característica comportamental analizada (orden y método), no ha permitido establecer relaciones significativas (ni intensas, ni de menor intensidad, ni leves). 


\subsubsection{Relaciones entre la actitud y el estilo de liderazgo}

\begin{tabular}{|c|l|r|r|r|r|}
\hline \multicolumn{2}{|c|}{} & $\begin{array}{c}\text { Estilo } \\
\text { directivo } \\
\text { (alta dirección y } \\
\text { poco apoyo) }\end{array}$ & $\begin{array}{c}\text { Estilo } \\
\text { consultivo } \\
\text { (alta dirección y } \\
\text { mucho apoyo) }\end{array}$ & $\begin{array}{c}\text { Estilo } \\
\text { participativo } \\
\text { (alto apoyo y poca } \\
\text { dirección) }\end{array}$ & $\begin{array}{c}\text { Estilo } \\
\text { delegativo } \\
\text { (poco apoyo y } \\
\text { baja dirección) }\end{array}$ \\
\hline $\begin{array}{c}\text { Actitud } \\
\text { hacia la } \\
\text { RS }\end{array}$ & Correlación de Pearson &,- 248 &, 046 &, 143 &,- 035 \\
\cline { 2 - 6 } & Sig. (bilateral) &, 001 &, 528 &, 050 &, 632 \\
\hline
\end{tabular}

Cuadro 173: Correlaciones bivariadas entre estilos de liderazgo y actitud hacia la responsabilidad social.

Los datos del cuadro superior (173) no han revelado la existencia de relaciones de intensidad alta ni moderada entre los estilos de liderazgo y la actitud hacia la responsabilidad social en los máximos responsables empresariales.

Se ha registrado una leve relación inversa entre el estilo directivo y la actitud a favor de la Responsabilidad Social Corporativa $(-0,217)$. En cierto sentido, aunque la relación es poco intensa, hemos entendido que esta correlación indica que el liderazgo centrado de modo exclusivo en la instrucción, y que descarta la utilización del apoyo en el ejercicio del liderazgo, es el que más se aleja de la filosofía que representa la Responsabilidad Social Corporativa.

La hipótesis formulada guarda correspondencia con los resultados alcanzados en esta investigación. Cuando hemos analizado el liderazgo y la Responsabilidad Social Corporativa, hemos comprobado como el estilo directivo tenía una tendencia a reducir su importancia en el 
comportamiento del líder, aunque es un estilo con poco peso en su toma de decisiones, a medida que se intensificaba la actitud del máximo responsable a favor de la responsabilidad social.

\subsubsection{Relaciones entre el estilo de liderazgo y los valores personales}

\begin{tabular}{|c|l|r|r|r|r|r|r|}
\hline \multicolumn{2}{|c|}{} & Practicidad & Resultados & Variedad & Decisión & $\begin{array}{c}\text { Orden y } \\
\text { método }\end{array}$ & Metas \\
\hline \multirow{2}{*}{$\begin{array}{c}\text { Estilo } \\
\text { directivo }\end{array}$} & Correlación de Pearson &, 119 &, 007 &,- 014 &,- 084 &, 028 &,- 056 \\
\cline { 2 - 8 } & Sig. (bilateral) &, 104 &, 920 &, 848 &, 248 &, 703 &, 445 \\
\hline \multirow{2}{*}{$\begin{array}{c}\text { Estilo } \\
\text { consultivo }\end{array}$} & Correlación de Pearson &, 053 &, 006 &, 074 &, 039 &,- 053 &,- 114 \\
\cline { 2 - 8 } & Sig. (bilateral) &, 471 &, 939 &, 313 &, 594 &, 473 &, 120 \\
\hline $\begin{array}{c}\text { Estilo } \\
\text { participativo }\end{array}$ & Correlación de Pearson &,- 159 &,- 020 &,- 006 &, 126 &,- 080 &, 142 \\
\cline { 2 - 8 } & Sig. (bilateral) &, 029 &, 782 &, 940 &, 083 &, 277 &, 051 \\
\hline $\begin{array}{c}\text { Estilo } \\
\text { delegativo }\end{array}$ & Correlación de Pearson &, 022 &,- 044 &, 051 &,- 135 &, 124 &,- 063 \\
\cline { 2 - 8 }$y$ & Sig. (bilateral) &, 769 &, 551 &, 489 &, 064 &, 090 &, 392 \\
\hline
\end{tabular}

Cuadro 174: Correlaciones bivariadas entre estilos de liderazgo y “valores” personales.

La información sobre el análisis de las correlaciones que aporta el cuadro 174 no ha permitido establecer relaciones significativas entre los estilos de liderazgo analizados en el estudio (directivo, consultivo, participativo y delegativo) y la característica comportamental (orden y método), las competencias genéricas (metas y resultados) y los rasgos de personalidad considerados en la investigación (practicidad, decisión y variedad). 


\subsubsection{Relaciones entre la actitud hacia la}

responsabilidad social y los ítems de control

\begin{tabular}{|c|c|c|c|c|c|c|}
\hline & & & $\begin{array}{l}\text { Conseguir que } \\
\text { mi organización } \\
\text { sea rentable }\end{array}$ & $\begin{array}{l}\text { Desarrollar } \\
\text { políticas de RS en } \\
\text { mi organización }\end{array}$ & $\begin{array}{l}\text { Conseguir que mi } \\
\text { organización sea } \\
\text { líder en el mercado }\end{array}$ & $\begin{array}{l}\text { Actitud } \\
\text { hacia } \\
\text { la RS }\end{array}$ \\
\hline \multirow{8}{*}{$\begin{array}{c}\text { Tau_b de } \\
\text { Kendall }\end{array}$} & \multirow{2}{*}{$\begin{array}{l}\text { Conseguir que mi } \\
\text { organización sea } \\
\text { rentable }\end{array}$} & Coef. de correlación & 1,000 &,- 311 &,- 331 & ,008 \\
\hline & & Sig. (bilateral) & . &, 000 &, 000 & ,898 \\
\hline & \multirow{2}{*}{$\begin{array}{l}\text { Desarrollar políticas } \\
\text { de RS en mi } \\
\text { organización } \\
\end{array}$} & Coef. de correlación &,- 311 & 1,000 &,- 632 &,- 115 \\
\hline & & Sig. (bilateral) &, 000 & &, 000 &, 071 \\
\hline & \multirow{2}{*}{$\begin{array}{l}\text { Conseguir que mi } \\
\text { organización sea } \\
\text { líder en el mercado }\end{array}$} & Coef. de correlación &,- 331 &,- 632 & 1,000 & ,114 \\
\hline & & Sig. (bilateral) &, 000 &, 000 & . & ,076 \\
\hline & \multirow{2}{*}{ Actitud hacia la RS } & Coef. de correlación &, 008 &,- 115 & ,114 & 1,000 \\
\hline & & Sig. (bilateral) & ,898 & ,071 & 076 & \\
\hline \multirow{8}{*}{$\begin{array}{l}\text { Rho de } \\
\text { Spearman }\end{array}$} & \multirow{2}{*}{$\begin{array}{l}\text { Conseguir que mi } \\
\text { organización sea } \\
\text { rentable }\end{array}$} & Coef. de correlación & 1,000 &,- 349 &,- 370 &, 009 \\
\hline & & Sig. (bilateral) & &, 000 &, 000 & 901 \\
\hline & \multirow{2}{*}{$\begin{array}{l}\text { Desarrollar políticas } \\
\text { de RS en mi } \\
\text { organización }\end{array}$} & Coef. de correlación &,- 349 & 1,000 &,- 708 &,- 128 \\
\hline & & Sig. (bilateral) &, 000 & &, 000 &, 080 \\
\hline & \multirow{2}{*}{$\begin{array}{l}\text { Conseguir que mi } \\
\text { organización sea } \\
\text { líder en el mercado }\end{array}$} & Coef. de correlación &,- 370 &,- 708 & 1,000 & , 130 \\
\hline & & Sig. (bilateral) &, 000 & ,000 & . & 075 \\
\hline & \multirow{2}{*}{ Actitud hacia la RS } & Coef. de correlación &, 009 &,- 128 & , 130 & 1,000 \\
\hline & & Sig. (bilateral) & ,901 &, 080 & ,075 & \\
\hline
\end{tabular}

Cuadro 175: Correlaciones bivariadas entre la actitud hacia la responsabilidad social y los ítems de control sobre la actitud.

Los datos que muestra el cuadro 175 han permitido establecer una relación muy intensa y de tipo inverso entre dos ítem: "desarrollar políticas de responsabilidad social en mi organización” y "conseguir que mi organización sea líder en el mercado" $(-0,632$ en Tau b de Kendall y $-0,708$ en Rho de Spearman).

Hemos entendido que esta correspondencia indica que la búsqueda del liderazgo en el mercado no se relaciona con el ejercicio de la responsabilidad social. Es posible que el “cortoplacismo" en la búsqueda de esta posición destacada desplace la apuesta por la responsabilidad social, cuyos 
beneficios tienen un carácter más estratégico y una orientación mayor al largo plazo.

Las correlaciones también han permitido establecer dos relaciones de intensidad débil e inversas.

Una es la que se ha registrado entre el ítem "conseguir que mi organización sea rentable" y el ítem "desarrollar políticas de responsabilidad social en mi organización" ( $-0,311$ en Tau b de Kendall y $-0,349$ en Rho de Spearman). Hemos considerado que esta relación está explicada, en cierto sentido, por una visión negativa de la responsabilidad social, donde esta es entendida como un recurso incapaz de generar valor a las organizaciones.

Otra correlación es la que se ha producido entre el ítem "conseguir que mi organización sea rentable" y el ítem "conseguir que mi organización sea líder en el mercado" ( $-0,331$ en Tau b de Kendall y $-0,370$ en Rho de Spearman). Hemos entendido que esta correlación podría estar explicada, en cierta medida, por un cierto antagonismo en algunos planteamientos de la concepción de la rentabilidad empresarial donde no se contempla la conquista de la excelencia en el mercado. Esta hipótesis, claro está, no hace referencia al ámbito de actuación de las empresas que compiten en sectores en los que la variable más sensible del marketing es el precio reducido. 


\subsubsection{Relación entre la formación en}

\section{responsabilidad social y el desarrollo de acciones en responsabilidad social}

\begin{tabular}{|c|c|c|c|c|}
\hline & & & Formación en RS & Acciones de RS \\
\hline \multirow{4}{*}{ Tau_b de Kendall } & \multirow{2}{*}{ Formación en RS } & Coeficiente de correlación & 1,000 & 175 \\
\hline & & Sig. (bilateral) & & 205 \\
\hline & \multirow{2}{*}{ Acciones de RS } & Coeficiente de correlación & 175 & 1,000 \\
\hline & & Sig. (bilateral) & 205 & \\
\hline \multirow{4}{*}{ Rho de Spearman } & \multirow{2}{*}{ Formación en RS } & Coeficiente de correlación & 1,000 & ,206 \\
\hline & & Sig. (bilateral) & & ,209 \\
\hline & \multirow{2}{*}{ Acciones de RS } & Coeficiente de correlación & ,206 & 1,000 \\
\hline & & Sig. (bilateral) & 209 & \\
\hline
\end{tabular}

Cuadro 176: Correlaciones bivariadas entre la formación en responsabilidad social y las acciones de responsabilidad social.

La información que ofrece el cuadro 176 no ha revelado la existencia de relaciones de intensidad alta o moderada entre las acciones formativas enmarcadas en el ámbito de la responsabilidad social que impulsan las organizaciones y la actuación en materia de Responsabilidad Social Corporativa que desarrollan las empresas.

Se ha registrado una leve correlación directa y positiva (0,175 en Tau b de Kendall y 0,206 en Rho de Spearman) entre las empresas que han realizado acciones de responsabilidad social y las que han desarrollado acciones formativas en este ámbito.

Este resultado parece indicar que parte de las organizaciones que impulsan acciones en el ámbito de la responsabilidad social (el $51,9 \%$ de las empresas de procedencia de los líderes entrevistados en el estudio) 
también desarrollan acciones formativas en este campo (el $20,6 \%$ de las organizaciones de origen de los líderes que han participado en la investigación) o viceversa, que algunas de las empresas que ponen en marcha cursos para formar a sus colaboradores sobre Responsabilidad Social Corporativa también desarrollan actuaciones relacionadas con esta disciplina.

Para profundizar en esta observación hemos incorporado el cuadro 177 con información sobre el desarrollo de acciones de responsabilidad social en las organizaciones y el impulso de iniciativas formativas sobre esta materia.

\begin{tabular}{|c|c|c|c|c|c|c|c|c|c|c|}
\hline & & & \multicolumn{7}{|c|}{ Horas de formación en responsabilidad social } & \multirow{2}{*}{ Total } \\
\hline & & & Menos de 11 & De 11 a 50 & De 51 a 100 & De 101 a 150 & De 151 a 200 & De 201 a $1000 \mid$ & Más de 1000 & \\
\hline \multirow{6}{*}{$\begin{array}{l}\text { Acciones } \\
\text { de resp. } \\
\text { social }\end{array}$} & \multirow{2}{*}{$\begin{array}{l}\text { Sí, acciones } \\
\text { puntuales }\end{array}$} & $\%$ dentro de acciones & $36,4 \%$ & $18,2 \%$ & $9,1 \%$ & $27,3 \%$ & $0 \%$ & $9,1 \%$ & $0 \%$ & $100,0 \%$ \\
\hline & & $\%$ dentro de horas & $40,0 \%$ & $18,2 \%$ & $20,0 \%$ & $42,9 \%$ & $0 \%$ & $50,0 \%$ & $0 \%$ & $28,2 \%$ \\
\hline & \multirow{2}{*}{$\begin{array}{l}\text { Sí, acciones } \\
\text { frecuentes sin } \\
\text { una política } \\
\text { definida de RS }\end{array}$} & $\%$ dentro de acciones & $25,0 \%$ & $50,0 \%$ & $25,0 \%$ & $0 \%$ & $0 \%$ & $0 \%$ & $0 \%$ & $100,0 \%$ \\
\hline & & $\%$ dentro de horas & $20,0 \%$ & $36,4 \%$ & $40,0 \%$ & $0 \%$ & $0 \%$ & $0 \%$ & $0 \%$ & $20,5 \%$ \\
\hline & \multirow{2}{*}{\begin{tabular}{|l|} 
Sí, acciones \\
integradas en \\
una política de \\
RS \\
\end{tabular}} & $\%$ dentro de acciones & $20,0 \%$ & $25,0 \%$ & $10,0 \%$ & $20,0 \%$ & $5,0 \%$ & $5,0 \%$ & $15,0 \%$ & $100,0 \%$ \\
\hline & & $\%$ dentro de horas & $40,0 \%$ & $45,5 \%$ & $40,0 \%$ & $57,1 \%$ & $100,0 \%$ & $50,0 \%$ & $100,0 \%$ & $51,3 \%$ \\
\hline \multirow{2}{*}{\multicolumn{2}{|c|}{ TOTAL }} & $\%$ dentro de acciones & $25,6 \%$ & $28,2 \%$ & $12,8 \%$ & $17,9 \%$ & $2,6 \%$ & $5,1 \%$ & $7,7 \%$ & $100,0 \%$ \\
\hline & & $\%$ dentro de horas & $100,0 \%$ & $100,0 \%$ & $100,0 \%$ & $100,0 \%$ & $100,0 \%$ & $100,0 \%$ & $100,0 \%$ & $100,0 \%$ \\
\hline
\end{tabular}

Cuadro 177: Tabla de contingencia de realización de acciones de responsabilidad social y formación en responsabilidad social.

Los datos del cuadro 177 indican que, efectivamente, todas las empresas que desarrollan acciones formativas enmarcadas en el ámbito de la responsabilidad social muestran algún tipo de comportamiento socialmente responsable (puntual, frecuente o integrado en una política definida). 
Además el cuadro 177 también muestra que las organizaciones tienen preferencia por el desarrollo de acciones formativas de extensión reducida enmarcadas en el ámbito de la responsabilidad social (de 1 a 150 horas anuales en el $90,9 \%$ de las organizaciones que impulsan acciones puntuales, de 1 a 100 horas anuales en el 100\% de las empresas que desarrollan acciones frecuentes y de 1 a 150 horas anuales en el $75 \%$ de las organizaciones que impulsan actuaciones dentro de una política definida de Responsabilidad Social Corporativa).

Los datos del cuadro 177 también indican que el tipo de comportamiento socialmente de las organizaciones incide en que las organizaciones se involucren en actuaciones formativas de responsabilidad social. De todas las empresas de la muestra que impulsan este tipo de iniciativas formativas poco más de una de cada cuatro $(28,2 \%)$ desarrolla acciones puntuales de responsabilidad social, mientras que algo más de la mitad $(51,3 \%)$ cuenta con una política definida en materia de responsabilidad social. Estos datos muestran que la elevada implicación de la empresa en la responsabilidad social representa una mayor preocupación por mejorar la formación de sus colaboradores en aspectos afines a la Responsabilidad Social Corporativa que están relacionados con su ámbito de actividad. 


\subsubsection{Relaciones entre la flexibilidad, la efectividad y el estilo de liderazgo}

Hemos realizado un modelo de regresión lineal, utilizando como variable dependiente el estilo de liderazgo y como independientes la efectividad y la flexibilidad de estilo.

\begin{tabular}{|l|r|r|r|r|r|}
\hline & \multicolumn{2}{|c|}{ Coeficientes no estandarizados } & Coeficientes tipificados & \multirow{2}{*}{ t } & \multirow{2}{*}{ Sig. } \\
\cline { 2 - 5 } & B & Error típ. & Beta & & \\
\hline (Constante) & $-2,870$ & 1,417 & & $-2,026$ &, 044 \\
\hline Flexibilidad &, 314 &, 027 &, 655 & 11,638 &, 000 \\
\hline Efectividad &,- 011 &, 022 &,- 029 &,- 517 &, 606 \\
\hline
\end{tabular}

Cuadro 178: Coeficientes del modelo de regresión entre el estilo directivo y la flexibilidad y efectividad de estilo.

La flexibilidad y la efectividad de estilo (cuadro 178) han explicado el 43,2\% del comportamiento del estilo directivo ( $r$ cuadrado corregido ha sido 0,432). En este caso ambas variables han tenido una incidencia relativa en la utilización del estilo directivo aunque la incidencia de la flexibilidad ha sido muy superior en el modelo realizado.

Este resultado indica, aunque de un modo muy débil, que la tendencia del máximo responsable a mostrar flexibilidad en su rol implica una cierta predisposición a utilizar el estilo directivo. Aunque esta correspondencia la hemos comentado anteriormente al tratar la relación entre la flexibilidad y los estilos de liderazgo en este caso podemos añadir, en relación con los datos que ofrece el modelo de regresión, que la elevada flexibilidad también puede precisar de un protagonismo relevante de las 
instrucciones en el rol de liderazgo o que la falta de dominio de varios estilos de liderazgo (aspecto que puede estar asociado a una alta flexibilidad de estilo) estimula la necesidad de utilizar con frecuencia un modo de dirección autoritario que se corresponde con el estilo directivo.

En relación con el estilo consultivo, la flexibilidad y la efectividad de estilo no han explicado el comportamiento de este estilo de liderazgo ( $r$ cuadrado corregido ha presentado un valor de 0,001).

\begin{tabular}{|l|r|r|r|r|r|}
\hline & \multicolumn{2}{|c|}{ Coeficientes no estandarizados } & Coeficientes tipificados & \multirow{2}{*}{ t } & \multirow{2}{*}{ Sig. } \\
\cline { 2 - 4 } & B & Error tip. & Beta & & \\
\hline (Constante) & 14,056 & 2,254 & & 6,236 &, 000 \\
\hline Flexibilidad &,- 408 &, 043 &,- 577 & $-9,516$ &, 000 \\
\hline Efectividad &, 027 &, 034 &, 048 &, 796 &, 427 \\
\hline
\end{tabular}

Cuadro 179: Coeficientes del modelo de regresión entre el estilo participativo y la flexibilidad y efectividad de estilo.

Tal y como indica el cuadro 179 la flexibilidad y la efectividad de estilo han explicado el 34,1\% del comportamiento del estilo participativo ( $r$ cuadrado corregido ha presentado un valor de 0,341). En este caso las dos variables han tenido una muy leve incidencia en la utilización del estilo participativo. Ambas han registrado una incidencia relativa en la utilización del estilo participativo, aunque la incidencia de la flexibilidad ha sido muy superior en el modelo realizado.

Este resultado indica, aunque con bastante debilidad, que la baja flexibilidad de estilo implica, en cierto grado, la utilización del estilo participativo por parte del líder que 
está centrado en el apoyo (esta correspondencia también la hemos indicado anteriormente al tratar la relación entre la flexibilidad y los estilos de liderazgo).

En relación con el estilo delegativo, su comportamiento no ha sido explicado por la flexibilidad y la efectividad de estilo ( $r$ cuadrado corregido ha presentado un valor de 0,114$)$.

\subsubsection{Relación entre los valores personales, el estilo de liderazgo y la actitud ante la Responsabilidad Social Corporativa}

Hemos realizado un modelo de regresión lineal, utilizando como variable dependiente la actitud ante la responsabilidad social y como variables independientes los valores personales y el estilo de liderazgo.

\begin{tabular}{|l|r|r|r|r|r|}
\hline & \multicolumn{2}{|c|}{ Coeficientes no estandarizados } & Coeficientes tipificados & \multirow{2}{*}{ t } & \multirow{2}{*}{ Sig. } \\
\cline { 2 - 4 } & $\mathrm{B}$ & \multicolumn{1}{|c|}{ Error típ. } & \multicolumn{1}{c}{ Beta } & & \\
\hline (Constante) & 7,652 & 4,877 & & 1,569 &, 118 \\
\hline Practicidad &,- 013 &, 055 &,- 051 &,- 232 &, 817 \\
\hline Resultados &, 012 &, 052 &, 046 &, 238 &, 812 \\
\hline Variedad &,- 005 &, 052 &,- 027 &,- 096 &, 923 \\
\hline Decisión &,- 010 &, 055 &,- 040 &,- 185 &, 854 \\
\hline Orden y método &,- 005 &, 055 &,- 028 &,- 100 &, 920 \\
\hline Metas &, 017 &, 053 &, 075 &, 319 &, 750 \\
\hline Estilo directivo &,- 136 &, 086 &,- 263 & $-1,584$ &, 115 \\
\hline Estilo consultivo &, 001 &, 078 &, 002 &, 011 &, 991 \\
\hline Estilo participativo &,- 012 &, 078 &,- 035 &,- 157 &, 876 \\
\hline Estilo delegativo &,- 021 &, 085 &,- 039 &,- 244 &, 807 \\
\hline
\end{tabular}

Cuadro 180: Coeficientes del modelo de regresión entre la actitud y los valores personales y el estilo de liderazgo. 
Los datos del estudio de regresión (cuadro 180) han indicado que las competencias genéricas contempladas en el estudio, los rasgos de personalidad considerados, las características comportamentales analizadas y los estilos de liderazgo han explicado el 2,3\% de la actitud del líder hacia la responsabilidad social.

Es decir, la variabilidad de la actitud hacia la responsabilidad social no ha estado explicada ni por los rasgos de personalidad revisados en este estudio, ni por las competencias genéricas consideradas en este análisis, ni por las características comportamentales examinadas en este trabajo, ni por los estilos de liderazgo evaluados en esta investigación. 



\section{7- CONCLUSIONES Y DISCUSIÓN}





\subsection{CONCLUSIONES SOBRE LA ACTITUD DE} LOS LÍDERES HACIA LA RESPONSABILIDAD SOCIAL Y EL COMPORTAMIENTO SOCIALMENTE RESPONSABLE DE LAS ORGANIZACIONES

1. Los líderes empresariales muestran una actitud favorable hacia la Responsabilidad Social Corporativa. Hemos entendido que ha influido en este dato, en gran medida, la gran presión social que se ha venido realizando desde distintos estamentos en las últimas décadas por fomentar esta disposición.

2. La actitud de los líderes hacia la responsabilidad social presenta una baja heterogeneidad. Hemos considerado que la importante influencia social para motivar una disposición favorable hacia esta disciplina también ha impulsado una amplia asimilación de ciertos aspectos generales asociados a la Responsabilidad Social Corporativa.

3. Algo más de la mitad de las empresas realizan, en mayor o menor medida, acciones de Responsabilidad Social Corporativa. Este dato refleja la importancia que las organizaciones conceden a esta materia, dado el momento económicamente difícil en el que la información ha sido recogida. 
4. La responsabilidad social presenta un grado de integración débil en las organizaciones ya que, prácticamente, solo dos de cada diez organizaciones desarrollan iniciativas de responsabilidad social que forman parte de una política de actuación definida en este ámbito. Este dato indica que aunque la responsabilidad tiene buena acogida en el sector empresarial, no es una materia con la que las empresas tiendan a establecer vínculos estratégicos a medio y largo plazo.

5. El desarrollo de acciones formativas encuadradas en el ámbito de la responsabilidad social no representa una práctica habitual en el mercado. Los datos del estudio han mostrado que algo más de 8 de cada 10 organizaciones no impulsan iniciativas para instruir a sus públicos internos en esta disciplina y, en algunos casos, se contempla como formación en responsabilidad social la mejora en la cualificación profesional de los colaboradores que está más relacionada con su cometido. De todos modos también hemos entendido que la información obtenida indica la existencia de un grado, aunque reducido al menos consolidado, de preocupación por sensibilizar a los colaboradores de las empresas sobre la Responsabilidad Social Corporativa.

6. Existe una relación muy intensa y de tipo inverso entre el desarrollo de políticas de responsabilidad social en las organizaciones y la búsqueda de liderazgo en el mercado. Hemos entendido que esta relación podría 
estar explicada, al menos en parte, por la presión con la que se relacionan las empresas con el tiempo en el mercado. En este sentido la búsqueda de un liderazgo en el corto plazo desplazaría la apuesta por la responsabilidad social, cuyos beneficios tienen un carácter estratégico y están más centrados en el largo plazo.

7. La actitud de los líderes empresariales hacia la responsabilidad social es mayor a medida que sus organizaciones de origen presentan un comportamiento socialmente responsable más intenso. Este dato parece indicar que el grado de afinidad de los líderes empresariales hacia la responsabilidad es un factor que influye, en cierta medida, en la apuesta de las organizaciones por la responsabilidad social.

8. Cuando contemplamos la relación entre la actitud hacia la responsabilidad social de los líderes empresariales y el desarrollo de acciones formativas encuadradas en el ámbito de la Responsabilidad Social Corporativa en sus organizaciones de procedencia, se constata que la actitud de los máximos cargos a favor de la responsabilidad social se acentúa cuando las iniciativas de formación de corta extensión incrementan su duración y, especialmente, cuando las organizaciones se involucran en cursos de gran extensión. Estos datos parecen indicar que el pequeño aumento de las iniciativas formativas puntuales sobre responsabilidad social y el desarrollo de acciones de formación de 
elevada duración están especialmente influidos por una mayor disposición favorable de los líderes hacia la responsabilidad social.

9. Hay una relación inversa de intensidad moderada entre el desarrollo de políticas de responsabilidad social en las empresas y la búsqueda de rentabilidad en el mercado. Hemos considerado que esta correlación está explicada, en cierto sentido, por una visión negativa de la responsabilidad social donde esta es entendida como un recurso incapaz de generar valor para las organizaciones.

10. La formación enmarcada en el ámbito de la responsabilidad social es un aspecto muy relacionado con el desarrollo de iniciativas sobre Responsabilidad Social Corporativa en las organizaciones, ya que todas las empresas que impulsan acciones formativas encuadradas en este ámbito presentan algún tipo de comportamiento socialmente responsable. Los datos también han indicado que las organizaciones tienen preferencia por promover actuaciones formativas sobre responsabilidad social de extensión reducida aunque también han revelado que las organizaciones especialmente implicadas en la Responsabilidad Social Corporativa están más preocupadas por mejorar la formación de sus colaboradores en esta materia (más de la mitad de las organizaciones de la muestra que desarrollan iniciativas formativas dirigidas a sus públicos internos apuestan estratégicamente por la 
responsabilidad social). Hemos entendido que existe coherencia en esta mayor implicación de las organizaciones en acciones de formación cuando su conducta socialmente responsable es más intensa, ya que el desarrollo de este tipo de iniciativas formativas no deja de ser una actuación más dentro de las que las empresas pueden desarrollar en el ámbito de la Responsabilidad Social Corporativa. 


\subsection{CONCLUSIONES SOBRE EL SEXO DE LOS LÍDERES Y LA RESPONSABILIDAD SOCIAL}

11. No existen diferencias significativas en la actitud de los líderes hacia la responsabilidad social según su sexo. Hemos considerado que la igualad de opciones que la sociedad actual ofrece a ambos sexos, tanto en el acceso a la formación como en el desarrollo de la carrera profesional, influye en la información indicada.

12. Las líderes femeninas tienden a tener menos presencia que sus homónimos masculinos en la cúpula de las organizaciones a medida que estas intensifican su comportamiento socialmente responsable. Este menor protagonismo se ha visto reflejado en el hecho de que casi uno de cada cuatro líderes masculinos está vinculado a organizaciones con una política definida de responsabilidad social mientras que en el caso de las mujeres, poco más de una de cada diez líderes femeninas se encuentra en ese estatus. Hemos considerado que aunque las mujeres tienen presencia en la dirección de las organizaciones, tal y como han indicado algunos trabajos revisados, también es cierto que los hombres presentan un mayor protagonismo en el máximo cargo de las empresas lo que podría explicar, en cierta medida, la información obtenida en este estudio. 
13. Pese a que las mujeres tengan un menor protagonismo en alta dirección de las organizaciones que actúan en el marco de la responsabilidad social, la presencia de líderes femeninas en empresas que impulsan acciones formativas sobre responsabilidad social de extensión reducida es sensiblemente mayor que la de sus homónimos masculinos. Este último dato parece indicar que aunque las líderes femeninas tengan menor presencia en el ámbito directivo que impulsa la responsabilidad social, estas parecen mostrar un mayor interés que los máximos dirigentes masculinos por impulsar iniciativas formativas sobre Responsabilidad Social Corporativa de extensión reducida.

14. La edad es una variable más discriminativa en las líderes femeninas que en los máximos responsables masculinos en relación con su actitud hacia la responsabilidad. Mientras el incremento de la edad de las líderes parece estar asociado a una actitud menos favorable hacia la responsabilidad social, en el caso de los hombres su disposición frente a la responsabilidad social no parece verse afectada por el paso del tiempo. Hemos entendido que un aspecto que podría explicar este dato es la mayor vinculación emocional de las mujeres con su experiencia vital (Nettle, 2006), lo que podría generar en las líderes un mayor desgaste a medida que su edad se incrementa y que también podría afectar, asimismo, a su disposición hacia la responsabilidad social. En esta observación es 
interesante considerar que las líderes más jóvenes presentan un entusiasmo especialmente destacado hacia la Responsabilidad Social Corporativa. Su actitud hacia esta disciplina es mayor, incluso, que la que muestran los máximos responsables masculinos, sea cual sea su edad.

15. Las empresas que presentan un comportamiento más afín a la responsabilidad social, ya sea porque realicen acciones de forma frecuente 0 las desarrollen integradas en una política definida, tienen mayor presencia de líderes femeninas jóvenes y de líderes masculinos de mediana edad. Hemos considerado que en la información indicada sobre las líderes femeninas ha podido influir el hecho de que algunos de los datos recabados para el estudio, en algunos casos concretos en los que no ha sido posible acceder a los máximos responsables empresariales, hayan sido recogidos directamente de mujeres encargadas de la Responsabilidad Social Corporativa en las organizaciones. En el caso de los hombres, hemos entendido que los datos sobre la edad de los líderes masculinos vinculados a organizaciones que presentan un comportamiento socialmente responsable más acentuado, responden a un perfil de líder más asentado en las organizaciones y con amplio poder de actuación. Los datos indicados sobre el comportamiento socialmente responsable de las organizaciones han tenido bastante correspondencia con los obtenidos 
sobre la formación encuadrada en el ámbito de la responsabilidad social que impulsan las empresas. En este caso las iniciativas formativas de horas reducidas son impulsadas por líderes de ambos sexos, aunque con especial protagonismo de las mujeres, ya sean jóvenes o de mediana edad. Pero las acciones formativas de mayor extensión son impulsadas, de forma mayoritaria, por los líderes masculinos de mediana edad.

16. En los dos sectores en los que los líderes presentan una actitud más favorable hacia la responsabilidad social (construcción e industria), las líderes femeninas muestran una actitud un poco más positiva hacia la responsabilidad social que la que presentan los máximos responsables masculinos. Este dato podría indicar que en los sectores en los que, por las externalidades derivadas de su actividad, se requiere de una mayor aproximación a la responsabilidad social, las mujeres muestran una leve mayor preocupación por la Responsabilidad Social Corporativa. Hemos considerado que esta hipótesis podría estar explicada, además de por la elevada implicación emocional de las mujeres, por su especial búsqueda de la excelencia en su rol de líderes. Hemos supuesto que el liderazgo empresarial femenino aún representa un estatus en proceso de consolidación social y que este hecho podría influir en que las dirigentes femeninas tengan una predisposición a favor de la responsabilidad social algo más acentuada que la de sus homónimos masculinos. 
17. Con independencia del sexo de los máximos dirigentes, las empresas del sector construcción presentan un comportamiento socialmente responsable menos destacado que las del sector industria. Hemos entendido que este dato podría estar explicado, como ya habíamos indicado, por la mayor incidencia en el medio ambiente de la actividad que se desarrolla en el sector industria respecto a la que se impulsa en el sector construcción. De todos modos el sexo sí podría tener algo de incidencia en la actuación responsable de las empresas ya en que en el sector industria y servicios las organizaciones lideradas por hombres parecen impulsar, en mayor grado que las gobernadas por mujeres, la actuación formativa sobre responsabilidad social destinada a sus públicos internos. En las empresas del sector industria guiadas por hombres se promueven más este tipo de iniciativas y en las organizaciones del sector servicios dirigidas por líderes masculinos las acciones de formación sobre responsabilidad social que se desarrollan son más extensas que las que impulsan las empresas lideradas por dirigentes femeninas.

18. Tanto en el caso de las líderes femeninas como en el caso de los líderes masculinos, el hecho de que estén vinculados a organizaciones grandes influye en que presenten una actitud más favorable hacia la responsabilidad social. Hemos entendido que el aumento de la dimensión de la organización eleva la 
exigencia social en relación con el comportamiento socialmente responsable que se espera de las organizaciones y, como consecuencia, se acentúa la actitud de sus máximos responsables a favor de la responsabilidad social con independencia de su sexo. De todos modos el crecimiento de la afinidad hacia la responsabilidad social a medida que aumenta el tamaño de las empresas no se ha registrado en las mujeres, ya que las líderes que proceden de organizaciones medianas han mostrado una actitud levemente menor que la que han registrado las que están asociadas a empresas pequeñas. Pueden existir muchos factores que expliquen este dato, aunque hemos considerado que podría tener una especial incidencia la mayor preocupación de las líderes femeninas por consolidar a las empresas de tamaño medio en el mercado respecto a las que dirigen organizaciones de dimensión pequeña. Hemos entendido que el tamaño mediano de las organizaciones, dimensión que presumiblemente supone la asunción de mayores riesgos empresariales, podría reducir levemente la preocupación de las dirigentes femeninas por la responsabilidad social si estas consideraran que la apuesta por esta materia no favoreciera el asentamiento de las empresas medianas en el corto plazo.

19. Existe una asociación entre el aumento del tamaño de las organizaciones y su mayor implicación en el desarrollo de acciones de responsabilidad social, tanto 
en las empresas lideradas por mujeres como en las organizaciones dirigidas por hombres. Hemos considerado que el hecho de que la Responsabilidad Social Corporativa represente, en cierto modo, una demanda social consolidada influye en esta dinámica ya que, en términos generales, un mayor tamaño empresarial suele estar asociado a un volumen de actividad empresarial más elevado y, por tanto, a un crecimiento de la exigencia a la organización en materia de responsabilidad social.

20. Cuando consideramos el sexo de los líderes y el tamaño de las organizaciones en relación con el desarrollo de acciones formativas encuadradas en el ámbito de la responsabilidad social, ninguna de las dos variables condicionan el desarrollo de dichas actuaciones. De todos modos los líderes masculinos tienden a promover iniciativas formativas de mayor duración con independencia del tamaño de su organización de procedencia. Hemos considerado que este dato indican una preocupación más acentuada en los líderes masculinos, respecto a sus homónimas femeninas, por formar a sus públicos internos en mayor profundidad sobre cuestiones enmarcadas en el ámbito de la responsabilidad social que se relacionan con la actividad específica que se desarrolla en cada organización.

21. Aunque los hombres y las mujeres presentan una actitud muy similar hacia la responsabilidad social (es 
levemente superior la de las mujeres), las líderes femeninas utilizan el estilo delegativo (poco apoyo y baja dirección) ligeramente menos que los hombres y se muestran un poco menos efectivas en su rol de líderes. Hemos considerado que estos datos podrían indicar que ante niveles similares de actitud hacia la responsabilidad social, los rasgos femeninos tienen incidencia en que el liderazgo se ejerza con un poco más de implicación y algo menos de efectividad.

22. Los líderes masculinos muestran dos tendencias que no guardan correspondencia con sus homónimas femeninas. La flexibilidad de los líderes masculinos tiende a decrecer a medida que su actitud favorable hacia la Responsabilidad Social Corporativa se intensifica, y su efectividad parece tender a aumentar a medida que se incrementa su disposición positiva hacia la responsabilidad social. Estos datos parecen indicar que la mayor asunción de los supuestos que representa la Responsabilidad Social Corporativa conlleva, en el caso de los máximos responsables masculinos, implican la utilización de menos estilos de liderazgo con mayor acierto. Esta observación tiene correspondencia con la tendencia detectada en las organizaciones que impulsan acciones formativas encuadradas en el ámbito de la responsabilidad social. En estas empresas también parece existir una cierta tendencia decreciente en la flexibilidad de estilo de sus máximos responsables masculinos a medida que 
aumentan las horas dedicadas a la formación enmarcada en el ámbito de la responsabilidad social.

23. Cuando consideramos el comportamiento socialmente responsable de las organizaciones, su mayor implicación en este tipo de actuaciones parece estar asociada a un estilo de dirección menos variado, especialmente en los máximos responsables masculinos, pero más efectivo en los líderes de ambos sexos. Este resultado parece indicar que la involucración empresarial en acciones de responsabilidad social mejora también la eficacia del liderazgo en las mujeres.

24. Aunque la actitud hacia la responsabilidad social es prácticamente igual en los líderes con independencia de su sexo (la actitud es ligeramente más afín a la responsabilidad social en las líderes femeninas), las mujeres conceden algo de más de importancia a la competencia genérica "metas" y, especialmente, a la característica comportamental “orden y método" y al rasgo de personalidad "variedad". Hemos entendido que estos datos podrían indicar que la preferencia por automatizar las tareas o planificarlas, dentro de lo posible, y la búsqueda de la diversidad, están más asociadas a la predisposición favorable hacia la responsabilidad social en las mujeres que en los hombres.

25. Las líderes femeninas parecen presentar una cierta tendencia decreciente en el rasgo de personalidad "variedad" a medida que se intensifica su actitud hacia 
la responsabilidad social. Esta tendencia parece indicar que la preferencia por abrir el ámbito de las actividades, encontrarse en situaciones nuevas y diferentes, y disfrutar de trabajos que no se desarrollan dentro de una rutina decrece a medida que aumenta la disposición de las líderes femeninas a favor de la Responsabilidad Social Corporativa. De todos modos hemos de tomar este dato con prudencia porque al considerar la implicación de las organizaciones de procedencia de las líderes en acciones formativas sobre responsabilidad social, el rasgo de personalidad "variedad" tiende a ganar relevancia a medida que se incrementa la duración de las iniciativas de formación.

26. En los máximos responsables masculinos la característica comportamental "orden y método" tiende a mantenerse estable aunque varie su actitud hacia la responsabilidad social. Este dato parece indicar que su preferencia por ser ordenado y tener un enfoque sistemático en sus actividades es independiente de su actitud hacia la Responsabilidad Social Corporativa.

27. Las líderes femeninas que proceden de organizaciones que no realizan ningún tipo de actuación en materia de responsabilidad social han manifestado ser más materialistas y con mayor preferencia por hacer cosas prácticas, útiles a corto plazo o económicamente ventajosas que las líderes procedentes de empresas que desarrollan algún tipo de iniciativa en el ámbito de la Responsabilidad Social Corporativa. Este dato se 
corresponde con el alcanzado al considerar el desarrollo de acciones formativas sobre responsabilidad social en las empresas: el rasgo de personalidad "practicidad" tiende a perder relevancia en las líderes femeninas a medida que su organización de origen dedica más horas a este tipo de actuaciones. En el caso de los hombres, hemos constatado que este rasgo de personalidad se reduce a medida que aumenta el comportamiento socialmente responsable de sus organizaciones de procedencia. Los datos parecen indicar que el rasgo de personalidad "practicidad" y la filosofía que representa la Responsabilidad Social Corporativa tienen un comportamiento inverso en el líder con independencia de su sexo. En otras palabras, que al distanciarse del materialismo y de la búsqueda del beneficio a corto plazo los líderes se aproximan a la visión que propone la responsabilidad social.

28. La característica comportamental "orden y método" muestra una tendencia a reducir su importancia en los máximos responsables masculinos a medida que aumenta el comportamiento socialmente responsable de las organizaciones a las que están vinculados. Este dato parece indicar que la involucración de las empresas en este tipo de actividades conlleva una reducción de la importancia que el líder concede al enfoque sistemático y ordenado. Hemos considerado que la incertidumbre que está asociada en muchos casos al desarrollo de acciones de responsabilidad 
social, sobre todo en relación con los beneficios que la empresa puede esperar de dichas actuaciones, podría tener incidencia en la explicación de esta tendencia.

29. La competencia genérica "metas" tiende a aumentar su importancia a medida que crece la intensidad del comportamiento socialmente responsable de la organización de procedencia del líder masculino. Hemos considerado que la mayor firmeza de la empresa en su apuesta por el desarrollo de acciones de responsabilidad social, algo que implica altos niveles de concreción y planteamientos estratégicos, también podría tener incidencia en que el máximo responsable masculino delimite en mayor grado los objetivos hacia los que dirige su esfuerzo.

30. A medida que las organizaciones aumentan el número de horas que dedican a acciones formativas enmarcadas en el ámbito de la responsabilidad social parece reducirse la importancia de la competencia genérica "resultados" para las líderes femeninas. Este dato podría indicar que el asentamiento en las empresas de su apuesta estratégica por la responsabilidad social, podría motivar que las dirigentes femeninas otorguen menos relevancia a la búsqueda de la excelencia y la perfección.

A continuación hemos incorporado en este apartado la figura 11 con las características más asociadas a una actitud 
más favorable hacia la responsabilidad social en cada sexo, de acuerdo a los datos obtenidos en el estudio:

\section{CARACTERÍSTICAS DE LOS LÍDERES MÁS ASOCIADAS CON UNA} ELEVADA ACTITUD HACIA LA RESPONSABILIDAD SOCIAL

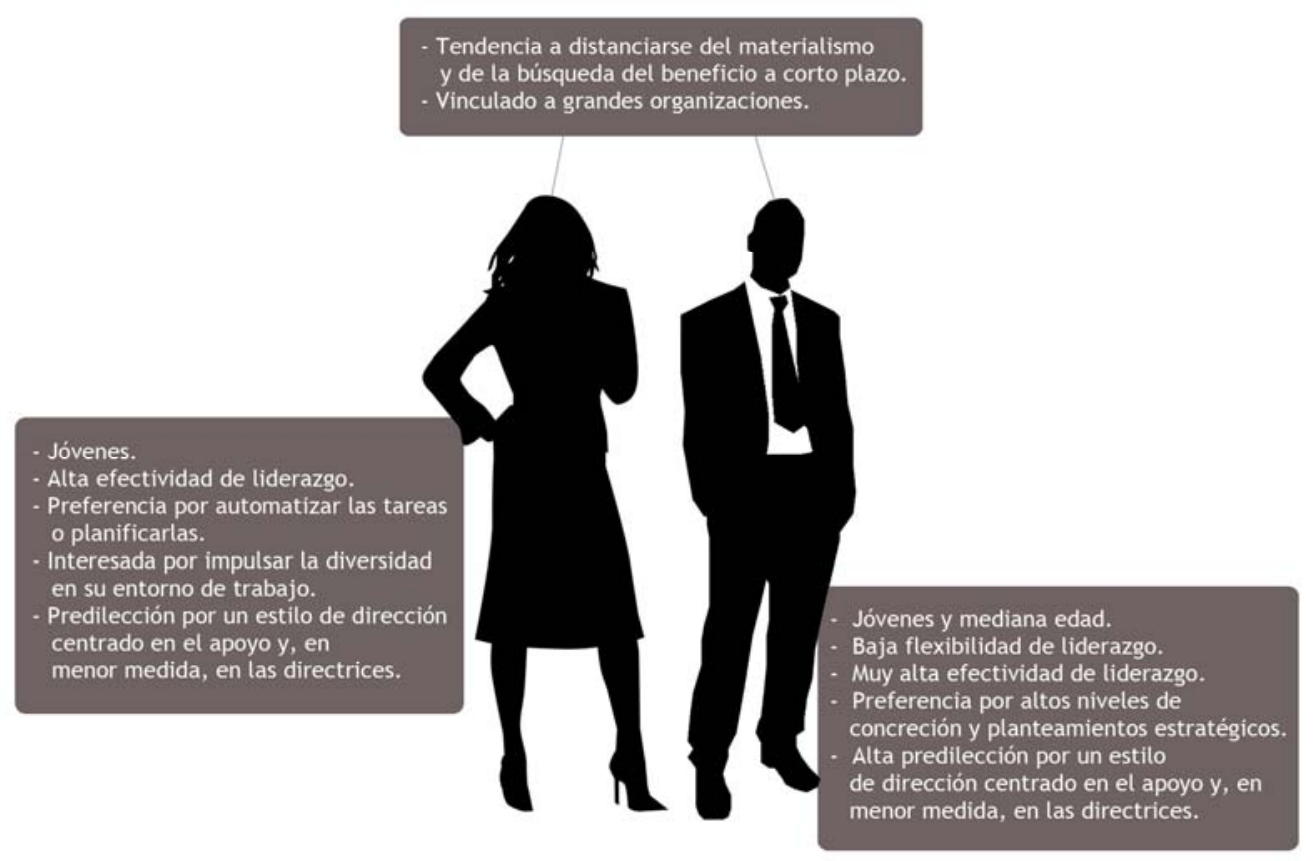

Figura 11: Características de los líderes más asociadas con una elevada actitud hacia la responsabilidad social.

Aunque, tal y como habíamos indicado previamente, la actitud hacia la responsabilidad social de los líderes de ambos sexos es prácticamente igual y responde a algunos rasgos que los dos perfiles comparten, también existen algunas características diferenciales (detalladas en la figura 11) que están más asociadas en cada caso a una elevada disposición favorable hacia la Responsabilidad Social Corporativa. 


\subsection{CONCLUSIONES SOBRE LA EDAD DE LOS LÍDERES Y LA RESPONSABILIDAD SOCIAL}

31. A pesar de que todos los líderes presentan una actitud favorable hacia la Responsabilidad Social Corporativa, el incremento de su edad parece ser un factor que reduce su disposición a favor de la misma. Aunque estos datos se podrían interpretar como una leve pérdida de sensibilidad hacia la responsabilidad social a medida que el líder tiene más edad, también hemos considerado que pueden existir otros factores implicados que expliquen este hecho como es el caso de la creciente relevancia que ha ido cobrando la Responsabilidad Social Corporativa en la formación empresarial. Algún estudio revisado en el marco teórico ha indicado que la formación especializada sobre responsabilidad social ha influido en la disposición más favorable que los directivos de menor edad presentan hacia esta disciplina.

32. Aunque casi uno de cada dos líderes, con independencia de su edad, se encuentra en organizaciones inactivas desde el punto de vista de la Responsabilidad Social Corporativa, la edad de los máximos responsables sí parece tener algo de influencia en el desarrollo de iniciativas sobre responsabilidad social por parte de las empresas. En las organizaciones que impulsan acciones 
formativas encuadradas en el ámbito de la responsabilidad social los líderes de mediana edad tienen más presencia que los más jóvenes. Por este motivo hemos entendido que la mayor edad del líder parece ser un factor discriminante en la formación sobre responsabilidad social que reciben los públicos internos de las organizaciones.

33. En el sector servicios y en el sector construcción parece darse un comportamiento inverso en relación con la edad y la actitud del líder hacia la Responsabilidad Social Corporativa. Mientras que en el sector servicios la actitud hacia la responsabilidad social de los máximos responsables decrece a medida que se incrementa su edad, en el sector construcción su disposición a favor de la responsabilidad social tiende a acentuarse cuando los líderes tienen más años. Hemos entendido que los mayores efectos medioambientales derivados de la actividad desarrollada en el sector construcción respecto al sector servicios pueden influir en que, con el paso del tiempo, los líderes tomen más en consideración los aspectos asociados a la responsabilidad social. En el sector servicios, donde la actividad desarrollada tiene menos repercusión medioambiental, hemos considerado que la tendencia decreciente de la actitud a favor la responsabilidad social es lógica y puede estar influida inicialmente por la mayor predisposición favorable hacia la Responsabilidad Social Corporativa que muestran los 
líderes más jóvenes de todos los sectores. Además también hemos contemplado que la mayor afinidad inicial por la responsabilidad social de los líderes más jóvenes del sector servicios también podría estar explicada por su atractivo como atributo de venta (ya que probablemente estos líderes conocen la Responsabilidad Social Corporativa al haber recibido formación específica sobre la misma) porque en este sector, donde el producto no está presente, el valor de la comunicación persuasiva en el proceso de compraventa entendemos que es mayor.

34. Los líderes más mayores del sector industrial tienen una actitud hacia la responsabilidad muy cercana a la de los máximos responsables más jóvenes, que son los líderes que han presentado la actitud más favorable hacia la Responsabilidad Social Corporativa de todos los máximos responsables procedentes de este sector. Hemos considerado que la gran repercusión medioambiental de la actividad desarrollada en este ámbito de actividad podría tener incidencia en la elevada sensibilidad que los líderes de más edad del sector industrial han mostrado hacia la responsabilidad social.

35. Los líderes de mediana edad tienen la mayor presencia en todos los sectores, sea cual sea el comportamiento socialmente responsable de su organización de procedencia, excepto en las organizaciones del sector servicios que impulsan de manera frecuente acciones 
de responsabilidad social, en las que el máximo dirigente mayoritario es más joven. Hemos considerado que el mayor protagonismo de los líderes de esta edad en las empresas que desarrollan habitualmente acciones de Responsabilidad Social Corporativa, dentro de un sector que tiene una exigencia de responsabilidad social menor, está especialmente motivado por la formación a la que han accedido los nuevos líderes empresariales desde finales del siglo XX y comienzos del siglo XXI. Esta observación guarda cierta correspondencia con los datos obtenidos al considerar la edad de los líderes y las acciones formativas sobre responsabilidad social que impulsan sus organizaciones de procedencia. Los máximos responsables más jóvenes han mostrado una presencia mayoritaria en las organizaciones del sector servicios e industria que impulsan iniciativas formativas de corta duración sobre responsabilidad social para sus públicos internos.

36. Sea cual sea el tamaño de las organizaciones, el incremento de la edad del líder supone una reducción de su actitud a favor de la Responsabilidad Social Corporativa. Hemos considerado que este dato indica que la edad del líder parece ser un factor más discriminante, en relación a su disposición frente a la Responsabilidad Social Corporativa, que el tamaño de su organización de procedencia (pese a que los líderes cuyo origen son empresas grandes presenten una actitud ligeramente superior hacia la responsabilidad 
social que la que tienen los máximos responsables vinculados a organizaciones pequeñas o medianas).

37. Sea cual sea el tamaño de las empresas y su comportamiento socialmente responsable, los máximos dirigentes de mediana edad son mayoría en todos los tipos de comportamiento socialmente responsable excepto en las empresas pequeñas y medianas que desarrollan acciones de responsabilidad social de modo frecuente, y en las empresas medianas y grandes que impulsan acciones puntuales, donde el líder con mayor presencia es más joven. Hemos considerado que el hecho de que las nuevas generaciones de líderes empresariales hayan tenido una formación más específica sobre responsabilidad social puede haber tenido incidencia en que el líder de menor edad presente este protagonismo en los segmentos indicados.

38. Los líderes de mediana edad son mayoría en las organizaciones de cualquier tamaño que desarrollan acciones formativas sobre Responsabilidad Social, Corporativa excepto en las empresas pequeñas y medianas que dedican pocas horas a este tipo de iniciativas en las que los líderes más jóvenes tienen una mayor presencia. Hemos considerado que la mayor concienciación de estos líderes de menor edad sobre la responsabilidad social, posiblemente por su formación empresarial, también podría tener de algún modo incidencia de nuevo en el dato comentado. 
39. A medida que avanza la edad de los líderes y decrece su disposición a favor de la responsabilidad social, también se reduce la importancia que conceden al estilo directivo (alta dirección y poco apoyo) y su flexibilidad de estilo, y aumenta la importancia que otorgan al estilo participativo (alto apoyo y poca dirección). Esta observación podría estar asociada a una tendencia en el liderazgo que no está vinculada con la menor o mayor afinidad de los máximos cargos por la responsabilidad social y sí con la edad: el paso del tiempo fomenta que los líderes utilicen menos estilos de liderazgo y se centren en mayor grado en el apoyo con independencia de su disposición hacia la Responsabilidad Social Corporativa.

40. Los líderes más jóvenes, los más afines a la responsabilidad social, parecen conceder menos importancia al estilo directivo (alta dirección y poco apoyo) a medida que aumenta su actitud positiva hacia la responsabilidad social. Este dato podría indicar que los máximos responsables empresariales de mayor juventud tienen tendencia a dar menos instrucciones 0 estar más preocupados por el estado emocional de sus colaboradores o ambas cosas al mismo tiempo, a medida que su actitud hacia la responsabilidad social se acentúa. Además estos líderes han mostrado una especial preferencia por el estilo participativo (alto apoyo y poca dirección) en las organizaciones que impulsan acciones formativas sobre responsabilidad 
social, lo que parece reforzar su preferencia por los aspectos motivacionales en la relación que establecen con sus colaboradores.

41. Los líderes más jóvenes y más mayores tienden a incrementar la efectividad de su liderazgo a medida que se acentúa la intensidad de su actitud a favor de la responsabilidad social. Entendemos que este dato podría estar motivado por la mayor empatía que ambos grupos establecen con la responsabilidad social respecto a los líderes de mediana edad. En el caso de los más jóvenes por su formación especializada, y en el caso de los más mayores por su mayor preocupación por los efectos derivados del legado empresarial que van a dejar en poco tiempo.

42. Excepto los líderes más mayores, el resto de máximos responsables muestran una tendencia a reducir su flexibilidad de estilo a medida que aumenta su actitud a favor de la Responsabilidad Social Corporativa. Entendemos que la mayor afinidad de estos máximos dirigentes por la responsabilidad social también podría suponer que tengan mayor confianza en una forma de dirección más concreta.

43. Los líderes de mediana edad muestran una tendencia a no variar la importancia que conceden al estilo consultivo aunque modifiquen su actitud hacia la responsabilidad social. Por tanto, las directrices y el apoyo suelen tener protagonismo en su estilo de dirección sea cual sea su actitud hacia la 
responsabilidad social. Este dato parece indicar que la confianza que conceden los líderes de mediana edad al estilo consultivo tiene más solidez que la que otorgan a este estilo los máximos responsables empresariales más mayores y más jóvenes.

44. Los líderes más jóvenes, que son los que presentan la disposición más favorable hacia la responsabilidad social, conceden una importancia más destacada que el resto a los rasgos de personalidad "variedad" y "practicidad" y a la competencia genérica "resultados". Es posible que estos datos puedan ofrecer, en alguna medida, algún tipo de explicación a la mayor afinidad de los líderes más jóvenes hacia la responsabilidad social. Especialmente por la búsqueda de retos (resultados) que puede constituir para ellos el desarrollo de acciones de responsabilidad social, y por la preferencia por ampliar el ámbito de actividades laborales (variedad) que suelen representar las actuaciones socialmente responsables.

45. Al considerar la actuación de las organizaciones en materia de responsabilidad social, se comprueba que los líderes de mediana edad y más mayores conceden menos importancia al rasgo de personalidad "practicidad" a medida que su organización de origen muestra un comportamiento más favorable hacia la responsabilidad social. Esta menor preferencia por la búsqueda de ventajas materiales en el corto plazo podría tener incidencia en la actuación más 
comprometida con la responsabilidad social de sus empresas de procedencia. Esta tendencia decreciente del rasgo de personalidad "practicidad" también se ha registrado, en cierto modo, en los máximos dirigentes de mediana edad cuando se ha considerado el aumento del número de horas que las organizaciones de procedencia del líder dedican a la formación enmarcada en el ámbito de la responsabilidad social.

46. Existe una tendencia decreciente en el rasgo de personalidad "variedad" a medida que aumenta la edad de los máximos responsables empresariales y decrece su actitud por la responsabilidad social. Este dato podría indicar que la comprensión de la responsabilidad social como una experiencia laboral que aporte variedad a la dinámica laboral es más propia de los líderes más jóvenes con elevada afinidad hacia la Responsabilidad Social Corporativa.

47. A medida que se incrementa la edad de los máximos responsables empresariales y se reduce su afinidad hacia la responsabilidad social, el rasgo de personalidad “decisión", la característica comportamental "orden y método" y la competencia genérica "metas" tienden a adquirir más relevancia en el líder. Hemos considerado que, especialmente, la capacidad para tomar decisiones firmes con rapidez (decisión), en cierto sentido como consecuencia de la experiencia que va acumulando el máximo dirigente, podría estar implicada en la menor afinidad hacia la responsabilidad 
social que muestra el líder al incrementarse su edad. De este modo, si la responsabilidad social no representa un ámbito de actuación que genere convicción en los máximos cargos, estos descartan de manera inmediata cualquier iniciativa vinculada. Cuando contemplamos el comportamiento socialmente responsable de la organización de procedencia de los líderes, los más mayores también conceden la importancia más alta al rasgo de personalidad "decisión" a medida que su organización de origen acentúa su conducta socialmente responsable.

48. Los líderes de mediana edad y más mayores conceden una menor importancia a la característica comportamental “orden y método" a medida que aumenta su afinidad hacia la responsabilidad social. Hemos entendido que esta actitud más favorable del máximo responsable empresarial podría estar asociada a una menor importancia otorgada a la planificación y a la automatización en el desempeño de su rol.

49. Los líderes más mayores han mostrado una tendencia a conceder más relevancia a la competencia genérica “metas" a medida que su organización de procedencia intensifica su comportamiento socialmente responsable. Es probable que en este dato tenga incidencia la comprensión de la actuación responsable como un objetivo perfectamente delimitado por parte del máximo dirigente. 


\subsection{CONCLUSIONES SOBRE EL SECTOR DE ACTIVIDAD Y LA RESPONSABILIDAD SOCIAL}

50. Los líderes del sector servicios tienen una actitud hacia la responsabilidad social un poco menos favorable que la que presentan los máximos responsables de otros sectores. Hemos considerado que un factor que puede explicar este resultado es la menor incidencia en el medio ambiente de este ámbito de actividad.

51. Existe una mayor presencia de líderes, con independencia de su sector de procedencia, en las organizaciones que no impulsan ninguna iniciativa de Responsabilidad Social Corporativa que en las empresas que desarrollan acciones puntuales, frecuentes 0 integradas en una política definida de responsabilidad social. Sin embargo en el ámbito industrial, en el que existe una mayor tendencia a la realización de acciones de responsabilidad social que en el resto de sectores analizados, casi dos de cada tres organizaciones realizan algún tipo de actividad responsable. Hemos considerado que este resultado, que se corresponde con el obtenido en otras investigaciones revisadas en el marco teórico, está relacionado con la mayor incidencia medioambiental de la actividad desarrollada en el sector industrial. 
52. En los sectores servicios y construcción el aumento del tamaño de la organización de procedencia del líder supone un incremento de su actitud a favor de la responsabilidad social. Hemos considerado que esta tendencia, que no se ha registrado en el sector industria, podría explicarse en cierta medida por la creciente preocupación de los máximos dirigentes por la vertiente social de la responsabilidad social, especialmente en relación con los públicos internos, a medida que sus organizaciones de origen de los sectores servicios y construcción aumentan su tamaño.

53. Mientras que los líderes de las empresas pequeñas con una actitud más favorable hacia la responsabilidad social proceden del sector industrial, los máximos responsables de las empresas medianas que han mostrado una mayor afinidad hacia la responsabilidad social están vinculados al sector construcción. Hemos considerado que el aumento del tamaño de las empresas del ámbito industrial no implica necesariamente un incremento de la actitud afín de sus líderes a la responsabilidad social porque las empresas pequeñas de este sector ya precisan, por su repercusión en el medio ambiente, de máximos responsables con una elevada preocupación por la Responsabilidad Social Corporativa.

54. En los sectores servicios y construcción existe una cierta tendencia a que el estilo participativo adquiera más protagonismo a medida que se incrementa la 
actitud favorable de los líderes hacia la responsabilidad social. Al considerar las actuaciones en materia de responsabilidad social que desarrollan las empresas del sector servicios también se ha producido la misma tendencia: los líderes de las empresas de este sector conceden una mayor importancia al estilo participativo cuando sus organizaciones desarrollan actuaciones socialmente responsables. Hemos considerado que las exigencias relacionadas con la implicación de la organización en acciones responsables están menos motivadas, en los sectores construcción y servicios, por la propia actividad que desarrolla la organización que en el caso de las empresas pertenecientes al ámbito industrial. En este sentido hemos entendido que la disposición personal es un factor más relevante para la adopción de este tipo de medidas en estos dos sectores, por lo que la utilización de un estilo de liderazgo que conceda mayor importancia al apoyo y menor relevancia a las directrices es indicativo de esta mayor afinidad del líder hacia la Responsabilidad Social Corporativa.

55. En el sector servicios se ha registrado una cierta tendencia a que la efectividad en el liderazgo de los máximos responsables empresariales se incremente a medida que se acentúa su afinidad hacia la responsabilidad social, sin embargo en el sector industria la efectividad de estilo tiende a decrecer según se intensifica la actitud de los líderes a favor de 
la responsabilidad social. Hemos considerado que posiblemente en el sector industria la adopción de medidas que impulsen la responsabilidad social no siempre permita optimizar el rendimiento de los procesos involucrados directamente en la Responsabilidad Social Corporativa, y que este hecho pueda tener incidencia en una pérdida de eficacia en el liderazgo. La tendencia creciente en la efectividad del liderazgo también se ha registrado cuando las organizaciones de origen de los líderes, con independencia de su sector de procedencia, han acentuado su comportamiento socialmente responsable. Esta dinámica de la efectividad también se ha advertido en los líderes procedentes de organizaciones que impulsan iniciativas formativas enmarcadas en el ámbito de la responsabilidad social dentro del sector servicios: a medida que se ha incrementado la extensión de dichas acciones los líderes han registrado una tendencia a ser más efectivos en su rol.

56. Se percibe una cierta tendencia decreciente en la flexibilidad de estilo de los líderes del sector servicios a medida que se intensifica su disposición favorable hacia la responsabilidad social. Hemos entendido que como la pérdida de flexibilidad asociada a una actitud más favorable hacia la responsabilidad social también supone un aumento de la eficacia de liderazgo en los máximos responsables del sector servicios, su mayor 
actitud a favor de la responsabilidad además contribuye a mejorar su capacidad para utilizar menos estilos de liderazgo de un modo más acertado. La tendencia indicada también guarda correspondencia con el dato obtenido en los sectores servicios y construcción, donde la flexibilidad de los líderes también ha mostrado una cierta tendencia decreciente a medida que se ha intensificado el comportamiento socialmente responsable de su organización de origen.

57. A medida que aumenta la actitud de los máximos responsables empresariales a favor de la responsabilidad social en el sector industria, el estilo directivo (aunque es un estilo con poca presencia en los líderes de este sector) tiende a perder importancia. Hemos considerado que esta tendencia se corresponde con una aproximación a un estilo menos centrado en las instrucciones y más en el apoyo a medida que se acentúa la actitud del líder a favor de la responsabilidad social, ya que esta manera de dirigir parece adecuarse en mejor modo al planteamiento que representa la Responsabilidad Social Corporativa.

58. Los líderes del sector servicios han mostrado una leve tendencia creciente en la competencia genérica "resultados" a medida que se ha incrementado su actitud hacia la responsabilidad social. Este dato parece indicar que la mayor afinidad por la responsabilidad social de los máximos dirigentes de este sector puede estar influida por una búsqueda más 
intensa de la excelencia. Refuerza esta apreciación el hecho de que, de los tres sectores contemplados en el estudio, sean los líderes procedentes del sector servicios quienes hayan otorgado una mayor relevancia a esta competencia genérica.

59. Los máximos responsables del sector construcción han registrado una tendencia a conceder más relevancia a la competencia genérica "metas" a medida que se ha intensificado su actitud afín hacia la Responsabilidad Social Corporativa. Además los líderes de este sector han concedido una mayor importancia a esta competencia genérica que la que han otorgado los máximos responsables de otros sectores. Hemos considerado que para los máximos responsables del ámbito de la construcción, que suelen trabajar con proyectos perfectamente definidos, la alta precisión en la delimitación de los objetivos resulta un aspecto esencial para que decidan involucrar a su organización en el desarrollo de iniciativas sobre responsabilidad social.

60. Los líderes del sector industria han mostrado una tendencia decreciente en el rasgo de personalidad "practicidad" a medida que su actitud a favor de la responsabilidad social ha sido mayor, mientras que en los máximos responsables empresariales del sector servicios la pérdida de trascendencia del rasgo de personalidad "practicidad" ha ido acompañada de un aumento del comportamiento socialmente responsable 
en sus organizaciones de origen. Hemos considerado que un aspecto que podría tener incidencia en la explicación de esta tendencia en ambos casos es el hecho de los líderes de los sectores industria y servicios contemplen la Responsabilidad Social Corporativa como una apuesta estratégica, lo que tendría correspondencia con una menor relevancia concedida a la búsqueda de ventajas materiales y de beneficios a corto plazo. 


\subsection{CONCLUSIONES SOBRE TAMAÑO DE LAS ORGANIZACIONES Y LA RESPONSABILIDAD SOCIAL}

61. El tamaño de la organización es un aspecto que tiene incidencia en la actitud de los líderes organizacionales hacia la Responsabilidad Social Corporativa. A medida que crece el tamaño de sus organizaciones de procedencia, se incrementa su actitud a favor de la responsabilidad social. De manera muy leve al pasar de los máximos responsables de organizaciones pequeñas a medianas, y de manera más pronunciada al pasar de los líderes de empresas medianas a los vinculados a organizaciones grandes. Este resultado se corresponde con los estudios revisados en el marco teórico que hacen referencia a la influencia del tamaño en la actitud favorable hacia la Responsabilidad Social Corporativa, aunque no se ha encontrado unanimidad en los resultados alcanzados por todas las investigaciones consultadas.

62. A medida que aumenta el tamaño de las empresas disminuye el porcentaje de organizaciones que rehúsan desarrollar acciones de Responsabilidad Social Corporativa y crece el número de empresas que ponen en marcha una política de actuación definida que 
articule estas iniciativas. Aunque esta tendencia no se mantiene de modo exacto en relación con el desarrollo de acciones formativas sobre responsabilidad social por parte de las organizaciones según aumenta su tamaño, las empresas grandes sí parecen estar más comprometidas con este tipo de actuaciones. Hemos considerado que un factor que explica este último dato, en cierta medida, es el hecho de que las empresas grandes requieran de sus colaboradores un mayor grado de especialización (aspecto que muchos líderes integran dentro de la formación etiquetada como "Responsabilidad Social Corporativa”).

63. Los estilos de liderazgo directivo y delegativo pierden relevancia para el máximo responsable empresarial a medida que aumenta el tamaño de sus empresas de procedencia $y$, por tanto, su disposición a favor de la responsabilidad social. Este resultado ha guardado correspondencia con el obtenido por parte del líder procedente de organizaciones pequeñas, donde se ha registrado una tendencia decreciente en la importancia que otorga al estilo delegativo al incrementarse la intensidad del comportamiento socialmente responsable en su organización de origen. La misma tendencia se ha producido, en relación con el comportamiento socialmente responsable de la organización de procedencia del líder, al considerar el estilo directivo de los máximos responsables de empresas medianas. El estilo directivo también ha 
tendido a perder peso en los líderes procedentes de organizaciones medianas que impulsan acciones formativas sobre responsabilidad social a medida que las empresas han incrementado la extensión de dichas acciones. Estos datos parecen indicar que la responsabilidad social está más asociada a un estilo de dirección en el que siempre está presente el apoyo (estilos participativo y consultivo) y en el que también puedan ofrecerse instrucciones (consultivo). De todos modos es una observación que debe tomarse con prudencia porque cuando se intensifica la actitud hacia la responsabilidad social de los líderes procedentes de empresas grandes, también se acentúa la importancia que conceden a los estilos directivo y delegativo (aun siendo reducida la relevancia que otorgan a estos estilos).

64. La importancia otorgada por el máximo dirigente empresarial a los estilos de liderazgo consultivo y participativo aumenta a medida que crece el tamaño de sus organizaciones de procedencia y su afinidad por la Responsabilidad Social Corporativa. Esta indicación guarda correspondencia con el hecho de que los estilos consultivo y participativo han tendido a ganar relevancia en el líder cuyo origen son organizaciones medianas que desarrollan acciones formativas sobre Responsabilidad Social Corporativa, a medida que estas empresas han aumentado el número de horas dedicadas a dichas acciones. De todas formas en los máximos 
responsables de organizaciones pequeñas ya existe un vínculo entre la disposición positiva hacia la responsabilidad social y el estilo participativo, aunque los datos no son concluyentes. Los líderes procedentes de las empresas pequeñas presentan una cierta tendencia creciente a conceder más importancia a dicho estilo a medida que se acentúa la actuación responsable de las empresas a las que están asociados, pero conceden la misma importancia al estilo participativo (alto apoyo y poca dirección) aunque su actitud hacia la responsabilidad social varíe de intensidad. Hemos considerado que estos datos tienen explicación en el ámbito de la responsabilidad social por el nexo común de los estilos consultivo y participativo: su preocupación por aspectos más afectivos que racionales en la relación que los líderes establecen con sus colaboradores.

65. En términos generales la flexibilidad de estilo pierde importancia según crece el tamaño empresarial y la disposición favorable del líder hacia la responsabilidad social. Dentro de los tamaños empresariales pequeño y mediano se han obtenido datos más específicos que indican que a media que la afinidad de los líderes a favor de la responsabilidad social es mayor, su flexibilidad de estilo se reduce. También se han obtenido evidencias de esta tendencia en los líderes procedentes de organizaciones medianas que impulsan acciones de Responsabilidad Social Corporativa de 
modo habitual o formando parte de una política definida (su flexibilidad de estilo es menor) y en los máximos responsables cuyo origen son organizaciones pequeñas que impulsan acciones de formación enmarcadas en el ámbito de la responsabilidad social (han registrado una menor flexibilidad de liderazgo a medida que sus organizaciones de origen han aumentado la extensión de la formación sobre responsabilidad social que dirigen a sus públicos internos). De todos modos, la tendencia indicada se ha manifestado especialmente en los líderes vinculados a empresas pequeñas (quienes han presentado una menor flexibilidad a medida que su disposición favorable hacia la responsabilidad social ha sido más intensa) mientras que en los líderes procedentes de las empresas grandes la flexibilidad se ha comportado al revés: los máximos responsables han incrementado su flexibilidad cuando su actitud positiva hacia la responsabilidad social se ha acentuado. Hemos entendido que esta tendencia de la flexibilidad en dirección opuesta a la actitud favorable a la responsabilidad social y también al tamaño empresarial (considerando en este caso solo el valor medio registrado por la actitud hacia la Responsabilidad Social Corporativa de los líderes procedentes de organizaciones grandes, no la variación de su actitud a medida que se modifica su flexibilidad de liderazgo), indica que la dimensión de las empresas parece ser un factor menos influyente que la disposición a favor de la 
responsabilidad social en la concreción del rol de liderazgo que parece ir asociado al desarrollo de iniciativas en este ámbito.

66. El líder tiende a aumentar la efectividad de su liderazgo según crece el tamaño de su organización de origen y su disposición a favor de la responsabilidad social. Además también se han detectado hallazgos específicos en cada uno de los tres tamaños empresariales contemplados que parecen indicar que, con independencia del tamaño empresarial, el impulso de la responsabilidad social en las organizaciones parece estimular la efectividad en el liderazgo. Los líderes procedentes de organizaciones pequeñas que impulsan actuaciones de responsabilidad social de modo frecuente o dentro de una política definida presentan una efectividad más acentuada que aquellos que están asociados a organizaciones que impulsan acciones puntuales o no desarrollan ningún tipo de iniciativa en el ámbito de la responsabilidad social. Los máximos responsables vinculados a empresas medianas implicadas en iniciativas de formación sobre Responsabilidad Social Corporativa se han mostrado más efectivos en su rol a medida que sus organizaciones de origen incrementan las horas dedicadas a dichas acciones de formación. Los líderes procedentes de empresas grandes aumentan la efectividad de su liderazgo cuando su actitud a favor de la responsabilidad social es más intensa. 
67. Los líderes procedentes de organizaciones que impulsan acciones formativas encuadradas en el ámbito de la responsabilidad social, sea cual sea el tamaño de dichas empresas, tienen tendencia a mostrar mayor preferencia por el estilo participativo que por el consultivo como estilo primario. Hemos considerado que este dato podría indicar que las acciones de responsabilidad que presentan un cariz formativo precisan de una gran demanda de apoyo y de una menor necesidad de directrices.

68. En consonancia con la mayor actitud favorable de los líderes hacia responsabilidad social a medida que se incrementa el tamaño empresarial de sus organizaciones de procedencia, se comporta la competencia genérica "metas". Además también se ha registrado, en términos generales, una tendencia creciente en la importancia que los máximos dirigentes cuyo origen son empresas grandes conceden a la competencia genérica "metas" a medida que se intensifica su actitud a favor de la responsabilidad social. Además, en los líderes procedentes de organizaciones de este tamaño empresarial la competencia genérica "metas" tiende a ganar relevancia a medida que su organización de origen intensifica su actuación socialmente responsable. Estos datos indican que la orientación a la tarea y la tendencia a centrar el esfuerzo en actividades bien delimitadas, hasta que estas estén finalizadas, son más 
relevante para los máximos responsables de las organizaciones grandes y están más acentuadas en aquellos líderes con una predisposición más favorable hacia la responsabilidad social. Es posible que el mayor grado de especialización que las grandes organizaciones requieren, lo que también afecta a las iniciativas de responsabilidad social que desarrollen, tenga incidencia en la explicación de esta tendencia.

69. El rasgo de personalidad "decisión" tiende a ganar relevancia, al igual que la actitud de los líderes a favor de la responsabilidad social, a medida que su organización de origen aumenta de tamaño. Pese a esta tendencia general, si realizamos un análisis más específico de este aspecto dentro del tamaño empresarial de la organización de procedencia de los líderes encontramos dos tendencias opuestas. En los líderes procedentes de organizaciones pequeñas la importancia concedida al rasgo de personalidad "decisión" se ha visto incrementada si la organización desarrolla algún tipo de comportamiento socialmente responsable. Pero en los máximos responsables procedentes de empresas grandes ocurre al contrario, el rasgo de personalidad “decisión" tiende a perder relevancia en el líder a medida que se intensifica su actitud a favor de la responsabilidad social. Hemos entendido que en la explicación de este dato podría tener incidencia el mayor desglose en la asignación de competencias a los colaboradores como consecuencia 
de las iniciativas de responsabilidad social que las organizaciones grandes impulsen.

70. El incremento de la actitud asociado al aumento del tamaño empresarial también guarda cierta correspondencia inversa con el rasgo de personalidad "variedad" y con la característica comportamental “orden y método". Es decir, a medida que aumenta el tamaño empresarial y se incrementa la disposición de los líderes a favor de la responsabilidad social, estos están menos predispuestos a involucrarse en actividades diferentes y a mantener un enfoque sistemático. De todos modos el rasgo de personalidad "variedad" tiende a ganar relevancia en los líderes procedentes de empresas medianas a medida que sus organizaciones de origen incrementan la duración de sus acciones formativas enmarcadas en el ámbito de la responsabilidad social, por lo que no podemos generalizar la observación indicada inicialmente.

71. Mientras los líderes procedentes de empresas pequeñas presentan una relativa tendencia a reducir el valor de la competencia genérica "resultados" a medida que se intensifica su actitud a favor de la responsabilidad social, el comportamiento de dicha competencia en los máximos responsables procedentes de empresas grandes no es homogéneo. Aunque tiende a crecer a medida que su actitud a favor la responsabilidad social se acentúa, también tiende a perder relevancia a medida que la organización de procedencia del líder 
intensifica su actuación socialmente responsable. Estos datos parecen indicar que la búsqueda de superación de los líderes procedentes de organizaciones pequeñas está asociada, en cierto modo, al decrecimiento de su actitud a favor de la responsabilidad social. Es posible que la dificultad para alcanzar la excelencia en entornos empresariales de reducida dimensión, donde tanto los líderes como los colaboradores deban realizar muchas tareas diferentes, pueda inhibir, en alguna medida, la apuesta organizacional por la responsabilidad social.

72. Los líderes procedentes de empresas pequeñas y medianas parecen mostrar una tendencia a conceder menos importancia al rasgo de personalidad "practicidad" a medida que se acentúa su afinidad hacia la responsabilidad social. En los máximos responsables procedentes de organizaciones pequeñas también se ha producido una cierta tendencia descendente en la relevancia otorgada al rasgo de personalidad "practicidad" a medida que se ha intensificado el comportamiento socialmente responsable de su organización de origen y a medida que dicha organización ha incrementado la duración de sus acciones formativas dirigidas a públicos internos sobre responsabilidad social. En los líderes procedentes de empresas medianas, el rasgo de personalidad "practicidad" también parece tender a perder relevancia a medida que se incrementa la actuación 
socialmente responsable de sus organizaciones de origen. Hemos considerado que puede tener influencia en la explicación de estos datos el hecho de que muchos líderes de empresas pequeñas y medianas no hayan tenido una formación tan especializada en el ámbito de la responsabilidad social como la que hayan recibido los líderes de las empresas grandes, lo que podría explicar que su aproximación a la Responsabilidad Social Corporativa también suponga un cierto distanciamiento del materialismo y de la búsqueda del beneficio en el corto plazo. 


\subsection{CONCLUSIONES SOBRE EL LIDERAZGO Y LA RESPONSABILIDAD SOCIAL}

73. El estilo directivo (alta dirección y poco apoyo) parece perder relevancia en el rol del líder, pese a ser un estilo con poco peso en sus decisiones, a medida que se intensifica su actitud a favor de la responsabilidad social. Hemos interpretado que este resultado podría indicar, de algún modo, que el liderazgo más próximo a la instrucción es el que más se aleja de la filosofía que representa la Responsabilidad Social Corporativa.

74. Todos los líderes, sea cual sea su actitud hacia la responsabilidad social, su sexo y su edad, utilizan como estilo de liderazgo primario el participativo (alto apoyo y poca dirección) y como estilo de liderazgo secundario el consultivo (alta dirección y mucho apoyo). Entendemos que este resultado refleja que la preferencia por ambos estilos de liderazgo en los máximos responsables empresariales está muy consolidada y no se ve afectada por fluctuaciones en su actitud hacia la responsabilidad social. El mismo protagonismo de estos dos estilos se ha registrado en los líderes, sea cual sea el comportamiento socialmente responsable de su organización de origen, y en la gran mayoría de los máximos responsables que proceden de 
empresas que impulsan acciones formativas sobre responsabilidad social.

75. El estilo participativo (alto apoyo y poca dirección) parece ganar protagonismo en el ejercicio del liderazgo a medida que el líder presenta una actitud más favorable hacia la responsabilidad social. Hemos considerado que este dato podría indicar que el estilo de liderazgo participativo es el más afín al planteamiento empresarial que representa la Responsabilidad Social Corporativa.

76. Los líderes que proceden de organizaciones que presentan algún tipo de comportamiento socialmente responsable conceden una mayor relevancia al estilo participativo (alto apoyo y poca dirección) que los máximos responsables cuyo origen son empresas que no desarrollan ningún tipo actuación en el ámbito de la responsabilidad social. Pese a ser el estilo de liderazgo primario en todos los líderes, sea cual sea la actuación de su organización de origen en materia de responsabilidad social, el estilo participativo parece adecuarse en mayor medida al desarrollo de actividades de responsabilidad social.

77. Los máximos responsables cuyo origen son empresas que impulsan acciones formativas en el ámbito de la responsabilidad social conceden una leve mayor relevancia al estilo participativo, salvo en los casos de líderes vinculados a organizaciones que dedican gran cantidad de horas a este tipo de iniciativas, a medida 
que sus empresas de procedencia dedican más horas a dichas acciones. La misma tendencia se ha producido, pero de forma inversa, en relación con el estilo consultivo. A medida que las organizaciones aumentan la extensión de sus acciones formativas sobre responsabilidad social, salvo en los casos de organizaciones que dedican gran cantidad de horas a dichas iniciativas, el estilo consultivo es propenso a adquirir menos importancia.

78. Parece existir una tendencia a que la flexibilidad sea más reducida en el rol de liderazgo a medida que la actitud de los líderes hacia la responsabilidad social es más favorable. Hemos entendido que esta tendencia podría guardar relación con la mayor proximidad de la responsabilidad social a unos estilos de liderazgo (participativo) y con su mayor distanciamiento de otros (directivo). Esta tendencia a la pérdida de flexibilidad de liderazgo en los máximos dirigentes también se ha registrado cuando su organización de origen ha incrementado la intensidad de su comportamiento socialmente responsable.

79. Parece producirse un aumento en la efectividad del liderazgo del máximo responsable organizacional a medida que presenta una disposición más favorable hacia la Responsabilidad Social Corporativa. Este dato podría indicar que la mayor afinidad con la responsabilidad social agudiza la destreza para acertar con el estilo de liderazgo más idóneo que requiere cada 
situación. Este aumento de la efectividad del líder también se ha producido cuando su organización de origen ha elevado el tono de su actuación en materia de responsabilidad social.

80. Se ha registrado una leve relación inversa entre el estilo directivo y la actitud del máximo dirigente a favor de la Responsabilidad Social Corporativa. En cierto sentido, aunque la relación es poco intensa, hemos entendido que indica que el liderazgo centrado de modo exclusivo en la instrucción, y que descarta la utilización del apoyo en el ejercicio del rol de líder, es el que más se aleja de la filosofía que representa la Responsabilidad Social Corporativa.

81. La competencia genérica "metas", el rasgo de personalidad "variedad", la efectividad de estilo y el estilo participativo parecen tender a aumentar en los líderes empresariales a medida que se intensifica su disposición a favor de la responsabilidad social. Además los estilos participativo y consultivo y su efectividad de estilo muestran tendencia a cobrar más protagonismo a medida que se incrementa la actuación socialmente responsable de la organización de procedencia del máximo dirigente. Estos datos parecen indicar que en el líder existe una cierta asociación entre el aumento de su preferencia por hacer cosas nuevas y diferentes, su mayor predilección por disponer de objetivos perfectamente definidos, y el incremento de su preferencia por un estilo de dirección en el que 
predomine el apoyo en su mayor afinidad por la responsabilidad social. Asociación que parece tener incidencia en la mayor efectividad en el rol de liderazgo.

82. El rasgo de personalidad "practicidad", el estilo de liderazgo directivo y la flexibilidad de estilo son aspectos que reducen su protagonismo en los líderes a medida que se intensifica el comportamiento socialmente responsable de las empresas de las que proceden. Este dato parece indicar que la menor preferencia por las ventajas materiales en el corto plazo, la pérdida de relevancia de la instrucción en el comportamiento de liderazgo y la utilización de un menor número de estilos de liderazgo son aspectos que pueden estar asociados a la mayor afinidad hacia la responsabilidad social que presentan los líderes que promueven una mayor actuación en el campo de la responsabilidad social. 


\subsection{CONCLUSIONES SOBRE VALORES Y LA RESPONSABILIDAD SOCIAL}

83. Todos los líderes, con independencia que su actitud hacia la responsabilidad social sea más o menos favorable, de su sector de procedencia y del comportamiento socialmente responsable de su organización de origen, conceden más importancia a la competencia genérica "metas" que al resto de aspectos evaluados que tienen incidencia en la toma de decisiones de los máximos dirigentes empresariales (los rasgos de personalidad "practicidad”, “decisión” y “variedad", la característica comportamental “orden y método" y la característica genérica “resultados”). Este resultado indica que los máximos responsables empresariales, sea cual sea su grado de disposición favorable hacia la responsabilidad social, valoran muy especialmente tener una meta definida en la que trabajar, mantenerse en un problema hasta que este sea resuelto, dirigir el esfuerzo propio hacia objetivos bien delimitados y conocer con precisión en qué están pensando. Las líderes femeninas vinculadas a organizaciones que impulsan acciones formativas enmarcadas en el ámbito de la responsabilidad social han mostrado una cierta tendencia a conceder más importancia a esta competencia genérica a medida que 
su organización de procedencia ampliaba la extensión de sus iniciativas formativas.

84. La competencia genérica "resultados" muestra una leve tendencia a cobrar relevancia en el líder a medida que se incrementa su disposición favorable hacia la Responsabilidad Social Corporativa. Hemos considerado que esta tendencia puede estar asociada a una comprensión de la responsabilidad social como un reto que la empresa debe afrontar, que se agudiza cuanto más intensifican los máximos responsables empresariales su actitud a favor de la responsabilidad social.

85. El incremento de la actuación socialmente responsable de las organizaciones parece estar asociado en los líderes empresariales, en cierta medida, a una reducción de sus metas materialistas y de la búsqueda de beneficios a corto plazo. Esta tendencia guarda bastante lógica con su aproximación a la filosofía que representa la Responsabilidad Social Corporativa, más centrada en beneficios no materiales y en apuestas estratégicas a medio y largo plazo.

86. El rasgo de personalidad "variedad" de los máximos dirigentes empresariales parece adquirir mayor importancia a medida que crece la implicación de sus organizaciones de origen en actuaciones socialmente responsables. Este dato parece indicar que, frente a los máximos responsables vinculados a empresas que no desarrollan ningún tipo de actuación en materia de 
Responsabilidad Social Corporativa, los líderes procedentes de organizaciones con políticas establecidas de responsabilidad social tienen más afinidad con el desarrollo de nuevas actividades que rompan su rutina.

87. La competencia genérica "metas" ha mostrado una cierta tendencia a cobrar más relevancia en los máximos responsables empresariales a medida que las empresas acentúan su actuación socialmente responsable. Este dato podría indicar que la apuesta organizacional por el desarrollo de iniciativas socialmente responsables podría estar asociada a una mayor preferencia de sus líderes por objetivos bien definidos en los que centrar su esfuerzo. De todos modos es necesario tomar con prudencia esta consideración porque la tendencia creciente, por parte del líder, a otorgar más importancia a la competencia genérica "metas" no se ha mantenido cuando hemos contemplado las iniciativas formativas desarrolladas por sus organizaciones de procedencia: en este caso la importancia otorgada a esta competencia genérica no ha crecido a medida que las empresas han incrementado la duración de sus acciones formativas enmarcadas en el ámbito de la responsabilidad social. 


\subsection{DISCUSIÓN}

En este capítulo hemos procedido a cotejar los resultados y las conclusiones obtenidas con las hipótesis de investigación reflejadas en el capítulo 5. Además, hemos contrastado los resultados con los datos recabados de otros estudios que se han indicado en la primera parte de esta investigación dedicada a los fundamentos teóricos (capítulos $1,2$ y 3$)$.

\subsubsection{Hipótesis 1: Los líderes que tienen una actitud más favorable hacia la responsabilidad social están vinculados a organizaciones que tienen una política de Responsabilidad Social Corporativa más definida}

De acuerdo a los resultados alcanzados en esta investigación, el desarrollo de acciones de responsabilidad social integradas en una política definida es una práctica poco extendida en el mercado dentro de las organizaciones que presentan algún tipo de comportamiento socialmente responsable: solo dos de cada diez empresas que realizan este tipo de actuaciones desarrollan iniciativas de responsabilidad social integradas en una política 
previamente definida. Aspecto que, a nuestro juicio, indica que la Responsabilidad Social Corporativa no representa una aspiración estratégica para las organizaciones aunque tenga buena acogida en el mercado (algo más de la mitad de las empresas impulsan iniciativas en este ámbito), ya que la gran mayoría de las organizaciones no establecen vínculos a medio y largo plazo en el campo de la responsabilidad social.

Además los datos del estudio también han indicado que los líderes empresariales presentan, en términos generales, una actitud favorable hacia la Responsabilidad Social Corporativa basada en criterios compartidos. Afinidad hacia la responsabilidad social en la que, desde nuestro punto de vista, ha ejercicio una poderosa influencia la gran presión social que se ha venido realizando en las últimas décadas desde distintos estamentos (académicos, institucionales, gubernamentales, mediáticos...) por impulsar el asentamiento de esta disciplina.

La investigación también ha revelado que pese a la elevada disposición favorable hacia la responsabilidad social de los líderes organizacionales, los máximos responsables empresariales tienen una mayor afinidad por este ámbito a medida que su organización de origen intensifica su apuesta por la Responsabilidad Social Corporativa. En este sentido los líderes que han presentado una actitud más favorable hacia la responsabilidad social han estado vinculados a empresas con una política definida de responsabilidad social. Estos datos parecen indicar que la disposición 
positiva de gran intensidad hacia la Responsabilidad Social Corporativa en los máximos cargos organizacionales es un factor que acentúa el comportamiento socialmente responsable de las empresas.

Hemos considerado que estos datos son especialmente interesantes porque los líderes empresariales han declarado que el desarrollo de políticas de responsabilidad social no favorece, en términos generales, la conquista del liderazgo en el mercado y, en cierta medida, la rentabilidad. Hemos entendido que el hecho de que los líderes con una disposición más favorable hacia la responsabilidad social se encuentren en organizaciones con una política definida en este campo también indica que disponen de una comprensión estratégica de la responsabilidad social que está vinculada a la obtención de beneficios a largo plazo.

En los trabajos revisados para realizar este estudio no se han localizado investigaciones que verificaran completamente la hipótesis planteada, aunque sí se han revisado trabajos que han presentado cierta correspondencia con los resultados comentados previamente.

En este sentido, hay investigaciones que han indicado que las empresas que intentan institucionalizar culturas éticas para favorecer el desarrollo moral en la organización desarrollan iniciativas como la implantación de códigos 
éticos y el desarrollo de acciones formativas (Trevino y Nelson, 2004).

Hemos entendido que este tipo de empresas estarán más interesadas en líderes con una disposición muy favorable hacia aspectos afines a la responsabilidad social, como por ejemplo la ética. Además, los altos cargos que presenten esa predisposición también estarán interesados en ese tipo de organizaciones. Los líderes, como el resto de personas, también buscan involucrarse en conductas consistentes con sus propias actitudes para que estas se vean fortalecidas (DeBono y Snyder, 1995).

También se han realizado investigaciones que han confirmado que la cultura organizacional ejerce una influencia significativa en la actitud de los líderes empresariales hacia la ética en los negocios (Christie, Kwon, Stoeberl y Baumhart, 2003).

Estos resultados ejemplifican como el desempeño de un rol específico influye finalmente en la formación de las actitudes personales (Carnahan y McFarland, 2007; Haslam y Reicher, 2007; Zimbardo, 2007). Hemos supuesto que las culturas que ejerzan, efectivamente, dicha influencia, probablemente también impulsen iniciativas en el ámbito de la responsabilidad social.

Existen también propuestas que han relacionado la adopción de la responsabilidad social por parte de las organizaciones con la presencia de valores más orientados 
hacia el idealismo y el altruismo (frente a la visión comercial de los negocios) en sus líderes, y más centrados en su preocupación por todos los afectados por la actividad de la empresa que por su propio estatus individual (Hemingway y Maclagan, 2004). Hemos entendido que dado el carácter guía de los valores en las actitudes (Hofstede, 1998), las indicaciones ofrecidas en este modelo están en consonancia con la hipótesis 1.

También se han realizado otras investigaciones que han mostrado que la sensibilidad hacia los grupos de interés aumenta cuando la cultura de las organizaciones presenta un esfuerzo por eliminar la incertidumbre (Blodgett, Lu, Rose y Vitell, 2001). Hemos entendido que tanto la búsqueda de una mayor sensibilidad hacia otras personas como el esfuerzo por fomentar no solo una gestión competente sino también la transparencia, guardan relación con la disposición favorable de los líderes hacia la responsabilidad social y con el desarrollo de acciones de Responsabilidad Social Corporativa en las organizaciones. 


\subsubsection{Hipótesis 2: Los líderes que tienen una} actitud más favorable hacia la Responsabilidad Social Corporativa utilizan un estilo de liderazgo que presenta preferencia por los estilos "participativo" y "delegativo"

Los líderes organizacionales que han participado en esta investigación, sea cual sea su actitud hacia la responsabilidad social, su sexo y su edad, comparten preferencia por el estilo participativo (alto apoyo y poca dirección) como estilo de liderazgo primario. Entendemos que este resultado refleja que la predilección por este estilo de liderazgo en los máximos responsables empresariales está muy consolidada y no se ve afectada, en términos generales, por fluctuaciones en su actitud hacia la responsabilidad social. Refuerza esta consideración el hecho de que el estilo participativo sigue siendo el estilo primario de los líderes, sea cual sea el comportamiento socialmente responsable de su organización de origen.

Pese a esta tendencia general, el estilo participativo (alto apoyo y poca dirección) parece ganar protagonismo en el ejercicio del liderazgo a medida que el líder presenta una actitud más favorable hacia la responsabilidad social. Hemos considerado que esta tendencia podría estar motivada porque el estilo de liderazgo participativo tiene 
más afinidad con el planteamiento empresarial que representa la responsabilidad social, orientado en mayor grado a la preocupación por los grupos de interés (stakeholders entre los que se encuentran los colaboradores).

Refuerza este último planteamiento el hecho de que los máximos responsables que proceden de organizaciones con algún tipo de comportamiento socialmente responsable, en los que también se incluyen aquellos cuyas empresas impulsan acciones formativas de pequeña o mediana extensión en el ámbito de la responsabilidad social, conceden una relevancia mayor al estilo participativo (alto apoyo y poca dirección) que los máximos responsables cuyo origen son empresas que no desarrollan ningún tipo actuación en el ámbito de la Responsabilidad Social Corporativa. Estos datos parece indicar que pese a que el estilo de liderazgo participativo es el estilo de liderazgo primario en todos los líderes, sea cual sea la actuación de su organización de origen en materia de responsabilidad social, esta conducta de dirección parece adecuarse en mayor medida al desarrollo de actividades de responsabilidad social $y$, por tanto, parece tener más sintonía con la filosofía que representa la Responsabilidad Social Corporativa.

En cuanto al estilo de liderazgo delegativo (poco apoyo y baja dirección), aunque es un estilo con poca relevancia para los líderes parece perder relevancia en el 
máximo responsable empresarial a medida que se acentúa su actitud hacia la responsabilidad social. En los líderes procedentes de organizaciones pequeñas se ha registrado una tendencia decreciente en la importancia que otorgan al estilo delegativo a medida que crece la intensidad del comportamiento socialmente responsable de sus empresas de origen. Además, a medida que aumenta el tamaño de las organizaciones los líderes han mostrado una actitud más acentuada a favor de la responsabilidad social y una menor preferencia por el estilo delegativo. Estos datos parecen indicar que el estilo delegativo, aunque ya de por sí es un estilo con protagonismo reducido en el rol de liderazgo de los máximos responsables empresariales, tiene tendencia a perder relevancia a medida que se intensifica la aproximación de los líderes organizacionales hacia la responsabilidad social. Esta observación parece indicar que el desarrollo de acciones de Responsabilidad Social Corporativa impulsa el diálogo con los colaboradores.

Los estilo participativo (alto apoyo y poca dirección) y delegativo (poco apoyo y baja dirección) conceden poca relevancia a las instrucciones y conducen, por tanto, a un estilo de liderazgo caracterizado por la presencia o no del apoyo. Si tomamos en consideración las observaciones planteadas previamente en relación con el mayor acercamiento de los líderes a la responsabilidad social a medida que utilizan en mayor grado el estilo participativo y en menor medida el delegativo, el nexo entre ambos estilos vendría determinado por una mayor exigencia de apoyo en 
la relación que los máximos dirigentes empresariales establecen con los colaboradores.

En los trabajos revisados en el marco teórico, no hemos encontrado estudios que trataran la influencia de ambos estilos de liderazgo, o del comportamiento del rol de líder más centrado en el apoyo o en la delegación, en la actitud de los líderes empresariales hacia la responsabilidad social.

Cuando hemos formulado la hipótesis 2, hemos supuesto que este rasgo sería característico de un estilo de liderazgo asociado a una actitud más favorable hacia la responsabilidad social (tal como ha sido el caso en el estilo participativo). De todos modos hemos considerado que algunos de los estilos de liderazgo más actuales que presentan una orientación más sensible hacia el colaborador, así como su propia motivación, también podrían intensificar la actitud del líder a favor de la responsabilidad social.

En este sentido, sería interesante realizar investigaciones para constatar si existen correlaciones entre la actitud favorable a la responsabilidad social de los máximos cargos empresariales y la "motivación inspiradora" (Avolio y Bass, 1991; Bass, 1998; Sosik, Potosky y Jung, 2002) que fomenta el liderazgo transformacional para generar entusiasmo, ánimo y optimismo en los colaboradores. 
También parece una empresa atractiva la revisión de la posible relación existente entre dicha actitud y el liderazgo respetuoso que impulsa ofrecer el mismo trato en el trabajo que el que reciben los colaboradores en su vida privada (Mason, 1994; Van Quaquebeke y Brodbeck, 2008).

Otro enfoque con el que podría ser interesante analizar la correspondencia es con el liderazgo de servicio (Greenleaf, 1977; Dennos, 2004; Dennis y Winston, 2003; Laub, 2005; Winston, 2004), que defiende que el líder está más orientado a servir a los demás que a satisfacer sus creencias y su ego. Algunos estudios próximos a este enfoque han confirmado que los líderes con un comportamiento más colectivo y cooperativo, en contra de los que persiguen satisfacer su propio beneficio, asignan más importancia a la ética y a la responsabilidad social (Godos, Fernández y Martínez, 2010).

En esta línea también podría verificarse la relación entre las propuestas teóricas que persiguen impulsar un liderazgo centrado en el desarrollo de la sensibilidad humana del líder (Covey, 2005) y la actitud favorable de los máximos responsables empresariales hacia la responsabilidad social.

Además también hemos considerado que cuando las culturas influyen en la disposición ética de los líderes (Christie, Kwon, Stoeberl y Baumhart, 2003), también están afectando al rol de liderazgo que se utiliza en las organizaciones. 
En relación con dicho planteamiento, hemos entendido que también sería interesante revisar la influencia de la orientación cultural en la adopción de disposiciones favorables hacia la responsabilidad social por parte de los máximos cargos organizacionales. Algunos estudios (Castro y Lupano, 2005) ya han indicado que en las culturas más “transformacionales" el prototipo de líder que se demanda es más participativo, democrático y con una elevada preocupación por el colaborador.

De todos modos también hemos recogido la observación de Corte y Carrasco (2012) cuando indican que puede que no sea posible determinar un estilo de liderazgo efectivo para la responsabilidad social en todas las culturas y organizaciones.

\subsubsection{Hipótesis 3: Los líderes que tienen una actitud más favorable hacia la Responsabilidad Social Corporativa presentan una puntuación más elevada en los "valores" personales "resultados" y "practicidad"}

La competencia genérica "resultados" hace referencia a la preferencia por afrontar problemas difíciles, tener un trabajo complicado al que enfrentarse, abordar algo 
importante tratando de encontrar la perfección, superarse constantemente y hacer un trabajo excelente en cualquier cosa que se intente (Gordon, 2010). Cuando hemos diseñado la investigación, hemos supuesto que se trataría de un aspecto importante en el ámbito de la responsabilidad social siempre y cuando los líderes conciban esta disciplina como un desafío que debe acometerse.

Los resultados de este estudio han indicado que la competencia genérica "resultados" presenta una leve tendencia a cobrar relevancia en el líder a medida que se incrementa su disposición favorable hacia la Responsabilidad Social Corporativa. Hemos considerado que esta tendencia podría indicar que cuanto más se intensifica la actitud de los máximos responsables empresariales a favor de la Responsabilidad Social Corporativa, más crece su comprensión de la responsabilidad social como un reto que debe afrontar la empresa.

El rasgo de personalidad "practicidad" hace alusión a que la persona quiere hacer cosas que le den beneficio, conseguir lo mejor de su dinero, cuidar de sus propiedades 0 pertenencias y sacarle fruto (Gordon, 2010). En los prolegómenos de esta investigación hemos planteado que este rasgo de personalidad tendría incidencia en el ámbito de la responsabilidad social para los líderes que consideraran las acciones de Responsabilidad Social Corporativa como algo que aporta algún tipo de valor para sus organizaciones. 
Los datos del estudio han indicado que el incremento de la actuación socialmente responsable de las organizaciones parece estar asociado, en cierta medida, a una reducción de las metas materialistas y de la búsqueda de beneficios a corto plazo en los líderes empresariales. Hemos considerado que esta tendencia guarda bastante lógica con una aproximación de los máximos responsables a la filosofía que representa la Responsabilidad Social Corporativa, más centrada en beneficios no materiales y en apuestas estratégicas a medio y largo plazo, a medida que su organización se involucra en iniciativas desarrolladas en este ámbito. Estos resultados tienen correspondencia con los alcanzados en otros estudios que han indicado que la preocupación por los stakeholders se acentúa cuando la cultura organizacional pretende reducir el énfasis por la adquisición de elementos materiales (Blodgett, Lu, Rose y Vitell, 2001).

De todos modos los resultados alcanzados indican que tanto "practicidad", "resultados", como el resto de competencias genéricas, rasgos de personalidad y características comportamentales estudiadas presentan, en el mejor de los casos, una leve asociación con el incremento de la actitud de los líderes hacia la Responsabilidad Social Corporativa. Dato que, a nuestro juicio, revela que aspectos alejados inicialmente de la responsabilidad social, como los estudiados, no parecen tener una incidencia determinante en la actitud de los líderes hacia la responsabilidad social 
(aunque sí evidencien que los máximos responsables empresariales con mayor afinidad por la Responsabilidad Social Corporativa comparten ciertas características).

Hemos supuesto que una mayor incidencia en la disposición positiva de los líderes organizacionales hacia Responsabilidad Social Corporativa podría estar determinada, en un mayor grado, por aspectos más próximos a este ámbito como son, por ejemplo, los valores vinculados con la ética. Esta asociación ha sido verificada por algunos estudios que han indicado que los líderes que conceden más importancia a la ética también otorgan más relevancia a la responsabilidad social (Godos, Fernández y Martínez, 2010).

Estos resultados tienen cierta lógica con la presumible incidencia de los valores en las actitudes. En este sentido, algunos autores han indicado que los valores determinan las actitudes (Arciniega, 2001) aunque, por otra parte, no siempre las actitudes se traducen en un tipo específico de comportamiento (Fazio y Roskos-Ewoldson, 1994; Tesser, Martín y Cornell, 1996).

Es probable que se desarrolle una elevada producción científica sobre la relación que establecen los valores éticos y la actitud favorable hacia la responsabilidad social en los entornos de trabajo.

Se ha constatado la existencia de un emergente campo de estudio que intenta establecer una relación entre los 
valores personales de los líderes y el desarrollo de marcos de trabajo éticos (Mudrack, 2007; Strautmanis, 2008), línea de investigación que seguramente aportará trabajos sobre la relación entre los valores éticos y la disposición favorable de los líderes hacia la Responsabilidad Social Corporativa.

También se han desarrollado otros estudios que han arrojado algunas conclusiones interesantes sobre otros valores menos afines, a priori, a la responsabilidad social, que también podrían estar implicados en una actitud favorable de los líderes hacia este ámbito.

Hay investigaciones que han indicado que la proximidad de los líderes hacia la Responsabilidad Social Corporativa se ve favorecida cuando estos experimentan satisfacción laboral (Valentine y Fleischman, 2008). En este sentido "valores" como el "placer" o la "competencia" (Rokeach, 1973), que pueden actuar como motivadores en la búsqueda de satisfacción laboral, podrían tener incidencia en la disposición favorable de los líderes hacia la responsabilidad social.

También se han desarrollado trabajos que han observado que la percepción favorable de la responsabilidad social está condicionada por la visión de su potencial para producir beneficios (Zu y Song, 2008; Lindorff y Peck, 2010). De este modo, algunos los "valores" que podrían tener incidencia en una disposición positiva hacia la 
Responsabilidad Social Corporativa podrían ser "ambición" o “sentido de logro" (Rokeach, 1973).

\subsubsection{Hipótesis 4: Las organizaciones que impulsan la formación de sus colaboradores en materia de responsabilidad social están más implicadas en la realización de acciones en este ámbito}

Este estudio ha revelado que el impulso en las organizaciones de la formación enmarcada en el ámbito de la responsabilidad social es un aspecto muy relacionado con el desarrollo de iniciativas sobre responsabilidad social, ya que todas las empresas que desarrollan acciones formativas enmarcadas en el ámbito de la responsabilidad social muestran algún tipo de comportamiento socialmente responsable.

Además los datos también han indicado que las empresas, en términos generales, tienen preferencia por el desarrollo de acciones formativas de extensión reducida enmarcadas en el ámbito de la responsabilidad social, aunque también han constatado que la elevada implicación organizacional en la responsabilidad social representa una mayor preocupación de los líderes por mejorar la formación de sus colaboradores en esta materia (más de la mitad de las empresas que desarrollan iniciativas formativas dirigidas 
a sus públicos internos apuestan estratégicamente por la responsabilidad social).

Hemos entendido que existe coherencia en esta mayor implicación organizacional de las empresas en acciones formativas sobre responsabilidad social cuando su comportamiento socialmente responsable es más intenso. El desarrollo de este tipo de iniciativas formativas, que está relacionado con una mayor aproximación de los líderes organizacionales hacia la responsabilidad social, no deja de ser una actuación más dentro de las que pueden desarrollar las empresas en el ámbito de la Responsabilidad Social Corporativa.

Estos resultados tienen cierta relación con los alcanzados por Trevino y Nelson (2004) cuando indican que la formación en materia de responsabilidad social está asociada a organizaciones que intentan establecer culturas éticas. Es bastante factible que las empresas de este perfil sean más proclives a impulsar acciones integradas en el ámbito de la responsabilidad social.

En este sentido es probable que, de acuerdo a las investigaciones que se han realizado sobre valores y culturas y a las correspondencias que hemos encontrado en dichos estudios con la responsabilidad social, la formación en esta materia tenga más acogida en las culturas corporativas que presenten ciertos rasgos como: el fomento de la preocupación personal por todos los integrantes de la organización (Parsons, 1951; Kluckhohn y Strodtbeck, 1961; Hofstede, 1979, 1980, 1991), la preocupación por personas 
de otros colectivos (Hofstede, 1979, 1980, 1991; Schwartz, 1999a) y la búsqueda de armonía en la relación con el medio ambiente (Schwartz, 1999a).

\subsubsection{Hipótesis 5: Las organizaciones que actúan en el sector servicios, supuestamente más sensibilizadas con el trato personal, presentan líderes con una actitud más favorable hacia la Responsabilidad Social Corporativa}

Los resultados de esta investigación han indicado que los líderes del sector servicios, en el que se incluye el comercio, presentan una actitud un poco menos favorable hacia la responsabilidad social que los máximos responsables de otros sectores, como los que proceden de los ámbitos industrial y construcción. Hemos entendido que un factor que puede explicar este dato es la menor incidencia en el medio ambiente de la actividad desarrollada por las empresas del sector servicios, ya que hay estudios que han indicado que la responsabilidad social es un asunto de mayor trascendencia y utilidad económica para las empresas industriales que para el resto (Godos, y Fernández, 2011).

A pesar de estos datos, hemos considerado interesante destacar varios aspectos indicativos de una disposición más favorable hacia la Responsabilidad Social Corporativa que se 
han detectado en las entrevistas realizadas a los líderes del sector servicios.

Uno de estos factores es el tamaño de su organización de procedencia. A medida que su dimensión es mayor los líderes del sector servicios han mostrado una actitud más intensa a favor de la responsabilidad social. Hemos considerado que esta tendencia podría explicarse, en cierta medida, por la mayor preocupación de los líderes de este ámbito de actividad por la vertiente social de la responsabilidad social, especialmente en relación con los públicos internos, a medida que sus organizaciones de origen aumentan su tamaño.

Además, los líderes del sector servicios muestran una disposición más favorable hacia la responsabilidad social según crece la importancia que conceden al estilo participativo. Hemos considerado que en este sector, en el que las exigencias relacionadas con la implicación de la organización en acciones responsables no están especialmente motivadas por la propia actividad que desarrollan las organizaciones, la disposición personal del líder es un factor más relevante para la puesta en marcha de iniciativas que en otros ámbitos sectoriales. En este sentido, hemos entendido que la adopción de un estilo de liderazgo que conceda más importancia al apoyo y menos relevancia a las directrices es reflejo de esta mayor afinidad del líder hacia la Responsabilidad Social Corporativa. Esta 
correspondencia también se ha dado al contemplar la importancia que el líder otorga al estilo participativo en función del comportamiento socialmente responsable de su organización de procedencia: los máximos dirigentes de las empresas de este sector conceden una mayor importancia al estilo participativo cuando sus organizaciones desarrollan actuaciones socialmente responsables.

Los máximos cargos del sector servicios también han presentado una tendencia a reducir su flexibilidad de liderazgo y a aumentar su efectividad a medida que se ha acentuado su afinidad hacia la Responsabilidad Social Corporativa (tendencia que también se ha mantenido al considerar el aumento de la intensidad del comportamiento socialmente responsable de sus organizaciones de origen y, en el caso de la efectividad, al contemplar el incremento de la extensión de los cursos formativos enmarcados en el ámbito de la responsabilidad social que ofrecen a sus públicos internos). Como la pérdida de flexibilidad asociada a una actitud más favorable hacia la responsabilidad social también supone un aumento de la eficacia de liderazgo en los máximos responsables del sector servicios, hemos entendido que su mayor actitud a favor de la responsabilidad contribuye a mejorar su capacidad para utilizar menos estilos de liderazgo de un modo más acertado. 
Por otra parte los líderes del sector servicios han concedido una leve mayor importancia a la competencia genérica "resultados" a medida que se ha incrementado su actitud hacia la responsabilidad social. Hemos considerado que este dato puede ser indicativo de que la mayor afinidad de los líderes de este sector por la responsabilidad social puede estar influida por una búsqueda más intensa de la excelencia en su cometido. Observación que se ve reforzada por el hecho de que los líderes del sector son, de los tres sectores contemplados en el estudio, los que han concedido una mayor importancia a esta competencia genérica.

Otro aspecto que también influye en la mayor actitud del líder del sector servicios hacia la responsabilidad social es su edad: a medida que el máximo responsable de este ámbito es más mayor su actitud hacia la responsabilidad social tiende a ser menos favorable. En este sentido, la juventud es un aspecto que acentúa la disposición del líder a favor de la responsabilidad social (no solo en el sector servicios, sino en todos los sectores). De todos modos hemos considerado que en el sector servicios es más relevante el potencial de esta disciplina como atributo de venta que en el resto de sectores estudiados, aspecto que asimismo también podría explicar la mayor afinidad de los líderes más jóvenes de este sector por la responsabilidad social. La razón es que estos líderes, que probablemente hayan recibido formación específica sobre Responsabilidad Social Corporativa, tienden a conceder más importancia a la 
responsabilidad social en la comunicación comercial debido a la mayor dificultad que entraña la compra-venta en un ámbito donde no hay productos. En esta línea, el líder empresarial también actuaría como modelo prototípico de la fuerza de ventas para incentivar un mayor uso de la filosofía que representa la responsabilidad social como atributo de venta. Hemos entendido que ambos aspectos podrían motivar en los líderes más jóvenes del sector servicios la formación de creencias afines a la responsabilidad social y, por tanto, el desarrollo de una actitud más favorable sobre esta disciplina (Ajzen y Fishbein, 1980; Ajzen, 1991).

En la revisión inicial de estudios se han encontrado investigaciones que han indicado que los empresarios de áreas rurales están más preparados que los de las zonas urbanas en temas como la ética empresarial (Hornsby, Kuratko, Naffziger, LaFollete y Hodgetts, 1994). Hemos entendido que la ubicación geográfica de la empresa es un factor que también podría tener incidencia en la actitud que presentan los líderes de los distintos sectores porque algunos ámbitos de actividad mercantil, como el de servicios, parecen tener más protagonismo en zonas urbanas que otros. Suposición que guardaría cierta correspondencia con los resultados alcanzados en esta investigación. 


\subsubsection{Hipótesis 6: Las organizaciones de gran} tamaño, supuestamente más preocupadas por su reputación corporativa, presentan líderes con una actitud más favorable hacia la Responsabilidad Social Corporativa

De acuerdo con los datos que ha alcanzado esta investigación, los líderes de empresas grandes presentan una actitud más favorable hacia la responsabilidad social que la que muestran los líderes de empresas pequeñas y medianas.

Estos resultados se corresponden con los alcanzados por alguno de los estudios revisados.

En una investigación desarrollada con altos cargos en España (por Godos y Fernández, 2011), se ha concluido que los directivos que conceden más importancia a la responsabilidad social se encuentran en las empresas de mayor tamaño.

En otra investigación se ha indicado que, en un alto porcentaje, los directivos de grandes compañías presentan una disposición favorable hacia la Responsabilidad Social Corporativa. De todos modos en este estudio no se ha realizado una comparación entre la actitud de los responsables empresariales a partir del tamaño de su organización de origen (Post, Rahman y Rubow, 2011). 
También hay estudios que no han confirmado que los directivos, más próximos a organizaciones de mayor tamaño, presenten una actitud más favorable hacia la responsabilidad social que los empresarios, más vinculados a organizaciones de menor dimensión.

En un estudio comparativo que se ha desarrollado entre empresarios de pequeñas y medianas empresas con directivos de grandes empresas (Mubabu, 2010), no se ha afirmado que los empresarios tengan valores éticos y de responsabilidad social diferentes de los que muestran los directivos.

De todos modos sí se indican diferencias cualitativas en la actitud de ambos colectivos relacionadas con aspectos que influyen en su configuración. Mientras los directivos parecen estar más influidos por la formación adquirida en sus actitudes hacia la responsabilidad social, los empresarios parecen estar más afectados por la presión social en su disposición favorable hacia la Responsabilidad Social Corporativa.

Un estudio realizado con futuros gestores empresariales parece corroborar el peso de la instrucción en la actitud hacia la responsabilidad social. La investigación ha concluido que los futuros máximos responsables empresariales muestran preocupación por temas éticos y de responsabilidad social (Vázquez, Oliveira y Seabra, 2012).

También se han realizado otras investigaciones que indican que el mayor tamaño de las organizaciones influye 
negativamente en la actitud de los líderes hacia la responsabilidad social.

En un test a empresarios de organizaciones pequeñas y medianas y a directivos de grandes empresas en Eslovenia y Rusia, se ha concluido que los empresarios tienen más actitudes éticas que los directivos (Bucar, Glas y Hisrich, 2003). De todos modos este resultado se ha de tomar con cierta cautela porque en la primera década del siglo XXI Rusia ha sido un país con un débil entorno institucional, en el que se ha producido un abuso de las leyes y donde la actuación del gobierno ha sido débil o no se ha respetado (Kuznetsov y Kuznetsova, 2003). Es decir, la situación estructural puede haber alterado la posible influencia del tamaño empresarial en la disposición de los líderes hacia la responsabilidad social. Los resultados alcanzados por otra investigación realizada en Rusia (Kutnesov, Kutnesova y Warren, 2009) parece demostrar la influencia del contexto en la percepción de la responsabilidad social. En este estudio gerentes empresariales han manifestado que para las empresas supone un valor reducido a largo plazo que se muestren responsables ante la sociedad, y que las actuaciones empresariales que responden a requerimientos legales estándar o al mínimo de responsabilidad social exigible a una organización empresarial (como pagar los impuestos, crear empleo y respetar la ley) son actuaciones vinculadas al ámbito de la Responsabilidad Social Corporativa. 
En la revisión de algunos estudios más antiguos que se han realizado (Longenecker, McKinney, y Moore, 1989), se ha concluido que los empresarios presentan un nivel más alto que los directivos y que los empleados de grandes empresas en ética empresarial. De todos modos también se ha indicado que los instrumentos utilizados en los análisis comparativos sobre Responsabilidad Social Corporativa entre directivos y empresarios no han sido idóneos. El motivo es que algunas de las variables seleccionadas en estas herramientas han sesgado las respuestas que se habían obtenido.

Investigaciones más actuales, como la realizada por $\mathrm{Zu}$ y Song (2008), han indicado que los responsables empresariales que presentan una disposición más favorable hacia la responsabilidad social están presentes en organizaciones de tamaño pequeño.

También se han revisado otros estudios que no han indicado en qué medida el tamaño de una organización afecta a la actitud de los líderes empresariales hacia la responsabilidad social, aunque sí han concluido que las percepciones de los empresarios de las pequeñas y medianas empresas sobre la Responsabilidad Social Corporativa se diferencian de las actitudes de los directivos de las grandes empresas o multinacionales (Longenecker, McKinney y Moore, 1989; Payne y Joyner, 2006). 
La variedad de los resultados alcanzados en los estudios revisados no permite concluir que el tamaño de las organizaciones sea determinante en la actitud de sus máximos responsables hacia la responsabilidad social, pese a que esta investigación ha indicado que el mayor tamaño de las organizaciones influye en que los líderes empresariales tengan una actitud con mayor afinidad hacia la responsabilidad social. Es posible que otros factores, que en mayor o menor medida afectan a la disposición ética de los líderes empresariales, como el grado de desarrollo de la economía en la que la organización desarrolla su actividad (García y García, 2008) o la competitividad de su entorno (Bacus y Near, 1991), también moderen la influencia que tiene el tamaño de una empresa en la disposición de su líder hacia la responsabilidad social.

En los resultados de esta investigación hay varios aspectos asociados al perfil del líder que parecen incidir en que el tamaño empresarial influya, en mayor medida, en la formación de una actitud más favorable hacia la responsabilidad social en los líderes organizacionales. Este es el caso de la búsqueda de claridad en la toma de decisiones y de retos en los líderes cuyo origen son empresas pequeñas, el distanciamiento de metas materialistas y de la preferencia por actividades útiles a corto plazo o económicamente ventajosas en los líderes procedentes de empresas pequeñas y medianas, y la preferencia por actividades bien delimitadas en los líderes vinculados a organizaciones grandes. 


\subsubsection{Hipótesis 7: La edad de los líderes de las organizaciones no resulta un factor indicativo de cómo de favorable es su actitud hacia la Responsabilidad Social Corporativa}

Los datos que ha arrojado este estudio han indicado que aunque todos los líderes presentan una actitud favorable hacia la Responsabilidad Social Corporativa, el incremento de su edad parece ser un factor que reduce su disposición favorable hacia la misma. Estos resultados se corresponden con los alcanzados por un estudio realizado en España, diseñado para evaluar la percepción de la responsabilidad social de los directivos, que concluyó que los líderes más jóvenes son los que otorgan más valor a la Responsabilidad Social Corporativa (Godos, y Fernández, 2011).

Aunque estos datos se podrían interpretar como una leve pérdida de sensibilidad del líder hacia la responsabilidad social a medida que tiene más edad, hemos considerado que también pueden existir otros factores implicados que expliquen este hecho, como la creciente relevancia que ha ido cobrando la Responsabilidad Social Corporativa en la formación de los altos directivos empresariales. 
Hay estudios que parecen confirmar que la formación especializada afecta a la disposición más favorable de los directivos más jóvenes hacia esta disciplina (Vázquez, Oliveira y Seabra, 2012), aunque también se han realizado diversos trabajos que han indicado que la enseñanza en dirección de empresas ha influido en la configuración de un comportamiento oportunista de los líderes (Ferraro, Pfeffer y Sutton, 2005; McCabe, Butterfield y Treviño, 2006) que no favorece el desarrollo de iniciativas en el ámbito de la responsabilidad social.

Estos últimos datos presentan cierta correspondencia con otros resultados alcanzados en nuestro estudio en los que la menor edad no ha sido un factor determinante en la aproximación de los líderes hacia la responsabilidad social.

Este es el caso de la mayor presencia de líderes de mediana edad en las organizaciones que impulsan acciones formativas encuadradas en el ámbito de la responsabilidad social, aunque estos datos también podrían explicarse por el mayor poder de actuación del que suelen disponer los líderes de mediana edad respecto a los más jóvenes.

Además los líderes más mayores del sector industrial presentan una actitud hacia la responsabilidad muy cercana a la de los máximos responsables más jóvenes, que son quienes han presentado la actitud más favorable hacia la Responsabilidad Social Corporativa en este sector. En este caso consideramos que la gran repercusión medioambiental de la actividad desarrollada en este ámbito de actividad 
podría tener incidencia en la elevada sensibilidad hacia la responsabilidad que presentan los líderes de más edad.

También hemos detectado otros factores, aportados a continuación, que influyen en el aumento de la actitud a favor de la Responsabilidad Social Corporativa en los líderes menos jóvenes.

Uno de estos factores es la mayor relevancia que conceden a la característica comportamental "orden y método", que parece estar asociada al incremento de la actitud a favor de la responsabilidad social (algo que no se produce en los líderes más jóvenes). Este dato podría indicar que la mayor edad implica que la disposición pro responsabilidad social pueda estar vinculada con la concesión de una menor importancia a la planificación y a la automatización en el desempeño.

Otro de estos factores es la tendencia a otorgar una menor importancia al rasgo de personalidad "practicidad", ya que a medida que las organizaciones han mostrado un comportamiento más favorable hacia la responsabilidad social los líderes de mediana edad, y más mayores, han acentuado su actitud a favor de la responsabilidad social. Hemos supuesto que este dato indica que la menor preferencia por la búsqueda de ventajas materiales en el corto plazo podría tener incidencia, a medida que los líderes incrementan su edad, en una actuación más comprometida con la responsabilidad social en las empresas. Refuerza esta apreciación el hecho de que esta tendencia decreciente del rasgo de personalidad 
"practicidad" también se haya registrado, en cierto modo, en los líderes de mediana edad al considerar el aumento del número de horas que sus organizaciones de procedencia dedican a la formación enmarcada en el ámbito de la responsabilidad social.

Nuestro estudio también ha ofrecido otros resultados que han reforzado el valor predictor de la edad en relación con la actitud de los líderes empresariales de menos años hacia la responsabilidad social.

El análisis de la información ha indicado que los líderes más jóvenes tienen una presencia mayoritaria en las organizaciones del sector servicios e industria que impulsan iniciativas formativas de corta duración sobre responsabilidad social para sus públicos internos.

Además la edad ha mostrado una capacidad discriminante más determinante que el tamaño de la organización de procedencia de los líderes (pese a que los líderes cuyo origen son empresas grandes presentan una actitud hacia la responsabilidad social ligeramente superior a la que muestran los máximos responsables vinculados a organizaciones pequeñas o medianas) en relación con su disposición favorable hacia a la Responsabilidad Social Corporativa

Los resultados alcanzados también han revelado que existen otros factores asociados a una actitud pro responsabilidad social más acentuada en los líderes más jóvenes. 
De los aspectos hallados, uno es la menor importancia que estos líderes parecen otorgar al estilo directivo (alta dirección y poco apoyo) a medida que se intensifica su actitud a favor de la responsabilidad social. Este dato podría indicar que los líderes más jóvenes tienen tendencia a dar menos instrucciones o estar más preocupados por el estado emocional de sus colaboradores o ambas cosas al mismo tiempo, a medida que su actitud hacia la responsabilidad social se acentúa. Aspecto que se ve reforzado por el hecho de que estos líderes hayan mostrado una especial preferencia por el estilo participativo (alto apoyo y poca dirección) en las organizaciones que realizan acciones formativas sobre responsabilidad social, lo que parece reflejar su preferencia por los aspectos motivacionales en la relación que establecen con sus colaboradores.

Otro de los factores descubiertos es que estos líderes de menor edad conceden una importancia más destacada que el resto a los rasgos de personalidad "variedad" y "practicidad" y a la competencia genérica "resultados". Es posible que estos datos puedan ofrecer, en alguna medida, algún tipo de explicación a la mayor afinidad que muestran los líderes más jóvenes hacia la responsabilidad social. Especialmente por la búsqueda de retos (resultados) que puede constituir para ellos el desarrollo de acciones de responsabilidad social, y por la preferencia por ampliar el ámbito de actividades laborales (variedad) que suelen representar las actuaciones socialmente responsables. 
También hemos detectado que existe una tendencia decreciente en el rasgo de personalidad "variedad" a medida que aumenta la edad de los líderes y decrece su actitud por la responsabilidad social. Este dato podría indicar que los líderes más jóvenes son más propensos a disponer de una comprensión de la responsabilidad social más próxima a una experiencia laboral que aporta variedad a su dinámica empresarial.

Otro factor que hemos encontrado es que a medida que se incrementa la edad de los líderes empresariales y se reduce su afinidad hacia la responsabilidad social, el rasgo de personalidad "decisión" tiende a adquirir más relevancia en el líder. Este dato podría indicar que los líderes más jóvenes, que tienen menos experiencia laboral, precisan de más tiempo en su toma de decisiones. En este sentido, la apuesta de estos líderes por la Responsabilidad Social Corporativa podría estar motivada su certeza sobre el acierto que supone impulsar actuaciones en este ámbito.

Un último aspecto que hemos descubierto es que los líderes más jóvenes y de mediana edad muestran una mayor tendencia a reducir su flexibilidad de estilo a medida que aumenta su actitud a favor de la Responsabilidad Social Corporativa. Entendemos que la mayor afinidad de estos líderes por la responsabilidad social también podría suponer que tengan mayor confianza en una forma más concreta de dirección, que parece debilitarse cuando los líderes alcanzan una edad más avanzada. 
Aunque, en términos generales, los resultados indican que la edad de los líderes influye en su actitud hacia la responsabilidad social, hemos considerado que también sería interesante investigar el peso de otros actores sociales de especial relevancia, como el protagonismo adquirido por las ONG's y por otros organismos muy implicados en el desarrollo de la responsabilidad social (como el Foro para la Evaluación de la Gestión Ética -Forética- o el Observatorio de Responsabilidad Social Corporativa) en la disposición favorable de los líderes más jóvenes hacia la responsabilidad social.

\subsubsection{Hipótesis 8: El sexo de los líderes de las organizaciones no es un factor indicativo de cómo de favorable es su actitud hacia la Responsabilidad Social Corporativa}

Los resultados de este estudio han indicado que no existen diferencias significativas en la actitud de los líderes hacia la responsabilidad social según su sexo. Hemos considerado que la igualad de opciones que ofrece la sociedad actual a máximos responsables femeninos y masculinos, tanto en la formación como en el desarrollo de su carrera profesional, ha sido un factor de influencia en este resultado. 
Otros datos de este estudio también parecen indicar que el sexo no es un factor discriminante en la disposición de los líderes hacia la responsabilidad social. Por ejemplo la involucración empresarial en acciones de Responsabilidad Social Corporativa parece mejorar de igual modo la eficacia del liderazgo en ambos sexos, y el distanciamiento del materialismo y de la búsqueda del beneficio a corto plazo aproxima a ambos sexos, de igual modo, a la visión que propone la responsabilidad social.

De todos modos, la investigación sí ha arrojado algunos datos que podrían matizar la observación general que hemos ofrecido previamente.

El estudio ha indicado que existen algunos aspectos asociados a una actitud más favorable hacia la responsabilidad social por parte de las mujeres.

Un primer aspecto que destacamos es que, pese a que las mujeres tienen un menor protagonismo en alta dirección de las organizaciones que actúan en el marco de la responsabilidad social, la presencia de líderes femeninas en empresas que impulsan acciones formativas sobre responsabilidad social de extensión reducida es sensiblemente mayor que la de sus homónimos masculinos. Este dato parece indicar que las mujeres poseen un mayor interés que los hombres en introducir a los integrantes de su organización en la Responsabilidad Social Corporativa. 
Un segundo aspecto que incluimos es que el incremento de la edad de las líderes parece estar relacionada con una actitud menos favorable hacia la responsabilidad social (asociación que no se da en los hombres). Hemos entendido que la mayor vinculación emocional de las mujeres con su experiencia vital podría tener incidencia en la explicación de este resultado, ya que genera en las líderes un mayor desgaste a medida que se incrementa su edad y que podría afectar a su disposición hacia la responsabilidad social. En esta observación es interesante tener presente que las líderes más jóvenes presentan un entusiasmo especialmente destacado hacia la Responsabilidad Social Corporativa, ya que su actitud hacia la misma es mayor que la que muestran los máximos responsables masculinos sea cual sea su edad.

Un tercer aspecto de influencia favorable en la actitud hacia la responsabilidad social que destacamos en las líderes femeninas es que su vinculación a determinados ámbitos de actividad parece favorecer dicha disposición. En los dos sectores en los que los líderes presentan una actitud más favorable hacia la responsabilidad social, construcción e industria, las líderes femeninas muestran una actitud un poco más favorable hacia la responsabilidad social que la que presentan los líderes masculinos. Este dato parece indicar que en los sectores en los que se requiere una mayor aproximación a la responsabilidad social por las externalidades derivadas de su actividad, las mujeres muestran una leve mayor preocupación por la 
Responsabilidad Social Corporativa. Hemos considerado que esta hipótesis podría estar explicada, además de por la elevada implicación emocional de las mujeres, por la búsqueda de excelencia en su rol de líderes. Hemos supuesto que el liderazgo empresarial femenino aún representa un estatus en proceso de consolidación social y este aspecto podría acentuar, en mayor grado que en sus homónimos masculinos, su predisposición a favor de la responsabilidad social.

Un cuarto aspecto que destacamos es que ante niveles similares de actitud hacia la responsabilidad social, las mujeres conceden algo de más de importancia a la competencia genérica "metas" $\mathrm{y}$, especialmente, a la característica comportamental "orden y método" y al rasgo de personalidad "variedad". Hemos entendido que estos datos podrían sugerir que la preferencia por automatizar las tareas o planificarlas, dentro de lo posible, y la búsqueda de la diversidad, pueden estar más asociadas a una predisposición favorable hacia la responsabilidad social en las mujeres.

La investigación también ha revelado que hay rasgos implicados en que los hombres muestren una disposición más afín hacia la responsabilidad social.

Unos de estos aspectos es que los líderes masculinos tienen más oportunidades que las mujeres de impulsar iniciativas que denoten su actitud favorable hacia la 
Responsabilidad Social Corporativa porque, aunque tienen presencia, las líderes femeninas disponen de menos protagonismo en la cúpula de las organizaciones a medida que estas intensifican su comportamiento socialmente responsable. Mientras casi uno de cada cuatro líderes masculinos está vinculado a organizaciones con una política definida de responsabilidad social, en el caso de las mujeres es poco más de una de cada diez líderes.

Otro aspecto que aportamos es que las acciones formativas de mayor extensión enmarcadas en el ámbito de la responsabilidad social son impulsadas, de forma mayoritaria, por los líderes masculinos de mediana edad. Este hecho podría indicar que los máximos responsables masculinos tienen más preocupación por formar en profundidad a sus públicos internos sobre cuestiones de responsabilidad social relacionadas con la actividad específica que desarrolla su organización.

La investigación también ha revelado que los máximos responsables masculinos muestran una tendencia a conceder menos importancia a la característica comportamental "orden y método" a medida que el comportamiento socialmente responsable de su organización de origen se acentúa. Este dato parece indicar que la involucración de las organizaciones en este tipo de actividades conlleva una reducción de la importancia que el líder concede al enfoque sistemático y ordenado. Hemos considerado que la incertidumbre asociada, en muchos casos, al desarrollo de acciones de responsabilidad social, sobre todo en relación 
con los beneficios que la empresa puede esperar de dichas actuaciones, podría tener incidencia en la explicación de esta tendencia.

Los líderes masculinos también han concedido una mayor importancia a la competencia genérica "metas" a medida que ha crecido la intensidad del comportamiento socialmente responsable de sus organizaciones de procedencia. Hemos considerado que la mayor firmeza en la apuesta de la organización por acciones de responsabilidad social, algo que implica altos niveles de concreción y planteamientos estratégicos, también podría tener incidencia en que el máximo responsable masculino delimite en mayor grado los objetivos hacia los que dirige su esfuerzo.

Además de las aportaciones indicadas, también hemos querido aportar en la discusión de esta hipótesis algunas aportaciones vinculadas con nuestros supuestos iniciales en relación con la influencia del sexo en la actitud a favor de la responsabilidad social.

En los prolegómenos de la investigación habíamos planteado que no deberíamos descartar que las mujeres presentaran una disposición más favorable que los hombres hacia la responsabilidad social. En este sentido habíamos pensado que en el desarrollo del marco teórico encontraríamos estudios que vincularan especialmente algunos de los valores y dimensiones que hemos asociado a la responsabilidad social, como la "disposición servicial" 
(Rokeach, 1973) o la dimensión “colectivismo" (Johnston, 1995), a la actitud favorable de las mujeres hacia la Responsabilidad Social Corporativa. Pese a la ausencia de hallazgos en este sentido hemos considerado que sería interesante realizar investigaciones con un enfoque cualitativo para conocer la posible influencia de las diferencias antropológicas existentes entre los hombres y las mujeres en su disposición hacia la responsabilidad social.

También habíamos pensado que algunos resultados de los estudios revisados confirmarían la asociación directa entre la responsabilidad social y la religiosidad, y que dicho vínculo sería más intenso en el sexo femenino. Sin embargo las investigaciones revisadas no ha ofrecido resultados concluyentes en la relación entre la religiosidad de las personas y su comportamiento ético o socialmente responsable (Ramasamy, Yeung y $\mathrm{Au}, 2010$ ). Existen algunos investigadores que han destacado que los resultados sí confirman esta relación, aunque solo están basados en pequeñas muestras y se centran fundamentalmente en la religión cristiana (Brammer, Willimas y Zinkin, 2006). 


\subsubsection{Hipótesis 9: El estilo de liderazgo}

participativo, de acuerdo a lo que hemos medido los responsables de la investigación, está más asociado a la flexibilidad de estilo que al resto de estilos de liderazgo

Esta investigación ha revelado la existencia de una correlación alta e inversa entre el estilo participativo y la flexibilidad. Hemos entendido que este resultado indica que los líderes más propensos a centrarse en el apoyo emocional son menos proclives a utilizar otros estilos de liderazgo, observación que también implica que los líderes que utilizan en mayor medida el estilo participativo precisen, en menor grado que el resto de líderes, de otros estilos de liderazgo para desempeñar su rol.

El estudio también ha indicado que parece existir una tendencia a que la flexibilidad sea más reducida en el rol de liderazgo a medida que la actitud de los máximos cargos empresariales hacia la responsabilidad social es más favorable. Hemos entendido que esta tendencia podría guardar relación con una mayor proximidad de la responsabilidad social al estilo de liderazgo participativo, ya que se trata de un estilo centrado en el apoyo y con bastante sintonía, por tanto, con el valor del diálogo que promueve la Responsabilidad Social Corporativa con sus grupos de interés. Los resultados alcanzados en la 
investigación parecen validar esta hipótesis ya que han mostrado que el estilo participativo tiende a cobrar más relevancia en los líderes empresariales a medida que se intensifica su disposición a favor de la responsabilidad social.

Además hemos considerado que estos resultados también muestran la existencia de una relación inversa entre la flexibilidad de liderazgo y la actitud pro responsabilidad social, porque los líderes también tienen propensión a reducir el número de estilos de liderazgo que utilizan cuando su organización de origen incrementa la intensidad de su comportamiento socialmente responsable. 


\subsubsection{Limitaciones y sugerencias para futuras investigaciones}

a) Limitaciones

Como es obvio, esta investigación no está exenta de limitaciones. En la introducción ya aludimos de manera general a algunas de las dificultades propias de la investigación en las ciencias sociales.

Hemos indicado aquí algunas otras más concretas que se nos han revelado al terminar el trabajo:

1. La imposibilidad de seleccionar la muestra al azar, que ha sido el criterio que inicialmente hemos intentado seguir pero que ha sido necesario corregir para conseguir una muestra suficiente.

2. El desconocimiento de la causa por la que algunos líderes empresariales no se han animado a participar en la investigación, lo que nos ha hecho cuestionarnos si los máximos responsables que han sido entrevistados son los que presentan una disposición más favorable hacia la responsabilidad social.

3. La escasa presencia de líderes del sector de la construcción (14), que nos ha hecho 
cuestionarnos si el rechazo a participar en la investigación estaría motivado porque los máximos responsables de este ámbito tengan una actitud más desfavorable que los máximos responsables de otros sectores hacia la responsabilidad social. Sin embargo, los resultados obtenidos en la actitud hacia la responsabilidad social de los líderes de este sector nos han hecho descartar este supuesto. Quizá se trate de un sector cuyos máximos responsables presenten, en especial, un mayor rechazo a participar en estudios de investigación por diversos motivos y hubiera sido necesario diseñar otro procedimiento específico de recogida de datos para ellos.

4. El número de organizaciones de la muestra que han realizado acciones formativas en el ámbito de la responsabilidad social no es suficientemente amplio como para generalizar los resultados (39 casos). Quizá habría sido más deseable, en relación con el estudio de esta variable, realizar un procedimiento de recogida de datos en el que solo se recabara información de los líderes vinculados a empresas que desarrollaran este tipo de acciones formativas.

5. El tiempo de duración de las entrevistas personales ha sido excesivamente largo, aunque ha permitido recoger información en profundidad 
de diversas variables cuya interrelación ha enriquecido el estudio. Quizá habría sido deseable plantear otros posibles diseños que permitieran dividir la investigación en fases, de modo que se recogiera la información sobre las variables estudiadas en diferentes momentos.

6. La utilización de otra técnica de recogida de información de naturaleza cualitativa, como el desarrollo de varios grupos de discusión para diferentes perfiles empresariales, podría haber proporcionado información de contraste aunque también podría haber supuesto que el proceso de recogida de información se hubiera alargado más en el tiempo.

7. La recogida de información, a causa de la crisis económica, se ha realizado en un momento de retroceso en los planteamientos de gestión de los líderes empresariales. Hemos considerado que este ha sido un factor que ha influido en los resultados de la investigación porque ha afectado de forma negativa, con bastante seguridad, a la actitud que se ha registrado hacia la Responsabilidad Social Corporativa en los máximos responsables empresariales. 
b) Sugerencias

1. En relación con las muestras, hemos considerado que conocer con más profundidad las características, los intereses y la motivación de los líderes que han participado en la investigación ayudaría a mejorar la interpretación de los resultados.

2. En relación con el diseño, realizar un estudio longitudinal con datos recogidos en diferentes momentos. Aunque esto requiere la existencia de alguna línea de investigación estable por parte de los estamentos que la promuevan y algún tipo de apoyo económico, en este caso habría permitido establecer posibles relaciones causales entre las variables estudiadas.

3. En relación con las entrevista, reducir con algún procedimiento estadístico el número de preguntas que forman parte del guión preestablecido. Podría ser interesante porque supondría una economía de tiempo y esto redundaría en una mayor participación (se han producido casos de líderes que han declinado participar en la investigación cuando han visto el guión de la entrevista).

4. En relación a las características personales estudiadas, centrar más la investigación es los 
aspectos que presentan más afinidad a la responsabilidad social. Se ha constatado que los características personales con menor proximidad hacia la responsabilidad social, como las estudiadas, no tienen una elevada incidencia en la actitud de los máximos responsables empresariales hacia esta disciplina y además se han revisado trabajos que han indicado que existen valores próximos a la responsabilidad social que ejercen un alto influjo en la formación de actitudes favorables en este campo. Esta observación es especialmente relevante por la posible implicación de los resultados alcanzados por las investigaciones desarrolladas en este campo en la formación de los futuros líderes empresariales.

5. En relación con los estilos de liderazgo analizados, ampliar el abanico de los estilos de liderazgo estudiados incorporando otros estilos, como el liderazgo de servicio, que podrían tener alta incidencia en la formación de actitudes favorables hacia la responsabilidad social.

6. En relación con el entorno de los líderes empresariales, verificar en qué medida otros aspectos más generales no contemplados en la investigación pueden tener incidencia en su actitud hacia la responsabilidad social, como la cultura de las organizaciones o la presión social 
desarrollada por otros actores con protagonismo en el entorno como las ONG. 
ANEXOS 

ANEXO 1. ESCALA ARS19 

A continuación encontrará una lista de juicios sobre las organizaciones y la Responsabilidad Social Corporativa (RSC). Por favor indique "sí" en todos los enunciados con los que está de acuerdo y "no" con todos aquellos con los que está en desacuerdo.

Muchas gracias por su colaboración

\section{JUICIOS}

Las organizaciones que aplicaran políticas de Responsabilidad Social Corporativa (RSC):

1. ...deberían interpretar la RSC como una moda pasajera.

2. ...no deberían dialogar con sus grupos de interés (inversores, clientes, comunidad local, etc.).

3. ...deberían evaluar detalladamente su impacto medioambiental.

4. ...no deberían respetar las recomendaciones de expertos en RSC.

5. ...deberían fomentar la preocupación social por el medio ambiente dentro de sus posibilidades.

6. ...deberían utilizar sus fuentes de energía de manera muy eficiente.

7. ...deberían utilizar criterios medioambientales para seleccionar proveedores.

8. ...sería recomendable que tuvieran expertos para encargarse de su RSC.

9. ...deberían favorecer el desarrollo de la sociedad dentro de sus posibilidades.

10. ...solo deberían estar interesadas en utilizar la RSC para mejorar su imagen.

11. ...no deberían plantear la RSC como algo que contribuya exclusivamente a su beneficio económico.

12. ...deberían realizar menciones completamente ciertas en su publicidad a la RSC.

13. ...no deberían mantenerlas en época de crisis.

14. ...jamás deberían preocuparse por el medio ambiente.

15. ...nunca deberían fomentar el respeto a los derechos humanos.

16. ...no deberían preocuparse porque todos sus colaboradores conozcan su RSC.

17. ...siempre que su posición lo permita deberían establecer precios abusivos en el mercado.

18. ...solo deberían comunicarse de modo transparente cuando la organización salga beneficiada.

19. ...nunca deberían formar a sus colaboradores en responsabilidad social. 

ANEXO 2. CUESTIONARIO SPV DE GORDON 

Las siguientes frases expresan cosas que las personas consideran importantes sobre su modo de vivir. Se presentan en tríadas, es decir, agrupadas de tres en tres.

Por favor, lea atentamente las tres frases de cada tríada y elija, aunque en algunos casos sea difícil decidirse, la que indique lo más importante para usted. Para señalarla, solo hay que rodear la alternativa de la columna " + ". Luego debe elegir, entre las dos frases restantes, la que indique lo menos importante para usted. y rodear la alternativa de la columna "-".

Es posible que en algunos casos resulte difícil decidirse por una frase. En este caso elija la frase que más se aproxime a su modo de pensar. No existen contestaciones "buenas" ni "malas"; esto no es una prueba de inteligencia o habilidad, sino solo una apreciación de lo que usted valora en mayor o menor medida.

Por favor trabaje rápidamente, conteste a todos los grupos de tres frases y responda con sinceridad. Muchas gracias por su tiempo y su disposición.

\begin{tabular}{|c|c|c|c|c|}
\hline \multirow{3}{*}{1} & 1 & Trabajar en algo difícil. & + & - \\
\hline & 2 & Tener bien definidos los objetivos y metas. & + & - \\
\hline & 3 & Tener mis asuntos claros y en orden. & + & - \\
\hline \multirow{3}{*}{2} & 1 & Ser práctico y eficiente. & + & - \\
\hline & 2 & Buscar diversión y entretenimiento. & + & - \\
\hline & 3 & Mejorar de modo continuo mis capacidades. & + & - \\
\hline \multirow{3}{*}{3} & 1 & Saber exactamente lo que intento llevar a cabo. & + & - \\
\hline & 2 & Considerar las cosas desde un punto de vista práctico. & + & - \\
\hline & 3 & Dirigir mi atención a la resolución de los problemas. & + & - \\
\hline \multirow{3}{*}{4} & 1 & Hacer cosas nuevas y diferentes. & + & - \\
\hline & 2 & Hacer las cosas con toda perfección. & + & - \\
\hline & 3 & Tener un objetivo muy definido a donde dirigirme. & + & - \\
\hline \multirow{3}{*}{5} & 1 & Mantener muy claras mis metas. & + & - \\
\hline & 2 & Programar mi tiempo con antelación. & + & - \\
\hline & 3 & Actuar con una firme convicción. & + & - \\
\hline \multirow{3}{*}{6} & 1 & Tomar decisiones sin retrasos. & + & - \\
\hline & 2 & Sacarle buen partido a todo lo que poseo. & + & - \\
\hline & 3 & Dirigir mis esfuerzos a objetivos claros y precisos. & + & - \\
\hline \multirow{3}{*}{7} & 1 & Alcanzar la calidad más alta en mi trabajo. & + & - \\
\hline & 2 & Llevar una vida bien organizada. & + & - \\
\hline & 3 & Poder viajar mucho. & + & - \\
\hline \multirow{3}{*}{8} & 1 & Poner mucho cuidado en mis asuntos. & + & - \\
\hline & 2 & Solucionar un problema con rapidez. & + & - \\
\hline & 3 & Ser metódico en lo que hago. & + & - \\
\hline \multirow{3}{*}{9} & 1 & Tener experiencias nuevas o poco habituales. & + & - \\
\hline & 2 & Sacar el mejor partido del dinero que gasto. & + & - \\
\hline & 3 & Tener muy organizados mis hábitos de trabajo. & + & - \\
\hline
\end{tabular}




\begin{tabular}{|c|c|c|c|c|}
\hline \multirow{3}{*}{10} & 1 & Hacer cosas que jamás había hecho antes. & + & - \\
\hline & 2 & Hacer más de lo que generalmente se espera de mí. & + & - \\
\hline & 3 & Conocer exactamente el fin al que me dirijo. & + & - \\
\hline \multirow{3}{*}{11} & 1 & Mantenerme firmemente en mis convicciones. & + & - \\
\hline & 2 & Tener experiencias variadas. & + & - \\
\hline & 3 & Acabar lo que he comenzado. & + & - \\
\hline \multirow{3}{*}{12} & 1 & Buscar e informarme bien antes de comprar. & + & - \\
\hline & 2 & Llegar a decisiones bien definidas en los asuntos. & + & - \\
\hline & 3 & Ordenar bien las cosas en su sitio. & + & - \\
\hline
\end{tabular}

13 \begin{tabular}{|l|l|c|c}
1 & Ser metódico en mi trabajo. & + & - \\
\hline 2 & Tener la experiencia del riesgo. & + & - \\
\hline 3 & Enfrentarme a un problema complejo. & +
\end{tabular}

\begin{tabular}{l|l|l|c|c}
1 & Tener una tarea competitiva que me ponga a prueba. & + & - \\
\hline 2 & Visitar lugares nuevos y diferentes. & + & - \\
\hline 3 & Tener una meta definida a donde orientar mi trabajo. & +
\end{tabular}

\begin{tabular}{l|l|l|l|l} 
& 1 & Cuidar bien lo que me pertenece. & + & - \\
\hline 2 & 2 & Mantenerme firme en mis propias opiniones y creencias. & + & - \\
\hline 3 & Planificar mi trabajo con antelación. & + & +
\end{tabular}

16 \begin{tabular}{|l|l|l|l|}
1 & Tener un objetivo en mente y trabajar en esa dirección. & + & - \\
\hline 2 & Hacer cosas que son muy provechosas. & + & - \\
\hline 3 & Hacer algo importante. & + & -
\end{tabular}

\begin{tabular}{l|l|l|l|l|l|}
\hline 1 & Intentar cosas diferentes. & + & - \\
\hline 2 & Hacer las cosas de manera organizada. & + & - \\
\hline 3 & Tener mucho éxito en todo lo que intento. & + & - \\
18 & 1 & Llevar una vida muy ordenada. & + & - \\
\hline & 2 & Ser muy cuidadoso con mis pertenencias. & + & - \\
\hline 3 & Ir siempre directamente al punto clave. & + & -
\end{tabular}

\begin{tabular}{l|l|l|l|l}
1 & Ir a lugares extraños y poco habituales. & + & - \\
\hline 2 & Ser sistemático en mi trabajo. & + & - \\
\hline 3 & Proseguir un problema hasta su solución. & + & + \\
\hline & 1 & Ponerme cotas muy altas en mis exigencias. & + & + \\
\hline & 2 & Tener metas y objetivos muy específicos. & + & + \\
\hline 3 & Hacer cosas que son nuevas y diferentes. & +
\end{tabular}


Mantener en buenas condiciones mis asuntos.

Dedicar toda mi energía en la realización de una meta.

3 Tener una posición muy clara sobre los temas.

\begin{tabular}{|c|c|c|c|c|}
\hline \multirow{3}{*}{22} & 1 & Hacer frecuentes viajes. & + & - \\
\hline & 2 & Hacer las cosas según un plan preestablecido. & + & - \\
\hline & 3 & Tomar las decisiones rápidamente. & + & - \\
\hline \multirow{3}{*}{23} & 1 & Ser muy cuidadoso con mi dinero. & + & - \\
\hline & 2 & Ser capaz de superar cualquier obstáculo. & + & - \\
\hline & 3 & Hacer cosas que son peligrosas o excitantes. & + & - \\
\hline
\end{tabular}

\begin{tabular}{l|l|l|l|l}
1 & Tener convicciones firmes y fuertes. & + & - \\
\hline 2 & Tener objetivos bien definidos. & + & - \\
\hline 3 & Mantenerme siempre limpio e impecable. & +
\end{tabular}

\begin{tabular}{l|l|l|l|l}
1 & Hacer cosas bien remuneradas. & + & - \\
\hline 2 & Ser una persona muy ordenada. & + & - \\
\hline 3 & Tener una posición muy clara en todo. & + & -
\end{tabular}

\begin{tabular}{l|l|l|l|l}
\hline & Experimentar lo que sale de lo corriente. & + & - \\
\hline 2 & Sacar el mejor partido de mi dinero. & + & - \\
\hline 3 & Trabajar en un problema difícil. & + & +
\end{tabular}

27 \begin{tabular}{|l|l|l|l}
1 & Tener una tarea importante que me ponga a prueba. & + & - \\
\hline 2 & Abordar directamente un problema. & + & - \\
\hline 3 & Hacer las cosas de manera metódica. & +
\end{tabular}

\begin{tabular}{l|l|l|l|l}
1 & Saber con precisión a donde me dirijo. & + & - \\
\hline 2 & Esforzarme por cumplir alguna cosa importante. & + & - \\
\hline 3 & Hacer las cosas de modo práctico y eficiente. & + & -
\end{tabular}

\begin{tabular}{l|l|l|l|l}
\hline & Tener un enfoque sistemático para hacer las cosas. & + & - \\
\hline 2 & Llegar a una decisión y mantenerme en ella. & + & - \\
\hline 3 & Tener mucho cuidado de lo que me pertenece. & + & +
\end{tabular}

\begin{tabular}{l|l|l|l|l}
1 & Buscar la aventura. & + & - \\
\hline 2 & Tener en mente un camino claro de acción. & + & - \\
\hline 3 & Ser capaz de hacer las cosas de una manera mejor. & + & +
\end{tabular}



ANEXO 3. CUESTIONARIO LBA II 

A continuación se presentan 20 situaciones de trabajo típicas que corresponde resolver a un líder o a uno o más integrantes de su equipo.

En cada una de estas situaciones típicas se ofrecen 4 posibles decisiones 0 acciones.

Imagínese que es usted el líder encargado de la resolución de dichas 20 situaciones. En cada una de ellas debe decidirse por 1 de las 4 acciones dadas.

Marque con un círculo la letra correspondiente a la decisión que usted crea más apropiada. Por favor, marque solamente una respuesta.

Muchas gracias por su tiempo y por su colaboración.

1. Usted le ha pedido a uno de sus colaboradores que le elabore un informe acerca de la adquisición de un nuevo equipo para su división. Por lo regular, a este colaborador se le puede dar un trabajo y, con su apoyo, contar con que lo termine a tiempo. El plazo para dicho informe ha vencido. Usted...

a) Le diría que quiere el informe, le explicaría qué debe recoger y revisaría su realización cada día.

b) Le daría más tiempo para terminar el trabajo.

c) Le diría qué es lo que usted quiere que haga y cuándo quiere el informe terminado, pero hablaría con él para saber por qué el informe no está terminado.

d) Le motivaría para que terminara el informe.

2. El grupo interdepartamental que usted dirige ha estado trabajando duro para terminar el informe de toda su división. Se le ha asignado un nuevo colaborador a su cargo en el grupo de trabajo, el cual tiene que terminar un análisis de costes de su departamento para la reunión de la próxima semana del grupo de trabajo. Pero no sabe nada acerca de las necesidades del grupo de trabajo ni de la extensión del informe. El nuevo integrante del grupo de trabajo está emocionado y entusiasmado por aprender más en relación con su participación en el grupo de trabajo. Usted....

a) Le diría exactamente qué se necesita en este informe y supervisaría muy de cerca su progreso.

b) Preguntaría si hay algo en lo cual pudiera ayudarle y apoyaría su entusiasmo por ser un nuevo integrante del equipo de trabajo.

c) Especificaría la extensión del informe y los aspectos que debe tratar, pero incluiría cualquier idea o sugerencia que él pudiera tener.

d) Le daría la bienvenida al equipo de trabajo y le pondría en contacto con otros integrantes de este colectivo que podrían ayudarle a preparar dicho informe. 
3. Últimamente usted ha empezado a tener problemas con una de las personas que supervisa. El colaborador se ha retrasado y solo su constante insistencia ha permitido que complete su trabajo. Por motivos que atañen al historial del trabajo, usted se imagina que él puede carecer de la experiencia necesaria para terminar trabajos de mayor importancia que le ha dado. Usted...

a) Continuaría aportando sus esfuerzos para completar esta labor.

b) Continuaría supervisando muy de cerca su trabajo, pero trataría de conocer sus actitudes y sentimientos en relación con la labor encomendada.

c) Le tendría en cuenta para solucionar los problemas relacionados con esta labor y utilizaría sus ideas para terminar el proyecto en curso.

d) Le informaría de que ésta es una labor importante y le pediría que se pusiera en contacto con usted en caso de tener dudas o problemas.

4. Su grupo de trabajo habitualmente ha funcionado bien, con su apoyo y dirección. Sin embargo, la eficiencia del grupo ha bajado drásticamente. El grupo necesita más formación y experiencia para incrementar su eficiencia. Su jefe se ha empezado a preocupar. Usted...

a) Expresaría la necesidad de un trabajo más eficiente y le pediría al grupo que resolviera sus problemas por sí solo.

b) Se aseguraría de que los plazos se cumplen y de que la calidad del trabajo es buena, pero hablaría con el grupo de trabajo para obtener sus sugerencias.

c) Informaría al grupo exactamente de qué es lo que desea, para cuándo se necesita la información y cuáles podrían ser algunas de las consecuencias de la mala eficiencia demostrada.

d) Ayudaría al grupo a determinar qué es lo que se necesita hacer y lo apoyaría para dar los pasos necesarios.

5. Por motivo de las restricciones impuestas en el presupuesto del departamento es necesario consolidarlo. Usted le tiene que pedir a un miembro altamente experimentado del departamento que haga los ajustes. Esta persona ha trabajado en todas las áreas del departamento. Mientras usted cree que tiene mucha habilidad para desarrollar esta labor, él parece indiferente ante la importancia de esta tarea. Usted...

a) Se haría cargo de los ajustes, asegurándose de escuchar sus sugerencias.

b) Le asignaría el proyecto a él y le dejaría que determinara cómo terminarlo.

c) Discutiría la situación con él y le animaría a que acepte la tarea debido a su habilidad y experiencia.

d) Se haría cargo de los ajustes y le indicaría precisamente qué hacer. Supervisaría de cerca su trabajo. 
6. Una mujer altamente capaz y eficiente del personal ha pedido su ayuda para un proyecto. Está acostumbrada a trabajar eficientemente, sin ayuda de nadie. Recientemente se han presentado problemas de trabajo que ella cree que no puede resolver por sí misma. Usted...
a) Analizaría los problemas y planearía métodos para resolverlos.
b) Continuaría permitiéndole encontrar una solución de forma independiente.
c) Determinaría e implementaría una solución apropiada, pero trabajaría con ella en la solución de problemas.
d) Lo comentaría con ella y la apoyaría en sus esfuerzos para encontrar soluciones apropiadas.

7. Usted le ha pedido a uno de los colaboradores más antiguos que acepte un trabajo nuevo. En sus otras responsabilidades ha actuado adecuadamente. El trabajo que le ha pedido que acepte es importante para el futuro del grupo de trabajo. El colaborador está emocionado con la nueva tarea, pero no sabe por dónde empezar debido a su falta de experiencia en este tipo de tareas. Usted...
a) Hablaría del trabajo con él, apoyando su habilidad para hacerlo y mencionando su excelente eficiencia en el pasado.
b) Definiría las actividades necesarias para ejecutar el trabajo con éxito y regularmente supervisaría su progreso.
c) Le daría el trabajo y le dejaría determinar cómo hacerlo. Le diría que le comentara si tiene algún problema.
d) Le especificaría lo que tiene que hacer, pero le pediría las ideas que él pudiera tener.

8. Un integrante de su personal se siente inseguro acerca de un trabajo que usted le ha dado. Es muy competente y usted sabe que tiene capacidad para completar con éxito y eficientemente esta tarea. Usted...
a) Escucharía sus preocupaciones y alabaría su habilidad para completar la tarea.
b) Estructuraría la tarea para que estuviera clara, pero tomaría en cuenta cualquier sugerencia que él pudiera aportar.
c) Le diría exactamente qué hacer para ejecutar la tarea y revisaría su trabajo diariamente.
d) Le dejaría resolver cómo ejecutar la tarea por sí mismo. 
9. Los integrantes del grupo de trabajo le han pedido que considere algunos cambios en sus horarios de trabajo. En el pasado usted ha estimulado y apoyado sus sugerencias. En este caso los miembros del grupo de trabajo son conscientes de la necesidad de cambios, están dispuestos a hacer sugerencias y le proponen poner a prueba un horario alternado. Son muy competentes y trabajan muy bien como grupo. Usted...

a) Permitiría la participación de los integrantes del grupo en el desarrollo de un horario nuevo y apoyaría sus sugerencias.

b) Diseñaría e implantaría un nuevo horario usted solo, pero incorporaría las recomendaciones del grupo.

c) Permitiría que los participantes del grupo diseñaran e implementaran un nuevo horario de trabajo por sí mismos.

d) Diseñaría un nuevo horario y muy de cerca vigilaría su cumplimiento.

10. Usted ha llegado 30 minutos tarde a las reuniones de trabajo. Cuando llega las reuniones no ha empezado aún. Las investigaciones muestran que dos integrantes del grupo de trabajo han intentado iniciar las reuniones, pero la mayoría de sus miembros se sienten desanimados por la falta de cooperación de alguno de ellos. Esta situación le sorprende, porque el progreso del grupo en este proyecto era muy bueno. Usted...

a) Explicaría el propósito de la reunión y entonces dejaría que el grupo funcionara sin su intervención, al menos hasta que le pidiera su ayuda.

b) Tomaría el control inmediatamente y dirigiría al grupo hacia la terminación del proyecto.

c) Dirigiría la interacción grupal hacia la terminación del proyecto y les animaría a exponer sus problemas y sentimientos.

d) Le pediría al grupo que continuara comentando las tareas asignadas y que apoyaran sin fisuras y con entusiasmo el proyecto tanto como les fuera posible.

11.Un integrante de su departamento ha tenido un buen historial de éxitos con estímulo y apoyo, pero con poca dirección. Se le han dado tareas similares para el siguiente año y usted debe decidir cómo supervisarlas. Usted...

a) Le dejaría que actuara por sí mismo, guiándose por su propio estímulo y dirección.

b) Le haría notar la importancia de cumplir con los plazos y encaminaría sus esfuerzos a la finalización de las labores asignadas.

c) Hablaría con él y establecería metas y objetivos para el desarrollo de su labor, pero tomaría en cuenta sus sugerencias.

d) Le haría participar en la fijación de metas y apoyaría sus esfuerzos. 
12. Dirigiendo y apoyando sus esfuerzos, la productividad ha llegado a un nivel alto y la gente convive de modo armonioso. Reconociendo sus habilidades, usted cree que ahora pueden trabajar más por sí mismos. Usted ha redirigido sus energías a nuevas áreas y continúan produciendo buenos resultados. Usted ahora debe pedirles que acepten un trabajo adicional. Usted...

a) Les daría el trabajo, asegurándose exactamente de que sepan qué les corresponde hacer y les supervisaría muy de cerca.

b) Les daría el trabajo, les diría que su trabajo en el pasado ha sido bueno y que van a seguir haciéndolo bien.

c) Se aseguraría de que ellos estén informados de qué es lo que se espera de ellos, pero aceptaría cualquier sugerencia útil que pudieran tener.

d) Les permitiría determinar cómo desarrollar sus labores.

13. Recientemente a usted se le ha asignado un trabajador nuevo que efectuará un trabajo importante en la oficina. Aunque es inexperto está entusiasmado y desea hacer el trabajo. Usted...

a) Le dejaría determinar en qué consiste el trabajo y cómo hacerlo.

b) Le diría exactamente en qué consiste el trabajo, qué espera de él y supervisaría su trabajo muy de cerca y frecuentemente.

c) Le informaría de qué es exactamente lo que quiere que haga, pero vería si tiene algunas sugerencias o ideas.

d) Apoyaría y alentaría su entusiasmo y le preguntaría cómo resolvería él este trabajo.

14. Su jefe le ha pedido que su división incremente su productividad en un $10 \%$. Usted sabe que esto se puede hacer, pero requeriría una participación activa. Para liberarse de hacer esto, usted debe reasignar la creación de un sistema de control de costes a un colaborador de la división. La persona a quien usted está pensando dar este proyecto ha tenido considerable experiencia en sistemas de control de costes, pero está un poquito insegura de poder elaborar este proyecto por sí misma. Usted...

a) Le pediría que aceptara el proyecto. Le apoyaría y estimularía sus esfuerzos.

b) Comentaría el proyecto con él. Le explicaría cómo se debe hacer el trabajo, pero vería si tiene algunas ideas.

c) Le daría el proyecto y le dejaría que determinara cómo hacerlo.

d) Le daría el proyecto y prepararía un memorándum detallado, explicando todos los pasos necesarios para elaborar el proyecto. 
15. Uno de sus colaboradores ha hecho una sugerencia para un cambio en las operaciones de la unidad que para usted tiene mucho sentido. En el pasado ha sido capaz de ofrecer e implementar otras sugerencias útiles de manera productiva, con su apoyo y estímulo. Usted tiene confianza en su habilidad. Usted...

a) Se haría cargo de la sugerencia y la dirigiría en su ejecución.

b) Comentaría la sugerencia con él y le apoyaría en sus esfuerzos para dirigir su ejecución.

c) Organizaría la ejecución pero incluiría las ideas de él.

d) Le daría la responsabilidad de ejecutar la sugerencia, sin ninguna intervención por parte suya.

16. Debido a una enfermedad en su familia usted se ha visto forzado a faltar a las primeras dos reuniones de un comité que dirige. Usted ha descubierto a su llegada a la tercera reunión que el comité está funcionando bien y que han progresado en la ejecución de sus metas. Usted no está seguro en lo referido a cómo debe incorporarse al grupo y qué papel debe asumir. Usted...

a) Asistiría pero dejaría al grupo continuar trabajando, tal y como lo ha estado haciendo en las dos primeras reuniones.

b) Tomaría el control del comité y comenzaría a dirigir las actividades.

c) Haría todo lo posible por hacer sentir importante al comité y apoyaría sus esfuerzos en el pasado.

d) Dirigiría las actividades del grupo pero utilizaría sus sugerencias.

17. Los miembros de su equipo de trabajo son muy competentes y capaces de trabajar bien por sí solos. Por lo general les ha dejado solos y ha dado las responsabilidades clave a miembros individuales del grupo. Sus logros han sido excelentes. Usted...

a) Daría apoyo y estímulo constantes a los miembros del grupo.

b) Dirigiría y supervisaría de cerca las actividades del personal.

c) Continuaría dejando que el grupo trabajara solo.

d) Dirigiría sus esfuerzos pero trabajaría muy de cerca con los miembros del grupo para pedirles sus sugerencias. 
18. Usted y sus superiores han decidido que debe adoptarse un nuevo método en su departamento si es que se quieren obtener logros a largo plazo en eficiencia. En el pasado cuando se aplicaban estos métodos, el grupo de trabajo había deseado usarlos aunque inicialmente carecía de habilidad para utilizarlos. Usted...

a) Se aseguraría de dirigir la implantación del nuevo método, pero haría participar al grupo en la discusión de alternativas.

b) Dirigiría muy de cerca al grupo en el uso inicial del nuevo método.

c) Haría participar al grupo para que comentara sus impresiones sobre el nuevo método y les apoyaría para que participaran y cooperaran en su implementación.

d) Permitiría que el grupo formulara e implementara el nuevo método por sí mismo.

19. Recientemente usted ha sido nombrado jefe de una división. Bajo la dirección del anterior jefe, el grupo de trabajo funcionaba adecuadamente con considerable supervisión y apoyo. Sin embargo desde que usted se hizo cargo, el personal parece estar más preocupado en actividades sociales que en cumplir sus responsabilidades. Hasta la fecha la actuación del grupo de trabajo ha sido muy pobre. Usted...

a) Discutiría con ellos la baja actuación del personal y apoyaría sus esfuerzos para determinar una acción correctiva.

b) Dirigiría y organizaría la acción correctiva necesaria, pero solicitaría información y sugerencias del grupo de trabajo.

c) Enfocaría el problema y permitiría que los miembros del grupo definieran sus propias responsabilidades y labores.

d) Definiría las actividades, las responsabilidades y las expectativas, y las revisaría frecuentemente para ver si sus logros están mejorando.

20. Una de sus colaboradoras no está dispuesta a aceptar una nueva labor. Ella ha tenido muy poca experiencia en el área en el cual usted quiere que trabaje y ha hecho una buena labor con otros trabajos que le ha dado. Usted...

a) Le explicaría qué es lo que debe hacer y cómo hacerlo, pero escucharía por qué no está dispuesta a aceptar la labor.

b) Le daría la nueva labor y le dejaría determinar la mejor manera de hacerlo.

c) Animaría a la colaboradora a tratar de hacer el trabajo y le apoyaría en sus esfuerzos, a través de ayuda en la solución de problemas.

d) Le diría exactamente qué es lo que debe hacerse para completar con éxito la labor y supervisaría sus resultados frecuentemente. 



\section{ANEXO 4. DEFINICIONES DE LIDERAZGO APORTADAS POR BASS EN EL PRIMER \\ CAPÍTULO DE SU LIBRO “THE BASS \\ HANDBOOK OF LEADERSHIP"}



Bass agrupa las definiciones en tres áreas: líderes y liderazgo (leadercentric), liderazgo como un efecto, y liderazgo en términos de interacción entre el líder y el grupo.

\section{Líderes y liderazgo}

El primer grupo de definiciones se centran en la combinación de rasgos que son necesarios para que un líder induzca a otros a realizar un cometido (Tead, 1929).

\section{a) El liderazgo como rasgo de personalidad}

Hace referencia a varias teorías iniciales que intentaban explicar por qué unas personas eran mejores que otras en el ejercicio del liderazgo.

Como la propuesta por Bowden (1926), quien equiparó el liderazgo con la fortaleza de la personalidad: "de hecho (indica Bowden), la cantidad de personalidad atribuida a un individuo puede no ser injustamente estimada por el grado de influencia que puede ejercer sobre los otros".

O la de Bingham (1927), para quien el líder es una persona que posee el mayor número de rasgos deseables de personalidad y carácter. 


\section{b) Liderazgo como una atribución}

La mayoría de las personas tienen en su cabeza teorías implícitas acerca de qué cualidades deberían tener los líderes y qué comportamientos deberían exhibir. Algunas investigaciones aportan datos que apoyan esta hipótesis.

Uno de estos trabajos hace referencia a la investigación desarrollada con 378 estudiantes universitarios que fueron preguntados por las características que eran necesarias para que un nuevo líder fuera aceptado por el grupo. En lo alto de la lista situaron: que aprendiera los objetivos del grupo, que asumiera el mando y que fuera una persona agradable (Kenney, Blascovich \& Shaver, 1994).

Otro estudio, realizado con más de 15.000 encuestados, indicó que las primeras cuatro características preseleccionadas para describir a líderes admirados (de un total de veinte) eran: ser honesto, ser previsor, ser inspirador y ser competente (Kouzes \& Posner, 2002).

\section{c) Líderes como centro de los procesos del grupo}

Enseguida las definiciones de liderazgo reflejaron la tendencia a ver al líder como el centro del proceso, actividad y cambio del grupo.

Un primer grupo de autores entendieron que todas las importantes decisiones y su implementación estaban centradas en el culto al líder, incluso cuando la toma de decisiones real es difusa (como ocurre en una democracia 
parlamentaria). Para estos autores el líder encarna la voluntad colectiva. Es quien organiza los problemas esenciales, ofrece posibles soluciones, establece prioridades y emprende operaciones de desarrollo.

Dentro de este planteamiento Cooley (1902) mantuvo que el líder es siempre el núcleo de una tendencia y que en cualquier movimiento social, detenidamente examinado, se encontrará dicho núcleo.

Mumford (1906-1907), por otra parte, observó que el "liderazgo es la preeminencia de uno o pocos individuos en un grupo en el proceso de control del fenómeno social”.

Blackmar (1911) consideró el liderazgo como la "centralización del esfuerzo en una persona" que representa "una manifestación de poder".

Smith (1934) sostuvo que "el grupo social que expresa su unidad en una actividad relacionada está siempre compuesto de dos elementos esenciales: el centro de su actividad principal y el individuo que actúa en relación con el centro".

Redl (1942) indicó que el líder es una persona central o principal que integra al grupo. Como una nación en desarrollo, el grupo necesita un lugar centralizado para que opere, que puede ser alcanzado solamente por un líder individual (Babikan, 1981).

Otro grupo de autores destacaron el papel central del líder en el grupo dentro del ejercicio del liderazgo. 
En esta línea Brown (1936) mencionó que "el líder puede no estar separado del grupo, pero puede ser tratado como tal por ser una eminencia en el ámbito".

Otros autores como Krech y Crutchfield (1948) observaron que el líder: "por virtud de su especial posición en el grupo (...) sirve como un agente primario para la determinación de la estructura del grupo, la atmósfera del grupo, los objetivos del grupo, la ideología del grupo y las actividades del grupo".

Knickerbocker (1948), en términos de la dinámica del comportamiento social humano, arguyó que el liderazgo es una función de necesidades existentes dentro de una situación dada, compuesta de una relación entre un individuo y un grupo.

Cambell (1992), por otra parte, sugirió que no importa cómo de competente y motivado esté un grupo, este no puede ser efectivo colectivamente sin un líder que actúe como foco central.

Otros autores destacaron del líder su capacidad para atender a la actividad del grupo, lo que condujo al análisis de la estructura y los procesos de los grupos en el estudio en el liderazgo.

Uno de estos autores fue Chapin (1924), quien concibió el liderazgo como un punto de polarización para la cooperación del grupo.

Otro fue Bernard (1927), quien manifestó que los líderes estaban influenciados por las necesidades y los 
deseos de los integrantes de su grupo. Los líderes enfocaban la atención y desataban las energías de los integrantes del grupo, de modo individual, en una dirección deseada.

\section{d) El líder como un símbolo}

Katz y Kahn (1978) indicaron que los líderes realizan una función simbólica y sirven como representantes de su grupo a quienes no pertenecen a él. Aportan una manera de simplificar y encontrar significado en el entorno externo del grupo. Al hacer esto, los líderes utilizan símbolos para reforzar el significado de los acontecimientos y las circunstancias (Gronn, 1995).

\section{e) Liderazgo como creación de significado}

Los líderes aportan comprensión y significado para las situaciones que los seguidores encuentran confusas, ambiguas, poco claras, vagas e inciertas. Ellos definen la realidad para sus seguidores. Ellos proveen de explicaciones creíbles, interpretaciones, historias, parábolas y explicaciones acerca de lo que ha sucedido, lo que está sucediendo y lo que sucederá. Crean el sentido de una situación para sus seguidores.

Gronn (1995) declaró que los líderes transmiten los valores que son aceptables para sus seguidores y que pueden guiar sus acciones posteriores. 


\section{f) Liderazgo de pensamiento}

Clark y Clark (1994) indicaron que este liderazgo es ejercido a través de lecturas, escritos o descubrimientos como los realizados por Darwin, Marx y Einstein, cuyas actividades intelectuales originales eran intensas $y$ apasionantes.

\section{g) Liderazgo como un propósito del comportamiento}

Una escuela de teóricos ha preferido definir el liderazgo en términos de actividades o comportamientos. Es decir, las actividades particulares a las que un líder se dedica en el curso de la dirección y coordinación del trabajo de los integrantes del grupo. Pueden suponer actos tales como estructurar las relaciones de trabajo, elogiar o criticar a los miembros del grupo, y mostrar consideración por el bienestar y los sentimientos de los líderes. Bass menciona algunas aportaciones integradas en esta forma de entender el liderazgo.

Una de estas contribuciones es la de Carter (1953), quien consideró que los comportamientos del líder son cualquier tipo de actuación que se designe como tal o, en términos más generales, cualquier conducta que los expertos en el área desean considerar como comportamiento de liderazgo.

Shartle (1956) entendió que un acto de liderazgo "surge como resultado de la actuación de los otros 0 responde a una dirección compartida”. 
Hemphill (1949) sugirió que "el liderazgo puede ser definido como el comportamiento de un individuo mientras esté envuelto en actividades de dirección de grupos". Planteamiento muy similar al propuesto por Fiedler (1967).

Heifitz (1994), por otra parte, sostuvo que el liderazgo es un trabajo adaptativo consistente en la actividad de movilización del sistema social para hacer frente a los desafíos, clarificar las aspiraciones y adaptarse a los retos que se afrontan.

Jacobs y Jaques (1987) entendieron que los líderes dan un sentido de propósito a otros con el objetivo de gastar y movilizar energía para intentar competir.

Hollander (1986) hizo referencia a que los beneficios son más fácilmente atribuidos al líder. Así también es probable que cuando las cosas vayan mal, el líder sea tomado como responsable o incluso destituido.

\section{h) Liderazgo como un comportamiento persuasivo}

La persuasión es una forma de liderazgo. Gran parte de lo aprendido en los estudios de la persuasión puede ser incorporado al conocimiento del liderazgo. La persuasión es un instrumento poderoso para formar expectativas $y$ creencias, especialmente en asuntos políticos, sociales y religiosos.

La definición de liderazgo como una forma de persuasión es impulsada por tanto por los estudiosos de los movimientos sociales y políticos como por los teóricos 
industriales y militares, quienes estaban en contra de conceptos autoritarios. Además la concepción del liderazgo como una forma de persuasión también es trabajada por los teóricos de la retórica y la comunicación.

Esta investigación desarrollada sobre persuasión y comunicación es paralela al estudio sobre el liderazgo.

Bass destaca algunas personalidades y autores que han enfatizado el aspecto persuasivo del liderazgo.

Este es el caso de Truman (1958, p. 139), el presidente norteamericano, señaló que "un líder es un hombre que tiene la habilidad de convencer a otras personas para que hagan lo que necesita ser hecho, y no quieren hacer, y lo disfruten".

$\mathrm{O}$ de Eisenhower, el presidente norteamericano, quien indicó que el liderazgo es "la habilidad de decidir lo que necesita ser hecho y entonces conseguir que otros quieran hacerlo" (Larson, 1968, p. 21).

O de Lippmann (1922), quien sostuvo que la persuasión es duradera ya que "el test final de un líder es dejar tras de sí otros hombres con la convicción y la voluntad de continuar".

Bass también menciona a varios teóricos que han definido el liderazgo como una persuasión de éxito sin coacción. En esta concepción del liderazgo, los seguidores son convencidos por la excelencia del argumento y no por el poder coercitivo del argumentador. 
Tal es el caso de Neustadt (1960), quien concluyó, en su estudio de los presidentes de los Estados Unidos que el liderazgo presidencial es producto de la capacidad de persuasión.

O de Schenk (1928), para quien "el liderazgo es la gestión de los hombres por la persuasión e inspiración más que por el trato coercitivo directo o indirecto".

Bass también nombra a Merton (1969), quien consideró el liderazgo como "una relación interpersonal en la que los otros obedecen las indicaciones porque ellos quieren, no porque tengan que hacerlo".

Otros autores incluidos en esta concepción del liderazgo son Cleeton y Mason (1934), quienes entendieron que "el liderazgo indica la habilidad para influir en las personas y asegurar resultados a través de recursos emocionales, en mayor medida que utilizando el recurso de la autoridad".

También Copeland (1942), quien mantuvo que el liderazgo es el arte de influir a un número de personas, a través de la persuasión o el ejemplo, para seguir una línea de acción. Lo que nunca debiera ser confundido con la imposición, es decir, obligar un número de personas a seguir una línea de acción por la intimidación o la fuerza.

Y Odier (1948), quien diferenció entre el valor y la valencia de un líder. Valencia es el poder de una persona para fortalecer o debilitar el valor de otras personas, esto es, la influencia ejercida en los demás. 
Además de Koontz y O’Donnell (1955), quienes consideraron el liderazgo como "la actividad de persuadir a las personas para colaborar en el logro de un objetivo común”.

\section{i) Liderazgo como iniciación de la estructura}

Bass indica tres grupos dentro de esta orientación.

Varios autores vieron el liderazgo no como una ocupación pasiva de una posición o la adquisición de un rol, sino como un proceso de originación y mantenimiento de la estructura del rol, es decir, como el modelo de las relaciones de rol.

Uno de estos autores es Smith (1935), quien igualó el liderazgo con la gestión de las diferencias sociales a través de procesos en los que se proveen estímulos a los que otras personas reaccionan de modo integrador.

Otros son LaPiere y Farnsworth (1936), quienes observaron que las situaciones pueden ser distinguidas unas de otras, en la medida en que están organizadas por un miembro del grupo. Tal organización es habitualmente una manifestación del liderazgo, con sus variaciones de naturaleza y grado, en diferentes situaciones sociales.

Otros autores destacaron la importancia de que el grupo esté completamente estructurado para hablar de actos de liderazgo. 
En este sentido Bass destaca a Gouldner (1950), quien sugiere que hay una diferencia entre el estímulo de un seguidor y el de un líder. El estímulo de un líder tiene una probabilidad más alta de estructurar el comportamiento del grupo porque el grupo cree que el líder es una fuente legítima de tal estímulo. Gouldner está en desacuerdo con Gibb (1947) en relación con la noción de que una vez que la actividad del grupo es dominada por una organización establecida y esta se acepta, el liderazgo tiende a desaparecer.

También menciona a Bavelas (1960), quien define el liderazgo organizacional como la función de "mantener la efectividad operacional del sistema de toma de decisiones que comprende la gestión de la organización".

Algunos autores destacaron la importancia de la interacción. $Y$ varios de estos destacaron las variables que aumentan la diferenciación y el mantenimiento de las estructuras de rol en los grupos, con el objetivo de poner en relieve que el liderazgo es más que solo la iniciación a la estructura.

Uno de estos autores es Homans (1950), quien identificó el líder de un grupo como un miembro que "genera interacción".

Otro es Hemphill (1954), quien sostuvo que "liderar es participar en un acto que inicie un mecanismo de interacciones como parte del proceso de solución de un problema común". 
Y otro es Stogdill (1959), quien definió el liderazgo como "la iniciación y mantenimiento de una estructura en expectación e interacción".

\section{j) Liderazgo como el ejercicio de la influencia}

El concepto de influencia reconoce el hecho de que los individuos difieren en el alcance en que sus comportamientos afectan a las actividades de un grupo.

Ello implica una relación recíproca entre el líder y sus seguidores que no está necesariamente caracterizada por la dominación, control o inducción de sumisión ejercida por el líder. Simplemente indica que el liderazgo, si es exitoso, tiene un efecto determinante sobre el comportamiento de los miembros de los grupos y sobre las actividades del colectivo.

Gracias al concepto de influencia algunos autores orientan la definición de liderazgo hacia la generalidad y la abstracción.

Uno de estos autores es Nash (1929), quien sugirió que el "liderazgo implica influencia de cambio en la conducta de la gente".

Otro es Tead (1935), quien definió el liderazgo como "la actividad de influenciar a la gente para cooperar en algún objetivo que encuentran deseable".

Otro es Stodgill (1950), quien describió el liderazgo como "el proceso de influir en las actividades de un grupo 
organizado para el establecimiento y el logro del objetivo". Hunt (1991) indicó que la influencia puede ser directa o indirecta.

Otro autor destacado por Bass es Shartle (1951a, b), quien propuso que el líder sea considerado como un individuo "que ejerce actos de influencia positiva sobre otros" o "que ejerce actos de influencia más importantes que cualquier otro miembro del grupo u organización".

Bass también menciona la aportación de Tannenbaum, Weschler y Massarik (1961), quienes definen el liderazgo como una "influencia interpersonal ejercida en una situación y dirigida hacia el logro de un objetivo u objetivos específicos a través del proceso de comunicación”. Ferris y Rowland (1981) ampliaron esta definición al concebir el proceso de influencia en el liderazgo como una influencia contextual que tiene un impacto sobre las actitudes y el rendimiento de los subordinados, gracias al efecto del liderazgo sobre su percepción del trabajo.

Para algunos autores se hizo evidente cómo el aspecto interactivo estaba relacionado en el liderazgo, por definición, a los procesos de influencia.

Uno de estos autores es Haiman (1951), quien sugirió que "el liderazgo directo es un proceso de interacción en el que un individuo, usualmente a través del discurso, influye en el comportamiento de otros hacia un fin particular".

Bass también menciona a Gerth y Mills (1953), quienes entendieron que el "el liderazgo (...) es una relación entre el 
líder y el subordinado en la que el líder ejerce más influencia que la que ejercen sobre él. Gracias al líder, aquellos que son dirigidos actúan o se sienten de forma distinta a como lo harían de no ser así".

Otro autor es Cartwright (1965), quien equiparó el liderazgo con el "dominio de la influencia".

Además también menciona a Katz y Kahn (1966), quienes consideraron que "la esencia del liderazgo organizacional debe ser el aumento de la influencia, además de la conformidad mecánica con las directrices rutinarias de la organización". Observaron que aunque todos los supervisores de un mismo nivel tienen el mismo poder en una organización, no suelen usarlo con la misma efectividad para influir en los individuos y la entidad organizacional.

$Y$ finalmente, Bass incluye en esta concepción a Hollander y Julian (1969), quienes sugirieron que "el liderazgo, en el más amplio sentido, implica la presencia de una relación de influencia particular entre dos o más personas".

Otro autor incorpora matices en función del efecto provocado por el ejercicio de influencia que el liderazgo representa.

Se trata de Hemphill (1949), quien sostuvo que el esfuerzo individual para cambiar el comportamiento de otros es un liderazgo “intentado". Cuando los otros miembros en realidad cambian, este resultado representa un liderazgo "exitoso". Si los otros son premiados o 
recompensados para cambiar su comportamiento, este logro provocado es un liderazgo "efectivo".

Las distinciones entre liderazgo intentado, exitoso y efectivo son importantes porque la dinámica de cada uno es bastante diferente. El liderazgo "efectivo" es una influencia de éxito del líder que trae como resultado el logro de los objetivos por los seguidores a los que se ha influenciado. Definir el liderazgo "efectivo" en términos de los objetivos logrados es especialmente útil porque permite la aplicación de la teoría de refuerzo para comprender el comportamiento líder-seguidor (Bass, 1960).

El liderazgo "saliente" es un término más ampliamente usado para referirse a todo lo que ocurre cuando el liderazgo se intenta ejercer aunque sea efectivo o exitoso o no lo sea.

En relación a las relaciones de influencia recíproca entre líderes y seguidores, Bass también menciona algunas aportaciones.

El propio Bass (1960) entendió que si A influye en $B$ más de lo que $B$ influye en $A$, $A$ está liderando a $B$ y $B$ es seguidor de $A$.

Otro autor es Simonton (1994), quien sugirió que el líder es el miembro cuya influencia en las actitudes del grupo, en su rendimiento o en la toma de decisiones que se realicen excede ampliamente sobre la media de todos los integrantes. 
Además Bass (2008) indicó que la definición de influencia también reconoce que los líderes, por su propio ejemplo, pueden influir en otros miembros del grupo. El teniente israelí lidera con la llamada "seguidme”. El líder sirve como modelo para los seguidores. Como Gandhi sugirió "los ejemplos limpios tienen un curioso método de multiplicación por sí mismos” (Paige, 1977, p. 65).

\section{k) Liderazgo como una influencia discrecional}

Numerosos teóricos han querido limitar el concepto de liderazgo para influir en lo que no está incluido en el rol del líder.

Un ejemplo se encuentra en Katz y Kahn (1966), quienes definieron el liderazgo como un influyente incremento que va más allá de la conformidad de las rutinas directivas de una organización.

Otro autor que realizó otra aportación es esta línea es Miller (1973), quien vio a los líderes como ejerciendo influencia al margen para compensar por lo que se estaba perdiendo en una estructura y proceso específico.

También se destaca a Jacobs y Jaques (1987), quienes concibieron y consideraron el liderazgo en las organizaciones complejas como "la acción discrecional dirigida hacia el trato con acontecimientos no anticipados que de otro modo influirían en los beneficios de las tareas críticas al nivel de actor". 
Otros autores mencionados son Osborn, Hunt y Jauch (1980), quienes pusieron su atención en el liderazgo discrecional como una influencia que va más allá de la conformidad, que es típicamente otorgada a un rol y que es típicamente requerida de su posición, lo que se debe a procesos, reglas y regulaciones formales. Entienden que los jefes son líderes solo cuando responden adecuadamente a la oportunidad de ejercer influencia sobre las actividades, más allá de lo que ha sido prescrito como un requerimiento de su rol.

\section{l) Liderazgo como el arte de inducir conformidad}

Los teóricos de la "inducción a la conformidad", quizá incluso más que los teóricos de la personalidad, tendieron a considerar el liderazgo como un ejercicio unidireccional de influencia y como un instrumento para moldear el grupo a la voluntad del líder. Ellos expresaron poco reconocimiento de los derechos, deseos y necesidades de los miembros del grupo o de las normas y tradiciones del grupo.

Esta inferencia sobre los seguidores y el grupo fue rechazada por otros teóricos que eliminaban, por definición, cualquier posibilidad de legitimar un concepto autoritario de liderazgo.

Bass indica que todavía, a pesar de los sentimientos de algunos científicos conductistas, no podemos ignorar que mucho liderazgo es autoritario, directivo e incluso coercitivo. Sus efectos son vistos con conformidad pública 
pero no necesariamente con aceptación privada. Sea como fuere, Bass declara que la conformidad con el punto de vista del líder puede ser reforzada a través de la identificación con su persona y con la internacionalización de su perspectiva por parte de los seguidores.

Uno de los autores mencionados en esta concepción del liderazgo es Munson (1921), quien lo definió como "la habilidad de tratar con los hombres para que logren lo máximo con la menor fricción y la máxima cooperación”.

Otro es Ailport (1924), quien entendió que "el liderazgo (...) es control social personal".

Otra mención de Bass es la de Moore (1927), quien presentó los resultados de una conferencia en la que el liderazgo fue definido como "la habilidad para que la voluntad del líder impacte sobre los que guía y para que induzca obediencia, respecto, lealtad y cooperación".

Y otra es la de Bundel (1930), quien consideró el liderazgo como "el arte de inducir a otros a que hagan lo que uno quiere que hagan".

Bass también incorpora en este grupo a Phillips (1939), quien entendió que el liderazgo es "la imposición, mantenimiento y dirección de la unidad moral a nuestro fines".

También menciona a Warriner (1955), quien sugirió que "el liderazgo, como una forma de relación entre personas, que requiere que una o varias personas actúen en conformidad con lo que la otra persona solicita". 
Otro experto incluido en esta concepción del liderazgo es Bennis (1959), quien indicó que "el liderazgo puede ser definido como el proceso por el que un agente induce a un subordinado a comportarse en un modo deseado". Barker (1994) consideró que esta definición es atribuible a las ideas de Maquiavelo relacionadas con la concepción del liderazgo como una cuestión de control sobre los demás.

\section{Liderazgo como un efecto}

El segundo grupo de definiciones consideran la definición del liderazgo como un efecto.

a) El líder como un instrumento para el logro del objetivo

Numerosos teóricos han incluido la idea del logro del objetivo en su definición.

Varios investigadores han definido el liderazgo en función de su valor instrumental para conseguir los objetivos de un grupo y la satisfacción de sus necesidades.

Entre ellos se encuentra Cowley (1928), quien indicó que "un líder es una persona que tiene un programa y está dirigiéndose con su grupo hacia un objetivo de un modo preestablecido".

Otro autor que se encuentra en esta línea es Bellows (1959), quien define el liderazgo como "el proceso de organizar una situación para que varios miembros de un 
grupo, incluido el líder, puedan lograr objetivos comunes con la máxima economía y un mínimo de tiempo y trabajo”.

También Knickerbocker (1948), quien sostuvo que "el liderazgo existe cuando el grupo percibe que el líder controla los medios para la satisfacción de sus necesidades".

Algunos teóricos organizacionales clásicos definieron el liderazgo en función del logro de los objetivos del grupo.

Uno de estos autores es Davis (1942), quien se refirió al liderazgo como "la principal fuerza dinámica que motiva y coordina la organización en el cumplimiento de sus objetivos".

Bass también menciona a Urwick (1953), quien sostuvo que el líder es “la personificación del propósito común, no solo en relación a todos los que trabajan en la propia empresa sino a todo el mundo externo que también está implicado".

Otro autor es Davis (1962), quien definió el liderazgo como "el factor humano que mantiene un grupo unido y lo motiva hacia el cumplimiento de los objetivos".

Otro experto es Cattell (1951), quien llevó a la posición extrema el planteamiento de esta línea al defender que el liderazgo es cualquier cosa o cualquiera que contribuya al rendimiento del grupo. Para medir el liderazgo de cada uno de los integrantes del grupo, Catell propuso observar lo que sucede en el rendimiento del grupo cuando se saca al integrante evaluado del mismo. 
También Calder (1977), además de Pfeffer (1977), plantearon que el liderazgo es principalmente influencia atribuida los participantes incluso después de que el liderazgo se haya ejercido. Las atribuciones pueden estar basadas en las Teorías Implícitas de Liderazgo (Rush, Thomas y Lord, 1977). Estas teorías son lo que se espera que los líderes digan y hagan, los rasgos y comportamientos que se atribuyen a los estereotipos de un líder. Offerman, Kennedy y Wirtz (1994) revisaron el contenido, estructura y el carácter universal de las Teorías Implícitas de Liderazgo.

Algunos teóricos entendieron que el liderazgo puede transformar a los seguidores, crear visiones de los objetivos que pueden ser alcanzados y articular las maneras de alcanzar esos objetivos para los seguidores.

Un ejemplo de este planteamiento se encuentra en Burns (1978), Bennis (1983), Bass (1985), y Tichy y Devanna (1986), quienes sostuvieron la visión anteriormente indicada.

O Luis Muñoz Marín, antiguo gobernador de Puerto Rico, quien expresó: "un líder político es una persona con la habilidad para imaginar estados no existentes de asuntos combinada con la habilidad para convencer a los demás de lo que tienen que hacer” (Paige, 1977, p. 65).

Otros autores sostuvieron que la previsión de objetivos, implica intuición, fantasía y ser capaz de soñar, y 
no solo procesos de pensamiento analíticos, sistemáticos y conscientes.

En este planteamiento Sparks, jefe ejecutivo que transformó la Whirlpool Corporation, indicó que "la visión vino después de años de meditar sobre la clase de organización que Whirlpool podría ser y después de su constante interacción con personas de otras organizaciones y académicos. La visión era de Sparks y el proceso de planificación estratégica se volvió el vehículo, no su fuente, para implementar dicha visón (Tichy y Devanna, 1986, p. 138).

Bass también menciona a Tucker (1981), quien observó que la mayoría de los políticos actuales deben dirigir la atención de sus electores sobre programas y objetivos al corto plazo. De todos modos la opinión de que los líderes son necesarios para impulsar y dirigir una democracia hacia el logro de objetivos a largo plazo, tales como la estabilización de la población, la mejora del entorno y el control armamentístico, es más propio de una visión estadística.

b) Liderazgo como un efecto de la interacción

Varios teóricos han visto el liderazgo no como una causa o control, sino como un efecto de la acción del grupo. Los teóricos de este grupo eran relevantes porque llamaron la atención sobre el hecho de que el liderazgo emergente surge del propio proceso de interacción. Sostienen que el 
liderazgo existe verdaderamente solo cuando es reconocido y conferido por otros miembros del grupo.

Aunque estos autores probablemente no quisieron insinuarlo, sus definiciones sugieren que esta cualidad equivale a poco más que la aceptación pasiva de la importancia del estatus de alguien. Un individuo a menudo emerge como un líder a consecuencia de las interacciones dentro del grupo, que despiertan expectativas de que él o ella pueden servir al grupo de un modo más útil que otros a alcanzar sus objetivos.

En esta línea Bogardus (1929) expuso que "como un proceso social, el liderazgo es esa inter-estimulación social que causa que un número de personas se embarquen en un viejo objetivo con nuevo entusiasmo o hacia un nuevo objetivo con un coraje prometedor con diversas personas que tienen diferentes roles".

También en este planteamiento Pigors (1935) sostuvo que "el liderazgo es un proceso de mutua estimulación por el que, gracias a la interacción de éxito de las diferentes personas, los seres humanos controlan la energía en la búsqueda de un objetivo compartido".

Otro autor que Bass incluye en este grupo es Anderson (1940), quien sostuvo que "un verdadero líder, en el sentido psicológico, es el que puede sacar provecho de la mayoría de las diferencias individuales, que puede sacar las mayores diferencias en el grupo y por lo tanto revelar al grupo una base más sólida para definir el objetivo común". 


\section{Liderazgo en términos de interacción líder- grupo}

El tercer grupo de definiciones comparten la visión del estudio del liderazgo en términos de interacción entre el líder y el grupo.

\section{a) Liderazgo como un proceso}

Esta concepción del liderazgo como un proceso se está volviendo cada vez más popular. Se interesa por las cogniciones, los comportamientos interpersonales y las atribuciones, tanto de los líderes como de los seguidores, en el sentido de cómo afectan en cada caso a la persecución de sus objetivos comunes.

Uno de los autores de este grupo es Northouse (2001), quien entendió que el liderazgo es un proceso en el que una persona influye en un grupo de individuos para lograr un objetivo común. El liderazgo no es unidireccional sino más bien un proceso bidireccional interactivo entre un líder y un seguidor.

Bass también incluye en este planteamiento a Homans (1950) y Dansereau, Graen y Haga (1975) quienes, entre muchos otros, concibieron el proceso como un intercambio o transacción entre el líder y el grupo de seguidores. Tal liderazgo puede ser representado por cualquier miembro del grupo, no solo por el líder designado o formalmente elegido. 
Los líderes y los seguidores pueden intercambiar los roles durante el proceso.

Otro autor asociado a esta línea es Yukl (1994), quien definió el liderazgo en las organizaciones como procesos de influencia que interpretan los acontecimientos para los seguidores, la elección de los objetivos para el grupo u organización, la planificación del trabajo para lograr los objetivos, el mantenimiento del grupo de trabajo y las relaciones de cooperación y el reclutamiento de personas externas para apoyar y cooperar con el grupo u organización.

\section{b) Liderazgo como una relación de poder}

La mayoría de los teóricos políticos, desde Maquiavelo, pasando por Marx, hasta los científicos políticos académicos del siglo XXI concibieron el poder como la base del liderazgo político.

En esta línea se encuentra Barker (1996), quien sostiene que los líderes tenían que concentrarse sobre lo que estaba bajo su control, no sobre lo que estaba bajo el control de otros. En este sentido el liderazgo es un esfuerzo para crear y mantener el poder sobre otros.

En esta sintonía también se sitúan French (1956), y Raven y French (1958a, 1958b), psicólogos sociales, quienes definieron el liderazgo en términos de las relaciones de poder que marcan la diferencia entre los miembros de un 
grupo. El poder puede ser de referencia, experto, de recompensa, de coacción o legítimo. El poder es “un resultante de la fuerza máxima que $A$ puede inducir sobre $B$ contra la fuerza de máxima resistencia que B puede ejercer en la dirección opuesta".

También se encuentra en esta línea Janda (1960), quien definió el liderazgo como "un tipo particular de relación de poder caracterizado por la percepción de un miembro del grupo de que otro miembro del grupo tiene el derecho a prescribir patrones de comportamiento para el primero en lo que concierne a su actividad como un integrante de un grupo particular".

Bass también cita a Smith (1948), quien equiparó el liderazgo con el control del proceso de interacción. Así, “el iniciador de una interacción, A, estimula a un segundo participante, B. A impone su control al interferir en el curso de acción original de B". El uso del poder es considerado como una forma de relación de influencia. Algunos líderes tienden a transformar cualquier oportunidad para ejercer liderazgo en una relación de poder manifiesta. De hecho, la alta frecuencia de esta observación, combinada con las a menudo consecuencias indeseables para los individuos y las sociedades, indujo a mucho teóricos a rechazar la noción de liderazgo autoritario.

Otro autor mencionado por Bass es Bennis (1970), uno de los muchos que rechazaban la noción de liderazgo autoritario. Pertenece a un grupo de autores que estaban más comprometidos anteriormente con la apertura, los 
enfoques participativos y la construcción de confianza. Estos autores sostenían que se enfrentaban al mundo tal y como era, no como a ellos les gustaría que fuera, por lo que volvieron a reconocer la importancia de las relaciones de poder en la comprensión del liderazgo.

También se incluyen en esta línea las propuestas de Gerth y Mills (1953), quienes indicaron que las relaciones de poder pueden ser imperceptibles u oscuras: "una relación de poder (...) puede ser conocida por ambos, líder y seguidor, o desconocida por cualquiera de los dos".

Finalmente Bass también menciona a Denhart (1987), quien sostuvo que los mitos y los símbolos sobre las relaciones amo-esclavo pueden inconscientemente ejercer influencia en las relaciones superior-subordinado en las organizaciones modernas.

\section{c) Liderazgo como una diferencia de rol}

Según este planteamiento, cada miembro de una sociedad ocupa una posición en una comunidad así como en varios grupos, organizaciones e instituciones. En cada ubicación se espera que el individuo juegue un rol más o menos definido. Miembros diferentes, ocupando posiciones diferentes, juegan roles diferentes.

El nacimiento y la clase pueden forzar la diferenciación de los roles. De acuerdo al líder de Ponape, Heinrich Iriarte, algunos micronesianos son nacidos para 
gobernar mientras otros son nacidos para servir (Page, 1977, p. 6R).

De todas las definiciones disponibles, el concepto de liderazgo como un rol es el más firmemente respaldado por la investigación (Bass, 2008).

Las diversas aportaciones de este apartado pueden agruparse en dos bloques.

El primero basado en una comprensión del liderazgo como un aspecto de la diferenciación del rol.

En esta línea se encuentra Jennings (1944), quien observó que "el liderazgo aparece como una manera de interacción que incluye una forma de comportarse con el resto de individuos".

También Gibb (1954), quien consideró el liderazgo del grupo como una posición que emerge del propio proceso de interacción.

Y también Gordon (1955), quien entendió que el liderazgo era una interacción entre una persona y un grupo, o con más precisión, entre una persona y los miembros del grupo. Cada participante en esta interacción juega un rol. Estos roles difieren en cada caso. La base de esta diferencia es un asunto de influencia: una persona, el líder, el que influye, y las otras personas las que responden.

El segundo bloque está más centrado en las aportaciones de otros autores relacionadas con el refuerzo, 
la confirmación y la estructuración de expectativas, que también se aplican al estudio del liderazgo.

En esta línea se encuentran Sherif y Sherif (1956), quienes sugirieron que el liderazgo es un rol dentro del esquema de relaciones y es definido por expectativas recíprocas entre el líder y otros miembros. El rol de liderazgo, como otros roles, es definido por expectativas estabilizadas (normas) que, en la mayoría de las cuestiones y situaciones que son relevantes para el grupo, son más exigentes y requieren obligaciones más grandes del líder que del resto de los miembros del grupo. El reconocimiento del liderazgo como un instrumento de consecución de objetivos, como un producto de procesos de interacción y como un rol diferenciado, amplía el desarrollo de la teoría coherente que encaja con la mayoría de los hechos disponibles hasta la fecha. El liderazgo como un rol diferenciado es demandado para integrar al resto de roles del grupo y mantener la unidad de acción en los esfuerzos del grupo para alcanzar sus objetivos.

También se sitúan en esta línea Newcomb, Turner y Converse (1965), quienes observaron que los miembros de un grupo hacían diferentes contribuciones al logro de los objetivos. En la medida en que las contribuciones de cualquier miembro eran indispensables, ellos podrían ser considerados casi líderes; y en la medida en que cualquier miembro era reconocido por otros como una fuente digna de confianza de tales atribuciones, él o ella eran considerados casi líderes. Ser reconocido era equivalente a tener una 
relación de rol con otros miembros. Mucha de la investigación sobre la emergencia y la diferenciación de roles pertenece igualmente al liderazgo.

Y Bass también cita de nuevo a Sherif y Sherif (1956), quienes indicaron que los roles son definidos en términos de las expectativas que los miembros del grupo desarrollan en relación con otros miembros y también con ellos mismos.

\section{d) Liderazgo como consecuencia del reconocimiento del líder por el grupo de seguidores}

Ajustar el prototipo de liderazgo de rasgos y comportamientos con el contacto cara a cara requiere un proceso cognitivo más controlado. Lord y Maher (1991) entendieron que el ajuste se fundamenta en los procesos comunicados socialmente.

Estas teorías implícitas de representación social del liderazgo varían en diferentes grupos profesionales, como fue demostrado cuando a 257 profesionales franceses se les solicitó que definieran una persona que consideraban que era más adecuada para liderar un grupo (François, 1993).

Lord y Maher (1991) encontraron una correlación de .83 entre prototipos de liderazgo en los negocios y las finanzas pero una correlación de solo .18 entre prototipos de liderazgo en negocios y deportes.

De modo similar, ellos encontraron una correlación de .80 entre prototipos religiosos y prototipos educacionales 
pero ninguna correlación entre prototipos religiosos y prototipos de liderazgo en los medios de comunicación.

\section{e) Liderazgo como consecuencia de la identificación con el líder}

Shamir (1991) sostuvo que hay una conexión emocional entre el líder y el seguidor. El líder provee un ejemplo para que sea imitado por los seguidores. Las aspiraciones del líder se vuelven las propias aspiraciones de los seguidores.

\section{f) Liderazgo como una combinación de elementos}

Algunos expertos combinan varias definiciones de liderazgo para cubrir un conjunto más grande de significados.

Uno de estos autores es Bogardus (1934), quien definió el liderazgo como "la personalidad en acción bajo las condiciones del grupo (...)". En este sentido "no solo es el liderazgo una personalidad y un fenómeno de grupo, es también un proceso social que afecta a un número de personas en contacto en el que una asume el dominio sobre los demás". Previamente Bogardus (1928) describió el liderazgo como la creación y el establecimiento de patrones de comportamiento excepcional ante los que responderán otras personas.

Bass también incluye en este grupo a Jago (1982), quien entendió que el liderazgo es el ejercicio de la 
influencia sin coacción para coordinar a los integrantes de un grupo organizado en el logro de los objetivos del grupo.

Bass también indica que el liderazgo es un conjunto de propiedades atribuidas a quienes son percibidos por el uso de su influencia de modo satisfactorio. Dentro de este planteamiento genérico se encuentra Barrow (1977), que ha combinado en su definición de liderazgo la influencia interpersonal y los esfuerzos colectivos para alcanzar los objetivos. O Dupuy y Dupuy (1959), quienes señalaron que el liderazgo también incluye obediencia, confianza, respecto y cooperación leal de los seguidores.

Otros autores han definido el liderazgo como una colección de roles que emergen desde un proceso centrado en las interacciones. Tichy y Devanna (1986) sostuvieron que la combinación de poder con la personalidad definió al líder transformacional como un agente de cambio experto y entendido con poder, legitimidad y energía. Tal líder era valeroso, considerado, dirigido por valores y capaz de tratar con ambigüedad y complejidad. 
ANEXO 5. CUADERNILLO DE RECOGIDA DE DATOS 



\section{Buenos días.}

La Universidad San Jorge y Universidad de Valladolid están desarrollando un proyecto de $\mathrm{I}+\mathrm{D}+\mathrm{i}$ centrado en la responsabilidad social de las organizaciones.

Los resultados de la investigación se trasladarán a todos las personas que, amablemente, han ofrecido sus impresiones sobre las cuestiones tratadas. Se considera que es una información valiosa para la toma de decisiones empresariales, ya que refleja las opiniones personales de los líderes del mercado en cuestiones tan esenciales como la actitud ante la responsabilidad social y considera, al mismo tiempo, la relación de dicha actitud con los valores personales o el estilo de liderazgo. En las páginas siguientes encontrará tres cuestionarios para medir cada uno de estos tres aspectos.

Los responsables de la investigación agradecen, enormemente, el tiempo dedicado y esperan que el posterior informe de resultados que se entregará permita compensar su valiosa colaboración.

Antes de cumplimentar los cuestionarios le agradeceríamos que nos indicara la siguiente información:

Sexo: $\square$ Mujer $\square$ Hombre

Mail (para el envío de resultados):

País:

Edad:

$\square 31-40$

$\square$ 41-50

$\square 51-60$

$\square 61-65$

$\square$ Más de 65

Sector:

$\square$ Servicios (incluye comercio)

$\square$ Construcción

$\square$ Industria

Tamaño:
$\square$ Pequeña (1-9 integrantes)
$\square$ Mediana (10-250 integrantes)
$\square$ Grande (más de 250 integrantes)

¿Cómo definiría su organización en términos de $I+D+i$ (investigación, desarrollo e innovación)?:
$\square$ Bajo desarrollo
$\square$ Medio desarrollo
$\square$ Alto desarrollo

\section{¿Su organización dedica horas de formación al año a la responsabilidad social?}

$\square$ No

$\square$ Sí. Indique cuantas:

¿Su organización realiza acciones de responsabilidad social?

$\square$ No

$\square \mathrm{Si}$. Indique si se trata de:

$\square$ Acciones puntuales

$\square$ Acciones frecuentes sin una política definida de responsabilidad social

$\square$ Acciones integradas en una política definida de responsabilidad social 
A continuación encontrará una lista de juicios sobre las organizaciones y la Responsabilidad Social Corporativa (RSC). Por favor indique "sí" en todos los enunciados con los que está de acuerdo y "no" con todos aquellos con los que está en desacuerdo.

Muchas gracias por su colaboración

\section{JUICIOS}

Las organizaciones que aplicaran políticas de Responsabilidad Social Corporativa (RSC):

1. ...deberían interpretar la RSC como una moda pasajera.

2. ...no deberían dialogar con sus grupos de interés (inversores, clientes, comunidad local, etc.).

3. ...deberían evaluar detalladamente su impacto medioambiental.

4. ...no deberían respetar las recomendaciones de expertos en RSC.

5. ...deberían fomentar la preocupación social por el medio ambiente dentro de sus posibilidades.

6. ...deberían utilizar sus fuentes de energía de manera muy eficiente.

7. ...deberían utilizar criterios medioambientales para seleccionar proveedores.

8. ...sería recomendable que tuvieran expertos para encargarse de su RSC.

9. ....deberían favorecer el desarrollo de la sociedad dentro de sus posibilidades.

10. ...solo deberían estar interesadas en utilizar la RSC para mejorar su imagen.

11. ...no deberían plantear la RSC como algo que contribuya exclusivamente a su beneficio económico.

12. ...deberían realizar menciones completamente ciertas en su publicidad a la RSC.

13. ...no deberían mantenerlas en época de crisis.

14. ...jamás deberían preocuparse por el medio ambiente.

15. ...nunca deberían fomentar el respeto a los derechos humanos.

16. ...no deberían preocuparse porque todos sus colaboradores conozcan su RSC.

17. ...siempre que su posición lo permita deberían establecer precios abusivos en el mercado.

18. ...solo deberían comunicarse de modo transparente cuando la organización salga beneficiada.

19. ...nunca deberían formar a sus colaboradores en responsabilidad social.

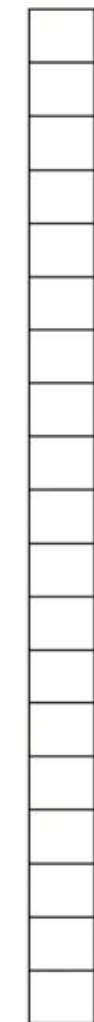

Las siguientes frases expresan cosas que las personas consideran importantes sobre su modo de vivir. Se presentan en triadas, es decir, agrupadas de tres en tres.

Por favor, lea atentamente las tres frases de cada triada y elija, aunque en algunos casos sea difícil decidirse, la que indique lo más importante para usted. Para señalarla, solo hay que rodear la alternativa de la columna " + ". Luego debe elegir, entre las dos frases restantes, la que indique lo menos importante para usted y rodear la alternativa de la columna "-".

Es posible que en algunos casos resulte difícil decidirse por una frase. En este caso elija la frase que más se aproxime a su modo de pensar. No existen contestaciones "buenas" ni "malas"; esto no es una prueba de inteligencia o habilidad, sino solo una apreciación de lo que usted valora en mayor o menor medida.

Por favor trabaje rápidamente, conteste a todos los grupos de tres frases y responda con sinceridad.

Muchas gracias por su tiempo y su disposición.

\begin{tabular}{|c|c|c|c|c|}
\hline \multirow{3}{*}{1} & 1 & Trabajar en algo difícil. & + & - \\
\hline & 2 & Tener bien definidos los objetivos y metas. & + & - \\
\hline & 3 & Tener mis asuntos claros y en orden. & + & - \\
\hline \multirow{3}{*}{2} & 1 & Ser práctico y eficiente. & + & - \\
\hline & 2 & Buscar diversión y entretenimiento. & + & - \\
\hline & 3 & Mejorar de modo continuo mis capacidades. & + & - \\
\hline
\end{tabular}


Saber exactamente lo que intento llevar a cabo.

Considerar las cosas desde un punto de vista práctico.

Dirigir mi atención a la resolución de los problemas.

1 Hacer cosas nuevas y diferentes.

4.2 Hacer las cosas con toda perfección.

3 Tener un objetivo muy definido a donde dirigirme.

1 Mantener muy claras mis metas.

52 Programar mi tiempo con antelación.

3 Actuar con una firme convicción.

1 Tomar decisiones sin retrasos.

62 Sacarle buen partido a todo lo que poseo.

3 Dirigir mis esfuerzos a objetivos claros y precisos.

1 Alcanzar la calidad más alta en mi trabajo.

72 Llevar una vida bien organizada.

3 Poder viajar mucho.

$8 \quad 1$ Poner mucho cuidado en mis asuntos.

3 Ser metódico en lo que hago.

1 Tener experiencias nuevas o poco habituales.

92 Sacar el mejor partido del dinero que gasto.

3 Tener muy organizados mis hábitos de trabajo.

1 Hacer cosas que jamás había hecho antes.

102 Hacer más de lo que generalmente se espera de mí.

3 Conocer exactamente el fin al que me dirijo.

1 Mantenerme firmemente en mis convicciones.

112 Tener experiencias variadas.

3 Acabar lo que he comenzado.

1 Buscar e informarme bien antes de comprar.

122 Llegar a decisiones bien definidas en los asuntos.

3 Ordenar bien las cosas en su sitio.

1 Ser metódico en mi trabajo.

132 Tener la experiencia del riesgo.

3 Enfrentarme a un problema complejo.

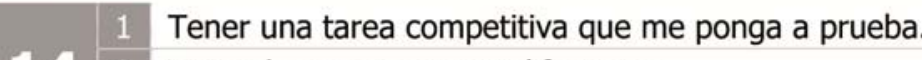

Visitar lugares nuevos y diferentes.

3 Tener una meta definida a donde orientar mi trabajo.

151 Cuidar bien lo que me pertenece.

152 Mantenerme firme en mis propias opiniones y creencias.

3 Planificar mi trabajo con antelación.

Tener un objetivo en mente y trabajar en esa dirección.

Hacer cosas que son muy provechosas.

3 Hacer algo importante.

1 Intentar cosas diferentes.

1.72 Hacer las cosas de manera organizada.

3 Tener mucho éxito en todo lo que intento.

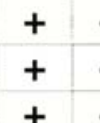

$+-$

$+$

$+$

$+\quad-$

$+-$

$+-$

$+-$

$+$

$+$

$+-$

$+-$

$+-$

$+-$

$+-$

$+\quad-$

$+-$

$+-$

$+-$
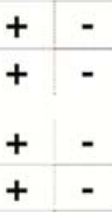

$+-$

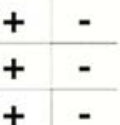

$+$

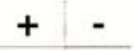

$+$

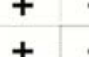

$+1$

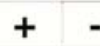

$+$

$+$

$+$

+ -

$+-$

$+$

$+-$

$+-$ 
1 Llevar una vida muy ordenada.

182 Ser muy cuidadoso con mis pertenencias.

3 Ir siempre directamente al punto clave.

1 Ir a lugares extraños y poco habituales.

1 e 2 Ser sistemático en mi trabajo.

3 Proseguir un problema hasta su solución.

Ponerme cotas muy altas en mis exigencias.

Tener metas y objetivos muy específicos.

3 Hacer cosas que son nuevas y diferentes.

1 Mantener en buenas condiciones mis asuntos.

21. 2 Dedicar toda mi energía en la realización de una meta.

3 Tener una posición muy clara sobre los temas.

1 Hacer frecuentes viajes.

22 Hacer las cosas según un plan preestablecido.

3 Tomar las decisiones rápidamente.

Conseguir que mi organización sea rentable.

Desarrollar políticas de responsabilidad social en mi organización.

3 Conseguir que mi organización sea líder en el mercado.

1 Ser muy cuidadoso con mi dinero.

24. 2 Ser capaz de superar cualquier obstáculo.

3 Hacer cosas que son peligrosas o excitantes.

1 Tener convicciones firmes y fuertes.

252 Tener objetivos bien definidos.

3 Mantenerme siempre limpio e impecable.

1 Hacer cosas bien remuneradas.

262 Ser una persona muy ordenada.

3 Tener una posición muy clara en todo.

1 Experimentar lo que sale de lo corriente.

272 Sacar el mejor partido de mi dinero.

3 Trabajar en un problema difícil.

\begin{tabular}{l|l|l|}
\hline & 1 & Tener una tarea importante que me ponga a prueba. \\
\hline 2 & 2 & Abordar directamente un problema.
\end{tabular}

3 Hacer las cosas de manera metódica.

1 Saber con precisión a donde me dirijo.

292 Esforzarme por cumplir alguna cosa importante.

3 Hacer las cosas de modo práctico y eficiente.

1 Tener un enfoque sistemático para hacer las cosas.

302 Llegar a una decisión y mantenerme en ella.

3 Tener mucho cuidado de lo que me pertenece.

1 Buscar la aventura.

31. 2 Tener en mente un camino claro de acción.

3 Ser capaz de hacer las cosas de una manera mejor.
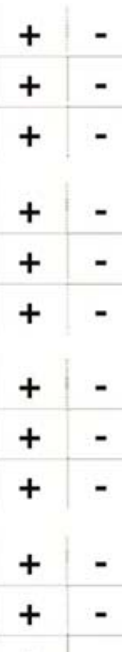
A continuación se presentan 20 situaciones de trabajo típicas que corresponde resolver a un líder o a uno o más integrantes de su equipo.

En cada una de estas situaciones típicas se ofrecen 4 posibles decisiones o acciones.

Imagínese que es usted el líder encargado de la resolución de dichas 20 situaciones. En cada una de ellas debe decidirse por 1 de las $\mathbf{4}$ acciones dadas.

Marque con un círculo la letra correspondiente a la decisión que usted crea más apropiada. Por favor, marque solamente una respuesta.

Muchas gracias por su tiempo y por su colaboración.

1. Usted le ha pedido a uno de sus colaboradores que le elabore un informe acerca de la adquisición de un nuevo equipo para su división. Por lo regular, a este colaborador se le puede dar un trabajo y, con su apoyo, contar con que lo termine a tiempo. El plazo para dicho informe ha vencido. Usted...

a) Le diría que quiere el informe, le explicaría qué debe recoger y revisaría su realización cada día.

b) Le daría más tiempo para terminar el trabajo.

c) Le diría qué es lo que usted quiere que haga y cuándo quiere el informe terminado, pero hablaría con él para saber porqué el informe no está terminado.

d) Le motivaría para que terminara el informe.

2. El grupo interdepartamental que usted dirige ha estado trabajando duro para terminar el informe de toda su división. Se le ha asignado un nuevo colaborador a su cargo en el grupo de trabajo, el cual tiene que terminar un análisis de costes de su departamento para la reunión de la próxima semana del grupo de trabajo. Pero no sabe nada acerca de las necesidades del grupo de trabajo ni de la extensión del informe. El nuevo integrante del grupo de trabajo está emocionado y entusiasmado por aprender más en relación con su participación en el grupo de trabajo. Usted...

a) Le diría exactamente qué se necesita en este informe y supervisaría muy de cerca su progreso.

b) Preguntaría si hay algo en lo cual pudiera ayudarle y apoyaría su entusiasmo por ser un nuevo integrante del equipo de trabajo.

c) Especificaría la extensión del informe y los aspectos que debe tratar, pero incluiría cualquier idea o sugerencia que él pudiera tener.

d) Le daría la bienvenida al equipo de trabajo y le pondría en contacto con otros integrantes de este colectivo que podrían ayudarle a preparar dicho informe.

3. Últimamente usted ha empezado a tener problemas con una de las personas que supervisa. El colaborador se ha retrasado y solo su constante insistencia ha permitido que complete su trabajo. Por motivos que atañen al historial del trabajo, usted se imagina que él puede carecer de la experiencia necesaria para terminar trabajos de mayor importancia que le ha dado. Usted...

a) Continuaría aportando sus esfuerzos para completar esta labor.

b) Continuaría supervisando muy de cerca su trabajo, pero trataría de conocer sus actitudes y sentimientos en relación con la labor encomendada.

c) Le tendría en cuenta para solucionar los problemas relacionados con esta labor y utilizaría sus ideas para terminar el proyecto en curso.

d) Le informaría de que ésta es una labor importante y le pediría que se pusiera en contacto con usted en caso de tener dudas o problemas.

4. Su grupo de trabajo habitualmente ha funcionado bien, con su apoyo y dirección. Sin embargo, la eficiencia del grupo ha bajado drásticamente. El grupo necesita más formación y experiencia para incrementar su eficiencia. Su jefe se ha empezado a preocupar. Usted..

a) Expresaría la necesidad de un trabajo más eficiente y le pediría al grupo que resolviera sus problemas por sí solo.

b) Se aseguraría de que los plazos se cumplen y de que la calidad del trabajo es buena, pero hablaría con el grupo de trabajo para obtener sus sugerencias.

c) Informaría al grupo exactamente de qué es lo que desea, para cuándo se necesita la información y cuáles podrían ser algunas de las consecuencias de la mala eficiencia demostrada.

d) Ayudaría al grupo a determinar qué es lo que se necesita hacer y lo apoyaría para dar los pasos necesarios. 
5. Por motivo de las restricciones impuestas en el presupuesto del departamento es necesario consolidarlo. Usted le tiene que pedir a un miembro altamente experimentado del departamento que haga los ajustes. Esta persona ha trabajado en todas las áreas del departamento. Mientras usted cree que tiene mucha habilidad para desarrollar esta labor, él parece indiferente ante la importancia de esta tarea. Usted..

a) Se haría cargo de los ajustes, asegurándose de escuchar sus sugerencias.

b) Le asignaría el proyecto a él y le dejaría que determinara cómo terminarlo.

c) Discutiría la situación con él y le animaría a que acepte la tarea debido a su habilidad y experiencia.

d) Se haría cargo de los ajustes y le indicaría precisamente qué hacer. Supervisaría de cerca su trabajo.

6. Una mujer altamente capaz y eficiente del personal ha pedido su ayuda para un proyecto. Está acostumbrada a trabajar eficientemente, sin ayuda de nadie. Recientemente se han presentado problemas de trabajo que ella cree que no puede resolver por si misma. Usted..

a) Analizaría los problemas y planearía métodos para resolverlos.

b) Continuaría permitiéndole encontrar una solución de forma independiente.

c) Determinaría e implementaría una solución apropiada, pero trabajaría con ella en la solución de problemas.

d) Lo comentaría con ella y la apoyaría en sus esfuerzos para encontrar soluciones apropiadas.

7. Usted le ha pedido a uno de los colaboradores más antiguos que acepte un trabajo nuevo. En sus otras responsabilidades ha actuado adecuadamente. El trabajo que le ha pedido que acepte es importante para el futuro del grupo de trabajo. El colaborador está emocionado con la nueva tarea, pero no sabe por donde empezar debido a su falta de experiencia en este tipo de tareas. Usted..

a) Hablaría del trabajo con él, apoyando su habilidad para hacerlo y mencionando su excelente eficiencia en el pasado.

b) Definiría las actividades necesarias para ejecutar el trabajo con éxito y regularmente supervisaría su progreso.

c) Le daría el trabajo y le dejaría determinar cómo hacerlo. Le diría que le comentara si tiene algún problema.

d) Le especificaría lo que tiene que hacer, pero le pediría las ideas que él pudiera tener.

8. Un integrante de su personal se siente inseguro acerca de un trabajo que usted le ha dado. Es muy competente y usted sabe que tiene capacidad para completar con éxito y eficientemente esta tarea. Usted..

a) Escucharía sus preocupaciones y alabaría su habilidad para completar la tarea.

b) Estructuraría la tarea para que estuviera clara, pero tomaría en cuenta cualquier sugerencia que él pudiera aportar.

c) Le diría exactamente qué hacer para ejecutar la tarea y revisaría su trabajo diariamente.

d) Le dejaría resolver cómo ejecutar la tarea por sí mismo.

9. Los integrantes del grupo de trabajo le han pedido que considere algunos cambios en sus horarios de trabajo. En el pasado usted ha estimulado y apoyado sus sugerencias. En este caso los miembros del grupo de trabajo son conscientes de la necesidad de cambios, están dispuestos a hacer sugerencias y le proponen poner a prueba un horario alternado. Son muy competentes y trabajan muy bien como grupo. Usted...

a) Permitiría la participación de los integrantes del grupo en el desarrollo de un horario nuevo y apoyaría sus sugerencias.

b) Diseñaría e implantaría un nuevo horario usted solo, pero incorporaría las recomendaciones del grupo.

c) Permitiría que los participantes del grupo diseñaran e implementaran un nuevo horario de trabajo por sí mismos.

d) Diseñaría un nuevo horario y muy de cerca vigilaría su cumplimiento. 
10.Usted ha llegado 30 minutos tarde a las reuniones de trabajo. Cuando llega las reuniones no ha empezado aún. Las investigaciones muestran que dos integrantes del grupo de trabajo han intentado iniciar las reuniones, pero la mayoría de sus miembros se sienten desanimados por la falta de cooperación de alguno de ellos. Esta situación le sorprende, porque el progreso del grupo en este proyecto era muy bueno. Usted..
a) Explicaría el propósito de la reunión y entonces dejaría que el grupo funcionara sin su intervención, al menos hasta que le pidiera su ayuda.
b) Tomaría el control inmediatamente y dirigiría al grupo hacia la terminación del proyecto.
c) Dirigiría la interacción grupal hacia la terminación del proyecto y les animaría a exponer sus problemas y sentimientos.
d) Le pediría al grupo que continuara comentando las tareas asignadas y que apoyaran sin fisuras y con entusiasmo el proyecto tanto como les fuera posible.

11.Un integrante de su departamento ha tenido un buen historial de éxitos con estímulo y apoyo, pero con poca dirección. Se le han dado tareas similares para el siguiente año y usted debe decidir cómo supervisarlas. Usted.
a) Le dejaría que actuara por sí mismo, guiándose por su propio estímulo y dirección.
b) Le haría notar la importancia de cumplir con los plazos y encaminaría sus esfuerzos a la finalización de las labores asignadas.
c) Hablaría con él y establecería metas y objetivos para el desarrollo de su labor, pero tomaría en cuenta sus sugerencias.
d) Le haría participar en la fijación de metas y apoyaría sus esfuerzos.

12. Dirigiendo y apoyando sus esfuerzos, la productividad ha llegado a un nivel alto y la gente convive de modo armonioso. Reconociendo sus habilidades, usted cree que ahora pueden trabajar más por sí mismos. Usted ha redirigido sus energías a nuevas áreas y continúan produciendo buenos resultados. Usted ahora debe pedirles que acepten un trabajo adicional. Usted...
a) Les daría el trabajo, asegurándose exactamente de que sepan qué les corresponde hacer y les supervisaría muy de cerca.
b) Les daría el trabajo, les diría que su trabajo en el pasado ha sido bueno y que van a seguir haciéndolo bien.
c) Se aseguraría de que ellos estén informados de qué es lo que se espera de ellos, pero aceptaría cualquier sugerencia útil que pudieran tener.
d) Les permitiría determinar cómo desarrollar sus labores.

13. Recientemente a usted se le ha asignado un trabajador nuevo que efectuará un trabajo importante en la oficina. Aunque es inexperto está entusiasmado y desea hacer el trabajo. Usted..
a) Le dejaría determinar en qué consiste el trabajo y cómo hacerlo.
b) Le diría exactamente en qué consiste el trabajo, qué espera de él y supervisaría su trabajo muy de cerca y frecuentemente.
c) Le informaría de qué es exactamente lo que quiere que haga, pero vería si tiene algunas sugerencias 0 ideas.
d) Apoyaría y alentaría su entusiasmo y le preguntaría cómo resolvería él este trabajo.

14.Su jefe le ha pedido que su división incremente su productividad en un $10 \%$. Usted sabe que esto se puede hacer, pero requeriría una participación activa. Para liberarse de hacer esto, usted debe reasignar la creación de un sistema de control de costes a un colaborador de la división. La persona a quien usted está pensando dar este proyecto ha tenido considerable experiencia en sistemas de control de costes, pero está un poquito insegura de poder elaborar este proyecto por sí misma. Usted...

a) Le pediría que aceptara el proyecto. Le apoyaría y estimularía sus esfuerzos.

b) Comentaría el proyecto con él. Le explicaría cómo se debe hacer el trabajo, pero vería si tiene algunas ideas.

c) Le daría el proyecto y le dejaría que determinara cómo hacerlo. d) Le daría el proyecto y prepararía un memorándum detallado, explicando todos los pasos necesarios
para elaborar el proyecto. 
15. Uno de sus colaboradores ha hecho una sugerencia para un cambio en las operaciones de la unidad que para usted tiene mucho sentido. En el pasado ha sido capaz de ofrecer e implementar otras sugerencias útiles de manera productiva, con su apoyo y estímulo. Usted tiene confianza en su habilidad. Usted...
a) Se haría cargo de la sugerencia y la dirigiría en su ejecución.
b) Comentaría la sugerencia con él y le apoyaría en sus esfuerzos para dirigir su ejecución.
c) Organizaría la ejecución pero incluiría las ideas de él.
d) Le daría la responsabilidad de ejecutar la sugerencia, sin ninguna intervención por parte suya.

16. Debido a una enfermedad en su familia usted se ha visto forzado a faltar a las primeras dos reuniones de un comité que dirige. Usted ha descubierto a su llegada a la tercera reunión que el comité está funcionando bien y que han progresado en la ejecución de sus metas. Usted no esta seguro en lo referido a cómo debe incorporarse al grupo y que papel debe asumir. Usted...
a) Asistiría pero dejaría al grupo continuar trabajando, tal y como lo ha estado haciendo en las dos primeras reuniones.
b) Tomaría el control del comité y comenzaría a dirigir las actividades.
c) Haría todo lo posible por hacer sentir importante al comité y apoyaría sus esfuerzos en el pasado.
d) Dirigiría las actividades del grupo pero utilizaría sus sugerencias.

17. Los miembros de su equipo de trabajo son muy competentes y capaces de trabajar bien por sí solos. Por lo general les ha dejado solos y ha dado las responsabilidades clave a miembros individuales del grupo. Sus logros han sido excelentes. Usted..
a) Daría apoyo y estímulo constantes a los miembros del grupo.
b) Dirigiría y supervisaría de cerca las actividades del personal.
c) Continuaría dejando que el grupo trabajara solo.
d) Dirigiría sus esfuerzos pero trabajaría muy de cerca con los miembros del grupo para pedirles sus sugerencias.

18.Usted y sus superiores han decidido que debe adoptarse un nuevo método en su departamento si es que se quieren obtener logros a largo plazo en eficiencia. En el pasado cuando se aplicaban estos métodos, el grupo de trabajo había deseado usarlos aunque inicialmente carecía de habilidad para utilizarlos. Usted..
a) Se aseguraría de dirigir la implantación del nuevo método, pero haría participar al grupo en la discusión de alternativas.
b) Dirigiría muy de cerca al grupo en el uso inicial del nuevo método.
c) Haría participar al grupo para que comentara sus impresiones sobre el nuevo método y les apoyaría para que participaran y cooperaran en su implementación.
d) Permitiría que el grupo formulara e implementara el nuevo método por sí mismo.

19. Recientemente usted ha sido nombrado jefe de una división. Bajo la dirección del anterior jefe, el grupo de trabajo funcionaba adecuadamente con considerable supervisión y apoyo. Sin embargo desde que usted se hizo cargo, el personal parece estar más preocupado en actividades sociales que en cumplir sus responsabilidades. Hasta la fecha la actuación del grupo de trabajo ha sido muy pobre. Usted..

a) Discutiría con ellos la baja actuación del personal y apoyaría sus esfuerzos para determinar una acción correctiva.

b) Dirigiría y organizaría la acción correctiva necesaria, pero solicitaría información y sugerencias del grupo de trabajo.

c) Enfocaría el problema y permitiría que los miembros del grupo definieran sus propias responsabilidades y labores.

d) Definiría las actividades, las responsabilidades y las expectativas, y las revisaría frecuentemente para ver si sus logros están mejorando.

20.Una de sus colaboradoras no está dispuesta a aceptar una nueva labor. Ella ha tenido muy poca experiencia en el área en el cual usted quiere que trabaje y ha hecho una buena labor con otros trabajos que le ha dado. Usted..

a) Le explicaría qué es lo que debe hacer y cómo hacerlo, pero escucharía por qué no esta dispuesta a aceptar la labor.

b) Le daría la nueva labor y le dejaría determinar la mejor manera de hacerlo.

c) Animaría a la colaboradora a tratar de hacer el trabajo y le apoyaría en sus esfuerzos, a través de ayuda en la solución de problemas.

d) Le diría exactamente qué es lo que debe hacerse para completar con éxito la labor y supervisaría sus resultados frecuentemente. 
ANEXO 6. TABLAS DE VALIDEZ DEL SPV 



\begin{tabular}{|l|c|c|c|c|c|c|c|c|}
\hline \multicolumn{10}{|c|}{ Escalas del SPV } \\
\hline Variable & $\mathrm{P}$ & $\mathrm{A}$ & $\mathrm{V}$ & $\mathrm{D}$ & $\mathrm{O}$ & $\mathrm{G}$ & Media & $\mathrm{Dt}$ \\
\hline DAT-VR & -6 & 12 & 11 & 6 & -15 & -7 & 14,06 & 4,70 \\
\hline DAT-NA & -3 & 15 & 6 & 13 & -20 & -8 & 8,82 & 4,00 \\
\hline DAT-AR & 6 & 15 & 9 & -1 & -17 & -10 & 13,85 & 6,05 \\
\hline DAT-SR & 3 & 14 & 12 & -2 & -13 & -12 & 15,24 & 5,97 \\
\hline PPG-IPG-Asc & -19 & 5 & 1 & 18 & -13 & 10 & 23,09 & 4,36 \\
\hline PPG-IPG-Res & -6 & 11 & -14 & -6 & 12 & 4 & 27,02 & 3,49 \\
\hline PPG-IPG-Est & -12 & 4 & -5 & 3 & -0 & 12 & 24,74 & 4,51 \\
\hline PPG-IPG-Soc & -10 & 2 & 0 & 11 & -12 & 8 & 20,74 & 3,58 \\
\hline PPG-IPG-Cau & -3 & -3 & -34 & -17 & 35 & 20 & 27,60 & 4,05 \\
\hline PPG-IPG-Ori & -20 & 20 & 4 & 2 & -6 & 1 & 27,66 & 4,02 \\
\hline PPG-IPG-Com & -9 & 2 & -11 & 3 & 12 & 4 & 25,35 & 4,36 \\
\hline PPG-IPG-Vit & -8 & 17 & 5 & 7 & -7 & 10 & 26,58 & 3,97 \\
\hline SIV-S & 9 & -7 & 1 & -7 & 3 & 2 & 14,20 & 4,77 \\
\hline SIV-C & 8 & -12 & -37 & -5 & 36 & 12 & 20,36 & 4,79 \\
\hline SIV-R & -10 & 7 & -6 & -2 & -0 & 10 & 10,04 & 3,90 \\
\hline SIV-I & 21 & -12 & 25 & -3 & -16 & -16 & 13,52 & 6,20 \\
\hline SIV-B & -5 & 7 & -1 & -4 & 7 & -4 & 17,26 & 5,28 \\
\hline SIV-L & -21 & 17 & 7 & 15 & -17 & 1 & 14,46 & 6,77 \\
\hline Media & 14,20 & 20,29 & 10,10 & 13,49 & 17,31 & 14,47 & & \\
\hline Dt & 4,77 & 4,80 & 3,90 & 6,17 & 5,27 & 6,77 & & \\
\hline
\end{tabular}

Cuadro 181: Relaciones del SPV con otras variables en adultos ( $N=339$ ). Fuente: Gordon (2010)

\begin{tabular}{|l|c|c|c|c|c|c|c|c|}
\hline \multicolumn{1}{|c|}{ Escalas del SPV } \\
\hline Variable & $\mathrm{P}$ & $\mathrm{A}$ & $\mathrm{V}$ & $\mathrm{D}$ & $\mathrm{O}$ & $\mathrm{G}$ & Media & $\mathrm{Dt}$ \\
\hline IGF-T & 16 & -6 & -5 & -7 & -1 & 7 & 40,41 & 8,97 \\
\hline IGF-INV & 14 & 3 & -3 & -12 & -1 & 5 & 20,50 & 4,69 \\
\hline IGF-IV & 16 & -13 & -6 & -1 & -1 & 8 & 19,91 & 520 \\
\hline IGF-R & 13 & 2 & -4 & -9 & -2 & 6 & 12,54 & 2,95 \\
\hline IGF-E & 12 & 3 & -1 & -14 & 2 & 3 & 7,96 & 2,23 \\
\hline IGF-V & 16 & -14 & -4 & 1 & -5 & 8 & 12,00 & 3,36 \\
\hline IGF-N & 11 & -8 & -8 & -5 & 5 & 6 & 7,91 & 2,29 \\
\hline RFM & -1 & 11 & -7 & -8 & 2 & -1 & 9,31 & 10,87 \\
\hline DAT-MR & 2 & 7 & -4 & -11 & 7 & 3 & 50,14 & 7,61 \\
\hline Media & 13,16 & 16,57 & 6,05 & 14,20 & 18,15 & 20,67 & & \\
\hline Dt & 4,58 & 4,00 & 4,90 & 4,46 & 4,99 & 4,75 & & \\
\hline
\end{tabular}

Cuadro 182: Relaciones del SPV con variables aptitudinales ( $N=246)$. Fuente: Gordon (2010) 


\begin{tabular}{|l|c|c|c|c|c|c|c|c|}
\hline \multicolumn{10}{|c|}{ Escalas del SPV } \\
\hline Variable & P & A & V & D & O & G & Media & Dt \\
\hline Raven & 3 & 3 & 4 & 8 & -8 & -5 & 23,48 & 4,87 \\
\hline Cambios & 4 & 4 & 1 & 4 & -5 & -1 & 13,82 & 5,06 \\
\hline SIV-S & 6 & -13 & 19 & -2 & -6 & -6 & 16,33 & 4,74 \\
\hline SIV-C & -8 & -1 & -43 & -7 & 38 & 26 & 16,66 & 5,59 \\
\hline SIV-R & 11 & 5 & 5 & -13 & 1 & -8 & 9,44 & 3,94 \\
\hline SIV-I & 6 & -11 & 28 & 16 & -29 & -10 & 16,42 & 6,44 \\
\hline SIV-B & -18 & 1 & -10 & 3 & 13 & 12 & 19,98 & 5,76 \\
\hline SIV-L & 8 & 20 & 1 & 1 & -13 & -10 & 10,36 & 5,84 \\
\hline Media & 13,04 & 15,70 & 10,26 & 16,28 & 14,52 & 19,18 & & \\
\hline Dt & 4,22 & 4,17 & 6,59 & 4,24 & 5,65 & 5,15 & & \\
\hline
\end{tabular}

Cuadro 183: Relaciones del SPV con aptitudes y SIV ( $N=3.047)$. Fuente: Gordon (2010)

\begin{tabular}{|c|c|c|c|c|c|c|c|c|c|c|c|c|c|c|c|}
\hline \multirow{2}{*}{ Variable } & \multicolumn{5}{|c|}{ Adultos - V } & \multicolumn{5}{|c|}{ Adolescentes - V } & \multicolumn{5}{|c|}{ Adolescentes - M } \\
\hline & $h^{2}$ & I & II & III & IV & $h^{2}$ & I & II & III & IV & $h^{2}$ & I & II & III & IV \\
\hline SPV-P & 49 & & & & -66 & 52 & & & & -69 & 40 & & & & -60 \\
\hline SPV-A & 49 & -25 & & & 62 & 55 & & & -54 & 46 & 57 & & 40 & -39 & 50 \\
\hline SPV-V & 58 & -76 & & & & 77 & -83 & & 26 & & 72 & -81 & & & \\
\hline SPV-D & 45 & & & & 64 & 78 & -39 & & & 78 & 74 & -27 & & & 80 \\
\hline SPV-O & 52 & 68 & & & 72 & 74 & & & & -39 & 72 & 67 & & & -51 \\
\hline SPV-G & 56 & 64 & & -35 & & 33 & 56 & & & 34 & 56 & & & & \\
\hline SIV-S & 76 & & 73 & 30 & -29 & 70 & -37 & 65 & 39 & & 63 & -56 & 40 & 34 & \\
\hline SIV-C & 61 & 67 & -25 & 31 & & 58 & 71 & & & & 56 & 70 & & 27 & \\
\hline SIV-R & 76 & & 82 & -25 & & 78 & & 86 & & & 72 & -24 & 78 & & \\
\hline SIV-I & 73 & -39 & -57 & & -47 & 71 & -50 & -67 & & & 79 & -26 & -81 & -25 & \\
\hline SIV-B & 68 & & & 79 & & 55 & 32 & & 60 & 29 & 59 & & & 69 & 27 \\
\hline SIV-L & 77 & & 38 & -76 & 38 & 77 & & -86 & & & 76 & & & -87 & \\
\hline \multirow[t]{6}{*}{ VT\% } & 62 & 19 & 14 & 14 & 15 & 65 & 23 & 14 & 14 & 13 & 63 & 21 & 14 & 14 & 14 \\
\hline & & $\mathbf{I}$ & II & III & IV & & I & II & III & IV & & $\mathbf{I}$ & II & III & IV \\
\hline & $I$ & * & & & & 1 & * & & & & I & * & & & \\
\hline & II & 7 & * & & & II & 1 & * & & & II & 2 & * & & \\
\hline & III & 1 & -1 & * & & III & 10 & 2 & * & & III & 11 & -3 & * & \\
\hline & IV & -5 & -0 & -5 & * & IV & 9 & -7 & -1 & * & IV & 7 & -7 & -4 & * \\
\hline
\end{tabular}

Cuadro 184: Análisis factoriales de los valores (SPV y SIV). Fuente: Gordon (2010) ${ }^{8}$

${ }^{8}$ Se incluye en la primera columna las comunalidades o proporción de varianza que explica cada variable $\left(\mathrm{h}^{2}\right)$. Debajo de las medidas se indica el porcentaje (VT\%) de varianza total explicada en el análisis con 24 variables (un 63\%) y debajo de las columnas de cada factor se indica el porcentaje que aporta cada uno. Las siete dimensiones a las que corresponden los número romanos son: I-Dimensión general de inteligencia; II-Socialización o conformidad con la cultura frente a la fluidez; III-Estabilidad de tipo extravertido que influye en algunos de los valores interpersonales; IV-Dependencia; V-Amabilidad; VI-Socialización; VII-Tendencia al desafío. 


\begin{tabular}{|c|c|c|c|c|c|c|c|c|}
\hline Variable & $h^{2}$ & 1 & ॥ & IIII & IV & $\mathrm{v}$ & $\mathrm{VI}$ & VII \\
\hline SPV-P & 50 & & & & & & & -66 \\
\hline SPV-A & 65 & & & & & & -74 & \\
\hline SPV-V & 63 & & -74 & & & & & \\
\hline SPV-D & 84 & & & & & & & 88 \\
\hline SPV-O & 57 & & 64 & & & & & -32 \\
\hline SPV-G & 69 & & 48 & & & & 60 & \\
\hline SIV-S & 65 & & & -27 & 63 & & 27 & \\
\hline SIV-C & 61 & -36 & 52 & & -27 & 31 & & \\
\hline SIV-R & 79 & & & & 83 & -27 & & \\
\hline SIV-I & 76 & & -28 & -28 & -66 & & & \\
\hline SIV-B & 84 & & & 25 & & 87 & & \\
\hline SIV-L & 67 & & & 33 & & -69 & & \\
\hline PPG-IPG-Asc & 72 & & & 80 & & & & \\
\hline PPG-IPG-Res & 49 & 40 & 45 & & & & & \\
\hline PPG-IPG-Est & 39 & 30 & 35 & 24 & & -25 & & \\
\hline PPG-IPG-Soc & 81 & & & 83 & & & & \\
\hline PPG-IPG-Cau & 54 & & 68 & & & & & \\
\hline PPG-IPG-Ori & 40 & 29 & & 50 & & & & \\
\hline PPG-IPG-Com & 55 & & 66 & & & & & \\
\hline PPG-IPG-Vit & 36 & & & & & & -58 & \\
\hline DAT-VR & 66 & 81 & & & & & & \\
\hline DAT-NA & 50 & 69 & & & & & & \\
\hline DAT-AR & 74 & 85 & & & & & & \\
\hline DAT-SR & 66 & 80 & & & & & & \\
\hline \multirow[t]{9}{*}{ VT\% } & 63 & 14 & 11 & 10 & 8 & 7 & 7 & 7 \\
\hline & & I & II & III & IV & v & VI & VII \\
\hline & I & * & & & & & & \\
\hline & II & -2 & * & & & & & \\
\hline & III & 14 & 11 & * & & & & \\
\hline & IV & 16 & 5 & 6 & * & & & \\
\hline & v & 7 & -2 & 13 & -6 & * & & \\
\hline & VI & -11 & 3 & -12 & 8 & 5 & * & \\
\hline & VII & -2 & -3 & 14 & 7 & -9 & -10 & * \\
\hline
\end{tabular}

Cuadro 185: Análisis factorial general del SPV. Fuente: Gordon (2010) ${ }^{9}$

${ }^{9}$ Se incluye en la primera columna las comunalidades o proporción de varianza que explica cada variable $\left(h^{2}\right)$. Debajo de las medidas se indica el porcentaje (VT\%) de varianza total explicada en el análisis con 24 variables (un 63\%) y debajo de las columnas de cada factor se indica el porcentaje que aporta cada uno. Las siete dimensiones a las que corresponden los número romanos son: I-Dimensión general de inteligencia; II-Socialización o conformidad con la cultura frente a la fluidez; III-Estabilidad de tipo extravertido que influye en algunos de los valores interpersonales; IV-Dependencia; V-Amabilidad; VI-Socialización; VII-Tendencia al desafío. 

REFERENCIAS BIBLIOGRÁFICAS 

Accenture (2010). A New Era of Sustainability. UN Global CompactAccenture CEO Study 2010. Consultado el 4 de marzo de 2013, en http://www.unglobalcompact.org/docs/news_events/8.1/UNGC_ Accenture_CEO_Study_2010.pdf

AccountAbility (2007). El estado de la competitividad responsable. Consultado el 16 de mayo de 2013, en http://www.accountability.org/images/content/1/0/108/El\%20E stado\%20de\%20la\%20Competitividad\%20Responsable\%202007.pdf

Adecco (2009). Informe de Responsabilidad Social Corporativa Adecco España 2009. Consultado el 4 de marzo de 2013, de www.fundacionadecco.es/_data/SalaPrensa/Memorias/Pdf/9.pdf

Agulló, E. (1998). El alcoholismo en el trabajo como inadaptación laboral: una propuesta de reflexión, conceptualización e intervención. Revista electrónica iberoamericana de psicología social: R.E.I.P.S., 1 (0). Consultado el 12 de febrero de 2013, en http://www.psico.uniovi.es/REIPS/v1n0/articulo5.html

Agulló, E. (1999). La encrucijada del trabajo: ¿la emergencia de una nueva civilización? En E. Agulló, J.A. Fernández, F.J. Grossi, A.I. García y J. Fernández, Siglo XXI: problemas, perspectivas y desafíos (pp, 341-350). Oviedo: Universidad de Oviedo

Agulló, E. (1999). La vida en un chip, nuevas relaciones sociales en la era digital. En E. Agulló, J.A. Fernández, F.J. Grossi, A.I. García y J. Fernández, Siglo XXI: problemas, perspectivas y desafíos (pp, 395-402). Oviedo: Universidad de Oviedo

Agulló, E. \& Ovejero, A. (2001). Trabajo, individuo y sociedad: perspectivas psicosociológicas sobre el futuro del trabajo. Madrid: Pirámide

Agulló, E. \& Agulló, M.S. (2002). Un lugar en la empresa, un espacio en la sociedad. Más allá del empleo en los jóvenes. En F.J. Palací y G. Topa, La persona en la empresa. Iniciativas de integración y desarrollo. (pp. 21-38). Madrid: UNED

Agulló, E. \& Rodríguez, J. (2002). Psicología social y ocio: una articulación necesaria. Psicothema, 14 (1), 124-133

Agulló, E. \& Segurado, A. (2002). Calidad de vida laboral: hacia un enfoque integrador desde la psicología social. Psicothema, 14 (4), 828-836

Agulló, E.; Boada, J. \& Diego, R. (2004). El burnout y las manifestaciones psicosomáticas como consecuencia del clima organizacional y la motivación laboral. Psicothema, 16 (1), 125131 
Agulló, E., Boada, J. Mañas, M.A. y Diego, R. (2005). El absentismo laboral como consecuente de variables organizacionales. Psicothema, 17 (2), 212-218

Agulló, E. (Ed.) (2011). Nuevas formas de organización del trabajo y la empleabilidad. Oviedo: Universidad de Oviedo

Ajzen, I. (1991). The theory of planned behavior. Organizational Behavior and Human Decision Processes, 50, 179-211

Ajzen, I., \& Fishbein, M. (1980). Understanding attitudes and predicting social behavior. Englewood Cliffs, NJ: Prentice-Hall.

Alba, I; Lupiani, M.; Gala, F.J. \& Guillén, C. (2003). Catástrofes, desastres y emergencias: concepto, clasificación, tipos y generalidades. Scientia: revista multidisciplinar de ciencias de la salud, 8, 49-67

Alba, I; Raja, R.; Lupiani, M.; Gala, F.J. \& Guillén, C. (2003). Influencia de las creencias religiosas en las actitudes del personal de enfermería ante la muerte. Enfermería científica, 260/261, 38-51

Allport, G. (1935). Attitudes. En C. Murchison (Ed.), A handbook of social psychology (pp. 798-844.) New York: Clark University Press

Almagro, J.J. (2007). Aproximación a la responsabilidad social de la empresa: reflexiones y propuestas de un modelo. Tesis doctoral inédita, Universidad de Cádiz, Cádiz

Alonso, E. (1994): Desarrollo Organizacional. Un modelo de intervención en las organizaciones. En J.M. Peiró y J. Ramos (Dirs.). Intervención Psicosocial en las Organizaciones. Barcelona: P.P.U.

Alonso, M.E. (1998). Valores en la Vida y Valores en el Trabajo en Técnicos Especialistas. Revista de Psicología del Trabajo y de las Organizaciones, 15 (1), 77-95

Altman, B.W. (1998). Corporate community relations in the 1990s: A study in transformation. Business \& Society, 37 (2), 221-228.

Anawati, D., \& Craig, A. (2006). Behavioral adaptation within crosscultural virtual teams. IEEE Transactions on Professional Communication, 49 (1), 44-56

Anderson, H.H. (1940). An examination of the concepts of domination and integration in relation to dominance and ascendance. Psychological Review, 47, 21-3790

Angulo, J.A. (2013). Cultura organizacional, clima laboral y liderazgo en organizaciones educativas. Tesis doctoral inédita, Universidad de Valladolid, Valladolid 
Anseel, F., \& Lievens, F. (2007). The long-term impact of the feedback environment on job satisfaction: A field study in a Belgian context. Applied Psychology: An International Review, 56, 254-266

Antón, R. \& Diego, R. (1990). Estudio sobre la prostitución femenina en la Comunidad de Castilla y León. Valladolid: Consejería de Sanidad y Bienestar Social

Aplei News, (2012). Los 7 hábitos de la gente altamente efectiva (reseña). Consultado el 27 de enero de 2013, en http://www.apleinews.com/Los-7-habitos-de-la-gentealtamente-efectiva_a205.html

Aragonés, R. (1997). Comercio electrónico. ¿Revolución o espejismo virtual?. Distribución y consumo, 35 (agosto/septiembre), 20-24

Arciniega, L.M. (2001). Desarrollo y validación de un modelo heurístico sobre valores en el trabajo. Tesis doctoral inédita. Universidad de Salamanca, Facultad de Psicología, Salamanca

Ares, A.; Sánchez, A. \& Ramírez, I. (1987). Papel de la psicología en la formación del trabajador social. Papeles del psicólogo, 28/29, 15-16

Ares, A. (1993). El liderazgo del trabajador social en lo equipos de trabajo. Cuadernos de trabajo social , 6, 25-32

Ares, A. (1999). Técnicas de selección para no especialistas. Capital humano: revista para la integración y desarrollo de los recursos humanos, 12 (127), 10-18

Ares, A. (2000). La formación en la empresa. En C. Guillén (Ed.), Psicología del trabajo para relaciones laborales (pp. 227-247). Madrid: McGraw-Hill Interamericana de España

Ares, A. (2001). El curso de Experto en creación y gestión de empresas de atención a personas mayores: Una experiencia de la conexión entre Universidad y mundo laboral. Cuadernos de trabajo social, $14,363-370$

Ares, A. \& Fernández, T. (2002). Gestión de los procesos de información y comunicación. En T. Fernández y A. Ares (Eds.), Servicios sociales: dirección, gestión y planificación (147-168). Madrid: Alianza

Ares, A. (2004). La conducta proactiva de los emprendedores. Portularia: Revista de Trabajo Social , 4, 493-498

Ares, A. (2004). Gestión de la conducta laboral. Aedipe: Revista de la Asociación Española de Dirección de Personal, 29, p. 42 
Ares, A. (2008). La conducta proactiva como conducta estratégica opuesta a la conducta pasiva. Revista de análisis transaccional y psicología humanista, 58, 129-136

Ares, A.; Guillén, C.; Sánchez, S.; Suárez, M.; Sainz, B. \& Soto, M.L. (2010). Estrés laboral: prevalencia en una corporación local. Revista de la Sociedad Española de Medicina y Seguridad del Trabaj 0, 5 (4), 194-201

Argyris, C. (1957). Personality and organization. New York: Harper Collins

Argyris, C. (1962). Interpersonal competence and organizational effectiveness. Homewood, Ill: Dorsey Press

Argyris, C. (1964). Integrating the individual and the organization. New York: Wiley

Armitage, C.J. \& Conner, M. (2000). Attitudinal ambivalence: A test of three key hypotheses. Personality and Social Psychology Bulletin, 26, 1421-1432

Arnau, J. (1995). Metodología de la investigación psicológica. En M.T. Angera, J. Arnau, M. Ato, R. Martínez, J. Pascual y G. Vallejo. Métodos de investigación en psicología (pp. 23-44). Madrid: Síntesis

Arnau, L. (2010). La orientación de personas desempleadas para la adaptación al cambio profesional: elaboración, aplicación y evaluación de un programa de orientación aplicado a alumnos de formación profesional para el empleo. Tesis doctoral inédita, Universidad Autónoma de Barcelona, Barcelona (Bellaterra)

Arnau, L. \& Montané, J. (2010). Aportaciones sobre la relación conceptual entre actitud y competencia, desde la teoría del cambio de actitudes. Electronic journal of research in educational psychology, 8 (22), 1283-1302

Aronson, E. (1968). Dissonance theory: Progress and problems. In R. Abelson, E. Aronson, W. McGuire, T. New-comb, M. Rosenberg \& P. Tannenbaum (Eds.), The cognitive consistency theories: A source book (pp. 5-27). Chicago: Ran McNally

Aronson, E., Fried, C. \& Stone, J. (1991). Overcoming denial: Increasing the intention to use condoms through the induction of hypocrisy. American J ournal of Public Health, 18, 1636-1640

Asociación Española de Contabilidad y Administración de Empresas (1979). Objetivos y constitución. Consultado el 20 de noviembre de 2013, en http://www.aeca.es/comisiones/comisionpc.htm 
Asociación Española de Contabilidad y Administración de Empresas, AECA (2003). Marco Conceptual de la Responsabilidad Social Corporativa, Documentos AECA, Serie Responsabilidad Social Corporativa, 1

Avolio, B. J., \& Bass, B. M. (1991). The full range leadership development program: Basic and advanced manuals. Binghamton, NY: Bass, Avolio \& Associates

Avolio, B. J., Bass, B. M., \& Jung, D. I. (1999). Re-examining the components of transformational and transactional leadership using the Multifactor Leadership Questionnaire. Journal of Occupational and Organizational Psychology, 72, 441-462

Avolio, B.J., Kahai, S.S., \& Dodge, G. (2000). E-leading in organizations and its implications for theory, research and practice. Leadership Quarterly, 11, 615-670

Avolio, B.J.; Sosik, J.J.; Jung, D.I. \& Berson, Y. (2003). Leadership Models, Methods, and Applications. En W.C. Borman, D.R. Ilgen \& R.J. Klimoski (Eds.), Handbook of psychology (vol. 12). Industrial and Organizational Psychology (pp. 277-307). New Jersey: Hoboken

Avolio, B.J. (2007). Promoting more integrative strategies for leadership theory-building. American Psychologist, 62, 25-33

Azjen, I. \& Fishbein, M. (1980). Understanding attitudes and predicting social behavior. Englewood Cliffs, NJ: Prentice-Hall

Azjen, I. (1991). The theory of planned behavior: Special issue: Theories of cognitive self-regulation. Organizational Behavior and Human decision Processes, 50, 179-211

Balbanis, G., Phillips, H.C. y Lyall, J. (1998). Corporate social responsibility and economic performance in the top British companies: are they linked?. European Business Review, 98 (1), $25-44$

Bales, R.F. (1950). Interaction Process Analysis: a method for the study of small groups. Reading, Mass: Addison-Wesley

Bales, R.F. \& Slater, P.F. (1955). Role differentiation in small social groups. En T. Parsons, R.F. Bales y E.A. Shils (Eds.), Family, socialisation and interaction process (pp. 259-306). Glencoe, IL : Free Press

Bandura, A. (1969). Principles of behavior modification. New York: Holt, Rinehart \& Winston

Bandura, A. \& Walters, R. (1982). Aprendizaje social y desarrollo de la personalidad. Madrid: Alianza 
Bandura, A. (1983). Principios de aprendizaje social. Madrid: Espasa Calpe

Bandura, A. (1986). Pensamiento y acción. Barcelona: Martínez Roca

Bandura, A. (1997). Self-efficacy: The exercise of control. New York: W.H. Freeman and Co, Publishers

Bandura, A. (1998). Personal and collective efficacy in human adaptation and change. En J.G. Adai, D. Belanger y K. L. Dion (Eds.). Advances in psychological science (vol. 1). Social, personal, and cultural aspects (pp. 51-71). Hove, England UK: Psychology Press/Erlbaum (UK) Taylor \& Francis

Bañegil, T. \& Chamorro, A. (2001). Las memorias de sostenibilidad como reflejo de la responsabilidad medioambiental de las empresas. Revista Interdisciplinar de Gestión Ambiental, 35, 112

Barberá, E. \& Ramos, A. (2004). Liderazgo y discriminación de género. Revista de psicología general y aplicada, 57 (2), 147-160

Bargh, J.A. (1997). The automaticity of everyday life. In R.S. Wyer (Ed.), Advances in social cognition (Vol. 10, pp. 1-61). Mahwah, $\mathrm{NJ}$ : Erlbaum

Barker, J.R. (1996). Communal-rational authority as the basis for leadership on self-managing teams. Advances in Interdisciplinary Studies of Work Teams, 3, 105-126

Barker, R.A. (1994). The rethinking of leadership. J ournal of Leadership Studies, 1, 47-48 (46-64)

Barney, J. (1991). Firm Resources and Sustained Competitive Advantage. J ournal of Management, 17 (1), 99-120

Baron, R.A. \& Byrne, D. (2005). Psicología social (10 ${ }^{\mathrm{a}}$ ed.). Madrid: Pearson Prentice Hall

Bass, B.M. (1960). Leadership, psychology and organizational behavior. New York: Harper

Bass, B.M. (1985). Leadership and performance beyond expectations. New York: Free Press

Bass, B.M. (1990). Bass and Stogdill's handbook of leadership: Theory, research and applications ( $3^{a}$ ed.). New York: Free Press

Bass, B.M. \& Avolio, B.J. (1994). Improving Organizational Effectiveness Through Transformational Leadership. Thousand Oaks, CA: Stage

Bass, B.M. (1998). Transformational leadership: Industrial, military and educational impact. Mahwah, NJ: Lawrence Erlbaum Associates Inc. 
Bass, B.M. (1999). Two decades of research and development in transformational leadership. European Journal of Work and Organizational Psychology, 8 (1), 9-25

Bass, B. \& P. Steidlmeier (1999). Ethics, character and authentic transformational leadership behavior. Leadership Quarterly, 10, $181-217$

Bass, B.M. (2008). The Bass handbook of leadership. Theory, Research and Managerial Applications ( $4^{\text {a }}$ ed.). New York: Free Press

Basu, R., \& Green, S.G. (1997). Leader-member exchange and transformational leadership: An empirical examination of innovative behaviors in leader-member dyads. J ournal of Applied Social Psychology, 27, 477-499

Barquero, C. \& Sánchez, E. (2000). Análisis de la fiabilidad del LEAD. Anales de psicología, 16 (2), 167-175

Barrow, J.C. (1977). The variables of leadership: A review and conceptual framework. Academy of Management Review, 2, 231251

Baucus, M.S. \& Near, J.P. (1991). Can illegal corporate behavior be predicted? An event history analysis. Academy of Management J ournal, 34, 1-28

Bauman, Z. (2002). Modernidad líquida. Fondo de Cultura Económica: Buenos Aires

Bavelas, A. (1950). Communication patterns in task-oriented groups. J ournal of Acoustical Society of America, 22, 725-730

Bechtel, W., \& Abrahamsen, A. (2002). Connectionism and the mind: Parallel processing, dynamics, and evolution in networks. Cambridge, MA: Basil Blackwell

Becoña, E. (1990). El diferencial semántico en la medición de actitudes. Revista de psicología general y aplicada: Revista de la Federación Española de Asociaciones de Psicología, 43, (3), 301312

Beer, M. (1989). Gestión de Recursos Humanos. Madrid: Ministerio de Trabajo

Bellows, R.M. (1959). Creative leadership. Englewood Cliffs, NJ: Prentice Hall

Benítez, C; Gala, F.J. \& Guillén, C. (1999). La orientación laboral en la formación ocupacional. En M.C. Rodríguez-Piñero y A. Galán (Eds.), Inserción laboral: I J ornadas Andaluzas de Relaciones Laborales (371-376). Huelva: Universidad de Huelva 
Bennett, J. B., Cook, R. F., \& Pelletier, K. R. (2001). Toward an integrated framework for comprehensive organizational wellness: Concepts, practices, and research in workplace health promotion. En J. C. Quick y L. E. Tetrick (Eds.), Handbook of occupational health psychology (pp. 69-95). Washington D.C.: American Psychological Association

Bennis, W.G. (1959). Leadership theory and administrative behavior: The problems of authority. Administrative Science Quarterly, 4, 259-301

Bennis, W.G. (1970). American bureaucracy. Chicago: Aldine

Bennis, W.G. (1983). Transformative leadership. Harvard University Newsletter, April

Benson (1977). Innovation and crisis in organisational analysis. Sociological Quarterly, 18, 3-16

Berbel, G., Reyes, J.D. y Gómez, M. (2007). La responsabilidad social en las organizaciones (RSO): análisis y comparación entre guías y normas de gestión e información. Innovar, 17 (29), 43-54

Berger, R., Yepes, M., Gómez Benito, J., Quijano, S., \& Brodbeck, F. (2011). Validez de la escala corta de liderazgo transformacional en el marco de la Auditoría del Sistema Humano, en cuatro países Europeos (HSA-TFL). Universitas Psychologica, 10 (3)

Bernard, L.L. (1927). Leadership and propaganda. En J. Davis y H.E. Barnes (eds.), An introduction to Sociology, 34, 296-315

Bertalanffy Von, L. (1976). Teoría General de Ios Sistemas. México: Fondo de Cultura Económica

Bigné, E.; Chumpitaz, R.; Andreu, L. \& Swaen, V. (2005). Percepción de la responsabilidad social corporativa: un análisis crosscultural. Universia Business Review, 5, 14-27

Bingham, W. V. 1927. Leadership. En H. C. Metcalf (Ed.), The psychological foundations of management (pp. 56-74). New York: Shaw.

Bogardus, E.S. (1933). A social distance scale. Sociological Social Research, 17, 265-271

Blackmar, E.W. (1911). Leadership in reform. American Journal of Sociology, 16, 626-644

Blake, R.R. \& Mouton, J.S. (1964). The managerial grid. Houston: Gulf

Blake, R.R. \& Mouton, J.S. (1982). Theory and research for developing a science of leadership. Journal of Applied Behavioral Science, $18,275-292$ 
Blanco, A. \& Fernández, M. (1989). Psicología académica y psicología profesional en el campo social y de las organizaciones. Anuario de psicología, 41, 75-110

Blanchard, K.H., Hambleton, R., Zigarmi, D. \& Forsyth, D. (1982). Leader Behavior Analysis (Self and Other), Escondido, CA: Blanchard Training and Development Inc.

Blanchard, K.H.; Zigarmi, D. \& Zigarmi, P. (1985). Leadership and the One Minute Manager. New York: Morrow

Blanchard, K.H., Zigarmi, D. \& Zigarmi, P. (1986). El líder ejecutivo al minuto: cómo aumentar la eficacia por medio del liderazgo situacional. Barcelona: Grijalbo

Blanchard, K.H.; Zigarmi, D. \& Nelson, R.B. (1993). Situational leadership after 25 years: a retrospective. The Journal of Leadership Studies, 1, 1

Blanchard, K.H. (2001). Situational Leadership II: The article. Sunrise, FL: The Ken Blanchard Companies

Blank, W. Weitzel, J.R. \& Green, S.G. (1990). A Test of the Situational Leadership Theory. Personnel Psychology, 43, 579-597

Blodgett, J.G.; Lu, L.C.; Rose, G.M. \& Vitell, S.J. (2001). Ethical Sensitivity to Stakeholder Interests: A Cross- Cultural Comparison. J ournal of the Academy of Marketing Science 29 (2), 190-202

Bloom, P.L., Hussein, P.Y. \& Szykman, L.R. (1993). Benefiting society and the bottom line. Marketing Management, 3 (4), 8-18

Boada, J. (1998). La psicología transcultural. Revista de psicología Universitas Tarraconensis, 10 (2), p. 113

Boada, J.; Diego, R. \& Agulló, T. (2004). El burnout y las manifestaciones psicosomáticas como consecuentes del clima organizacional y de la motivación laboral. Psicothema, 16 (1), 125-131

Boada, J.; Diego, R.; Agulló, T. \& Mañas, M.A. (2005). El absentismo laboral como consecuente de variables organizacionales. Psicothema, 17 (2), 212-218

Boada, J.; Diego, R. \& Vigil, A. (2005). La medición de las manifestaciones psicosomáticas (PSICOSOM-27) en el trabajo. En J.R. Martínez (Ed.), R.A. García (Ed.) y J.E. Real (Comp.), Psicología de las organizaciones, del trabajo y recursos humanos y de la salud (vol. 4, pp. 113-120). Madrid: Biblioteca Nueva

Boada, J.; Diego, R.; Llanos, E. \& Vigil, A. (2011). Versión breve en español del team climate inventory $(\mathrm{TCl}-14)$ : desarrollo y propiedades psicométricas. Psicothema, 23 (2), 308-313 
Boada, J.; Sánchez, J.C.; Prizmic, A.J. \& Vigil, A. (2012). Salud y seguridad en el trabajo en el sector del transporte: estructura factorial, fiabilidad y validez de la escala TRANS-18. Archivos de prevención de riesgos laborales, 15 (3), 144

Bogardus, E.S. (1928). World leadership types. Sociology and Social Research, 13, 377-387

Bogardus, E.S. (1929). Leadership and attitudes. Sociology and Social Research, 12, 573-599

Bogardus, E.S. (1934). Leaders and leadership. New York: AppletonCentury

Bohner, G. \& Wänke, M. (2002). Attitudes and attitude Change. New York, NY: Psychology Press

Bolívar, A. (1995). La evaluación de valores y actitudes. Madrid: Anaya

Borden, A.O. (1926). A study of the personality of student leaders in the United Status. Journal of Abnormal and Social Psichology, $21,149-160$

Bouchard, T.J.Jr., Arvey, R.D., Keller, L.M. \& Segal, N.L. (1992). Genetic influences on job satisfaction: A reply to Cropanzano and Hames. J ournal of Applied Psychology, 77, 89-93

Bowen, H. (1953). Social Responsibilities of the Businessman. New York: Harper \& Row

Boyatzis, R.E. (1982). The competent manager: A model for effective performance. Nueva York: John Wiley \& Sons

Boyatzis, R.E. (1994). Stimulating self-directed learning through the Managerial Assessment and Development Course. Journal of Management Education, 18 (3), 304-323

Boyatzis, R.E. (1995). Cornerstones of change: building the path for self-directed learning. En R.E. Boyatzis, S.C. Cowen y D. A. Kolb (Eds.), Innovation in professional education: steps on a journey from teaching to learning (pp. 50-91). San Francisco, CA: JosseyBass

Boyatzis, R.E.; Murphy, A.J. \& Wheeler, J.V. (1998). Philosophy as the missing link between values and behavior. Working Paper 97$3(3 a)$ of the Department of Organizational Behavior (Manuscrito no publicado). Cleveland: Case Western Reserve University

Boyatzis, R.E. (2002). El desarrollo de competencias sin valores es como el sexo sin amor. Revista de Psicología del Trabajo y de las Organizaciones, 18 (2-3), 247-258 
Brammer, S.; Williams, G. \& Zinkin, J. (2007). Religion and attitudes to corporate social responsibility in a large cross-country sample. J ournal of Business Ethics, 71 (3), 229-243

Brass, D.J. (2001). Social capital and organizational leadership. In J. S. Zaccaro \& R. J. Klimoski (Eds.), The nature of organizational leadership: Understanding the imperatives confronting today's leaders (pp. 132-152). San Francisco: Josey-Bass

Brehm, J.W. (1966). A theory of psychological reactance. New York: Academic Press

Brewer, M.B. (1988). A dual process model of impression formation. En T. Srull y R. Wyer Jr (Eds.), Advances in social cognition (vol. 1, pp. 1-36). Hillsdale, N.J.: Earlbaum

Bronchain, P. (2003). Towards a sustainable corporate social responsibility. Dublin: European Foundation for the Improvement of Living and Working Conditions

Brown, D.J. \& King, J.B. (1982). Small business ethics: Influences and perceptions. J ournal of Small Business Management, January, 1118

Brummer, J. (1991). Corporate responsibility and legitimacy. New York: Greenwood Press

Bryman, A. (1996). Leadership in organizations. En S.R. Clegg, C. Hardy y W.R. Nord (Eds.), Handbook of Organizational Studies (pp. 276-292). Londres: Sage

Brown, J.F. (1936). Psychology and the social order. New York: McGraw-Hill

Bucar, B., Glas, M. \& Hisrich, R.D. (2003). Ethics and entrepreneurs: An international comparative study. Journal of Business Venturing, 18, 261-281

Bucher (1970). Social process and power in medical school. En M. Zald (Ed.), Power in Organizations, Nashville: Vanderbilt Univ. Press, 3-48

Burdel, C.M. (1930). Is leadership losing its importante? Infantry J ournal, 36, 339-349

Burns, J.M. (1978). Leadership. New York: Harper \& Row

Buss, D.M. (1999). Evolutionary psychology: The new science of the mind. Boston: Allyn and Bacon

Buunk, B.P., Doosje, B.J., Jans, L.G.J.M., \& Hopstaken, L.E.M. (1993). Perceived reciprocity, social support, and stress at work: the role of exchange and communal orientation. Journal of Personality and Social Psychology, 65, 801-811 
Caballer, A., Gracia, F., Peiró, J.M., (2005). Affective responses to work process and outcomes in virtual teams: Effects of communication media and time pressure. Journal of Managerial Psychology, 20 (3/4), 245-260

Cacioppo, J.T.; Petty, R.E.; Losch, M.E. \& Kim, H.S. (1986). Electromiographic activity over facial muscle regions can differenciate the valence and intensity of affective reactions. J ournal of Personality, 50, 260-268

CaixaBank (2011). Código Ético y Principios de Actuación de CaixaBank. Consultado el 8 de enero de 2014, de http: / / portal.lacaixa.es/deployedfiles/particulars/Estaticos/PDF s/ResponsabilidadCorporativa/Codigo_etico_CaixaBank_es.pdf

Calder, B.J. (1977). An attribution theory of behavior. En B.M. Staw \& G.R. Salancik (eds.), New Directions in Organizational Behavior. Chicago: St. Clair

Camisón, C.; Garrigós, F.J. \& Palacios, D. (2007). Estrategias competitivas y desempeño empresarial: estudio comparativo de los modelos de Robinson \& Pearce y Miles \& Snow en el sector hotelero español. Investigaciones Europeas de Dirección y Economía de la Empresa, 13 (3), 161-182

Campbell, D. T. (1963). Social attitudes and other acquired behavioral dispositions. En S. Koch (Ed.), Psychology: A study of a science (Vol. 6, pp. 94-171). New York: McGraw-Hill

Campbell, D.P. (1991). The challenge of assessing leadership characteristics. Issues and Observations, 11, 1-8.

Campbell, D.P. (1992). The leadership characteristics of leadership researchers. En K.E. Clark, M.B. Clark \& D.P.Campbell (eds.), The impact of leadership. Greensboro, NC: Center for Creative Leadersip

Cardona, P. \& Rey, C. (2009). El liderazgo centrado en la misión. Harvard Deusto business review, 180, 46-56

Carew, D.K., Parisi-Carew, E. \& Blanchard, K.H. (1986). Group development and situational leadership: a model for managing groups. Training and Development J ournal, 40 (6), 46-50

Carnahan, T. \& McFarland, S. (2007). Revisiting the Stanford Prison Experiment: Could participant self-selection have led to the cruelty? Personality and Social Psychology Bulletin, 33, 603-614

Carrasco, I. (2007). Corporate social responsibility, values and cooperation. Internacional Advances in Economic Research, 13 (4), 454-460 
Carroll, A.B. (1979). A three-dimensional conceptual model of corporate social performance. Academy of Management Review, 4, 497-505

Carroll, A.B. (1983). Corporate social responsibility: Will industry respond to cutbacks in social program funding?. Vital Speeches of the Day, 49, 604-608

Carroll, A.B. (1991). The pyramid of corporate social responsibility: Toward the moral management of organizational stakeholders. Business Horizons, Julio-Agosto

Carroll, A.B. (1999). Corporate social responsibility: Evolution of a definitional construct. Business \& Society, 38 (3), 268-295

Carter, L.F. (1953). Leadership and small group behavior. En M. Sherif \& M.O. Wilson (eds.). Group relations at the crossroads. New York: Harper

Castelló, E. (2003). Los nuevos valores en las organizaciones empresariales. Boletín de Estudios Económicos, 58 (180), 421-444

Castillo, A. (1996). Aproximación metodológica al contenido de la responsabilidad social de la empresa. ESIC-Market, 93

Cartwright, D. (1965). Influence, leadership, control. En J.G. March (Ed.). Handbook of organizations. Chicago: Rand McNally

Castro, A. \& Nader, M. (2004). Estilos de liderazgo, contexto y cultura organizacional. Un estudio comparativo en población civil y militar. Boletín de Psicología, 82, 45-63

Castro, A. \& Lupano, M. (2005). Diferencias individuales en las teorías implícitas del liderazgo y la cultura organizacional percibida. Boletín de Psicología, 85, 89-109

Castro, A. (2006). Teorías implícitas del liderazgo, contexto y capacidad de conducción. Anales de psicología, 22 (1), 89-97

Castro, A. \& Fernández, M. (2006). Teorías implícitas del liderazgo. Estructura factorial y generalizabilidad de una escala de atributos de líder en diferentes grupos. Boletín de Psicología, 86, 85-107

Cattell, R.B. (1951). New concepts for measuring leadership in terms of group syntality. Human relations, 4, 161-184

Chaiken, S., Liberman, A. \& Eagly, A.H. (1989). Heuristic and systematic processing within and beyond persuasion context. In J.S. Uleman \& J.A. Bargh (Eds.), Unintended thought (pp. 212252). New York: Guilford 
Chaiken, S., Giner-Sorolla, R. \& Chen, S. (1996). Beyond accuracy: Defense and impression motives in heuristic and systematic processing. In P.M. Gollwizer \& J.A. Bargh (Eds.), The psychology action: Linking motivation and cognition to behavior (553-578). New York: Guilford

Chandler, A.D. (1962). Strategy and structure. Chapters in the history of the American Industrial Enterprise. Cambridge: The M.I.T. Press

Chapin, F.S. (1924). Leadership and group activity. J ournal of Applied Sociology, 8, 141-145

Chen, M. \& Bargh, J.A. (1999). Consequences of automatic evaluation: immediate behavioural predispositions to approach or avoid stimulus. Personality and Social Psychology Bulletin, 25 (2), 215224

Christie, P.M.; Kwon, I. G.; Stoeberl, P. A. \& Baumhart, R. (2003). A Cross-Cultural Comparison of Ethical Attitudes of Business Managers. India, Korea and the United States. J ournal of Business Ethics, 46 (3), 263-287

Cialdini, R.B. \& Petty, R., (1979). Anticipatory opinion effects. In B. Petty, T. OStrom \& T. Brock (Eds.), Cognitive responses in persuasion. Hillsdale, NJ: Erlbaum

Cid, B.; Rascado, M.P. \& Fernández, M. (1998). La flexibilidad organizacional. En G. Gómez-Jarabo y M. Fernández (Eds.), Diseño de puestos de trabajo para personas con discapacidad (195-208). Madrid: Ministerio de Trabajo y Asuntos Sociales, Instituto de Migraciones y Servicios Sociales (Imserso)

Clark, K.E. \& Clark, M.B. (1994). Choosing to lead. Greensboro, NC: Center for Creative Leadership Press

Cleeton, G.U. \& Mason, C.W. (1934). Executive ability: Its discovery and development. Yellow Springs, $\mathrm{OH}$ : Antioch Press

Clemente, M. (1992): Psicología social. Métodos y técnicas de investigación. Eudema. Madrid.

Club de Excelencia en Sostenibilidad (2002). Misión y visión. Consltado el 20 de noviembre de 2013, en http://www.clubsostenibilidad.org/main.asp?id_pagina=2

Comín, A. (2007). La responsabilidad social empresarial y la economía social. Cuadernos de Economía Social, 4, 1-6

Comisión de las Comunidades Europeas (2001). LIBRO VERDE. Fomentar un marco europeo para la responsabilidad social de las empresas. Consultado el 6 de febrero de 2013, en http://www.observatoriorsc.org/images/documentos/politicas_p ublicas/ue/libroverde.pdf 
Comisión de las Comunidades Europeas (2002). La responsabilidad social de las empresas: una contribución empresarial al desarrollo sostenible. Consultado el 28 de abril de 2013, en http: / /eur-

lex.europa.eu/LexUriServ/LexUriServ.do?uri=COM:2002:0347:FIN: es:PDF

Comisión de las Comunidades Europeas (2006). Poner en práctica la asociación para el crecimiento y el empleo: hacer de Europa un polo de excelencia de la responsabilidad social de las empresas. Consultado el 28 de abril de 2013, en http://eurlex.europa.eu/LexUriServ/LexUriServ.do?uri=COM:2006:0136:FIN: es:PDF

Comisión de las Comunidades Europeas (2008). European Competitiveness Report 2008. Consultado el 1 de mayo de 2013, en http://ec.europa.eu/enterprise/policies/industrialcompetitiveness/competitiveness-analysis/europeancompetitiveness-report/index_en.htm

Comisión Europea (2011). Estrategia renovada de la UE para 2011-2014 sobre la responsabilidad social de las empresas. Consultado el 20 de noviembre de 2013, enhttp:/ / eurlex.europa.eu/LexUriServ/LexUriServ.do?uri=COM:2 011:0681:FIN:ES:PDF

Confederación de Consumidores y Usuarios, CECU (2008). La opinión y valoración de los consumidores sobre la Responsabilidad Social de la Empresa en España. Consultado el 4 de marzo de 2013, en http://www.cecu.es/GuiaRSE3.pdf

Confederación de Consumidores y Usuarios, CECU (2010). La opinión y valoración de los consumidores sobre la Responsabilidad Social de la Empresa en España. Consultado el 4 de marzo de 2013, en http://www.cecu.es/publicaciones/rse2010.pdf

Conger, J. \& Kanungo, R. (1987). Toward a behavioral theory of charismatic leaderhip in organizational settings, Academy of Managemente Review, 12, 637-647

Conger, J. (1999). Charismatic and transformational leadership in organizations: an insider's perspective on these developing streams of research. Leadership Quarterly, 10 (2), 145-179

Conner, M.T. \& McMillan, B. (1999). Interaction effects in the theory of planned behavior: Studying cannabis use. British J ournal of Social Psychology, 38, 195-222

Cooley, C.W. (1902). Human nature and the social order. New York: Scribner's 
Cooper, J. \& Scher, S.J. (1994). Actions and attitudes: The role of responsibility and aversive consequences in persuasion. In $\mathrm{T}$. Brock \& S. Shavitt (Eds), Persuasion (pp. 95-111). San Francisco: Freeman

Copeland, N. (1942). Psychology and the soldier. Harrisburg, PA: Military Service Publishing

Corte, L.; Rico, R.; Fernández, M. \& San Martín, R. (2005). Spanish firms flexibility. Psicothema, 17 (4), 620-626

Corte, C. \& Carrasco, A.M. (2011-2012). El Rol de los estilos de liderazgo en la implantación de la responsabilidad social como filosofía del nuevo modelo post-crisis. Revista andaluza de relaciones laborales, 25-26, 219-233

Covey, S.R. (1990). Los 7 hábitos dela gente altamente efectiva. Madrid: Paidós

Covey, S.R. (2005). El 8ạ hábito. Barcelona: Paidós

Covey, S.R. (2007). El factor confianza. Barcelona: Paidós

Cowley, W.H. (1928). Three distinctions in the study of leaders. J ournal of Abnormal and Social Psychology, 23, 144-157

Cox, R. (2009). ¿Cómo es la responsabilidad social empresarial en las PYMES?. En F.J. Cossío (Ed.), Administrando en entornos inciertos (actas de Congreso Nacional). Sevilla: Asociación Europea de Dirección y Economía de Empresa

Crano, W.D. (1995) Attitude strength and vested interes. In R.E. Petty \& J.A. Krosnick (Eds.), Attitude strength: Antecedents and consequences (Vols. 4, 131-157). Hillsdale, NJ: Erlbaum

Crano, W.D. \& Prislin, R. (1995). Components of vested interest and attitude-bahavior consistency. Basic and Applied Social Psychology, 17, 1-21

Crano, W.D. (1997). Vested interest, symbolic politics and attitudebahavior consistency. Journal of Personality and Social Psychology, 72, 485-491

Crelia, R. \& Tesser, A. (1996). Attitude heritability and attitude reinforcement: A replication. Personality and Individual Difference, 21, 803-808

Crespo, A. (2009). Margaret Thatcher: un liderazgo para recordar. Grupo de Estudios Estratégicos, 7 diciembre 2009, $\mathrm{n}^{\circ} 7370$. Consultada el 13 mayo 2011, en http://www.gees.org/articulos/margaret_thatcher_un_liderazgo _para_recordar_7370 
Cuesta, M \& Valor, C. (2003). Responsabilidad social de la empresa. Concepto, medición y desarrollo en España. Boletín Económico del ICE, 2755, 7-19

Cuesta, M.; Almagro, J.J. \& Martínez, E. (2009). Modelos de responsabilidad social en las universidades españolas. En $\mathrm{R}$. Jáuregui (Ed.), Actas de Jornadas sobre Responsabilidad Social 2009 (pp. 31-38). Valladolid: Universidad de Valladolid.

Cuesta, M.; Valor, C. \& Holgado, F.P. (2011). Aproximación a la medición del compromiso de las empresas con los derechos humanos: un análisis de las empresas españolas del iBEX 35. Innovar: revista de ciencias administrativas y sociales, 21, 197208

Curto, M. (2012). La responsabilidad social interna de la empresa. Cuadernos de la Cátedra "la Caixa" de Responsabilidad Social de la Empresa y Gobierno Corporativo del IESE, 16, 1-24

Dansereau, F.; Graen, G. \& Haga, W. (1975). A vertical dyad approach to leadership within formal organizations. Organizational Behavior and Human Performance, 13, 46-78

Davis, K. (1962). Human relations at work. New York: McGraw-Hill

Davis, R.C. (1951). The Fundamentals of top management. New York: Harper

DeBono, K.G. \& Snyder, M. (1995). Acting on one's attitudes: The role of a history of choosing situations. Personality and Social Psychology Bulletin, 21, 629-636

De la Fuente, J.M. y De Quevedo, E. (2003). Empirical analysis of the relationship between corporate reputation and financial performance: A survey of the literature. Corporate Reputation Review, 6 (2), 161-177

De Lara, M. I. (2003). La Responsabilidad social de la Empresa: Implicaciones contables. Madrid: Edisofer

De Miguel, J., Fernández, M. \& Rico, R. (1997). Liderazgo Situacional: El modelo de Hersey y Blanchard. En M. Fernández Ríos y J.C. Sánchez. Manual de Prácticas de Psicología Organizacional (pp. 115-146). Salamanca: Amaru

De Vries, R.E.; Roe, R.A. \& Taillieu, Th. C.B. (1999). On charisma and need for leadership. European Journal of Work and Organizational Psychology, 8 (1), 109-126

Delgado, F.A. (2012). La formación socialmente responsable y su impacto en el desempeño empresarial. Un análisis del sector turístico portugués. Tesis doctoral inédita, Universidad de Extremadura, Badajoz 
Delgado, V. \& Olarte, C. (2009). Responsabilidad social corporativa. El caso de la televisión en España. En A. Celant y T. Iturralde (Eds.). Creativity and survival of the firm under uncertainty. Madrid: Academia Europea de Dirección y Economía de la Empresa, (AEDEM)

Deming, W.E. (1989). Calidad, productividad y competitividad: la salida de la crisis. Madrid: Díaz de Santos

Denhart, R.B. (1987). Images of death and slavery in organizational life. J ournal of Management, 13 (3), 529-541

Deniz, M.C. \& García, J.M. (2002). Factores determinantes de la respuesta social en las empresas internacionales. Un aplicación empírica. Cuadernos de Economía y Dirección de la Empresa, 11

Déniz, M.C. \& Cabrera, M.K. (2005). Corporate Social Responsibility and Family Business in Spain. Journal of Business Ethics, 56 (1), 27-41

Derue, D.S.; Nahrgang, J.D.; Wellman N. \& Humphrey, S.E. (2011). Trair and behavioral theories of leadership: A meta-analytic test of their relative validity. Personnel Psychology, 64 (1), 7-52

Dessler, G. (1988). Personnel Management. Englewood Cliffs: Prentice Hall

Diego, R. y Diego, J. A. (1990). Medidas laborales en la empresa: CST90. Valladolid: ASE-Psiké

Diego, J.A. \& Diego, R. (1990). Cuestiones sobre método y medida en Psicología. Salamanca: Amarú

Diego, R; Diego, J.A. \& Jiménez, F. (1991). Medida de la satisfacción laboral de personal encuadrado en instituciones cerradas. Revista de estudios penitenciarios, 244, 83-108

Diego, R. (1992). Proyecto docente: Evaluación Psicológica. Universidad de Valladolid: No publicado

Diego, J.A.; Sánchez, G.; Diego, R. \& Jiménez, F. (1997). Comparación de puntuaciones psicométricas en grupos de delincuentes y no delincuentes. Iberpsicología: Revista Electrónica de la Federación española de Asociaciones de Psicología, 2 (1)

Diego, R. y Garrote, G. (1998). The Team Climate Inventory in Spain. Universidad de Valladolid. Comunicación IV Congreso Nacional de Psicología del Trabajo y de las Organizaciones

Diego, R. (2001). Estudio sobre la percepción de igualdad de oportunidades entre mujeres en Castilla y León. Valladolid: Dirección General de la Mujer e Igualdad de Oportunidades 
Diego, R.; Diego, J.A. \& Olivar, S. (2001). Job Satisfaction in Banking Workers. Psicothema, 13 (4), 629-635

Diego, R. (2002). La integración laboral de la mujer en Castilla y León (vol. 4). (Colección de estudios del Consejo Económico y Social de Castilla y León). Valladolid: Consejo Económico y Social de Castilla y León

Diego, R., Fraile, A. \& Boada, J. (2004). Training needs among sport technicians. Psicothema, 16 (1), 84-87

Diego, R. \& Chico, M. (2006). Prácticas de psicología social (4 ${ }^{a}$ ed). Madrid: Pirámide

Diego, R. \& Fraile, A. (2006). Motivaciones de los escolares europeos para la práctica del deporte escolar: un estudio realizado en España, Italia, Francia y Portugal. Revista internacional de sociología, 44, 85-109

Diego, R. \& Fuente, R. (Eds.) (2007). Estrategias de liderazgo y desarrollo de personas en las organizaciones. Madrid: Pirámide

Diego, R. \& Guillén, C. (2008). Mediación: proceso, tácticas y técnicas ( $2^{\mathrm{a}}$ ed.). Madrid: Pirámide

Diego, R., Fuente, R. y Boada, J. (2009). Clima laboral en la empresa. En R. De la Fuente, y R. De Diego. (Eds.), Estrategias de liderazgo y desarrollo de personas en las organizaciones, (pp. 4166). Madrid: Pirámide.

Diego, J. (2011). La RSC en la Ley de Economía Sostenible Destacado. Consultado el 28 de abril de 2013, en http: //www. responsabilidadcorporativa.es/component/k2/item/90-la-rsc-en-la-ley-deeconom\%C3\%ADa-sostenible

Dienesch, R.M., \& Liden, R.C. (1986). Leader-member exchange model of leadership: A critique and further development. Academy of Management Review, 11, 618-634

Domínguez, R. (2008). La Responsabilidad Social Global Empresarial (RSGE): el sector privado y la lucha contra la pobreza. Revista del Ministerio de Trabajo e Inmigración, 76, 59-93

Donovan, D. (2003). An Exploratory Study of Leadership Styles Among Club Managers. Club Managers Association of America. Consultado el 24 de julio de 2012, en http: / /www.cmaa.org/template. aspx?id=6030

Doob, L. W. (1947). The behavior of attitudes. Psychological Review, $54,135-156$ 
Dopacio, C.I.; Valor, C. \& García, J.C. (2007). Los productos socialmente responsables y su actividad comercializadora por los proveedores de servicios financieros de la economía social: sociedades cooperativas de crédito y cajas de ahorro. CIRIEC España. Revista de economía pública, social y cooperativa, 57, 173-192

Dorado, M.A., Mañas, M.A., Martínez, I., Medina, F.J. \& Munduate, L. (2004). Efectos positivos de la activación del conflicto de tarea sobre el clima de los equipos de trabajo. Revista de Psicología Social, 19 (1), 3-15

Drucker, P. (2002). Escritos fundamentales. Tomo II. Buenos Aires: Sudamericana

Duarte, F. (2010). Working with Corporate Social Responsibility in Brazilian Companies: The Role of Managers' Values in the Maintenance of CSR Cultures. J ournal of Business Ethics, 96, 355368

Duchon, D., Green, S. G., \& Taber, T. D. (1986). Vertical dyad linkage: A longitudinal assessment of antecedents, measures and consequences. J ournal of Applied Psychology, 71, 56-60

Duck, J.M., Terry, D.J. \& Hogg, M.A. (1998). Perceptions of a media campaign: The role of social identity and the changing intergroup context. Personality and Social Psychology Bulletin, 24, 3-16

Dupuy, R.E. \& Dupuy, T.N. (1959). Brave men and great captains. New York: Harper \& Row

Duran, A. (2005). Análisis del proceso de elaboración e implantación de instrumentos de responsabilidad social corporativa. Tesis doctoral inédita, Universidad Carlos III de Madrid, Madrid

Duro, A.; Fernández, M. \& San Martín, R. (1998). Modelo integrado de liderazgo organizacional: su prueba empírica inicial. Revista de psicología del trabajo y de las organizaciones, 14 (2), 169-192

Duro, A.; Fernández, M. \& San Martín, R. (1999). Modelo integrado de liderazgo organizacional: efectos sobre subordinados $y$ desempeño en objetivo. Revista de psicología del trabajo y de las organizaciones, 15 (3), 331-350

Dweck, C.S.; Chiu, C. \& Hong, Y. (1995). Implicit theories and their role in judgments and reactions: A world from two perspectives. Psychological Inquiry, 6, 267-285

Eagly, A. H. \& Chaiken, S. (1993). The psychology of attitudes. Fort Worth (Texas): Harcourt Brace College Publishers 
Eagly, A.H. \& Chaiken, S. (1998). Attitude structure and function. In G. Lindsey, S.T., Fiske \& D.T. Gilbert (Eds.), Handbook of social psychology $\left(4^{a}\right.$ ed.). New York: Oxford University Press and McGraw-Hill

Eagly, A.H., Chen, S., Chaiken, S. \& Shaw-Barnes, K. (1999). The impact of attitudes on memory: An affair to remember. Psychological Bulletin, 124, 64-89

Eagly, A.H., Kulesa, P., Brannon, L.A., Shaw, K. \& Hutson-Comeaux, S. (2000). Why counterattitudinal messages are as memorable as proattitudinal messages: The importance of active defense against attack. Personality and Social Psychology Bulletin, 26, 1392-1408

Eagly, A. \& Chaiken, S. (2005). Attitude research in the $21^{\text {st }}$ century: The current state of knowledge. En D. Albarracín, B. Jonson, y M. Zanna. The Handbook of Attitudes (pp. 743-767). Mahwah, New Jersey, USA: Lawrence Erlbaum

Eagly, A.H., \& Chaiken, S. (2007). The advantages of an inclusive definition of attitude. Social Cognition, 25, 582-602

Egri, C.P. \& Ralston, D.A. (2008). Corporate responsibility: A review of international management research from 1998 to 2007, J ournal of International Management, 14, 319-339

Elliot, A.J. \& Devine, P.G. (1994). On the motivational nature of cognitive dissonance: Dissonance as psychological discomfort. J ournal of Personality and Social Psychology, 67, 382-394

El Pais (1994). Ex directivos del $\mathrm{BCCl}$, condenados a penas de prisión en Abu Dabi. Consultado el 10 de enero de 2014, de http://elpais.com/diario/1994/06/15/economia/771631205_850 215.html

Epitropaki, O. \& Martin, R. (2004). Implicit Leadership Theories in Applied Settings: Factor structure, generalizability, and stability over time. J ournal of Applied Psychology, 89 (2), 293-310

Erdogan, B., Liden, R.C., \& Kraimer, M.L. (2006). Justice and leadermember exchange: The moderating role of organization culture. Academy of Management J ournal, 49, 395-406

Erwin, P. (2001). Attitudes and persuasion. New York: Psychology Press

Esteban, G. (2000). Actitudes de los españoles ante los problemas ambientales. Observatorio medioambiental, 3, 107-122

Ética, Economía y Dirección (1987). Home. Consultado el 20 de noviembre de 2013, en http://www.eticaed.org/quees.htm 
Estrada, A. (2002a). Actitudes hacia la Estadística e instrumentos de evaluación. En Actas de las Jornades Europees d' Estadística (pp. 369-384). Palma de Mallorca: Instituto Balear de Estadística

Estrada, A. (2002b). Análisis de las actitudes y conocimientos estadísticos elementales en la formación del profesorado. Tesis doctoral inédita, Universidad Autónoma de Barcelona, Barcelona (Bellaterra)

Ethisphere Institute (2013). 2012 World's Most Ethical Companies. Consultado el 16 de mayo de 2013, en http://www.ethisphere.com/wme/

Europa Press (2006). Fundación Entorno y 16 grandes empresas Ianzan una campaña conjunta a favor del desarrollo sostenible. Consultado el 20 de noviembre de 2013, en http: / /www.corresponsables.com/actualidad/fundacionentorno-y-16-grandes-empresas-lanzan-una-campana-conjuntafavor-del-desarrollo-

Evans, M.G. (1970). The effects of supervisory behavior on the pathgoal relationship. Organizational Behavior and Human Performance, 5, 277-298

Evan, W.M \& Freeman, R.E. (1998). A stakeholder theory of the modern corporation: Kantian capitalism. En T. Beauchamp y N. Bowie (Eds.), Ethical theory business. New Jersey: Prentice hall, Englewood Clifis, 75-93

Galán, J.I. (2005, 10 de enero). Gobierno corporativo y desarrollo económico. Expansión

Fazio, R.H. (1989). On the power and functionality of attitudes: the role of attitude accessibility. In A.R. Pratkanis, S.J. Breckler \& A.G. greenwald (Eds.), Attitude structure and function (pp. 153179). Hillsdale, NJ: Erlbaum

Fazio, R.H. \& Roskos-Ewoldsen, D.R. (1994). Acting as we feel: When and how attitudes guide behavior. In S. Shavitt \& T.C. Brock (Eds.), Persuasion (71-93). Boston: Allyn and Bacon

Feather, N.T. \& Newton, J.W. (1982). Values, expectations, and the prediction of social action: An expectancy-valence analysis. Motivation and Emotion, 6 (3), 217-244

Feather, N.T. (1992). Values, valences, expectations, and actions. J ournal of Social Issues, 48 (2), 109-124

Festinger, L. (1954). A theory of social comparison processes. Human Relations, 7, 117-140

Fernández, C.F. \& Vecchio, R.P. (1997). Situational Leadership Theory Revisited: A Test of an Across-Jobs Perspective. Leadership Quarterly, 8, 1, 6, 67-84 
Fernández, J.M.; Giménez, L. \& Fernández, M. (1985). Guía documental de psicología industrial y organizacional. Estudios de Psicología, 21, 114-128

Fernández, M. (1991). La calidad en la gestión de los recursos humanos. Boletín del Círculo de Empresarios, 53, 65-82

Fernández, M.; Munduate, L.; Prieto, F.; Díaz, D.; Osa, J.C. \& Menéndez, J. (1993). Psicología del trabajo y de las organizaciones en España: marco teórico. Papeles del psicólogo, 57, 29-35

Fernández, M. \& Moreno, B. (1994). Toma de decisiones y participación. En J.R. López y J.M. Peiró (Eds.), Intervención social en las organizaciones (419-466). Barcelona: PPU

Fernández, M. (1995). Análisis y descripción de puestos de trabajo: teoría, métodos y ejercicios. Madrid: Díaz de Santos

Fernández, M. (1995). La psicología organizacional en una encrucijada tecnológica y cultural. Revista de Psicología del trabajo y de las organizaciones, 11 (31), 49-76

Fernández, M. (1996). Condiciones éxito-fracaso de la mediación laboral. Revista de Psicología del trabajo y de las organizaciones, $12(2-3), 149-174$

Fernández, M. (1996). Formación de mediadores. Revista de Psicología del trabajo y de las organizaciones, 12 (2-3), 221-230

Fernández, M. \& Sánchez, J.C. (1997). Eficacia Organizacional. Concepto, desarrollo y evaluación. Madrid: Díaz de Santos

Fernández, M. \& Sánchez, J.C. (1997). Valoración de puestos de trabaj 0: fundamentos, métodos y ejercicios. Madrid: Díaz de Santos

Fernández, M. (1999). Diccionario de recursos humanos. Organización y dirección. Barcelona: Díaz de Santos

Fernández, M. (2007). Gestión y desarrollo de recursos humanos. En J. Romay (Ed.), Perspectivas y retrospectivas de la psicología social en los albores del siglo XXI (pp. 81-96). Madrid: Biblioteca Nueva

Fernández, M.; San Martín, R. \& Miguel, J.M. (2008). Dimensiones básicas en el diseño del trabajo: nuevos aportes a la flexibilidad funcional. Psicothema, 20 (4), 773-779

Ferraro, F., Pfeffer, J. \& Sutton R.I. (2005). Economics language and assumptions: How theories can become self-fulfilling. Academy of Management Review, 30 (1), 8-24

Ferreiro, T. \& Tanco, M. (1997). El comercio electrónico en Internet. Distribución y Consumo, 35 (agosto/septiembre), 26-30 
Ferrell, O.C., Fraedrich, J. Y Ferrell, L. (2000). Business ethics. Ethical decision making and cases. Boston: Houghton Mifflin Company

Festinger, L. (1954). A theory of social comparison processes. Human Relations, 7, 117-140

Festinger, L. (1957). A theory of cognitive dissonance. Stanford, CA: Stanford University Press

Festinger, L. \& Carlsmith, J.M. (1959). Cognitive consequences of forced compliance. Journal of Abnormal and Social Psychology, $58,203-210$

Festinger, L. (1964). Conflict, decision and dissonance. Stanford, CA: Stanford University Press

Fiedler, F.E. (1953). The psychological distance dimension in interpersonal relations. J ournal of Personality, 22, 142-150

Fiedler, F.E. (1964). A contingency model of leadership effectiveness. En L. Berkowitz (Ed.), Advances in Experimental Social Psychology (vol. 1). Nueva York: Academic Press

Fiedler, F.E. (1967). A theory of leadership effectiveness. New York: McGraw-Hill

Fiedler, F.E. (1972). Personality, motivational systems and behavior of high and low LPC persons. Human Relations, 25, 391-412

Fiedler, F.E. (1978). The contingency model and the dynamics of leadership process. En L. Berkowitz (Ed.), Advances in Experimental Social Psychology (vol. 11). New York: Academic Press

Fiedler, F.E. \& Chemers, M.M. (1985). Liderazgo y administración efectiva. México: Trillas

Fiedler, F.E. \& Garcia, J.E. (1987). New approaches to effective leadership: cognitive resources and organizational performance. New York: Wiley

Fielding, K; \& Hogg, M.A. (1997). Social identity, self-categorization, and leadership: A field study of small interactive groups. Group Dynamics: Theory, Research, and Practice, 1, 39-51

Fiol, C.; Harris, D. y R. House (1999). Charismatic Leadership: Strategies for Effecting Social Change. Leadership Quarterly, 10, 449-482

Fishbein, M., \& Ajzen, I. (1974). Attitudes towards objects as predictors of single and multiple behavioral criteria. Psychological Review, 81, 59-74 
Fishbein, M. \& Ajzen, I. (1975). Belief, attitude, intention and behavior. Reading, MA: Addison-Wesley

Forética (1999). Presentación. Consultado el 20 de noviembre de 2013, en http://www.foretica.org/presentacion?lang=es

Forética (2011). Informe Forética 2011 (versión extendida). Consultado el 12 de abril de 2013, en http://www. foretica.org/biblioteca/informesforetica/doc_details/298-informe-foretica-2011-versionextendida-?lang=es

Foro de Expertos sobre RSE (2007). Informe del Foro de Expertos en Responsabilidad Social de las Empresas. Consultado el 28 de abril de 2013, en http://www.empleo.gob.es/es/sec_trabajo/autonomos/economi a-

soc/RespoSocEmpresas/foro_expertos/contenidos/INFORME_FOR OEXPERTOS_RSE.pdf

Fleishman, E.A. (1951). Relationship between supervisory behavior and leadership climate. Columbus, Ohio: Ohio State University Personnel Research Board

Fleishman, E.A. \& Hunt, J.G. (1973). Current developments in the study of leadership. Carbondale, Ill.: Southern Illinois University Press

Fleishman, E.A. (1998). Consideration and structure: Another look at their role in leadership research. En F. Dansereau y F.J. Yammarino (Eds.), Leadership: The multiple-level approaches (pp. 51-60). Stanford: JAI

Fraile, A. (2004) (Ed.) Didáctica de la educación física: una perspectiva crítica y transversal. Madrid: Biblioteca Nueva

Fraile, A. (2004) Temas transversales, educación en valores y educación física: del discurso al desarrollo en la práctica. En V.M. López, C. Velázquez y R. Monjas (Eds.), Actas del IV Congreso Estatal y II Iberoamericano de Actividades Físicas Cooperativas, Educación en valores y actividades físicas cooperativas [Archivo de ordenador]. Segovia

Fraile, A. (2010). La autoevaluación: una estrategia docente para el cambio de valores educativos en el aula. Ser Corporal, 3, 6-18

Fraile, A.; Diego, R. \& Boada, J. (2011). El perfil de los técnicos del deporte escolar en un contexto europeo. Revista Internacional de Medicina y Ciencias de la Actividad Física y del Deporte, 42, 4 pp. 
François, P.H. (1993). Représentations socials et contingencies du leadership en milieu organisationnel. Tesis doctoral inédita, University of Bordeaux, Bordeaux (France)

Frankental, P. (2001). Corporate social responsability: a PR invention?. Corporate Communication: An International J ournal, 6 (1), 18-23

Frederick, W.C. (1986). Towards CSR3: Why ethical analysis is indispensable and unavoidable in corporate affairs. California Management Review, 28 (2), 126-41

Freedman, J.L. \& Fraser, S.C. (1966). Compliance without pressure: The foot-in-the-door technique. J ournal of Personality and Social Psychology, 4, 195-202

Freeman, R.E. (1970). The social responsibility of business is to increase its profits. New York Times Magazine, September 13, 32-33

Freeman, R.E. (1984). Strategic management: a stakeholder approach. Boston: Pitman

Freeman, R.E. \& McVea, J. (2001). A Stakeholder Approach to Strategic Management. Darden Business School Working Paper, 12

French, J.R.P. (1956). A formal theory of social power. Psychological Review, 63, 181-194

French, W. \& Bell, C. (1978): Organization Development. London: Prentice Hall

French, J. \& Raven, B. (1959). The basis of social power. En D. Cartwright (Ed.), Studies in social power. Ann Arbor, Institute for Social Research: University of Michigan Press

Friedman, M. (1962). Capitalism and freedom. Chicago: University of Chicago Press

Friedman, M. (1970). The social responsibility of business is to increase its profits. New York Times Magazine, September 13, 32-33

Fry, LW. \& Cohen, M.P. (2008). Spiritual Leadership as a Paradigm for Organizational Transformation and Recovery from Extended Work Hours Cultures. J ournal of Business Ethics, 84 (2), 265-278

Fundación Alternativas (2009). Informe 2009: La Responsabilidad Social Corporativa en España. Consultado el 4 de marzo de 2013, en

http://www. falternativas.org/laboratorio/documentos/documen tos-de-trabajo/la-responsabilidad-social-corporativa-en-espanalos-nuevos-desafios-de-la-rsc 
Fundación Adecco (2013). 3er informe: El ciudadano español y la RC. Consultado el 16 de mayo de 2013, en http://www.fundacionadecco.es/_data/SalaPrensa/SalaPrensa/P df/500.pdf

Fundación Empresa y Sociedad (1985). La Fundación. Consultado el 20 de noviembre de 2011, en http: / /www.empresaysociedad.org/lafundacion

Fundación Empresa y Sociedad (2009). El ciudadano ante las actuaciones empresariales relacionadas con la integración de personas desfavorecidas. Consultado el 4 de marzo de 2013, en http://www.compromisorse.com/upload/noticias/000/13/opinio nciudadano.pdf

Fundación Entorno (1995). La Fundación. Consultado el 20 de noviembre 2013,

http://www.fundacionentorno.org/Fundacion

Galvao, C.M.; Trevizan, M.A.; Sawada, N.O. \& Mendes, I.A. (1997). Situational leadership: a model for application in Brazilian nursing. Revista da Escola de Enfermagem da USP, 31 (2), 227 236

García, A.M. \& García, M.G. (2008). La influencia de los rasgos psicológicos en las actitudes hacia el empleo. Revista de Psicología del Trabaj o y las Organizaciones, 24 (2), 203-233

García, B. (2000). El valor de compartir beneficios - las ONGD y el marketing con causa: retos y oportunidades. Bilbao: Universidad de Deusto

García, I; Gibaja, J.J. \& Mujika, A. (2001). Marketing social corporativo - la respuesta a una demanda social. Estudios Empresariales, 105, 26-32

García, I. \& Sánchez (2005). Estilos de dirección y bases de poder. En J. Romay y R. García Mira (Eds.). Psicología social y problemas sociales (vol. 4, pp. 277-283). Madrid: Biblioteca Nueva

García, I. (2006). La formación del clima psicológico y su relación con los estilos de liderazgo. Tesis doctoral inédita, Universidad de Granada, Granada

García, C.; Quintanilla, L.; Garriga, A.J.; Fontes, S.; Pérez-Llantada, M.C. \& Sarriá, E. (2003). Diseños de investigación en psicología. Madrid: UNED

García, M.A. (2001, noviembre 27).Una sociedad más solidaria. El País (extra), p. 2

García, R. \& Suárez, E. (2005). Informe Aldama: el gobierno corporativo en la Web. Partida doble, 167, 68-75 
Garrido, A. \& Álvaro, J.L. (2007). Psicología social. Madrid: McGrawHill

Garriga, E. \& Melé, D. (2004). Corporate social responsibility theories: Mapping the territory. J ournal of Business Ethics, 53, 51-71

Garrigues, A. \& Trullenque, F. (2008). Responsabilidad social corporativa: ¿papel mojado o necesidad estratégica?. Harvard Deusto Business Review, 3098, 19-36

George, J.M. (1990). Personality, affect and behavior in groups. Journal of Applied Psychology, 75, 107-116

Georgopulos, B.S.; Mahoney, G.M. \& Jones, N.W. (1957). A path-goal approach to productivity. J ournal of Applied Psychology, 41, 354353

Gerth, H. \& Mills, C.W. (1953). Character and social structure. New York: Harcourt, Brace

Gerstner, C.R., \& Day, D.V. (1997). Meta-Analytic review of leadermember exchange theory: Correlates and construct issues. Journal of Applied Psychology, 82, 827-844

Gervey, B.M.; Chiu, C.; Hong, Y. \& Dweck, C.S. (1999). Differential use of person information in decisions about guilt versus innocence: The role of implicit theories. Personality and Social Psychology Bulletin, 25, 17-27

Gibb, C.A. (1947). The principles and traits of leadership. J ournal of Abnormal and Social Psychology, 42, 267-284

Gibb, C.A. (1954). Leadership. En G. Lindzey (Ed.), Handbook of social psychology. Cambridge, MA: Addison, Wesley

Gibbons, F.X., Eggleston, T.J. \& Benthin, A.C. (1997). Cognitive reactions to smoking relapse: The reciprocal relation between dissonance and self-esteem. Journal of Personality and Social Psychology, 72, 184-195

Giba, C.A. (1969). Leadership. En G. Lindsey y E. Aronson (Eds.), The handbook of Social Psychology ( $2^{\mathrm{a}}$ ed.) (vol. 4, pp. 205-282). Reading, Mass: Addison-Wesley

Giessner, S., Sleebos, E., \& Van Knippenberg, D. (2003, junio). License to fail?: Leader prototypicality, leader performance, and leadership endorsement. Ponencia presentada en el EAESP Small Group Meeting on New Directions in Leadership Research, Amsterdam, Holanda 
Giffing, R.R. (2011). A comparison of teachers' perceptions of principal effectiveness in National Blue Ribbon Schools and matched sets of selected Non-Blue Ribbon School in Pennsylvania. Tesis doctoral inédita, Temple University, Philadelphia (Estados Unidos)

Gil, F. (2003). Dirección y liderazgo. En F. Gil y C.M Alcocer (Coor.), Introducción a la Psicología de las Organizaciones (pp. 285-319). Madrid: Alianza

Giner-Sorolla, R. \& Chaiken, S. (1994). The causes of hostile media effects. J ournal of Experimental Social Psychology, 30, 165-180

Giner-Sorolla, R. \& Chaiken, S. (1997). Selective use for heuristic and systematic processing under defense motivation. Personality and Social Psychology Bulletin, 23, 84-97

Global Reporting Initiative, GRI (2011). Guía para la elaboración de memorias de sostenibilidad. Consultado el 22 de febrero de 2014, en https://www.globalreporting.org/resourcelibrary/SpanishG3.1-Complete.pdf

Global Reporting Initiative, GRI (2013a). What is GRI?. Consultado el 7 de abril de 2013, en https: //www.globalreporting.org/information/about-gri/what-isGRI/Pages/default.aspx

Global Reporting Initiative, GRI (2013b). Sustainability Disclosure Database. Consultado el 20 de noviembre de 2013, en http://database.globalreporting.org

Global Reporting Initiative, GRI (2013c). Memoria España 2012. Informe de responsabilidad empresarial. Accenture Spain. Consultado el 22 de febrero de 2014, de http://static.globalreporting.org/reportpdfs/2013/8f65ed04579b721331aa134b380b81de.pdf

Gobierno de España (2013). Proyecto de ley de Transparencia, Acceso a la Información Pública y Buen Gobierno. Consultado el 28 de abril de 2013, en http://www.leydetransparencia.gob.es/anteproyecto/index.htm

Godos. J.L.; Fernández, R. \& Martínez, Al. (2010). ¿Cómo influyen los altos directivos en las prácticas de RSC? Análisis del efecto mediador del papel percibido de la ética y la responsabilidad social. Nuevas tendencias en dirección de empresas, 8, 1-25

Godos. J.L. \& Fernández, R. (2011). ¿Cómo se percibe la dirección socialmente responsable por parte de los altos directivos de empresas en España? Universia Business Review, 29, 32-49 
Golden, T., \& Veiga, J. (2008). The impact of superior-subordinate relationships on the commitment, job satisfaction, and performance of virtual workers. Leadership Quarterly, 19 (1), 7788

Gómez, A.; Benítez, C.; Gala, F.J. \& Guillén, C. (2000). Motivación y satisfacción laboral. En C. Guillén (Ed.), Psicología del trabajo para las relaciones laborales (pp. 195-209). Madrid: McGraw-Hill Interamericana de España

Gómez, A.; Lupiani, M.; Gala, F.J. \& Guillén, C. (2003). Intervención y prevención del estrés laboral. Psiquis: Revista de psiquiatría, psicología médica y psicosomática, 24 (5), 22-31

Gómez, G.; Vidal, J.; Fawaz, J. \& Ysern, J.L. (2002). Valores y formación docente. Horizontes Educacionales, 7 (1), 23-29

Gómez, J. (2010). Nuevas perspectivas socio-económicas en la gestión de las entidades prestadoras de servicios de atención a las personas mayores y en situación de dependencia. Especial referencia a la gestión basada en la calidad y en la responsabilidad social corporativa (RSC). En C. Lasarte y M.F. Moretón (Eds.), Residencias y alojamientos alternativos para personas mayores en situación de dependencia (pp. 83-107). Madrid: Colex

Gómez-Jarabo, G. \& Fernández, M. (Eds.) (1998). Diseño de puestos de trabajo para personas con discapacidad. Madrid: Ministerio de Trabajo y Asuntos Sociales, Instituto de Migraciones y Servicios Sociales (Imserso)

González, M.P. (1995). Orientaciones teóricas fundamentales en psicología de los grupos. Barcelona: EUB

González, M.P. (1997). Psicología de los grupos: teoría y aplicación. Madrid: Síntesis

González-Roma, V. \& Peiró, J.M. (1999). Clima en las organizaciones laborales. Revista de Psicología General y Aplicada, 52 (2-3), 269-285

González, M.P. \& Vendrell, E. (Dir.) (1987). El grupo de experiencia como instrumento de formación. Barcelona: PPU

González, M.P. Silva, M \& Cornejo, J.M. (1996). Equipos de trabajo efectivos. Barcelona: EUB

Gonzalo, J.A. (2003). Libro Blanco para la reforma de la contabilidad en España y gobernanza empresarial. Revista Valenciana de Economía y Hacienda, 7, 9-23

Gioia, D. A., Thomas, J. B., Clark, S. M., \& Chittipeddi, K. (1994). Symbolism and strategic change in academia: The dynamics of sensemaking and influence. Organization Science, 5, 363-383 
Gordon, L.V. (1960). Survey of personal values. Chicago: Science Research Associates

Gordon, L.V. (1967). Survey of interpersonal values. Chicago: Science Research Associates

Gordon, L.V. (1970). Measurement of bureaucratic orientation. Personnel Psychology, 23, 1-11

Gordon, L.V. (2010). Manual Cuestionario de Valores Personales (4 ed.). Madrid: TEA Ediciones

Gordon, T. (1955). Group-centered leadership: A way of releasing the creative power of groups. Boston: Houghton Mifflin

Gouldner, A.W. (Ed.) (1950). Sudies in leadership. New York: Harper

Graafland, J.J.; Van de Ven, B.W. \& Stoffele, N. (2003). Strategies and instruments for organising CSR by small and large business in the Netherlands. J ournal of Business Ethics, 47 (1), 45-60

Gracia, F., Martínez-Tur. V. \& Peiró, J.M. (2001). Tendencias y controversias en el futuro de la gestión y del desarrollo de los recursos humanos. En E. Agulló y A. Ovejero (Eds.), Trabajo, individuo y sociedad. Madrid: Pirámide

Graeff, C.L. (1983). The Situational Leadership Theory: a Critical View. Academy of Management Review, 8, 2, 285-291

Graeff, C.L. (1997). Evolution of Situational Leadership Theory: a Critical View. Leadership Quarterly, 8, 2, 154-170

Graen, G.B., \& Cashman, J.F. (1975). A role-making model of leadership in formal organizations: A developmental approach. En J.G. Hunt, y L.L. Larson (Eds.), Leadership frontiers (pp. 143165). Kent, OH: Kent State University Press

Graen, G. B., \& Schiemann, W. (1978). Leader-member agreement: A vertical dyad linkage approach. Journal of Applied Psychology, 63, 206-212

Graen, G.B., Novak, M.A., \& Sommerkamp, P. (1982). The effects of leader-member exchange and job design on productivity and satisfaction: Testing a dual attachment model. Organizational Behavior and Human Performance, 30, 109-131

Graen, G.B., \& Scandura, T.A. (1987). Toward a psychology of dyadic organizing. Research in Organizational Behavior, 9, 175-208

Graen, G.B., \& Uhl-Bien, M. (1995). Relationship-based approach to leadership: Development of leader-member exchange (LMX) theory of leadership over 25 years: Applying a multi-level multidomain perspective. Leadership Quarterly, 6, 219-247 
Graen, G.B. (Ed.). (2003). Dealing with diversity, LMX leadership: The series (vol. 1). Greenwich, CT: Information Age Publishing

Grant Thornton (2012). Women in senior management: still not enough (Grant Thornton International Business Report 2012).

Consultado el 31 de Julio de 2012, en http: / / www.internationalbusinessreport.com/files/ibr2012\%20\%20women\%20in\%20senior\%20management\%20master.pdf

Greenleaf, R.K., Spears, L.C., \& Covey, S.R. (2002). Servant leadership: A journey into the nature of legitimate power and greatness. Mahwah, NJ: Paulist Press

Griffin, J.J. \& Mahon, J.F. (1997). The corporate social performance and corporate financial performance debate: twenty-five years of incomparable research. Business $\&$ Society, 36, 5-31

Gronn, P. (1995). From transactions to transformations: A new world order in the study of leadership? Lecture, Educational and Administration Society, Balliol College, Oxford University, Oxford, England

Grupo Daorje (2013). Informe de Responsabilidad Social Corporativa 2012. Consultado el 8 de enero de 2014, de http: / /www.grupodaorje.es/upadm/rscinformes_adjunto/DAORJ E_RSC_2012.pdf

Guédez, Víctor (2006). Ética y Práctica de la Responsabilidad Social Empresarial. El aporte de la empresa al Capital Social. Caracas: Arte C.A.

Guest, D. (1994). Organizational Psichology and Human Resources Management: Towards a European Approach. European J ournal of W\&O Psychology, 4 (3), 251-270

Guijo, V. (2002). Estudio multifactorial de la conducta prosocial en niños de cinco y seis años. Tesis doctoral inédita, Universidad de Burgos, Burgos

Guillén, C. (1999). La escuela como organización y como sistema social. En M. Guil (Ed.), Psicología social de la educación: una guía académica (229-238). Sevilla: Kolaios

Guillén, C. (Ed.) (2000). Psicología del trabajo para relaciones Iaborales. Madrid: McGraw-Hill Interamericana de España

Guillén, C. (2004). Los equipos de trabajo. En J. Moreno y M. Castro (Eds.), Aprender para la sociedad de la innovación: actas de las I Jornadas Internacionales del Proyecto Europeo CReA, 21-23 mayo 2003 (pp. 46-56). Cádiz: Universidad de Cádiz

Guillén, C. (2005). La importancia del estrés laboral en el mundo actual. Ateneo: revista cultural del Ateneo de Cádiz, 5, 84-95 
Guillén, C.; León, J.M.; Cartelle, J; Sánchez, S. \& Ramos, E. (2005). Una intervención organizacional en la administración pública a través de la supervisión de equipos. En J.R. Martínez (Ed.), R.A. García (Ed.) y J.E. Real (Comp.), Psicología social y problemas sociales (vol. 4 - Psicología de las organizaciones, del trabajo y recursos humanos y de la salud, pp. 427-432). Madrid: Biblioteca Nueva

Guillén, C.; León, J.M.; Gala, F.J.; Sánchez, S. \& Ramos, E. (2005). Evaluación del estrés laboral en personal de la Administración Pública. En J.R. Martínez (Ed.), R.A. García (Ed.) y J.E. Real (Comp.), Psicología social y problemas sociales (vol. 4 Psicología de las organizaciones, del trabajo y recursos humanos y de la salud, pp. 41-46). Madrid: Biblioteca Nueva

Guillén, C. \& Depolo, M. (2006). Mobbing. Una forma de violencia en el trabajo. En M.D. Cervilla y F. Fuentes (Eds.), Mujer, violencia y derecho (pp. 219-243). Cádiz: Universidad de Cádiz

Gutiérrez, J.M. (2006). El Contrato Psicológico. Gestión Práctica de Riesgos Laborales: Integración y desarrollo de la gestión de la prevención, 24, 10-11

Hahn, T. \& Scheermesser, M. (2006). Approaches to corporate sustainability among German companies. Corporate Social Responsibility and Environmental Management, 13, 150-165

Haiman, F.S. (1951). Group leadership and democratic action. Boston: Houghton Mifflin

Hains, S.C., Hogg, M.A., \& Duck, J.M. (1997). Self-categorization and leadership: Effects of group prototypicality and leader stereotypicality. Personality and Social Psychology Bulletin, 23, 1087-1100

Hambleton, R.K. \& Gumpert, R. (1982). The validity of Hersey and Blanchard's Theory of Leader Effectiveness. Group and Organization Studies, 7, 2, 225-242

Hanges, P. (2004): Research Methodology. En R. J. House, P.J. Hanges, M. Javidan, P.W. Dorfman y V. Gupta (Eds.), Leadership, culture and organizations: The GLOBE study of 62 societies (pp. 91-101). London: Sage Publications.

Hanges, P.J. \& Dickson, M.W. (2004). The development and validation of the GLOBE culture and leadership scales. En R. J. House, P.J. Hanges, M. Javidan, P.W. Dorfman y V. Gupta (Eds.), Leadership, culture and organizations: The GLOBE study of 62 societies. (pp. 122-151). London: Sage Publications.

Hansen, A.M. (2009). Employee engagement: interpersonal leadership predictors and identification. Tesis doctoral inédita, Colorado State University, Colorado 
Halpin, A.W., \& Winer, B.J. (1957). A factorial study of the leader behavior descriptions. In R.M. Stogdill \& A.E. Coons (Eds.), Leader behaviors: Its description and measurement (pp. 39-51). Columbus: Ohio State University, Bureau of Business Research

Haslam, S.A.; Platow, M.J.; Turner, J.C.; Reynolds, K.J.; McGarty, C.; Oakes, P.J., Johnson, S; Ryan, M.K. \& Veenstra, K. (2001). Social identity and the Romance of Leadership: The importance of being seen to be "doing it for us". Group Processes \& Intergroup Relations, 4 (3), 191-205

Haslam, S.A. \& Reicher, S. (2007). Beyond the banality of evil: Three dynamics of an interactionist social psychology of tyranny. Personality and Social Psychology Bulletin, 33, 615-622

Hastorf, A.H.; Schneider, D. \& Polefka, J. (1970). Person perception. Reading, MA: Addison-Wesley

Heider (1946). Attitudes and cognitive organization. Journal of Psychology, 21, 107-112

Heider (1958). The psychology of interpersonal relations. New York: Wiley

Heifitz, R. (1994). Leadership without easy answers. Cambridge, MA: Harvard University Press

Heine, S.J. \& Lehman, D.R. (1997). Culture, dissonance and selfaffirmation. Personality and Social Psychology Bulletin, 23, 389400

Hemingway, C.A. \& Maclagan, P.W. (2004). Managers' Personal Values as Drivers of Corporate Social Responsibility. J ournal of Business Ethics, 50, 33-33

Hemphill, J.K. (1949). The leader and his group. Journal of Educational Research, 28, 225-229, 245-246

Hemphill, J.K. (1954). A proposed theory of leadership in small groups (Tech. Rep.). Columbus: Ohio State University, Personnel Research Board

Hemphill, J.K. (1956). Group dimensions: a manual for their measurement. Columbus, Ohio: Bureau of Business Research, Ohio State University

Henderson, D. (2001). The case against corporate social responsibility. Policy, 17 (2), 28-32

Hernández, C.E. (2011). La realidad de la Responsabilidad Social Corporativa. Miguel Hernández Communication J ournal, 2, 82-92 
Herranz, J.M. (2006). La comunicación y la transparencia en las organizaciones no lucrativas. Tesis doctoral inédita, Universidad Complutense de Madrid, Madrid

Hershberger, S.L., Lichtenstein, P. \& Knox, S.S. (1994). Genetic and environmental influences on perceptions of organizational climate. J ournal of Applied Psychology, 55, 239-247

Hersey, P. \& Blanchard, K.H. (1969a). Management of organizational behavior. Englewood Cliffs, New Jersey: Prentice Hall

Hersey, P. \& Blanchard, K.H. (1969b). The life cycle theory of leadership. Training and Development Journal, 23 (5), 26-34

Hersey, P. \& Blanchard, K.H. (1974). So you want to know your leadership style? Training and Development J ournal, 28 (2), 2237

Hersey, P. \& Blanchard, K.H. (1977). Management of Organizational Behavior. (3rd edition). Englewood Cliffs, New Jersey: Prentice Hall

Hersey, P., Blanchard, K.H. \& Natemeyer, W.E. (1979). Situational leadership, perception and the impact of power. Group and Organization Studies, 4 (4), 418-428

Hersey, P.; Angelini, A.L. \& Carakushansky, S. (1982). The impact of situational leadership and classroom structure on learning effectiveness. Group \& Organization Studies, 7 (2), 216224

Hersey, P. \& Blanchard, K.H. (1982a). Management of organizational behavior. Utilizing human resources. (4a ed.). Englewood Cliffs, New Jersey: Prentice Hall

Hersey, P. \& Blanchard, K.H. (1982b). Leadership style: attitudes and behavior. Training and Development J ournal, 36 (2), 50-52

Hersey, P. y Blanchard, K.H. (1988). Management of organizational behavior: Utilizing human resources. ( $5^{\text {a }}$ ed.). Englewood Cliffs, NJ: Prentice-Hall

Hersey, P. \& Blanchard, K.H. (1996). Great ideas revisited. Training and Development J ournal, 50 (1), 42-47

Hersey, P., Blanchard, K.H. y Johnson, D. (1998). Administración del comportamiento organizacional ( $7^{\text {a }}$ Edición). México: Prentice Hall

Hersey, P. \& Blanchard, K. H. (1988a). Management of organization behavior: utilizing human resources ( $5^{\mathrm{a}}$ ed.). Englewood Cliffs, NJ: Prentice-Hall

Hersey, P. \& Blanchard, K. H. (1988b). Estilo eficaz de dirigir: liderazgo situacional. México: IDH Ediciones 
Hersey, P. \& Blanchard, K. H. (1993). Management of organizational behavior, utilizing human resources $\left(6^{\mathrm{a}} \mathrm{ed}\right.$.). Englewood Cliffs, New Jersey: Prentice-Hall

Hersey, P. \& Blanchard, K. H. \& Johnson, D.E. (1996). Management of organizational behavior, utilizing human resources $\left(7^{\mathrm{a}}\right.$ ed.). Englewood Cliffs, New Jersey: Prentice-Hall

Hofstede, G. (1979). Hierarchical Power Distance in Forty Countries. En C.J. Lammers y D.J. Hickson (Eds.), Organizations Alike and Unlike: Towards a Comparative Sociology of Organizations (pp. 97-119). London: Routledge and Kegan Paul

Hofstede, G. (1980). Culture's Consequences: International Differences in Work-Related Values. Beverly Hills CA: Sage Publications

Hofstede, G. (1991). Management in a Multicultural Society, Malaysian Management Review, 25 (1), 3-12

Hofstede, G. (1998). Attitudes, Values and Organizational Culture: Disentangling the Concepts. Organization Studies, 19 (3), 477-493

Hofstede, G. (2006). What did GLOBE really measure? Researchers' minds versus respondents' minds. Journal of International Business Studies, 37, 882-896

Hogg, M.A., Hains, S.C., \& Mason, I. (1998). Identification and leadership in small groups: Salience, frame of reference, and leader stereotypicality effects on leader evaluations. J ournal of Personality and Social Psychology, 75, 1248-1263

Hogg, M.A. (2001). A social identity theory of leadership. Personality and Social Psychology Review, 5, 184-200

Hogg, M. A., \& Van Knippenberg, D. (2003). Social identity and leadership processes in groups. En M.P. Zanna (Ed.), Advances in experimental social psychology (vol. 35, pp. 1-52). San Diego, CA: Academic Press

Hollander, E.P. \& Julian, J.W. (1969). Contemporary trends in the analysis of leadership processes. Psychological Bulletin, 71, 387397

Hollander, E.P. (1978). Leadership Dynamics. A practical guide to effective relationship. New York: Free Press

Hollander, E.P. (1986). On the central role of leadership processes. International Review of Applied Psychology, 35, 39-52

Hontangas, P. \& Peiró, J.M. (1996). Ajuste persona-trabajo. En Peiró J.M. y Prieto, F. (Eds.), Tratado de Psicología del Trabajo. Vol. I: La actividad laboral en su contexto (pp. 251-281). Madrid: Síntesis 
Homans, G.C. (1950). The human group. New York: Harcourt, Brace

Hornsby, J.S., Kuratko, D.F., Naffziger, D.W., LaFollette, W.R. \& Hodgetts, R.M. (1994). The ethical perceptions of small business owners: A factor analytic study. Journal of Small Business Management, October, 9-16

House, R.J. \& Dessler, G. (1974). The path goal theory of leadership: Some post hoc and priori tests. En J. Hunt y L. Larson (Eds.), Contingency approaches in leadership. (pp. 29-55). Carbondale: Southern Illinois University Press

House, R.J. \& Mitchell, T.R. (1974): Path goal theory of leadership. J ournal of Contemporary Business, 3, 81-97

House, R.J. (1977). A 1976 theory of charismatic leadership. En J.G. Hunt \& L.L. Larson (Eds.), Leadership: The cutting edge (pp. 189207). Carbondale, IL: Southern Illinois University Press

House, R.J. \& Shamir, B. (1993). Toward the integration of transformational, charismatic and visionary theories. En M.M. Chemers \& R. Ayman (Eds.), Leadership theory and research: perspectives and directions. San Diego: Academic Press

House, R.J., \& Aditya, R.N. (1997). The social scientific study of leadership: Quo Vadis? J ournal of Management, 23, 409-473

House, R.J.; Hanges, P.J.; Javidan, M.; Dorfan, P.W. \& Gupta, V. (Eds.) (2004), Leadership, culture and organizations: The GLOBE study of 62 societies. London: Sage Publications

Hovland, C.I., Janis, I.L., \& Kelley, H.H. (1953). Communication and persuasion: Psychological studies of opinion change. New Haven, CT: Yale University Press

Howell, J.M. \& Higgins, C.A. (1990). Leadership behaviors, influence tactics, and career experiences of champions of technological innovation. Leadership Quarterly, 1, 249-264

Hoyos, P.A., Cardona, M.A. \& Correa, D. Humanizar los contextos de salud, cuestión de liderazgo. Investigación y educación en enfermería, 26, 2

Hsieh, N. (2009). Corporate Social Responsibility and the Priority of Shareholders. J ournal of Business Ethics, 88, 553-560

Hulin, C.L \& Judge, T. (2003). Job Attitudes. En W.C. Borman, D.R. Ilgen \& R.J. Klimoski (Eds.), Handbook of psychology. Industrial and Organizational Psychology (vol. 12, pp. 255-276). New Jersey: Hoboken

Hull, C. L. (1943). Principles of behavior: An introduction to behavior theory. New York: Appleton-Century-Crofts 
Hunt, J.G. (1991). Leadership: A new synthesis. Newbury Park: Sage Publications

Husenman, S. (1985). Gestión de Recursos Humanos. Un enfoque estratégico. Tesis doctoral inédita, Universidad Autónoma de Barcelona, Barcelona

Iberdrola (2013). Informe de sostenibilidad. Consultado el 8 de enero de 2014, en https://www.iberdrola.es/webibd/gc/prod/es/doc/IA_InformeSo stenibilidad12.pdf

Ilies, R., Nahrgang, J. D., \& Morgeson, F. P. (2007). Leader-member exchange and citizenship behaviors: A meta-analysis. J ournal of Applied Psychology, 92, 269-277

Informe Reporta (2010). Acerca de. Consultado el 20 de noviembre de 2013, en http://informereporta.es/acerca-de/

Inkeless, A. \& Levinson, D.J. (1969). National character: The study of modal personality and sociocultural systems. En G. Lindzey y E. Aronson (Eds.). The Handbook of Social Psychology (pp. 418-506). Reading, MA: Addison-Wesley

Instituto de la Mujer (2012). Población ocupada según tipo de ocupación. Consultado el 16 de octubre de 2013, en http: //www.inmujer.gob.es/estadisticas/consulta.do?area=5

Instituto Nacional de Estadística (2009). Clasificación Nacional de Actividades Económicas (CNAE-2009). Consultado el 5 de octubre de 2011, en http://www.ine.es/daco/daco42/clasificaciones/cnae09/estruct ura.pdf

Instituto Nacional de Estadística (2012). Estructura y Demografía Empresarial (Directorio Central de Empresas). Consultado el 16 de octubre de 2013, en http://www.ine.es/prensa/np732.pdf

International Co-operative Alliance (1844). Co-operative identity, values \& principles. Consultado el 20 de noviembre de 2013, en http://ica.coop/es/node/1625

International Institute for Sustainable Development (2013). SA8000. Consultado el 12 de enero de 2014, de http: / / www.iisd.org/business/tools/systems_sa.aspx

International Organization for Standardization, ISO (2013). ISO 26000 Social responsability. Consultado el 3 de abril de 2013, en http://www. iso.org/iso/home/standards/iso26000.htm

Ireland, R.D., \& Hitt, M.A. (1999). Achieving and maintaining strategic competitiveness in the twenty-first century: The role of strategic leadership. Academy of Management Executive, 13, 43-57 
Ito, T.A., Larsen, J.T., Smith, N.K. \& Cacioppo, J.T. (1998). Negative information weighs more heavily on the brain: The negativity bias in evaluative categorizations. Journal of Personality and Social Psychology, 75, 887-900.

Jacobs, T.O. \& Jacques, E. (1987). Leadership in complex organizations. En J.A. Zeidner (Ed.), Human productivity enhancement (vol. 2). New York: Praeger

Jacobs, T.O. \& Jacques, E. (1990). Military executive leadership. En K.E. Clark \& M.B. Clark (eds.), Measures of Leadership. Greensboro, NC: Center for Creative Leadership

Jago, A.G. (1982). Leadership: Perspectives in theory and research. Management Science, 28, 315-336

Janda, K.F. (1960). Towards the explication of the concept of leadership in terms of the concept of power. Human Relations, $13,345-363$

Jaumà, J. (2013). RSE.- Miguel Ángel García Martín : "Tendremos Plan Nacional de RSE antes de verano". Consultado el 28 de abril de 2013, en http: / /www.diarioresponsable.com/portada/destacados/16401miguel-angel-garcia-martin-qtendremos-plan-nacional-de-rseantes-de-veranoq.html

Jelinek, M.; Smircich, L. \& Hirsch, P. (1983). Introduction: a code of many colors. Administrative Science Quarterly, 28, 331 - 338

Jennings, H.H. (1944). Leadership and sociometric choice. Sociometry, 10, 32-49

Jensen, M.C. Value maximization, stakeholder theory, and the corporate objective function. En M. Beer y N. Nohria (Eds.), Breaking the code of change. Boston: Harvard Business School Press, 2000

Johns, H. E. \& Moser, H. R. (1989). From trait to transformation: The evolution of leadership theories. Education, 110 (1), 115-123

Johnson, B.T. (1994). Effects of outcome-relevant involvement and prior information on persuasion. J ournal of Experimental Social Psychology, 30, 556-579

Johnson, B.T., Maio, G. R., \& Smith-McLallen, A. (2005). Communication and attitude change: Causes, processes, and effects. En D. Albarracín, B.T. Johnson, \& M.P. Zanna (Eds.), The handbook of attitudes (pp. 617-669). Mahwah, NJ: Lawrence Erlbaum

Johnston, C.S. (1995). The Rokeach Value Survey: Underlying structure and multidimensional scaling. Journal of Psychology, 129 (5), 583-59 
Jose, A. \& Thibodeaux, M.S. (1999). Institutionalization of Ethics: The Perspective of Managers. J ournal of Business Ethics, 22, 133-143

Judge, T. A., \& Piccolo, R. F. (2004). Transformational and transactional leadership: A meta-analytic test of their relative validity. J ournal of Applied Psychology, 89, 755-768

Kavanagh, M.J.; Gueutal, H.G. \& Tannenbaum, S.I. (1990). Human resource information systems: development and application. Boston: Pws-Kent

Karatsu, H. (1991). CTC: La sabiduría japonesa. Control total de calidad. Barcelona: Gestión 2000

Kark, R.; Shamir, B. y Gilad, C. (2003). The Two Faces of Transformational Leadership: Empowerment and Dependency. J ournal of Applied Psychology, 88, 246-255

Kast, F.E. \& Rosenzweig, J.E. (1979). Organization and management. New York: McGraw-Hill

Katz, D. (1960). The functional approach to the study of attitudes. J ournal of Abnormal and Social Psychology, 70, 1037-1051

Katz, D; Maccoby, N. \& Morse, N.C. (1950). Productivity, supervision and morale in an office situation. Ann Arbor, Mich.: Survey Research Center University of Michigan

Katz, D. \& Kahn, R.L. (1966). The social psychology of organizations ( $1^{\mathrm{a}}$ ed. $)$. New York: Wiley \& Sons

Katz, D. \& Kahn, R.L. (1978). The social psychology of organizations ( $2^{\mathrm{a}}$ ed. $)$. New York: Wiley \& Sons

Kelman, H. (1961). Processes of opinion change. Public Opinion Quarterly, 25, 57-78

Kelman, H. (1980). The role of action in attitude change. En H.E. Howe y M. Page (Eds.), Nebraska Symposium on Motivation, 1979: Attitudes, values, and beliefs (pp. 117-194). Lincoln: University of Nebraska Press

Kenney, R. A., Schwartz-Kenney, B. M., \& Blascovich, J. (1996). Implicit leadership theories: Defining leaders described as worthy of influence. Personality \& Social Psychology Bulletin, 22, 11281143

Kenny, R.A., Blascovich, J. \& Shaver, P.R. (1994). Corporate transitions, Lynchburg, Va. Basic \& Applied Psychology, 15, 409437

Kerr, S. \& Schriesheim, C.A. (1974). Consideration, initiating structure and organizational criteria. An update of Korman's 1966 review. Personnel Psychology, 27, 555-568 
Kerr, S.; Schriesheim, C.A.; Murphy, C.J. \& Stogdill, R.M. (1974). Toward a contingency theory of leadership based upon the consideration and initiating structure literature. Organizational Behavior and Human Performance, 12, 62-82

Kim, K.I., \& Organ, D.W. (1982). Determinants of leader-subordinate exchange relationships. Group \& Organization Studies, 7, 77-89

Kirkpatrick, S.A. \& Locke, E.A. (1991). Leadership: Do traits matter?. Academy of Management Executive, 5 (2), 49-60

Kolb D.A. (1984). Experiential Learning experience as a source of learning and development. New Jersey: Prentice Hall

Klein, N. (2007). La doctrina del shock. Barcelona: Paidós

Klein, N. (2007). No Logo. Barcelona: Paidós

Kliksberg, B. (2005). La agenda ética pendiente de Latinoamérica. México: Fondo de cultura económica

Kluckhohn, C. K. (1951). Values and value orientations in the Theory of Action. En T. Parsons y E.A. Shils (Eds.), Toward a General Theory of Action (pp. 388-433). Cambridge: Harvard University Press

Kluckhohn, F.R., \& Strodtbeck, F. L. (1961). Variations in Value Orientations. Evanston, IL: Row, Peterson

Knickerbocker, I. (1948). Leadership: A conception and some implications. J ournal of Social Issues, 4, 23-40

Koh, J., Kim, Y.G., Butler, B., \& Bock, G.W. (2007). Encouraging participation in virtual communities. Communications of the ACM, 50 (2), 68-73

Koontz, H. \& O’Donnell, C. (1955). Principles of management. New York: McGraw-Hill

Kotler, P. \& Zaltman, G. (1971). Social marketing: an approach to planned social change. J ournal of Marketing, 35, 3-12

Kotler, P. \& Andreasen, A. R. (1996). Strategic marketing for nonprofit organizations. Upper Saddle River: Prentice Hall

Korman, A.K. (1966). Consideration, initiating structure and organizational criteria: a review. Personnel Psychology, 19. 349361

Kouzes, J.M. \& Posner, B.Z. (1992). The leadership challenge: How to get extraordinary things done in organizations. San Francisco: Jossey-Blass

Krech, D. \& Crutchfield, R.S. (1948). Theory and problems of social psychology. New York: McGraw-Hill 
Krosnick, J.A. (1988). The role of attitude importance in social evaluation: A study of political preference, presidential candidate evaluations and voting behavior. J ournal of Personality and Social Psychology, 55, 196-210

Krosnick, J.A. (1989). Attitude importance and attitude accessibility. Personality and Social Psychology Bulletin, 15, 297-308

Krosnick, J.A., Betz, A.L., Jussim, L.J. \& Lynn, A.R. (1992). Subliminal conditioning of attitudes. Personality and Social Psychology Bulletin, 18, 152-162

Krosnick, J.A., Boninger, D.S. Chuang, Y.C., Berent, M.K. \& Carnot, C.G. (1993). Attitude strength: One construct or many related constructs? Journal of Personality and Social Psychology, 65, $1132-1151$

Kuznetsov, A. \& Kuznetsova, O. (2003). Institutions, business and the state in Russia. Europe-Asia Studies, 55 (6), 907-922

Kutnesov, A.; Kutnesova, O. \& Warren, R. (2009). CSR and the legitimacy of business in transition economies: The case of Russia. Scandinavian J ournal of Management, 25, 37-45

Lacey, R. \& Kennett-Hensel, P.A. (2010). Longitudinal Effects of Corporate Social Responsibility on Customer Relationships. J ournal of Business Ethics, 97, 581-597

Lamberth, J. (1989). Psicología social. Madrid: Pirámide

LaPiere, R.T. (1934). Attitude and actions. Social Forces, 13, 230-237

LaPiere, R.T. \& Farnsworth, F.R. (1936). Social psychology. New York: McGraw-Hill

Larson, A. (1968). Eisenhower: The president nobody knew. New York: Popular Library

Lawler, E. E., III, Nadler, D. A., \& Cammann, C. (1980). Organizational perspectives on the measurement of organizational behavior and the quality of work life. New York: Wiley-Interscience

Lee, M.P. (2008). A review of the theories of corporate social responsibility: its evolutionary path and the road ahead. International J ournal of Management Reviews, 10 (1), 53-73

León, J.L. \& Guillén, C. (2005). Habilidades de mediación. En J. Sánchez (Ed.), Aproximación interdisciplinar al conflicto y a la negociación (pp. 117-128). Cádiz: Universidad de Cádiz

León, O. \& Montero, I. (1997). Diseño de investigaciones (2a ed.). Madrid: McGraw-Hill 
Letza, S., Sun, X. \& Kirkbride, J. (2004). Shareholding versus stakeholding: a critical review of corporate governance. Corporate Governance, 12 (3), 242-262

Levy, S \& Gutman, L. (1976). Values and attitudes of Israel high school youth. Jerusalem: The Israel Institute of Applied Social Research

Lewin, K; Lippet, R. \& White, R. (1960). Leader Behavior and Member Reaction in Three Social Climates. En D. Cartwright y A. Zander (Eds.), Group Dynamics: Research and Theory (2a Ed.), Evanston, IL: Row Peterson \& Company

Liden, R. C., Wayne, S. J., \& Stilwell, D. (1993). A longitudinal study on the early development of leader-member exchanges. J ournal of Applied Psychology, 78, 662-674

Likert, R. (1932). A technique for the measurement of the attitudes. Archives of psychology, 140, 1-55

Likert, R. (1961). New patterns of management. New York: McGrawHill

Lindorff, M. \& Peck, J. (2010). Exploring Australian financial leaders' views of corporate social responsability. J ournal of Management $\&$ Organization, 16, 48-65

Lipkus, I.M., Green, J.D., Feaganes, J.R. \& Sedikides, C. (2001). The relationship between attitudinal ambivalence and desire to quit smoking among college smokers. Journal of Applied Social Psychology, 31, 113-133

Lippmann, W. (1922). Public opinion. New York: Harcourt, Brace

Lisbona, A.; Palací, F.J. \& Agulló, Agulló, E. (2008). Escala de aspiraciones de control y responsabilidad: adaptación española y su relación con la iniciativa personal. Psicothema, 20 (2), 249253

Lizcano, J.L. (2002). Confianza en los mercados y responsabilidad social corporativa. Dirección y Progreso, 184, 25-30

Llopis, J.A. \& Ballester, M.R. (2001). Valores y virtudes en la educación. Valencia: Tirant lo Blanch

Llopis, R. (2009). Consumo responsable y globalización reflexiva: un estudio referido al comercio justo en España. Revista española del tercer sector, 11, 145-165

Longenecker, J.G., McKinney, J.A. \& Moore, C.W. (1989). Ethics in small business. J ournal of Small Business Management, January, 27-31 
Locke, E.A. (1984). Job Satisfaction. M. Gruneberg y T. Wall (Eds.), Social Psychology and Organization Behavior (pp. 93-117). Londres: John Wiley and Sons

Locke, E.A. (1991). The motivation sequence, the motivation hub and the motivation core. Organizational Behavior \& Human Decision Processes, 50, 288-299

López Zafra, E. (1998). Liderazgo carismático: utilizando niveles de análisis para la comprensión de la relación carismática. Tesis doctoral inédita, Universidad Nacional de Educación a Distancia, Madrid

Lord, R.G., Foti, R.J. \& Phillips, J.S. (1982). A theory of leadership categorization. En J.G. Hunt, Sekaran, V. y Schriesheim, C. (Eds.), Leadership: Beyond establishment views. Carbondale, South: Illinois University Press

Lord, R.G.; Foti, R. \& De Vader, C. (1984). A test of leadership categorization theory: Internal structure, information processing and leadership perceptions. Organizational behavior and Human Performance, 34, 343-378

Lord, R.G. (1985). An information processing approach to social perceptions, leader-ship perceptions and behavioral measurement in organizational settings. En B. M. Staw y L. L. Cummings (Eds.), Research in organizational behaviour, Vol. 7 (pp. 87 - 128). Greenweech, CT: JAI Press

Lord, R.G. \& Alliger, G.M. (1985). A comparison of four information processing models of leadership and social perceptions. Human Relations, 38, 47-65

Lord, R.G. \& Maher, K.J. (1991). Leadership and information processing: Linking perceptions and performance. Boston: Unwin Hyman

Lord, R.G., Brown, D.J. \& Harvey, J.L. (2001). System constraints on leadership perceptions, behaviour and influence: An example of connectionist level processes. En M.A. Hogg y S. Tindale (Eds.), Blackwell handbook of social psychology: Group processes (pp. 283-310). Oxford (UK): Blackwell

Lord, R.G.; Brown, D.J.; Harvey, J.L. \& Hall, R.J. (2001). Contextual constraints on prototype generation and their multi- level consequences for leadership perception. Leadership Quarterly, $12,311-338$

Lord, C.G., Ross, L. \& Lepper, M.R. (1979). Biased assimilation and attitude polarization: The effects of prior theories on subsequently considered evidence. Journal of Personality and Social Psychology, 37, 2098-2109 
Lowe, K.B., Kroeck, K. G., \& Sivasubramaniam, N. (1996). Effectiveness correlates of transformational and transactional leadership: A meta-analytic review of the MLQ literature. Leadership Quarterly, 7, 385-425

Lowe, K.B., \& Gardner, W.L. (2000). Ten years of the Leadership Quarterly: Contributions and challenges for the future. Leadership Quarterly, 11, 459-514

Lowin, A.; Hrapchak, W.J. \& Kavanagh, M.J. (1969). Consideration and initiating structure: an experimental investigation of leadership traits. Administrative Science Quarterly, 14, 238-253

Lucas, S. \& Diego, R. (1998). La formación y orientación laboral en el ámbito educativo. En J.D. Valdivieso y R. Diego (Eds.), Psicología del trabajo: nuevos conceptos, controversias y aplicaciones: IV Congreso Nacional de Psicología del Trabajo y de las Organizaciones (pp. 173-182). Madrid: Pirámide

Lupano, M.L. \& Castro, A. (2005). Estudios sobre el liderazgo. Teorías y evaluación. Psicodebate, 6, 107-121

Lurey, J. S., \& Raisinghani, M. S. (2001). An empirical study of best practices in virtual teams. Information \& Management, 38 (8), 523-544

Mababu, R. (2010). Actitudes de los empresarios y directivos hacia la Responsabilidad Social Corporativa. Revista de Psicología del Trabajo y de las Organizaciones, 26 (2), 101-114

Macip, J.R.; Boada, J. \& Diego, R. (2001). Cultura Organizacional y Formación Continua: incidencia en la Prevención de Riesgos Laborales. Revista de psicología del trabajo y de las organizaciones, 17 (1), 91-107

Maheswaran, D. \& Chaiken, S. (1991). Promoting systematic processing in low-motivation settings: Effect of incongruent information on processing and judgment. Journal of Personality and Social Psychology, 61, 13-25

Maignan I. (2001). Consumers perceptions of corporate social responsibilities: a cross-cultural comparison. Journal of Business Ethics, 30 (1), 57-72

Maio, G.R., Esses, V.M. \& Bell, D.W. (1994). The formation of attitudes toward new immigrant groups. Journal of Applied Social Psychology, 24, 1762-1776

Maloof, A. (2005). Identidades asesinas. Madrid: Alianza

Mambabu, R. (2010). Attitudes of Entrepreneurs and Managers to Corporate Social Responsibility. Revista de Psicología del Trabajo y de las Organizaciones, 26 (2), 101-114 
Man, R.D. (1959). A review of the relationships between personality and performance in small groups. Psychological Bulletin, 56, 241270

Mañas, M.A.; Peiró, J.M. \& González-Roma, V. (1999). El clima de los equipos de trabajo: determinantes y consecuencias. Almería: Universidad de Almería

Mañas, M.A. \& González, E. (2005). Desarrollo y estimulación de los recursos humanos. Granada: Conzepto Comunicación Creativa

Mañas, M.A.; Pullido, M. \& Luque, P.J. (2005). Gestión de los grupos y habilidades para el desarrollo de la organización. Granada: Conzepto Comunicación Creativa

Mañas, M.A. (2006). La comunicación interna: experiencias en una Administración Pública. Almería: Instituto de Estudios Almerienses

Mañas, M.A.; Salvador, C.M.; Boada, J.; González, E. \& Agulló, E. (2007). La satisfacción y el bienestar psicológico como antecedentes del compromiso organizacional. Psicothema, 19 (3), 395-400

Mañas, M.A.; Díaz, P.A. \& Pecino, V. (2008). Desarrollo de carrera laboral. En A. Rodríguez, V. Zarco, M.A. Mañas y A. Delgado (Eds.), Psicología de los recursos humanos (pp. 169-194). Madrid: Pirámide

Mañas, M.A.; Giménez, G.; Mayor, J.M.; Martínez-Tur, V.; Purificación, C. \& Cantos, M. (2008). Los tangibles como predictores de la satisfacción del usuario en servicios deportivos. Psicothema, 20 (2), 243-248

Mañas, M.A. \& Jiménez, G. (2008). Fomación. En A. Rodríguez, V. Zarco, M.A. Mañas y A. Delgado (Eds.), Psicología de los recursos humanos (pp. 195-220). Madrid: Pirámide

Mañas, M.A.; Carmona, L. \& Díaz, P.A. (2011). La negociación en la mediación. En R. López, Aportaciones de la mediación en el marco de la prevención, gestión y solución de conflictos familiares (pp. 23-32). Granada: Comares

Mañas, M.A.; Muñoz, E. \& Pecino, V. (2012). Realidad organizacional y teletrabajo. Comunitania: Revista internacional de trabajo social y ciencias sociales, 4, 105-122

Margolis, J.D. and Walsh, J.P. (2003). Misery loves companies: rethinking social initiatives by business. Administrative Science Quarterly, 48, 268-305 
Martin, R \& Epitropaki, O. (2001). Role of organizational identification on implicit leadership theories (ILTS), transformational leadership and work attitudes. Group processes y Intergroup Relations, 4(3), 247-262

Martín, V.M. (2006). Actitudes de los internados en prisión, menores de veintiún años, ante la función reeducadora del medio penitenciario en el ámbito andaluz. Tesis doctoral inédita, Universidad de Málaga, Málaga

Martínez, B.C. \& Rocabert, E. (2000). Comparación de las diferentes escalas de valores en el trabajo. Revista de Psicología del Trabajo y de las Organizaciones, 16 (1), 45-61

Maslyn, J.M., \& Uhl-Bien, M. (2001). Leader-member exchange and its dimensions: Effects of self-effort and other's effort on relationship quality. J ournal of Applied Psychology, 86, 697-708

Massachusetts Institute of Technology, MIT (2009). The Business of Sustainability: Results and insights from the first annual MIT Sloan Management Review Global Sustainability. MIT Sloan Management Review, 51 (1), 1-13

Mayfield, J., \& Mayfield, M. (1998). Increasing worker outcomes by improving leader follower relations. The J ournal of Leadership Studies, 5, 72-81

Mayo, E. (1933). The human problems of an industrial civilization. New York: The MacMillan Company

Mayo, E. \& Lombard, G.F. (1943). Teamwork and labor turnover in aircraft industry of Southern California. Boston MA: Harvard University (Graduate School of Business Administration)

McCabe, D.L., Butterfield, K.D. \& Treviño, L.K. (2006). Academia dishonesty in graduate business programs: Prevalence, causes, and proposed action. Academy of Management Learning \& Education, 5 (3), 294-305

McGuire, W. (1969). The nature of attitudes an attitude change. En G. Lindzey y E. Aronson (Eds.), The handbook of social psychology III ( $2^{\text {a }}$ ed., vol. 3, pp. 136-314). Reading, MA: Addison-Wesley

McKinsey \& Company (2009). McKinsey Global Survey Results: Valuing corporate social responsibility. Consultado el 4 de marzo de 2013, http://www.mckinseyquarterly.com/Valuing_corporate_social_re sponsibility_McKinsey_Global_Survey_Results_2309

McKinsey \& Company (2009). Making the most of corporate social responsibility. Consultado el 4 de marzo de 2013, en http://www.mckinseyquarterly.com/Valuing_corporate_social_re sponsibility_McKinsey_Global_Survey_Results_2309 
McWilliams, A. and Siegel, D. (2000). Corporate social responsibility and financial performance: correlation or misspecification?. Strategic Management J ournal, 21 (5), 603-609

Meindl, J.R. (1998). The romance of leadership as a follower-centric theory: A social constructionist approach. En F. Dansereau y F.J. Yammarino (Eds.), Leadership: the multiple-level-approaches (pp. 285-298). Stanford: JAI Press

Menárguez, J.F. (1999). Importancia de los factores organizacionales en la calidad asistencial de los servicios de atención primaria. Tesis doctoral inédita, Universidad de Murcia, Murcia

Méndez, E. \& Rojas, L.R. (2009). La transmutación del liderazgo en las organizaciones. Revista de Formación Gerencial, 8 (1), 11-32

Méndez, G. (2002). Norma SA8000: La gestión de la responsabilidad social en las empresas. Noticias de la Economía Pública Social y Cooperativa, 35, 35-39

Mercadona (2012). Memoria Anual Mercadona 2012. Consultado del 8 de enero de 2014, de http://www.mercadona.es/corp/esphtml/memoria2012.html

Mercer (2009). Shedding Light on responsable investment: approaches, returns and impacts. Consultado el 8 de agosto de 2013, en http://www.law.harvard.edu/programs/lwp/pensions/conferenc es/cm_europe12_09/Shedding_light_on_responsible_investment_ free_version.pdf

MERCO (2013). Ranking de empresas responsables en España. Consultado el 16 de mayo de 2013, en http: //www.merco.info/es/countries/4/rankings/14

Merck (2013). Merk for mothers. Consultado el 9 de enero de 2014, de http://www.merckformothers.com/

Merton, R.K. (1969). The social nature of leadership. American J ournal of Nursing, 69, 2614-2618

Mestre, J.M.; Guil, M. \& Guillén, C. (2000). Estrés laboral. En C. Guillén (Ed.), Psicología del trabajo para las relaciones laborales (pp. 269-296). Madrid: McGraw-Hill Interamericana de España

Mestre, J.M.; Guil, M. \& Guillén, C. (2000). La evaluación del rendimiento. En C. Guillén (Ed.), Psicología del trabajo para las relaciones laborales (pp. 249-268). Madrid: McGraw-Hill Interamericana de España

Mestre, J.M.; Guil, M. \& Guillén, C. (2000). Liderazgo, y estilo de dirección. En C. Guillén (Ed.), Psicología del trabajo para las relaciones laborales (pp. 297-312). Madrid: McGraw-Hill Interamericana de España 
Miguel, J.M.; Schweiger, I.; Fernández, M. \& Ruíz, M.A. (2010). El efecto del grupo de pertenencia en la metarrepresentación de la organización. Psicothema, 22 (4), 835-840

Mintzberg, H. (1988). La estructuración de las organizaciones. Barcelona: Ariel

Mintzberg, H. (1991). Mintzberg y la Dirección. Madrid: Díaz de Santos

Miles, R.E. \& Snow, C.C. (1978). Organizational Strategy, Structure and process. New York: McGraw-Hill

Miller, A.G., McHoskey, J.W., Bane, C.M. \& Drowd, T.G. (1993). The attitude polarization phenomenon: Role of response measure, attitude extremity and behavioral consequences of reported attitude change. Journal of Personality and Social Psychology, $64,516-574$

Miller, J.A. (1973). Structuring/ destructing: Leadership in open systems (Tech. Rep. $N^{\circ}$ 64). Rochester, NY: Universtity of Rochester, Management Research Center

Miller, J.G. (1978). Living Systems. New York: McGraw-Hill

Molero, F. (2002). Cultura y liderazgo. Una relación polifacética. Boletín de Psicología, 76, 53-75

Moneva, J.M. \& Ortas, E. (2009). Desarrollo sostenible e información corporativa: evolución y situación actual. Economía Industrial, $371,139-154$

Montané, J.; Jariot, M. \& Rodríguez, M. (2007). Actitudes, cambio de actitudes y conducción segura. Un enfoque crítico aplicado a la reducción de los accidentes de tráfico. Barcelona: Laertes

Montmollin, G. (1991). El cambio de actitud. En S. Moscovici, Psicología Social I (pp. 117- 173). Barcelona: Paidós

Moore, B.V. (1927). The May conference on leadership. Personnel J ournal , 6, 124-128

Moore, G. (2001). Corporate social and financial performance: an investigation in the UK supermarket industry. J ournal of Business Ethics, 34 (3-4), 167-180

Moriano, J.A; Topa, G. \& Lévy, J.P. (2009). Leadership in Nonprofit Organizations of Nicaragua and El Salvador: A Study from the Social Identity Theory. The Spanish J ournal of Psychology, 12 (2), 667-676

Morin, E. (1997). Introducción al pensamiento complejo. Barcelona: Gedisa 
Morojele, N. \& Stephenson, G.M. (1994). Addictive behaviors: Prediction of abstinence intentions and expectations in the theory of planned behavior. In D.R. Rutter \& L. Quine (Eds.), Social psychology and health: European perspectives (pp. 47-70). Aldershot, UK: Avesbury

Morse, N.C. \& Reimer, E. (1956). The experimental change of a major organizational variable. Journal of abnormal and social psychology, 52, 120-129

Mozas, A. \& Puentes, R. (2010). La responsabilidad social corporativa y su paralelismo con las sociedades cooperativas. Revesco, 103, 75-100

MOW, Meaning of Working (International Research Team) (1987). The meaning of working: An International View. London: Academic Press

Mudrack, P. (2007). Individual personality factors that affect normative beliefs about the rightness of corporate social responsibility. Business and Society, 46 (1), 33-62

Mugarra, A. (2001). Responsabilidad y Balance Social hoy en día: un reto para las cooperativas. CIRIEC-España, Revista de Economía Pública, Social y Cooperativa, 39, 25-50

Mumford, E. (1906-1907). Origins of leadership. American J ournal of Sociology, 12, 216-240, 367-397, 500-531

Munduate, L. (1985). El impacto sociolaboral de las nuevas tecnologías. Temas Laborales. Revista andaluza de Trabajo y Bienestar Social, 4, 55-70

Munduate, L. (1994). Nuevas tecnologías, automatización y conducta en las organizaciones. En Peiró J.M. y Ramos, J. (Dir.), Intervención Psicosocial en Ias Organizaciones. Barcelona: PPU

Munro, G.D. \& Ditto, P.H. (1997). Biased assimilation, attitude polarization and effect in reactions to stereotype-relevant scientific information. Personality and Social Psychology Bulletin, 23, 636-653

Munson, E.L. (1921). The management of men. New York: Holt

Muñoz, A.M. \& Guillén, C. (2002). Estrés laboral, En T. Fernández \& A. Ares (Eds.), Servicios sociales: dirección, gestión y planificación (pp. 185-212). Madrid: Alianza

Myers, D. (2011). Psicología (9a ed.). Madrid: Editorial Médica Panamericana

Myrick, M.B.; Bushardt, S.C. \& Cadenhead, G. (1988). Managerial success: sex-role behaviour and nursing leadership. Today's OR Nurse, 10, 31-34 
Naciones Unidas (1987). Nuestro futuro común. Consultado el 3 de abril de 2013, en http://www.un.org/es/comun/docs/?symbol=A/42/427

Nash, J.B. (1929). Leadership. Phi Delta Kappan, 12, 24-25

Naciones Unidas (1987). Los Diez Principios del Pacto Mundial. Consultado el 28 de abril de 2013, en http:/ / www.pactomundial.org/quienes-somos/10-principios

Navarro, J.; Quijano, S.D.; Berger, R. \& Meneses, R. (2011). Grupos en las organizaciones: herramienta básica para gestionar la incertidumbre y ambigüedad crecientes. Papeles del Psicólogo, $32(1), 17-28$

Nettel, D. (2006). Felicidad. La ciencia tras la sonrisa. Barcelona: Ares y Mares

Neustadt, R. (1960). Presidential power. New Cork: Wiley

Newcomb, T.M.; Turner, R.H. \& Converse, P.E. (1965). Social psychology. New York: Holt, Rinehart \& Winston

Ng, E.S. \& Burke, R.J. (2010). Predictor of business students' attitudes toward sustainable business practices. J ournal of Business Ethics, 95, 603-615

Nicholls, J.R. (1985). A New Approach to Situational Leadership. Leadership and Organizational Development J ournal, 6, 4, 2-7

Nieto, M. \& Fernández, R. (2004). Responsabilidad social corporativa: La última innovación en management. Universia Business Review, 1, 28-39

Nihenhuis, A.E., Manstead, A.S.R. \& Spears, R. (2001). Multiple motives and persuasive communication: Creative elaboration as a result of impression motivation and accuracy motivation. Personality and Social Psychology Bulletin, 27, 118-132

Nogales, R. (2007). Aparición y evolución de la empresa social en Europa. La sociedad cooperativa, 39, 44-48

Nogales, R. (2011). La empresa social en la lucha contra la exclusión: Tres casos innovadores en el campo de la cultura. Revista española del tercer sector, 17, 86-110

Norris, W. \& Vecchio, R.P. (1992). Situational Leadership Theory: A Replication. Group and Organization Management, 17, 3, 331-342

Northouse, P.G. (2001). Leadership theory and practice ( $2^{\mathrm{a}}$ ed.). Thousand Oaks, CA: Sage 
Nutt, P.C. y Backoff, R.W. (1995): Transforming organizations with second-order change. En W. A. Pasmore and E.W. Woodman (Eds.). Research in Organizational Change and Development. Greenwich: Co. Jai Press

Observatorio de Economía Solidaria (2004). Home. Consultado el 20 de noviembre de 2013, en http://www.oesolidaria.org

Observatorio de Economía Solidaria (2010). Responshabilidad se escribe con h. Consultado el 13 de mayo de 2013, en http: / /oesolidaria.bubok.es/

Observatorio de Responsabilidad Social Corporativa (2004). ¿Qué es el observatorio de RSC? Consultado el 20 de noviembre de 2011, en http://www.observatoriorsc.org/index.php?option=com_content \&view=article\&id=12\&ltemid=27\&lang=es

Offerman, L.R.; Kennedy, J.K. \& Wirtz, P.W. (1994). Implicit leadership theories: Content, structure and generalizability. Leadership Quarterly, 5 (1), 43-58

Olivar, J.S.; Diego, J.A. \& Diego, R. (2001). Satisfacción laboral de los trabajadores de banca. Psicothema, 14 (4), 629-635

Oliver, C. \& Agulló, E. (1993). Técnicas de reuniones para directivos. Madrid: Colegio de Oficiales de la Marina Mercante Española

Orlitzky, M. (2001). Does firm size confound the relationship between corporate social performance and firm financial performance?. Journal of Business Ethics, 33 (2), 167-180

Osborn, R.N., Hunt, J.G. \& Jauch, L.R. (1980). Organization theory: An integrated approach. New York: Wiley

Osgood, C.E.; Suci, G.J. \& Tannenbaum, P.H. (1957). The Measurement of Meaning. Urbana: University of Illinois Press

Osgood, C.E. (1960). Cognitive dynamics in the conduct of human affairs. Public Opinion Quarterly 24, 341-365

Odier, C. (1948). Valeur et valence du chef. Schweizerisches Archiv ffir Neurologisches Psychiatrie, 61, 408-410

Orbell, S.; Blair, C.; Sherlock, K. \& Conner, M. (2001). The theory of planned behavior and ecstasy use: Roles for habit and perceived control over taking versus obtaining substances. Journal of Applied Social Psychology, 31, 31-47

Ortega, M. \& Luque, F.J. (2009). Obama es el mensaje: Una interpretación macluhaniana del nuevo liderazgo presidencial estadounidense. Psicología Política, 39, 19-38

Paige, G.D. (1977). The scientific study of political leadership. New York: Free Press 
Parsons, T. (1951). The Social System. New York: Free Press

Pastor, G. (1978). Conducta Interpersonal. Ensayo de Psicología Social Sistemática. Salamanca: Publicaciones de la Universidad Pontificia

Pastor, G. (1978). Síndrome frío de personalidad sagaz: Psicología social del maquiavelismo. Salamanca: Universidad Pontificia de Salamanca

Pastor, G. (1986). Ideologías: su medición psicosocial. Barcelona: Herder

Pastor, G. (2008). Cambio de valores: los medios como agentes de socialización y desinformación. En M. Fernández (Coord.). Comunicación en la sociedad red: la construcción mediática de la realidad (pp. 119-135). Ávila: Universidad Católica de Ávila

Paublete, M.C.; Díaz, M.; Palenzuela, F.; Lupiani, M.; Bas, P.; Gala, F.J. \& Guillén, C. (1998). Efectos psicofisiológicos del ruido en el trabajo. Revista de psicología del trabajo y de las organizaciones, 14 (2), 155-168

Payne, D. \& Joyner, B.E. (2006). Successful U.S. entrepreneurs: identifying ethical decision-making and social responsibility behaviors. J ournal of Business Ethics, 65, 203-217

Peiró, J.M. (1983-84). Psicología de la Organización ( $5^{\mathrm{a}}$ ed.). Madrid: Uned, 2 vols.

Peiró, J.M. (1987). Organizational Structure. In Bass, B. Drenth P. y Weissenberg, P. (Eds.). Advances in Organizational Psychology. California, Beverly: Sage

Peiró, J.M. (1990). Organizaciones. Nuevas perspectivas psicosociológicas. Barcelona: PPU

Peiró, J.M. (1991). Psicología de la organización. Madrid: Universidad Nacional de Educación a Distancia (UNED)

Peiró, J.M. (1996a). Función Directiva en la Administración Pública: Una perspectiva Psicosocial. Sevilla: Instituto Andaluz de Administración Pública

Peiró, J.M. (1996b). Cultura i canvi organitzacional. Revista d'Etnología de Catalunya, 9, 16-27

Peiró, J.M. (1999a). El modelo "AMIGO": Marco contextualizador del desarrollo y la gestión de Recursos Humanos en las Organizaciones. Papeles del Psicólogo, 72, 3-15 
Peiró, J.M. (1999b). Valoración de riesgos laborales y estrategias de prevención: el modelo AMIGO como base de la metodología Prevenla-Psicosocial. Revista de psicología del trabajo y de las organizaciones, 15 (2), 267-314

Peiró, J.M. (2000). Assessment of psychology risk and prevention strategies: The AMIGO model as the basis of the PREVENLAB/PSICOSOCIAL methodology. Psychology in Spain, 4 (1), 139-166

Peiró, J.M. (2003). Metodología Prevenlab para el análisis y prevención de riesgos psicosociales. Capital Humano, 167, 82-90

Peiró, J.M. \& Martínez-Tur, V. (2008). Organizational development and change. En N. Chimel (Ed.), An introduction to work and organisational psychology $\left(2^{\mathrm{a}}\right.$ ed., pp. 351-376). London: Blackwell

Peiró, J.M. \& Rodríguez, I. (2008). Estrés laboral, liderazgo y salud organizacional. Papeles del psicólogo, 29 (1), 68-82

Peloza, J. \& Shang, J. (2011). How can corporate social responsability activities create value for stakeholders? A systematic review. J ournal of the Academy of Marketing Science, 39, 117-135

Perdiguero, T.G. \& García-Reche, A. (Coord.) (2012). Cultura, Políticas y Prácticas de Responsabilidad de las Empresas del IBEX 35. Consultado el 3 de marzo de 2013, en http://www.observatorio-

rse.org.es/Publicaciones/Estudio\%202012\%20Cultura,\%20Pol\%C3\% ADticas\%20y\%20Pr\%C3\%A1cticas\%20de\%20Responsabilidad\%20Socia l\%20de\%20las\%20empresas\%20del\%20IBEX35.pdf

Pérez, F. (1987). Evaluación Organizacional de un Hospital. Tesis doctoral inédita, Universidad de la Laguna, Tenerife

Pérez-Velasco, V.M. \& Fernández, M. (1985). La Evaluación Organizacional. Revista de Psicología del Trabajo y de las Organizaciones, 1 (1), 18-35

Perrow, C. (1970). Organizational Analysis: A sociological view. Belmont, Calif.: Brooks/Cole

Petkova, K.G., Azjen, I. \& Driver, B.L. (1995). Salience of antiabortion beliefs and commitment to an attitudinal position: On the strength, structure and predictive validity of anty-abortion attitudes. J ournal of Applied Social Psychology, 25, 463-483

Petty, R.J. \& Cacioppo, J.T. (1986). The elaboration likelihood model of persuasion. In L. Berkowitz (Ed.), Advances in experimental social psychology, (Vol. 19, pp. 123-205). New York: Academic Press 
Petty, R.J. \& Cacioppo, J.T. (1990). Involvement and persuasion: Tradition versus integration. Psychology Bulletin, 107, 367-374

Petty, R.J., Cacioppo, J.T., Strathman, A.J. \& Priester, J.R. (1994). To think or not to think: Exploring two routes to persuasion. In S. Shavitt \& T.C. Brock (Eds.), Persuasion (pp. 113-147). Boston: Allyn and Bacon.

Petty, R.J. \& Krosnick, J.A. (Eds.) (1995). Attitude strength: Antecedents and consequences (Vol. 4). Hillsdale, NJ: Erlbaum

Petty, R.E. \& Wegener, D.T. (1998). Attitude change. En D. Gilbert, S. Fiske y G. Lindzey (Eds.), The Handbook of Social Psychology $\left(4^{a}\right.$ ed., Vol. 1, pp. 323-390). New York: McGraw-Hill

Pervin, L.A. (1984). Personality. New York: Wiley

Pillis, E. d., \& Furumo, K. 2007. Counting the Cost of Virtual Teams. Communications of the ACM, 50 (12), 93-95

Phillips, T.R. (1939). Leader and led. Journal of the Coast Artillery, $82,45-58$

Phillips, J.S. (1984). The accuracy of leadership ratings: A cognitive categorization perspective. Organizational Behavior and Human Performance, 33, 125 - 138

Pigors, P. (1935). Leadership or domination. Boston: Houghton Mifflin

Platow, M.J., Reid, S. \& Andrew, S. (1998). Leadership endorsement: The role of distributive and procedural behavior in interpersonal and intergroup contexts. Group Processes and Intergroup Relations, 1, 35-47

Platow, M.J., \& van Knippenberg, D. (2001). A social identity analysis of leadership endorsement: The effects of leader ingroup prototypicality and distributive intergroup fairness. Personality and Social Psychology Bulletin, 27, 1508-1519

Pomerantz, E.M., Chaiken, S. \& Tordesilla, S. (1995). Attitude strength and resistance processes. Journal of Personality and Social Psychology, 69, 408-419

Porter, M.E. \& Kramer, M.R. (2006). Strategy \& Society: the link between competitive advantage and corporate social responsibility. Harvard Business Review, 84 (12), 78-92

Portero, F. (2006, 2 de mayo). Blair, acaba el ciclo moral. ABC

Post, C.; Rahman, N. \& Rublow, E. (2011). Green Governance: Boards of Directors' Composition and Environmental Corporate Social Responsibility. Business \& Society, 50, 189-223

Pozo, M. (1997). Cultura empresarial y comunicación interna. Madrid: Fragua 
Prakash, S. (1975). Dimensions of corporate social performance: an analytical framework for measurement and analysis. California Management Review, 17 (3), 58-64

Pratkanis, A.R. (1989). The attitude heuristic and selective fact identification. British J ournal of Social Psychology, 28, 257-263

Priester, J.R. \& Petty, R.E. (2001). Extending the bases of subjective attitudinal ambivalence: Interpersonal and intrapersonal antecedents of evaluative tension. Journal of Personality and Social Psychology, 80, 19-34

Puentes, R \& Velasco, M.M. (2009). Importancia de las sociedades cooperativas como medio para contribuir al desarrollo económico, social y medioambiental, de forma sostenible y responsable. Revista de Estudios Cooperativos (REVESCO), 99, 104-129

Quazi, A.M. \& O’Brien, D. (2000). An empirical test of a cross-national model of corporate social responsibility. Journal of Business Ethics, 25, 33-51

Quijano, S. \& Navarro, J. (1999). El ASH (Auditoría del Sistema Humano), los modelos de calidad y la evaluación organizativa. Revista de Psicología General y Aplicada, 52 (2-3), 301-328

Quijano, S.; Cornejo, J.M.; Yepes, M. \& Flores, R. (2005). La calidad de los procesos y recursos humanos (CPRH) como componente de la calidad del sistema humano de la organización: conceptualización y medida. Anuario de Psicología, 36 (1), 7-36

Quijano, S. (Dir.) (2006). Dirección de recursos humanos y consultoría en las organizaciones. Aspectos diferenciales. El ASH (Auditoría del Sistema Humano). Barcelona: Icaria Editorial

Quijano, S.; Navarro, J.; Yepes, M.; Berger, R. \& Romeo, M. (2008), La Auditoría del Sistema Humano (ASH) para el análisis del comportamiento humano en las organizaciones. Papeles del Psicólogo, 29(1), pp. 92-106

Quijano, S. \& Navarro, J. (2009). La auditoría del sistema humano (ASH) para el análisis del comportamiento humano en las organizaciones. Papeles del psicólogo, 29 (1), 92-106

Quinn, R.E. \& Rohrbaugh, J. (1983). A spatial model of effectiveness criteria: towards a competing values approach to organizational analysis. Management Science, 29, 363-377

Ramasamy, B.; Yeung, M.C.H. \& Au, A.K.M. (2010). Consumer Support for Corporate Social Responsability (CSR): The Role of Religion and Values. J ournal of Business Ethics, 91, 61-62 
Ramió, A. (2005). Valores y actitudes profesionales. Estudio de la práctica profesional enfermera en Cataluña. Tesis doctoral inédita, Universidad de Barcelona, Barcelona

Ramos, J.A. \& Periáñez, I. (2003). Delimitación del Marketing con Causa o Marketing Social Corporativo mediante el análisis de empresas que realizan acciones de responsabilidad social. Cuadernos de Gestión, 3 (1 y 2), 65-82

Raven, B.H. \& French, J.R.P. (1958a). Group support, legitimate power and social influence. J ournal of Personality, 26, 400-409

Raven, B.H. \& French, J.R.P. (1958b). Legitimate power. En P. Swingle (Ed.), The structure of conflict. New York: Academic Press

Raven, B. \& Kruglanski, W. (1975). Conflict and power. En P. Swingle (Ed.). The structure of conflict. New York: Academic Press

Ravlin, E.C. \& Megglino, B.M. (1987). Effects of values on perception and decision making: A study of alternative work values measures. J ournal of Applied Psychology, 72, 666-673

Ravlin, E.C., \& Meglino, B.M. (1989). The transitivity of work values: Hierarchical preference ordering of socially desirable stimuli. Organizational Behavior and Human Decision Processes, 44, 494508

Recio, M. \& Ortiz, A. (2000). Marketing con causa. Marketing \& Ventas, 36, 26-33

Redding, W.J. (1967). The 3-D Management Style Theory. Training and Development Journal, 21, 8-17

Red Pacto Mundial España (2013a). Red Española Pacto Mundial. Consultado el 22 de noviembre de 2013, en http://www.pactomundial.org/quienes-somos/red-espanolapacto

Red Pacto Mundial España (2013b). Memoria de actividades 2012. Consultado el 22 de noviembre de 2013, en http: / / pactomundial.org/wpcontent/uploads/2013/06/memoria-actividades-2012.pdf

Redl, F. (1942). Group emotion and leadership. Psychiatry, 5, 573-596

Rey, C.A. (2000). El machismo y el trastorno disocial: un estudio con padres e hij os. Tesis doctoral inédita, Universidad de Salamanca, Salamanca

Rhodewalt, F. \& Davidson, J.Jr. (1983). Reactance and the coronary prone behaviour pattern: The role of self-attribution in response to reduced behavioural freedom. Journal of Personality and Social Psychology, 44, 220-228 
Riaño, F. (2010). Corporate government, Ethical, Values and Corporate Responsability: Management of the Diversity (the case of the disability: implications, challenges, opportunities and challenges for the company). Sociedad y utopía: Revista de ciencias sociales, 35, 159-180

Rice, A.W. (1978b). Construct validity of the least preferred coworker. Psychological Bulletin, 85, 1195-1237

Rico, R., Fernández, M. \& Sánchez, J.C. (2001). Procesos estratégicos y estructura organizacional: implicaciones para el rendimiento. Psicothema, 13 (1), 29-39

Rico, R. \& Fernández, M. (2002). Diseño de organizaciones como proceso simbólico. Psicothema, 14 (2), 415-425

Rico, R.; Fernández, M. \& San Martín, R. (2004). La organización como sistema de significados. Psicothema, 16 (2), 222-228

Rico, R.; Fernández, M.; Rascado, P. \& Sánchez, M. (2004). Teorías implícitas, diseño organizacional y eficacia. Interamerican journal of psychology, 38 (1), 121-130

Riess, M. \& Schlenker, B.R. (1977). Attitude change and responsibility avoidance as modes of dilemma resolution in forced-compliance situations. J ournal of Personality and Social Psychology, 35, 2130

Rivera, J. (1992). Emotional Climate: Social Structure and Emotional Dynamics. En K. T. Strongman (Ed.). International Review of Studies on Emotion (Vol. 2, pp. 197-218). New York: John Wiley and Sons

Rodríguez, J.M. (2007). Responsabilidad social corporativa y análisis económico. Economiaz, 65, 12-49

Rodríguez, I.; González-Morales, M.G. \& Carbonell, S. (2007). El modelo AMIGO y la metodología PREVENLAB-PSICOSOCIAL. Seguridad y salud en el trabajo, 42, 18-25

Rodríguez, A.; Sánchez, E.; Zarco, E. \& Martín, M.A. (2004). El grupo como unidad de análisis. En A. Rodríguez (Ed.), Psicología de las Organizaciones (pp. 167-230). Barcelona: UOC

Rodríguez, A.; Zarco, V.; Mañas, M.A. \& Delgado, A. (2008). Psicología de los recursos humanos. Madrid: Pirámide

Rokeach, M. (1968). A theory of organization and change within valueattitude systems. J ournal of Social Issues, 24, 13-33

Rokeach, M. (1973). The nature of human values. New York: Free Press 
Rokeach, M. (1974). Change and stability in American value systems, 1968-1971. Public Opinion Quarterly, 38, 222-238

Romero, N. (2010). Responsabilidad social corporativa: ¿una estrategia de cambio hacia un modelo ético de desarrollo?. Revista de Ciencias Sociales (RCS), 16 (3), 456-467

Rosch, E. (1978). Principle in categorization. En E. Rosch y B. B. Lloyd (Eds.), Cognition and categorization (pp. 28-48). Hillsdale, NJ: Erlbaum

Rousseau, D.M. (2001). Clima y cultura organizativos. En La Enciclopedia de Salud y Seguridad en el trabajo (vol. 2, parte V, cap. 34, 41-43). Organización Internacional del Trabajo y Ministerio de Trabajo y Asuntos Sociales. Consultado el 1 de octubre de 2011, en http: //www.mtas.es/insht/EncOIT/pdf/tomo2/34.pdf

Roy, A. (2002). El álgebra de la justicia infinita. Barcelona: Anagrama

Ruiz, J.I. (2006). Clima emocional y sobreocupación en prisión: una evaluación mediante informantes clave. Suma Psicológica, 13 (2) 159-172

Ruiz, L.M.; Rodríguez, P.; Martinek. T.; Ruiz, L.M.; Schilling, T.; Durán, L.J. \& Jiménez, P. (2006). El Proyecto Esfuerzo: un modelo para el desarrollo de la responsabilidad personal y social a través del deporte. Revista de educación, 341, 933-960

Rush, M.C.; Thomas, J.C. \& Lord, R.G. (1977). Implicit leadership theory: A potential threat to the internal validity of leader behavior questionnaires. Organizational Behavior and Human Performance, 20, 93-110

Saegert, J. (1979). Another look at subliminal perception. J ournal of Advertising Research, 19, 55-57

Salas, S. (2009). A study of the relationship between employee virtuality and technology deviance as mediated by leadership and employee perceptions. Tesis doctoral inédita, Florida International University, Miami

Salanova, M.; Moyano, C.; Calvo, M.; Prieto, F. \& Peiró, J.M. (1991). Valoración de aspectos laborales en jóvenes que se incorporan a una organización laboral. Psicología del Trabajo y las Organizaciones, 7 (19), 85-100

Salanova, M.; Prieto, F. \& Peiró, J.M. (1996). Grupos de trabajo. En J.M. Peiró y F. Prieto (Eds.): Tratado de Psicología del Trabajo. Vol. II: Aspectos psicosociales del trabajo (pp. 101-136). Madrid: Síntesis 
Sánchez, E. (1998). Liderazgo y estilos de dirección. En A. Rodríguez (Ed.), Introducción a la Psicología del Trabajo y de las Organizaciones (pp. 153-166). Madrid: Pirámide

Sánchez, E. \& González, J.M. (1998). ¿Diferencias sexuales en los estilos de dirección en la administración pública? Revista de Psicología del Trabajo y de las Organizaciones, 14 (2), 141-154

Sánchez, E. (2000). Teoría del liderazgo situacional en la Administración local: validez del modelo. Psicothema, 12 (3), 435-439

Sánchez, E. y Rodríguez, A. (2010). 40 años de liderazgo de la teoría situacional: una revisión. Revista Latinoamericana de Psicología, 42, 1, 29-39

Sánchez, J.C. (2002). Psicología de los grupos. Madrid: McGraw-Hil

Sánchez, S; Ramos, E.; Mena, J.E. \& Guillén, C. (2005). El conflicto intrapersonal. En J. Sánchez (Ed.), Aproximación interdisciplinar al conflicto y a la negociación (pp. 87-100). Cádiz: Universidad de Cádiz

Sánchez, S.; Guillén, C.; León, J.M. (2006). La autoeficacia percibida en el afrontamiento de riesgos laborales psicosociales como variable moduladora del burnout. Ansiedad y estrés, 12 (2/3), 495-504

Salvador, C. \& Mañas, M.A. (2009). Actitudes hacia el trabajo: satisfacción, implicación y compromiso laboral. En A. Rodríguez, V. Zarco, y J.M. González (Eds.), Psicología del trabajo (pp. 4570). Madrid: Pirámide

Sauter, S.L., Murphy, L.R., Hurrell, J.J., \& Levi, L. (1998). Factores psicosociales y de organización. En J.M. Stellman (Dir.), Enciclopedia de Salud y Seguridad en el Trabajo. Ginebra: OIT

Santesmases, M. (1991). Marketing: conceptos y estrategias (5ed 2004). Madrid: Pirámide

Scandura, T.A., \& Graen, G.B. (1984). Moderating effects of initial leader-member exchange status on the effects of a leadership intervention. J ournal of Applied Psychology, 69, 428-436

Scott, K. A., \& Brown, D. J. (2006). Female first, leader second? Gender bias in the encoding of leadership behavior. Organizational Behavior and Human Decision Processes, 101, 230242.

Schaefer, A. (2004): Corporate sustainability - integrating environmental and social concerns? Corporate Social Responsibility and Environmental Management, 11, 179-187 
Schein, E.H. (1956). The Chinese indoctrination program for prisoners of war: A study of attempted brainwashing. Psychiatry, 19, 149172

Schein, E.H. (1968). Organizational socialization and the professional management, Industrial Management Review, 9, 1-15

Schein, E.H. (1977). El individuo, la organización y la carrera: un modelo conceptual. En D.A. Kolb, I.M., Rubin y J.M. Mclntyre (Eds.), Psicología de las organizaciones. Problemas contemporáneos (pp. 200-217). Madrid: Del Castillo

Schein, V.E. (1973). The relationship between sex role stereotypes and requisite management characteristics. Journal of Applied Psychology, 57, 95-100

Schein, E. H. (1978). Organizational Psichology ( $2^{\mathrm{a}}$ ed.). Engewood Cliffs: Prentice Hall

Schenk, C. (1928). Leadership. Infantry J ournal, 33, 111-122

Schwartz, S.H. \& Blisky, W. (1987). Toward a universal psychological structure of human values. J ournal of Personality and Social Psychology, 53, 550-562

Schwartz, S.H. \& Blisky, W. (1990). Toward a theory of the universal content and structure of values: extensions and cross-cultural replications. Journal of Personality and Social Psychology, 58, 878-891

Schwartz, S. H. (1992). Universals in the content and structure of values: Theory and empirical tests in 20 countries. En M. Zanna (Ed.), Advances in experimental social psychology (Vol. 25) (pp. 1-65). New York: Academic Press

Schwartz, S.H. (1999a). Cultural value differences: Some implications for work. Applied Psychology: An International Review, 48, 23-47

Schwartz, S.H. (1999b). A theory of cultural values and some implications for work. Applied Psychology: An International Review, 48, 23-47.

Schwartz, S. H., Melech, G., Lehmann, A., Burgess, S., \& Harris, M. (2001). Extending the cross-cultural validity of the theory of basic human values with a different method of measurement. J ournal of Cross Cultural Psychology, 32, 519-542.

Schwartz, S.H. (2006). Value orientations: Measurement, antecedents and consequences across nations. En R. Jowell, C. Roberts, R. Fitzgerald, \& G. Eva (Eds.), Measuring attitudes cross-nationally - Iessons from the European Social Survey. London: Sage 
Schyns, B., \& Meindl, J. R. (Eds.) (2005). Implicit leadership theories: Essays and explorations. Greenwich, CT: Information Age Publishing

Schyns, B., Paul, T., Mohr, G., \& Blank, H. (2005). Comparing antecedents and consequences of Leader-Member Exchange in a German working context to findings in the US. European J ournal of Work and Organizational Psychology, 14, 1-22

Segurado, A.; Agulló, E.; Rodríguez, J.; Agulló, M.; Boada, J. \& Medina, R. (2008). Las relaciones interpersonales como fuente de riesgo de acoso laboral en la Policía Local. Psicothema, 20 (4), 739-744

Segurado, A.; Agulló, E.; Rodríguez, J.; Agulló, M.; Boada, J., Medina, R. \& Castro, R. (2011). El "mobbing" como riesgo psicosocial: una propuesta de intervención. En E. Agulló (Ed.), Nuevas formas de organización del trabajo y la empleabilidad (pp. 399-408). Oviedo: Universidad de Oviedo

Server, R.J. \& Villalonga, I. (2005). La Responsabilidad Social Corporativa (RSC) y su gestión integrada, CIRIEC-España, Revista de Economía Pública, Social y Cooperativa, 53, 136-161

Server, R.J. \& Villalonga, I. (2008). Responsabilidad social y cooperativismo. Estudios de economía aplicada, 26 (1), 133-158

Server, R.J. \& Capó, J. (2009). La Responsabilidad Social Empresarial en un contexto de crisis. Repercusión en las Sociedades Cooperativas. CIRIEC-España, Revista de Economía Pública, Social y Cooperativa, 65, 7-31

Sevilla, S.; Ramos, E.; Mena, J.E. \& Guillén, C. (2005). Aproximación genérica a la mediación. En J. Sánchez (Ed.), Aproximación genérica a la mediación (pp. 59-72). Cádiz: Universidad de Cádiz

Sevilla, S.; Ramos, E.; Mena, J.E. \& Guillén, C. (2005). Aproximación genérica a la negociación. En J. Sánchez (Ed.), Aproximación interdisciplinar al conflicto y a la negociación (pp. 33-44). Cádiz: Universidad de Cádiz

Shamir, B. (1991). The charismatic relationship: Alternative explanations and predictions. Leadership Quarterly, 2, 81-104

Shamir, B.; House, R.J. \& Arthur, M.B. (1993). The motivational effects of charismatic leadership: A self-concept based theory. Organization Science, 4, 577-594

Shamir, B.; Arthur, M.B. \& House, R.J. (1994). The rhetoric of charismatic leadership: a theoretical extension, a case study, and implications for research. Leadership Quarterly, 5, 1, 25-42

Shartle, C.L. (1951a). Leader behavior in jobs. Occupations, 30, 164166 
Shartle, C.L. (1951b). Studies in naval leadership. En H. Guetzkow (Ed.), Group, leadership, and men. Pittsburgh, PA: Carnegie Press

Shartle, C.L. (1956). Executive performance and leadership. Englewood Cliffs, NJ: Prentice-Hall

Shaver, J. (1993, August 9). America's legal immigrants: Who they are and where they go. Newsweek, 20-21

Shavitt, S. (1989). Operationalizing functional theories of attitudes. In A.R. Pratkanis, S.J. Breckler \& A.G. Greenwald (Eds.), Attitude structure and function (311-377). Hillsdale, NJ: Erlbaum

Shavitt, S. (1990). The role of attitude objects in attitude functions. J ournal of Experimental Social Psychology, 26, 124-148

Sheldon, O. (1923). The philosophy of management. London: Pitman

Sherif, M. \& Sherif, C.W. (1956). An outline of social psychology. New York: Harper

Shewhart, W.A. (1931). Economic control of quality of manufactured product. Toronto: D. Van Nostrand Company

Sierra, R. (2008). Técnicas de investigación social (14 ed.). Madrid: Thomson

Simon, L., Greenberg, J. \& Brehm, J. (1995). Trivialization: The forgotten mode of dissonance reduction. J ournal of Personality and Social Psychology, 68, 247-260

Simpson, W.G. \& Kohers, T. (2002). The link between corporate social and financial performance evidence from the banking industry. J ournal of Business Ethics, 35 (2), 97-109

Skinner, B.F. (1953). Science and Human Behavior. New York: Macmillan

Skinner, B.F. (1961). Analysis of behavior. New York: McGraw-Hill

Simon, H. (1973). Las ciencias de lo artificial. Barcelona: ATE

Smith, A. (1997). La teoría de los sentimientos morales. Madrid: Alianza

Smith, E.R. \& Mackie, D.M. (1997). Psicología social. Madrid. Editorial Médica Panamericana

Smith, M. (1934). Personality dominance and leadership. Sociology and Social Research, 19, 18-25

Smith, M. (1935). Leadership: The management of social differentials. J ournal of Abnormal and Social Psychology, 30, 348-358 
Smith, M. (1948). Control interaction. Journal of Social Psychology, 28, 263-273

Smith, M.N.; Bruner, J.S. \& White, R.W. (1956). Opinions and personality. New York: John Wiley \& Sons

Smith, P.B. \& Peterson, M.F. (1990). Liderazgo, organizaciones y cultura. Un modelo de dirección de sucesos. Madrid: Ediciones Pirámide

Social Accountability International, SAI (2013). SA8000 Standard. Consultado el 11 de abril de 20013, de http://www.saintl.org/index.cfm?fuseaction=Page. ViewPage\&pageld=937

Social Accountability Internacional, SAI (2014). SA8000:2014 Revision Process. Consultado el 12 de enero de 2014, de http://www.saintl. org $/$ index.cfm?fuseaction=Page. ViewPage\&pageld $=1546$

Social Accountability Accreditation Services (2014). SA8000. Consultado el 12 de enero de 2014, de http: / /www.saasaccreditation.org/faqanswers.htm\#recognized

Solomon, J.F. \& Darby, L. (2005). Is private social, ethical and environmental reporting mythicizing or demythologizing reality? Accounting Forum, 29, 27-47

Sosik, J.; Potosky D. \& D. Jung, (2002). Adaptive Self-Regulation: Meetings Others' Expectations of Leadership and Performance. The J ournal of Social Psychology, 142, 211-232

Steele, C.M., Sounthwick, L. \& Critchlow, B. (1981). Dissonance and alcohol: Drinking your troubles away. J ournal of Personality and Social Psychology, 41, 831-846

Steele, C.M., Spencer, S.J. \& Lynch, M. (1993). Self-image resilience and dissonance: The role of affirmational resources. Journal of Personality and Social Psychology, 64, 885-896

Steiner, G.A. (1971). Business and society. New York: Random House,

Stogdill, R.M. (1948). Personal factors associated with leadership: A survey of the literature. J ournal of Personality, 25, 35-71

Stogdill, R.M. (1950). Leadership, membership and organization. Psychology Bulletin, 47, 1-14

Stogdill, R.M. (1959). Individual behavior and group achievement. New York: Oxford University Press

Stogdill, R.M. (1974). Handbook of leadership. New York: Free Press

Stone, J., Wiegand, A.W., Cooper, J \& Aronson, E. (1997). When exemplification fails: Hypocrisy and the motives for selfintegrity. J ournal of Personality and Social Psychology, 72, 54-65 
Strautmanis, J. (2008). Employees' Value Orientation in the Context of Corporate Social Responsibility. Baltic J ournal of Management, 3 (3), 346-356

Sulbarán, J.P. (1992). El concepto de responsabilidad social de la empresa. Revista Economía, Universidad de los Andes, 10, 228248

Tamayo, E. (2012). En entredicho el Pacto mundial de la ONU con las transnacionales. Consultado el 30 de abril de 2013, en http: / /alainet.org/active/1835\&lang=es

Tannenbaum, R. \& Schmidt, W.H. (1958). How to choose a leadership pattern. Harvard Business Review, 36 (2), 95-102

Tannenbaum, R., Weschler, I.R. \& Massarik, F. (1961). Leadership and organization. New York: McGraw-Hill

Tannenbaum, P. (1967). The congruity principle revisited: Studies in the reduction, induction, and generalization of persuasion. En $\mathrm{L}$. Berkowitz (Ed.), Advances in Experimental Social Psychology, (vol. 3). New York: Academic Press

Tannenbaum, R. \& Schmidt, W.H. (1973). How to choose a leadership pattern. Harvard Business Review, 51 (3), 162-180

Taylor, F.W. (1911). The principles of Scientific Management. New York: Harper y Brothers

Taylor, F.W. (1970). Management Científico. Barcelona: Oikos-Tau

Tea Ediciones (2010). Catálogo. Madrid: Tea Ediciones

Tead, 0. (1929). The technique of creative leadership. In human nature and management. New York: McGraw-Hill

Tead, O. (1935). The art of Ieadership. New Cork: McGraw-Hill

Terman, L.M. (1904). A preliminary study of the psychology and pedagogy of leadership. J ournal of Genetic Psycchology, 11, 413451

Tesser, A. (1993). On the importance of heritability in psychological research: The case of attitudes. Psychological review, 100, 129142

Tesser, A., Martin, L.L. \& Cornell, D.P. (1996). On the substitutability of the self-protecting mechanisms. En P. Gollwitzer \& J. Bargh (Eds.), The psychology of action (pp. 48-68). New York: Guilford

The Chinese Culture Connection (1987). Chinese values and the search for culture-free dimensions of culture, J ournal of Cross-Cultural Psychology, 18 (2), 143-164 
Thompson, A.A.JR. \& Strickland, A.J.III (1994). Dirección y Administración Estratégicas. Conceptos, casos y lecturas. Argentina: Addison-Wesley Iberoamericana

Thompson, M.M., Zanna, M.P. \& Griffin, D.W. (1995). Let's not be indifferent about attitudes ambivalence. En R.E. Petty \& J.A. Kosnick (Eds.), Attitude strength: Antecedents and consequences (361-368). Mahwah, NJ: Erlbaum

Thurstone, L. L. (1928). Attitudes can be measured. American J ournal of Sociology, 33, 529-554

Thurstone, L. L. (1929). Theory of attitude measurement. Psychological Review, 36, 222-241

Thurstone, L. L. \& Chave, E.J. (1929). The measurement of attitudes. Chicago: University Chicago Press

Thurstone, L. L. (1931). The Measurement of Social Attitudes. Chicago: University Chicago Press

Thurstone, L.L. (1976). Las actitudes pueden medirse. En C.H. Wainerman (Ed.), Escalas de medición en ciencias sociales (pp. 261-289). Buenos Aires: Nueva Visión

Tichy, N. \& Devanna, M. (1986). Transformational leadership. New York: Wiley

Tierno, B. (1996). Guía para educar en valores humanos: (persona, familia, escuela, sociedad). Madrid: Taller de Editores

Tierno, B. \& Tierno, J. (2002). Valores en el trabajo: estrategias para afrontar y superar los nuevos retos laborales. Madrid: La Esfera de los Libros

Trevino, L.K. \& Nelson, K.A. (2004). Managing Business Ethics: Stright talk about How To Do It Right ( $3^{\mathrm{a}}$ ed.). New York: Wiley \& Sons

Triandis, H.C. (1971). Actitudes y cambio de actitudes. Barcelona: Toray

Trillo, M.A. (2010). La inversión en Responsabilidad Social a través del Capital Humano como medio de transformación empresarial. Capital humano: revista para la integración y desarrollo de los recursos humanos, 23, 88-94

Triodos (1980). Nuestra misión. Consultado el 8 de enero de 2014, de http://www.triodos.es/es/conozca-triodos-bank/quienessomos/mision-triodos/

Trist, E.L. (1993). A socio-technical critique of scientific management. En E. Trist \& H. Murray (Eds.), The social engagement of social science: A Tavistock anthology (pp. 580-598). Philadelphia: University of Pennsylvania Press 
Trompenaars, F. (1998). Riding the Waves of Culture: Understanding Diversity in Global Business ( $2^{\mathrm{a}}$ ed.). New York: McGraw Hill

Tucker (1981). Politics as leadership. Columbia: University of Missouri Press

Tziner, A. (2013). Corporate social responsibility (CSR) activities in the workplace: A comment on Aguinis and Glavas. Journal of Work and Organizational Psychology, 29, 91-93

Ullrich, J., Christ, O., \& Van Dick, R. (2009). Substitutes for procedural fairness: Prototypical leaders are endorsed whether they are fair or not. J ournal of Applied Psychology, 94, 235-244.

Ullmann, A.A. (1985). Data in search of a theory: a critical examination of the relationships among social performance, social disclosure, and economic performance of U. S. firms. Academy of Management Review, 10, 540-557

Unión General de Trabajadores, UGT (2012). Cultura, políticas y prácticas de responsabilidad social de las empresas del IBEX 35. Consultado el 16 de mayo de 2013, en http://www.observatoriorse.org.es/Estudios\%20e\%2OInformes/Estudio\%202012\%20Cultura, \%20Pol\%C3\%ADticas\%20y\%20Pr\%C3\%A1cticas\%20de\%20Responsabili dad\%20Social\%20de\%20las\%20empresas\%20del\%20IBEX35.pdf

United Nations (2013a). Overview of the UN Global Compact. Consultado el 7 de abril de 2013, en http: / /www.unglobalcompact.org/AboutTheGC/index.html

United Nations (2013b). Participant Search. Consultado el 20 de noviembre de 2013, en http://www.unglobalcompact.org/participants/search?commit=S earch\&keyword=\&joined_after=\&joined_before=\&business_type=

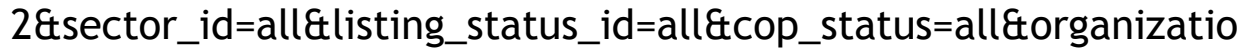
n_type_id=etcommit=Search

Urwick, L.F. (1953). Leadership and morale. Columbus: Ohio State University, College of Commerce and Administration

Valdivieso, J.D. \& Diego, R. (Eds.) (1998). Psicología del trabajo: nuevos conceptos, controversias y aplicaciones. IV Congreso Nacional de Psicología del Trabajo y de las Organizaciones. Madrid: Pirámide

Valentine, S. \& Burnett, T. (2002). Ethics Codes and Sales Professional' Perceptions of Their Organizations' Ethical Values'. J ournal of Business Ethics, 40, 191-200

Valentine, S. \& Fleischman, G. (2008). Ethics Programs, Perceived Corporate Social Responsability and Job Satisfaction, Journal of Business Ethics, 77, 159-172 
Vallejo, M.C. (2007). El compromiso en la empresa familiar bajo una óptica de liderazgo transformacional y aprendizaje organizacional. Investigaciones Europeas de Dirección y Economía de la Empresa, 13 (3), 217-234

Vallone, R., Ross, L. \& Lepper, M. (1985). Social status, cognitive alternatives and intergroup relations. In $\mathrm{H}$. Tajfel (Ed.), Differentiation between social groups (pp. 201-226). London: Academic Press

Van De Ven, H.A. \& Ferry, D.L. (1980). Measuring and assessing organizations. Nueva York: Wiley \& Sons

Van Gils, S., Van Quaquebeke, N., \& Van Knippenberg, D. (2010). The $X$-factor: On the relevance of implicit leadership and followership theories for leader-member exchange agreement. European J ournal of Work and Organizational Psychology, 19 (3), 333-363

Van Knippenberg, D. \& Hogg, M.A. (2001). Social identity processes in organizations. Group Processes and Intergroup Relations, 4, 185189

Van Knippenberg, D., \& Hogg, M.A. (2003). A social identity model of leadership effectiveness. En R.M. Kramer \& B.M. Staw (Eds.), Research in organizational behavior, (vol. 25, pp. 245-297). Amsterdam: Elsevier

Van Knippenberg, D., Lossie, N., \& Wilke, H. (1994). In-group prototypicality and persuasion: Determinants of heuristic and systematic message processing. British Journal of Social Psychology, 33, 289-300

Van Knippenberg, B. \& Van Knippenberg, D. (2005). Leader selfsacrifice and leadership effectiveness: The moderating role of leader prototypicality. J ournal of Applied Psychology, 90, 25-37

Van Knippenberg, D., Van Knippenberg, B., De Cremer, D., \& Hogg, M.A. (2004). Leadership, self, and identity: A review and research agenda. The Leadership Quarterly, 15, 825-856.

Vargas, A. \& Vaca, R.M. (2005). Responsabilidad social corporativa y cooperativismo: ventajas y potencialidades. CIRIEC-España, Revista de Economía Pública, Social y Cooperativa, 53, 241-260

Vaz, N.; Fernández-Feijoó, B. \& Ruiz, S. (2012). España en el GRI: empresas que comunican y empresas que verifican. Revista Digital del Instituto Internacional de Costos, 1, 147-169

Vázquez-Brust, D.A.; Liston-Heyes, C.; Paza-Úbeda \& Burgos-Jiménez, J. (2010). Stakeholders Pressures and Strategic Prioritisation: An Empirical Analysis of Environmental Responses in Argentinean Firms. J ournal of Business Ethics, 91, 171-192 
Vázquez, D. G., Oliveira, F. J., \& Seabra, F. M. Responsabilidad social y aspectos éticos en las organizaciones. Un análisis de actitudes de los futuros gestores empresariales. Observatorio Iberoamericano de Contabilidad y Gestión, 16. Consultado el 29 de julio de 2013, en http://www.observatorioiberoamericano.org/RICG/N\%C2\%BA_16/Dolores_Gallardo,_Fatim a_Jorge_y_Fernando_Seabra.pdf

Vázquez, O. (2006). Responsabilidad Social Empresarial: matices conceptuales. Lan Harremanak, 14, 13-23

Vecchio, R.P. (1987). Situational Leadership Theory: An Examination of a Prescriptive Theory. J ournal of Applied Psychology, 72, 3, 444-451

Vecchio, R.P., \& Norris, W. (1996). Predicting employee turnover from performance, satisfaction, and leader-member exchange. Journal of Business and Psychology, 11, 113-125

Velasco, M.M., Puentes, P. \& Vilar, J. (2010). El código unificado de buen gobierno: su nivel de seguimiento por empresas socialmente responsables. Revista de Estudios Empresariales. Segunda Época, 2, 99-113

Velázquez, R.; Gala, F.J. \& Guillén, C. (2000). Clima organizacional. En C. Guillén (Ed.), Psicología del trabajo para relaciones laborales (pp. 165-179). Madrid: McGraw-Hill Interamericana de España

Velázquez, R.; León, J.M. \& Guillén, C. (2005). El conflicto interpersonal. En J. Sánchez (Ed.), Aproximación interdisciplinar al conflicto y a la negociación (pp. 73-86). Cádiz: Universidad de Cádiz

Verbo, H. (2003). Estratificación social y desigualdad: el conflicto de clases en perspectiva histórica y comparada. Madrid: McGraw-Hill

Vigotsky, L.S. (1984). Pensamiento y lenguaje. Buenos Aires: La Pleyade

Vilanova, M.; Lozano, J.M. \& Arenas, D. (2009). Exploring the nature of the relationship between CSR and Competitiveness. J ournal of Business Ethics, 87, 57-69

Vilaseca, B. (2010). El principito se pone la corbata. Madrid: Planeta (Colección Booket)

Vogel, D. (2005). The market for virtue: the potential and limits of corporate social responsibility. Washington, D.C.: Brookings Institution Press

Voltes, P. (2002). La edad de oro de los escándalos financieros. Clio: Revista de Historia, 8, 50-54 
Votaw, D. (1972). Genius became rare: a comment on the doctrine of social responsibility. California Management Review, 15 (2), 2531

Vroom, V.H. \& Jago, A.G. (1990). El nuevo liderazgo. Dirección de la participación en las organizaciones. Madrid: Díaz de Santos

Waddock, S.A. and Graves, S.B. (1997). The corporate social performance-financial performance link. Strategic Management Journal, 18 (4), 303-319

Waller, N.G., Kojetin, B.A., Brochard, T.J.Jr., Lykken, D.T. \& Tellegen, A. (1990). Genetic and environmental influences on religious interest, attitudes, and values: A study of twins reared apart and together. Psychological Science, 1, 138-142

Walster, E., Walster, G.W., \& Berscheid, E. (1978). Equity: Theory and research. Boston: Allyn \& Bacon

Warriner, C.K. (1955). Leadership in the small group. American Journal of Sociology, 60, 361-369

Wartick, S.L. \& Rude, R.E. (1986). Issues management: corporate fad or corporate function?. California Management Review, 29 (1), 124-132

Watt, A.H. (2007). The impact of managerial virtuality on employee performance. Tesis doctoral inédita, Rensselaer Polytechnic Institute, New York

Wech, C.E.; Lundstrum, R.H. \& Moore, A. (1989). Bogus-pipeline effects on self-reported college student drug use, problems and attitudes. The international J ournal of the Addictions, 24, 10031010

Weick, K.E. (1995). Sensemaking in Organizations. Thousand Oaks, CA: Sage

Weinberger, D. (2008). Autenticidad: ¿es real o es marketing? Harvard Business Review, 86 (3), 24-34

Weirnert, A.B. (1985). Manual de Psicología de la Organización. La conducta humana en las organizaciones. Barcelona: Herder

Weisbord, M. (1987). Productive workplaces: Organizing and managing for dignity, meaning and community. San Francisco: Jossey-Bass

Werther, W.J. and Chandler, D. (2005). Strategic corporate social responsibility as global brand insurance. Business Horizons, 48 (4), 317-324

Wexley, K. N. \& Yukl, G. A. (1977). Organizational behavior and personnel psychology. Homewood, IL: Irwin 
Wood, D.J. (1991). Social issues in management: theory and research in corporate social performance. Journal of Management, 17 (2), 383-406

Wooford, J.C. \& Liska, L.Z. (1993). Path goal theories of leadership: A meta-analysis. J ournal of Management, 19 (4), 857-876

Woodward, J. (1958). Management and technology. London: H.M Stationary Office

Woodward, J. (1965). Industrial Organization: theory and practice. Oxford: Oxford University Press

World Business Council on Sustainable Development (WBCSD) (2002). Corporate social responsibility. The WBCSD's J ourney. Génova: WBCSD

WOSY, Work Socialization of Youth (Internacional Research Group) (1989). Interview schedule of the work socialization of youth study. Mimeo: Universidad de Gante

Yoder, D. \& Heneman, H.G. (1977). Handbook's of personnel and industrial relations. Washington: Bureau of National Affairs (BNA)

Yukl, G.A. (1981). Leadership in organizations. Englewood Cliffs, NJ: Prentice Hall

Yukl, G.A. (1994). Leadership in organizations ( $3^{\mathrm{a}}$ ed.). Englewood Cliffs, NJ: Prentice Hall

Yukl, G. (1999). An evaluation of conceptual weaknesses in transformational and charismatic leadership theories. Leadership Quarterly, 10, 285-305

Yukl, G. (2002). Leadership in Organizations (5aed.). Prentice-Hall: Upper Saddle River

Yukl, G.A. \& Van Fleet, D.D. (1992). Theory and research on leadership in organizations. En M.D. Dunnette y L.H. Hough (Eds.), Handbook of Industrial and Organizational Psychology (pp. 147-197). Palo Alto, CA: Consulting Psychologist Press

Zaccaro, S.J., \& Klimoski, R.J. (2001). The nature of organizational leadership: Understanding the imperatives confronting today's leaders. San Francisco: Jossey-Bass

Zadec, S. \& MacGillivray, A. (2007). The state of responsible competitiveness 2007. Consultado el 5 de marzo de 2013, en http://www.accountability.org/images/content/0/7/075/The\%2 OState\%20of\%20Responsible\%20Competitiveness.pdf

Zanna, M.P. \& Aziza, C. (1976). On the interaction of repressionsensitization and attention in resolving cognitive dissonance. J ournal of Personality and Social Psychology, 44, 577-593 
Zerilli, A. (1985). Fundamentos de Organización y Dirección General. Bilbao: Deusto

Zhang, J. (2010). Employee Orientation and Performance: An Exploration of the Mediating Role of Consumer Orientation. J ournal of Business Ethics, 91, 111-121

Zigarmi, D. Edeburn, C. \& Blanchard, K. (1991). Research on the LBAll: A validity and reliability study. Escondido, CA: Blanchard Training and Development

Zigarmi, D. Edeburn, C. \& Blanchard, K. (1995). Getting to know the LBAll: Research, validity and reliability of the self and other forms. Escondido, CA: Blanchard Training and Development

Zigarmi, D. Edeburn, C. \& Blanchard, K. (1997). Getting to know the LBAll: Research, validity and reliability of the self and other forms ( $4^{\mathrm{a}}$ ed.). Escondido, CA: The Ken Blanchard Companies

Zimbardo, P. (2007). Person x situation x system dynamics. Consultado el 6 de junio de 2013, en http://www.psychologicalscience.org/index.php/publications/ob server/2007/september-07/person-x-situation-x-systemdynamics.html

Zorzona, A., Salanoa, M \& Peiró, J.M. (1996). Trabajo en grupo. En Peiró, J.M. y Prieto, F. (Eds.): Tratado de Psicología del Trabajo. Vol. II: Aspectos psicosociales del trabajo (pp. 137-160). Madrid: Síntesis

Zu, L. \& Song, L. (2009). Determinants of managerial values on Corporate Social Responsibility: Evidence from China. J ournal of Business Ethics, 88, 105-117 